Utah State University

DigitalCommons@USU

All U.S. Government Documents (Utah Regional U.S. Government Documents (Utah Regional Depository)

1873

Sixth Annual Report of the United States Geological Survey of the Territories, Embracing Portions of Montana, Idaho, Wyoming, and Utah; Being a Report of Progress of the Explorations for the Year 1872

F. V. Hayden

Follow this and additional works at: https://digitalcommons.usu.edu/govdocs

Part of the Environmental Indicators and Impact Assessment Commons

Recommended Citation

42nd Congress, 3rd Session. Mis. Doc. No. 112

This Report is brought to you for free and open access by the U.S. Government Documents (Utah Regional Depository) at DigitalCommons@USU. It has been accepted for inclusion in All U.S. Government Documents (Utah Regional Depository) by an authorized administrator of DigitalCommons@USU. For more information, please contact digitalcommons@usu.edu.

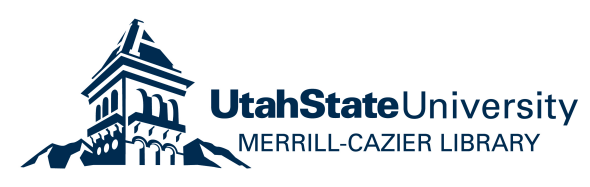




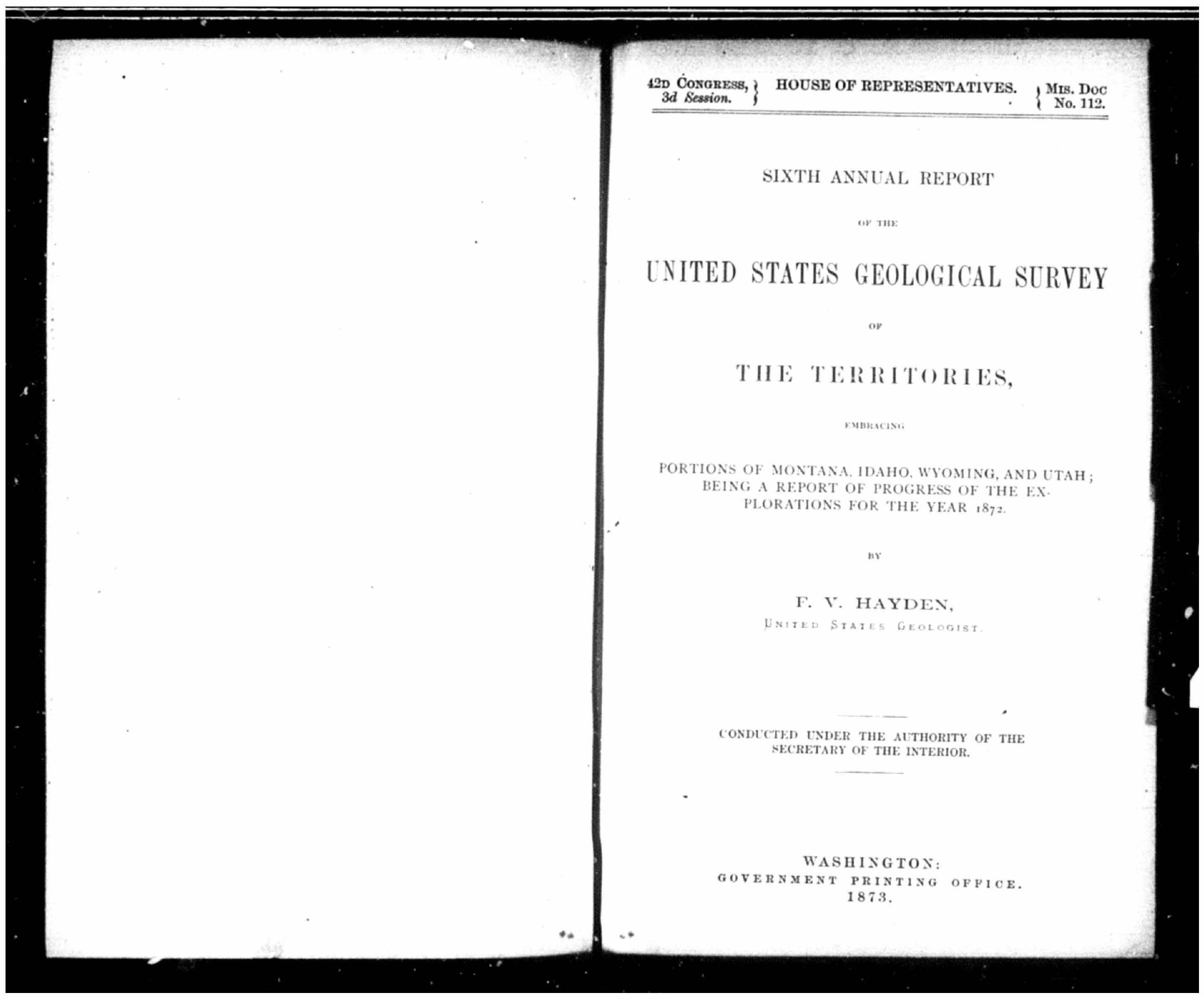




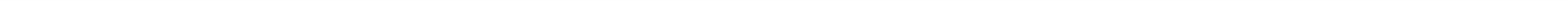


BPECLLL RAPOTT ON GEOLOG AND PALEONTOLOGY

Lignitic for nation and Fossil tlora, by Leo. Lesquereur.

Part 1.-Details of explorations in the Lignitic formations of the Rocky Mountains

Faton Mountain

The Arkansas Valley, from Puoblo to Cafion City

Colorado Springs to Denver

Soutb Platte to Cheyenne.

Cheyenne to Carbon Station.

Carbon to Black Butte Station

Black Butte to Rock Spring

Green River Station.

Evanston

Coalville, Utah.

The Western Lignitic formation considered as Eocene.

General charactens of the flora of the American Eocene. ...

The American Eocene identical with thrt of Europe by general characters,

Part 2,-The Lignite; its formation. -

The Lignitic considered in its applicability - areal distribution and thickness of the strata

The Northern Lignitic Basin.

The New Mexico Lignitic Basin...

Tle Coloralo Lignitic Basin, from Pueblo to Cheyenne.

The Lignitic deposits along the Union Pacific Railroal, from Cheyenne to Evanston.

Coneluding remarkw...........

Euumeration and description of Fossil plants from the Western Tertiary formations.

General remarks

Table of distribution of the species of Fossil plants from the Tertiary for-

mations of North America

Description of species of Fossil plants from the Cretaceous of Kansas. Conclusion.

Paseontologicai report by F. B. Meek ...

General reinarks

Silurian $a_{p} \cdot \mathrm{e}$.

Carboniferous a:o

Jurasic age.

Cretaceous age

Tertiary age .

Lists of fossils collected

Silurian species.

Carboniferous species

Jurassic species .

Cretaceous list.

Tertiary species.

Description of new species of fossil

Silurian forms

Cretaceous forms.

Tertiary forms

Report of a geological reconnoiseance along the Union Pacifie Railroad, by $\mathrm{H}$.

M. Bannister

Page.

318

322

325

327

331

350

330

30

339

325 by E. D. Cope

Mammalia .

Quadruman

Carnivora

Ungulats

Proboscidia .

Eobasileida

Bathmodoutide

Periseodactyla

Rodentia

Mansupialia

Reptilia

Crocodilia

Testudinata

Lacertilia.

Ophidia .

Batrachia.

Pisces

Review of the vertebrate fauna of the Eocene of W yoming

Kemains of primitive art in the Bridger Basin of Sonthern Wyorning, by Joseph

Leidy.....

A tucient mounds of Dakota, by $\mathrm{C}$. Thomas.

PART III

SPECIAL REPORTS ON ZOOLOGY AND BOTANY ......................... 659

Report on the mammals and birds of the expedition, by C. H. Merriam ....... 661

Stammals

Rapacia

Rodentia

Ruminantia

Cheiroptera

Birds

Passeres.

Strisores

Zygodactyli

Raptores.

Gralla

Lamellirostres

Longipennes

Oology

List of birds found in T6ton Basin

List of birds found in Fire Hole Basin

List of birds found in Utah Territory

Coleoptera, by G. H. Horn

Notes on Orthoptera, by C. Thomas

Odonata from the Yellowstone, by H. Hagen.

Descriptions of new specie of Mallophaga, by A. 8. Packard, jr.................

Description of new parasitic worms found in the brain and other parts of birds,

by A. S. Packard, jr.

Description of new insects, by A. S. Packard, jr............................

Insects inhabiting Great Balt Iake and otber saline and alkaline lakes of the

West, by A. 8. Packard, jr... 
Botany, by J. M. Coulter

Page.

Phonogatia fornd on beth slopes, (1int)

only on the east. rn slope, (list).

Cyperacea, by 8. T. Olney

only on the wi tern slope, (list)

Gratuinaceas, by Geo. Vasey

Musci, by Leo. Lesquereux

Lichens, by Henry Willey

Fungi, oy Chas. H. Peck.

ASTRONOMY AND UYPBOMETIY

Report on astronomy and hypometry, by Henry Gannett..................... 79

Notes on the climate of Moutana, by Granville Stuart.........

R6sumb of meteorological olservations taken at Fort Ellis, Jontana.......... 811

General index...

Index of systematic names

LIST OF NEW SPECIES DESCRIBED.

Mrverals:

Pealite...

Blackmorite

Fossit Plustr:

Ophioglosum Alleni

Planera longifolia.

Sequoia angustifolia.

Thuya Garmani .

Abies Nevadeusis.

Chondrites subsimples bulbosus

Halymenites striatns

$$
\text { major . }
$$

Delessaria incrassata lingulata.

Dombeyopsis obtusa

Sclerotium rubellum

Delesseria fulva.

Pteris anceps.

Sabal Goldiata.

Quereus stramineus .

Ulmus irregularis

Ficus spectabilis$$
\text { auriculata. }
$$

Dombeyopsis trivin

Sapindas caudatusentalis.

Ceanothus fibrillosu

Rhamuus Cleburni

$$
\text { Goldiants. }
$$

Canlinites fecunda

Cercis eocenica.

Populus decipiens

Ficus oblanceolata
Coccoloba lieviante.

Pager

Asimina eocentea...

Zizyphus Meekii

Spheria Myrica

Opegrapha antiqua.

Caulinites sparganioides

Myrica Torreyi...

Ficus planicostat.

Clintoni

corylifolius

Haydenii

Viburuum marginatum.

$$
\text { contortum }
$$

Cissus lobato-crenatms.

Aleurites eocenica.

Paliurus zizyphoides.

Rhannus discolor

Viburuum dichotomum

Querens Wyomingiana

Calycites hexaphylla ...

Carpolithes arachioides.

Abies setigera...

Nyma lanceolata

Hy menophyllum cretaceum

Canlinitee spinosa.

Populites fagifolia. salinas
aftinis

Ficus Sternbergii

Saseafras mirabilis

recurvatus.

Laurophylinm reticulatum

Pterospermites Sternbergii

rugosus

Fossul. Isvetrantes:

Iphidea sculptilis

Asaphus gouiocercus

Bathyurus serratus.

Haydeni..

Bathyurellus Bradloyi.

Conocoryphe Gallatinensis.

Ostrea soieniscus...

$$
\text { anomioides . }
$$

Avicula propleura.

rhytophora

gastrodes

Sodiola multilinigera

Trapezium mieronems

Corbiculs inflexa

$$
\text { securis... }
$$

Cyrena Carletoni...
387

388

390

390

391

391

392

393

393

394

394

394

395

396

396

397

397

398

399
460

460

402

403

404

404

407

421

422

422

423

423

423
424

424

425

495

426

479

480

480

482

484

485

485 
Pharella Pealei....

Corbula nematophora

Neritina bellatala

$$
\text { patelliformis . }
$$

Bannisteri

pisum .

pisiformis

Admete rhomboides.

$$
\text { gregaria . }
$$

ubfasiformis

Turritella Coalvillensis

$$
\begin{aligned}
& \text { spironema } \\
& \text { micronema }
\end{aligned}
$$

Fusus Gabb

$$
\text { Utahensis }
$$

Turbonilla Coalvillensis

Eulima funicula.

$$
\text { chrysallis }
$$

inconspicu

Valvata nana

Physa Carletoni.

Ostrea $W$ yomingensis

Anomia gryphorhynchu

Corbicnla cy theriformis

$$
\text { Banuisteri }
$$

Corbula undifera

$$
\text { tropidophora }
$$

Goniobasis insculpta.

Melania Wyomingensis

Pbysa Brulgerensis.

Limnea compactilis

Pupa Leidyi .

Fossil Rertiles:

Diplocynodus polyodon.

Trionyx beteroglyptus.

$$
\text { scutumantiquam }
$$

Plastomenus multifoveatu

Baöna ponderosa

Emys euthnetus.

$$
\text { megaulax }
$$$$
\text { pachylomus }
$$

Foserl. Fisur:

Clastes anax

Pappichtys, gen. nov

$$
\begin{aligned}
& \text { plicatus... } \\
& \text { sclerops... } \\
& \text { lavis ...... } \\
& \text { symphysis } \\
& \text { Consonil ... }
\end{aligned}
$$

Pbareodon sericeus.

Rhineastes radulns

calvus .

areuatus

Netnorteru:

Mesothemis composita.

Mrmeleon diversus

MazLophaga:

Menopon picicola.

Goniodes Yerriamant. mephitidis...

Nirmus buteonivoru Docophorus syruii.

\section{1}

Parastric worats

Eustrongylus buteonis

$$
\text { chordeilis }
$$

Aracirsida :

Argan Americana.

Plasts:

Dicentra uniflora.

Peziza Vuleanalis

Spiaria Coulteri

LIST OF ILLUSTRATIONS.

1. Molern lake deposits, capped with basalt, two miles above Boteler'a Ranel Pag valley of the Yellowstone...

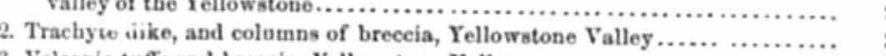

3. Volcanic tuffs and breccia, Yellowstone Valley.

4. Voleabie breceia at the head of Cafion and Rock Creeks

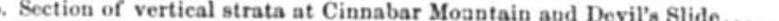

7. Carbouiferous limentone section of Bola Bite.

4. Iadex and Pilot Peaks ....

9. Basaltic columns, Yeliowstone, near mouth of Tower Creek

10. Yellowstone Lake, (east side).

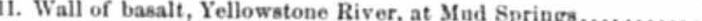

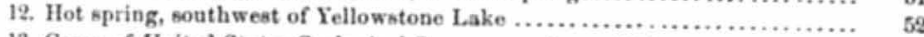

13. Camp of United States Geological Survey, on shore of lake ..................

14. United States Geological Survey cn route...............................

15. Yellowstone Geysers...

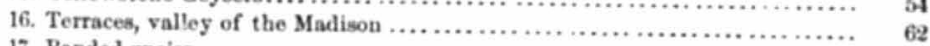

17. Banded gneies...

19. Dike on the Missouri

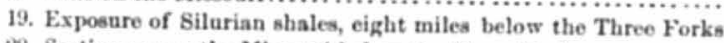

20. Section across the Missouri below the Three Fork

21. Connection between Missouri and Gallatin.

22. Silurian beds of the Gallatin .

23. Deceptive weathering, Liberty Peak

24. Section through Flathead Pasa

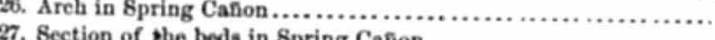

27. Section of the beds in Spring Cañon....................................... 110

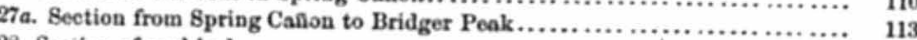

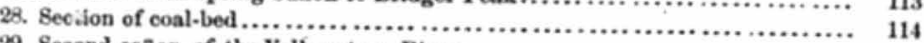

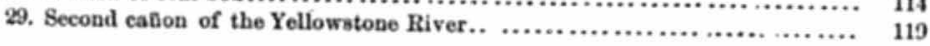


3). Section from Gardiner's River to Cinnabar Mountain

31. Basins of Hot Springa at Garliners Biver, Yellowsto

32. Urnamental rim of extinet spring, Gardiner's River.

33. Grand Canion of the Yellowstone

34. Lower Fall of the Yellowstone

35. Upper Fall of Yellowstoue River.

36. Crystal Falls on Cascade Creek .

36a. Half-Way Bpringo, Fire-Hole River

38. Globular raases in the crater of the Turban Geyser.

39. Oblong geyser near the Giant, Upper Basin, showing the ornamental character of the borders of the springs.

40. Plan of Grotto Geyser.

41. Inverted beds of Jackass Creek

150

42. Section from Gallatin River to Madison River, Montana Territory ............

43. Bear River Springs ............................................. 173

44. Ideal sketch.

45. Section, Ogden Cañon.

49. Shoshone Lake ........................ 249

49. Panoramic view around Yellowstone Lake ................................... 251

50. T6ton Rango.... .................................................. 202

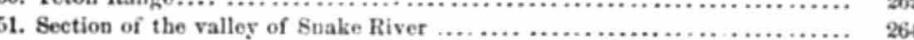

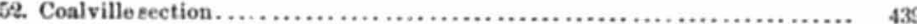

33, Section on Sulphur Creek, near Bear River ...

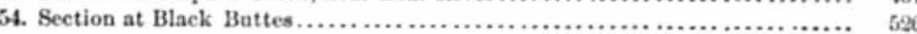

55. Section along Bitter Creek from Table Rock to Salt Wells. .................. 534

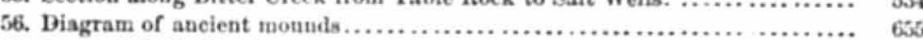

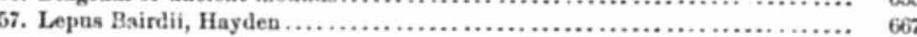

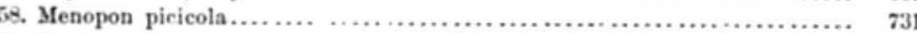

69. Goniodes Yerriatmannus

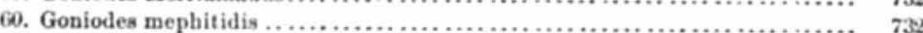

61. Niruns buteonivorus ..................................................... 733

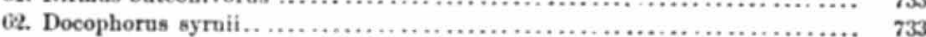

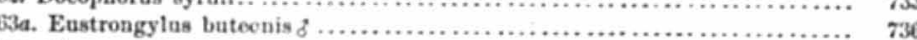

63b. Eustrongylus buteonis \& ................................................ 730

64. Eustrongylus chordeilis.

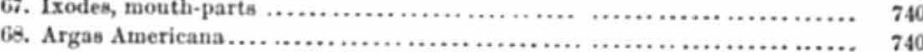

PLATES.

1. Loxolophodon cornutus, Cope

3. Loxolophoton

3. Loxolophodon cornutus, Cope .................................... 569

4. Loxolophodon cornutus, Cope .................................... 571

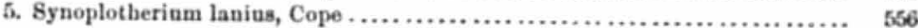

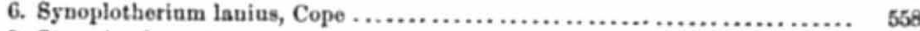

7 Stone implements............................................ 651

Fig. 1. Wrought llake of gray and black striped jasper.

Fig. 2. Implement of pinkish quartzite.
8. Stone implements

Fig. 3. Flake of gray and black striped jasper.

Fig. 4. Flake of brownish-yellow jasper.

9. Stone implementa

Fig. 5. Flake of black tlint.

Fig. 6. Implement of yellowish flint.

Fig. 7. Flake of brownish-black flint.

10. Stone implement

Fig. R. Chipped stone of cbecolate-brown quartzite.

11. Stove implement

Fig. 9. Chipped stone of gray flint or jasper.

12. Stone im-lements

Fig. 10. Flake of brownish-black tint.

Fig. 11. Flake of black flint.

Fig. 12. Flake of gray jasper.

Fig. 13. Modern stone implement of gray quartzite.

$$
\text { Mars. }
$$

i. Sap of the mining regions of Clark's Foi $k$ of the Yellowstone.

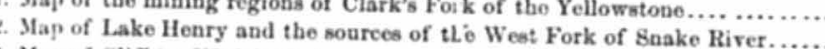

Map of Cliff (or Wade's) Lake.

4. Mar of the Shoshone Geysen

Map of the sources of Snake River

\section{DLarsas.}

Dingram illustrating the phylogeny of the Mammalian orter . Diagram illustrating the phylogeny of the Teatndinat a.

Diagram showing the curves of the horary oscillations of the barometer at Fort 


\section{LETTER TO THE SECRETARY.}

W ASHINGTON, D. O., March 10, 1873.

SIR : I have the honor to present for your approval and for publication the sixth annual report of the United States Geological Survey of the Territories, containing a preliminary account of explorations made during the summer of 1872, about the sources of Snake and Missouri Rivers.

The liberal appropriation granted for the survey by the Fortysecond Congress enabled the Chief Geologist to organize two large and well-equipped parties for fleld-work. These parties we:e each provided with a geologist, topographer, astronomer, meteorulogist, with their assistants. A number of young men aeted as collectors of objects in natural history,

One party, under my immediate direction, took Fort Ellis as its initial point. We spent several days at this point and at Bozeman purchasing our animals and securing supplies and other outfit. After our preparations were inade. we passed over the divide to the Yellowstone Valley, traversing nearly the same route as last year. The Yellowstone River, from the lower cañon to its source in the Yellowstone Lake, waz carefully surveyeu. Some of the branches, as the East Fork, were more fully examined than at any time previously. From the lake the party passed over the clivide into the Geyser Basin of Madison River, and ex. plored that river and its branches to the Three Forks. We then ascended the Gallatin River and examined it to its sources. The inter. esting cañon of the Gallatin, which is about seventy miles in length, had never bren explored previously, and was unknown even to the ju. habitants of the lower part of the valley. From the Gallatin Caũon we passed over the divide into the Yellowstone Valley, near the second cañon, and made a more detailed survey of the Snowy or Yellowstone Range, then passed down the valley through the first or lower cañon, and then along the divide between the branches of the East Gallatin and Shields Rivers to Flat Head Pass; thence across the rugged hills to a point about ten miles below the Three Forks, on the Missouri River. We then returned to Bozeman along the base of the mountains on the east side of the East Gallatin Fork, and the field-work of this party was closed. The materials for an aceurate map of the district examined were secured, and most important discoveries in geology and large collections in all departments were made.

The second party was placed under the general direction of Mr. James 
Stevenson, whose experience in this wild life for sixteen years, as my principal assistant, gave him great advantages over any one else l could secure for that trust. This party started from Ogden, Utah, surveyed a ronte to Fort Hall, and there laid in supplies and made the necessary preparations for a pack-train up the unknown regiou of the Upper Snake Valley. The party was also provided with a chief geologist, topographer, meteorologist, botanist, and other necessary assistants. From Fort Hall this party proceeded up the west side of Snake River. Two weeks were spent in making a careful survey of the previously unknown Teton Basin. The range of the Three Tetons was carefully mapped. Eleren of the party attempted to ascend the highest peak, the Grand Teton. Only two of these succeeded, Messrs. Stevenson and Langford. So far as we can ascertain they are the only white men that ever reached its summit.

In the summer of 1860 the party under the command of Colonel W. F. Raynolds, to which I was attached as geologist, camped for several days at the base of this range. We hal with us as guide Mr. James Bridger, who was more familiar with the western country and the events in its history for the past tifty years than any living man. He regarded the ascent of this peak as improssible, and many of the old mountaineers aud trappers state that it has been attempted many times without snccess.

Immense masses of snow and lakes of ice were found on its sides, and abundant signs of modern glacial action. At certain seasons of the year, usually in August and September, the air is filled to a great height with grasshoppers flying in every direction. They sometimes rise to the height of many thousands of feet. As they passed over this Teton Range they became chilled and dropped on the snow and ice in vast numbers and gradually melted the suow, so that the myrials of little boles which they formed gave to the surface a peculiar roughness. It was due to this fact that Messrs. Stevenson and Langford were able to cling to the almost vertical icy sides of the peak, and complete the ascent. They found the elevation to be 13,858 feet above the sea, thus entitling it to rank among the monarch peaks of our continent.

Yet on the summit of this peak there were indications that human beings had made the ascent at sorne period in the past. On the top of the Grand Teton, and for 300 feet below, are great quantities of granite blocks or slabs of different sizes. These blocks lad been placed on end, forming a breastwork about three feet high, inclosing a circular space six or seven feet in diameter, and while on the surrounding rocks there is not a particle of dust or sand, yet the bottom of this inclosure is covered with a bed of minute particles of granite, not larger than the grains of conmon sand, which must have been worn off by the ele. ments from the vertical blocks until it is nearly a foot in deptb. There was every appearance that these granite slabs had been placed in their present position by Indians, as a protection from the wind, many centuries ago.
The scenery of the Teton Range is truly alpine in its character, ap. proaching that type more nearly than any other known in the West.

Leaving the Teton Basin, the party proceeded up Henry's Fork of Snake River, and at its source, surveyed one of the most interesting and important geographical points in the West. At the head of Heury's Fork are four remarkable passes, representing the four points of the compass, with Henry's Lake located in the center. The Targee, or East Pass, is 7,063 feet elevation, and forms one of the gateways to the Mad. ison Valley and to the sources of the Madison and Yellowstone. Henry's, or South Pass, is about 6,250 feet elevation, and opeus into the great valley of the Suake River from the Atlantic slope. Red Rock, or West Pass, is 7,271 feet elevation, and connects the great valley of the Jefferson Fork, while the Raynolds or North P.sy, 6,911 feet elevation, leads into the valley of the Lower Madison. These remarkable passes, thus linking the Atlantic with the Pacific slope, are so smooth that a carriage could be driven over them at a high rate of speed. In a practical point of view these passes, as well as the Snake River Valley, must soon become of great importance to the West.

The Snake River and Henry's Fork Valleys form by far the most feas. ible routes for railroads, connecting Yontaua and the entire Northwest with the interior basin and the Pacific slope. Compared with the pres. ent stage-routes to Montana, a road by this vallev would be from one hundred to one hundred and fifty miles shorter, and would open up for settlement a vast area of arable and pastoral laud. The immense jorests of pine timber would be made available, and I am convinced that in a few years, on account of the scarcity of good timher in the interior basin, this will become one of the most important lumber regions in the West. If the railroad which contemplates connecting Corinne, Utah, with Helena, Montana, passes up Henry's Fork, it will render available two thousand five hundred square miles of pine timber. All the wouders of our great National Park can be seen in one day's travel on horseback from this route.

About ten miles northwest of Henry's Lake a new lake was discov: ered, which from its peculiar character merits some notice here. It is called "Cliff Lake" on the map, from the fact that it seems to be con. fined to a deep fissure in the basaltic rocks. It is triangular in shape, its length about one and a half miles, and half a mile in its greatest width. Several streams of considerable size flow into it, but no outlet could be discovered. High, nearly vertical walls inclose it on every side.

From Henry's Lake the party crossed the water-shed by way of the Targee Pass iuto the Madison Valley, and passed up that stream to the Fire Hole Basin, where both of the parties met on the same day, Au. gust 14, though starting about two months previously from points sev. eral hundred miles apart. The Snake Biver division remained in this 
basin several days, until supplies could be obtained from Virginia Oity for the retarn trip to Fort Hall.

The party then continued its way up the valley of the Madison to its source, and pent some days exploring the different branches of Snake River and the Madison. There is perhaps no more unknown or more in. teresting geographical region in America than this great water divide of our continent. The maps which are now in process of construction in the office, and which will be işsued to the public in the course of the present year, will almost entirely change the geography of this wonderful region. Within a radius of ten miles, may be found the sources of thres of the largest rivers in America. The general elevation is from 7,000 to 8,000 feet above the sea, while the mountains whose eternal snows form the sourses of these great rivere, rise to a height of 10,000 to 12,000 feet. Flowing northward are the numerous branches of the Missouri, Yellowstone, and Wind Rivers, which all eventually unite into one mighty stream, the Missuuri! To the south are the branches of Green River, which unites with the Colorado and finally empties into the Gulf of California, while south and west flow the branches of Snake River, which, uniting with the Columbia, pour their vast volume of water into the Pacific.

The exploration of this remarkable water divide proves that the Mad. ison Fork has its sonree in a small lake not hitherto noted on any map, and that the so-called Madison Lake belongs entirely on the Pacific slope. This latter lake was found to be about twelve miles long and eight miles wi.le. From this body of water flows a stream nearly one huodred feet wide, which, after a distance of about five miles, empties into a secuud lake which is four miles long and one and a balf ailes wide. The former of these lakes was named Lake Shoshone, and the latter Lake Lewis, in honor of the great pinneer explorer of the Northwest.

At the upper end of Lake Shoshonc a new geyser basin was discovered, with from serenty-five to one huntred springs, many of them geysers of considerable power. Theornamentation about these springs was regarded as more interesting and elaborate than those in Fire Hole Basin. The divide between the Yellowstone Lake and Lake Lewis was found to be about 50 feet above the former, and 200 feet above the latter. This low ridge in the great water divide of the continent has donbtless given rise to the story of the Two.Ocean River, and such a stream has found its way to most of our printed maps.

From the summit of Red Mountain the scope of vision embraced a radius of one hundred and fifty miles, within which four hundred and seventy mountain-peaks worthy of a name could be distinetly observed. The area that conld be swept by the eye from this pint conld not have been less than fifty thonsand square miles, embracing every variety of grand and beautiful scenery, of mountain and valley, probably withont a parallel on the continent. Ten large lokes and several smaller ones were embraced in the view, and the entire Yellow stone Park was spread out under the eye. To those who are familiar with the remarkable purity of the atmosphere in these high latitudes, these statements need not appear incredible. To the east the Wind River and Big Horn Ranges, with the snow-clad summits of Fremont's, Union, and Clond Peaks, bounded the view. On the north the Yellowstone Range, with Smigrant Peak and many of the ioftiest mountains in Montana, were ciearly seen. To the west the numerons ranges comprised in what are called the Salmon River Mountains of Idaho form the horizon of vision in that direction, while the mountains near Fort Hall and the Wahsatch Range completed the mighty amphitheater. This remarkable view em. braced a large portiol of Wyoming, Montana, Idaho, and Utah Terri. tories.

About forty small streams, which unite and form the upper portion of Snake River, were carefully examined. The party then proceeded down the valley of Suake River, through its remarkable cañons, examined Jack. son's Like and the numerous streams that empty into the main river on either side. About the middle of October the party arrired at Fort Hall, where it was soon after disbanded.

It will be seen from this report, and the more elaborate inal reports which wil' iollow in due time, that the scientific as well as the practical results th se explors ii ns are of great importance to the material in. terests of the West. They have already enlisted the interest and sym. pathy of all classes of intelligent people of our country from Maine to Florida, as the numerous letters and applications for the reports afford ample testimony.

The two principal field parties were organized as follows:

The first division-Adolf Burek, chief topographer; Henry Ganuett, astrouomer; A. E. Brown, assistant topographer; E. I. Wakefleld, meteorologist; Dr. A. C. Peale, mineralogist ; W. H. Holmes, artist; Walter B. Platt, naturalist; W. B. Logan, secretary ; A. E. Bingham, Joseph Savage, and T. O. C. Sloane, general assistants.

Second, or Suake River division-James Stevenson, director; Profes. sor Frank H. Bradley, chief geologist; W. R. Taggart, assistant geologist; Gustavus R. Bechler, chief topographer; Rudolph Hering and Thomas W. Jaycox, assistant topographers; William Nicholson, meteorologist; John M. Coulter, botanist; Dr. Josiah Curtis, surgeon and microscopist; C. Hart Merriam, ornithologist ; Campbell Carrington, naturalist; William H. Jackson, photographer; Charles R. Campbell, assistant; Robert Adams, P. J. Beveridge, J. S. Negley, W. A. West, S. F. Hamp, T. B. Brown, and S. C. Jones, general assistants; Hon. N. P. Langford, C. S. Speneer, and Dr. Reagles accompanied the Snake River dirision from Fort Hall as guests. Mr. William Blackmore of London, England, accompanied my party from Fort Ellis to the Gesser Basin for several weeks as guest, for the purpose of examining the National Park.

Although most of the members of both parties labored with great zeal 
to advance the objects of the survey, yet the burden of executive duty was so great in managing the affuirs of so large an organization that a large part of my time and force has been abstracted from the purely scientifie labors, and for this reason my personal report will be unch less elaborate and important than heretofore. I trust, however, that the report as a whole will not be surpassed in interest and value by any of the preceding ones.

My first assistant, Mr. James Stevenson, performed his duties with his usual zeal and fidelity. In his management of the Suake River party, he exhibited executive abilities of the highest order. Professor Bradley made some important discoveries in geology. The discovery of an upper member of the Potsdam group will prove an important addi. tion to our knowledge of western geology. Amowg the fossils brought back by Professor Bradley, Mr. Meek has identified the equivalent of the Spergen Hill beds of Indiana, (Saint Lonis limestone of the western carboniferons series.) The report of Dr. A. C. Peale will show his great industry and care. I regard it as one of much importance. W. H. Holmes, as artist, renderel most important services in all departments of the survey. His sections and sketches have proved useful not only for the geological reports, but have been of great value to the topographers in preparing their maps. Mr. William H. Jackson, the photographer, was more successful than in any preceding year. In testimony of the importance of his labors, I quote from a notice of his photograpls from the January number of the American Jonrual of Sciences, by Professor J. D. Dana :

Next to a pernonal visit to this land of geysers, hot springs, fountains of boiling mod, waterfalls, lakes, and majestic mountains, is a morning sient over these photo graphs. They wonld doeredit to the best photographic lahoratery, over these photodiftienlties inberent in a bog and arduons jourey, Yellowstone series well illustrutes the advantago of phote inga in bringing wastag over any hand-drawings in bringing out details of structure, especially where the artist is guidel by the geologist in selecting the best points of view. Among the novelties which are a posi. tive addition to onr knowledge of orography we mention particularly the views of the Three Tetons. Among the gerser views there are two of "Old Faith tul " in full of the which are exceedingly effective; othen of bavins action of the surface may be studied with much of the atisfaetion is be hatied tracery amination; amination; others, of long cascale slopes which have been gravefully terracel by the mineral depositions of the waters, and whose basins, brimful to their delicate edges with the petrifying waters, reflect mirror-like the surrounding objects; othersshowing large areas of the geyser region with the geysers in action. Such views give an opportunity for the geologist to compare beds of chemieal lepesition with limestones.

Mr. C. Hart Merriam's report will show his zeal in his special depart. ment. Mr. Join M. Coulter acted as botanist, and his report exhits an unusual number of species of plants for a single season's labor. Mr. Walter B. Platt made interesting collections about the sources of the Yel. lowstone and Missonri Rivers. The plants were added to those of Mr. Coulter, and the birds and mammals to those of Mr. Merriam. The new species of plants have been described by the eminent botanist, Professor Thomas C. Porter, of Easton, Pennsylvania. Of flowering plants there were one new, genus and six new species, besides several varieties. They number about nine hundred species. Of grasses there were about sixty species; mosses, fifty-three; lichens, witi probably one new species and two new to this continent, sixty-seven; other cryptogamia, with two new species of fungi, seventy. There will probably be oue thousand two hundred species in all. The report of Dr. Cartis, on the micro. scopic forms of that region, and especially about the hot springs, must prove of interest to microscopists.

It is believed that the results of the survey as a whole will be found to be worthy of the liberal appropriation made by Cougress for the purpose.

The results of the labors of the topographical corps will be visible in the series of maps, which will be published as soon as possible. Some of the smaller ones, prepared by Mr. Bechler, accompany this report. Mr. Bechler labored with the utmost zeal and fidelity, and his maps of the Snake River Valley and its tributaries cannot but prove a most im. portant addition to the geography of one of the least known portions of our continent. The observations for latitude and longitude were taken by Mr. Rudolph Hering, who also superintended the meteorolog. ical observations. He was assisted in the field by Mr. Jaycox. Mr. William Nicholson remained at Fort Hall and made a most valuable series of meteorological observations. Mr. Adolph Burck, assisted by Messrs. Gannett and Brown, secured the materials for a map of the Yellowstone, Madison, and Gallatin Rivers, with their branches, com. prising an area of about nine thousand square miles. The sudden death of Mr. Burck before the completion of his map, threw additional labor upon Mr. Gannett. Mr. Gannett has performed his duties both in the field and in the oflice with the highest credit to himself and to the survey.

Besides the two main parties, several smaller parties have been operating under the auspices of the survey in different portions of the West. It is a part of the policy of the survey to invite distinguished speeialists to examine some of the more obscure and difficult problems in the geology of the West. There has been for $\mathrm{n}$ long time some differences of opinion in regard to the exact age of some portions of the Cretaceons and Tertiary groups of the West. I desired to gather all the evidence that could be serured for the solution of the question the present season. Professor Joseph Leidy and Professor E. D. Cope spent a large part of the summer in studying the ancient lake-basins in the interior of the continent, which have now become celebrated all over the world for the richness and variety of their vertebrate fossils. These eminent gentlemen were most successful and obtained a vast quantity of valuable material, which will be embodied in a series of memoirs illustrated with plates, which will form volume $I$ of the quarto series of final reports. 
Part I, volume I, by Professor Leidy, containing thirty-six plates, is now passing through the press. Part II, by Professor Cope, with fifty to sixty plates, will be ready for publication during the year.

Professor Leo Lesquereux, our great authority in fossil botany, made a careful study of the coal regions of the West, with one assistant, and procared a mass of valuable information and many new species of fos. sil plants. He has been engaged for some time past on an exhaustive memoir on the ancient flora of the Cretaceous and Tertiary formations west of the Mississippi in the service of the survey. This will form Part II, volume II. Part I, by Dr. J. S. Newberry, containing about sixty plates, is nearly ready for publication.

Volume III, by the eminent paleontologist, Mr. F. B. Meek, will contain the invertebrate fossils of the survey, with about eighty plates. About forty of the plates have been engraved. Mr. Meek, assisted by Mr. H. M. Bannister, spent about two months during the past summer aloug the line of the Union Pacific Railroad and procured much evidence fiom the fossil invertebrata. All these gentlemen have prepared essays of great value for the present annual report.

Volume IV will contain the profiles, sections, and other illustrations with descriptive text by the chief geologist. Part I will contain abont one hundred illustrations, printed by the Albertype process from pho. tographic uegatives taken by Mr. Jackson. The views will embrace some of the most remarkable scenery of the West. Part II will contain the profiles and sections, with suitable descriptive text.

Volume $\mathrm{V}$ will embrace memoirs on the recent zoology and botany of the survey. The first memoir of this volume, "Synopsis of Acridida of North America," by Professor Cyrus Thomas, is now passing through the press. Special menoirs by the most eminent authorities are in preparation on the new species of mammals, birds, fishes, reptiles, in. sects, indeed all the new forms of life, animal or vegetable, collected by the survey.

It will be seen that the survey contemplates two classes of publieations : the annual reports and miscellaneous memoirs in octavo, contain. ing an account of the preliminary work, catalogues and snch matter as may be regarded of popular interest, and are, therefore, printed in large editions and distributed to the people generally, and a series of quarto volumes which will contain the new and more technical results of the survey. The quarto volumes may be regarded as containing positive ad. ditions to knowledge, and are intended more especially for distribution to libraries and men of science.

The collections of the survey, which are very great in all departments, are deposited in the Smithonian Institution, in accordance with a law of Congress. The first and most complete series will be selected for the National Musenm, and the daplicates divided into sets and distributed to the museums and institutions of learning in our country.

I have agaiu the pleasure of acknowledging important favors from the military anthorities. Hon. W. W. Belknap, Secretary of War, issued the same order on the military posts of the West as last year. His personal iaterest in the success of the survey has been of great material value. There is not space to mention the names of all the officers who exhibited a kindly interest in our success. From General Ord, com. mander of Department of the Platte, at Omaha, our party received the most prompt and generous aid in every way in his power. He has alwass manifested the greatest interest in the exploration and development of the West by all parties, eivil or military.

By Colonel C. A. Reynolds, of Fort D. A. Russell, Captain Putnam, Lieutenants King and Nelson of Fort Hall, and Major Forsyth and Lieutenant McAdams, of Fort Ellis, special favors were granted, for which $I$ beg them to accept $m y$ cordial thanks. By the citizens of the western Territories everywhere we were always received with great good will and aided in our work. To bis excellency Governor Potts, J. L. Corbett, A. B. Knight, and Raymoud Brothers, of Virginia City; to Willson and Rich and Nelson Story, of Bozeman, Warren, Hussey \& Co., Salt Lake City, and Nat Stein, of Coriane, and many others, we are under many obligations for favors of great importance.

To the officers of the Union Pacific Railroad, Hon. Horace F. Clark, president, and General T. E. Sickles, general superintendent, the survey is under the most important material obligations for free transportation for nearly all the members of the party. From the Central Pacific Kansas Pacific, Denver Pacific, Chicago, Burlington and Quincy, and the Denver and Rio Grande roads we received a liberal number of passes. I wish to extend my cordial thanks to the officers and employés of all the railroads of the West for uniform courtesy and marked sympathy in all our operations.

I would again express my sincere thanks to the press in all parts of our country for their uniform interest and encouragement in our work. Since the commencement of our surveys in the West, there has not been an unkind expression from the press, secular or scientific, in this country or in Europe.

To the editors of the Illustrated Christian Weekly I am indebted for some most valuable electrotypes which have been used in this report. Thanks are also due to Professors Henry and Baird, of the Smithsonian Institution, for many favors of great value.

The success which has attended the operations of the survey for the past six years; the publication of six annual reports which have been received with great favor not onls by the people of our own country, but in all parts of the world, would appear to entitle it to the continued confidence of Congress. Its organization is becoming more efficient and more perfect every year, and it is believed that it occupies a position under the General Government not filled by any other body devoted to kindred pursuits. From the great interest which the people of our country have continually manifested in its success, it would appear to supply an existing want, and it is capable of expansion to meet the 
necessities of the Government so far as its duties are concerned. I therefore venture to ask that additional power be given it to increase its eff. ciency, that it may continue to commanil the respect not only of men of science, but of the intelligent world generally.

To render the organization more perfect, so far as the topographical portion is concerned, Mr. J. T. Gardner, so long favorably known as the chief topographer of the geological survey of the fortieth parallel, under the direction of Mr. Clarence King, has become associated with me as chief of the topographical staff. Mr. Gardner brings with him to this dnty the ripm experience of ten years of topographieal work, ex. tending over an area from the Pacific coast to the east base of the Rocks Mountains. Mr. Gardner thus expresses his conception of a true topographical map for geological purposes:

For making maps suited to geological purjoses it is necesary to earry over the country a systematic trigonounetric aud topographical survey, ebeeked by astronomi. eal observations. The maps mnst represent the features of the conntry acenrately, add in boll relief; or, in other words, they must be a pieture of the earth's surface as one would see it looking down from above.

The work of the survey as contemplated by the present organization demands the very highest order of talent. To conmand this, it is neces. sary that the young men who may embark in this enterprise should feel a confldence in the permanency of the work, instead of regarding it as a stepping-stone to more lucrative positions. Each professional assist. ant is worth to the Government from 50 to 100 per cent. more, every succeeding year. To make thorough astronomical, topographical, meteorological, geological, and botanical researebes, and to develop the min. ing and agricultural resources properly, trained experts in all the differ. ent departments are absolutely essential. Such men to identify them. selves permanently with the survey must be paid in proportion to their abilities.

In conclusion, I would again extend my cordial thauks to the honorable Secretary of the Interior, and to Hon. B. R. Cowen, Assistant Secretary, for their prompt action and sympathy in every moversent that tended to promote the best interests of the survey. The broad discretion and freedom of action which has at all times been given to the Chief Geologist uuder the Department of the Interior have contributed very greatly to its success.

Very respectfully, your obedient servant,

F. V. HAYDEN,

United States Geologist

PART I.

REPORT OF F. V. HAYDEN.

Hon. C. Delaxo,

Secretary of the Interior. 


\section{GEOLOGICAL SURVEY OF THE TERRITORIES.}

\section{CHAPTER I.}

\section{INTRODUCTORY.}

I bad intended in this report to present a careful résumé of the geol. ogy of the Northwest, so far as my explorations have extended; but the unusual pressure of executive duties, in connection with so large a party, has prevented me. I shall, therefore, in this chapter pass hastily in review some of the more important points that occur along our route, from Cheyenne to the Yellowstone region.

I wil! first notice briefly the lignitic formations as they appear along our route. Inasmuch as there has been some diversity of opinion among geologists in regard to the precise position in the geological scale of the great coal or lignitic group of the West, I desired to secure all the evi. dence possible bearing on that point. For this purpose Professor Lesquereux, our great authority on fossil botany, was directed to spend a few months in exploring the coal-beds of the West. He passed along the Kansas Pacific Railway to Denver, Colorado, examining the Cretaceous coal-beds on the ronte. From Denver he proceeded along the base of the mountains to Santa Fé, and returning, made a carefbl stndy of the coal-groups as shown in the vicinity of Denver. He then visited the principal points of interest along the Union Pacific Railroad to Salt Lake City. The reader is referred to his valuable reports in this volume for the results of his examinations.

Besides the lignitic group, there is a series of extensive lake-basing in the interior of our continent which have already yielded an astonish. ing number of remarkable vertebrate remains. Inasmuch as greater weight is attached by some geologists to the testimony of the higher order of organic remains, Professor Joseph Leidy and Professor E. D. Cope, both of whom are justly regarded as the most eminent compara. tive anatomists of our country, made a careful exploration of the lignitic and more modern lake groups, under the auspices of the survey. Their reports, appended to this volume, will throw great light on the age of these formations.

Mr. F. B. Meek, paleontologist of the survey, assisted by Mr. H. M. Bannister, made a careful study of the lignitic group from the invertebrate side, and their reports contain most valuable results. The time has been so short for the preparation of this report that I have not been able to examine the results of the studies of these eminent gentlemen and therefore cannot present their conclnsions in regard to the age of Its with certainty. I am of the Professor Lesquereux concludes, from his study of the foesil plants, that the lignitic strata are mostly Eccene. Mr. Meek believes tham to be upper Cretaceous, passing up through a series of transition beds to Eocene; while Professor Cope regards them as of Cretaceons Age. All these gentlemen must be regarded as individually responsible for the opinions expressed in their reports. 
I will just here state briefly the history of the growth of the evidence in regard to the age of the lignitic group as expressed in my previons reports. As far back as 1854 and 1855 , the writer was exploring the Tertiary formations along the Missouri River, and made large collec. tions of shells and plants, most of which were new to science. These explorations were continued each year up to the autumn of 1860 , in various parts of the North west, and anunally large additions were made to the collections both of vegetable and animal remains, The sholls were all of extinct species, of brackish or fresh-water origin, and, while they did not appear to be positively characteristic of ans age, were regarded by Mr. Meek as more nearly resembling Tertiary types than any other. The fossil plants were mostly of extinct species; aud in his most valuable chapters contributed to the "Report of the Exploration of the Yellowstone and Missouri Kivers," during the years 1859-60, Dr. Newberry expressly states that they are of Tertiary age, and nost prob. abiy Miocene. Now, these lignitic strata occupy a vast area in the Upper Missouri Valley, extending far southward, with very little inter. ruption, to New Mexico, and westward into the interior of the continent. I have many times, in iny previous reports, expressed the opinion that the lignitic formations of the West were all portions of one great group, interrupted here and there by mountain-chains, or concealed by more molern deposits. Having, therefore, fixed the age of these beds on the Upper Missouri, and subsequently tracing them across the country, southward below Santa Fé, and westward uearly to Salt Lake Valley, I ventured to express the opiuion, from the identity of the Lussil flora, that all the lignitic strata of the West might be of Tertiary age. In the summer of 1868, I made an examination of the lower coal.beds at Bear River City and at Coalville, Utah, and made the statement that the evidence seemed to point to the Cretaceous age of these beds. Since that time the proof of the Cretaceous age of the lower coal-beds in Utah, especially at Bear River and Coalville, appears to be conclusive. But if we admit that the coal-beds of Wyoming atid Colorado are all of Cretaceous age, I think we nay extend them all over the Northwest and ignore the evidence from the fossil flora entirely. The facts, as we possess them at the present time, seem to point to the conclusion that the deposition of the lignitic strata commenced during the latter portion the Cretaceous period, and continued on into Tertiary times withont any marked physical break, so that many of the Uretaceous types, especially of the vertebrata, may have lingered on through the transition period, even into the Tertiary epoch. I propose to discuss this very important problem in detail at some futurề time. Each year's explora tion adds immensely to our knowledge of the vast Cretaceous and Terti. ary groups of the West, and the time cannot be far distant wheu the facts accumulated will enable us to reconstruct the physical history of those remarkable periods.

Although the survey began its labors near Ogden in the Great Salt Lake Basiu, yet we shall delay only to note a few features which seem important. The geology of this great basin, from the Sierras to the Wahsatch Range, will doubtless be ably discusset in the forthcoming volumes of Mr. Clarence King, in charge of the geological exploration of the fortieth parallel. The results of this survey will prove of the highest importince to Rocky.Mountain geology. The survey under my charge is annually accumulatiog materials looking towazd a more complete discussion of the principal geological features of this interior region, should the much-looked-for period of leisure ever arrive to digest them. A portion of the observations made on sereral expeditions have been given in the reports of the survey for the years 1870 and 1871 .

By examining a good map of Utah, it will be seen that the Wahsatch Range forms the eastern boundary of the great interior basin. In many respects this is the most remarkable range of mountains in the interior of our continent. Mr. King, in Chapter VII, Mining Industry, has briefly but most graphically described its general structure. He remarks that the materials of this range are identical with the numerous great cbains of the interior basin, though developed on a scale of grandeur observed nowhere else. The basis rocks are a series of alternating layers of quartzose, mica and hornblendic schists. A bove these rests a heavy bed of quartzite, with very regular and marked stratifica. tion. Above the quartzite comes a bed of very hard ashen.gray lime. stones, probably of Silurian age; then a group of shales, clays, quartzites, \&c.; and then a great thickness of limestones, the upper portion of which has been shown by the organic remains to be of Carboniferous age.' In the Weber Cañon and on the east side of the range from Ogden, there is a large group of quartzites, passing up into siliceous limestones and capped with a bed of red sandstone, which, so far as my own observations are con. cerned, is of doubtful age, but may be Triassic. Above these comes a thick group of bluish-gray limestones, with characteristic Jurassic fossils. These ranges, which seem to me to run in nearly parallel lines, about north and south, appenr to possessa common structure and point to a common origin, and cannot be treated in a comprehensive manner except by a geologist familiar with the entire basin and its surroundings. These ranges rise ap in long, sharp ridges, apparently from the plains, while the lowlands are covered with a group of modern deposits, which jut up ugaiust the base of the mountain chains on either side. Since the crumpling, or folding, of the earth's crust, which gave origin to this wonderful series of mountain chains, the erosion has been immense. It is most probable that at a comparatively modern period the vast area between the Wahsateh Mountains on the east and the Sierra Nevada on the west was one great lake, the mountains rising up as islands in this vast inland sea. The lakes, large aud small, which we find scattered over the basin at the present time, are only remuants of this former sea. The modern deposits which cover the lowlands are mostly calcareons and arenaceous beds, and sometimes reach a thickness of 800 to 1,200 feet, and often filled with fresh-water or land shells, indicating a very wodern origin, probably not older than the Pliocene period. At any rate, the strata are all borizontal or nearly so, showing that no disturliance of any great importance has occurred since their deposition. These ranges of mountains extend, with greater or less intervals in their continuity, far uorthward into ldaho and Montana. Certain changes in the details of structure are apparent as we pass northward to Snake River Basin, but there is a remarkable similarity in the rock-materials as far as the great water-divide of the continent, when rather marked changes occur in the monntain-ranges of Montana, where the quartzites give place to geat thicknesses of limestones. Indeed, in Montana the quartzites, which are so well shown in Jtah, have no existeuce, though far to the westward in the Salmon River Mountains they continue in full force. We bave not the materials as yet for a critical study of these remarkable folds or wrinkles in the earth's erust that are scattered throughont this interior basin, more or less parallel to each other. Sometimes the granitic nueleus is revealed, with the unchanged beds obscurely exposed around the sides or base of the range. Usually the very bard limestones have served as a sort of protection, 
and are generally seen in full force. In the Waheatch Range some of the peaks rise to the regions of perpetaal snow, and on either side deep and most picturesque eeñons are carved out of the solid mass into the valleys below. Little and Big Cottonwood and American Fork Cañons are only examples of hundreds of these wonderfal cañons, having, on either side, nearly vertical walls 1,000 to 2,000 feet in beight. The Oquirrh Mountains at the south end of Salt Lake form a flue illus. tration of an oblong quaquaversal, an interrupted fold or puff, with the strata inclining at various angles from all sides. From Lyou Hill the geologist can see the Carboniferons limestones inclining sonthward from the south end of the range, and as he follows along the base northward the quartzites, shales, or limestones which compose the sedimentary group incline westward, while at the north end near the lake, the strata bend around, and apparently dip under the waters of the lake, while on the east side, these beds incline to the eastward, and apparently mass nuder the valley. We can see, therefore, that these valley are really synclinals, which have been excavated more or less by erosion. Tha islands in Salt Lake are only the crests of these folds, while the waters occupy the synclinal valleys; and this remnant illustrates on a small scale the scenic beauty of the great inland sea when it extended over the entire basin. Ophir Cañon is one of the deep gorges carreci out of the west side of the Oquirrb Range, at right angles to the axis of elevation, revealing the strata on either side in a wosderfully clear manner. Regularly-stratified quartzites rest upon a series of granitoid strata, which are exposed only here and there in these deep gorges. The quartzites pass up into micaceous clays or shales, then gradually up into limestones, in which are located some of the richest silver-mines in Utah. It is quite probable that the lower beds of quartzites and limestones are of Silurian age, perhaps as old as the Potslam group, while we know that at least the greater portion of the second limestone-bed is of Carboniferous age. On Lyon Hill, the silver-mines are located in limestones that are full of characteristic Carboniferous fossils. Another interesting feature which tends to complicate the structure of these ranges is the great number of dikes of every size. In some instances the igneons matter has poured ont over a considerable area Again, it has pever reached the surfice, as is shown only in the deep has never reaclied the surface, as is stown only in the deep waterearred gorges. In Brigham Cañon, on the east side of the Oquirrh Range, are several well-marked dikes; also on Lyon $\mathrm{Hill}$ and Ophir Cañon. At the north end of this range the effect of erosion is well shown by the ontcropping edges of the beds of limestone that are exposed on the bottom and extend even into the lake. Black rock appears to be a mass of Carboniferons limestone, a remnant of a bet appears to that once extended over the area occupied by the monntains, but now probably dipping beneath the valley and the lake-basin. Church Island is composed almost entirely of quartzites. Antelope Island has a tableshaped top, which would indicate that the terraces reached as bigh as its present summit.

As a fine illustration of erosion in connection with these remarkable anticlinal folds and synclinal valleys, we might take the Wahsatch Range from Salt Lake City northward. To the sontheast and east of Salt Lake City we can see, with great clearness, the deep water-woru cañons cleaving the mountains from summit to base, while on either side are the sharp angular peaks rising ap among the regions of perpetual 8now. Twin Peaks are among the loftiest of the range, and may be seen at a is one of the most picturesque in this very picturesque region. At the head of it is loeated the celebrated Emma Mine. The walls on either side rise to the beight of 200 to 300 feet. We have at the base the beantiful gray massive syenite, which is employed in the construction of the Mormon Temple, and resembles our best this rests a series of feldspathic gneissic strata, and upon these were deposited the lower qaartzites unconformably. The dip of the were deposited the lower qaartzites uncouformably. The dip of the gneiss is south or southeast, while the quartzites incline north or east of north. The order of superposition is most elearly shown br these wonderful gorges. But as examples of erosion they excite wonder.

The evidence of drift or glacial action is everywhere seen on a grand scale. The sides of the cañons are worn and furrowed by the masses of snow and ice that have slidden down for centurics. The waters gathering and freezing in the fissures on the sides and of the cañons pry off, as it were, immense masses of rock, which fall down into the valley below. Masses, 50 to 100 feet in diarneter, block up the pathway. Near the entrance of the cañon from the valley the amount of drift-material wbich has been swept down from above is prodigious, showing tle results of forces not now in operation. As we pass along the west side of the range, we shall find a vast thickness of the selimentary rocks, rangiug through the Silurian, Carboniferons, Triassie, Jurassic, and Tertiary, inclining from the mountains toward the plains, showing the original anticlinal structure of the entire range.

In City Creek Cañon, just in the rear of Salt Lake City, we find near the head, all the older rocks, up to the iurassic inclusire, etanding nearly vertical, or incliniug at a high angle, with the conglomerates of the Wahsatch group, jutting against the Jurassic beds, also inclining at moderate augle. I have never yet observed any rocks on the west at a of the Wahsatch Range filling up the interval between the Jarassie fimestone and the Wahsatch conglomerates. Wetween the Jurassic south of Utah Lake, the interval is filled. We know, bowever, that group, which seems to be, froun the coalthat fossils, the same as that so well shown at Coalville on the east side of the Wabsatch. We see by this fact that the conglomerates, although not conspicuons the present time, on the east side of the slley, did, bowever, extend at the range into the valley, and may, for aught we knower, extend over time, extend far across the valley, for they are shown with at the present ness on the west side from City Coreat thickwest side from City Creek Cañon for several miles to the Fromard.

From among the Tertiary clays and conglomerates north of the eity near the Hot Springs and above, the dark steel-gray limestones of the Carboniferous period crop out in unmerons places. Abont ten miles north of Salt Lake City all this immense mass of sedimentary beds, at least 10,000 feet in thickness, has been swept away, leaving the gneissic nucleus bare with the modern drift which underlies leaving the gneissio against the sides. From Farmington to Weber Cañon, a distance of about twenty-five miles, the beds of the little streams which flow in great numbers and carve out deep cañons in the sides of the monntains furnish no trace of any unchanged rocks.

Standing upon some high point and casting the eye northward along the range, the very granitoid nucleus would appear to have been worn away, and the east side of the anticlinal to appear with the uptnrned edges of the strata cropping out toward the valley near Ogden. This monoclinal condition of the range continues north war' berond Corinne, and in the interrals are some very fine exhibitions of theyond Corinne, and there the granitic rocks appear from continuously. If we take the position $2 \mathrm{GS}$ 
range of mountains, which we call the Wahsateh Range, was originally a complete anticlinal fold, then it forms a fine illustration of the erosive effects of water in comparatively modern geological times, which for so great a distance has swept away the entire half of the range. We may also suppose that beneath the great thickness of superficial deposits which compose the terraces, the edges of the strata which form the west side of compose the terraces, the edges of the strata which form the west side of
the fold now exist, dipping beneath the valley, but rising again on the side of some other fold in the basin as Antelope Island, \&c. If our suppositions are true, the next question that at once arises in the mind would be as to the cause of this tremendous erosion. We have neither space nor time, all the facts, to discnss this most interesting problem in the present report, bnt we promise our readers to recur to it again at some future time. We may, however, suppose that the Wabsatch Range formed the eastern shore of the great iulaud sea which, at a comparatively modern geologieal period, covered the entire basin. How great a depth it ever attained it is difficult now to determine, but at some period its waters must have reached high upon the sides of the loftiest ranges, so that they appeared scattered bere and there as islands proiecting shove the surronding waters. It is probable that during the gradual decrease of the waters of this lake the greater portion of the erosion of the cañons was performed. Up the valleys of all the little streams that lead into Salt Lake are the terraces and peculiar lake-deposits, showing that the lake-waters extended far up beyond the wall-like shores. It is altogether probable, from the proofs which are found everywhere in these valleys, that there were continued oscillations in the depth of the lake-waters, a rise and fall, and long periods when the waters would remain at a fixed level. If we take the position that the present results of erosion have all been brought abont by the slow destruction of the rock-materials by water, and that this force is produced by the agitation of the waters beating upon the shores, then we may suppose that the winds from the west and southwest ,revailed and gave to the water the force that slowly produced the erosive resnlts that we now see on the east and northeast sides of the valley. Other causes may have united in producing these results, which we bope to present at some other time.

From Salt Lake Valley the Snake River division of the survey pro. ceeded northward, by way of the parallel valley, to the valley of Snake River near Fort Hall. In my report for $A 871,1$ recorded most of our observations on this ronte, aud now refer the reader to the more com. plete account of Professor Bradley in this report.

As we proceed northward toward the divide between the waters of the basin aud Snake River, the quartzites seem to diminish and the cal careous beds to increase, and the conditions seem to have been more favorable for the preservation of organic remains. The Carboniferous limestones seem to be well developed, and charged in some places with characteristic fossils. On the divide between Koss Fork and Lincoln Valley, near Fort Hall, Professor Bradley obtained a stray mass of limestone, in which was crowded together a mass of minute fossils, nearly forty species, many of them identienl with species found at Spergen Hili, Indiana. (See Catalogue of Fossils, by Mr. Meek.) This is certainly a most important discovery, extending the existence of this formation very much farther west than it had ever been known before. Previons to this time not a single species of this group had been found west of Iowa or Missouri. It indicates that quite probably, if the great mass of Paleozoic rocks of the West could be examined in detail, they might be separated into numerous subdivisions, as we find them where ther have been studied so minutely east of the Mississippi. The evidence, how. ever; $s 0$ far as I have been able to procure it as yet, is against any well. defined lines of denarkation; that the fossils which bave been employed by paleontologists at the East to characterize certain beds pass from one to the other in these western groups, so that no well defined line can be drawn in most cases.

As far back as 1857, while the writer was connected with the exploring expedition of Lientenant. Warren, United States Topographical Engineers, he obtained, from a series of reddish calcareons sandstones, a group of fossils, which Mr. Meek at once identified as belonging to the horizon of the Potsdam sandstone of New York. The key having been nnce secured to the age, it was not difficult to extend the area of this group farther west and north and south on a geological map, and one was pre. pared by me and published in connection with my report for 1869 , which indicated the existence of this division all along the margins of the eastern Rocky Mountain ranges. But it was not known uutil the present season that still higher members of this gromp existed in the far West. While the Snake River division was passing up the Malade Valley, Professor Bradley discovered masses of limestone flled with fragments of trilobites that indicated the existence of the Quebec group. The proof once made known from some favored locality, it was not difficult to extend the geographical area over the greater part, or perhaps all the area, of the Northwest. At any rate, the party nnder my direction found this group well developed over the greater portion of Montana. Along the Gallatin River, near the Three Forks, and below, the Silnrian beds reach an aggregate thickness of 1,600 to 2,000 feet, and most probably include the entire Potsdam group. Future explorations in localities where the conditions are favorable, may reveal the existence of other subdivisions of the Silurian, Devonian, or Carboniferous. The discovery of the well-known Silurian coral, Halysites catenipora, in the summer of 1871 , near the sources of Ogden Creek, points to the existence of the Niagara group.

In the spring of 1859, a large expedition was organized under the War Department for the purpose of exploring the sources of the Mis sonri and Yellowstone Rivers, and placed under the direction of Captain William F. Raynolds, Topographieal Engineers. To this expedition the writer was attached as geologist. The party started across the country from Fort Pierre, on the Missouri River, in the spring of 1859, passed along the north side of the Black Hills to the valley of the Yel. lowstone, and then up that valley to the month of the Big Horu Rirer, and then $\mathrm{np}$ the valley of the Big Horn to the Big Horn Mountains sonthward to Deer Creek, a tributary of the North Platte about one hundred miles above Fort Laramie, where they spent the winter. In the spring, the party passed up the North Platte, by way of-the Red Buttes, to the valley of Wind River, ascended that stream to its source, and crossed the Wind River Mountains over Union Pass into the valley of Snake River, crossed that stream near Jackson's Hole, passed up the valley northward across the sources of the little streams running into Henry's Fork on the east side, and entered the valley of the Madison through Low or Raynolds's Pass. Captain Raynolds's report, accompauied by an excellent map, was pnblished by Congress in 1868, and the report of the geologist, accompanied by a geological map in colors, was published in 1869. As these reports are now out of print, I take the liberty of making such extracts as will be of interest in this connection. The portion recording my observations of the geology about the Wind River Mountains, Snake River Valley, Tetons, \&c., is comprised in the 
following extracts from Chapter $\mathrm{X}$, commencing at the bottom of page 85. I have quoted the chapter without corrections, that it may be compared with the mora careful observations which were made by the party the past season. Only one prominent error occurs, and that is the statement that the central portion of the Teton Range is composed of erupted rocks, whereas Professor Bradley has shown that they are formed mostly of gneissic strata, penetrated here and there by dikes.

"June 1.-On the wesc slope of the Wind River Mountains we met with a thick deposit of drift material, which, as we descended to Gros Ventres Fork, soon expanded into a great thickness of recent strata, evidently quite recent Tertiary. The banks of the Gros Ventres Fork present high bluffs, some 300 to 600 feet high, but I shuuld think that this formation had been deposited after the surface of the country had attained, for the most part, its present configuration. The strata consist of loose fine arenaceous clays, the layers containing more or less arenaceous matter,
which does not effervesce, and layers of harder rock, a fine-grained and coarse sandstone, and sometimes an aggregation of grains of quart: with ferruginous matter and particles of mica. The materials are all evidently derived from the vicinity. Some of the masses of rock present a compact fine siliceous structure and effervesce feebly.

"June 4-To-day the Tertiary strata begin to assume a good deal of importance. We have the brick-like materials which result from the burning out of the lignite beds. There were also masses of indurated clay, covered with vegetable remains and impure lignite beds; indeed, all the indications which the lignite Tertiary beds present on the east side of the mountains. The beds are also much disturbed, inclining at varions angles. The following section of the lignite beds was taken various angle here, which will serve to show their resemblance to those on the eastern side of the mountains :

9. A yellow fine-grained sandstone and a dark gray limestone, with a parting of clay. The limestone is quite brittle, breaking into thin lamine, and contrins impressions of dicotyledonous leaves and a distinct species of $U$ nio. 15 feet ; inclination, $28^{\circ}$.

8. Light yellow sandy marl. 15 feet.

7. Impure iignite. 4 feet.

6. A series of marly clays which, when saturated with water, forms a thick paste, variegated in color. Near the summit, just below the lignite, is a thin seam, four to six inches, of hard-shell limestone, with the $\varepsilon$ hells in the most comminuted condition. I recognized Unios, Viriparas, \&c., sufficient to show that the deposit is fresh water. 150 feet.

5. Alternate dark gray and brown-yellow gray, fine sandy and clay layers, with some calcareous matter and a few seams of incoherent sandstone, sometimes assuming a concretionary character. 200 sands

4. Impure lignite and clay. 8 inches.

3. Yellowish.gray clay. 4 feet.

2. Impnre lignite. 6 inches.

1. Yellowish clay, with some calcareous matter.

The general inclination of all these beds was abont $20^{\circ}$.

June 5.-We ascended a high ridge, from which we conld see to a great distance. Looking to the dividing crest of Wind River Mountains, we find the exposed belt of granite to be not more than four or five miles in width, and gradually lost in the basaltic or eruptive range, which also renders itself conspicnons. The Tertiary beds seem to reuch fully np to the crest on the west side, and often passing what appears to be the junction of the Big Horn Range, even to the entire divide of the mountains. We also see, high up on the flanks of the monntains, a foll series of the more recent Tertiary beds, with pinkish bands, precisely similar to those in the Wind River Valley. These pass up into yellow sandy marls and sandstones. I have estimated the entire thickness of the Tertiary beds on the west side of the mountains at 1,200 to 1,500 feet. In the lignite beds and vicinity are great quantities of selenite and silicified wood. All over the highest hills near the erest of the mountains, 10,000 feet above the sea, are the recent Tertiary beds. A large portion of the superficial Tertiary strata incline from Wahsateh and Green River Mountains, showing that these deposits were probably disturbed at the same time by the uplift of these ranges. In the dis. tance are the Three Tétons, rugged peaks of erupted rocks, towering high above the rest. These peaks are sharply pointed, piercing the clouds like needles, and it is said that the trappers have never been able to get near them. So far as we have yet seen, at least fifty miles of the dividing crest of the mountains are covered with Tertiary roeks.

'June 7.-We passed up a ravine to-day, which runsnorth and sonth, and is close to the divide which overlooks Snake River. The lignite strata incline nearly northeast at an angle of $10^{\circ}$, and as we ascend, many of the lower members of the lignite strata are exposed. We also see quite large areas covered with eruptive rocks, and also a sort of basaltic conglomerate composed of large augular masses of rock cemented with the melted material. Mr. Bridger informed me that these same formations continne all along the Wahsatch Mountains to Bear Spring and Henry's Fork, and down Snake River neary to Blackfoot Creek. It also covers the valley of the Yellowstone to points below the lake. There is simply a band of granite along the diride in the form of a garrow belt.

- Descending the Gros Ventres to its junction with the Bnake River, we find the sume Tertiary beds prevailing to a great extent, and sometimes assuming a variety of lithological characters, at one locality a thickness of 200 feet of worn pebbles and sand, the whole inclining from 200 to $35^{\circ}$. Gradually the Cretaceous rocks appear along the valley of the stream. A section of these rocks would be as follows :

3. A series of sandstone, arenaceous limestone, and laminated marls. 150 feet; inclination, $20^{\circ}$.

2. A series of thin indurated beds of clay, sandy marl, limestone and sandstone, with six or eight seams of impure lignite, which has ignited in several places, giving to the earth in contact a brick-red color. 80 feet.

1. Gray ash-colored sandy laminated marls, with layers of fine sand. stone. Sandy matter predominates. 100 feet.

"In the upper beds were quite abnndant fossils, consisting of a buge Inoceramus, two species of Ostrea, a large Pinna four inches long, a Cardium, and many small shells. The whole deposit indicates shoal water in a shore-deposit, and there are also fragments of wood. As we descend, the Jurassic is exposed with Ostrea and Belemniter densus, and there is an enormous development of the red arenaceous beds, making a thickness of 1,000 to 1,200 feet or more. Near the middle of the red bed is a layer of gypsum 4 feet in thickness. Thore are other seams or layers of gypsum, each with partings of the red marl. The dip is quite variable, at one place $29{ }^{\circ}$, at another $15^{\circ}$, and again $7 \circ$.

"The Cretaceous beds differ from those on the east side of the Wind 
River Mountains, both lithologically and paleontologieally, but the Jurassic and red deposits are, so far as could be observed, precisely alike in their character and contents. 1 believe, however, that all these formations at one time extended continuously over the entire divide of the Rocky Mountains.

" $\mathrm{As}$ we descend into Jackson's Hole, we find the Oarboniferons lime. stoues with their usual lithological characters, a very hard brittle yellow rock, with much cherty material, iuclining $12^{\circ}$ to $15^{\circ}$. There is one thick cherty layer, 15 feet thick, dark bluish color, inclining $12{ }^{\circ}$. We find these limestones along the mountains on both sides of Jackson's Hole, but the central portions of the mountain-ridges are composed of eruptive rock.

"Near Snake River, on the right bank, is a rather low range of bills, which presented the appearance at a distance of being composed of stratified rocks. On examination the rocks appear to be a bluisb, very hard eherty limestone, appareutly Carboniferous, 160 to 200 feet thick, passing up into a compact siliceous gray rock with a reddish tiuge. In the limestone are numerons fossils, mollusea, and corals, but too much broken and obscure to determine. On the left side of Snake River I saw limestones charged with fossils, especially corals. These limestones are scattered promiscuonsly along the flanks of the lower hills and ridges, and while in many places they are in part or entirely removed by the erosive action of water, the evidence is elear that they were deposited here with a thickness fully equal, and were possessed of a similar eharacter, to those on the eastern slope of the mountains. The valley of Suake River is broad, fertile, and beautiful, and very few traces of the Tertiary beds are seen, and $\mathbf{I}$ am now inclined to think that we can see, to a very great extent, the configuration of the main portion of the Snake River Basin as it was prior to the Tertiary period; for the Tertiary beds, being of a loose friable material, were easily eroded away, leaving along the banks large areas covered with it.

"June 18.-Crossing over Snake River, we ascend the pass 1,900 feet above the bed of Snake Fork. The mountain-ridge over which we passed could not be less than 1,000 or 1,100 feet higher, so that these mountains are between 9,000 and 10,000 feet above the sea. The highest Téton, was measured with the sextant and made to be about 10,000 feet. All along the margins of the ridges we see a plenty of the blue, cherty Carboniferons, limestone; also, the siliceous rocks which lie above, and a great many granitic masses, and also gray micaceons slates. We have seen much of the Carboniferous rock along our road to-day; also red arenaceous beds, with now and then an erupted ridge. The central portions of the mountains are composed entirely of the eruptive material.

"June 19.-We trareled nearly due north twenty miles, down Pierre's fork into Pierre's Hole, a beantiful valley, surrounded by mountains, abont fifteen miles wide and thirty loug. On our right is the Téton Range, composed entirely of eruptive rocks, with a general inclination west or a little north of west. It wonld seem as though this whole val. ley bad been formed by the drainage accumulating in a fissure of the upheaval, for the mountains all seem to incline in the same direction. The hills are composed in part of a sort of vesicular trachyte, exceed. ingly porous, some of the cavities being an inch in diameter. The broad, level prairie is composed, to a large extent, of well-worn rocks, basalts, obsidians, granites, \&c.

"June 20.-We continued our conrse directly north, and soon began to ascend low ridges, breaking the level of the prairie. These ridges extend
GEOLOGICAL SURVEY OF THE TERRITORIES.

down from the monntains on each side, and seem to give sibape to the vallers of the multitude of little streams. We have here and there an exposure of the roeks, which are undoubtedly eruptive, and present the appearance of stratifled deposits. They are arranged in more or less thin layers, some of which sound under the hammer like elink-stone, and are quite compact. Sotnetimes the brealkage-joints, or cleavage, are vertical in a single layer, but from their external appearance I would snppose the bluffs of vertical rocks were a dark-gray marly limestone, charged with fossils. There is also a good deal of uniformity in its composition, the only difference being that some of it is more compract than others. The eruptive material in this valley assumes a variety of form; some of it has a black, opaque crystalline appearance, like obsidian; then a sort of sandstone, easily decomposing, or, as it were, exfoliating; then a sort of lava, or slag; then a vesicnlar trachyte. There are also veins of quartz, sometimes ribbon-like, oue-fourth of an inch wide. The greater part of these rocks, however, wonld seem to have been melted or heated under of these rocks, however, would seem to have been melted or heated under comprise almost the only rocks on the western slope, and therefore it may be called a basalt country. Many of these rocks seem to yield very readily to the decomposing agencies of the atmosphere, and furnish en. tirely the soil of the valley, which is quite black and fertile, sustaining a luxuriant growth of vegetation. The streams that issue from the mountains are very numeross, the water pure as crystal, and the val. leys clothed with rank herbage; but the timber, which fringes the little streams here and there, is very scarce. There are also many beautiful springs and lakes.

"June 20.-We passed up the valley of the Lake Fork and crossed the lividing crest of the mountains to the Madison Fork of the Missouri. High hills of eruptive rock surround us on every side, with now and then small patches of limestone along their sides, inelining at various augles. There are, also, mica schists, talcose slates, and quartzose limestones often underlying the layers of eruptive material, and conforming to them in inclination, which is from $30^{\circ}$ to $60^{\circ}$. Many of the ridges are 2,000 feet or more above us, and are covered with snow. The Low or Raynold's Pass is like a lawn-smooth and covered with grass, with a large superficial deposit composed of the rocks in the vicinity. It is plain that the eroding agency of water has had its effect in smoothing this pass, though it has uot formed it. It is undoubtedly due, to a great extent, to a break in the continuity of the elevatory force. The mountains here do not seem to follow any fixed lines of fracture, or in fixed directions, but to be a series of protrusions, forming, in many instances, a continuous line for a great distance; but the irregularity of the ontline of the crest is due, to a great extent, to the irregularity of the force along the line of continuity, though a small portion may be due to atmospheric agencies. The facts above stated are true from the fact that the different strata of sedimentary rocks, which must, prior to the upheaval of these ridges, have covered the surface, lie in regular order of sequence outward from the ridges. We have every variety of volcanic rocks and metamorphic conditions. Washed out of the Madison cañon and scittered over the terraces along that stream are every variety of granitoid rocks, mica slates, hornblende, \&c. There is every variety of these rocks, depending npon the greater or less predominance of some constituent, and dissem inated through the rock are seams of white quartz. None of the red feldspathic rocks which so prevail in the Black Hills are seen in this region. Along the rivers is a series of terraces which are covered with bowlders, slightly worn, exhibiting the rock-character of the mountains 
from which these streams take their rise. As we descend the Madison we find that the valley seems to pass along a sort of anticlinal axis, and on each side lofty, neariy vertical walls of trachyte, arranged in thick layers. The lower portion appears to yield quite readily to atmospherio agencies, owing to the ferruginous matter contained, which renders it a loosely aggregated mass of erystals of feldspar. As we ascend apward the rocks become more compact, and the upper layers are a cellular trachyte. In some places the upper compaet beds assume a columnar structure, breaking into the form of vertical columns; these break in pieces and cover the sides of the hills with masses of rock. Lower down on the Madison we find layers of the red feldspar, which present the appearance of stratified beds like the Azoic rocks, with an inclina. tion in the same direction with the overlying basaltic rocks. There are numerous seams of white quartz, also trap, running across the country in every direction, many of which indicate the presence of gold-bearing rock. The sumuits, or crests, of the bigh mountains are ragged, not from erosions siuce upheaval, bat owing to the manner of the upheaval. Each peak assumes, to a certain extent, the form of an independent uplift, with layers of roek inclining aronud from every side; and yet it is by a series of these peaks connected together, more or less, that a mountain range is formed. Wherever these peaks or groups of peaks are separated a short distance, a low point is male in the range, which gives passage to streams. Very many of these low passes have no streams issuing from them at this time. The Madison forms a caunon by cutting throngh one of these

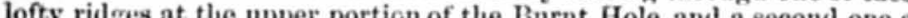
the lower ent of the same villog. the lower end of the same villey. Still below the felaspar beds aud near the junction of the Three Forks of the Missouri we have bedis of exceedingly slaty character, inclining at angles of $31^{\circ}$ and passing down into the granitoid rocks below.

"In the valleys of these streams is a series of marls and marly sands and conglomerates, precisely like the upper beds of the White River Tertiary. These maris are mostly of a tlesh-color, sometitnes assuning the texture of a quartzose sandstone. Its greatest thickness in this region is about 200 feet, and not conforming to the Carboniferous rocks beneath, but inclining in the same direction about $8^{\circ}$.

"The Carboniferous rocks are largely developed in this region, and incliue at very large augles from the monntains. The lower part of these limestones have been so afficted by beat that the stratification has been very nearly obliterated, aud presents a very rough appearance. Above this is a bed which is undoubtedly Carboniferous limestone ehanged, but which now very mueh resembles basalt, but contains more arenaceous matter, and appears to have had the stratification but partially changed. From the Thire Forks these limestones extend westward or southwest ward about twenty to twenty-five miles, and then continued northward toward the gate of the mountains along the Missouri. They also extend to the northwest to a range of mountains, in which is the Blackfoot Pass of Lewis and Clarke.

"July 3.-Visited the plateau, mentioned by Lewis and Clarke, between the mouths of the Gallatin and Madison. It is a long flat ridge of limestone, represinting the portion of the incliued rocks which form the left side of the cañon below.

"The rocks on that side ineline $24^{\circ}$, continuing far on the distant bills. The base of this small ridge is a bluish cberty limestone, sometimes yellowish, very compact or hard, breakizg into fragments just like the Carboniferous limestones before seen. Dip, 330. This bed corresponds with a portion of the right side of the cañon next to the water. There are traces of abundant fossils, as broken crinoidal remains and other mollus: ca. It weathers so as to expose upon its sides small flinty masses of ehert This bed passes up into a light-gray limestone with drusy cavities, ath. breaking into irregular fragments in the winetion cavities, aud form of frature bed is 310 . Obsenre traces of fossils arenifous rocks. The dip of this on up, divided by thin parting layers continu thickness. Then comes artings; otbers aro solid, from 6 to 20 feet in thickness. Then comes a bed without distinct lines of stratification often assuming the form of a sort of conglomerate, with inasses of lime stone on all sides, cemented together with sulphate of lime; There is then a return to the former condition of of lime; dip, 200 It is full of dog.tooth spar and seams of crystalline matter. I should estimate the limestone to be about 500 feet in thickness.

"On the right side of the Gallatin, and dipping eastward from the cañon at an angle of $8^{\circ}$, is a bed of yellow-gray sandstone and marl. It does not quite conform to the Carboniferous limestone, though dippin in the same direction. The Gallatin Fork, from its where it issues from the mountains, is abon for poin a beautiful valley well fringed with cottonwood miles, flowing throngh tonwood. The upper portion of this valley bas trees, mostly bitter cotsmoothed by the uper portion of this valley bas been most beautifully base of the the erosive action of water, leaving a space between the base of the mountain-ridges and the upturned edges of the sedimentary rocks of twenty or thirty miles which is smooth like a lawn. The Car. bouiferous rocks present a series of monoclinals of thinn. The Caring character. Underneath them is a series of of the most interestrepresent the Putsdam sandstone. I have yet seen. In order of descent the most variable series which rock, mostly rock, mostly fine grained, compact, guartzose, siliceous, almost the appearance of a metamorphic rock. It is sometimes made up of an aggregation of grains of quartz. Beneath is a series made up of an dark steel-gray micaceous sandstone, sometimes beries of thin strata of gation of water-worn pebbles passing down into what appears to be ark-brown clay-slate, gradually cal seams of white quartz ruming that the of that the eruptive rocks have been thrust in between the partings of rock, so that we have a bed of eruptive rock, and then a layer of the sandstone, and so on alteruating.

"From the Gallatin we passed up one of the little forks emptying into that river, over Carboniferous rocks, on to the source of Bmith's or mountaius. which empties into the Missouri below the gate of the basaltic or. Reaching the vicinity of the mountains, we find that the Onalic or eruptive rocks prevail to a very large extent over all others. Ou a little branch flowing into Smith's River near its over all others. dark steel-brown bed, 50 feet in thickness, a fine conglomerate at base, but gradually growing coarse nutil toward the summit it is composed of large angular blocks of mixed gray basalt, aggregated with a reddish material. The beds dip northeast $45^{\circ}$. The imbedded masses are or less water-worn. This bed seems to continue s sometimes vertical; sometimes the peons to continue a long distance, and is the littles vertical; sometimes the pebbles are as much worn as those of the little streams; and it seems to me that they have been changed since deposition, for they now partake much of the color and character of the matrix, except that they are much harder. The basaltic rocks along our route are developed to an enormons extent, and present every variety of texture, that which yields readily to atmospheric agencies predom-

"July 6.-Passing along the Smith's River, I saw this series of curions, 
somber, apparently basaltic rocks, which, except for their structure and color, I would regard as Cretaceous or Tertiary. The whole series is arranged in beds of marl, with more or less compact layers of barder noek, which project out the same as in those formations. In there niper beck, I found fragments of wood, and in the upperinost beds were fragments of leaves, which I eannot but regard as of Tertiary age, and that the whole series of beds have been greatly affected by heat so that the lowest beds have been entirely changed. Passing up the mountain we found ourselves in a synelinai basin, with the strata dipping at a low angle, those at the southeast at an angle varying from $30^{\circ}$ to $60^{\circ}$, apparently comprising the different formations from Tertiary to Carboniferons. The rocks do not show so many signs of heat as heretofore. Our conrse has been directly north, and mostly through Carboniferous rocks, dipping about southeast at an angle of $20^{\circ}$. There are, in the cuñon that we passet through, at least 1,000 feet of limestone exposed, and as we leave the cañon northward we flnd 200 to 300 feet of red marly limestones, much like the red deposits we have before met with, only harder. These rocks are peculiar, differing from any before seen. They pass from a red loose slate down into a compact clay-slate, gradually varying from a deep red to black thin slates, becouning more and more compact as we descend, until they appear to be a melted rock, and the joints are so elose that they separate the whole mass into small fraginents. The rock does not effervesce at all with sulphuric acid, but is of a very compact texture. In regard to the age of these beds I can form no exact idea, no fossils having been detected, though frequent sun-cracks are seen upon the surface of the slates."

The following paragraph, describing one of the four passes near Henry's Lake, is taken from the report of Colonel W. F. Raynolds of his explorations in 1860 , page 98 :

"The pass is only four miles from, and 200 feet above, the lake, and so level that it is difficult to locate the exact point at which the waters divide. It is about a mile in width, with the sides sloping gently to the center. The barometer stood at 23.65 inches, indicating a beight of 6.350 feet above the sea-level, or 1,500 feet lower than the summit of the South Pass. The approaches upon either side are remarkable, being of about a uniform ascent of 50 feet to the mile, and thus afforring un. eqtaled facilities for either wagon-road or railroad purposes. I named it Low Pass, and deem it to be one of the most remarkable and important features of the topography of the Rocky Mountains."

This beantiful pass has been so carefully described by Colonel Rey. nolds that I gladly record its name on an official map as Reynolds's Pass; the name Low Pass, given it by Colonel Reyuolds, not being sufficiently distinctive for a geographical name.

\section{CHAPTER II.}

\section{GALLATIN VALLEY-YELLOWSTONE VALLEY.}

In my annual report for 1871 I gave a brief description of the Gallatin Valley ; but inasmuch as one division of the survey took Fort Ellis as its initial point again in 1872 , I shall render the present acconnt more clear by presenting a résumé of the geology of the valley.

In beauty and fortility the valley of the Gallatin surpasses all others in Montana which have come within the limit of our explorations. The town of Bozeman is located near the upper or sonth end, and Fort Ellis lies about three miles to the southeast, under the shadow of the monntain-ranges that form the water-shed between the Missouri and the ain-ranges that form the water-shed between the Missouri and the
Yellowstone. On the east side of the valley is the Gallatin Range of mountains, which gives origin to numerous branches of the Gallatin River on the west side, anil many branehes of Shield's Biver on the east side. On the north side of the valley is a series of broken ranges, which gire origin to numbers of branches of the Dast and West Gilatin, which ow divide extends down between the Gellatinallatin Rivers. The Gallatin and Madison alleys, and entirely disappears before reaching the junction of the Three Forks. This valley is about forty miles in length from north to south, and five to fifteen miles in width. This valley may be regarded as typical of the general character of the surface of Montana, regarded parts of the adjacent Territory which were examined by the survey. Two general divisious might be made of the entire surface, mountain and valley. The valleys and the portions which are open to settlement are, at the present time, occupied to a greater or less extent by thriving farmers, with here and there prosperous villages. They are for the most part old lake-basins, geologically of comparatively modern datc. Along nearly all the more important rivers, from their sources to their entrance upon the plains, there is a chain of these valleys, varying in length from a mile to fifty or sixty miles, aud connected by a cleft. or gorge in the monntains, throngh which the river has worn its way. In all these valleys there is a greater or less thickness of deposits, very similar in character, of a light-gray or cream color, and composed mostly of elay, lime, and silies in varions proportions. Very few fossils have been fonnd in sica posits about the sources of the great rivers, but it is most probable that the deposits are of the same age in Western Idaho, Oregon, and Califor. nia which have yielded large quantities of vertebrate remains. In the summer of 1871 I discovered in these lake beds species of Anchitherium in the bead of the Jefferson Fork, and with it were associated fresh-water and land shells. But these berls yield the most beantifnl forms of silici. fied wood that are found in any part of the continent. It is som called opalized wood, and it wgs donbtess continent. It is sometimes springs. It is most probable that during the Pliocene period hot springs. It is most probable that during the Pliocene period hot springs prevailed to a greater or less extent all over the western portion of our continent, and their action may serve to accont for many problems which now seem obscure. This deposit varies from a few feet in thiek. ness to 1,000 or 1,500 feet, and is usually nearly horizontal thick. unconformably upon the older rocks. Not infrequently these $5^{\circ}$, indicating slight changes in the general level of the beds incline their deposition slight changes in the general level of the surface since Then wosition.

Then we have a vast thickness of what may be called coal-strata in the West, the age of which seems obscure. They contain the great and valuable deposits of coal in the West, and are thus of the nreat and portance in an economical point of view. This thus of the utmost im. from 1,000 to 5,000 feet, and in thickness of 10,000 feet. conclnsion that 1000 feet. The evidence at the present time points to the conclusion that the lower portions of this group are Uretaceons, passing up by gradual transition into the Tertiary, and that the greater portion may be regarded as of the age of the later period. Then follow in descending order the Cretaceons, Jurassic, Carboniferons, and fow in de ness of Subearbouiferous strata, most probably of Silurian age. The Silurian beds usually repose unconformably on metamorphic strata, com. 
posed of gneissic or granitoid rocks of every possible texture. These constitute the nueleus of nearly all the principal mountain-ranges.

From the above brief outline it will be meen that two divisions of the geological seale, Triassic and Devonian, are not represented in Montana, 80 far as we have the evidence up to the present time. We may state, however, in this connection, that we do not deny the existence of these formations in this portion of the West, only that the rocks have yielded us no such information as yet. When we reflect that, in countries where the geological formations have been studied for nearly a century by the ablest minds under the most favorable circumstances, they are yielding up new and startling facts every year, we cannot hope in a preliminary survey of so vast an aren to exhaust the discoveries.

In the great area which comprises what we term the Rocky Mountain region, the groups of strata mentioned above appear and disappear in a strange manner at times, thus rendering their study more difficult and laborious than one might suppose at first sight.

Sometimes the Carboniferous limestones, with their characteristic fossils, appear to rest on the gneissic beds below; then again there wil be 1,500 to 2,000 feet of Silurian strata intervening. At one locality a certain group of metamorphic beds will oceur, and at another, a series quite distinct in texture. In one locality the red beds will be well developed, reminding one of the possible existence of the Triassie; in another locality, not far distant, no trace of these can be found. The same may be said of all the grotps of strata. One peculiarity of the coal-strata consists in their dark somber color, which $I$ have observed nowhere else except in this region.

In order that all the details of the local geology may be more clearly set forth, I have continued the same plan in this report which was adopted in the previous ones, of describing the geological features of the country as observed along the routes traveled.

The party nuder my direction left Fort Ellis for the Yellowstone Valley July 20. Much scientific work had been done previous to that time, but during the present season the deep snows on the mountain-ranges wonld have prevented successful exploration in Montana before the 10th of July. The previons winter had been one of the severest ever known in the Territory, and the snow remained until late in the summer. Dur ing the melting of these winter-snows the streams are 80 high that traveling becomes very difficult. The season of exploration is comparatively short.

Our entire ontfit having been completed at Bozeman and Fort Ellis, we passed up the grassy valley of Spring Creek, by way of Bozeman Pros, to the summit of the divide. Just opposite Fort Ellis, on the east side of the creek, is a ridge of gray and grayish-white marly sands and sandstones, with nearly horizontal strata jutting up against the older rocks. This ridge presents a fine example of the lake-deposits which are 80 common in the valleys all over the West. It has evidently es. caped the erosion which has swept away the greater portion of these deposits, and this ridge may now be regarded as a remnant-a monament left to indicate the approximate thickness of the original beds. The greatest thickness of these beds in this valley was probably about 1,500 feet. The summit of this ridge is 800 feet above the valley, ${ }^{\prime}$ and its greatest thickness could not have been less tban 1.000 feet. The evidence is clear that all these valleys were once filled with water, so that only the summits of the loftier portions were exposed; that prob. ably, during what geologists term the Quarternury period, these waters gradually subsided, sweeping downward, to the lowlands near the main
Missouri and the Mississippi, the greater yortion of these deposits to form the great Yellow Marl or Loess group. That the origin of these deposits dates back to the Pliocene period at least, we believe from the evidence given by the organic remains; and there is other evidence that points to the conclusion that these lakes continued up neariy or quite to our present period. The surface is nsually corered to a greater or less extent with the nsual drift deposit of the conntry, and mot unfre quently the groups of rounded bowlders are so arranged as to indicate that no iniportant changes have taken place since the that no important changes have taken place since the waters subsided. In the Yellowstone Valley, about two miles above Boteler's ranch, the river has exposed a section of the Pliocene beds, (Fig. 1,) which reveals Fig. 1 .

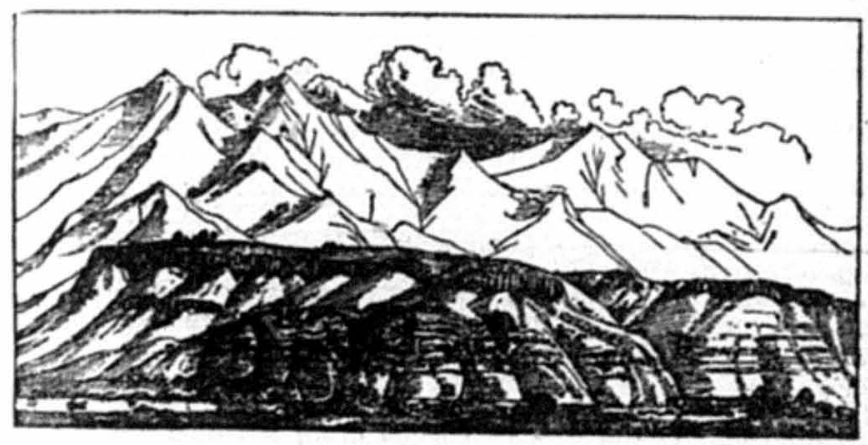

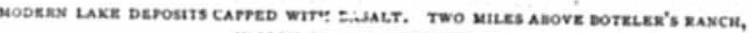

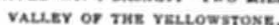

about 200 feet of light-gray marly sands and sandstone, passing up into about 100 feet of pebbly drift, the whole capped with a bed of basalt that must bave overflowed since the lakes existed in full force. A little distance back of the river, extending to the base of the moantains, there is evidence in the superticial deposits that this lake continned a long time after the overflow of the igueous matter.

I shall pass rapidly over the geology of the region about the source of the Gallatin, referring the reader to the excellent report of Dr. Peale, who made a minute examination of Spring Cañon, Mystic Lake, and the district about. Alount Blackmore.

In general terms, the Gallatin Range is composed of gneissic and guartz. itic beds as a base, with a great thickness, 1,700 to 1,800 ieet, of Lower Silurian strata resting unconformably upon them. Above these, and apparently conforming, is a thiciness of 1,000 to 2,000 feet of well. marked Carbo aiferous rocks, mostiy limestones, more or less pure; then running eastward from the Gallatin Valley and inclining at varions angles in the same general directioa are the Jurassic, Cretaceous and Coal groups, with an aggregate thic'suess of 10,000 to 15,000 feet. This entire group of strata, which compose the Gallatin Range and its foot hills, extends nearly to Shields's River, a distance of twenty miles in straight line. The Carboniferons limestones, which are very hard an yield less readily to atmospheric infuences. form, with their upturned edges, the very summit of the Gallatin Range, including Bridger's Peak, Union Peak, \&s. On the west side of the Gallatin Range the foot-hillsare 
very abrupt, rising at once to a height of 800 to 1,200 feet, while the peaks and the sharp ridges are 2,000 to 2,500 feet above the valley below. On the east side the hills, composed of the more modern groups, descend gradually to the immediate valley of Shields's Biver.

We thus see that this range constitutes the east portion of an anti. clinal, and, so far as we know, a huge monoclinal. We may hereafter discover fragments of the west portion. So far as the line of uplift is concerned, the Gallatia continued southeastward, crossing the Yellow. stone River, forming what we have located on the map as the Lower Cañon. The mountains about the sources of the branches of the East Gallatin, and those between the East and West Gallatin Rivers, are largely composed of the limestones thrown up in great confusion apparently, but really all having an in lination in the same general direction. In my report of last sear, I statel that there seemed to be a true anti. clinal extending over to the Yellowstone, ind that Trail Creek might flow in the valley between the two portions, but the more careful explorations of the past season have shown that all the uplifts belong to one side of the anticlinal, however chaotic the strata may appear. This great monoclinal is very remarkable. It commences down below the Three Forks, with a is very remarkable. It commences down below the Three Forks, with a the beds are inverted, and the whole series exposed down to the granitic, then again all are concealed except the coal strata. From Bridger Cañon to Spring Cañon, a distance of four miles, there is a complete break in the range, forming several passes, which are easily traversed with wagoa. roads, in which no rocks older than the Coal group are seeu. Then in Spring Cañon the older rocks are again brought to the surface in full force.

The investigations of the present season have shown that what appeared to be fragments of the western portion of an anticlinal are only frag. ments of the one great mass which have been broken of in the nplift and now lie scattered around in the valleys, on the foot-hills and monntain sides, in apparent confusion. $\Delta$ s I have before remarked, the main range of sedimentary beds continues east by south, forming the high divide between the waters of the Gallatin on one side and those of Shields's River and the Yellowstone on the other, but crosses the Yellow. stone, forming the Lower Cañon, and inclining from the east side of the great range of monntains in which the Bowlder, Rosebud, and che grest with their numerens branehes, take their rise. In the termediate space, sometimes low down in the valley of Trail Creek, and sometimes on the mountain-sides, are beds of coal, the strata above and below being rertical or horizontal, as the case may be. This region has been very earefully prospected for coal. The artificial excarations that were made threw great light on the position of those fragments, which seem to have been broken off and fallen down in the general uplift. At the present time it is only by most carefully following the chatnels of the streams as they cut down into the sides of the mountains, or by studying the artificial excavatious, that we can gain any of the details of structure. With the exception of the main ridges of upheaval, the strata are mostly concealed by modern superficial deposits, which are covered with a thick growth of grass. Occasionally, also, these frag. ments crop out from buneath the monntains of trachyte, and rolcanic breecia, which are so remarkable in this region. As previously stated, breecia, which are so remarkable in this region. As previousiy stnted,
the limestone seems to have yielded less readily to atmospheric agencies, anu consequently projects high up above the surrounding hills, and forms the leading topo caphical feature. In tracing it across the conntry, we may call it a limestone ridge, as it loses the name of Gallatin
Range east of the source of the Gallatin River, although the ridge continues on eastward, or south by east, to an unknown distance.

The Carboniferous limestoues are always well defined, not only by their texture, but from the fact that they always contain fossils charac teristic of that age in greater or less quantities, In some localities strata of considerable thickness are made up of an aggregate of fossils in a fine state of preservation. The almost universal distribution of these fossi's would point to a uniform moderate depth for the waters of the Old Carboniferous ocean.

The Lower Cañon is about three miles in length, and the Yellowstone has cut its way through the ridge at right angles, so that as complete a section of the strata is shown on eitber side as one could desire. It was this limestone ridge that checked the waters above which formed the lake-basin, extending from the Lower Cañon to the Second Cañon, a distance of abont thirty miles, and it was undoubtedly the slow wearing. out of the channel or caũon through the ridge that gradually drained the lake-basins above. After leaviug the Gallatin Range, the older group of beds, which we have called Lower Silurian, ceases to be as conspicuous. The limestones of this group have a much older look, are more compact and contain a greater per cent. of silica, are full of cavities lined with crystals of quartz, and weather into much more rugged forms. The lower portious, instead of being composed of clays, shales, saudstone, \&c., are quartzites or quartzose sandstones, entirely destitute of any traces of organic forms. They seem gradually to change their character and thin out very much in their eastern extension, so that not more than 100 or 200 feet in thickness rest upon the gueissic rocks in the Yellowstone Range east of the Lower Cañon. In the West Gallatin Caũon the same change in the Silurian group is observed.

Above the cañon the Yellowstone Valley expands out to an average width of ten miles, and was undoubtedly one of the old lake-basins peculiar to the West. From any of the peaks of the Yellowstone Range on the east side, one may obtain a complete view of the eastern valley, and the landscape thus presented to the eye is one of great beanty. The sides of the valley slope like a dish, so that the immediate base may be 800 to 1,200 feet above the bed of the river. These slopes are grassed over, and to tha eye at a distance they appear as smooth as a lawn, gradually descending to the river-bottom. They are, however, oftentimes rery much cut up by the little mountain-streams that wear deep channels through them. These channels afford excellent sections of the -e modern deposits.

On the east side of the Yellowstone River, commencing near the Lower Caũon, is one of the most symmetrical and beautiful ranges of monut. ains in Montaua. In order that I might obtain a more definite knowl. elge of the structure of this range, I ascended one of the highest peaks that overlook the broad plains along the Yellowstone to the northeast. Last year I had supposed, from an examination of Emigrant Peak and its vicinity, that these mountains were mostly of igneous origin, but found, on a more careful examination of the northern portion, that the rocks are principally granitic and of the kind characteristic of the mountain-ranges generally. Our camp was located on the riverbottom about three miles above the Lower Cañon, and the peak which we ascencled is situated a little south of east of the cañon. For a distance of four miles we ascended the grassy slope, covered here and there very thickly with ronnded bowlders, which greatly impeded traveling scattered here and there are isolated hills of limestone, remnants left after the erosion of the valley. The sides of these mountains are every. 
where almost vertical, and difficrlt of ascent, so that we were obliged to follow up the rocky bed of a strean for a long distance. Hugb masses of gneissic granite blocked our was at every step. In some of the cañons gneisoic kinds of rocks along he course of any of these mountain-streams usually gives one a pretty clear idea of the structure of the mountain in which they have their origin. The first ridge, which is about 3,000 feet above the riv er bottom, is composed mostly of the metamorphic quartzites. The second ridge, which is about 500 feet higher, is composed largely of micaschists and granitoid the vegetation is about 9.000 fethists andere the amill oragry spruces lie prosth feet, where the small scragby spruces fie prostrute, nud aro wot more than fonr feet in leugth. Above these no more tree-vegetation is seen. From the summit of this peak, a broad area is compassed in the field of vision. Far east and southeast, along the head-waters of the Stillwater, Big Rosebul, and Rock Creek, the gue:ssic rocks extend, with their sharp ridgelike peaks standing up like piunceles among the perpetnal snows. For tifty miles in every direction there is a chaos of mountain-peaks, rarying in form according to the rock-materials of which they are com. posed. For grand rugged scenery 1 know of no portion of the West that surpasses this range. The little streaus have cut innumerable gurges deep down through the very heart of the mountains, 2,500 to 3,000 feet in depth, and the exceedingly close texture of the granites and ountzites, of which the rocks are mostly composed, has prevented the atmospheric forces from wearing off the angularities, so that they appear as sharp aud angular as if but recently bronght to the surface. The examples of ribbed or banded gueiss are quite remarkable for their perfect. tion and regularity. The juuction of the uuchanged beds with the metamotphic is remarkably well shown in the gorges on the north side of the rauge. The general incliuation of the limestone is abont 300 to of the r. mistone, with 1,200 to 1,500 feet of to 1,500 feet of outcropping strata, may be most clearly seen for a distauce of twenty or thirty miles east and west, forming a remarkable natural section. Extending far to the eastward and opening out into the plains, are the gradually descending ridges of the Jurassic, Creta ceous, and Tertiary beds, presenting an irregular rugged surface depending upon the nature of the rock-inaterials of which they are composed. ing a yon the junetion The Yellowstose kiver really energes into the pin belor the junction of Shields's River, and thence to the junction of the Yellowstone with the Missonri the Cretaceons and Tertiary formations prevail. On either side of the Yellowstone, at a distance, may be seen isolated small ranges of mountains until we pass below the mouth of Tongue River.

It is most interesting as well as instructive to explore with care among the deep gorges which the watery agents have worn lown through these lofty mountain-ranges. The amount of débris or broken rocks which one encounter, excites surprise. Water and frost are ever at work, and have been busy for ages in breaking down the siles of the gorge aud extending it farther back in the rauge. We discover bere the sources of the myriads of perpetnal streams, which we tind in the low lands, and which we see meandering through the plains like the veins in the human body. Each one of these little streams, towarl its source, branches out into numbers of small tributaries like the capillary vessels, and each one of these little capillary streams has eaten out its deep gorge or cañon, which adds to the ruggedness of the mountain-scenery. There is in this Yellowstone Range an unlimitos field for the artist; photographic views of the most startling kind could be obtained with. put nubber. I am convinced that this range of mountains, and the valley at its base, will at no distant period be visited by multitudes of tourists, and afford many a subject for correspondence for the secular press.

Glancing at the map, it will be seen that numerons little streams flow down from the base of the mountains and empty their waters into the Yellowstone. Each one of these streams in the mountains spreads ont into a great number of branches five to twenty miles in length. It is to these littie streams that we are indebted for the inner history of these grand mountains. We may say in general terms that the uncleus of the Yellowstone Range is composed of granitic rocks, and that the greater portion is made up of these, while far to the south and sontleast the summits are covered to a greater oc less extent with rol. canic rocks. The greater portion of Emigrant Peak is made up of volcanic material. There is no doubt that at some prior period the volcanie rocks and breccia or conglomerate extended over a much larger area and with a greater thickness than at the present time. Many of the high, bald, rounded granite mountains bear all over them the marks of territic erosion.

In the report for 1871 , I described somewhat briefly the interesting !ake-basin which now forms the valley of the Yeliowstone be. tween the First and Second Cañons. At the risk of some repetition, I may be permitted to take this as the type of these lake basins, and describe it somewhat in detail, although each one bas some features not common to the rest. ' 't seems to me, however, that they must all have one common origin, whatever that may be. Many of the basins have been formed by erosion, out not altogether so. Although the lakebasin which we are now describing is largely due to the action of the erosive forces, yet I am of the opinion that its outline was marked out in the process of upheaval. On the east side is the remarkable range of wonntains which I have called the Yellowstone, constituting the nuclens or central portion of a distinct anticlinal; while-on the opposite or west side there is a chatic mass of rolcanic peaks and ridges, which bave no necessary connection with the Yellowstone Range. At the lower end of the valley, however, are a number of isolated hills of limestone, with strata incliuing in the same direction with the main ridge, which forms the cañon below, and these can easily be traced across the valley as remnants of what were once high ridges extending directly aeross. Other remnants may be observed fartler up the valley, which seem to couvey a presty clear conception of the immeasity of the erosive action in the past. In noticing this lake-basin as typical of a series or system of lakes in the West, I do not refer to those great lake-basins of the earlier Tertiary period, in which were entombed such vast numbers of animal remains in Wyoming, Nebraska, \&c. Those which I am now describing belong to a type of more molern date, which probably com. menced in the Pliocene period, and extended up very nearly to our pres. ent era.

We shall not go back beyond the time of the existence of this lake-basin and endeavor to indicate the condition of the surface or the climate at that time, but simply remark that we believe that al these valleys were the reservoirs for the accumulatel waters from the drainage of the mountains in the vicinity. When they were full, so as to overflow the barriers which were raised in the uplifting of the mount. ain-ranges, the waters, following the law of gravitation, gradually wore a channel throngh these barriers, as, for example, at the Lower Cañon, where they lave carved out a channel 800 to 1,000 feet deep, directly through the maesive limestone, at right angles to the direction of uplift. 
The process of wearing ont this cbannel for three miles in length throngh snch a thickness of hard limestone must br equired ages, sufficient for the waters of the lake to have deposited 1,000 to 1,500 feet safiein downed, of sediment, and, as the channel was cut down down the river. We have now the evidence that the waters of the lake must hare reached high now the evidence that the waters of the laing, entering far up the open side-valleys, up on the sides of the moutaride or water-shed. The line of demar. in some cases nearly upto the mount. cation between the modern deposits as they jut ap agemselves, is quite ain-sid 28 , and the natural débris of the mountains themselves, is quite distinct, and is even shown by the vegetation. When we reflect that the productiveness, as well as the possible settlement of these monutain. regions, is due to the former existence of these lakes, we shall at once regions, is dheir history will become invested understand thein in valleys that farming.lands with a greater interest. It is only in these valless can be found. The sediments which were accumulated in the bottoms of the lakes were derived from the destruction of a great variety of rocks, so that the mixture is most remarkable for its fertility. The metamorphic and igneous rocks, and the limestones of the Silurian and metamorphic and is all contributed to them. As the lake Carboniferons epoctis has bom were worn out and smoothed as we drained slowly away, the bottoms were worn out and smoothed as we see them now. Here and there we find that these superfil formations have been stripped off, so as to expose remnants of the olit formations which constituted the original skeleton. Patches of limestone are observed here and there, enongh to indicate something in regard to the former bistory of this surfice, or skeleton, as it might be called.

Although this valles was originally largely due to erosion no donbt, Althor or a fissure in which yet it was not altogether for their operations, as was the case with the waters gained a foothold for their operaton, as was tyone, as we many of the valleys. The main feature of the mountain-range, as we see it now on the east side of the Yellowstone River, never crossed to tho west side, but formed the east shore of the lake. That the valley was greatly enlarged by the wearing away of the sides of the mountwas greatly entarget ains by the waters of up 9,000 and 10,000 feet abore west side of the valley the now the sea-level, Unt are mostly volcanic and most probably conceal a vas thickness of sedimentary bels. The igneous rocks seem to bave issued from numerous fissures, and to have spread over the surface to an enormons thickness. But the rocks which prevail over all the rest are those wous thickness. Fut out of fragments, dust, ashes, \&c., which unst which bave bo canic craters into the surand sedimentary beds. rounding waters, and been afrerward deposited The massive basalts or trachytes may be considered the exception, while we find 2,000 to 4,000 feet in thickness, of volcanic breccia or conglomerate, reaching to the very summits of the bighest mountains, conglomerate, reach well-marked horizontal stratification. Materials of and presentiog somber bue, are found. almost every variety Immense tnasces bave fallen cos sides, composed of fraguents of trachyte of every possible texture aa color. Sometimes these fragments are very coarse, several feet in diam. eter, and again they are small, like pudding-stones. Sometimes they are angnlar as if they had not been subject to erosion in water, and again they are much ronnded. The cement is also more or less fine again they are volcanic material, partly, pertaps the materials from the ronnded volcanic fissures, and partly the eroded materials from the rounded rials. The conglonerates prevail, but there will be fond interstratifled seams or local beds of several feet in thickness, of a fine white-rellow or brick-red voleanio dust and ashes, so that when these beds are eroded the surface around presents the appearance of the gronnd abont an old furnace. - I know of no district where there is a better opportunity to study the great varieties of volcanie action in past geological times than in the range of mountains which separates the Gallatin Valley from the Yellowstone. On the west side of the valley, from the Lover Cañon to the Second Cañon, a distance of at least thirty miles, the indications of ancient voleanie action are most remarkable and varied in their character. The erosive forces hsve cut deep eañons into the sides of these mountains, 2,500 to 3,000 feet through the conglomerates, and have worn the portions remaining into the most wonderful architectural forms. Domes, pyramids, pinnacles, palnces, indeed almost any form which one conld conceive, can be seen here. One gorge was called the Palace Cañon on acconnt of the symmetrical palace-like forms which could be seen everywhere. The sides cf these gorges are vertical walls, inaccessible, except in a few localities, to man or beast. One can stand in the bed of a little stream and look up the vertical walls on either side 2,500 or 3,000 feet. Such gorges as these. extending from five to twenty miles oftentimes, are very numemus. Literally hundreds of them may be found in these ranges extending up to the very crest or water-divide, carved out of the solid aass of conglomerate or trachyte. There is certainly no limit to the remarkable scenery which the artist could select in this prolific field.

Cropping out here and there in the bottom of these deep gorges may be seen the older sedimentary strata, as the Carboniferous limestones, and even those of later date, as the Jurassic, Cretaceous, or Tertiary. The general dip of the unchanged strata is about northeast, and in the valley of Trail Creek the sandstones and clays of the Brown.Coal period may he seen passing beneath the huge mountains of volcanic conglomerate. Farther south and west the limestones appear, and the metamorphic rocks are not seen to any extent until we enter the West Gallatin Cañon. We are thus enabled to gain a pretty clear idea of the original shape of this valley, that it was roglly marked ont in the process of upheaval. I will remark bere that I shall attempt to show hereafter that the streams, in coming out of their channels, did not follow any preformed chasms or fissures, but quite the reverse. Most of the cañons were formed by the streams cutting their way direetly through the ridges, at right angles to the axis of uphearal.

As I have previously remarked, the granitic rocks are mostly confined to the main ridge of monntains on the east side of the valley, but in the valleys of the smaller sireams that flow into the Yellowstone from the west side just below the Second Cañon, as Rock Creek and Cañon Oreek, the metamorphic rocks are largely exposed. The Second Cañon is composed of metamorphic rocks entirely. Scattered over the surface of the valley below are many huge bowlders of granite, which could not bave been transported to their present position by any forces now in operation. It is quite evident that all the forces, whaterer they may have been, operated from above down the valley. Upon the foot-hills, and in one instance on the top of the basaltic floor, several hundred feet above the present bed of the river, are buge rounded bowlders, 25 to 50 feet in diameter, which must have been transported either from the canons of those little streams above mentioned or from the Second Cañon, a distance of ten to fifteen miles. 1 know of no power exeept the combined action of water and ice that conld bave bronght about these results. A 
very large portion of the foot-hills and terraces, as well as the immediate bottom of the river, is literally paved with rounded bowlders, 80 mueh so as to render almost worthless, except for grazing, much land which ronld otherwise be excellent for farming. Along the bottoms also are old river beds 50 to 100 fuet above the present bed. These old channels old river-berls so to 100 fet above the prenent bed are covered thickly with the rounded bowiders, and walls of them are piled up on either side. These are results of very modern date. They must represent the latest period of the draining of the lake-basins. We believe that the temperature was much lower than at present; that the surronnding mountains that form the drainage into these lakes were covered with vast masses of snow and ice which, at certain seasons of covered be the year, becane detached and flontertion fnom the sourees of the Yellow. hellow. stone and Missouri down to the plains below, and thus the hnge icebergs, loaded with immense quantities of bowlilers, floated over the valleys, dropping their contents here and there, as we find them at the present time. Most of the bowlders in this valley conld have been moved along by the action of swift torrents of water alone, but not even the strongest by the action of so whe moved great numbers of the huge granitic rocks which we find high up on the foot-hills or terraces, at least ten or fifteen miles from their original position. No forces now in operation, even if we were to suppose that the melting of the spring-snows would raise the river so as to overflow all the lowlands, could have trausported these bowlders. As it is, they cover an area several miles in widh, quite above the reach of the river. waters at their highest stage.

Another point I may allude to here again in this connection, and that is the more modern outflow of basalt which is seen in several localities in the valley. It is probable that the basalt spread all over the valley at one time in the form of a cap, and that it has been swept away in the process of erusion. On the west side, about two miles below Boteler' proces of erencen it that the surface is ghaet. so smoothed by the passage of ice over it that the surface is glazed. There are also numerous small grooves or seratebes. The surface is covered thickly with rounded granite bowlders, but one of them was worthy of special note from its size, which measured 12 feet in height aud ou feet in dinineter. It is perfectly massive, comprosed of a coarse age aggregate of gurts, foldspre with smas a tendency to break into imperfect pentagonal columns. Underneath it are 100 to 200 feet of what I have called Pliocene deposits, bu they are composed vary largely of rounded pebbles and bowlders, witl light-gray marly clay. On the east side of the Yellowstone, abont two miles above the ranch, the river has cut a vertital section through the marly clays and sandstones 100 feet or more, with 50 to 80 feet of loose hift bow drift bowlders and pebbles, the whole cappred with 20 to 30 feet of basalt This outflow of igneous matter was among the latest events. Nearly al the lake-basins have this basaltic cap to a greater or less extent, and th evidence indicates that the outflow was synchronous. In the Suake River Basin this cap covers an area of fifty to eighty miles in width and several hundred miles in length, and quite large streams sink beneath it and flow into Snake River. The geological relations of this cap or bed of basalt are about the same wherever it occurs, pointing to a commen cause as well as time.

I believe that it occurred before the waters subsided, so that we may trace a portion of its history at least. The lake deposits are certainly of very moderate date, at least as late, and perhaps later, than Pliocene.
Upon this rests a huge bed of drift, which was deposited still later, and then comes the outflow of basalt before the waters subsided, as is shown by the texture of the rocks, as well as the superficial deposits over it; then the waters were drained slowly away, sweeping with them wost of the basalt, with the exception of here and there a remnant, and also most of the deposits beneath, thus giving shape to the valley. All these events must have taken place subsequent to the completion of the general ont. line of the country by the upheaval of the monntains. It is probable, also, that during this period, and probably throughout the greater portion of the Tertiary period, hot springs were very abundant every where, and it is doubtless due to these that the organic remains found in these deposits have been preserved in such a high state of perfection and beauty. The silicified or opalized wood, we believe, indicates the presence of these springs. There are a few warm or moderately hot presence of these springh, There are a
springs in this valley at the present time.

$\Delta s$ an iliustration of the volcanic action in this valles, the reader is referred to Fig. 2, which was sketched by Mr. Holmes, about two miles

Fig. 2 .

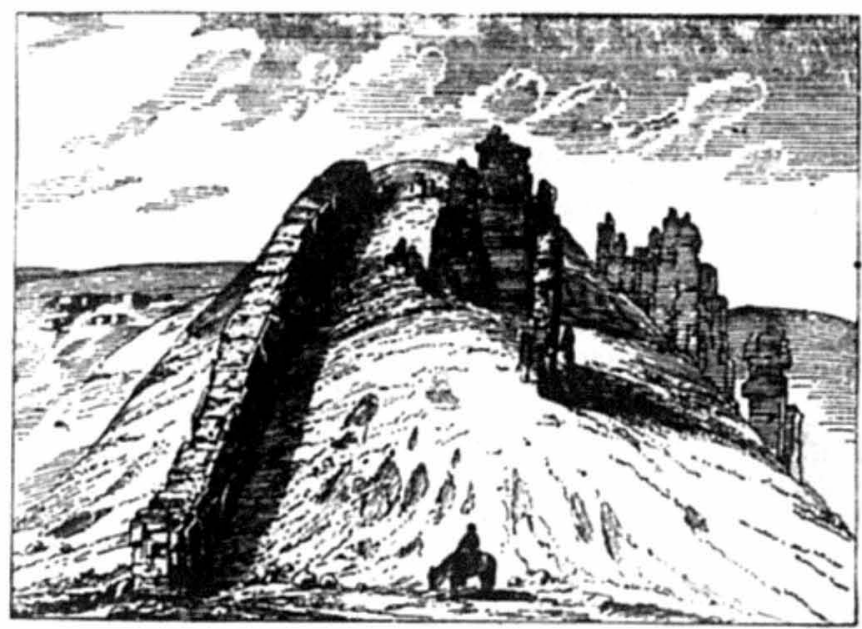

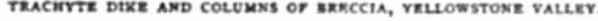

above Boteler's ranch on the west side of the Yellowstone Valley. The long, wall-like mass that extends down from the side of the hill is a dike of trachyte, while on either side are the tufas and breccias, which have been weathered into columns of varied forms. This may also repre. sent one of the numerous fissures or oblong craters from which much of the volcanic material was ejected. Fig. 3 shows quite elearly the stratified character of the tufas aud breccias. This illustration was taken about a mile above Fig. 2, on the same side of the Yellowstone. The entire mass is most curiously variegated in color, from an ashencream color to deep purple. This series of gray volcanic ashes alternates with more or less coarse strats of breccias, the fragments cemented 
with the tufas. In Fig. 3 we see a curious instance of a sort of unconformability, showing, probably, the periods of deposition. The under.

Fig. 3.

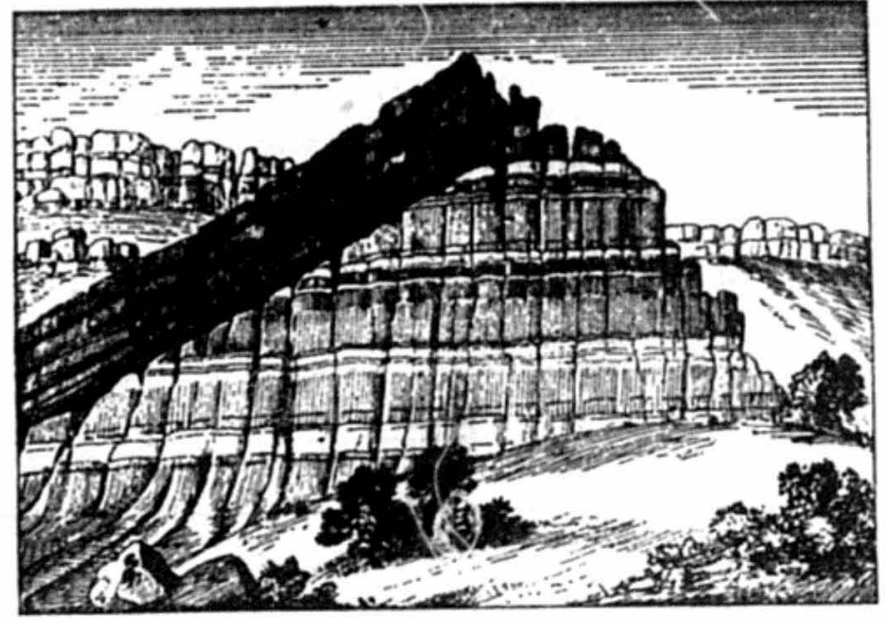

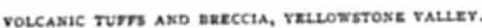

Jying portion had been worn into a conical shape by the waters of the lake prior to the deposition of the slanting mass. In the back-ground there is a lofty range of volcanic breccia or conglomerates, rising 3,000 feet above tbe valley,

We will now take our leave of this beantiful valley and proceed up the river throngh the Second Cañon. We may bastily notice the charthe river the divide between the Yellowstone acter of the rocks on either side. The divide between the Yellowstone and the Gallatin is quite sharp and narrow, the numerous little stream. cutting deep channels down from the crest to the river. The divide itself is formed entirely of the volcan ir conglomerate, weathered into the most singular architectural forms. West of the cañon, at the heai of Cañon and Rock Creeks, this conglomerate is at least 1,000 feet of Cats thick, horizontally stratitien, a These conglomerates extend down the Gothic columns. (See Fig. 4.) These conglonerates extend down the ridges between the little streams for several miles, while the gorges are cleft deepdown to the metamorphic rocks. The cañon itself, on either side, is composed entirely of gneissic strata. Silicified wood is found in these conglomerates in great quantities, and sometiwes huge logs and stumps conglomerates in great quasition in the walls. Near the head of Cañon are exposed in a vertical position wich bust have been at least thirteen Creek, I saw the stump of a tree which mos thas or fourteen feet in diameter originally. It was firmly inclosed in the breccia. The question arises in the mind, Whence originated this vast deposit of breccia or conglomerate, and what were the physical conditions under which the materials were deposited As to their origin, we must conclude that they were thrown out by volcanoes into the surmoting waters mula are ejected from moder rounding waters much as sime We find, however, that these breccias vere of immense thickness, sometimes 4,000 to 5,000 feet, as at the sonrees of the East Fork and In the mountains at the head of the Upper Yellowstone above the lake. Some of the bighest monntains in the Northwest are capped with these volcanic breccias arrauged in horizon. tal strata, and showing most clearly that the agent was water. In tal strata, and showing most clearly that the agent was water. In
almost all cases these stratifled breccias are perfectly horixontal from base to summit, thereby indicating the probability that there has been no important morement of the eartl's crust since their depositiou. We

Fig. 4 .

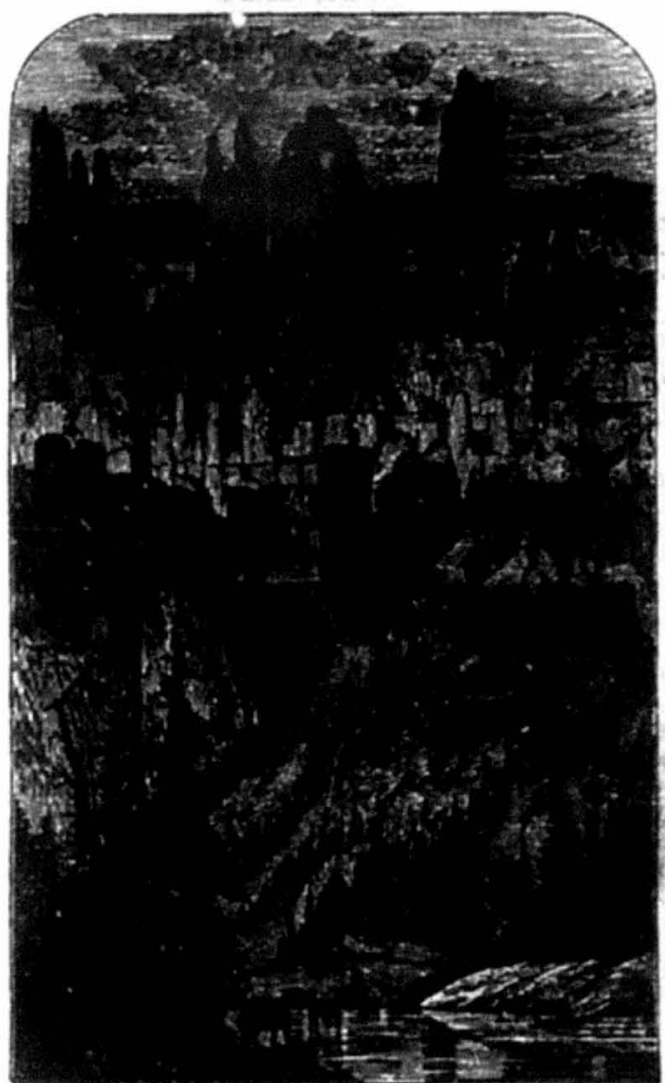

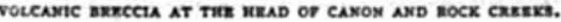

must conclude, then, that at a comparatively modern date the waters so corered these mountain-ranges of the Northwest that not even the sum. mits of the loftiest peaks were above the surface. It is barely possible that we might make an exception in the case of the Grand Tétons. We may suppose that the materials were supplied from the numberless vol. canic fissures in unlimited quantities in a comparatively brief space of time; but the period which would be required for the waters to arrange 
this matter in the remarkably uniform and compact series of atrata which we find at the present time must have been great. The results have been carried on upon such a stupendons scale that the aind finds with difficulty the courage to grapple with them or attempt to explain them. difficulty the courage to grapple with them or attenormous beds of con. And then, subsequent to the deposition of these enortmous beds of conglomerates, has been the wearing-out of cañons and valleys 2,000 to 4,000 feet in depth, the seulpturing of some of the most marrelously grand and unique scenery on the continent. In passing up the valley of the Upper Yellowstone, which is abont three miles wide and has been carved out of this hard breceia, one could easily imagine himself in carved out of this hard breccia, one coulde, were castles and palaces some enchanted
without number.

Without number. We may, therefore, conclude that all the surface-phenomena we tind
bere at the present time are only the insiguificant remuants of the past; that the lakes, streams, hot springs, \&c., are only the dim departing evidences of a series of events which once were performed here on a scale evidences of a series of events conception. The Second Cañon is formed by that almost baffes torty walls of gneisi. the passage of the Yellows Mountain, a vast rounded mass of granite On the east side is Dome Mountain, a vast rounded mass of granite
rising 2,500 feet above the river flowing at its base. On the west side are two or three roundec, naked, granite peaks, 1,500 to 2,000 feet above the river, but less conspicuous. The summits and sides of these above the distinctly the effects of glacial action. granitic the in ass, and glazed as it were, and Thesurfaces lying about loose are great utumbers of ron that stripped of the thick coveriog of volcanic conglomentes lent their traces on the barder rocks below. To the westward the gueissic rocks soon pass out of sight beneath the volcanic conglomerates. I shal attempt to show in a subsequent ehapter of this report that the gneissic rocks of wisthest to an unknown which extenls across the country the main

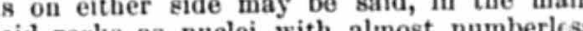
to be composed of granitoid rocks as nuclei, with almost numberiss outflows of igneous matter. Although this statement would indicate that the geological features were remarkably simple, yet the rounded forms which these igneous rocks assume, and the chaotic condition of the surese volcanic movements, renders the surnotion of the structure quite difticult in its details. In the unraveling of the structure quite present a general view of the present report I cannot do more than present a general riew of the of 1871 for more detailed information.

The next point of importance is the Cinnabar Mountain and the socalled Deril's Slide. We were enabled the past season to make a more caliof careful exat the spot by Mr. Holmes is very expressive and accurate. (Fig. J.) Cinnabar Mountain comprises a group of nearly vertical beds, rising at one point 2,000 feet above the Yellowstone. The ridge, or mountain, as it may be called, is about one mile in length, and in this distance are exposed probably 10,000 feet of strata from the metamorphic quartzites to the bard rocky strata stand op on the to the have been wasbed away; the direction of inclination southwest trends about northwest and southeast. The following section is given somewhat is detail. It conmences with the well-marked Cretaceous shaly clays, which are probably Middle or Lower Cretaceous.
1. Dark-brown shaly clay, with thin layers of brown sandstone. With geodes of ealc-spar. The whole gradually passing to a slaty shale. 500 feet.

2. A bed of broken sandstone, fine-grained, frequently ris. ing above the surface. 4 feet.

3. Dark slaty shale. 30 feet.

4. A somber brown quartzose sandstone projecting up on the side of the mountain like a wall. 50 to 80 feet.

5. Dark-brown shale, with three layers of sandstone, 4 to 10 feet thick. Toward thesum. mit of the bill or monntain, which is 700 to 1,200 feet above the base, the sand. stones project up with very rugged, irregular edges. The rosk is very compact, chalky, fracturing easily. 300 feet.

6. A rusty-brown mud-quartzite. Inclination, $75^{\circ}$. 100 feet.

7. Interval of softer brown mud. shale. 500 feet.

8. Browu sandstone, rising ap in a high wall 100 feet. Be. low it are some thin beds of sandstone, one of which, 2 feet thick, is made up of small pebbles, cemented with sand. 30 feet; dip, $80^{\circ}$.

9. Interval of brown, arenaceous, shaly, laminated sandstone.

10. High wall of brown sandstone, with huge, concretious, ir. regular bedding, with fine illustrations of wave-markings. 20 feet.

11. Low intersil of soft material, black shale or slate. 300 feet.

12. High wall of rusty brown quartzite, so hard and brit. tle aud broken by jointage as to appear metamorphic. as to appear meta.
20 feet; dip, 700 .

13. Three or four thin beds of quartzite, ragged edges standing up 5 to 30 feet above the surface, with softer clays intervening. 100 feet.

14. Grassy interval,probably slaty clay. 75 feet.

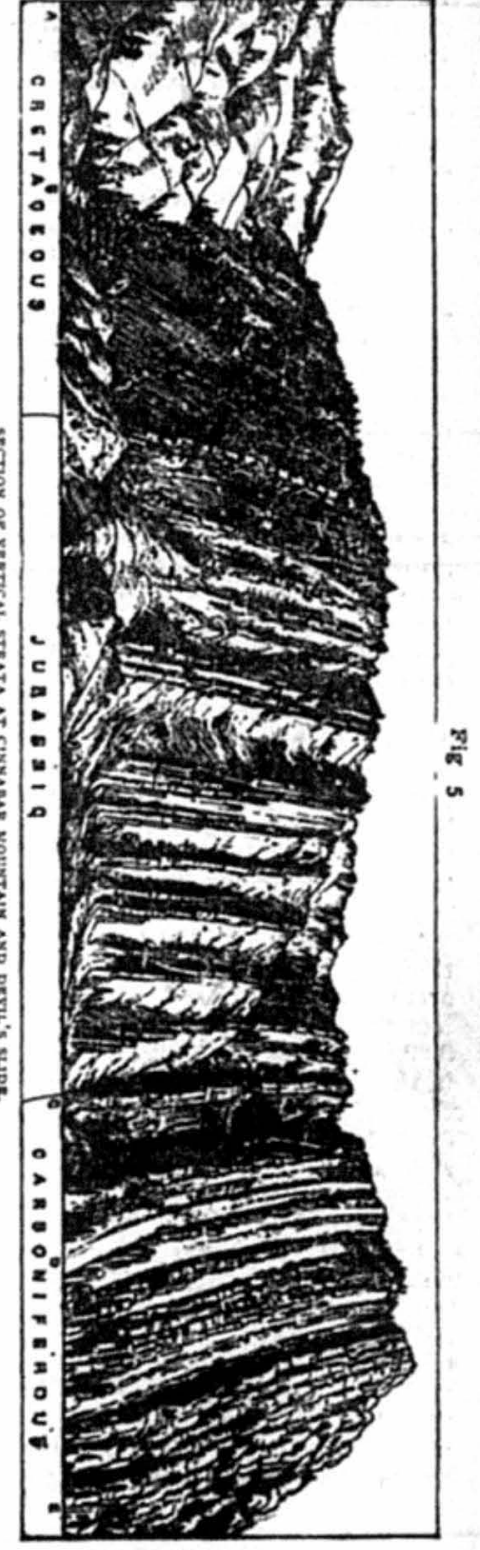


15. High wall of quartzite, rising at one point 150 feet, with intervals of reci banded shale. 100 feet.

16. Three beds of quartzite, with slaty intervals. 200 feet.

17. Blnish.green shale, full of Jurassic fossils, 150 feet.

17. Bluish-green shale, fort wide. Inclines $700^{\circ}$. Shown in Fig. at $c$.

19. Black slate, metamorphosed when it is in contact with the dike-material. 200 feet.

20. A huge wall of trown arenaceous limestone. 80 feet.

21. Yellow and red banded arenaceous clay, giving name to the mount. ain by its bright-red color. 75 feet.

22. Several beds of arenaceons limestone, with partings of elay, very thin; some of it with a reddish tinge; carboniferous fossils. 500 feet.

23. Massive limestone, extending down to the metamorphic quartzites, on which it rests unconformably. 1,500 to 2,000 feet.

The fossils from bed 17 are enumerated in the catalogue by Mr. Meek. The lower portion of the limestoue of bed No. 23 is.full of geode cavi. ties, lined with crystals of ealc-spar. The rock is very bard, compact, brittle, easily fracturing into small angular fragments, the whole inass resisting the atmosphere quite successfully. The greater portion of resisting the at this limestone is, most probably, of Caronis though it differs mneh in doubt that the lowest part is Lower Silurian, though it differs much in texture and general appearance from the Silurian strata in the Gallatin Valley. The exact line of separation between the Silurian and Carbon iferous is difticult to determine. The partial metamorphosis of the lower limestones has rendered this more obscure. The dike, as shown in the $\mathrm{Fig}$ at $c$, is the most remarkable feature in this section. It may

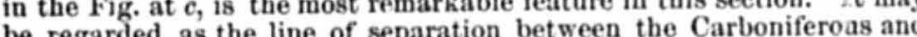
be regarded as the line of separation between the Carboniferoas and Jurassic strata. The dark Carboniferous shales have bees changed into slates on either side of the dike, and portions of the slate are attached to the mass which now rises above the side of the mountain. At the lower part of the mountain the igneous matter seems to have been thrust up between the strata and to have filled the cavities like a mold, but toward the top it has apparently cut across the layers slightly, producing some singular faults.

Continuing eastward beyond the Cretaceous clays as noted in the sec. tion, we find a vast series of arenaceous clays, sandstones, quartzites, arenaceons limestones, with beds of liguitic clay, and good coal 6 or 8 feet thick. I estimated the thickness of this Coal group at 2,000 to 3,000 feet, and this estimate may be too low. There is much confusion in the position of the bels. some of them inclining 450 to $50^{\circ}$ for a.lit. tle distance, and then suddenly becoming almost horizontal, inclining $5^{\circ}$ to $10^{\circ}$. Yet there seemed to be no want of conformity. There is a kind of irregular synclinal here, by which the Coal group bas been crushed together in such a way as to produce chaos, so far as position is concerned.

From the Cinnabar Mountain the beds seem to incline almost south. west, while from the high mountains between the Gallatin and Yel. lowstone the incernal forces seem to have operated in an opposite direction. Thus, within the space of six or eight miles, extending from the summit of Electric Peak to the Yellowstone River, we have the full series of sedimentary rocks from the Silurian to the limits of the Coal strata inclusive, forming a synclinal. The Cretaceous beds, which are noted as the black shales in the section, may be seen high up on the sides of the mountain, dipping about northeast at an angle of
250 , while the limestones form the entire upper portion of a peak which rises to a height of over 10,000 feet above tide-water. It is probable that a portion of this Coal group is of Cretaceons age, but I also believe that the beds pass up into the Tertiary period, as we find them in other portions of the West. Ammonites and baculites and other Cretaceous chells were found below the coal in a fine state of preserration, but no plants or other fossils were found above. On the east side of the Yel. lowstone the more modern beds, probably Tertiary, are largely shown, inclining in such a way as to indieate that the Yellowstone lad made its way, for a few miles here, throngh an anticlinal fissure. Opposite the Hot Springs on Gardiner's River, there is a vertical wall of Crotaceous and Tertiary strata, exposing 1,500 feet or more in thickness. Coal. beds occur here also. All the way to Tower Falls, or the foot of the Grand Cañon, fragments of the sedimentary group occur of greater or less extent. They crop out from under mountains of voleanic conglomerate and basalt. The evidence becomes stronger every year of exploration that the erosive forces have acted on a more stupendous scale than I have ever conceived or expressed in any of my former reports; that the entire series of sedimentary struta, from the lowest Silurian to the high. est Tertiary known in the West, has estended in an unbroken mass all over the Northwest; and we fiud here and there by the exposure of the entire series, as at C.nnabar Mountain, and in many other localities, the most satisfactory proof of the statement which I have so often made. This single statement implies that from 10,000 to 15,000 feet in thickness of unchanged rocks have been removed from this mountain-region, except what might be called remnants left behind, occupying restricted areas. Of course, the older the group the larger the area over which it has es. caped erosion. The hard and compact limestones of the Carboniferons and Silurian ages are found to a greater or less extent all over the North. west. They yield much less readily than the more modern beds, and are consequently found on the summits of some of the highest mountains, 10,000 and 12,000 feet above the sea. Indeed, these isolated patches of all the formations which occur here and there render it necessary to ex. plore the country with much detail, in order to prepare a geological map in colors with any degree of accuracy. These isolated fragments are liable to be met with in the most unexpected places-on the tops of mountaius, or cropping out of the sides of cañons or ravines. Around the sources of Gardiner's River and Tower Creek, the mountains and hills appear to be entirely of voleanic origin at a distance, and many of them are; but underneath the vast volcanic mass, is a series of the grayish-brown beds of the Coal group, so that many of the lower hills from which the volcanic material has been denuded are covered with an indurated calcareous clay, flled with deciduous leaves in an excellent state of preservation. Farther down these streams, toward their junction with the Yollowstone, ontcroppings of the true Cretaceous, Jurassic, and Carboniferous oceur here and there. To what extent these trachytes and volcanic conglomerates covered the surface at one time, it is bardly possible to determine, but there is evidence that they must have ex. tended in an unbroken mass over a very large area.

The question continually arises in the mind, At what time in geologieal history did this period of intense volcanit activity occur 1 Evidences of greater or less igneous action are found in rocks of all ages, from the lowest metamorphic up to the present time, but there seems to have been, as it were, a culmination of the volcanic forces some time during the later Tertiary period. It may be that the accumulated forces, which had
lation been since the Cretaceous era gathering in the interior of the earth, 
and had gradually elevated the western portion of the continent to its and present posing power. I am now leaving tolition inclined to believe that when our western country is more thoroughi explored by competent geologists, it will be found that the area covered with voleanic rocks is far greater than we have hitherto suspected. Like the more modern Tertiary beld, the basalts and conglomerates of voleanic origin have been subjected to terrific erosion, and ouly a portion of their wonderful magnitude is left behind.

So the main portion of the voleanic material of the West has been thrown ont at a comparatively modern date. Amoug the Cretaceous and coal-bearing gronps are irreg. ular interstratified beds of basalt, but the great mass of trachyte, basalt, aud volcanic conglomerates seems to bave been erupted since the surface aud volcanic conglomeration. The conglomerates attained pretty n, 3,000 feet at least, although in some in position. The position of the trachytes, which have overflowed the mountain ranges, indicates that they could not have been very ancient, perhaps not older than later Miocene or early Pliocene, while the true basalts are extremely modern, approaching closely to our present era. In the report of last vear I deseribed the modern basaltic outtlows on The the below the junction of the both siches of the Yeilowe of the granitie monntains, at lifferent eleva East Fork. On the sites of the granitic mountains, at different eleva tions, the black igneous outflows can be seen, looking like hot spring-deposits, were it not for their dark color. The liquid material seems to have oozed out from fissures in the metamorphic rocks in numerous places. These basalts fracture readily into small fragments, and the débris re semble a pile of lull authracite coal. These very modern basalts seen serable a pile of dill anthrate cissures in the Cretacecas and Ter. also to have oozed up through the fisstes rellowetas tiary beds, as shown on the east side of the Yellowstone opposite the mouth of Gardiner's River. Here the outcropping edges of several hun. dred feet of strata are shown for some miles, spotted with the patches of the black débris, from the breaking in pieces of the basalt that had flowed out at different points. We may, therefore, conclude that this periol of intense voleauic activity probably commenced somewhere dur. period of intense volcauic activity probably com reached its greatest ing the later Miocene or early Pliocene epoch, reached its greatest power, and then slowly declined, the bot springs and geysers of the present time being the faint departing remnants of these once terrific forces.

\section{CHAPTER III.}

FROM EAST FORK TO THE MINING DISTRICT ON CLARK'S FORK AND RETURN-YELLOWSTONE VALLEY AND HOT SPRINGS-GEYSER BASINS AND MADISON RIVER.

On the 1st day of August I staited from the forks of the East Fork for the Clark's Fork mines, in company with Mr. William Blackmore, and Mr. Holmes, artist of the surver. The camp was stationed down below the bridge in $\mathrm{a}$ sheltered valley, where the animals would be secure from danger and get a good supply of food. This trip was to take userer new ground that bad been omitted in onr explorations of last year. Our course was up the valley of the middle branch, past Soda
Butte, which was deseribed last year. (Fig. 6.) I will, however, call to mind bere the remark in the preceding chapter in regard to the outcropping of limestones of Carboniferons age in most unexpected places. On the east side of the Enst Fork the granite rocks seem to have pre. vailed. On the summits were some trachytes or conglomerates, but before reaching the forks of the East Fork, the high mountains are com. posed mostly of the conglomerate, while at the very base, the limestones crop out 50 to 100 feet thick. Soda Butte is located about the midd? of the ralley, and is an ex. tinct geyser.
(Fig. 7.) The materials of the mound are mostly caleure. ous, and show clearty these lime. der the valley, and that the waters of the geysersarose to the surface throngh them, dissolvingmore or less lime in the passage up. ward. this valley, soon find we toon find our. selves hemmed by walls of vol. cauic breceia 2,000 to 3,000 fee: in height. The upper portions have been weathered into the most re narkable and aftractive pyra midal and cas tellated forms. Indeed, all

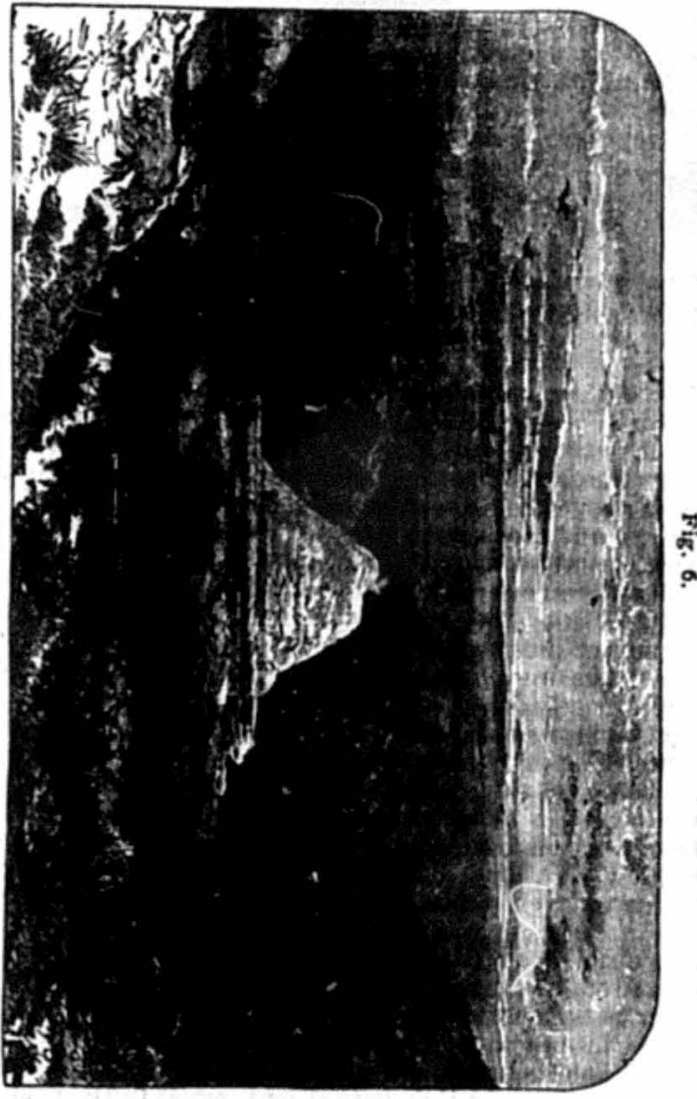
these volcanic conglomerates have a tendency to waste away into very artistic architectural forms. On the east side of the valley there is an irregular terrace-area covered mostly wilh quaking-aspens and pines, formed by land-slides. On this terrace, which is elevated about 250 feet above the river, there are a the snows from the mountain.sides. a mile long, and is full of trout varyine in leng is about one fourth of We might and is full of trout varying in length from 10 to 15 inches. We might here ask the question how these little lakes, so far above the 
main streams, became so stocked with tront. One thing is certain, there is no communication for the fish with the main stream.

Fig. 7 is intended to represent an ideal section of Soda Butte, show.

Fig. 7.

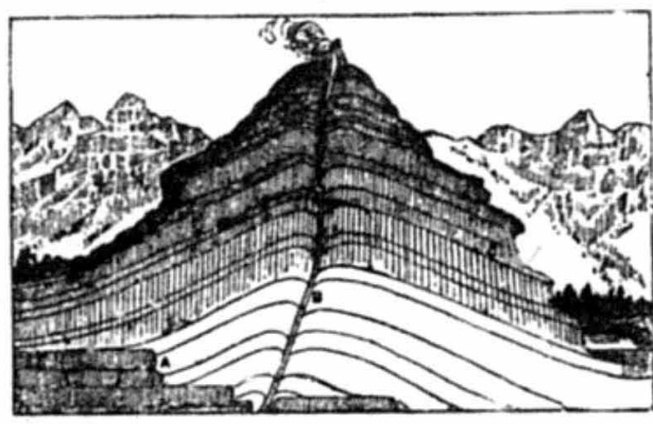

CAMB: LUE:

ing the pipe or orifice and the manner of the deposition of the lasers, or the growth of the mound.

The limestone that cropped out for a lit. tledistance below the forks disappeared again for about ten miles up the middle branch, when it reappeared on both sides of the valles, and continued up to the Clark's Fork di. vide. The snows are quite deep on the

sices of the mountains in the gorges even at this time, and it is probable that they remsin all the rear. The width of the valley will average about that they of and a mile, and is thickly wooded with several kinds erous trees, with here and there groups of the aspen-poplar. About five miles above the forks, fragments of limestone began to appear on the surface, and soon the regular strata commence to rike above the bed of the stream, and about ten miles above, the limestones were exposed in vertieal walls on either side of the cañon from beneath the conglomerates 500 to 1,200 feet. The unper to 1,200 feet. Th amount of denudation prior to the deposition of the conglomerate. The limestones are yellow, brown, and in many localities brick-red. The mass is alternately depressed or elevated; that is, sometimes a very bigh vertical wall is exposed with the strata inclining at various angles, again it is depressed nearly to the bed of the stream. There is one locality near the senree of the Middle Fork, where thelimestones rise up 1,000 to 1,200 , when seem to Ted to deternine, these limestones seem to be of Carboniferons age. Numerons fossils were found, which were all of that age, and I saw no locality where the Silurian limestones appeared to crop out. One curions fact oould be observed here, which shows the vastness of the eroding forces. The rocky walls on eitler side of this cañon are alike, and reveal the fact that the entire valley has been chis carved of the masive rocks mhich must have been far wore extensive carved ont of the massice rocks than we see them at present. From the source of this branch to the entrance into the main valley, a distance of fifteen miles, a mass of rock-materials has been worn out one-fourth of a mile in widtb, almost fifteen miles in length, and of a thickness at least equal to the summits of the highest peaks, some of which are 3,000 feet above the valley below. We cannot now estimate how much of the surface may have been wasted away, but the erisence is elear that no inconsiderable portion bas been remorel. When the limestones are exposed underneath the conglomerates on one side of the cañon, the corresponding strata are seen on the opposite side. The conglomerates are very nearly or quite borizontal, the lower portion adapting itself to the irregular snrface of the limestone like any other sedimentury depoeits. This valley or cañon is only an illustration of many others. I have no doubt that the Carbon- 
one of the main branches of Clark's Fork. This divide or pass was fond to be 8,500 feet. The riew from the monntain-summit was grand in the extreme. Extending far to the south is a chaotic mass of volcanic in the extreme. Extending far to tbe south is a chaotic mass of volcanic
peaks, varying from 9,500 to 11,000 . feet. Pilot and Finger Peaks are located near together, on the divide between the East Fork of iellow. stone and Clark's Fork. (Fig. 8.) One of them derives its name from its shape, like a closed hand with the index-finger extending upward, while the other is visible for so great a distance from every side that it forms an excellent laudmark for the wandering miner, and thus its appropriate name of Pilot Peak. The metamorphic rocks underlie the inestones every where, and in the valley of Clark's Fork they are exposed over quite large areas. At least one bundred small tributaries pour into the river and its main branches from the lofty snowy mountains. Each one seems to rise in a small lake, and as we pass onr eyes along the rounded low low granite numbers of these reservoirs, glistening like gems in the sunlight. On the east side of Clark's Fork is a remarkably rugged granite range, covered with perpetual snows. On the west side, low down in the val. ley, the massive walls of limestone-strata may be seen most distinctly. The beds of limestone do not seem to incline at very great angles, lut to have been elevated to different heights. Sometimes a group oi oirata will be found in the bed of the valley, and then again lifted up in a nearly horizontal position on the mountain-sides 1,000 or 1,500 feet above the bed of the river. Although the scenery is so rugged and grand, yet an air of desolation reigus over the whole. Perpetual snow is seen everywhere, and the somber nakedness of the volcanic peaks adds to the gloom; but toward evening the setting sun envelops them with such a delicate golden haze that one seems wafted into the land of enchantment. The delicious colors are blended with a delicacy and a richness that no artist has yet fixed on canvas. Toward the north and stretching off to the Yellowstone are a great number of sugar-loaf peaks, giving origin to Stillwater, Rock Creek. and Bowlder Creek, with their numereus branches on one side, and Slough Creek, with many other creeks that flow into the Yellowstone or East Fork, on the opposite side. Slough Creek rises in a little lake about 7,300 feet above the sea. This little lake is about three fourths of a mile long and half a mile wide, and so full of trout that they cannot find sufficient food for their subsistence. At any rate, Mr. Blackmore eaught over one hondred trout in a few hours, which areraged from 12 to 15 inches in length. Every Every oni but the unaters are turned in an opposite direction from those flowing into the lake at the source of Slough Creek. Rock Creek those flowing into the lake at the source of Slough Creek. Rock Creek channel deep through the limestones into the metamorphic rocks, and forming some of the most interesting scenery in this region. Nothing could exceed the beauty of the waterfalls on Rock Creek, where the water dashes over the rocks 1,500 feet in a distance of two miles. The photographer conld here find subjects for his art without number. The tops of the mountains on the immediate divide are mostly limestone, and on every side the conical or pyramidal peaks have been cut down so as to expose the metamorphic rocks to a greater or less extent. In the valleys where the massive feldspathic granites are revealed, they have been so worn by glacial action that a smooth surface like enamel has been formed.

We followed down the somewhat difficult valley or cañon of Slough Creek on our return. The distance was about eighteen miles. A num. ber of quite inportant branches, which also have cut deep cañons for ten or twelve miles back to the divide, flow into Slongh Creek on either side. The sides of the valley are everywhere from 2,500 to 3,000 feet in height, and are much more irregular than in the caũon of Middle Fork. In the granites are seams of felilspar and quartz two feet in width. So abundant in some localities are these seams that thes become a notice. able feature.

The valley for the first twelve miles irom its sonrce is from one-fourth to half a mile in width. The upper portion of the valley is volcanic, but seems to have cut down to the granites, so that in the bottom we travel for the most part over huge granite-bowlders.

About twelve miles dowu the stream we came to an open bottom threefourths of a mile wide, covered thickly with sage. This continued about three miles, then the valley closed up again within grauite walls, and the waters of the stream formed a beautiful cascade. Again the valley expauded ont and limestones were revealed on either side in regular strata, from 100 to 300 feet in thickness. Again the valley closed up in a granite cañon, and soon opened out into the valley of East Fork. It is plain that the valley of Slough Creek is purely one of erosion. Throngh the volcanic rocks and the limestones the waters have carved a clean sinooth chamnel, but immense masses of granite have been left in the lower portion of the valley. The surface of the metamorphic or granitoid rocks seems to have been very irregular, and when the limestones have been stripped off by denudation, the valley would be obstrncted by masses 50 to 150 feet high, over which the waters seem to have rolled for ages without making much impression. At any rate, the evidence is clear that the voleanic rocks and the limestones yield far more readily to meteoric agencies than the granites.

We may say, in conclusion, in regard to the rocks of this district. that we fiud a series of limestones probably of Silurian, and containing Notue of Carboniferous age, resting npon an irregular surface of metamorphic gueiss, and upon the irregular surface of these limestones reposes a greater or less thickness of voleanic trachyte und conglomerate. We may julge of the different elevations at which we find the granite where the i 'aks capped with limestone are 1,000 to 1,500 feet higher than the valleys with the rocks holding the kame relations. We thus see that while lepression of some portions of the surface may come in as an element, yet elevation has really been the most prominent direetion of the force.

We left this most interesting region with regret. I do not believe that there is, at the present time, $\boldsymbol{n}$ more novel or interesting portion of our continent for exploration than that abont the sources of the various branches of the Yellowstone, from the Lower Cañon to the mouth of the Big Horn River. The numerous large streams like the Bowlder, Rosebud, Bock Creek, Clark's Fork, Pryor's Fork, \&c., cut deep and most picturesque gorkes down the sides of the monntains until they flow ont into the plaius. We have probably expressed the geology of this region in general terms in the present report, but the amount of interesting detail which must yet be wrought out before the formations can be colored properly on a map inust be very great.

We returned to onr camp below the mouth of East Fork, and the following day pursued our way up the main valley of the Yellowstone. For a detailed description of this valley, its falls, eañons, hot springs, \&c., the reader is referred to the Report of the United. States Geologial Survey for 1871 . The exploration of the present season developed but little that was new in this region. More careful instrumental

$$
4 \text { G s }
$$


observations were made by different members of the party, and some additional facts were obtained by Dr. Peale. These will all appear in subsequent portions of this reprort. We will, therefore, paes by the won. derful basaltic columns, wbich are 80 finely shown in Fig. 9. Tower Falls,

Fig. 9 .

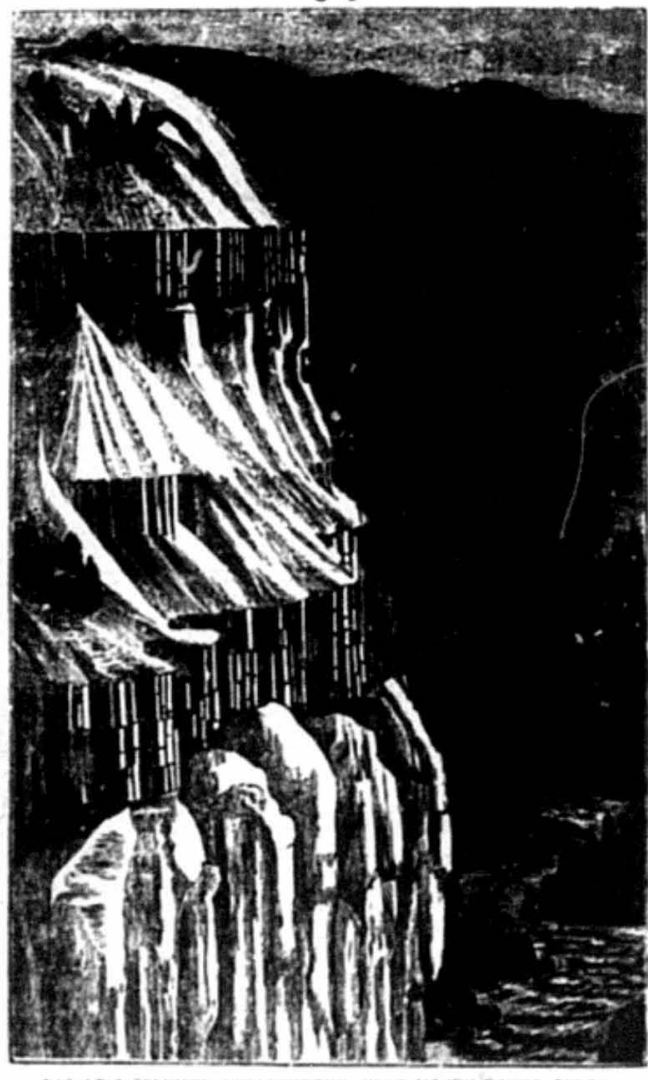

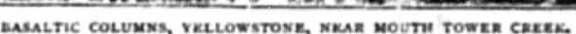
Grand Cañon, Uppe and Lower Falls of the Yellowstone, as well the numerons gronps of bot springs, which are abundant, can only be alluded to in gen eral terms. Some new roups of springs were list, but none that threw any additional light on their history. There are, no doubt, many small groups of spring yet undiscovered. Glowing accouts werning acoount were given to us of a very interesting group at the very source of the West Branch of Gardiuer's River. When the Nationa When the National Park has been rendered more easily ac cessible for iravelero. many curisus discov eries will, no doubt, be made which will in. crease the public in terest in this wonder ful region. The origin of the remarkable lake-basiu, in which the greater part of the the then most interesting in a geological poin: of view. I am convinced that it is notaltogether one of erosion, but in part of elevation. It seems probalble, howerer, that the intense volcanic action, of which we sev everywhere such unmistakable indications, occurred at a very modern geological period, not further back than the Pliocene period, and perhaps even not later than what we usually denominate the Quaternary or Drift. At any rate, it is probable that the waters surrounded aud perhaps covered the hig st mountain.peaks, inasmuch as we not only find drift-bowlders upon most of the loftiest ranges, but the voleanic conglomerates, tuffe, se are arranged in a stratified and, for the ust part, horizont as high as the most elevated peaks in the Yellowstone Basin. On the west side of the lake some of the highest peaks, as Pomeroy, Langford, Stevenson, Doane, and others, are seemingly huge roleanic cones, com

OVERSIZE FOLDOUT(S) FOUND HERE IN THE PRINTED EDITION OF THIS VOLUME ARE FOUND FOLLOWING THE LAST PAGE OF TEXT IN THIS MICROFICAE EDITION.

SEE FOLDOUT NO 
posed of compact trachyte, but surrounded with stratifled hreccia or conglomerate, jutting up against the sides and reaching nearly or quite to the summits. Indeed, some of the highest peaks are apparently made up of the conglomerate. We may conclude, not only that the carving out of the channel of the Grand Cañon was a very modern event, but that the deposition of the entire material which forms the cañon is, in a geological rense, quite a modern occurrence. The drainage of the country commenced long before the excavation of the present water-courses, but it is difficult to answer the question how this great drainage was brought about, unless we aeconnt for it by a general elevation of the entire country, gradually sonding this immeuse body of water, which must have prevailed all over the Northwest at least, perhaps all over the Rocky Mountain region, westward into the Pacifle and eastward into the Atlantic. As the waters slowly subsided they were separated into lakes of greater or less size, and then came the excaration of the Grand Cañon, which slowly drained the great lake-basin above the falls, so that now we have only the comparatively small remnant, the Yellowstone Lake. (Fig. 10.) Other small fragments are seattered about in the vicin. ity, which now form reservoirs for the local drainage. Undonbtedly the same series of remarkable physical events oceurred in Oregon and in California and in Idaho and Washington Territories, and, perhaps, far southward into Mexico, judging from the published reports. The Hot Springs, which are now slowly dying out, are, of conrse, the last of this series of events. The evidence seems clear that all over the West during this great period of voleanic activity the hot springs and perhaps even geysers were very numerons. We everywhere find the remains or deposits in all the States and Territories west of the Mississippi, and now and then a warm or hot spring remains to indicate the story of their former power.

Fig. 11 .

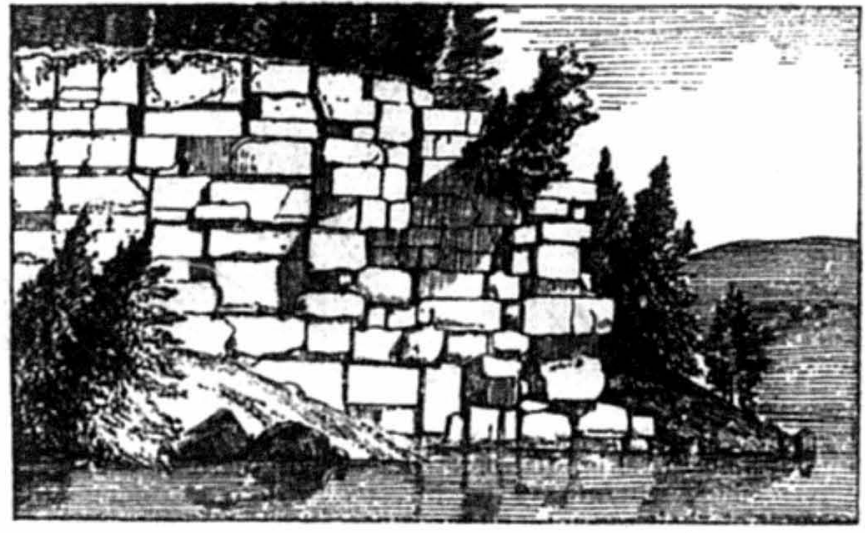

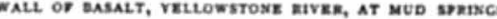

Fig. 11 is intended to illustrate the probable avenues through which the meteoric waters pass down through the rocks to the heated portions. At Mud Springs, aiout six milen below the Yellowstone Lake, there is a vertical wall of basalt, about 50 feet high. This wall is only a remnant 
of a vast mass which extended all along the river, but which has now been dissolved into clay of varied colors by the hot springs. The joints are very regular.

In my report of 1871, page 100, I described the Hot Spring mounds that extended into the lake from the shore, and stated that a person

Fig. 12.

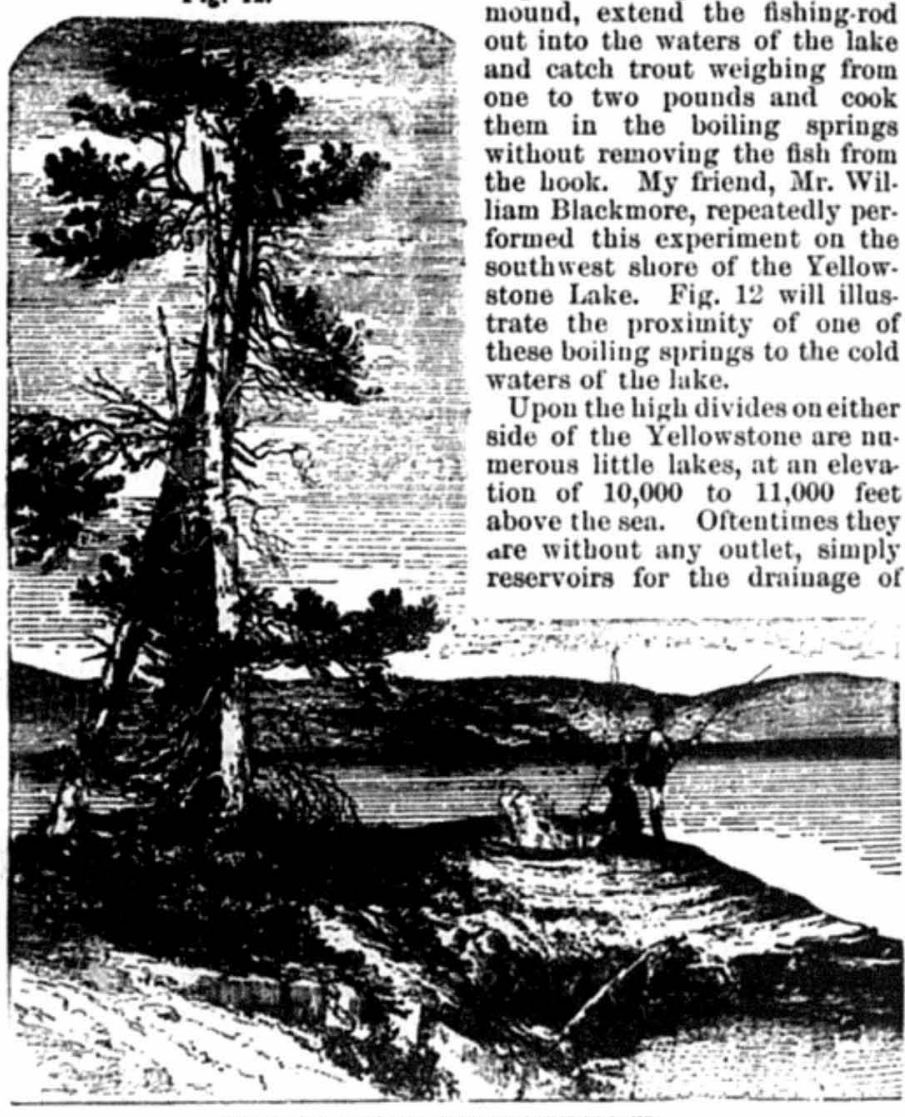

not sranc, soutuwest or vetowstonx LAKE.

the high platean. Fig. 13 represents one of these elevated bodies of water which will always be invested with a charming interest on account of their romantic picturesqueness. Fig. 13 shows our camp at night after the party had made a long, tedious mareh from the Yellowstone Lake on the way to the sonrce of the East Fork. Fig. 14 represents the party on horseback as it left the camp the following morning. The cuts were engraved from photographs taken by Mr. Jackson. The photographs show the whole party reflected in a remarkable manner in the clear waters of the lake.
OVERSIZE FOLDOUT(S) FOUND HERE IN THE PRINTED EDITION OF THIS VOLUME ARE FOUND FOLLOWING THE LAST PAGE OF TEXT IN THIS MICROFICHE EDITION.

SEE FOLDOUT NO 2 


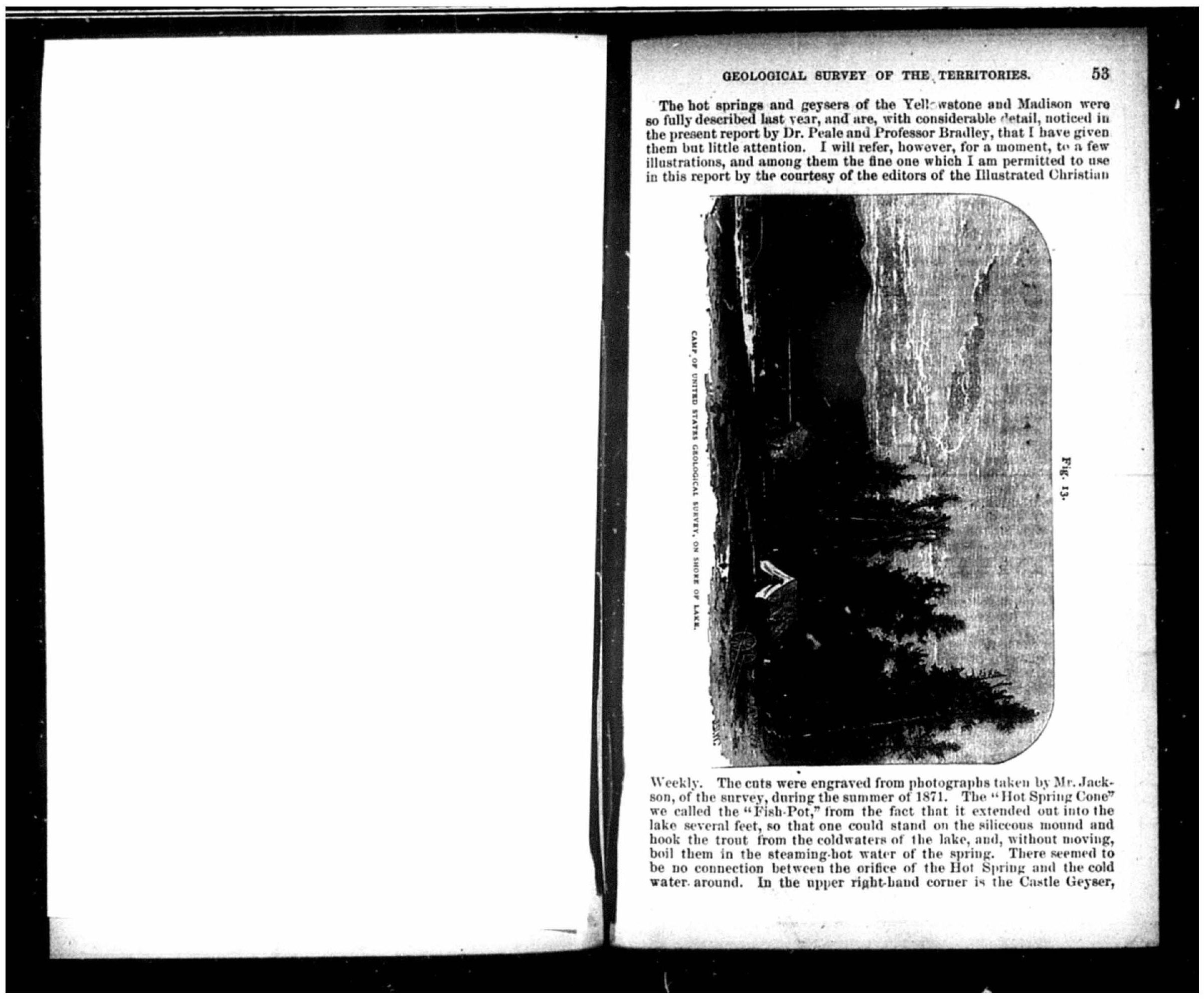


and the most beautiful spring in the Upper Geyser Basin of the Madi. son. The Grotto and Giant Geysers ure first-class sponters, throw. ing a column of water up from 100 to 200 feet and contiuning the oper. ation from one to two hours. The "Boiling Spring," at Sulphur Moun. tain, is located in the valley of the Yellowstone, about ten miles below the lake, at a locality known as the "Seven Hills." It is indicated on the chart in the report of 1871 , page 88 , and described on page 89 . This spring is known as the Sulphur Spring, and the open portion is abont 15 feet in diameter. The orvamentation about this spting is bestifit in the extreme. At the iower right hand corner is a small sketch of the Calcareous Springs on Gardner's River, with the curious terraces and bathing pools which were dezcribed in detail last season.

So far as we could ascertain in onr explorations, all the rocks about the sources of the Yellowstone and the Madison are of volcanic origin. It 's true that in the valleys, the very moderu lake-deposits reach a thickness of several tumdrect feet, tout they aro selchom account as distinet geological formations. Still, they are found every. where in the valleys. The foot-hills that border the Yellowstone Valley between the falls and the lake are entirely made up of them, and mus have an aggregate thickness of 600 to 800 feet at least. Between the Yellowstone Valley and the head-waters of Madison and Suake Bivers, these modern deposits are seen every where, filling up the inerustitis of the surface of the underlying volcanic rocks, and giving a rounded smoothness to the present surface. They form the soil upon which the existing vegetation grows. These deposits are all plaiuly local in their origin; that is, they are derived from the rocks in the immediate vicin ity, or within the limits of the drainage in which the specife beds are fonnd. For example, the modern lake deposits of the Yellowstone Basin v ere all derived, so far as I could observe, from the rocks within the limits of the drainage of the Yellowstone River above the falls. The local origin of the modern drift-deposits seems every where appar ent. The same deposits are found to a less extent in the Gesser Basins of the Madison. On the west side of the Madison, above anil below the junction of East Fork, the bluff bank is 400 to 500 feet high, conposed of trachyte. In the basin are a number of long, low ridges or hills, composed of porphyritic obsidian and trachyte, which, I think, are only the remnants of the great continuons mass out of which the entire valley has been carved. The Twin Buttes are also partially-disconnecterl portions nearer the high trachyte ranges that border the basiu. Mnch of the rock is made up of rounded masses with a radiate structure, as if the igneous rocks were partially crystalline; other masses are con posed of concentrie coats, with cavities filled with feldspar, which, decomposing readily, give to the extensive surface a rough appearance, Frotn the junction of East Fork down six miles, the Madison flows very majestically and most beautifully. The banks are low, and fringed with vegetation of the most vivid green, while visible throngh the water, the patehes of vegetation give a most pleasing variety to the current. The warmth of the water seems to have gives a kind of tropical luxuriance to the vegetation, stimulating to an unnatural growth. There comes a series of rapids of great beauty, with walls on the west side 600 to 800 feet, rising nearly vertically, and composed of layers of trachste. Much of it is made up of rounded masses from the size of a pea to sereral inches in diaweter, either with as semi.crystalline rutiate $s^{t}$ ructnre, or fillet inside with feldspar. The ese or ridges, until a certain elevation is rearbed, when, as far as the eye can reach, nothing can be seen but a dense forest of pines. We

\begin{abstract}
OVERSIZE FOLDOUT(S) FOUND HERE IN THE PRINTED EDITION OF THIS VOLUME ARE FOUND FOLLOWING THE LAST PAGE OF TEXT IN THIS MICROFICHE EDITION.
\end{abstract}

\author{
SEE FOLDOUT NO 3
}


camped the night of Angust 21 in a very romantic place, at the june. tion of Gibbon's Fork with the Madioon. Gibbon's Fork is a beantiful stream that flows into the Madison on the east side, about 100 feet wide, quite unknown on any of our maps. We have named this stream in honor of General John Gibbon, United States Army, who has been in military command of Montana for some years, and has, on many occa. sions, rendered the survey most important services.

About half a mile up Gibbon's Fork on the west side are some very interesting hot springs. They are located near the immediate base of the hills that inclose the valley, elevated about 100 feet above the bed of the stream, and cover severai acres with their peculiar deposit. The raried colors of the jelly-like substance were fine, and other vegetable forms are abundant. Several quite large streams flow away from the springs in winding channels, with beautifully-scalloped edges. One large spring forms a reservoir about 200 feet long, and on an average large spring forms a reservoir about 200 feet long, and on an average
50 feet wide. At one end of this reservoir are two orifices, one quite large in mass, two feet or more, boiling constantly. There it also a small side-orifice. From the sides of the hill several small hot springs flow into the reservoir along most elegantly-ornamented chaunels. If in were not for the greater and more important group of springs ubove, this small group would attract much attention at some future period. The old deposit has now become dry, but it was formed into quite large terraces, somewhat like those made by the calcareous springs, with larger reservoirs or pools, instead of the more delicate ones in the Geyser Basin. In the reservoirs and along the channels of the living springs are most beat tiful masses or locks of vivid green confervoid veretation, floating in the water like locks of wool. There are several other fine springs, but mostly of low temperature, with the inner surface of the basins covered over with a thick, deep, rusty-yellow, leathery snbstance, which gives them the look of a tan vat. The rocks on either side of the Madison are trachyte, but apparently arrauged in vertical layers, so that the river seems to have worn its channel through them. The rocks appear as if they had originally been formed in horizontal layers, but had been tilted up subsequently into a nearly vertical position ; but it is probable that this slaty fracture is due to some procens of cooling. In the cañon where the walls rise on either side to a vertical beight of 800 to 1,400 feet, there is uo evidence of any tilting of the rocks of mod. ern clate. The valley through the caũon is about 300 yards wide, cov ered thickly with suall pines. About five miles town the roñon on the right side, there are rather imperfect basaltic columns. In one instance a most picturesque arch is formed. On the summit of the cañon there is a bed of somber-brown rock that looks like basalt. The lower portions, which we have usually called trachyte, probably cooled under considerable pressure and is older, while the basalt is the result of a second outflow under far less pressure, is less compact and yields readily to meteoric agencies.

After passing throngh the cañon, which is about eight miles in length, we came out into a vast basin with a remarkable system of terraces on both sides of the Jadison. The river is beantiful in its quiet flow. The water is shallow, clear, and at the bottom the bright regetation mas be seen like little green islands. As we come out of the caunon we have the bold basaltic peaks about the sources of Gardiner's River, extending down between the Yellowstone and the Madisou on the routh is the long, low wooled divide between the waters of the Madison and Snake Rivers, very seldom rising above 7,000 or 8,000 feet; on the west side of the basin is the grand range, which extends on both sides of 
the Madison, through which the river has carved the Middle Oañon. The modern deposits in this basin are quite extensive, reaching an aggregate thickness of 400 to 800 feet, but they are co posed mostiy of vol. canie sand and gravel or coarse drift-material, wich worn, with only a small proportion of the light-gray marls, which we find so abundant in the valley of the Three Forks. Vast quantities of ronuded bowlden are seattered over the surfacesall of whicb, 80 far as $I$ could ascertain, are of volcanic origin. This pasin is mostly covered with a thick growth of pines, with here and there open meadow-like spaces or parks.

From this basin we made a short side-trip to Henry's Lake, which forms the source of one of the main branches of Snake Kiver. After traveling several miles across the bottoms through dense pine-woods, traveling several miles across the bottom throug from the west. Crossing $t$... is we have a broad open meadow for several miles until we reach the Tuhgee Pass, which leads over to the valley of Henry's Fork. The scenery was very attractive in every direetion. This branch, which has never yet been laid down on any of our maps, is abont 100 feet wide, and on an average one foot deep, and wind most atmus followed the old The The the ol chief of the Bannacks. This is a low level pass over which a coach and four might travel on a gallop. It is underlaid mostly with limestones, but as we approach Heury's Lake, the quartzite and gneissic rocks appear beneat $b$ the limestones. The lower portion of these unchanged rocks are pebbly arevaceous limestones and sandstones. The pebbles are much worn, and are either quartz or micaceous gneiss, showing that the sediments were derived directiy from the metamorphic rocks.

In this pass there is a group of huge hemlocks that will at once arrest the traveler's attention. They seem to belong to another age. There are teu of them, and several others have perished. They are four to six feet in diameter, and rise to a beight of 100 to 150 feet. This group of trees is the more conspicuons from the fact that they are larger than any others in this region, and have a very ancient appearance.

There is one peculiarity of the tree-vegetation all over this portion of the West, that it has a fresh, young look. The pines are seldom more than two feet in diameter, sending up a straight stem 100 to 150 feet high, and a large aged pine, or tree of any kind, is a landmark as well as a curiosity. We ascended the monntains on the north sicle of Henry's Iake, and from this point obtained a fine view of the country in every direction. The view down Henry's Fork was remarkably fine. The air was clear and pure, and the valley to the junetion with Snake River was spread out like a pieture, while the magnificent range of the Tétons, full fifty miles distant, seemed not half that distance. The metamorphic rocks are best shown on the west side of this range. Henry's Lake was at onr feet, shallow and full of little islands, only a remnant of its former self. To the west there is a beautiful grassy valley, with a small stream that flows into Henry's Lake. This valley leads up to the divide from which the west fork of the Madison takes its rise. South of this val ley there is a belt of metamorphic rocks extending off far to the west rising 800 to 1,200 feet above the lake. On the sonth side, and extend ing to the sonthest toward Red Rock Lake, is another valley, which (two passes is grassed over or thinly-wooded with pines. While the range on the south side of the lake, which extends off in a southwest direction from Henry's Fork Valley, is rery heavily timbered. This is a fine range, and is at this time covered with large patehes of snow. The

OVERSIZE FOLDOUT(S) FOUND HERE IN THE PRINTED EDITION OF THIS VOLUME ARE FOUND FOLLOWING THE LAST PAGE OF TEXT IN THIS MICROFICHE EDITION.

SEE FOLDOUT NO 4 
Af the the second peak 10,500 , and first peak to the east is about 10,000 feet. This will afford some idea of the reneral elevation of these mountains. On the east side the mount. the general elevation of down to the valley, but are covered with a dense ains gradually bend down thward extends the valley of Henry's Forkgrowth of pines. Far couthward extends ther portion, for an extent of a marvel of beanty and freshness. The upper portion, Ior an exteat of twenty to twenty-five miles in length and five to ten miles in breadth, is like a meadow, eovered with a luxuriant growth of grass; while flowing from the lake and winding through the middle of the valley, receiving from the side numerons branches, is Henry's Fork. Still farther southon either side borizon, more ward is a dond miles distant, is the range of monntains that forms than one handred thes Hall. North of one side of the rim of the Buke in whe the southeast the shark-teeth summits of the Grand Tetons are most conspicuous and clearly defined, rising so high above all other monntain peaks that they stand isolated, monarchs of all. To the northeast of the Titons there is a broad extent of table-land, with a general eleva the To 3,000 to 8,500 feet, cosered with a dense growth of pines. This tion of 8,000 to 8,500 feet, covered wicanic rocks, On the east or north. platean is probably covered with volcancilocks which cuts through a range east is the Tahgee Pass, and Bannack Trail, which cuts through a rage of mountains, the highest peaks of which are 9,000 feet, down the east ward slope, to the pine table-lands about the sources of the Madison and Yellowstone. Nearly all the rocks on the sontheast side of the Tahgee Passare voleanic. Yet on the sides of the pass are a few outcroppings of Pass are vol We limestone. We know that different kinds of rocks can only be shown by The area occupied by the different kinds of rocks can only be stime. On colors on the geological map, which will be prepared in due time. On the north side of Henry's Lake is the range of monntains which forms the divide between the Snake and Madison Bivers, and throngh which the Madison cuts its way in forming its Middle Cañon. Henrys Lake is a fine illustration of a remunt, dating back probahly to Plocene times, when all these valleys were filled with water, perhaps connecting the draimage of the Missouri with that of the Columbia, and as the waters subsided, formed the vast chain of lake-basins along all the important streams on both the Atlantic and Pacific slopes, of which our present lakes are only insignificant remnants.

present lakes are on that the lowest strata of nnchangel rocks about Henry's Lake are Silurian, probably of the Potsdam group, but I looked Heury in vain for any traces of organic remais. Fossils. I regarl this as one of the most interesting geographical points in the West. IVithin a circle of most fifteen miles in diameter there are four most important cle or the four points of the compass. The East or Tahgee Pass connects the Yellowpoints of the compass. The East or the Madison, and the Yellowstone, stone National rark, the sources of the Siadison, and feet. The second with the Pacifle coast. It has an elevation of 7,063 feet. The second may be called the North or Raynolds Pass, and leads from the Snake Valley, by way of Henry's Lake, over a smooth, grassy lawn, into the Lower Madison Valley. The third is the Red Rock or West Pass, which opens into the valley of the Jefferson by way of Red Rock Lake, and is as smoth and as easily traveled as the Madison Pass. The South os Henry's Pass completes the circle, and is lower than either of the other three. three. The ease with which ralroad ineredible to one that bas not made them a sulject of study, and the great area of valuable territory which 
may be opened to settlement throngh them may entitle them to the appellation of the Great Gateways of the West.

On the night of August 24 we camped at the upper end of the Middle Cañon of the Madison, and here remained a day or two in the midst of nos: instruetive illustrations of mountain-scenery. The relations of the inmestones to the metamorphie rocks below are most elearly sbown. The strata have been lifted up in mass at various elevations, and the outcropping edges have been smoothly worn off, so that the line of separa tion is unmistakable. There is always a want of conformity. The limestones sometimes cap mountain-peaks that are full 10,000 feet bigh. Terrific chasms have been cut deep down throagh the limestones into the metamorphic rocks in every direction from 1,500 to 2,500 feet deep. The geology is as easily read as in the pages of an open book. The acimirable sketches of Mr. Holmes cannot fail to make the relations of the struta clear to the general reader as well as the professional geologist.

The valley of the Madison above the Middle Cañon is a marvel of picturesque beauty. The descent must be slig'it, for the river, with the branches which come in on either side, meanders through the grassy meadow with the most remarkably sinuous conrse I bave ever seen. The skillful landscape-gurdener could gather some useful hints it his art from this region. The channel appears as though it had been cut ont by the hand of art, and the little islands in the cbannel are of every conceivable form and of great beauty. Although only a portion of this basin comes within the limits of the park, yet this lower portion, with such a marvellously beautiful landscape, will ever remain one of the wonders of this region in a purely esthetic point of view. $A 3$ a study for the artist $I$ have nowhere seen any view of the kind that conld compare visitors at some period in the futnre. In the lower half of the basin there is but little pine-timber, and high up, on both the east and west branches, which enter the Madison near together at this point, the snr face is covered with a luxuriant growth of grass. I estimated that the grass-land in the lower portion of this basin exceeded one hundred and fifty square miles. The slopes from the base of the mountains on either side down to the river are most admirable illustrations of lawus on a grand scale. The bottom ascends to the foot of the monntains with a very gentle slope, and the latter rise abruptly with almost inaccessible sides. The East Fork rises near Mount Gallatia and receives a portion of its waters, and winds its sinuous course through the basin for a dis. tance of twenty to twenty-five miles. This fork seems to drain the entire range west of the sonrces of the Gallatin, about twenty or thirts miles in length, and a stream about 150 feet wide and 1 foot in depth. on an average, is the result. The four branches, which we find entering the Madison below the Lower Ceyser Basin, are very handsome streams and about the same size. For several miles, before reaching the immediate entrance to the Middle Canion, the valley slowly closes up, and on either side some rery interesting facts may be read. On the enst side of the Madison the limestones are remarkably well exmsed, but incline at all angles. I found it difficult to obtain any local dip that would apply over large areas. There is, however, a system in the aggregate, and I think the general inclination is sonth and sonthwest. The lower beds of limestones are very cherty, brittle, and entirely destitute of fossils. My entire party searched diligently for a day or $t$ and no trace of life could be found, but in the upper limestones great quantities of mollusca, corals, \&c., characteristic of the Carboniferous period, were obtained. Thiek beds of limestone were entirely composed of an aggregate of these fougils Most of them were in an excellent state of preaervation. Thros is barely possible that some other divisions of the Silurian occur between the Potsdam group and the Carboniferous, but as set we have no evidence, and until it is discosered we will take it for granted that the Carboniferons limestones and the Silurian beds are in apposition, and that they all rest on the metamorphic rocks. The limestones seem to dip benenth the busin on the south side of the range, and as we to dip the high and at , we pass ridge after ridge of limestone, each inclining at a greater angle, until, on the summit, they are vertical and stand up in lofty massive walls. Thus exposed for ages to the elements, they have been weathered into the greatest variety of columns and other picturesaue forms. Between these ridges are beautiful grassy valleys, 2,000 and 3,000 feet above the river, to which the mountain sheep seem to delight to descend from the rocky pinnacles to graze.

Near the head of the Gallatin there is a very prominent cone-shaped mountain, to which Captain Raynolds gave the name of Mount Gallatin twelve years ago. It is visible from a great distance on either side, prolnibly tor a radius of fifty miles. On each side of this peak, and in close prosimity, are two smaller peaks of nearly the same height. Mount Gallatin is about 10,000 feet high, while the smaller peaks are about 9,000 and 9,500 feet. These peaks are composed mostly of limestones, and the intermediate space to the cañon of the Madison, a distance of thirty miles, is occupied to a great extent with these rocks. I have no donbt that in the divide between the Gallatin and the East Fork some of the more modern beds occur. Dr. Peale found the Jurassic beds at one losality on the East Fork rising up from beneath the limestones. It is probable that here there has been an inversion of the strata, as we find to occur, in a marked manner, only a few miles below. Basaltic rocks are found to a greater or less extent everywhere among the limestones, sometimes at the base of the mountains, and again at the summits or high up on the sules. The igneous material seems to have issued forth from fissures whenever a favorable opportunity presented itself. The gorges are quite remarkable. In some places the waters seem to have gouged out, as it were, a semicircular mass, with a vertical descent of 1,200 to 1,500 feet, and on the sides the massive strata of limestone are worn into columus or pinuacles, se unsteady in their position that the loose rocks may be pushed over into the gorge below. The bottom of the cañon is full of débris, and doubtless ice hat much to do in wearing these very curions and immense gorges into the monntain-side. What may be called the secondary series of hills or ridges are 2,000 to 2,500 feet above the Madison, while the higher peaks rise 3,000 to 3,500 feet, and here and there a peak sends its sharp summit 4,000 feet or more. The proofs of erosion are everywbere on the most gigantic scale. The eaũon has been worn ont in the same manner as those on the Yellow stone, but in the mean time the narrow channel doubtless became gorged from time to time. The basin which we have attempted to describe, which is about thirty miles in length and ten to fifteen in brealth, was once a fresh-water lake, but the water slowly wrought its way through this high range of monntains. Near the immediate entrance of the caũon, on the east side of the river, there is a short, bigh, terrace-like ridge, abotit one-fourth of a mile long, 250 feet high above the bed of the river, paved on the surface with rounded bowlders, and, I bave no doubt, made up of a loeal drift. The upper end is quite abrupt, steep, and at 
this point in the side of the mountain there is a small añon, from which a considerable amount of water must flow at certan seasons of the year, and the mat:Tials from this cañon may have assisted in bvilding year, and the mat.Tials from the cover, that the uppe: portion of the up the jidge. Thave no doubt, fowed up with loose bowlders and drift cañon has been at some period when the gorge broke away, most of it transported from above, and when the gorge lroke anas, most of it was carried down the river, but that this portion was in some way pro. tected. The entire valiey between the moustians is lirerally pared with monded bowlders, and there is no doubt that this sanecearse material extends beneath to a great depth. In the cañon itself there is a still exten prominent ridge, and the loose rocks on every side are much larger more prominent ridge, a the and more abundant. A norrow gorge for ains on the east side. This little stream has che 2.500 to 3 , is an abrupt bend in the river just avove this ridge of bowlder-drift, which may account in part for its accumulation at this particular sput. Which may account in part his range are imostly micaceous gueiss, some 2..e entry pariations parts vers compact, in gra in textnre and color are very great, as is on the east side of the river, roeks. From the summit of the high ridge on the eant silareser, at a height of abont 9,500 feet, we werenble to take in a large scope of conntry, and study out the character of these rugged monntain-peaks. In this range, which is a limited one, there are a dozen peaks which will In the 0,800 to 10,950 feet, while two of them are alsout 10,500 feet. The reach 9,o rocks ire all ruets pact, so effectually resisting the metoric forcs summits of the highest peaks are as slarp and anghar as if only frac turel within the present season. These unworn angles give a preculiar sharp ruggeduess to the view, as the eve passen across fhe sumits of she many peaks or descends into the innumerable gorges on every side. the the fallatin, the strata of limestone To the easr, tom or dise gorges, may be most clearly seen where they liven Sometimes thes dip down yet holding a great varicty of positions. Som suddenly in the valles and pass out of sight, then name hing are ele vated bodily to the summit of a high peak, resting on the metamorphic rocks. On the west side of the Madison there are three or four peak which are at least 10,000 feet high. Among these mountain-gorges we which are at in the aygregate see the sources of the inyriad small bra the craggy cliffis are here and form the large river. Nestled among the aboy cling of the anows there little ponus of clear water, derived rom the melting of the snown seldom ever seen except by the birds and the game that visit then to gnench their thirst. The tendency of all these gorges is to work their way inwarl toward the divide. Great masses of snow and ice accumulate in them during the winter, and the water, flowing down among the fracin them dung the wister, and year tears tured masses, freeze, and expands down a portiou, that falls into the depthis below and is swe by by the torreut. The aggregate of the forces which hare contimued in operation throngh a series of ages, which no man can determine now, operich or atmospheric, are the and combined actione been far more entective in ages past ba the caunon, we discovered a gorges which lead down to the river in the canch, whe complete inversion of the strata, and this condition of things was found afterward to prevail to a large extent in thene nountain-moges. I would refer the reader to Dr. Peale's report, and also to the descrip.

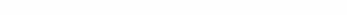




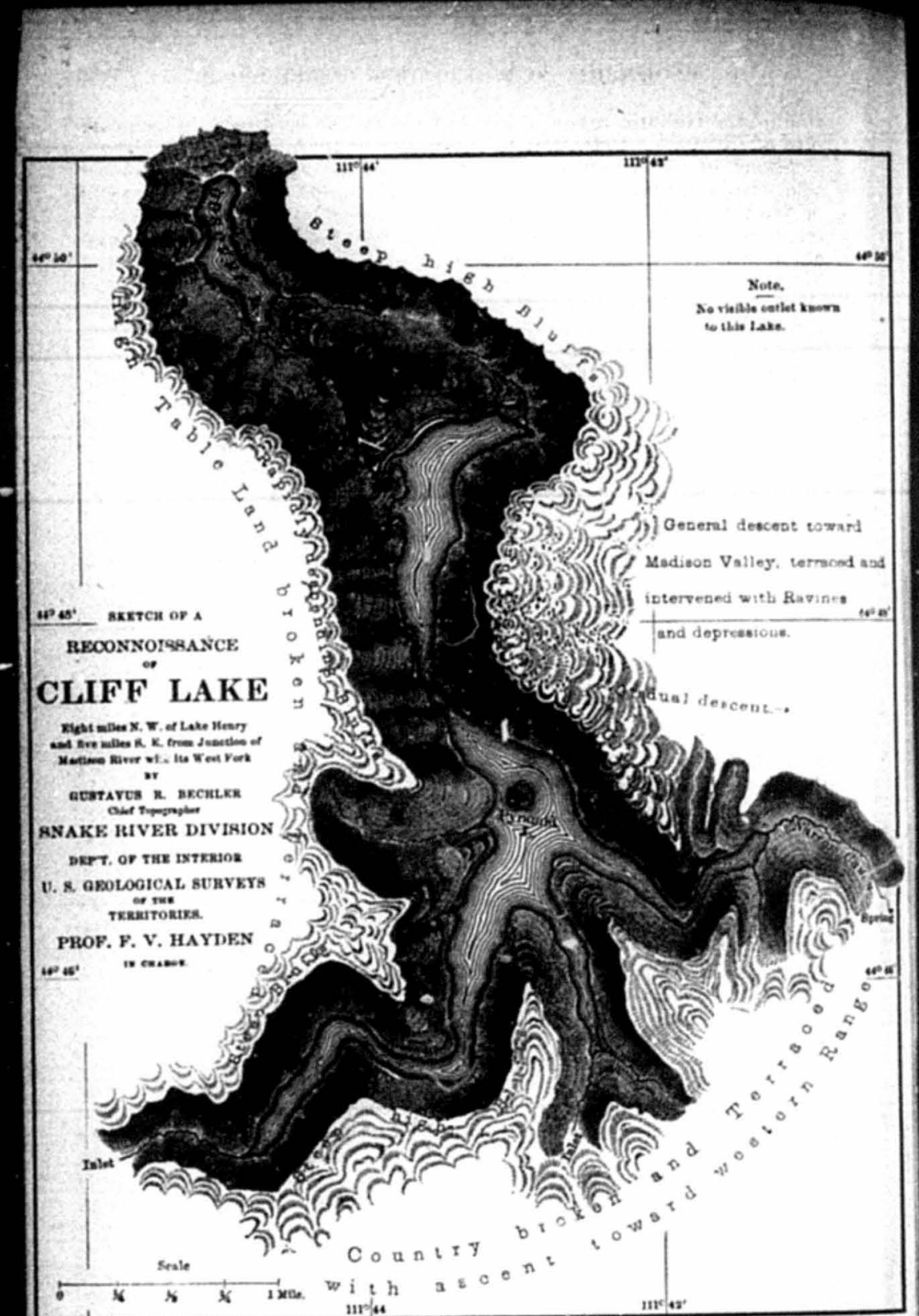

GEOLOGICAL SURVEY CF THE TERBITORIES.

tion of the Gallatin range in a subsequent chapter, where other exam. ples of inversivil of strata will be noticed.

ples of iuversiu. of strata widdle Cañon, a $\Lambda$ bout ten miles northwe small stream, which has its origin in the Rayno or Wade's Lake. The little stream has cut a singalar gorge through the trachyte-rocks, with vertical walls 400 to 600 feet high, runs southwest trachyte reches

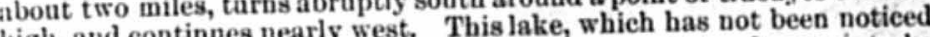
high, aud conting said to have no outlet. It seem's to be on auy of the existing maps, is said to have rocks, and is surrounded by formed in a huge fissure i.

The beautiful This lake was carefully explored was prepared by him. He says map of it, accomanyll streams flowing into it, but has no visible outlet, that it has three small streams passes under the basaltic cap. The sides but the surplus water prossible to travel near of the lake are so steep and high the the shore, but Mr. Bechler asceuded the surtounding scenery. The high and obtained a beautiful view of the surrounding baenltic cliffs that inclose it suggested the name of Clifr Lake. Near the w..ldle of the lake, there is a small, conical island, about 150 feet in The vicinity, all of them apparentl There were several sticte

formed in these basaltic fissures, and without ang expands unti it

The valley below the Middle Cañon gradually expands unti it becomes six to ten miles in width. At the upper eud of the valley the terraces do not show as well as below, but in no other portion of the We beantiful a series of terraces as in West chance to this basin. I point this out here to the readerable region. At visit the country, as one of the wonders of this well defined and show the upper end of the basin the terraces are quite writ detsed and show a most extensive deposit of loose material at the bottom of the lake. The surface of the entire valley is covered with bowlders of greater or less size, many of them huge massive granite. On both sides of the river are caps of basalt covering and proteeting from erosion the under. river are capsosits. From these basalt-capped bills or terraces I infer lying lake deposits. that the moteru lake-deposits must ther has cut its way through this feet thick, perhaps much more. The river has cat its with the basaltic deposit, forming in some instances a narrow gorge with mountains cap on either sicle like a high terrace, while the foot of the moun thas on both sides is distant from half a mile to ond mile. We can thus understand pretty elearly what must have been the thickness of these lake deposits immediately after the outflow of the igneons matter. As lake-deposits imtuediater all this basaltic floor has remained, and the we pass down the river all this bide to side, smoothed like a lawn. entire surfnce of the valley, from side to side, soothalt I cannot state Whether there was one period or several of out tlow of basalt caunotstate positively. In the vertical sides of the river-channel the basalt way been positivent and therefore, it may have at diflere were several periods of outfiow. In many localities the basalt is exposed in the form of a of outtiow. In also varies, high vertical wall with a partial columuar appearance. in color as well as in texture, from a very dark-brown to a purplish-drab. All the lake-deposits, as well as the igneous rocks, lie in horizontal positiou, and, so far as cau he observed, have not been affected by any suber mas, therefore, infer that the forces whic subsequent movents position, and tilted raised the surrounding mountains to their present posita, operated prior to the existence of these fresh-water lakes. 
There may have been periods of elevation and subsidence since the ex. istence of the lakes; if so, the disturluance bas never been great. In

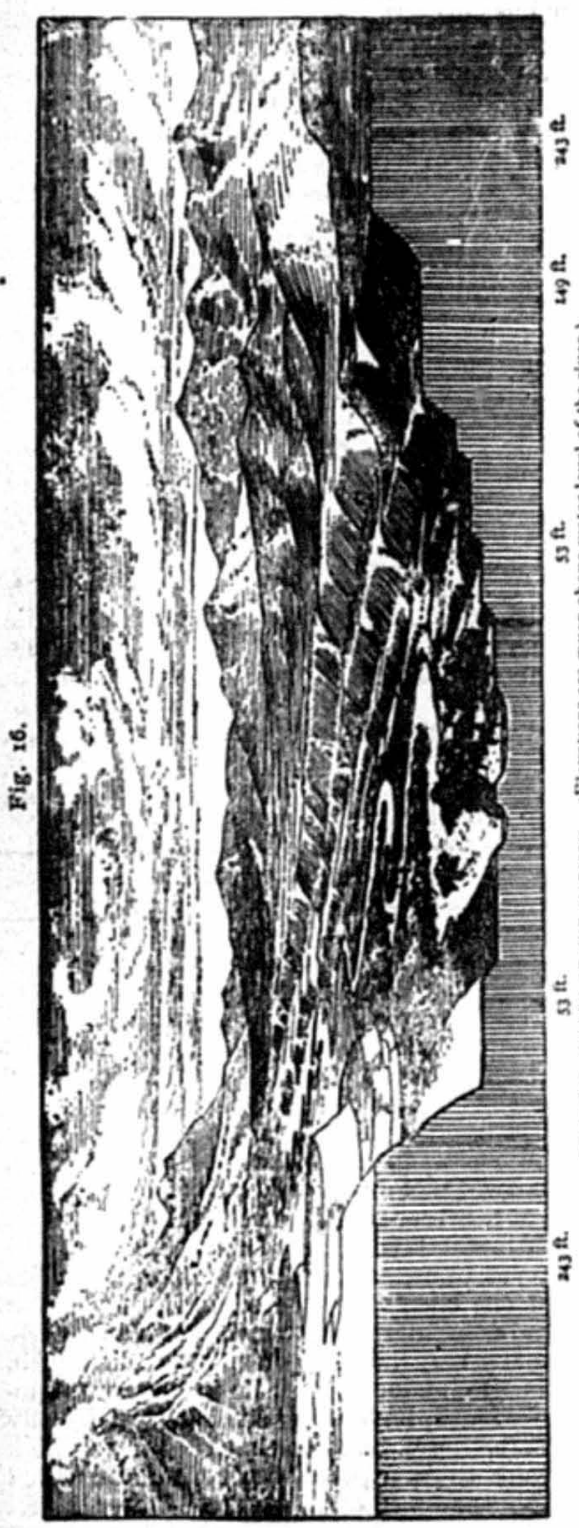

some cases, where the river some cases, whero the river times, has washed the foot of the mountains, the old trachytes bave been re. moved, exposing the gran. ites at the base.

This basin is about fifty miles in length, with an average of five miles in width. The lower thirty miles present the most remarkable system of ter. races that $I$ baveever seen. There are usually three of the terraces on either side the terraces on either side
of the Madison, and locally they may be mereased to six or eight. The great feature in regard to them is their persistency and uniformity, each terrace being at the same eleva. tion as the corresponding one on both sides. This is quite unusual. Generally, the terraces will be well displayed on one side of a stream and scarcely seen if they are shown on both sides, there is not neces. sarily the same elevation to corresponding terraces. The lake must have been drained through the Lower Cañon very slowly. The general elevation of these terraces may be estimated, above the bed of the river. about as follows: First terrace, 10 feet; second terrace, 30 feet; third terGanuett and Brown made quite an extensive series of observations with the barometer, and the results will be given in a subse. quent portion of this re port. These terraces are well shown in Fig. 16.

Av interesting feature may be observed in this on the opposite side; and, race, 100 feet. Messrs. basin in the character of the bowlder-deposits. At the upper end of the basin the entire surface is paved with rounded masses of granite and basalt, some of great size; but as we descend they become smaller in size and less abnudant, so that the lower portion of the basin reveals 2 considerable thickness of the light-gray marls and sands, which give evi. dence of having been deposited in comparatively quiet waters. So thiek are the bowlders over the upper half of the basia that it ean never be nsed except for grazing-purposes, while the lower half is already occnpied with fine farms. The rush of the waters through the Middle Cañon inust always have been very great, but their force almost entirely sub. sided before reaching the Lower Cañon.

Between the Madison Valley and that of Passamari Creek there is a long somewhat irregular range of mountains, the geology of which I can present in this report only in general terms. Although the structure is comparatively simple, it would require long and faithful labor to work out all the details. The general elevation is not great, 7,000 to 8,000 feet, and only two or three peaks rise up so as to be prominent, Pyroxene Peak and Old Baldy. As usmal, the nucleus is composed of the varions kinds of metamorphic strata, with effasions of igueous rocks, while the unchanged sedimentary strata, mostly the Paleozoic, are observed at all elevations resting on the granites. The evidences of erosion are more striking in this range than in the mountains between the Madison and the Gallatin, probably iecause their general elevation is at least 1,500 to 2,000 feet lower, and they were much longer exposed to the wasting iufluences of the aqueous forces. Deep cañons are worn into the mountains on either side, and the numbers of old dry ravines or gorges are almost countless. Prior to the effusion of the igneous rocks the greater part of the erosion took place, though comparatively little had been done to produce the present configuration The skeleton or framework was formed of the metamorphic rocks with the remnants of the Silurian and Carboniferous strata that were left after the vast work of erosion, which occurred prior to the outfiow of the igneous roeks. In subsequent erosions the latter hare protected the sedimentary beds over a great area, so that they are exposed in little patches ererywhere, sometimes on the summits of the mountains or at all elevations in the ravines or cañons. Sometimes the iguents rocks have been worn away from the surface for a considerable area, leaving a greater or less thickness of the limestones. In some localities they present a great vertical thickness and then again thin ont or disappear entirely. 'There is an interesting but obscure feature which is shown in the mountains on both sides of the Madison. There is, in restricted localities, an enorm. ous development of a very hard gray quartzitic sandstone, apparently partially metamorphosed. It evidently forms the underlying rocks of the sedimentary strata, resting on the strictly metamorphie gneiss. The various members of the survey have examined it most earefully, but bave never been able to find any trace of organic life, yet it nndoubtedly belongs to the oldest Silurian. It makes its appearance quite abruptly, with a thickness of 1,000 to 2,000 feet, and as abruptly disappears or thins out. It is well shown in the Middle Cañon of the Madison and in the lower part of the cañon of the Gallatin, and is thinly represented in several ether localities. We may say of all these different groups of strata that they appear at times in grand proportions, and are soon lost or are only thinly shown. Along the enst side of the Gallatin River, above the Three Forks, at least 1,600 feet of sbules, clays, sandstones, \&e., which belong nudoubtedly to the Potsdam group of the Lower 
Silurian, are clearly shown, and set, at a distance of thirty miles to the northward, this entire group seems to be wanting.

In the report of the survey of last season I described the country abont Virginia City in brief terms, aud but little more can be added from the examiuations of the present season. Alder Gulch is well known to the mining world as one of the richest placers in the West. It is estimated that about thirty millions of gold have been taken out of it. The bowlder-drift is a marked feature in the gulch. Upon the sides of the hills patches of black basalt may be seen in considerable numbers, indicating the very latest period of eruption. The older trachytes also oceur on both sides of the golch, which have been erupted at different periodsand have overflowed tivegneissic rocks. None of theigneous rocks observed by me, however, were old in a geological sense; none that date back further than the Pliocene epoch. A more careful serutiny of the rocks might have resulted in detecting igneous rocks of different geological ages, but very few seem to date back beyond the Pliocene. It is not uncommon to find the basalts interstratified with Cretaceons and Tertiary beds, but I do not think it follows that the eraption took place during these periods. In the high bluff opposite the Mammoth Hot Springs, on Gardiner's River, thick beds of basalt are exposed in the upper portion of the bluff of irregular exteut. On-the summit is a very thick bed lying across the upturned edges of the strata, and the line of contact is quite red, showing the influence of the melted lava on the sedimentary strata immediately beneath. I am disposed to believe these short intercalated beds of basalt may have been of very modern origin.

At the head of Alder Gulch there is a high wall of limestone of which Old Baldy is the highest point. The aggregate dip seems to be about southeast $30^{\circ}$ to $45^{\circ}$. The exposure is a fine one, with 1,200 to 1,000 feet of verical strata. The lower portions of the sedimentary beds are quartzose, sometimes pebbly, very hard, compact, gradual's passing up into limestones, which are also very hard and splintery, destitute of fos. sils. But in the upper portion of both sides of Old Baldy the characteristic Carboniferous fossils are very abundant. Thick beds of limestones are a simple aggregate of well-preserved fossils, aud among these some very interesting crinoids. For a list of the fossils from this local ity the reader is referred to the catalogue of Mr. Meek. The high ridge or mountain-range of limestones of which Old Baldy forms a part trends and Red Rock Creeks, to an unknown distance. These huge ridges, which extend in such long lines across the. Northwest, are undoubtedly portions of grand anticlinals. It will prove a great source of pleasure at some future time to trace these great axes of elevation across the country and aggregate them into a symmetrical group. Until this is cone it will bally be possible for us to comis graphy or geology of this region.

We will return to the Madison Valley. That the period of the eruption of the igneous rocks began before the mountain-ranges had reached their present height and form is shown by the position of some of the ridges of tracbyte that extend down the sides of the monntains into the valley on the west side of the Madison. The ridges of trachyte have been so eroded that the bluff-sides present a stratified appearance and the inclination is $\sigma^{\circ}$ to $10^{\circ}$, the beds passing from near the summit of the divide down beneath the superficial or lake deposits of the basin. As we descend the Madison the ragge of mountains on the west side is more purely metamorphic, few of the igueous rocks being observed, and no sedimentary at all. This continues nearly to the Jefr. erson Fork, where the Bouth Bowlder Range is cut off by a narrow synclinal which forms the valley of the Jefferson. The limestones incline away from the north end of the South Bowlder Range, but the greater portion, inclucling all the lofts peaks, is composed of granitic rocks.

The divide which separates the basin which we have just deseribed from the lower basin about the Three Forks is composed almost entirely of metamorphie strata. Here and there we observe au outflow of igne. ons matter, but very seldom. In the ravines and depressions, as it were filling up the inequalities of the surface of the metumorphie rocks, are the lake-deposits, which show so clearly that at a modern period the Iadison Basin was connected by water with the entire valley of the Three Forks, eveu far below their junction. As the waters subsided so as to expose this granite-divide, they gravitated toward that portion of the basin where they now flow through the granite-eañon. What eansed the waters to wear out the present ehannel is not obvious at this time. The ridge or divide may bave been lower at that point or there may have been a slight fissure which determined its choice.

In following up the channels of some of the little streams that flow out of the mountains on the east side of the Madison, Dr. Peale and Mr. Hulmes fonnd that the strata were inverted. In the eañon of Jackass Creck all the beds, from the lowest Silurian to the Tertiary inclusive, were inverted so that the youngest Tertiary beds were at the bottom in orcler of superposition. For a more complete account of the geology of this rugion, as well as the Cherry Creek mines, the realer is referred to the report of Dr. Peale.

\section{CHAPTER IV.}

YADISON VALLEY-THREE FORKS-GALLATIN VALLEY AVI) CA SON TO SOURCE OF KIVER-FROM THREE FORKS TU HELENA.

Just below the mouth of Elk Creek, the Madison Valley expands iuto au open basin with high, rather rounded hills of the lake-deposits on the east side about ten miles distant from the rim, while on the wext side are bluff.lands, cut by the river, exposing the strata clearly and showing ibeir horizontal position. In none of the upper basins are the lake-deposits as well exposed, and the character of the sediments shows that they were deposited in comparatively quiet waters. The long point or tongue which extends down to the junction of the Porks long point or tongwe which extends down to the junction of the Forks, between the Madison and the Gallatin, is composed of these deposits,
and in the rarines, which in some places cut deep into the ridge, large masses of very beautiful silicified wood are found. I have no doubt that bones might be found by diligent search; for in the Jefferson Valley, in the same kind of deposits, I discovered the teeth and jaws of an Anchitherium, and a species of Helix. Of conrse these basins were all connected at one time far up the valley of the Jefferson as well as the Gallatin, but during the gradnal period of subsidence became disconnected and ended in quite distinct lake-basins. The Bouth Bowlder Range formed a shore-line on the west side. The waters must have reached so high up on the sides that little more than the summits of the peaks were above the surface and therefore most of the ranges were then represented only by small islands. The Madison and the Gallatin Ranges on the east were also shore-lines, but became more conspienons as the waters diminished; and while thin patehes of the peculiar lake$5 \mathrm{G} \mathrm{s}$ 
lepesits are found high up on the mountain-sides, showing that at a very modern date the valleys of most of the streams must have been connected through the low passes, yet the principal sediments are in the lower basins. Indeed, I conld imagine that the entire Northwes: (and how much more of the country I cannot now positively determine) presented much the appearance of the basin of Great Salt Lake, with the numerous mountain-ranges rising above the waters. Now, if we can imagine the entire area of the great basin between the Wahsatch Mountains and the Sierra Nevada covered with water to a height which it must have reached at a comparatively modern geological period, the vast number of mountain-ranges of greater or less size which now exist within these limits would represent eo many roeky islands in this vast inland sea. Here and there in the valleys of the Madison, as well as the Gallatin, the older rocks are exposed beneath the lake-deposits, even where the latter prevail. We can trace out with more detail the skeleton of the surface prior to the laying down of the lake-deposits. In the lower valleys it is quite rare to find rocks more modern than the Carbonilerons, but the limestones and granites crop ont oftentimes in the most unexpected places. The stripping away of the lake-deposits from the metamorphic rocks in the range through whieh the Lower Cañon is formed has exposed a moderately rich min. ing distriet. There are a number of mines which are wronght with success at this time, and on the whole the mining prospects of all this region are becoming better every sear. The excellent reports of $\mathrm{Mr}$. R. W. Raymond, Commissioner of Mining Statisties, are so full in regard to the mines of Montana that 1 shall at present touch this sub. ject very briefly.

It is my iutention to study all the mining distriets of Montana at some future period with special reference to their geological relat tions, carefully mapping the lodes, and endeavoring to stady ont if possible their natural history. I believe, that Montana is rich in valuable mines, and that, when railroad communication bas beet estab. lished between it and the world at large, an impulse will be given to the mining interests of the Territory that will satisfy the most sangnine. It bebooves the enterprising citizens not to let the subject of railroadcommunieation rest from this time until it becomes an accomplisbed fact. The world will then begin to appreciate the resources of the Territory, which, so faras 1 have examined it, surpassesany of the others in the West. The Cherry Creek Mines occur in what has been called the Madison range. The reader is referred to the report of Dr. Peale for such informa. tion as he has been able to secure in a brief visit to them. This mining. belt passes across the Madikon by way of the Lower Caṽon, and extend to the Sonth Bowlder Monntains. Hundreds of lodes have been opened, many of them worthless; but many others would donbtless prove valnable if transportation and labor were not so costly and dificult to obtain in the country. The lodes are all found in the metamorphic strata, the age of which it would be difficult to decide. We only know that they form a vast thickness of stratified rocks with varied texture and composition. They seem here to have been subjected to considerable erosion after the limestones were washed away. These metamorphic strata underlie the entire country and appear everywhere where the unchanged beds have been worn away or when not concealed by the vutflow of igneons matter. The work of reducing these metamorphic straca to a system, and connecting them over extended areas, has not jet been attempted, and it seems to me an almost hopeless as well as fraitless task. It wil be enough for the present generation, perhaps, if we are enabled to work out pretty cleariy the story of the sedimentary formations of the West. Along the valley of the Madison below the mouth of Cherry Creek, there is a remarkable exhibition of the gneissic beds. For several miles the strata are exposed so that the succession is perfectly clear for thousands of feet in thiokness. All the varieties of composition and the flexures in the bedding peculiar to mining-rocks are seen in perfection. Veins of feldspar and quartz extend across the bedding a foot or more Vein the a lode. Masses of a very compact black hornblendic gneiss, 4 to 6 feet thiek, and 8 to 10 feet long, lie between the strata as if they were old intrusions of trap. I have never seen a better opportunity for a detailed stuily of the gneissic roeks, for they gneissie rocks, for they
are shown bere in high are shown bere in high
rertical walls for six miles, inelining in the same direction 300 to 50 . The beautiful ex. amples of banded gueiss, as shown in Fig. 17, are not uncommon, and excite much attention. I have used the term gueiss in its broadest rense, to signify granitic rock composed of quartz, feldspar, and miea, arranged in well-defock composed of quartz, feldspar, and miea, arranged in well-defect. All the different forms which the metamorphic rocks assume are noted in the catalogue of Dr. Peale, appended to his report of this and last year. In my report of last year I described quits minutely the basin of the Three Forks. I then stated that the immediate valleys of the streams near the junction bad been carved ont of the lake-deposits, and on either side of the Madison Valley, on the east side of the Jefterson and the west side of the Gallatin, the bluffs exposed fine sections of these modern beds. From the courses of these great streams the source of the waters during the lake-period might be read from the character of the sediments. We find that they must have rushed with great force along the valleys from the sonreps, after the impetus was gained throngh the Upper Cañon, then throngh the Middle Cañon, and begin. ning to lose a portion of this force and moving along more quietly just before entering the Lower Cañon, and when reaching the basin of the Three Forks, the water must have heen as quiet as in ordinary fresh. water lakes of the present day. The indications of swif eurrents are not seen about the immediate sonrces of these streams, so that the sedi. ments of the gejser-basins are comparatively fine, indieating moderately quiet waters. All the other rivers tell pretty mnch the same story. These sediments, made up as they are of the different kinds of rocks in the vicinity, are much mixed in their character. They are a mixture of elay, sand, and marl, in raried proportion. Bometimes thin indurated layers of elay will inclnde suveral feet, then sand will predominate or sandstones in thin beds, or sort of indurated jellow or eream-eolored marl, and then, perhaps, a bed of loose gravel or pudding-stone. There is a remarkable ubiformity in the color and character of these sediments all over the West, from our north line to 
Mesico. I hare estimated the aggregate thickness of these deposits in this lower basin at the present time at about 1,200 feet. Ocenpying the area that they do, we can thus see that they possess an importance which demands the notice of the geologist. Between the junction of the Madison with the Jefferson and the month of the Gallatin, a dis. tance of about half a mile, there is on the south side a remuant of a limestone ridge cut of by the Gallatin from the main mass below, 50 to 100 feet high, and trending abont northeast and southwest. This is a somewhat peculiar remnant, but it aids much in reconstructing the former surface of the conntry prior to the great erosion. The Missouri River, immediately below the entrance of the Gallatin, passes throngh a sort of rift in the upturned ridge, the strata on either side inclining in the same direction. How, in the changing of the channel of the river, this remnant was left, is not clear at this time. There are a num. bes of other remnants of the limestone scattered through the basin, which shows that it was originally scooped out of the series of ridges which probably sent their sharp summits up a thousand feet or more above the general level. All the imestones immediately about the junction of the Three Forks are of Carboniterons age, as the fossils
Fig. 18.

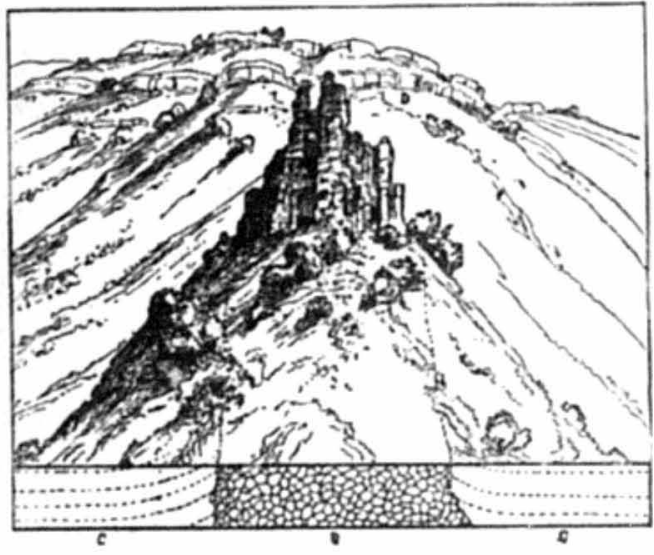

DIKE ON ThK Missoune. testify But above and below, the Siln. rian stratia are re. markably well ex. posed. Below the Three Forks the structure, though simple in general terms as above, is very much compli. cated by the ehaotic condition in which the strata have been left after upheaval. There are a number of local synclinals as well as anticlinals, but to work them ont in as great detail as I desired would require more time than we had at far disA. Dike of basalt B Supposed contintation of dikntmatter below posal. The Missouri

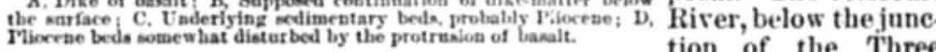

Forks, flows along a sort of rift in the ridges of lion of the Three the west side these ridges are worn across, so that the waters followed the intervening valley but a short distance.

On the east side the waters run close up by high limestone-walls for abont one fourth of a mile, and then the valley expands a few hun dred yards in width for about three miles and then eloses again for a short distance, a mile or so, and then again expands to a width of three to five miles. These vallejs are evidently worn out of the group of uplifted ridges, as is shown by the remnants here and there in the valley and in the bed of the river. On the east side, immediately below the entrance of the Gallatin, the river has worn a well-defined terrace in the limestone for a half a mile below, forming a sort of eontinnation of the isolated low ridge in the bottom just above the Gallatin. In the second expansion of the valley the second expansion of the valley there is a broad bottom about two
miles wide. On the east side of miles wide. On the east side of
the valley are quite thick depos. its of the Lake period cut up into ridges, which are weathered into architectural forms like what we arce nsurilly bave usually termed in the West, "bad lands." The lower portion eareous shale, passing by degrees into an indurated sandstone capped by a large thickn is of conglom. emo. This is made up to a great extent of rounded masses of lime. stone iosely held together by a sand cement or with a whitish marly paste. In many localities in these deposits there are dikes of basalt which seem to have been formed during the existence of the lake, and that the basalt had been exposed by the wearing out of the ravines which have been ent into these motern deposits at a very moderu date. (Fig. 18.) Formiles aloug the high mountains that horder the river, hundreds of deep caniens or gullies, from three to six miles song, are carved deep into the sides. The modern beds are nearly or quite horizontal, with no evidence of disturbance since their deposition, and they lap on to the much-tilted strata of the older rocks. There are here, as near as I can estimate, about 2,000 feet of more or less metamorphosed slates, clays, and quartzites of all textures and colors, but mostly thinly lam. inated. Much of it is rery slaty. Here and there a dike is seen which shows an effusion of melted matter at some period subsequent to the upheaval. No fossils could be found, but I have no doubt that they belong to the Potsdam group, so woll shown on the Gallatin, and, indeed, the same beds are much more changed. As we ascend the mountain the compact gray limestones, which are also of the Silu. rian age, are well developed and,
above these limestones, full of well. detined carbonifer ons fossils. (Fig. 19.)

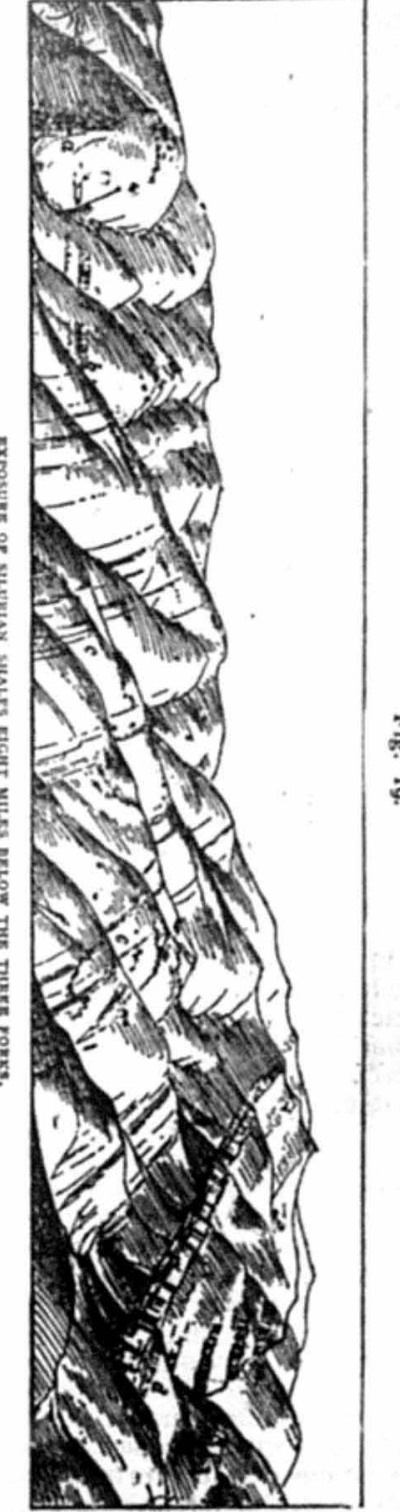


Silurian beds extend I do not know, but they were visible at least fifty miles below the junetion of the Three Forits. It will at some futnre day be an interesting and profitable task to stad $y$ the geology of this region in detail. The few facts that $I$ am able to present at ris time may serve to call attention to it. There is bere the largest deveiopment may berilnrian strata I have ever seen in the West. They are, however, of the Silurian strata $I$ saverer system in the upheaval of the rocks. Here and there they are bronght to the surface. The lake-basin is about five mil $\mathrm{gg}$, and on an average
two miles wide, and the aggregate thicknes. the modern deposits about 800 feet.

On the west side of the Missouri, immediately below the Three Forks, there is a most interesting synclinal, which will be shown in the illustration. The river, as it enters the cañon at the Three Forks, may bave started in a rift, but it seems to have immediately disregarded it and cut across the ridges, so that the channel now cuts diagonally across all the ridges of the Carboniferous series and a large portion of the Juassic within a distance of ten miles. The ruggedness of this region is rery gruat, the little branches that flow from the hills on either side is very gent, the little brosing the strato in high walls on either sicle. fasbing deep canons, exposing the strata fn high wallg ond eitber side. By following one of these little streams from the main river up to the divide, we get a fair section of the strata. About five miles below the Three Forks, on the west side, the .Jnrassic ridges come in close to the river-side. In the ridges of limestone above this point is an abund ance of characteristic Carboniferous fossils, so that we regard the age of these rocks settled.

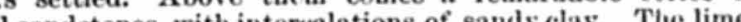
quartzites and sandstones, with intercalations of sandy clay. Tue limestones seem to pass gradually up into quartzites, so that the apper beds are compact, brittle, gray quartzites. The want of continuicy of the strata between the Jurassic series and the Carboniferous group below is shown in the ahsence, in most cases of some hundred fiet, of strata which are well shew of quarzite is about 300 feet thick, with a dip of 4 . In the lower part is an intrnsive bed of igneous rock. The second ridge is a rusty brown sandstone, with layers composed of fossils, mostly fragments, as Ostrea, and sotne beautiful but undescribed forms. The inclination of the strata is $35^{\circ}$ to $40^{\circ}$. There is in this ridge a remarkable intrusive bed of igneous rock, very irregalar in thi kness and horizontal extent, sometimes 50 to 100 feet thick, pincbing out and then re-appearing in full force. The calcareous sand. stones above and below are full of fossils, and do not seem to bave been affected by contact. There is a kind of cleavage in the igneous rocks hat gires to the entire mass the appearauce of stratified rocks, but precisely opposite in inclination to the sedimentary beds which inclose them. Then comes a series of beds weathering a dull, purplish color, composed of sandstones, quartgites, with loose clays and shales, passing con up into browh sandstones, then a bed of dark.brown quarzites. Tuen comes a series of layers of reddish-yellow sandstones of varions textures, with intercalations of arenaceous clay. Still farther above are a series of red and purplish clays with greenish-blue bands passing up into gray marls and arenaceous limestone. The aggregate thickness of the mass of Jurasic strata was estimated to be about 1,500 feet. The direction of the dip is abont northwest. Then comes a series of brown th is about northwest. Then comes a 80 to 800 feet and rusty-yellow arenaceous clays and sandstones 500 to 800 feet in thiekness, with an abundance of well-detined Cretaceous fossils. In the middle of the synelinal is a limited thickness of the Coal strata with layers of impure coal. At the junction of the two sides of the synclinal the beds are much crushed, so that they are rendered rery obscure. On the opposite side we pass over the upturned edges of the seme series, commenc. ing with the Coal strats but with ing with the a reversed dip. The complete series has been tilted beyond a vertical, so that some of the high ridges of lime stone incline $45^{\circ}$. (Figs. 20 and 21 .) Near the upper portion of the Jurassic group there is a bed of gray limestone six feet thick, made up of an aggregate of small Gasteropod. ous shells. This bed is well exposed in both divisions of the synclinal. Patches of the lake-deposits are thinly seattered over the surface, filling up the irregularities, occasionally showing a moderate thickness either of marls or conglomerates. As we pass up the Gallatin Valley from its month we observe that the river flows aloug a bigh-bluff wall on the east side. There are several local synclinals as well as anticlinals, but to have beeu affected. In the low hills east of the river, about five miles above the mouth, is a sort of local depression, in which are remnants of the Jurassic group. As I have so often repeated in this report and in my previous reports, the evidence is continually shown that the formations all originally exteuded over the country in a horizontal position at one period; that they have since been removed to a great extent by erosion, but here and there ve find indications of their former existence. The section will show a most exten. sive series of Carboniferous limestones rising gradually as we ascend the Gallatin. I described these beis somewhat in detail in my report for 1871. The series of Carboniferous limestones is remarkably well shown for a distance of about five miles above the mouth of the Gal. latin. Just opposite the grist-mill the sery compact, brittle beds, which are supposed to be of Silnrian age, come in, forming massive bluff-ex posures. Just beneath these mass. ive beds of limestone is a series of loose, brown shales and clays with thin layers of impure limestone.

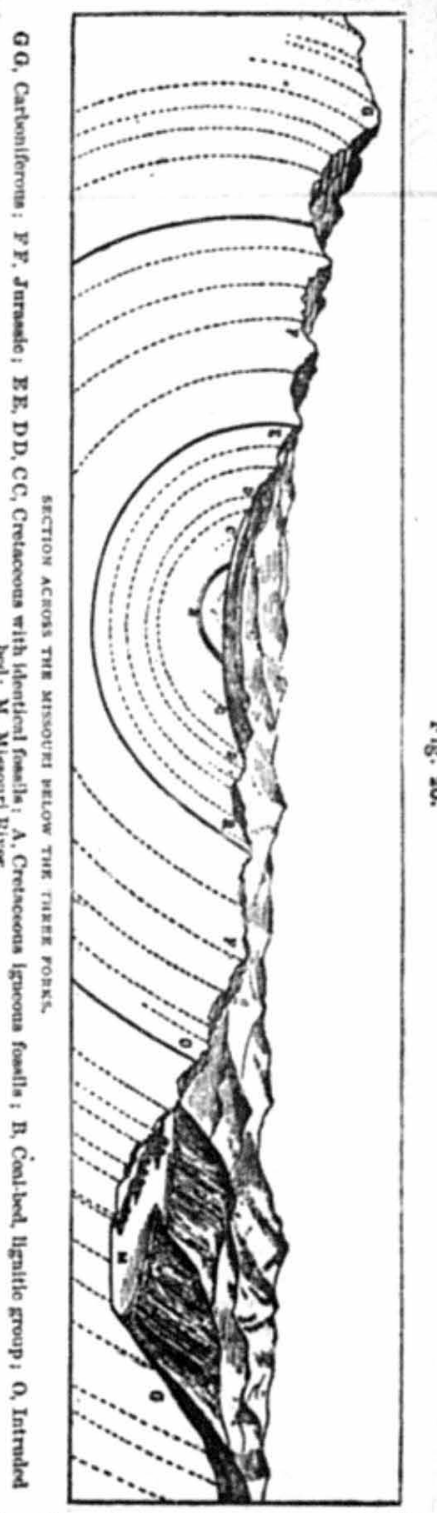

In the shales are layers of lime 
stone an inch or two in thickness, composed of trilobites mostly in

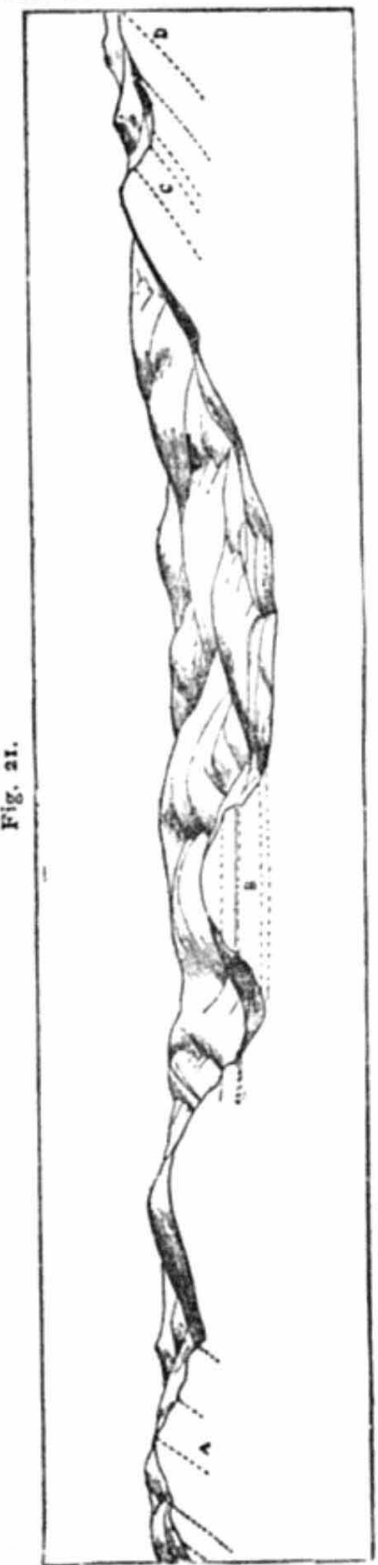

beds of the Middle Cretaceous. a fragmentary condition, but with now and then a specimen so preserved as to characterize it. There were great numbers and variety of these old Silurian fossils, and they uncloubtedly belong to the Potsum (a) tions represented by Figs. 20,21 , and 22 are continuous and occupy a distance of about thirty miles. The accompanying illustration will show the consecutive series of strata with their inclination. (Fig. 22.) The thickness of the entire series of Lower Silurian strata here is esti. mated at 1,600 feet. The massive lime. stones which I have referred to the Potsdam group are about 400 feet thick, then gradually pass down into 50 feet of thinly-laminated, cherty limestone or calcareons muther with abundast organic remains. Then 5 come layers of greenish sand and clays with shells and trilobites quite distinct from those above. Some of the layers of sandstone have small rounded pebbles, though not properly a conglomeiate. Then comes a purplish sandstone, and below these ¿ variegated shaly clays, yellow, green, \&e., then hard, dull purplish-brown quartzose sandstone, inclining $45^{\circ}$, apparentls metamorphosed in part, To feet. Then comes a grassy inter val, and then a ridge of very compact $=$ brownish-gray quartzite, with irreg nlar layers of sandstone, inclining $45^{\circ}$. Then alternate layers of brown caleareons sandstone and yellowish erown shaly class. Then drab-brown quartzites and black slates alternate, 150 feet. Then comes the steel-brown quartzite, which has the appearance at a little distance in the fracture of cotnpact basalt, 100 feet. Then a series of

black slates 150 feet thick. Then comes a dark micaceons sandstone, alternating with calcareous slates or shales, 300 to 500 feet in thickness. This last group of beds continues along the river in high bluffs for abont fire miles and presents a great variety of structure. In some in. stances the shales weather to a soft. yellow, chalky material, and remind one at a distance of the yellow-chalk Then we have a brown somewhat worn andstone, which has much the look of basalt or a compact, fine quartzite. Then come one or two rather thick beds of cherty limestone in the beds of shale, and in come instances immense some ins rounded, flat concretions feet in diameter, but not more than 6 or 12 inches certain; these brown mi. certain; the istones and shales continue down to the metamorphic rocks. It the interval between the What-fiead Pass and the Missonri River there are several local auticluals and synelinals, in which all the series of rocks are ex. losed in their order from the Lower Silurian to the Cretaceons, inclusive. Here and there are patches of igneous rocks which appear to have produced in some clinals. Far ap in the val. leys of all the little streams that flow into the Gallatin River may be seen the mod. ern deposits, which show the extent of the old-lake waters, and as they slowly subsided the present drain. by the stripping off of these modern beds that the posi. tion of the underlyingstrat is rendered apparent. . It. minutely describing the geological features from point to point much repetition is necessary. There is a certain variety in the ontlines of the surface in differrent localities, even if the geological formations are the same or similar, and the shades of difference strike the eye, but cannot always be expressed clearly in words. In the ralleys of all the little streams that flow into the Gallatin from the Gallatin Range, there is a greater or less thickness of the lake-

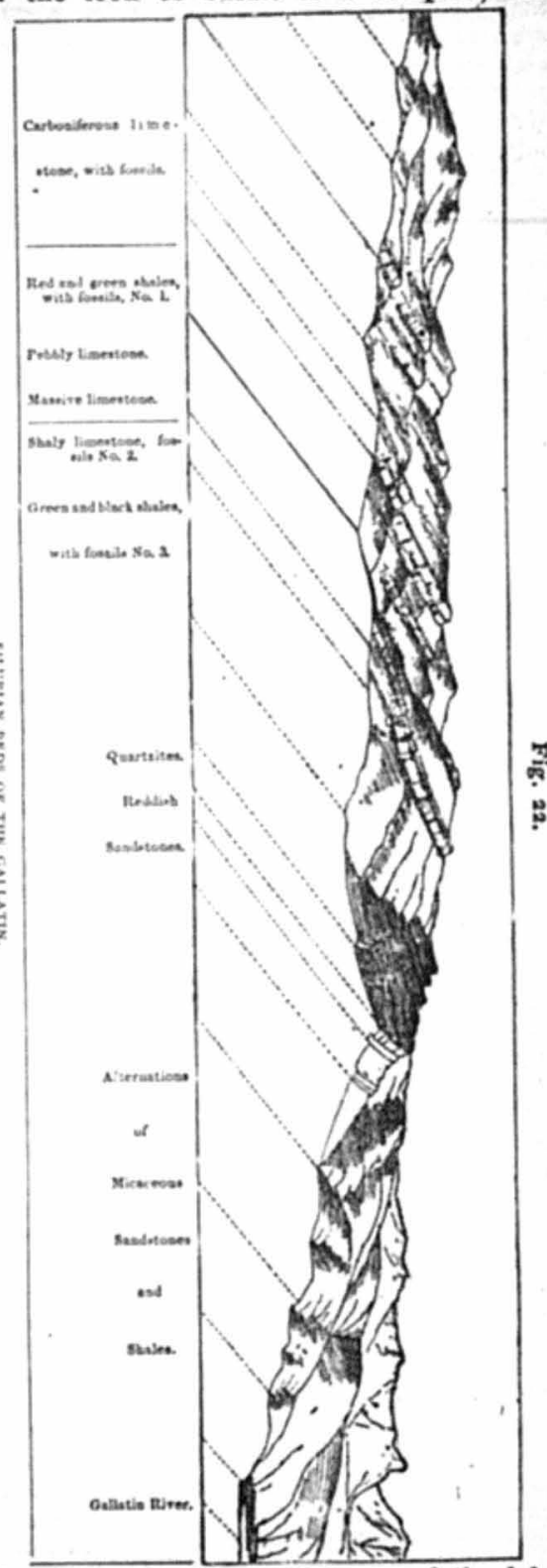

क्ञ

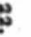
of cherty limestone several thick. So far as I conld as. instances these short anti. age was marked ont. It is 
deposits, with here and there a large amount of modern drift. The surface is covered with water-worn bowlders, the remains of the last acts in the drama. I have so often called attention to these very modern drift-deposits that it is ouly necessary to state that they cover the entire surface of the country, except the summits of the highest peaks. The origin of the forces that transported these bowlders and scattered them over the surface in this irregular manner will be discussed in another place. The details of the structnre of the Gallatin Range are numerous, and could be best presented by an account of the different routes traveled in exploring it, but I will only describe the two sides in general terms. The range itself is probably a monoclinal, that is, it is an elevated ridge with the strata all inclining in the same direction, and the position of the opposite portion is not yet known with certainty. The older beds on the west side have a marked reversed dip, but the central beds of limestone are nearly vertical, while the Jnrassie, Cretaceous, and Coa strata, inclining at various augles from $5 \circ$ to 500 , gradually descend in step-like ridges from the summit of the range to Shields's River, castward a distance of about fifteen or twenty niles. The aggregate inclination seems to be about northeast. Bridger Creek, near the Union Pass, flows sonthward along the east base of the main ridge for abont ten miles, and bends around, wearing a very deep caíon through the south end of the range through the limestones, and enters the East Gallatin about five miles below Bozeman. The Jurassic beds are crushed together in the nplift to such an extent that they are quite obseure, and do not appear to much advantage, bat in Union and FlatHead Passes they are much better exposed, but the Cretaceons and Coal groups are enormously developed, reaching an aggregate thickness of more than 10,000 feet. By the Coal gronj I always mean the series of beds which are pirobably Cretaceous in part, passing up into Lower Ter. tiary and containing the coal-beds of the West. The axis of the Gallatin Range is somewhat zig-zag in its trend. The great mass of the monutain inclines eastward or northeastward, but bends abruptly west in two or three places, forming interesting passes, as Union and FlatHead Passes. The outcropping edges of the limestone-strata have been rounded off by atmospheric agencies, ret for a $v$ i.ue belt along the very summit each layer is clearly shown, like irregular bands from one end of the range to the other, a distance of about twenty-five miles. The highest peak, which is nearly 9,000 feet, shows the upturned edges of the limestone-layers most clearly. As I have before remarked, the central mass and the highest portions are those which seem to have resisted erosion best. These beds are tisually nerrly vertical in position, seldom inclining past a vertical, while the Silurian group has a reversed inclination irom 50 to $15{ }^{\circ}$. On the west side of Union Pass the underlying graw'toid rocks are exposed, dipping in the opposite direction, as if in the uplift there had been forces acting not only vertically but tangentially. The Silurian group is exposed on the foot-hills, vary. ing from 800 to 1,200 feet in height from Bridger's Pass across to a point about fire miles north of Flat.Head Pass, a distance of nearly twenty miles. The consecutiveness of the beds is much obscured by the great thickness of detritus and grass, but the rocks crop out all orer the hills, so that they can be studied with confidence. Then we know that they are only an extension sonthward of the same gronp of beds which is so admirably well shown along the Gallatiu, and which has been described in a previous portion of this chapter. From the Missouri River southeast to the Yellowstone River, there is a series of rather low, broken ranges of mountain-ridges, of which the Gallatin
Range is the central and the largest one. On the east side, between the Gallatin Range and the intermediate valley of Shields's River, tbere. is a belt of country ten to fitteen miles in width, made np of Cretaceons is a bett of couts and Tertiary beds, wich an unusnal Bomber ly been affected more or less by heat. Here and there are indications of the effusion of basalt, usually in the form of a dike, without generally affecting to any great extent the position of the sedimentary strata, but sometimes throwing them into various positions. The highest bills are from 800 to 1,200 feet above the surrounding country, but descend westward in step-like ridges. The belt is exceediugly rugged from the nature of the upheaval, the beds having been lifted up at varions elevations; but of the upheaval, the beds having in they are cut down in every direction by the little streams in addition they are cut down in every direction by the little streams that flow into Shields's River on one side and into the Gallatin on the patches of aspen, and the remainder thickly grassed over, forming most excellent pastarage for stock of all kiuds. In the valley of Shiclds's Rirer are hundreds of excellent farms, which would long since have been taken up by farmers had it not been for fear of hostile Indians.

The Flat-Head Pass is the great thoronghare for the Flat-Head and Bannack Indians on their way to the buffalo-districts on the Muselesliell, Missonri, aud Lower Yellowstone. The hostile Sionx have made several raids through this pass into the Gullatin Valles, murdering the sotters and running off their stock. The illustratire-section which was taken at Flat.Head Pass shows the situation of the range with great clearness. Passing along the west base of the range from Flat-Head Pass to Fori Ellis, we find the slope from the Gallatin River to the im. mediate foot of the mountains dotted with cultivated farms. Where the superficial deposits are cut through by the numerous small streams, a great thickness of the modern lake-deposits and drift is exposed. In some instances the modern beds are hardened into a calcareous sanclstone that is nsed for building purposes. These deposits jut up against the sides of the monntain in such a manner that the old shore-line is distinetly marked. From Flat-Head Pass to Union Pass, a distance of about fifteen miles, the abrupt foot-hills are composed entirely of the Silurian group, lifted up in such a manner as to incline past a vertical. The character, as well as the order of superposition of the beds, must be the same as of those noted along the Gallatin a few miles below, but the hills are so covered with detritus and grassed over that I found it im. possible to obtain a consecutive section. Nearly all the nore compact strata crop ont at different points, so that the principal beds were detected. In Union Pass the streams have worn a passage through the range, so that the strata are well exposed, and we find here underneath the Silurian gronp a granitic base, as shown in the section. In the mas. sive limest ones of Union Pass, which are probably of the Potsdam epoch, there is a singular illustration of jointage, well shown in Fig. 23, which would at once arrest the attention of the geologist. At first, one would be much puzzled to determine the true stratification from the false. It forms a portion of Liberty Peak, which rises about 8,000 feet, and is probably due to partial metamorphic action. The granitic rocks continue to increase in thickness up to Bridger Cañon, a distance of fifteen miles. Here there seems to have been a less powerfil foree of fifteen miles. Here there seems to have been a less powerfil force and Coal strata are found on the summits of the range. Bridger and Bozeman Passes are low depressions in the range. As we pass across the numerous branches of the Gallatin, as they emerge from the monutaius, we see the Carboniferous and Silurian limestones inclining from 
the sides of the lower bills and passing under the valley. Here and there a high ridge is observed jutting up against the base of the mountains, a remnt of the lake-deposit which has escaped erosion. The central portion of the range, in which the different branches of the East
Fig. 23.

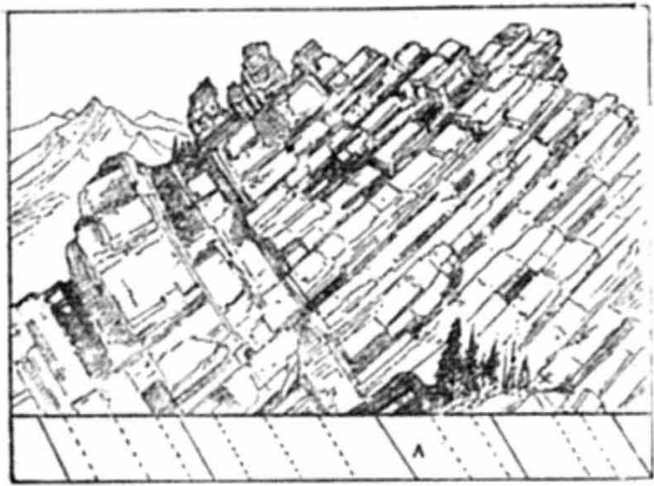

DECE. TIYE WEATH, BIKG, UMERTY TEAK

A. True dip of bede. Gallatin have their origin, is composet mainly of basalt, basaltic tuffs, and bree. cia. These bave been worn into the most orms. Mr. Jackson, the photograpber of the survey, pene. trated this region for the first time last ummer, and ob. sained from it some tainet frem it some most marvelotisly eantiful views of the scenery. I doubt whether there is a portion of the West where all the ele. ments of landscape beanty are more happily combined. Palace Cañon and Palace Butte are formed of stratified tuffs and breceia, and these palace-like forms are carved out of tive solid lads by the slow process of erosion by water. In the cañons, the limestone-strata frequently crop out from beneath 1,500 to 2000 feet in tialches of this rolenie material. The r. 2,000 feet in t th the report of Dr. Peale for the details of the geology of this most interesting region. From the East Gailatin to the West Ga!latin Cañon there are perhaps fifteen or twenty listle branches, each of which rises near the erest of the range and carves out a gorge from five to tifteen miles in length. Each of the:e cañons would afford a grand study for the geologisi as well as the photographer. But we could examine only a few of them. From the entrance of West Gallatin Cañon the view down the valley caunot be surpassed for beanty in this land of pictur. esque scenery. The gently-roling, grass-covered hills; the little streans meandering through theni, fringed on either side with a thick growth of cottonwoods; the nemerons farms, golden with their fields of wheat; and orer all, in the distance, that peculiar, soft, golden haze, which characterizes the autumn-days in this monntuin-region, lends to the whole vision a charm ihat is long remembered. As the setting san of autumn shines upou the valley and surrounding mountains, all objects seem to be invested with an unusual beauty, which reminds one of the lines of the poet:

$$
\begin{aligned}
& \text { And sweet, calm days, witb golden baze, } \\
& \text { Melt down the ambersky. }
\end{aligned}
$$

The little side streams that come in from the monntains, and the various main branches as they traverse the broad, grasky, rolling val. ley, with their fringes or belts of green cottonwood foliage, adiled mneh te the charming beanty of the scene. Then, hemming it in on every side, are fine ranges of mountains, which now seem depressed into low passes or are isolated, then rise or swell intc lofty peaks, which seem as it were to have been thrust up from the level plains around. Late in the day the atmosphere appears unusually elear and transparent, and rery peak and cañon stands out in a relief so bold that one seems able tc look into the very recesses of these grand ranges. So close do they appear to the beholder, and so distinetly are the details bronght out, that they seem to lose a portion of that dignity which arises from their grand loftiness. The mountains on the south side of the valley from Spring Cañon to the cañon of the West Gallatin are not very rugged, and are coveced more or less with timber and a vast amount of superficial material, concealing the rocks, except in the valleys of the streams. The valleys or gorges of the streams that issue from the monntains lisclose the strata of Carboniferous and Silurian limestones, and, though the beds are thrown into remarkable confusion, yet the general inclina. tion is evidently northeast. The great mass of the bowlders that are the cañons into the bottoms below is of igneous origin.

In the morning the east ranges are usually covered with a smoky haze which makes them appear distant and indistinct, while the ranges opposite the su* are bronght out with a singular relief. In no country ast the varied phases of scenery better shown than in this. For the attist this country must open up a new world.

IVe will now ascend the Gallatin Cuñon to the source of the river. This cañon had never been explored by any scientific party previously, aud even tue settlers in the open valley below knew nothing about it. A few harly miners had ascended it in search of precious minerals, The Gallatin River seems as it were to be crowded in between the two great rivers, the Yellowstone and the Madison, and it has therefore cut a continnous gorge through the rocks for more than severty miles, with walls on either side rising from 1,000 to 2,000 feet. As a geolog. ical section it has hardly a parallel in the West. On this account, as well as from the novelty of the region, I wisb to describe the cañon in detail.

Just on the west side of the Gallatin, aboat half a mi.e below the cañon, is a ridge of Pliocene sauds and sandstones, inelining at a slight angle from a thin series of arenaceous limestones. Then comes a ridge or two of the older limestones, probably Silurian, inclining 100. Taen mulernea $\mathrm{h}$, and farther up the cañon, the reddish feldspathic quariz. ites and c: her rocks apparently conforming at this locality. The river at the mouth of the caũon is 100 to 150 feet wide, and rolls swiftly over its rocky bed, with an average depth of 12 to 18 inches. There are well-marked terraces along the river, though not peculiar, like those on the Madison. At the lower portion of the cañon the gueissic rocks are well exposed, the hills on either side rising to a height of 600 to 1,000 feet, with the strata nearly vertical or inclining northwest. At first view the limestones seem to conform with the granitic strata, but the former dip northeast, the latter northwest, $50^{\circ}$ to $80^{\circ}$. The peculiar banded appearance of the gueiss is shown in a marked manner.

About three miles up the cañon, near the entrance of Spanish Creek, the Gallatin flows between uplifted ridges of limestone. The river flows nearly north, while the inclination of the limestone-beds is about northeast, and the cliannel is cut partly across the ridges and partly in the intervals between. So that on the east side the limestones present a remarkable wall of the outeropping edges of the strata, 1,000 to 1,500 feet in height. In looking directly at the wall the strata seem nearly horizontal, but a side view shows the dip to be $15 \circ$ to $\% 5^{\circ}$. On the west side of the Gallatin the strata incline like a steep roor and the ridges of areneceous limestone rise to a beight of 1,800 to 2,500 feet, and are undoubtedly of Jilurian age. Underneath the arenaceous 
limestone on the weat side of the river is a considlerable thiekness of the rusty-brown sandstones, pudding-stones, clays, \&ce, that elaraoterize the Silurian near the Three Forks; but these beds are thinniug ont very rapidly in their sonthward extension. Spanish Creek flows into the Gallatin from the divide on the west side, and nearly separates the unchanged strata above from the gneissic rock below. A few patebes of limestones occur here and there. In the limestones on the east side of the Gallatin, great quantities of fossils ocenr, Productus semireliculatus, P. Tongispinus, Strophomena analoga, Hemipronetes crenistria, and many others (see catalogue of Mr. Meek) of Carboniferons age. On the west side of the river thelimestone-ridges soon disappear and the massive granitoid rocksappear, rising toan enormous height, covered with great quantities of hnge fragments. On theeast side, the Carboniferous and Silurian beds extend up for about fire miles, when they slowly disappear over the summits of the granitie monntains. At first the Carboniferons lime stones extend down to the water's edge, but in ascending the river the strata rise rapidly until the entire mass is exposed, resting upon the granitic group. Although there is no positive non-conformity between the Carboniferons and Silurian, set there appears to be a well-defined physical line of separation. The Silnrian limestones are more massive, brittle, cherty, and have an ancient look, while the Carboniferous beds are more pure limestone, and with thin, well-defined layers. These upper limestones also have a more modern appearance. The sides of the mountains on both sides of the Gallatin, from crest to erest, are wonderfully rugged and picturesque. The limestones are frequently weathered into the most peculiar columns, while the granites are worn into grand, castellated forms. The crest of the ranges on the entire divide on the east side is composed of voleanic rock, while on the west side the central mass is granitic, rising in high, sharp peaks, 10,000 to 10,500 feet above the sea. The pines cover the sides of the mountains quite thickly in many places, sending their roots among the rocks where the descent is almost vertical. About ten miles above the entrance of the cañon the granitic rocka rise to the surface on the eust side of the Gallatin, and extend ten miles up the river in full force on both sides, rising quickly to a height of 2,000 to 2,500 feet above the bed of the river. At first, detached beds of limestone may be seen upon the high granite-walls, as they disappear upon the summits of the mountains. The little streams, as they flow down from the divides on either side, have cut fearful gorges through the granites. The narrow valley on both sides of the river is covered with immense rounded granite-bowlders, rendering the traveling very difficult. For a distunce of ten miles we were obliged to travel with our pack-train very slowly and with great risk. In no part of the West have we found a more difficult trail, and this may account for the fact that so few yersons have ascended the stream. As we crossed one of the little streams that flow inte the Gallatin from the west side, we observed that the water was very muddy. Mr. Sloane, a prospecter, who accompanie; us for protection while he was searching for mines, snspecting that somewhere near the head of the stream a fellow-miner bad found a good thing and was working it ont, quietly followed the stream up to it source. He found near the head that a few days before lightning hat struck the ground, plowing it up in long lines sometimes 100 yards or more and six feet in depth. The pines grew very thickly, but over an area 150 feet wide and about 600 yards long the trees were torn down and broken in pieces. Trees two and a half feet in diameter were broken off and were thrown several hundred yards down the stream.
As the water flowed over the broken ground it became muddy, and at its cutrance into the Gallatin looked like the water of a mining.guleh. $\mathbf{A}$ few dayn previously there was a terrific thunder-storm, accompanied by strong wind.

d bout twenty miles up the eañon the granitic rocks cease, and a remarkable ridge of limestones extends across the river with a trend abont sontheast and northwest. On the east side of the river the abarp ri rise up to is height of 1,000 to 2,000 west. The sides as well as the summits of these ridges are remarkably rugged and jagged. A little stream comes into the Gallatin from the Sphynx, a High peak on the divide between the Gallatin and the Madi. son. This stream has worn its rather wide grassy val!ey out of the sof materials of the Jurassie beds, leaving the harder Carboniferons and Silurian lying against the sides of the mountain-range like a huge wall extending from Cinnabar Monntain northwest across the Gallatin and Madison Rivers. The Gallatin River euts this ridge nearly at right angles. In the bed of a little stream on the west side several of the onteropping edges of the limestone-strata are seen which have been worn down to the level of the valley. This group of sedimentary strata forms the sonthwest portion of the antielinal of which the gronp of lime stones described a short distance above the entrance of the cañon is the northeast portion. We see, therefore, that all these rivers, the Madison, uortheast portion. We see, therefore, that all these rivers, the Madison, Gallatin, and Yellowstone, have cut their channels direetly throngh the range. Just above this range the valley expands to a mile in width, and the bills on either side are much broken and are so covered with the selimentary beils that the granitic rocks are seldom seen. In the bottom is a group of springs flowing frum beneath the limestones that are full of rauk, algous vegetation. The temperature of the water is respectively $54^{\circ}, 56^{\circ}, 55^{\circ}, 54^{\circ}, 43^{\circ}, 44^{\circ}$. These springs may once have been very hot, like those about the sources of the Madison. Warm springs are not uncommon at various points far down the valley of the Yellowstone as low as the month of Big Horn River. The Bilurian and Carioniferous strata are the same as those noticed on the opposite side of the range. Conforming to the Carboniferons limestones, 80 far as can be detected by the eye, is a group of sandstones, arenaceous limestones, clays, \&c., which are undoubtedly of Jurassic age. High up on the range on the east side of the Gallatin are patehes of the Cretaceons and Coal gronps, as seen on the Yellowstone near Cinnabar Monntain. Above the granitic portion of the cañon there is a marked depression on both aides of the Gallatin, and small streams flow into the river over the oofter Jumase beds. These beds incline at 80 great an angle for a distauce of only abont half a mile, when they abruptly become horizontal. In the elevation of the mountain-range in which the granitic nucleus bursts through the sedi. meatary mass, tipping off on either side the strata, the whole conntr was elevated to a .greater or less extent. The central or granitic mas was raised up in the form of peaks from 9,500 to 10,500 feet abore tide water, and the sedimentary beds were broken off and lie on the sides of the granitio nuclens in a nearly vertical position; while, a short distance above them, the crust was not so much affeeted by the force, the same above them, the crust was not so mueh affeeted by the force, the same
beds, though they may have been elevated to a greater or less height in beds, though they may have been elevated to a greater or less height in mass, still retain their horizontal position nearly. So we find a group of brown sandstones, conglomerates or pudding-stones, and quartzites passing down into clays, sandstones, and arenaceous limestones. Some of the limestone-strata are made up of an aggregate of shells which ap pear to be of the Jurassic age. We pass up the open valley of the Gallatin a distance of about four miles, with bigh walls of Jurassic 
strata on either side, forming an aggregate of about 1,200 feet in thickness. At the upper end of the little basin or open valley, the Carboniferous limestones rise up from beneath the Jurassie and soon form bigh vertical walls on both sides of the river. From this point to the sonree of the river, Carboniferous limestones prevail to a greater or less extent. For abont fifteen miles the river las earved out a cañon with the nearly horizontal strata of limestones rising with vertical walls on either side Sou to 1,200 feet. The incel than $1^{\circ}$ to $3^{\circ}$. The limestones are mostly in rather thin layers, but some of them form massive beds. The entire group presents the usual variety of texture common to limestones of this age. The fossils are quite abundant, and all, so far as could be determined, of well known Carbon. iferons typex. This part of the cañon is most picturesque; the high limestone-walls on either side are weathered into towers and Gothic piunacles and in some instances wonderfully grotesqne forms. It would harilly be possible to find as complete a section of the strata anywhere in the Northwest as is shown in this canion.

For the entire distance of seventy miles the river has earved its chan. nel out of the solid mass, most of the way hemmed in with narrow vertieal walls, but here and there expanding ont a little with a narrow open basin, but soon closing up again. We can bere obtain something like a correct estimate of the thickness of these groups of strata. I estimate the Jurassie group at 1,200 feet and the Carboniferons at 2,500 to 3,000, the Silurian group, 800 to 1,000 feet. From time to time we see some irregularities in the ntrata, but these seem to arise from local influences. But at a point in the Gallatin Valley, about opposite Cinnabar Mountain, the entire mass of sedimentary beds is again suddenly tilted at an angle $50^{\circ}$ to 7100 abont west or southwest. The entire series of beds seems to be exprosed here from the Silurian to the Coal group inclusive. The Jurassie grot! of beds inclines about $50^{\circ}$, but a little farther up on the west side of the Gallatin, and extending up toward the divide, are the Cretaceons and Tertiary (coal) groups, nearly in a horizontal posi. tion, cappes with basaltic rocks. In this valley, from crest to crest of the livide, the strata lave been throw in the divide, the strati have been thrown into the inost chantic positions. No system coula be nrought out of the confusion. Sometimes the lower limestones capped the highest hills and the youngest beds, as Cretaceous aud Tertiary would be found nearly horizontal in the lowest valleys on the divide between the Gallatin and Yellowstone. At one point we discovered a gronp of springs that deserves a notice here. These sptings gos a out of the sidle of the mountain from the limestones about 100 feet above the river, and in the aggregate form quite a stream of water. Great quantities of Calcareons tufa surround the springs, and the vegetation is remarkably luxuriaut. Helices are seattered thickly for some distance in every direction, sometimes giving the surface a snow-white appearance in the distance. These land-shells occur in greater or less abundance among the limestones. The river is now fed almost entirely by springs which issue from beneath the limestone-strata which prevail everywhere. The Jurassic, Cretaceous, and Tertiary occur only in isolated patehes. As we continue on up the valley we find it suficiently open for good roads, sometimes extending out one-fourth to one-half a nile in width. Grass is good, and in many places quite wide ravines extend down from the divide on either side that have excellent grass. For this resson this valley, or cañon, as it might be called, has been in times past a grrat resort for Indians. Traces of the camps are seen everywhere. The high walls that hem it in on either side furnished a protection, not only from their enemies, but from high winds and severe cold. A tribe could remain here an entire season well protected, while the young men could go out on either side among the mountains in search of game. At obe point great quantities of dry jines have been washed down from the mountain-side as if by a sort of local flood. The fires frequently run over the mountuins, killing the green pines, so that soon after they fall down covering the ground. Here they had acenmn lated in inmense piles, and the Indians had at some period coctanthem in building fortifleations for themselves and their animals, as pro. tection frotn their enemies.

The well-known Bamnock trail passes by this valley. Near the forks of the Gallatin some igneous rocks rise up from beneath the limestone 200 to 600 feet high. They are exposed for a mile or more, and appear to be the same as those composing the dike in the DeviPs Slide on the Yel. lowstone. The limestones have been pushed up, as it were, so that they incline from either side, passing down beneath'the general level from the igneous exposure. Several quite large streams come in on either side to form the Gallatin, each cutting a deep gorge throngh the roeks from the erest to the river-bed. The main branch rises at the foot of Mount Gallatin. A dome-shaped peak, which orerlooks the vallers of the Yellowstone and Gallatin, is one of the finest monntain in range, and commands a most extended view in every direction. The forces seem to have operated with great irregularity, breaking the limestone-crust in every direction and produeing chaos. Sometimes a great thickness of the beds is found in the lower valleys in a nearly horizontal position; again they cap the highest monntains, eitber inclining at greater or less angle from the sides or lifted up bodily to the summit. We have thus atternpted to describe in some detail the geologieal strue. ture of this remarkable valley. No man had ever looked upon it before with the eye of the geologist, and very few persons bad ever visited it for any purpose. The topography was entirely new. In a subsequent report, when we have to present a general view of the geology of the Northwest, we hope to make the subject still clearer by means of the beautiful illustrative-section taken by the artist of the expedition, Mr. Holmes.

We will now return to the Three Forks and record the few hasty notes taken on our return homeward by way of Helena. It is not possible to do justice to the geology of this most interesting region now, but at some future time we hope to return to this work again.

I have already described briefly the geological features of the country abont the Three Forks. The interesting synelinal shown in the cut extended toward the northwest. The stage-road to Helena passes along the northwest end, so that we conld see the relations of the sedialong the northwest end, so that we could see the relations of the sedi-
mentary beds to the underiying granites. We thns ascertained, what we had previously suspected, that the entire series of beds had been we had previonsly suspected, that the entire series of beds had been lifted up in such a way that they now all inelined more or less past a vertieal, varying from 200 to $45^{\circ}$. On the west side of this ridge the granitic rocks rise up from beneath the Silurian beds over a broad area. Many of them are much rounded from having formed the bottom of the old Plioeene lake. The irregularities of the surface are now filled up
of with these lake-deposits. Passing beyond the ridge northward toward Helena, we come to the broad valley of Crow Creek, about twelve miles wide, a stream which flows into the Missonri from the west. The ares which forms the drainage of this creek is underlaid with granitie roeks and rich placer-mines are wronght in the grolches of the grall boeks, Radersbugh was fonnded on the $6 \mathrm{os}$ 
still sustained more or less by them. The limestone-ridges, which ean be seen on either sicle of this broad valley, are only remnants of what must once have extended over a large ares of country. In the ridge west of the town of Radersburgh the lower strata are inverted, inclining past a vertical $45^{\circ}$, while the Carboniferous limestones stand nearly vertical, though the quartzites and red sandstones of the Jurassic are either vertical or incline past $5^{\circ}$. These red Jurassie beds I think are the same as those shown along the bauks of the Missouri, at the Great Falls. The thickness of these beds is greatly increased as we proceed northward, and at this point must be 1,000 to 1,500 feet thiek. The sedimentary beds extend to Indian Creek, and then suddenly disappear and then along the flanks of the mountains on the west side of the road only a great thickness of drift-material is seen. The little streams, which bave worn deep gulches into the monntain-sides, have also worn channels through the drift, exposing its thickness and character very clearly.

The placer-mines are very extensive. Some valuable silver-mines hare been discovered in the mountains. The Missouri Valley here is about twenty to twenty-five miles in width, with high ranges of mountains on both sides. From Radersburgh the road passes over the vertical edges of the dull, purplish Jurassic beds for twelve miles, to Indian Creek. The drift is made up of rounded bowlders mostly, and must be 300 to 500 feet thick. Extending eastward toward the Mis souri, in the belt of sedimentary beds between Radersburgh and Indian Creek, may be seen a rather level, rounded, cretaceous hill, so grassed over that few out-croppings could be observed. I bad very little opportunity of examining the roeks about Helena, bu: believe that they are mostly granitie, eapped here and there with strata of the Silurian age. It is also probable that there are remnants of Curboniferous beds in some places in the vicivity.

In passing along the stage road a little west of south from Helena to the valley of the Jefferson Fork, a fer patehes of the older Silurian beds are seen, while among the low hills the lake-deposits show that the entire country was a vast fresh-water lake at a comparatively modern period. The high hills on either side of the road are weathered into euriously rounded forms and covered with grass. Prickly Pear Cañon is a remarkable distriet for placer-mines. Water seems to be abundant. The rocks are mostly rusty.brown gneisses, weathering into forms much like those in the Laramie Range near Sheranan, Union Pacific Railroad. These granitic rocks extend to the source of Prickly Pear Creek, and the high hills on either side are covered thiekly with pines. Jef ferson City is located among the reddish-granitie hills. From the head of Prickly Pear Ureek we erossed the divide to the valley of North Bowlder, and in the valley on either side the massive granites rise in low, singularly-shaped columns, piles, \&c., giving to the region the appearance of old ruins. Wherever gold-mines are found, whether in the iodes or gulebes, we may be assured that the gneissic rocks are exposed.

We have up to this time been able to do little more than make a reconnaissance of one of the most interesting and instructive portions of the $T$ iest, in a geological point of viev. The reports of the surveys for 1871 and 1872 can certainly claim to be valuable contributions toward the geology of Montana and Idaho, and at some future period, when the country has become more easily accessible, the work may be resumed and carried on to completion.

We have thus far attempted to describe briefly the main geological features of the district explored by the party during the past season.
Nowhere in Montana have I fond the anticlinal folds or the synclinal valleys so distinetly defined as in the interior basin of Utah Still, there are frequent loea synelinals and antielinals, as we find them
developed below the Three Forks. The prominent features, however, are the widely-extended areas of elevation, though a single anticlinal may embrace several apparently distiuct ranges of mountains. Theoperations of the survey during the past season more strongly convipee position that I have so often taken in my reports of the onginally extended and continnons charaeter of the rentine is entire group of sedimentary strata; that where that continuity is broken it is the result of upheaval attended with erosion. It is possible that the later Tertiary group may not have been continuons, but existed in basins. But from the Silurian to the Upper Lignite group, inclusive, a thickness of 10,000 to 15,000 feet extended, in an unbroken, horizontal mass, over nearly entire area of Montana, and probably much more widely; and that what we find remaining at the present time are only remnants of this rast mass. Oceasionally the entire series of formations is exposed, as in the Bast Gallatin Range, where for twenty miles, on a line from east to west, the entire series of sedimentary strata may be seen from the Silurian to the top of the Lignite group in consecutive order. (See Fig. 24.) The groups of limestones and other rocks, as we see them inclining from the Yellowstone Range, in the Yellowstone Valley, show that they once ex. tended uninterrnpted $y$ orer the entire arealley, show that they once $x$. tended uninterruptedly over the entire area, where now mountain-peaks rise amid perpetaal snows, 11,000 feet above the sea. The Bilurian group increases in importance as we proceed northward from the Three Forks, and southward from that point it diminishes in thiekness and changes rery much its mineral texture. Toward the sonth we find little of the thin shaly and mud layers with the variegated sandstone, but in their stead, a quartzite passing up into a very hard, brittle limestone. Still, we believe that this grong in some form and with greater or less thickness underlies the greater part of the Rocky Mountain region. About the Black Hills of Dakota and the Big Horn Range, the Potsdam group presents a different mineral structure from the rocks of the same age about the sources of the Missouri.

The Carboniferous group, like most sea-deposited rocks, is very widely distributed. It is probable that it will erentually appear that this group of beds, as it is known, west of the Mississippi will be found to cover a wider extent of territory and to maintain a more uniformly similar mineral texture than any other formation in the scale. B reference to the list of fossils prepared for this report by Mr. Meek, it will be seen that, even in the most widely-separated loenlities, there is a similarity or identity in the organic remains. Old Baldy, at the bead of Alder Guleh, forms a portion of a limestone-ridge in which the series of beds is shown with a rertical thickness of 1,000 to 2,000 feet and extends off to the southwest, girivg origin to the Stinking Water, Black Tail Deer Creek, Red Rock Creek, and many others These beds have a genefal dip to the southeast. We believe also that the Jurassie and Cretaceons group bad a very wide extension, thongh perhaps not as great as that of the older formations. They bare been more extensively worn away so that at the present time they occur in fragments among the upheaved mountaiu-ridges and covering restricted areas. So far as the position of the sedimentary rocks is concerned, they may oecur at any elevation. The beds may pass under the lowest valleys or be found eapping the gneissic rocks upon the summit of the highest mountains. This is certainly not due to any inequality of the surface of the gneissie roek prior to the deposition of the succeeding beds, but unquestionably to npheaval. 


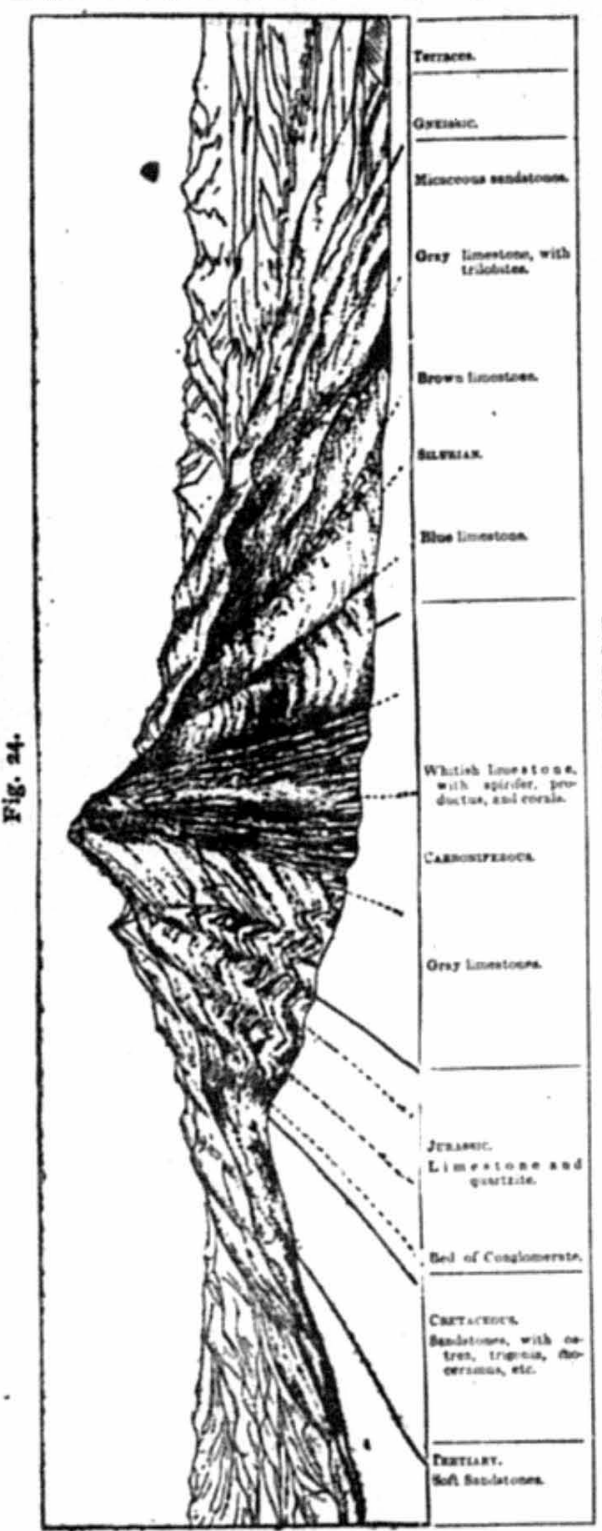

fontanah observed by the survey of the past seasons for the firs: time anu not noticed in such a marked degree in any other portion of Weat and that is in the inversion of the sed. imentary beds, so that the oldest incline at a greater or less angle on those of more modern ages. This phenomenon occurs at a number of places, but the most marked are in the mid. dle cañon of the Madi. son, at the head of Jackass Creek, and in the East Gallatin range. Several illustrations are given in this report which will reuder this matter clear. The fol. lowing illustration rep resents a section from resents a section from east to west through the East Gallatin range. (Fig. 24.) The Silurian strata incline past a rertical $30^{\circ}$ to $50^{\circ}$. The central pertions of the range ous limestones and are nearly or quite vertical, while eastward the Jn. rassic, Cretaceous, and liguitic strats incline vitions angles and pass down in step-like ridges to the valley of Shields's River, as they were gradually elevated by the uplift of the range. We will not enter into a discussion here of the origin of the forces that brought about these results, but it would appear that there were two in operation, one which raised the mass vertically, and a side or tangential force which crowded the Sllurian beds over past a vertical. In some instances all the beds are inverted from the Silurian to the liguite inclusive.

Another interesting point $I$ hare reserved for discussion at a more favorable time is the formation of cañons and valleys of the rivers, which enter into the scenery of the country as a most conspicnous fear ture. The fact that the streams seem to have ent their way directly ture. The fact that the streams seem to have cut their way directiy through mountain-ranges, instead of following synclinal depresaions, indicgtes that they began the process of erosion at the time of the commencement of the elevation of the surface. This is shown all along the ralley of the Yellowstone, and more conspicuousiy in the valleys of the Madison and Gallatin, which bave carved immunse can gorges directly through two of the loftiest ranges of mountains in Mongorges Weliere that the course of these streams was marked out at or near the close of the Cretaceous period, and as the ranges of mountains were in process of elevation to their present height the erosion of the channels continued. The details of the observations which con. tribute to form this opinion would occupy a chapter or two.

The superficial or drift deposits which some times attain a great thick. ness are regarded as of loeal origin. As I have so often stated in my previous reports, $I$ have never been able to find sny evidence in th Rocky Mountain region of what is usually termed a northern drift. There are many other points of great interest which, if time and opportunity occur in the years that are to come, we hope to treat as exhausttring as our observations will permit, and we regret that we have not been able to make more than a passing allusion to them in this report.

The brief report of Hon. N. P. Langford, superintendent of the Yellowstone National Park, who accompanied the Snake River division, will be read with great interest for its practical character. The thanks of the survey are extended to him, not only for the interesting and val uable report, but also for the great services he rendered the party while on the ronte. The remarkable feat of Messrs. Stevenson and Langford in ascending the Grand Téton, which will soon become familiar to the reading public through the pages of Seribner's Monthly, will always invest this region with an interest second only to the wonders of the National Park.

I had expected a valuable report from Mr. William Blackmore, who accompanied the surrey for sereral weeks as a guest. The survey is under many obligations for most raluable services from this very liberal and intelligent gentleman, and it is prond to regard him as one of its four houorary members. It is probably dne to Mr. Blackmore's absenee in Europe that we are deprived of his valuable views in regard to the laying out of the park.

I would also eall attention to the report of Mr. Hering, which we bope will be useful to railroad-men as well as to the general public. 


\section{REPORT OF N. P. LANGFORD ON THE RESOURCES OF} SNAKE RIVER VALLEY.

DeAR SIR: In conpliance with your request, I herewith submit for your use a connected report of the observations I was enabled to make while accompanying that portion of the geologieal survey under the superintendence of Mr. James Sterenson, from Fort Hall, Idaho, to the Geyser Basin, Fire-Hole River, and thence down the Yellowstone and on to the Three Forks of the Missouri. The only knowledge that conle be obtained of the country through which we were to pass was derived from old trapners, and such accounts as, upon the faith of his informants Mr. Irving had incorporated in his interesting volumes of Astoria and Bonneville's Adventures, neither of them very flattering pictures.

One grand object of the surrey, nest to a topographieal description of the country, was to ascertain its adaptability for wagon-road and railroad improvements and its industrial resonrces. If it could be made accessible by these means, it would present a new, practicable, and much shorter route for travel from the Union and Ceutral Pacifle Rail reads to the settled portious of Montana Territory and to the great wonders of the Upper Yellowstone; and it was especially with a view to determine this question that I noted the general appearance and character of the country.

To any one who has ever read in the writings of Mr. Irving the varions descriptions of the Upper Valley of snake River, the idea of penetrating it by a railroad wonld seem lndicrons in the extreme; but in these days, when railroads go everywhere that civilization goes, we may venture the confldent assertion that the day is not far distan when the obstructions of this hitherto unpromising region will be wholly subdued by them.

On that part of our route lying between Fort Hall and the North Fork of Snake River, the country is in a great measure barren, being, for most of the distance, a sandy plain. There are a few rocky eminences between Snake River Bridge aud the North Fork of the river; none, however, which would require a grade of over 50 feet to the mile or any great deriation from an air-line. Any road along this part of the route would follow the general course of the river, crossing its meanders, which are neither numerons nor large. Much of the Upper Valley of Snake River presents on either shore a level table of trap-rock, which could be utilized as a road-bed with great advantage. The most difficult part of the entire route, as I conceive, would be between Market Lake and the month of the North Fork. Onr party deflected on this route from a direct course of travel so as to visit the Three T6́tons, the famous mountain land-marks of Snake River Valley. This journey took us some twenty-two miles out of our course. Soon after crossing the North Fork, we began to meet with evidences of a more promising country. Bunch-grass was found in the richest profusion, and after a few days' travel we entered the T'éton Basin, which lay spread out before us like the land which Lot saw when he parted from Abraham. This basin is more than eight hundred square miles in extent, is cov. ered with perennial grasses, well watered by large streams fringed with an abundant growth of cottonwood, furnishing sufficient timber for al the practical purposes of life, while the adjacent mountains are covered with tall pints, furnishing the fuest timber in the world. The soil, receiving its nutrition from the detritus washed down from the monntains and from the deposits of frequent overflows, is rich, deep, and strong,
yielding readily to culture. Ample facilities for irrigation are afforded by the river and small streans that feed it. There is not a finer stock raising region on the continent. Favored in its location with a dry, pure atmosphere, rain occurring only for a few days in the spring, snow seldom falling in the valley of sufficient depth to bury the berbage, and the weather, with the exception of an occasional day in winter, never $\checkmark$ cold as to render a shelter z zcessary for eattle, it seemed to us to unite more of the needful elements for successful stock-raising than ayy other equal portion of the mountain-region. My opinion in this respect hat been fully realized by the experience of eattle and sheep raisers in like regions of Montana, who upon these extenisive valley ranges, which afford constant and abundant food both winter and sum. mer, producing beef and mutton equal in fatness and superior in flavor to the best stall-fed meats of Illinois, bave found the country peculiarly fuvorable to the increase of their flocks and herds. Heifers give birth to young oftener at the age of fifteen to eighteen months than at any later period. Frequently those of more mature age produce twins, and with many flocks of ewes a single lamb at a birth is an exception to the common experience. Disease of any kind is unknown among cattle and sheep, and it is only when the snows are very deep and the weather very cold that they suffer from exposure. With ordinary care and provision this exigency could be easily anticipated. In addition to the Téton Basin, there is enough of the Territory which we passed through that is thus favored to feed millions of cattleand sheep for all time to come.

Nature has furnished this far-away region with a valley and river sys. tem peculiarly adapted to its isolated geographical position, and with. out which, even in its present form, it would be comparately valueless. Cast your eye upon the map at the junction of the three streams which form the Missouri, the Jefferson, Madison, and Gallatin. Each of these rivers, divided from the others by lofty mountain-ranges, flows through a broad and fertile valley of great extent and beauty. These valleys are from sixty to eighty miles in length, with an average width of ten miles. The Gallatin is the largest and most picturesque, and, perhaps, the best adapted of the thrce to all the purposes of culture. The river, which from its source to its mouth is a continuous torrent, divides the valley centrally, and furnishes, by its deposits, a black soil of a mile in width on either side, which is covered for the most part with a dense, beavy growth of cottonwood, suffleient for all the purposes of fencing and fuel for many years to come. Outside of this continuous grove of cottonwood, the valley spreads away on either side of the river a distance of six or eight miles, to the low grass-covered foot-hills, which in their turn extend to the base of parallel ranges of lofty inountains. Every foot of the land thus inclosed, embraciug a territory nearly as large as Ver. mont, affords in its natural condition the richest pasturage in the world. By the simple cultivation of the plow and harrow, it can, in a single sea. son, be converted into a wheat-field which will yield an average crop of son, be converted into a wheat-field which will yield an average crop of
fcrty bushels to the acre. Crops of vegetables raised in this soil will average, in size, one-third more and some-cabbages, turvips, and especially beets-one-half more than the best ruot-crops of the Western States. I have never seen such abundant and perfect crops of wheat, oats, barley, potatoes, and all vegetables, as are commonly raised in these valleys. Indian corn, unless of the small flint variety, is an un. certain crop, on account of the early frosts, and but very little has yet been raised for harvesting. 
The climate of these valleys is very dry, no rain of ant consequence falling during the summer months, but this want is supplied by cheap and simple process of irrigation, under which, from the fact that water can be supplied in abundance whenever it is needed, crops thriro much better, are much larger, and more perfect than when they are de. pending upon the uncertain, capricious, and often untimely visits of rain. Ditches for irrigating purposes are either connected with the river or some of the mountain-streams that feed it, and are extended throngh contiguous ranches by farmers, who make of them a joint-stock property. The two enemies which have been most dreaded by the farmer thus far are the grasshopper and early frost. The first of these has now disappeared; the latter is orercome by early sowing and planting; and the wheat-crop is now regarded as more certain in these valleys than in any of the States. It is also, as a general thing, from twice to three times more abundant. But few experiments have yet been made in fruit. raising, but the prospect for the successful culture of the hardy varie. ties of apples and pears is very good.

What $I$ have here said of the valley of the Gallatin is true of all the valleys embraced within the limits of the snmmer's explorations.

At the agricultural fair held in Helena in September last, the exhi. bition of farm products from these vallers would have been creditable to a much older community, and the stock, mostly of our own native variety, would have put to shame mauy similar exhibitions in the best of our stock-raising States. There is not one-tenth part of the arable lands of these valleys yet occupied, though the development of their productive qualities during the past two years has turned the attention of many of the inhabitants engaged in other pursuits to that of agricul. ture.

There is another resource to which I have barely alluded, which, for years to come, must render this region a desirable locality for a large class of producers. I mean its facilities for stock-raising. It is covered with the richest pasturuge in the world. The bunch and buffalo grasses of the plains and mountain-regions, unlike the tame grasses of the States, are perennial. At the earliest approach of spring, and before the snow has left the bills, they begin to appear fresh anil green. The spring rains, which, though of brief duration, are in many localities profuse, give them strength and expansion and they retain their verdnre throngh the heat of midsummer. The dryness of the season prevents their decay, and the heat of the sun gralually cures them in the blade, so that they motain all the nourishment in the dried stalk and leaf of the best-preserved hay. They continue in this condition thronghont the winter, and, at all times, except when storms are excessive or snows are very deep-not common occurrences in the valleys-tbe cattle feed upon them and grow fat through all the cold months. Farmers and owners of large herds of eattle, who put up hay as a precautionary measure, seldom have occasion to use it at all, and never unless an exi. gency like that I have just mentioned ocenrs. In the spring the green blade shoots out from the root of the previous year, imparting renewed life to the entire herbage of the valleys and adjacent foot-hills. With the exception of the mountain-ranges, which are either bare rocks or covered with pines, the surface is one entire pasture. No country in the world affords superior facilities, uniting convenience with economy, to stock-raisers. The meats perfected on these grasses are extremely fat and succulent and of rich flavor. The produets of the dairy are proportionably larger, and the ranchman whoowns a dozen good cows in the vieinity of any of the larger towns has in his possession the elements of a comfortable present subsistence and of a certain fortune in the futnre. Milk, butter, and cheese command a ready sale, at high prices. Already numerous flocks and herds are to be seen in these val. prices. Already numerous flocks and herds are to be seen in these val. of stock-raising, with a dozen cows, are now the owners of herds num bering hundreds.

There are large bodies of land in the Téton Basin, and in the valleys along the streams flowing into Snake River, which may be profitably cultivated with wheat and vegetables. Water for irrigation in abund. ance, flowing from the surrounding mountains, may be cheaply and easily utilized. A railroad along the north fork of the Snake would pass within ten miles of this basin, and the ronte for this distance conld be readily improved by a wagon-road. The foot-hills and mountains surrounding the valley are covered with dense forests of pine. Lum. bering must ultimately become a very extensive and profitable branch of business over nearly all parts of the route from Market Lake to the Yellowstone. The streams are very numerous, and all furnish abundant water-power for both saw and grist mills. There is no better market for this product in the west than western and northern Utah. This business alone will, in time, warrant the construction of a railroad orer this route, to say nothing of its varions sources of revenue derivable from a connection with the settled portions of Montana Territory.

We carried out the intention, with which we started, of visiting and properly locating the three Tétons, and of ascending to the summit of the highest of them. Assured by our guide, and others who had long been familiar with the conntry, that it would be impossible to clamber up this mountain, that though repeatedly attempted it was a feat which had never been achieved, we did not undertake the task without great misgivings as to the result. The most northeriy, or Graud Téton, whteb has received the name of, and will hereafter be known as, Mount Hay. den, presents to the eye an ontline very similar to that of the Matterhorn in the Alps. Its very appearance, unlike that of most of our mountains, seems to forbid all attempts to seale it, and for most of the distance the ascent can only be accomplished by climbing with both feet and hands. The face of the mountain presents an angle never less than $45^{\circ}$ and frequently $60^{\circ}$, much more abrupt than the steepest stairways. Glaciers of greater or lesser dimensions are met with every few hundred feet, and in several instances they proved almost insurmountable. The irregular stratifications of the rocks were often such as to leave us with no support other than our hands at points and turnings where a failure in our hold would have precipitated us hundreds of feet down the face of the mountain. At one or two points when nearing the summit we would have been obliged to abandon the task but for the aid we : 3 . ceived by easting a rope over prominent projections and pulling ourselves over them, to places where we could obtain secure footholds. In one of these efforts Mr. Stereason came near losing his bold and falling down a precipice nearly a thousand feet. Another of our company, while ascending along the edge of a glacier, losing his hold, slid down a smooth ridge of ice, a distance of 40 feet, with fearful rapidity. His own presence of mind, in hastily throwing bimself astride the edge of the glacier and descending it in that position, cansed him to fall into a snow-bed at the bottom, and on the extreme edge of the preeipice. This saved him from falling at least 800 feet. Of nine of the company who commenced the ascent Mr. Stevenson and mrself were alone succenth of the mountain, evidence that at some former period it had been visited 
by human beings. There was a circular inclosure about seven feet in diameter, formed by vertical slabs of rongh granite, and about three feet in height, the interior of which was half flled with the detritas that long exposure to the elements had worn from these walls. It could not have been constructed less than half a centary ago, when Indians only inhabited this region.

The summit of the Téton is very small, not more than 30 by 40 feet in diameter, with a precipitons descent on all sides. Its height, by tri. angular measurement, is 13,833 feet. The view from it embrices the valley of the Snake River and territory contiguous, over a diameter of at least one hundred and sixty miles. For grandenr, vastness, and va riety it is nowhere excelled in the region of the Rocky Mountains. Should the railroad to the Upper Yellowstone pass through this valler, the Téton Range would form one of the attractire features of a visit to that wonderful country.

On our descent of the mountain, while yet at a height of 10,300 feet, we crossed a lake, 600 yards long by 200 wide, of perpetual ice, which in thickness was about three feet, not unlike in character the descriptions giren of the most elevated glaciers of the Alps. Passing over the immense snow-fields which covered the platean adjoining, we descended into the grass-covered valley which bordered the Téton Kiver, and pursued the most direct course to the north or Heury's Fork of Snake River. Along the margin of this stream we traveled over a solid natural road-bed to its source in Sawtelle's or Heury's Lake. This part of the country is peculiarly favorable for railroad improvements. The grades would be very light, not exceeding 20 feet to the mile, and for much of the distance very little, if auy, excavation would be necessary to prepare the ground for the : rack. There are some obstructions from fallen timber along tho entire rouk, which can be removed without dif ficulty. Doubtless in a conntry so fill of irregularities of one kind and another, the toot-hil's and mountains would present occasional interruptions to a direct 'course, but it surprises one, in passing over the country, to see how few these interruptions are and how realily they may be overcome.

In our explorations from the Téton Basin to the north, we carefully observed the four passes on the north, east, west, and south of Saw. telle's Lake, each one of which will doubtless be particularly described by Mr. Stevenson. These passes are equally farorable for all kinds of rond improvements. Our company passed through the east or Tyghee Pass, entering the valley of the Madison. Noperson nnacquainted with the topography of the country would believe while crossing this pass that he was crossing the summit of the Rocky Range. The same may be said of the other three passes in the immediate vicinity, each pointing to a separate point of the cumpass. From the point of entrance into the valley of the Madison, down that river to its junction with the Jefferson and Gallatin at the Three Forks, there are no serious obstructions to a railroad. Two of the cañons would require, perhaps, to be shelved for a roadway, in all, for a distance of about twenty-five miles. No more direct route for a railroad from Utah to the settled portions of Montana can be found than that from the junction of the Union and Central Pacific Railroads to Fort Hall; thence up Snake River to the head of the North Fork; thence by either the Sawtelle or the Targee Pass, down the Madison to the Three Forks, passing within twelve miles of Virginia City, the capital of Montana; thence, through the valleys of the Missonri and Prickly Pear, to Helena; and there are no engiueering difficultie which canuot be easily overcome.
An enterprise of such comprehensive ntility as this road should not suffer a moment's delay in the work necessary to its speedy completion for want of capital; for where can an investment be found which will be safer or more certain of a profitable return ?

A singie caleulation based upon one source of its revenues will demonstrate how speedy, certain, and abundant must be the return made by this enterprise after its completion. The present population of Montana, at a very moderate estimate, is twenty-five thousand, who are all anxiously looking forward to the time when they will be counected with the States by rail. Suppose (and this ealculation, at the prices which now prevail in Montana, and which the inhabitants of that Territory can afford to pay for all the necessaries of life not obtainable from the soil, is much too low) that each one of this number pays an average sum of 8200 more per annum for groceries, dry-goods, wearing apparel, \&c. than at Omaha or San Francisco for like articles. As the merchants of Montana do not make greater profits on their sales than do the merchants of those cities, this 8200 per capita, aggregating $85,000,000$ per annum, is paid for the transportatiou of goods, the larger portiou of it being now received by the Upper Missouri River transportation companies, but which will nearly all go into the treasury of this road when completed, to be shared by it with the Union Pacific and Central Pacific Railroads. With the tide of emigration flowing into this Territory in anticipation of the completion of this road, it is but reasonable to suppose that this population will be doubled when that event occurs. Of course the revenue will be correspondingly increased from this one source, but by no means the most profitable source of income to the road.

To this is to be added what the road may reasonably anticipate from the great-wheat fields of Montana, from its inexhaustible timber, from it silver-mines, from its stock-growers, and from the great stream of transieut travel for business, pleasure, and obsersation. A few years only can elapse before the marvels of the Upper Yellowstone, its gey. sers, boiling mud-springs, and sulphur monntains, the Great Falls of the Missouri, the singular scenery of the Bad Lands below Fort Benton, the picturesque beauties of the Prickly Pear Cañon, and the stupendons architecture of the Rocky Mountains will attract thousands of visitors annually to that distant country to view the wonders of nature and the grandear of our mountain-scenery. This enterprise cannot without sacrifice ig delayed a day louger than competent force, abundant means, and ample material require to convert the project into an established and

There were rery many incidents connected with our journey which would prove of great interest to the general reader. Many of these have met the pnbiis eye through the correspondence of the gentlemen who accompanied us, and others doubtless will be used to embellish the various articles which may hereafter appear in our magazines, deserip. tive of the marvelous region which we explored. Let us hope that the time is not far distant when the geysers, cataracts, lakes, hot springs, and magnificent mountain scenery.of our national park will become as familiar to the world of art as Niagara and Yosemite, both of which they so greatly surpass.

$$
\text { N. P. LANGFORD, }
$$

Dr. F. V. HAYDEN Superintendent of the Yelloucstone National Park. United States Geological Survey, Washington, D. C. 
MEANS OF ACCESS TO THE YELLOWSTONE NATIONAL PARK BY RAII ROADS.

SrR : As the park will soon become an object of general interest, and be the resort of thousands of visitors, the question of proper and convenient access is of great importance at present. A journcy by wagon from the Central Pacific or Northern Pacific Railroads would prove long and tedions; we must, therefore, look for a railroad to carry tourists within a much shorter distance from the park, allowing, if any, but one or two days' journey by wagon. A project for such a road has already been conceived but enconntered pecuniary difficnlties sufficient to im. pede its immediate construction. As this line would become the main route connecting the Central Pacific or Union Pacific Railroad with the Northern Pacific Railroad, and also furnish the best means of reaching the land of wonders, a few detailed remarks in regard to distances and elevations will show its entire practicability.

Branching off froin the Central Pacific Railroad at Corinne, Utah, the line would run up Malade Valley with a very gradual and regular ascent toward the north, cross the divide from Salt Lake waters into Pacific waters, with a grade of not more than 100 feet per mile, follow down Marsh Valley to the Port Neaf River, and wind with a grade of less than 30 feet per mile into the open and flat conntry west of Fort Hall. The distance from Corinne to this point would not exceed one hnndred and twenty-five miles. It wonld then take a northeasterly course for about sixty miles and cross Snake River at a point about five miles east of the mouth of Henry's Fork. This conntry being gen. erally level, the question of grade conld not be of interest. From that point the route would be unquestionably taken toward the north-northeast, following up the valley of Henry's Fork to the lake near its Rource, where it wonld be two linndred and thirty-five miles from Corinne. Thenee per mile into the Madison Valley, it would follow it down to the settlements of Montana and connect with the Northern Pacific Railroad.

From points along this line either wagon or rail roads can be built with no unusual expense to all the principal parts of the park, and I will now endeavor to give as detailed a statement of the most practica. ble lines as a general reconnaissance of the ground will permit. This railroad would give access to the park from- the sonth and west. The country east of the park appears to be unfitted for approach by roads, as the Big Horn and Wind River Mountains form a continnous, steep, and rough barrier.

The principal objects of interest within the limits of the park to be reached by roads are the Geyscr-basins, the Yellowstone Lake, with Monnt Sheridan to the south, and the Grand Cañon of the Yellowstone, including the Falls. Mammoth Hot Springs can be passed on a line of a northern approach from Fort Ellis, which has been examined by Mr. Gannett. As these points are all situated on the Atlantic slope, and the proposed railroad from Corinne to Montana is in the valley of Henry's Fork, which drains into the Pacitic, and where we intend to branch off, it will first be necessary to examine the passes over the main Rocky Mountain water-shed. There is in the sonthern part of the park a very tlat, open pass, if at all deserving that name, situated between Lewis and Yellowstone Lake, which can be crossed with a grade of only
90 feet per mile. Farther west another low divide is found between Shoshone Lake and the Fire-Hole River, which can be passed with a grade of not over 105 feet per mile. Following the water-sbed in a northwesterly direction it gently varies in elevation and can be croseed by wagon-roads at many points. For a railroad the Tyghee Pass is the next and last available one. Another obstacle in the way of approach from the sonth of the park might be seen in the Téton Range, but on closer ezamination a pass is discovered near the sonthwest corner of the closer ezamination a pass is discovered near the sonthwest corner of the
park where that grand ehain diminishes so considerably in height and park where that grand chain diminishes so considerably in height and Finding no serious obstruction, therefore, we proceed to consider the special locilities best alapted for lines of approach.

Commeneing in the sonth we first propose a route which is equally well suited for a wagon or rail road, as the grade is es 7 and water and timber are abundant.

Leaving the above-described proposed railroad from Corinne to Montana a few minutes north of the forty-fourth parallel, in the valley of Henry's Fork, it would run eastwardly, following up the valley of Falls River. For thirteen miles the average grade would be 41 feet per mile for the next twenty miles it would be 61 feet per mile, which would bring the road to the western slope of the Teton Range through a slightly undulating country. At the month of Falls River Pass the most diff. cult portion of the whole line would commence and extend for six miles up to the divide near the Beulah Lakes. It would require an average grade of 96 feet per mile, reaching an elevation of abont 7,525 feet. The valley ascends gradually and presents no serious difficulty in obtaining a uniform grade for the entire distance. In entering Falls River Pass we, at the same time, enter a gateway of the park, as the boundary-line crosses at the entrance. Gradually ascending, the road leads through a fine valley a few miles wide, bordered on both sides with rocky blufis, inclosing a beautiful river which, taking its source from five enormons springs breaking ont of the steep rocky walls and thence flowing through the Lower Benlah Lake, descends the valley in a number of rapids and falls which have suggested its name. The largest fall, 145 rapids and falls which have suggested its name. The largest fall, 145 much like Tower Falls near the Yellowstone River. After reaching the lakes, the road would continue eastwardly for about six miles, rising with a very slight grade and following the northern slope of the valley over a divide hardly perceptible, and not to be located withont careful examination. Here it reaches the valley of the Union or Lake Fork of Snake River, entering upon a platean or mesa from which the river can be seen several hundred feet below, flowing through a steep and gloomy eañon. On either side of the cañon the ground is gently rolling and is well fitted for a road, especially upon the eastern bank. Follow. ing nearly parallel with the river a distance of eleven miles, we would be bronght to Lewis Lake, at the foot of Mount Sheridan, which could be easily visited from this point. It is the loftiest peak of a prominent group, entirely surrounded by comparatively flat country and affording the most extensive panoramic view of any mountain in the park. A more minute description of this peak can be found elsewhere in the report. From Lewis Lake it would be advisable to separate into two branches, one taking a northwesterly course to the Geysers and another a northeasterly to the Yellowstone Lake, River, aud Cañon. The firstmentioned could take the following route: About ten miles on a level to. Shoshone Geyser Basin; thence four miles, with a grade of 70 feet 
per mile, to the main Rocky Mountain divide, at an elevation of 8,717 seet, from whence a descent of 105 feet per mile for five miles would bring the line into the valley of the Fire-Hole River; following this river for an additional five miles, with a grade of 37 feet per mile, the railroad would be amidst the grand geysers of the Upper Basin. Proceeding eight miles further, with a descent of 17 feet per mile, it would arrive at the Lower Basin, which would form the terminus to this branch of the line. The other, diverging northeasterly from Lewis Lake, wonld cross the main Rocky Monntain water-shed within flve miles, at a grade of $\mathbf{4 3}$ feet per mile, and descend to the Hot Bprings at miles, at a grade of $\mathbf{4 3}$ feet per mile, and descend to the Hot Springs at
Yellowstone Lake within three miles, at a grade of 94 feet per mile. No Yellowstone Lake within three miles, at a grade of 94 fcet per mile. No
diffenity in grade wonld now be met with either along the shores of the lake or down the valley of the Yellowstone River to the falls and Grand Cañon.

The following is a review of distances and elevations on this route, commencing at the point where it would leave the main railroad in Henry's Fork Valley.

\begin{tabular}{|c|c|c|c|}
\hline , & $\begin{array}{l}\text { Dintance from } \\
\text { Heury's Fork } \\
\text { is miles. }\end{array}$ & $\begin{array}{l}\text { Distance from } \\
\text { Coritune in miles. }\end{array}$ & $\begin{array}{l}\text { Elevation } \\
\text { in feet. }\end{array}$ \\
\hline 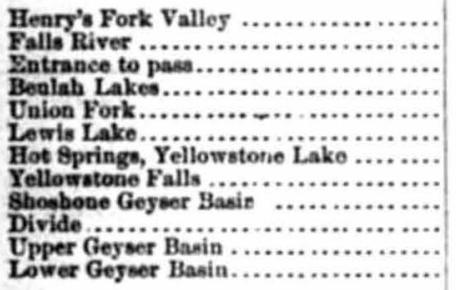 & $\begin{array}{r}0 \\
13 \\
33 \\
39 \\
45 \\
56 \\
64 \\
94 \\
66 \\
70 \\
20 \\
08\end{array}$ & $\begin{array}{l}145 \\
158 \\
178 \\
144 \\
190 \\
201 \\
909 \\
290 \\
211 \\
215 \\
225 \\
2.01\end{array}$ & $\begin{array}{l}5,130 \\
5,600 \\
6,200 \\
7,605 \\
7,800 \\
7,828 \\
7,788 \\
7,700 \\
7,800 \\
8,717 \\
7,790 \\
7,200\end{array}$ \\
\hline
\end{tabular}

Having thus followed the entire line of the route through Falls River Pass to the principal points of interest, we now will examine a second route running through the Tyghee Pass, which presents equal facilities for a railroad.

Leaving the proposed Corinne and Montana Railroad at Henry's Lake, a distance of six miles with a slight upward grade would bring it to the Tyghee Pass, and the divitle could be reached within four miles, at a grade of 130 feet per mile. The Madison or Fire-Hole River Valley now lies open before us, and, gradually descending, the line would fol. low the northern slope of the mountains down to the level of the river. With a gradual ascent of 10 feet per mile it wonld follow up the valles, entering the park at the entrance to the cañon to Gibbon's cance of twenty-three miles from Tyghee Pase Trom tance of twenty-three miles from Tyghee Pass. From this point the Lower Geyser Basin is reached within eight miles, at a grade of 70 feet per mile, where the line would connect with the first route described as approaching the park throngh the Falls River Pass.

The following statement of distances and elevations along the second route, starting at Henry's Lake, will review the line:

\begin{tabular}{|c|c|c|c|}
\hline & $\begin{array}{l}\text { Distance from } \\
\text { Henty's Lake. }\end{array}$ & $\begin{array}{c}\text { Distance from } \\
\text { Corinne. }\end{array}$ & Elevation. \\
\hline 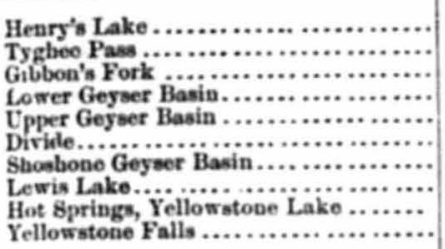 & $\begin{array}{r}0 \\
10 \\
33 \\
40 \\
48 \\
58 \\
62 \\
72 \\
80 \\
110\end{array}$ & $\begin{array}{l}235 \\
245 \\
248 \\
275 \\
203 \\
983 \\
297 \\
307 \\
315 \\
345\end{array}$ & $\begin{array}{l}6,443 \\
7,063 \\
6,808 \\
7,200 \\
7,390 \\
8,717 \\
7,881 \\
7,815 \\
7,789 \\
7,700\end{array}$ \\
\hline
\end{tabular}

Alistance of six miles may be sared by running from divide directly to the outlet of Fellowstone Lake. By a comparison of the two tables of distances an opinion may be formed as to the best route. Both are within a short distauce of rivers which never run dry, and both run over thickly.timbered lands. In all the high regions of that country there is but little soil and, therefore, excavations are mostly rendered vory expensive by being in roek. However, this is a disadvantage pertaining equally to both routes and, therefore, favoring the shorter dis.
tance. All the trappers throughout the whole region state, concerning tance. All the trappers throughout the whole region state, concerning
the climate during the winter, that, although there is heavy snow, it is rarely aceompanied by winds, so that drifts are rare exceptions. This will also apply equalls to both routes and the maintenance of railroads generally.

Hoping sincerely that the above will furnish an incentive toward opening this grand and wonderful park to the multitudes, both at home and abroad, that are ever anxiously seeking instruetion and pleasure, I remain, yours respectfully,

Professor F. V. HAYdex,

R. HERING. 


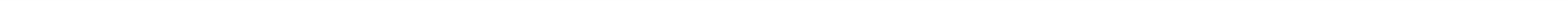


REPORT OF A. C. PEALE, M. D.

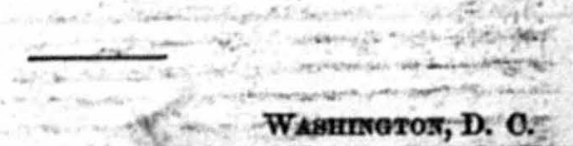

DEAR SIR : I have the honor to transmit herewith my report for the

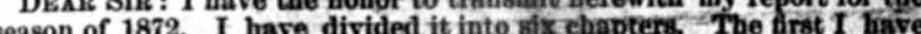
devoted to the description of a short trip inte Uplorado and Utah, made before the organization of the party was comphted. The secondehapter to Gardiner's River, in the Yellowstone National Parts; including an account of the Hot Springs at the latter place. The third chapter contains a description of the springs-in the Yellowstone Valles from Gardiner's Rirer to Yellowstone Lake. The fourth chapter is devoted to diner's Rirer to Yellowslone Lake.

the geyser-basins of Fire-Hole River.
The time we were in the geyser-basins was somewhat Timited, and the observations must thereforo be to some extent necessarily incumplete. To work up this most interesting section thoronghly will require the time of at least one entire season, so that data may be obtained as to the influence the different portions of the year. may have upou the geysers. Then, also; more could be definitely learned in regard to their gegsers. Then, aiso; more irregularity. As far as the time permitted, I have endeav. regularity or irregularity. As far as the time permitted, I have endeav
ored to make the observations as complete as possible. ored to make the observations as complete as possible.
At this point I wish to express ny thanks to Dr. F. M. Kndlich, of the Smithsonian, for assistance rendered in analysis. That $I$ am able to present so many analyses, especially of specimens irom the gessers, is due largely to his assistanee. I wish also to refer to Mr. W. B. Platt,

of the expedition, who aleo assisted in analysis. My fifth and sixth chapters I have devoted to the consideration of the
Jadison and Gallatin.Valteys. Appended to the repcrt arecafalogues of the rocks and minerals colleoted during the summer? I have incor porated in them the specimens colleeted by both branches of the expe. dition. I have also done the sating in the cataloge of thermar sprines, which is apıended to the report. In the latter catalogne I bate-for thie sake of comparison, ineluded observations of some of the spribga taken
in previous years (prineipally by Loog and by Fremont) wherever there was no donbt as to the localitien being the same.

The collections of geyserite this sear-are particularly-large, and present all the rarieties in form and texture to be found in the region.

In conelnsion I wish to exprees my thanke to allithe niembens of tho expedition for their nuiform kinduess and so-operation. I woula rofer particularly to Mr. T. O'C. Bloane, who for mbile acted as my assistant, particularly to Mr. T. OC. Sloane, who for while acted as my assistant
and who, by his zeal and aetivity, contributed largely to the collections, and who, by his zeal and aetivity, contributed largely to the collections.
To the editors of the "New York Intustrated Christian Weekly" I ain To the editors of the "New York IHnstrated Christian Weekly" I ain indebted for some of thest wood-cuts ifinstrating my report.

Trusting this report-may prove satisfactory, I have the honor toloe your obedient servant,

Dr. F. V. Harters

United States Ǵeologist.

A. O. PEATR. 


\section{CHAPTER I.}

COLORADO AND UTAH.

While the expedition was being organized at Ogden, Utah Territory, Mr. W. H. Jackson was ordered to make a photographie tour through a portion of Colorado. Fortunately, I was able to accompany him, and whiie assisting him took a few notes in regard to the lithology and, and ogy of the places we visited. Colorado City and Golden City and geol. prineipal points, and it is of them I will speak more particalarly. We were limited as to time, and the area over which we passed was so small that I shall have to restrict all I have to say to each immediate locality; still I hope it may not be without some little interest. We left Omaha on the 20th of May, and the following evening reached Deuver, in Colorado Territory. In passing, let me say a word or two about Denver. Thirteen years ago a log-cabin represented this city, that now contains a popula. tion of over 14,000 people, and which is in every way a thriviug and prosperous place, bidding fair to becoune the metropolis of the far West. Four years ago there was not even a mile of railroad in th's Territory, and to-day Denver is the center of five distinct lines of railroad, and still more are being built. The city is beautifully situated on the banks of Cherry Creek, about twelre miles from the moyntains. The plain upon which it is built is so covered with the superficial drift of the mountains that the underlying rocks are entirely concealed. There is little donbt, howevcr, as to what they are, for, as we proceed toward the mountains, we come upon the upturned edges of Tertiary sandstones, containing beds of coal, the tipping up of which is explained by the grand range immediately in front of us, from which Gras's Peas and Long's Peak raise their snowy heads, seeming almost to pierce the beavens. Leaving Denver we took the Denver and Rio Grande Railroad to Colorado Springs, gome seventy-six miles farther south. This railroad is a narrow-gange road, and the first of any length that bas been built. It threatens to work an important revolution in the railroad. system of the West. The road gradually ascends upon leaving Denver until we reach the summit of the Colorado divide. This is a spur or high ridge, projecting from the monntains at right angles to their tur It forms the dividing lome the waters of the Platte River and those of the Arkansas. It is very thickly timbered, and lumbering is carried on quite extensirely. The ascent from Denver to the summit of the divide is very gradual, nnd it is a little difficult to believe that one has ascended 2,000 feet. The elevation of the divide at the snmmit is 8,000 feet above the sea. Smoky-quartz crystals are found here quite abundantly, and are called topaz by the people. I was shown several good speeimens said to have been picked up near the railroad. The roeks as seen from the cars seem to be mostly red and gray Tertiary sandstones. From the divide the railroad has a gentle descent, and after a ride of twenty.four miles, passing some beantifnl scenery, we reach Colorndo Springs. This is a new colony, jnst established on time line of the railrosd. It is abont eight miles from the monntain. It site is covered with local drift from the hills. To the east the country spreads out into the plains. We spent several days at Colorado Springs, making e:cursions to the various points of interest. Our first day wa spent in the "Garden of the Gocis," about four miles northwest from Colorado Springs and two miles north of Colorado City. This interest. ing and peculiar place is a valley in the foot-hills of the range, and is inclosed by an almost vertical wall of massive sandstone of Cretaceous age. The rocks which we find inside have been subjected to an inmense deal of erosion, and the many ridges and tower-like forms lef standing throughout the garden are the remnants of the parallel strata which dip to the northeaet at a very great angle. In some places they which dip to the northeast at a very great angle. In some places they
Beem to dip a few degrees in the opposite direction. As we go toward the mountains, thedip deoreases. These rocks are fine-grained sandstopes, of a deep brick-red color, with here and there layers and spots of a lighter red, and sometimes white. The ridges are exposed for some distance to the north, while to the south, after bending toward the east, they ap. pear to be covered by the debris from the mountains. The entrance to the "garden" is through the "Beautiful Gate," an opening through one the "garden" is through the "Beautiful Gate," an opening through one
of the highest ridges of red sandstone. We cstimated the height of this ridge to be 300 feet. The northern end is considerably higher, and view. ing it so as to see the end alone the resemblance to the tower of a grand eathedral induced us to call it "Cathedral Rock." Another collection of rocks inside the "garden" had the name of "Montezuma's Cathedral." On the western surface of the ridge mentioned above, the water has worn quite a large care. The sandstone is very soft in most places and can be readily eruahed in the fingers. The softness is due probably to the effect of the weather. As we go toward the west the hardness increases. Outside of the red layers, and a few hundred feet farther to the east, there is a layer of white sandstone parallel to the red and tipped np at the same angle, sbout $70^{\circ}$. Ontside of this, and in contact with it is a bed of gypsum which is of considerable thickness. From it I obtained spe. cimens of selenite and sativ-spar. The specimens of amorphous gypsum I obtained are exceedingly beautiful, the white variety being of course the most abundant. I got also some very pretty pink varieties.

The following day we spent in visiting Glen Eyrie and the Soda Springs on the "Fontaine qui Bouille." Glen Eyrie is also sometimes called the "Little Garden of the Gods," from its resemblance to the "Garden of the Gods," whieh we first visited, and which is farther to the south. The entrance is through a natural gateway, cut through a mass. ive ridge of gray sandstone by Camp Creek, which flows through thr glen. The sandstones are covered with moss, giving them a most picturesoue appearance, and General Palmer, who has made his home here, has given them the name of "Painted Rocks" The ridge forms a high wall, dipping northeast at an angle of $60^{\circ}$. The age of this sand. stone is Cretaceous. Just inside of it there is a lajer of limestone, which is probably Jurassic, and next to this is a lajer of gypsum, the continuation of the bed I mentioned above. Then follow soit, red sand. stones, corresponding to those in the "Garden of the Gods," although they are lighter in color, at a distance seeming to be of a flesh-color. They are eroded into curious, fantastic forms. One in particular deserves mention. It is a mass of red rock, 30 feet in diameter, aud rising to the height of 206 feet. It is a monolith, the top of which is larger than at the base, and looking at it one almost expects to see it toppling over. It is called "Needle Rock." The area included in the "Little Garden of the Gods " is much less than in the other garden. The red sandstones, as we approach the hills, become harder, seeming to be almost crystal. line, and have a deeper color. The angle of the dip has decreased, and at this point is only 200 . Where Camp Creek has cut its way through these hard layers there is a fine exposnre of the strata. Here is Glen Eyrie proper, and a wild, weird-looking place it is. The dark-red rocks and the bright-green foliage, through which we catch an ocea. sional glimpse of the stream, form parts of a picture well worthy the 
visit of one who loves the beautiful. We did not have time to penetrate farther up the canion, but below these sandstones I believe there are Carboniferong limestones. The thickness of these rocks, however, is not very great I cannot give the exact thiekness, as I had no means of measuring them.

Leaving Glen Eyrie we passed a second time, throngh the "Garden of the Gods", and after a ride of some six miles reached the Spriugs on the Fontaine qui Bonille, a branch of the Arkansas River. There are five principal springs. The first one is the "Manitou" or "Doctor Spring." It is on the left bank of the river, and is quite small, measuring hardly a foot in diameter. The percentage of carbonic acid, and there is a slight bubbling, cansed by the escape of the gas. The water is more agreeable to the taste than that of any of the other springs. There is quite an abundant deposit of carbonates about the spring reaching to the edge of the river. The overflow of water is very spring refolid matter to the small. The water contains about $57^{\circ} \mathrm{F}$. It is feeblv alkaline. An analysis, made by Mr. Frazer in 1869, revealed the following contents:

Carbonate of sodu.

Carbonate of potassa.

Carbonate of lime.

Chloride of sodium.

Alumina.

Trace of iron.

The next spring is the "Comanche." This is a chalybeate spring, ituated in small thicket, on low, marshy ground, on the right bank of stuated is no deposit about, save a the river, near the of slight one of oxide of iron, and the escupe of gas is very insignificant. The iron is quite perceptible on tasting the water. Its temperature was $480.5 \mathrm{~F}$.

The next spring, in size the second, is the "Shoshone." It is also on the right bank of the river, and is close to the wagon-road. There is a the right bas it, but the taste of the contingut witon. It is surrounded by ef considerable deposit, consisting mostly of carbonates of soda and potassa, with also a trace of sulphur. (Frazer, 1869.) Its temperature is $55^{\circ} .5 \mathrm{~F}$. Below the Shoshone Spring, on the elge of the river, is the "Nashataga," an unimportant spring, having a temperature of $\tilde{J}_{20}^{\circ} \mathrm{F}$.

The largest spring is the "Bathing Spring." It is almost opposite

The largest opening the Manitou, and has a very abundant deposit, in which the opening of the spring is about five feet in diameter. The escape of gas is more violent than in any of the other springs. Its 'temperature is $60^{\circ} \mathrm{F}$. Water is conveyed from it in iron pipes to a bath-honse, which has been recently erected. An analysis of the deposit from these springs, made by Dr. Drown in 1871, is as follows:

Chloride of sodium.................................................. 36, 6 Chloride of potassium ........................................................ 10.0

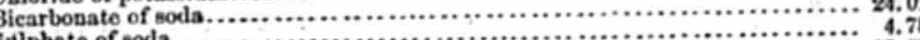

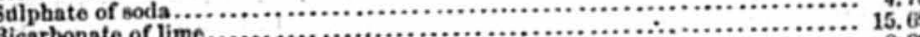

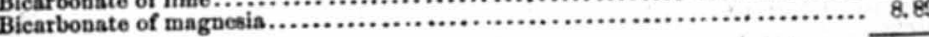
Total

The names of some of the other nnimportant springs are the "Iron Ute," "Navajo," the "Arapahoe," and the "Pawnee."
Freimont visited these springs in 1843 and took the temperature of two of them. I will give his temperatures and those I took in tabular form, so that they can more easily be compared. His nper spring corresponds, I believe from his description, to the Bathing Spring, and the lower spring to the Shoshone.

Temperatures of Frlmont, July, 1843

\begin{tabular}{|c|c|c|c|}
\hline Time. & $\begin{array}{l}\text { Temperature of } \\
\text { upper spring. }\end{array}$ & $\begin{array}{l}\text { Temperature of } \\
\text { lower spring. }\end{array}$ & $\begin{array}{c}\text { Temperature of } \\
\text { air. }\end{array}$ \\
\hline 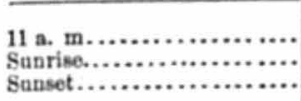 & $\begin{array}{l}69^{\circ} \mathbf{F} . \\
61 \\
54.3\end{array}$ & $\begin{array}{l}60.5 \mathrm{~F} . \\
58 \\
57\end{array}$ & $\begin{array}{l}73^{\circ} \mathrm{F} . \\
66 \\
67.5\end{array}$ \\
\hline
\end{tabular}

Tempenatures, May, 1872 .

\begin{tabular}{|c|c|c|c|}
\hline Same of spring. & Time. & Temp. of air. & Temp. of spring. \\
\hline 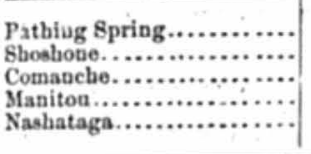 & $\begin{array}{l}\text { Afiernoon. } \\
\text { Afternoon. } \\
\text { Affernoon. } \\
\text { Afternoon. } \\
\text { Afternoon. }\end{array}$ & $\begin{array}{l}70{ }^{\circ} \mathrm{F} . \\
70 \\
70 \\
70 \\
70\end{array}$ & $\begin{array}{l}600 \mathrm{~F} \\
55.5 \\
48.5 \\
57 \\
62\end{array}$ \\
\hline
\end{tabular}

A comparisoh of the above tables would seem to show that in the last twenty-nine years the water of the springs bas become cooler. Sotne of the difference in temperature may, perhaps, be due to the difference in ther. mometers used. A large hotel has been built near the springs for the accommodation of invalids and tourists, and there is no doubt that before long this will be one of the favorite sanitariums of the West. The site been laid ont to which the name of Maniton bas been given. Iearing the springs we followed the road up the cation to the Ute Pass. The road through this pass leads to the silver tmines of the South Park. It has been ent through solid granites. The sañon is a most romantic one, and the stream rushes down the deep, narrow gorge in series of cascades and falls. The largest fall; Ute Frll, is 60 feet in height. The granite throngh which the stream has cot it pros way is a red porphyritic granite, presenting a beautiful appearance, due to the large red crystals of feldspar, (Orthoclase.) The mica is somewhat smaller in quantity and of a black color. The rock would doubtless be capable of a very high polish. As a building-stone I do not think it will have mnch valne, as it readily breaks down on exposure to the weather. I noticed at varions places on the walls of the cañon stains and discolorations, due to the infiltration of mineral waters.

The junction of the sedimentary rocks with the granites is well shown in the pass. In some places the former are lifted high npon the hills, dipping northeast, at angles varying from $10^{\circ}$ to $30^{\circ}$. The rock immediately upon the granites is a hard fine-grained sandstone containing irregular seams of pebbles. Its color raries from a yeilowish gray to red. The dip was north $40^{\circ}$ east; angle, $20^{\circ}$.

Our next trip was made to Chiann Cañon, through which Chiann Creek fows to join the Fontaine qui Bouille. In company with Messrs. 
Nettleton, Fuller, and Potter, and Dr. Gatehell, of Colorado Springs, we started early in the morning, and after a ride of four miles over the mesas, reached the mouth of the cañon, where we left our wagons and mnles and proceeded the rest of the way on foot, carrying the photo. graphic apparatus and materials on our backs. The caũon is very narrow and the granite walls rise precipitously on either side to the height of 600 feet above the bed of the stream. We were obliged to cross and recross the stream many times in order to get along, as the banks in some places were too steep to allow our passing along them. After a walk of about a mile and a half we came to a fall, or rather a series of falls, which prevented any farther progress up stream. There were three distinct falls, one above the other, the entire height being 300 feet. The water in falling strikes numerons ledges, which churn it into a mass of foam. It has worn in the solid granite a rounded basin surrounding which are walls reaching the height of 800 feet. The best view of the falls is to be had abont a quarter of a mile below on the side of the cañon. At a point 300 feet above the bed of the creek we have a magnificent view of the entire falls, while back of them rise the hills which stand at the foot of Pike's Peak, and in the fore-ground, far below us, we catch a glimpse of the creek as it reflects the sunlight through the foliage of the pines.

The following is a list of the minerals I obtained while at Colorado Bprings: Snowy gypsum, pink gypsum, selenite, satin-spar, (fibrous gypsum, yellow calcite, (crystallized,) amazon stone, (orthoclase,) amethyst, smoky quartz, white quartz, opal, and agate.

We left Colorado Springs on the 27 th of Mas, and on the 29th arrived at Cheyenne, Wyoming Territory. On the $3 \mathrm{~d}$ of June we started on a second trip, our destination this time being Golden City. Golden City is about twenty miles, almost due west, from Denver, at the base of the foot-bills of the main range of the Rocky Mountains. It is situated in a valley, between the hills and two mesas, or table-like mountains. They stand between the town and the plain, and between them is the Golden Gate, through which Clear Creek flows out to the plains. Both the mesas are surmounted by layers of basalt. The north mesa, called Table Mountain, is about a mile in width and a little more than two miles in length. On the western side, overlooking the town, is a prominent mass of bare rock, which is called the Castle. The south mesa has the same width as the one on the north, but is longer, extending for four miles. The upper portion of the basalt capping these mesas is more compact than the lower layers and is somewhat colnmnar. Beneath the basalt are Tertiary formations-sandstones and clays. The surface of the mesas is somewhat irregalar and covered with grass. They form the grazing grounds for large herds of cattle. The Tertiary beds continue some distance west of the mesas, and contain coal. The principal bed varies in thickness from a few inches to eight feet. It is almost vertical. There are four openings into it, three of which are owned by the Mineral Land Company and leased to the Hazleton Company. Only one of them, however, is worked at present; one of the others has been burned out-since which work has not been resumei- while the third is filled with water. A fourth opening is owned by Judge Johnson. Only enough coal is mined to supply the local demand. The ridge abore the coal is a white sandstone con taining impressions of deciduoss leaves, while beneath the coal is a bed of elay. The strike of these beds is almost due north and sonth. Be low the coal-beds are red and gray sandstones with a layer of limestone. These andstones rest immediately on the metamorphie rocks at an angle of abont 450. The effect of erosion here has been to so level these beds that it is difficult to trace the succession of the various layers.

We made several excursions while at Golden City, one of which was plear Creek Cañon, through which the Colorado Central Railroad, up Clear Creek Con fished it will penetrate to the min. a narrow-gauge road, runs. When we vigited it ing-districts of Georgetown and Central City. When we visited it the road-bed was graded some ten miles above Golden City. The ereek has cut its way through the hills in a tortuous conrse, leaving high walls of gneiss and granite standing on either side. In the gneisses I walls of gueiss and grand magnetite. There has been some gold-mining carried on in Clear Creek Cañon, but $I$ judge it was with but little profit. At any rate, at the present time the diggings are abandoned.

At any rate, at the present Colorado Central Railroad I obtained speci. mens of ores from Central City, consisting mainly of gold quartz, pyrites, and argentiferons galena.

Having completed our work we left Golden City and started for Ogden, Utah Territory, where we joined the main party in camp on the 8th of Jnne. The Wasatch Range, at the foot of which the town of Ogden is June. The built, has a trend north and soun which cut deeply into it almost atright angles to the trend. It is in these cañons that the profitable mines of Utah are situated. The cañons near Ogden are Ogden Cañon aud Weber Cañon. Through the latter the Union Pacifie Railroad finds its way into the Great Salt Lake Basin. Between these two there are a way cantons which cut the mountains only partially. Two number of smaller canons of our camp, are Taylor's Uañon and the of these, immediately back of our camp, are Taylor's Cañon and the also some miners claim to have discovered tin. An examination of specimens proves, however, the absence of any metal and showed the specinen to consist almost entirely of hornblende. The Waterfall Cañon is uamed from the occurrence in it of a fall some 300 feet in height. The water falls over a ledge of white quartzite. Above it rises Mount The water falls over a ledge of white quartzite. A the monntains near Bechler, whose height is 9,716 feet. The base of the monntains near Ogden is for the most part a red syenite, wbose specife gravity is about

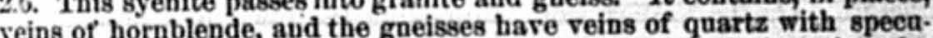
lar in lar iron. Sever prospectors. The largest is width and penetrates the rock to a depth of thirty feet hori. four feet in width and penetrates the rock to a depth of thirty feet hori-
zontally. The walls on either side are gneisses, stained with the green carbonate of copper, (malachite.) The gangue is quartz and serpentine. Associated with the specular iron or micaceons hematite are iron pyrites And stainings of copper. The iron is in veins varying from the fraction afd staide of Ogden Cañon of anch to smaller, in chloritic schists, which, at I found another opening, much smaller, in chloritic schists, which, at this point, lie just above the syenite. The gangue here was white quartz, containing veins of micaceons hematite. The schists contained beds of gnartzite, the lower bed of which is conglomerate, the siliceous matrix containing pebbles of bright-red jasper. The quartzites have a matrix containing per ar ang in some specific gravity of 2.6 and are mostly of white color, although in some places they are pink and again dark brown, becoming highly ferruginous. A bove thequartzites are heavy beds of dark-blne magnesian limestones of Silurian age, above which are Carboniferous limestones. I was shown a specimen of graphite from near North Ogden, a village six miles above Ogden. At the upper end of Ogden Cañon galena is found associated 
with carbonate of copper in limestones. This corresponds to the loca. tion of the most productive silver mines in Utah. They are almost situated in limestones at the herds of the cañons, and the ores are ores of lead containing silver. The minerals I obtained at Ogden are the following t micaceons hematite, iron pyrites, maguetite, graphite, azurite, malachite, garnets, quartz, chlorite, talc, serpentine, jasper, hornblende, serpentine, and calcite.

On the 19th of June Mr. Jacksou started on a photographic trip to Little Cottonwood Oalion, on which trip I accompanied. From Ogden to Salt Lake Oity we took the Utah Central Railroad, which skirts the edge of the monntains. The granitic rocks extend for some distance below " weber Cutron, but as Cike City the limestones form the base of the mountains, near which are a number of limekilns. The limestone for the kilns seemed to be taken from the upper layers, prob. ably because the lower ones are siliceous, as at Ogden.

The eaĨons which cut through the Wahsateh Range near Salt Lake City are as follows, in their order from north to sonth: Red Butte, Emi. gration, Parley's, Mill Creek, Big Cottonwood, and Little Cottonwond. At the head of the latter are some of the best silver mines to be found in Utah, and among them is the famons Emma mine. Leaving Salt Lake City we take the State road, and after a ride of ten miles in a southeasterly direction, passing between thriving farms dotted with comfortable-looking houses, we turn to the left and strike across the country to the mountains. Directly before us is the highest point in the Wahsateh Range, the Twin Peaks, over 12,000 feet above sea-level. As we ride along we see distinctly marked on the sides of the mountains in front of us the water-lines of the former shore of the Great Salt Lake. These old shore-lines are distinctly marked on the mountains, on all sides of the lake, and on the islands in the lake. We pass over numerous terraees and at length reach the mouth of the eañon. Here there are no less than seven distinct terraces, some of them, how. ever, due to the aetion of the Cottonwood Creek. Near the mouth of the cañon there are smelting-works, to which ore is brought from the mines

Fig. 25.

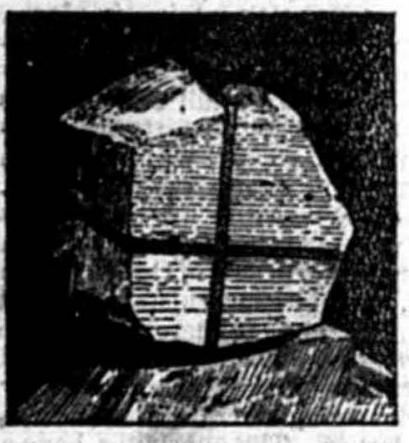
196,) referring to these, says "These granites are probably metamorphic, of coglomerates, an opinion first suggested to me by Professor W. P. Blake." As he also further states, there is a pebble-like ronndness in the particles of quarti in this granite which points to a mechanical origin. The roek is quite uniform in its structure. $\mathbf{A}$ mile or two in the cañon we came to a small village called Graniteville. It is neas here that the grauite, of which the Mormon temple is being built, is quarried. Instead of working into the rock on the sides of the cañon, the gnarrying is conflned to the huge blocks of granite which are scat: tered over the bottom on both sides of the creek. Some of these blocks tered over the bottom on both sides of the creek. Some of thess blocks size. Our road for about five miles leads us between the granite walls that tower far above us, surmonnted by dome-like masses, whose summits are corered with snow, fiving origin to the numerons falls and eascades which abound on the sides of the cañon. The Little Cottonwood Creek flowing past us falls about 500 feet to the mile. It rushes along furionsly over its rocky bed, seeming to be at war with the immense bowlders that dispute its right of way. As we proceed we leave tha grauites behind us, and above us project the sharp, jagged edges of quartzite beds. These quartzites have a reddish color, and are followed by slates upon which rest thick beds of white limestone. The lower beds are crystalline and probably Silurian, although I was nuable to find any fossils in them. The upper layers are dolomitic, and are Carboniferous in age. It is in these limestones that the ores occur. The principal mine is the Bmma. Unfortunately, owing to a disturbance at the time of our visit, 1 was unable to see the Emma mine, but visited the Flagstaff and the Silver Star. I quote the following analysis and remarks upon the ore of the Emma mine from an article by Professor Silliman:•

I am able to present an analysis of an average sample of 82 tons ( $=183,080$ pounds) of first-class ore from the Emma mine, made by James P. Merry, of Swansea, April, 1871 , which is as followa

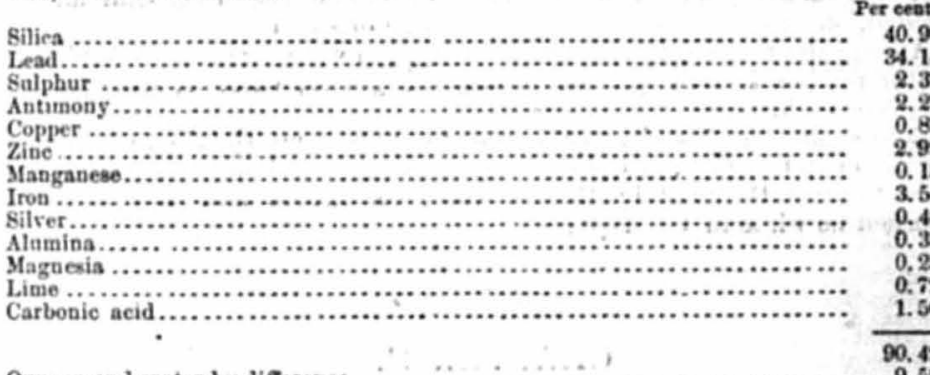

Oxygen and water by difference..........................................

The quantity of silver obtained from this lof was 150 troy ources to the gross ton of 2,240 pounds.

This analysis sbeds important light on the ehemical history of thin remarkable metallie deposit, and will aid ns in the study of the paragenesis of the derived ppecies. It is pretty eertain that all the beavy me. Als have existed ofiginally as sulphides, abd wo may, therefore, state the analyais thus, allowing 8.62 per cent. sulphur to cotvert
the heary metals to this state:

Silica .............................................................. 40.90

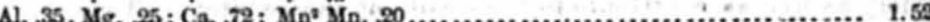

Water, carbonic acid, and losen........................................ 
This ealeulation aseneses that the sulphides ane as follows, vis:

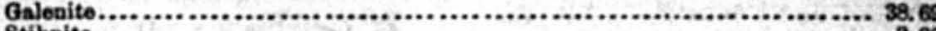
Btibnite.............................................................. 3, 30

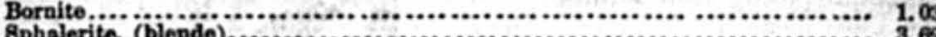
8phalerite, (blende) ......................................................... 3.

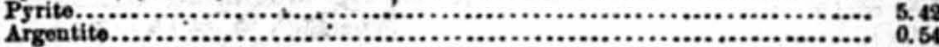

This statement excludes the presence of any other gangue than siliea, and, considerIng that the ores exint in limestone, the almost total abeonce of lime in tho composition of the averape mass is certainly remarkable. The amount of silica found is notioeable, other parts of the mine. The silica can have existed in chemical combination only in the most ineonsiderable quantity, since the bases with which it coul' have cotnbined are present to the extent of less than 1 i per cent.; nor do we fin 4 in the mine an noticeable quantity of kaolin or lithomarge resulting from the decou-poeition of ail. feates, nor are thero any foldspathio minerals. It is most probable that the silliea existed in a state of minute subdivision, diffneed in the sulphides as I have seen it in some of the unchanged silver-ores of Lion Hill, in the Oquirrth Range.

The abeence of etlorine and of phosphorie acid in the analysis correaponds well with the absence of the species cerargyrite and pyrotsorphite, of which no trace coald be

From the Flagstaff and Silver Star I obtained specimens of wulfenite, aurichaleite, galenite, lithomarge, massicot, cervantite, and cerussite. The wulfenite I found in minnte, brilliant, yellow, tabular crystals, in cavities in ochraceous ores, and also associated with cerussite. Other minerals found at this locality are azurite, malachite, calamine, anglerite, sphalerite, pyrite, argentite, antimonial, galenite, anglesite, kaolin, and limonite.

A specimen of galena from the Vallejo tunnel of the Silver Star mine yielded, on examination, a small percentage of silver.

Among the rocks I obtained while at Ogden were specimens of aplite, protogine, hornblendic gneiss, protogenic gneiss, chlorite, schist, and micaceons schist.

Before closing this chapter I wish to express my thanks to Messrs. Nettleton and Somers, of Colorado Springs, and the officers of the Colorado Central Railroad in Golden City, for favors and information afforded us while in Colorado.

\section{CHAPTER H}

FORT ELLIS TO GARDINER'S RIVER.

On the 22d of June the expedition was divided into two parties at Ogdeu, and I found myself a member of the party which was to mak Fort Ellis, Montana, the base of operations. Accordingly, after a long and tedions stage-ride, we pitched our tents near Fort Ellis on the 29th of June. Fort Elis is situated at the head of the Gallatin Valley, on one of the many small streams that eontribute to form the East Gallatin River. The Gallatin Valley is one of the most fertile in Montans Territory, and is surrounded by ranges of mountains which contain ehoicest bits of scenery as well as contribute to the wealth of the Territory. The prin. cipal towns of the Gallatin Valley are Bozeman, Hamilton, and Gallatin City. The former contains a popnlation of f bont five hnndred inhabitants. Between Bozeman and Gallatin Oity there are numerous Fell-cultivated and produetive furms.
The streams that form the headwaters of the Gallatin River have cut profoundly into the mountain. ranges; the the most beautini manner. The first of the cañons to which I will refer is Spring or Roek Cañon. This cañon forms a most interesting sub.
ject of stady, and will answer ad. mimbly as a type of the others. It is a V-shaped chasm, eut through : the end of an anticlinal range by the stream. The trend of this range is northwest and sontheast. The first thing that attracts our attention after we are fairly inside the cañon is the occurrence, on the lefthand side of the ereek, of an arch that erosses the road, and, deserib. ing a semicircle on the hill, again crosses the road at the upper end of the cañon. (Fig. 26.) The first prominent bed we meet is a layer a of coarse, gray calcareuns sand. stone, containing fragments of fos. sils. Proceeding up the cañon we find the center of the arch is occupied by masses of Carboniferous limestone, which tower far above the creek, giving a most picturesque appearance to the cañon. Still farther along we come to the other extremity of the arch and find the same layer that we saw at the opposite end. Following this layer at the western end of the cañon, that nearest Fort Ellis, we find the dip at the bed of the croek to be sonth $45^{\circ}$ west; angle, $30^{\circ}-10^{\circ}$. Farther along we find it to be south $80^{\circ}$ west, the angle remaining about है the same. Still higher up on the ridge it is north 500 west; angle, \& $15^{\circ}-25^{\circ}$; and when we reach the highest point on the ridge it dips s due north at an angle of about $25^{\circ}$. Taking this same layer again at the level of the creek, this time at the eastern end of the cañon, we find the dip to be in the same direction, although the angle is greater. As ty we go toward the scath it ap. $x$ proacbes more and more to the vertical, until the dip becomes northeast and the range therefore be. comes a true anticlinal. The read. ing just above the creek on the

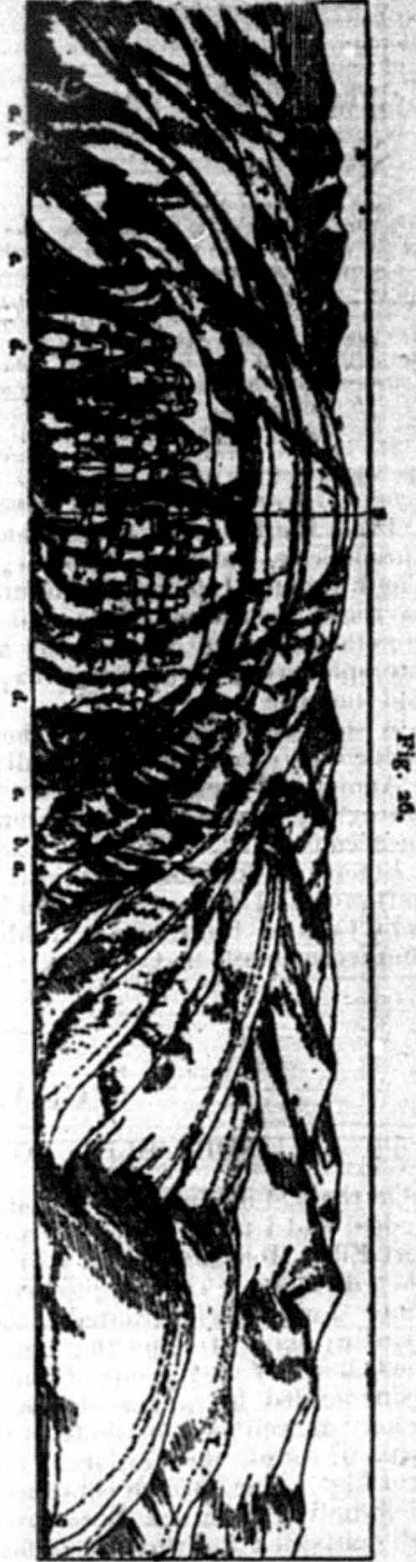


Fig. a7.

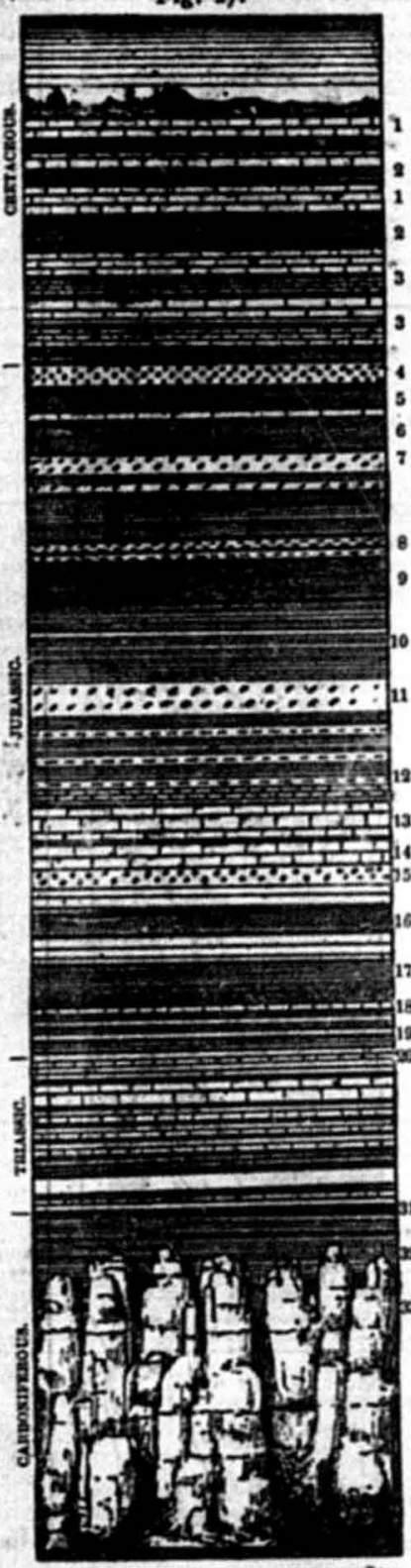

actove of the ridge toward the north, it is socith $30^{\circ}-35^{\circ}$ west; angle, $80^{\circ}-85^{\circ}$. Stil bigher up it is sonth $20^{\circ}$ west; angle, $85^{\circ}$. and then becomes, within a vary shor distance, south $10^{\circ}$ west; angle, $88^{\circ}-900$ As 10 progress it passes the vertical and dips northeast at a ligh angle, and dips northeast at a ling angle, which gradnally decreases, the dip be coming more and more northerly until the arch is completed. At the western end of the cañon beneath the limestone. which immediately succeeds the fossiliferons sandstone, there is a fine exposure of quartzite-beds, the top layers of which are somewhat calcareciss. Then comes a layer of conglomerate made up of green and brown flint pebbles, varying from the size of a walnut to eight inches in diameter. Associated with these peb bles are geodes of quartz, some of which contain calcite.

The best section of all the beds exposed in Spring Cañon is obtained in the center of the cañon at the point marked in Fig. 26 by the dotted line 8 . We commence at the top of the hill, which rises 1,160 feet above the level of the creek. The first bed we notice is a highly metamorphic-looking quartzite, which crops out along the summit of the bill. Its general color is a dull red, passing in places into a dull purple and again becoming light gray, with bright red and yellow streaks. 'Some of them have an almost flinty fracture. We esti. mated the thickness of the beds at 50 feet. Next below these beds are quartz. ites and light gray sandstones followed by conglomerates, in the lower layers of for which tire pebbles are followed by brown limestones and sandstones, the weath. ering of which gives a red tinge to the soil. These beds are succeeded by fine, sandstones, which from two to fonr Next to these are the inches thickness. Next to these are the coarse-grained fossiliferous sandstones that I have referred to above, (layer No. 7 in the section,) containing frag. ments of Ostrea and Camptonectes. They mint stones from the amount of lime they stones from the amount of lime they grains of sand and more properly de. serve the name of sandstones. Inter- laminated with them are light-brown shale-like sandstones, which are quite soft and break into numerous lamins. The layers of this sandstone vary in thickness from a few inches to eight feet. Just below these beds are very coarse-grained limestones. The thickness from the bottom of these limestones to the top of the light-gray sandatones mentioned above is 260 feet. The coarse limestones are followed by finegrained compact limestones, the weathered surfaces of which are white. These pass by gradationsinto bluishargillaceonsshales, containing a large percentage of lime, (layer No. 11 in the section.) These shales weather of a white color and contain the following fossils: Trigonia Americanus, Pinna, Camptonectes, and Modiola, proving their Jumssic age. They are very fine-grained and separateinto lamina of half an inch to two inches thickness. They are very brittle also, and break readily, the plane of cleavage being at right angles to the plane of deposit. The angle of
dip of these beds is $20^{\circ}$. The distance from the bottom of these layers to the top of the compact limstone is 100 feet. All the above beds to the conglomerates are probably Jurassic, while those above are Cretaceous. Next below the limestones are flve feet of yellowish-brown sandstone, followed by a bed of quartzite containing veins of qnartz and calcite in geodes, from which I obtained large erystals of calcite of the variety known as dog-tooth spar. The lower portion of this bed, which is abont ten feet thick, is very irregular in composition, seeming to have been deposited in rongh waters. It is succeeded by four feet of very compact quartzite, which in turn is followed by a pebbly con. glomerate of two feet. Next comes eight feet of quartzite succeeded by alternate beds of quartzite and linestone, the thickness of the whole being 110 feet. Next come 30 feet of red sandstones, which are probably Jurassic, although not even a trace of any fossils can be found in them to prove it. Thie upper layers of these red beds contain lime, the percentage of which decreases as we descend. The angle of the dip is about $25^{\circ}$. The succession of these beds is shown in the section given below. Below the red beds are immense beds of carboniferous limestone, reaching to the bed of the creek, a distance of 435 feet. The upper layers of this limestone are arenaceons. The force that caused the tipping up of the strata in Spring Cañon was some distance to the south and was dying away at this end of the range, so that the older beds were not elevated sufticiently to be exposed to the action of the stream and are therefore not shown. The carbouiferous beds are crusbed together in a confused mass, and it is diffieult to get at the true dip. The ereek eutting through them has left huge masses standing out on the sides, resembling castles, towers, sc.

The following section, corresponding with Fig. 27, will perhaps show the succession of the beds more clearly. The thicknesses are estimated. The section is in descending order.

Thlekneas
in foot.

1. Red, purple, and gray metamorphosed sandatones ..................... 30

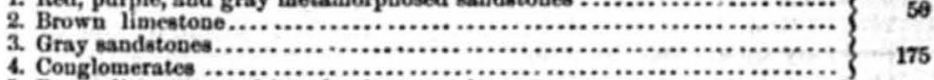

5. Brown limestone and interlaminate sandstones

6. Gray sandatone ......................................

7. $\left\{\begin{array}{l}\text { Coaroe calcareous fossiliferous sandaton } \\ \text { With interlaminated shaly sandstones.. }\end{array}\right.$

10. Compact limenton

10. Compact limentone

11. Shaly argilaceons limeaton

13. Quartelite with reins of chleito. 


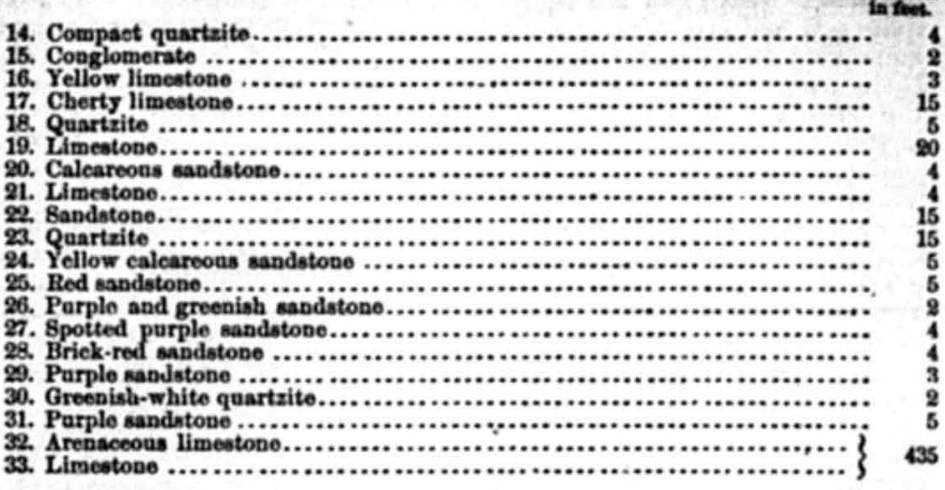

Ontside of the quartsite bed, with which I have headed the above section, there is a succession of beds of hard quartzites and conglomerates followed by soft randstones of steel-gray colors. Just below these sandstones, which are Cretaceous, there is a layer of hard, green shale containing fossils. Outside of them there occurs a bed of limestone. All these beds curve around the Spring. Oañon layers, to which they seem to be conformable. Above the Cretaceous beds there is an immense thickness of brown and dark-gray Tertiary sandstones, (Eocene, ${ }_{2}$ contain. ing beds of coal. They also follow the eurve of the Cretaceous beds and are seemingly conformable to them. They extend for four or five miles.

About five miles north of Spring Cañon there is a range, the Bridger Range, the trend of which is north and south. I shall here refer only to the sonthern end and western side of this range, reserving any further consideration of it to a subsequent chapter. Near the south. ern end of the range there is quite a high peak known as Bridger's Peak, which is 9,000 feet above the sea. The crest of the range is made up of Carboniferous limestone, dipping southeast, containing Hemi. pronites orenestria, Productus longispinus. Then follows a snccession of beds as we found them in Spring Uañon. Following these, and still dipping southeast, are the Cretaceous beds that we noticed ontside of Spring Cañon. In a layer of hard, green shales I found Gryphaca, Avi. cula, Pinna, Inoceramus, Turritella, Crassatella, \&o., proving their un. donbted Cretaceous age. Next we find the Tertiary saudstones, which are unconformable to the Bridger layers. There is therefore between Spring Cañon and the Bridger Range a synclinal valley the floor of which is Cretaceous. fllled in with the Tertiary san lstones, dipping north west, north, and northeast at an average angle of $40^{\circ}$. Many of these sand. stones are calcareons and contain veins of calcite. The thickness of thest beds must exceed 1,000 feet, and from the specimens of fossil-plants found in them they are for the most part Eocene. Some of the upper layers may be of Miocene age.

Opposite Fort Ellis, between our camp and Bridger Peak, there are bluffis composed of Pliocene sandstones, marls, and conglomerates. The strata are for the most part horizontal, although inclining sometimes at a very small angle, which is never more than $5^{\circ}$. The height of these bluffs above the level of the creek is 175 feet. They are the remnants of Pliocene formations that once spread over the entire valley of the Gallatin, and formed the bottom of a vast lake that spread over what are now the valleys of the Jefferson, Yadison, and Gallatin Rivers, reach ing to the junction of the three strtens. The hills between the Gu. latin and Madison, and between the Madison and Jefferson, are Pliocene, remnants of the same beds, and when we ascend the mountains the southern border of this old lake-basin the whole plan lies sprend out before ns. Bach of the rivers has out deeply into these Pliocene rocks, and their valleys are the results of the erosion that has taket place since the draining of the ancient lake. The question of priority of elevation of the Bridger Range, and that into which Spring Cafien is cat, is one of some interest. That there bas been more than one force at work to give the surface its present configuration is evident. The question is, whether or not they acted synchronously. The forven that elevated the layers of Spring Cañon ard those of Bridger were, I take it, entirely distinet from each other and separated by long periods of time. The Bridger Range was the first to be elevated, and its eleve tion oceurred probably about the end of the Cretaceous period, and before the beginning of the Eocene, while the range running sonth from Spring Cañon was elevated some time after the Eocene and prior to the deposition of the Pliocene strata. This is proved by the fact that the Cretaceons rocks on one side of the valley are conformable to the Bridger Range and on the other side to the Spring Cañon larers. while the Eocene rocks are conformable only to the latter, and the Pliocene rocks have been affected by ueither range. I believe also that the elevation of the Bridger Range thas

the more gradual of the two. The elevation of the Spring Cañon layers was due to voleanic action, the center of which lies to the south. There have been sev. eral periods of erup tion, for in the valley of the Yellowstone Juraetio; $F$, Carboniferous; $G$, Drifi: $\mathrm{H}$, Tertiary billa. Kiver we find Pliocene sandstones and marl capped by basaltic plateans, while at Fort Ellis there is nothing of the kind, and we will see in a subsequent chapter that, some distance farther south, we find Eocene bed lifted high up on the mountains. The section shown in Fig. 27a will give the relations of the beds between Spring Cañon and Bridger Peak.

I have referred above to the oceurrence of coal near Fort Ellis. The only rocks in which I noticed it were those of Eocene age. At only one point has there ever been any mining attempted. This one point is east of Spring Cañon, about four miles southeast of Fort Ellis. Coa was discovered here in 1867 by two blacksmiths, of Bozeman. Colonel J. D. Chestnut, hearing of the discovery, offered to furuish provision: to get men to work into the bed, if they would give him a share. This they did, and afterward left him solo owner of the claim, which includes one hundred and sixty acres. Fig. 28 is a section of the coal bed, $\mathrm{C}$ showing the opening into it. The shaft penetrates the bed in a horizontal direction, and Las reached a depth of 250 feet from the entrance. The width of the shaft is 14 feet at the widest part. The bed of coal is considerably wider, and dips north $50^{\circ}$ east; angle, $80^{\circ}$.

On each side of the coal there are beds of blaish argiliaceous sand $8 \mathrm{G} \mathrm{s}$ 
stones, which are followed br coarse, gray sandstones. When the bed was ore seral seams of clay in it, but as the shaft pene. trated deeper they gradually thinned out, and at present there is only

Fig. 28.

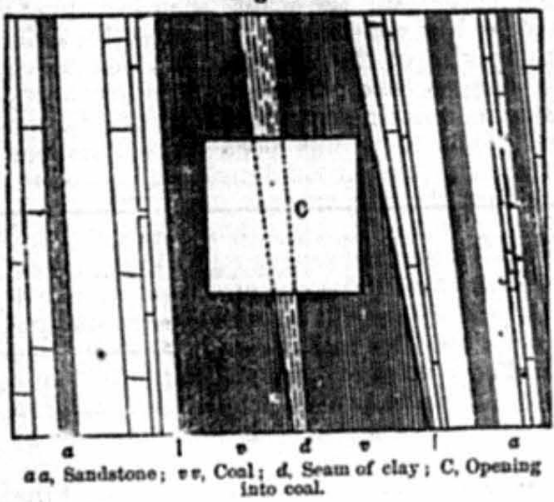
one in the center of the coal baving a thickness of abou twelve inclues. The coal is a lignite, and is well adapted for blacksmiths' purposes. It is used, I believe, by black. It is us of Bozeman, who like it vers of Bozeman, who like it very much. Some of the coal was taken to Helena, and is said to have yielded five cubic feet of gas to the pound. As the shaft goes deeper the quality of the coal seems to improve. Up to the present time there has been but little demand for coal. One reason of this, perhaps, is the abundance of timber in the mountains near Bozeman, and another reason, perbaps, is, that bitherto there near Lave been few facited is but little donbt, Cañon having only lately been completed. Then the however, that altimately this coal writs this region the utility of the Northern Pacific Railroad is built through this more apparent.

coal-beds near Fort Ellis will become more and. No. 1 is a poor speci.

$I$ have male the following analysis of the coal. No. men, No. 2 medium, and No. 3 the best. The coal is black, (brown in powder, has a ligh luster, irregular fracture, specife gravity. The coke is moderately good, and has a bigh luster:

$$
\text { Analgxis No. } 1 .
$$

Water

Volatile matters.

Coke

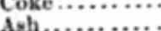

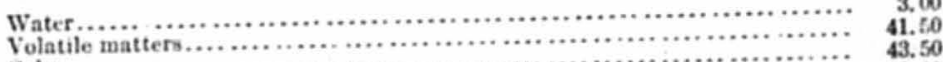

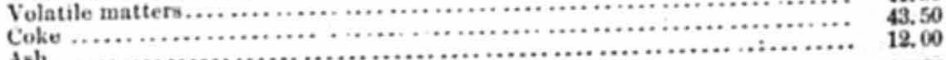

Analysis No. 3.

Water

Volatile matters

Coke

Ash, (white).
Per cent.

7. 00

60,50

8,00

100.00
For purposes of comparison $I$ insert here analyses of coal from Utah: Analyoio of coal from Evanuton, Dhal, (mine of the Bocky Mouatain Coal and Iron Company.)

Per 00

Water. 42.00 Volatile matters ............................................................... 45,00

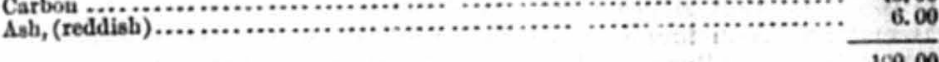
100.00

Arerage of three analyaca of coal from Eranatow, Ctah, by Peraifor Fhaser, jr., and $F$. Platt, esq., (United Statea Geological Survey of Wyoming, 1670, page 184.)

Per ceat.

Water 5.83 Volatile substances Fised carbon. 7.46 100.19

The following is an analysis of coal from the mine of Buel \& Bateman, at Coalville, Utah Territory. This was formerly called Sprigg's mine :

Analysis. Per cent.

Water 6.50
41.70 Volatile substances................................................... 44. 40

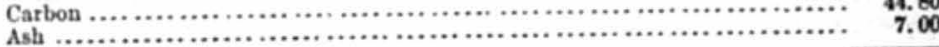
$\frac{7.00}{100.00}$

Analyois of specimen, from the same mine, by Pereifor Fraser, jr., (Cnited Statea Geological Survey of ityoming, page 183.)

Per cent.

Water and volatile substances ................................... 50

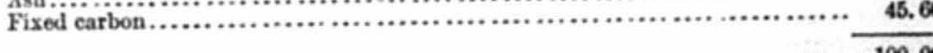

About a mile or two south of Spring Cañon I visited a second cañon About a mile which another branch of eral direction of the stream in this canon is north ure of the Upper Cretaceous beds is perhaps better here than in Spring Cañon. The first exposure is a bed of white erystalline limestone, dipping south $50^{\circ}$ west; angle, $50^{\circ}$. This litmestone is followed by red and yellow sandstones, which are themselves succeeded by a bed of brown yellow sandstones, which are themselves sucesecupy between one and twestor w wastones that I noticed near Spring Cañon and Bridger Peak. They continue for about balf a mile, when we come to Jurassic rocks, the first bed of which we recog nize as one of the Spring Cañon layers. It dips south $40^{\circ}$ west; angle, $85^{\circ}$. It is followed by the same beds we saw in Spring Cañon. They are in fact only a continuation of the same. The Carboniferons lime- 
stones form the center of the ridge, the onter layers on either side dipping in opposite directions, on the eastern side dipping northeast and those on the western side southwest. The general strike is south 300 east. The exposures in the cañon were very ine, but I found nothing diffuring from what $I$ have described in Spring Oañon.

On the 13th of July I started on a trip to Mystic Lake, about twelve miles nearly south from Fort Ellis. After a pleasant ride over the grassy plain that slopes gently from the mountain's edge we began to ascend and soon fonnd onrselves entangled in a mass of dead and fallen timber. After considerable trouble we reached the summit of the hill to find that we had to descend again on the opposite side. The hills are 80 covered with vegetation and debris that the character of its rocks cannot be made out certainly. High up on the sides, however, there are small exposures of limestones and sandstones, and it is probable that the valley is underlaid by Cretaceous formations. What their exact relation is to the ridge running south from Spring Cañon it is rather difficult to determine, though it is probabie that the trail runs throngh a synclinal valley on one side of which lies the Spring Cañon Ridge.

The trail leads us now through pine-foreste and anon across beautiful 15ttle valleys, each a garden of wild flowers. At last, after crossing several ridges, we reach the lake. Mystic Lake is the head of Bosemat Creek, one of the branches of the East Gallatin River. Near it, on a level fully one hundred feet higher, are two exquisitely beautiful lakes, whose beanty is half hid by the trees fringing their banks. One of them we named Emerald Lake, from the deep-green tint of its waters.

The valley in which these lakes are situated is syuclinal, one side being the continuation of the Spring Cañon Ridge and the other a sour running south from Mount Ellis. Opposite the lake, to the soutb-ast, there is a volcanic range, at the base of which we find the Bpring Cañon layers, having a general dip to the southwest. The other side of the synelinal cuts obliquely across the lower end of Mystic Lake, the strata dipping north $40^{\circ}$ east; angle, $500^{\circ}-60^{\circ}$. At present the lake is about three-fourths of a mile in length and about one-fotrth of a mile wide. It once extended farther up the valley and lay in a sacer-like depression. From the gradual eles ation of the valley or some other cause, as the draining of the lake by the erosion caused by its outlet, at present it occupies the lower end of the valley, lying on the edges of the Cretaceous, Jurassic, and Carboniferous strata.

The conrse of the stream of which Mystic Lake is an expansion is about soutb $20^{\circ}$ west, making an angle of about $60^{\circ}$ with the strike of the strata. On the western shore of the lake there are exposures of Jurassic sandstones and limestones precisely like those of Spring Cañon, and in which oceur Ostrea and Camptonectes. Below the Jurassie come immense bedis of quartzites and limestones, the upper layers of which are undouhtedly Carboniferous, containing Produetus longispinus, Spirifer lineata, Hemipronites crenestria, Productus scabriculus, Zaphrentis, \&c. The thickness of these beds is over 2,000 feet, and the lower strata should probably be referred to alower geological horizon than the Carboniferouis. As we go sonth the strata turn more and more toward the west. As we go toward the north we find Mount Ellis, the extreme northern end of the spur or ridge. The elevation of Monnt Ellis is 8,419 feet abore the sea. It is composed mainly of Uarboniferous limestones, while to the west and at the base are gneissic rocks. The elevation of this ridge was probably contemporanevus with that of the Bridger Range, as its formation seems to be similar. As we follow the ridge southward is curves until the trend is a.most east and west. It probably once formed portion of tlie sonthern shore of the ancient lake, as the Bridger Range did part of the eastern shore, while Monnt pllis and Bridger Peak may have been promontories projecting into it. The action of volcanie forces within a very short distance, however, has complinated matters to such an extent that any opinion must be conjectural, and future careful study will be required to prove or disprove. The elevation of the lake above sea-level is 6,468 feet, which is 1,533 feet higher than the clevation of our camp at Fort Ellis. The synclinal valley, which I referred to abore, has no later rocks than the Cretaceons. Why there should be no Tertiary beds here is perhaps a little difheult to understand. That there have never been any is evident, or there would be some remnant or trace of them left. Erosion could scarcely have removed all without some trace being left. Moreover, this is not a valley caused by erosion. Perhaps the elevation of this point, which may have been greater in the past, precluded the possibility of the Tertiary beds reach. ing this point.

Bozeman Creek, leaving Mystic Lake, flows at first a little west of soutb, and turning flors more toward the west, until finally it flows in a northwesterly direction. At first it cuts its way in a deep gorge almost at right angles to the strata, over which it rushes in a series of cascades half hidden by the overhanging vines and brush. Within a quarter of a mile it falls about five hundred feet. Just below the lake it is joined by a stream coming in from the left. It heads at the base of the voleanie range, whieh lies to the east of Mystic Lake. Following the course of this creek there is a bed of volcanic breceia which has flowed from the head of the valley. It is composed of sharp angular fragments of basalt, varying in size from three inches to a foot. The prevailing colors are black and a brick red. The cementing material of this breccia seems to contain fragments of sandstone like those seen in the Eocene beds. The belt covered by this bed of breccia is not over a quarter of a mile in width.

The minerals I obtained while at Fort Ellis are as follows, viz: rhomb. spar, dog-tooth spar, quartz, agate, red and yellow jasper, and coal.

We left Fort Ellis on the 2uth of July and started for the valley of the Yellowstone. For about threa miles our course was in an easterly direction, when we turned toward the southeast and followed one of the branches of Mill Creek, the stream that flows through Spring Caũon. Our road led us over Tertiary sandstones. Camp No. 2 was in a mono. clinal valley, near the head of Mill Creek. The hills on the east side of the valley were Tertiary, while those on the west, dipping in the same direction, were Cretaceous. The former were about 400 feet high and composed of saudstones, the texture of which varied, some of the layers being quite soft, while others were very hard, seeming to have been metamorphosed. Many of them contained impressious of deciduous leares, which Professor Lesquereax has determined to be Eocene. Among them he found Platanus aceroides, Fagus antipofi, Salisburia polymorpha, Juglans denticulata, and Gymnogramma Haydenii. He says, "The most interesting discovery is that of Salisburia polymorpha, deseribed from Evan's specimens of Vancouvers Island, a loug time ago." This would indicate a correspondence in the Tertiary flora of the Pacifie coast, and that on the east side of the Rocky Mountain divide as at present consti. tuted, and thus points to the modern eleration of the range. Mr. Meek tinds also a correspoudence in the Cretaceous shells of the two localities referred to, and says also that they do not correspoud to the forms found farther east, which wonld lead us to suppose that at the period of their deposition the divide of the Rocky Mountain must have been more to the 
eastward of the present divide. One of the layers containing the best fos. sils showed a plane of cleavage that was obliqus to the plane of deposit, rendering it extremely difficnlt to get perfect specimens. The color of ssing in places in to Intercalated with them were some beds of basalt, which was probably the cause of the metamorphism observed. In climbing over these hilis I found numerous inciications of coal-beds, one of which was just above our camp. There was no outerop visible, but a prairie-dog in burrowing had penetrater the bed, and revealed its presence by the coal he had dug out. On the 21 st I risited the hills west of camp. The first ridge was 410 feet above the level of the creek, and composed of gray and green sand. stones contain ing Inoceramus and other Cretaceous fossils. The dip of these strata is $50^{\circ}$ northeast; angle of iuclination, $65^{\circ}$. The layers be tween this ridge and the Eocene on the opposite side of the valley, having been soft sandstones, have been washed away to form the bed of the stream. From this first ridre I ascended to the next, still higher, bnt parallel to the first. The first strata were light.gray sandstones, very much metamorphosed. These beds, which I take to be of Oretaceous age, continued for about half a mile, and were followed by 50 feet of coarse, reddish sandstones, the lower layers of which were conglomerate Next came a layer of very hard sandstone containing fragments of fossils. This was abont 10 feet in thickness, and is followed by 30 feet of white quartzite. The summit of this ridge is 818 feet above the valley and 402 feet above the top of the first ridge. I followed it until valley and 402 feet above the top of the first ridge. I followed it until
the timber obstructed my passage, and I returned to the valley. These beds are a continuation of those exposed at Spring Cañon, and are underlail by the Jurassic and Carboniferous. Our course on the 21st was up the valley to its l:ad, when we crossed the divide to Trail Oreek, a tributary of the Yeilow tove River, which we followesl and camped in

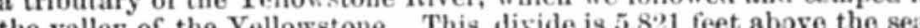

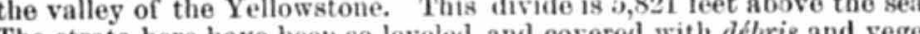
The strata here have been so leveled and covered with débris and vegetation that it becomes very diflicuit to trace the varions berls. It is probable, however, that they curve toward the east and eross the valley, for a few miles after leaving the divide there is on the left hand side of the roul an exposure of Carloniferons limestones dipping a little east the rorth. On the right haut, a few miles to the south and west there are numerons voleanie peaks, their sharp, jagged edges standing out boldly against the sky. As we neared the valley of the Yellowstone, we came to a bed of volcanic breccia, resembling that at Mystic Lake and originating evidently in the same center of eruption. Trail Creek has cut through this breccia leaving a high butte standing on the left bank of the ereek a few miles from its montl. The top of this butte seems to be composed of compact rock. A few miles from the divide on Trail Creek there are coal-beds, none of which, however, have ever been mined.

Camp No. 3 was in the Yellowstone Valley, on Eight.Mile Creek, a few miles from its junction with the river. The valley of the Yellowstone is tilled with Pliocene deposits of about 150 feet thickness, on top of which there are horizontal beds of basalt, which once probably ex. tended over the whole valley forming an inmense platean through which the river has cut its bed, removing immense quantities of material. The basalt is covered with local drift from the mountains. The foot-hills on the western side of the : alley are composed of volcanic breccia. There has evidently been more than one period of eruption, for farther up the valley there are several layers of basait, between which there are Plocene sandstones. The columnar form is beautifully shown in many places throughout the valley.

From Camp No. 3 I ascended the foot-hills which lie to the west, bo-d cring the Yellowstone Valley. These hills rise abont 3,000 feet above bo. crive the river. Proceeding three miles from the river we reached the bre of the hills and found the lower ones composed almost entirely the base of the hills and found the lower ones composed almost entirely of breccia, while farther back we find laminated trachytes, which are inclined at an angle of about $40^{\circ}$, as though the lava had been poared forth in successive layers and, after cooling, had been thped tip by sub sequent voleanic action. It is probable that une this we would find all the sedimentars rocks, from the Cretaceos to the Carboniferous or even lower. A few mills, we find rocks containin small streams have cut deeply into the hills, we find rocks containing
Cretaceous fossils. Farther up, however, the volcanic rocks conceal all the underlying formations.

Our next amp, No. 4, was some eight or ten miles farther up the calley, on a basaltic plateau near Bottler's ranch. The general elevation of this platean above the river is between 100 and 200 feet. Near tiont ox there are sereral good exhitions of basaltic columns, and on bottler the underlying marls and wite sand. the opposite side milas west of Bottler's we find ourselves in the midst of volcanic rocks of all kimds and colors, basalts predominating. The prevailing color of these rocks is a brick-red and dull purple. Scattered che hills, as well as throughont the entire valley of the Yellor. stone, we find chips of black obsidian, chalcedony, agate, and jasper. I got some very good specimens of red jasper assaci. ated with blue chal. cedony, and also specimens of olis: specimens of olic.
inte from the basalt. We left Bottlet's on the 24th, ant started up the cal. lev, camping in the ley, camping in the No. 5) on Cañon Creek, eleven uniles alore Bott'or's. Cañon Creek joins the Yellowstone just after the latter just after the latter has emerged fron (Fig.29.) The rocks of the second cañon are all gneissic, and as Idescribed them in the report fo 1871, I will pass them here. Be tween Bottler's and

the recold of the way at a cousiderable height above the river on blufts of volcauic

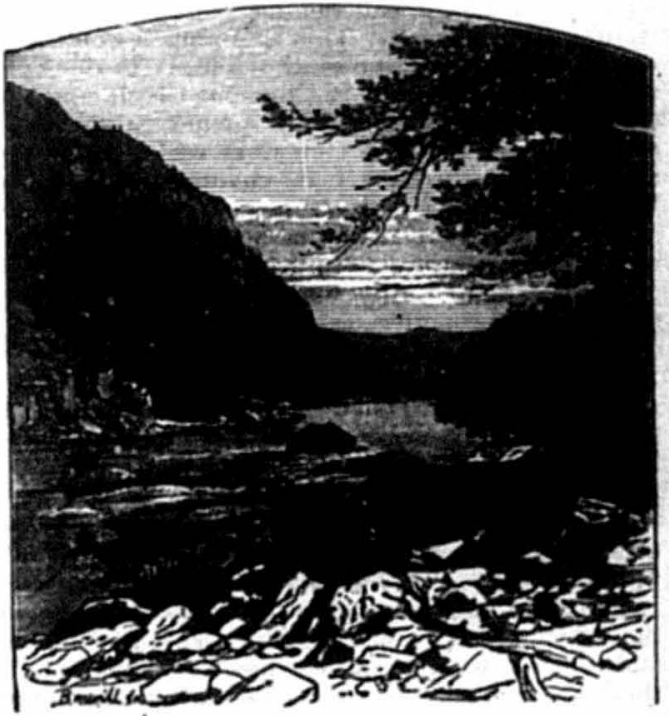

casor or yeurstore mive 
breccia. The prevailing color of this breceia is a gray, but the included masses have an almost inflnite variety of color, green, purple, and red masses being abundant.

On the 24th of July, in company with Messrs. Wakefeld and Savage of the expedition, I started up Cañon Creek from camp No. 5 with the intention of crossing the hills west of the second cañon and striking the Yellowstone River near Ciunabar Mountain, where the party ex. pected to camp. The valley of Cañon Creek is quite wide and well watered, there being several small lakes bordering it. We followed the course of the stream but a short distance, when we struck np on the hills. The volcanic rocks here seem to be in contact with the gueisses. Scattered among the rolcanic rocks I found silicified wood in abundance. After a long and arduous elimb over the lower hills we reached a long ridge of volcanic 'breccia, which seemed to be a spur of the main ridge, and to the summit of which it led. It projected from it at a right angle. So following it w) we at last gained the top, and found ourselves on the edge of a precipice, which formed a portion of the opposite side of the ridge. Looking over the precipice we saw we were on the top of a blank vertical wall of over 2,000 feet in Leight. The elevation of the mountain we were on was 9,478 feet above sea-level and 4,377 feet above the camp (No. 5) we had just left. The view from the summit, how. ever, repaid us well for our toilsome climb. To the south and west the entire conntry seemed to have been subjected to the most intense vol. canic action, followed by an immenso amount of erosion. Sombercolored ridges, with sharp, piercing peaks and conical crater-like points, with deep gorges between, testify to the former disturbances. All abont us were deep banks of snow. In order to descend we were obliged to follow the ridge toward the north nutil we came to a spur projecting at right angles from it. This spur sloped gradually to the valley of Cin. nabar Creek, a small stream tributary to the Yellowstone River. We descended on this spur to Cinnabar Creek, and then followed it around - Cinnabar Monntain, reaching camp at night-fall. Cinnabar Mountain shows a patch of the sedimentary rocks that everywhere else near here - seemed either to have been covered by the outflow of lava or to have been washed away. It is probable that both causes have operated. The northern portion of the mountain is made up of granitic rocks, a -continuation of those seen in the second cañon. Upon :hese rocks rest quartzites, followed by limestones, the upper lasers of which are nudoubtedly Carboniferous. The limestones are followed by quartzites again. One ridge of this quartzite forms the northern wall of the Devil's Slide, while the southern wall is formed of a dike of dark green porphyritic rock. This dike probably separates the Carboniferous from the Jurassic. Beiween these two almost vertical walls the softer material has been washed out. Adhering to the ditse are pieces of a blue-clay slate, and following it we find Jurassic beds of slates and limestones containing Myascites subcompressa, Pholadomya, and Camptonectes. Next come Cretaceous beds, in which there are indications of coal, and containing .Scaphites, Ventricosa, Baculites, Ostrea, Inoceramus, and Trigonia. All the beds I have mentioned above have a dip to the southwest and an incl. tion of from $50^{\circ}$ to $80^{\circ}$. About a half mile above the Devil's Slide we find that the beds seem very much crushed together, and within a rery short distance dip southwest, and are horizontal and dipping northeast. A risit to one of the high peaks in the neighborhood gave us a clew to this curious contortion of the strata.

On the morning of the 26th of July Messrs. Gannett, Brown, and myself started to make the ascent of the peak, which lay to the south. weat of camp. Onr way was up a long ridge, which seemed to us to lead to the sunmit of the peak. The rocks immeliately beneath us were Cretaceous saudstones. On reaching the timber-line (9,442 feet above sea-level) we found we would have to finish the ascent on foot, us the ulope became too steep for the horses. So dismonnting we picketed them, and started for the summit. The sandstones over which we passed reach within 500 feet of the top, dipping to the northwest. The sum. mit of the peak seemed to be made up of an immense pile of broken np rolcanic rock, (a rusty-gray trachyte.) When we were within about 500 f $s$ t of the top a storm came up, and about 500 fr $\mathrm{ft}$ of the top a storm camed in clouds. The ascent here was very difficult, as the fragments of rock were very sharp, and most of them loose, slid. ing from veneath us as we climbed over them. Mr. Gannett succeeded in attaining the highest point and depositing his instruments, when he discovered that he was in the midst of an electrical clond, and his feelings not being of the most agreeable sort he retreated. As he neared us we observed that his hair was standing on end, as though he were on an electrical stool, and we conld bear a series of snapping sound as though he were receiving the charges of a number of electrical frictional machines. $\mathrm{Mr}$. Brown next tried to go up, but received a sbock which deterred bim. The cloud now began to settle about us, and we descended some 500 feet, and waited until the storm passed over. A bout 4 o'clock in the afternoon we succeeded in reaching the top, and Mr. Gannett found the altitude of the peak to be 10,992 feet above the sea. We uamed it Electric Peak. The eastern side is hollowed, and from the base two smal creeks flow to join the Yellowstone. Between the peak and the Hot Springs, on Gardiner's the peak and the hot springs, on a volcanic River, there must have been a center of voleanic
action, for the sedimentary beds opposite the springs dip in the opposite direction to that o the beds on the western side of Electric Peak, and the space between is filled with voleanic material, from which a cone-like mountain rises. This will also explain the crushing together of the strata above the Devil's Slide. Descending the peak after completing our observations we reached our horses about 6 o'clock in the evening, and soon were on the way toward camp, with, however, but little hope of reaching it that night, as the main party had started up the river in the morning after we left.camp. After dark we enmped on the banks of Cache Creek, some miles from the valley of the Yellowstone. The next day about noon we reached

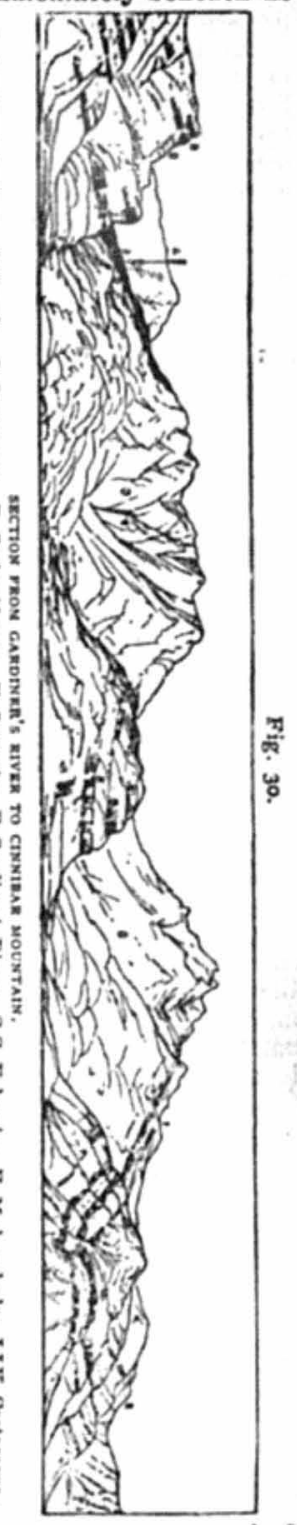


camp at the Hot Springs, on Gardiner's River. Opposite the springs there is a high wall, which presents the edge of Cretaceous and Lower Tertiary strata for a vertical distance of nearly 2,000 feet. The river has cut its way through a sort of a monoclinal valley, resting on either Carboniferons or Jurassic beds, while on the east side of the river we have the Cretaceous beds I spoke of above. The lower layers ais rery calcareons, and contain thin beds of limestone, from which I obtained good specimens of calcite and Icelaud or double-refracting spar. Near the forks of the river, about half a mile above the springs, we have exposures of lower beds, in which there ate seams of earthy lignite, associated with which I observed selenite, coating some of the argillaceous sandstones. There is an exposure of this eurthy lignito some four miles farther down the river, a continuation probably of the same be!l . Near the top of the wall there are Tertiary beds inter culated with basalt. The topmost layer of the latter stretches away to che cast in a iroad platean, and on the edge the columnar form is well shown. It probably once extended on both sides of the river, and came from a point west of the springs. All the beds mentioned above dip to the northeast at an angle which averages about $15^{\circ}$. The limestones which dip under Gardiner's River extend under the Hot Springs, and are probably the source of the lime observed in the waters and deposits, The section shown in Fig. 30 will perluaps show mone clear!y the relations of the various beds near the Hot Spriugs. The springs were so fully described in the report of last year (1s71) that I wil not take the room to deseribe them again, inasmuchas it wonld be a mere repetition. We spent two days in camp there this year, duriug which time I mate a more complete record of the springs and their temperi-

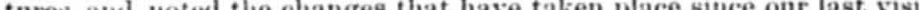
Since then there have been a number of cabins and bath-houses erected, and uot withstanding the difficulties of reaching the springs there weic abont thirty persons there eujoying the beuetits to be derived fiom drinking and bathing in the waters.

The top of the gorge in which the springs are situated is 1,285 feet above the level of the river. I will commence with the springs at the level of the river. These are seven in number, and remain about the same as they were last year, with the exception that some of then lave been artificially enlarged. The temperatures here are lower than wo find higher up, and the springs are filled with bright green Conjer. voidea. The following table gives all the points of interest in regurd to these springs:

Springs at the lerel of the rirer.

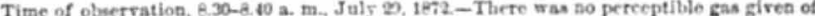

\begin{tabular}{|c|c|c|c|c|c|}
\hline No. & Size of spring. & Depth. & $\begin{array}{c}\text { Tempenature } \\
\text { of air. }\end{array}$ & $\begin{array}{l}\text { Temperature } \\
\text { of spring. }\end{array}$ & $\begin{array}{l}\text { Elevation above } \\
\text { sea-level. }\end{array}$ \\
\hline $\begin{array}{l}1 \\
2 \\
3 \\
4 \\
5 \\
6 \\
7\end{array}$ & 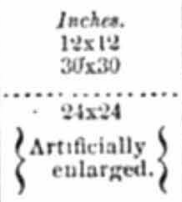 & 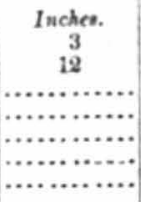 & $\begin{array}{l}70^{\circ} \mathrm{F} . \\
70 \\
70 \\
70 \\
70 \\
70 \\
70\end{array}$ & $\begin{array}{l}104^{\circ} \mathrm{F} . \\
104 \\
111 \\
114 \\
112 \\
94 \\
132\end{array}$ & $\begin{array}{l}F c e t . \\
5,750 \\
5,750 \\
5,750 \\
5,750 \\
5,750 \\
5,750 \\
5,750\end{array}$ \\
\hline
\end{tabular}

As we go from the river up the hill toward the main springs we meet with a large pool of hot water of about 100 feet diameter. It is 230 feet above the level of the river, and on its edge there are several prings of two I took the temperatures, and found them both to be springs. tion 8 a. m. A short distance farther up we came to the main mass of springs, arranged on a series of terraces at different levels, The first terrace is 528 feet above the level of the river. The principal springs are on the first ten terraces, and as we go up the valley we find that, although there were once mauy springs here of a most active character, the proent time they have nearly all died out. The first four or five at the pro lont time they have nearly all died out. The first four or fre 193 ग.5 to $200^{\circ} .9$. I give the temperatures, \&c., below in tabular form. The observations were all made on the 28 th of July.

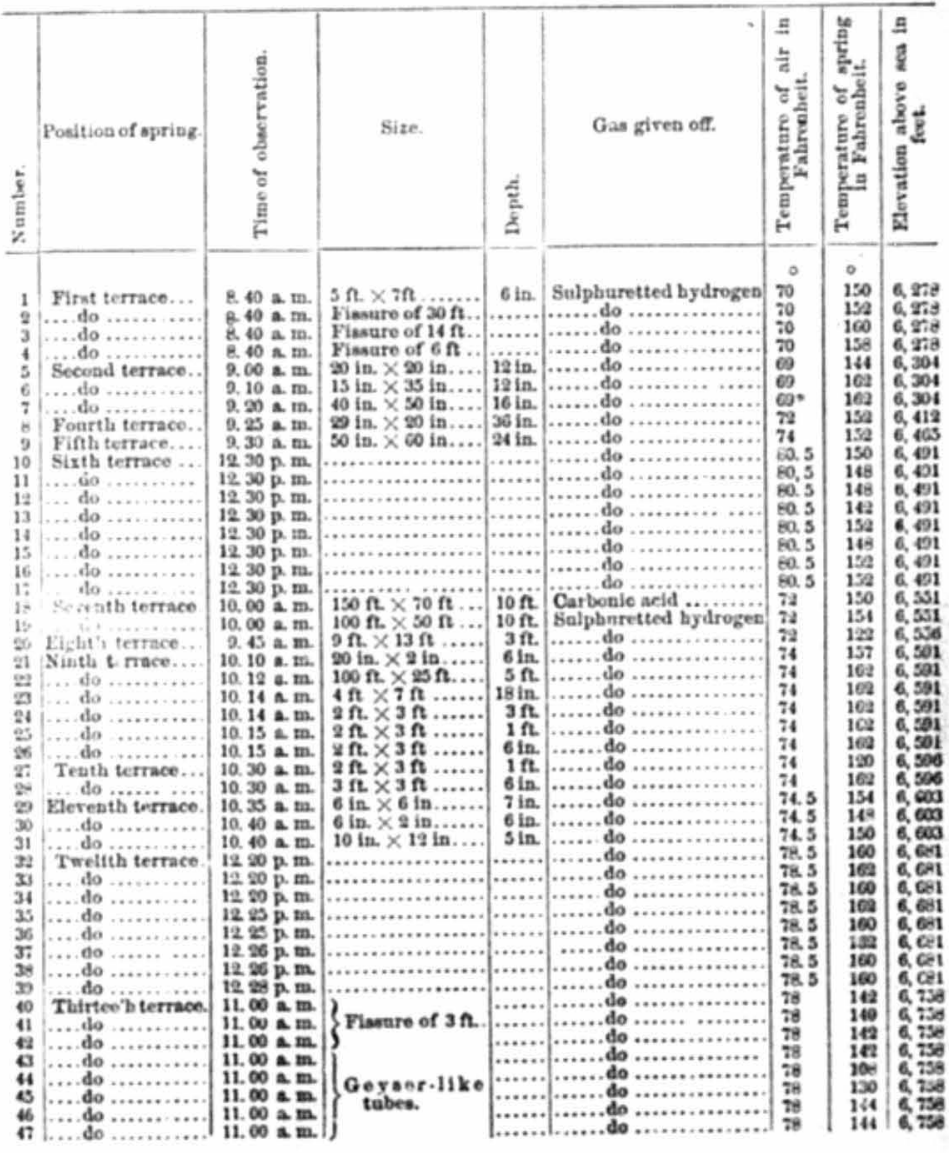




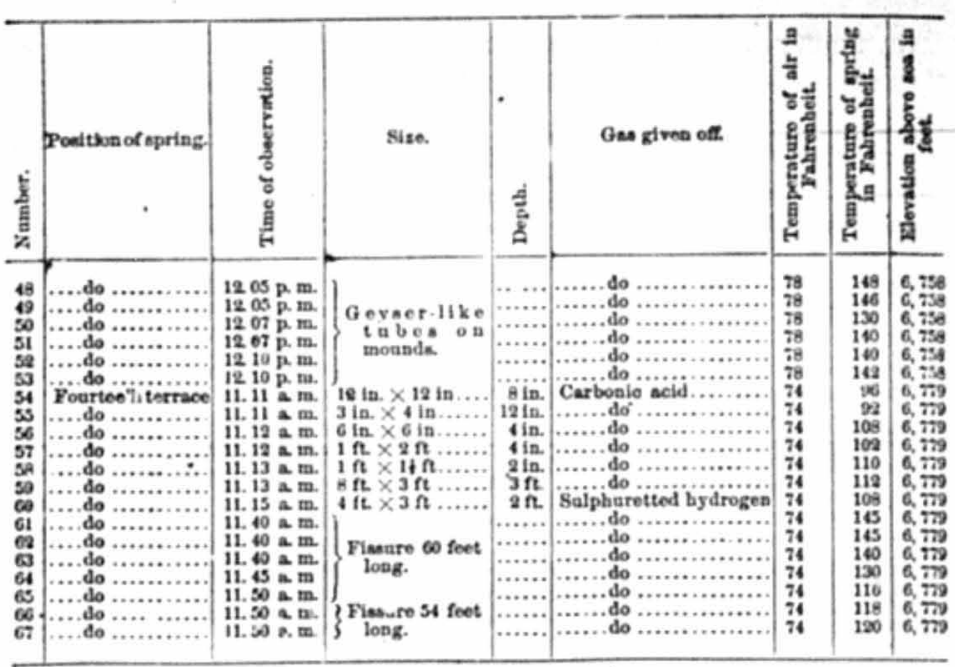

The elevation of the ridge just above the fourteenth terrace is 7,035 feet. The greatest change Pig. 3r. in the springs was no-

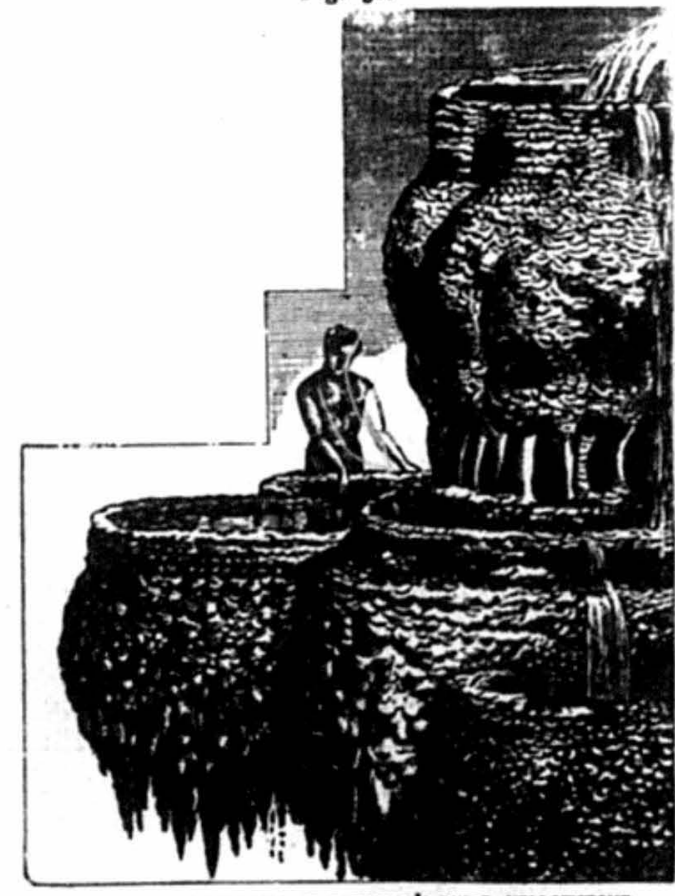
ticed on the ninth and twelfth terraces. The former in 1871 was al. most entirely covered with water, through which the various springs could be noted by the points of ebullition. It was impossible to walk any. where but around the edge. Now, however, the most of the wate has disappeared, and only the springs remain, aud one can walk almost snywhere on the terrace. On the twelfth terrace there are a great many new apring gll of which cprings, all of which have a high temperature. Carbonic-acic gas can be detected in the springs of the fourteenth terrace by the torte. These bpritug are hid in the grass, and it is only by care ful searehing that they

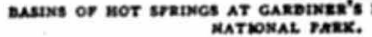
are found.
Dr. Endlich has made the following analysis of the deposits from these springs :

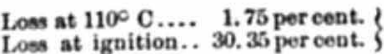

Per cent

32. 10

Lime.

Silica......

Ferric oxyd.

Alumina.

57.70

Maguesia.

3., 32

3.31

Trace.

$\overline{100.05}$

Figures 31 and 32, drawn by Mr. Holmes, will perhaps give the reader a good idea of some of the peculiar formations noticed at these spriugs. Fig. 31 shows the pools or basins which were so fully described by Dr. Hayden in the report for 1871 , and which fort one of the most beantiful features of the springs. The water in all of them is either warm or bot according to their position, the lower ones having the coolest water. The water has also that exquisitely beau. tiful blue tint which is beyond descriptiou, and which forms such handsome contrasts to the white, marble-lise basins in which it is. The water ponrs from one basin to another and forms stalactitic processes, which hang from their sides as seen in the pieture. At the bottom of the upper basin in the illustration the processes

rig. 32 .

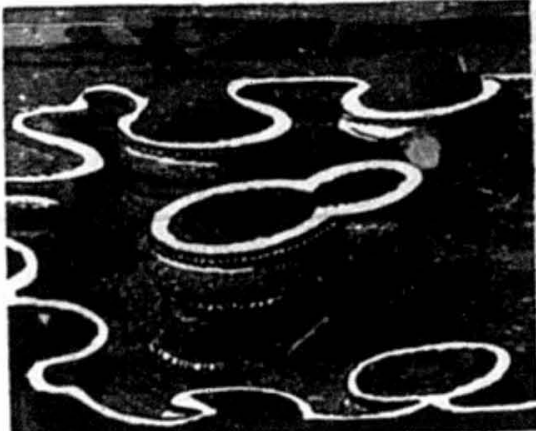

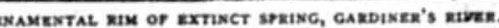
from below by the dropping of the water, while in the lower basin they have not yet come together, but still form true stalactitic processes. Over the ontside surfaces of the basins we find also bead-like processes, caused also by the dropping of the water. The great amount of lime in these deposits gives them a beautifu! white appearance.

\section{CHAPTER III.}

\section{GARDINER'S RIVER TO MUD.VOLCANOES, YELLOWSTONE} VALLEY.

We left the Hot Springs on the 29th of July and made our next ctimp on Blark.Tail Deer Creek near the Yellowstone, a few miles above Gardiner's River. Our camp was on a portion of the platean that extends eastward from the top of the bluff-wall opposite the springs. The rock immediately beneath as ras a violet-colored trachyte containing crys-

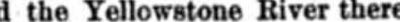
were some exposures of Carboniferous limestone, evidently the direct -By spectroscopio examination. 
prolengation of the layers noticed in the last chapter as occurring at Cinnabar Mountain. Just below these outcroppings the rive passes through the third eañon, the rocks of which are gneissic, npon which the limestones rest. On the west side of the river there are fine exposures of black wicaseous are the opposite side there are three streams which cut their way to the river through the solid granite. About a mile east of camp I visited a butte of limestone which rose above the surrounding volcanic rock like a huge monument. The dip was southwest at an angle of about $500^{\circ}$. From these layers I obtained hemipronites, spirifer, and rhynchonella.

The following day we moved our camp to the Yellowstone and pitched our tents in a beautiful grassy valley on Elk Creek, about one mile from the Yellowstone River. About two miles above us the East Fork of the Yellowstone joined the main river. Otr camp (No. 9) was 334 feet lower than the previous one, (No. 8.) The descent from the plateau was rather abrupt, and gave us a chance to see the structure of the Eocene beds, which were here composed of coarse, yellowish-brown sandstones, intercalated with basalt and irgchyte. The sandstones in some places are conglomerate, and all are considerably metamorphosed. Some of the layers contained impressions of decidnons leaves, amon which Professor Lesquereux has found Flatanus nobilis, Fagus antipofi, and a new species described in his report. The volcanic rocks, mostly basaltic, contained a large percentage of iron, asd, on weathering, presented a rusty appearance. In some I found green jasper and chal cedony. The valley of Elk Creek below our camp presented a curions appearance. The river and the small streams h'ive ent their way deeply through the Tertiary beds, leaving table-like buttes standing between each one, beiug capped with a volcanic layer, the top of which is perfectly level. They are merely the remnants of layers that once extended over the entire valley. Beneath the volcanic layers the soft gray and brown sandstones have yielded readily to the action of the water, and the cañons are deep, with perpendicular walls.

The Tertiary beds seem to rest immediately on the gneissic rocks at this point, and before their deposition there was undonbtedl a great deal of erosion. The thickness of the Tertiary beds, includ. ing the rolcanic layers, is about 400 feet. Througbout the valley in which we were camped there was an immense number of granite-bowl ders of all sizes, which were evidently washed down the valley of the East Fork, for we find them strewn along that river for some distance above its junction with the Yellowstone. On the east side of the Yellowstone, near Hell Roaring Creek, there are some high granite mountains, and the entire surrounding country is very rugged and will some day form a most interesting field of study. Our time was too limited to attempt to penetrate it at all. Near the junction of the two forks of the Yellowstone there has been a bridge thrown across the main stream. Just at this point we find an exposure of granite. This passes into micaceous gneiss, which is overlaid by sandstones, on top of which there is a bed of conglomerate, made up mostly of voleanic frag ments. Crossing the river we soon find ourselves surrounded with vol. canic rocks. A short distance from the river there is an isolated tablelike butte, rising 600 feet above the level of the river. It id capped with besalt of considerable thickness, beneath which are soft Tertiary sandstones. The floor of the butte is quite level, and is strewn with granite-bowlders. It is evidently only another remnant of the basaltio laser I have referred to above, which once extended over an imunenso area. As we proceed up the Yellowstone, it becomes thicker. Follow. ing the river we found that a short distance above the bridge it emerges from a deep cañon. At tise lower end of this cañon there are a number of hot gprings on the edge of the river. We could distinguish at least forr. They were surrounded by a considerable deposit of suiphur and iron. They give off sulphuretted hydrogen abundantly. We were some 500 feet above them, and yet the surrounding air was strongly impreg. 500 feet above them, and yet the surrounding air was strongly irapreg. nated with it. It was impossible to reach the springs to take their
temperatures. The cañon is about \& mile in leugth, extending from the temperatures. The cañon is about \& mile in leugth, extending from the
month of Tower Creek, opposite Tower Falls. It is one of the finest can̂ons I have ever seev. The walls are perpendicular and the river flowing below is a perfect torrent, of an emerald-green tint, capped with white foam. The fall of the river for $2 \frac{1}{2}$ miles is 229 feet. On the western side of. the canon the rocks have been weathered into towers, western side of. the canon the rocks have been weathered into
with sharp pinnacles, giving it a most picturesque appearance.

The height of the easteru wall is 346 feet above the level of the river opposite Tower Falis. At the lower end the height probably reaches 500 feet. This wall, from top to bottom, is composed as follows :

$$
\left.\begin{array}{l}
\text { 1. Soft, gray sandstone. } \\
\text { 2. Columnar basalt. } \\
\text { 3. Conglomerate. } \\
\text { 4. Columnar basalt. } \\
\text { 5. Trachyte. } \\
\text { 6. Limestone (१). }
\end{array}\right\} 346 \text { feet. }
$$

The larers of basalt mentioned above, Nos, 2 and 4, extend the length The have ever seen anywhere in the West. It was impossible to obtain the have ever seen anywhere in the West. It was impossible to obtain the exact measurements, but I shonld estimate those in layer No. 2 to be 15 feet in height, while those of No. 4 were probably between 20 and
30 feet. The conglomerate No. 3 was probably about 100 feet in thickness, and composed of large fragments of all kinds of rocks, the volcanie predominating. It was so infiltrated with sulphur that the whole caich lo bright yellow sellow color, especially noticeable at the upper end of the crũon. The sandstones on the top were very soft, and had weath ered so as to give a rounded top to the wall. The general color of the tracbyte was a violet, and it rested, I am inclined to think, on limestones, although on this point I am not quite certain. Above the cañon the Yellowstone River flows through quite a wide vulley, which on one side is comparatively open and on the other side which slope to within a short distance of the river's edge. Just abov this valley is the lower end of the Grand Cañon. Both sides of the river above Tower Creek have once been the seat of hot-springs, whose most active period has been long passed. There are at present only a few springs remaining on the western bank, while on the east there are extensive deposits containing snlphor, selenite, and alum. Wu spent four days in camp No. 9, while Dr. Hayden and a small party made a side trip to Clarke's Fork of the Yellowstone. During this time, in addition to some trips to Tower Falls and the vicinity, I also made two trips up the East Fork of the Yellowstone to a locality where one of the members of the expedition discovered some very fine crystals of amethyst. This locality is some ten miles from the main Yellowstone. The about 1,000 feet in height and the summit entirely destitute of timber, the rock covering it being basaltic. Over the basaltic floor, quartz, agate, jasper, and silicified wood are found in quantity. There seems once to have been a forest standing here which the lava bas inclosed 
and silicified. Imbedded in the rock we find numerous cyliadrieal masses of chalcedony a foot and more in diameter. In some of these masses we can still trace the form of the woody fluers, while others have bits of silicifled wood that bas not been changed to chalcedony. In the center of many of these cylinders we find erystals of ametbyst. They are large and have a fine color. If we had been able to penetrate to a greater depth there i to a greater depth there is no doubt but thut me mould bave found handsomer specimens. In other specimens the wood seems to have formed a nucleus around which the quartz has crystallized, chalcedony forming the center and milky quartz the exterior. In one place on this hill I found a great variety of jaspers, with also agates and semi-opal.

The following is a complete list of the minerals found at this loeslity : Amethyst,(amethystine quartz,) iimpid quartz, milky quartz,(ferruginous quartz,) chalcedony, carnelian, clirysoprase, prase, banded agate, flint, red, yellow, gray, blue, and black jaspers, semi-opal, and calcite.

The calcite is found in the center of agate-geodes. The jaspers are very fine, containing three and four colors in some of the pieces. The rystals of quartz and amethyst are ull large aud fine.

Throughout the entire valley of the Yellowstone quartz, chalcedony, agate, and obsidian-chips are common, while almost all the trachytes contain crystuls of sanidine. Among the specimens brought from Clarke's Fork were argentiferous galena; and the blue and green carbonates of copper from the Clarke's Fork mines.

We left Elk Creek on the 4 th of August, and made our next camp at the foot of Mount Wasbburne, on the eastern side, in a small, densely. timbered valley bordering the Grand Canon. Close to our eamp there was a small gulley containing some springs, of which I recorded the temperatures. A small stream ran through the gulles, and throughont the entire bed there were springs whose preseace was revealed by the bubbling of carbonic acid and sulphuretted hydrogen through the water. On either side of the stream there are abundant deposits, of a white color, containing lime, silica, and sulphur, giving evidence that at some past time this place was the seat of a large group of active springs, of which those now existing are a mere trace. It may not be many years before they will be entirely extinct. The specific description of these springs is as follows: No. 1 is eight feet by flve, and gave off sulphuretted bydrogen abundantly. The temperature was only $52^{\circ} \mathrm{F}$. No. 2 is three by four feet, and has a temperature of $53^{\circ} \mathrm{F}$. Nos. 4 and 5 were merely small boles in the deposit on the bank of the stream. The tem. perature of the former was $94^{\circ} \mathrm{F}$. and that of the latter $115^{\circ} \mathrm{F}$. The remaining springs were as follows: No. 6, $188^{\circ} \mathrm{F}$.; No. $7,188^{\circ} \mathrm{F}$.; and No. $8,190^{\circ} \mathrm{F}$. The boiling-point here would be $198^{\circ} .3 \mathrm{~F}$. The tem. perature of the air during these observations was $76^{\circ}$ F., the time being about $7.30 \mathrm{a} . \mathrm{m}$. The elevation above sea-level was 8,117 feet. From this group of springs we caught a glimpse of a white spot through the trees, which indicated that there were more springs to the north of these. Toward this place we turned our heads, and while riding along through the woods we came to a pool of water which would measure probably thirty yards by fitty. The surfacu of the water was almost all in agitation from the number of points of evolution of carburetted hydrogen. The temperature of the water was only $54^{\circ} \mathrm{F}$, while the air still remained at $76^{\circ} \mathrm{F}$. This pool was on about the same level as the springs mentioned above. A short ride from this pool brought us to the spot we were seeking, and. we found ourselves in the midst of an active group of mud springs or salses. The springs are distributed over the side of a hill which steams from top to bottom. It was a most hor. rible-looking place, and bronght to our minds pietures of the infernal regions. The-black and red colors of the mud and iron deposits gave the hill the appearance of having been burned, while here and there were masses. of bright-yellow sulphur. The air was flled with the fumes of sulphuretted lydrogen. The noise made by the throbbing and pulsating masses of mud was continuous. This, with the splashing and spluttering of some of the springs, the plop-plop of the thicker mud, combined with the nnesrthly appearance of the scene, made ns feel that we were on dangerous ground, and in walking about the springs we did so care. fully, fearing that we might break through the crust. The mud in these springs is black in some, lavender-colored in others, and again yellow, while in consistency it is of all grades, from that of a thick mush to a mere inky-black water. In the thick-mud spring the steam seems to escape with an effort after several vain attempts. The und rises in a hemispherical mass, falls and agaiu rises, and after several repetitíons the steam bursts from it, sometimes throwing the mud to a distance of 20 feet.

1 divide the springs at this locality into two groups, the second group being some distance bigher up the bill. The following is the description of the springs in the first group: The first one contained a rather thin lavender-colored mud. It is a cavernous-like opening on the side of the h.ll, and is the topmost spring of abont five springs that are situated in a line, one above the other, at different levels. There seems at one time to have been a fissure bere which determined their position. It was the only spring of the five that could be approached, but the temperature even of this could not be taken on account of the steam coming from it. It was probably at the boiling point. The mnd was in active molion, and the steam came from it with a continuuus roar. The spring alsc gave off sulphuretted hydrogen gas.

Yo. 2 was a large pool of muddy water, through which a number of stear jets forced their way, giving the spring the appearance of a sieve fall of water, throngh the bottom of which the stream was forced. The temperature of the water was $194^{\circ} \mathrm{F}$., and the air $78^{\circ} \mathrm{F}$., the time of observation being about 9 o'clock in the morning. This spring was 30 feet above No. 1 . Near it there was a spring of very ihick, blue mud, the temperature of which I was unable to take, it not beiug safe to approach near it, as the mud on the banks was very soft. A short distance to the right of No. 2 , and a little above it, is No. 3 , a large, yellow, muddy pool 30 feet by 50 feet in diameter, in which there was a great deal of bubbling, the water near the edge of the spring being especially agitated. The temperature was $140 \mathrm{~F}$., the air remaining at $78^{\circ} \mathrm{F}$. On the banks of this pool there was an abundant deposit of sulphur and alum. No. 4 is the most active spring of the group. It is about 20 feet higher up the hill than No. 3 , aud is about 30 feet in diameter, somewhat irregular in shape. The mud has formed a rim about it which is 2 feet above the spring on one side and 3 feet on the other. It contains a very thin blue-black mnd, which is in violent ebullition, rising at times to the leight of 3 and 4 feet. A dense column of steam, mingled with sulphuretted hydrogen gas, is continually escaping from it. I was able to take the temperature only at the edge, where I found it to be $190^{\circ} \mathrm{F}$; air, $78^{\circ} \mathrm{F}$. "In the center it was probably at the boiling.point, which at this elevation is $198^{\circ} .2 \mathrm{~F}$. About 20 feet below No, 4, and a little to the right, is No. 5. It is 15 feet long and 5 feet wide at the widest place, being somewhat triangular in shape. One edge of the bank over9 G 8 
hangs the water and coated with a deposit of sulphur, which is deposited by the sulphuretted hydrogen gas. The water here is cleaner than in by of the surres is in violent any of the surroter ebulition from the escape of steam. The teniterature $00^{\circ}$ The the edge of the spring was $184^{\circ}$ F., the air being $78^{\circ}$. The second group has a general elevation of about 150 feet above the first, and is also situated on the slope of a hill. The first spring in this group we called the "Mush.Pot." It is abont 20 feet in diameter, and has three openings, each about 10 feet in depth. The mud at the bottom of these openings color. The mass heaves and holes is very thick and of a luish it. It was impossible to take the throbs as the steam escupes through it. It was impossible to take the temperature of the mud, as the steam scattered it in all directions, ren-
dering it impossible even to look into it with safety.

No. 2 was namel the "Paint.Pot," the mud in it resembling lead. colorel paint. The entire surface was in violent agitation. The diameter of this spring is narrower at the top than at the surface of the dianeter of this sprom is bround. The mud nud, which was eight feet below the snrflec of tho groud. The is scattered in all directions, as in the last-mentioned spring, rendering it impossible to obtain its temperature. At intervals of about three

minutes it seems to take a rest, remaining quite for a few seconds. No. 3 is a tisstre of heack-mul springs, their average temperature there are a number was $790 \mathrm{~F}$. This fissure is about 200 feet above spring No. 1 .

No. 4 is a similar fissure of about the same length. It is about 100 feet above the precelling one, auk contains mud-springs of the same character, the average temperature being $190 \mathrm{\circ}$. The boiling-point at this elevation is $197^{\circ} .6 \mathrm{~F}$. All arouvd this fissure there is an abundant deposit of sulphur and alum, the sulphur-crystals being exreedingly brilliant and delicate.

No. 5 is a blue-mud spring of about three feet in diameter, having a temperature of $190^{\circ} \mathrm{F}$. Nos. 6, 7, 8, 9, and 10 form a small group distinguished by the abundance of sulphur surrounding them. The mud in them was very thick and varied in color from blue to black. The ground about them was too treacherous to allow of a near approach, but but their temperature sides the springs I have described above there were numerons stnaller ones and a great many steam vents. I bave only mentioned the most important springs. Both the groups are situated in banks of clay, and the deposits consist mainly of clay, alum, and sulphur. All the springs are acid in reaction from the presence of sulphuric acid. The sulphur results from the decomposition of the sulphuretted hydrogen which is results front in this locality. The oxidation of the sulphur and it so abundunt in this locality. The oxidlion union with the alumina and iron gives us the alum which we find here.

Our next camp (No. 11) was on Cascade Creek, s few miles from the Lower Falls of the Yellowstone and the Grand Cañon. Caseade Creek, near our camp, flows through a valley covered with sedimentary rocks into which it bas cut a short distance. It is made up partly of sand into particles of volonie material. It is probably Pliocene in its origin, and particles of voleauie material. It is probably Plocene in its origin, and was deposited at the bottom of a lake which was very likely a prolongation of the ancient Yellowstone Lake, and existed here at a comparatively recent period. The strata are soft and contain particles of obsidian in abundance, and are also in part contributed to by voleanic ashes, for here we find ourselves in the midst of a volcauic country. This sedimentary deposit extends over the eutire valley of the Yellowstone at this point. The carving out of the Grand Cañon (Fig. 33) gives us an excellent opportunity to study the various roeks that underlie the valley. At the head of the Grand Cañon is the lower fall of the Yellowstone, hickr was messured this year by triangulation and found to be 397 feet in height. At the foot of the fall the depth of the cañon is 675 feet. This depth increases as we go down the river, and about river, and about balf a mile below it is 1,000 feet, measured with all aneroid barom. eter. The fall of the river from the the river from the foot of the fall to the mouth of Tower Creek, a distance of twenty. two miles, aver. ages 4 (1) feet to the ile. On the west mile. On the west cañon, some dis. tance above the top of the lower fall, there is an ex posure of a very tine soft sandstone having a light-yel. Fig. 33.

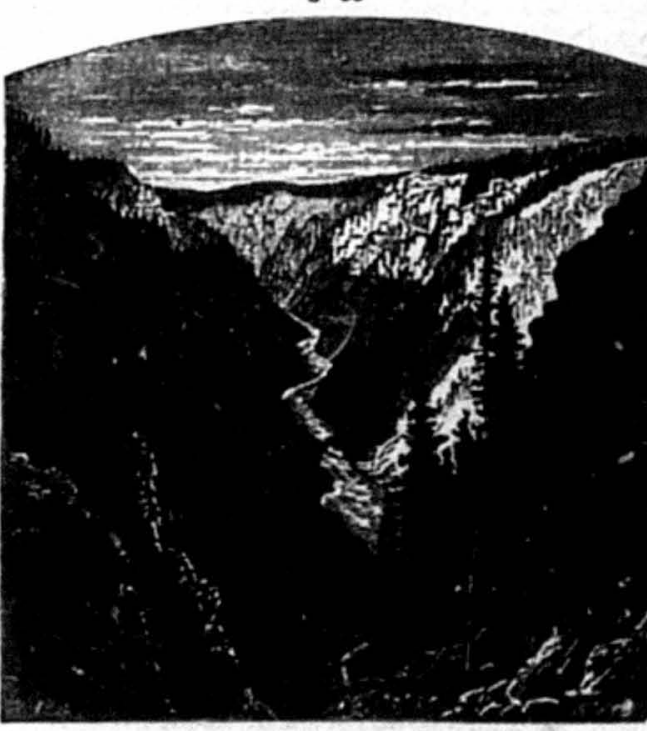

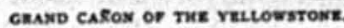

yellow color. This must have been deposited in very quiet waters and is probably of Post-pliocene age. On the eastern side we find the rock to be as follows: The top of the cañon above the falls is made up of obsilian, which is porphrritic, containing erystals of sanidine. The rock is rery irregular in composition and color, the latter varying from black to brown. It passes into a perlite-like rock of a light-bluish color, black to brown. It passes into a perite-like rock of a light-bluish color, in some places is white. This has in places perlite-like truchyteporphyry, containing small feldspathic balis with a radiated fibrou structure, (spherulites,) mixed with small bits of obsidian, the whole mass having a general color that resembles blue lead. A little farthe lown we find in this same rock jasper-geodes containing varieties of chal in the interior. Ther vary in sine opal in the diameter, while others are balf a fouc. They are of a brown color on the exterior and botryoidal in shape, and are porpbyritic, containing crystals of sanidine. Breaking them open we find that the mass often presents a beantiful appearance, some of the specimens having a rich-brown color, mingled with bright red and green, while the cavities are lined with pink, white, or blue semi-opal in some cases and in others by byalite. The rariety in the shades of color is almost infinite. Just above the fall there is a slide of rock reaching from the top of the cañon to the river's edge, and here we fonnd many good specimens that had broken ont of the more massive rock and fallen down.

At the brink of the fall the rock over which the water pours, and which extends some 50 or 75 feet above it, is a compact trachyte por- 
phyry of a light violet color containing erystals of sanidine. As ive pro. ceed down the river we find that this rock is replaced by an argillo trachyte-porphyry, the white color of which contrasts strongly with the other colors seen on the sides of the cañon. The unecral hardness of the different rocks bas allowed it to weather into curious and fan

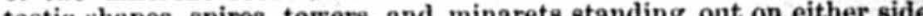
tastic slapes, spires, towers, and he rets stand There bave once been adiding to the picturesqueness of the srenery. There bave once been many hot springs throughout this region, and it is to them that the greater portion of the coloring seen in the cañon is due, the iron deposits giving the reds and the sulphur the yellows. There still are a number of springs along the river's edge, althongh from the top of the caunon they cannot be distingnished. The center of attraction, however, is the they Jower fall, (Fig. 34). The river saddenly narrows to a wath of only 100 feet and rushes over a ledge of trachyte, falling 397 feet to the bottom of the cañon. The water at the edge of the fall is very deep and of a deep-green color. Hnge bowlders thrown in are carried by the force of the current far out from the edge of the fall. When we approach the brink and look over into the abyss we begin to realize the littleness of man when in the presence of nature's grand masterpieces. Down, down goes the whirling mass, battling and writhing as the water dasbes against the rocks with a noise like the discharge of artillery. Here and there a resisting rock is met with and the wates rebonds, broken into myriads of drops, which throw back to us the sunlight resolved into it

Fig. 35.

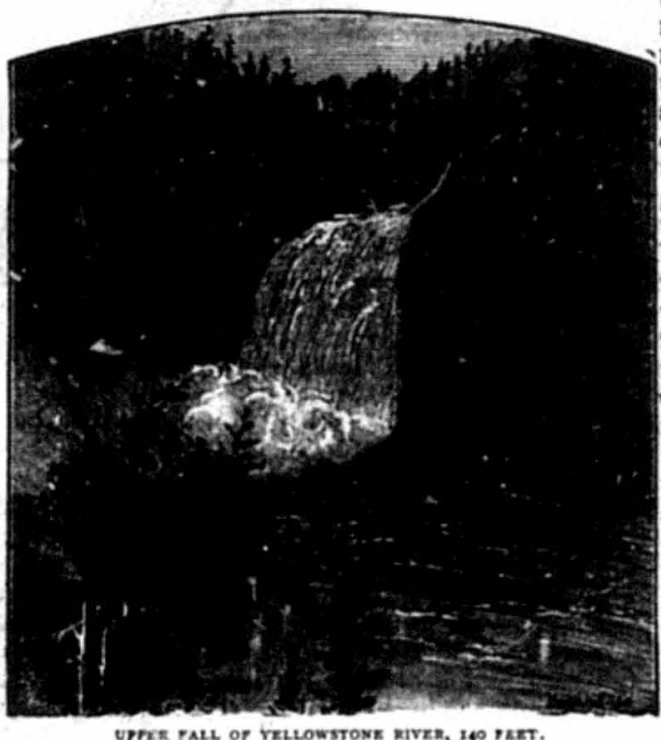

primitive colors. The bottom of the cañon reached, the immense mass of water seems to dissolve itself into spray, and then recov. ering, it flows down the gorge an emerald. green stream, dasbed with patehes of wite, besting with forion waves the rocky walls that imprison it Taken in connection with the varied tints of the cañon itself, red, yellow, orange, white, the dark-green pinesfringing the top, and the bright green of the spray-nour. ished moss on the ished of the fall, have a pieture of al have a picture of al most nnequaled mag ificence and gran. deur. It is a scene of which one sever tires and in the description of which langnage fails. As we stand above the lower fall and look toward the south we bave a fine view of the upper fall, (Fig. 35, which is distant about half a mile. This fall differs altogether from the lower one and does not so soon impress one with its height, which is 140 feet. The water pouring over the edge 
strikes a number of ledges of rock, which eburn it into a mass of foam. A portion of the water is projected out like a broad fan, and striking the water below makes a sort of ricochet, while the main mass ing the water below. cal line let fall from the top. The water has cut out of the solid rock a cal line let fall from the top. The water has cut out of the solid rock a rounded basin, from which the course of the river is almost at right
angles to the course above the fall. For some distance above the fall

Fig. $3^{6}$.

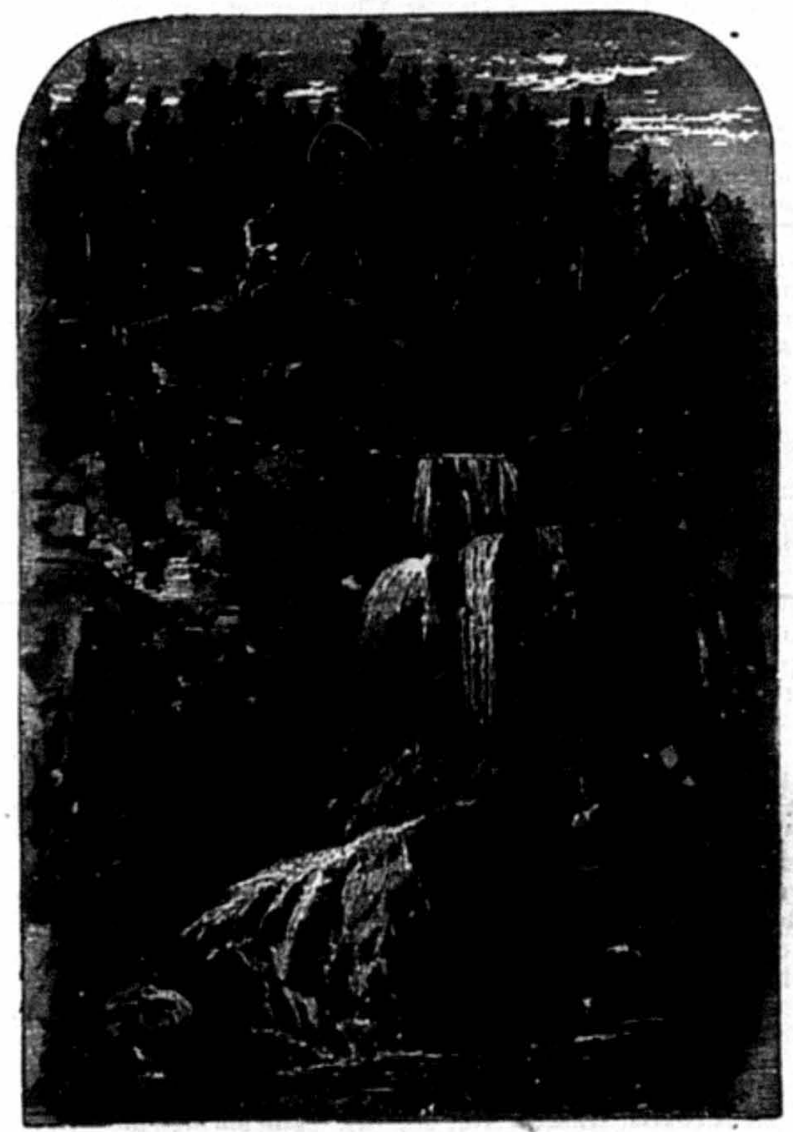

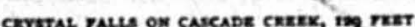

there is a series of rapids over which the current is very swift. The cañon between the two falls is about balf a mile long and the fall of ase walls of this cañon

vary in height from 100 to 200 feet.

Cascade Creek flows into the Yellowst one River on the west side between the falls. A short distance above its mouth we find a beautiful fall, (Fig. 36 ,) or rather cascade, for it is made up of three distinct falls, the 
aggregate height of which is 129 feet. The stream, after passing through a deep, gloomy gorge, makes a leap of about 21 feet and then falls again in three streams a distance of over 50 feet into a beautiful, rounded basin, in which the water is perfectly clear and quiet. From this basin the final leap is taken and the water flows on to the Yellowstone River. Leaving Cascade Creek our next camp (No. 13) was at Mud Volea. noes near the Yellowstone River, about eight miles below the lake. We spent three days here, waiting for a supply-train to join us from Fort Ellis. During this time I visited a number of the various hot-8pring localities in this portion of the valley. The underlying rocks here are Pliocene and Post-pliocene, in horizontal strata, and presenting the same characters that were observed near the Grand Cañon, and probably resting, as those do, upon volcanic rocks. In some places I noticed iron as forming a prominent part of these sedimentary cieposits, which, with the obsidian, makes very landsome specimens. The river flows quietly through the valley, the fall per mile, from Yellowstone Lake to the top of the upper fall, being only 8 feet, and almost all of this is in the rapids just above the upper fall. The first springs I visited were on a branch of Alum Creek about five miles Lorthwest of camp. We named the small stream Violet Creek, frusa the profusion of violets growing upon its banks.

The first spring we met with was on the right bank of the ereek, in a siliceous cone-like mound that rises six feet above the bed of the stream. Its temperature was $126^{\circ} \mathrm{F}$, the air being at $70^{\circ} \mathrm{F}$. 'The bed of the creek was filled with confervoidea, leading us to suspect that there were springs still farther up. After a further ride of about a quarter of a mile we came to quite a large group of hot springs lining both sides of the ereek. The first spring I will describe is on the right bank of the creek, in the center of a white monnd 20 feet in diameter and rising 10 feet above the bed of the ereek. This mound is formed of the deposits from the water, which consist mainly of various carbonates and silica. The orifice of the spring is cireular and about three inches in diameter and looks as though it had been artificially punched in the deposit, so mathematically exact is it. The water gives off carbonic-acid gas, leaving a deposit of iron. Its temperature was $190^{\circ} \mathrm{F}$, the air being $70^{\circ} \mathrm{F}$. Spring No. 2 is on the opposite sille of the creek and has a basin measuring 4 feet by 2 feet; the temperature of the water was $1600 \mathrm{~F}$., the air remaining at $700 \mathrm{~F}$. No. 3 has a circular basin two feet in diameter, which is lined with an abundant deposit of iron. Carbonic-acid gas bubbles throngh the water. Its temperature was $158^{\circ}$ F. No. 4 is 6 feet deep and 1 foot by 3 feet in diameter, and has a temperatare of $188^{\circ} \mathrm{F}$. The next three springs had temperatures as follows: No. 5, $192 \circ$ F.; No. 6 , $194^{\circ}$ F.; and No. 7, $185^{\circ}$ F.; the air still remaining at $70^{\circ} \mathrm{F}$. All these springs have circular oritices of about six inches diameter, and the water proceecling from thein flows over a series of small terraces, resembling those of the Gardiner's River springs on a miniature seale. These basins are lined with a gelatinous form of silica, which has a leathery appearance and is coated with an iron deposit. The springs are about 10 feet above the level of the ereek and all give off carbonic-acid gas. No. 8 is very irregular in shape and almost hid in the crass, about 40 feet from the creek. There is a slight bubbling in it and its temperature was $178^{\circ} \mathrm{F}$. No. 9 is a small spring, 2 feet in diameter and 1 foot deep, lined with confervoidea and haring a temperature of $1400 \mathrm{~F}$. No. 10 is a very pretty spring, about four feet above the ereek, and has a bean tiful seallotved edge, moss-lined on one side. Its temperature was $175^{\circ}$ F. The boiling.point $\mathrm{x}$ t this locality is $198^{\circ} .3 \mathrm{~F}$. None of the springs reached this temperature, $194^{\circ} \mathrm{F}$. being the nearest approach. The rocks exposed near these springs are sedimentary and contain a great desil of obsidian.

About three-fourths of a mile farther up-stream we came to the bead of the creek and fond that it originated in a most important group of the creek artuated in a semicircular basin, bounded by a low springs. They are situated in a semicircular basin, vounded by a low hill wooded on the summit. The sides of this hill are perfectly bare and way. Looking down into the basin from the top of the hill is like looking into a voleanic crater. The fumaroles, solfataras and mud-springs scattered throngh it give it a most peculiar appearance. The geveral color throughout the basin is a glaring white, relieved here and there by patches of brick-red iron deposits and the yellow of sulphur-masses by patches of brick-red iron deposits and the jellow of sulphur-masses basin is lined with beantiful crystals of sulphur. On the lert of this basin there is a ravine, covered with deposits of the same character but containing no springs. There are a few fumaroles remaining, the evilence that once the ravine was the site of active springs. A few yards on the opposite side of the basin there is a second ravine similar to the first, and in which also the springs are all dead, nothing remaining but the rust-colored deposits. I will give the different springs in this basin below in tabular form.

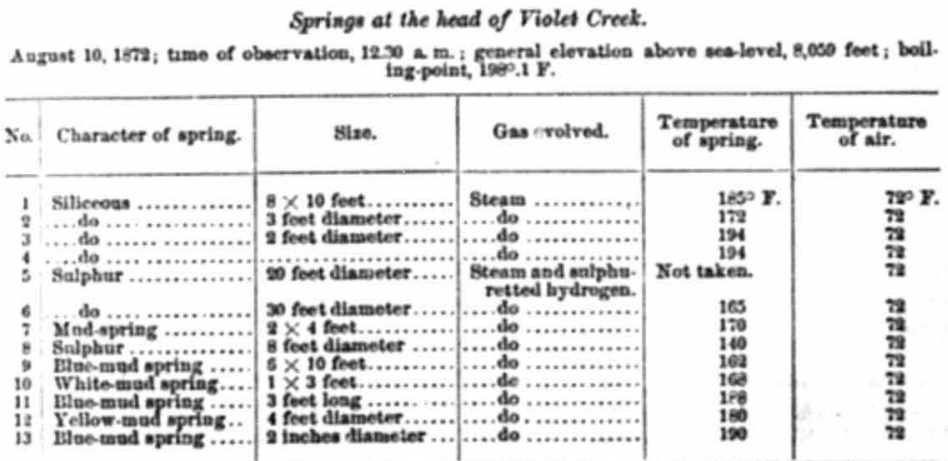

Besides the springs enumerated in the table there were many smaller ones and a few large pools through which the gases bubbled at various points. The ground near the majority of them was too treacherons to theat many steam-vents lined with sulphnr-erystals. The hardened deposit about some of the mndsprings is an indurated clay, that has been deposited by the springs. one was in violent ebnllition, the water at times rising four feet above the ordinary surface. In No. 10 I found butterflies that had fallen into the water and been killed by the heat. The odor of sulphuretted hydmogn was not so strong at this locality as at the foot of phuretted hydrogan

$\mathrm{O}$ a the way back to camp we eame across another group of springs, about a mile sontheast of the group given above, and have an elevation about 200 feet lower. They are situated in a ravine bordering a small branch of Violet Creek. The following table will show them all at a glance: 
Springs on branch of Trolet Orek.

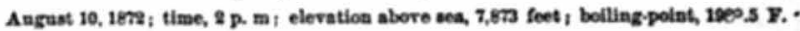

\begin{tabular}{|c|c|c|c|c|}
\hline No. & Sise. & Gas erotred. & $\begin{array}{c}\text { Temperatare } \\
\text { of alr. }\end{array}$ & $\begin{array}{l}\text { Temperature } \\
\text { of oprisg. }\end{array}$ \\
\hline $\begin{array}{l}1 \\
2 \\
3 \\
4 \\
5 \\
6 \\
7 \\
8 \\
9\end{array}$ & 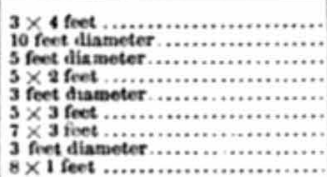 & 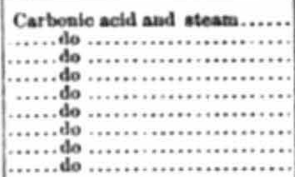 & 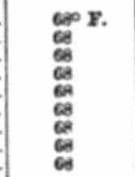 & 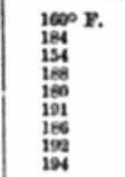 \\
\hline
\end{tabular}

The amount of carbonic-acid gas given off from these springs is small, and, although tbere is considerable bubbling in some of the springs, it is eaused mostly by the escape of steam. This in some is enongh to canse the ground to tremble beneath. All the springs deposit iron. The first three springs given in the table are on the edge of a pool of water having a diameter of 100 feet by 50 feet, in which the thermometer stcod at $120^{\circ} \mathrm{F}$. There is also one spring in the midst of this pool which was: be: ond reach. The bottom of the pool is lined with gelatinous silica, which is conted with oxide o.' iron. The edge of the pool next the creek slopes to the level of the stream in a series of small basins over which the water flows. The creek itself is divided into a number of basins formed of the deposits, (mostly carbonates, and the water flows from one basin to the other, they being at different levels. These basins are filled with a luxuriant growth of very bright green confervoidea. The temperature of the water in the creek a short distance below the springs is $140^{\circ} \mathrm{F}$.

The two gronps of springs given above have never before been de. scribed, not being in our line of march last year. There are donbtless many more gronps throughont the same valley that have never been studied yet, especially on the eastern side of the Yellowstone River, which here is not fordable, on account of quicksands.

The next group of springs to which I will refer is that at Crater Hills, near the Yellowstone River, about four miles below our camp. This place takes its name from the occurrence here of two high buttes or hills, one of which is 150 feet from top to base, and a second 140 feet. They are made up in part of a tracbytic tuff and hot-spriog deposits, the prevail. ing color of which is white, and a red, dne to the weathering of the deposits, which contain iron. All of the springs are acidulous and contain sulphur as a prominent constituent. The principal spring is the boiling. sulphur spring near the base of the hills. The description of this spring was given in the report of last year, and I will not delay to redescribe it. I again twok its temperatnre, which $I$ found to be $178^{\circ} \mathrm{F}$, the air being $50^{\circ} \mathrm{F}$, at about 10 o'elock in the morning. The temperature given in last year's report is $183^{\circ} .5 \mathrm{~F}$., which was probabiy taken nearer the center of the spring than I was able to take it this year, 'je water being in violent agitation.

The next spring of importance is a large blue-mud $\varepsilon_{2}$,ring near the large sulphur spring, the temperature of which $\left(164^{\circ} \mathrm{F}\right.$.) this year varies only $1^{\circ}$ from that taken last year, when it was $163^{\circ} \mathrm{F}$. All the springs at this locality are noticeable, not only for the sulphur they contain, but also for their alum, which I take to be an jiron alum. The small stream to which the springs give origin ing branch of Alum Creek, and in both the main is of a piece of deposit from the edge of the boilingentipur sis of a piece of deposit from the edge of the boiling sulphur spring, made by Mr. W. B. Platt, of the expedition, gives the following result:
Water.

Per cent

23,48
3,23

silica (..... tron oxide...

Soda...

Organic matte

........

$\overline{26.71}$

1.800

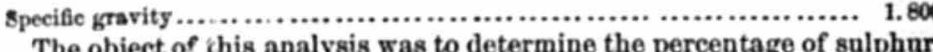
The object of this analysis was

The group of mud and sulphur springs just south of the two springs referred to above was mentioned in last year's report, but as the obser. vations of this year are more complete, and include a large number of springs, I will present this group below.

Springs at Crater Hills.

General elevation above mea-level, 7,e2s foet; bolling point, $1900.2 \mathrm{~F}$.

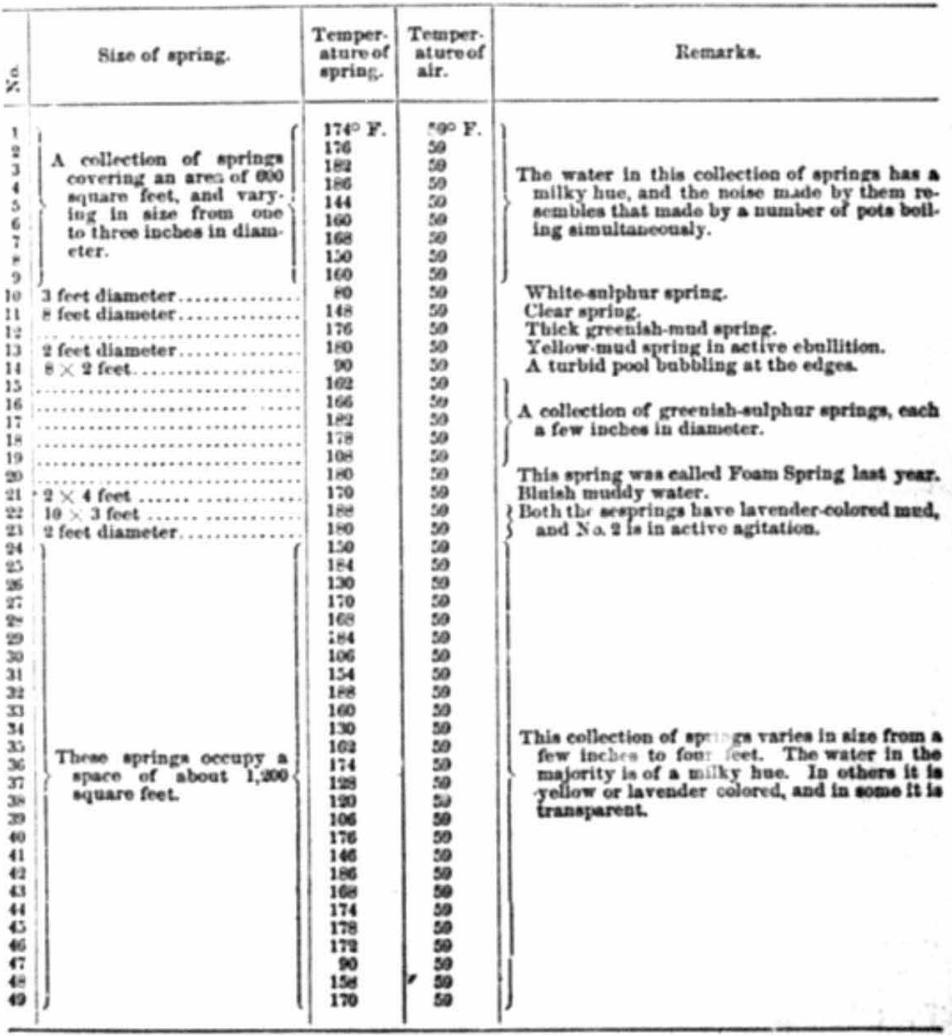


Having completed observations on these springs, I devoted the remainder of my time to those nesr camp, which presented a great deal of interest. I was enabled to make more accurate observations than were male last year, and was greatly assisted by Mr. A. B. Brown, who determined the beights of the mud.geyser for me. The mud-geyser is the prineipal spring in the group at Mud Volcanoes, and was situated a few yards above our camp. It has a basin of about 60 feet diameter, surrounded by a rim that slopes inward, at an angle of $30^{\circ}$, to a funnel shaped orifice in the center. This basin, which is the basin proper of the geyser, is made up principally of clay and silica, and is situated in another basin which measures 200 feet by 150 feet. The wall of this latter basin rises about 8 feet, on an average, above the level of the other basin, and between the two rims there is a deposit of clay which has been left by the water and has become hard, resembling a very fine clay slate. On one side of the onter basin there is a small ravine like opening cut into the bank, through which water evidently flows sometimes, probably during the spring when there is more water in the basin. In several places on the banks I noticed small holes lined with sulphur from which the steam escapes. Besides the geyser there are two small springs at one end of the large basin. These springs are entirely independent of the geyser, and are constantly in action, bubbling quietly. They do not seem to be affected in the least by the eruptions of the geyser. The following is the description of an eruption: The water gradually rises until the inner basin is flled, when there is noticed a bubbling in the center. Suddenly, without any fur. ther warning, it becomes violently agitated and an immense mass of muddy water, mingled with clonds of steam, is thrown into the air. This action lasts a few minutes and is followed by a lull, the action not ceasing entirely. Then it recommences with renewed violence, and the water fills the entire outer basin, the water striking the banks in a succes. sion of waves. The water is thrown up in a succession of impulses that follow each other rapidly, and sometimes the water is throwu obliquely and seems as though it would overwhelm one standing on the bank. The mass of water and mud is immense. After the maxinum height is obtained the jets become smailer and smaller, and the eruption ends as suddenly as it began. It is a very inpressive sight, and the stopping is like a calm afier a storm. The water of the geyser is very muddy, and bluish in color, having an acid reaction, due to the presence of sul phuric acid.

I will transcribe my field-notes below and then give the result in tabn lar form, so that the whole may be placed before the eye at once.

\section{August 11.}

$4.02 \mathrm{p} . \mathrm{m}$.-The temperature of water in the basin is $140^{\circ} \mathrm{F}$, and the air $50^{\circ} \mathrm{F}$

4.37 p. $m$.-The water is rising rapidly and there is considerable bubbling in the center of the basin, the temperature remaining the same.

$4.42 \mathrm{p} . \mathrm{m}$. to $4.52 \mathrm{p} . \mathrm{m}$.-The water is still rising aud flows in currents, giving it a variable temperature of $140^{\circ} \mathrm{F}$. to $180^{\circ} \mathrm{F}$.

$5.02 \mathrm{p} . \mathrm{m}$.-The temperature is still $180^{\circ} \mathrm{F}$. at the edge, althongh in the center it must be considerably higher. It is still in ebullition.

5.C4 p. m.-The eruption commences.

5.10 p. $\mathrm{m}$.-There is a lull in the action.

5.14 p. $m$.-The maximum (40 feet) is attained.

5.17 p. $m$.-The eruption ends and the water at the edge of the basin has a temperature of $172^{\circ} \mathrm{F}$.
$5.52 \mathrm{p} . \mathrm{m}$-Temperature of water is $148^{\circ} \mathrm{F}$, and the air $48^{\circ} \mathrm{F}$. The water is fon feet lower than it was during the ernption, and the gides of the basin are shown sloping inward. Several steam.vents, not seen before, are now made apparent. The surface of the water is quite placid, save in the center, whers a slight bubbling takes place. The water seems to be rising slowly.

6.37 p. m.-The water has risen one foot since the last observation and is still rising.

7.37 p. $m$.-The water is now six inches above the level last observed. 9.35 p. m.-The eruption commences.

9.48 p. m.- The eruption ends. The maximum height was estimated at 20 feet, it being too dark to take any angles.

August 12.

6.19 a. m.-The geyser has evidently had an r aption during the night. The basin is full and the center in eballition.

6.31 a. m.-The eraption commences.

6. 35 a. m.-There is a lull.

6.42 a. m.-The eruption ends. The maximum height was 25 feet, and I noticed that the ground shook beneath me while the eruption was going on.

10.19 a. m.-The temperature of the water at the edge of the basin is $148^{\circ} \mathrm{F}$. and the air is $60^{\circ} \mathrm{F}$. The center is bubbling, and a black, oily substance floats on the surface.

10.29 a. m.-The temperature of the water is from $140^{\circ} \mathrm{F}$. to $180^{\circ} \mathrm{F}$., and it is rapidly fllling the basin.

10.49 a. m.-The eruption commences.

10.55 a. m.-There is a lull.

10.58 a. m.-The maximum (18 feet) is attained

11.02 a. $\mathrm{m}$.-The eruption ends.

$11.08 \mathrm{a} . \mathrm{m}$.-The temperature at the edge of the basin is $170^{\circ} \mathrm{F}$; air, $60^{\circ} \mathrm{F}$. The water has fallen a foot already.

11.15 a. m.-Water, $150^{\circ} \mathrm{F}$; air, $60^{\circ} \mathrm{F}$. The water has fallen eighteen inches.

11.20 a. $m$.-The water has fallen five inches since the last measure. ment.

11.24 a. m. to 11.29 a. $m$.-The water still has a vemperature of $150^{\circ}$ F., and has fallen 2 feet 10 inches.

11.39 a. $m$.-The water has fallen 3 feet 2 inches since the eruption ceased, (lowest point.)

11.49 a. $\mathrm{m}$.-The water is rising slowly.

2.39 p. m.-The water is*within one foot of the top of the basin asd bubbling in the center. Its temperature near the edge is $146^{\circ} \mathrm{F}$., the air still being $60^{\circ} \mathrm{F}$.

3.14 p. m.-Temperature ontside the rim of the basin is $125^{\circ} \mathrm{F}$.

3.15 p. m.-The eruption commences.

$3.21 \mathrm{p} . \mathrm{m}$. -There is a lull.

3.25 p. m.-The maximum (22 feet) is reached.

3.27 p. m.-The eruption ends. Temperature of water at edge of basin $170^{\circ} \mathrm{F}$.

7.39 p. m.-The eruption commences.

7.44 p. m.-There is a lull.

7.48 p. m.-The maximum (19 feet) is reached.

7.51 p. $\mathrm{m}$.-The eruption ends. 
Mr. Sloane took observations of two eruptions on August 9, as follows: 12.40 p. m.-Eruption commences.

12.47 p. m.-Lull.

13.49 p. m.-Maximum estimated at 25 feet.

12.52.30. p. m.-Eraption ends.

4.58 p. m.-Eruption commences.

5.04 p. m.-Lull.

5.07 p. m.-Maximum estimated at 30 feet.

5.11 p. m.-Eruption ended.

The following table gives the result of these observations:

\begin{tabular}{|c|c|c|c|c|c|c|}
\hline Date. & 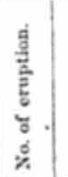 & 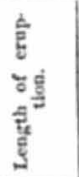 & 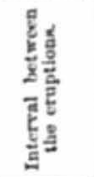 & 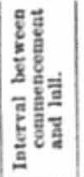 & 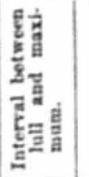 & 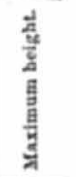 \\
\hline 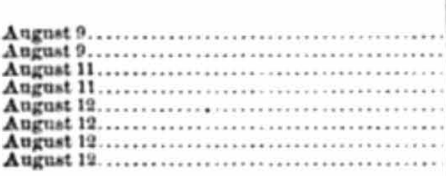 & 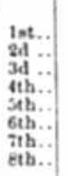 & $\begin{array}{l}7.5 \\
12 \\
1300 \\
13 \\
1300 \\
1300 \\
1100 \\
1300 \\
12 \infty \\
1200\end{array}$ & 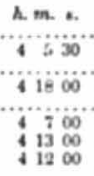 & $\begin{array}{c}m . \\
6 \\
6 \\
6 \\
1 \\
6 \\
6 \\
3\end{array}$ & $\begin{array}{l}m \\
3 \\
3 \\
4\end{array}$ & 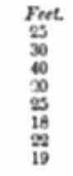 \\
\hline $\begin{array}{l}\text { Average length of eruption ............... } \\
\text { Average interval between eruptions... } \\
\text { Average interval between commencetme } \\
\text { Average interval between lull and max }\end{array}$ & & & & (n... & $\begin{array}{cc}\text { A. } & \text { m. } \\
0 & 12 \\
4 & 11 \\
& 5 \\
& 3\end{array}$ & $\begin{array}{l}26.75 \\
6 \\
34.28 \\
30\end{array}$ \\
\hline
\end{tabular}

The remainder of the springs at Mud Volcanoes I will give in a table, as I did those of Crater Hills.

Last year, when at this localits, we noticed that the trees near the Giant's Caldron had their brances coated with mud, and the question was raised as to how the mud got there, we concluded that the geyser sometimes ejected its contents. This year, however, investigation seemed to prove that the mud is carried up mechanically, mixed with the steam that is constantly rising from the caldron, and that the spring never has any eruptions. We were led to this opinion first by noticing that it was only the under side of the branches that held the mud. Mr. Holmes then placed some dead branches in such a position that the steam came upon them and in a few hours they bad a coating of mud. A gain, some of the trees on which the branches are coated are living, which wonld hardly be the case had they received the mud from an eruption. Another reason also is found in the fact that the surface of the spring is constantly agitated, which is rarely or never the case with a true geyser. Still in the past it may have been a gesser and had regular eruptions.
Springs at Mud Voloanoes.

General elovation abovo ses level, 7,77s feet; bolling-polnt 1985.5 F.

\begin{tabular}{|c|c|c|c|c|c|}
\hline ش & Sim of spriag. & 㩆总 & 旡富 & 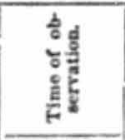 & Remarke. \\
\hline & & $\circ \boldsymbol{F}$ & & & \\
\hline & $\begin{array}{l}3 \text { feet dlameter............ } \\
10 \text { fret diameter........ }\end{array}$ & $\begin{array}{l}100 \\
168\end{array}$ & $\begin{array}{l}30 \\
30\end{array}$ & & $\begin{array}{l}\text { Yery thick tuod aprisg } \\
\text { These springs are in the same banits }\end{array}$ \\
\hline & $\begin{array}{l}10 \text { fet dias } \\
6 \text { feet diar }\end{array}$ & $i_{12 \pi}$ & 50 & 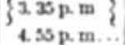 & 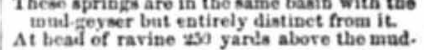 \\
\hline 5 & $15 \times 3$ feet... & 156 & 40 & & 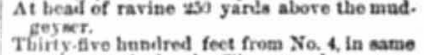 \\
\hline 6 & & & & & 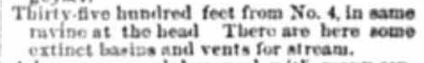 \\
\hline$i$ & is feet diameter. & 134 & $\theta$ & 11. $9 \mathrm{Oa} . \mathrm{m}$. & 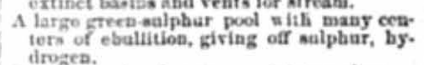 \\
\hline 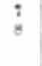 & $\begin{array}{l}3 \text { finet diameter. } \\
12.20 \text { feet....... }\end{array}$ & $\stackrel{136}{80}$ & $\stackrel{s}{2}$ & 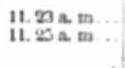 & 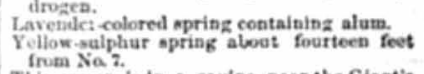 \\
\hline $\begin{array}{l}9 \\
10 \\
11\end{array}$ & 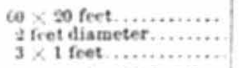 & $\begin{array}{l}1+0 \\
194 \\
160\end{array}$ & $\int_{3}^{2}$ & $\begin{array}{l}\text { 11. } 30 \mathrm{am} \\
\text { i. } 30 \mathrm{~mm} \\
\text { ii. } 30 \mathrm{am} .\end{array}$ & 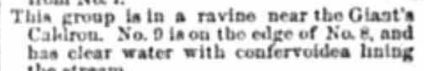 \\
\hline 12 & $\begin{array}{l}\text { Grotta, } 3 \text { feet high, o feet } \\
\text { wude, w feet dicep. }\end{array}$ & 12 & 3 & II. Sam. & 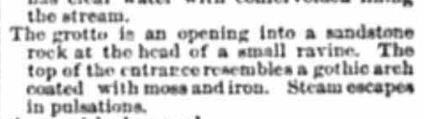 \\
\hline 13 & & $\underset{1 \rightarrow 0}{94}$ & $\stackrel{s}{s}$ & $\begin{array}{l}\text { I1. } \\
\text { ii. } 40 \mathrm{am} \mathrm{m} \text {. }\end{array}$ & 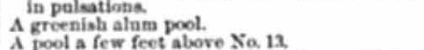 \\
\hline is & of feet diameter.. & iss & so & i1. $20 \mathrm{a} . \mathrm{m}$. & A phol a few mud spring io feet deet \\
\hline & $\begin{array}{l}\text { Pool, }: 00 \times 60 \text { feet } \\
\text { Bmall boles, } 1 \text { inch di- , }\end{array}$ & & sit & & \\
\hline & ameter. & 178 & 3 & & Sulpluar \\
\hline & & 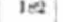 & & & \\
\hline
\end{tabular}

\section{CHAPTER IV}

GEYSER-BASINS OF FIRE-HOLE RIVER.

We left Ind Voleanoes on the 13th of August and started for the lower gesser-basin of Fire Hole River. Onr course at first led us up an open valley that once formed part of the ancient bed of Yellow. stone Iaks. At the head of the valley we struck our cld trail of last stone Lakis At the head of the valley we struck our cld trail of last
year, which we followed until we reached the east fork of the Fire-Hols River. The divide between the Yellowstone River and the Fire-Hole River at this point is 8.164 feet above sea-level. The summit seems to be made up mostly of obsidia s, which is all porphyritic. The timber is so thick that it is difficult to trace the connection, but, as we descend, we come across trachytes that seem to underlie the obsidian. It is very corupact and porphyritic, containing crystals of sanidine. The general color is a light blue, approaching violet. It is through these trachytes that the headwaters of the Madison cut their channels. Near the sum. mit, on the Madison side of the diride, there is an old hot-spring basin in which the springs are now all extinct, although there are a great many steam.vents from which steam still escapes; these vents are lined with sul. phur. Besides sulphur the deposits consist mainly of silica and iron. phur. Besides sulphur the deposits consist mainly of silica and iron.
The descent from the divide is very steep and rocky, and through thick timber, a great deal of which is dead and fallen. The valley of the east fork of tue Madison or Fire-Hole at the point we reached it is very 
marshy and full of springs, which canse tho water in the stream to bave a temperature of some degrees more warmth than the air. We folhave the lowed the iner and canped at a level sor. lower than our camp (No. 12) at Mud Volcanoes, having traveled nineteen niles. Some of the party who had preceded us a day came into camp in the erening and reported that they had met the advance party of the Snake River division of the expedition, under Mr. Stevenson so the following morning we moved down into the lower basin, and in the evening found that the main body of the Snake River division were encamped within a mile of us, having got in about the same time we did. The next day they moved their camp and joined us.

On the way from camp we passed a number of nnimportant springs which I will incorporate in the catalogue appended to my report. I shal devote but little space to the springs of the lower geyser-basin, as they were rered to at length in the report last year. During the three days and a balf that I was in the lower geviser-basin this year, I was occupiei (o most of the time in packing specimens to be sent to Virginia City, so that I was able to visit but one group of springs. As this, however, 18 typical group, I will insert the description. They are situated just south of camp in an open space bonnded on two sides by timber, while the front looks out into the main open basin. Thes occupy a space of a little over 3,000 square yards. The springs are as follows:

Gourd Spring.-This spring was named from its shape. It is in the center of a large, circular mound of siliceous material, and is 15 fett long by 10 feet wide and 12 feet in depth. The bed of the small stream, car rying away the overflow from the spring is coated with iron, and a short distance below we find the gelatinous material that we see in so many of the springs that have a low temperature. The temperature of the water in the spring was $171^{\circ} \mathrm{F}$; air, $62 \circ \mathrm{F}$., at $9 \mathrm{a} . \mathrm{m}$.

Thud Spring.-This spring is 375 feet southwest from the Gonrd, and mensures 18 feet by 16 feet. The depth varies from 8 to 13 feet. This of course refers only to the basin of the spring, as at the bottom there are orifices the depth of which cannot be scertained by the line. There seem to be three centers of ebullition, two of which are very active. At seen to of a minutes there seems to be an accumulation of steam, the escape of which shakes the ground, making a thud-like noise, whence its name. On looking into this spring the water seems to have an inky green color, and had a temperature of $192 \circ \mathrm{F}$; air, $62 \circ \mathrm{F}$., at $9.30 \mathrm{a}$. m. Oak Leaf Spring.-This spring is 345 feet north of the spring nex described. The deposit about it has a gray color, and the margin of the spriug has the appearance of being fruged with oak-leaves. The the spring the water appear

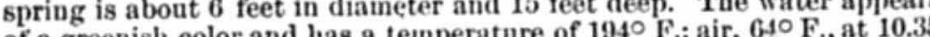
of a greenish color and has a temperature of $194^{\circ} \mathrm{F}$; air, $6.0 \mathrm{~F}$, at 10.35 2. $\mathrm{m}$. About 7 feet from this spring there is a small cone of 2 feet diameter, rising e inches above the surrounding level. The tempe rature of the water in this cone was $190^{\circ} \mathrm{F}$.

Fungoid Spring.-This kpring is 140 feet west of the Thud Spring, and 345 feet south of the spring described above. The basin of this spring measures 13 feet by 17 feet and averages 6 inches in depth. The deposit is pure-white siliceous sinter, giving it the appearance of a marble basin. In the center of this basin there is another 5 feet in diameter and 7 feet deep. Here the water bas a greenish tinge, which forms a pretty contrast with the white sim outside. The spring has a margin of the siliceons material that resembies a row of fungoid growths on sbort pedestals. There are two small streams proceecing trom the spring, which are lined with orange-colored dejosit. Surronnding the spring, there is are line amount of siliceons sinter, forming a mound, as is the case with the other springs of the group. The temperature of the water in the spring is $1620^{\circ} \mathrm{F}$; air, $64^{\circ} \mathrm{F}$., at $11.05 \mathrm{a}$. m. Near the spring there are two small boles, in which the water is at $190^{\circ} \mathrm{F}$. and $180^{\circ} \mathrm{F}$.

Kidney Spring.-This spring is very irregular in shape, and consists of two arms that are ulmost at right angles to each other. The length one way is 19 feet and the other 15 feet, the average width being abont 6 feet. The depth is abont 1 foot. The spring is fringed with large scallops, each one of which is made up of smaller scallops. There are three fissure. like centers of ebullition in which the thermometer records $184^{\circ} \mathrm{F}$., $190^{\circ}$ $\mathrm{F}, 184^{\circ} \mathrm{F}$; air at $64^{\circ} \mathrm{F}$, at $11.10 \mathrm{a} . \mathrm{m}$. The spring is 180 feet northwest of the Oalk Leaf.

Cliff Spring.-This spring is 240 feet sontheast of the spring last described and 122 feet east of the Oak Leaf. It measures 4 feet by 8 feet and is 5 feet in depth. The deepest portion is at one end of the spring, where there is a caverno 3 opening, overhung by a scalloped edge. The water here is oi a light-green colo- At the other end there is a rugged fissure, to which the edge of the spring slopes from the surface, having the form in miniature of cliffs. These, above the water, lave a brown color and below a deep pnrple. The temperature of the water is from $1020 \mathrm{~F}$, to $1950 \mathrm{~F}$, air, of water finds its way from the spring over an orange-colored bed.

Jug Spring is 123 feet sontheast of the Cliff and 150 feet east of the O lk Leaf. It measures 4 feet by 5 feet and is 3 feet deep. Its tempera. ture was $188^{\circ} \mathrm{F}$; air, $64^{\circ} \mathrm{F}$., at $12.09 \mathrm{p} . \mathrm{m}$.

Stirrup Spring is 8 feet by 9 feet and 5 feet deep. There are two holes in the bottom of this spring from which the steam escapes, and a fissure also, which makes the spring resemble the head of an old woman with a cap on, the scalloped edge of the spring representing the ruffles of the cap and the fissure the mouth, while the other steam-vents represent the eyes. The temperature of the water was $188^{\circ}$ F.; air, $64^{\circ} \mathrm{F}$, at $12.35 \mathrm{p}$. m. There are two small holes near this spring in which the thermometer records $182^{\circ} \mathrm{F}$.

Lone Spring.-This spring is some distance northeast of the other springs of the group, and is on the side of a hill some 40 feet higher. It is $4 d$ feet in depth and measures 9 feet by 16 feet. Its temperature at $8.30 \mathrm{a} . \mathrm{m}$. was $186^{\circ} \mathrm{F}$, the air being $62^{\circ} \mathrm{F}$.

The general elevation of the group just described is 7,162 feet above sea-level, the boiling-point being about $1999^{\circ} .3 \mathrm{~F}$. All the springs are somewhat globular in shape, widening below the surface, having overbanging edges, and narrowing below to fissures or tube-like orifices. They all belong to the class of springs that are constantly agitated, and, although this agitation is greater at some times than at others, I doubt if any of the springs in the group ever project a colnmn of water into the air.

The area of the lower gevser-basin is about thirty square miles, and aithough it contains a far larger number of springs than the upper basin, there are not 80 many true geysers, and the water is not thrown as high into the air as in the upper basin. The geysers of the lower basin that bave been seen to spout 30 feet or upwards are the "Great Fountain," "The Fountain," the "Steady Geyser," "The Jet," and two small gey. sers not named, which are a few yards below the Fountain. Having had no time while in the lower basin to visit these geysers, I will here insert the following exe.llent deseription, kindly furnished me by Mr. Holmes, artist to the survey : 
During our somewhat protracted stay in the lower basin, I found time to obeerve pretty carefully all the geysers of any cunsiderable importance. Among the six of posecesos the dignity and grandeur of the great geysers of the upper basin. Although, in some respects, it is much inferior to its more popnlar rivals, in others it is cer. tainly superior. In approaching the crater of this geyser the observer is not at fint impressed with its importance, as the outer rim of the basin or rather table-in the center of which the fissure is situated-is raised but two or three feet above the general level. This elevated part I should estimate to be upwards of 120 feet in diameter, and, with the exception of the crater, it is built up neariy to a level with the border. The surface, formed entirely of siliceons deposit, is diversified by an infinite number of forms and colors. The depreased parts in some places are so lovel and white and hard that a name could be engraved as easily and as well as upon the bark of a beech-tree.
In others thern -5 unost exquisitely modeled basins and poekets, with ornamented rims In others therr ".c most exquisitely modeled basins and pockets, with ornamented rims of geyserite could be seen iying in the white, velvety bottoms. Rising above the geaeral level are innumerable little masses and nodes of cauliflower-like and beaded eilica, standing ont of the shallow water like no mas islands. Those near the erater swell int, very large rounded mawis. The whole sarface is so solid that I waiked, by step-
ping from one elevation to another, up to the very brink of the fissure, where I looked down with no little spprehension into the seething caldron, whore, 12 or 15 feet below, was a mass of dark-green water in a state of constant agitation, threatening an ernption. The crater is about 10 feet in diameter, lined with an irregular coating of beaded silica. The water soon began to rise, plunging from side to side in great surges, sending up masses of steam and emitting angry, rumbling sounds. This de:notstration caused a precipitate retreat, on $\mathrm{my}$ part, to the border of the basin, thinking that could appreciate the beautics of a Bcaling shower-bath in the utmost confusion, spread. ing out at every angle and whirling in every direction, some jets rising vertically to the height of 60 or 80 feet, then separating into large glistening drops and falling back into the whirling mans of vater and steam; others shooting at an angle of $45^{\circ}$ and falling npon the islands and pools 30 or 40 feet from the base. The eruptive force, fur a moment, dies away and the water sinks back into the tnbe. Then, with apother tremendous effort, a second body of water is diven into the air, but with a motion so mucb mos a simple than before that the whole mass assumes a more regular form and is like a great fountain with a thonsand jets, describing curves almost equal on all sides and forming a sycortion chang. the forms or movements the same. The eruptions are repeated at irregular intervals of a few hours and are not known to vary essentially from the manner of action bere described; yet I have good reason to believe that at certain times there is a much greater exhibition of powe:. It must be borne in mind that all the elevations, such an the tnbes, rims, and mounds about the crater of a geyser, are bnilt by the evaporation of the water, and the portion of surface covered by the beaded silica indicatea precisely the area over which the eropted water falls. In no case did I observe the water fall outside of a circle of 60 feet in dinmeter, and the additional force necensary to scatter it over twice that amount of surface must produce a display truly magnificent. That this display actually occurs is attesied by ote of our moantaineers and aimost demob-

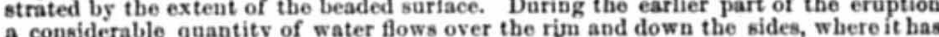
formed a series of basing somewhat sivilar in form and color to those at the springs on Gardiner's River. Falling from one to another of these it passes off cown the alope and joins a large stream of hot water which issues from a steady spring not far away. A few hundred yards farther up the ravine, and on the opposite side of the creek, 1 discovered a small spring that deserves in a quiet way to bo one of the grea: attractions of this attractive rrgion. It is isolated from the neighboring springs and nestled in ageinst an abrupt bank, no obscured by tall pines that the visitor is liable to pass it by uunoticed. In approaching from the creek 1 passed up a gradually ascending slope down which the water flows, covering in its meauderings more than an acre of ground and leaving, wherever it toucbes, brilliant streas's of color. About a hundred yarde from the creek I came upon the spring, the waters of which stand nearly on a level with the surronuding surface. Approach ubles of steam slowly rising to the surface and pansing off into the air. The larger of these bubbles wonld lift up a considerable and passing of into the air. The larger of these bubles wonld lift up a considerable quantity of water sometimes to the height of 3 or 4 cet, producing a kind of spasrounded by an irregalar rim which stands a fow inches above the geveral level of the water. The basin is 20 feet long and 10 feet wide, one end being narrower and par-
tially separated from the main basin by an irregular row of beaded islabds and proJections.
Althongh the spring and basin are very ehaste and delieate in form as well as color, there are otber springa more beantifal In those respects. But when I ascended the bank asd looked down upon ths spring and its surroundinge, I concluded, without the least hesitation, that I had never seen anything 00 uniqueiy beautiful. On the npper side of the spring, next to the bank, the water in overflowing ran into large shallow pools, painting whatever it touched with the colors of the rainbow. Beds of rich, ereamy white and rich yellows were interiaid with patohes of siennas and purples, and d vided up and surrounded by the most fantastic patterns of delicate grays and rich browns. Wa the sildo wext In those where the water is still hot, the colors are bright, varying from a creamy white to wow of the larger pools are stained with still darker colors, frequently of a purple tint and reflecting the picturesque gropps of pines on their dark surfaces. Seattered irregnlarl over the whole surface are numberleas little areas of dry deposit, from which the brighter tint. have faded but which still retain such a great variety of purple and blue grays that the harmony of the whole fleld of color is complete.

Mr. Holmes, in his description of the Great Fonntain, refers to the pebbles of geyserite in the pocket-like depressions surronnding it These pebbles vary in size from that of a pea to two or three inches in diameter. They are made up of concentric layers. The following analysis which $I$ hare made will give their composition :

Analysis.

Loss at $100^{\circ} \mathrm{C} . .$.

Loss on ignition.

Alica..................

Mime............

Sagnesia

Potash:

Farther up the ravine, at the mouth of which this geyser is situated, is a group of springs around which the deposit, instead of being white, as in the case of other springs, is black. These springs were reforred to in the report of 1871 , page 184 . I have made an analysis of this deposit and find it to consist as follows

\section{Analysis.}

Per cent.

Loss at $110^{\circ} \mathrm{C}$.

Loss on ignition...

Alumina.

Iron .

Magnesia

Soda:

Matash ....

The color of the specimen I believe to be due to the large amount of organic matter included in the above analysis under the loss by ignition.

There was one quite large group of springs in the lower basin, during the summer, which escaped our notice during the season of 1871 . For a 
full description of it I refer to Professor Bradley's report. A specimen from this group was handed to me for analysis. Composition, irregular color, rusty brown; fracture, conchoidal; luster, vitreous; hardness, 5.5-6.

$$
\text { Analysis. }
$$

Loss at $110^{\circ} \mathrm{c}$

Loss on

Bilica................

Lime..

Magnesia
Soda*.

Potasea:

Lithia*. The Fountain Geyser is the second in importance in the lower basin, and
is centrally situated. It is on a slight eminence, and from it the deposit slopes gradually toward the river, studded with innumerable springs, This geyser was fully described in the report for 1871, so I will pass it by here. Back of the Fountain are the Mud Puffs, which were also fully described last year. I wish to insert here an analysis, by Dr. End. lich, of a pink mud from this locality. A portion of the silica is doubt. less combined with some of the alumina as a silicate.

$$
\text { A nalysis. }
$$

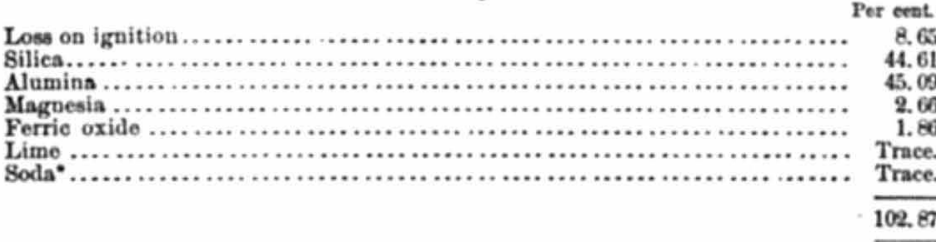

Between the Fountain Geyser and the Mrd Puffis, we find pieces of wood coated with geyserite, which assumed a beaded form, sometimes branching like certain forms of coral. Most of the specimens are translucent and have a vitreous luster. The color is generally a light pink. An analysis made by me of this form of geyserite gives the following result :

Analysis.

Water.

Alumina and iro

Magnesi

Lithia*

Wood may be found in varions stages of silicification, and if the problem can ever be solved as to the process of silicification," think a sojonrt in the geyser-basing of Fire-Hole River will be of the highest importance in assisting us to conclusions upon the subject. My space here is too limited to do more tisan refer to it.

The area of the lower geyser-basin is about thirty square miles, and the valley seems to be underlaid by a sedimentary, probably Post-plio cene, formation of which pert is composed of broken bits of geyserite. The highest temperature that was recorded is $198^{\circ} \mathrm{F}$., but there is no doubt that many of the springs are at the boiling-point, (1990.5 F., it being impossible to determine it on acconnt of the spouting of the water.

The general elevation of the lower basin above sea-level is 7,275 feet.

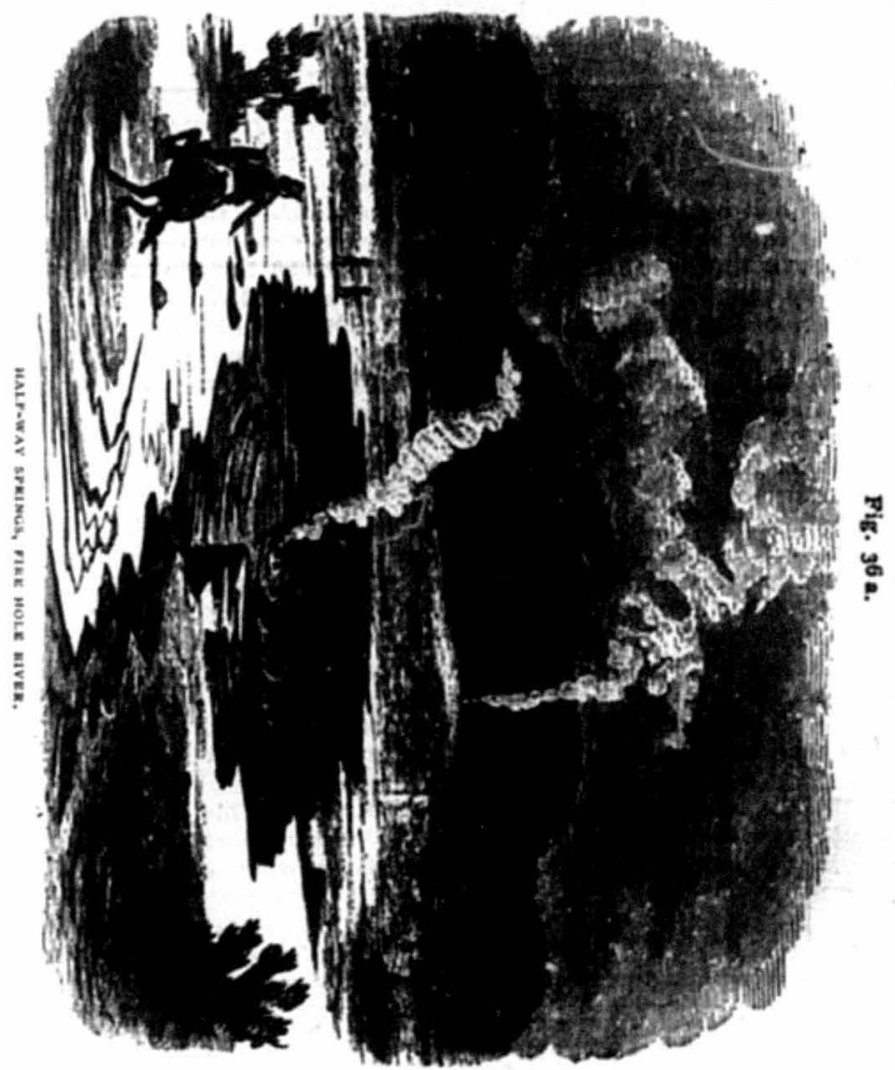

At the lower end of the basin the Fire-Hole River is joined by Fairy Fall Creek, at the head of which there is a beantiful fall called the Fairy Fall. This fall is 250 . feet high, and the water falls into a beantiful basin at the foot of a cliff. From the mouth of this creek to the mouth of Iron Spring Creek, at the lower end of the upper geyser-basin, the distance is five and a half miles in a bee-line. Batween the two there 18 a large group of springs that can be included in neither, and to which

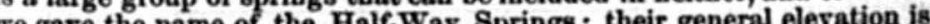
og (the report for 1871. The illustration (Fig.36a) by Mr. Elliot shows cog of the princi-

- By spectrosocopic examination. 
pal springs in the group. The peculiar lamination of the deposit at the edges is well shown. The elevation at the lower end of the upper basin is 7,321 feet, and at Old Frithfnl, at the upper end, 7,397 feet.

On the morning of Angust 17 all the specimens were sent to Virginia City by pack-train, and in the afternoon, in company with Messrs. Brown, Sloane, and Bingham, I proceeded to the upper basin to make observations on its principal geysers. These are named as follows: Old Faithfal, Bee-Hive, Giantess, Castle, Grand, Turban, Saw-Mill, Giant, Grotto, the Riverside, the Fan, and the Soda Geyser. All of these, save the Giant and the Fan, were seev in action this year. Oar stay being but three days in length necessarily renders the observations somewhat incomplete. There is but little doubt that a longer stay would develop many new geysers. We spent one day at Old Faithful, as it spouts more frequently than any of the others, and is also at the head of the valley, making a good starting.point. I will refer to them all separately below.

Old Faithful.-The mouth of this geyser slopes inward, mensuring outside 8 feet by 4 feet and inside 6 feet by 2 feet. It is in a $T$, sund of geyserite that rises 11 feet 11 inches above the surrounding level, and measures at the base 145 feet by 215 feet and at the top 54 feet by 20 feet. The mound is arranged in a series of small basins, rising one above the other, in which the water, beantifully clear, stands after the eruptions. The edges of these basins, as well as the throat of the gey. ser-tube are ornamented with bead-like silica. We triect to sonnd the depth of the geyser-tube, and after letting ont the entire length of rope, 360 feet, and withdrawing it, we found the end completely tangled, which was the case in every attempt. It was impossible to get the temperature of the water, for immediately after the eruption the water sank out of sight, and at other times there was so mnch steam escaping that we conld not even look into the tnbe. There are four conical wounds about Old Faithful that were probably geysers at some time in ths past. The eruptions of the geyser commence with a few abortive attempts, followed by a rapid succession of jets, which soon reach the maximum, and then gradually subside and are followed by a slight escape of steam. We measured a base-line of 100 feet, and Mr. Brown was able to get the heights of five eruptions, although there were altogether seventeen witnessed during our stay, as follows :

\begin{tabular}{|c|c|c|c|c|c|c|c|c|}
\hline 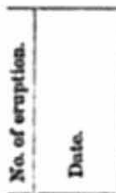 & 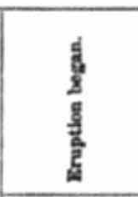 & 竞 & 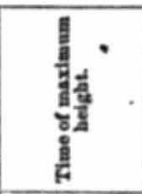 & 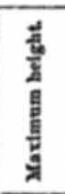 & 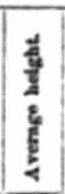 & 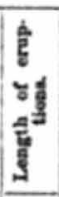 & 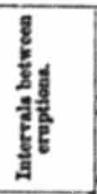 & 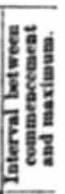 \\
\hline \multirow{6}{*}{ 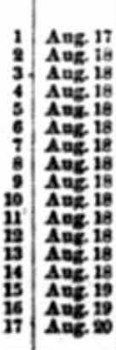 } & \multirow{6}{*}{ 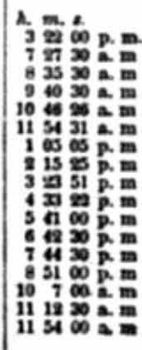 } & & $x=2$. & pet. & Fove. & \multirow{5}{*}{ 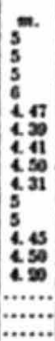 } & \multirow{6}{*}{\multicolumn{2}{|c|}{$100 \mathrm{ss}$}} \\
\hline & & & & & & & & \\
\hline & & 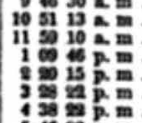 & 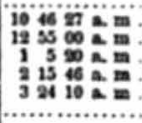 & 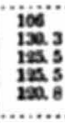 & 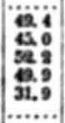 & & & \\
\hline & & & & & ;.:. & & & \\
\hline & & iiiian & & ...... & 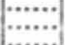 & & & \\
\hline & & & & & & & & \\
\hline
\end{tabular}

The Bee Hive is on the opposite side of the river from Old Faithfal, and abont 300 yards distant in a northwesterly direction. It is on the bank of the river and recoguizable at once by its cone, which is 3 fcet in height and almost eircular, measuring 3 feet by 4 feet at the top and 20 cect in eireumference at the bace. It is coated with beautifully beaded formations which, in some places, have a pearly aspect. The orifice at the top of the cone measures 3 feet by 2 feet, and the line dropped into the tube reaches a depth of 21 feet. The eruptions are very fine, and peculiar to this geyser. The water and steam escape from the orib se with great force in s steady atream. The average of the height of the colnmn, which is fan-shaped, is very high, and, what is the eurious, no water falls from it, but it seems to be entirely resolved into spray, vhich evaporates as soon as formed. Three eruptions were wit. nessed, int all from a distance, and we were able to get the height of but one, which was over 100 feet.

The following table gives the eruptions we saw :

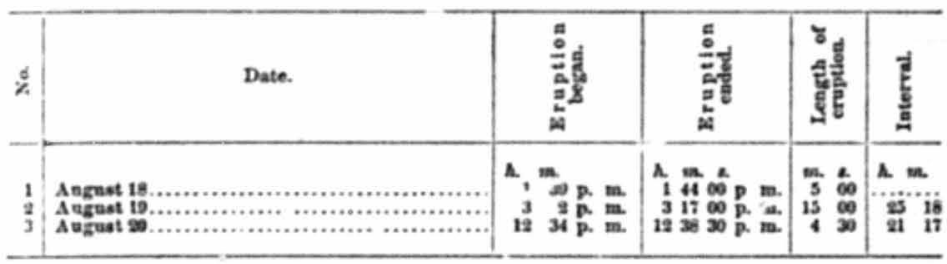

The duration and interval are both seen to vary, although a greater number of observations are necessary to deduce ary conclusions, as there may be as it were a sort of regular irregularity.

Giantess.-This geyser is on the same side of the river as the BeeHive and only 200 yards from it. It has a large basin, measuring 23 d feet by $32 \frac{1}{2}$ feet, in which the water is 63 feet deep and appears of a green color. When I took its temperature, two days after the eruption, the water was level with the rim and perfectly quiet, the mercury recording $192^{\circ} \mathrm{F}$; air, $56^{\circ} \mathrm{F}$, at $11.50 \mathrm{a} . \mathrm{m}$. The only time we observed it in action was on the evening of Angust 18. The ernption commeneed at $6.56 .30 \mathrm{p} . \mathrm{m}$. , and lasted 17 minutes, starting again at $7.43 .30 \mathrm{p} . \mathrm{m}$. This lasted about the same length of time; at $8.48 .30 \mathrm{p}$. m. it was followed by a third. The maximum height of the water was 39 feet; average, 30 feet; the steam reaching a height of 69 feet. The angles for beight were taken from the end of a base-line 200 feet in length. There was an immense mass of water thrown up which surged and splashed in all directions, with seventy.three pulsations per minnte. After the eruption the water sank 20 feet in the basin.

$\Delta$ round the Bee-Hive and Giantess there is to group of springs in which I took ten temperatures, ranging from $118^{\circ} \mathrm{F}$. to $196^{\circ} \mathrm{F}$., the average being $173^{\circ} .6 \mathrm{~F}$. Among them are a number of cones, which are probably geysers srouting at long intervals, although none of them were seen in action. On one of these I saw the bodies of about a dozen mice, that had the appearance of having been scalded to death.

Castle Geyser is farther down the river, 430 yards from the Giantess, on the opposite side. It has one of the most noticeable craters that is found in the basin. The cone is on a platform measuring 75 by 100 feet and 3 feet in height. Above this platform it rises 11 feet 11 inches. It is 120 feet in circumference at the base and 20 feet diameter 
on top. The orifice of the geyser tube is circular and 3 feet in diameter, and its throat is lined with large globular masses, of an orange-color, and beantifully beaded, as is seen so nniversally throughont both geyser. basins. An eruption is as follows: It commences with a succession of jets of water, in number about twenty per minute, which rise to various heights. These last about fifteen minutes and are succeeded by steam, mingled with spray, which escapes with a sort of pulsating movement. This soon changes to a steady escape. It seems as though the water were exhausted and the steam was being forced out as rapidly as pos. sible. This again changes, and the steam escapes in eloud.like masses with a roaring sound, like the escape of steam from some vast escapepipe, which in reality it is. This gradually dies away and the eruption is ended, having lasted about an hour and twenty minutes. We witnessed one fall eruption and parts of two others, as follows: Fir feet.

Se ond eruption, August $19 .-10.30$ a. m., commencement; 10.6 .40 a. m., maximum of water-period, height 93 feet; 10.18 a. m., maximum of steam, height 115 feet; $11.25 \mathrm{a}$. m., end of eruption.

Mean height of water, 57 feet ; of steam, 81 feet.

Third eruption, August $20,-7.24$ a. m., eruption began ; 7.40 .20 a. m., eruption ended.

We did not see the begiuning of the first eruption, and did not, there. fore, wait until it was over. The augles for height were taken from the end of a base-line of 100 feet, measured from the center of the orifice, and the heights are above the end of the base-line. The third was wit. nessed from a distance, and the height was not ascertained. At the base of the Castle there is a spring, measuring 12 feet by 7 feet, which bubbles intermittently. The water was at the boiling.point, $\left(199^{\circ}\right.$;) air, $64^{\circ} \mathrm{F}$., at $11.35 \mathrm{a}$. m. Twelve feet from this there is a second spring of the same character, measuring 6 feet by 3 feet and having a temperature of $192 \circ \mathrm{F}$. The bed of the stream flowing from these springs is coated with bright-red oxide of iron. The water in these springs rose and fell repeatedly during the eruption of the Castle While ste

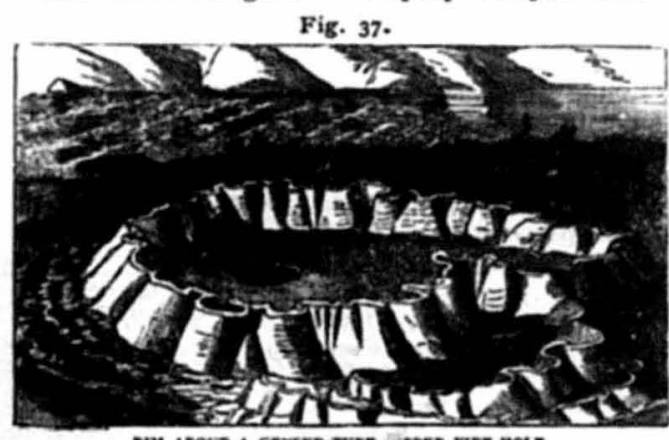

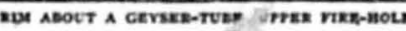
was out of sight in these springs, and when steam alono es. caped they were ac. tive, spurting to the beight of 3 feet. The principal spring near the Castle is a large blue spring, almost circular in shape, measuring 19 by 21 feet. It bas a most regular and beautiful scalloped edge, and looks as though it were lined with white

marble. This white basin slopes to a large funnel-8haped orifice, which is on the side next the Castle. This is 40 feet deep. The surface of the water is placid and appears of a most intense blue, esp ially over the orifice. The temperature of the water was $180^{\circ} \mathrm{F}$.; air, $58^{\circ} \mathrm{F}$., at $9.08 \mathrm{a}$. m. Fig. 37 is an illustration of one of the springs near the Cast, Lowing the ap. pearance of the crater when the water has receded into the tube. A few hundred yards south of the Castle, separated from it by a small belt of timber, there is a group of guiet springs, ranging in temperature from 1000 F. to $190^{\circ} \mathrm{F}$., the average being $1710.3 \mathrm{~F}$. A number of them are mud. springs, and it is the only place in the upper basin where I noticed any sulphur. The analysis of a specimen of blue clay from one of these springs, by Dr. Endlich, gives the following result :

Losa by i
Bilica....
Alumina.

Ferric oxide.

Magnesia

Sulphuric acic

Per cont

15. 15

80.70

3.96

Trace.

Trace.

Trace.

$\overline{100.98}$

Grand Geyser is 460 yards from the Castle, across the river. It is situated at the base of a small hill, and, unlike the majority of the gey. sers, has ne raised cone, but only a basin sunk below the general level. One would scarcely take it to be an important geyser, unless he witnessed one of its eruptions. The basin is 52 feet in diameter and 1 foot in depth. In the center is the mouth of the geyser-tube, measuring 4 feet by 2 feet. The depth was not ascertained. Ail the eruptions we saw took place early in the morning, and we were unable to get the height of but one, and in order to do this we camped immediately in front of it and kept guard by turns through the night. It did not spout, however, until daylight, but we succeeded in ascertaining the exact height of the column. The eruptions are as follows:

First eruption, August 18,-5.20 a. m., eruption began; 5.35 a. m., eruption ended.

Second eruption, August $19 .-3.35$ s. m., eruption began; $4.12 \mathrm{a} . \mathrm{m}$., eruption ended.

Third eruption, August 20.-6.33 a. m., eruption began : 6.36 a. m., eruption suspended; maximum height, 122 feet; mean, 79 fet. 6.49 a. m., eruption began again ; 6.46 a. m., eruption suspended; maximum
height, 173 feet; mean, 149 feet. 6.56 a. m., action recommenced. 7.5 a. m., eruption ended; maximum height, 84 feet; mean, $\mathbf{5 3}$ feet.

As is shown above the eruption consists of three distinet periods of action, after each one of which the water sank completely ont of sight, and water overflowed from the Turban, which is in close proximity, into the tube of the Grand. The water during the eruption is carried ap in a succession of jets, the main mass of water being large. Through this a column will shoot at intervals to the greatest height. The shape of the entire column is, therefore, pyramidal, broad at the base and tapering to a point. Immense clouds of steam accompany the water, and the latter in falling back shakes the ground. The third eruption was not as high as some that were not measured. The height must sometimes exceed 200 feet. The interval between the first and second eruptions was 22 hours, and between the second and third 26 hours and 21 minutes. During the thirì eruption there were at flrat 73 pulsations per minute, which afterward were reduced to 71 .

Turban Gey $r$.-Although this is one of the minor geysers of the upper basin, it has, perhaps, one of the most uniquely beautiful eraters. It spouts very frequently, but as all our time was occupied with the more important ones, we ascertained the height of but one eruption and 
obtained no lata as to the interval. The crater is only a few feet from the Graud Geyser, above which it rises about 3 feet. It is 23 feet long and 11 feet wide and 6 feet in depth. The sides and bottom of this large basin are covered with globular masses that look like large squashes ur pumpkins. (Fig, 38, This resemblance is increased by their rellow

Pig. 38.

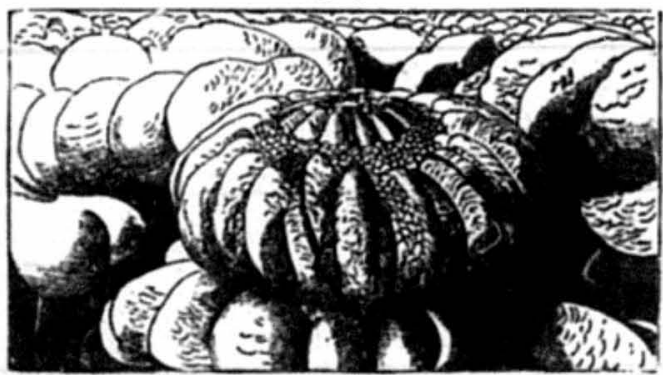
entire basin empty. Preceding the eruption the basin flls, and the height wat is 80 great that it cannot be projected to any great agitated and the escaping steam splashes it about in all directions.

The following is the eruption we witnessed :

August $20 .-7.5 .30$ a. m. eruption begaa ; 7.5 .45 a. m. eruption ended. Maximum height, 25 feet; mean height, 19 feet.

Sato-Mill Geyser.-This also is one of the smaller geysers as well as one of the prettiest in the basin. The mass of water thrown up is not very great in quantity and is so broken into spray that it presents a most delicate fountain-like stream. I saw but one eruption closely, and before I had time to ascertain the height of the column, the Grand Geyser, which is quite near, began to spout, and I was obliged to leare the Baw-Mill. During its eruption there are noticed four distinet periods of action per minute, each one made up of fifteen impulses. The main body of water is carried up about 5 feet and then at intervals a stream is suddenly shot through this mass to the beight of about 15 or 20 feet. I stood between the geyser and the sun, and on one side of the column there was the half-arch of a raihbow.

Giant Geyser.-This geyser was not seen in action by any member of the expedition this year, although last year it was one of the most active in the group. It is $\mathbf{5 0 0}$ yards northwest from the Grand Geyser, on the oppesite side of the river, near the water's edge. It has a rough conelike crater, 10 feet in height, measuring 24 by 25 feet at the base. The top is about 8 feet in diameter, the orifice from which the water is projected being about 5 feet in diameter. This cone is situated on a platform of guyserite, which rises 4 feet above the surrounding level and has a cireumference of $\mathbf{3 4 2}$ yards. The sounding-line reached a depth of 25 feet in this cone. On the same platform there is a second cone, or rather a mound, 232 feet in diameter and 6 feet high, which bas two orifices from which water sponts to the beight of 12 to 15 feet at irregular intervals. The first orifice measures 6 feet by 21 feet, and at the bottom there are two holes from which the water is projected simulta neously. The greatest depth which the line reaches here is $17 \frac{1}{2}$ feet.
Orifice No. 3 is 3 feet above the first. It is 1 foot in diameter and 12 feet deep. Besides these principal openings there is a large number of smaller orifices and springs scattered over the platform, some of which are quiet and some of which spont. Some of the temperatures are as

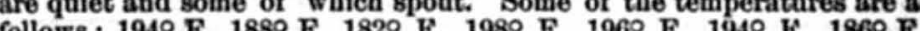
$196^{\circ} \mathrm{F}$, $194^{\circ} \mathrm{F}$; air, $68^{\circ} \mathrm{F}$; t time, $4.25 \mathrm{p}$. m. The water in the Giant $196^{\circ} \mathrm{F}, 194^{\circ} \mathrm{F} . ;$ air, $68^{\circ} \mathrm{F} . ;$ time, $4.25 \mathrm{p} . \mathrm{m}$. The water in the Giant seemed to be considerably agitated, but never reached a greater height
than about 3 feet above the top of the cone. The platform is made up of successive layers of geyserite, and on the side next the river the water has so cut into it that the layers are well exposed. They are very irregular in composition, but as a rule the lower we go the harder we find them. In one of the layers I obtained pieces that bore a remarkable resemblance to true opal, the color and specific gravity being that of semi-opal rather than geyserite. The colors are white, red, and green. Two of these specimens were submitted to Dr. F. Endlieh, of the Smitbsonian Institution, who has sent me the following communication in regard to them.

Wasumetox, D. C.

Dran SIR : I have examined the specimens from the Giant Geyser that you have kindly submitted to me, and give you herewith the results. From their position at the crater of the geyser, it may bo deduced that they are older than the geyserite at the surface. The minerals form plates of about + to 1 inch in thickness, $15 i n g$ horizontal when in position, and are also distributed in irregular nodules, bordered on al sides by geyserite. For particulars in regard to locality I refer to your report. The

No. 1. - Strueture, amorphons; hardnebe, 6-6.5; specific gravity, 2.4903; color, milky white; fracture, sub-conchoidal; lnster, dull.

Analyois.

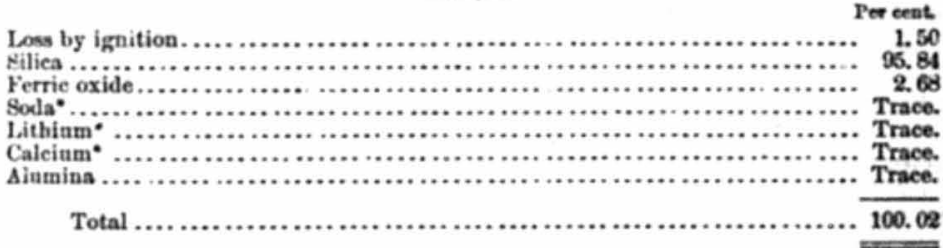

No. 2.-Structure, amorpbous; hardness, 6-6.5; specifie gravity, 2.0816 ; color, lightgreenish brown ; fracture, conchoidtal ; Comparing with quartz, opal, and geyserite, we find the position of this mineral an

\begin{tabular}{|c|c|c|c|c|}
\hline & Hardness. & Speeific gravity. & $\begin{array}{c}\text { Pereentage of } \\
\text { silica. }\end{array}$ & $\begin{array}{c}\text { Percentage of } \\
\text { water. }\end{array}$ \\
\hline 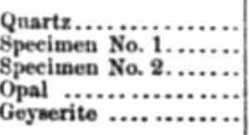 & $\begin{array}{r}7.0 \\
6.0-6.5 \\
6.0-6,5 \\
5.5-6.5 \\
5.0\end{array}$ & $\begin{array}{r}2.5-2.8 \\
2.4 \\
2.08 \\
1.9-2.3 \\
1.8-2.0\end{array}$ & $\begin{array}{l}99 \\
95 \\
\dddot{93} \\
87\end{array}$ & $\begin{array}{r}0.3 \\
1.5 \\
6.3 \\
7.00 \\
10.00\end{array}$ \\
\hline
\end{tabular}

We therefore have a mineral resembling in mome points sebir-opal; in this cane, bowever, having but little water, a comparatively high specifie gravity, and an eatirely tion between quartz and opal. As the characteristic feature of opal is the presence of 
Water, it must, in a chemical system, be referred to that species; but, taking into consideration the speeific gravity, the snuall percentago of water, and the circumstances

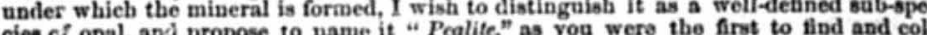
lect the miners.

Vory ros; ectfully,

FREDERIC M. ENDLICH.

Dr. A. C. Prat.

The following are analyses by Dr. Endlich of specimens frotn the same locality. The first is from the top of one of the cones, and is a typical specimen of gesserite. It is one of the latest formed and is covered with beantifnl bead-like processes, having a pearly luster. The second specimen is also from the Giant Gesser, but is from one of the lower layers and is much older. It is opaloid and in layers some of which are white and others red. The latter have a flesh-color, like rav-beef.

A nalysis of specimen No. 1.

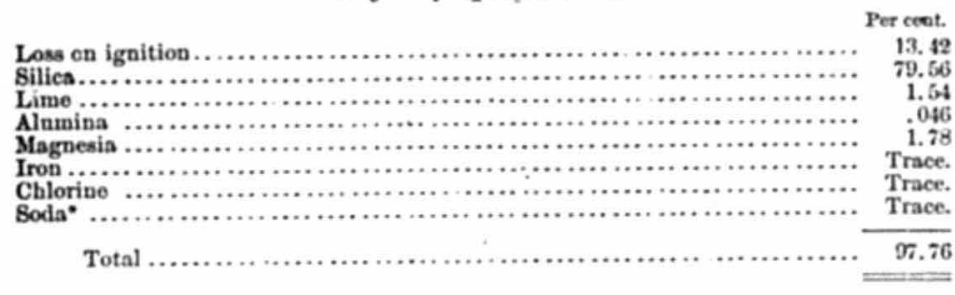

Analysis of specimen No. 2.

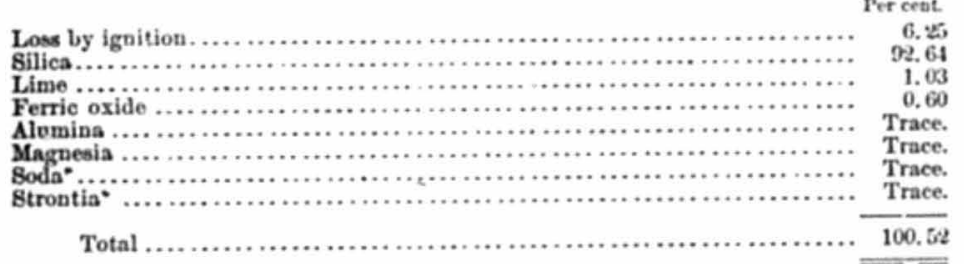

Fig. 39 is an illustration of one of the minor geysers of the Upper Basin.

The Grotto Geyser is 400 feet northwest from the Giant, and separated from it by a line of trees. Th re are two conez which spout alter. nately during the eruption. The larger one, which we will call No. 1, is very irregular and is 8 feet in height. The tube from which the water is projected measures 6 feet by 2 feet and is 19 feet deep. The other cone, No. 2, is 19 feet in diameter at the base and 14 on top. It is 4 feet high, and the orifice on top is qualrangular in shape, measuring 5 feet by 3 feet. When not in action the water is from 10 to 15 feet below the top. The basin is 16 feet deep. The entire length, including both cones, is 53 feet and width 20 feet, the centers of the two being 30 feet apart. The plan shown in Fig. 40 gives the relation of the two.
30 . Between them there are two small ge! sor-tubes which spout whenever the main cones are in action. The eruptions consist of a series of jets areraging about 20 per minute.

- Spectroscople examination.
First cruption, August 16. -2.45 p. m., eruption began ; 3.23 p. m.; eruption ended.

Cone No. 1. Maximum height, 32 feet; mean beight, 13 feet. Cone No. 2. Maximnm height, 24 feet; mean beight, 8 feet.

Second eruption, A ugust 19.-1.27 p. m., eruption began ; 2.40 .30 p. m. maximum of No. 1, 31 feet; 2.42 .30 p. m., maximum of No. 2, 41 feet; 4.0.0. p. m., eruption ended.

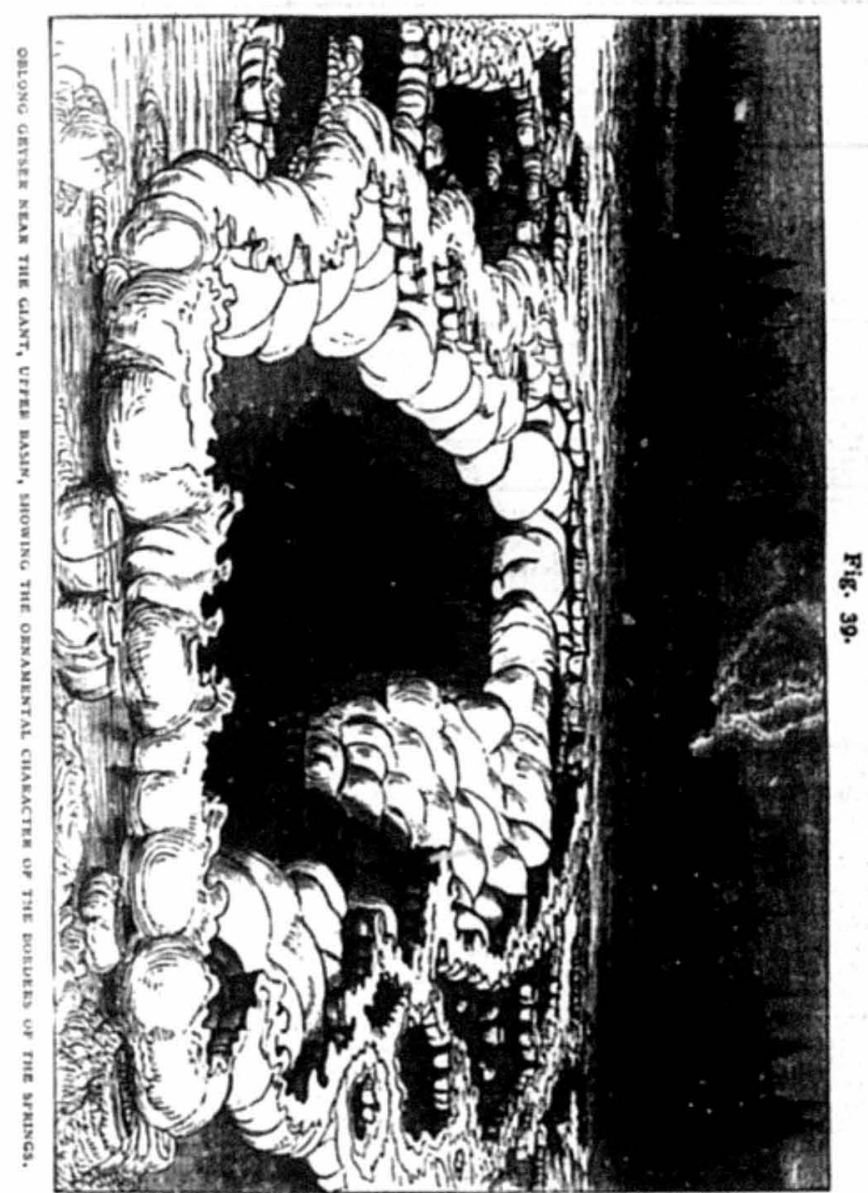

Mean height of No. 1, 16 feet; of No. 2, 13 feet.

After the eruption the water sank rapidly to about 20 feet in No. 2 and 15 feet in No. 1.

The following table will present the results of the observations on the various geysers as made by myself. Other points of interest will be found in the rarious reports: 


\begin{tabular}{|c|c|c|c|c|c|}
\hline Same & 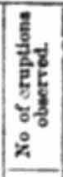 & $\begin{array}{l}\text { Average } \\
\text { lengthe of } \\
\text { eruptiones }\end{array}$ & $\begin{array}{l}\text { A verapo is } \\
\text { terval be } \\
\text { tween erup- } \\
\text { tiona }\end{array}$ & 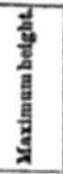 & $\frac{1}{60}$ \\
\hline 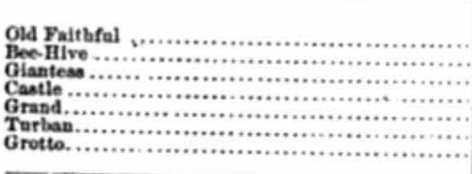 & $\begin{array}{r}17 \\
3 \\
1 \\
3 \\
3 \\
1 \\
1 \\
2\end{array}$ & $\begin{array}{l}m \sin ^{2} m \\
10 \\
713 \\
1530 \\
2300 \\
1500 \\
1250\end{array}$ & 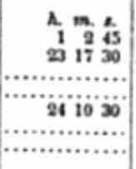 & 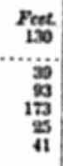 & $\begin{array}{l}\text { Fet } \\
7,307 \\
i, 402 \\
i, 400 \\
7,>7 \\
7,37 \\
7,327\end{array}$ \\
\hline
\end{tabular}

As we go from the Grotto Geyser down the river on the oppsite side, we pass through the timber at the foot of a hill. Emerging from the

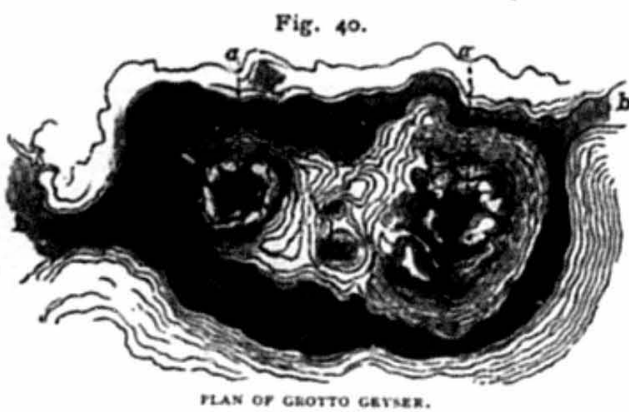
trees the first spring we meet with is situ. ated at the top of the ated at the top of the bin some distance above the level of the river. This spring is flower-like forms of geyserite, which have a greenish tinge. 'The water flows from the spring in several small streams, the bed of each one being a bright orange color. The a a, Orisces of cones; $\Delta b$, Outlets for water. water flowing down the hill becomes cool long before it reaches the river. An analysis of a specimen from the edge of this spring is as follows:

Color, grecaish-gray ; fracture, conchoidal ; luster, dull ; hardness outairlo 3 , inside 6. Analysis.

\begin{tabular}{|c|c|c|}
\hline \multicolumn{2}{|r|}{ 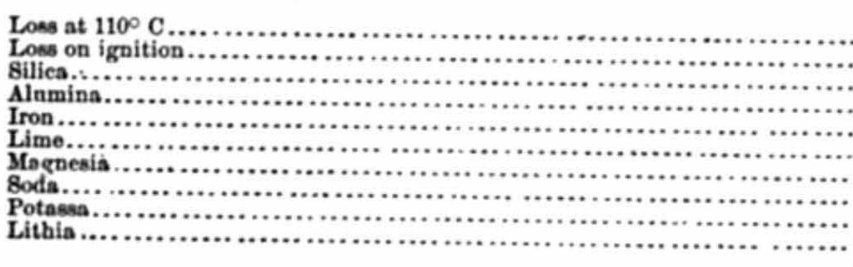 } & $\begin{array}{r}\text { Per cent } \\
2.00 \\
10.20 \\
86.10 \\
1.96 \\
.717 \\
.28 \\
\text { Trace. } \\
\text { Trace. } \\
\text { Tracs. } \\
\text { Trace. }\end{array}$ \\
\hline
\end{tabular}

Thinking that the hot springs would have considerable influence on the temperature of the water in the river, I took the following tempern tures in the Fire-Hole and Madison Rive. $d$ :

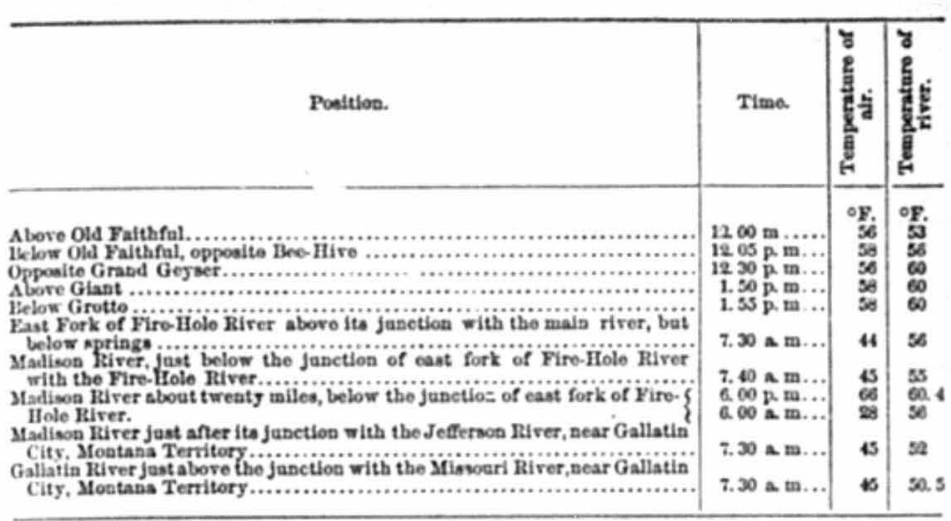

These observations were all made in August, with the exception of the last two, which were made September 10, 1872 .

The following analyses are of specimens collected by the Snake River division of the expedition:

No. 1.-Geyserite ball from geysers of Shoshone Lake. Composition, irregular; luster, dull; structure, amorphous; hardness, 5.5; color, grayish white.

Analysis.

Loss at $110^{\circ} \mathrm{C}$.

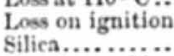

Alumina and iron

Lime.....

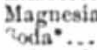

otassa"

No. 2.-Bluish-gray geyserite from geysers of Shoshone Lake. Amorphous; lamidated: luster, dull; hardness, 5 .

\section{Analysis.}

Per cent.

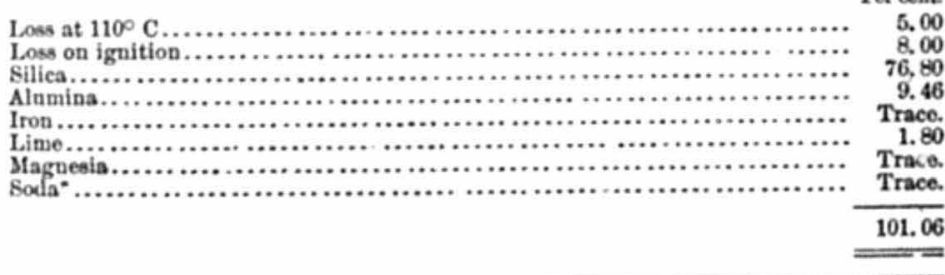

- By spectroscopic examination. 


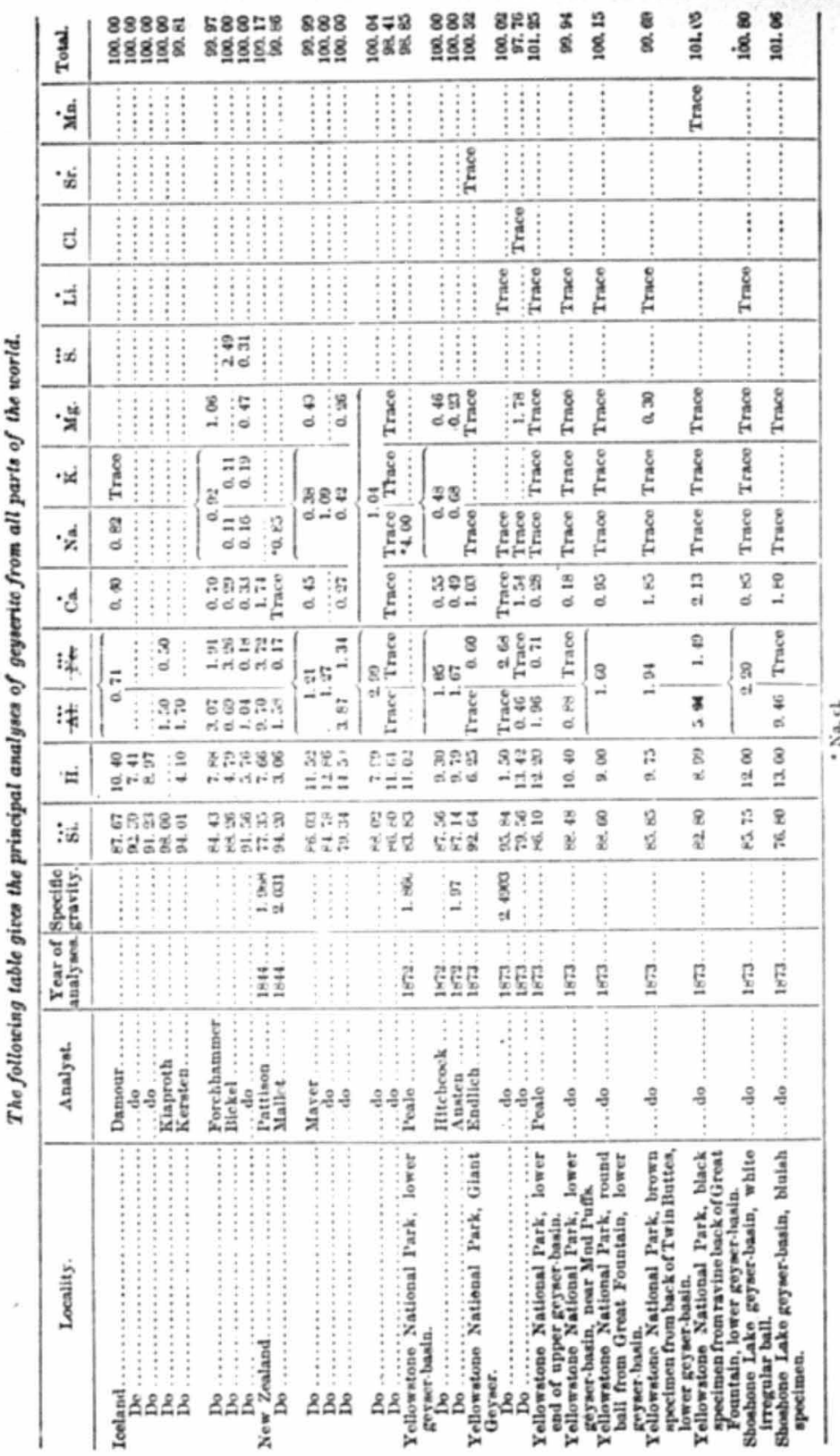

\section{CHAP'TER V.}

MADISON VALLEY GEYSER-BASINS TO GALLATIN OITY, CHERRY CREEK MINES.

Iate in the afternoon of August 20 we left the upper geyser-basin ate found Captain Stevenson's party still encamped, Dr. Hayden having moved down the river. As it was still encamped, Dr. Haydeu having moved down the river. As it was too late to follow we waited until morning, when we started at daylight, Fork, a branuh of the Madison, which joins it five miles below the junction of the east fork. The rocks between these two points are all reanie, trachyte porphyries, resembling those we saw at the Grand Cañon of the Yellowstone. In one place I noticed the same ronnd geodic masses that I saw there, only here they were much larger, measuring as much as 6 inches in diameter.

Some of the trachytes are laminated, and seem to have been twisted after baring been deposited. On the left bank of the river there is a high bluff wall extending from below the east fork of the Fire.Hole to Gibbon's Fork of the Madison. About three miles above Gibbon's Fork, in a gloomy gorge, is a very fine fall of about 40 feet in height. On reaching Gibbon's Fork I followed it up a few miles, to visit some hot springs which Dr. Hayden reported to me. These springs are on the right side of the river, in a valley about a mile in length and half a mile in width. The springs are situated at the foot of a ridge rising about 1,000 feet above them. This ridge is cut by numerons ravines, the divides between being rounded, thus giring to the top of the ridge the appearance of a range of conical peaks. On the opposite side of the Ifadison there are vertical walis of trachyte 1,500 feet in height. The springs are seven in number. The largest one is in reality a small lake, iil which the water has a temperature of $140^{\circ} \mathrm{F}$. It is supplied by two smali streams, which have their origin each in two small surings a few feet above. One of these is a pulsating spring, the water rising about a foot above the basin. The temperatures are $135^{\circ}, \mathrm{F}$. to $150^{\circ} \mathrm{F}$. A short distance to the east of this lake there are two other springs, having respectively the temperatures of 1000 $\mathrm{F}$. and $1290 \mathrm{~F}$. The temperature of the air during these observations was $610 \mathrm{~F}$. About the center of the valley there is an old ipring basin composed of three termees, rising abont 18 inches on above the other, in much the same manner as the terraces of the Gardiner's River springs. Here the springs are extinct and the terraces are overgrown with grass. There is considerable lime, and a coating of iron lines all the channels of the streams, carrying away the overflow of these springs. They have all doubtless passed their most active period.

Messrs. Jackson and Conlter, with some other members of the survey who followed Gibbon's Fork some ten miles above its mouth, have given me the following notes in regard to a fall which they discovered:

About eigbt or nine wiles above the mouth of Gibbon's Fork the valley gradually narrows into a deep cañon, the walls of roci- rising with a steep alope on both sides from near the water's edge, leaving scarcely room enough for a rough trail. After following this canion for about a mile, the slopes becoming steeper atd the trail narrower the rirer seems to issue from a perpendicular wall standing directly across the bead of the cafion. On refening this precipice, uowever, wo found that the river makes a sharp bend to the rigat, forming nearly a right angle with las former course, and fust 
lar to the apper fall of the Yellowstone. The stream does not leap sheer over the precipice in oue anbroken fall, but anter a fow feet of perpendicala decents pore out the leost warning, the noise of the fall being shu' of both by the intervining wall of rock and the rapids, ir'o which the river is broken Lelow. Abovo the fall the river

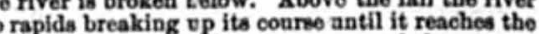
very brink of the precipice, over which it plunges into the narrow gorge below.

Leaving Gibbon's Fork we find ourselves almost immediately in the upper cañon of the Madison, which arerages about half a mile in width and is eight miles in length. The hills on either side rise from 1,200 to 1,500 feet above the river, those on the left side being almost vertical. The valley is partially timbered, and the hills also, wherever the trees can find a foothold. Near the lower end of the cañon there is a fine exposure of colnuns high up on the right-hand side. The rock is mostly a rough, purplish trachyte, with sanidine crystals. Emerging from the a rough, purplish trachyte, with sanidine crystals. Emerging from the cañon we find ourselves in a wide valley, through which the east fork of the Madison flows to join the main river. Both cut their channels in serpentine manner through the modern beds, which are made up of
Pliocene sands, containing a considerable amount of obsidian, which gives them a dark color. The valley is partially timbered, and must be nearly fifty miles in width. On the $22 \mathrm{~d}$ we encamped near the junction of the east fork, just above the middle cañon, where we spent two days waiting for Dr. Hayden to join us from a side-trip through Taghee Pass to Henry's Lake. I made a trip up the valley of the east fork and ascended one of the hills bordering it on the north. The view from this point was one of the fairest that I have ever gazed upon. It seemed to unite all the elements of beauty - hill, grassy plains, and winding streams. Both forks of the Madison wind through the valley in a series of graceful curves. The rocks were not well exposed on this hili, but as far as I could judge the dip seems to be northeast at an angle of about $75^{\circ}$ to $80^{\circ}$. Proceeding toward the river I came across limestones, the upper layers of which I take to be Carboniferous, although I conld find uperils to prove it. The lower layers are probably Silurian and rest no fossils to prove wich pass into mica-schists and gneisses. The angle of the dip of these limestones is still very great. At the head of the valley of the east fork there is a range of mountains that appear to be volcanic, and is probably part of the same range that $I$ noticed from near the hot springs on Gardiner's River, which I referred to in a previons top of the modern beds layers of trachyte, which seem to have had top of the modern beds layers

their origin in these mountains.
On the 25 th we moved camp down the river and camped in the midst of the middle cañon. In one of the gullies at the upper end of the cañon I found grains of glauconite in a quartzite-rock. The western side of the cañon seems to be composed entirely of metamorphic rocks, side of the canile stones, which at the upper end incline northeast at a high angle.

stones, which at the upper end incline northeast the eastern side of the river, through which a small creek flows to join the Madison, a short distance above camp. It was so narrow and rocky that we were obliged to leave our horses at the month. The first rocks we enconntered were guartzols tered were gnartzechist ingly at right angles to the course of the stream, the dip being sonth west. The next rocks were very compact limestones, dipping nnderneath the chlorite-schists. The lines of junction could not be seen, but they seemed to be conformable. The angle of inelination was about $60^{\circ}$.
These beds I took to be Silurian, although I could find no fossils. They were followed by Carboniferous limestones, dipping unconformably be. neath them at an angle of $50^{\circ}$. This unconformability was cansed, most likely, by the force of apheaval. There appears to be a complete inversion of the strata, which a few miles farther np the river we saw almost vertical, but dipping northeast. On the opposite side of the river I found quartz-sebists, but they were so covered by detritus and the timber that very little could be determined in regard to them. I will refer again to the inversion of the strata further on.

The middle cañon is serenteen miles long, and its direction from the upper end to the creek, where I found the inverted strata, is northwest. Here, however, it takes an abrupt turn toward the west, almost at right angles to its former direction, and is cut throngh chloritie and gneissic rocks.

On the 27 th we camped just outside the cañon, and from this point, in company with Messrs. Gannett, Holmes, and Savage, I made a trip through Raynold's Pass to Henry's Lake, and thence across the divide, again to the valley of Red Rock Lake. The metamorphíc strata stili continued dipping sonthwest. At Taghee Pass, east of Henry's Lake, I believe they are capped with Carboniferous limestone. Raynolds Pass is low, only 6,911 feet in height. The ascent is very gradual, and it is difficult to determine exactly where the stream running into the Madison ends and that running into Henry's Lake begins. To the southwest of Heury's Lake I noticed in the distance a voleanic range. This section of country, however, will probably be fully treated of by Professor Bradley, and I therefore pass it. The diride between Henry's Lake and Red Rock Lake is 7,271 feet high, the distauce between the lakes being about eight mil $\mathrm{s}$. On the Red Rock side of the divide I found in the valley of a small stream an excellent exposure of reddish quartz schists, the thickness of which I estimated at about 2,000 feet. 1 am of the opinion that they rest immediately on the granites. They dip southwest at an angle of 200 . Viewed from a short listance the out-crop has the appearance of a buge staircase. Between Red Rock Lake and the Madison Valley the formations are mostly moderu, mingled with igneous rocks, the exact relations of which I had not time to determine carefully.

After leaving the middle cañon, the Madison River makes another turn of nearly $90^{\circ}$ toward the north, and when we reach the point a short dis. tance below, near Indian Creek, we find the limestones which we saw ia the middle cañon again making their appearance. I made several trips into the Madison Range, one above Indian Creek, one at Bear Creek, and a third up Jackass Creek, at the lower end of the valley. Above Indian Creek I found the ridges and peaks made up of mica-schists, which were so covered with detritus that little conld be deternined in regard to them. We had a great deal of bad weather about this time, which also interfered much with my work. Among the specimens i obtained are aplite, micaceous gueiss, and quartz. Bear Oreek is a small stream, joining the Madison on the right side, about forty-eight miles below the cañon. The rocks at the month are hard blne and 5 el low limestones, containing fragments of corals and crinoids. These I take to be either Upper Silurian or Devonian. The layers are very much contorted, but the dip is about west, or, perhaps, a little north of west; angle, $20^{\circ}$ to $30^{\circ}$. These beds are followed by dark-blue Carboniferous limestones, containing Strophomena, Spirifer, Productus, and Orthis.

$11 \mathrm{G} \mathrm{s}$ 
Fig. 4x.

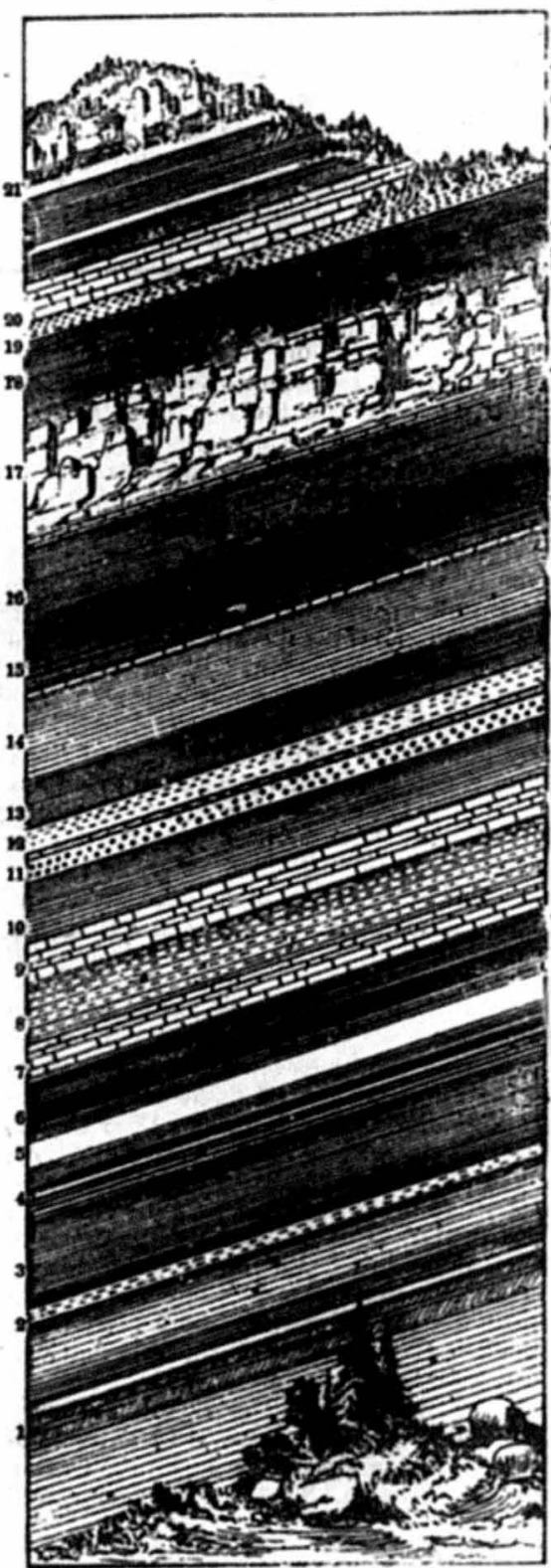

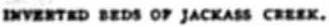

The entire exposure of limestones is about 800 reet in thickness. The upr or rather lower, layersfor they are inverted as I found then in the middle cañon-are magnesian, and contain in places bladed crystals of tremolite. The limestones are followed by 430 feet of massive quart. zites, which are at first white and then dark from the presence of iron. Be neath the quartzites, and dipping in the same direc tion at an angle of $20^{\circ}$, are alternate layers of sands and calcareous shales, with interlaminated bando of corlike slates, wich coal-like slates, which break readily at right an. gles to the plane of deposi. tion. They are followed by greenish-gray caleare ous sandstones, breaking into lamina from $\frac{1}{2}$ inch to 2 or 3 inches in thickness. These contain Trigonia, Mo diola, and other fossils. proving their undonbted Jurassic age. All of these rocks are conformable to each other.

Jackass Creek joins the Madison at the lower end of the valley, just above the lower eañon. This creek, like the others, cuts deeply into the range, affording an excellen chance to get at its strue ture. The range, however, is so long and so rugged, capped with so many sharp peaks, that to determine its geology with precision will require the work of sev eral seasons, and I will be able, therefore, to give only a general idea of it. Stil I think future research will modify but little my idea and only fill in the de. talls that are wanting. There is no doubt but that it presents one of the most interesting flelds of study to be found in the West. Jackass Oreel emerges from the mountains throngh a canion, the mouth of which is very narrow and bordered by goeisses, which are very micaceous and of a black color. As we proceed up the stream they become lighter. The exposure on the right bank is very fine, the bedding being conspicuons, dipping northwest at an angle of $20^{\circ}$ to $30^{\circ}$. About $\mathrm{a}$ mile inside the cañon we meet first with the limestones, which seem to dip underneath the gneissic rocks. On the left-hand side of the cañon, as we go up stream, there are two hills, on one of which the ont-crop is gneissic and on the other limestone. Between is a deep gully, in which the line of junction is so obscured that even with the most careful investigation it could not be determined. Just abore the limestones we find shales and quartzites, which probably represent the Potsdam group. Between there is a very compact porphyritic rock which I take to be an old intrusion of igneous material. The limestones are very compact and brittle, and in layers of about 6 incbes in thick. aess, dipping northwest at an angle of $30^{\circ}$, seemingly conformable with the gneisses. They are probably Silurian, and we found in them the fragment of $a$ tribolite and lingulepis. Still farther up the cañon we find Carboniferous limestones, containing well-defined Carboniferons fossils, dipping northwest, conformably, with the Bilurian beds. Theselasers above weather a blue color, those below yellow, and between them red. Then follows a porphyritic layer, resembling the one seen above the Silurian rocks. It is followed by what I take to be Jurassic beds. Although I found no fossils here, the rocks are precisely of the same character as those I found in Bear Creek, which contained Trigonia, \&c. Then followed more modern beds, made up of soft, gray eal careous sandstones and clay-slates. The lowest layer observed was igneous material. The accompanying illustration, Fig. 41, corresponds with the following section:

1. Igneous rock.

2. Clay-slates.

3. Soft, gray sandstone. Containing fragments of leaves.

4. Green and black shales.

5. Gray shales.

6. Green and black shales.

7. Quartzite.

8. Shales.

9. Quartzite.

10. Limeston

11. Conglomerate

12. Porphyritic, igneous rock.

13. Dark-blue limestone.

14. Reddish limestone.

15. Yellowish limestone. $\}$ spirifer, Productus, and Zaphreretis.

16. Bluish limestone.

17. Silurian limestodes.-Trilobite and Linguleris.

18. Shaly sandstones.

19. Porphyritic, igneous rock.

20. Quartzite.

21. Gueiss.

Toward the north the strike of these rocks seems to bend more and more toward the east, and probably extend across to the Gallatin, where I shall refer to them again further on.

The valley of the Madison from the middle cañon to the lower cañon is fifty miles long and averages six miles in width. It once formed 
the bed of a lake, which was probably one arm of the lake to which I

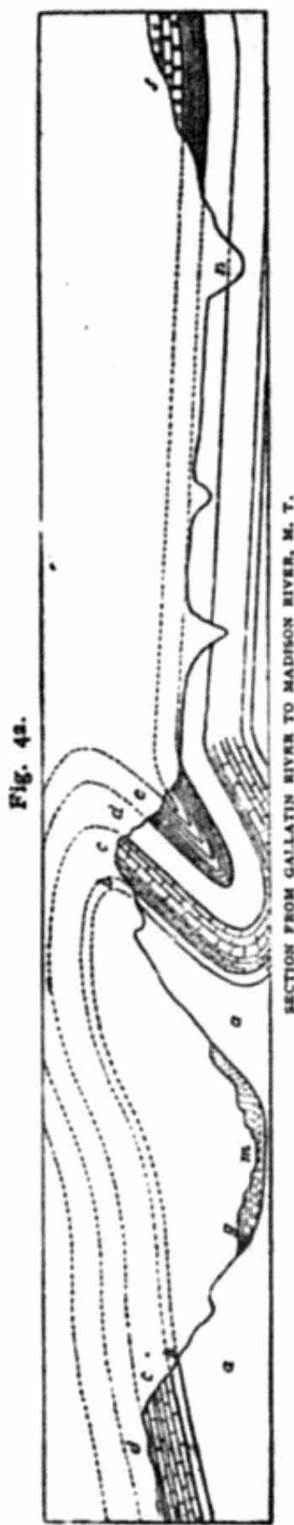
have referred before as covering he country about the Three Forks of the Missonri, and extencling also into the valleys of the Gallatin and Jefferson Rivers. Since the subsidence of the waters the gradual elevation of the conntry at the head of the river has caused it to carve out of these deposits a beautiful set of terraces, the most perfect I have ever seen. At the head of the valley there are fonr o? them, all well defined. Some are capped with basalt and trachyte, which is columnar above and laminatea below. Opposite Virginia City there are two, the first of which, on the west side of the river, is 53 feet in beight and on the east. ern side is wanting. The top of the seoond terrace is 243.5 feet above the level of the river on the western side and 149 feet ou the eastern side. These terraces are but the remnants of what once filled up the entire ralley, and are composed above of very soft sandstones, containing fine grains of mica. These sandstones pass down into conglomerates. The beds are all culcareous and nearly A horizontal in position. On the western side of the Mrdison Valley we find granites out cropping, upon which are limestones probably from the Silurian upward. The Carboniferous beds, at any rate, are present in considerable thickness. The underlying rocks in the valley, upon which the lake-deposits rest, I take to be granites. The accompanying illustration (Fig. 4:2) will show what I conceive to be the struc ture of the country. It represents a section across the country in a westerly direction from the east side of the Gallatin River to the west side of the Madieon. The dotted lines repre. sent the relation of the inverted beds, extend. ing along the entire Madison Range to the beds resting on the granites on the west side of the Madison. The force which inverted the beds of the Madison range was probably oblique in tis direction. The amount of ero ique in its direction. The anount of erosion since the upheaval must have been enormous. I sball refer to this section again when speak ing of the Gallatiu Cañon.

When I visited Jackass Creek with Mr. Holmes and one of our packers, we left the main party on the west side of the river, on which side they intended to proceed down stream some distance before erossing, while stream some distance before crossing, while
we were to go down on the east side skirting the lower cañon as elosely as possible, and after visiting the Cherry Creek mines to join them as soon as we conld overtake thex. We left Jackass Creek on the morning of the 8 th and proceeded to the river, which we followed until we reached the point where it enters the middle cañoa. We then struck up on to the hills, which we found to be composed of granitoid rocks, mostly gueisses. We were unable to get very near the eañon, on account of the rnggedness of the conntry. We spent the day descending into deep ravines and erossing high ridges. The conntry is very rough and we had no trail to follow. Several times we thought we migbt be obliged to turn back. The bighest point we reached bad an elevation of 8,000 feet. This was on the divide between the Gallatin and the Madison, and we had a good view of the valleys of the Gallatin Madison, and Jefferson, which lay spread out before ns, the relations to each other of the different patches of lake-deposits between the rivers be ing beautifully shown. In the gneisses over which we were passing, which dip northwest, there are numerous veins of white quartz. In oue place I noticed immense masses of it containing a green mica, fuchsite which was so abundant that it gave a green color to the entire mass. We camped late in the evening at the head of Pole Creek, which we mis. took for Uherry Creek. In the morning we proceeded down stream hoping to reach the mines. We found that the gneissic rocks continued for some distance and were succeeded by beds of massive guartzite resting conformably on them. These quartzites are succeeded by sand. stones, shales, and shaly limestones, above which, we find a bed of . jasper and flint containing a beantiful rariety of specimens. Above this is a bed of limestone. All of these beds are probably Lower Bilurian. Reaching the mouth of Pole Creek we found that it was a branch of Cherry Creek, and we were four miles below the mines. We then turned our horses' beads up atream and reached the mines about noon. We spent two hours examining them, duriug which timeI obtained the follow. ing information: The mines are situated in gneissic rocks of distinct bedding, dipping northeast. All the openings have been made on the side of the hill, which faces toward the south. The first discovery was made at the Havana lode, near the Madison River, some fon miles northwest of the present camp, in May, 1872. Next, the Devils Gate lode was discovered, 3,000 feet southeast of the Havana. In June the discovery was made at the present camp. There has really very little been done, as yet, beyond the staking of claims and the beginning of shafts into them. I will give the names of the various lodes that I visited, with various points of interest concerning them:

Eberhardt lode.-This lode was discovered on the 5th of June, 1872. It is three feet in width and strikes north $75^{\circ}$ west, dipping north $15^{\circ}$ east; angle, $40^{\circ}$. The walls are gueissic. The gangue is quartz ane jasper containing native silver. The assays of the ore are said to aver. age 8600 per ton. There are two claims on the lode, one called the Eberhardt Discovery and the other the Eberhardt Extension. A shaf has been sunk in each to the depth of 15 feet. Not more than four or five tons of ore have been taken from these shafts mereral sales in sales in this lode have been made siace its discovery, averaging about 150 per 100 feet.

The Heintzleman lode was also discovered on the 5th of June, 1872. It is above and parallel with the Eberhardt. The strike is north $80^{\circ}$ west; din, north $10^{\circ}$ east; angle, $40^{\circ}$; width, 3 feet. The walls are gueissie; the gangue is the same as in the Eberhardt, containing native silver and pyrites. There are two elaims, and two tunnels are being driven into it. One has reached a depth of 25 feet and the other 30 feet. The ore is said to average 8900 to the ton, none of the assays ever having been less than $\$ 300$; the greatest (a picked specimen) gave a result of \$5,670 to the ton. One hundred and fifty feet of this lode 
were sold for $\$ 3,500$, with the agreement that a shaft was to be sunk to the depth of 100 feet.

Clarke lode.-This lode was discovered Jnue 11, 1872. The strike is northwest; dip, northeast; angle, $50^{\circ}$; width, 21 feet.

Alabana lode.-This lode is below the others. Strike, north $70^{\circ}$ west; Alabama lode. -This northeast; angle, $60^{\circ}$. It is only a few inches in width, and at present there is only a small opeuing into it.

Pennsyleania lode was discovered June 11, 1872. This is also quite narrow, not exceeding a foot in width. The strike is north $30^{\circ}$ west; dip, northeast; angle, $65 \circ$. Assays are suid to yield $\$ 54$ in gold and 2.75 in silver.

G. W. Rea lode is 31 inches in width. The ore isas never been assayed.

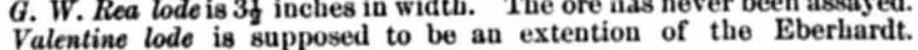
Valentine lode is supposed to be an
Very little work has been done on it yet.

Z. Daniel's lode.-This lode was discovered June 7,1872 . It has a shaft 10 feet in depth. The crevice is 2 feet in width. The strike is nortluwest; dip, northeast; angle, $50^{\circ}$.

Home lode.-This lode was discovered June 9, 1872, and is one of the Home lode.- district, the ore Leing said to have ass;yed 83,200 per richest in the district, the ore leing said to have bas;yed 83,200 per ton. The strike is north $30^{\circ}$ west; cip, northeast; angle, 48. The width is 3 feet. There have been two shafts sutk on it, one reaching $10 \mathrm{fot}$ in deptb, the other 15 feet. The strike sesmo to turn to the souchwest, nd the angle decreases to $45^{\circ}$. A three-fourtiv interest in this lode $(1,125$ feet) has been sold at $\$ 900$.

Parasol lode is anove the Heintzleman, and parallel with it. It dips

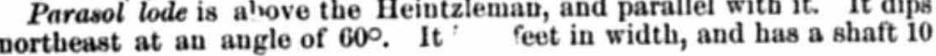
feet in depth.

Emma lode is above the Parasol, and parallel with it. It is 2 feet in width.

Nero Haven lode is on top of the ridge above the Emma, and is 18 ine lodes in this district are the Claggett, Yankee Doodle, Merrimac, Davis, Silver Crouen, and Monarch.

The Harper lode is opposite the Cherry Creek district, on the opposite side of Cherry Creek, and is in limestones instead of gneisses. It is 25 feet wide, and the strike is nearly east and west; dip, south. It was discovered July 12, 1872 . The ore is said to assay $\$ 37$ in gold and $\$ 7$ in silver per ton.

When 1 visited them there were fifty men working at the Cherry Creek mines, their wages being $\$ 4$ per day, or $\$ 75$ per month with board. This is the first important discovery of silver in the Territory, and there are no mills for the rednction of the ore at present. Whether the ore is in ore.beds or bedded veius cannot be determined without further investigation. Some of the lodes have been traced from the Sudien piver a distance of mere than fontry.rock Cill be is all gueissic, and the lodes are parallel with each other. It will be noticed that they are all narrow, but it is elaimed that they widen as we desceud. The metallic silver is very apparent in the ore, having the form of arborescent crystals.

On the opposite side of the Madison we find the Silver Shourer district, coutaiving silver mines, which were discovered abont the 28th of June, $187^{2}$. It is probable that they are merely extensions of the ledges we have described on the east side of the Mudison, as the ore is said to be have described on the east side of the Hudison, as the ore is said to be The principal lodes in the Silver Shower district are the Silver Shoner, the Pilgrim, the Stunercall Jackson, the Chloride, and the Cross.Key. The assays are said to vary from $\$ 650$ to $\$ 900$ per ton. Native silver is not seen so abundantly as in the specimens from Cherry Creek. Specimens from the Stonewall Jackson lode contain galena, which is not seen at Cherry Creek.

Leaving Cherry Creek we crossed the hills to Elk Oreek, which runs almost parallel to Cherry Creek. On the way we passed, or top of the ridge, several openings, none of which were developed to any great extent. Reaching Blk Creek we followed it to the Madison, where we learned at a ranch that the party had passed down tle river the day previous. We camped for the night a few miles below the month of Elk Creek, and the next morning started down the Madison. The bluffs on either side of the river are made up of Pliocene marls and sandstones, the remunants of the lake-leposits. In some of the ravines, cut in these bluffs by the little streams, we find beantifal specimens of silieified wood. We reached Gallatin City at the Three Forks of the Missouri about noon, and learned that the party had eamped there the night before and had left early in the morning on their way up the Gallatin
River. We followed and joined them at night-fall. Above Gallatin City, on the north side of the river, there are several fine exposures of Carboniferous and Silurian rocks, the consideration of which I reserve for the next chapter. About four miles ab ve Gallatin City, on the right-hand side of the stage-road leading to Bozuman, I noticed bum the of brown, flinty rock, resembling those I saw on Pole Creek, but was unable to determine whence they came. The following day, September 11, we reached Fort Ellis, and camped on our old camp-grounds, from which we had been absent almost two months.

\section{CHAPTER VI.}

GALLATIN VALLEY, BOZEMAN CREEK, MIDDLE CREEK, MOUNT BLACKMORE, AND WEST GALLATIN RIVER.

On the 14th of September, in company with Messrs. Gannett and Holmes, I left Fort Ellis to ascend Mount Blackmore and investigate the geology of the country sonth of the Gallatin Valley. The range in which the peak is situated gives origin to the branches of the East Gal. latiu, and once formed a portion of the southern shore-line of the late which exteuded over the conntry about the Three Forks. Although the peak stunds up prominently, and is in plain sight from Fort Ellis and Bozeman, it was difficult to determine exactly which stream would lead us to its base. We selected Bozeman Ureek as the one to follow, hoping that if it did not lead us to the right point we would be able to cross the ridges and thus accomplish our purpose. We camped in the evening, just inside the mountains, in the cañon of Bozeman Creek, and the next day pushed on up stream. The timber along the creek was so thick that we ascended the bills, hoping to fled traveling less difficult. We were obliged, however, to return to the bottom of the cañon. From the month of the eañon for aboat five miles the granites are the only rocks exposed. Succeeding them are the limestones to which I referred in the second chapter when speaking of Mystic Lake. The hills come down so abruptly to the edge of the creek and the eañon is so densely timbered that, in order to make any progress at all, we were often obliged to wade in the bed of the stream. On reaching Mystic Lake we found that it would be impossible to take our animals across the ridges which 
separated us from Mount Blackmore, and that our best plan would be to try the next ereek to the westward. Bo, joined by Mr. Jackson and his party, who had been at Mystic Lake several days photographing its fine scenery, we returned to the plain of the Gallatin Valley, and the next morning, skirting the edge of the mountains until we reached Middie Creek, we entered its eañon. We found the lower part of the cañon quite open and had very easy traveling for about two miles, when it began to narrow, and the granite rocks towered bigh above ns on both sides of the stream, which here rushes furiously over its rocky bed. Im. mense slides of rock extend from the cliffs above to the water's edge, and, with the dense pine-forest through which we were obliged to cut our way with the ax, rendered our progress slow and difficult. The rocks are mostly gneissic, dipping northeast at an angle of about $70^{\circ}$. After five miles of this rough traveling we came ont into a small open valley or park, bounded on either side by rather low rounded bills covered with sage-brush; here we camped. Shortly after getting ont of the cañon we find limestones crossing the creek, the strike being almost at right angles to its course. On the left bank of the ereek there is a bluff showing a fine exposure of the layers, which I take to be Silurian, although no fossils ould be found. They dip sonth of east $45^{\circ}$ to $50^{\circ}$. They are, probably, a prolongation of the layers below Mystic Lake. Between the two points there must be a rather abrupt turn in the strike. When at Mystic Lake, however, I noticed that the layers began to turn more and more toward the west as we followed them below the lake. A little farther up the valley of Middle Creek we found true Carboniferous beds containing Orthis, Spirifer, Strophomena, Atrypa, and other Car. boniferous fossils. Still farther up the valley we tind that the dip is reversed, and we have crossed a synclinal which is at right angles to the course of the stream. The occurrence of volcanic outbursts at the head of the stream has thrown the sedimentary beds into some confu sion, 80 it is difficult to reduce them to any system. On the 17 th we camped in one of the most picturesque valleys or parks that I have ever seen. It is about a quarter of a mile in length and almost oval in shape, bordered by a line of grand old pines. Through the center of the park Middlu Creek flows. Back of the trees on the east side of the park, ris ing to the height of over 3,000 feet above the bed of the creek, is an almost bluff wall of volcanic rock, the prevailing color of which is black relieved here and there by streaks of red and green, as though it had been painted. This wall is surmounted by dome and spire like points of rock, in whose crevices lay deep snow-banks. At some points on the wall we could distinguish groups of stuvited pines. On the opposite side of the park is a similar wall, which has been more affected by the processes of weathering and presents many curious architectural forms. It does not require a very vivid imagination to trace on its front the forms of castles and fortress-walls. At the head of the park the wall makes a slight turn to the east, and here there are three monument-like piles of rock, dome-shaped masses surmonnting perpendicular walls, on which we could see numerous waterfalls, looking like silver threads against the black backgronnd. To the most prominent of the three we gave the name of Palace Butte and the other two we called the Twin Buttes. The park in which we were camped we called Palace Park. From this point we concluded to strike out for the ascent of Mount Blackmore, which, althongh not in sight, we knew to be to the westward of us and not far off. The following morning we started, and, reaching the summit of the first ridge, saw the peak immediately before us and separated from us by a deep ravine which we were obliged to cross. On this first ridge we passed over the upturned edges of limestones, dipping about northeast, and on the opposite side of the ravine, on the side of the ridge which culminates in Mount Blackmore, there is also an ex. posure of limestone, dipping in the same direction. The upper layers posure of limestone, dipping in the same direction. The upper layers
have an inelination of about $30 \circ$, while the lower ones incline only $10 \%$. These limestones are capped with voleanic material, which seems at first to have tipped them up and afterward crushed them. Mount Black. more itself is a volcanic peak, and the nearness of the sedimentar mock to the cer east, has affected them to a great extent and thrown them into great confusion. Taking our horses to the timber-line $(9,550$ feet) we finishei the ascent on foot with comparative ease. The rock of which the peak is composed is basaltic in its character, of black and red colors. On the summit it is very compact and massive, while below we find it laminated and somewhat porpbyritic. On the way up I found excellent specimens of Hyalite in globular concretions, as clear as glass, coating the rocks and making them look as though coated with ice. I also found Chalce. dony and a yellow variety of opal resembling somewhat fire-opal. It varies in color from a boney-yellow with a greenish tinge to a brownish red. It is opaque; luster vitreous; hardness, 5; specitic gravity, 2.172. Considering its physical properties it might be distinguished as a variety of opal between fire-opal and the ordinary semi-opal. I protose for it the name of Blackmorite, from its locality, Mount Blackmore. An analysis of it is as follows:

Analysis.

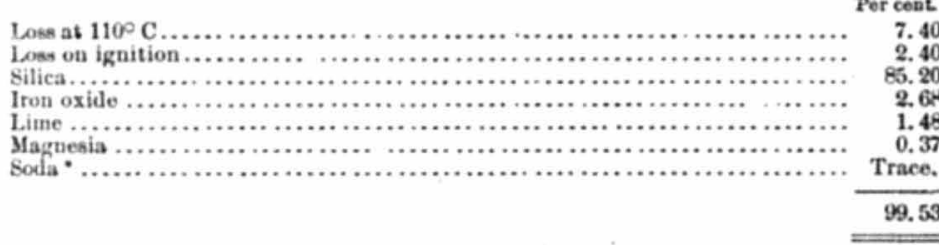

The view from the summit of Mount Blackmore is grand in the extreme. When -we turn to the south we overlook an intensely rugged country, stulded with numerons sharp voleanic peaks. Qnite near the peak there is one point which looks as though it were once the center of volcanic action, the sloping sides bearing a striking resemblance to the sides of an old crater. To the north the fleld of vision is immense. The valley of the Gallatin, from its sonrces at our feet to the Three Forks, lies spread out before us, ant beyond we could distinguish in the dim distance even the Missouri. Here we could trace the layers of limestone from Mystic Lake to Middle Creek, thence across the Cottonwood, the next stream to the west, and thence across to the West Cottonwood, the next stream to the west, and thence across to the West
Gallatin. All these streams have cut their way directly across the strata at right angles to the strike. To the west we could see the Madison Range, and on the east the snowy range of the Yellowstone. The eleration of the peak above sea-level is 10,134 feet. The following morning we followed Middlo creek to its sonrces, and fond that the valley abounded in wost magniflcent scenery, foliage, rocke and un ous water-falls and cascades combining to form the most beautifnl pic-

- By spectroscopie examination. 
tures, and Mr. Jackeon concluded to remain soveral days in the valley. $W_{\theta}$ continued on our way, hoping to be able to cross the range and descend to the West Gallatin, where we expected to join the main party the next day. We reached an elevation of 9,000 feet, and found our. the next day. We reached selves surrounded by a semicirealar wall, immense banks of snow. To dicular height above ns. At the base lay immense banks of suow. To cross was impossible, 80 we ratraced our steps, and on reaching the first open space above the cañon where we bad encamped three days before, we crossed the ridge to Cottonwood Creek, which we followed to the plain. We then proceeded along the edge of the mountains until we reached the month of thu West Gallatin Cañon, and, striking the trail reached the mouth of thoshed up stream as rapidly as possible. The of the main party, we pushed up stream as rapial as possible. The rocks at the mouth of the cañon are gneisses, which dip northwest at an angle of about $75^{\circ}$. They are followed by immense beds of limestone, which at first, I think, dip in a southerly direction, but soon change to the northeast. The angle varies from $20^{\circ}$ to $30^{\circ}$. They are the direct prolongation of the layers which we observed on Middle and the direct prolongation which we also noticed on Pole and Cherry Cottonwood Creeks, and whe limestones Creeks when we were on our way dow are again succeeded by gneisses, probably the continuation of those throngh which the Madison cuts the Iower Cañon. Theu follow lime stones dipping southwest. These i believe to be the continnation of the lascrs in the Madison Range, which I referred to as making a turn towaril the east near. Jackass Creek. To the east of the Galiatin River it toward the east no is diflection to trace then, region. That there is some connection between this ridge and the lay ers outcropping on Cinnabar Mountain is highly probable. Just above this last ridge of limestone we found the main party eneamped. On the opposite side of the river there was a high bluff wall made up of Cretaceous and Jurassic rocks. Our camp on the western side was cron Juras in a ren the Jadison Range. The weather became tle slope from the Gallatin to the Madison kange. The so suowy and unfavorable for work that i was not able to follow the beds to the westward, as I desired, but the section shown in Fig. 42 which 1 referred to in the preceding chapter, will show what I beliere to be the relation of the beds exposed on the Gallatin, opposite our to Madison Range. To definitely settle their rela camp, to those the western sile of the Madison Range will have to be tion, lowerer, the western worked out in more detail than it has been up to the present time. The cañon of the West Gallatin is so fully treated of in other portions of the report that $I$ bave thou: ht it best merely to refer to it. Leaving the Gallatin River we crossed the duvide to the Yellowstone River. On the very sumnit I obtained specimens of silicified wood embedded in basaltio very sub ist meck, which is beride at the point been very much metamorphosed. The elevationof thedivideathe point we crossed it is 9,317 feet. We struck the Yellowstone just below the second cañon, and followed it down to Bottler's ranch. While at this point 1 crossed the Yellowstone River and went up Emigrant Gulch, one of the regions in which gold miuing has been carried on to a somewhat lime monntain-range for some dis tanithe me rocks near the month of tance in a geveral southeasterly direction. the gulch are chlosite schists, which dip in a northerly direction, or perbaps a little west of north, at an angle of $40^{\circ}$ to $45^{\circ}$. These chlo. ritic rocks extend for abont two miles aud a half, and are followed by gneisses, which dip underneath them. These gneisses are probably continuation of those exposed in the second cañon of the Yellowstone.
They exiend for a short distance, when we find igneous rocks resting upon their upturned edges. These igueous rocks rise to a great height on either side of the guleb, and in fact form the crest of the entire range, as I noticed when on the summit of Emigraut Peak last year. The stream descends very rapidly as it flows down the gulch, and there are numerous cascades and waterfalls in its course. At the mouth of the gulch there was formerly quite a large settlement, but at present nothing remains save the stone chimneys of Yellowstone City. As we ascend the creek the gulch narrows very rapidly. There are two mining. camps, one at the head of the stream, the other at the month of the guleb. The mines are all placer-diggings, and at present there are only twenty or thirty men working here. The highest yield is $\$ 15$ per day, the average being about $\$ 5$ per day to each man. There are four elaims worked at the lower camp and three at the upper, and since the dis. covery, in 1864, it is estimated that the gulch has yielded over $\$ 100,000$. The chloritic rocks, which are exposed in Emigrant Gulch, extend along the range as far 'north as the Lower Cañon of the Yellowstone. Near the latter, in one of the smaller gulches, I obtained specimens of Itacolumite in lamina about an inch in thickness and having a greenish color. None of the specimens were flexible. Unr next camp, after leaving Bottler's, was just above the Lower Cañon of the Yellowstone. Here the limestones extend across the river, which cuts throngh them almost at right angles to the strike. The dip of the beds is east of north. They are probably the continuation of one branch of the anticlinal, which we have referred to before in Spring Cañon. On the north side of the cañon we find Jurassic lasers resting immediately on thick beds of quartzite, which lie between them and the Carboniferous limestones. The inelination of the beds is about $25^{\circ}$. The Jurassic beds consist of alternate layers of calcareous clay shales, which weather blue, and hard, sellow limestone. They contain great quantities of fossil, among which are Trigonia, Ammonites, Ostrea, and Pinna. These are sncceeded by Cretaceons sandstones, which are in torn followed by Tertiary strata, which are from 1,500 to 2,000 feet in thickness. After passing through the Lower Cañon, we turned to the left and proceeded up Divide Creek, a small stream flowing into the Yellowstone from the western side. Its valley, for the most part, is a monoclinal valley, between Cretaceous and Tertiary strata. The Tertiary beds are composed of sandstones, which are generally quite soft and of a gray color. The lower layers are often quite hard, and of a somber brown color, seeming to have been some what changed. which this change may be attributed. The general dip is in a northerly or northeasterly direction, and the angle about $35^{\circ}$ to $40^{\circ}$.

Reaching the head of the stream, we crossed the divide, and fonnd ourselves at the head of the creek which flows through Spring Here we turned toward the right and crossed to Briduer Creek wañon. we followed up around the eastern side of the Bridger Range to Flat. Head Pass, through which we went to the Gallatin Valley. The rocks on the eastern side of the range at Flat-Head Pass are Cretaceous sandstones, dipping a little north of east, angle, $30^{\circ}$ to $500^{\circ}$, succeeded by Jurassic lasers, which are for the most part covered with grass, conceal. ing them. The center of the range is made up of Carboniferons limestones, which are almost vertical. As we pass toward the westward, lowever, they begin to dip in a westerly direction. They are followed by Silurian beds, which also dip in the same direction. The Silurian layers are composed of slaty limestones, pebbly conglomerate limestones, and compact brittle limestones, containing fragments of trilobites. 
They are followed by very hard, compact, micaceous sandstones. During the npheaval of this range, the line of force seems at first to have been vertical, and tipped up the layers as we see them on the eastern side. Then the force seems to bave acted in a liue oblique to its former direetion, and, breakıng through the Silurian and partialy th:ough the Carboniferous layers, carried their lower edges to the westward; so that while the Cretaceous, Jurassic, and a portion of the Carboniferous layers dip in an easterly direction, the remainder of the Carboniferons and all of the Silurian beds dip toward the west. Tuis remarkable occurrence is fully treated of in Dr. Hayden's report, in which there is also a section showing the various beds.

From Flat-Head Pass we crossed the contry in a northwesterly directiou to the Missouri River, striking it at Horse-Shoe Bend, below the Three Forks. Between these two points there are a number of local synclinals and anticlinals. From Horse-Shoe Bend, we proceeded up the Missonri River to the junction of the Gallativ. About four miles above Gallatin City there is a magnificent exposnre of strat a on is east side of the river. The followng section is in asceuding order from the lowest exposure to the Jurassic beds.

1. Micaceous sandstones, interlaminated with blue, shaly lime stones, weathering brownish, in bands, varying from a few inches to a foot or more in thickness. The upper layers o the sandstone are of a steel-gray color, breaking into cubical blocks, that give it the appearance, from a distance, of basalt. The general color of the sandstones is an olive-green. They contain tine grains of mica and small pebbles of quartz, mixed with a few opaque crystals of white feldspar. The rock is very bird, and has been little affected by the weather. It extends in high bluffs for considerable distauce along the river. Sorre of the limestunes contain flat, rounded concretions of about 6 inches in diameter and 3 inches in thickness. The sandstones vary in tbickn ss from 2 to 4 feet. The general dip is northwest, inclination being $25^{\circ}$ to $30^{\circ}$. The thick

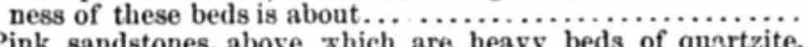

2. Pink sandstones, above thich are heavy The genet 1 dip is about $30^{\circ}$ northwest. Thickness, esti-

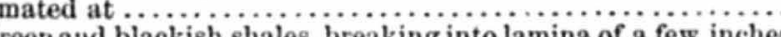

3. Green and blackisk shales, breaking into lemina of a few inches thickness. Low down we find layers that are of a deep pur plish, red color. Short distance abore these lacter, we find a very hard calcareous saudstone, containing grains of a mine. ral sesembling glauconite. In them we find also the remains of trilobites. A short distance above this layer we find sand. stones of about 3 inches thickness, interlaminated with green argillaceous shales, containing trilobites, Lingulepis, Conocerypie, dc. The estimated thickness of these beds is.

4. Layers of very hard limestone, incaking into lamina of an incis or more in thickness and containing immense quantities of trilobites. Thickness.

5. Black, shalr iimestones, containing a small İingula, Acrovleta, and Obolella, followed by rather thin iayers of very compact, blue limestone. Thiekness

6. Pebbly beds of limestose, containing trilobites, and Lingulepis.
Feet.
7. Reddish and greenish calcareous shales, with interlaminated limestones, containing trilobites. Thickness ..............

8. Limestonee, weatheriug to a brownish color, shaly in many places.

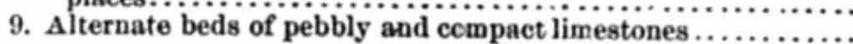

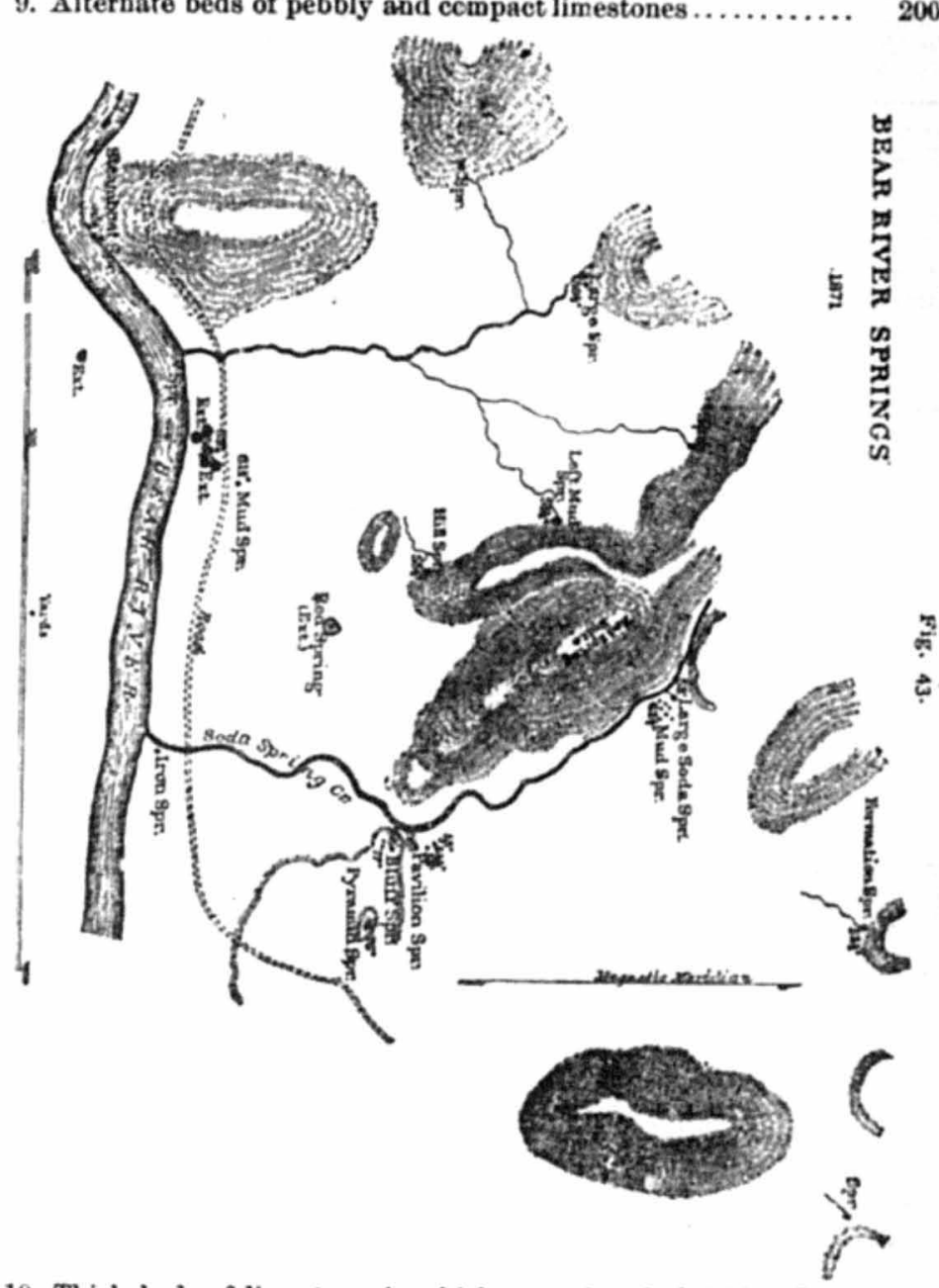

10. Thick beds of limestone in which were found Spirifer, Pro. ductus, Chonetes, Zaphrentis. The lower layers weather yell. $w$. The layer in which the fossils occur is of a blue color, and

very compact. Thickness, estimated at.............. 1,000

11. White quartzite

12. Jurassic beds.

000


For a complete list of the fossils found at this locality I refer to Pro. fessor Meek's report.

Layers 10 and 11 probably represent the entire extent of the Carboniferous beds. No. 1 should probably be referred to the Huronian series, while No. 2, I believe, represe 1 ts the Potsdam group, or at least a portion of it. From No. 3 to No. 9 ineludes the remainder of the Silurian berls. The section given above was made with all the care possible in the limited time afforded. More extended observation will no doubt result in the discovery of new organic forms and the more accnrate de. termination of the age of the various beds. We followed up the East Gallatin River, reaching Bozeman on the 15th of October, when the expedition disbanded for the season.

Fig. 43 shows the relations of the various springs on Bear River, which were described in the report of 1871 . These springs were described by Fremont in 1843, and called the Beer Springs, from the agreeable taste of the water.

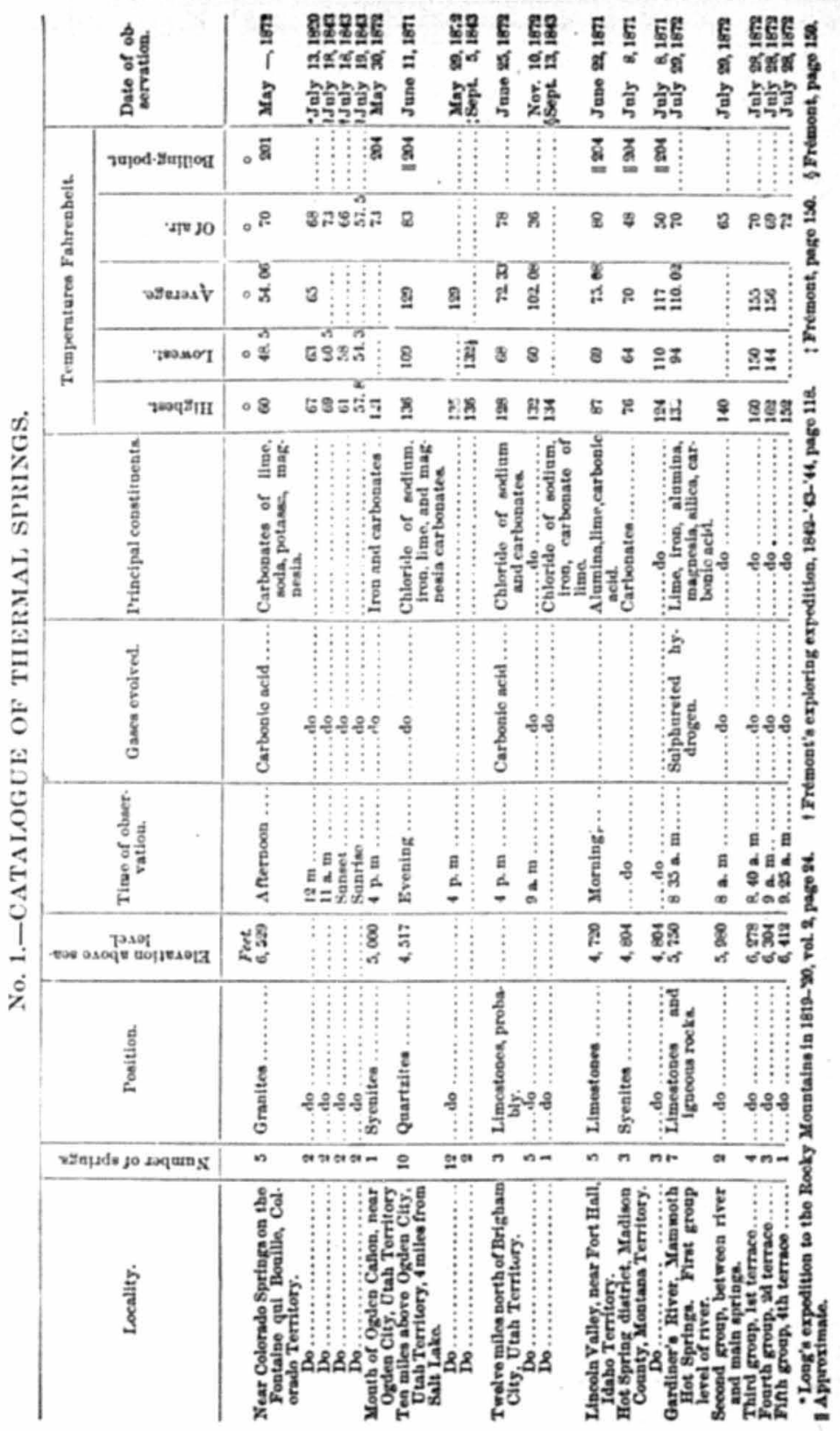




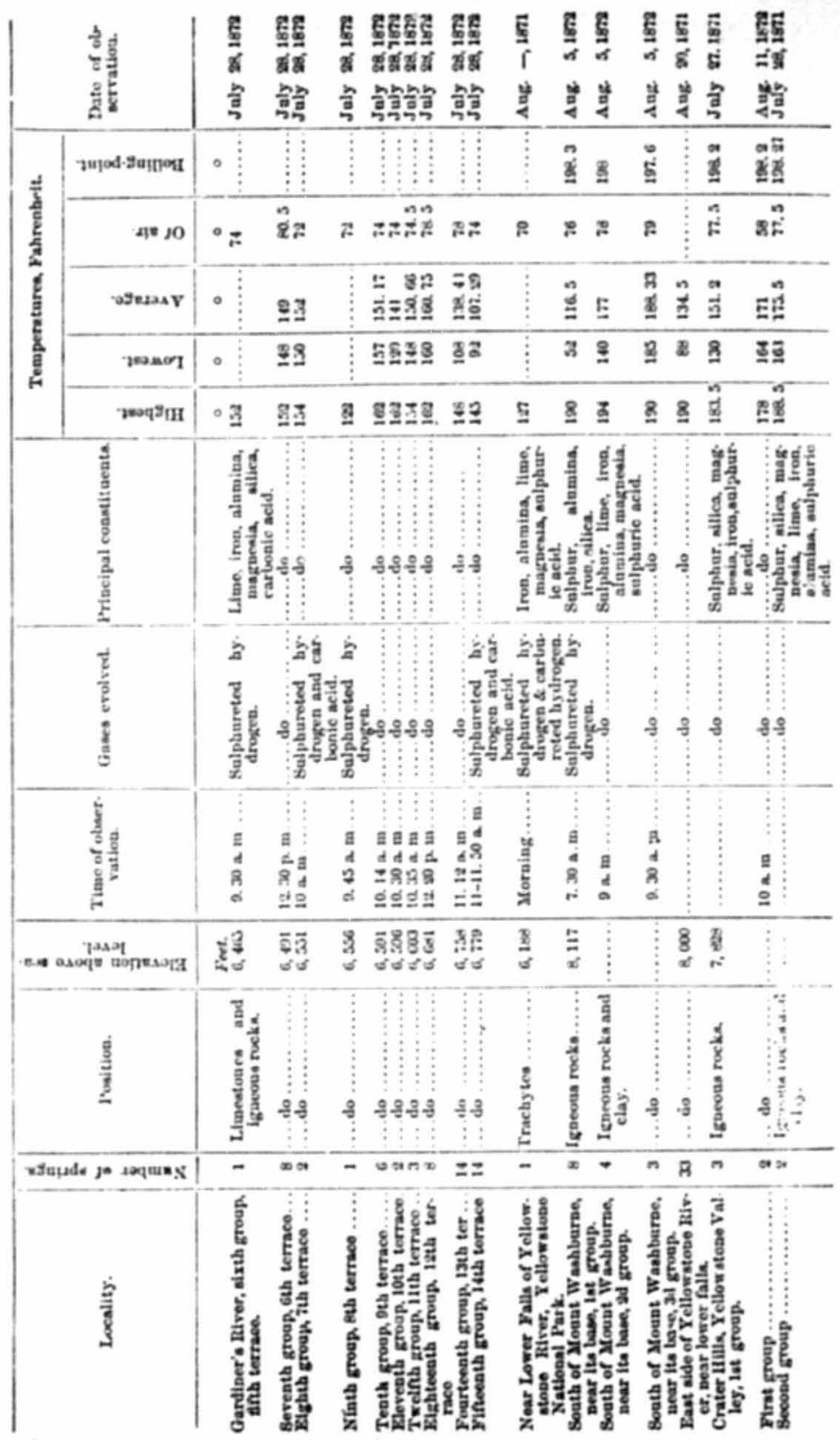

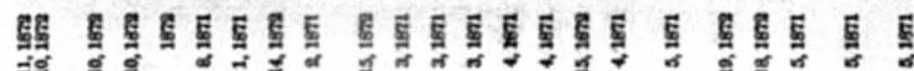

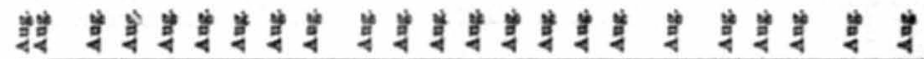

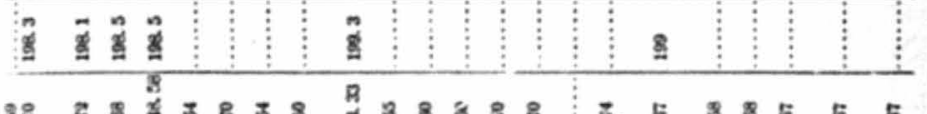
ห유

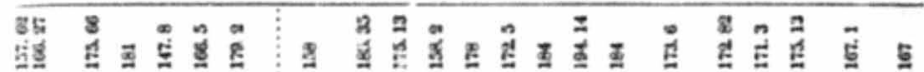

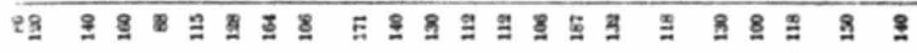

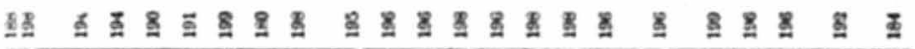

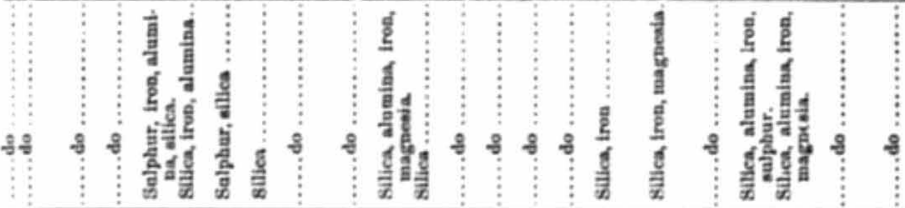

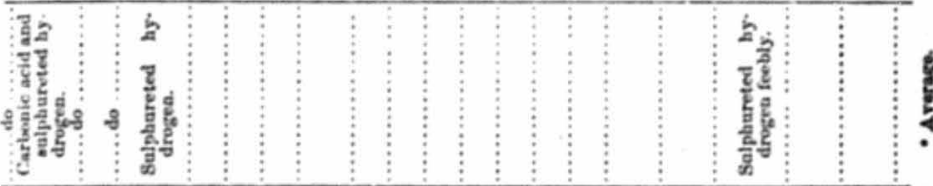

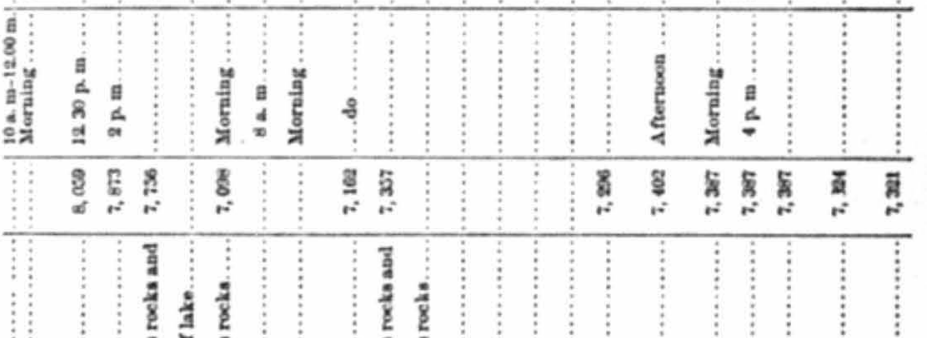

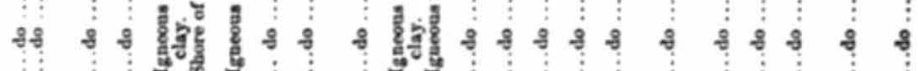

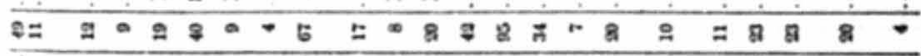

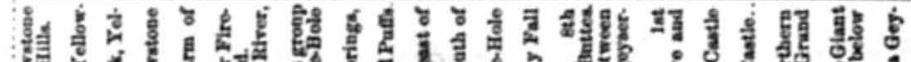

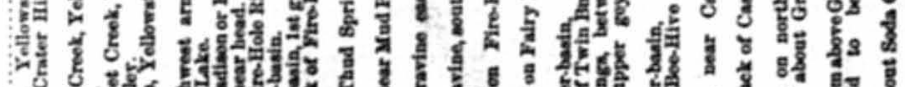

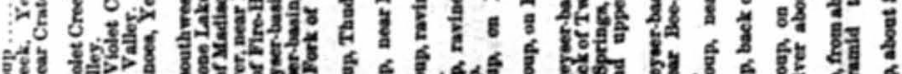

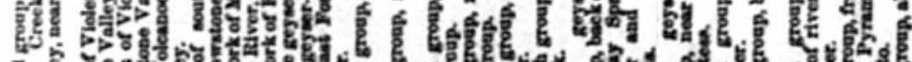

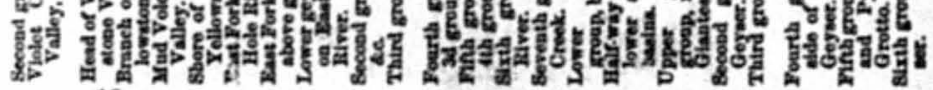




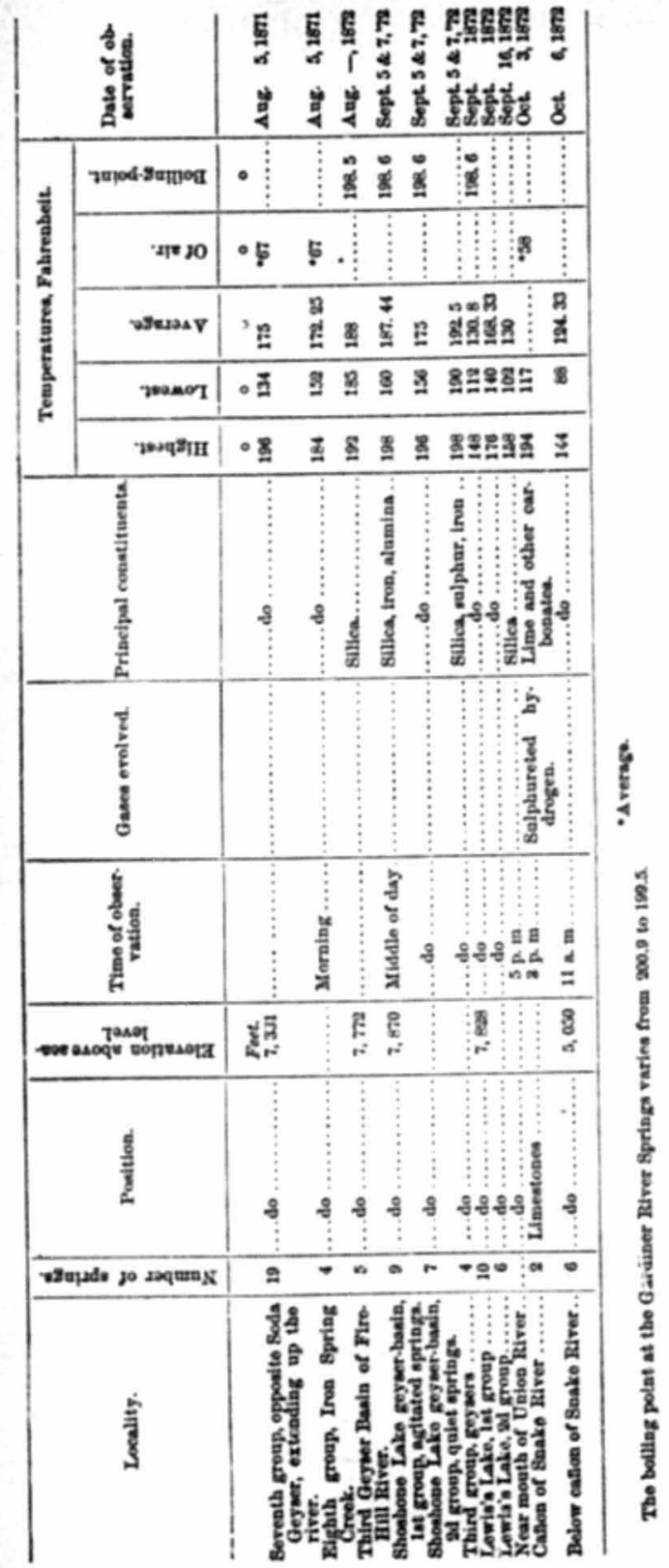

\section{No. 2,-OATALOGUE OF MingRaLS.}

Agate. (See Quartz.)

Amethyst. (Bee Quarts.)

Azurite, (blue carbonate of copper.) In Ogden Cañon, Utah Territory near the head of Clarke's Fork of the Yellowstone River, Montana Territory ; Little Cottonwood Uañon, Utah Territory; near Virginia City, Montana Territory.

Amphibole. Tremolite in Bear Creek Cañon, in Madison Range, Montana Territory. Asbestus, near Henry's Lake, Idaho Territory. Horn. blende in syenites, near Ogden, Utah Territory ; on the east side of the Madison River, in Middle Cañon, Montana Territory ; in rocks of the Téton Range, Idaho Territory; on the east side of Henry's Lake, Idaho Territory; in slates, near Virginia City, Montana Ter. ritory ; in gneissic rocks, in second cañon of Yellowstone, above Boteler's; in basaltic rocks, near Boteler's, in Yellowstone Valley; in acicular erystals, in rocks on the summit of Mount Washburne, Yellowstone National Park.

Asbestus. (See Amphibole)

Aurichalcite. Jittle Cottonwood Uañon, Utah Territory.

Biotite, (black miea.) Granites of Little Cottonwood Cañon; in basalts of Emigrant Guleh, Montana Territory.

Calamine, (silicate of zinc.) Head of Little Cottonwood Cañon, Utah Territory.

Calcite, (carbonate of lime.) Rhomb-spar in blue limestones, near Ogden, Utah Territory ; in sandstones, near Fort Ellis, Montana Territory; at Cinnabar Mountain and other points of the Yellowstone Valley, associated with agate and quartz in geodes; in geodes of agate from the East Fork of Yellowstone River; east side of Madison River, in the Middle Cañon, Montana Territory ; blnff, opposite the Hot Springs, on Gardíner's River; cañon of Jackass Creek, in Madison Range, Montana Territory, Crystals, sellow, from Colorado Springs, Colorado Territory ; Spring Cañon, near Fort Ellis, Mon. taua Territory; Bridger's Peak, near Fort Ellis, Montana Territory; east side of Madison River, in Middle Cañon, Montana Territory Sawtelle's Peak, Idaho Territory. Stalactites, from cañon on east side of Middle Cañon of Madison River, Montana Territory; from cave at Gardiner's River, Hot Springs, Yellowstone National Park. Cerrussite, (carbonate of lead.) From head of Little Cottonwood Cañon, Utah Territory.

Cervantite, (oxide of antimony.) From head of Little Cottonwood Cañon, Utah Territory.

Chalcedony. (See Quartz.)

Chalcopyrite (copper pyrites.) Near Virginia City, Montana Territory ; Clarke's Fork of Yellowstone River, Montana Territory.

Chlorite. (See Ripidolite.)

Chrysoprase. (See Quartz.)

Coal, (Tertiary.) Near Spring Cañon, Fort Ellis, Montana Territory ; six miles above Spring Cañon, in hills head of Trail Creek, Montana Territory; (Cretaceous,) near Cinnabar Monntain, Montana Territory ; poor quality opposite Gardiner's River Springs; on Hnnter's River, near Mount Hancoek, Yellowstone National.Park.

Copper, (native.) Near Virgin!a City, Montana Territory.

Crprite, (red oxide of copper.) Near Virginia City, Montana Territory. Epidote. In crystals from tbe Téton Range, Idaho Territory. 
Feldspar, (Orthoolase) In Byenites at Ogden, Utah Territory; in granites at Colorado Springs, Colomdo Territory, in red masses ; in granites thronghont Idabo and Montan Territories. Bcnidine, in trachytes throngbout the Yellowstone National Park and Montana and Idaho Territories. Amazon stone, near Colorado Oity, Colorado Territory. Flint. (Bee Quartz.)

Garnets. In gneissic rocks near Golden City, Colorado Territory ; in gneiss near Ogden, Utah Territory; in second cañon of the Yelgowstory ; in Emigrant Guleb, lowstone, above Boteler', Mlack-Tail Deer Creek, ( near Gardiner's River; Hot Springs, near lower cañon of 'Madison River, in gneiss; in gneiss on Cherry Creek, Montana Territory near Henry's Lake, Idaho Territory; in rocks of the T'́ton Range, Idaho Territory.

Galenite, (sulphide of lead,) (argentiferous.) Little Cottonwood Cañon, Utah Territory; Central City, Colorado Territory; Emigrant Gulch, Montana Territory; Clarke's Fork of the Yellowstone River; Yellowstone National Park; Hot Springs district, Silver Shower district, and other mining districts in Montana Territory.

Geyserite. (See Opal.)

Glanconite. East side of Madison River, in Middle Cañon, Montans Territory; near Gallatin City, Montana Territory ; Téton Mountains, Idaho Territory.

Gold. Central City, Colorado Territory; Emigrant Gulch, Yellow. stone Valley, Montana Territory; near Virginia City, Montans Territory; Hot Springs district, Madison County, Montana Territory; Upper waters of Snake River, Idaho Territory ; near Taylor's Bridge, Idaho Territory.

Graphite. Twelve miles north of Ogden, Utah Territory.

Gspsum, (sulphate of lime.) Colorado Springs, Colorado Territory. Selenite, Colorado Springs, Colorado Territory; opposite Ho Springs, at Gardiner's River, Yellowstone National Park; in old hot-spring deposits, opposite Tower Creek, on Yellowstone River Yellowstone National Park; in Grand Cañon of Snake River, Idaho Territory. Satin-spar, Colorado Springs, Colorado Territory.

Halite, (common salt.) In springs on Turbid Lake, near Yellowstone Lake, Yellowstone National Park; Great Salt Lake, Utah, in fine crystals coating wood; in springs in ldaho Territory ; springs above Ogden, Utah Territory.

Hematite, (oxide of iron,) (micaceous.) Near Ugden, Utah Territory; nea Brigham City, Utah Territory ; near Madison Cañon, Montans Territory. Iron-stone, Emigrant Gulch, Montana Territory.

Hornblende. (See Amphibole.)

Jasper. (Bee Quartz.)

Limonite, (sesquioxide of iron.) Little Cottonwood Cañon, Utah Terri tory; near Fort Ellis, Montana Territory.

Lithomarge. Little Cottonwood Cañon, Utah Territory.

Magnetite (magnetic-iron ore.) In gneissic rock, near Golden City, Colorado Territory ; in gneisses near Ogden, Utah Territory.

Malachite, (green carbonate of copper. U Upper end of Ogden Oañon, near Ogden City, Utah Territory ; near Virginia City, Montana Territory; Clarke's Fork of Yellowstone River, Montana Territory. Tassicot (lead-ocher.) Little Cottonwood Cañon, Utah Territory

Mascovite, (common mica.) Near second cañon of Yellowstone; near Black-Tail Deer Oreek, Montana Territory ; Téton Monutains, Idaho Territory ; (var., Fuchsite,) from east side of Madison Cañon, Montana Territory.
Nephelite. In trachytes in Grand Cañon of Snake River, Idaho Territory. Obsidian, (voleanio glaes.) Ou Trail Oreek, near Yellowstone Valley in chips throughout the Yellowstone Valley, from the lowez eaño to Yellowstone Lake. Spherulitic, from Grand Cañon of Yellowstone River. Porphyritio, from Grand Cañon of the Yellowstone; divide between Yellowstone and Madison Rivers; Yellowstone Nationsl Park; east side of Snake River, Idaho Territory; in basin of Henry's Lake, Idaho Territory; head of Falls River, Idaho Territory; Lewis's Lake, Wyoming Territory ; valley of Madison River, Montana Territory; West Gallatin Cañon, Montana Territory ; near Missouri River, below Horseshoe Bend, Montana Territory.

Olivine. In basalts in Yellowstone Valley, opposite Boteler's Ranch, Montans Territory; in basalts on Snake River and Henry's Fork, Idabo Territory.

Opal. East Fork of Yellowstone River, Grand Cañon of Yellowstone; summit of Mount Blackmore, Montana Territory ; Colorado Springs, Colorado Territory. Hydrophane, Grand Cañon of Yellowstone. Wood-opal, East Fork of Yellowstone River, near Gallatin City, Montana Territory; Jefferson County, MontanaTerritory. Dendritie Hot Springs district, Montana Territory. Hyalite, Grand Cañon of Yeliowstone River. Excellent specimens; elear, in colorless globnlar concretions, from summit of Mount Blackmore, Montana Territory ; near Jackson's Lake, Wyoming Territory. Geyserite, (siliceons sinter,) geyser-basins of Fire-Hole River, presenting white, gray, greenish, pink, and red varieties, massive, porous, filamentons, compact, cauliflower-like, beaded, or pearly. The specimens vary from translucent to opaque, some being very friable while oivers are firm, even on drying; Hot Springs, on southwest arm of Yellowstone Lake; geyser-basin of Shoshone Lake, Yellowstone National Park.

Plasma. (See Quartz.)

Prase. (See Quartz.)

Pummice. Emigrant Gulch, Montana Territory.

Pyrite, (iron pyrites.) With galena, Central City, Colorado Territory with serpentine and bematite, near Ogden, Utah Territory; in quartzite, in Emigrant Gulch, Montana Territory ; Clarke's Fork of Yellowstone River, Montana Territory. Pentagonal dodecahedral crystals, from Téton Mountains, Idaho Territory ; Little Cottonwood Cañon, Utah Territory.

Quartz. In granites throughont Rocky Mountains. Rock-crystal, Ogden, Utah Territory ; in geodes, with chalcedony and calcite, from East Fork of Yellowstone River; from Sawtelle's Peak, near Heury's Lake, Idaho Territory ; in granites of Téton Mountains, Iduho Territory; divide between Ross Fork and Fort Ball, Idaho Territory. Amethystine (amesthyst,) from the Colorado divide south of Denrer, Colorado Territory ; fue crystals in large geodes of chalcedony from East Fork of Yellowstone River, about ten miles abore the junction of the Yellowstone. The specimens are found on the summit of a bold bill on the sonth side of the river. Blue, near second cañon of the Yellowstone. Smoky (cairngorm stone, Colorado divide, Colorado Territory. Milky, near second cañon of Yellow. stone; East Fork of Yellowstone River. Chaloedony, Spring Cañon, near Fort Ellis, Montana Territory ; in chips throughont the Yel lowstone Valley ; in geodes with caleite and quartz, above seeond cañon in Yellowstone Valley; associated with jasper from Elk Creek. near Yellowstone River, Montana Territory ; forming the ontside of geodes from Bast Fork of Yellowstone River; also associated with calcite at same locality, from Grand Oañon of Yellowstone River; in rounded pebbles on shores of Yellowstone Lake; from summit of 
Mount Blackmore, Montana Territory; beautiful blue specimenis with jasper, in Hot Spring district, Montana Territory ; from Jackson's Lake, Wyoming Territory. Cainelian, from Grand Cañon of Yellowstone. Ohrysoprase, Bast Fork of Yellowstone River. of Yellows Merritory; Wil Prase, low Canton, Utah Territory ment Montan Ter Montana Territory. Agate, banded, near Fort Ellis, Mostada Ter ritory; in Yellowstone Valley, above second canos, East Fork of Yellowstone River, near Elk Creek, Yellowstone Valley, Oolorado Springs, Colorado Territory. Mochastone (moss-agate, nearBoteler's ranch, Yellowstone Valley, Montana Territory. Flint, (bluish rach, in valles of Yellowstone: West Gallatin River; (brown vavariety, in valley or Territory ; (black riety,) Pole Creek near Madison River, Montana Tertitory ( black variety,) East Fork of Yellowstone River. Jasper, (red variety, in conglomerates, near Ogden, Utah Territory ; near Fort Ellis, Montana Territory; Yellowstone Valley, Montana Territory; back of Boteler's ranch, Montana Territory; Bast Fork of Yellowstono Boteler's rancb, Montana Tentana Territory ; east side of Middle River; near Elk Creek, Mridger Peak, near Fort Cañon of Madison Territory; East Fork of Yellowstone River; (gray Ellis, Montana Territory; Last Fork of Yellowstone River; (gray variety,) East Fork of Yellowstone; (green variety,) East Fork of Yellowstone River; near Horseshoe Bend of Missouri River, below Gallatin C'ty, Montaua Territory ; on Henry's Fork of Snake River; (black varieiy,) East Fork of Yellowstone River. Silicified wood, (black varieiy, East Fork abundant throughout the ralleys of Yellowal Park. Itacolumite, latin Rivers, and on the Yellowstone National Park. Yacolumite, Ripidolite. In metamorphic rocks, near Ogden, Utah Territory ; east side of Middle Cañon of Madison River, Montana Territory ; near Henry's Lake, Idaho Territory ; Téton Mountains, Idaho Territory. Sanidine. (See Feldspar.)

Satin-spar. (See Gypsum.)

Selenite. (See Gypsum.)

Serpentine. Near Ogden, Utah Territory; in Snowy Range of Yellow. stone; divide between Madison and Gallatin Rivers; Alder Gulch, near Virginia City, Montana Territory; Cañon Creek, a branch of Téton River, Idabo Territory.

Silicifled moot. (See Quartz.)

Silver, (Native.) Cherry Creek mines, Madison County, Montana Territory; in galena, from Little Cotton wood Cañon; Clarke's Fork mines. Sphalerite, (zinc blend.) Little Cottonwood Cañon, Utah Territory.

Strontianite, (carbonate of strontia.) Sawtelle's Peak, near Henry's Lake, Idaho Territory.

Sulphur. In crystals, at Gardiner River Hot Springs; on bluffs op posite Tower Falls ; in Mnd Springs, near Mount Washburne, in posite Tower Fals ; Hills, Yellowstone Valley ; geyser-basin of small crystals; Crater Hills, Yellowstone Valley; geyser-basin of Yellowstone and Fire-Hole Rivers.

Talc Near Ogden, Utah Territory; in Snowy Range of Yellowstone, Montan Territory near Henry's Lake, Idaho Territory; Téton Mountains, Idaho Territory.

Tremolite. (Bee Amphibole.)

Tufa, (Caleareous.) At Hot Springs, Gardiner's River; Warm Springs, near Fort Ball, Idaho Territory; Grand Cañon of Bnake Biver, Idaho Territory.

Wulfenite. Little Cottonwood Cañon, Utah Territory.

\section{No. 3.-OATALOGUE OF ROCKS.}

Catalogue of rocka collected by the Yelloncatone divinion of the expedition, A. C. Peale.

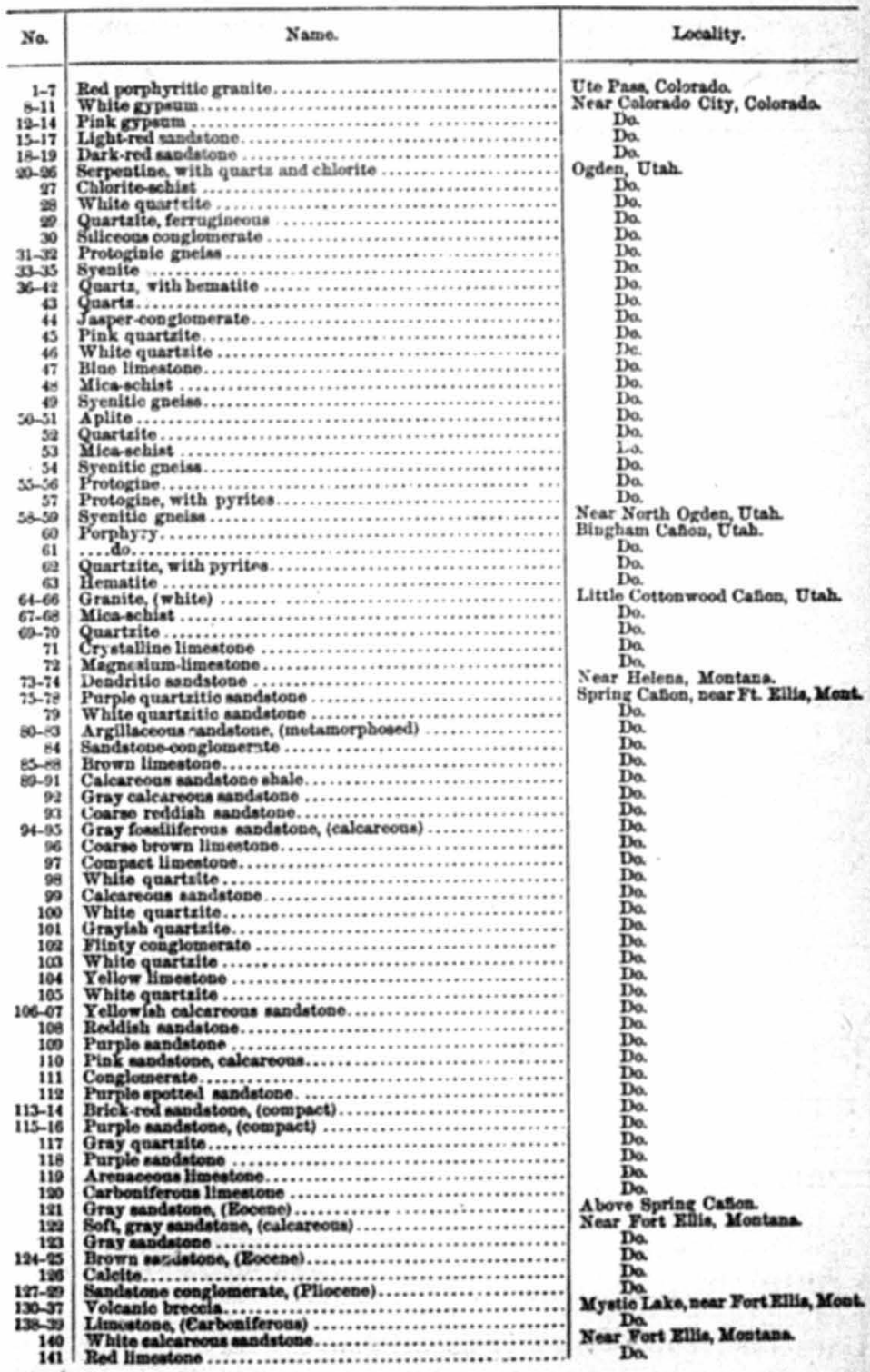


Catalogue of rocka collected, fa-Continued.

\begin{tabular}{|c|c|c|}
\hline sá. & Nama & Locality. \\
\hline $142-4$ & Gray sandatopa, (Crotaceoun) ............ & Bridger Peak, near Fort Enice \\
\hline $\begin{aligned} 167-4 \\
199 \\
130\end{aligned}$ & 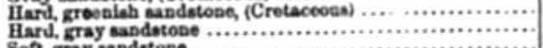 & Hoad of Muddio Creok, Montans \\
\hline $\begin{array}{l}150 \\
151\end{array}$ & 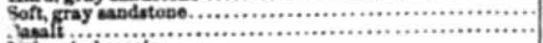 & $\begin{array}{l}\text { Do. } \\
\text { Valley of Yellozatone River. }\end{array}$ \\
\hline $150-54$ & julcanio breocia................... & Near Botoler's, Montane. \\
\hline 152.54 & 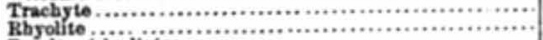 & $\begin{array}{l}\mathrm{Da} \\
\mathrm{Da}\end{array}$ \\
\hline $136-57$ & Bacelt with ollivine ... & $\mathrm{Da}$ \\
\hline $\begin{array}{l}150 \\
190\end{array}$ & 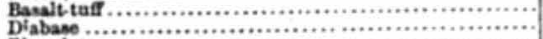 & Cinuabar Mountaln, Montana. \\
\hline 160 & M 10 olate....................... & $\begin{array}{l}\text { Do. } \\
\text { Electric Prax, Yellowrtone Valler. }\end{array}$ \\
\hline $102-6$ & 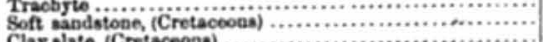 & $\begin{array}{l}\text { Do. } \\
\text { Do. }\end{array}$ \\
\hline${ }_{16}^{164}$ & $\begin{array}{l}\text { Clay alate, (Cretaceoan) ........ } \\
\text { Merl........................ }\end{array}$ & $\begin{array}{l}\text { Da. Yellowelose River, near } \\
\text { Valley of YX } \\
\text { Boteler's }\end{array}$ \\
\hline 166 & $\begin{array}{l}\text { Basadatone, (Tertiary) .... } \\
\text { Quartzile, (Crotaceoas)... }\end{array}$ & $\begin{array}{l}\text { Bluff opposite Gardiser's River. } \\
\text { Da. }\end{array}$ \\
\hline & 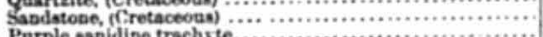 & $\underset{\mathrm{Da}}{\mathrm{Da}}$ \\
\hline $\begin{array}{l}169 \\
170\end{array}$ & 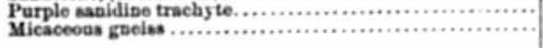 & $\begin{array}{l}\text { Mouth of Black-Tall Deer Croek, } \\
\text { Montans }\end{array}$ \\
\hline 171 & Limeatose, (Carboniferous) ........... & Near mooth of Black-Tail Deer \\
\hline $173-74$ & $\begin{array}{l}\text { Brown sandotone metamorphosed, (Tertiary } \\
\text { Trachyte-breccia }\end{array}$ & Near Eix Creek, Muatana. \\
\hline $\begin{array}{ll}173-74 \\
175\end{array}$ & 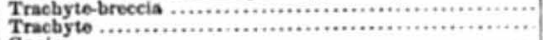 & \\
\hline $176-77$ & 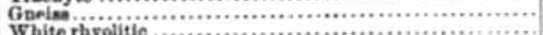 & $\begin{array}{l}\text { Do } \\
\text { Do. } \\
\text { Yast Fof Yellowretnen Piver. }\end{array}$ \\
\hline 1 1ั & $\begin{array}{l}\text { White rhyolitio..... } \\
\text { Volcanic andatope. }\end{array}$ & $\begin{array}{l}\text { East Fork of Yellowntage Piver. } \\
\text { Sear Tower Creek, Yellowntoce }\end{array}$ \\
\hline 180 & Gray aandatone....... & $\begin{array}{l}\text { Yalley, Montans } \\
\text { Snar juctitum of East Fork of Yel. }\end{array}$ \\
\hline 181 & Micaceons greiss ....... & $\begin{array}{l}\text { lowstone, Motatasa. } \\
\text { Do. }\end{array}$ \\
\hline 183 & 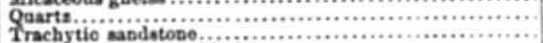 & $\begin{array}{l}\mathrm{D}_{0} \\
\mathrm{~B} \text { a. } \\
\mathrm{B}\end{array}$ \\
\hline 194 & $\begin{array}{l}\text { Trachytio sandatose ........ } \\
\text { Obedilat porpliys. (black). }\end{array}$ & Near Grand Cabos of Yellowstone. \\
\hline iss & $\begin{array}{l}\text { Obeidlan porphyry, (browr) } \\
\text { Obaldian porptyrry, (perlite-like) }\end{array}$ & $\mathrm{Da}$ \\
\hline 159 & $\begin{array}{l}\text { Obaldian porphyzy, (perlite-ilke) } \\
\text { Porphysitio obsldan............ }\end{array}$ & $\begin{array}{l}\mathrm{Da} \\
\mathrm{Da}\end{array}$ \\
\hline 188 & 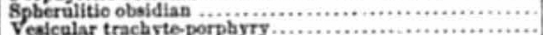 & Do. \\
\hline 190 & Wbite trachyteporphyry........ & $\begin{array}{l}\mathrm{Da} \\
\mathrm{Da}\end{array}$ \\
\hline $191-92$ & Rbyolite...................... & $\mathrm{Do}$ \\
\hline${ }_{193}^{193}$ & $\begin{array}{l}\text { Japer - } \\
\text { Perlite-like tractiyte porphyry }\end{array}$ & $\begin{array}{l}\mathrm{Do} \\
\mathrm{Da}\end{array}$ \\
\hline is & Groen and brourn yasper...... & $\mathrm{Da}$ \\
\hline $1 n^{106}$ & $\begin{array}{l}\text { Cavernotas tracbyie-porpbyry. } \\
\text { Commoo trachyte-porpayry... }\end{array}$ & $\mathrm{Da}$ \\
\hline 190 & $\begin{array}{l}\text { Cognmoo trachyte-porphyry... } \\
\text { White trachyte...................... }\end{array}$ & $\begin{array}{l}\mathrm{Da} \\
\mathrm{Da}\end{array}$ \\
\hline 2000 & 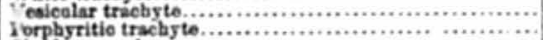 & $\begin{array}{l}\text { Gruad Callos of Yellowntone River. } \\
\text { Do. }\end{array}$ \\
\hline wi & Obedian porphyrg $\cdots \cdots \cdots \ldots \ldots \ldots \ldots$ & $\mathrm{Da}$ \\
\hline $204-13$ & 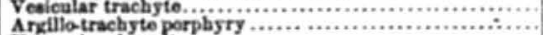 & $\begin{array}{l}\mathrm{Do}_{0} \\
\mathrm{Da}\end{array}$ \\
\hline 214 & Hot-epring depott.................... & Violet Croek, valley of the Yellow. \\
\hline ne-18 215 & 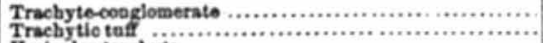 & $\begin{array}{l}\text { Crater Hils, Yellowatone Valley. } \\
\text { Du. }\end{array}$ \\
\hline 219 & Vealeular trachyte............................................ & $\begin{array}{l}\text { Sear Mod Voleaboes, Yellowstone } \\
\text { Valler. }\end{array}$ \\
\hline 200 & 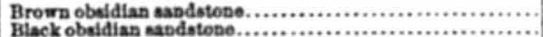 & $\mathrm{Do}_{0}$ \\
\hline$\frac{21}{2 m 2}$ & abio conglometrato................... & $\mathrm{Da}$ \\
\hline 跑 & onglomérato ..................... & $\mathrm{Da}$ \\
\hline$\underset{2 z S}{24}$ & $\begin{array}{l}\text { White trachy } \\
\text { Tracbyto por }\end{array}$ & $\begin{array}{l}\mathrm{Da} \\
\mathrm{Da}\end{array}$ \\
\hline 200 & 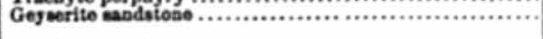 & $\begin{array}{l}\text { Fire Holo Basina, Yellowntone Na. } \\
\text { tional Part. }\end{array}$ \\
\hline$\underset{z}{z}$ & $\begin{array}{l}\text { Trachyte porphyrg } \ldots \ldots \ldots \ldots \ldots \\
\text { Phyollto }\end{array}$ & $\begin{array}{l}\text { Upper Cabon of Madinon River. } \\
\text { Da. }\end{array}$ \\
\hline$\underset{200}{200}$ & 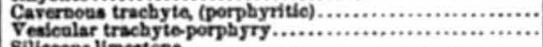 & $\begin{array}{l}\mathrm{Da} \\
\mathrm{Da} \\
\mathrm{Da}\end{array}$ \\
\hline $\mathbf{m}$ & 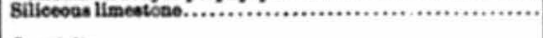 & $\begin{array}{l}\text { Esat idide of Madison River, near } \\
\text { Muddle Cation. }\end{array}$ \\
\hline$\underline{m}$ & $\begin{array}{l}\text { Gartaite ..................... } \\
\text { Gryy calcareous aspdetope }\end{array}$ & $\frac{\mathrm{Da}}{\mathrm{Da}}$ \\
\hline$\underset{20}{20}$ & 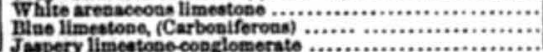 & $\begin{array}{l}\mathrm{Da} \\
\mathrm{Da}\end{array}$ \\
\hline & & \\
\hline
\end{tabular}

Catalogue of rocka collected, \$a-Continued.

\begin{tabular}{|c|c|c|}
\hline Na. & Name. & Locality. \\
\hline$m$ & Pebbly lizbestoes, (Silurian) ... & \multirow{10}{*}{ 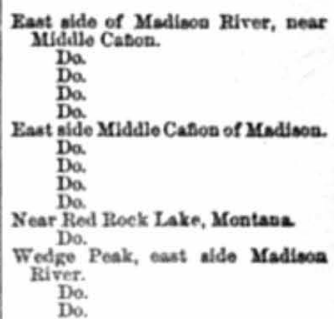 } \\
\hline $\begin{array}{c}298 \\
2 ?\end{array}$ & 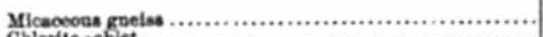 & \\
\hline $\begin{array}{l}27 \\
240 \\
341\end{array}$ & & \\
\hline 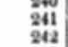 & at. & \\
\hline 22 & 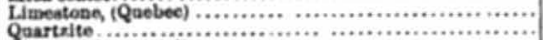 & \\
\hline $\begin{array}{l}24 \\
245\end{array}$ & Glabconitio quartiaito........ & \\
\hline $240-17$ & 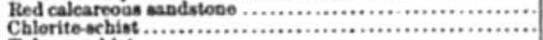 & \\
\hline $\begin{aligned} 248 \\
269\end{aligned}$ & Taleose ochint .. & \\
\hline 250 & 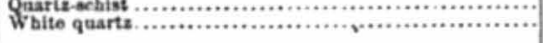 & \\
\hline 251 & Milen-achist .... & \\
\hline 20 & $\begin{array}{l}\text { Geis .............. } \\
\text { Micacooue gneins. }\end{array}$ & \multirow{8}{*}{ 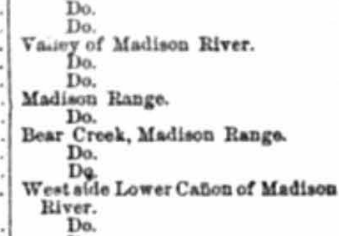 } \\
\hline 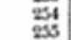 & Trachyte & \\
\hline $\begin{aligned} 250 \\
\text { sis }\end{aligned}$ & $\begin{array}{l}\text { Slaty trac } \\
\text { Parplist }\end{array}$ & \\
\hline $\begin{array}{ll}25 i=30 \\
250\end{array}$ & Gaeies. & \\
\hline $\begin{array}{l}20 \\
200\end{array}$ & 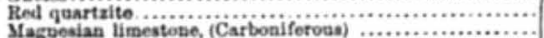 & \\
\hline 201 & (Carbotiferous) ......... & \\
\hline 赵 & 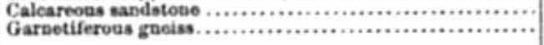 & \\
\hline$\underset{206}{20}$ & Quarta....... & \\
\hline$\$ 6$ & $\begin{array}{l}\text { Fine grained } \\
\text { Gray gaeiso. }\end{array}$ & $\underset{\mathrm{Da}}{\mathrm{Da}}$ \\
\hline $\mathscr{T}_{d}$ & $\begin{array}{l}\text { Gray gnelas......... } \\
\text { Slaty gaolas ....... }\end{array}$ & $\mathrm{Da}$. \\
\hline$\underset{m o}{200}$ & 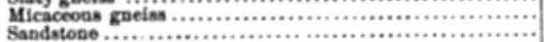 & Da. \\
\hline gii & & $\begin{array}{l}\text { Jackaso Creek, Mootana. } \\
\text { Polo Creek, Montana. }\end{array}$ \\
\hline$\frac{2}{2}$ & Basalt, (black) & $\begin{array}{l}\text { Polo Creok, Montapa } \\
\text { Mount Blackmore, Mlontana. }\end{array}$ \\
\hline$\stackrel{m}{m}$ & $\begin{array}{l}\text { Basalt, if } \\
\text { Gabbro. }\end{array}$ & $\begin{array}{l}\text { Do } \\
\text { Wet Gallatin Caton, Moptana. }\end{array}$ \\
\hline$m$ & & $\begin{array}{l}\text { Weat Gallatin Catoon, Montana. } \\
\text { Do. }\end{array}$ \\
\hline$m$ & andatooe (Crotac & $\mathrm{Da}_{\mathrm{O}}$ \\
\hline 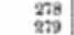 & $\begin{array}{l}\text { Gray sandatone, Crotaceo } \\
\text { Brae limestone, (Carbonife }\end{array}$ & $\begin{array}{l}\mathrm{Da} \\
\mathrm{Da}\end{array}$ \\
\hline$g=0$ & Crystallive litmeatope, (Ca) & $\begin{array}{l}\text { Da. } \\
\text { Da. }\end{array}$ \\
\hline 201 & oolitie & $\mathrm{Da}$ \\
\hline 200 & 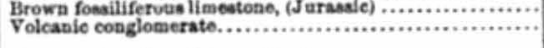 & Weat Gallatio and \\
\hline 25 & 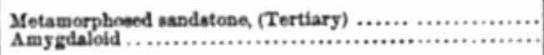 & Valley of Yellowrtone, above Bot \\
\hline $20-67$ & 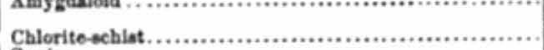 & $\begin{array}{l}\text { Valley or Yellowatone, above Bo } \\
\text { pera. } \\
\text { Emigrant Gulch, Montana. }\end{array}$ \\
\hline & & \\
\hline & & \\
\hline $\boldsymbol{m}_{1-92}$ & $\begin{array}{l}\text { Banal } \\
\text { Basal }\end{array}$ & $\begin{array}{l}\mathrm{Da} \\
\mathrm{Da}\end{array}$ \\
\hline 20 & & $\mathrm{Da}$ \\
\hline D4 & Quar & \\
\hline$\underset{20}{203}$ & & $\begin{array}{l}\text { Year Boteler's, Yellowstope Valloy. } \\
\text { Yt. Coman, Yeliowstono Valley. }\end{array}$ \\
\hline$\approx 7$ & vilie, (cotamon) & Ha. \\
\hline 20 & & $\begin{array}{c}\mathrm{Do} \\
\mathrm{Do}\end{array}$ \\
\hline 200 & TTertiary & Divide Cree \\
\hline 301 & otiferous). & Viathead $\mathrm{Pa}_{\mathrm{a}}$ \\
\hline 302 & & $\begin{array}{c}\mathrm{Da} \\
\mathrm{Da}\end{array}$ \\
\hline${ }_{304}^{304}$ & 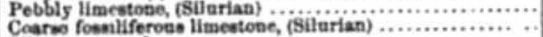 & $\begin{array}{l}\text { Da. } \\
\text { Da. }\end{array}$ \\
\hline 30506 & & Horacelboe Bead, Mineourt \\
\hline & 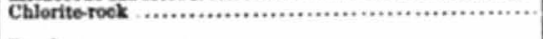 & $\begin{array}{l}\text { ar Horacaboe Bend, Mineouri } \\
\text { ureer, Mootana }\end{array}$ \\
\hline $\begin{aligned} 300 \\
302-10\end{aligned}$ & Silarias). & $\begin{array}{l}\mathrm{Da} . \\
\mathrm{Da}\end{array}$ \\
\hline $32-13$ & & $\mathrm{Da}$ \\
\hline $314-15$ & $\begin{array}{l}\text { Blae arfillace } \\
\text { Trap, (from al }\end{array}$ & Mitanouri River, below Gallatia \\
\hline 316 & 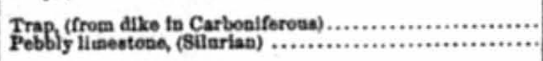 & Sear Gallatin Rirer, above Gallatia \\
\hline $\begin{array}{l}318 \\
319\end{array}$ & & $\mathrm{Ba}_{\mathrm{Da}}$ \\
\hline & & \\
\hline
\end{tabular}


Catalogue of rocka collected, da-Continued.

\begin{tabular}{|c|c|c|}
\hline sa. & Name. & Loxallty. \\
\hline 320 & Blae alaty limeotone, (Bllarlan) ........... & $\begin{array}{l}\text { Sear Gallatin River, abore Gallinet: } \\
\text { City, Montana }\end{array}$ \\
\hline 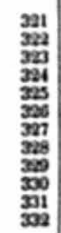 & 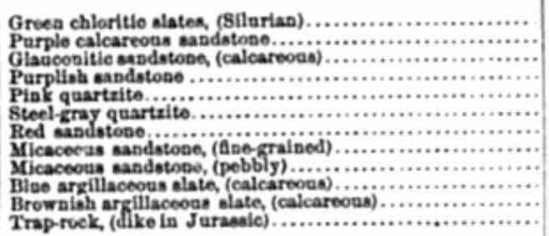 & 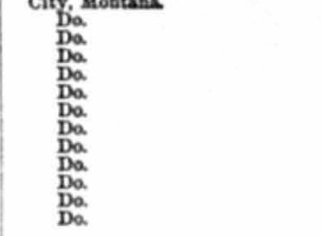 \\
\hline
\end{tabular}

Rock collected by the Snake River division of the erpedition, Profestor F. H. Bradley and W. R. Taggart.

\begin{tabular}{|c|c|c|}
\hline No. & Natne. & Locallty. \\
\hline & Hetaatite ................................. & $\begin{array}{l}\text { Near Brighani City, Dtah. } \\
\text { Bear Rirer Bridgo b tah. }\end{array}$ \\
\hline & $\begin{array}{l}\text { Oolitio limestote, (Tortiary) } \\
\text { Fonsiliferoas limestone, (Quebeo group). }\end{array}$ & $\begin{array}{l}\text { Hear Giver Brdga Utah. } \\
\text { dalade City, Utah. }\end{array}$ \\
\hline & Gray limeatobe, (Tertlary)..................... & \\
\hline 12:-14 & 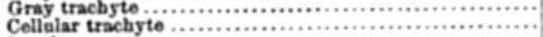 & $\begin{array}{l}\text { Near Fort Hall, Idaba } \\
\text { Sasd Hill Mountain, Idaba. }\end{array}$ \\
\hline is-17 & hasalt . & Fallo Wuver, Idaba. \\
\hline $12-90$ & 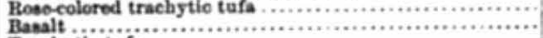 & Plerro's Fiver, Idaba \\
\hline 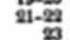 & Trachy tio tufa...... & Da \\
\hline 2 & 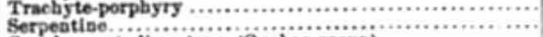 & $\begin{array}{ll}\mathrm{Da} \\
\mathrm{Do}\end{array}$ \\
\hline $25-96$ & 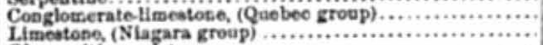 & $\begin{array}{l}\text { Tuton Caston, Idaba } \\
\text { Tbton Creek, Idabo }\end{array}$ \\
\hline 蛒 & 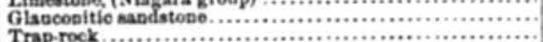 & Tetou Mountaine, Idaba \\
\hline 30 & $\begin{array}{l}\text { Trap-rock .............. } \\
\text { Slaty trachste .......... }\end{array}$ & Bechlet's River, Idabo. \\
\hline$\stackrel{31}{32}$ & 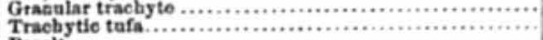 & Crater bear Henry in Lake, Iduba. \\
\hline $20-32$ & 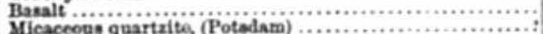 & $\begin{array}{l}\text { Samtello' Peak fdaba. } \\
\text { Tyzheo Pass, Idaba }\end{array}$ \\
\hline 3.-30 & $\begin{array}{l}\text { Sandine trackyto. .............. } \\
\text { Hot spriag depoeit, (calcaroona)... }\end{array}$ & $\begin{array}{l}\text { Upper Madioon Cabon, Montana } \\
\text { Gibbon's Fork of Madison River, }\end{array}$ \\
\hline 40 & 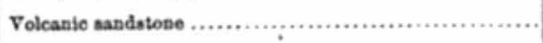 & Lower geymer-basin, Yellowateso \\
\hline 41-12 & Volcanlo sandotone, compach, twetamorphoned...... & $\begin{array}{l}\text { Sbothope Lake, Yellowatone } \mathrm{S} \text { - } \\
\text { tiobal Park. }\end{array}$ \\
\hline$\frac{43-14}{5-16}$ & $\begin{array}{l}\text { Volcanie sandatone, cog glomerate. } \\
\text { Brown porplyyritic obsidian....... }\end{array}$ & $\begin{array}{l}\text { Da } \\
\text { Sear Stoobone Lake, Yellewatcoee } \\
\text { National Park. }\end{array}$ \\
\hline $\begin{array}{cc}47-48 \\
19\end{array}$ & $\begin{array}{l}\text { Voleanie sandatone ........... } \\
\text { Sanidise trachyte ......... }\end{array}$ & $\begin{array}{l}\text { Da } \\
\text { Tro milies sonth of Sbonbose Lake, } \\
\text { Yellowrotooe National Park. }\end{array}$ \\
\hline $\begin{array}{ll}50-51 \\
52-65\end{array}$ & 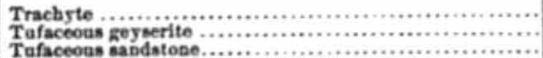 & $\begin{array}{l}\text { Lewisto Lake, W yoming } \\
\text { Daa } \\
\text { Da }\end{array}$ \\
\hline & Compoet gognerite......... & $\begin{array}{cc}\mathrm{Da} \\
\mathrm{Da}\end{array}$ \\
\hline 6 & 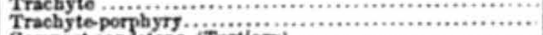 & \\
\hline $71-70$ & 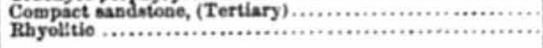 & $\begin{array}{l}\text { Huater's River, Wyoming } \\
\text { Eant side casion of Unlon River, }\end{array}$ \\
\hline 78 & White rolcanlo andstone. & 些a \\
\hline$\infty-61$ & $\begin{array}{l}\text { Porphyritie obsidian, ( } \\
\text { Spberulitio obeidian ... }\end{array}$ & $\begin{array}{l}\mathrm{Da} \\
\mathrm{Da}\end{array}$ \\
\hline${ }_{80}^{22}$ & 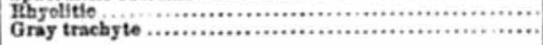 & Weat aide cation of Uniou Rir \\
\hline $\begin{array}{l}84 \\
85\end{array}$ & 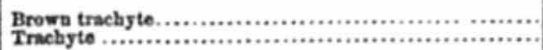 & $\begin{array}{l}\text { Womilig. } \\
\text { Pad weat of Coulter's Creek, }\end{array}$ \\
\hline$\frac{66}{67}$ & $\begin{array}{l}\text { Red trachyto } \\
\text { Cellular trachyte. }\end{array}$ & Da. \\
\hline
\end{tabular}

Rocks colleoted by the Snake River liriaien of the expedition, sa--Continued.

\begin{tabular}{|c|c|c|}
\hline sa. & Sama. & Leality. \\
\hline ses & 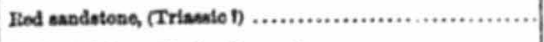 & $\begin{array}{l}\text { Thiru cation of Snake River, w go } \\
\text { mibg. }\end{array}$ \\
\hline$\infty$ & 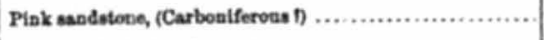 & $\begin{array}{l}\text { Oppooflio moith of Unlon River, } \\
\text { Wy goming }\end{array}$ \\
\hline$\stackrel{\mathscr{P}_{n}}{1}$ & 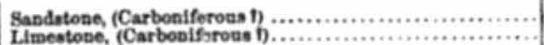 & ${ }_{\mathrm{Da}} \mathrm{Da}_{\mathrm{Da}}$ \\
\hline 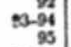 & 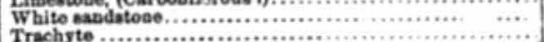 & $\mathrm{Da}$ \\
\hline $96-95$ & 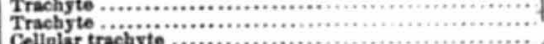 & Do. \\
\hline $\begin{array}{c}9 \\
100 \\
101\end{array}$ & 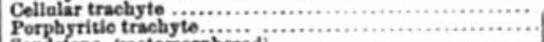 & $\begin{array}{l}\text { Do } \\
\text { Head of Fall Rirer, wyotning }\end{array}$ \\
\hline ioi & Sandacone, (metamorphosed)........ & $\begin{array}{l}\text { Weat slde outlet of Jackson's Lake, } \\
\text { W yountag. }\end{array}$ \\
\hline $\begin{aligned} 100 \\
100 \\
10405\end{aligned}$ & $\begin{array}{l}\text { Cavernous trachyre....... } \\
\text { Gray trachyto }\end{array}$ & $\frac{\mathrm{Da}}{\mathrm{Da}}$ \\
\hline 10405 & $\begin{array}{l}\text { Amygdaloldal trachyto. } \\
\text { Volcanlo tufa.............. }\end{array}$ & $\mathrm{Da}_{\mathrm{Da}}$ \\
\hline 107 & Jandatone. & $\begin{array}{l}\text { Mouth of Buffalo Fork of Snake } \\
\text { River W Woming }\end{array}$ \\
\hline 100 & Limentone, (laminated) ............... & $\begin{array}{l}\text { Bned of "Boffalo Fork of Snake } \\
\text { River, w yoming. }\end{array}$ \\
\hline 100 & 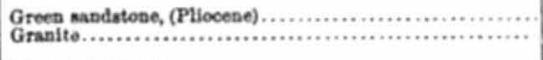 & 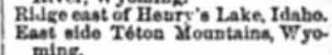 \\
\hline${ }_{112}^{111}$ & 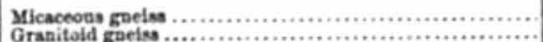 & $\begin{array}{l}\operatorname{ming} \\
D_{0} \\
D_{a}\end{array}$ \\
\hline 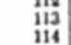 & Goart & $\begin{array}{l}\mathrm{Da} \\
\mathrm{Da}\end{array}$ \\
\hline 然 & Grante (Carbouilieroua) ...................................... & $\begin{array}{l}\text { Da } \\
\text { Serth Gros Ventre Batte, wyo. }\end{array}$ \\
\hline 116 & Siliconona limeatone, (Pliocene) ...... & $\begin{array}{l}\text { ming } \\
\text { Do. }\end{array}$ \\
\hline 1178 & Quartzitio andatoos (Potedarn î. & $\mathrm{Do}$ \\
\hline 112,110 & 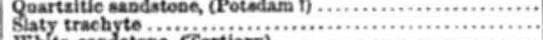 & $\begin{array}{l}\text { Da. } \\
\text { Da. }\end{array}$ \\
\hline 㕶 & 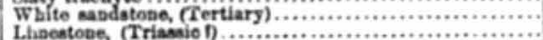 & Gros Veatre River, Wyoming. \\
\hline 124.65 & Red napdatone, (Triagaicici). & $\frac{1 \mathrm{Da}}{\mathrm{Da}}$ \\
\hline 128 & $\begin{array}{l}\text { Umentose, (Carbouiferoas) } \\
\text { Rhygolito...................... }\end{array}$ & $\begin{array}{l}\text { Da } \\
\text { South Gros Ventre Datte, Wyo }\end{array}$ \\
\hline $135-36$ & $\begin{array}{l}\text { Staty trachyte } \\
\text { White quartaltio nasdatione (Cartbooilforouas).... }\end{array}$ & $\begin{array}{l}\text { ming } \\
\text { Da. } \\
\text { Weat aide Túton Pans w roenils }\end{array}$ \\
\hline $\operatorname{lng} \rightarrow$ & 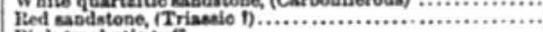 & $\begin{array}{l}\text { Weat alde Téton Pases, W yotnlts } \\
\text { Do. }\end{array}$ \\
\hline $160-1 !$ & Pink trachytio tafl.... & $\mathrm{Da}$ \\
\hline $\begin{array}{lll}102-14 \\
105-19\end{array}$ & 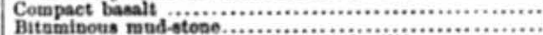 & Da \\
\hline $\operatorname{los}_{1001}$ & 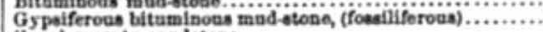 & $\begin{array}{l}\text { Snake River Cason, W yountag } \\
\text { Da. }\end{array}$ \\
\hline 1525 & & $\mathrm{Da}$ \\
\hline & $\begin{array}{l}\text { Fise grained gavdstono..... } \\
\text { Chert, (Carbonlferoua) .... }\end{array}$ & $\mathrm{Da}$ \\
\hline 161 & Hot sprisg depotit ........... & $\begin{array}{l}\mathrm{Da} \\
\mathrm{Da}\end{array}$ \\
\hline $102-6$ & slaty trachyto .................... & Saake Hiver, below mouth of Salt \\
\hline $164-65$ & Veaienlar trachyto .................. & $\begin{array}{l}\text { River, Wyoming } \\
\text { Suake. River, bead of upper ba }\end{array}$ \\
\hline $\begin{array}{l}160-8 \\
10070\end{array}$ & Porphyritio trachyto .................................. & $\begin{array}{l}\text { alceason, w yomisg } \\
\text { Da }\end{array}$ \\
\hline 171-72 & & $\begin{array}{l}\text { an Vall } \\
\text { Da. }\end{array}$ \\
\hline & Compact limes & $\mathrm{Da}_{\mathrm{a}}$ \\
\hline $\begin{array}{l}173 \\
176\end{array}$ & andotone.......... & $\begin{array}{l}\mathrm{Da} \\
\mathrm{Da}\end{array}$ \\
\hline $17 \pi 6$ & 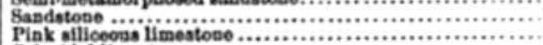 & $\begin{array}{l}\mathrm{Do} \\
\mathrm{Do}\end{array}$ \\
\hline 1 19 & Criboldal limeatone ................................... & $\mathrm{Da}$ \\
\hline $\begin{array}{l}180 \\
101\end{array}$ & af limeatone. & $\underset{\mathrm{Da}}{\mathrm{Da}}$ \\
\hline $\begin{array}{l}1+2 \\
150\end{array}$ & $\begin{array}{l}\text { Chert ................. } \\
\text { Purplo trachyto....... }\end{array}$ & $\begin{array}{l}\mathrm{Da} \\
\text { Sonth side of uppez banalteation }\end{array}$ \\
\hline $180_{-68}^{184}$ & 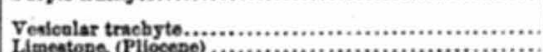 & $\begin{array}{l}\text { Idabo. } \\
\text { Da. }\end{array}$ \\
\hline 18:- & 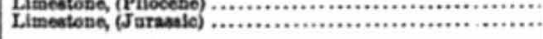 & $\begin{array}{l}\text { Near Yort Hall, Idaho. Fort Hall, } \\
\text { Lincola Valley, Dcar Fon }\end{array}$ \\
\hline $\begin{array}{l}191-\infty 2 \\
130\end{array}$ & 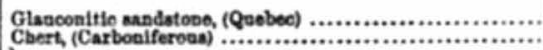 & $\begin{array}{l}\text { Nesr Fort Hall, Idaba. } \\
\text { Lincoln Valley, Idaba }\end{array}$ \\
\hline $\begin{array}{l}194 \\
200\end{array}$ & \}Compact limeetona (Pliocene) .................................. & Da. \\
\hline
\end{tabular}




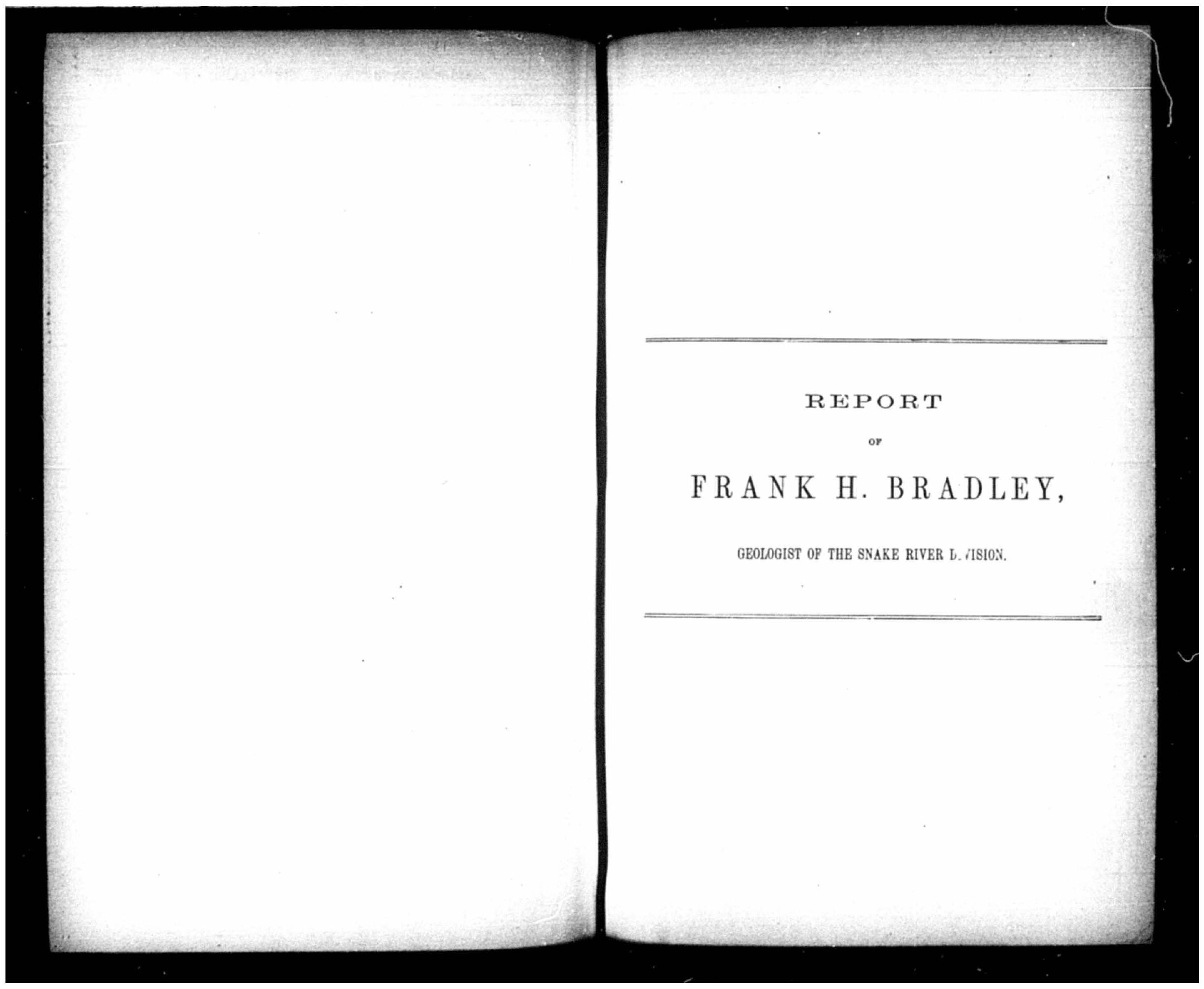




\section{REP0RT OF FRANK H. BRADLEY, GEOLOGIST.}

WAsHingtos, D. O., April 5, 1873.

SIR : I hand you herewith my report upon the region examined by me during the past season, while accompanying the Snake River division of your party.

After working for about a month at Ogden, while our outfitting was being completed, we followed well-marked roads to Fort Hall, Idaho and thence to Market Lake Station. Here we torned off into the almost unbroken wilderness, and spent some time in examining the Téton Mount. ains, from which region we passed up the valley of Henry's Fork to its head, and crossed by Tyghee Pass to the Upper Madison, which we also followed to its source, in Madison Lake, after stopping by the way to examine the geysers and hot springs of the Fire-Hole Basins. Thence we crossed the divide to Shoshone Lake, examined all the head-waters of the main Snake River, and descended that stream, ria Jackson's Lake and the Grand Cañon, to its emergence into the Great Basin, reaching the latter at a point only a few miles from Fort Hall.

From Ogden to Fort Hall, we were able to examine but a narrow strip of country ; but, beyond the latter point, frequent side trips enabled ns to understand the general features of quite wide areas, though, at several points, we were so much hurried as to neglect certain small spaces, which are now seen to have been essential to absolute certainty regard. ing the connections of different parts of our work. Upon the whole, bowerer, though much yet remains to be done by subsequent explorers in that region, I am satisfled that they will fiud but few errors in our results.

I am indebted to Mr. Bechler, our chief topographer, for many distances and bearings, as well as for the very accurate map which he has now nearly completed, and upon which I expect to color the outerops of the various formations. I am also indebted to Mr. Hering, astronomer and meteorologist, for the determination of most of the levels indicated in this report. Mr. Gaunett, of your own party, has also aided me in this matter. As Mr. Nicholson remained at Fort Hall dnring our absence. taking hourly observations, while previous barometric comparisons of Fort Hall and Ogden had been made by Messrs. Gannett and Hering I place much reliance on the determinations of elevations throughout the region examined.

The skillful pencil of Mr. Holmes has supplied the sketches which accompany this report, the materials being mostly obtained from the photographs of Mr. Jackson, who accompanied us as far as to the Fire. Hole, and from Mr. Bechler's field-notes.

Mr. Taggart acted as my assistant during most of the trip; and his work was satisfactory.

I have to thank our surgeon, Dr. Curtis, for information on certain microscopical points, as well as for much personal kindness.

Yours, very respectfully,

Dr. F. V. HAYDEN,

FRANK H. BRADLEY, Ohief Assistant Geologist.

In eharge of the United States Geological Survey of the Territories. 
CHAPTER I.

\section{WAHSATCE MOUNTAINS-OGDEN TO FORT HALL.}

The first installment of the party reached Ogden, Utah, which had been determined on as our rendezvous, upon the evening of Friday, May 24; and the work of the season was commenced on the following day by the ascent of a peak of the Wabsateh Range, which stanids di. day, by the a (his is the culminating point of that block of mountains which is separated from the northerly and southerly continuations of the range by the cañons of Weber and Ogden Rivers. No mercurial barometer was taken to the summit; but its height was twice measured with aneroid barometers, and once ronghls, with a pocket-level. The elevation was thns approx. imately determined at 5,298 feet above the railroad at Ogden Station, or 9,638 feet above the sea-level.

The mountain was originally pretty well covered with a tolerably thiek growth of small-sized pine and spruce, with some cedar along the limestone outerops, except on the steepest slopes, which, where not entirely bare of soil, had, and still have, very dense, low growths of a form of "Jersey tea," (Ceanothus velutinus,) and of small "mountain mahog. any," (Cercocarpus ledifolius, ) mostly so depressed by the winter's snows as to have taken a permanent downward slope, which greatly increases the difficulty of the steep ascent, but often renders the descent altogether too easy. The timber has mostly been ent, except on the highest parts of the mountain; and, along the small cañons and lower slopes, the places of the pine and spruce have been taken by a small growth of scrub-oak (Quercus alba) and maples, (Acer glabrum and $A$. grandidentatum.) This oak also abounds along most of the small streams which flow from all the cañons, and extends in small groves far out npon the terraces. I think that we may reasonably expect these and other "hard woods" to increase and take the place of the pines which baveso nearly disappeared, aud which have here but very few descendants.

Upon onr tirst ascent of the monntain, we reached the lower edge of the snow, apon a spur, at about 2,000 feet below the summit, and, on our return, descended to nearly the same level, in a ravine, by "sitting glissades," over the soft surface.

At the time of our arrival, the streams issuing from the cañons were pretty full, though variable, by reason of the daily meltings and nightly freezes; but, before our departure for the northward, the snow.drifts were so greatly reduced that their flow had nearly ceased; and the irri. gation of the lower ground immediately about the town, until then depending on these streams, was supplied entirely from Ogden River by a diteh starting at the mouth of Ogden Cañon. This failure during the summer will render the culcivation of the higher terraces impossible, or at least extremely precarions, until ditches are run up the 0 gden or the Weber River far enough to take water at quite a high level.

Except along the immediate banks of the streams, these terraces are mostly overgrown with sage-brush, though the scrub-oaks before mentioned also spread out over considerable areas, and there are some patehes of almost barren sand and gravel. Along most of the mountain, there are only three prominent terraces, marking old lake-levels, the highest reaching the level of about 876 feet above the railroad, or 960 feet abovo the present late avel, but they are mpch more numerong near the mouths of the streams, where the stream-currents have dis. tributed their sediment, when the lake-waters were at these bigher levels. Thirteen of these terraces were observed on a line betwoen tho center of the town and the mouth of Ogden Cafion, the higkiest of which was less than $\mathbf{1 0 0}$ feet above the railroad. Above this point, the foot of the mountain has been swept so bare of rubbish as to show no terrace until we reach the highest, whicb was slightly outlined on the upper slopes.

Most of the material of these terraces is entirely uncompacted, and the edges expose berls of drifting sand and loose gravel; bnt, at two or three levels, there are layers, a few feet in thickness, in whieh a cal. careons cement has more or less consolidated the gravel into still rather loose and porous conglomerates.

The dBbris thus deposited along the base of the mountain has $80 \mathrm{cov}$. ered the solid strata as to make it difficult to determine their exact positions at this low level; but the upper slopes show so much bare rock as to make the general strue. ture very evident. The beds form, as was stated in last year's report, $\mathrm{a}$ huge anticlinal, whose axis makes a small angle with the general trend of the range; but it proves to be much more complicated than was then supposed. While its eastern slope is nearly regular, its western is quite irregular, inclnding at least two subordinate folds, large portions of which have been eroded, so that one must study closely, to be able to supply the miseing links.

The aceompanying sketch (Fig. 44) shows, in a general way, the actual and theoretical section through the range, at Ogden Peak.

In the more northern portion of this block of mountain, both of the folds of the western slope make considerable outerops; but their axes are so much inclined to the horizon that the bottoms of the folds rise rapidly as we go south. ward, until they pass above the ward, until they pass above the
present surface, leaving the westpresent surface, leaving the western slope here entirely composed of metamorphic rocks, in which no continuation of these particular folds can be traced. The sonthern portion of the eastern slope was not examined; so that I cannot say just at what point of the eastern

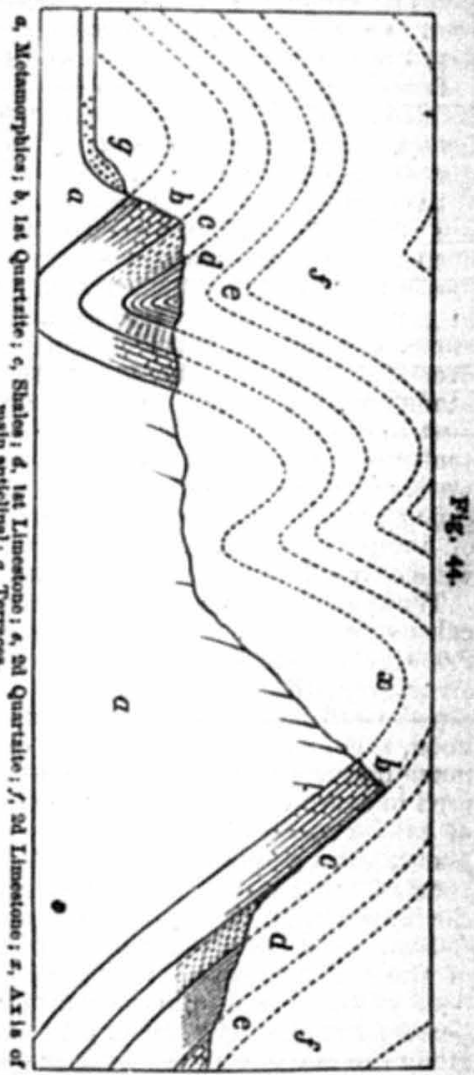
base the unmetamorphosed rocks disappear from it; but they certainly show no outerop in the section displayed along Weber Cañon. At two or three points, the metamorphic rocks show some slight easteriy dips; but most of their dips are strong westerly, and the overlying beds are plainly unconformable. The metamorphics are mostly hornblendie 13 o s 
gneisses, with some granites and occasionally chloritic and talco-mica sohists, all more or less penetrated by quartz-veins. One of these veins, near the summit, contains considerable quantities of translucent semicrystalline masses of hematite. These veins have been opened at varions places by prospectors; but nothing of any value has yet been reported. places by prospectors; of these openings were examined; but a few small scattered Several of these openings were examined; but a few small scattered "tis-mine" was not visited. Samples of its "ore" appeared to be merely maseive hornblende, whorie high specific gravity, due to the presence of iron, probably originated the idea of its metallie character. A "graphite mine," about twelve miles north of Ogden, near the Hot Springs, was examined, in company with its owners, and found to be a small opening in an irregular quartz-vein which contains a few small flakes of graphite, but gives no indication of the presence of any valuable bodies of that mineral. On the whole, it appears probable that no valuable mines will be fonnd in the metamorphic rocks of this neighborhood.

Immediately upon the metamorphics we find about 1,500 feet of heavy. bedded quartzite, partly white, but mostly quite ferruginous. Its lowest layers consist of a coarse conglomerate of large, red, gray, and white quartz, and jasper pebbles. The upper portions are mostly finer grained, with occasional streaks of very small pebbles. The lines of false bedding are rather irregular, but mostly face the west or southwest, indieating open sea in that direction at the time of their deposition. The only fossils fonnd in these beds are indistinct fucoidal markings, resembling in general appearance the Arthrophycus Harlani of the Medina sand. stone, but plainly not identical with it. From the sharacter of the overlying strata, I am inclined to refer this bed to the age of the Potsdam sandstone. It forms the grand arch figured in the report for 1871. Just to the sonth of this arch, the herizontal edges of its outcrop, in the continnation of the axis of the arch, form a high cliff, over which the waters of one of the small mountain-streams falls, first in a steep cas. cade 52 feet, and then in one leap 263 -in all, 315 feet-to the bottom of a narrow ravine. The tumbling rocks under the spray of the fall were covered with numerous snails, (Helix. sp.)

These quartzites are overlafd by something over 1,000 feet of gray calcareous shales, without fossils so far as seen, and these by nearly 2,000 feet of compact blue and gray dolomitic limestone, partly oolitic in structure, partly silicious and even cherty, partly filled with irregular streaks and patches of ferruginous clay. In this immediate neighborstreaks and patches of ferruginous clay. In this immediate neighbor-
hood, this bed of limestone is exposed only where the strata have been much disturbed, and it has consequently been mcstly thoroughly shiv. ered in every direction, though afterward recemented by the thin sheets of calcite which fill all the crevices. No fossils were fond in it hereabont, but a single specimen of Halysites catentulata, the characteristic coral of the Niagara group, was obtained by the survey, in 1871, from coral of the Niagara group, was obtained by the survey, in 1871, from Cañon, some twenty-five miles north of Ogden. From the character of the rock, however, I judge that at least the larger part of the bed, together with the underlying calcareous shale, belongs to the Qneo along the Malade Valley farther north. It is not impossible that here, along the Malade Valley farther north. It is not impossible that here, miles farther north, the deposition of limestone might havs been con. tinuous from the Quebec epoch onward to the Niagara epoch or even later.

This limestone is followed by a second heavy bed of quartzite, mostly ferruginons, from 2,060 to 2,500 feet in thickness. No fossils were seen in it, and I know of notbing which would give any grounds for judging as to its age.

This is followed by probably 3,000 feet of quite compact, mostly thinbedded gray and drab limestone,. largely silicious, the lower part even cherty and somewhat geodiferous. These beds contain a few fossils, Zaphrentis, \&c., which are plainly of Carboniferous age.

These higher beds make no ap- $\frac{1}{3}$ pearance upon the western slope of : this mountain-block, except in the immediate neighborhood of Ogden Cañon. The erest of the mountain consists of the lower quartzites, as shown in the section previously given. The upper of the two subor. dinate folds on the western slope has its eastern side much steeper than its western, and at some points al. most pinched out. The lower and more westerly one has both sides quite steep, and the two edges of the thin plate of limestone which forms its central portion are folded 60 closely together as to appear, at first sight, when seen from below, near the limekiln, like a single out. crop; higher on the spur, where they perhaps spread a little more than they do below, the eastern edge has a dip of only from $50^{\circ}$ to $53^{\circ}$, and the western one of 750

The following is a section of the strata as they are exposed in Ogden Cañon. (Fig. 45.) The two subordinate folds of the western slope of the anticlinal, having more westerly trends than the mountain-range it. self, pass under the valley before reaching $O$ gden Cañon, and, accord. ingly, are not seen in this section.

In ascending the stream the first grand fold of the upper limestone is so much concealed by the débris as to be unnoticed until we pass the second bridge and come to the "wedge" figured in the report of 1871 , and even then it is difficult to trace the ontlines of the fold on the upper slopes. The second fold, however, is very prominent, forming an immense tilted " $\mathrm{Z}$ " upon the mountain-side, a half mile long and at least 1,000 feet higb. The

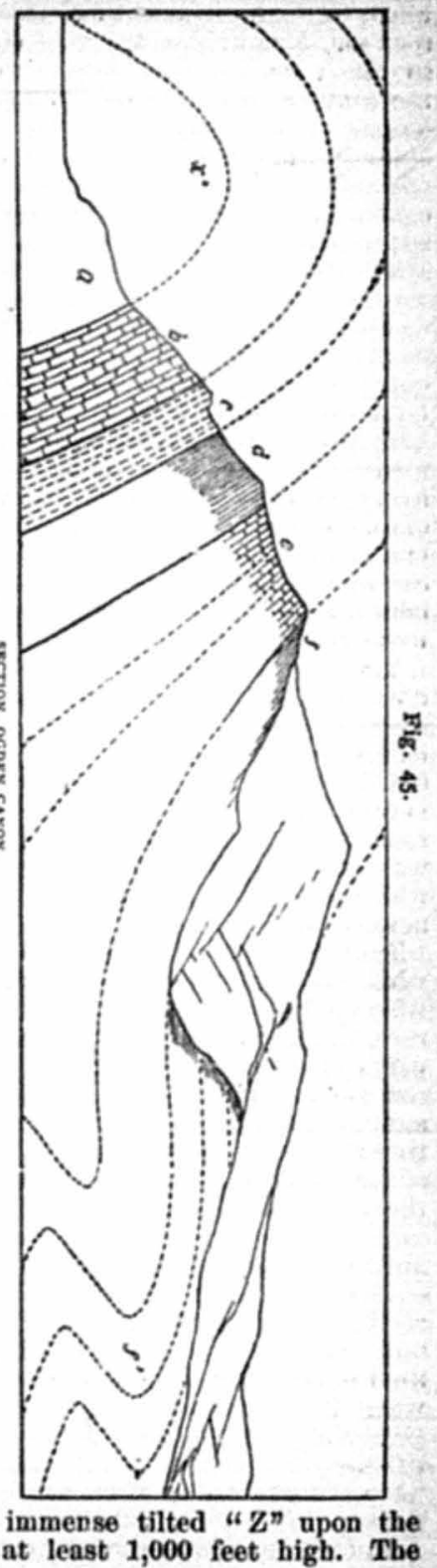


npper bar of the " $\mathrm{Z}$ " dips $16^{\circ}$ and the lower one 110 to the east. ward, while the connecting stroke has a dip of $49^{\circ}$ in the opposite di. rection. The angles are very sbarp, and the rocks, correspondingly, sockn broken that they have yielded readily to water-action on so sonth side of the cañon, known as Walker's Cañon, which gives the south side of the caun, kulied by the melting snows of the great passage to a large stream supplied by the melting snows of the great hollows on the northeast side of Ogden Peak. Small cold springs, depositing calcareous tufa, were noticed along the rocky aides of this cañon. At Dr. Cannon's, half way down Ogden Cañon, a strong sulphur spring flows from the second quartzite on the north side of the river. Tring The foot brige, whis generally washed away, and this stream was not fordable at the time of our visit, so that we could not measure its temperature. The water was said to be warm but drinkable. The escape of gas was strong enough to be noticeable as we passed along the roed on the opposite side of the stream. Near the mouth of the cañon there are two small clusters of hot springs, both of which are saline and ferruginons. The npper cluster, just below theloser bridge, and within the month of the cañon, flow from the granites, make but little deposit, and have a temperature of 130 . The lower ones, just outside the month of the cañon, bave formed a considerable mound of calcareous tufa, and, for that reason, are supposed to come up through the lower limestones, one of the folds of which should be in place beneath the terrace about at this point. The thermometer nsed here beneath the ter simply indicated a temperature of $125^{\circ}$ or higher.

The lower part of the cañon thrnugh all its length, but especially near its mouth, is more or less lined with heavy beds of coarse gravel, thoroughly consoliduted by a ferruginous cement. In some places, this forms the bed as well as the banks of the stream; but, at others, it is cat through, and the original well-worn rock-bottom of the eld cbannel is exposed beneath the gravel by the side of the road. It is evident that when this cañon was originally excavated, the Great Balt Lake was not far, if at all, above its present level; so that the rushing torrent which wore out this old rounded bottom met no elieck until it had passed entirely beyond the mouth of the caifion. There followed a time when the lake filled nearly or quite to its highest terrace; and, mean. while, the Ogden River continued to bring down the sand and jebbles while the Orer race, but now, checked by the rising lake, deposited them in the lower parts of its old channel, until they accumnlated to a very high level, not yet accurately located. Again, the lake retired, and the stream again cut down its channel, sometimes reaching its old level and sometimes not. It is evident that there were some pretty good sized cas. cades, at least, if not large falls, in the old river where it passed over cades, at lease lid limestones and quartzites, and wore away the softer the more solid limestones and quartzites, and wore away the softer
underlying shales and schists. The conglomerated gravel has worn more evenly, though it is far from homogeneous.

The lower bed of limestone was fornerly burned in small kilns, about a mile above the mouth of the cañon; but the local supply of wood is now nearly exhansted, and the kilns are deserted. The same bed is now nearly exhauted, and Taylor's , where it is burned with coal from Evanston, which is delivered at the Ogden station for 85 per ton. Hauling to the kiln, on the return trips of teams which hanl down the lime, costs 2.66 per ton. Three tons burn 100 bushels of lime, which sells readily at 50 cents per bushel, delivered in Ogden. The kiln burns about 60 bushels per day.

In order to examine briefly the southern continuation of this range, and to get some idea as to the uniformity of character of its formations, I accompanied Messra. Jackson (our photographer) and Peale (minera) ogist) to Balt Lake Oity and Little Cottonwood Cafion, the latter being about fifty miles south of Ogden. At that time, June 20, immense snow-drifts still remained in all the upper parts of the cafion, and made it impossible to obtain more than a very general idea of the sectsin. The outer (western) part of the cafion is walled solely by the rimost white granite, which is extensively quarried, near its mouth, for the Mormon temple, as well as for other nacs aby is entirely diforent from anything of the bedding it is erident that the netrike of the bedding, it is evident that the line of outorop would pass con. siderably to the eastward of the erest of the mountain, in making only a few miles of northing. The dip is westward, as is the case with most of the metamorphic roeles near Ogden. Several of the las with most granite exposed in the quarry showed angular and rounded patehes of darker material, which were evidently sections of what had been more or less rounded pebbles in the conglomerated mass, before its metamor. phism. Unconformably upon this granite lies a heavy mass of ferrigunous quartzites, whose northern continuation forms the Twin Peaks, said to be the highest points of the range. Upon this, apparently con, formably, lies a series of limestones, the lower part rather thin bedded, the upper part in heavier layers. The lowest beds conld not conveniently be visited. A short distance sonth of the Flagstaff mine, a small mass of rock was found to be full of small fossils, including some char. acteristic forms of the Sub carboniferous. A few others were found scattered about in such condition as to satisfy me that the whole elus. ter of mines surrounding the Emma and the Flagstaff is in Carboniferous and Sub carboniferons rocks, so far as yet developed. While the age of the lower part of the series was not determined, yet it was evi. dent that there is nothing in the character of these beds which should cause as to anticipate any considerable decrease in the metallic deposits before reaching the underlying quartaites. At that level, however, they are likely to be greatly diminished, if not entirely wanting.

Even on the comparatively moderate slopes of the head of the valley, climbing is very wearisome; and the lower part of the cañon is hemmed in by immense nearly vertical walls of granite, standing up ont of steepest slopes of débris. From these bare walls and steep slopes descend, in. winter, the avalanehes which have buried so many teamsters and others, and which will continue to thus destroy life and property until the mining companies shall unite in construeting either a covered or an elevated road for the transmission of ore and supplies as well as of pas. sengers. The inexhanstible supply of granite, already broken by na. ture to manageable size, wonld seem to make the construction of a covered way extremely feasible.

The limestones which form the base of the high-terrace shoulder of the mountain, at the Warm Springs, just north of Salt Lake City, show at one point a dip of $250 \mathrm{~S} .380 \mathrm{~F}$. They ordinate fold of the western slope of the main anticlinal, similar to those already described.

On June 24 we started from Ogden on our northward jon aey, and camped at the Hot Springs, abunt ten miles from that eity. After crossing Ogden River, about two miles below the mouth of its canion,

- As this report is passing through the press, I find that, in the Engineering and Mining Journal of March 11, 1873, Mr. Henry Engelman states that a secood quartaite in in place in the Cottonwood section. The lower limestones must therefore be no- 
we saw the village of North Ogdel, some four or five miles to the right of our route, at the foot of the mountain, in an angle of the lower terrace. at the mouth of the pass which afforded communication with Ogden Hole before the construction of the road through the previonsly impass. able cañon. The monntain between this pass and the cañon has a base of metamorphics, a precipitous face of the lower quartzite, an upper modnrate slope of the calcareous shales and lower limestone, and a crest of the upper quartzite. In the portion trending back toward the pass. the shales and limestones descend somewhat, and have been weathered out into an immense amphitheater, reported as being very grand by Dr. Peale, who examined it.

The hot springs are located immediatel $;$ at the foot of a high shoulder of the mountain, consisting of the upper terrase, preserved from wear and upheld by a mass of quartzites, shales, and limestones, which form the continuation of the uppermost of the subordinate folds on the west flank of Ogden Peak. Thongh the connecting portion is gone, so far as can be seen, yet some portions of these beds are doubtless in place beneath the plain which stretches past North Ogden to near the moutly of Ogden Cañon. The terrace at the hot springs exposes both sides of the fold very plainly ; and here we find, as on Ogden Peak, that the eastern side of the fold is much the steepest, and has been pinched out, $s 0$ as to show but a thin outcrop. The portion of the terrace next to the mountain consists of metamorphic rocks, as does also far the larger part of the mountain-face. The rocks are mainly hornblendic gneiss and syenite, with quartz-veins. The crest of the mountain here consists of the second quartzite, and reaches an elevation so nearly identical with that of Ogden Peak that I am in doubt which is the higher.

The hot springs flow from the quartzites of the west side of the fold at the end of the terrace, practically on the same line of crack as those just outside the mouth of Ogden Cañon.

Just beyond the springs, several of the high spurs of the mountain form very prominent pinnacles, being capped with masses of the first quartzite, from above which the overlying calcareous shales, by reason of their softness and the easterly dip, have been readily eroded. This structure, as well as the general bedding before described, can be plainly seen by those who may pass on the cars between Ogden and Corinne A fine fall leaps over this quartzite in Willow Creek Cañon, opposite Willard City.

As we pass northward, the mountain bears farther to the east, the axis of upheaval passes ont under the plain, and the quartzites and limestones decline from high dips to nearly level positions, the second quartzite passing from the very crest to the very bottom of the mount ain just north of Box Elder Cañon, back of Brigham City, and about twelve miles from the hot springs. The high monoclinal dips seen by Dr. Hayden along this cañon in 1871 probably represent the continua tion of the axis of either the "wedge" or the " $\mathrm{Z}$ " of the npper limestones in Ogden Cañon, but show greater disturbance than was there experienced. For about six miles north of Brigham City, the upper quartzite forms the base of the mountain; but then disappears, and the upper limestone alone outcrops, though a thin local bed of quartzite appears about the middle of its section for a short distance. At Mr. Barnard's place, about five miles above Brigham City, I was slown a fragment of galena in calcite, with some green carbonate of copper, from an opening in the limestone about a thousand feet tp the mount- ain. Thelode was said to be about four feet thick. The ore is reported to be rich in silver, and arrangements have since been made for working it.

Some of the limestone along bere is quite compact and furnishe good bvilding-stone, which dresses well, and has been extensively nsed in this neighborhood for houses and barns, the supply being mostly obtained from the piles of large masses swept down along the channels of the small but rapid mountain-streams. While passing down thi road, upon my return in November, I saw a dozen or more mediumsized two-story stone dwellings in process o? building or just com. pleted, in as many miles, evincing a much higher degree of general prosperity and thrift than one would have expected from a view of the small adobe cottages previously occupied. The soil is evidently fertile wherever irrigated. Stacks of wheat and corn and huge piles of pumpkins were constant features along this road at the close of the season.

About twelve miles north of Brigham City we came to another small cluster of hot springs, of temperatures varying from 1210 to 1280 . These are strongly chalybeate and saline. By the side of them is another cluster of springs only feebly saline, free from iron, and of much lower temperature, mostly about $68^{\circ}$. Upon my return in November these reached $72^{\circ}$, but had a much smaller supply of water. The hot springs were also weaker, and reached $132{ }^{\circ}$. Fremont reports them at $134^{\circ}$ in 1843 . The water of these springs supplies a long narrow pond, hemmed in by portions of the lower terrace upon which the road runs at this point. Cool springs are said to break ont along this pond; but we did not succeed in finding them, and so made our camp on the henk of Bear River, about two miles farther on. This stream is here slng. gish, having nearly reached the level of the lake, though yet some miles distant from it.

Passing up the road abont seven miles farther, we approached Hampton's Bridge, where the stream is much more rapid. The channel of the river here makes a sharp turn to the eastward, passing through the front range of the Wahsatch Mountains on our right, while the northern continuation of the valley in front of the range is occupied by a tributary now known only by the name of Malade River, though sometimes referred to in old publications as Roseanx or Red Creek.

The immediate channel of Bear River, where it breaks through the mountain, at the point known as "The Gates," is narrow, with high precipitons walls of light-drab, compact limestone, partly siliceons, from which I could obtain no fossils; but, from its position, it must be Carboniferons. The strata show a westerly dip of about $25 \circ$, and evi. dently belong to the west side of the anticlinal upleenval, whose nonthern continuation has been mentioned as crossing Box Elder and Ogden Cañons. The cliffs of this narrow channel reach nearly to the level of the top of the second principal terrace. On the north side of "The Gaves," a short distance back from the edge of this channel, there is another considerable break in the npper terrace, showing a second channel to have existed when the stream was at this level; and, as se from this north side, the appearance of the surface on the sout indicated the probable exjstence of still a third old channel, nlong the line now occupied by the Utah Northern Railroad, (narrow gauge, which there crosses the range into Cacbe Valley. At the level of the
whe upper terrace, the old valley of. Bear River spreads ont to a width of about five miles. The upper terrace itself consists almost entirely of a grayish-white limestone, partly fine prained and compact partly coareo and porons, and mostly pebbly. $A$ il of it is more or less oolitio The compact layers are entirely destitute of fossils; but the more pebbly 
portions contain very nnmerons individnals of a few species of fresh. wster shells, which are sufficient to mark the bed as of late Tertiary (Pliocene f) age. (Dr. Ourtis, of our party, afterward obtained from the shore at the southern end of 'Elt Lake specimens of oolitie sand, which show that this kind of calcareous deposit is still forming abundantly in this basin.) The beds exposed are about 200 feet thiek. They show, at this point, a dip of about $25^{\circ}$ south, $68^{\circ}$ west. As ne corresponding disturbance of the surface of the terraces is apparent, it is evident that the upheaval antedates the Terrace epoch. The lower terraces show extensive deposits of coarse gravel, which is well exposed in the cuts of extensive deposits of coarse gravel, which is well exposed in the cuts of of superior ballast.

After crossing Bear River, the Tertiary limestones are found covering the entire foot of the mountain, for two or three miles, though the monntain itself is still plainly composed of the older limestone, which appears on its summit. Then the Tertiary disappears altogether, and the upper guartzite rises so as to form the face of the ridge, for four or five niles. Then the Tertiary comes in again, in a heavy body of compact flinty limestones and siliceous shales, running to the very tops of the hills, which are here much depressed. The strata are mainly nearly level, only the portion nearest the valley having a westerly dip, which at some points reaches $40^{\circ}$. About nineteen miles above Hampton's Bridge, the mountain rises again, and the Tertiaries disappear again, exposing the face of the lower limestone, which has now risen so as to form the entire mass of the mountain. At the junction of the two series of strata, it is evident that the Tertiaries lie unconformably upon the older limestones, many layers of which are here crowded with fragments of tril. obites and other fossils, which are plainly of the age of the Quebec group. Among the specimens from this locality which have already been worked up, there are at least fifteen trilobites of the genera Conocoryphe, Bathyurus, Dicellocephalus, Agnostus, \&c., five brachiopods, two gasteropods, and one pteropod. As we approach Malade City the mountain becomes higher and more precipitons, a point about three mile sonth of that place being found to be about 2,500 feet above the river. Of this total, about 2,000 feet are exposed in the face of the mountain, the terraces being mostly washed away. All the strata exposed belong to the Quebee Group, and consist mainly of limestones, though including perhaps 200 feet in all of sandstones, partly shaly, but mostly thickbedded and quartzitic, as well as an indeterminate amount of interlam. inated greenish calcareous shales. The uppermost limestones are com. pact and full of nodnles and layers of chert; the lower ones vary greatly, from pure compact to coarsely fragmentary, to fine-grained silicions, and to oolitio and coarsely concretionary forms. The colors vary from drab to blue, gray, buff, flesh-color, and pale red, sometimes uniform, sometimes mottled and streaked. Some of the beds, of both the limestones and the sandstones, would make good building-stone; but these are rather too high in the section to be conveniently quarried on the face of the mountain; though they could probably be easily reached by ascending some of the numerous caũons which break through the range in this neighborhood. The fossils occur at varions levels, from bottom to to of the section, though some portions of considerable thickness are entirely barren. They can be most easlly obtained from the tumbled masses of the different beds which lie numeronsly along the foot of the mountain. As Malade City is only one day's ride, by stage, from Corinne, the locality can easily be visited by collectors who may be pass. ing nver the Central Pacific Railroad. The section shonld be more care- fnlly examined, so as to determine the positions of any special horizons which may be marked by special groups of foesils. Time did not-per. mit me to meke so thorongh examinations of the different beds ae sach determinations would require.

The finding of distinctively Quebee Group fossils, in such abundance and throngh go great a thickness of atrata, was a matter of considerable interest, since this was, I believe, the first identifleation of this hori. zon on the western side of the Rocky Monntain divide; and, indeed, but few specimens from that or any other part of the Silurian, had ever been obtained from any part of the country west of Minnesota, Mis. souri, and Texas. As no fossils were found in the lower limestones at Ogden, the age of those beds was in doubt until the identity of stratigraphical position and of lithologieal character showed that they muet be of the same age. The first examination of these Malade rocks was made at a point where the section terminated below in a very was made at a point where the section terminated below in a very quartzitic sandstone, which ocenpied the relative position of the Potsdam, and was accordingly referred with doubt to that group in a letterextract which was published in the August number of the American really a part of the true Quebec, whose base is not here exposed.

The valley of the Malade is broad and flat; the stream itself is slug gish and mostly deep, with steep banks and muddy bed. At a few points there is rock or gravel bottom, but crossings are few. The bordering flats are rich, and considerable portions are well cuitivated, prodncing heavy crops of wheat and some corn. They are well watered by numerous large springs, which burst up at various points, doubtless being supplied by subterranean streams flowing through and escaping from the limes tones of the monntain. These are mostly pure and cold from the limestones of the mountain. These are mostly pure and cold
springs; but at one point near the stage-road, about a mile south of Malade City, there is a low monnd of calcareons tufa, surrounding s small spring which is rather warm, but still drinkable. Only a smal amount of land has yet been irrigated about here. The ridge which forms the western boundary of the valley is lower and more rounded in ontline than that upon the east. It was not visited, but the apparent outline than that upon the east. It was not visited, but the apparent
structure and color of its bare slopes render it probable that it also consists of Quebec Group rocks.

The old route across the divide, to the Snake River Valles, passed on to the head of' the Malade, and thence to the left and down Bannock Creek. The stage-route now turns a little to the right at Malade City, and crosses to Marsh Creek. Following it, we camped at Keeney's Station, four miles above Malade City, and stopped over one day, June 28, to examine the neighborhood. The side valley, which the road follows, makes a broad break through the eastern mountain, up which the ter races extend, and conneets with anarrower valley lying between this and the next range. Messrs. Taggart and Coulter accompanied Mr. Jackson to the summit of the monntain north of the gap, found it to be the regular continuation of that to the sonthward, and brought in a few character. istic fossils. Mr. Adams accompanied me to the southward, where we found the back-slopes of the mountain covered with Tertiary beds, consisting mostly of thin-bedded, light-drab, clinking limestones, partls pure, partly earthy, with some silicious shales. Some of these beds wonld probably make good hydranlic cement. A few minute ostracoids and small, indistinct fresh-water gasteropods were the only fossils found. From the summit of the monntain, it became evident that these Tertiary beds extend np this back valley to that of Bear River, and that this crest formed two long, narrow islands in the old Tertiary lake. Tiv beds have a slight easterly dip. 
The next range east was also examined in a hasty reconnaissance up New Cañon, which opens into the valley about four miles east of Keeney's Station. The lower portion of the cañon is walled with heavy beds of ferruginons quartzite, belonging with the lower beds at Ogden, and, like them, referred with little doubt to the Potsdam. Bome small axd hations have been made by mining prospectors in some of the more thinly.bedded portions, but without any success. Their rubbish gave thinly-bedded portions, but without any success. Their rubbish gave no indication of anything which should have enconraged such excavations. A bore the quartzite lie heavy-bedded, dark-blue and ferruginons, impure limestones, which belong to the Quebec group; but no fossils were found. The dips are all easterly and reach $500^{\circ}$. The upper part were roube. of the canon is heaven of Malade City have combilyed to make a good wagon-road up it, for the purpose of more readily obtaining a supply of timber for buildin, purposes and for fuel. The sharp dips of the cañon are much flattened, a little farther south, so that in the course of a few miles the quartzite and the lower portion of the limestone disappear beneath the upper edge of the abutting Tertiaries of the valley. A cañon un the east side edge of the abinting amont of maple-timber, a foot or more through at the butt, and 30 to 40 feet long.

The small stream-valley which the stage-road follows runs over to the east side of the main valley between the ridges, and leaves the Tertiaries exposed in white banks upon the slopes of the western ridge. Mr. Stevenson reported having examined these for fossils withont success.

the divide between the waters of the Great Basin and those of the Columbia. The upper lake-terrace, which has been a marked feature of the country thus far upon our journey, with small exceptions, here becomes a little irregular and much washed, but apparently reaches to the very summit, as if this might have been a point of dribbling ontflow for the waters of the great might hat in also true of the point in the upper course of Bear River, where the Port Nenf most nearly approaches that stream in the sาme broad valley, with only remnants of the old terraces forming the divide between them. The level of the divide between the head of Marsh Creek and the Bear River drainage, at Red Rock Pass, as ascertained by the party of 1871, indicates that this was probably another point of outflow ; and the divide between the head of the Mrably have been a that very probably have been fourth, since Captain Mullan reports that as "prairie-surface of clear gravel formation." (See Wagon-road Report, 1863, p. 76.) Time for bade our working out the details of these points by the way, and I can, therefore, only offer these suggestions as to points worthy of more deliberate examination. Without any very accurate determinations of levels, I am ret inclined to believe that the terrace-levels rise somewhat as we pass to this northern rim of the basin, implying a moderate up. heaval of the whole country in that region, which may have taken place while the lake was yet full, and so have been the first means of separating the Great Basin from the Columbia drainage. I agree, however, with those who hold that the decline of the lake from these old terrace-lerels has been due mainly to a climatal change, which decreased terracer but either left the evaporation constant or increased it. These variations in the lake-level are still going on, as is shown in the recorded rise of the surface for about twelve years, until, two years ago it began to decline again. I have questioned, in my own mind, whether this latter decline does not really represent the result of dimin ished rain-fall theoretically consequent upon the largely-increased con. sumption of timber in the building and since the completion of the Pacifie Railroad. On the other hand, upon the same theory, we may refer the previotus rise to the results of eultivation of land and planting of trees, and may expect that, as these increase, the lake will again begin to rise and to spread over larger areas.

As we pass down from the Malade divide into Marsh Valley, the Quebeo Group limestone and underlying (Potsdam i) quartzite onterop on our right, until the valley spreads, and they disappear beneath on our right, until the valley spreads, and they disappear beneath
the level of the lower terrace. These terraces are very strongly marked through the whole length of this valley; and an upper one is readil identified, though not so prominent, at the level of about 1,000 feet above the stream. They are on too large a scale, and the valley is too wide, to have resulted from merely the drainage of the small area of mountains about the head of the stream; and I am strongly of the opinion that this must have been at one time the channel for a large out. flow from the Great Basin.

Rain caused us a day's delay at Watson's ranch, (formerly Carpen. ter's,) but on the next day (July 1) we moved onward, though showers still continued. At Watson's, a road turns off to the upper eañon of the Port Neuf, $*$ throngh which it passes to the head-waters of that stream, where it meets the Soda Springs road, and then crosses the divide to Fort Hall. We had proposed to follow this, but found that the river was still high and the fords bad, so that we decided to continue on the stage-road. The distances by the two routes are almost identical.

The face of the high terrace at Watson's consists of Quebec Group limestone, partly quite cherty, with abundant characteristic fossils, though. mostly in fragmentary condition. This is overlaid by heavy beds of white quartzite, followed by Carboniferons limestones. The dips are all easterly, varying from $20^{\circ}$ to $40^{\circ}$,

A short distance above the junction of Marsh Creek with the Port Neuf, we met with the first appearance of the basalt-rock which fills the Great Snake River Basin. It makes its first appearance as a narrow stream, which forms the floor of the npper cañon of the Port Neuf through its whole length, having had its source in one of the old craters still standing near Soda Springs, though their fires have long been extinct. A short distance up the stream from the point where the stage-road strikes it, we found the lowest of a long series of calcareous spring-deposits, which form a prominent feature of the cañon for several miles, damming the stream at numerous points, so as to make small but pretty waterfalls. This lower dam is about 20 feet high, but with a per. pendicular fall of only about 12 feet. In the cañon, the river is sometimes one side of the basalt and sometimes on the other. Where it strikes the wider level of the continuation of Marsh Valley, it has basalt on both sides at first, but soon passes to the right, where it has dug ont a channel in the upturned edges of the bordering limestones, leaving the basalt as a perpendicular barrier on the left, which rapidly increases in height as the stream descends. The surface of the basalt has, of course, some slope, corresponding with that of the valley at the time of the voleanic outflow; but it is here much more moderate than that of the present stream, which rushes along rapidly, with oceasional leaps of a few feet. The foot and face of the hill on the east side of the valley con. sist of mostly tuin-bedded limestones of the Quebec Group, dipping

- So named after an old French-Canadian trapper. 
abont 200 N. $510 \mathrm{E}$, and containing a few fossils. These beds are overlaid by the quartzites beiore mentioned, which here form a lofty monntain-crest running northwerd for many miles. As they show here great thickness and only moderate disturbance, I consider this a very favorable locality at which to examine them for fossil remains; but none were found, and the precise age of the formation is uncertain. At the angle of the canion, a large knob of the limestones, perhaps 500 feet in aigh flat topped ridge, 0 cect basalt appears as a high flat-topped ridge, occupying the center of the valley, on the weat side of which the narrow ralley of Goose Creek has been hollowed out of the edges of the lower quartzites. A small stream also comes in from the right, and has changed its channel once or twice, so that a considerable knob of limestone and some small ones of basalt stand ont in the valley; but the streams finally eross to the left side of the valley, leaving the basalt entirely on the right. The road crosses the valley, leaving the basait entirely on the right. this for some distance, passing among walls and piles of the columnar where the basalt abruptly terminates.

At the angle of the cañon, we had turned sharply to the west, so that, instead of following the strike of the strata, as beretofore, we were now traveling directly across the edges of the outcrops. Soon after we turn, we meet the onterop of the lower quartzites, npturned at varions high angles and strongly metamorphosed. The continuation of this cross. section is confused: one anticlinal is plain and others probably exist; but quartzites, limestones, calcareous schists, all highly metamorphosed, are exposed with various dips; and time and mosquitoes forbade the morking ont of the details. These, however, though of local interest, working out of the details haveno general injortance, sineo they are-not in the drect gorthern connection.

Though we encountered mosquitoes and gnats in very tronblesome quantities at several other points on our trip, yet they nowhere equalled the mass which met us between Black Rock Station and the lower angle of the cañon. Hundreds of thousands, at least, perished at our hands, as we bastened through; and such passages are of daily occurrence at this season, but with no perceptible decrease in their numbers. My im. pression is that this, being a somewhat sheltered point, is a sort of gen. eral rendezvous for those of them who are tired of facing the strong winds which so frequently sweep over the unobstructed levels of the broas Snake River plain, into which the cañon now opens, upon turning nortirward again, after making five or six miles of westing.

Here, again, we encounter basalt; but ít seems to belong to a lower layer than that we left at Black Rock. All over the great plain, indeed, we find two or more layers of basalt, separated by greater or less thick. nesses of sand and gravel, partly loose, partly consolidated by ferrugi. nous, silicions, or calcareous cement. If two layers should be found superimposed, at any point in the upper part of the cañon, I shonld

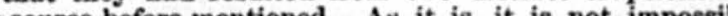
voleanic source before mentioned. As it is, it is not impossible that these layers in the outer plain have been ejected from some central source, have overflowed the plain, and $s 0$ have run up into the mouths of the valleys opening upon it. It seems hardly possible that, after flowing seventy or eighty miles, the lava should still have retained snfficient flnidity to spread out in a solid layer over the plain. What ever the source, the material bad evidently become quite viscid; for, at some points, where it ran over small inequalities of the surface beneath, it now stands in low mounds, which would not have been the case if it had been very fluid. That these monnds were not all formed by as nndermining and sinking of the surronnding mass, to which some of them have very properly been referred, is proved by the tapering sbape of the elosely-fitting blocks which form the arch. But there is stil room for study on all these points.

As the cañon opens toward the plain, white and drab friable sand. stones, probably of Pliocene age, make their appearance on the flanks of the bordering hills. As nothing of the kind was apparent within the cañon, it would seem either that the whole width of ths cañon has been thoroughly scoured out since the deposition of the Plicsene beds, or else that the stream carried so much and so rapidly-flowing water during the Pliocene epoch as to prevent the deposition of such beds. These sandstones dip about $30^{\circ} \mathrm{N}$. $110 \mathrm{~W}$., showing that the disturbances, of which we have such abundant evidence, continued to 8 very late period. The terraces themselves show no evidence of any local disturbances; their levels were not determined, however, with sufficient accuracy to enable us to judge whether or not any genera upheaval, such as bas already been suggested, might have affected this region.

Leaving the Snake River plain at Ross's Fork, we followed up the valley of that stream some six or eight miles, and then crossed a divia. ing ridge to Lincoln Valley and Fort Hall, which post we reached about noon on July 3. Thus far we had followed well-traveled roads, and had transported ovr baggage and provisions in wagons; but now we were soon to leave roads entirely, and accordingly turned in our wagons anc fitted ont a train of pack-mules. During the week thus occupied, we were enabled to examine a considerable territory in the neighborhood of the post.

At Ross's Fork we had struck the line of the old emigrant-road acrose the mountains to Uregon. This road erossed from Green River to the head of Bear River, down that stream to Soda Springs, thence acrose the head of Port Neuf, and through a low gap to the head of Ross's Fork. Near the month of Ross's Fork it crossed Snake River, and thence ran in almost a direct line past the westernmost of the Three Buttes to the foot of the Salmon River Monntains.

Lincoln Valley, as a whole, is broad and flat, with mostly gentle slopes rising to the crests of the bounding ridges. On the set bottoms, large quantities of a coarse grass are cut for the stables at the post. The slopes are covered with varions grasses, sedges, and other forage-plants, whieh make fine grazing for nearly the whole year. In this excessively dry atmosphere, these plants, which are ripe and have stopped growing by midsummer, lose their moisture so rapidly as to escape the decay common in the damp air of the Eastern States, and so become natural hay -while still standing, and mostly retain their uutritious qualities until the melting of the snow and the setting in of the spring-rains, which start the new growth while occasioning the decay of the old. Here in the foot-hills, the snows sometimes lie deep enough to prevent the stock from reaching the standing grass, and 80 a supply
of hay is essential to their wintering. Only a feg miles westward, how. ever, the snows are generally so ligbt and melt so rapidly that, in an ordinary winter, no hay is needed; and stock range through the whole winter, never even coming to the ranches of their own accord. This neighborhood was formerly one of the favorite winter-rendezvons of the trappers and fur-traders; and the plains and foot-hills then supported vast herds of buffalc, as well as many antelope, deer, elk, and bears. The region is now eo much frequented that none of these animals are 
often seen, except when the deep snows drive them out of the mountains, and the buffalo is here entirely exterminated.

Hollows on the northern slopes, where the snow lies late in the spring, and so furnishes the requisite moisture, are mostly flled with little copses of scrubby cottonwood. The higher and more roeky parts of the hills bear large numbers of stunted cedars, (Juniperus ocoidentalis.) One of these was seen, a balf mile east of the fort, which measured 41 inches in diameter, while only 12 feet high, a form probably resulting from the great dryness of the atmosphere. Large pines are bronght from the cañons in the north slopes of Mount Putnam, (formerly known as Sub. lett's Peak.)

The spur which divides Ross's Fork from Lincoln Valley seems to be the final termination of the limestone ridge which formed the eastern boundary of Marsh Valley and of the upper part of the lower eañon of the Port Neuf, and is mainly a monoclinal ridge with strong easterly dips. Its culminating point is a lofty peak, now called Mount Putnam, standing about twelve miles south of Fort Hall. Its western base was not examined; but it is evident that the lower quartzite forms a large portion of its lower face, followed above by from 200 to 300 feet of drab, thin-bedded limestone, in which no fossils were seen; then, from 100 to 150 feet of compact, coarse, pebbly sandstone, nearly pure white; then several hundred feet of dark drab, pebbly limestone, evidently of Quebec Group age, though only fragmentary fossils could be found, with the exception of a single Ophileta. A covered space follows, appar. ently underlaid by the continuation of the last-named limestone, and then comes an outerop of about 50 feet of compact, fine-grained, white Bandstone, overlaid by from 200 to 300 feet of a light-drab vesicular limestone, much resembling in texture the Niagara limestone of Indiana and Illinois, aud probably representing either the Upper Silürian or the Devonian. Neitber of these beds showed fossils. Immediately above come heavy beds of Carboniferous limestones, 300 feet or more in thickness. Their lowest layers include some pretty pure limestones, some of which are partly oolitic and contain great numbers of minute fossils, the mass looking much like the lavers of the Saint Louis limestone at the famons locality of Spergen Hill, Indiana, except that the color is a dark-bluish drab. From masses collected here, over forty species of brachiopods, conchifers, gasteropods, pentremites, corals, and bryozoans have been separated, of which $\mathrm{Mr}$. Meek has already identified fourteen with well-known Spergen Hill forms. Mr. Meek informs me that these are the first distinctively Spergen Hill forms yet brought from the Rocky Mountains. It will be remembered that a few allied forms from Little Cottonwood Cañon, Utah, have already been mentioned in this report. These beds are followed by s9veral hundred feet of very cherty limestone, rarely containing any fossils, except a large Zaphrentis (Z. Stansburyi,) which is very abundant in some layers. The upper part of the series consists of mostly pure limestones, from which a few specimens of Spirifer, Productus, \&c., were obtained. The rocks of this series form the upper part of the western face as well as the summit and eastern slepe of Mount Putnam.

Passing northward along the line of this ridge we find it much eroded and, in two places, cut entirely through by small tributaries of Ross's Fork. In these gaps, the lower quartzites outcrop clear through the ridge, while the intermediate knobs are capped with the Quebec group ridge, while the intermediate knobs are capped with the Quebec group limestone. The strike of the beds runs a little to the east of the line of spur and form the high knob which stands at the south end of the main part of Lincoln Valley. On the eastern alope of this knob appear the overlying beds, consisting of a few hundred feet of thin-bedded ferruginous sandstone, with few fossils, apparently Carboniferous, with a hundred feet or more of bright-red saudstones, possibly Triassic, foilowed by brown and drab thin-bedded limestones, crowded with Preudomonotis, Lingula, A vieulopecten (9, \&c., which are evidently of Jurassic age. The dip of these latter beds is here $15^{\circ}$, N. $44^{\circ} \mathrm{E}$.; and no unconformability is evident from the very base of the lower quartzite to the top of is evident from the very base of the lower quartzite to the top of
the exposed beds. At other points in the neighborhood, however, certain distortions and displacements led me to suspect a partial uncon. formability between the Carboniferous and the Jurassic.

Passing farther out on the main spur, nearly to the road running from Fort Hall to Ross's Fork the, older beds mostly disappear, only a thin outcrop of the shelly Jnrassic limestones being located by loose blocks in the soil on the west slopes, while the crest and eastern slopes of the spur consist of white and light-gray Pliocene sandstones and limestones, interlaminated with trachytic porphyries and coarse volcanic sandstones; all dipping about north 54\% east, at angles varying from $15^{\circ}$ to $30^{\circ}$. These dipa, which gave renewed evidence of late disturbance, even later than the commencement of volcanic eruptions in this region, continue with little change to the very extremity of the spur, where the opposite side of the anticlinal fold is also apparent in the basalts, which dip $72 \circ$, S. $34^{\circ} \mathrm{W}$. The examination was not carried far enough to ascertain certainly whether these tilted basalts are, or are not, continuous with either of the beds which floor the great plain.

On the east side of Lincoln Valley there is either a small fault or a very sharp donble fold. Abont five miles south of the fort, on the east side of the road to Soda Springs, the Jurassic shaly limestones lie at the foot of the ridge, with a dip of about $35^{\circ}, \mathrm{N} .19^{\circ} \mathrm{E}$., while its higher portions include sandstones and interlaminated limestones, probably of Carboniferous age, dipping $65^{\circ}, \mathrm{N}$. $45^{\circ} \mathrm{E}$. A more eastern portion of this same ridge shows the other side of a synclinal in these same Carboniferous sandstones, dipping $46^{\circ}, \mathrm{S} .55^{\circ} \mathrm{W}$. In the axis of the synclinal the Triassic red sandstone shows a thickness of 100 feet or more, at a point about one and a half miles east of Fort Hall, and visible from that post. The most easterly portion of this ridge, approaching the valley of Blackfoot Fork, exhibits another anticlinal and another synclinal, the eastern edge of the latter culminating in the highest point of the outer end of the spur, which received from our topographers the name of Higham's Peak, in honor of the proprietor of the nearest ranch. From this high point it becomes evident that the valley of Blackfoot Fork occupies, for a considerable distance, the axis of a broad anticlinal; and considerable thicknesses, of Carboniferous limestones are exposed on both sides. The immediate mouth of this valley is rather wide and flat, thongh the channel of the stream itself is comparatively deep and narrow, but, from a point above five miles up, the stream is for many miles deeply cañoned in basalt which floors the valley as a corresponding stream does that of Port Neuf; and it is probable that, here as there, the valley has given exit to the overflow of some volcano near its head, which is very near to the head of Port Neuf and the Soda Springs. The extremity of the dividing ridge beyond Higham's Peak consists of the Carboniferous sandstones, nearly or quite to the level of the plain. If any voleanic rocks have ever rested upon it, they have been so thoroughly eroded as to leave no trace; but the ridge next east of Blackfoot Fork terminates in a mass of porphyries. 
CHAPTER II.

MARKET LAKE-CRATER BUTTES-TETON MOUNTAINSHENRY'S FORK-HENRY'S LAKE-MADISON RIVER-GEY. SER BASL-REUNION.

Having completed our outfit, through the kind assistance of Captain Putnam and his aids, who did all in their power to forward our plans, though at the same time showing such courteons bospitality that we were loth to leave them, we started again, on the 12th of July, and were loth to leave them, we started again, on the 12th of Juil, and seren miles. This stream was named after the well-known Indian tribe whose warriors once infested this region to the great discomfort and danger and frequently loss of the trappers and traders passing through or wintering near here. At present members of the tribe are rarely, if ever, seen on this side of the mountains, and the generally peaceable tribes of Shoshones, Bannoc'is, and Boises, whose reservation reaches to tribes of Shoshones, Bannoc's, and Boises, whose reservation reaches to on the entire trip.

Either westerly winds or the wares of the old lake, which is supposed to have covered this broad plain, have accumnlated in this neighborhood considerable bodies of fine sand. As we approach the mouth of Lincoln Valley we encountered broad stretches of this sand, partly covered with a scattered vegetation, partly bare and drifting. 'On one of these drifting patches lies the bleached trunk of a large cottonwood though no such trees are now to be found for miles around. Has the gradual drying up of the country ov'y recently permitted the sands to grift and acemplate here And did its accumulation kill off a formerly drift and accum extensive growth of trees at this point 1 Here also appears the first of a long range of sand.knobs, which are seen at short intervals for some
iniles, until they finally are lost in the irregular sand-plain along the lower course of Sand Creek.

The road we are now following, between Ross's Fork and Taylor's bridge, is much used by drovers and freighters, when they are going south with empty wagons. Being less traveled than the stage-road, south with empty wagons. Berng hess thing is generally better, while which follows directly up the river, the grazing is generally better, while Hall are not very steep, being only about 88 feet to the mile.

$\Lambda$ fine roung greyhound had accompanied us from the post, but the march of thirteen miles, from Blackfoot Creek to Sand Creek crossing, nnder a scorching sun and without water, was tóo much for her endur. ance, and she died of thirst, about a mile from our camp on the latter stream. This creek is said to have been entirely dry on June 24, 1871, when crossed by Dr. Hayden's party, and we accordingly attributed its fullness at the time of our arrival solely to the unusually large supply of water furnished by the immense snow-fall of the previous winter; pht, from 12 to 15 feet of water, and were obliged to look to some other source for the ehange. Our guide, Richard Leigh, generally known as "Beaver Dick," who has long lived in this region, informed ns that for many years this channel had carried no water except during rains, when it gathered small amounts from its immediate banks, but that two or three years since, Willow Creek, whieh had previonsly emptied its water into Snake River by two months, one abont a half-mile and the other about two miles above Taylor's Bridge, broke over its. banks in time of flood and poured part of its surplus into Sand Creek. Since then, the latter stream has, during the spring, carried more or less water, which, however, has all sunk into the sands of the lower part of the channel before reaching Blackfoot, to which it shonld natnrally be tributary, if we may judge by the shape of the country as seen from Higham's Peak. Indeed, from that point, certain water-courses were seen which lead me to suspect that, after once sinking, it again escapes from the sand and revews its individnality, at least for a short space. At present, it is evident that the connecting channel has been so deeply cut that Sand Creek carries far more water than does the original channel of Willow Creek below the separation; and, if this continues to be the case, it is not improbable that it may succeed in clearing away the sand-obstructions from its lower channel and in establishing complete surface-connection with Blackfoot. The tracing of these old channelsand of others which doubtless exist in this broad flat plain-and the de. termination of the relative dates of their occupation will be of mnch local interest to geologists who may, in the fnture, make their homes hereabout. On the upper course of Sand Creek, later in the season, we found many shells in the soil of the banks, giving further proof of the lateral movements of the old channels, while yet the general conrse of the drainage was unchanged.

Crossing Snake River at Taylor's or Eagle Rock Bridge, we encamped on its west bank, abont seven miles above. The stream was very full carrying an immense body of water, whose surface was constantly broken by the eddying whirls characteristic of irregular bottoms. After a long, hot day, the temperature of the stream, at $6.20 \mathrm{p}$. m., was $62 \circ$, the ai being at $78^{\circ}$. At 4.20 , on the next morning, with the air at $47{ }^{\circ}$, (the minimum thermometer marking $44^{\circ}$,) the river was still at $62^{\circ}$. Only a very large and much-disturbed flow of water could thus eseape all effects of so great an atmospheric change of temperature.

At medium and low stages of water, the river is confined, at the bridge, to a single narrow and deep channel, worn in the basalt; but, in times of flood, it here occupies two bridged channels, and elsewhere spreads considerably upon its banks. On either side there are old channels, more or less plainly marked, which were occupied by the stream at times before it had worn its present channel so deep into the rock. In passing northward, we found many of these, mostly dry, though some of them are occupied, during the rainy scason, by the drainage of the neighboring plain and retain some pools through most of the year. The road here follows the bottoms, withont anywhere rising to the level of the surrounding plain.

On the morning of Jaly-16, we left the stage-road at Market Lake Station, and turned eastward toward the Tétons, whose highest peak had been visible at intervals, just above the horizon, ever since we crossed the river. The basalt-terrace, which here stands from 50 to 60 feet above the stream, is much broken near its borders, the edge being more or less andermined and sunken. At short distances within the borders are many depressed areas, occupying a few acres each, whose walls appear to have once inclosed small ponds; but these have long since been drained through the underlying sand and gravel, when the river cut its channel to this lower level. Here, again, we see many of the unbroken knolls of basalt, evidently consequent upon the shape of the underlying surface at the time of the overflow.

Since leaving Sand Creek, we had had constantly in view two rounded buttes of moderate elevation, which were now immediately in front of ns. As we approached, we found that they stood in the lower angle between $14 \mathrm{G} \mathrm{s}$ 
Henry's Fork and the main Sriake River, and were separated from the Henry s iain to the west by a broad depression of springy ground, which basalt plain to the west by a biver in times of flood. This was probably once a channel, it not the malley on the east side of the buttes, formed one ble that this, with the valiey on the east sidese hills; for these Orater broad river-plain before the more norther Buttes, as we called thew, are was examined with some care. It rises aboat soo feet abovo the river, upon an oval base of about one by one and a half miles in diameter. It crest is rugged, showing some small cliffs, while its slopes consist mostly of sliding sand, both fine and coarse, and are mostly more or lese mostly of sliding sand, woth a straggling growth of bushy shrubs and small pines and covered with a stragg is about a half mile long by about a quarter cedars. Its crater is about feet deep. At one or two points, smal mile wide and perhaps 150 feet deep. At one or two pors; but the quantities of pretty compact lava were found in thin layers; but the mass of the rock exposed, inside and out, is mainly a sandstone, thinly laminated and very friable, consisting of comminuted scoriaceous and compact lavas, including many well rounded pebbles of quartz and comartian partialiy-rounded masses of basalt the beds of river-gravel which are in bles evident comparaterlaminated with the basalt layers, and assist in proving the stratification tively recent date of the construction of these cons. of the sandstone mostly corresponds closely with the slopes of the interior and exterior surfaces, changing from very steep to nearly horizontal as we reach the foot of the butte. The layers are, I think, more tal as we revild have been if deposited sub-aerially, in the regular than the whole, strongly impressed with the midst of rain; and $I$ am, on the place belief that the eruption and deposition were subaqueons alse when this whole plain was corered by the waters of a lake. A small secondary crater, from 200 to 300 feet across, was noticed on the crest of this cone near the northwest corner. The main crater opens towar the sontheast; but nolava-stream was found there. The more sonther the southeast; but $\mathrm{Fr}$. Bechler, who reports its crater as rather large cone was visited two cones are united and not quite so deep as that just described. The two cones are united at the base, and their combined deposits make something of a platrorm about them. This is more or less washed up to about 50 or 60 feet, as though the waters had been for some time ponded about their base, and waves had been dashed against them. This erosion has separated some waves had been dasted from the platform. One of these, in approach masses of the sandstone from the prominent feature of the landscape, and ing from north or south, made a prominent feature of the landscape, and was named, by Mr. Adams, "Kenilworth Castle," from a supposed resemblance to those famous ruins. The sandstone is irregular in its degree of solidity, and has weathered out into chamber-like hollows, sometimes reaching far enough in to make comfortable shelters, some of which have evidentiy afforded temporary protection to Indians, while others are evidently atick forming the beds of wild partly flled with accumulations of sticks, worn passages completely beasts. The weathering has, in some places, worn passages completely throngh projecting masses, which thus take the form of flying buttresses. Under the eastern overhanging side of this block, there were numerous rude carvings, representing men, horses, bisons, cranes, jack-rabbits, bears' claws, \&c., evidently cut by Indians in recent times. The roek bears claws, contiquity weathers away too rapidiy to allow us to aty the scratchings of an idle to these figures. They are evidently only the scratchings of an the hour. This fragile sandstone apparently never continued acroe the western channel to the basalt-terrace; and from this fact, as well as from the indications already named, I infer that the valley in the basalt-plain had heen mainly eroded before the ponding of the waters and the volcanic eruptions which these buttes record.

The valley on the east of the buttes is flat and partly swampy for a considerable distance on either side of the stream, forming very valua. ble stretches of farm.l ad, though the lower portions are liable to over. flow during the sprin $s$-lloods. Large quantities of hay are cut here for nse at the neighboring stage-stations, and two or three trappers com. monly winter in the immediate neighborhood, since their stock here find abundant feed all the season. The water of Henry's Fork, having been turned from its direct course by the volcanic eruptions, now flows for some miles up a channel parallel with the Snake before being able to find exit into that river.

The surface of the basalt is exposed here in places, and shows a striated structure, with lines of elongated bubble-like eavities, such as we might expect to find on the surface of a viscid fluid inflated with gas, and running slowly down a very gentle incline. The course of this structure is about north $38^{\circ}$ east, nearly corresponding with the direction of the lower half of the valley of Henry's Fork, and indicates a probable source of volcanic ontflow toward the bead of that stream. Here we caught the first of the fine tront which fill these monntain. streams, and which afterward so frequently eked out onr scanty campfare.

We here left the ralley of the main stream, which now bends off to the southeast, and turued up that of Henry's Fork. This stream was named after one of the partners of the Missouri Fur Company, who, in 1810 , built a fort on the banks of this stream about twenty-five miles from its mouth.

About ten miles above the Crater Buttes, a low donble-erested knob makes a prominent appearance, though it rises only 75 or 80 feet above the plain. It consists principally of laminated traehyte, with much scattered brown and brick-red scoria. This was probably an old volcanic vent, though so much material has been worn away that nothing like a crater can now be traced.

Four or five miles due north from here stand the so-called Sand Hills, more properly the Sand Hill Mountains. As we approach we find them surrounded by a belt of sand-dunes, from a half mile to a mile in wisth and reaching, on the south side of the mountains, elevations of 250 avd 300 feet above the plain, though not more than 100 or 150 feet high st the enstern end. The central portion of this belt is almost entire's barren, consisting of fine, drifting, gray, and ferruginous quartz-saud, with some comminuted lava ; only here and there a few straggling shoots of a long-rooted grass appear. The glare of these uniform surfaces was almost as dazzling beneath the mid-day sun as if they had been of snow. From the hollows the sand has been mostly blown away, while the coarser materials are left, forming a sort of pavement of sometimes large masses of porous, gray trachyte, and again small bits of the same mingled with fragments of brick-red scoria, chalcedony, agate, and silicifled wood. The first impression was that these vast accumnlations of sand marked ronghly an old lake-level against this island.like monntain but I afterward beeame satisfled that the sole agent in the case had been the rehement southwest winds, which sweep over the broad plain and break against these isolated points, piling up the sand in these huge drifts. The surfaces of the drifts are everywhere beantifully marled with wind-ripples, except at the very summits of the varions little ridges, where the winds pile it into steep crests, on the lee side of which the sand lies at 80 sharp in angle as to slide at the least tonch, and so 
retains no wind-marks. At the angle of $33^{\circ}$ the sand will rest for an instant but apparently holds no permanent position when the angle of instant, but appar than $33^{\circ}$. The upper and lower edges of the dunes slope is greater than 3 . The are marked by dense thickets of sage-brush. Aboves, covered with base of the mountain shows solid foundations 12 to 15 feet high. Then follow eer. considerable groves of cedar, from 12 to 15 feet high. Then lollow cer. ered slopes, thickly beset with Jersey tea (Cecnothus velutinus) and sumac, (Rhus glaber, ) and spotted with blossoms of Geranium Richardsonit, ani various Compositis and Umbelliferse, and, finally, irregular masses of various Compositro and capts at the height of about 1,200 feet coarsely-porous trachyte cap the souble one, the southern portion being above the valley. The range is a doubleone, the southern portion bef for the longer and larger, which runs about northeast and slope, mueh broken into perhaps ten miles, with a moderate soutbern slope, mach broten into long spurs, and a steep northern one, descending almost unbroken into a valley perhaps 200 feet above the plain, and about a mile wide, which a valley perhaps 200 fas thence been filled with the barren drifting opens westward, and has thence into drifts reaching to the very crest of sands. These bave been bame elevation as the other the more northern ridge, which attai, but apparently somewhat spurred with generally steep sonthern slopes, but appare The range, as a whole, on the northern, where it descends to the plain. The range, as a whole, has no apparent connection with any other, the rocks have no definite. bedding, and I an inclined to believe that the two main ridges, facing

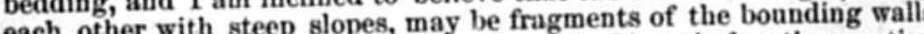
each other wertinguished long before the eruption of a huge crater, whose fres were and even before the eruption of at at the Crater Buttes commenced, and even floor the plain.

least the later of the basalt-layers which floor the plain.

Looking southwestward from these crests, we see the rough, almost impassable, basalt plain, thickly overgrown with sage-brush, stretchin away toward Market Lake. To the west and northwest spread the barren sands of the dunes, which are several miles in widtin where crossed by the stage-road, near Sand-Holes Station. These also extend northby the stage-road, near edge forms a ridge from 100 to 150 feet high, ward, and their eastern edge forms a main divide of the Rocky Mount. joining the Sand-Hill Monntains to the main divide of the of the valley ains near Camas Creek, and forming the western border of the valles of Henry's Fork. These absorbent sands, and the cracked and cavernof Henry's Fork. Tha and fravel foundations together, may well acconnt ous basalt with sand and gear the head of Henry's Fork to the Malade for the fact that, from near the head Shoshone Falls, a distance of fully River, which enters below the Great Shoshone jains the Snake by a surthree hundred miles by the river, no stream joins the Snake by a surface channel, though several good-sized ones reach the plain from the Salmon River Mountains. Along the bank of the Snake, bowever, at several points, there are large cold springs escaping from the basalt several pore and, in the lower part of the ralls of the cañon, thts escaping from the said to leap boldly from the ralls of the canen fined for many miles. subterranean channels to which they have been c fined for many miles. The low plain bordering Henry's Fork on the west is from two to eight or ten miles in width, partly well grassed, though with many dense pares of sage-brush. About half way between the Sand-Hill Mountains patches of sage- there is a low hill, in the shape of a horseshoe, opening and the river, there is a lently was once a crater; but it has now been to the south, which apparenty was wil that no rock is visible.

so much worn away and covered wonntains we crossed Henry's Fork, at Nearly opposite the Band-Hill Monntains we crossed Henry's Fork, at Eagle-Nest Ford. The river is here, perhaps, three bundred yards wide, with from one to three feet of water, with pebbly bottom, a bluff bank on the west side and a low one on the east, which is overflowed during on the spring freshets, so as to donble the width of the stream. At that date, July 17, the pools left by the freshets had not quite disappeared. From a short distance above the ford, the river flows over a basalt.bottom for some miles, occasionally entting rather deeply and leaping over small fails, but generally having low banks.

Thus far, we had been accompanied by a large wagon from Fort Eall, which carried some of our hesviest supplies, so that our pack-animals might become accustomed to light loade before receiving heavy ones. Having now reached the limit of convenient wagoning, though it wonld have been possible to take vehicles even to the very base of the Teton range, we sent the wagon back, and spent one day in re-arranging packs and in examining the proposed ronte up Téton River, or Pierre's Rivez, as it is more properly ealled, since this latter name was long since com. monly applied to it among traders and trappers, as well as upon maps of the region. The trappers of the present day, having little or no knowledge of the names used by their predecessors, have, of course, applied their own terms to the landmarks with which they are familiar;

but the adoption of these by geographers wonld be contrary to all rules.

Upon examining Pierre's River about six miles south of our camp, at a point not far above its junction with Henry's Fork, Mr. Stevenson re ported it as occupying a deep though narrow channel, walled on either side by perpendicular cliffs of basalt, 60 feet in height, which frequently come to the water's edge, so as to make travel along the bottoms im. possible. Onr guide, Beaver Dick, stated that these cliffs increased rapidiy to several hundred feet in height, rendering the stream nnapproachable by stock for over thirty miles. As we were not in condition, being $s 0$ heavily loaded, to make so long a mareh without water, we turned northward for a few miles, to pass up the valley of the next tributary, which Beaver Dick called the middle fork of the Snake. Since neither by position nor by size is this,stream entitled to be considered a fork of the main Snake, we have applied to it another name, Falls River, for reasons which will appear later in this report. Camping just above where we struck the stream, we found it about 3 feet deep and from 50 to 60 feet wide. On the opposite bank, a bluff of basalt, about 30 feet high, showed a distinct prismatic structure through the upper 10 feet, while the central portion was amorphons and the lower 5 feet, again prismatic, the whole looking as if the upper and lower portions bad been affected by rapid cooling and consequent contraction of the surfaces of the sheet of lava, while the central portion, cooling much more slowly, did not reach the same state of tension. Just above camp, on the south side of the stream, there is a considerable bluff of light-pink porons porpluyry, with an indistinct bedding, apparently $\mathrm{np}$. turned nearly to verticality, with a nearly north and south strike. The upheaval evidently occurred before the flow of the basalt.

As we leave the valley of Henry's Fork, July 20, the country rises, and becomes more broken and rolling. The abundant growth of grasses, sedges, and other flowering herbs shows plainly that only slight irrigation would be necessary to make this valuable farming-land; and some crops would succeed without that. Most of it wonld be fine land for stock-raiaing, the only exceptions being those portions along deeplycañoned streams, where water is diffleult of access. We bore a little to the southward to-day, teward the upper waters of Pierre's River. About eight miles from camp, two roeky knolls, rising about 50 feet above their connecting saddle, and perhaps 350 or 400 feet above the nearest creek, mark two points of the rim of an old, broken-down crater, which faces nearly due east. The iava is a latninated mixture of quartz, obsidian, and feldspar; but ne mass seemed to be in situ, so that direction of strncture could not be determined. 
As we approach camp on Conant Creek, there is a marked change in the flora, from that of the dry plains, which are mostly bare through the winter, to that of the vetter hills, on which the snow then lies in drifts. Aspens hegin to a; pear in considerable numbers, and antelopes are becoming rather abundant.

July 21.-The country is becoming much more rolling, with a slight general slope of the surface toward Pierre's River. Keaching the lowest tributary of that stream, we found it flowing between nearly vertical banks, from 250 to 300 feet high, the lower parts of which are composed of light and dark pink compact porpbyries, mostly ringing under the of light and dark consist of gray basalt, somewhat porous and partly coarsely vesicular. On the hills between the streams, porous porphyritic trachytes reach the highest crest8. Crossing the eañon, we camped on a small run which falls over the biuff just below. The cañon has here a very tortuous course. Mr. Bechler descended to its junction with that of the main Eiream of Pierre's River, and found it everywhere with that of the main vertical walls, here from 600 to 700 feet in beight. bounded by nearly vertical the fip so far as reported, was killed near this point. These reptiles are said to be slways rare in the higher parts of the mountains. Strawberries were abundant at this camp.

The peak of the Grand Téton had becon gradually rising as we hail approached, until now it was so near that strong glasses could give us pretty good ideas of its structure. It was now plainly evident that thi pretty good ideas of its structure. was not a volcanie peak, as had been red wh cañon consisted largely of granites, gneisses, serpentines, \&c.; which rave sure indications of the existence of these metamorphic rocks about the sources of these streams; so that the probabilities were strong that the central peaks would prove to be grauitic. A few limestone-peb bles were also seen, but these were mostly pretty well ground up.

From near this camp there is a general depression of the surface, stretehing across to the nearest point of Pierre's Hole, (or Téton Basin, as it is sometimes called,) and suggesting the possibility that it may have been a broad stream-valley, after the outflow of the basalt and before the erosion of the cañons. If this were ever the case, the weathering of the slopes has destroyed any distinct ehannel, and so has rendered a decision of the case vary difticult. By very moriente slopes we descended into Pierre's Hole. 'This has a nearly plain surface for a length of about twenty miles and a breadth varying from about five to twelve or fifteen miles, beyond whicl. limit gentle slopes atretch up far among the foot-hills. The general slope of the plain, as a whole, is so extremely gradnal that the flow of the strean:s which pass through is extrethely gretches of swampy groun along their banks, which are not at all bettered by being oceupied by along their banks, Which are not at all locttered by being as they emerge from the mountains, are divided into several channels, which take very dif ferent courses to the river. Most of the plain is thickly covered with a luxuriant growth of grasses and other good forage-plants, though some small areas are sandy and comparatively barren. Abundant supplie small areas are santy and comparatively barren. Abutessary, ean be of water for irrigation, it this should ever become necessary, can be shert for corn, but wheat should succeed well here. Considering the richness of the soi! and the abundance of water, this is one of the most inviting valleys of the region, and wonld doubtless soun be settled if railroads shonld come within convenient distances. TLis was formerly one of the farorite summer-rendezvons of the old fur-traders, and was the scene, in 1832, of a sharp fight with Blackfoot Indians, which is vividly described by Irving in his Bouneville's Adventures. In his description of that battle tive woods are said to havo been "tangled with vines." On the other haud, the entire absence of every kind of vines from all this region, with the exception of scattered plants of Olema. tis along the banks of ditches and creeks, is one of the notable features along the whole length of onr ronte. It is reported that vines grow luxuriantly on some of the islands in the Yellowstone Lake.

The extreme northeastern angle of this basin is occupied by a shallow pond about five huudred yards in diameter, with marshy borders, whose surface was covered with tracks of antelope, deer, and elk. This pond is supplied by springs bursting out at the base of the surrounding foothills. Cne of these, of the temperature of $45^{\circ}$, is about 50 feet across and throws out a rapid stream 10 feet wide and 1 foot deep, with a clean bottom of fine volcanic sand. The water evidently comes from the rapidly melting banks of snow upon the moutains, and finds its way by subterranean channels through the porous voleanic rocks of the lower slopes.

Crossing this basin, we at length eamped, on July 23, in the mouth of the cañon of the largest tributary of Pierre's River, which is known as Téton Creek, or Big Téton Creek, because it heads directly toward the high. est Téton and its valley gives a fine view of that peak. Though it heads in the very center of the rauge, still it does not gather the drainage of the Téton peaks themselves, but that escapes into a stream ralled Téton River, which flows to the east and joins the Snake River in Jackson's Hole. Under the circumstances, we can hardly displace either name and must be satisfied to distinguish them by the use of the adjectived titles Fast and West.

The valley which we now entered is wider than those of the other trib. utaries of Pierre's River, and, unlik - them, has a broad tongue of the prairie running up it for two or three miles, so that good camping. places ean be found with abundant pasture for the stock, while steep slopes on either side will check their propensity to stray. It had, there. fore, been selected for the location of a permanent camp, while small parties were going ont in various directions to explore the neighborhood. The lower slopes of the foot-hills of the rauge, up to a height of from 400 to 500 feet above the plain, consist of variously-colored porphyries. representing the extreme edge of the great voleanic district, which had become so wearisome to us by reason of its sameness. Though the line of junction with the older rocks was not found, yet these latier outcrop at such points as to show that the porphyries were deposied against originally steep slopes. I did not succeed in finding any beds of porphyry so tilted as to indicate auy modern continuance of the upheaval of which the old - rocks give abundant evidence.

From beneath the upper elges of the porphyries emerge first about $\because, 000$ feet of compact, often quite cherty, gray to drab Carboniferons limestones, mostly rather barren of fossils, except a few of the lower layers, which are crowded with Zaphrentis, Cyathaxonia, Syringopora, Produetus, Spirifer, and other forms, mostly silicified, and so weathering out finely upon the surface of exposed slabs. These beds, however, are but slightly exposed, except on the higher crests: where they appear low down in the cañons, they are almost always covered up by the débris of the bigher layers.

Beneath them appear abont 600 feet of a heary-bedded, drab to light. buff vesicular magnesian limestone, entirely destitute of fossils, so far as I could ascertain, except minute fragments of crinoid stems; but, 
from both its ci. acter and its position, I refer it, with but little doubt, the Upper Silurian. It may, to the age of the Upper however, have been deposited continuously Carboniferous age. The bed Silurian to the commencement of the cañons wherever it is exposed, forms tall, castellated cliffs along the cañons wherever it is exposed,
adding much to the beauty of the scenery. This is followed, in descend. ing order, by about 400 feet of a blue, very impure, thin-bedded and ing order, a limestone, much of which is a nass of pebbles, and from partly shar of which Mr. Taggart and I, after long-continued the lower portion of Conocoryphe and Dicellocephalus ( $\varphi$ ) These would not be sufficient of themselves to determine the precise age of the strpta, but, taken in connection with the lithological chisacter of the beds and the identification of precisely similar layers only a short distance to the southward, they justify the conclusion that this limestone is of Quebec Group age. The thin lamination of the strata causes their easy weathering; so that they generally present slopes of débris rather than bluffis of solid rock. In generally present slopes of debris rather than blufts of solid rock. In. many places, however, these debris are more or less thoroughly reconsoli.
dated by a cement of the lime first dissolved and then redeposited by percolating rain-water. The rock is somewhat cavernous, and gives percolation to nnmerons streams flowing from the melted snows, which passage to nañ escape in lare springs at me reaching only $35^{\circ}$ and $40^{\circ}$, while the air these points is still very cold, was at $72^{\circ}$. One of these springs was intermittent; but its periods were not ascertained. At auother outcrop of these limestones, they are immediately underlaid by about 300 feet of partly compact and partly shaly glanconitic sandstones, which are evidently equivalent to the socalled Knox sandstones of Safford, which form, in Tennessee, the lower part of the Qubee grous part of the gnbec gually distributed, since no corresponding bed are apparenty unequally distributed, since no corresponding beds appear along the cañon of West Téton Creek. Beneath them, and often present when they are absent, we generally find from 50 to 75 feet of : very compact ferruginous quartzite, which must represent the Potsdam, though this also is sometimes wanting.

Where these lower limestones are first encountered, near the mouth of the cañon, they are nearly horizontal; but, as we pass in toward the center of the mountain, we find them rising considerably, until they reach angles of $15^{\circ}, 20^{\circ}$, and even $30^{\circ}$, dipping westerly and sonth westerly, and resting uncouformably upon the edges of granites which dip in various directions. At the forks of West Teton Creek, where the eranites are first seen, their bedding dips $35^{\circ} \mathrm{N} .78^{\circ} \mathrm{E}$. Up the left hand fork they rise rapidly, causing beautiful cascades a huudred feet or more in height, and finally occupying the whole upper basin of that btream and reaching the very erest of the ridge. They also occupy the valley of the right-hand fork for a considerable distance, forming smooth, bare cliffs on the left as we ascend, and finally are exposed in broai surfaces on its floor. The right-hand wall of the cañon is abrupt for 1.200 feet or more reaching well up into the Carboniferous limestones, the npper parts of which form crests here reaching more than 3,000 feet above the cañon and about 10,000 feet above the sea.

The granites, gneisses, and schists, which form the central nuclens of the mountain, vary greatly in character and position. They are partly micaceons, partly hornblendic, and partly talcose and chloritic. No reguar tinged with pink, and occur in thick, solid beds. The other rocks are much broken up and tilted in various ways, and are crossed in every direction by innumerable large and small veins, mostly of quartz, but a few granitic. None of these are metalliferons, so far as I could ascer. tain $A t$ two or three points there are beds of trap-rock from 50 to 70 feet thick, which appeared at first sight to be dikes; but, upon further feet thick, which appeared at first sight to be dikes; but, upon further
examination, it became evident that they lay conformably between regularly-bedded members of the granitic series, and it seemed as if they might have been deposited as broad sleets of lava, like those which we have seen flooring the Snake River plain, but deposited ages ago in the bed of the ocean, where were then accumulating the sedimentary sandstones which were metamorphosed into these granites before the Silurian age began. But, again, the trap shows no columnar structure, but is indistinctly laminated parallel to its walling planes; and this would seem to indicate that it might, when quite viscid, have been forced with difficulty between the solid granites after their uphearal, and so have received its laminated structure, while between calls of such slow.conducting power it did not take on the columnar tructure. $O r$ it is possible that, having been deposited horizontally among the sedimunts, as aforesaid, it may have lost a columnar structure, originally possessed, during the metamorphism of the surrounding beds. The trap weathers much more rapidly than the granite; so that its out. crops are plainly marked and readily traced from a distance by a sharp notch on the crests as well as by its débris on the slopes of the mount. in Grand Téton, was thus traced across the Great Cañon, and up the side of its perpendicular western wall, where at least 2,000 feet high; and its termination was then capped by the Potslam quartzite, showing that it is at least older than that rock. Both this trap and its inclosing granites contain much epidote, partiy compact, partly crystalline, and some porite. Near to this bed of trap are two very noticeable beds of ranite, one being of the deepest flesh-red, the other almost pure white; hoth contain very little mica. The white bed bas its constituent minerals much segregated; so that we find in some places large masses of pure feldspar, (orthoclase,) cleaving with broad surfaces, and again fine speeimens of (raphin granite, (pegmatite.) From a neighboring bed come mentell crystallized. $A$ few large masses o. mice (mut we found no la.ge or particularly good small garnets were seen, but we found no la

rystals either of this or of any other mineral. While the beds are generally so much disturbed as to prevent the accurate determination of any regular or prevailing dip, yet the general trike is approximately east and west; and this has determined, to some estent, the structure of the range. The spurs running east and west from the crest peak are each dotted with three or four subordinate peaks, which would be thought large, if they were not belittled by their peaks, which would be thought large, if they were not belittled by their extremely sharp-even sharper than the natural weathering of the granites, if level, wonld have made them. The highest of them all are risible from rent distances in every direction, both on account of their reat great elevation and sy reason, there is little danger of them. From whatever point they may be seen, theres being markedly mistaking their identity, their abrupt, pointed ontlines being markediy
different from those of any other peaks of the region. From their prom. inence, affording good landmarks for travelers, they have sometimes been called the Pilot Knobs, (see Irring's Astoria, chap. xxix;) but the name commonly upplied, from the earliest times, is that of Tétons, or Pape As only thee of the reaks are nsually seen at a distance, they Paps. As only three of the reaks are ustally seen atly ar ar more dis. 
tinct peaks in the range; but those upon its northern and southern por-

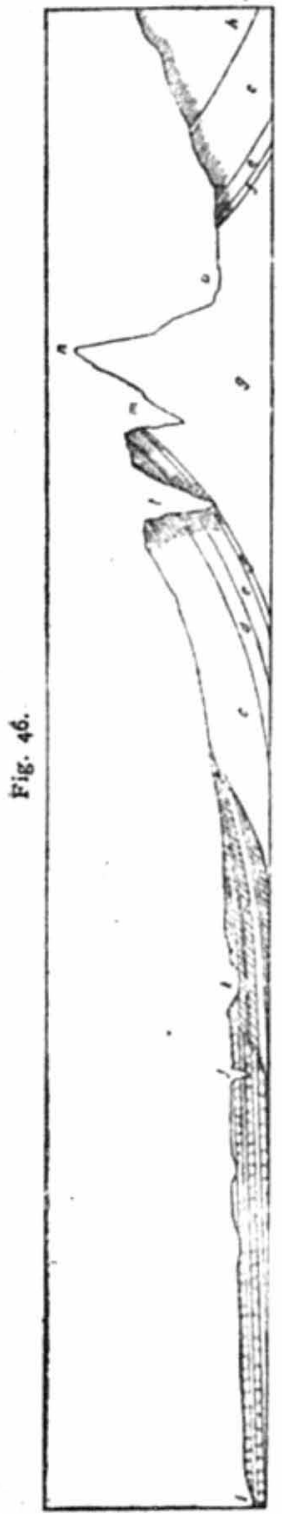
tions are uemewhat lower than the central ones, and hnve more of the high western parts of the range opposite to them, so that $\frac{6}{6}$ they are mostly hidden in that direction . until we approach quite closely.

The following section, (Fig. 46,) though If will give a good general idea of the country $<$ thus passed through in coming from Henry's s. Fork to the crest of the Téton range. The Froad, gradually-rising, high terrace of ba. E salt and trachytes, cut by the deep cañons o. into the rounded depression of Pierre's Hole, $f$ whence the slopes of porphyries rise more rapidly to the still steeper outcrops of the Carboniferous and other limestones.

These, again, are cut by the deep cañons of West Téton Creek and others of similar character, some of which slightly expose the granite, while some do not. Between this western drainage $(l)$ and the Great Cañon, $(m$,$) which breaks tbrough the range$ to the eastward, there is, in some cases, a block of limestones as here represented, while, in others, the divide is entirely of metarnic rocks. Finally reaching the metamorphic rocks. Finally reaching the crests, we look down, over clean sheer gran. ite-walls, to the broad sage-covered plain of Jackson's Hole, bordered on the other side with the rolling foot-hills of the main range of the Rocky Mountains.

We had postponed our attempt upon the highest peak until we could make it under the most favorable circumstances, and Messrs. Stevenson and Langford had made some preliminary examinations, so as to select the best route. Soon after sunrise, on July 29 , from a temporary camp previ. ously formed at the nearest convenient point, in the right-band fork of the cañon of West Téton Creek, we started for the sum. mit. Cold streams fall in beautiful cascades, for from 200 to 300 feet, over the cañon-wall on our left. Climbing over piles of loose debris, from the deep envities of which we heard the frequent kid.like bleat of the rare little coney, Lagomys princeps, so seldom seen, and over rock-slopes nearly as steep as any we saw that day, we reached the top of the cliff and found a broad valley, leading from the very verge of the cañon-wall di. rectly toward the peak, bounded on either side by more or less precipitous walls of Quebec Group limestone, above which ap. peared some isolated patches of the bed which we have referred to the
Niagara group. Here we began to enconnter the masses of snow whose melting supplied the cascade-streams. Up to their very edges, the sata. rated ground, though not entirely hidden, was profusely ornamented with the large glossy blossoms of white and yellow butter-cups, (Ranunculus, ) many of which, indeed, as if tired of waiting for the removal of their covering, had burst through the edges of the snow, where the drifts were not more than two or three inches deep. But these impatient in. dividuals had generally suffered, in their upward passage, and were rarely as perfect as their more favored companions, either in flower or in leaf; for, while vegetative growth had evolved heat enongh to melt a passage for the plant, yet contact with the snow had been suffeient to check the development of its parts. In passing over the drifts, we found many grasshoppers lying motionless and apparently frozen, in small pits in the surface from two to three inches deep, the suow having apparently been melted from beneath them by the heat of their bodies. As the sun got higher, however, they were soon thawed ont, and became as active as any of their race. It is possible that they found microscopic plant-food upon the surface of the drifts, and had purposely come here for it; but it is more probable that they had been blown over from neid. borirg patches of vegetation by the high winds which almost con. stant iy sweep over these crests. The high levels on either side of this valley were entireiy destitute of the high.growing plants of lower levels, but presented a large variety of the Alpine plants, now mostly in ful blossom, showing a great profusion of white, blue, purple, crimson, and yellow stars on their carpet of moss-like leaves. The crests of this part of the range reach about 10,500 feet above the sea, running some 300 or 400 feet above what is here the apparent limit of pines and spruces. From here it was evident that the range lying on the west side of Pierre's Hole reached to about the same elevation, with no sbarp peaks, and mostly rounded surfaces on its eastern face.

The walls of the valley along which we had male our unobstructed way now approached each other, leaving a gap only fifty or sixty yards in width, to reach which we climbed a sharp slope of stumbling rub. bish, and then found onrselves on a narrow crest, overlooking an im. mense cañon, the Great Téton Cañon, which separates the three higher peaks from the mass of the mountain west and north of them, and finally breaks out to the eastward toward Jackson's Hole. The descent from this crest is very steep; and, in dodging falling masses of rock, started by those behind him, Mr. Bechler unfortunately got a secere sprain, which troubled him for several days. Just to the left of this gap, the crest of an immense snow-drift, from 80 to 100 feet high, reached up to the rocks, and gave some of us an easy passage down. Of course, no pas. sage with horses would have been possible at this point; but I think it conld be made by striking direetly up the ridge at the forks of West Téton Creek, about three miles west of our main camp, and turning down into the Great Cañon about two hundred sards west of the gap just described. From the gap, it was evident that the huge lateral spur of the sonthern Téton must be crossed before we could reach the base of the central peak. An attempt to pass around it would involve several miles of
peral travel in very deep cañons. In these upper basins the snow had melted much less than on the outer slopes; and about a mile of it stretehed be. tween us and the spur aforesaid. On our right, and behind ns, rose a nearly vertical cliff of Quebee gronp anndstones and limestones, ruming off southeasterly, past the souther of the montain beyol of the monntain beyond. Beneath our feet was the Potsdam (?) quartzite, while only metamorphics lay ahead of us. Bearing but a little to our 
right, we found ourselves on the divide between the head of the Great Cañon and that of a smaller one, which opened direetly ont toward Jack. son's Hole. In the hcad of this latter, perhaps 200 feet below us, lay a small ice-covered lake, with no surface-outflow, but probably draining throngh the siopes of débris which hemmed it in on either side. The through the siopes lin point has been accompanying anthe taken from the top of the western wall of the Great Cañon. (Fig. 47.) taken from the top of the western wall of the Great Canon. (Fig. 47. .
In the broad head of the Great Cañon, which we now crossed, there are three or four small and apparently shallow ponds, partly covered with ice, though partly clear. The outtlow of one, buried in rubbish for some distance, finally appears on the edge of a cliff and nakes a pretty little fall, perhaps 30 feet high, at the head of which, with a favorable wind, one perapsily ret a spray.bath at short notice. At the head of this pond, a slight depresion of the crest of the spur indicates probably the best point for crossing, though the slopes are of fine sliding rubbish, which makes climbing tedious. Tuose who preferred climbing over solid rock crossed a little farther out on the spur. Another short haltmile of snow brought us at length to the foot of the central peak. In meither of these two snow.basins was there any apparent consolidation of the snow into glacier-like bodies of ice, thongh small icy patches of the snow into glacier-like bodies of ice, thongli smacked as if by in. were seen, and the compacted suow wasccadionally cracked as if by iu. complete every season, so that no glacier-like masses can be formed. We afterward saw abudant evidence that this valley, like others in the range, was once the scene of intense glacial action.

range, was once the scene of intense glacia action.

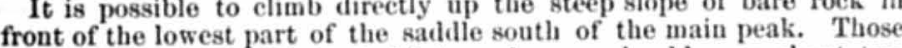
who prefer gentler slopes of débris and snow should pass abont two hundred yards farther north, where such a slope reaches to a higher point of the saddle.

Several of the party had already turned back, and Mr. Bechler's injeveral or the party mentioned, made it imprudent for him to attempt these steepar slopes. Accordingly, he turned ofl and examined the cañon for a mile or so lower down. Fire of us reached the saddleMessrs. Stevenson, Langford, Hamp and Spencer, and myself. Here I stopped, at 12 o'clock, at the elevation of about 11,400 feet, to wait for a mercurial bameter, which Mr. West had undertaken to deliver to me a that mint, so that I might take it to the summit I afterwant at that point, soche withen

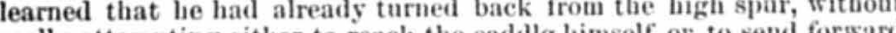
really attempting either to reach the saddle himself or to send forwarc the barometer by any other person. Meanwhile, I examined the rocks upon and east of the saddle. Climbing is here much hindered by steep slopes of snow, some of which consist wholly of hail-stones from a thiri to a half inch in diameter. A tierce west wind, blowing forty to fifty miles per hour, was sweeping across the saddle with such force that the londest shouts were inandible fifty yards to windward. I experienced no inconvenience from the rarity of the air at this elevation. My highest point was about 12,000 feet, about a half mile east of the main sad dle, from which point 1 had a limited view ont to the basin of Jackson's Hole. The mountain descended in bare rock-slopes over 4,000 feet, until, with gentler slopes, there appearel a belt of pines and spruces. In the uper edge of this belt, a small lake, partly iced over, occupied a the upper edge of this belt, a small lake, partly ine the base of the meuntain immediately beneath me. The timber stretched in a heavy body down along a small stream flowing past the base of the monntain out to its junction with Suake River. In plain sight were the butte above the mouth of Gros Ventre Fork and the

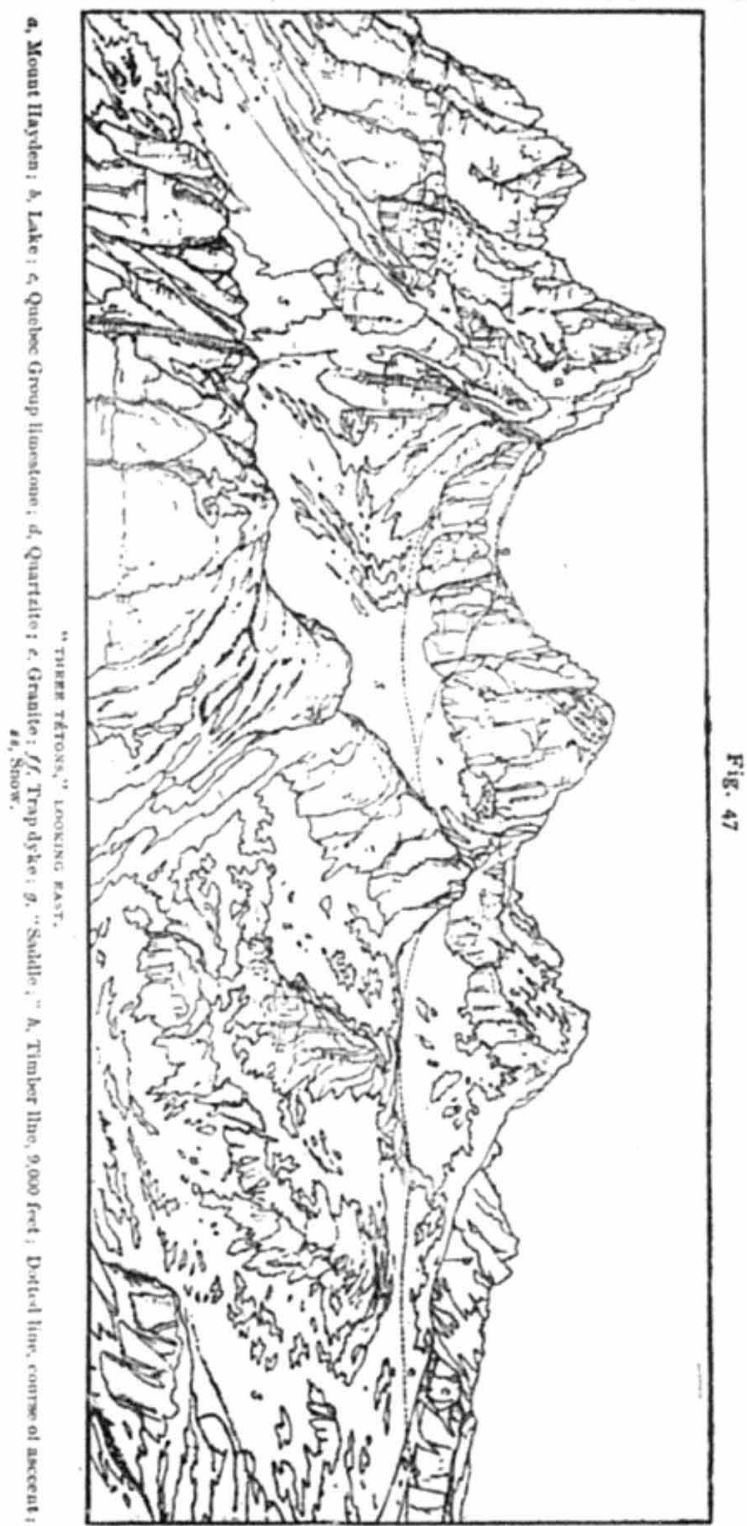

valley of that stream runving far into the eastern mountains, with 
bright-red cliffs on either hand, while the channel of the Snake itself meandered northward throngh broad sage-covered piains, till its npper course was hidden by hills. This view was as if set in a frame formed by the sharp spurs running ont on either hand and cutting off its continuations.

A few smail Alpine plants reach this level, and even higher, though Ir- Stevenson states that all vegetation except lichens ceased about 300 feet below the summit.

Busied with these examinations, I waited longer than I should have done for the missing barometer, and found that time would not then permit me to complete the ascent. The others who reached the saddle passed directly up the long slope of debris leading from it into the gorge on the west side of the peak, and report that Messrs. Sterensou and Langford reached the summit, while Yessry Hamp and Spen. cer stopped abont 300 feet below. They state that the sim spit is

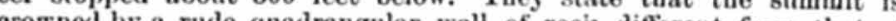
erowned by a rude quadrangular wall of rock, different from that of which the summit of the peak is itself composed, which must have been brought up from some distance below, and which is very much disinte. grated by the action of the weather. If their account is correct, the hardest part of the ascent is past when the high saddle is reached.

Mr. Stevenson reported that the Great Cañon seemed to break down suddenly to the plain, so as to be apparently impassable for animals. Examinations on the east side of the mountain in September strength. ened this probability, though they were not full enongh to determine positively that the cañon is impassable.

To the north of the eañon, one peak of the range, which we have called Mount Leidy, has a long wedge-shaped summit, upon the top of which a long oval elevation has, from a distance, much the appearance of a huge moucd, like those erected so numerously by the mound builders in the valleys of the Mississippi and its tributaries. This sum. mit, however, was not visited. These peaks have been described by some as "snow-covered" the year round, while others have said that they are so steep that snow will not lie on them, even in winter. The truth lies between the two, for immense cliffs doubtless continue bare through the entire winter, while in some of the ravines and crevices bands of suow run nearly to the summit, though not so abundantly as as to appear like a mostly snow-covered surface. We dragged our wears limbs back to camp, where each had his story to tell of individual adren ture and mishap.

Messrs. Stevenson and Langford claim the right to name this peak, as being the first white men to reach its summit, so far as known, and have called it Mount Hayden, in honor of the director of our survey. As no individual name had been previously applied to it, other than Big Téton or Grand Téton, there appears to be no reason why this name should not stand and pass down for ages the name of one who has probably explored a greater extent of the crests and eastern slopes of the Rocky Mountains than any other living scientist. The reported reading of Mr. Stevenson's aneroid gires the elevation of the peak as
about 13,400 feet ; but the gradienter measurements, taken by Mr. Hering, indieate an elevation of 13,858 feet, which has been adopted as aitogether the most reliable determination.

Though glacial seratehes were seen only in the highest portion of the cañon of West Téton Creek, yet abundant evidence of glacial action was seen in all the lower part of the valley in the immense numbers of bowlders, both of granite and of limestone, which are distributed over its bottom and on its sides up to about 400 feet. The surfaces of these bowlders, however, have been so much weathered, disintegrated by fires, and worn by the streams which, during the subsequent ceuturies, have flooded and deepened the valley, that I was unable ts decide whether the absence of striations was or was not due to the bowlders having been carried upon the surface or in the mass of tbo glacier rather than in its grinding foot. These bowlder-deposits oxtend well out to the mouth of the cañon. No true terminal moraine was recognized; and I am at present inelined to refer its absence to the floating off of the end of the glacier upon the waters of a lake which once evidently, and perbaps at that very time, filled the basin of Pierre's Hole and the lover portions of all these onter cañons up to not far from the level mentioned.

The scenery of the region, as a whole, is wonderfully interesting. Its dense spruce-forests, though now greatly injured by fire, gradually opening upward until they terminate in scattered groves of individual beacty ; its sharp, deep cañons, with massive, precipitons walls; its beautiful and varied cascades; its broas snow.fields, and was ; its rugged, lofty peaks, together form a combination of beauty and grand eur rarely equaled. Though its peaks are surpassed by many in actnal elevation above the sea, few such stand among so broad, deep valleys as to give so great relative elevations and to be seen prominently over so wide an extent of conntry. When the region becomes more accessible by means of already projected railroads, this must become a favorite resort for tourists. The ronte by which we reached Mount Hayden appears to be the most feasible for those who would approach it from the west, though its base can be more closely approached with animals on the east side, so that possibly less persongl exertion would be needed in climbing it from that side. When we left the peak, I hoped to reach this eastern base early enongh to make another attempt upon its summit, and so to retrieve my lost honors; but the early snows of September had, before our arrival, covered the upper slopes and made the attempt too hazardous to be justifiable. July and August seem to be the months most favorable to the ascent.

The sportsman need not despise the region. Antelope still abound on the plain; the tracks of deer and elk were abundant about the swampy bottoms of Pierre's Hole; several bears were seen, and one small griszly was shot by Messrs. Carrington and Brown; a moose-cow and two calves were shot in a thicket on West Téton Creek; and abundaut tracks of mountain-sheep were found as high as the sadille south of Mount Hayden, where no other animals were seen larger than the swallows, which were skimming a ing insect-food. The thickets along the streams, and especially the groves near the upper line of the timbor, are full of two or three varie-
ties of grouse, while ducks and geese abouad in the swamp-ponds of ties of grouse,

Our original plans contemplated the passage of our main train across Téton Pass into Jackson's Hole and party should examine the Snake River Cañon, in the sonthern continuation of the Téton Range; but our guides threatened us with impassable fords on that route, by reason of the continued high water from the melting snows. It was then proposed to cross the range by the broad depression at the head of Falls River; but this was declared to be also impassable by reason of fallen timber. This information was afterward proved to have been false; but, accepting it as true, we now turned up the valley of Henry's Pork, loaving returning in River. The next day, tre reached the banks of Falls River, finding it a 

large stream, flowing directly from the broad depression north of the ing groves of aspens, pines, and spruces had been seen thus far; but, ing groves of aspens, pines, and spruces had bodies of pines and spruces. after crossing, we at once passed into dense bodies of pines and spruces
large areas of which had long since been burned over and were mostly grown up again with dense young pines, from one to six years old, and smaller numbers of quaking aspens. The country is much cut up by smaller numbers of quaking aspens. precipitous cañons, from 50 to at short intervals. A few purple-nacred nnios occur in these streams.

Approaching the Spring Fork of Henry's River, two buttes are prom. inent, consisting of porphyries and loose-textured voleanic sandstone. Their tops are much cut by ravines, with flat, grassy hollows at their heads, which at first remind one of craters; but closer examination heads, which at frst remistinct voleanic cones, but are merely frag shows that these are not distinct voln ments of the terrace-like mountain to the northecs wat, whe cut off from it and left behind in the general erosion of the valleys. On the slopes of one of these buttes we found a profusion of large, blu huckleberries, growing on rather small bushes a foot or so high; bu these were not again seen on the whole trip. A sunaller trailing species these were however, fort a vieasan spruce, and bearing a very small, deep-crimson berry, with a fieasant acid flavor, now began to appear, and was afterward found abundantly, through all the pine-country, until we reached Jackson's Lake, late in September.

Spring Fork, where we crossed it, is about 100 feet wide, and was then carrying about 150 feet of water. Its banks are very steep, consisting caring mainly of the drab and pink porphyses so horizontal. If Raynolds's are here well laminated and nearly or quite horizontal. If Raynolds's distances and ours are both correct, our camp must have been abont two miles below the immense spring, described by him as leaping over a 30 . foot fall into the stream, and furnishing to it fully two-thirds of its water as well as its name. This sudden increase would explain the evi dent inconistency between the size of the stream and the apparent exdent inconsister bein. We did not at the time understand our relation tent of its apper basin. Wo dia not at the the und his spring. Start to Raynolds's route, or we should have tried to reach this spring. Starting from this camp the next merning, August 5 , the steep bank proved too exciting for one of the usv .lly most obstreperoas of our mules, and, in attempting to kick herself iree from her pack, she lost her footing and rolled lown hill turning fice complete somersaults before reaching the rolttem, where, the quietly went to grazing, with only one or two slight scratches. For want of any other name, at the time, we called this, among ourselves, the Mormon Mule's Creek.

Shortly after leaving this stream, we found the soil becoming notice. ably thinner, and masses of basalt began to appear upon the surface. The loosely juinted character of the basalt seems to have given to the soil, as fast as it formed, a ready passage downward with the water of soil, as fast as it formed, a reaty pange do pes, broad surfaces of the rains and melting snows; so that, in many places, broad sarface or the rock appear, with barely enough soil upon them to support a few small herbs and grasses. The basalt is doubtless underlaid here, as it is elsewhere, by sands and gravels, which not only readily absorb all waters percolating through the crevices of the basalt, but also furnishes covered passage-ways for the large streams which supply large springs, of which passage There are many examplestered and has suffered less from fire than in the tracts we had recently crossed. The basalt is much bulged up into low domes, like those before encountered and described. Many of these are broken away at the top, and the basins are often occupied by ponds; these being the exact equivalent of the pond-holes already described as baving been seen near Market Lake, only these are at a less advanced stage. By the dribbling ontlet of one of these ponds, whose water was, during the middle of the day at least, too warm to be agreeable for drink. ing, we found a small flow of quite cold chalybeate water, of medium strength. By one of these ponds, on the slopes toward Henry's Fork, we camped on the evening of the $5 \mathrm{th}$.

Next morning, a few of us turned southwestward, to try to find the re. ported falls of Henry's Fork. About two miles from camp we struck the bauk of the river, at a point where it was just entering a basalt-cañon. Following down stream for several miles, we found the walls gradually increasing to 50 feet or more in height, but finally turned back without reaching the falls, after having gone vearly twice the reported distance. The falls are said to be below the end of this cañon and about 80 feet in height, the upper 40 feet consisting of rapids and the lower 40 being a clear leap. For about ten miles above the canon the conntry is open, with gently-sloping, broad grassy bottoms and scattered groves. At several points, large cold spriugs break out from beneath the basalt, evi. dently being the ontflow of stresms which bave been swallowed bodily, bigher up, by this eavernous bed. These are full of delicious trout. For the next ten miles, dense timber runs to the river, which is again walled by low outerops of basalt. At first, fallen timber was very troublesome and delayed the train badly. Since the second day out from our Téton eamp, we had been obliged to make our own road, but now, on the banks of Fishing Creek, we found a trail which had, at some recent time, been used by wagons, followiug our general course, though it led us up Fishing Creek instead of the valley of Henry's Fork, which here makes a large bend to the westward. Before long, the trail became less marked and finally disappeared; but we kept on to the head of the stream, which proved to be one of the large springs so commen here, and then bore a little westward to regain the main stream, though guided mainly by the summit of a peak which was said to stand on the south side of Henry's Lake. Here we encountered excessively dense growths of young pine, through which we forced our way with very great difficulty, the packs continually requiring replacement. At length we reached Henry's Fork and a trail almost simultaneously, and soon re. joiced in a good road and a camp. We were now done with bad timber for some time.

The season was now so far advanced that we began to find that min. gling of spring and fall flowers which is characteristic of regions where the summers are short. In the same field we often found violets, straw. berry blossoms and fruit, monk's.hood, geraniums, everlastings, and fringed gentians, (G. crinita.) This last was first seen on August 4. Strawberries were found in considerable numbers as late as September 9 .

August 8.-Mr. Bechler examined the stream below our camp, and found that it ran for several miles through a deep basalt cañon. At anıl above camp, its bottoms are broad and flat, including some beaverdams, and the valley continues of that general character to the lake, which is only a few miles distant. The groves are somewhat open, jet nearly all the comparatively bare spots are well set with seedling pines, which plainly need only protection from fire to soon make good all previous losses. Passing these, we soon enter the open grassy basin which surrounds Henry's Lake.

This is a broad, shallow sheet of water, said to average not more than $15 \mathrm{G} \mathrm{s}$ 
8 feet in deptb, which is practically the bead of Eenry's Fork, thongh several small streams flow into it from various directions. Though the shore is very winding, and numerous points project into the lake, yet, as a whole, it is a pretty regular body of water, about three miles long by from one and a half to two miles wide. Several small islands are scatiered over its surface. From its borlers, which are mostly marshy, the plain rises very the plain rises very gradually to the gravelly terrace of an old lakeshore, from 80 to 90 reet above the present water-level. When at that level, the lake would have been some eight or ten miles in diameter. No higher terraces were apparent. The upper level is covered with sagebrush, but the lower flat supports luxuriant growths of grasses, sedges, and other rich forage-plants. Near Sawtelle's ranch, at the head of the lake, large amounts of hay were curing in the hot sun; while a mowing. lake, large a till in active operation on the meadows. Messrs. Sawtelle machive was stili in active operade in fresh fisi, caught in the lake and its outlet, which they pack in ice and haul tifty miles to Virginia City. They at first attempted raising stock on these rich meadows; but the immense numbers of horse-flies aud gnats which breed in the swampy borders of the lake soon compelled them to abandon that business. They report that gam is still abundant in the neighborhood-ante. lope, deer, elk, moose, bear, and mountain-sheep, as well as smaller aniruals.

In approaching this basin, the trail passed with the river to the west side of the valles, leaving the main muntain two or three miles to the right. This consists of coarse voleanic saudstone, mostly composed of obsidian. Two or three deep eañons here reach the valley, showing that water once worked powerfully in them, but these are now dry, except where springs burst out of the sandstone at their very mouths, and apparently bave carried no water for many years past, except during the times of most rapid melting of the snow in the spring. In examinations made later by Mr. Bechler, when crossing westward from the Fire.Hole Busin, the upper conrse of these cañons proved to be of the same character; here aud there large springs burst ont, but soon the same character; here and there lirese surings but disappear again in the porous sandstones, which, ia that direction, form the surface of the entire mountain. Passing a little to the northward,
older rocks appear on the higher slopes of the mountain aud soon form its entire face, the voleanic rocks disappearing beneath the valley.

On the opposite side, these appear again in the high mountain lying directly sonth of Alenry's Lake, known to us as Sawtelle's Peak, whose lower spurs run down nearly to the lake-shore. The rugged precipitous sides of the peak, withont well-marked stratification, led to the suspicion that it might be of volcanic origin, aud it was accordingly visited by Mr. Taggart and myself. It was found to constitute the eastern and north. eastern wall of a great crater, some 1,200 or 1,500 feet deep, whose east and west diameter is about a mile and a half, with a traneverse diameter and we the bottom filled up; but, from the position of the portions of what was apparently the original wall which are still standiug, it is probable that the original crater had very nearly the dimeusions above given. The walls con. sist of ragged, cellular, largely amygilaloilal porbpyry, containing erys. tals of quartz, calcite, \&u., partly wrathering witl a very rough surface, partly clecompasing into coarse brittle sand, and making very treach. erous footing. Lower down, the s!opes consist of very dense, nearly black, basalt. The westeru and northwestern walls were not visited; but their style of weathering inlicates much softer material than was found on the part visited. Considerable portions of the crater, as, well as tho outer slopes of the mountain, were well covered with tall pines aud apruces; while the higher portions bad only seattered and stunted trees and the erests were entirely bare. thengl enough dead stems of small pines or cedars were found even there to make s small signal-fine. The small plants of the summit are mostly of Alpine forms. Trailse mountain - kheep were abundant, but the only vertebrate seen was a large gopher, (9) very distinct from any species of which I bave been able to find a description, or figure, or mounted skin ; nnfortunately, he escaped my bullet. The elevation of the peak, as indicated by two readings of $\mathrm{my}$ aneroid barometer, is about 10,600 feet.

No lines of outflow were traced down to the plain; but, from the size and position of the crater, and the character of the lava of its lewer portion, it is evident that his was a prolific source of the lasalt which so many times flled the great plaiu stretubing off to the soutb and west. The isolated cluster of mountaius, alont balf way between this peak and the Sand-Hill Mountains, has apparently the same structure, and may have been another source of ontflow. The lowest gap in the crater-wall of Sawtelle's Peak faces northward; and the principal ontflow of lava was probably from that point, escaping thence down the valley of Henry's Fork, though other portions may very probably have escaped through subtermanean paseages and cracks in other directions, as is through subterranean paseages and cracks in other directions, as is
frequently the case ia those volcanoes whose modern eruptions have giveu opportunities for the observation of their phenomena. The portions of the lava next to the mountain and out to the center of the valley are all pretty solid basalt, while the farther side of the valleydeposits, and those which form the slopes of the eastern mountain, consist of the older porphyries and volcanie sandstones.

The peaks of the westward continuation of the range of wbich Saw. telle's Peak forms the eastern termiuation show such structure, as seen from a distance, as to indicate that they also are of volcanic origin, and may have been other sources of the basaltic outflow. It is not known to any of the present inhabitants of the region that any of these vol. canoes have been active in modern times; but Irving, in his Astoria, states that Mr. Robert Stuart, a partner of Mr. Ast $r$ in the Pacifie Fur Company, when crossing the mountain-range west of Pierre's Hole, in the fall of 1812, " observed to the nurtbrest, between Henry's Fort and the sourve of the Missouri, several very high peaks covered with snow, from two of which smoke aseended in considernble rolumes, apparenty from craters in a state of eruption." The location indicatel worlity well to peaks of the range now well to peaks of the range now under consideration. It is hardly to be supposed that so experienced a montaineer should have been deceived by'timber-fires, or that such fires should occur near the summits of peaks covered with snow.

The ranges on the north and south sides of Henry's Lake are nearly parallel, while the cross-range west of it is nearly at right angles with them, thus giving a quadrangular form to the plain, which here termi-
nates the bruad valley of Henry's Fork. From three points it has easy passages to the neighboring valleys and the region beyond. From our cainp on the east side of the valley, Tyghee Pass, named for an old Shoshone chief who was wont to use it, gives a smooth road, with very geutle grades, into the ralley of the Upper Madison. From the north end of the lake, a brow, grassy plain, with scarcely a perceptible ise to the divide, abont four miles distant, shows a clear road to Virgivia City and the Lower Madison. This is called Raynolds's Pass, from having been used by that officer in his expedition of 1659-60, and described in his report. Tyghee Pass is also mentioned and mapped in that report 
as having been examined by Dr. Hayden. From the southwest angle of the valley, ked Rock Pass affords a broad, flat, grassy openitug to Red Rock Lake, one of the ultimate sources of Beaver-Head Fork of the Jefferson. This was not visited by us, though seen from a distance. It was afterward examined by Messrs. Peale and Holmes, of Dr. Hay. den's branch of the expedition. The levels, as decided by the observations of both parties, are as follows: Henry's Lake, 6,492 feet; Tyghee Pass. 7,063 feet; Raynolds's Pass, 6,911 feet; Red Rock Pass, 7,271 feet. The wost favorabie route for a railroal from Montana to Corinue, which is Dow talked of, is apparently via Raynolds's Pass and the valley of Henry's Fork. Down this ralley the grales would be very easy, averag. iug only about 25 feet per mile from the pass to Taylor's Bridge, on Snake River, and the cost of grading very slight, while the large valleys which open on the east, containing large areas of valuable grazing and farming land, would be opened to settlement, and would very soon furnish cousiderable local business.

The short range on the west side of Henry's Lake shows at base, near Sawtelle's ranch, a considerable body of dark hornblendic, slaty schist ; but the mass of the ridge consists of much-foliled metamorphic lime stone, which, in its lower portions, shows a considerable thickness of light drab, almost white, rock, which would make very fine building material. Its higher portions, however, contain very uumerous thick and thin bands of white, often transparent, ytuartz, corresponding, in general appearance and relations, with the bands of chert which accompany certain portions of the Carboniferuas limestones in this region. From this character, in the absence of any opportunity to determine its age by tracing the bed to its unmetamorphosed portion, I have referred it, with very little doubt, to the Carboniferous. Upou the crest of the ridge, we found the outcrop of a dike of trap, about 60 feet wide, standin conformably between the layers of the limestone, and therefore supposed to have been deposited in that relative position beforo the beds were upheaved into their present nearly vertical position. The subsequent metamorphism of the whole series has obliterated any marks of alteration of the adjoining beds of litnestone, which we might other wise have looked for. From the crest of tho ridge it was evident that the back spurs were of the same general structure and composition at the main ridge, at least for two or three miles.

On the east side of Raynolds's Pass, metamorphic rocks form the base and lower slopes of the mountain, while quartzites and limestones appear near its summit. This structure continues nearly to Tyghee Pass, where the upper rocks come down to the level of the plain, for two or three miles, and then rise again, exposing the granites, gneisses, horn blende schists, \&c., until we reach the outcrop of volcanic sandstone before described. Just west of our camp, at the mouth of Tyghee Pass, the lowest of the quartzites is exposed on the bank of a small creek. The bedding is nearly vertical, with a strike trending about $\mathrm{N}$. $53^{\circ} \mathrm{E}$. Unconformably upon the edges of this bed lie abont 200 feet of a light-drab, impure limestone, of Quebee Group age, from which we obtained with difficulty three fragments of characteristic trilobites. The dip is about $45^{\circ} \mathrm{N}$. $54^{\circ} \mathrm{E}$. As we bave elsewhere found guartzites of supposable Potsdam age lying conformably beoeath the Quebec Group, we are led to question whether this quartzite may not possibly be of still earlier age ; but, in the absence of fossils, there are no means of decidiug the question. But this may very well be Potsdam, as I presume it really is, without making it necessary that it should every where else lie, as here, unconformably beneath the Quebec.
At the quartzite-outcrop, about a fourth of a mile west of our camp on Pass Creek, another small creek comes ont of the hills by our camp distinet eañon. But, on going up the pass abont a balf entirely cañons unite into one valley, with barely enough divide to sepurate tho streams; set these continuedistinct and enough divide to sepurate the tions. At this point, a stream.terrace of about 30 feet eleration is very prominent; but it is not continued out to the main valley. What conld have been the conditions under which these two cañons were thus formed Porphyry appears in place high on the mountain-side at several formed and in the stream.bottoms in this junction-ralley, but several points, eastern cañon, so far as I observed. so that I inferned only in the more of the porphyry had stopped up the original eastern cañon, and filled up all the upper valley; that, in subsequent erosion, the new cañon had first been worn through the limestones and erosion, the new canon had a terrace-like deposit of sand being meanwhile formed at the westwrit, a terrace-like deposit of sand being meanwhile formed at the head of it by the partially-checked stream; and that afterward, when the new chasnel had been cut low enough to reach the old-stream gravel, and the porphyry had been eroded from the main valiey ontside, the percolation of water throngh the gravel of the old channel undermined the overlying porphyry and opened the cañon anew for the more eastern streaun.

The porphyry is now so much worn away from the pass that the ont. crops of the older rocks can be traced. in the cañons of the Téton range, we see the limestonesec group, as the bighest summits. At one point, the castellated ruins of the Niag ara (1) limestone, with their intermediate pine-clad hollow promiuent show prominent show upon the hill-sides. The Carborriferous limestones, from which a few eharacteristic fossils were brought by Mr. West, are mainly thin-beddei; but one heavy bed caps some of the highest points. The pass has very little timber and affurds trees reen during the whole season sto No notes of their size were taken at the time, but I remember them as abont four feet through. They all seemed to be dying.

On the Madison side of the range, the porphyry, which appears at intervals all throngh the pass, is replaced by basalt. The broad bottoms are covered with basaltic sand, bearing a thin streams have in cauic kand, partially cemented into a the valley the timber becomes mas up resembles resembles the artificial grouping of parks, with arenues opening in every direction. There is, however, no turf, the volcanic sand being only sparsely covered with a growth of coarse plants, often including only sage-brush. Through a broad bottom, occupied by nuciuding much dams, a large stream, carrying perbaps 80 feet of water, comes in from the soutb, which was afterward traced by Mr. Bechler to its sonrce in the mountains, where it grows rapidly from the large springscharacteristic of the porons volcanic sandstone. The Madison itself was carrying
possibly 200 feet of water, sometimes thinly spread out in a broad channel, sometimes narrow and deep, with dangerous boles. Trout were shy and appeared to be few. Antelope and black-tailed deer were seen in considerable numbers in this park-like region, which continued up to Thouth of the upper cañon of the Madison.

The cañon is varrow, with lofty eliffs on either hand, running up to $800,1,000$, and 1,200 feet at different points. Passing up the north bank, our trail lay for much of the distauce along the edge of the river, on the steep debris.slopes of the monntain. The cliffs consist mainly of 
colnmnar porphyry, which disintegrates rapidly, forming pretty solid but rery porous slopes, aud so yield numerous springs and form many small bogs along the river's edge. Ripe red raspberries were abundant along these slopes, but were not seen elsewhere, I believe, on the whole trip. The springy character of these débris is apparently the only serious obstacle to the building of a railroad through the cañon, vhich has been suggested by parties who desire to facilitate access to the geyser-lasins; but the disintegrated rock reconsolidates so well that I should antici. pate no trouble from the springs. A noticeable feature of the river pate no trouble from the springs. A noticeable feature of the river down to the water's edge, and no accumulations of drift-wood were observed. Does the heat which escapes so freely in these upper basjus remove the snows so constantly and steadily throaghout the winter that no accumulations are left to cause freshets by rapid melting in spring?

The cliffs along the cañon at various points are both beautiful cad grand; but we resisted the temptation to give names to all the different points, which is said to have overcome others who have passed this way; though Mr. Raymond has not yet seen fit to publish the names for which he wonld claim priority. (See Christian Union, New York, May, 1872, p. 437 .

We had supposel ourselves the only travelers in this region, when suddenly we enconntered a party of officers and soldiers from Fort Ellis and other northern posts, uuder the leadership of General Gibbon, who had been visiting the wonders of the Yellowstone aud geyner regions. After a brief exchange of conrtesies and information, both parties were again on the march, aud we soou emerged from the cañon and canuet

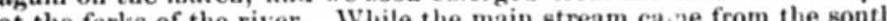
at the forks of the river. While the tanin ktream casie from the south. ward, yet the real continuation of the valley we had been following was occupied by the stream coming from the eastward with perhaps 40 feet of water. $\Lambda$ s this stream had been partially explored by Geueral Gibbon, who gave ns some useful information conceruing it, we have culled it Gibbon's Fork of the Madison. Its valley continues eastward for some eight or ten miles, when the depression termiuates, the stream entering it from the nortb, where its sources evidently lie bigh up on the entering it from the north, where its sources evidently lie high up on the
divide toward Gardiner's River. Following directions given by General Gibbon, we found, abont half a mile above our camp, the first indication of our approach to the geyser region, in a cluster of hot springs, which huve formed a terrace a little back from the north bank of the stream, have from 00 to 80 feet above its level. The water flows from a dozen o more different opeuings, of which the principal one is a pit from 2 to 3 feet in diameter and 15 feet or more in depth, from which water is ejected with constant ebullition to a height of from 1 foot to 3 feet above the level of the surrounding pool. The pool itself is of an irregular form, something like the outline of a goat-skin bottle, with the spring in the month of it, abont 900 feet long by from 50 to 90 feet wide in its main part, while the narrowest part of the neck is from 10 to 15 feet wide. The temperature, at the poiut of nearest safe approach to the center of ebullition, was $146^{\circ} ; 100$ feet distant, the water escaping from the pool gave $126^{\circ}$; while the farthest point of the pool gave $120^{\circ}$ The exit flow was rapid, along a chaunel averaging about 3 feet wic's by 9 inches deep. This bad built up its banks a few inches above the scrrounding level, and at two or three points the deposic bad even bridget the stream. The second pool in size was quadrangolar in form and meacured about 50 feet on a side. The center of ebohition could not be ap Iruached; and the water along the edges of the pool gare only $113^{\circ}$. The smaller flows varied from 1100 up to $1344^{\circ}$, and in one case up to 1500 . Several old openings along the onter edge of the terrace were long since deserted; and the flow is now only from higher levels farther back. The deposit thus appears to stop up the channels and so to force the water back until it finds or makes new openings in the disintegrating jointed masses of the porphyry which form the underlying stratum and the bill behind the terrace. At only one point is there a strong flow frotn below: this is on the immediate bank of the stream, and the temperature, being only $92 \circ$, indicates a mingling of cold and hot springs.

The other fork of the Madison has from this point been called the Fire-Hole River; but it is hardly a distinct stream, and should more properly be called the Fire-Hole Fork of the Madison. For abont five miles above its mouth it passes through a succession of small caũons with precipitous walls, which render the stream inaccessible in most places. At one point there is a fine fall of about 30 feet. There are also two long successions of rapids, with many points of artistic beauty. After emerging from the cañon, and getting far enough ont in the bottoms to clear the timber and look back, we found that we had risen so rapidly as to be now on the level of the top of the cliffs on the south side of the great cañon throngh which we had passed on the previous day, while those on the north sicle are seen to rise rapidly from the borders of the cañon into a lofty monntain-mass, whose northern slopes must give tise to some of the bead waters of Gallatin River.

We now come to the stream which Dr. Hayclen descended in coming from the Yellowstone in 1871, and which was named to him, by his guides, as the east fork of the Madison. That name has been applied to at least three different streams. If snch a point-of-compass title is ever proper, this should most properly belong to that part of the stream
which comes ont of the Galiatin Monntains and joins the Madison nearly opposite Tyguee Pass. We row propose to call the stream which join the Madison at the lower end of the gerser-basins Hayden's Fork, after its first known explorer. Here we first met with the hot spriugs of the lower geyser-basin. One of the first, directly on the bank of the river, had a temperature of $197 \circ$. In the mucilaginons deposit upon its sides, Dr. Curtis fond skeletons of diatoms, but no living ones; bot fur furtber statements of these microscopical observations, I must refer to his detailed report. Abont a quarter mile farther up the stream, above the first bend, a strong spring, boiling intermittently, but rarely over a loot in Leight, with a pool about 25 feet long by from 6 to 12 feet in width, gave a temperature of 2000 the lighest fonal in the whole region, and a fraction abore the boiling-point theoretieally due to that elevation. And now we were in the midst of bot springs and geysers, and shortly camped on a wooded knoll whieh overlooks a considerable part of the Lower Basin. We had expected to meet Dr. Hay. den's party in this neighborhood, and soon learued that they had reached the Basin, coming frmm Bozeman, ria the Yellowstone valley, a few hours before us, and had pitehed camp abont a mile further east. Next morning, therefore, we moved over and joined them. The collections of both parties were now packed up; specimens were gathered from the gevisers; and Mr. Stevenson started with them, on Angust 17, for Virgiuia City, both to ship the specimens and to procure provisions for on return trip. Dr. Hayden's party also started down the Madison, on the $20 t b$, and we were again nearly alone, though a few visitors from Mon. tana were also in the Basin and camped near us part of the time. Among them was probably the first lady who ever saw the geysersMrs. Stone, of Bozeman. 
a favorite graxing-ground of deer and elk, whose tracks abounded, even on the steepest slopes. I was here the victim of a curions delusion. Looking up toward the fall, I saw what appeared to be patehes of small flowers, of a rich, blue color, elosely resenbling the patches of brilliant blue "forget-me-nots," which ornament the higher crests above us. In parsuit of them, I pressed on until the spray became a drenching rain, when suddenly I saw at my feet patehes of the same blue; but they were only sky reflections from the wet rocks! The walls of the cañon are largely composed of soft voleauic asbes, hardly cemented, which disintegrate rapidly; and the slopes are largely covered with sliding masses of the sand thus formed. Where this is reached bythespray of the fall, it is partly further disintegrated into a bluish-gray mud, and suosequently partially cemented into a fine-grained argillaceons sandstone, stratified narallel to the slopes. These slopes descend directly into the river, so that, even at the bottom, the utmost care must be used in walking. Along the edge of the river, sereral small hot springs occur, which steam moderately, but rarely to such an extent as to be visible from the top of the cañon. I was able to reach but one of these, which had a temperature of 1500 . (In the opposite bank, a miniature gesser was in opera. tion; from the top of a steep cone, about a foot high, a half-ineb stream was constantly spirting about a foot from the orifice. In ascending, I followed the track of an elk, part of the way, and found much less dim. culty than in the descent. On the east slope, regular game-trails are numerons; and I think that most of the animals which graze on the western spray-slope approach and leave it by fording or swimming the river.

The upper fall, though less than one-third the beight of the lower, appears far grauder, by reason of the momentum of the mass of water, gained while rushing down the rapids wich extend about a half mile up stream.

A bout 11 a. m. on the $23 \mathrm{~d}$, we started southward, passing the Crater Hills and the Mud Geysers, and camped on the shore of the lake, near its outiet, abont 5 p. m., the distance being eighteen miles. The trails were distinet and tolerably level. The soil here is very loose and washes easily; so that, in many places, the trails made in 1870 and 1871 are already badly gullied. This should be considered, in laying out roads and trails through the park.

On most of the early maps of this region, a large lake is represented at the bead of the Yellowstone, nnder the name of Eustis's Lake, a name supposed to have been given in honor of General Eustis, of the Engineer Bureau. Later, it appears as Sublette's Lake; and uow, for several years, it has been calied by the general name of Yellowstone Lake. If any law of "priority" is to hold in gègraphy, it would appear that the name of Eustis should be again and permanently applied to it, unless the original Indian name be ascertained and substituted for all lates oues. Aside from this general prineiple of priority, there is no doabt that the present name is the best; and it has become so generally known that it is likely to bold. The first map which, so far as known, represeuts the lake with anything like its true form is a manuscript one by Jedediah S. Stnith, who hunted throngh the mountains from California to the British Possessions, during the years from 1821 to 830 . The original was purchased in Oregon for the War Department, bat is supposed to bave nerer reacher! Washington. A copy, taken in 1853 , exists in the hands of Mr. Gecrge Gibbs, of New Haven, Connecticut.

When we arrived at the lake, in the afternoon, the nsual daily wind was blowing, and considerable waves were dashing upon the beach; but

full. The slopes which gre thus kept wet are well covered with grasues and flowers, of which several species wero gatlered. This is evideatly 
both wind and waves subsided daring the night, and both air and water were perfeetly calm at sunriee next morning. While getting breakfast, we heard every few momenis a curious sound, between a whistle and a hoarse whine, whose locality and character we conld not at firnt determine, though we were inclined to refer it to water-fowl on the otherside of the lake. As the sun got higher, the sound increased in foroe, and it now became evident that gusts of wind were passing through the air above us, though the pines did not as yet indicate the least motion in the lower atmosphere. We started before the almost daily westerly wind, of which these gusts were evidently the forerunners, lad began to ruffle the lake.

Grasshoppers were so scarce that we did not succeed in catehing a single one of the wormy trout for which the lake is famons.

Keaching the mud-geysers ubout 10 o'elock, we found the principal spring just ready to erupt, and so were detainet only a few minutes.

Having thus briefly inspected the wonders of the Yellowstone, we turned back along the regular trail toward the geyser-basins, and got to camp that night by a rather hard march of about thirty seven miles. Considering the characters of ground and timber along this trail, we were satisfied that we lost. nothing by leaving it on our ontward trip.

During this time, Mr. Bechler hal gone, with his assistants, to examine the divide to the west of the Fire.Hole, and to locate a stream sopposed to exist in that direction and which had been mapped as the sonth fork of the Marlison. But no snch stream exists, unless it be the short one before described as forming in the north face of the mountsin, just east of Tyghee Pass. The ilivide is high aud largely covered with dense tim ber, mostly youug, the old growth having been burued off. Only vol canic rocks were found, being mostly obsidian sandstones, which are very porous. Accordingly, he found but little water. Springs and pools occasionally appeared in the cañons, but soon sank again. From what I saw elsewbere in this neighborhoot, I judge that he wonld probably have found more open timber and more water along the spors than he did along the cañons. Hollows among and upon the spurs become partially puddled, and so frequently hold water; while the flow of springs, constantly wearing their channels, howeve: slightly, is quickly absorbed by porous soils. At two points the party found small clusters of hot springs, some of which spouted a little, but no considerable geysers. The cañons, running west warl, finally lead out to the basin of Henry's Lake, whence the party returned by our old trail through Tyghee Pass.

Concerning the geysers, springs, and pools of the main geyser-basins on Fire-Hole Fork, so much bas already been written that I propose to merely note a few of the more prominent points which especially at. tracted my attention, and which have to do rather with generalities than with details, except in case of localities not visited by those who have $p: a b$. lished descriptions. In this latter case 1 think it best to be pretty full, in orrler that we may reach as far toward a complete deacription of this interesting region as is possible for those who only make brief visits to it. It is to be boped that means will be found, ere long, to locate two or three persons bere for an entire season, so that, by protracted detailed observations, we may obtain something like an approximate idea of the laws which govern the wonderful phenomena here displayed on so grand a seale.

At one point in the lower basio, near the Architectural Geyser, we found masses of volcanic sandstone, perforatel by numerous irregular holes from a quarter inch te an inch in diameter, which hal evidently been dissolred out by the hot watern, in their escape to the surface.
Here, I think, we bave an example, on a small scale, of the process by which the large eavernous pools, of which so many examples ocour all about us, have beea excavated. It would appear that, in many oases at least, the hot alkaline (1) water, as it reaches the nurface, is not thorougbly saturated with silica, and accordingly dissolves away the walls of its oriflces, Bo as to undermine the surrounding area, the surface of which falls in, until, in many cases, large caverns are excavated. This action appears to be limited in two ways: first, the pool may reach such dimensions that the quantity of water constantly supplied bears 80 small a ratio to the whole contents that the whole pool becomes partially cooled as weil as somewhat concentrated by evaporation, and so the exeavation is ehecked, if not stopped; aud, secondly, the supply. pipe may become almost entirely stopped up, so that barely enough water is supplied to make good the loss by evaporation, in which case the solution of silica would become supersaturated, and the siliea itself be deposited on the walls and bottom of the pool until it be ultimatels elosed again, unless the stoppage of the tube be removed, and the succession of conditions thus begun again. If, however, the stoppage of the tube be complete, the siliea will soon all be de. posited by reason of the evaporation of the water, and the pool will become a dry cavern, except in positions where it may be kept full by the drainage of surface-waters. The large deep pools, however, are generally very hot, showing a constant supply from beneath, and many of them are in constant ebullition, though rarely true geysers; indeed, 1 believe that the Giantess, in the Upper Basin, is tbe sole exception to the rule, so far as yet observed; and this is probably in its last stage and near extinetion, if we may judge by the length and irregularity of its intervals.

The smaller vents vary greatly in temperature, depending apparentls upon the greater or less freedom of their connection with the heat centers below. In some cases they are few and solitary, with little or no deposit about them, as if they had been but recently opened. A gain, they are in large clusters, of which the more elevated vents are generally though not always, the hotlest. It wonld appear that the comparatively compact deposit of nearls pure silica, formed by the flowing water, is mueb less readily dissolved and disintegrated, by the hot flow beneatb, than is the silica of the more porous and partly argillaceous voleanic rock which forms the slopes of the hills; so that, when a vent is once stopped, it is very rarely re-opened, unless by earthquake-cracking, anc the ehecked water is forced backward and escapes at higher and higher yoints on the hill-sides. In the geysers, the tube, being exposed to the air at frequent intervale, while it is yet dripping with the rapidly evaporating water of previous eruptions, receives constantly new layers of silica, which are but slightly, if at all, re-dissolved by the next erup tion; and so its size is constantly decreased, until the tube becomes entirely elosed and a new vent is opened elsewbere.

In the clusters of small vents, there is geuerally more or less aympsthetic action, showing that they open into soma common chamber below, but that the connecting passages are more or less contracted, so that the flow of stean and water is far from being controlled by the ordi. nary laws of bydrostaties. Frequently a large vent, whether a geyser or simply a boiling pool, is surrounded uy a number of sinall ones, whiek are active while it is quiet and quiet while it is active. I stood, one morning, upon the mound of Fountain Geyser, in the Lower Baxin whose pool was fliled to overflowing, and was wutching a volbement steam.jet, a bundred yards away, on the lower slopes of the ternace. 
Suddenly this ceased, and, at the same instant, Fountain commenced playing, throwing a body of water, some 10 feet in diameter, though mostly broken into drops, to constantly varying heights of from 5 to over 40 feet. This continued for abont thirty minutes, and then ceased rather abruptly; as suddenly, the steat jet commenced again. About twenty minutes later it ceased again, and a small pool, a few yards from Fountain, which had been empty before the latter's eruption, but par. tially filled by its overflow, immediately began to boil and to spit water from 5 to 10 feet high, and continued intermittently for a half honr or more. During its periods of moderate boiling, the steam.jet opened again, but ceased when the boiling became more violent. Other yents in the neighborhood seemed to have some slight sympathy with these. Similar facts were noted elsewhere. Thus, in the Upper Basin, Grand Geyser has only a small pool, and erupts only at long intervals. Close by its side. Turban Geyver is almost constantly disturbed, and has fre. quent small jettings of from 5 to 20 feet; but, when Grand, without gi ing any warning, sprang suddenly into its magnificent eruption, nearly 200 feet in height, Turban seemed startled into more violent action, reaching 70 or 80 feet, and rising and falling synchrononsly with Grand. Giant stanis, with another good-sized mound, upon a broal platform on the river-bank. As I first saw it, water was spirting, intermittently, to heights varying from 6 inches to 20 feet, from some fifteen or twenty sinall vents on various parts of this plat form. When the two large vents began to show activity, though boiling to only small elevations, these little ones became quict. When Fan Geyser was in full eruption, its partner, 30 yards off, was steaming gently. Fan stopped for a moment, and its partner fairly roared with a rush of steam, which stopped as soon as Fan opened again. Yet they are not in full sympathy; for, on another oc casion, Fan was steaming or boiling very gently, wbile its partuer was boiling furiously, and throwing water 5 or 10 feet high, but with quiet intervals, during which Fan showed no access of force. (Under such circnmstances, one is inclined to question whether Fan's partner may not possibly serve as the vent for two distinct geyser-tubes.) The three pools which surround Giantess lost much water by her eruption, but were not drained as low as the bottom of ber pit when that was empty.

In many cases, however, venis almost side by side show not the least sympathy. About 200 feet east of the Steady Geyser, in the Lower Basin, which constantly spouts from 5 to 20 feet, Young Hopefal spirts from 2 to 10 feet high for from sixty.five to eighty seconds, with quiet intervals of about the same length. About 60 feet from it, another smal vent spirts from 6 inches to 2 feet, for from thirty to forty seconds, with intervals of from forty-tive to sixty seconds. Here is evidently no sympatby.

The deposits made by the springs and geysers vary greatly. Where the flow is gentle, the deposition generally takes place in thin lamina. of thickness varying from that of a sheet of paper to a quarter inch. Though, as previously staterl, this is so compact as to be dissolved with diticulty from below, yet its thin lamina are readily separated and broken by frost, and form a very peculiar fine gravel, immediately rec ognized after having been once seen, which has served to iudicate the former location of bot springs over broal areas which give no otber evidence of such vents ever having existed. In the small ponls which surround many of the gersers, we frequently find great numbers of apparently water-worn pebbles; but, upon breaking them, we find their strneture eoncentric, and it becomes evident that they have grown by constaps surface-aceretions, while the frequent agitation of the pools,
GROLOGICAZ BURVEY OF THE TERRTTORIES.

by water falling from the geyser-jets, has prevented their being cemented to the bottom, anu has at the same time aided in keeping them smooth. Where these are few, so as to have plenty of room for rolling, they are commonly quite regular, and often nearly spherical; but, where they are numerous and erowded, they wear each other quite irregularly, so that polvhedral forms abound. Orten, while the lower portions are thus poly. hedral, the exposed upper surfaces are quite regularly spheroidal. The original centers of concretion seem to have been very minute fragments. broken from the surfaces of the geyser-cones, probably by the rnsh of the eruption. In some cases, the npper surfaces of these concrutions are pearly, in others they are beaded; oceasionally the wholesurface is beaded, or is covered with prickly points. These surfaces are slso frequently deposited upon fragments of the laninated material which may have by any means found their way into these crystallizing baths. These pearly and beaded and prickly surfaces are also individual characteris. tics of the deposits of different geysers, and vary greatly in detail. The immedjate orifice of a geyser is almost universally beaded, and this character extends to greater or less distances from it, according to the distribution of the falling water, surfaces frequently thus washed or sprinkled being almost universally of this character. Such surfaces, on the contrary, as are frequently bathed in steam, without much spray, are nearly always pearly, as if the steam itself carried enough silica to form the extremely thin layers which are essential to pearly luster. This is commonly the eharacter of the npper surfaces of those coral-like growths which form along the borders of many of the quiet hot pools, whilo their lower surfaces are covered with prickly points. In nearly every pool, except where ebullition is so strong as to break up such ten. der tissues, we see gelatinous vegetable forms allied to mycelium, or the "mother" of vinegar, sometimes in broad, thick sbeets, sometimes in thick branching forms, resembling sponges, sometimes in long waving tibers. The former kinds are generally either green or rusty brown; the fibrons forms are generally pure white. These are very common in the rapidly-flowing outlets of the hot pools, and are continually reproduced as these channels fill up with newly-deposited silica; so that, in breaking through the crust, we often find lamins filled with molds of those fibers, and sometimes to such an extent as to closely resemble silieified wood.

Froun our caanp on the east side of the lower basin we saw on severnl occasions tall columns of steam rising from near the foot of the ridge on the extreme western side of the basin, but at first referred them to the eluster among which we had camped on the evening of our arrival. But upon examination we found a considerablestream coming from west of the Twin Buttes, which had not been seen by previons explorers, and whose valley included a cluster of large geyser-mounds, from which these columns of steam must have escaped. Though this group was visited ot three different oceasions, none of us were so fortunate as to witness any eruption from these vents. On entering the valley from below, we see before us a runge of four large mounds running diagonally across it. The two central ones are the highest, and appear so mueh as if they were guarding the upper valley that this was called Sentinel Braneh. Approaching this row from the east, the first spring observed is apon a low mound, near the foot of the spur which separates this valley from the main one. It is a deep oval pool, whose two diameters are about 12 and 15 feet, with a beantifully-scalloped edge, not raised above the general surface of the mound. The temperature is $198^{\circ}$, and this is probably a geyser. Several small vents also appea? on this mound, but 
no other is important. A little to the left, as we advance across the valley, upon a very flat mound, we find a eluster of four large and several gmall vents. The beady deposit about them is very pretty. One of the larger vents apparently spouts moderately, thongh not frequenuy. of the larger vents apparently spouts moderately, thongh not frequendy.
The temperatures vary from $191^{\circ}$ to $193^{\circ}$. A few rods farther on, we come to a truncated conical mound, rising abont 22 feet above the creek, on whose bank it stands. Upon the summit is a shallow, nearly eircular, pool, about nine feet across, bordered with an exquisite frilled edging, from four to six inches high from the surface of the mound. From this, three or fonr small streams flow over the edge and down the side of the mound through deeply-imbedded channels. This appears to be a strong spouter, aud is probably the source of the tall column of steam before mentioned. The creek cuts into the base of the mound on the north and west sides, and will probably before many years cut into the central tabe and canse the eruptions to take a horizontal direction, as well as, or instend of, a vertical one. The temperature is 1980 . A fer rods or inatend of, a vertical one. The temperature is 1 farther, on the west side of the ereek, stands another mound of the same form, but from two to three feet lower, and its pool is a little less regular. It has also a small conical vent just outside the pool. This bas probably been a strong spouter, but I thiuk that it does not now erupt; temperature, $197 \circ$. The ornamentation about these two pools appeared to me, as well as to others, to be the most beautiful of any in the whole to me, an wall as is otlers, to be the in the extreme ealge of the valley. on the top of a low mound, a cluster of four vents, from one to two and a half feet across, quite irregular in shape, and all boiling too violently to allow one to take the temperatures. All were surrounded by bead-like inerustations. I juige that they all spout moderately. Along this western side of the valley, the base of the hill is thoroughly saturated by the flow of very numerons cold and slightly warm springs. About a quarter-mile above the monnds, we found the creek flowing rapidly in a quarter-mile above the mounds, we found the creek fiowing rapidily in
a narrow deep channel with inudidy banks, aud not easily crossed. Its temperature of $52 \circ$, and the entire absence of the siliceons fragments elsewhere so abundant, satisfied us that no hot springs exist in the upper part of its valley. Returning to oor former crosesing, between the high mounds, we turned sonth along the east side of the valley. Here is a

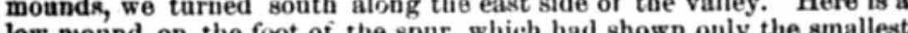
whiffs of steat, and had been supposed to be nearly extiuct; but, upon approaching the vent, we found a deep basin, apparently bollowed out of dark bakalt, but really lined with a smooth-suriaced dark reddish. brown siliceons deposit, made by the spring itself. This is very different in color from any other known in the whole Fire.Hole Valley, and wrs in color the Iron Pot. It was boiling moderatels at ubont six feet belos

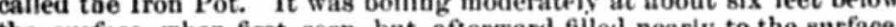
the surface, when first seen, but afterward filled nearly to the surface. Its temperature conld not be obtained. The form of che pool is ovate, abont 7 feet by 5 at the lowest level seen, and expaniling above to about 10 feet by 7 . Thongh it may often fill its pool, it probubly loes not spout much. A hundred rards farther south, along the foot of the spur, there is an irregularly-oblong, steaming pool, about 100 feet by 30 , and from 15 to 20 feet deep, with two or three deeper pits. At the east end it boils constantly and sends off dense clonds of steam. Along the edge at this end; the ordinary pearly.beaded deposits are alundaut, while a fow inches witbin the rim, and sometimas attachel to it, were numerous coral or mushroom like forms with broad tops expanding Irom a slender base. The portions of these forms which are towaril the steam, and re minding one of the polyp-cells of the Madrepores, while the oppo- site sides, which must be alternately wetted by the steam and spray and dried by the wind, have the beautiful pearly lnster, partis due to the thin lamination of its structure and partis to the opaline composition of the material. The west end of the pool is shal. opaline composition of the material. The west end of the pool is shal-
low, and the water flows from it to the foot of the slope over broad and shallow terracel stepe, resembling the deposits of the calcareons springs of Gardiner's River, though on a inuch smaller scale. The main pool nowbere showed a higher temperature than $187 \circ$, but a little veut two feet from its rim gave 19,0. Severai smull pools and veuts were noticed in the adjoining timber, but none that deserve special mention.

Though this whole valley is more or less miry, yet its luxuriant growth of grasses and other forage-plants attracts the game, whose trails abound in every direction; and this is probably the best location for a ranch that can be found in the Lower Basin. The camping-ground on the east side of the valley is low aud damp, so as to be unhealthy for a prolonged stay. If a hotel were to be located in the region, the best place would probably be on the foot-bills on the east sile c? the river,
between the Lower and Upper Basins, since cold springs and abundant forage within easy reach would there be combined with dry locations for building, while the wonders and beauties of either basin would be but short distance off.

Most of the cold ponds fonnd at intervals throughout the valley are plainly extiuct hot springs; but, umong the timbered hills about a half mile southwest of the White Dome Geyser, there is a large one which is not of this ct uructer. It has no outlet. Just south of it is another hollow, once occupind by a still larger pond, of which only a small pool now remains, while the old bottom is covered with a very luxuriant growth of grasses aud sedges.

Between the two basina, Rabbit Branch enters the river from the east, with a strong flow of hut water. The whole of its short valley is filled with warm and hot springs. The principal one, at the bead of the northern fork, a large steamiug pool, reaches $148^{\circ}$, and is not surpassed by any of its neighbors. About the forks of the stream, a considerable cluster of steam-vents, pools, and mud-pots give various temperatures up to $186^{\circ}$ and $192^{\circ}$; yet, as a whole, the group shows but little activity. Steam.vents and small pools run far up the side of the mountain. At the heal oi the southern fork, separated from the last group by from 200 to 3100 yards of timber, is a cluster of mostly small springs, which shows rather greater activity. The principal vent is situated under the precipitous bank, and is apparently working backward by undermining the overhan zing roek. Large masses have already slipped off and fallen into the narrow pool, so as to greatly interfere with the free motion of the water; and, accordingly, though steaming and boiling farionsly, it spatters only a short distance. It was in.possible to reacir the boiling center; the nearest accessible part of the pool gave a temperature of $192^{\circ}$. Crossing the spur to the sonthward, we found, instead of a broad, flat valley, like the one we had just left, a narrow, steep ravine, purtly with precipitons sides, at only one point of which did we see slight indications of warm springs. There was, however, an abundant flow of cold springs, fully equal in volume to that of the bot springs of Rabbit Branch. As no difference was noticed in the rocks of the two hollows, we could refer their difference in form of erosion only to the solvent power of the hot waters.

As we approach the Upper Basin, we find considerable stretches of swampy flats, now nearly destitute of any signs of bot-spring action, but probably occupied by such springs in former times. In the Upper 
Basin, we find fewer of the mire-holes which render 2 . avel difficult and even dangerons in some parts of the Lower Basin. The surface is made up largely of the thinly-laminated sinter, broken up by frost and sun, and partly of the elay left behind in the disintegration of the voleanic rocks aud the remoral of the silica by the hot waters.

The larger geysers, so far as yet kuown, are clustered within a rather limited area, so that one can generally wateh three or four at once. The different ones have very different periods of eruption; and, in many, the successive intervals of any one vary considerably. The violence of eruptions also varies greatly; but no law of connection between relative violence and length of intersal has yet been determined. Many of the vivere ant withont any noise, other than the mere rush of water and gevsers erupt wichout any no severnt of the larger ones are constantly steam ; bat the ermptions of several of the laree ones aro constsutly accompanied by violent regular pulsations, audible to a considerable distance, and sbaking the carth for many rods, as if a fifty-thousand. horse-power steam.pum, were in full action down below. In one eruption of Giantess, five or six pulsations were heard before the water be. gau to rise. Their rate was at first seventy-hree per minute, but gau to rise. The r rate whe at of the erion slightly decreased toward the elose of the er (n) to seventy, in the course of twenty minutes, and became fainter and fainter. Another, of the same geyser, started at seventy-three per minnte, slowing gradually. In most iustances, these pulsations cease when the flow of water ceases; but they were once observed to continue for the sotne minutes after the opening of the flnal rnsh of stea that the of steam often comes with greater velocity and noise than that of the water, and is really a part of the eruption, though generally not so con-
sidered.

The erosion effected by the erupted water is generally very slight, being coufined, eren in case of the most abundant flow, to the channels by which the water escanes and to the space immediately about the vy which the water eseres an creased by deposition from evaporation ratler than eroded by the fall. ing jet. In the case of Fan Geyser, the main jet, instead of being vertical or nearly so, escapes at an angle of about $60^{\circ}$ with the horizon, and the falling water has holle ved out the disintegrating sinter quite deeply for a space of about 115 feet from the vent.

In some of the bhallower hot nools, we find beantiful osettes of sin ter, of variuble thickness, sligitly attached to the bottom. In their earliest stages, these are extremely thin, and from the lower side small spiny processes fall to the bottom, much like the rooting-processes of the bryozoans, or the roots which depend from the branches of the mangrove and the banyan. Judging by their general appearance and conditions, these probably originate as fragments of vers thin pellicles conditions, these probably origin the very surface of the pool, and, broken up by the wind, each fragment tends to sink; but some of them escape that fite, and inore material accumulates by evaporation upon their wet edges so that they become basin-shaped and float securely. I cannot accout for the basal spires, about which a solid pedestal fiually accumuiates, ex cept by supposing that they bave central nuclei of the swall fibers of mycelium, which are floating in all these pools in greater or less abun. myceli

With the exception of these low-grade vegetables, and the larves of Helicopsyche, found by Mr. Taggart in water of temperature of 1800 , we saw no evidence of the existence of 'iving forms in these very hot pools.
A small stream, carrying, perhaps, 15 feet of water, enters the river from the west, just below the month of Iron Spring Creek. It rises far up on the western divide. Abont a half mile up from the river, we enter a sharp, narrow cañon, along which small bot springs still occur, and arrive, in about a balf mile farther, at a fine fall and cascade, some 80 arrive, in about a balf mile fartber, at a fine fall and cascade, some 80
or 90 feet high. The chief interest of the spot is in the inclined bedding of the volcanic sandstone, which dips strongly to the southwest. So far as I could judge, this was not consequent upon disturbance and np hearal of the beds, but upon the slope of the surface upon which the materials were originally deposited. Upon the west side of Sentinel Branch. I fond westerly dips, and upon the divide, toward the Yellowstone, northeasterly dips. Though the question cannot positively be decided without many more detailed observations, yet I am strongly inclined to believe that we have at these points remnants of the outward slopes of a huge crater, whose central area was large enough to ivclude most if ot all of the heat-vents of the two geyrer-basins. Possibly tlere wa a central crosg-division between the two basins; bnt I noticed no decisive dips thereabout. On the foot-hills of the eastI noticed no decisive dips thereabout. On the foothilis of the east westerly dips occur, which, according to the above supposition, must represent the internai slope of the crater.

Mr. Stevenson returned from Virginia City with supplies on the last day of $A$ ugust, and we started upon our return-trip the next day. Stopping one day in the upper basin, to make our final observations upon the geysers, whose like we expected to see no more for years, we again moved southward on September 3.

Above Old Faithful, which is recognized as the last large geyser of the upper basiu, there are ouly a few hot springs, mostly small, jnclud. ing one small geyser. The valley soon narrows to a deep, impassable cax̃on, with perpendicular walls of tracbyte, with nearly vertical dips and east and west strike. The trail is here forced to the top of the bank, following the east side of the cañon, and, in the next half mile, passes close by a set of beautiful cascades at the head of long rapids. The principal fall is 30 feet higb and 40 feet wide, with a side jet abont 5 feet wide, like a mill-tail. The water was about 1 foot deep on the crest of the fall. Fifty yards below, all this water is forced through a passage only about 5 feet wide, and rushes with great violence into a deep, still pool below. From a rocky point directly in front of the fall, there are fine views up and down the ravine; and it is well worthy of a visit from all who would see the beanties as well as the wonders of the geyser-yasins. The main fall much resembles the Middle Fall at Trenton, New York. From this point, the parties of 1871 turned across the divide toward Yellowstone Lake. The rapids above the fall are moderate, and the banks spread out into a flat bottom, much of which is swampy. To aroid this swampy ground, the trail, which here crosses the river, turns np over the bounding range of hills on the west. In the hollows, we now fud many sinall ponds covered with lily-pods; but only a few of the sellow blossoms appeared. A few of these ponds have small ontlets, and Binall but apparently constant supplies of water, but most of them are entirely inclosed by hills. The surface is here densely timbered, but mostly with young growth.

These hills soon approach the river again, which has bere a very narrow valley. This, however, suddenly widens again into a thiri geyser basin. The first intimation of hot springs, if we follow np the river-bank, is a strong column of steam npearing among the timber on the east side of the valley, just as we enter the basin. Mr. Taggart $16 \mathrm{G} \mathrm{s}$ 
visited this vent and reported a boiling pool, temperature $190^{\circ}$, overhung by rocky banks, which showed no signs of spouting. As we emerge from the timber on the weat side, we find the lower angle of the basin occupied by an area of hot springs, perhaps 500 feet long by 250 feet widle, with the nsual floor of disintegrating silicious sinter, and containing numerous vents, mostly active. Near the center of this aren stands the chimney of a single geyser. This is a dome-shaped monnd, averaging 15 feet in diameter and from 11 to 14 feet high, completely covered with most elegant varieties of the pearly beads before deseribed. It is striped verticalfy with bands of white, dark.green, brownish black, and various shates of vellow and orange, the white being ordinary geyserite, while the other colors are applarently of purely vegetable origin. On the north side of the dome, where the main flow from the eruptions is now generally scattered, the geyserite has also a beautiful, delicate pink tinge. The summit of the northwest side, as seen froni the northeast, is ornamented with a fine profle of a mild-featured human face done in the bead-work. The top of the mound is perforated with numerous small three, four, and five-angled apertures, and a single larger one between 2 and 3 inches in diameter. In ernption, this larger openiug throws a stream from 20 to 50 , and even to 70 , feet in beight. mostly in drops with much steam. Though the amount of water ejected is small, yet the force is very great; and, in this respect, the ernptions much remindeil ns of those of the Castle Geyser. Its highest jets are generally abont the mildlle of the period of eruption. Eruptions take place at somewhat irregular intervals, but generally are about two hours apart. During such as were carefully observed, there was first a periof violent activity, continuing from three to four minutes and ceasing suddenly; then, a quiet 'aterval of from eleven to twenty-fonr minutes; then, a second active period of from twenty-three to twenty-six minutes, closing gradually witi a rush of steam and occasional water-jets. The small vents spit furiously all through the eruption, their jets reacbing 3 feet or more in height when the main jet was at its culmination. About 10 yards off, on the platform, a small vent is in sympathy, but is so nearly stopped up as to be generally overlooked. I think it probable that this was wider in the younger days of the geyser, and has become stopped up equally with the latter. It is evident that eruption at this point must soon cease, unless the great force developed beneath shall be able to break away the upper part of the dome. It is more probable. however, from facts observed in the other basins, that a new vent will be opeved and a new mound built. I could rot obtain the temperature of the water of the geyser, since the water, except just before and during the eruption, retirel below the surface-cpenings; and we had no self-registering thermometers with which to ineasure its beat from a safe distance. The surrounding springs, which are nearly all boiling, gave temperatures varying from $185^{\circ}$ to $192 \circ$. The general elevation of the basin is about 7,770 feet, at which the theoretical boiling-point is about 1980. The single geyser of the basin was called the Solitary.

This small basin spreads perhaps a half mile from the stream, and includes, near its nortbwest corner, another cluster of hot springs, some of which reach $186^{\circ}$, surrounded by varionsly colored deposits, including some sulphur. The trail of onr main train entered the basin at this point. The central part of the basin slows the vents and deposits of numerous seattered springs, most of which are nearly or quite extinet, only a few of them still boiling.

A small stream, which comes in from the west near onr camp, has a fine cascade, 130 feet high, about a quarter mile from the river. Its supply apparently comes from the flow of the numerous small ponds among the hills before mentined.

Showers for two days had softened the soil so mnch that portions of ground immediately about the springs, which are perfectly safe in dry weather, were now too soft for passage, o. latting one down a foot or so, and that, too, in places where at that depth one was likely to find scalding-hot mud. Fortunately, no serious accidents occnired.

After a short interval of timber, another small meadow-like basin opens to view, occupied by a few small warm springs of no importance. Again the mountains close in; so that the stream flow for nearlyce. mile through a narrow rocky cañon, with sharp ridges rising from 1,000 to 1,200 feet high on either side, down whose almost precipituus elopes
beautiful cascades rushcd to the riser. The of obsidian cascades rushcd to the river. The banks are mostly composed of obsidian sandstone in tumbling masses; so that I had great difficulty in leading my horse through it, while the train was obliged to climb over the bounding ridge on the east. The strata are mostly upturned at various angles through the cañon, but become more nearly borizontal at its upper end, where we approach the level of the last flat basin about the head of the river. Mr. Bechler reports $\|$ large amphitheater, resembling a crater, passed by the train as it reached the top of the resembling a crater, passed by the
ridge on the east side of the cañon.

The basin surrounding the head of the river is occnpied by quite large meadow, tolerably dry in the along, but very swampy all around its borders, where numerous cold springs escape from the rocky hills. The sites of a few old hot springs, long since extinct, are marked by patches of the much-disintegrated white geyserite, now mostly buried under the tall grasses and sedges which cover the meadow. A buried under the tall grasses and sedges which cover the meadow. A small lake, covering perhaps sixty acres, son of the posse the titimate lake-source of the by the hunters name Madison lake, which has heretotore been applied divide, under the mistake sheet of water upon the other side of the divide, under the mistaken idea that it was the head of this river. The lake once occupied the entire extent of the basin, having then covered a curving area abont two miles long by about a half mile wide, but has been mostly drained by the erosion of the last cañon. wide, but has borlers of the old lake are faintly indicated at some points, but not so rlainly that their elevation conl be lefinitely boter border of the timber, from 20 to present part of the lower part of the basin, marks the lowest level at which the lake stood for any considerable time. Though the basin receives only three small brooks, supplied by the banks of snow which constantly rest small portior $s$ of the divide, ret the nain stream, where it leaves the upon carries a good body of water, mostly supplied by the large springs across, with a strong fom 10 to 20 feet across, with a strong flow of water boiling up from buneatb, sometimes throngh quicksand, sometimes through numerous large openings in the ift clay bottom.

A storm of iningled snow, sleet, and rain detained us here for one day, September 5; but next morning it cleared, the snow rapidly melted, and we went on. Our hunter, Frank Mounts, had reported a valley about two miles south of us, throngh which a stream flowed westward. Acrordingly, while the train moved about three miles nearly due east. to a new camp on Sboshone Lake, Mr. Bechler and I crossed the sonth. rn divide to the head of the newly-reported river. We found it to be large stream, formed, within a short distance, from the abundant flow of 
numerous large springs bursting from low down in the sides of a high platean of very porons voleanic sandstones, which we afterward found to extend for several miles to the sonthward. This was evidently the head of one branch of the stream crossed and camped on by us on the even. ing of Angust 3, as we were ascending the valley of Henry's Fork. In ing of $A$ ingest 3 , the absence of any prior designation, 1 have called this Bechler's kiver. Its upper course is among deep ravines, with sharp slopes, but well timbered, for some six or eight miles. It then passes through 8 rather narrow cañon, with bare, precipitons walls, whose extent was not de. termined, and emerges into a broad, grassy basin, which reaches nearly to our lower crossing place.

The snow lying among the timber gave us an opportunity of observing the game-trails; and we were surprised at seeing so few. $\mathbf{A}$ few miles farther east, game is very abundant.

In crossing the diside eastward from Madison Lake, the western slopes are quite steep, and porphyritic obsidian sandstone appears in beavy rounded masses, but slightly disintegratec. On the eastern face the slopes are much more easy, and the rock is much disintegrated into a very loose, spongy soil, which, where the tibber bas been burned from the upper spurs, makes very slumpy traveling, at least in wet weather.

Descending the valley of a small but rapid stream, the prineipal affluent of this part of the lake, the trail crosses a considerable area of hot springs and geysers, to a good camping ground on the edge of the marsh, which here prevents easy access to the immediate shore of Shoshone Lake."

If we had not been fresh from the wonders of the Great Geyser. Basins of the Fire-Hole Fork, we should have considered the ptenomena now about us as extremely grand and beantiful. In beauty, indeed, these springs are probably unsurpassed; but the geyser-eruptions ex. hibit much less force than those we had just left. Still, I consider it desirable to make the recorded descriptions of all these phenomena pretty full, and will therefore give a general description of the vents of the Shoshone Lake Geyser-Basin. The area occupied by active springs

- This lake was seen by Dr. Hayden in 1871, while he was returning, with a small party, from the Fire-Hole Basins to Yellowstone Lake, but at a point some miles east of this camp. His guides itsormed him that the name Madison Lake had been applied to it by the hunters, and that it was considered tho heal of a fork of the Madisoa hiver. ficiently to verify or dippore the antements the maps of last year's report give the ficiently to verify or disprove the a stream whe was Madison River. Its connection proving not to be with the Madison and Missouri, but with the Snake and the Columbia, it became at once a queation whether the old name should any longer be used for this body of water or sbould be tranaferred to the trat lake-source of the Madison. This latter courso wan unanimonsis decided on. The latest published map of this region, for many localities tho best, and supposably the beat for this partieular neighborthood, anee the author claimn to have traveled bere, is one recently compiled by W. W. Delaceg, of Helena, and published by G. W. \& C. B. Coiton, of Nerr York, (elition of 1872.) This sbows a so-called Madison Lake, a so called DeLacey's Lake, located some milen west of the bead of the Liadison avd about aifoen mately obly ded ake Bessic was at once rejected, as having been originally proponed for the lake long known to the bunters of the region as Heart Lake, for changing whose namo there was and is no valid reason. The numerous and outrageous errors of the maap soow that neither an discoverer nor as mapper of this lake has Mr. DeLacey any elaim to a perpetuation of his unme; and, since the lake oceupies a position entirely differen from that assigned to DeLacey's Lake, wo have decided to drop that title, and to call this, in our mape and reports, stostione Lake, as being the head of ond pal forks of the Sheshone or Suake River.

OVERSIZE FOLDOUT(S) FOUND HERE IN THE PRINTED EDITION OF THIS VOLUME ARE FOUND FOLLOWING THE LAST PAGE OF TEXT IN THIS MICROFICHE EDITION.

SEE FOLDOUT NO 5 
extends up the stream on both sides abont a jalf mile. In the upper edge of the narrow belt of timber which separates the spring-area from the lake-shore, is a small mnd-pot, whose borders were ornamented with exquisite cock'Bcomb-like deposits of a blaish-gray geyserite, con. taining safileient clay to give their pointed tips far more tonghes: than their form would lead one to expect. These forms have not been seen at any other point.

About fifty yards west from this point stands the most important geyser of the basin. It has now three vents, standing elosely in a row, each of which has built up a small mound, beantifnlly taaded without and pointed within. The eastern vent has an irregularly-oblong opening, about 2 feet long and from 8 to 12 inches wide; its mound is about a foot high, and stands upon a base of about 3 feet by 4 . The central mound is abont 5 feet in diameter at the bese, and abont 3 feet high, with a deep central, triangular opening, measuriag about 30 inebes on a side. The western one is about 1 foot high, on a base of about 20 by 30 inches, with two small openings about 2 or 3 inehes in diameter. These stand in the montl of an old geyser, once probably of great power, though now nearly inactive, of which there remains a deep pool about 8 feet wide by 12 feet long, in which the surface of the water during our stay at this camp was abont 3 feet below the top; but it evidently overflows at times, and it is possible that it stili sponts oceasionally. It showed no sympathy with the present vents during their eruptions. The section of the layers constituting the old mound is well shown in the walls of this pit. During eruptions, the west vent sponts a little water, 2 or 3 feet high, for from 1 to 2 minutes, and the vields a moderate flom of ateam. Menn ing a very powerful jet from 70 to 90 feet into the air, which, after about 5 minutes, gradualiy gives place to steam, the mingled steam and water giving the bighest jets. The east vent, spouting from 10 to 50 feet, throws a solid body of water for about 10 minutes, when the whole supply of water seems to be exhansted, and the rush of steam from all the vents becomes more violent and continues some 40 to 50 minutes longer, gradually declining, however, though with many spasmodic renewals. A small flat opening in the space between the central and western vents gives exit to a little water while the geyser is preparing for eruption, but takes no part in the eruption itself. We ealled this Union Geyser, becanse of its combination of the varions forms of geyseric action. Its temperature, immediateiy before eruption, was 1980. Its periods of eruption are irregular, and no law of irregularity was ascertained. An eruption was heard by the men on guard on the nigat after onr arrival, but the time was not noted. The first recorded one began at $10.28 \mathrm{a} . \mathrm{m}$., and continued, steam and all, 47 minutes. It highest jet reached the elevation of 92 feet. The next began at 1.55 p. $m$. on the same day, reached 70 feet in height, and lasted ह5 mingtes. Still another was heard at $10.25 \mathrm{p}$. $\mathrm{m}$, bnt no further time obser were recorded.

Abont this spot, there are several quiet and boiling springs; but none of the latter spout more than from 1 to 3 feet. Passing up this side of the stream, however, for about a hundred yards, we find, just above the point of the hill upon our right, the first of a group of larger rents, of which seversil seemed to ns to deserve names. This, which was called the Minnte Man, bas built up a monnd about 4 feet bigh and from 12 to 15 feet across, beantimilly with the oharg pints wich with the sharp points which usually accompany the more frequent and abundant flows of water. This ormameutal work spreads far beyond 
the mound, covering an area at least 40 feet acrose. Just behind the mound, and at its immediate base, there is a large ornamented opening. which partly fills before eruptions, but is emptied by them. Mnch of the ejected water falls in such a way as to flow back to this reservoir, so as to keep up the supply necessary to the eruptions. These oceur 80 as to keep up the supply necessary to the eruptions. These oceur
pretty regularly for some hours, at intervals of from 2 to 3 minutes, but gradually decline in force, until the supply of water becomes exhansted. Then the geyser ig silent for several hours, until all the creviees, as weil as the surface-pools, are again filled with water, when its eruptious recommence with much violence, the jets then reaching altitudes of from 30 to 40 feet. These again, thectir from 30 to is repeated. As water gets low, the back pool sometimes receives some of the steam-pressure and spouts from 5 to 8 feet. At one point on the top of the mound. there are some small sulphur-vents, whieh seem to be entirely disconnected with the water-pipes, bat maintain communicatious of their own with the voleanic laboratory beneath.

Nbout 50 feet farther on, Shield Geyser has an ornamented mound about 15 inches high, which incloses a shielil-shaped opeuing, measuring about 8 feet on each of two sides and 7 feet on the third, at the top, but narrowing to 4 feet on each of the two sides and 3 feet on the third, a little lower, at what was water-level when I measured it. This spouts moderately at intervals of a few hours, but no special notes of its eraptions were taken. By its side its partuer has an irregular opening abont 8 feet loug and vary about 8 feet long and varying from 10 inches to 3 feet in width. These reuts exhibited no sympathy with Minute Man. Their temperature is $1900^{\circ}$

Between Shield Geyser and the foot of the hill, Rosette Spring bas a to iangular basin with sides of abont 15,20 , and 25 feet, in whose shal. low waters form many most perfect specimens of the beautiful thin. leaved rosettes already described as occurring in the Fire-Hole Basin. The muddy bottom of this spring contains much sulphur.

$\Delta$ little roeky knoll intervenes between this and the Buiging Spring, which every few momeuts gives vent to large bubbles of steam, which raise a cousiderable part of its surface from 1 foot to 3 feet, with a bulging sound like that of liquid escaping from the bung of an overturned barrel.

Forty feet beyond, the Soap-Kettle keeps up a furious boiling of col. ored water, more or less covered with foam, looking like dirty soap-suds. Its basin is lined with a yellowish-brown deposit. This has probably been a strong spouter, but now erupts ouly at long intervals, if at all. Its monnd is about $\checkmark$ feet across, and is still 1 foot higb, though disintegrating.

Forty yards farther, the Black Suiphur Geyser has three vents, in small dark-colored mounds, which alnost constantly spit, but do not spont much. An abundant black sulphnrous deposit is formed along the run from these vents.

The Twins are two small symmetrical rents, from 4 to 6 inches aeross, in a sinall mound which stands back against the foot of the hill. They spout rarely and to but small elevations.

Several boiling springs oceur at short intervals along the bottom. About seventy yard's farther on, a tlat mound includes two large flat openings which spout to the heif $\mathrm{st}$ of from 20 to 30 feet at short intervals; temperature, 1920. Above this point, the sp:ings are of little importance, tbongh a few rents and old deposits oecar at intervals for a mile or two up the valley. One, near those last described, is a nar- row fissure, along whieh fos 6 or 8 feet the water boils constantly. Near this is a swall geyser-mound strongly colored with iron.

On the opposite sice of the creek is a broad terrace of the siliceons spring-deposits, upon which stand several small mounds very prettily ornamented, from 1 foot to 2 feet high, whose pools boil cunsiderably, ani evideutly spout occasionally, though no one of them was seen in eruption. One of these, near the creek and nearly opposite to Minute Man, is shaped like a conch-shell and strongly colored with iron, and was called Iron-Conch Geyser.

Nearer the base of the hills, there are several large hot pools. One of them was so well furuished with coralliform masses, standing in the shallow water near its edge, as to be called the Coral Pool. This meas. ared about 40 feet by 50 , with a shallow boruer, and a deep central pit about 10 feet across, from which numerous bubbles of gas were cscapr. ing. There is a strong flow of water of the temperature of $160^{\circ}$. A little to the west of this, a valley runs well up into the hills and contains several large boiling pools, but no geysers. One boils with great riolence, with a very large escape of steatn. The pools and old deserted basins extend up the slopes of the hills to elevations of from 100 to 150 basins extend up the
feet above the creek.

$\Lambda$ s a whole, these springs and geysers show far greater amounts of sulphur, and especially of iron, in their deposits than any of those on the Madison. The geysers also show much greater irregularities of eruptions. The group seems to me, as a whole, younger than those in the Fire-Hole Basins. The little geysers on the west side of the creek are plainly young, and are just beginning mounds which promise to attain considerable size.

On the east side of the creek, between it and the lakes, we find a elus. ter of ragged hills, separated by erateriform hollows and valleys, which are occupied more or less completely by mud-springs and sulphur-vents. Upon breaking up the surface-crust about these latter, we find all its hollows lined with sulphur, either in distinct crystals or in moss-like aggregations of imperfect oues. Upon first observing the shape and contents of these hollows, one would naturally suppose them to be old voleanic craters, whose connections with the interior fires were becom. ing nearly stopped up; but, upon more careful examination, it becomes evident that they have been hollowed ont of the surronnding sandstone by the action of the hot springs themselves, which have disintegrated and removed portions of the sandstone and conglomerate of the old and retnoved portions of the sandstone and conglomerate of the old
lake-terrace. Worn bits of rocks, penetrated by numerous small irregular holes, are abundant $\mathrm{cn}$ all the lower parts of the slopes, as well as about the existing vents, showing that the process is still going on. These springs are evidently much affected by variations in the supply of water. Many which were entirely dry gave abundant eridence that ther rometimes give forth considerable streams. The effects of these variable supplies upon the activity of the different springs and geysers are probably very different in different cases. Sibce a full basin seems to be essential to an eruption, a greater supply of water to flll the place of that ejected would, in many cases, canse more frequent and powerful eruptions. On the other hand, it is probable that too large s supply, causing a continuous stream to pass throngh and escape from the basin of a gesser, would cool down its contents below the temperature essential to an eruption.

The springs extend eastward along the shore of the lake for several miles near its present level, and some were seen boiling ap from it bottom, several yards from shore. Many occur also in the marsh about 
the mouth of the creek, which is constantly extending itself into the lake. Some large lagoons are here inclosed by narrow kand-bars, some of which are scantily covered with pines. On this marsh, a little baek from its present border and a foot or so above its level, an old shore. line is faintly marked. The only plainly-marked terrace is about 112 feet above the lake. It consists of thick beds of sand and gravel, which form the bills just described. The gravel has ismed a loose conglon. erate, but the sand has been compacted into a pretty solid quartzite by the siliceous deposits of the springs which filled it when it was beneath the lake-waters. This consolidation, so diametrically opposed to the disintegration just now described, was probably consequent upon the pressure of the overlying lake, which caused a very siow percolation of the spring-waters through the saud, except at the points of more active ebullition.

The present level of the lake is about 7,792 feet, at which the theoretical boiling point of water is about 198.1\%. Springs were observed in active ebullition at various temperatures, from 1980 to $182 \circ$, and one even st 160\%; in this latter case the ebullition was probably dne to an escape of gas, though that was nut apparent. Quiet springs were of all temperatures, up to $186^{\circ}$. Certain sulphur-vents gave $190^{\circ}$.

For sone six or eight miles north, along the divide, the ridges consist mainly of obsidian-kandstone, inclosing heavy bands of reddish-brown and variegated obsidian, having a nearly east and west strike. Most of the subordinate rilger had abont the same course. All of this distriet is heavily timbered, with few openings, so that it became necessary to climb trees when we wished to get any idea of the surrounding country, even upon the highest crests.

On September 9 th we moved to the ontlet. The lake is of a very irreg. ular form, something like that of a well-filled pnrse, contraeted in the middle to quite a narrow passage. Besides the Geyser Creek, it receives only one strean of any size, which enters at the southern end of its more eastern pocket, coming from the high platean on the sonth, before mentioned. The northern and eastern shores and the central part of the sonthern ones are mostly precipitons, with deep water near them, but along the western and parts of the sonthern shores one can ride unost of the way in the edge of the water, thus avoiding the swampy ground and fallen timber of the steep hill-sides. The center of the lake was apparently deep, though, as we did not put the boat together here, we were not able to take any soundings. The water was clear, and the shore sand and gravel quite clean, even from diatomaceons growth, cept at the months of the streams. At the entrance of the southeastern tributary, a considerable marsh has formed, on the eastern side of which small spring deposits were noticed; but no springs were seen here except cold ones.

Near the ontlet, the rocks are mainly mottled black and red spiernlitic obsidian-porphyry.

At 6.33 p. m., (9th,) just as we were camping, we felt three slight earthquake shocks.

On the 10th we moved about five miles, to a camp at the north end of Lewis's Lake. In leaving Shoshone Lake, the river has at first wide bottoms, but the valley soon becomes quite narrow, with steep bauks. Abont one and a balf miles below the lake, the stream widens to betwcen 600 and 700 feet, and becomes very shallow, with inuddy bottom. Then it narrows sudilenly, and rushes throngh a rocky gateway, perhaps 75 feet across, formed by the projection into the stream of a mass consist. ing of two layers of obsidian-sandstone, with a rapidly disintegrating central layer of pink porphyry. There was evidently a flne fall here at one time, and the valley which cones to the river on the north bank, just below the gate, was then a second channel of the stream. Below, the it reaches Iowis's Lake."

This is a much more regular and symmetrical body of water than Shoshone Iake. It is about two and a balf miles long and from one to one and a half miles wide, tapering southward, and is surronnded by mostly gently-sloping shores. These are steepest on the west side, where few bluffs ruh ont into deep water. Our eant ass-boat being put together, Mr. Adams took a series of soundings, with the results indicsted upon the aceompany. ing sketeh, (Fig. 48, in which the depths are given in fathoms. The deepest part found is seen to be 108 feet. somewhat south of the center of the lake. The deepest sounding yet obtained in Yellow. stone Lake, 300 feet, was made also by $\mathrm{Mr}$. Adams in 1871.

From our eamp at the north end of the lake, the valley of its outlet at the south end lay directly in a line toward the Tétons; and, early in the moruing, before thelake was stirred by the wind, those suow-patehed peaks, though forty miles away, were most perfectly reflected by its mirror-like surface. In its setting of the deep-green foliage o the pine and sprues forests which cover the surrounding slopes, this seems to ns one ot the most beantiful o the many fine views seen upon our trip. Fig. $4^{8}$.

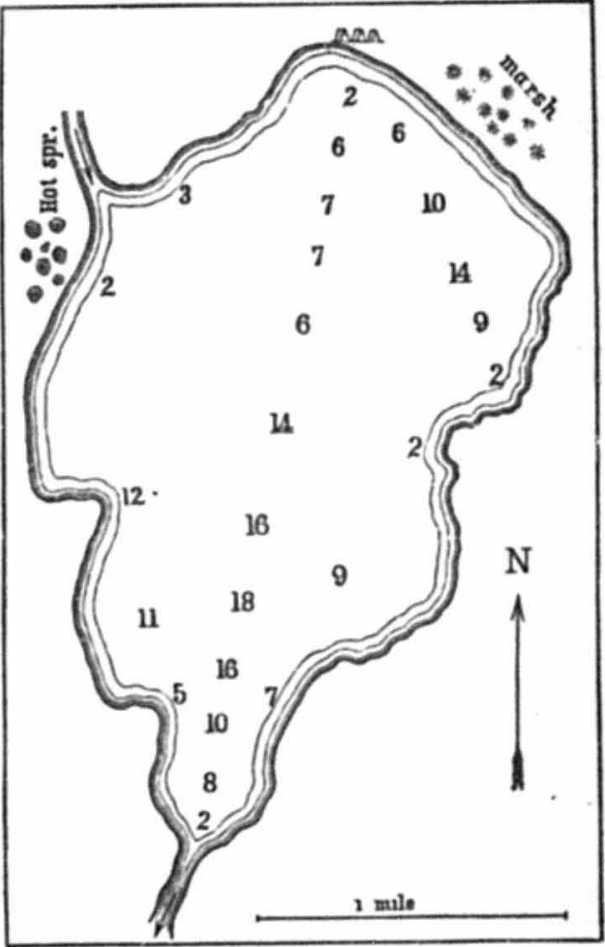

-This lake was seen frotn a diatance, in 1Fa1, by Mr. Bebönborn, and was located, from his notes, by Mr. Hergesbeimer, but its connections were not kuown. It was also seen on two oceasions, and once visited, in the same year, by Captain Barlow; but if two bodies of water, eome miles apart, and of very different outlines. As it had no name, so far as we could ascertain, wo decided to call it Lewis's Lake, in memory of that pallant explorer, Captain Merriwether Lowis. The south fork of the Columbia, which was to have perpetnated his name, has reverted to its Indian title, Bboshope, and is contmonly known by that name, or by ita translation, Snake River. As this lake lies near the bend of ote of the prineipal forks of that stream, it may not inappropriately be called Lewis's Lake. 
The accompanying panoramic view, (Fig. 49,) taken from Mr. Bechler's fleld-notes, will give a general idea of the relative positions of the Tétons, the lake, and the slopes of the Red Mountain group, of which Mount Sheridan is the culminating point.

On the west shore of the lake, near its northern end, numerous hot springs occu:, over a considerable area, a few being seen far up on the western ridge. Those near the lake were examined by Mr. Taggart, who reports as follows:

The hot springs found on the west bank of Lewis's Lako occur mgatly in two groups, separated by a low ridge. In the first gronp examined, all of the springs issued from the sides of a inarsh, and wero mostly covered eitber with mamoes of leafy vegetation

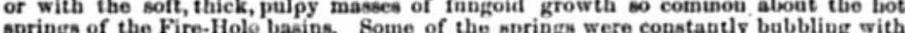
an escaping gas, wbose character was not uscertained. The temperatures of nill the springsare low. A few of them are as follows: $1122^{\circ}, 1222^{\circ}, 124,120^{\circ}, 124^{\circ}, 130^{\circ}, 133^{\circ}$, $140^{\circ}, 140^{\circ}$. As an interesting fart, I noted that all the spnngs whose temperatures reached or exceeded $120^{\circ}$ had the growth of fungohd pulp or a deposit of gray gey. serite, while those cooler than 120 - were covered with lrafty vegetation. This eluater of springs is evidently the last remnant of a much more active group. since, all along the shore of the lake at this point, there are large deposits of old geyserite. At some points, this extends far ont into the lake.

The necond group of springs differs from the one just described, in that its vents are larger abd the water hotter. The springw are surrounded by solid groutud, atd, in their general features, resemble the hot spings of the Fire-Holo basins, no that they the princer about 40 feet by 20 .

Both Mr. Stevenson and Mr. Taggart brought specimens of the gey. serite, including many regetable fragments, apparently some of the coarse sedges common along the lake-shore.

\section{H A P T E R I V.}

MOUNT SHERIDAN-HEADS OF SNAKE RIVER-FALLS RIVER PASS-JACKSON LAKE-GLACIER LAKES-GRAND CASON OF SNAKE RIVER-FORT HALL.

Leaving the main train to find its way soethward to t'so stream which flows from Heart Lake, a small party of us started, on the morning of the 11th, for Mount Sheridan aud the country beyond. At the north end of the lake, there is a consideraule marsh aud a lagoon, which, when full, throws good streams into the lake; but its outlets were now choked up with beach-sand. Its water comes from the drainage of the broad, flat area, partly in meadow, partly in timber, which stretches across to Yellowstone Lake. Our course, holding to the left of the main peak, led us over moderate slopes, for some miles, until, passing one or two small ponds, with no ontlets, we struck the foot of the spur which, run. ning out from the second crest of the Red Mountain range, counting ning out from the second crest or the Red Mountain range, counting
from the north end, forms the divide between Lewis's and Yellowstoule from the notth end, forms the divide between Lewis's and Yellowstone
Lakes. Upon that divide lies the small lake, withont ontlet, called Lake Riddle, visited by Dr. Hayden's party on their return frotn the Fire-

- "Lake Riddle" is a fagitive name, which has been located at several places, bat nowhere permanently. It is aupposed to have been nsed originally to designate the mythical lake, among the mountains, whenoe, according to the huthers, water flowed to both oceans. I have agreed to 3 r. Hering's proposal to attach the name to this lako,
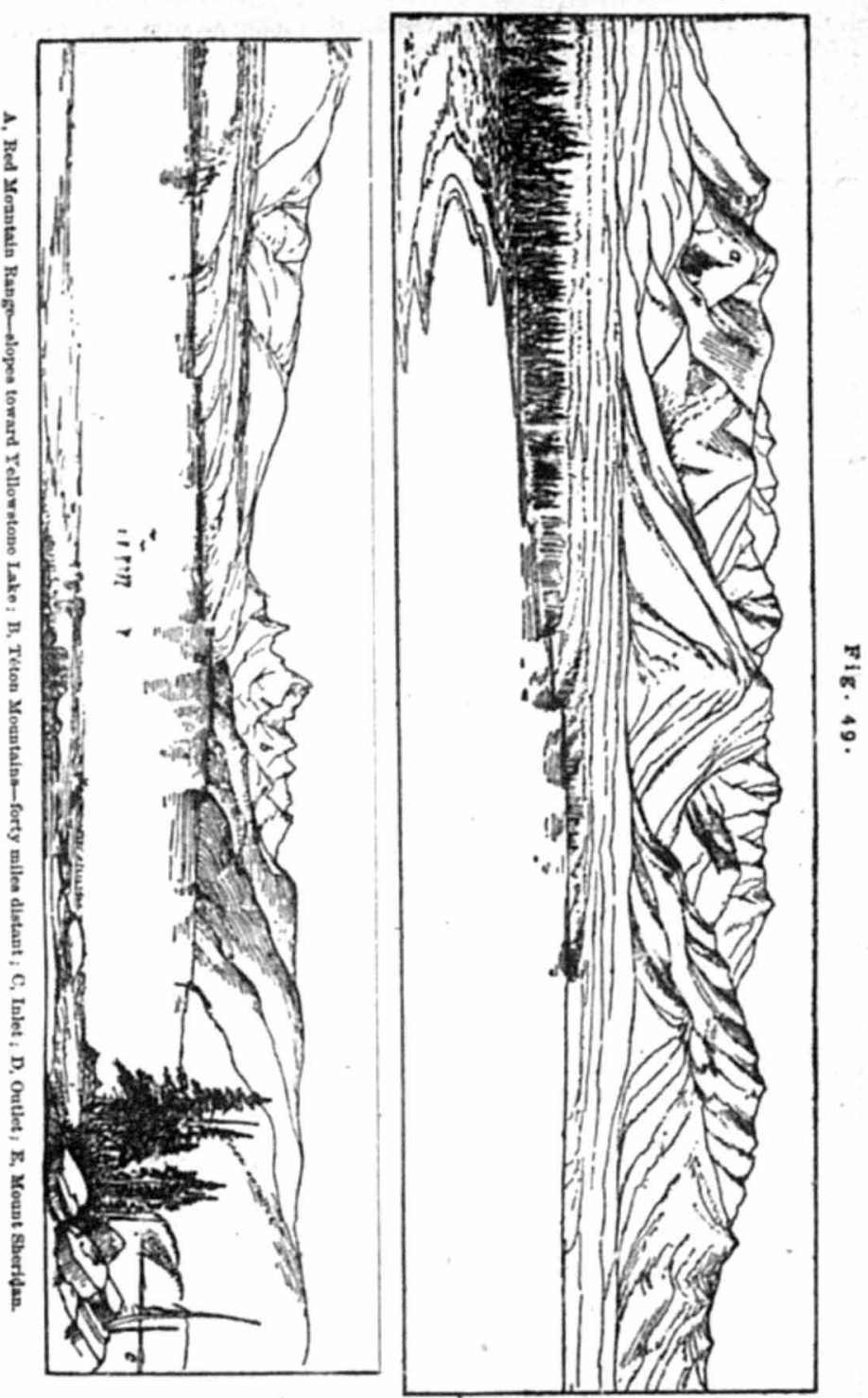
Hole basins in 1871. Mr. Hering visited this lake, and found it to be 7,999 feet above the sea, while Lewis's Lake is 7,750 feet and Yellowstone Lake is 7,788 feet. A bigh terrace is faintly indicated on the east side of Lewis's Lakt, but its level was not determined. This region should be more carefully examined, with a view to ascertain whether there is not some continuous terrace higher than the dividejust described, which shall prove that ' he whole of this broad comparatively flat area was, as its general form suggests, covered by a large lake, which was really tributary to bota oceans. The lowest point of the actual divide was determined to be 25 feet above Lake Riddle, or 8,024 feet above the sea. In ascending the mountain, we found the easiest slopes very steep, so as to make much zigzagging necessary in getting our animals to the summit. As we occasionally looked back, we saw beneath us, on our left, the large cluster of hot springs which occupies the head of the valley of the longest tributary of Heart Lake, and, beyond, canght glimpses of Yellowstone Lake. Upon reaching the first crest, both lakes lay spread ont before us, while, to the westward, Lewis's Lake and Shoshone Lake were also in full view. Between us and Heart Lake lay a great hollow of the mountain, looking mucit like a broken-down crater and very probably it may once have been one. The highest peak was still beyond os, and we made bat little delay, except to shoot gronse for sup. per, in riding to its crest. This range was called Red Mountain by Dr. Hayden's party of the previous year; bnt its highest peak lacked a name, until Captain Barlow visited its summit and dubbed it Mount Sheridan." It is one of the most sightly points in the whole region. Surrounded by deep valleys on all sides, and itself standing 10,420 feet above the sea, it gives one a range of vision over an iminense area. Sweeping round the horizon, $I$ counted four bundrel and seventy-five distinct mountain-summits, at distances varying from thirty to two hundred miles. The Tétons on the west loomed up grandly, while, through the broad depression just north of them, the Crater Buttes, the Three Buttes, the Salmon River Mountains, and Sawtelle's Peak, were in full sight. To the nort $\mathfrak{a}$, the Gallatin Mountains, the Belt Mountains, and Crazy Woman Mountains appeare ' close at hand, while along the eastern horizon stood the high walls of the ellowstone Range and of the Big Horn Mountains, aud far to the southeast stood what ve supposed to be Frémont's Peak and other crests of the Wind River range. There appeared to be a cousiderable depression in the Big Horn Mountains nearly due east from the head of Yellowstone Lake, as if there might be a practicable pass through the range at that point. This shonld be examined. Through. out all this wide area, with its numerous lofty crests, there were no "snow-corered" maks. though many large bodies of snow appeared near the summits in every direction.

The lower slopes of the mountain are beavily timbered; but, as we approach the summit, the trees become scattered and stunted, consisting mostly of Pinus flexilis and a small spruce, Abies Douglasii, both characteristic of high levels. The coarse, yellow lichen $($ Ever $(\xi)$ nia vulpina, often ealled "Montana moss," which is somewhat alundant at lower levele, but is there rarely found well fruited, grows here in immense qusntities, magnificently fruited, the spore-disks (apothecia) being fre- Mount Everts had been used for it, bnt that uame was already in use for a peak fartber north, and duplication of names is as oljectionable in keography as in the otber sciences. ison of the old maps was intended to apply, but the location of thet peak was so manay ison of the old maps was intended to apply, but the location of that peak was so maty
voiles distant from the position of this, avd bal wo different relations to surroundip ranges, that wo canioot consider the ideutification at all certain, and thereforv most reject the name. quently an ineh or more in diameter. At the very erest, vegetation is reduced to a few grasses and Alpine plants, and the gray, red, and yellow rock-lichens which so commonly make these high levels brilliant.

The extreme crest consists of a dark, breceiated porphyry; but, only a few feet lower, we find an abundance of the purplish-pink laminated porpbyry, which forms a large part of the mountain. All the rock is quite ferruginous, so that, on weathering, it attains the dark-red tint so characteristic of the monntain as seen from a distance.

In the south slope of the mountain there is another huge crater-like hollow, but I doubt its being really au old erater. Its slopes are steep, with loose rubbish, on which we could hardly stand, while at the same time we could with difficulty drag our horses down it to our chosen canping-spot in a grac opening by the side of the small stream formed from the suow.banks, which probably never entirely disappear from the head of this hollow. A snow.fed pond lies on a small flat near the head of the stream. A large dike of very compact trap crosses this ravine just above camp, running about north $44^{\circ}$ west. Mr. Hering, with his assistants, remained upon the summit until after dark, for star-observations, but succeeded in bringing his instruments s: foly to camp.

Next morning (13th) Mr. Hering and Mr. Stevenson returned to the main party, while the rest of us went on to examine the head-waters of the Snake, whose general position we had seen from the summit of the mountain. About a mile below our camp, we came to a curions little spring-pool, standing on a marshy bottom. Around its edge there was a dam.like border of roots, grass, and moss, by which the water was beld at perhaps a foot above the surrounding marsh. Apparently the spriug had burst up through an old turf, which had turned up at the ediges, and through which the water had never been able to break down an open passage, though escaping through its mass aud over its edges. Onr descent centinued to be quite rapid for nearly two miles farther, when we reached the meadow-like bottom of a strear coming in from the left, which apparently gathers the water from the springs which escape from the fcot of the mountain, nearly round to the basin of Heart Lake. From the junction of the two streams we held our course sontheasterly, over a spur about 500 feet high, until we struck Heart River not far above its junetion with Barlow's River. As the strean leaves Heart Lake, it flows for some miles through dense forests of pine and spruce, and then through a deep, narrow cañon, apparently of voleanio rock, from which it issues just above where we struck it. This river is evileutly not sabject to the great freshets which are common on many of the streams hereabout, and it is therefore probable that Heart Lake acts as a retaining reservoir for the waters of the melting snows, while the melting itself goes on more slowly in this densely-timbered basin than on the barer slopes.

The valley about the junction of the two streams contains a considerable area of beaver ponds. Continuing southward, up, the valley of Bar low's River, we rode for two or three miles over a level, sage-covered prairie, but little above high-water mark. The stream has a very wide, gravelly ebaunel, in coutrast with which its present flow seemed very small, though really of pretty good size. The lower slopes of Mount Hancock on the yest, and those of an unnamed peak of nearly equal height on the ease, soon close in upon the stream, forming a deep and narrow cañon. To avoid traveling in the bed of the stream, we followed some of the numerous game-trails, which led us to from 300 to 400 feet ahove its level, but finally bronght us down again abont ten miles from Heart River, and just below some small falls and tapids, where the 
stream descends about 30 feet in about 200. Abont two miles below this we began to find outerops of a fine-grained, ferruginous, laminated sandstone, destitute of fossils, but probably of Tertiary age. Some of the layers showed abundant ripple-marks. At the fulls, the rock is heavy-bedded. The dips are mostly abont 220 , varying, the rock is either side of due east. Just above the falls, and opposite to our camp, four thin layers of coal, varying from 1 inch to 6 inches in thicknes3, and two layers of clay ironstone, (iron carbonate, ) varying from 6 inches to 1 foot in thickness, are all included within 10 feet of shales. Abont three miles above this point, the cañon opens out into a broad valley, with rather narrow bottoms, but with broad, gentle, grassy slopes, topped with gently-rounded hills, partly timbered, partly [rassy. The huge rocks which lower down had encumbered both bottoms and slopes gave place to cobble-stones, pebbles, and sand. From this point Captain Barlow turned eastward, in 1871, after following np the cañon, as we had now done; and here we turned eastward to elimb the hills. From a bigher point, we saw that the rest of the valley is mainly a broad basin. There appears to be no pond at the head of the stream, which is apparently near the summit of a flat divicle, from the other sile ground, and the numerous game-trails give evislence that it is fregnented by deer and elk; indeed, we found two herds of elk, of about twenty each, among the groves on the top of the ridge. The mountains shut off the winds on all sides, and the valley lies so well to the su. that the snows must melt rapidly here, thus cansing the great freshets of which the broad. gravelly bottom of the river below had already given so abundant evidence. The npper slopes of the ridge on either side are mostly bare of timber, and many parts of them are badly washed. Those on the east are composed of mostly thin-bedded sandstones, probably of Tertiary age, at least 2,000 feet thick, with variable south easterly dips. $A$ few red layers appear, but the majority of them are gray. No fossils were found, thongh eareful search was masle for them.

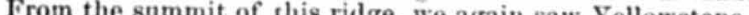

Lakes, and had a tine view of the rugged Tertiary (?) crests of the Big Horn Mountains to the east, running down to Unon Pass.

The scattered groves of spruces, with occasional pines, which are so constantly characteristic of the upper edge of the timber, oceur seat tered over these npper slopes, and nearly every cluster contains some young trees; but we nowhere encounter the patches of dense yonng growth which at a lower level so constantly start up, in a short time, whenever a body of old timber has been burned over and has fullen, and often even before the dead trees have fallen. The idea bas beet advanced that the burned patches are not thus renewed in these mountains; and, under some circtumstances, this seems to be true; but the rule is just the opposite, as those of us who have hat ocension to penetrate the vigorous growth of this dense young pine, whether alone or with a pack train, will most vividly remenber while memory lasts.

Crossing this ridge, we came to the valley of a stream which we after. ward ascertained to be the head of the main stream of Snake Rirer. At its upper extremity we found a flat valley-dividle, upon which are two small ponds, near together, covering from eighterte ten arres each, one of which is the ultimate source of Stuako liver: with the flow Selow Jackson's Lake. Ascending the high, sharp ridge on the west side of this valley, at least 500 feet high, we find its slop's to consist entirely of large and small weli-rounded pebbles of variousiy colored quartzites,

OVERSIZE FOLDOUT(S) FOUND HERE IN THE PRINTED EDITION OF THIS VOLUME ARE FOUND FOLLOWING THE LAST PAGE OF TEXT IN THIS MICROFICHE EDITION.

SEE FOLDOUT NO 
up to the very summit, where this deposit is jnst pierced by an outerop of the gray trachytie lavas and red basalt, partly vesicular, thongh mostly compact, which iorm the nuelens of the ridge. We bere stood most points in that neighborbood, about 8.654 feet abo so that we were entirely at a tosa which had flowed the large river which had distributed such immense amounts of gravel and sand. We conld obtain no local data which should enable us to judge whether the stream had flowed ncrthward or southward, but the general levels of the country would imply a northerly drainage. The deposit is evidently very ancient, but no considerable consolidation had taken place.

looking westward, a heary mass of mountains, brok'n by very few water-conrses, at least on their eastern face, lies between ns and the basin of Jackson's Lake, and I believe that this is here properly the "maiu range" of the Rocky Monntains. It is certainly part of the highest mass-connection between the Wiud iliver and Big Horn Monntains, on the east, which really form the northern termination of what is the main mange farther sonth, and the range west of the Three Forks of the Mixsouri, which there bears the name of Rocky Monntains, and the continuation of which really appears to be the main range farther north, so far as the best maps indicate.

Abore this mountain-mass the Tétons loom up grandls. A peak of that range, some fifteen or twenty miles north of Mount Hayden, is second only to that peak in elevation.

Passing westward the quartzite-gravel continues for several miles, thongh the mass of all the ridges is composed of a coarse volcanie breccia. The slopes are here much flatter and more rounded, with heavy growths of fine spruce, of which large areas have been burned and have fallen, so that we found some large patches absolutely impassable urith animals, and were obliged to make considerable détours to avoid them. The small streams heading here have flat valleys, with some good meadows.

Descending the valley of Coulter's Creek, we found that the high divide between the head of this creek and the head of Snake River consisted of rapidly-disintegrating voleanic rocks, mostly conglomerates of trachytic porphy obsidian, \&c. like those which form the very precipitous banks of the streams. Hany bare spots on the slopes indicate old land-slides, some of them of large size. The main valley is narrow and in some parts deeply cañoned, so that, with both steep, rocky slopes and badily-interlocked fallen timber, we had great diftieulty in making a passage out to the valley of the main Snake. This stream, we found, after a conrse of abont twelve miles from its ultimate sources, runing throngh a broad graveled channel, 200 feet or more in width, therraces on either bank, along which we the junction, of Barlow's River. The gravel is in some places washed away by the stream, so as to expose a solid river-bed of voleanic rocks. Nifit the junction, the terraces are at the levels of about 25,80 , and 140 feet above the present level of the bottoms. These are also developed to sothe extent along Barlow's River, which enters the Bnake at a sharp, reversed angle, through a narrow eañoned valley, from the npper slopes of with of whic we cothl seetho brome Though this fork brings at this season the most water to the united stream, and has the longest conrse, draining the largest area, yet the relative forms of the valleys at once decided that this could not properly be called the main Suake River.

On the broad lower terrace, about a mile west of the mouth of Barlow's 

River, stands a large conical mound, about 65 or 70 feet high and per.
haps 250 feet in diameter at the base. Though circnmstances prevented me frcas making the desired examination of it, yet, from the regnlarity of its ontline, 1 feel quite certain that it is it, yet, from the regularity Monnd-builders. npon the entire trip, unless the rude rock-wall reported people were seen apon the entire trip, unless the rude rock-wall reported by Mr. Steven. son as existing upon the summit of Mount Hayden should prove to be

The broad valley soon narrows again to a deep cañon, walled by red shaly sandstones, containing no fossils berond indistinet, walled by red inge, which are referred with doubt to the Triassic periol. The gray beds of the lower part of the series make their appearance in the lower end of the cañon. The stream is here broad and shallow and easily forded, so that the cañon can be easily traversed at this season. From this point the valley is wide and terraced, the bordering ridges being a mile or more apart; and this continues, gradually widening, to a basin of Jackson's Lake. Just at the month of the river bends sharply to the right and then to the left, so that the form of the slopes gives the descending traveler reason to expect here a large aftuent; but none exists. About a mile lower, we came suddenly upon a small basin of hot springs, most of which are now nearly extinet, though some large monnds on the river-bank give evidence of great activity in former times. The active vents seen were all in the bed on the bottoms of the rirer, so that their flow was more or less mingled with river-water; and no temperatures were taken. The deposits are Biliceous. Mr. The foot of the second ter race, several conical depressions, from 30 to 40 feet deep and from 75 to 100 feet in diameter, which might have been old spring-basins, though their origin is by no means certain. At the bottom of one of these lay two deac' rabbits, npon which there were no signs of violence. No other sighs of escaping gas were noticed.

This hot-spring basin occurs at the npper edge of a belt of basalt which forms, a little farther on, lofty vertical walls, from 300 to 500 feet high, through which a small stream, coming in from the north, has worn a deep, narrow cañon. Abont two miles below this, high walls of nearly white limestone appear on either band, though the figh walls of neariy ing prevented a clear understanding of the relatire position of the beds at the junction. It is probable that the basalt, escaping from some veit in the volcanic range of Red Mountain, flled a large north and south val. ley, of which the limestone had previously formed the western wall; and semi-metamorphism should be found in the limestones near the line of contact.

About three miles more brught us to the camp of the main party, at the month of Lake Fork, where the broad valley of the Snake makes a sweeping curve into its future southerly course, while Lake Fork itself joins it from the north through the narrow cañon which it has worn down through a high barrier of volcanic rock.

In descending from Lake Lewis, the main party found the river-bant, low and rocky for a short distance, before the strenm enters a canion $r$ ith walls from 150 to 200 feet high, in which were enconntered sharp rapids and a vertical fall of about 30 feet. Then, for a mile or two the slopes are gradual, with narrow, swampy bottoms along the river. Abont three miles below the lake, high, rocky banks indicate the appronch to a deep cañon, which really commences at about three and a balf miles, with perpendieular walls on both sides, inclosing a narrow ehannel with rapidly-sloping roeky floor, in some places partially obstrueted by huge tumbling masses of rock, but apparently without any acenmulation of gravel. Considerable rapids occur throngh nearly the whole cañon, and one fall of nearly 50 feet was noticed. The cañon deepens rapidiy to from 700 to 800 feet, with widths of less than half the depths at the deepest precipitous portions, though in some places widening above, so as to have sloping banks of alont 500 from the horizon. About three as to have sloping banks of about and is trnly grand. It has none of the brilliancy of coloring so cliaracteristic of the Yellowstone Cañon of the brilliancy of coloring so cliaracteristic of the Yellowstone Cañon,
but the somber tints of its gray, brown, and dark-red lichen-covered rocks, oceasionally variegated with smaller patehes of green and yollow, constitute a peculiar style of beauty and add greatly to the effect of its narrow dark depths. The only deficiency is in the supply of water, which is small at this season. The rocks are all volcanic, mostly por. phyries and trachytes, with some porphyritic obsidian. Some two miles below the end of the main cañon, the cliffs close in again to the river. for a few hundred feet, to a width of about 200 feet, with a beight of 400 feet or more, forming a suitabie gateway to the cañon from below. The valley below this is still narrow, but opens enough to give room for a few beaver-dams in its swampy bayou-banks before it rushes out into the valley of the Snake.

The high ridges which form the slopes about Lake Lewis bear back from the ricer and forn no part of its lofty cañon-walls. Between the river and this upper slope, on the west side, a large stream gather its waters from the abundant springs of the mountans and oceupies a broad flat valley on the lower level, filled with beaver-dams, whence it rushes, through a narrow, winding cañon and over a 30 -foot fall, to meet the river about a mile above its junetion with the Snake. On the foot. slopes of the monntain, along the west side of the beaver-dam flat, there are considerable numbers of warm springs oozing out, and con siderable accumulations of siliceous deposits are indicated by the soil. A small run, formed from a number of these springs, gave a tempera ture of 1010 . It is possible that active springs of some size exist in this neighborhood, but the contrary is indicated by the extensive bodies of dense timber, which also hinder exploration. From the south end of the cluster of beaver-dams aforesaid, a stream flows southward, whieh attaiis a pretty good size before it joins the Snake, about three miles below the eamp at the forks. Its source is probably in strong springs on the flat divide, which have been dammed up by the beavers so high that the ponded waters can escape in both directions.

The mountain which bears off westward from the head of the cañon forms the steep northern wall, while the extreme slopes of the Téton Range form the more gently-sloping southern boundary of a flat valley, from five to eight miles wide, which breaks through to the basin of Henry's Fork, and is oceupied by the sources and main stream of Falls kiver. The extreme source of this river is in the great water shed of the northern mountain, from whose southern face it bursts in four immense springs, which leap from its steep rocky sides as full-grown streams, and rush in beantiful cascades, from 75 to 100 feet high, down a slope of aboct $40^{\circ}$, to forin two large branches, which, a mile below, unite in a stream earrying about 20 feet of water. After a winding course of two or three miles, from sereral points of which it could with very little dif. ficulty be turned eastward into the main Snake, it flows with a still rupid current into the more northern of two small lakes, known to us as Beulah Lakes, which lie upon the lowest part of the divide and are each from 600 to 800 feet across. The southern one has now no surfaceoutlet, but marshy grounds extend to the more northern one, over which 17 a $\mathrm{s}$ 
ontflow must pass when the surface of the lake is from four to six feet higher. The divide toward the east is only 8 feet above the lake. From the west end of the more northern lake, about 30 feet of water flow ont rapidly, soon jumping over a fall of 12 feet. Strong branches soon join the stream from the north and one from the south, and donble its sup. ply of water. Five other falls succeed, of $6,12,40,20$, and 30 feet, be fore we reach the Great Falls. These show a total descent of 141 feet consisting of three larger falls above, the third being $\mathbf{4 7}$ feet high, with three small ones at the bottom. The upper two are somewhat of horse shoe form, while the third and highest has a nearly straight edge. The amonnt of water in the stream is fully 80 feet. The porphyritic trachyte of its walls forms perpendicular elifts, with rounded tops. A strean of some size comes in abont a half mile above there, on the south side, with fine caseades on its upper conse, while its sources lie in a basin of the monntain whose form indicates that it may inclose a small lake; the lefthand branch of this stream comes from two small lakes on the divide, as hereinafter described.

From the lakes downward, we find laminated porphyries, sncceeded by trachytes and red and black porphy ritic obsidian. Below the falls, a high knob cousists of a fiue-graiued, compact, white tracbyte, which contains disseminated plates of black mica, (muscovite ?) and which, with but a slight change of texture, might realily be mistaken for granite. From this knob we have a fine view westward to the lower basin of this river and its tributaries. The largest of these, Bechler's River, comes out of the plateau of the great water-shed, about ten miles to the northward, into a large basin apparently containingextensive grassy meadows, and then passes among rounded timbered hills to join Falls River, apparently but a few miles above our lower crossing of that streat. Large grassy meadows, some miles farther north, indicate auother large strean, probably tributary to Bechler's River; but it was impossible to trace its course with any certainty at that distance. Some miles down Falls River our guides repc : another fall, about 40 feet high; so that it will be seen that the stream deserves its name. The slopes near the river are mainly well-rounded and fairly timbered, though, at a few points, steep and even precipitous and bare. The stream presents the utmost variety of water-scenery within a short distance; from the still, deep pools, which accumpany a short stretch of beaver-dams, to short, sharp rushes over steep rock-slopes, to successions of steps, form ing various styles of rapids, and to vertical falls of various forms and sizes-a perfect treasury of artistic bits.

The elevation of this divide and the moderate character of the slopes, areraging abont 54 feet to the mile irom Henry's Fork to the summit, in. dieate this to be a favorable liue for railroal-access from the south to the region of Yellowstone Laie, if sneh should be thought desirable. From the main line up Henry's Fork to Montana, of which tbis would doubtless be a branch, the $r$ w would follow up the ridge on the south side of Falls River to the divide, thence keep around the foot of the northern mountain to Lake Lewis, cross Lake Fork, and, passing along the eastern shore of the lake, eross the flat divide, striking Yellowstone lake abont shore of the like, eross the flat diside, striking Yellow the ralley. the middle of its western side, and thence follow down the valley. It is probable that a route could be located from Lewis's Lake, past the north end of Shoshone Lake, to the Fire-Hole basins; but the most easy access to the Fire-Hole is by way of Henry's Lake Valley, Tyghee Pass, and the Uprer Maulison Cañon. Between the Fire-Hole and Yellow. stone Lake, the ridges are too sharp to be passed by railroads, unless $b y$ very winding routes or by long tunuels.
A short distance sonthwest of Benlah Lakes, over a divide about 300 feet high, and at a level about 100 feet lower, Mr. Bechler found two other cell lases at the bead of a branch of the stream which enters Falls River from the sonth, just abore the Great Falls. The upper one has an area of something over one hundred acres, with rocky banks, and flows to the lower, which oceupies about 40 acres in the center of a marshy basin of perhaps a hundred and forty acres.

Southeast of these latter lakes, over a divide about 350 feet high, we reach the head of a valley running eastward to the main Snake. its wer portion is a flat basin, abont one and a balf miles long by a mile wide, bounded on the east and norts by from 400 to 500 feet of voleanic rocks, of which the upper 200 feet present a vertical front, while the remainder is mainly covered by a slope of tumbling rubbish down to the stream. The other slopes are rounded, as are also wost of those along the lower course of the stream down to its junction with the Bnake.

AII this wide area, from these northern slopes of the Téton Range nearly to the Tyghee Pass and to the mountains on the north side of tho U Pic Madison, though actually quite elevated, is relatively mueh depressed below the summits of the limestone, quartzite, and granite monntains on either side. From the general distribution of the voleanic rocks, as well as from facts obverved elsewhere, I am inclined to believe that, before the ejection of these immense bodies of lavas, there was here a broad valley, through which the drainage of the upper monntain-region to the eastwarl fonnd its way ont to the great basin of the Snake, while the eañon by which it now escapes through the high mountain-mass south of the Tétons had not been eut down.

Immediately opposite the camp at the mouth of Lake Fork, there is a considerable cluster of dead and dying hot springs. Several monnds indieate the former positions of geysers of considerable size. The teraperatures of ten springs were taken by Mr. Taggart, varying from $102 \circ$ to $155^{\circ}$. Three were above $150 \%$. The ileposits are now rapidly disintegrat. $158^{\circ}$. Three were above $150^{\circ}$. The deposits are now rapidly disintegrat-
ing. Upon one large conical mound this process had developed a columuar or flbrous condition of the geyserite. Similar spring-deposits also occur on tue west side of the river, from one to four miles below this camp, and some of the mire holes so common in the Fire-Hole basins were also encountered. Upon looking back from below, two large columns of steam were seen, about a mile up the Beaver.Dam Creek, which seemed to indicate the possibility of geysers still existing there. The lower part of that stream was full of yurple-nacred unios, apparently like, or elosely allied to, those found in the branches of Henrs's Fork.

Along the east side of the river, the face of the high ridge shows the followiug rocks, according to notes taken and specimens bronght in by Mr. Taggart :-At the base lie abont 200 feet of white and light-gray quartzites, overlaid by from 500 to 600 feet of light-drab and dark-gray limestones, and about 100 feet of gray sandstones, followed by heavy beds of red, shaly sandstones, apparently the same as those seen higher np the river. I am not satisfied as to the age of either the limestone or the quartzite. The ridge is capped with beds of porphyritic trachytes, having a dip of about 300 to the southeast, while the limestones beneath dip about $40^{\circ}$ in the same direetion, showing that their ti!ting commenced before the deposition of the trachytes.

The main trail erosses the Suake abont a mile below camp, and passes over the bills so as to eut off a considerable bend of the river. From six to eight miles below the forks, a spur, which runs nearly to the west bank of the river, shows a high bluff face of porphyritic 
trachyte. The valley is here wide and flat, nostly marshy, with some large bayous. There are considerable areas of five grazing.ground and many large patches of willows. One island-like, rocky knob, with part of the first terrace, which has been protected by it from erosion, stauds out in the middle of the valley, about a mile below the cliffs. The river is here of moderate depth, with a bottom of small pebbles and muddy sand, but good fords are few and mostly diflicult of access by reason of the marshes bordering the stream, so that the necessary crossing to the east bank should be made near where our train crossed, unless special reasuns take one lown the west side. As we approach the lake, the stream gets deeper and more sluggisb, being somewhat checked by the back-water of the lake. Broad marshy flats stretch back from the shore of the lake on both sides of the river. On all these flats we find an abundance of "bitter cottonwood," which had formed, higher up, only a very small part of the timber-growth, though its young plants had, for the last fifteen or twenty miles, furnished rapidly-increasing patches of sellow and pale-red along the slopes, thus replacing, in some degree, the autumn tints of the hickories, chestnuts, and maples of more eastern regions, while a small mountain-ash was doing its best to replace the deeper crimsons of the oaks and of some of the maple The development of these tiats did not secm to be at all connected with any special increase of cold; and, indeed, we had been having frequent freezes all the summer, without any apparent efect upon the regetation, which seemed to be accustomed, as the grasshoppers are, to being frozen up every night and thawed out every morning.

The Téton Range had been before us for many days as a prominent feature of the landscape, bnt now its peaks stood up as the features of main interest, bounding the valley on the west with a series of roof-like ridges and pointed peaks, well besprinkled with patches of snow. Farther north and east, we bad been having pleasant weather, while this portion of the valley had several successive days of elond and rain, as reported from our guile, Beaver Dick, who met us again here, hav. ing erossed from the valley of Heury's Fork. When these storms reached the bigher portions of the mountains, their deposit took the form of snow, so that the drifts were now much larger than when we struck the range on the other side, in July.

On September 21, the minimum thermometer recorded $4 j^{\circ}$; and a clear sky, with cool weather, gave us unnsually fineviews. The peaks stood out sharply, while the gaps and cañons were full of a deep-blue, smoky light, which would touch the heart of the least artistic.

On the northeastern slopes of the range, several hundred feet of limestones represent the Lower and Upper Silurian and the Carboniferous, as on the other side of the range. Their area here is limited, and has not been traced to its abutment against the volcanic rocks, which fil the depression to the northward. The range is much flattened and rounded of at this extresity; and I am inclined to believe that the granitoid uncleus declines so much as to allow of the connection of the linestones of the east and west slopes being exposed between it and the voleanic rocks. At least, the dips indicate that such a warped connect. lon once existed; and I shall not be very fur wrong in coloring the map according to that supposition. The underlying quartzite (Potsdam ?) was not seen bere, but is probably in place, as it appears a few miles farther south. The most northern large cañon of the range exposes, beneath the limestones, a beavy body of dark micaceous gneiss, with both granite and quart $z$ veins. The loeal dip is northeasterly; but the main dip of the metamorphic rocks here is southerly.
Along the shores of Jackson's Lake th re are no outcrops which woulil enable one to decide where the different strata lie; but, at its sonthern end, there are high knobs of porphyries and trachytes, wiich indicate, by their position, at least a former connegtion with the more northern beds, which we traced to within five miles of the northern end of the lake.

Jackson's Lake is a very irregular body of water, much cut up along its borders by long, narrow promontories jutting ont into it from both sides, and containing one large island, which nearly separates the lake into two. The main lake is from two and a haif to three miles wide, and the total length is about eight miles. In the soundings taken by Yr. Adums, the greatest depth found, 258 feet, was about a mile from the western shore. The series of soundings was far from complete, by reason of a squall coming down from the Tétons and raising dangerons waves, so that they had to give up the rest of the work. Thelower slopes of the more northern Tétons come sharply down to the lake on the west, and these steep slopes, together with the tangled undergrowth of willow, cottonwood, mountain-ash, and iron-weed, with occasional box-elder and maple and some tracts of fallen timber, make passage along there difficult for a train; but its other shores are surrouuded by low hills and by broad meadows, largely occupied by beaver-dam and other swamps. These flats are much cut up by bayous, and include several ponds of considerable size. Others are found among the rounded hills of gravel, which remain from the upper terrace of the old riverborder. Two of these, lving from two to three miles east of the outlet, toward the valley of Buffalo Fork, are each about two miles long by a half mile wide. They apparently occupy portious of ancient river-channels. A stream of about the size of Barlow's River, with broad gravel. bottom and rapid current, comes out of the hills opposite the lower end of the lake and joins the Snake just after it has escaped from the lake. The views from the east shore of the lake are wonderfully grand. The Tétons rise majestically from its western shore to the height of 7.000 feet above its surface, with sharp slopes and walls of bare rock above, and their bases buried in a dark mass of pine and spruce, while at this season (September 24) their snow-covered summits give the beholder a strong sense of sublimity. At times they are wrapped in heavy masses of elond; but even then they are grand. The accompany. ing sketch of the face of the range, as seen from near the North Gros Ventre Butte, has been copied from Mr. Bechler's field-notes. (Fig. 50.)

A few miles below the lake, Buffalo Fork enters from the east tbrough $A$ few miles below the lake, Buffalo Fork enters from the east tbrough
a broad valley with grassy and willowy bottoms, bringing a very large boly of water. These bottonı contain some large groves of Menzies's spruce, (Abies Menziesii,) whose peculiar cones were seldom seen else. where by us. Near the month of the stream gray and buff, fine-grained, shaly sandstoues of indeterminate age dip sharply to the southeast, and similar rocks appear in the bed of Snake River, at the ford just above the month of Buffalo, but the dips are here much confused. above the month of Buffalo, but the dips are here much confused.
Mr. Bechler followed the Buffalo nearly to its head, and reports that, for abont twelve miles from its mouth, its broad, open valley shows no rock, but has rounded slopes covered with "quaking asp," (Populus tremuloides,) and bottoms full of beaver-dams. About twelve miles up, the valley narrows to a caûon from 350 to 400 feet deep by from 50 to 200 feet wide, for about three miles, with coarse, gray sandstone walls. 200 feet wide, for about three miles, with coarse, gray sandstone walls.
$\mathrm{A}$ bout one and a half miles of a rounded basin, with benver-dams, then intervenes before reaching the second cañon, which has nearly the same eharacter as the first and is abont two miles long. A broad basin 
succeeds, from five to seven miles across, reaching up to the foot of the high vertical limestcne-walls of the main divide (1), whose ragged crest shows plainly from the mouth of the valley, and from whose many gorges come the numerous small spring.branches which form the main

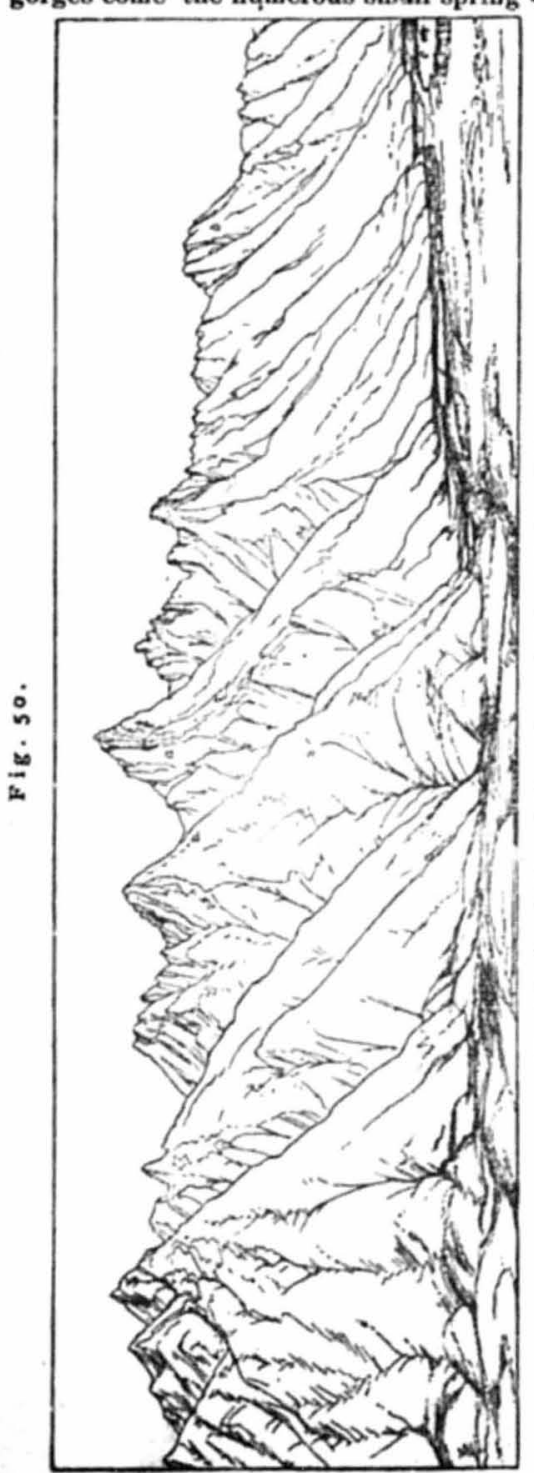
stream. Besides the main fork, seven or eight large creeks come in from either side, showing that the basim as a whole occupies a large area, and its amount of water makes this one of the most important tributaries of the Upper Snake. At this season, indeed, it ear. ried fully two-thirds as much water as the Snake itself. Abont the mouth of the valley, the slopes are covered with partially-ce mented Post-Tertiary sands and gravels, with occa ional exposures of white sional exposures of white - marly clays, supposed to be of the same age, though no fossils were seen. The gray sand-stones of the cañons are plainly the con. tinuation of the Tertiary (?) beds of Barlow's River directly to the northward and the limestones of the bigh cliffs at the head of the valley are probably of Quebec Group age, perhaps capped with Carboniferous. A small bit of fine-grained, compact sandstone, found loose on the rubbish-slope near the top of the moun. taín by Mr. Brown, contains fragments of some thinty trilobites of the thirty trilobites of the genlocephalus (f).

Snake River escapes from Jackson's Lake at its sonth eastern augle and runs of eastward to the valley of Bufrork Bufnalo Fork before renew ing its southerly course. Yet, from the top of the butte at the mouth of the lake, it is plainly seen that a broad valley extends directly sonthward from the southern extremity of the lake; and it at once becomes a question why the river has thus deserted its own proper valley and has turned off 80 far to the east to find another ontlet races are strongly marked along the river, and the third, above its present races are strongly marked along the river, and the third, above its present
level, forms broad plaius, on both sides of the river, below the month of Buffalo. Moreover, the old river-gravel, consisting mostly of quartzites, runs to the top of the island-like knobs in the center of the valley as well as of some of the hills which border it. Crossing westward over these broad plains, which are mostly covered with sage-brush except about the isolated ponds, which seem to give evidence that much of this third terrace has been worked over by the river and cut up by bayous, we cross a narrow belt of spruces covering the surface of the fourth terrace, and then descend to the old deserted channel of the river, which is nearly on a level with the third terrace. Crossing this valley directly toward the mountain, we come at once to a series of high, steep, narrow ridges, covered with immense masses of granite and heavily timbered. Within the last of these concentric ridges, we come to a small lake, lying at the mouth of a deep caũon which runs far back into the mountain ; and bere at last we have the clew to the mystery. This cañon, like all the othet large ones of this range, was occupied by a glacier, whose terminal moraines now hem in this lake; and, though the old river-valley seems to have been not fully blocked $\mathrm{np}$ by the flow of silt which passed beyond the moraines, so that its general features are still plainly marked, yet it is evident that the deposition which caused its bottom to slope from west $w$ east so much as we now find it to, was sufficient to con. siderably delay the weariug down of this channel. The cañon next north of this was also occupied by a glacier-a moraine-dammed pond will probably be found in the mouth of it-and doubtless its débris aided in checking the eroxion. At that time, the flow of water through all this region was much greater thau at present, and the duplicating of channels in the broad bottom was far from being uncommon. If a channel had then joined the eastern streams, thongh only as a bayou in time of flood, there was reason for its being ultimately cut down, so as to drain the western channel, which is the true valley of the Snake. The sum. mit of the highest and ontermost moraine is partly covered with river. gravel, as if the stream had at least once reached this height after the glacier began to recede. This crest is 122 feet above the bottom of the adjoining part of the old river-channel, 222 feet above the present level of the included lake, and 366 feet above Jackson's Lake. These aud other levels across the valley weré taken at my request by Mr. Her. ing, who has furnished the data for the aceompanying section from the lake, across the old channel and the present one of Snake River, to the easteru hills. The length of the sectiou is 80 great that it became necessary to distort it by increasing the elevations considerably beyond their pro. portional size. (Fig. 51.) We bave called this lake, which is abont two miles long by a half mile wide, Leigh's Lake, after our guide, Richard Leigh, (Beaver Dick.) It appears to be mostly shallow, and has a small island near its center. Can it be possible that the glacier, which was formed by the flow from two cañons whose junction is only a very short distance above the lake, split again after it emerged, so as to leave this islaud uneroded 9 . No special depression of the moraines opposite the island was noticed; but examinations just at that point were not care. fully made. On the other hand, if we pass to the north eud of the lake, we find a flat divide, not 5 feet above its level, and less than a hundred yards across, which separates it from a large beaver-pond, whose waters escape through two or three other ponds and marshes to the head of Jackon's Lake. A very trifling eut would thus give the lake a second 
outlet; and it appears not improbable that the glacier did split, as suggested, during at least a part of its existence, and flow out at this end as well as at the southern one. These waters come so near together that, without any connected examinations, and without recognition of the

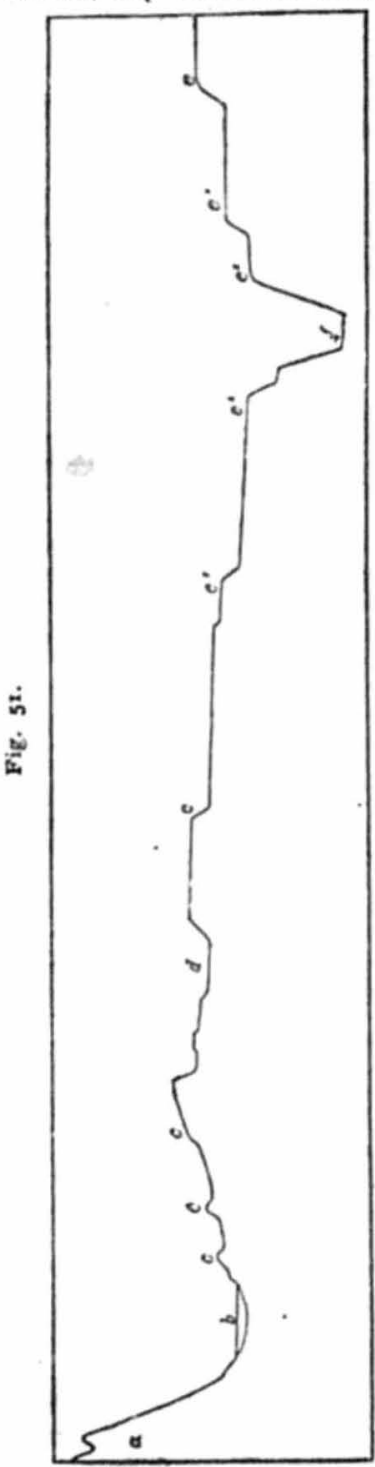
rise of 144 feet from Jackson's Lake to Leigh's Lake, water-communication between the two had been inferred and reported; and Mr. Adams attempted to find a passage across in his eanoe, but, failing in that, was obliged to make the long détour by the true outlet of Jackson's Lake.

About a mile south of Leigh's Lake, another, of about the same size, which we have called Jennie's Lake, after Mrs. Leigh, lies in the mouth of the Great Cañon of the Téton Range. Passing up this eañon for a short distance, Mr. Taggart found a cluster of falls and rapids about 250 feet high, with lofty, precipitous walls on either hand, which prevent ready access to the upper part of the cañon, which winds around to the western side of the peaks, where its lofty walls were seen by us in July. This cañon gathers the entire drainage of the gathers the entirce western side ur the three principal peaks, so long kuown as the Three Tétons. The water of these monntain. streams is so pure as to make it cer. tain that not the least glacial erosion is now going on at any point on the range. Though many seluists oceur in the Though andiny selists occur in the mountains, very few of them have contributed to the terminal mor. anes, nearly everything except the granites baving been ground or weathered tine during the downward passage. The moraines about Jennie's Lake are not very largely developed; possibly, the more abundant flow of water from beneath this glacier, con. sequent mpon the greater size of its hasin, washed away the débris from here unore thoronghly than was done elsevhere. At twro other carions far ther sont At two other canous, farther sonth, sinilar lakes occur. The more northern of the two, which we have called Taggart's Lake, is surrounded by five concentric moraines, the elevations of which above the old river-channel, which passes just ontside of them, were taken by Mr. Tag. gart, as follows: The outer one, $162 \frac{1}{2}$ feet; second, 206 feet; third, 271 feet; fourth, 316 feet; filth, 422 feet. The present level of the inclnded lake was found to be 249 feet above datum. The last of this series of lakes, which we have called Phelps's Lake after a hunter of the region, who bad seen and reported it, is hemmed in by three moraines, according to Mr. Taggart, the outer one 162 feet, the second 244 feet, and the third 287 feet above the lake itself, there being base. In this last case, the cañon forks above, aud the two arms extend in opposite directions along the line of separation between the granites aud the flanking limestones. Each of the two glaciess, therefore, gathered, from the roeks overbanging it, granites on one side and limestones on the other, so that after their junction, the central moraine of the united glacier conthis, aft iling the low central portios of the terminal moraine, while its high fianks, which received the material of the lateral moraines, are composed of the large bowlders. No remnants were any where seen of any lateral moraine deposits along the courses of the glaciers. It is possible that such may be found by more careful search, but the slopes are here so steep that most of their lower portions are buried in the tumbling rubbish, so that we can have little expectations of such a discovery beiug made.

A little zonth from the second large cañon south of Mount Hayden, the limestones come forward to the front of the mountain, above the granites, which shortly afterward disappear from sight altogether. The length of the exposure of the granitic nucleus of the range is about thirty miles.

Abont eight miles below Leigh's Lake, its outlet, wh; 'h we have called East Triton River, enters the Snake. A lundred yards back from the opposite bank stands a bigh, rocky butte, known is North Gros Ventre Butte. Its northern end consists mainly of Carboniferous limestone, dipping about $70^{\circ}$ N. $56^{\circ}$ E., and containing many characteristic fossils. Aloug the west face of the butte, none of the lower rocks are visible, being buried under the Post-Tertiary whitish sandstones and marls, inclosing fragments of limestone and elsert, but no fossils, of which all the southern part of the butte is composed; but, near the northeast corner, the lower part of the series of older limestones presents the conglomeratic texture so eharacteristic of the Quebec Gronp, on the rest side of the Téton. Range and elsewhere, and it is probable that they represent that group, thongh no fossils could be fonnd. Beneath this we tiud gray quartzitic sandstones, which are probably of Potsdan age.

This butte stands near the middle of the broad basin which has long been known by the barbarons name of Jackson's Hole. This has a length of about twenty miles, and raries from five to ten miles in width. This includes portions of the different terraces, all of which are more or less cor bage bad been burned off, and the grasses had grown up densely, forming fine been burned off, and the grasses had grown up densely, forming fine pasturage; and on these we again encountered antelope, which bad not is said that, luring the winter, when the grass is covered, they live upon the sage itself. This plant was now foll of seeds, and the inuumerable little chipmunks which burrow in the plains aud hills were busy gathering them, biting off the long spikes and stripping them from end to ing them, biting off the long spikes and stripping them from end to eud, passing

The pebbles "the terrace-gravel have thus far been mainly quartzites, 
and still continue such on the east side of the basin; but, nearer the western range, considerable proportions of granite and gneiss pebbles are now mingled with them. A considerable excitement was stirred up, a few years siuce, by reported discoveries of placer-gold in large quan. tities on the Upper Snake, and many prospectors visited this region. $\Lambda$ small hydraulic operation was undertaken near this point; but the gold was too fine and in too small quantities to pay, and the whole region was entirely abandoned after a few months. The coarse golil, found on the lower part of the Snake, appesars to have entered the river below the cañon, which is still to the southward of us.

The Gros Ventre Fork emerges from the eastern hills about opposite "yo North Butte, bat rung off down the valley, some eight or ten miles, before joining the Snake. Passing up its cañon for a short distance, the following section was taken

1. White, futuile, falsp-bedded sandstones, 10 feet.

2. Covered space about 100 feet.

malarly-bedied, pale gray and buff, magnesian limestones, 50 to ou feet. feet.

5. Compact, fine-grained, gray sandstone, 15 to 20 feet.

6. Brown, coarse, friable, false bedded sandstone, 60 to 80 feet.

7. Coarse, friable, red sandstone, $\hat{x} 0$ to 50 fiet.

8. Compact, dark-drab, fossiliterous limestones, 300 to 400 feet.

Near the mouth of the cañon, t'je Carboniferous limestones of No. 8 form the walls, eapped, as we axcend, by Nos. 7 and 6 . As these pass below the stream's level, No. 5, which forms the top of what I suppose to be Carboniferons, commences a new eliff, and is covered by the Triassic (i) beds of $\mathrm{No}$, 4 , which form prominent red bluffs along the stream for many miles. The compact to vesicular, varionsly-colorei and partly bituminous limestones of No. 3 showed no fossils, and $1 \mathrm{am}$ uncertain whether to refer them to the Triassic or to the Jurassic, bu favor the latter reference. The covered space of No. 2 showed nothing from which oue could even infer tha character of the buried strata. The friable saudstones of No, 1, which eap the hills for some miles, are probably late Tertiary. The dips of their false bediling imply an open sea to the northward during their deposition, while those of No. 6 face eastward and southeastward. The lower beds, which should make thei appearance along the face of tha mountain to the south of the Gros Ventre, are so much covered with the partially-cemented Post-Tertiary sands and gravels as to be not readily recognized from the plain, and time did not permit a closer examination. Judging from the dips of the lowest beds seen, I should expect to find here the lowest Silurian, under laid by metamorphic rocks, forming an axis which may connect the Tétons with the Wind River Range.

Just south of the mouth of the Gros Ventre, on the east side of the Snake, stand \& ciuster of hattes, known as the Sonth Gros Ventre Buttes. The western one has a high, broad northern face of red, gray, black, brown, and variegated porphyritic breccias, inclu.ing much jasper, but partly porous, loose-textured, and even ashy. The beds are much distorted, but have a general northwesterly dip. The lower end of the butteis tapering, long $₹$ ' Post-Tertiary sands and grav $1_{\mathrm{s}}$. At its sonthern extremity it rises quickly inte a sharp butte, composed of horizontal beds of gray limequickly into a beds form the face of the mountain to the eastward. Three other buttes lie east of the more nortbern part of this one, and evidently originally formed one with it.

These buttes grestly narrow the plain, which, immediately below them, expands into Jackson's Little Hole, whose flats are mainly upon the east side of the river and measure about foar miles wide by perhaps ten miles long. Here, also, the sage has been burned off and replaced bs grass. For several miles, from above the mouth of the Gros Ventre, the river has gravells bottoms from half a mile to three-fourths of a mile wide, cut up by the sereral channels and partly occupied by of a mile wide, cut up by the several channels
beaver dams. Of conrse, fords are numerons.

beaver dams. Of conrse, fords are numerous.
The only practicable pass across the Téton Range, so far as known, is abont opposite to these Sonth Buttes; and onr main party left the river at this point. Mr. Taggart reports both slopes of the pass tolerably regular and gentle, except for a short distance just at the summit, bnt that the eastern is somewhat the steeper. The Carboniferous limestones, which were the only rocks noticed until the summit was passed, are nearly horizontal, have only a slight southerly or southeasterly dip; but, in lescending the western slope, this dip increases to about $45^{\circ}$; and overlyiug, red, shaly sundstones, probably of Triassic age, appear at one point on the trail, while limestones, apparently those previously referred to the Upper Silnrian, form considerable clifls or spurs, a short distance to the northward. There wonld seem to be considerable displace. ment thereabout. The porphyries of Pierre's Hole appear at the mouth of the pass, at the elevation of abont 7,000 feet, and form all the foot-hills of the mountains on the sonthwest side of that basin, until the actual bottoms of the Snake are approached, where the basalt appears. The track of the party lay so far ont in the basin that there was little or no opportunity for examining the eharacter of auything more than the foot-hills of the western mountains.

At the lower end of Jackson's Little Hole, the so-called Grand Cañon of the Snake commences. The river turns sharply to the eastward and cnts through the laminated sandstones which apparently overlie the Carboniferons limestones. Just at the mouth of the cañon, the upper terraces close in, and are capped by bastioned walls, 100 feet or more in height, of a pale-red sandstone, overlaid, as we see in looking back from lower down the cañon, after this turns south again, by heavy beds of dark-red, sbaly sandstone, appearing like, and occupying nearly the relative position of, the Triassic ( $($ ) on the Gros Ventre, except that, below them, there come in several hundred feet of thick and thin bedded and shaly, gray and green sandstones, with interlaminated calcareons shales. These contain plant-remains, bnt so thoroughly comminuted that I wasnot able to find a single recognizable fragment. At the angle of the cañon, these dip strongly to abont N. $78^{\circ}$ E., and a long section of them is exposed on the east side of the stream; but in about a half mile they become horizontal, and, again, a mile lower, at the month of Hoback's River, dip $10^{\circ}$ to about $\mathrm{S}$. $63^{\circ} \mathrm{W}$.

Hoback's, so named for a hunter of the Pacific Fur Company in 1812, by Mr. Wilson G. Hunt, as reported in Irving's Astoria, brings in a large volnme of water from the eastward and plainly drains a large acen upon the western slope of the Wind River Mountains. Its valley, t:engh narrow near its mouth, was at one time the favorite route for the Indians in crossing to the Green River Valley; but, latterly, they bave preferred the Gros Ventre route for some reason. The red beds bold a prominent place near the top of the high eliffs, for a half mile or more above the forks, but the valley is too winding to give mnch of a view. Just below here, a strong creek comes in from the west, appar- 
ently draining a considerable area of the mountain. It approaches the river by a succession of cascades over successive layers of the sand. stones. As we desceud the river, these beds come up in two anticlinals, one low and flat and the second mountainous, with dips reaching $70 \circ$, and coming down steeply to the river on both sides. The axis of the second anticlinal is occupied by a narrow fold of limestone, through which escape several warm springs. A small cluster of these, escaping among the gravel in the edge of the river, on the south side, emit an abundance of sulphureted hydrogen. Though somewhat mixed with the river.water, they gave a temperatnre of $117^{\circ}$, Abont a hundred sards below this, a group of caleareous springs has built up a dam of tuff, so as to flcod several acres about the vents, which are now inacces. sible. The general flow from the pool gave a temperature of $94^{\circ}$. Just opposite these springs, in the lower part of the sandstones, as they re-appear on the west side of the anticlinal, there are exposures of two or three heavy beds of black, caleareous shale and friable clay, with some harder bituminous mud-stones, which appear, from short distances, precisely like coal outerops. Fragments of teeth and bones, probably belonging to amplibians, occur in these layers. Above them there are some thick beds of chert.

Here the ricer turns south again, and runs for about two miles along the west side of the anticlinal, with sharp slopes on either banks. Turning west again, we cross three anticlinals, in the third of which consid. crable displacement has taken place, so that the Carboniferons comes boldly up, and, after this, forms the mass of the mountain elear through the cañon. The lower portion of these beds consists largely of sand. stones and shales, though including heary beds of limestone; higher up, the limestones form a heav: mass for several hundred feet, partly compact, partly fragmentary, overlaid finally by more shaly beds, making a total thickness of 2,000 feet or more. A few fossils of the genera Spirifer, Macrocheilus, and Zaphrentis were seen in the débris. The lower layers weather to nearly white, while tie upper ones are strongly buff. All through this series, the cañon is narrow, with stcep, often perpendicular, slopes and harilly any bottoms. The river mainly occupies a deep channel, with a broad shelf of rock on one or both sides, which is barely corered at this season. Crossing would be impos. sible without swimming the stock. Many of the steep slopes are covered with spruces, and their angular tops, lapping over each other, on the opposite side of the cañon, give the effect of diamond-slating on a roof, though with the angles reverset. Upon these limestones we begin to find again great numbers of the small maples seen farther south. These are said by the hunters to be somewhat on the increase in this region. Abont ten miles through these limestones bring us to the month of the cañon. Through much of its npper course the stream is quite rapid, and almost deserves the name, Mad River, applied to this part of it by the early trappers; but there is little that would bave proved tronble. some to experienced royageurs, and probably none that would prove really dangerous. (See Irving's Astoria, chapter xxxi.)

The terraces, though only fragmentary through the cañon, now spread out into broad sage-covered flats on either side of the river, and the higher slopes become much more rounded. Just at the month of the eañon, Joln Gray's River, which heads far to the south; on the divide toward Bear River, comes from the southeast, through the same mountain mass, and with apparently just such a cañon as the one we have just left. At its mouth, a heavy mass of cemented bedded gravel shows down stream dips of $17 \circ$, apparently implying great rapidity of eurrent over a rapid into a deep pool at some former period.

About two miles below, Salt River also enters the Snake, through a broud-terraced valley, which looks as if it were really the continuation of the lower valley of the Snake. But for misinformation as to dis: tances, we should hare explored this valley up to the salt-works before descending the Snake. It seems to afford an easy passage through a valuable region. The cañon through which we hal just come, though having a reputation for very difficult traveling, was passed by us with ease, and really presents but very slight obstacles to building a railroad, if one were desired from this point to Yellowstone Lake or besond, or merely to give convenient access to the rich basins of Jackson's Hole merely to give cotvenient access to the rich basins of Jackson's Hole
and Little Hole. Furthermore, a road, reaching this point from either the lower or the upper Bear River Valley, would have then the alternation of passing down the Snake with easy grades to the east side of the valley of Henry's Fork, with the advantage of crossing the river where its channel is narrow aud its banks far above any floots

The Snake here turus sharply northward into the continuation of the valley of Salt River, with high monntains of Carboniferous limestones on the east, showing some castellated walls, and lower and more rounded ones on the west. Two or three miles below the mouth of Salt River, a small stream from the west was thick with mud from the Caribou gold-washings.

The valley is here located by an anticlinal fold; and the nearly vertical limestones of its axis are finely exposed along the foot of the western hills. Here, also, is located a eluster of warm springs, making cal careous, sulphurous, and saline deposits. The largest spring, the Wash-tub, tas built up a flaring table, 1 foot high, of an oval form, measuring about $4 t$ by $7 \frac{1}{2}$ feet, upon a mound consisting of calcareons mud, scarcely solidifiel, of from 5 to 7 feet above the creek.bottom in which it stands. The central table has contracted so as to crack across diagonally, and the flow now escapes at its western base, depositing a fine mud tinged in the full pools with a faint sulphur-yellow, but pure white in the dry ones. These pools cover the mound in descending steps of great beanty. The present flow is southward, though it has mound is still very soft, and showed at the time of our visit (October 6) the tracks of a swall bear, who had recently investigated the wonders the tracks of a small bear, who had recently investigated the wonders
of the mound, even setting his foot on the central table. One mound, no longer active, is 5 feet high, with a circular base of about 5 feet diameter and an oval summit of about 1 foot by 6 inches. Many smal springs escape along the bank for a hundred yards or more. The deposits vary greatly in color. At some points, the odors of sulphurous acid and of sulphureted hydrogen were quite noticeable. The older deposits have built up a bank 10 feet high, along the base of the terrace; and the beavers have taken possession and have dammed up on it the waters of the cold springs which flow from the second terrace at short interrals along this plain. On the opposite shore, two considerable springs have built up their deposits against the foot of the monntain, ote of which appears to be nearly dead. The highest temperature observed here was $144^{\circ}$. The Wash tut gave $142^{\circ}$ and others $142^{\circ}$. $140^{\circ}, 90^{\circ}, 88^{\circ}, \& \mathrm{c}$

The deep channel, seen through all the lower part of the cañon, con. tinues for several miles down the valley, and fords are at all points much rarer than in the upper valley. The stream is narrower on the average, and the amount of water has been much increased. 
As the valley turns westward, it becomes somewhat narrower; and laminated porphyritic trachytes appear on the northeastern side, at first capping the spurs like isolated forts, and then forming, as it were, a row of casemates just below the crests of the hills. At two points this roek descends nearly to the water's edge; but the valley soou opens out again, with broad bottoms on the east for several miles, to opposite the month of Fall Creek, where basalt appears upon the eastern side as it had doue on the western some miles higher up. The upper part of this valley-flat is covered with sage-brush, bat the lower half is fall of the richest of pasturage, except only such portions as are oceupied by beaver-dams and bayous. Along these water-courses, large thickets of black-haws were most thickly covered with ripe iruit, but the crop of service-berries was almost an entire failure in all this region. At sev. eral points we noticed the abundant rose-bushes covered with hips, which were so soft when ripe as to have the translucent appearance of berries and to be very pleasant eating. This did not appear to be a specific character, but was probably consequent upcn tise shortness of the season, which, after the fruit is well developed, prevents the secretion of the large amount of woody fiber which elsewhere commonly forms so hard a covering to the rose-hips. All through the canon, as well as along this lower valley, we noticen inuumerable yonug plants of the lupines, which abound in this region, prepared to make vigorous growth as soon as the short summer opens.

Fall Creek heads some miles to the sonthward, in John Gray's Lake, near the Caribon mines, and here leaps into the river over a terrace of basalt perhaps 30 feet bigh, forming a very pretty fall, which has given the local name to the stream. A short distance below, we forded with difficulty, the water coming over our sadilles. From this point the basalt lines both sides of the river, with very slight exceptions, to the Great Snake River Basin, and, according to report, to the Columbia. About four miles below Fall River, these basalt-walls close in the river's edge and form the lower cañon. At this point, two distinct beds of basalt appear, separated and underlaid by beds of river-sand, partly loose and nearly white, partly dark greenisin and rusty brown, and con siderably cemented with iron. These sands include great numbers of pebbles of basalt partly rounded. At one point, the lower bed of basalt slopes eastwari at an angle of about 150 , indicating a probable source of flow situated in the mountains to the southwestward, though possibly due rather to upheaval. At another point, the basalt is curved above beds of sand and gravel having a curved surface, which plaiuly formed a bar in the old river-bed. These deposits spread up against the edges of limestones and sandstones of the mountains on either side.

At the base of the mountain on the sonthwest sicle of the valley, just above the head of this lower can̂on, calcareous deposits, from now extinct springs, form a heavy mass, reaching about 100 feet up the mountain side. A small butte, nearly separated from the mountain behind, divides from the main valley the basiu of a small stream which goes by the name of Swan Valley. The base of these western mountains is com posed of gray quartzites, followed by conse and fine white sandstones, and a very fine grained white dolomitic limestone, all of uncertain age, though older than the overlying limestones, which contain a few Carboniferous fossils. The dips are sharp to the soutliwest, and the wash of the stream brings down fragments of red sandstone, which indicate that the higher beds here occupy their regular position.

The lower cañou is walled with basalt for from 200 to 400 feet, in many places perpendicularly, though elsewhere the slopes are more mod. erate. On the upper slopes, west of the broad plain which borders the top of these cliffs, there are two other beds of basalt and one of porphyritic trachyte, separated by only thin bels of sand and gravel, which reach to the top of the sonthern hills, about 6,700 feet above the sea The cañon bends northward to the base of the northern mountains, and The cañon bends northward to the base of the northern mountains, and
there winds for some fifteen or twenty miles before opening gradnally to the broad plain of the Great Busin of the Snake River.

As we had descended from the month of Salt River, the timber had gradually disappeared from the hills, until we now found only the seattered groves of small cottonwoods which mark the hollows where the snow lies late, or min mith the willows along the Danks of the few snall streams which escape from the hills into the sage-covered plain. From near the mouth of the cañon, a belt of cedars runs along the course of a high-water bayou on the south side of the river and forms a con. spicuous feature of the otherwise featureless plain for wany miles.

Some three or four miles below the mouth of this last canon, asmall hot spring, 4 or 5 feet across, stands on the north bank of the river, about 20 feet above the bottom. This was not visited by auy of our party, but was reported by our guide to be too hot for one to hold his hand in it for more than a balf minte. White spring-deposits were seen, from a distance, at several points on the north bank, but there is believed to be no flow at these points at the present time.

Joining the main party here on the evening of October 8 , we passed over the sage-plain described in the record of our ont ward trip, erossed Willow, Sand, and Blackfoot Creeks, and reacled Fort Hall on the 11th. The facts observed during that time, and during the fillowing trelve days, while we awaited Dr. Hayden's arrival to pay of and discharge the party, have been incorporated in the earlier part of this report. 


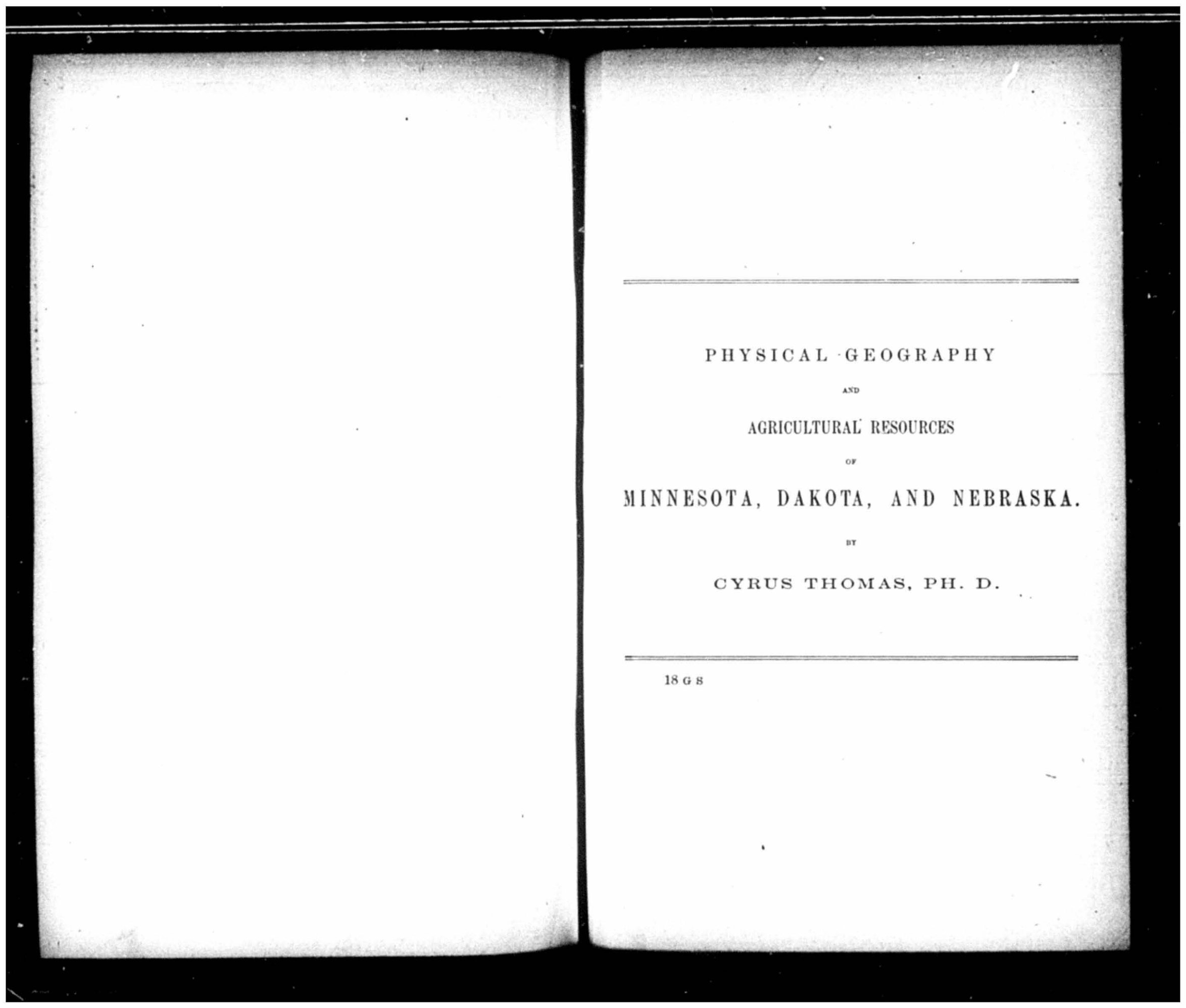




\section{PIIYSICAL GEOGRAPFY AND AGRICULTURAL RESOURCES OF MINNESOTA, DAKOTA, AND NEBRASKA.}

WAsHingtos, D. O., March 1, 1873.

DBAR Sm: Herewith I present a partial report of the results of my explorations of the year 1872 in Minnesota, Dakota, and Nebraska.

The time employed in preparing another report (which has already been submitted) and a temporary separation from the survey have prevented me from preparing and submitting at this time a full and complete report in regard to the agricultural resonrces of the very interest. ing region visited by me. I have, therefore, thought it best that I should prepare at present but a preliminary report, elaborating one or two points only which bear upon the agricultural resources of this section, and which I might make somewbat complete in time for publication the present season. Another important reason for this conrse, aside from the wart of time, was that, having entered ppon the discussion of the climatology of this region, as exhibited by the meteorological records, it became evident that important and valuable results might be obtained by a more full and complete discussion of all the records of that portion of the West situated between the Mississippi River and the Sierra Nevada Mto untaius. But to do this required more time than remained previous to the pulilication of your annual report for the year 1872. It also required the preparation and printing of certain charts, which could not be properly done in time. Therefore, with your consent, I determined to devote a portion of the present season to the preparation of a special to devote a portion of the present season to the preparation of a special
report on the climatology of the West. For this reason much of the material I had already prepared does not appear in this report.

These explanations will suffice to account for the meagerness of the report herewith submitted, althongh the material obtained was equal in amout and importance to that of any former year of my connection with the survey.

In my introductory remarks 1 give an ontline of what the full report may be expected to contain. At present 1 have confined myself chiefly to a discussion of the physical geography and topography of that portion of the Northwest visited during the summer of $18 \% 2$.

As in our former visits to the West, I have met with the kindest treatment at every point and on the part of all with whom my duties bronght me in contact. The railroad and stage companies in Minnesota, Nebraska, Dakota, and Kansas have, in every instance where I stated my business and my connection with your survey, granted me passes over their lines, thereby greatly lessening my expenses, and enabling me with the means at my command to extend my examinations over a much larger area than I could otherwise have done.

It is, perhaps, proper that $I$ should mention by name those companies from which I bare received these favors. The railway companies were Northern Pacific, Saint Panl and Pacific, Saint Paul and Sioux City, Illinois Central, Union Pacific, Burlington and Missouri River, and Kan. sas Pacific. I also received a pass from Mr. Blakesly over all the stagelines he represented in Minnesota, and from Messrs. Haskell \& Oheney 
over their line from Sioux City to Yankton. I am especially indebted to Governor Burbank, General McCook, General Beadle, and others, of Sontbern Dakota ; Colonel Stutsman, of Pembina; General H. Thomas, Colonel J. C. Bates, Dr. Dubose, Mr. Skinner, and others, for their as. sistance and for information furnished by them.

As a summary of results, I may state that, although in some respects the portion of our conntry visited did not meet entirely my expectations, founded on the exaggerated and glowing descriptions of speculators and others interested, yet it presents a bread-producing area equaled by but few and surpassed by none on the continent. Its capacity as a wheat-growing section is immense; so great, in fact, that the figures stagger our belief when first presented. As a beef-producing section its resources are grest, the grazing excellent throughout the entire area.

The fact of its great capacity in refrence to these two articles renders its development of great national importance.

Trusting that my action may meet with your approval and that this report may be satisfactory, I remain, yours, very respectílly

Professor F. V. HAYdEN.

\section{INTRODUCTORY REMARKS.}

The chief object of my explorations during the past season was to The chief object of my explorations during the past season to examine into and report upon the agricultural resources of Dakota ritory; yet it was expected that I would at the same time extend my observations to the immediately surrounding portions of the bearing npon the devel. opment of the resources of Dakota.

pment of the rosions knowledge A slight examination of this section, added to thoroughly I had obtaines in regard to it, suflced to convines me the understand its agricultural resources, it was important to investigate the climatology and physical geography of the great prairie-belt lying along the eastern margin of the great trans-Mississippi plains.

Here, runuing north and south, is found the dividing line between Fere, rutures other as that of Europe two regricultural, climatological, and from that of $\Delta$ sia ; here, in fact, in an physical point of view, is the real dividing line between the eastern and western portions of the continent. We have long looked upon the great Rocky Mountain Range as the dividing line of the continent, and, so far as the flow of water is concerned, this is so; but the more this region is examined the more apparent does it become that in other reregion is examined the rule. The chief diving line between spects this is far from bein south alon the two great continental chimatic areas streteheso the broad undulating plains of Kansas, Nebraskn, Dakota, \&c., and corresponds very nearly with the one hundredth meridian. Here, too, is the dividing line between great agricultural, fannal, and floral areas. In regard to climatology several important questions arise, two of wh wich, if possible, should receive which deserve simet relates to the isotherat least approximately correct answer. The mal liues through Wisconsin, Minnesota, and Dakota, especially the lines of mean summer temperature. This is the more mecessary from the fact that Mr. Blodgett, in his work on meteorology, has assumed that the mean lines of summer temperature make a rapid bend northward the mean lines of summer Michigan; and this statement has been used after passing west of Lake Micbigan; and to that portion of the North. argely in the efforts to induce enigration to west. If it is true that this remarkable flexurest, as a matter of course, have an important bearing npon onr estimate of the agricultural resources of this extensive region. I have, therefore, made it a special object to test the correctness of this assumption by all available data, which have been considerably increased since the date to withont intending date to which Mr. Biste is to forestall my investigations on this point, true a very remarkable flexure in the isothermal lines does occur here,
set the investigations 1 have made indicate that it is much less than $\mathrm{Mr}$.

Blodgett represents it to be.

The second elimatological question relates to the rain-fall. It is'well known that on the east side of the plains, as in Minnesota, Iowa, Missouri, and Arkansas, the average annual rain-fall is sufficient to supply the moisture necessary for the production of the cereals and other agricultural products. On the other hand, it is almost hs well known that irrigation is necessary at all points on the plains lying along the east base of the Rocky Mountains. Therefore, it is evident that the boundary 
between these two regions-that of sufficient and that of insafticient rain-must be found somewhere between the east base of the Rocky Monntains and the west line of the States last named. It becomes, therefore, very important to determine where this line is. It is true that the transition may be gradtal and render it difficult to fix it with any great degree of exactitude, yet it must be possible to determine it approximately. The importance of this will scarcely be appreciated by those who bave not come practically in contact with the question; but the individual who has gone beyond this line and opened a farm upon the broad prairie, depending upon the rain.fall alone to supply his crops, has learned by sad experience that knowledge which onght to be sup. plied to the public. But land-speculators and others, who are interested in settling up this portion of the West, are often too sanguine in their belief in regard to favorable climatic changes, or are regardless of the sufferings and hardships they cause by a too favorable representation of the climate of this uncertiin section. I dislike to make such statements, but I deem it a duty to speak plainly on this point. There is no necessity for any misrepresentations in regard to this part of the West; the facts are sufficiently favorable; and if these, aud these only, are pre sented, in the end the result will be better for the conntry and even for the particular section. I have, therefore, made this matter the subject of special investigation, but in this report will only give a short sum. mary of the facts, as I expect hereafter to present the whole. subject of the climate of the West in a special report.

Although the topography of the country presents great uniformity in eharacter, the general level being interrupted by no elevated peaks er extensive mountain-rąuges, yet the physical geography is not devoid of interesting and important features, as within the bonds of the region under consideration are the initial points of three of the most import. ant water-basins on the east side of the continent.

As the surface-soil also presents great uniformity in character, another important item to be examined was the natnre of the subsoil; but as this has been penetrated at comparatively few points in the newly. settled or unsettled pertions, the data obtained was necessarily meager; yet suflieient has been ascertained to show that it varies much more in the different sections than the surface-soil. I do not allude so much to its chemical ingredients as to its productive qualities.

Although a knowledge of the present condition of elimate, soil, and topography is sufficient to determine the agricultural value, yet there are some questions relating to the plysical conditions which are so intimately connected with these practical points that a full and exbaustire report should embrace them. I allnde particularly to the last geological changes which have resulted in the present condition of the surface and climate. I inelude "elimate" because I am thoroughly convinced, after studying this subject for several years, that, so far as the amount of moisture is concerned, the present condition has resulted, in part at least, from the effect of the last geological change that took place in the surface. But, unfortunately, my knowledge of geology is not sufficient to discuss this question properly, even if I had all the data necessary to do so, and the geological surveys which have been made of this section have not been directed particularly to the surface-features. It is true that Professor Haylen, in his very interesting resumé (Chapter XII) of his report of 1870 , touches upon this subject, alluding to its importance and expressing the desire to return to its investigation at some future time. It is to be hoped that he may be permitted to carry out this desire at an early day, as there is no one who more highly appreciates the value of the surface-geology of this section, in which he spent so many of the early days of his explorations, than which Professor Winchell, in his first annual rexplorations, than he does. Natural History Survey of Min and Mtural history Sarvey of Minnesota, has devoted a short chapter to this subject so far as it relates to that State. Owen, in his Report on the Geology of Wisconsin, Minuesota, and Iowa, mentions important facts bearing npon this subject, but loes not numerous specially. But no one, so far is 1 am aware, but does not discnss it specially. But no one, so far as I am aware, has as yet discussed the
relation of the last geologieal change relation of the last geological change is this section to its present climatic condition. This, therefore, still remains an open field for inquiry and investigation.

The valleys of the rivers, the wfathering of the bluffs and terraces, the dry coulces, as well as the vasi amount of loea drift and terraces, of the Rocky Monntains, show br yond a doubt that, at some very recent period in a geological sense, the amount of water which fell was mueb greater than at present. I allu le not to the remote perios when it wach submerged, bnt to a period sin e the waters receded, for it when it was geological ese to detect thes evidences and to deternine reguires no relate to a time long subseque at to the last emergence, hence attribut-

It is therefore evident that between that time and the present a great change has taken place in the climate in regard to humidity; that it is much less now in the was:en vortions of Dikota, Nebraska, and Kans than it was in the past. This question then arises: Has the change in this direction ceared ? If not, ther we are forced to the conclusion that this section is still growing drier. If it is true- and I think it will scarcely be denied by any who have directed their attention to the sub. ject-that such has been the direction of the climatio changes in the past, one of two conelusions is inevitable, viz, that there are no gronnd for expecting a more favorable climate (in regard to bare no gronda future, or that the change in the direction indicated has ceessed, and consequently a reaction must take place. On this importaut point I bave collected some data which I expect to present in my meteorological report.

As the immense belt under consideration is one almost continnons prairie, devoid of forests, which must be devoted almost wholly to fant ing and pastoral pursuits, it is apparent that its future development depends to a great degree upon the means of transporting its products to market and of reaching the forests of the States lying east of it. It is therefore very desirable, in this connection, to obtain some idea of the extent and character of the forests and the extent and direction of the coustructed and contemplated railroad-lines.

Although I have not made the former a special object of inquiry and investigation, yet sufticient information in regard thereto has been obtained upon which to fond a conclusion in regard to the adequacy of the supply of lumber for the next generation. To examine the immense forests of Minnesota and Wisconsin in person, with sufticient thorough ness to determine their character, wonld require several years; but ness to determine their character, would require several years; but, fortunately, these States have for several years been gathering statistic concerning them, which are acessible, and of which I shall avail myself in this or a future report so far as I deem it necessary to do so. Any report relating to the present extent of the railroads would be of but temporary value, as the various lines are being so rapidly extended, and new ones being formed in such rapid succession, that what is true to-day will fall far short of being true a few years hence.

A very important question, and one of national interest, arises in con. 
nection with this subject. What is, or is likely to be, the effect upon the indnstries and development of this portion of the country of land-grants to railroais by Congress 9 This has assumed such vast proportious that it behoor sume statesmen of our nation to examine the subject it behooves the states be led away by the simple and conceded fact that great care, and not be led away by the simple and conceded in which they are made.

This is a matter which already agitates the public mind; and ' $\mathrm{n}$ ? part of the country have we a better opportunity of studying its effect than in the Northwest, where the grants have been most numerous anc extensive.

When the public mind becomes aronsed in relation to a given subjeet, and a tendency to reaction becomes manifeat, politicians are apt to seize upon the opportunity of riding into position upon the current of opin. ion, and, instead of striving to lead it to a correct ronclusion, strive to carry it to the other extreme, and often thereby eripple national indas carry it to the other extremes ases. It is proper, therefore, that the fact tries instead of correcting abuses. in respect to such subjects shou examination of this im portant question, I desire to call attention to it.

\section{PHYSICAL GEOGRAPHY.}

As the surface features and configuration of any section have an im. portant bearing upon its climatology and agricultural resources, I will portant bearing upo of the physical geography of that portion of the present first a sketch of the physical geography of that portion of the Northwest at present under consideratiou. Although I shall, when 1 discuss the climatology, embrace a larger area, I will at present confine
my remarks chiefly to Minnesota, Dakota, Iowa, and Nebraska.

Foster, in his excellent work on the physical geography of the Missis. sippi Valley, has presented in a very attractive form a description of the sippi Vallest therefore it will be unnecessary for leading characteristics of the West; therefore it will be unecessary for me, in describing the features of a limited section, to repeat what has been so well set forth. I will, for this reason, confine myself to the more mixute details, and especially to the hypsometrical data.

Notwithstanding this region, which has been not inaptly termed the "New Northwest," presents no elevated mountain-ranges or lofty peaks, Now Nore dividing. to break the sometwat monotonous contour and form sharp diving lines between the water-systems, yet its geographical features are not devoid of interest in a scientifie point of view, nor without important influences on the climate. Who can predict with certainty what would be the climatic effect of a rugged forest-clad mountain-range running east and west from the base of the Rocky Mountains to the Mississippi east and west from the River 9 Who can tell what would be the result of winds which now sweep across these vast plains f Wh can foreses with certainty the effect even of a continued forest over this immense area 1

This country may be described in general terms as one immense com. paratively level area, consisting of slightly rolling and marshy, timbered sections in the northeas

west and southwest. The eastern portion, from Lake Superior to the Mississippi, is covered chiefly with pine and tamarack forests, and to a large extent more or less marshy, especially in the eastern and northeastern part of Minnesota, but fading out and changing somewhat in character as we move sonth ward, the marshes entirely disappearing in this direction. A lengthy but narrow forest-strip runs north and south along the west side of the
Mississippi River, consisting almost entirely of deciduons trees, such as nak, elm, ash, \&c. But this strip, as it approaches Iowa in its sonthern extremity, is more or less broken up by prairie-belts, and there confined chiefly to the river valleys.

The remaining portion o. the entire area lying west of this timber-line, and ex 'ending to the base of che Rocky Mountains, consists of broad, undulating, treeless plains, channeled by numerous streams, and dotted in its eastern portion with numerous small lakes, which decrease in num. bers and acquire a saline character as we move west ward. This part is, in fact, one section of the great plains of the interior, which stretch northward from Mexico to Arctic America.

The great uniformity in appearance and sameness of character of this part of the country would apparently forbid any lengthened description of its geographical features-and to a great extent this is true-yet there are some facts and peculiarities worthy of our attention and study, especially as there are some problems connected with these broad, open areas which have not as yet been satisfactorily solved. Why are they devoid of forests 9 is a query often propounded, and, althongh approach. ing solution, has not been answered to the entire satisfaction of our lead. ing physicists. If we reject the view of Lesquereux, that the "prairies are due to peat-growth," and the view of other physicists, that they are due "to the texture of the soil," and also exclude as unworthy of consideration the very general opinion that they have been produced by the annual burnings-for this applies only to their perpetuation and not to their production-and accept the very plausable theory of Newberry, Foster, Hayden, and others, that this condition arose from a want of sufficient moisture, we have advanced but one step in the process of soln. sufficient moisture, we have advanced but one step in the process of solu-
tion, and find ourselves confronted by another question equally difficalt to answer: What caused this lack of moisture on the plains? And why are the prairies of Nebraska, Kansas, and Dakota drier than those of Iowa and Illinois? Doubtless the presence of the large body of water in the lakes of the north-Superior and Michigan-over which currents of air already charged with moisture sweep down from the northeast, the approximation of the Gulf of Mexico, and the Mississippi running north and south along the border of the entire area, will go far toward furnishing an answer to the latter inquiry. But it is not my intention to pursne this investigation at this time; when I enter upon a discus. sion of the climatology I may present some facts which I think bear upon the subject.

The water-drainage of Minnesota and Dakota forms one of the most interesting and important features in the physical geography of this section of the West. Although there are no marked or prominent watersheds here, yet the streams which originate in this limited area belong to three different water systems or basins: that of Hudson Bay, the lake or Saint Lawrence Basin, and the Mississippi or Gulf Basin-one draining north, one east, and the other south, showing a bigher general elevation of the surface here than in either of these directions; that is to say, if we move nerth, east, or south from this area, we descend. "Professor Wenchell makes the following statement in regard to the topography of Minnesota:•

The intimate relation anbsiating between the geology and topography of the Srate is more evldent than in some of the other 8 tates in the Union. The causes which do the existene of the or the great continental water-shed are those which determiped the existence of the Laurentian and Lake Buperior rapges of igneous and metamorphic
rocks. The area of these rocks in Minnesota, as well as in Wisconsin and Miehigan, - Geological and Natural Hiatory Survey, Minuesots, (1873,) page 45. 
includes some of the sources of the great river-systems of the Northwest and of the continent. From this area, since pro-Silurian times, streams have run in all direetion: toward the ocean. Within this arra, in the State of Minnesots, are the headwaters of the Saint Lawrence system of drainage, which enters the Atlantio Ocean toward the east; those of the Miseissippi, which enter the Gulf of Mexico toward the soutb, and those of the Red River of the North, which, taking an opposite course, find the oceanconsists not in the form of a definite and abrupt ridge.

This fact, which does not find an exact parallel at any other point in the comparatively level portion of the interior of the continent, marks this area as one of peculiar interest in the study of the physical geography of the Mississippi Valley

The Mlississippi and Red Rivers form the chief lines of drainage, and it is worthy of notice that these run in exactly opposite directions. The Missouri River, from its great bend in the north west corner of Dakota, runs a little east of south, the Mississippi almost directly sonth, while the intermediate waters find their way directly north through Red River to Lake Winnepeg.

It has been remarked by some writer that geologists and geographers often fail to appreciate the value of the facts they obtain in regard to the direction of the leading streams and elevated ranges of the conn tries they explore. Athough I do not claim to be a geologist, yet I am strongly inclined to believe that the fixing of the channels of these streams belongs to the closing scene of the Drift period. And this opinion corresponds with the idea already expressed by Professor Hayden: $\bullet$

At a molera perion it is probalble that the waters of the ocean swept high upland, reaching nearly to the foot of the mountains. The great water-courses had alroady the fumediate valley of the Misiouri, but thinuing out as wo recede from it or the valleys of any of its branclies.

The cuts given in Professor Winchell's report on the survey of Belle Plaine, Minnesota, indicate that he holds substantially the same opinion. But in his geological report, before referred to, and which was received after this report was draughted, he expresses his opinion on this point as follows: $\dagger$

The conrse of the surface drainage is, in this case, (where the drift is very thick,) dependent very little on the elaracter of the uuderlying rock. But where the drif is lighter, the direction of the suborilinate st reams is ofen determined by the bearing of the sedimentary rocks. A streais is most likely to be located in the depression eaused by the erosion or other destruction of the onteropping edge of a soft or friable rock, the more persistent formation taljoining it, above and below, forming the divides botween it and other streams. Other causce, however, principally those superinduced by undulations in the strata over long distances, so as to canse them to leave the direotion of the prineipal or tributary valleys, and the variations of level brought about by the nnequal deposition of the drift daring the prevalance of the ice of the glacia epoch, have very getierally

The direction of the streams of Dakota and Northern Nebraska nn doubtedly falls within the last category, as their channels seldom reach the bottom of the drift. We may, therefore, safely assume that the direction and lines of water-drainage were already marked ont at the close of the Quarternary period, and donbtless previous to the last submergence of this portion of the Northwest.

An examination of the direction of the tributaries of the leading

* Report 11670, page 175.
t Geological and Natural History Survey of Minnesota, page 46. streams mentioned will serve to indieate the direction of the descent of the different parts of their basins. Thns, the tributaries of the Missouri which flow into it below the bend present a very marked contrast in direction; those on the west side, as Heart, Ree, Big Cheyenne, White and Niobrara Rivers, flow almost directly east; while those on the east side, as James, Vermillion, and Big Sioux, flow almost direetly sonth, showing clearly that the channel of the Missouri marks the termination of the effect of the descent from the monntains, and that east of it the descent is from the north. But it must not be inferred from this that the descegi toward the east absolutely ceases at the Mlissonri, for this is not correct, as (in Dakota) it continues-as will be seen by the tables of altitudes-as far east as the valley of Red River; but the channel of the Missouri is the boundary of the eastward flow. After giving the tables of altitudes I will again allnde to this subject, and mention some other causes for this ehange of direction.

A somewhat singular feature is presented by the tributaries of Red River; as a general rule, those on the west side flow southeast and those on the east side southwest until they strike the immediate valley of the river, where they bend abruptly northward. This would indicate a southern descent for the bordering plains, while it is evident the broad, level valley of the river has a slight northern descent.

Although, as will hereafter be shown by the tables of elevations, the plain from which the waters of the Upper Mississippi are gathered is, in a manner, segregated from the broad western slope, yet tha kame direction of drainage is preserved, the western tributaries flowing southeast, while the few eastern ones within Minnesota flow southward. This direction is preserved, notwithstanding, as in Southern Minnesota the descent of the bordering surface of the conntry is directly opposite to the course of the streams.

If we move sonthward to the latitude of Iowa and Nebraska, we shall find the drainage slmost wholly eastward or southeast, that toward the sonth being less marked than in the northern section. In Nebraska it
may be said to be entirely eastward, sotwe of the northern tribtaries of the Platte only bearing a little sontheast. The drainage of Iowa is in great part to the sontheast, a few minor streams running sonthwest into the Missouri River, indicating a narrow western slope along its western boundary.

It is evident that the vertical topography is of the utmost importance in studying the pbysical geography of any section, and more especially is this the case where the outlines are not rugged, but where the long rounded swells and apparently level plateaus are calculated to deceive the eye. I have, therefore, collected all the data to be obtained on this point, particularly what refers to the surface of Minnesota and Dakota; and fortunately the recent surveys of lines through this section of the Northwest for the purpose of locating railroads lave furnished us with sorthwest for the purpose of locating railroads have furnished us with
suftient material to euable us to form a tolerable correct idea of its topography. Therefore, before proceeding further, 1 insert the follow. ing lists of elevations and distances, which have been furnished in most cases from the officers of the roads mentioned. One or two have been copied from the report of Professor Winchell, heretofore referred to, and some of the tables furnished me have been corrected by this report. 
TABLE I. - A list of elevations and distances along the line of the Lake Buperior and Mississippi Railroad, running from Duluth on Lake Bupe. rior to Saint Paul, Minnesota.

\begin{tabular}{|c|c|c|}
\hline & $\begin{array}{l}\text { Distance from } \\
\text { Duluth. }\end{array}$ & $\begin{array}{l}\text { Height above } \\
\text { the nea. }\end{array}$ \\
\hline & Miles. & \\
\hline 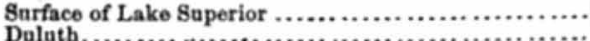 & ......... & \\
\hline $\begin{array}{l}\text { Duluth } \ldots \ldots \ldots \ldots \\
\text { Thomen }\end{array}$ & $\dddot{2} 2$ & 1,02 \\
\hline 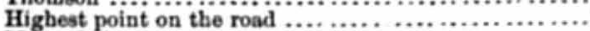 & 33 & 1,16 \\
\hline Moose Lake depot............................ & 45 & 1,0 \\
\hline 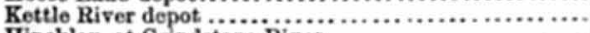 & 60 & 1,11 \\
\hline Hinckley, at Grindstone River ............. & 78 & \\
\hline Lowest between Hinckley and the next & & 1,0 \\
\hline (n) & 80 & 1,0 \\
\hline River & $\begin{array}{l}86 \\
90\end{array}$ & $\begin{array}{l}96 \\
94\end{array}$ \\
\hline 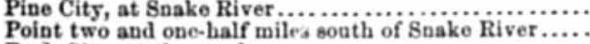 & & 94 \\
\hline reek................................ & 101 & 型 \\
\hline 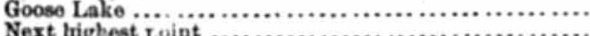 & ?..... & $\begin{array}{l}8 \% \\
91\end{array}$ \\
\hline $\begin{array}{l}\text { Next frighest } \\
\text { North Broint }\end{array}$ & $\mathrm{ii3}^{113}$ & $8^{91}$ \\
\hline Botween No:th Branch and wyoming ...................... & & \\
\hline 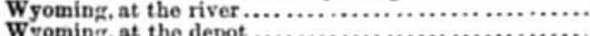 & 125 & \\
\hline 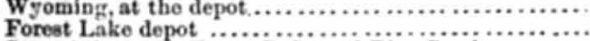 & 129 & \\
\hline Summit between Forest Lake and Rice Creek ............. & 132 & 9 \\
\hline & 1334 & \\
\hline & $138^{\circ}$ & \\
\hline Dent & 143 & \\
\hline aint Paul..... & 145 & \\
\hline Between Phalen's Lake a & 151 & \\
\hline 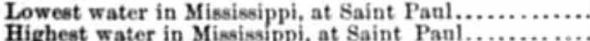 & 150 & 67 \\
\hline Standard generally used for Mississippi, at Saint & & \\
\hline
\end{tabular}

TABLE II.-A list of elerations and distances from the vestern extremity of Lake Superior, at Duluth, to the Missouri River at the mouth of Heart of Lake Superior, at Duluth, to the Missouri River at the
River, along the line of the Northern Pacific Railroad.

\begin{tabular}{|c|c|c|}
\hline & $\begin{array}{l}\text { Distance from } \\
\text { Duluth. }\end{array}$ & $\begin{array}{l}\text { Height above } \\
\text { the sea. }\end{array}$ \\
\hline Lake Superior, & Miles. & Feet. \\
\hline 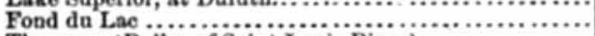 & & 606 \\
\hline Thomson, (Dalles of Salnt Louis River)................. & 22 & 1,036 \\
\hline 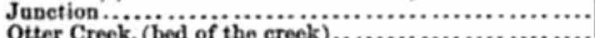 & 24 & 1,080 \\
\hline $\begin{array}{l}\text { Otter Creek, (bed of the } \text { ereek) } \ldots \ldots \ldots \\
\text { Norman, (natural ground) }\end{array}$ & 34 & $1,1,373$ \\
\hline Kettle River, (bed of the river) ........................... & 42 & 1,285 \\
\hline 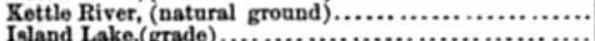 & 45 & 1,350 \\
\hline 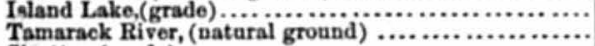 & $\begin{array}{l}46 \\
62\end{array}$ & $\begin{array}{l}1,302 \\
1,309\end{array}$ \\
\hline 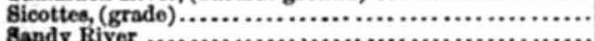 & 58 & 1,200 \\
\hline 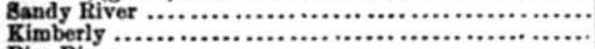 & 65 & 1,228 \\
\hline 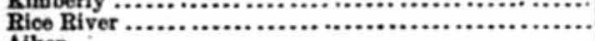 & 81 & 1,248 \\
\hline 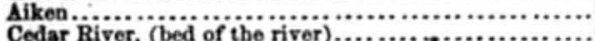 & $\underset{9}{88}$ & $\begin{array}{l}1,203 \\
1,193\end{array}$ \\
\hline 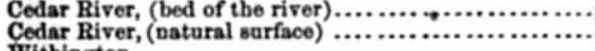 & 97 & 1,299 \\
\hline 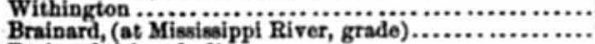 & $\begin{array}{r}98 \\
115\end{array}$ & $\begin{array}{l}1,290 \\
1,200\end{array}$ \\
\hline 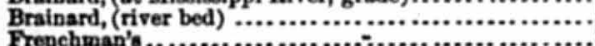 & & 1,138 \\
\hline 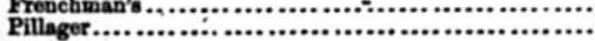 & $\begin{array}{l}121 \\
127\end{array}$ & $\begin{array}{l}1,206 \\
1,196\end{array}$ \\
\hline
\end{tabular}

TABLe II-A list of elevations and distanoes, do.-Continued.

\begin{tabular}{|c|c|c|}
\hline & $\begin{array}{c}\text { Distance from } \\
\text { Duluth. }\end{array}$ & $\begin{array}{l}\text { Height above } \\
\text { the sea. }\end{array}$ \\
\hline Crow Wing River, (bed of the river).. & $\begin{array}{l}\text { Mriles. } \\
136\end{array}$ & \\
\hline Motley ................................. & 137 & \\
\hline Hayden's Branch, (creek bed) ........... & 143 & \\
\hline 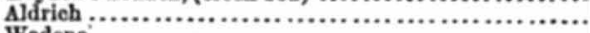 & 151 & \\
\hline Wadena & 161 & 1,0 \\
\hline Leaf River.............................. & 166 & 1,3 \\
\hline 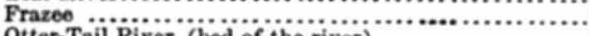 & 175 & \\
\hline Otter-Tail River, (bed of the river) ........ & 183 & 3 \\
\hline 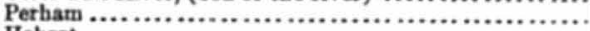 & 186 & i, \\
\hline Hobart $\ldots \ldots \ldots \ldots \ldots \ldots . \cdots \cdots$ & 196 & , \\
\hline Otter-Tail River, (natural ground). & 201 & \\
\hline Pelican River, (bed of the river) ............... & 206 & \\
\hline Detroit .............................. & 207 & 3 \\
\hline Oak Lake............................... & 211 & 3 \\
\hline 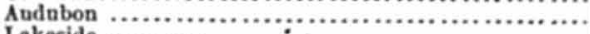 & 214 & \\
\hline Lakeside........................... & 219 & $\begin{array}{l}1, \\
1,\end{array}$ \\
\hline 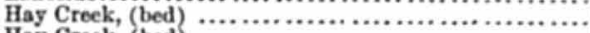 & 224.2 & \\
\hline 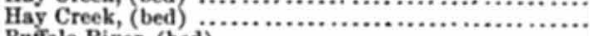 & 226.6 & i \\
\hline Buffalo River, (bed) ................... & 227.4 & 1 \\
\hline Buffalo River, (bed) ................... & 230.1 & \\
\hline 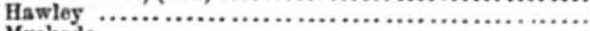 & 230.4 & i, \\
\hline Muskoda & 235 & \\
\hline Red River Flats....................... & 242 & \\
\hline 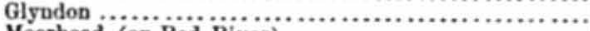 & 243 & \\
\hline 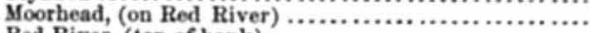 & 252 & \\
\hline ( & ......... & \\
\hline (bed of river)... & & 8 \\
\hline e crossing ......................... & 258 & \\
\hline 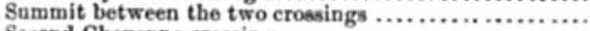 & 306 & 1 \\
\hline Second Cheyenne croseing ............................... & 311 & \\
\hline & 329 & 4 \\
\hline between Cheyenns and James Rivers......... & 32 & i, \\
\hline 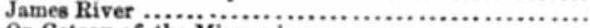 & 346 & \\
\hline 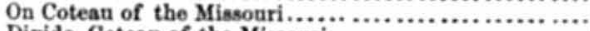 & & \\
\hline Divide, Cotean of the Minsouri............................ & 387 & 1,795 \\
\hline $\begin{array}{l}\text { On Cotean of the Missouri } \\
\text { Miseouri River, (at mouth of Heart River) }\end{array}$ & 425 & $\begin{array}{l}1,873 \\
1,700\end{array}$ \\
\hline Missouri River, (at mouth of Heart River) .............. & & \\
\hline
\end{tabular}

TABLE III $-A$ list of elevations and distances along the Saint Pauland $\mathrm{Pa}$ eific Railroad, from Baint Paul to Breckenridge, on Red River, assuming lov water in the Mississippi River at Saint Paul to be 680 feet above the sea.

\begin{tabular}{|c|c|c|}
\hline & $\begin{array}{l}\text { Distance from } \\
\text { Saint Paul. }\end{array}$ & $\begin{array}{l}\text { Height above } \\
\text { the sea. }\end{array}$ \\
\hline 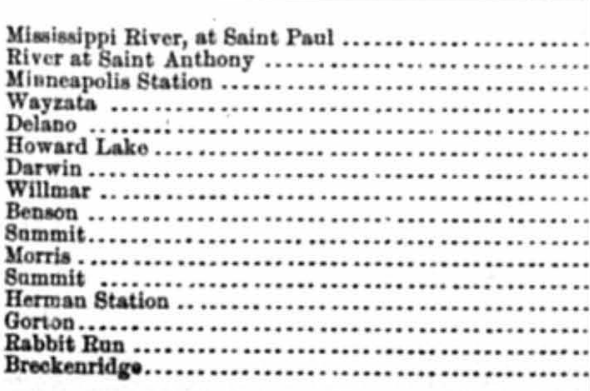 & $\begin{array}{l}\text { Miles. } \\
0 \\
9.5 \\
10.5 \\
24 \\
40 \\
54 \\
62 \\
105 \\
134 \\
151.5 \\
159 \\
161 \\
178 \\
18.5 \\
201 \\
217\end{array}$ & $\begin{array}{r}\text { Fet, } \\
680 \\
795 \\
825 \\
926 \\
918 \\
1,044 \\
1,192 \\
1,119 \\
1,037 \\
1,162 \\
1,117 \\
1,146 \\
1,068 \\
1,012 \\
972 \\
963\end{array}$ \\
\hline
\end{tabular}


TABLE IV.-A list of elevations and distances along the Baint Paul and Sioux City Railroad from Baint Paul to Le Mars, assuming lono vater at Baint Paul to be 680 feet above the sea-level.

\begin{tabular}{|c|c|c|}
\hline & $\begin{array}{l}\text { Distance from } \\
\text { Saint Paul. }\end{array}$ & $\begin{array}{l}\text { Height abovo } \\
\text { the sea. }\end{array}$ \\
\hline & Miles. & Feet. \\
\hline $\begin{array}{l}\text { Belle Plaine } \\
\text { Blakeley }\end{array}$ & $\begin{array}{l}47 \\
62\end{array}$ & $\begin{array}{l}786 \\
789\end{array}$ \\
\hline 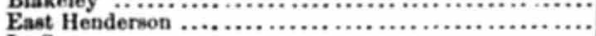 & 58 & 796 \\
\hline 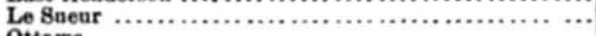 & 63 & 815 \\
\hline 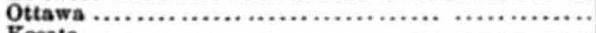 & 69 & 851 \\
\hline 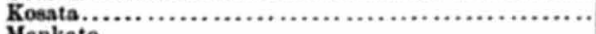 & 77 & 857 \\
\hline 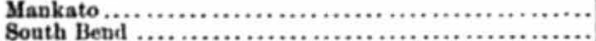 & 86 & 853 \\
\hline $\begin{array}{l}\text { South Bend } \\
\text { Eryat Lake }\end{array}$ & $\begin{array}{r}90 \\
100\end{array}$ & $\begin{array}{r}870 \\
1.057\end{array}$ \\
\hline 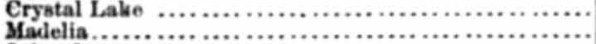 & 110 & 1,002 \\
\hline 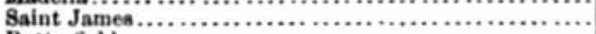 & 121 & 1,061 \\
\hline Butterfield .............................................. & 130 & 1,167 \\
\hline 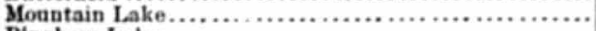 & 137 & 1,281 \\
\hline 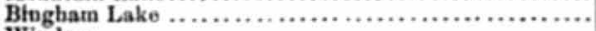 & 143 & 1,401 \\
\hline 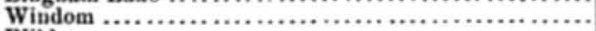 & 148 & 1,320 \\
\hline 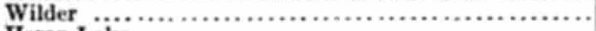 & 154 & 1,427 \\
\hline 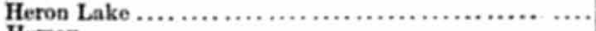 & 160 & 1,398 \\
\hline 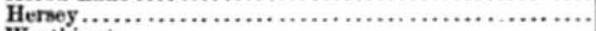 & 170 & 1,469 \\
\hline 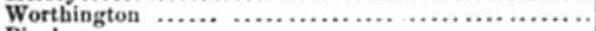 & 176 & 1,568 \\
\hline 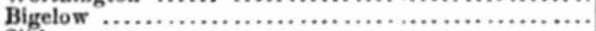 & 108 & 1,607 \\
\hline 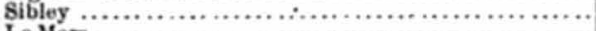 & 196 & 1,490 \\
\hline 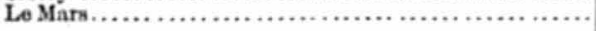 & 245 & 1,200 \\
\hline
\end{tabular}

TanLe V. A list of elerations along a line running from Morris, on the Saint Paul and Pacific Railroad, southcest across the Cotean of the Prairies and the Cotean of the Missouri to Fort Sully, on the Missouri River. Measured by Mr. J. D. Skinner, engineer. Estimated from low vater at Saint Paul.

\begin{tabular}{|c|c|}
\hline & $\begin{array}{l}\text { Height above } \\
\text { the sea. }\end{array}$ \\
\hline Low water at Saint Panl. & Fet. \\
\hline 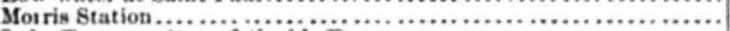 & 1,120 \\
\hline Lake Traverse, (top of the blaff) ................................. & 1,000 \\
\hline Lake Traverse, (bottom of the blufi) .......... & 960 \\
\hline 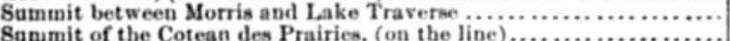 & 1,168 \\
\hline $\begin{array}{l}\text { Sunmit of the Cotean des Prairies, (on the line }) \ldots \ldots \\
\text { Western foot of the cotean }\end{array}$ & $\begin{array}{l}1,960 \\
1,498\end{array}$ \\
\hline Bank of James River...................................................... & 1,200 \\
\hline Water-level of James River......................................... & 1,200 \\
\hline 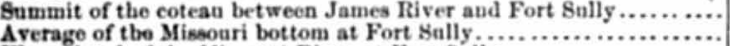 & $\begin{array}{l}1,942 \\
1,420\end{array}$ \\
\hline 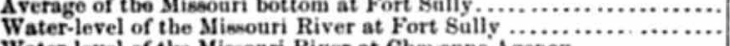 & 1,398 \\
\hline Water-level of the Missouri River at Chejenue Agency................ & 1,415 \\
\hline
\end{tabular}

TARLE VL-A miscellaneous list of elevations in various parts of Minne. sota and Dakota, mostly barometrical.

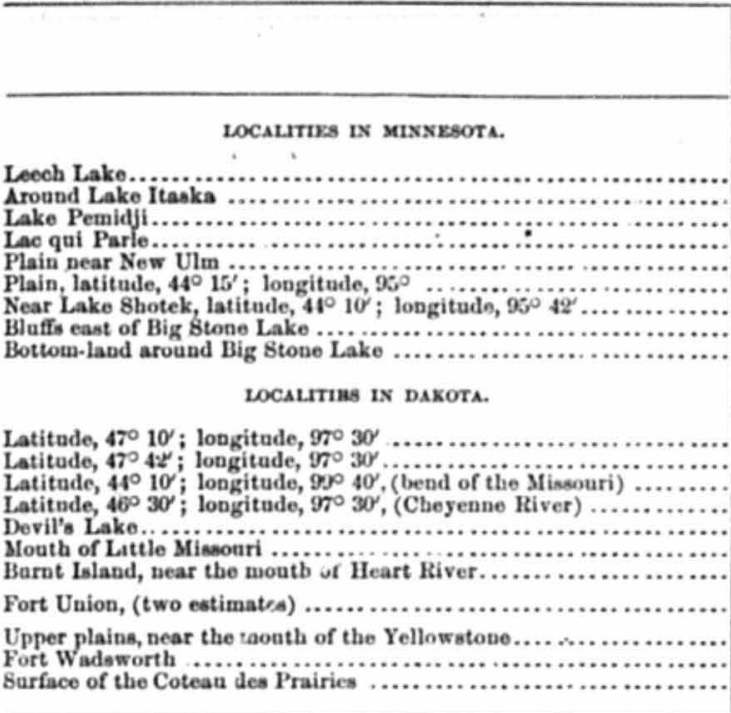

Height abovo

the sea.

Feet.
1,330
1,680
1,456
1,946
1,064
1,160
1,578
$1, \mathrm{c70}$
966

TABLE VII.-A list of elerations and distances along tico lines running northoard; one up the Mississippi, from Saint Paul to Brainard, the other along the Red Ricer Valley, from Glyudon, on the Northern Pacifio Railroad, to Pembina.•

\begin{tabular}{|c|c|c|}
\hline & $\begin{array}{l}\text { Distance from } \\
\text { Saint Paul. }\end{array}$ & $\begin{array}{l}\text { Height above } \\
\text { the sea. }\end{array}$ \\
\hline 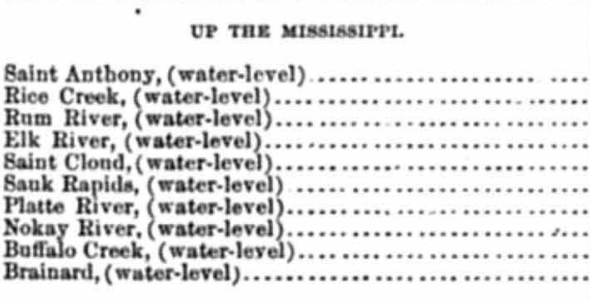 & $\begin{array}{c}\text { Milea. } \\
9.5 \\
17 \\
97.5 \\
43 \\
75 \\
\ldots \ldots . . \\
95 \\
120 \\
134 \\
137\end{array}$ & $\begin{array}{r}\text { Foet. } \\
791 \\
807 \\
831 \\
891 \\
963 \\
992 \\
1,054 \\
1,134 \\
1,167 \\
1,184\end{array}$ \\
\hline
\end{tabular}

- In this table lo- water at Saint Panl is eatimated at 676 feet above the sea-level. 
TARLE VII.-A list of elevations and distances, do-Continued.

\begin{tabular}{|c|c|c|}
\hline & $\begin{array}{c}\text { Distance from } \\
\text { Glyndon. }\end{array}$ & $\begin{array}{l}\text { Hoight above } \\
\text { the sea. }\end{array}$ \\
\hline FROM GLYSDON TO SAINT VISCKNT OR PEMAISA. & Milea. & Foet. \\
\hline 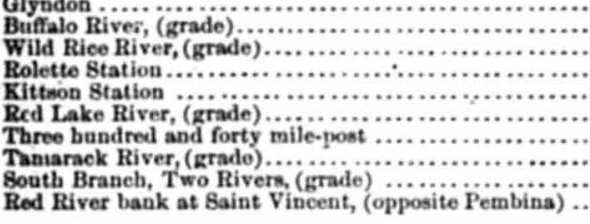 & $\begin{array}{c}3 \\
28 \\
42 \\
58 \\
64 \\
102 \\
113 \\
137 \\
156\end{array}$ & $\begin{array}{l}923 \\
919 \\
910 \\
894 \\
806 \\
862 \\
851 \\
830 \\
815 \\
792\end{array}$ \\
\hline
\end{tabular}

Four of these tables (II, III, IV, V,) give us the elevations of transverse sections almost and in some cases directly along east and west lines, crossing the direction of the leading streams at right angles, enabling us to judge quite correctly in regard to the topography so far as it relates to this direction. From Table VII we learn the descent of the Mississippi River from the crossing of the Northern Pacific Railroad to Baint Paul, and the descent of Red River from the same line northward to the British line; and by bringing together the elevations on the same meridian from the different lines mentioned in these tables and from the Union Pacific and Kansas Pacific lines, we can obtain at least an approximately correct idea of the topography along north and south lines.

Beginning with the north line along the Northern Pacific road and tracing it westward, we find a somewhat unexpected uniformity of elevation in the timbered district which extends from Lake Superior westward some fifty or sixty miles beyond (west of) the Mississippi River, and as we move farther westward, although, with one material exception, we find the variation to be gradnal and generally ascending, yet we shall notice very marked and striking changes in the character yet we shall notice very
of the conntry traversed.

of the country traversed.
Starting from the surface of Lake Superior at Dulnth with an altitude of 600 feet above the sea-level, we.rapidly ascend the rugged encireling bluffs, and in a few miles reach a height of 1,280 feet. This we find, by examining Table II, is about the average level of a line across the State of Minnesota at this latitucle, until we reach the valley of Red River, or Minnesta at this latitule, until we reach when we agan descend some 300 feet. Fromes along the railroad line seldom, if ever, vary more than 100 feet. There is a slight depression in the immediate valley of the Mississippi, as at Brainard and Pillager, but it is certainly much less than we would be led to infer from a comparison of the higher margins of this plain or platean with the much lower level of Lake Superior on one side and that of Red River Valley" on the other. Even this central depr will, in a great measure, disappear if we follow a direct line from Duluth to Moorhead, instead of following the southward curve of the road as it approaches the river, for in moving sonth it descends proportionally. As we approach the divide between the waters of the Mississippi and Red Rivers, there is an ascent of abont 100 feet above the average, and nearly 200 feet above the former river. As a matter of course, the rosd is constructed along the lowest levels; therefore our figures in the tables, as a rule, represent the lowest points of the surface, and give us but little idea of the local and isolated irregularities in the contoni especially is this the case where the line different water-basing. In this case we should probably all 150 or 2000 to the figures given in the table to get a true average of the elevation of this divide, which is here called Leaf River Hills, and which extends some distance north and soutb.

If we move north from the point where we cross the Mississippi, fol. lowing up its valley, we observe that the ascent is rather more rapid than toward the west, as will be seen by the following list of elevations taken from General Humphreys' report on the Mississippi River:

\begin{tabular}{|c|c|}
\hline & $\begin{array}{l}\text { Ahove the } \\
\text { sea-level. }\end{array}$ \\
\hline 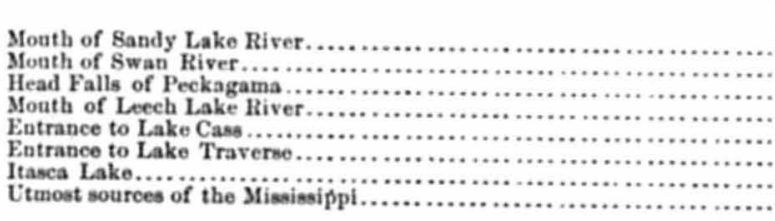 & $\begin{array}{l}\text { Fet. } \\
1,253 \\
1,290 \\
1,340 \\
1,356 \\
1,402 \\
1,456 \\
1,575 \\
1,600\end{array}$ \\
\hline
\end{tabular}

As a matter of course, before we pass the divide in this direction a still higher point will be reached, although there is no marked ridge separating this basin from that north of it.

If we pass westward to Red River we find the eleration, where the road crosses it, but 900 feet above the level of the sea ; and as we move northward along its conrse it gradually descends, until, at Pembina, the altitude, according to the railroal-survers, is but 792 feet above the sea. It is therefore evident that in passing from the basin of the Upper Mfississippi into Red River Valley we have descended to a general level about 400 feet lower, and in doing this have passed over a broad rim from 100 to 300 feet higher than the upper plateau.

What the vertical topography is northeast from the sonrces of the Mississippi, I am unable to say; but, as the waters of that section flow northward and eastward into anothêr basin, it is evident the descent is in that direction, and the list of heights along Nameukan and Rainy Lake Rivers, from Lake Superior to the Lake of the Woods, as given in part below from the geological report of Mr. Hind, will show at least the amonnt of this descent to that line or water-level. As a matter of conrse, there is some kind of a diride between these two basins, but those who bave passed over it at different points say that as a general thing it is an imperceptible swell; in some places it is marked by low ridges, which separate the numerous marshes of this portion of Minnesota. The prom. inent ridge marked in some maps as runuing eastward from the southeru margin of Red Lake is wholly imaginary.

The following list of elevations along the Namenkan and Rainy Lake Rivers, taken from the geological report of Mr. Hind, gives us the slope of the main channel of this northern international basin, and is very in. portant in this connection, although part of the link between it and the Mississippi Basin is wanting:

$$
10 \mathrm{G} \mathrm{s}
$$




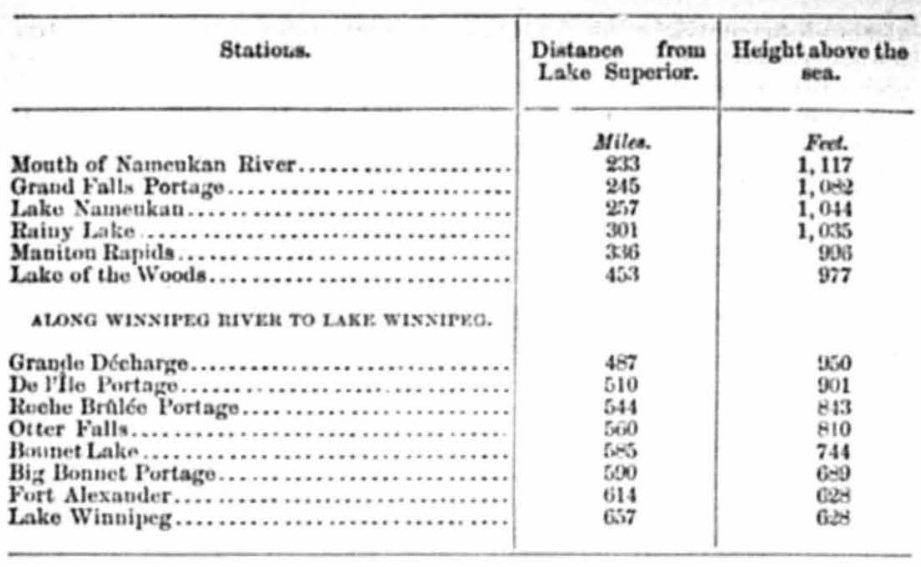

I regret that this line cannot be extended eastward direct from Rainy Lake to Lake Superior; but I hare been unable to find any record, if one was ever made. Yet from this list, imperfect as it is, we learn some important facts, among which the following mas be mentioned as of special interest in the present examination: That the divide between Lake Superior and Rainy Lake, which here is directed northeast, main. tains an elevation equal to that immediately west of Duluth. It is true that, at the point where Mr. Hind struck the channel, the eleration was a little less than that immediately back of Duluth, but the rest of the table as given in his work, but not quoted here, shows that at a short distance northeast of that point the altitude is 1,300 to 1,400 feet above the sea. And, as Owen asserts in his Geological Survey of Wis. consin, Iowa, and Minnesota, the bordering rim of the immediate Lake Superior Busin increases in height toward the northeast.

A second fact we learn from this list is that the slope of the Winnipeg Basin along this line is tolerably rapid toward the northwest, reach. ing at Lake Winnipeg a level only 28 feet above that of Lake Superior. It shows also that Rainy Lake is fully 600 feet lower than the extreme source of the Mississippi and the Lake of the Woods 700 feet lower.

The elevation of Red Lake may have been ascertained, but if it bas $I$ have been unable to find the record; yet I think we have good reason to infer that it is less than that given for the source of the Mississippi. It is drained into Red River at a point where the elevation is only about 850 feet above the sea; the length of Red Lake River, by which its waters are carried off, is probably not more than one bundred miles, twenty-flve or thirty of which are through the remarkably flat valley of Red River, and, so far as I can learn, the rest is without any con. siderable falls. I allude thus particularly to the elevation of this lake as it will assist us in determining the height of the rim of the Missis. sippi Basin on the northwest, and the cliaracter of the descent to the Red River Basin in that direction. By bringing together these facts we are enabled to form a tolerably correct idea of the configuration and elevation of the northern, northeastern, and northwestern boundary of the platean of the Upper Mississippi Basin.

The line of the Baint Pani and Pacific Railroad to Breckenridge, althongh presenting a less rapid ascent while passing throngh the timber-strip-some fifty miles in width-reaches an average of 1,100 feet above the sea when we arrive at the prairie-belt which forms the divide; but when we arrive at Breckenridge, near the head of Red River, we bave again descended to 953 feet above the sea and are only 50 feet higher than at Moorehead. If, instead of following the railroad-line, we move. up the valley of the Minnesota River to its sonrce in Big Stone Lake, cross over to Lake Traverse, and pass northward down Stone Lake, cross over to Lake Traverse, and pass northward down
Red River, we flnd a very remarkable channel, which reaches at no point an elevation of more than 960 or 970 feet above the sea-level, or abont 280 or 290 above the Mississippi at Saint Panl. This immense furrow, connecting the drainage of Hudsoh Bay with that of the Gulf of Mexico, reaching at no point an elevation of 1,000 feet above the sea, possesses great interest in the study of the physical geography and surface-geology of the Northwest. Here, in all probability, will be found the key to the last act in the great geological drama of this seetion, and here undonbtedly will be found the last traces of the uniou of the arctic and tropic oceans across the bosom of the continent. It was bere the waves of these two great seas gave tieir parting kiss before their long separation. But it is not $m y$ intention to dwell on this iuteresting topie; this is the work of the geologist who delights to dwell in the fading scenes of the far distant past. My business is with the present features, and the object $I$ bave now in view is the dull and prosy one of conveying an idea of the topography of the region drained by the headwaters of the great father of waters, our own noble Mississippi.

It is evident, therefore, from what has been said and from the lists of elevations given, that these waters are gathered from a moderately ele. vated and segregated platean, whose border, starting from the vicinity of I ake Superior, sweeps around northwest until it approaches the valley of Red River, attaining its maximum altitude in the direction of Red Lake; thence bending south it fades away in the rolling proiries as it approaches the channel of the Minuesota River. Rising from 300 to 1,000 feet above the surrounding regions it slopes southward and from the east and west sides, especially the latter, inwardly toward the cen. tral chanuel.

As before remarked, in traveling westward from Lake Superior to the Missouri River, although we may, as a general rule, find a very great uniformit $/$ in altitude, we shall, on the other hand, find very strong con. trasts in regard to the character and covering of the surface, and also marked elimatic differences. Leaving the last nntil the subject of elimate is introduced, I will call attention here to the other differences whlch are important items in making up our estimate of the agricultural resources.

This basin, as a whole, differs very materially from the regions farther west in the fact that the larger portion is covered with forests, the western and more elevated portions alone consisting of prairies. The ninety-fifth meridian corresponds very nearly with the division between the two portions, although there are west of this line some scattering oak-groves, and immediately east of it a few isolated prairies of smail extent. The entire portion of the State east and northeast of the Mississippi and for a short disiance west of it, north of Saint Panl, is covered almost entirely with pine and tamarack forests. And within this pine-covered area is found another very marked distinction from the section west of Red River. And I call special attention to these differences between Minnesota and Dakota, for the reason that, when we come to exarnine the elimate, especially the raiu.fall, we shall find a difference 
scarcely to be expected. The northeastern part of the State may be characterized as the region of swamps and bogs. A strip of some fif characterized as miles in width around the western end of the lake-wbich teen or twenty miles in width around the weff-and which is rapidly as is required to reach the snmmit or the blan cond is well drained cending and mostly rugged, as a matter of course is well drained; but as soou as we pass beyond this limit we enter upon a succes ion of bogs and swamps separated by low ridges a few feet in height, which continne until we come near to the Mississippi, and are, in fact, repeated for a short distance west of it at some points. These ridges, which apear to be composed entirely of drift-material similar in character und appear to be composed entirely of drif- rocks, seem to have a genera color to the underlying or neighboring rocks, seem to have a generl. ism of even these small swells between the boggy flats is but a repetiism of even these small swells between the boggy flats is but a repetition on a small scale of a remarkable feature of this part of the Northwivers. Owen calls special attention to it in his report on the geology of this region as follows, (chapter iv, p. 333 :) As what I conceive to have beea great valleys in the rocky strata of large portions
of Wisconsin and Mlinnesota have been filled up, and the country, in a great measnre, leveled by the accumulation of inmene deposits of drin, it is not possible to deternibe, with anything like aceuracy, the withli of the original valteys, bor the exact hines the anticlinal axis separating them but the datances rs the linear surveys of that another may be ascertained now, with as much precision as the ningred portion region, together with the dra gh the geological corps, will permit. Thus, from the of the Territory, by menibers of the geological corps, wint to that of the Upper Saint valley of Chippewa river, at the mouth of the course of the valleys, $i$, about nixty miles; and from the valley of the Saint Croix to that in which the Mlissinsippi flown, between the outlet of Sandy Lake and the month of Crow Wing River, in the same direction across the strike of the valleys, is about sixty-two miles; and from this portion of the valloy of the Mlississippi to the next parallel valley - in which Leech Lake is situated-is about finy miles; and from the valley of Leech Lake to the next great parallel valley northwest of it-the one in which ked Lake lics in about sixty-iggt miles; stowing a remarkable degree of wiformity in the undulations of the crus: of the earth thronghout a very extensive region of cosntry. three great systems of valleys in the Northwest, fesides unmerons anborilinate onen the ralleys of each system preserving a very nuiform antielinal axes.

He then proceeds to enumerate the various valleys of these systems by the names of the rirers occupsing them, showing this parallelism to to the larer valleys and prevail to such an extent, not only in prevain to such ater-conrses and valless, as to make it evident that it arises from some law connected with the geologieal forces and structure. He gives it as his opinion that the great structural features of the conntry are due to subterranea movements, acting at different periols on an immense extent of the movements, acting at with arent uniformity dnring each epoch, and not crust of the earth and with great inifority dinger to local disturbances only or to mere alterations of the surface from glacial or diluvial action, however much these agencies may have altered the face of the country.

This may be, and doubtless is, true in regard to the direction of the larger divices and valless, but it will scarcely appls to the small ridges larker divicles which separate the bogs alor smeller parallel ridges of Dakota and Nebraska. Water alone, or water and wind were certainly the forces that formed these; per

action may have played a part in originally outlining them.

Leaving the northeastern part of the State andary of the basin, we across the surface. covering. The pines with their dark.green foliage and the gloomy tanarack mradnally disappear, and for some distance tre pass throngh groves of deciduons trees, chiefly oak, with some intermixture of elm and ash. About the vinety-fifth meridian we emerge npon the open, rolling prairies; yet for some distance the ron uded billocks are often covered with open groves of oak, and the little intervening basins are occupied by elear, limpid lakes, presenting a charming landscape. Here perhaps will be fonnd some of the most beantiful spots in the Stateand by "here" I intend that strip running from Red Lake south, inclnd. ing Becker and Otter Tail counties aud following the divide between the basins-the green, grassy sward covering the gently-rounded knolls and gradual slopes and carpeting the surface amid the open oalk-groves, where the trees appear as regularly distanced as though they bad been planted by the hand of man. At the foot of almost every slope is a beautiful, elear lakelet, filled with finny tribes. We could searcely imggiuc a scene more charming.

It is a singular fact that the entire surface of this western prairie. divide, which separates the Upper Mississippi Basin from the valley of Red River and from the upper part of Minnzsota River Valley, is dotted with innumerable lakes of suall size, many of which are withont any visible ontlets. If we examine a good, late map of the State, made on a seale of sufficient size, we shall find an immense circlet of these lakes extending from Saint Paul northwest and then north and northeast, to the sonrce of the Mississippi, following, as a general rule, the more elevated portion $;$ of the country and the divides between the streams; it is said tiat not less than ten thousand of these lakes are to be fonnd in the State. Why are these found so generally on the divides and the higher gronnd 9 What connection is there between the two ? These are interesting questions, to which I mas hereafter recur either in this or a future report, for it is evident that the existence of these lakes in this position has an importunt bearing upon the hygrometric condition of the atmos. phere and the amount of the rain-fali in this portion of the country.

Continuing onr course westward along the same line upon which we originally started, ve next pass down a gentle slope of some 400 feet descent into the broad valley of Red River. This valley, or rather plain, for such it really is, extends northward from Lake Traverse to lake Winnipeg, having an average width of thirty or thirty-five miles, one uniform level scarcely interrupted by a swell or depression, save the chanuels cut by the tributaries, which enter almost at regular intervals. There is perhaps no place on the continent that so fully meets our idea of " flat" or "dead-level" country as this valley. Professor Oren las truly remarked that " nothing, however, but personal observation can trily remarked that " nothing, liowerer, but personal obsul plain. The line of tie horizon is so perfectly straight that it might plain. The line of tie horizon is so perfectly straight that it might
serve the purpose of astronomical observation for determining the altitude of the heavenly bodies. While standing on this great savanna, ctraining my eses in quest of some object more prominent than a blade of grass, it occurred to me that there is probably no spot on the globe more suitable than this on which to measure a degree of latitude." It is only personal observation that can couvey to the mind the effect of this singular feature; even the gentle slopes, which border it, appear in the distauce as abrupt Llufis when we gaze at them across this level surface.

The Saint Paul and Pacific Railrond, which runs diagonally across it for forty miles, during this distance is withont a curve, a flli, or a ent, save what is necessary to remove the sod. It is one immense meadow 
of tall, waving grass, interrupted every twelve or fifteen miles by a narrow fringe of trees, chiefly oak, that lines the bank of some tributary which flows into it from the east or west. The descent of the strean northward, connting along a direct line, is abont one foot to the mile, but if we follow its windings the fall will be less than this amount.

Passing westward beyond this valley we observe a very distinet change in the scenery. Here the treeless plains spread out before us in long, rolling swells, in that peculiar and somewhat semi-gloomy grandeur which belongs alone to the great trans-Mississippi plains, of which this is a part. The surface gradually ascends and becomes more undulating, broken into long, low, rounded ridges, smooth, grassy knolls and hil. locks, furrowed here and there by the narrow, deep cañon-like valley of some siream, or by a dry couléc, which marks the pathway of some ancient creek or river. Instead of the forests of the eastern basin, or the tall, waving grass of Red River Valley, we now see the low, pale. green swarl, or, as we move farther into the interior, the short bunch. grass, which formed the favorite fool of the immense herds of bufluloes and antelopes that once roamed over these plains. Here and there we see a lake amid the somewhat barren surroundings, but the white in. crustations on the bowlders which line its shores tell us too,truly, what our taste confirms, that its waters are brackish, mostly unfit for the use of man or beast; a few fresh-water lakes are found, but these are rare. Another feature, which causes us to have doubtiul forebodings of the distant future, is the frequency of what are significantly termed "dry lakes." These are the dry aud parched basins where but a compara. tively few years past lakes existed, not in the distant geological past, but in several instances within the memory of those now living. The surface of the country between the valley of Red River, on the east, and Missouri River, on the west, may be described, in general terms, as consisting of high, rolling prairies, intersected by the valleys of a fers streams which run south. But this general contonr is interrupted by two elevated plateaus, which staud high above the general level as monuments reared by the vast aquatic forces of the past, as if to give us some iclea of their stupendous power. The smaller of these elevated plains, the Coteau des Prairies, extends froun a point abont forty miles west of the north end of Lake Traverse, lacitude $46^{\circ}$ and longitnde

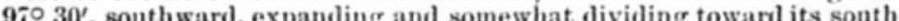
gro close upon James River Valley, about latitude $44^{\circ} 15^{\prime}$, where it euds; the other arm reaches southesst, passing down on the east side of the head-waters of Big Sioux, and gradually fades ont in the sontlwext corner of Minuesota. The elevation of its surfice averages nearly 2,000 feet above the level of the sea, varying from 1,860 feet to 2,046 feet, showing a rise above the plains east of it of about 800 feet aud above the valley west of it of 700 feet.

The other plateau is the Cotean of the Missonri. This hugs the ralley and follows the cuarse of the Missouri northward from Fort Sally to the great beud of the river near the mouth of the Yellowstone. Here it recedes and extents in a northwest direction into British Possessions, where it graulually fades out and is lost. It varies in width from thirty to fifty miles and in height from 1,800 to 2,200 feet above the sen; but the surface is more irregular than that of the other coteau, portions of it rising as much as 200 feet above the general average. The general elevation corresponds very closely with that of the Cotean des Prairies, showing very clearly some relation between the origin of the two. On each are numerous small lakes, mostly impregnated more or less with saline matter, and at many points on each bowlders are quite plenty. So much so is this the case with the Cotean of the Missous thit So Skinner remarks, in regard to the section where his line crossed it, that "it is very stony." This elevated plain will furnish us with the explun ation of the great bend of the Missouri in the northwest part of explan. and its clirection sontheast from that point.

and its lirection sontheast from that point.
Pembina Mountain, which is situated within the belt now

Pembina Mountain, which is situated within the belt now under con. sideration, and near the international br undary.line, is nothing more than an elevated plateau, similar in charac cer to those already described,

I may remark here that the country nurthward, even as far as the Saskatchewan, along this meridional belt, preserves about the same character that we see exhibited in Dakota. I was at first nnder the inpression that when we entered the valley of the Assiniboine we wonld find a section supplied with more moisture and renker vegetation than further south, but from information received from persons who bave loug lived in that region I am satisfied it is but a repetition of the type we see along the northern borler of Dakota.

Recurring again to the vertical topography, I wonld call attention to the fact that after we leave the valleys of Red and Minnesota Rivers wo notice a gradual westward ascent, and in order to obtain a correct idea of these slopes I estimate by the lowest water-levels, whenever these can be obtained, and where they are wanting I use the lowest landlevels, or such as represent the average elevations of extensive plains or valless. Following this rule we find that the ascent along the porth ern Pacific Railroad, west from Red River to the ascent along the North. a little over 4 feet to the mile. From Lake Traverse to the Missouri

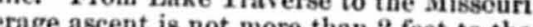
mile, and from the bend of Mlinnesota Piver to the Missoni, at the month of Big Sioux, it is not more than 1 feet to the mile; but in this case the land ascent, nntil we reach Le Mars, is about 2 feet to the mile.

The plains immediately east of Cheyenue River, and between it and James River, and west of the latter to the Cotean of the Missouri, have at average elevation of about 1,450 feet above the sea, and from 90 to 150 feet above the streams which traverse this region.

Devil's Lake appears to be situated on a platean or swell forming the divide between the Cheyenne River and the northern tributaries of Red River.

It has an elevation of 1,467 feet above the sea, or about 100 or 150 Be Birer at the point immedintely 150 site. But it is a general rule, as I have before stated, that the lakes in the prairie-portion of the Northwest aro situated on the divides between the streams. Lake Eekelson, on the line of the Northeru Pacitic, between Cheyenue and Jatnes Rivers, has an elevation of 1,418 feet above the sea-very nearly the same as Devil's Lake-188 feet above Chey. enne River, and 25 feet above James River

The leading ridges and land-swells, so far as my observations in the southern and northern part of the Territory have extended, appear to run nearly north and south, the direction being slightly west of north and east of south. But, as will be scen by reference to wap of the country, this corresponds with the scen by reference to a map of the country, this corresponds with the general direction of the streams;
and, as the drainage is southward from latitude $4 S^{\circ}$, we may infer that
there is a gradual descent south ward as well as eastward there is a gradual descent south ward as well as eastward. No sufficient data have yet been obtained for determining accurately the rate of this descent to the sonth, set we may approximate to it from the following items: James River, at the crossing of the Northern Pacific, (latitude 
$46^{\circ} 52^{\prime}$, ) is 1,393 feet above the sea, and at the point where Mr. Skinner's line crossed it-abont latitude $45^{\circ} 28^{\prime}-$ it is 1,267 feet above the sea. This would give an average descent along this valles of a little less than 1 foot to the mile. Missouri River, at Fort Union, has an eleless than 1 foot to the mile. Missouri River, at Fort Union, has an ele-
vation of 1,970 feet; at the mouth of Heart River, 1,700 feet, and at Fort Sully, 1,398 feet. Using these figures and calculating the distance moved directly south, we find the descent to be about 2 feet to the mile, or 140 feet to the degree of latitude. These figures would indicate that the elevation of the river at Yankton is abont 1,050 feet above the sea; but this estimate is probably a little too low, as the rate of descent doubtless decreases as we move eastward and probably as we move southward; 1,130 feet would likely be nearer the correct figure.

Another point in regard to the level of these leading streams worthy of cousideration is the difference between them at the same latitade. At latitude $46^{\circ} 50^{\prime}$ the Missouri is 1,700 feet above the sea; the James, 1,393; and Red River, 900. At latitude $45^{\circ} 30^{\prime}$ the Missouri is (about) 1,510 , while James River is but 1,260 ; yet the difference in longitude between the two is about the same at this lower point that it was at the uppe, each having moved eastward, in this distance, about half a degree.

Passing west of the Missonri we have only to look at the map to learn the clirection of the descent, all the tributaries which flow into it below the Little Missouri, as has before been stated, having an almost directly eastern course; but sufficient data have not been obtained to give the vertical topography of this western section.

If we enlarge our area, and include all nort's of Kansas River and west of the Mississippi as far as the one hundred and first meridian, aud compare the elevations of points corresponding in longitude along the different lines running west from the Mississippi, we will obtain a pretty correct idea of the topography of the Northwest, as estimated from the correct idea of the topography of the Northwest, as estimated from the
lower or water levels. It is true that this will not enable ns to form any idea of the higher intermediate points or the surface-contour, but know. ing, as we do, that there are no elevated ridges, no p:ominent peaks or rugged portions, the general slopes form the most important topograph. jeal feature.

First. Along the line of the Northern Pacific Railroad, which corre. sponds very nearly with the forty-seventh parallel of latitude: the Mis. sissippi at Brainard, 1.205; Red River at Moorhead, 903; James River at the crossing, 1,393; and the Missouri, at the mouth of Heart River, 1,700 feet above the level of the sea.

Secondly. Along a liue running from Saint Paul, by way of Lake Trav. erse to Fort Sully, which, though bending considerably, we may consider as corresponding with the forty fifth parallel of latitude: the Missis. sippi at Saint Paul, 680 ; Lake Traverse, 960 ; James River, at the point where Mi. Skinner crossed it, 1,260; Missouri River, at Fort Sully, 1,398 .

Thirdly. Along a line from Davenport, by way of Omaha and the Union Pacific Railroad, corresponding very nearly with the forty-first parallel: the Mississippi, at Davenport, 528; the Missouri, at Omaha, 966; Lone Tree, on the line of the Union Pacific, 1,686; aud North Platte Station, on the same line, 2,789 .

Fourtlly. On a liue running from Saint Lonis westward along the Kansas Pacific Railroad, and corresponding with the thirty-ninth parallel the Mississippi, at Saint Louis, 375 ; State-line, at the mouth of Kansas River, 648; Fort Harker, on the Kansas Pacific, 1,484; and Buffalo, on the same line, 2,678 .
The following data may be added as correspending with the forty. third parallel : the Mississippi, at Dubuque, 580 ; the Missouri, at Sioux City, 1,093.

By seleeting in succession the corresponding elevation fron these different lines, we will obtain the vertical topography along four different meridians, beginning in each case at the north and running south, one or two additional numbers being introduced where it is possible to extend the line.

The line of the Mississippi.-Rainy Lake, 1,035 ; the divide between the Rainy Lake and Mississippi Basins, (about) 1,700; Leech Lake, 1,330; Brainatd, 1,205 ; Saint Paul, 680; Dubuque, 58v; Davenport, 5.8; Saint Louis, 375 .

Along a line corresponding very nearly with the ninety-sixth meridian.Pembina, 790 ; Moorhead, 903 ; Lake Traverse, 966 ; Sioux City, 1,093; Omah:t, 966 ; mouth of Kansas River, 648.

Along or near the nincty.eighth meridian.-Devil's Lake, 1,467; James River, at the North Pacifie crossing, 1,393; same river, at Skinner's cross. ing, 1,260; the Missouri, at Yankton, (about) 1,130; Lone Tree, on the Union Pacific road, 1,636; Fort Harker, on the Kansas Pacifie road, 1,484 .

Along or near the one hundred and first meridian.-The Missouri, at the mouth of Heart River, 1,700; the same river, at Fort Sully, 1,398; North Platte station, on the Union Pacific road, 2,789; Buffalo station, on the Kansas Pacific road, 2,678.

It is apparent from these fignres that the plain or platean from which the Upper Mississippi gathers its waters is elevated considerably above the region north and northwest of it, and that it is separated from the western plains of Dakota and Sonthwectern Minuesota by the much lower valleys of Red and Minnesota Rivers.

In passing south along the ninety-sixth meridian, which corresponds very nearly with the line of Red River, after passing Lake Traverse, we do not again descend to the sane level until we reach Omaha, on the Missouri River, showing that the waters of the Big Sioux are gathered from a plain elevated considerably above the level of Lake Traverse. It is therefore evident, as heretofore stated, that there is a broad and somewhat elevated swell extending southeast from the Cotean des Prairies, which, though spresuding out into broad and apparently level prairies, continues for a considerable distance into Northwestern Iowa. Another, and perbaps the most important, fact, learned from the fig ures along these north and south lines is that the plains of Nebrask: and Kausas, after we have passed a short distance into the interior, are more elevated, and more rapidly asceuding (westward) than any portion of Dakota east or northeast of the Missouri; in other words, that as we move northward-say, for example, along the one hundred and first meridian-we descend, and this descent continues far into the British Possexsions; not that it is by any means uniform, but that as we pass from one plain to another, or from one basin to another, we descend, as a general rule.

\section{MINNESOTA.}

As before indicated, this State consists of two districts differing widely in regard to the covering and character of the surface, and also with respect to their agricultural resources. The northeastern portion, embracing probably one-third of the entire area, being covered almost entirely with coniferous forests, is partially interrupted by bogs and 
marshes. When the land in this part of the State has been denuded somewhat of its forest-covering, and shall be urgently demanded for agricultural purposes, a large portion of this marshy section may, and probably will, be rendered suitable for tillage by an extensive system of drainage; but this, to be successful, will require a large expenditure of labor and money, and will only be done when it shall have been deprived of its valnable covering of timber and after the more inviting agricul. tural regions to the west shall have been fully occupied. Notwithstand. ing the somewhat forbidding aspect of this section to the eye of the farmer who is seeking a home in the West, yet it is not impossible that the day may come when this, having been thoroughly drained, will be considered the richest agricultural portion of the State; such, at least, is the opinion of some, even among those who have no personal interest in the matter. Its chief value now is its timber; but this is by no means a small item, the lumbering interest being one of the most important of the State. The sections drained by the head-waters of the Mississippi and Saint Croix, as well as the regions bordering Lake Snperior, are clothed with immense forests, chiefly of pine. Although the timber of these forests is very valuable, it must not be supposed that the whole of this area is uniformly covered with timber that is valuable. As a gen. eral rule, so far as my observatious and information extend, the swamps and marshes are generally cosered by tamarack, of but little valne for any other purpose than fuel or fencing, and wholly unfit for lumber. The pine, as a general rule, is confined to the intervening low ridges and swells in the marshy sections, the more broken areas around the lake, and the lighter, sandy soils of the valleys of the streams.

On the west side of the Mississippi there is a tolerably broad and lengthy belt of timber, extending from Crow Wing River sonthward to within some sixty or seventy.five miles of the sonthern boundary of the State, consisting of deciduous trees, chiefly oak and elm, with an istermixture of ash and maple. This forest-strip covers one of the richest bodies of laud in the State, the soil being a dark, rich loam, heavil mixed with regetable mold, and reminding one much of the richest bottoms in the State of Missouri. This belt of timber is called the "Big Woods," and is about one hundred miles in length and forty miles wide.

The following statement of the lumbering operutions for 1869 and 1870 will give some idea of the extent of this business in Minnesota, to which if we add that of Wisconsin, (which is probably equal in amount to that of Minnesota,) we will be able to arrive at an approximate estimate of the lumber interests west of Lake Michigan:

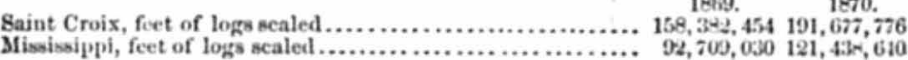

Total of these two districts..................... $251,091,484 \overline{313,116,416}$ Of the total leg-erop of 1870 , there were sent to market unmanufactured,

Sent to market as rnanufactured lumber, feot. $\overline{175,935,985}$

The western and southwestern portion of the State, as heretofore stated, consixts almost wholly of undulating prairies, until we reach the flat and broad valley of Red River.

In order to convey as correct an idea as possible of the northern and western portions of the State, (I omit the southeastern portion, as it is so well kuown that any description of it is wholly unnecessary,) so far as relates to the soil and agricultural resources, I cannot do better than insert the notes taken while passing along the leading railroad-lines. And, first, I insert the fow notes taken along the line from Saint Paul to Duluth.

For several miles out of Saint Paul until after we have passed a short distance beyond White Bear Lake, tbs conntry is rolling and slightly broken, and, where not in cultivation, is covered with onk-groves, mostly bushes near the city, but increasing in size after we have advanced some distance into the country. The surface of the conntry here appears to be knotted and pitted, thus affording basins for the numerons little lakes found in the northern part of this (Ramsey) county, and in fact over a considerable area in this part of the State. After passing White Bear Lake a slight change commences; the conifers begin to appear, especially in the low and swampy spots; the surface becomes more level, and the aspen (Populus tremuloides) appears in frequent groves, its white bark forming a strong contrast with the dark pines. About North Branch the country is quite level, and is covered with a pretty heavy growth of oak, which at a distance resembles the post-oak, (Q. obtusiloba.) The soil here also is very good, having a better appearance than that previonsly passed over. Minch of the surface be. tween Wyoming Station and this point is marshy, but we should bear in mind the fact that the past season, when I visited this section, was more than usually wet. From North Branch to Rush City the surface is level and rather wet, the soil rich, and the timber heavy, consisting chiefly of oak, elm, maple, and ash. Occasionally a hickory and butternut are seen, but these are rare. Conifers, in the swamps, are chiefly tamarack or black larch, (Larix Americana,) balsam-fir, (Abies Bal. samea,) \&c.

From Pine City, on Snake River, northward, the pine-forests prevail, and the surface of the country is more or less damp and swampy. At Kettle River we begin to meet with the low, rounded drift-ridges, the soil consisting of a reddish sandy clay, intermixed with small red bowl. ders; in many places the sand appears to be the chief ingredient. At this point, and also at several points along the Northern Pacific, we met with the wild strawberry in fruit, (July 3-10.)

As we approached the junction with the Northern Pacifie we were met by a cold northern mist, that compelled us to draw on our overcoats and made fire very comfortable. From bere to Duluth we descend the rugged bluff that surrounds Lake Superior; in going twenty miles we make a descent of nearly 600 feet. The dark waters of Saint Louis River rush down to our right over the ragged rocks with a deafening roar, plunging and dashing themselves into foam as they leap from ledge to ledge or drive through the narrow rugged gorges, presenting a scene of wildness and grandeur. Whether it will ever be utilized or not is more than I can say, yet it is true that here is an immense water-power.

It is scarcely within the scope of my duties to speak of the prospects of any town or eity in a commercial point of view, but as Duluth is destined to be the chief port of the western end of Lake Superior, and as a matter of course the principal shipping-point of Minnesota, so far as lake-transit is concerned, a few remarks in regard to it may not be out of place here.

Althongh it will labor nuder some material disadvantages, yet it is destined to make a place of considerable importance. Its disadvantages are as follows: The climate can by no means be called a favorable one, although what I saw could searcely be taken as a fair sample of summer weather. The winters, as I understand by those who have visited 
this point in search of health, are by no means as harsh and severe as we might suppose; but the spring is unpleasant, and the weather during this part of the year disagreeable. The second disadvantage is the fact that it cannot be said to have any'surrounding farming land to give it a loeal trade depending on agriculture. Thirdly, the shipping-season is short, closing rather too early to allow time to gather in the crops from the distant sections, where they are somewhat late.

Its advantages in part are as follows: It is the extreme western lake. point of the Northwest, which is a very important item; it is the nearest point of water-communication with the ocean for a very large area of country, viz, Minnesota, Dakota, and the grain-districts of British America northwest of the lakes; it has most excellent water-power elose at hand, in the Saint Lonis River; being the only important lake-port of Minnesota, it must necessarily have the influence and sympathy of that rapidly-growing State; and, finally, it is the eastern terminus of the great northern Trans-Continental kailway, which must make it an im. portant point. These are important advantages, which must, in spite of the disadvantages under which it labors, ultimately make a city of considerable size, and, so long as this line of road controls the trade of Manitoba and other portions of Western British America, give it an international character.

The following notes relate to the country along the Northern Pacific line:

After leaving the junction, as we move westward, we enter a long streteh of marshy lands, covered chiefly by forests of pine and tamarack, and this continnes, with but little variation, until we reach $A i k e n$. Here we notice a change in the surface and character of the land; the soil also shows a variation from that eastward. The surface becomes slightly undulating, the sub soil more sandy and mixed with gravel; oak also begins to make its appearance; and although there is occasion. ally a swamp, yet the country westward from here to Brainard may be fairly elassed as agricultural. The timber between these points is chiefly pine; yet there is a slight intermixture of oak, elm, and aspen, and oceasionally an ash. A short distance before reaching Brainard we enter upon a sandy level, which continues to the Mississippi, and is repeated for some distance on the west side. The soil here, notwith. standing its sandy character, is rich and productive, and will doubtless produce heavy crops of cereals. The Mississippi cuts its way throngh this level in a deep channel like a large canal, without low bottoms. After crossing to the west side we pass for some distance over a sandy level covered with an open pine-forest; in a few miles the soil gradually changes to a darker hue, and we oceasionally meet with wet and marshy spots, in which the ominous tamarack makes its appearance. Occasional broad low ridges now begin to be seen, elothed with deciduous trees, chiefly oak, elm, ash, and bass-wood; the soil is good, and, with the ex. ception of a few points, will make excellent farming lands. After leav. ing the sandy region the soil is mixed with clay and gravel. A short distance east of Wadena the surface becomes slightly undulating and somewhat destitute of timber, being partially covered with oak-bushes, which fade out as we enter upon the prairie-region; the surface-soil is quite rich.

From Leaf River westward, for some fifteen or twenty miles, we pass throngh a section alternating with low, broad ridges, and wet, narrow bottoms or "slashes," the ridges being composed almost wbolly of gravel, though the surface-soil is a rich mold, and mostly eovered with mixed timber, including an occasional large pine; but this tree is now mapidly disappearing as we move restward. As we approach Hobart Station we enter upon a beautiful undulating prairie, with a dark, rich surface-soil, but I noticed here that it is underlaid with a heavy gravel. deposit, which even a single furrow of the plow exposes to view. As we move on the surface becomes slightly more rolling, not broken, but gracefully rounded into hillocks, ridges, and valleys, with bere and there groves of oaks on the hillocks and along the bauks of the streams. We are now in that section which $I$ have beretofore spoken of as being the prettiest portion of the State, a description of which need not be repeated here. This beantiful undulating prairie-belt, with its green sward, occasional oak groves, (but these gradually disappear after we pass Detroit Lake,) and numerons clear lakelets continue until we begin to descend the divide into the valley of Red River. The soil is a rich dark loam; the subsoil appears to be composed generally of gravel and elay, with a marls appearance, mixed with bowlders, the former decreas. ing and the latter increasing - in proportion-as we move westward. The bowlders are mostly gray or red granite, though some of other rocks were seen.

I may remark, in passing, that I noticed the cuts through this hilly portion very carefully, to see if there was any evidence of stratified rocks or rocks of any kind in position; but no sign of such rocks were seen. At some points there are large accumulations of bowlders, but all these hills and the eutire surface-material for a considerable depth are evidently drift.

The descent to the valley of Red River is very gradual along the line of the road, but from the valley it is very apparent, risiug up in the form of a sloping bluff. It is unnecessary to repent the description of this valley; the surface-soil is black muck some 4 to 6 feet deep, the first 2 feet being filled with a matted mass of grass-roots; the subsoil, as will be seen from the following record of the boring for an $\Delta$ rtesian well at Fargo, is blue clay, which is very tenacious. The margins of the streams in this valley are lined with a narrow strip of timber, chiefly oak, with some elm.

The following is the record of the boring of the Artesian well at Fargo, so far as it had penetrated at the time I last visited that point, (September 3, 1872 :)

Soil

White and yellow (or drab) clay

Fine dark clay

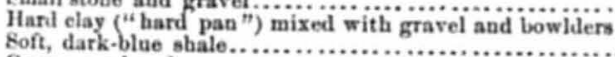
Coarse sand-rock.

After piercing the sand.rock water rose to within some 10 or 12 feet of the surface, with an apparently good supply. The depth of the well at that time was 262 feet, and the boring had stopped with little pros. peet then of being continued, as Mr. Barker, superintendent of the work, thought it useless to go farther, it being his opinion that the next rock will be the igueous or metamorphic. As will be seen from this, one drawback in this rich valley is the difficulty of obtaining a supply of water.

The next line passed over in Minnesota was that leading from Saint Paul to Breckenridge-a braneh of the Saint Panl and Pacific-a distance of two hundred and seventeen miles. The following is an abstract of the notes taken at the time I passed over this road: 
From Saint Paul to Lake Minnetonka the land is rolling and somewhat broken and sparsely covered with small oaks. There are here, as on the east side, a number of small lakes, but I noticed several small basins which appear to have contained formerly small lakes, but which are now only empty basins. After we pass this point the country is less billy, though still slightly rolling; the soil is generally rich and quite fertile; the forests are heavy, and timber large, chiefly oak, elm, and ash, with some unple and aspen. Of the oak there are two or three species, among which I noticed what I supposed to be the burr-oak or over-eup ( $Q$. macrocarpa) and the scarlet oak, ( $Q$. coccinea;) but I may have been mis. taken as to the species. As I have heretoforo remarked, this timbersection has a very dark, rich soil, very little of it being interrupted by swamps or to wet for eultivation. I noticed here both white and red clover growing luxuriantly. The few swampy flats seen were generally clothed with the gloomy tamarack. These characteristies continue until we come near to Darwin, where we enter npon a somewhat open country, having a prairie-like appearance, though we have not yet emerged upon the true prairies. The surface-soil is still dark and rich, and the surface slightly undulating, but the subsoil where exposed begins to show a heavy intermixture of gravel. At Darwin, or rather a short distance beyond it, we enter upon the prairies, though a considerable body of timber can still be seen to the north. The surface here is somewhat undulating, but less broken than at the corresponding point on the Northern Pacific line; there are also here scattered over the country numerous small lakes, indieating an approach to the divide between basins. The subsoil is still gravelly, but this character appears to be gradually disappearing as we move westward. When we reach Morris we enter upon a level plain, which continues without interruption to Red River; it is, in fact, an expansion of the valley of that river, and as far north and south as the eye can reach the same unvarying level is seen; and here for forty miles is a line of railroad as straiglit borizontally and rertieally as possible to make it, withont a ent or fill borizhntally and rertically as poil is me to make it, worthy of mentioning. The soil is much the same as at Glyndon, on the Northern Pacific; in fact, there is but little variation in the character of this valley its entire length. I am satistied that along the Saint Paul and Pacific Railroad nine-tenths of the land can be cultivated and will yield abuudant crops of such cereals as are adapted to the climate. And may be allowed to digress here for a moment to give an idea of the future prospects of this roal from the grain-trade.

Take the length in round numbers at two hundred miles and a strip twenty miles wide, giviag an area of four hundred square miles, or $2,560,000$ acres; deduct one-fifth as unfit for cultivation, and suppose one-balf of the remainder to be annually planted in wheat, $1,024,000$ acres, at 17 bushels to the acre, (the average yield in Minnesota, ames, allowing 400 bushels to the car, it wonld take 43,520 cars, or six trains per day of 24 cars to the train, ( 300 days in the year, to more this immense yield of but a twenty-mile strip of conntry. As a matter of conrse, it is not probable that this proportion of the las 1 will ever be cultivated in small grain, but certainly these figures do not overestimate its capability, and give us an idea of the bread-prolucing resources of this portion of the West. It is true the ratio assumed will not apply generally, but with a moderate deduction it will apply to the western balf of Minnesota, the greater portion of Iowa, a considerable area in Southeastern Dakota, and Eastern Nebraska.

I should have stated that at Morris, on this line, there is a flowing well of good water. The well was being dug for ordinary purposes, and

had reached a depth of about 30 feet, wben suddenly the water broke in upon the workmen, who escaped with difficulty. The water rose rapidly to the surface and has been flowing freely ever since that time. If we follow a line from Saint Paul to the southwest corner of the State we find the country somewhat similar to that toward Breckenridge. It is broken and timbered until we reach Crystal Lake, rather more so than toward the northwest. This strip of timber belongs to the Big Woods, and consists of deciduous trees, such as oak, elm, ash, \&c. After passing this point we enter upon a beantiful undulating prairiesection, devoid of timber, except the little strips along the banks of the streams, which continues to and beyond the southwestern border of the State. The soil is of an excellent quality, and the subsoil is generally more or less mixed with a kind of finely-comrninuted marl, though at some points it is composed in great part of clay. There are some small, clear lakes, but the surface is seldom marsby, the entire area as a gen. eral thing being susceptible of cultivation.

The following statistics, taken from the "Statistics of Minnesota for 1870 ," published by authority of the State, will give an idea of the amount and character of its agricultural products :

Crops or 1809 .

\begin{tabular}{|c|c|c|}
\hline Prodinct. & Acres cultivated. & Bushels produced. \\
\hline $\begin{array}{l}\text { Wheat } \\
\text { Oats } \\
\text { Corn } \\
\text { Jitley } \\
\text { Rye } \\
\text { Buckwheat } \\
\text { Potatoes } \ldots \\
\text { Beans } \ldots \ldots\end{array}$ & $\begin{array}{r}1,006,007 \\
278,407 \\
147,567 \\
35,201 \\
4,632 \\
3,023 \\
21,156 \\
1,910\end{array}$ & $\begin{array}{r}17,660,467 \\
10,510,969 \\
4,519,120 \\
938,466 \\
75,629 \\
51,025 \\
1,580,431 \\
29,002\end{array}$ \\
\hline
\end{tabular}

Sorghum, gallons ............ $35,144 \mid$ Cheese, pounds ............... 321,969

Sorghum, gallons Maple-sugar, ponnd Hotey, pounds. Hay, coltirated, tons. Hopo, pounds

Batter, pounds

Arerage yield of field-erope per acre.

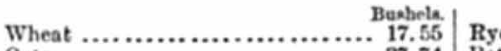

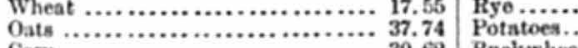

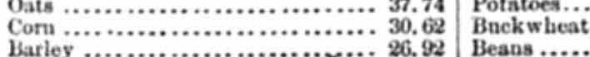

It is not probable that any considerable progress will be made in fruit. growing, as it is exident that the elimate is too rigorous for the profit able growing of any varieties except the most hardy small fruits, as strawberries, currants, gooseberries, \&c.

As before stated, the consideration of the climate is reserved ior a future report, which will be devoted to this subject.

DAKOTA.

This Territory has been so recently settled, except a small section in the sontheast corner, that but little can be said as to its agricultural prospects, save what we can infer from an inspection of its surfnce and 
soil, added to the slight knowledge we possess of its climate. And bere the last item becomes important in this estimate, as it is known that the line of sufficient rain-fall is found within its borders.

It possesses, probably, the smallest amount of timber of any State or Territory in the Union, the forests bearing a $\mathbf{r}^{n}$ io of not more than 3 to 5 per cent. to the entire area, and even this rucio is obtained by adding the amount supposed to be in that part of the Black Hills within its boundary.

With the exception of the west side of Red River Valley and the sur. face of the coteaus, the whole of that portion east of the Missour (which is the only part I shall allude to here) consists of elevated undulating prairies, very similar in character to the plains of the centra and western portions of Nebraska and Kansas. The streams, as a gen. era: thing, run through deep and narrow valleys, having but a small amount of water in them, and the fall being insufficient to carry the water upon the bordering uplands; hence, as a rule, in the northern and central portion, if the rain-full should prove insufticient for agrienltural purposes, there is but little hope of redeeming any portion by irrigation, except the narrow valleys which the streams traverse.

As a general rule the soil is good, and where there is a sufficiency of moisture there is no reason why good erops eannot be raised; but I have very strong doubts on this point, except for the southeast portion and a narrow belt along the eastern border.

The following notes, taken down while crossing from Fargo, on Red River, to James River, along the line of the Northern Pacific Railroad, will convey, I believe, a fair and correct idea of this section of the Ter. ritory, the fact being borne in mind that 1872 was a more than usually wet season.

For about eighteen or twenty miles the surface is very flat, being the west half of Red River Valley, and corresponding in appearance with that on the east side. The soil is also very similar to that on the east side, the only difference noted being that here, after leaving the river for a short distance, it becomes more or less impregnated with alkali, which is quite apparent where the sod has been turned or a cut made; yet I do not think this is sufficient in quantity to injure any of the ordi nary crops, for I have learned from iny observations in Colorado and Utah to look upon the presence of a moderate quantity of alkali in the soil with much less serious apprehensions than formerly.

Passing westward beyond the valley we gradually rise to an undnlating priirie, which becomes more rolling aud slightly broken until we reach the second crossing of Chejenne River. Although this section is evidently drier and not so rich as the Red River. Valley, yet I thiuk ex periment will show that it is tolerably good agricultural land and that the amount of moisture is sufficient for ordinary crops. But already this tronblesome question makes its appearance; already we see the grasu growing much suorter and beginuing to assume that peenliar character so well known on the western plains. Still I think this strip as far as the second crossing of the Cheyenne may be properly elassed with the lands suitable for farming purposes. The valley of the Cheyenne is quite narrow, affording but a small amount of tillable land and a very narrow strip of timber. After passing this valley there is a con siderable rise before reaching the general prairie-level beyond. I notice here, where the milroad cuts have exposed the subsoil, that it is chiet here, where the I might say entirely, compact drab clay, of considerable depth. The surface of the country on the west side is undulating, dotted here and there with lakes, most of which are strongly alkaline or saline, their peb. bly shores being frosted over with the alkaline deposit. Lake Eekelson, which is some six or eight miles long, and from one-fourth of a mile to one mile wide, is the largest in this immediate section; its waters are brackish, apparently more saline than alkaline.

Here we also meet with a phenomenon which leaves a very unfarora. ble impression upon the mind in regard to the climate in this section. I allude to what are called " dry lakes," the dry basins where lakes formerly existed, but which have in a few years past dried up from some cause not yet fully explained. As I have before stated, the fact should be borne in mind that 1872 - the time of my visit to this region-was unusually wet. I mean by this expression simply to state that the amount of rain which fell during the spring and summer was more than the average amount.

Not only did I find these dry lakes entirely deroid of water, but the snrface of the sediment which had been deposited by the water was dry and powdery and strongly alkaline. Even the lakes which contain water appear to be getting lower and lower, if we judge by the waterlines along the shores. And this calls to mind another fact bearing upon the condition of the climate, indicated by the facts stated, and that is that all through this section of country I noticed numerous evidences of former swampy spots where the grass still -is more lnxuriant than that surrounding it, but the water has disappeared from the surface. For some time I supposed that these were points where water accumu. lated and remained longest in the spring of the year; although this explanation will suffice for the condition of many, yet there are some things connected therewith which I can only explain by the supposition that they are gradually growing drier.

After passing Lake Eckeison the surface oi the conntry, althongh gradually ascending, is tolerable lerel until we reach the large conile where there appear to be two depressions or broad ravines running north and south, with an intervening ridge. Perhaps no better illustration of the Arabian trady is to be fonud on the western continent than these coulese. This very broad, dry ravine was eridently once the channel of a considerable stream, the shiftings and fluctuations of which may yet be detected; why is it no more filled with water? Beyond this the sur. face is slightly undulating, but somewhat more in the terrace-form to and west of James River until we reach the cotean of the Missonri. The valley of the James is narrow, not more than from one-half to one mile widr, with very little timber of any kind. The surface of the coteau is very irregular, being broken into ridges and hillocks, with here and there an occasional small lake; and from the best information I could obtain it appears to be true, althongh strange, that there is generally no difficulty in obtaining good water on this elevated platean by digging wells to a moderate depth. I know this to be true in regard to some of the elevated plains in the sonthern part of the Territory. The section where the greatest difficulty is experienced in obtaining water appears to be in Red River Valley and those areas underlaid by the heavy elay deposits.

Although the conntry west of the second crossing of the Cheyenne is well adapted to grazing and pastoral pursuits, yet 1 am satisfiel that the average rain-fall is not sufficient for profitable agricultural operations. There may be seasons when the supply may be sufficient to produce moderately good crops of the cereals, but i think these will form the exceptions instead of the rule. It is true no sufficient experiments bave been made to test this question, and it is due to the welfare of the Territory and those who are largely interested in this matter that I should 20 G s 
state that my opinion is not based upon direct experiments in this im. mediate section, and that the soil as a general thing is good; also that it is rery probable the bottem-lands along the streams will form an exit is very probable the botterts, the enief ception to this rule. I should also state that engiaeer of the Northern Pacifie Railroad, expresses a somewhat more favorable spinion in regard to this section. He may be right and I may be wrong; I only give my opinion, which is based on certain evidences which will be more fully set forth in my report on the climatology of the West.

I was informed by a gentleman who was for three years connected with the Indian agency at Fort Totten, on Devil's Lake, that the sur. rounding country there consists of undulating prairies, much the same as fonnd at the same longitude farther south along the line of the North Pacific, but that the lower lands immediately around the lake he thinks will, as a general thing, produce crops without irrigation, and that he fonnls his belief on some experiments which were made there.

fortion of $\mathrm{Da}$ kota sonth of the Northern Pacific road until we approach the south eastern extremity. This section has seldom been traversed with a view of studying its agricultural resources; yet from the little $I$ could learn with reference to it, I am satisfiec that there is a gradual im. provement southward. The valley of James River, south of $45^{\circ} 30^{\circ}$, provely expands and gives eridence of a greater degree of moisture. gradually expands and gives eridence of all probin Even the sothern portion of the Coteaus of thc Prairies bility prove productive and adapted to agriculture, notwithstanding it isolated elevation. I know from personal observation that the section drained by the Big Sioux is one of the most desirable and beautiful por tions of Dakota, almost every acre here being susceptible of profitable tivitivation. An in order to give something likea of this portion of the Territory, I will copy my notes taken while crossing from portion of the Territory,
Yankton to Sioux Falls.

After leaving the immediate bottoms of James River, we ascended some 60 or 70 feet to the upper or general prairie-level, where the surface is quite uadulating, not broken, but interrupted by long, roundec swells, with a dark, rich soil, thickly covered with a heavy growth of Inxuriant grass, but entirely treeless. Snch is the general character for twelve miles; I might add that most of thi3 distance there appears to be an ascending grade. Here we reach a small stream ealled Clay Creek, which runs through a deep, narrow valley, its pathway marked by a few scattering bushes or trees. Beyond this we cross a broad, rounded rilige for some eight or ten miles, the soil and covering being similar to those already described; and I may state here, in regard to this ridge, that which applies to all tioe principal ridges in this part of the Territors, its direction is nearly north and sonth, running a little the Territory, its direction is nearly north and south, runniug a little we enter upon a broad, level prairie, which, beginning in the vicinity of Turnersville, continues eastward to Sioux River, a distance of some twenty-five miles. Althongh I call this a level prairie, I do not intend thereby to convey the dideat it is "dead-level" flat such as Red River Valley, for such is not the case, but the undulations are slight, and, although sufficient for drainage, are scarcely noticed by the eye. The soil and grass are similar throughout the entire ronte, but running water-a stream of any kind-is wholly wanting on this level prairie. belt, save that at Turnersville, and the entire region is timberless.

It is apparent from these notes that there is a great sameness throngh. ont this portion of the Territory; and any attempt to give a descrip. tion of one part as contrasted with another would be useless, as there are no differences of any importance in an agricultaral point of view, with the single exception of the contrast between the Missouri bottoms and the upland prairies. And here the only difference is that the former is flat, the soil deeper and darker, being mixed with a larger proportion of vegetable mold, and partially supplied with timber, ehiefly cotton. wood groves.

The following description of Union County, (the southeast county of the Territory,) taken from "The Outlines of History of th3 Territory of Dakota," by James 8 . Foster, I found to be quite correct, and as it will apply pretty generally to the connties along the Missouri in this part of the Territory, I insert it here:

The surface of Union County resembles that of any of the Missouri River counties. It has, however, more bottom-lands than any other county. The sonth balf is level bottom-lands, only a fow feet above the high-water mark of the Missouri River; the
north half is rolling prairie, elevated about 20 to 50 feet above the bottom-lands. The north half is rolling prairie, elevated about 20 to 50 feet above the bottom-iands. The
bottotns are perfectly level and very smooth, presenting no obstacles to machine farming. The uplands are generally undulating, presenting to the eye a beantifal landscape. Th. soil of the bottoms is a dark, sandy loam, mixed with a large proportion of vegetabse mold the afford an excellent quality of nutritions grass, but not so loxuriant in growth as that of the bottoms. The latter produce excellent crmps of corn, wheat, osts, and vegetables, but the uplands, although capable of producing all kinds of grain and vegetables, are pre-eminent for wheat, thirty bushels to the acre being an ordinary yield. Along the Missouri, in the southern portion of the county, are large bodieo of heavy cotton-wood timber; there are also considerable Lodies of timber skirting the

The surface and soil of Clay Connty resemble those of Union; the surface of Yankton and Bon Homme Counties is rather more rolling, with less bottom-land, otherwise similar to Union. From the month of the Sioux River to Vermillion River, the bottom or immediate valley of the Mis souri is chiefly on the Dakota side, and varies in width from five to twelve miles. At Vermillion the bluffs-which form the escarpment of the upper level $c$ ' plateau-approach very near the river. Beyond this the bottom again snddenly expands, and continues until we reach the vicinity of Yankton, varying in width from five to ten or twelve miles. I was somewhat surprised to find this part of the Territory as well settled as it is, a large portion of the bottoms and a part of the upper prairie lands being already nuder cultivation. At the time of my first visit, judging by the state of the crops, the season really appeared to be more advanced here than in Northern Iowa, owing, I suppose, to the warin nature of the soil, which here is generally underlaid with a heavy deposit of yellow, sandy marl (loëss) which contains a large amonnt of the mineral elements of fertility. There appears to be but little diffculty in obtaining water on the uplands by means of wells, and the comparative elevation does not appear to make very great difference in the depth.

The farmers here have very wisely adopted the plan of planting out forest-trees as one of the first things they do after making a settlement, and notwithstanding all the wild theories which have been advanced, they have had the good common sense to select the native cotton-wood, which, in five years from planting, (not seeding,) will commence afford ing fuel for stoves. I noticed at several points thiekets of the wild plum (probably Prunus chicasa) loaded with fruit; also many grapevines (wild) in fruit.

One serious drawback in this section, which mnst be seriously felt as soon as the cotton.wood groves along the Missonri have been exhausted, is the deficiency in fuel and building material. The latter want will be 
partially supplied when the railroads having connection with the timberdistricts of Slinnesota are extended into this regiom; but these will scarcely supply fuel at a rate that will meet the wants of the farmers. It is true that coal can be brought in, but this will be a heavy tax on the farmers of small means, who live far back on the prairies, and are exhausting all their means and energy to start a farm into active operatiou; yet this will probably be the only method of meeting this neces. sity, unless corn is used for fuel, or forest-trees are timely planted and in sufficient quantity. What is said here on this point also applies to portions of Nebraska, and to some extent to the southwest portion of Minnesota. I kuow there is in the mind of the farmer of the States who bas labored hard through the hot days of summer in plowing his corn, and in the fall in gathering and garnering it, a very strong dis. like to the idea of using it for fuel; but the true method of testing this question is to count the cost. If, for illustration, sixty bushels of corn in the ear-about thirty shelled-sill equal, as fuel, one ton of coal, (I do not know that this amount is correct; it is but a guess,) will it pay to sell this corn at 20 cents per bushel (shelled measure) and buy coal at 88 or 89 per ton, besides the hauling to and froin a depot 9 It is a simple question of flgures and not of fancy, and it would be well if some one properly situated to do so would give us some practical infor. mation on this subject.

A kind of soft-chalk rock is found near Yankton, similar to that found in Nebraska and Kansas, which is used as a building-material. This can be easily cut into blocks of any sinape desired, but there is some doubt abont its durability, yet most of those who have tried it for a number of years say it stands the test of experiment.

In elosing this brief account of the agricultural resources of Eastern Dakota, I should state that, after carefully weighing all the data I bave been able to obtain, together with my own observations, I am satisfied that all west of James River Valley must be counted as in a district not sufficiently supplied with rain.

Taking all the records of the rain-fall which have been kept in the Territory for the fire years from 1867 to 1871 , inclusire, we find the average yearly amount to be only 14.09 inches, less than half that of Minnesota, Iowa, or Eastern Nebraska. This entire amount is not more than barely sufficient for the production of the cereals, and just so much as we take from this general average to increase the amount in the more favored sections, just in proportion do we lessen it in the others. And that this average is not far from correct is shown by the fact that there is no very great variation from it in either of the years included: $1867,13.78$ inches; $1868,14.03$ inches; $1869,14.17$ inches; $1870,15.12$ inches; $1871,13.35$ inches, The records, which are now being kept at Yankton, Fargo, and Pembina, will doubtless increase this average somewhat, but if an equal number of stations were made in the drier sections of the interior and west, 1 am sutisfled there would be no increase. The meteorological data, therefore, so far as obtained, corroborate the opinion I have advanced on this subject.

\section{NEBRASKA.}

I regret that I am compelled by want of time $t c$ cut short my proposed account of the agricultural resonrces of this young State, which is 80 rapidly filling up and rising to importance and influence, and which the late census shows as standing at the head of the list, so far as the ratio of common-school edacation to the population is concerned.
During my examination of the central and southern sectious in the summer oi 1872, I fond that in some respects I was compelled to change the opinion I had previonsly formed from hasty passages through the State. For example, I am now satisfied that Platte Valley can produce crops of the cerewd without irrigation farther west than I can produce supposed. Not thas the amount of rain which falls on this valley is any greater than that which fslls on the adjoining plains, but the moisture is longer retained; and, more than this, I strongly suspect that these valley-bottoms are largely underlaid with sand-deposit throngh which an underground river permeates. While I sm of deposit through which an this great valley, on the other hand I am now pretty thoroughly convinceu tiuat the sufficient supply of rain on the upper plains does not extend as far west as I formerly supposed. For Southern Nebraska, I do not thiuk this can safely be placed any farther west than Fort Kearney, except along the immediate valley of Republican Fork, and north of Platte this line will probably bend considerably east.

Notwithstanding it is don'tless true, as claimed by the residents, that the subsoil is well adaptec to sustain dronghts by its capability of absorbing moisture, yet it is also true that the evaporating power of the air is greater than is usually supposed. The records of the signal-station at Omaha show that on the 4 th of April the difference between the wet and dry bulb was as much as $27 \circ$, which, considering the fact that this is on the bauk of the Missouri River, the date early in the spring of rather wet season, is very great and indicates a very dry atmosphere.

There is another thing in connection with this subject, which I think is true both of this State and Kansas; that is that the amonnt of rain does not diminish so gradually as we ko west as I had supposed, the supply in the eastern part of these States being almost equal to that of the States immediately east of them. For instance, the average of five years (1866-1870) in Nebraska was 31.47 inches, while that of lowa was 40.65 inches; Kansas 40.98 inches, while that of Missouri was but 38.33 inches. But if we go westward to the middle of these States the precipitation will diminish to not more than half this amount. We should therefore bear in mind that these records which appear so favorable apply only to the eastern third of these States. Taking the average of all the stations in Nebraska for the years named, we find them to beas follows: 1866, 27.07 inches; 1867, 28.41 inches; 1868, 33.28 inches; $1869,42.11$ inches; 1870.26 .47 inches. This subject will be more fully discussed in my report on the climatology of the West.

The following answers to the inquiries contained in aircular sent out by the Secretary of the Interior, at the request of Dr. Hasden, is so full, ani, as a general thing, so fair a statement in regard to the agricultural resources of southeastern Nebraska that I think it is proper that it should be inserted here. It is true it is from the land proper the Burlington and Missouri River Railroad Company whe interested in sustaining the character of the lands in this section, yet, after a visit in person to the section described, I think I may safely state that it is correct. A few drawbacks are not mentioned, but I will allude to these, as they were not directly embraced in the questions propounded: STATE OF NEBRASKA.

To the Secretary of the Interior, Fankington, $D$. C.

$81 \mathrm{k}$ : In accordauce with the request contained in "Cirenlar No. 1," addressed from have the honor to report on the descriptington, D. C." and dated "Mareh 20,1872, "I of a portion of the 8tate of Nebraeka. I anawer the elimate, prodnetions, and markets to this scetion of land, and the questions and answers on number in the cirenlar relating 
BOUNDARIES.

The section of country to which this report applies lies betwoen the Platto River on the north and the porthern bondary of the State of Kansas on the wonth, and between the western bank of the Missonri River on the east and Fort Kearney on the woet.

DEscartios OP LAXD.

Question 1. The relative proportion of mountain, valley, and plain of your nection Proportion of timbered land and varietios of timber ?

Anster. Theto are vo mountains. The whole region forms a portion of the Trans Missouri Prairie, which rises gradually from the Missouri Bluffs in long swells ever where avaliable for cultivation. The rolling prairio offers no positive obstruction to the plow, and the broken prairie seldom. There is ittle or no timber in the section, except in the river-bottoms, where narrow strips of forest-troes are found. I here give a statement of

Elenation at the different station, along the Burlinglon and Missouri River Railroad, in

Statione
Plattsmouth

Plattsmouth .....

Louisville
South Bend

Ashland.

Greenwood

Waverly

Newton

Denton.

Highland.

\begin{tabular}{|c|c|}
\hline tion in ? & 8tations. \\
\hline ... 525 & \\
\hline .. 542. & Dorchester \\
\hline 592. & $\begin{array}{l}\text { Fair } \\
\text { Graf }\end{array}$ \\
\hline 643 & Har \\
\hline 682.10 & Inland. \\
\hline $\begin{array}{l}677.80 \\
602.60\end{array}$ & Juniata . \\
\hline $\begin{array}{l}692.60 \\
704.90\end{array}$ & $\begin{array}{l}\text { Kenesaw ... } \\
\text { Lowell..... }\end{array}$ \\
\hline${ }_{970}^{788}, 80$ & Kearney Juneti \\
\hline
\end{tabular}

Elevation in feet.

Remarks.-Kearuey Junction is above low water, Gulf of Mexico, 2,114 feet, and above Lincoln, (the State capital of Nebraska, 1,000'feet. To each elevation add 410 feet to get the altitude above low water, Gulf of Moxice.

Qucation 2. What portion can be irrigated and rendered tilla 46 , and what portion not irrigable is suitable for grazing $f$. What are the methods of irrigation; how many times do you Irrigate the different crops; what depth of water in inches is used dur-
ing the season; what is your method of regulating the aupply and price, and what the cost per acre of irrigation

Anscer. Irrigation is not required within the defined limits. The land, though devoid of forests, is not nubject to destrutive droughts. During the agricultural months the rain-fall is suicient for all the needs of the agriculturist, and it is regular. An average inches; A phi, ter-montbs of January, February year into three portions, these figurea give for the win5.22 inches; for the spring and fall months of March, Oetober, and November, an average total of 5.40 inches; and for the remaining six agricultural months, an average total for each year of 23.21 inches.: As the rain falls in largest and sufficient quantities exactly when it is most needed, the elouds themselves form a perfect system of irrigation. It is a fact that this section, as the wbole State of Nebraska, receives a lesen amount of rain-fall than other places in the same latitude; but following a natural law, as settlement proceeds and trees are grown, (for which latter see answer to question 7, the annual rain-fall will become fncreasingly larger, and the upper branches of the rivers and creeks- which are now dry, or partially dry, except during rains - will character of the country in this matter, it is necessary to add that the rich, black soil of the section reats on a subsoil of porons yellow clay. Moistare does not consolidate this subsoil into a mass, but water is received and beld as it would be by a sponge. and able alike to reaist drought or exceseive rain.

Qucation 3. What varieties of grains, vegetables, fruits, and other crops have been tried, which have proved best adapted to your section, and the averago yield per acro Anner. All cereals bave been tried, and succeed perfectly; but wheat standa fore-

The proper estimate is, from April to August, 19.72 inehes-T.

tThis very general opinion is very doubtfol, yet it is probably true that the distri. bution will be more equable and the amount more effective on vegetation.-T. most, and in weight of crop this section only falls below Collfornia. Wheat grows well on the high and tho low lands; and oata and barley yield abundantly, while maiz is every whero snecesefal. Taking a period of five years, an average yield of wheat is busbels ; barley, 26.75 bnshels; and buekwheat, 26.33 bustiels. The wheat jrown here ; and buck wheat, 26.33 bustela. The wheat grown here of the country; but atill it is desirable, now and again, to renew the seed. In view of this faet, the Burlington and Miasonri River Bailroad Company proposes to import from the old countries the beat descriptions of seed for those among the purehasers of its lands who may desire new seed. Potatoes, sweet potatoes, turnips, beets, and all root-crops
yield abundantly, the average production of potatoes for five years being 79.80 bushels yield abundantly, the average production of potatoes for five years being 79.80 bushels per acre. The systematio culture of the sugar-beot would give sn abundant supply of sugar. Sorghum is of free and rich growth; abd an excellent sirup is manufactured from it juice, thougt tba processes or mand

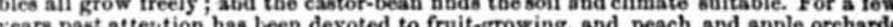
years past attetition has been devoted to fruit-growing, and peach and apple orehardi havo been established in many parts of this section. At one time there were doubt of theories that had aever been tested by experience; but now, and as the result of experience, they have been entirely dinsipated. In three years young peach-trees come into bearing; and spple-trees in from four to five. One etrong proof that fruit takee kindly to th- Nebraska soil is that, at the exhibition in 1871 of the National Fruit-Growers' Association, the premium for fruit was awarded to tho State of Nebraska, of which the section of country to which this report applies is one of the best parts. The grape is successful under proper conditions. The Missouri bluffs are similar in character to
the loess of the Rhine banks, and throughout the broken prairie the eulture of the the loess of the Rhine banks, and throughout the broken prairie the eulture of the strawberry and the raspberry of the timber-skirtings are of excellent flavor. Tobaces is grown to a small extent in the bottoms. The plant thrives, and the leaf comes to maturity. Flas has been grown in this section for need; bat both flax and hemp might of linen and agriculture might go band in hand, prorided immigrants who aro aceostomed to the twofold operation can be brooght into the State, for to this day it remains a fact that hand-made liuens can compete in the market with the productions of the power-loom. Acestos Anner. The raising of cattle has succeeded wherever tried. The native grassen which grows ou the bighlands, attaing the beight of aix feet; and a grass locally callei "tuley," which grows in the bottons of the Missonri and the Platte, is equally rich. These are both excellent as foeding grasses; but there are many others, apd moos of the year there is pasture upon the prairie, for even after the slight frosts of the fal have browned the grases they make good catte-food until they are entirely obriveled in the dead winter. Hay is aloo readily enred and stacked. The winters, as a rule are not long. Open weather continues to the end of November, and spring has fairly returned by the beginning of Mareh. Cattle, therefore, can be kept in the open air for most of the year; and during ordinary years, with the exception a fow weeks, all the year round. For these fow weekn, however, shelter is neeted; and when shelter is provided the worst winten experienced are not at all to be dreaded by the breeder. So far in the history of this country the stock-owner's worst enemy has been the earethe mill shelter for his stock, loss ensues;" The fanlt here indicatesl experience will correct. gool protit is male by purchasing Texan cattle and grazing them on the prairie for a

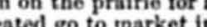
splendid condition. When cattle-breeding becomes one of the regular operations of the farmer, it is well to eross the Texan with the Durham. Horse-breeding will be one of the industries of the section. Except for the purposes of the farm not many horses have been raised; but qualified men are here and there turning their attention to the subjeet. The broken and rolling prairie, intersected by draws, (ravines,) in suitable for horse-breeding. As the land is not the best adapted for the plow, it is the cheapest of the lands in the section, thongh, as it is the most snitable for the stock furm, it is the most valuable of all. In tho draws water can al ways be found; and, from ever, for the in the shape of oats and corn, is readily raised. Sheep are valuable stook for thes prairie-lands; and will make large returns as well in wool as meat. Good pasture is plentiful, and the sheep require no more than the most ordinary shepherding; but that they mnat have. The dry, open winters condace to the health of the sheep, which are 
not fonnd to be subject to mach disease. The hog thrives, and with corn plentiful, tho "Log-crop" yields well. As a general retnark, the cost of raiaing stock here is minimum; and, as there is a command of markets, fair prices can be obtained.

Question '5. Time of plauting the various crops; and time of harvesting

Anvicer. Crops are of rapid growth, and rapid ripening. Spring-wheat is generally sown at the latter part of February, and corn is plsated in Aprí. But corn may bo planted much later; and in the land-ofilce at Lincoln of the Burlington and Missont coner vested in perfect condition spefore frost. The pratited on the 27 th of Jue, abd har tho seed nowu, by the middle of Sepenber.

Question 6, Character of your winters; amount of snow and rain-fall?

Ansicer. Rain-fall in the section is oven in auswer 1 . The ordinary average winter extends over three months-December, January, and February; and the entire fall of snow does not exceod 10 incL as. The heavient snow-falls of which we bave experience are frum 4 to 5 inches.

Qucotion 7. What has been lone in the way of tree-planting, and varieties best
adapted to yont section adapted to yous section

Anncer. The annual prairie-fires have, as a rule, prevented the growth of timber away
fom from the ravines of water-coursns. In these ravines, however, wood grows luxuriantly, of oak, elim, white black walnut, coftee-tree, aycamere and wild plum. The wild grape-vine is aleo abn last. But for the fires, by natural processes, the prairies woold be timbered and if

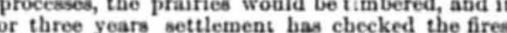
there is ash and cotton-wood brush which, in due course, will become wood." Planting is also proceeding, though not so rapidly as is to bo desired. However, last year, (1871.) ote farmer planted no fewer than 120,000 trees ; and very many farmers show disposition to surround their homesteads with wiad-breaks. By an act approved Feb. ruary 12, 1869, the Stato of Nebraska exempts "from taxation of the property of each tax-payer who shall, within the State, plant and snitably cultivate one or more acres of and coe planted healthy aud growing condition. Cotton-wood, which grows rapidly, is the farorite for groves; and the records show that theae trees in ten rear' growth height varying from 25 to 50 feet, and eircumference varying from 2 feet 5 inches to feet. The Osase ornoge is preferred for fences and wind varying from 2 feet 5 inches to planters who give choice to the honey-locust. Other suitable fe.uce-plants, an the wil low and whitethorn, are ased, though more rarely. Induced thereto by the lack of timber, and the preminm for its cultivation offered by the State, it is certain that the farmers of the section will more and more make the growth of wood an object. The Danish residents at Omaba have formed a tree-planting company; and this company intends to plant 2,560 aeres of suitable soil, within the limits of this section, in the nouthwestern corver of Adams County. The company proposes fruit (for which, by the act already quoted, property to the amount of 850 annualy is exemptel from tax ture. The fruit is to consist cbicfly of grape-vines, peaches, and apples: and the foret trees prineipally of evergreens. The Burlington and Missouri River Railroad Compang has now a contract out for the planting of c wenty-seren miles of cuts on the cort pany of the railroad, from the Sfiseuri River, at Plattsmouth, to Kearney Junetion.t Fronting the north, along these euts, there will be soven rows of trees arranged thns: ex treme north row, boney-locust; second row, cottos-wood and willow; third row, maple, ash, and box-elder; fourth row, Norway spruce and Seoteh fir; and the three inne: rows, Earopean larch. One main object of this planting is to furnish ties for the railroal; but it is also hoped that the operation will encourage settless to imitate the example.

Quetion 8. What are the kinds and cont of fenciag used on the prairies $?$ What has been done in the way of planting hedges

Annrer. This question is in great measure an swered in the reply to question 7 ; but it mas be stated that fencing is not a rapid procoss. When boards are used the work oceur, the sod being taken up on breaking. A strong and durable fence can be constrneted with this material, with no expense nave that incurred in piliug the sod in due form and order. This class of fence seetns to be suited for partial use on the prai-

- I fonnd this to be true not only at points in Eastern Nebraska, but also in Sonth. eastern Dakota, and in Minnesota, bnt it only applies to the rain-moistened districts, and sections but slightly grazed, for eattle, \&ce, are about as destruetive to the young

plants as fires.-T.
t The Northern Pacific Zailroad is adopting the same plan.-T. rie; but its value would be greatly increased if the wall were so built that it could be planted on the top with Oaago orauge. The honey-locust and the osage orange grow rapidly, and, if properly attended to, in four or five years they will make a fence that will turn cattle. The only cost of the live feace is the price of the seed and the labor. However, a settler frequeutly finds it necessary to obtain .eturns from his land before investing ovea the smalleat amoant of capital in any way bat themost ossential permanent improvemeats. Under these circumstances, the herd-law of Nebraska bas a beneweialo whil not allow bis auimals to treapass resuit of this law is - as live fences bave to grow and board foces are expenive. The when a locality is settlel the cattle are herdel together under charge of men or that, who are paid for their labor from a fand jointly and proportionally subseribed by stock-otrners. While at panture the berd is taken to the best feedingernonnds by the neighborbood. Every night the milebers are returned to the owners, the other cattlo being corraled. The law is considered to work well. It preventa the necessity of fencing when a farmer could not well afford the cost; but it must also bo added that it is a check on fencing when the work ought to be undertaken.

Question 9. Cost of getting stock and produce to market.

Anncer. The local market for wool and beef is a: the farmer's door, for the wholesale therchants of Chicago and Baint Louis collect produce by traveling agents. When a convet iently central position, which ded ho support a lown, one comes into being, i Produen is, therefore, readily marketed, and the wants of the farm and the housebold supplied. As the country, however, becomes moro thickly peopled, and its industry develops, the farmers and stock-raisers will probably deal more or less directly with the distant consuming markets. The way to Chicago and the eastern ports is opened by the Burlititon and Missouri River Railroad, and westward by the Burlington Company and the Uuiton Pacific Company. The Atchison and Nebraska Railroal atrike trom the Missonri at Atchison, Kansas, and the Baint Joseph and Denver Railroad from the Missouri at Saint Joseph, Missouri. As the mineral resources of the Roek Srountaits are developed this section of country-Nebrasks in the neareat agricultura the Mississippi, the sout - wissouri and

The drawbacks I alluded to are as follows: the difficulty in obtaining building materials and fuel, especially after you get west of Lincoln, for exactly the same remarks made in respect to Southeastern Dakota apply here. Another difficulty, though not a very serions one, is, that west of Crete wells must be sunk to a considerable depth-from 80 to 120 feet-to find water; and streams being scarce, it is difficult to obtain a supply of stock-water. A third drawback, which applies also with equal if not greater force to Dakota and Sonthwestern Minnesota, is the severity of the winter-storms. It is true these are not of very frequent oceurrence, but when they do come, and few winters pass without one or more, they are very severe, and often occasion many tardships and much suffering, but experience will teach the settlers how to prepare for and proteet themselves against these. 


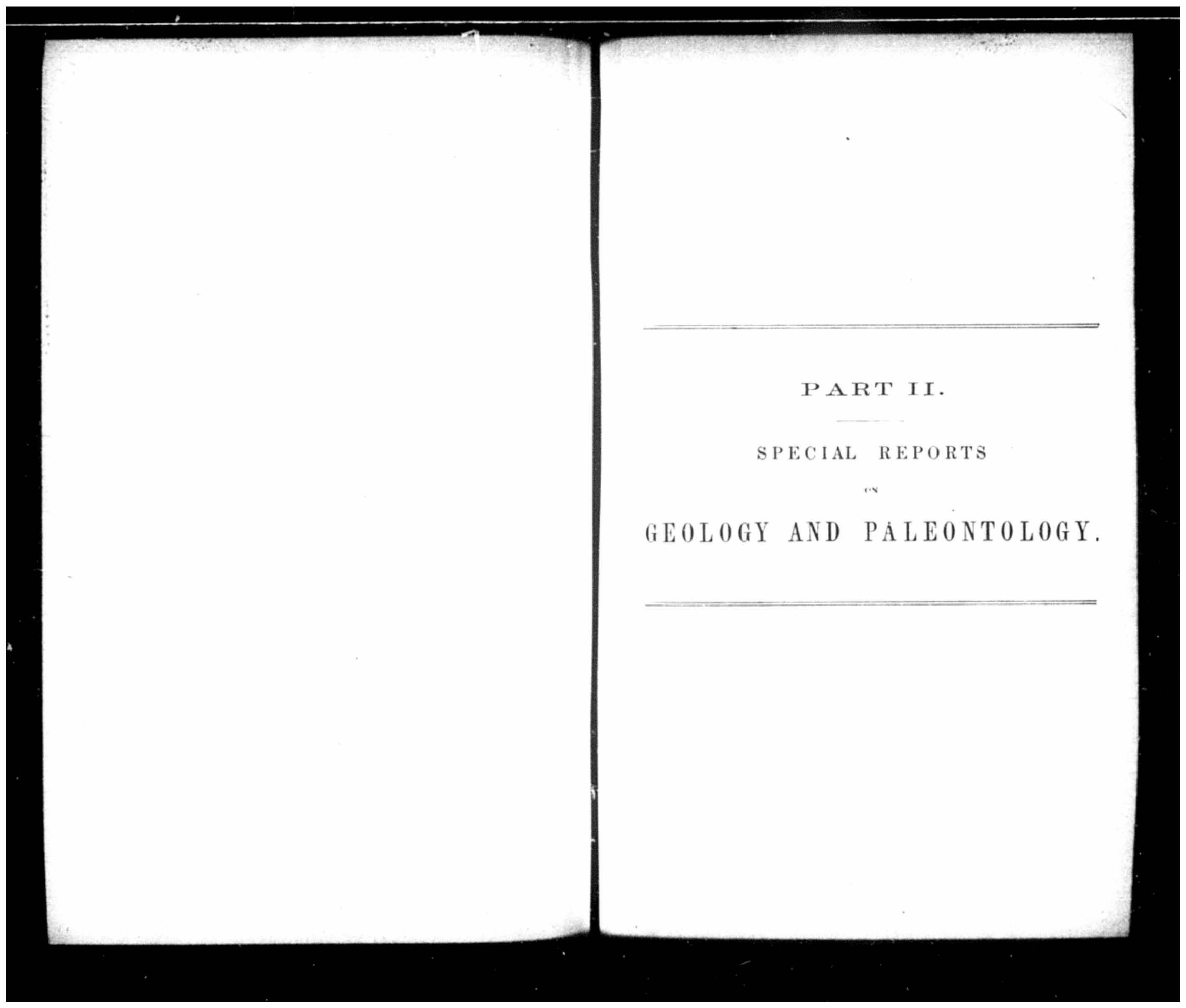




\section{LIGNITIC FORMATION AND FOSSIL FLORA.}

BY LEO. LESQUEREXX.

Columbus, OHro, March 25, 1873.

DEAr SIR: According to the directions received from you, I spent the months of July and Angust in exploring, first, the plant-bearing Cretaceous strata of the Dakota Group, in the valley of the Saline River and on the Smoky Hill Fork of the Kansas; then the Lignitic formation and on the Smoky Hill Fork of the Kansas; then the Lignitic formation Union Pacific Railroad to Evanston. You requested me to have these explorations especially directed in vies of positively ascertaining the age of the Lignitic formations, either from data obtainable in collect and examining fosil vegetable remeins, or from ans tions tions which I should be able to make.

The following report gives the details of these resear hes. Its divis, ions are marked by the nature of your instructions. The first partafter recording the facts derived from explorations at different localities, discuss the age of the Lignitic in considering geological and paleonto logical evidence. The second part reviews what is as yet known on the form ation of the lignite, the distribution of the lignitic basins, their productive capacity for combustible mineral, and the present application of the material. The third part enumerates the species of fossil-plants obtained in the explorations of this year, either by myself or other of your assistants, describes the new species, and compares their local distribution, \&e.

On this last point my rescarches have been very successful. I ob. tained, from the Cretaceous and from the Lignitic, a large number of good specimens, which, selected in place and there compared, allowed me to fix more positively the characters of many species either not satisfactorily known or as yet undescribed. This work was rendered especially profitable by the assistance of Mr. I Iesquerenx, jr, who pursued the researehes with scientifie interest and anceasing jo, who aul who frequently diseovered at remote or dist places the siche and who frequently discovered at remote or distant places the richest deposits of fossil vegetables.

Allow me, sir, to gratefully acknowledge the valuable assistance re. ceived from yourself in railroad passes, letters of introduction, still more by information from your former reports, and also to tion the kind assistance offered everywhere to my explorations by the superintendents of mines, the engineers of railroads, the proprietors, \&e., who generally manifested interest in my researches. At Fort Harker and Medicine Bow a generous hospitality was offered me by Lien. tenant Edward Randall and Lieutenant Hall, commanding the stations. I am also indebted to Messrs. B. C. Smith and Engene Ford for paases to Saint Louis, also to E. A. Ford for pass to Kansas City, and to Colonel Fisher for pass from Denver to Cheyenne.

Very respectiully, yours,

Professor F. V. HAYDEN,

L. LESQUEREUX.

United States Geologist, Washington. D. $O$ 


\section{PART I - DETAILS OF FXPLORATIONS IN THE LIGNITIC FOR} MATIONS OF THE ROCKY MOUNTAINS.

Before arriving at Denver, on the line of the Kansas Pacific Railroad, I had the opportunity of examining, at two different places, heaps of lignitic coal taken out of abandoned and elosed shafts. The lignite appeared of very poor quality, had been taken from various depths, and little evidence on the age of the strata could be obtained from the mixed and mostly disintegrated materials scattered around near the mouth of
the shafts. West of Denver, at Golden, Marshall's, \&c., I became more intimately acquainted with the general features of the so-called westert Lignitic formation. Afterward, from Denver, my explorations were pur sued sonthward to Colorado Springs; then in the Arkansas Valley, and from Cañon City, aiong the base of the Rocky Mountains, to Trinidad and the Raton J, As is at this last-named locality that I was for the first time able to see a well-exposed section of the whole formation, to study, therefore, its essential characters and the relative position of its more important members, I propose to begin, at the Raton Mountains, the descriptive narration of my researches, to pursue it hence northward to Denver and Cheyenne, and then along the Dnion Paeifle Railroad to Evanston, where the explorations were discontinued. In following this plan some preliminary general conclu. sions may be taken from the data ascer'ained at the beginning, and may be used henceforth as points of comparison and reference for facts anc observations obtained elsewhere, and which may afford confirmation or conflicting evidence.

\section{ફ) 1. Raton Mountains.}

The small town of Trinidad is pleasantly nestled on the south side and in the bottoms of the Purgatory River, which here rnns eastward, to take farther east a more northerly course to the Arkansas River. Behind the town a series of round, more and more elevated hills cover the base of the highest peak of the Raton : Fisher's Peak, a dark basaltic or voleanic mass, which towers above the country at an altitude of about 2,000 feet. Opposite Trinidad, on the south side of the river, appears an extensive range of hills capped by thick, mostly perpendicular rocks of sandstone, overlying black soft shale, which descend in steep slopes to the plain. On the western side the Raton Creek, running north, passes through the hills in a narrow, pleasant, green valley, entering passes through the Rilier three miles above Triuidad.

In passing obliquely from the town to the Raton Valley, in a north. west direction, the stage-road gently ascends about 150 feet to a platean which at first is seen formed, even at its surface, of the black shale No. 4 of the Cretaceons, "which here contains well-preserved, large, characteristiv shells in ferrnginons concretions. But soon the plain appears teristic shell in ferragir tops strewn with large broken flags of sandstone, over which no other trace of fossil remains but marine plants or fucoids are seen. A little farther from the town the same sandstone is in place, immediately and conformably overlying the black shale; and in entering the small val. ley of the Raton, the road curves around steep bills, whose base rests

- The divisions of the Cretaceous indicated in this report are those of Mesars. Meek 'The divisions of the Cretaceous indicated in this report are those of Mesars. Meek
and Hayden, marked in the geveral section of this formation in Dr. Haycen's report, and Hayden,
1070 , page 87 . upon the fucoidal sandstone, and whose sides, exposed by denundation, are blackened by onterops of coal at different altitndes. nearest place to the town where the coal is opened and sometimes worked in a very limited extent. These details render the locality easily recognizable.

A few sections of the Lignitic measures of the Raton Monntains bave been given already from the hills along the creek. ${ }^{\circ}$ They differ some. what in the records of the distance and of the thickness of the liguitebeds, but the differences are easily accounted fo: by the great variety remarked, even at short distances, in the disposition of the strats of those Lignitic formations. They are, therefore, perfectly reliable, and it is merely to complete them that the two following ones are given here. They point out the exact relation of the Lignitic formation to the Cretaceous, and mark, besides, what I consider to be the essential charpeter of a group of sandstone which separates these formations, and which, taken as yet as a kind of debatable ground, has been dubiously re. ferred either to the Cretaceous or to the Tertiary. The first of these sections is taken along the swall branch in whose banks the lignite-beds appear in succession down to the Raton Creek, and then following this creek to the Purgatory River, where the Cretaceous measures are ex. posed. It reads from top downward

$$
\text { Lionrric. }
$$

1. Sandstone and shale, covered with pines. Soft sbale, alternating with toft clay, (soapstone)

3. Outerop of lignite, indifferent

Soft-shale and fire-clay

Lignite outerop, thin

Aard gray shale, with fowil plants at base $t$

Soapatone shale

9. Lignite outerop, good

10. Fire-clay and shal

11. Lignite, exposed

12. Fire-elay.

13. Soft shale ....

14. Lignite,

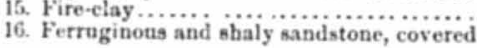

\section{SANDSTONK.}

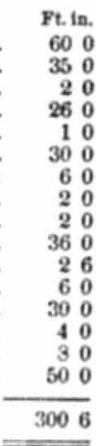

17. Brown, reddish shaly sandstone, with debris of land-vegetables.

18. Yellow sbaly sandstone, fall of fucoids

19. Ferruginous sandatode, barte

20. White compact sandstone, in bank and barren

21. Hard white sandatone, in bank, with fucoids.

22. Soft white sandatone, with fucoids

. Fery hard block sandstone, barren...

24. Ferruginous sandy bbale, with fucoids

20. Ferropinous

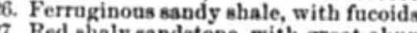

th great abupdance of fucoid

\section{0}

$\begin{array}{rr}5 & 6 \\ 11 & 0\end{array}$

$\begin{array}{rr}11 & 0 \\ 28 & 0 \\ 10 & 0\end{array}$

100

F. V. Hayden's Report of the United Statea Survey of Colorado and New Mexico, (1869,) pages 55 to 57 ; Notes on the Geology from 8moky Hills to Rio Grande, by T. 8 . , pp. 20 and 21 .

t At a short distance the sandstone No. 7 takes the place of the shale-bearing plants. 
This last stratum is underlaid by the Cretaceous black shale No. 4. In The section, and is, therefore, in some places No. 27 is the last the black shale. From No.17 to 28, and immediate superposition to the member, which is covered, the whole perhaps already from the upper member, which or ferruginons sand. measures form a single group of white or laminated clay, mostly sandy or stone-beds, separated by bands of bard laming 178 feet. The characters of passing to sandstone, the whized here, are as follows :

this group, as clearly recognized here, are so white indeed, sometimes,

13t. Its general color is whitish gray, so white indeed, sometimes, stone.

2d. Though generally hard, it weathers by exfoliation ander atmos. 2d. Though gend in round unduations; pheric infle and, as it is locally hardened by rerros so size concretionary or grooved in cavities, so thersitied in sometimes the face of the cliffs shows like the details of a compli. cated architecture.

$3 \mathrm{~d}$. It is entirely barren of remains of animals.

4th. On the contrary, from its lowest stratam to its upper part, it 4th. On the plants or fucoids, which, abounds in well-preserved even in the sandstone over lignite-beds.

at some localities, are seen even in the sandstes of this group are

5 th. In its upper part the sandstone or the sbales of this group are mixed with broken débris of land-vegetation, with which al remains are found more and more abundant in descending.

The disposition of the strata and River, opposite Trinidad, where the

the other side of the Purgatory

1. Hard ferruginons shaly sandstone witk few remains of fucoids, but abun-

dance of debris of land-plants..........

2. Hard whitish sandstone, full of fucoids.............

3. Shaly sasdstone, with same abundance of fucoids
4. Sor lamirated ferruginous sandy clay, with fucolid

5. Fert lamingons shale, with focoils

5. Ferrugious male, whe barre

6. White

8. Ferruginons shaly sandatone, with fucoids

9. Black shalo of No. 4, Cretaceous

9. Covered space, nandstone and shale to bed of rive

Feet.

In both these sections the remains of marine plants are remarked in most of the sandstone-strata and their intermediate clay-beds, and as ast of the and in this last section they are seen mixed with fragments of land-plants, even to the top of the sandistone cut like a tower at the point of the highest hill faciug Trini. daci.

In passing from the black shale of the Cretaceous No. 4 to this group In passing from the black it, the difference in the characters is strik. of sandstone-beds overlaying it, the difference in the class of fossil re. ing, not only in cousidering their compounds, but in the class of fossif re. mains which they contain, the traces of deep marine life predon:inating in the black shale, while here they have totally disappeared. The absence of the upper Cretaceous formation No. 5 might be taken into assence of the upper elsewhere that it is account not the car and the marine formadefinitely characterized by their fossil retn hos as a tion as the second group No. 4. Now, in the saudstone above No. 4 marine life still marks its activity only by the abundant remains of fucoids, indicating by their growth a comparatively shallow water. They point eat, therefore, to a slow upheaval of the bottom of the sea in which they appear to have lived ; for their stems penetrate the sandstone in every direction. And this indication is still mone manifest in the great abundance of debris of land.plants which seem as ground by the waves, thrown upon the shore and mixed in the sand
with fucoidal remains. This slow upheaval, and its result in the forma. tion of a new land, are read as in a book in the fossil remains of this group of sandstone, and every observer should forcibly admit that these memorials of old expose the beginning of a new era, or of what we call an formation. This conelasion, however, can by further researches we recognize that this fncoidal sandstone is not a mere local formation; that it covers a wide area, preserves everywhere its relative position to the Cretaceous under it, and to the lignitic beds above, and has always the same characters either in its compounds or in its fossil remains.

That this sandstone forms all over and around the Raton Monntains the base of what is called the Lignitic formation, and that it there overlies the blark shale No. 4, has been remarked by all the geologists who have explored the country. Dr. F. V. Hayden describes it briefly but very exactly in his scetion " as " a massice, heary-bedded sandstone, yellovish gray, (or whitish,) rather concretionary in structure, and weathering by exfoliation, over Cretaceous shales with Inoceramus and Ostrea," this last bed remarked elsewhere as Cretaceous No. 4. Nothing is said of the characters of its remains. But the specimens of fossil.plants gath. ered at the Raton Mountains by Dr. Hayden and his party, some of them marked : from the sandstone below the coal, bear fucoidal plants, representing the species of Halymenites, which, by the abundance of its remains, appears essentially characteristic of the marine flora of that period. Dr. Hayden still remarks it toward the sonthern end of the Raton Pass, where the Lignitic formation, 100 to 150 feet thick, containing two or three small seams of coal, rests immediately upon an irregular bed of alternate thin layers of mud, sandstone, and clay, which he calls beds of passage between the Cretaceous and the Tertiary of that region. Dr. John Leconte, considering the same strata as Cretaceous, mentions them in his report $\dagger$ as continuing southward of the Raton along the base of the Rocky Mountains, "forming like an inimense terrace, iohich extends as far south as the valley of the Tonejo, and perhaps even to the north bank of the Cimarron." They are evidently the same sandstone. beds as those of the Raton Mountains; for the same geologist remarks that they were observed by him northward from Trinidad and far toward the Arkansas. Indeed, from this place northward to the base of the Spanish Peak, these sandstone-beds, always with the same characters and the same thickness as marked for the cight first members of my second section, 207 feet, and always immediately over the Uretaceons No. 4, form like an immense terrace perpendicularly, cut like a wall facing east, high above the plain. They support the lignitic beds which still tower above them, either ascending in steep declivities from the top of the perpendicular sandstone, or receding at some distanco where they have been more deeply sapped by erosion. "This abrupt front, says Dr. Hayden, "scems to form a sort of shore-line of a voonderful basin, as if a body of tcater had stcept along and washed against the high bluff, as along some large river." $\ddagger$ The stage-road from Trinidad to Pueblo follows the base of the cliffs for thirty-two miles; and, from each station, a geologist has convenient opportunity for the exploration of these re-Report 1869, page 57.
$21 \mathrm{G} \mathrm{s}$ t Notes on Geology, \&ec, loc. cit., pp. 22 and 23. 
markable hills, and for the stady of the distribution of their geological strata and of their characters. South of Trinidad the lignitie measuics hav been followed nearly without interruption to the Maxwell estate, abont fifty miles. As it is not as yet ascertained, however, how far they go to the west, the area which they cover at and around the Rato go to the west, the ar it is not exaggerstion to Mountains cannot be estimate it at a few hundred, say six to eight hundred square miles. Besides this, the same formation is reported farther south, near and around Santa F6́; in the Gallisteo Valley; along the mountains to Albuquerque, and in the valley of the Rio Grande as far sonth as Fort Craig. Everywhere, with a single exception, which shall be considered reres. herearter, theselig indicate their base and constitute their foundation, by the homology of their marine and land flora, as recognized in the remains of fossil-plants which they contain in abundance, all the characters indicated above as anthorizing, if generally marked, the separation of this group from the Cretaceous formation.

\section{2. The arkansas Valley prom Pueblo to Cason City.}

From Pueblo to Cañon City, forty-five miles, the stage-road follows a broad valley, closed on the south side by the Greenhorn Mountains, on the north side by the Rim Range of the Colorado Mountains, over which north side's Peak, whose summit is visible all the time. The whole valley is essentially Cretaceous; all the eminences, either near the borders or in the middle, are hills of this formation, molded by the erosions ders or in the middle, are hills of this formation, molded by the erosions
of the Arkansas River, which has dug numerous beds in this soft ma. terial. The borders of its present bed, like those of its old ones, where the road sometimes meanders, as it a iabyrinth, are picturesquely marked by rocks of diversified forms, resembling monuments built by the has of man, towers, columns, ruins, \&c., often strewn by the hasd of man, On the south side of the river, however, about around in confusion. On the south side of the river, however, about modified by the appearance of a groap of hills of the Lignitic, filling the space from the base of the Greenhorn Mountains to the borders of the river, three to four miles in width. The whole area covered here by the ,ignitic is, from the report of Mr. Neilson Clark, civil engineer and superintendent of the mines, about thirty-three square miles.t The superintendent of the mines, about thirty-three square mily. lower strata, overlying the sandstone, rise abruptly about 50 feet the hills of the Upper Lignitic rise up to about 500 feet. The whole thickness of the lignite-bearing strata is estimated, in the journal quited abore at abont 600 feet. The following section is taken on the quoted the Colorado Improvement Company, where coal-beds are already now extensively worked. $\ddagger$ It is written from bottom up. ward :

Underlying the bottom ssnd-rock is a thick bed of clay, interlaid with seams of Underlying the bottom sand-rock is a thick bed of
and-rock, whose thickness cannot be less than 200 feet.

- Dr. F. V. Hayden's Report, 1809 , p. 57. had tho kindness to take me to the mines, the details of the following section, anel other valuable information.

t Details on the lignite, its comparative value, thickness, \&c., are given in a separato ehapter.
1. Bottom sand-roek grayish-yellow, flled with conerstions of red sandatone, stratinsed with red sandatone, decomposes easily into yellowish-white sand,

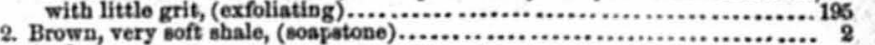

4. Brown (chocolate-colored) very sort shale, (soapstone)

5. Coal, separating in blocks by cleavage.

6. Brown, very soft shale, (like No. 4)...

7. Coal....

9. Clay

0. Coal.

1. Shale, with thin layen of argillaceons carbonate of iron.

12. Sand-rock.

14. Sand-rock

5. Shale, with thin layers of carbonate of iro

17. Slate.

18. Sand-rock

19. Shale

20. Coal. .

Rock and shale...

2. Coa

Rock and brown shalo.

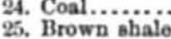

Brown shaik.

7. Slate.

28. Coal, (river-seam)

Then follows sorne 200 feet of sand-rock, containiug three neams of coal, varying from 10 to 20 inches, one of which yields pieces of coke. On the edge of the basin, the high bluffs continually appearing until, over the center of the basin, we find the highhigh blufts continually appearing

Mr. Clark still remarks : But in regard to the formation of the coal the regularity of the strata is wonderful.
It is true that, toward the north, the seams of coal are thinner, and the sandatone much thicker, than to the sorth; true, also, that at times the parting of the seams, mostly of er, than to thomewh in thickness, but over the whole extent of the basin, somet thitty-three square miles from outerop to outerop, the dip is conformable to the center with a few unimportant exceptions, and the thicknees of the seams an: the sand-rocks varies regalarly.

Mr. Clark's section has been carefully made from data obtained in mapping and surveying the whole extent of this lignitic basin. I therefore consider it as a favor to have the privilege of substituting it for my own, not only on acconnt of its being more detailed, but because it affords opportunity to consider here, as at the Raton Mountains, the essential characters of the Lignitic from observations presented under different points of view.

In the above section it is easy to recomnize from its composition, its color, its mode of disaggregation, the sandstone No. 1, about 200 feet thick, as the equivalent of the lower fucoidal sandstone of the Lig. nitic of the Raton Mountains. The essential character taken from its remains is net mentioned. But I had full opportunity to remark it, not oply in the lower beds under the coal worked by the Improvement Company, but also where the same sandstone is exposed, together with the upper Cretaceons strata, in the middle of the valley, half way between Pueblo and Cañon Uity. In my examination of the strata overlying the lignite of the same basin, I found not only a number of dicotyledo. nous leaves in the shaly sandstone, but in the intermediate beds of hard 
sand-rock too, many remains of fucoidal plants, espeeially of the spe. cies which, so easily recognized by its tuberculate surface, appears to be the most common one, and the more characteristio too of the Lig. nitic. This is a proof that the eocenic character of this formation is not limited to its base, and that the iower sandstone, together with the beds of lignite, are of the same formation; that, indeed, as it will be seen elsewhere, the lower sandstone sometimes includes in its divis. ions beds of lignite to its base."

Can we here determine the upper part or the end of this formation? At the Raton its lower stage is especially formed. I could see there nothing in ascending the highest hills or slopes covering the volcanic central group which indicated any change in the characters of the strata. But near the center of the Lignitic of the Arkansas Valley, the forma. tion is covered with high hills, and the 200 feet of lignite-bearing meas. ures above those marked in the section are overlaid by beds of coarse grit, mostly conglomerate sandstone, which I consider as the closing strata of the Eocene-Liguitic period. For this, as for the great sand. stone of the base, we have to see if these upper conglomerate strata have been observed elsewhere and in circumstances which may prove their immediate connection with the Lignitic. Here the 200 feet of measures under them are formed by an alternance of beds of soft clay or soapstone, with an abundance of silicified wood, beds of lignite, (the outcrop of one near the top indicating at least two feet,) berts of clay, which become hard, uninterrupted, blackened by carbonaceous matter; and over them, in immediate superposition, ferruginous conglomerate sandstone separated by bands of soft-grained sand.rock in a thickness of about 75 feet. No trace of organic remains are found in this top sandstone. I found fucoidal plants mixed with broken remains of Cyperacex as high as 300 feet below the top.

Three miles northeast of Cañon City 1 had opportnnity of examin. ing the formation which underlies No. 1 of Mr. Clark's section. It is a compound of thin beds of yellow, compact, sandy clay, separated by thin layers of coarse materials or of sandstone. It contains animal remains only, large scales of fishes and shells of Cretaceous characters overlying the black shale No. 4 , in a thickness of about 40 feet. What there remains of this upper group of the Cretaceous is not much, the materials being too soft, and having been swept away by erosion. But there is enough left to show at once the great difference existing in the compounds and nature of the strata of this Cretaceous upper formation, and of those of the lignitic sandstone, which here is immediately above. The superposition is seen, as remarked above, in the Arkansas Valley, on the banks of a ereek on the stage-road midway between Pueblo and Caũon City.

All this is not new. The same yellow, arenaceons clays of No. 5 in the Arkansas Valley are already exactly characterized and reported by Dr. Hayden, $\nmid$ who marks, too, their succession in ascending as " passing up into a somewhat extensive series of what 1 call mud.beds, composert of thin layers of clay and mud sandstones, with all kinds of mud-mark ings, sort of transition beds or beds of passage. In the upper portion of these layers I found an imperfect specimen of Inoceramus. This group of beds is from 50 to 100 feet in thickness. Resting upon them is a thick bed of rusty-yellow sandstone, which I regard as the lower bed of the Tertiary deposits," \&c. These mud-beds, with all kinds ( $f$ mud.

- Dr. Hayden has, from five miles south of Trinidad, specimens of the same piants t Dr. F. V. Hayden's Report, 1809 , p. 50 . markings, appear to belong to the lower part of the fucoidal sandstone, the remains of marine plants often resembling mud-marks of various kinds. The presence of a specimen of Inocerams in the upper part of the strata is an apparent contradiction to this conclusion. The matter is left aside for future discussion.

\section{Colorado Springs to Denver.}

From Pueblo northward no trace of the Lignitic is seen along the mountains till near the sonthern base of a range of hills, the Colorado Pinery, which, ia its eastern course, at right angles from the primitive monntains, forms the divide of the waters between the Arkansas and the Platte Rivers.

The succession of the Cretaceous strata is cleariy marked on the banks of Monument Creek In following it up from Colorado Spring the formation can be studied to the top of the black shale No. 4, and above this to a bed of brownish sandstone, separated from the black shale by chin layers of Tuten clay and soapstone, where the last remains of Cretaceons animals, especially fragments of Baculites, are still abundant. Over this is the sandstone, barren of any kind of remains, overlaid in the banks of the creek by a bed of fire-clay, or very sof chocolate-colored shale, which marks the base of the following section at low-water level of the creek:

1. Brown laminated fire-clay, or chocolate-colored soft abale, a componnd of remains of rootlets and leaves and brabches of undetermisable conifors.......

3. Chocolato-colored clay-8hale, like No. 1, with a still greater proportion of

4. Soft, yellowish, coanoo asadstone in bank

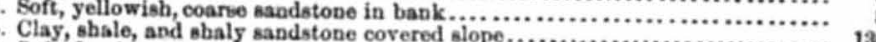

6 . Soft, laminated elay, interlaid by bands of limonite iren ore, thin lignite

seams, and fossil-wood.

7. Lignitio black clay, in banks.

8. Fine-grained conglomerate

9. Fine-grained sandatone

11. Sandstone.

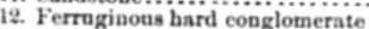

The soft, chocolate-colored, laminated clay, Nos. 1 and 3 of this section, has here the same composition, color, and characters as the clay under and above the coal-beds of the Raton Mountains and of the Arkansas Valley. Indeed, I have seen it the same, more or less darkly colored by bitumen, however, in connection with coal-beds, over the whole area of the Lignitic which has been passed in my exploration. This clay takes the place of the fire-clay so generally underiying the coal-beds of the Carboniferous fire-clay so generally underlying the coal-beds of the Carboniferous measures, where, as in the Lignitic, it forms, besides the floor, some bands,clay-partings, separating coal-strata, and soft strale overlying them. It has also been formed in the same way by immersed fresh-water plants, or true water-plants like Characee, by the innumerable divisions of the roots of trees living along or within the swamps, and by the dEbris of the trees, which appear to have been
mostly conifers. The fragments entering into the composition of this mostly conifers. The fragments entering into the composition of this clay-shale are much more divided and obscured by maceration than the remains preserved in sandstone or sandy shale, and, except for a few branches of conifers, I have not yet been able to determine any of them in a satisfactory manner. 
The sandstone over the Gelurung coal, No. 4 of the section, is by its appearance, its mode of weathering by effoliation, \&c., the equivalent of the lignitic fucoidal sandstone. On the south side of the river, where the coal is opened, it does not contain fossil remains of any kind, and is comparatively thin. But on the other side, its thickness increases to about 75 feet, and it has some remains of fucoids, and a thin bed of coal, ( 6 inches,) a mere streak in the sandstone. In its upper part, this sand. stone, ferruginous and shaly, contains a quantity of dicotyledonous leaves, Populus, Platanue, \&c., with large fragments of Sabal leaves, all species which, by identity with some found at the Raton and in the Arkansas Valley, do not leave any doubt about the contemporaneity of these Lignitic measures.

By far the most interesting member of the section at Gebrung's is the conglomerate formation at the top. These rocks are a componnd of smal grains or pebbles, mostly of white quartz, and of silex of varions colors, varying in size, at least for the largest proportion, from that of a pea to that of the head of a pin. Pebbles as large as a walnut are still abundant; the largest, like thit dant; the largest, like the irst, are rare, and especially found with fert thick at least, is couforma ble to the strata orerlying the coal of the base of the section, and here, as it will be still seen at other places, it overlies immediately thick bank of soft, laminated, bituminous, black clay. The materials forming this conglomerate are cemented together by a thin coating of carbonate of lime, which easily disagrregates under atmospheric infinence, except in the upper stratum, where the cement has been hardened by ferruginous in filtration. Its greater resistance has then locally preserved the wholemass from destruction. These conglomerate cliffs, which, from the hotel of Colorado Springs, arrest the view to the west, appearing like high bluffs of white sandstone, are evidently the mere vestiges of ac extensive formation, originally covering the base of the mountains from the Arkansas River, extending far inland to the east. For hundreds of miles the ground of Colorado Territory is formed by its debris. They have given to the soil that apparent sterility of surface which is so remarkably changed into fertility by the culture of the snbstratum com posed of softer-grained materials and lime. Nearer to and along the base of the Colorado Pinery, whose Lignitic hills have escaped destruc tion by the upheaval of the ridge, these conglomerates, still detached from the common mass, and molded into the most diversifled forms by disintegration, have scattered columns, pinnacles, round towers, and cupolas over a wide area, the far-famed Monument Park.

I have not had opportunity to examine the highest ridges of this Colorado Pinery, whose southern base is about five miles from Colorado Springs, and on the other side descends to five miles south of the South Platte. Dr. F. V. Hayden, who has surveyed the formation, considers it as Upper Miocene (1) (modern Tertiary deposits) comparing it to a group of rocks which covers the country from Fort Bridger to Weber Cañon, and also to a series of sands and sandstones along the Gallisteo Creek below Sante Fé, the Gallisteo group." We shall have opportunity to see this formation again, and to consider its age with more details. Here, as at other localitios it is conformable to the Lignitic which neHere, as at other localities, it is confor appears on the northern side of the ridge, along Cherry Creek and othe branches emptying into the Platte. No beds of Lignite are as yet reported along this slop 3 ; but the clay-beds have, as on the other side, an abundance of silicified wood. I have seen many fine specimens of it in the cabinet of Mr. Byers, ${ }^{\bullet}$ the redacteur of the Denver City News, and since $m y$ return have read in the same jonrnal the description of a fossil tree found at Oherry Creek, which, had I read it while at Denver, would have indnced me to visit the place and ascertain the exactnes: of assertions scarcely credible. This reported fossil palm-tree, which is hollow, measures at its base 22 feet in diameter, and 20 feet from base the diameter is still 15 feet. This is nearly equal to the size of the largest sequoia or giant tree of California. Such a size cannot be supposed, at least not for palm-trees. Whatever it may be of this dis
covery, the abundance of fossil-wood indicates at Cherry Oreek the same level as that of the beds of clay marked in the sectioh of Gehrung's as No. 6. I believe that the lignite-beds underlie there these fossil. trees at a distance of 100 to 150 feet. Not far from this place, fonrteen miles east of Denver, on the Kansas Pacific Railroad, a bed of lignite 8 feet thick was reached at 81 feet from the surface by a shaft, which is now closed, and whose section is worth future reference. I owe it to Mr. E. B. Mally, who superintended the work. The section is from top to bottom :

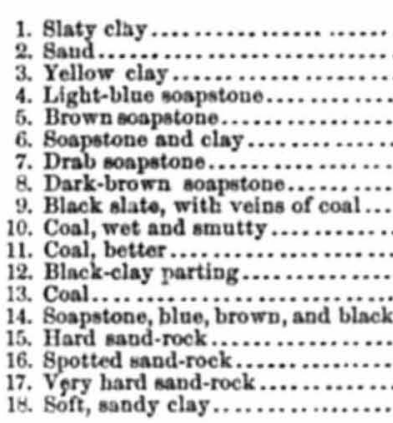

Ft. Is. 16 18 \% 3. Yellow ciay. 4. Light-blue soapstor

6. Soapstone and clay..

11. Coal, better.

13. Cont.

16. Spotted sand-roc

17. Vgry hard sand-rock.
16. Soft, sandy clay...

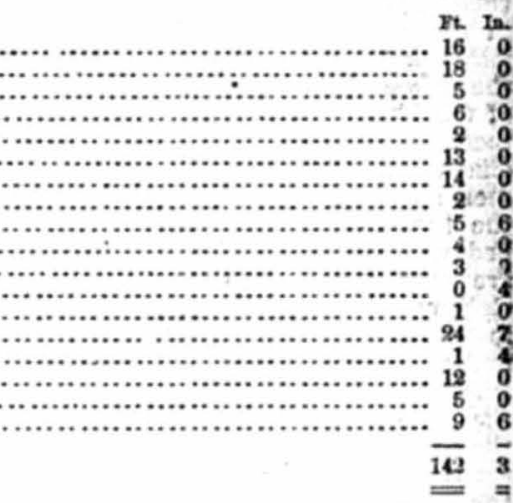

The work was abandoned on account of the poor quality of the coal but the section indicates the place of the bed, at the top of the great Lignitic or fucoidal sandstone under the series of beds of clay, soapstone, \&c., as at Gehrung's and at the Raton Mountains.

\section{South Platte to Cheyenne.}

From the month of Bear Creek into the Platte, a few miles west of Denver, the Lignitic: formation, abutting against the Cretaceous and diversely thrown up by the upheaval of the primitive mountains, follows the base of these mountains in a nearly continuous belt to Cheyenne. Though generally covered by detritus, the basin is deeply cut by all the creeks descending to the plain-Clear, Ralston, Coal, Erie, Boulder, Thorupson Creeks, and others-and the strata thus exposed can be studied in their relative position, their compounds, \&c., at many places. This study is most interesting, but the same ground has been already surveyed by geologists of repute, Dr. F. V. Hayden, Dr. John Leconte, Mr. James T. Hodge, \&c., who have given to their explorations more

- I owe to this gentleman valuable information on the distribution of the Hgaito beds around Denvers. 
time and experience than I had at my disposal. I shall therefore refer for details to the reports already published,- and restrict my observations to facts essentially connected with my line of researches-on the age of this Lignitic formation as indicated by vegetable remains.

Golden is on the banks of Clear Creek, at its ontlet from a deep cañon, and in the middle of a narrow valley, shut up on the west by the slopea of the primitive rooks and on the east by a bigh wall, a trap-dike, which here follows the same trend as that of the mountain at a distance of one to one and one-half mile. As it is generally the case along the eastern base of the Rocky Mountains, the more recent formations have been thrown up and forward, and their edges upraised to a certain degree nearest to the uplift, and thus succeeding each other by hog-backs facing the mountains, they pass toward the plains in diminished degrees of dip, and soon take their original horizontal position.

AtGolden, the Lignitic strata, compressed, as they are, between two walls of eruptive rocks, have been forced up on the western side in a nearly perpendicular position, while on the other they were thrown up at the same time by the basaltic dike, and thus folded or doubled age !nst their faces in the same way as the measures of the anthracite basin of Pennsyl. vania have been so often compressed in multiple folds between the chains of the Alleghany Mountains. In that way the lowest strata of the Lignitic, which are nearly perpendicular, overlie the Upper Cretaceous strata, which, following the slope of the mountain's plunge, inclined in a less degree. The line of superposition of both formations is seen a'ong a ditch opened for a canal of irrigation, about 200 feet from the tuunels made in a bank of clay which underlies the lower lignite. bed, and which is worked for pottery. These upper Cretaceous strats are seen in the same position, and exactly of the same nature as at Gehrung's: thin beds of soapstone, or laminated clay, with Cretaceons fossils, and abor's them the same kind of Tuten-clay, a few inches thick, under the lower sandstone of the Lignitic, which is there covered. The surface of the ridge formed by the upthrow is pierced by the edge of the perpendicular strata, especially of the hard sandstone, and there the characters of the lowest beds are recognized at many places as the same as those of the fucoidal sandstone of the Raton Mountains. At the cut made across the measures by Clear Creek, the lower sandstone appears proportionally thin, 10 to 20 feet. It is a white, soft-grained sandstone, hardened by metamorphism, containing, besides remains of decotyledonons leaves, some species of finely preserved fucoids; among them one species as yet undescribed and not seen elsewhere. In follow. ing the same sandstone to the sonth it is seen increasing in thickness, and near and under the Roe coal, five miles from Golden, it forms a
high, isolated ridge, at least 200 feet thick, barren of any kind of remains, except some fucoids.

By its compound the alternance of its coarse-grained and soft-rgrained strata, these being often mere clay or mud beds, its characters appear the same as those of the lower Lignitic sandstone of the Raton Mount. ains. It has, too, broken, undeterminable fragments of wood, cyperacere, \&c. Besides the species of fossil decotyledonous leaves found in the white sandstone of Golden, most of them homologous, or even identical with some species of the Raton and other localities, it has one of those very rare land-plants which have been described and recognized in Europe as pertaining as yet exclusively to the Eocene.

- Dr.F. V. Hayden, 8illiman's Journal, March, 1668, pp. 101; Geological Report, 1800 ,

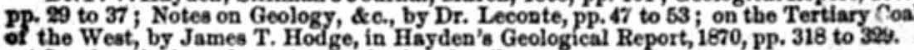
t See description of species for further details.
My researches at and aronnd Golden bave been rewarded by the dis. covery of the finest and best preserved specimens of fosil-leaves that have ever been found in this conntry, with the exception, perhaps, of those of Black Butte. They were obtained, 1st. From the hard white sandstone under and interlying the beds of coal, the white sandstone hardened by metamorphism as deseribed above; $2 \mathrm{~d}$. From beds of white clay upheaved against the sides of the basaltio dike, a clay hard as silex from metamorphism, having mostly remains of palm-leaves; 3 d. From three metamorphism, having mostly remains of paim-leaves; 3 d. From three the dike, but scarcely changed by heat and easily cut in large pieces. These specimens should indicato a different degree of hardening by heat, according to distance from the granitic mountains on one side, and from the basaltic dike on the other. It is remarkable, however, that the lignite obtained from the mines at Golden, like this plant-bearing sandstone, scarcely bears any trace of the action of heat.

In following the narrow valley from Golden to Murphy's coal-beds, the same strata worked at both places have been traced all along in a distance of more than flve miles. From Murphy's or Ralston Creek, the Liguitic is covered by débris, under which evidently the same formation is hidden, with the same kind of strata. For the lignite is worked at Leiden's, about two miles north of Murphy's, from same nearly vertical strata; and five miles farther north, the formation cut by Coal Creek exposes still the same Lignitic measures, now tending to their natural horizontal position by the disappearance of the basaltic dike. Still farther north, in the valley of Boulder Creek, at Marshall's, Wilson's, Brigg's, Erie, \&c., the Lignitic exposes, by the number and thickness of its veins of coal and of its beds of sandstone, a fallnesz of development remarkable indeed, and scarcely seen elsewhere. From Golden to Marshall's I have not obtained any specimens of fossil-plants. A careful examination of the numerous beds of sandstone exposed there would have demanded much more time than I had at my disposal. At Marshall's, besides specimens of interesting dicotyledonous leaves, $I$ found few fucoidal remains, the lower sandstone being there below the level of the country. The main coal, by the abundance of large trunks level of the country. The main coal, by the abundance of large trunks marked, too, at the main coal of the Arkansas River on the land of the Colorado Improvement Company. At Erie, the Lignitic is worked as at Marshall's, near the level of thecountry, and therefore no sandstone is exposed. In the shaly, sandy clay orerlying the coal, I found only remains of dicotyledonous leaves and palms.

remains of dicotyledonous leaves and palms.
The continuity of the Lignitio formation is still traced farther north by Dr. Hayden, who, in his report of 1869 , indicates a bed of coal opened and wronght to some extent, twenty miles south of Cheyenne. The section of the locality, as given on page 17 , positively marks the position of this Lignitic as above a massive sandstone 50 feet thick overlying Cretaceous No. 5; and the same section, too, identifies some of the strata with those of Marshall's and of Black Butte by beds or aggrega. tions of oyster-shells, Ostrea subtrigonalis? curiously represented by homologous or identical species at about the same horizon at these named localities. I believe that fartber north, to Cheyenne, the ssme formations are still present, only hidden by the mass of detritus brought over them from the mountains.

Around Oheyenne the predominant formation is a thick bed or a suc.

cession of beds of conglomerate sandstone of the same composition and in the same position as the conglomerate of Gehrung's or of Monument Park in Colorado. It here overlies, as at Gehrung's, thick beds of black 
bituminous clay 15 to 20 feet thick, as exposed to the level of the creek. The difference in the compounds of these conglomerate strata is merely in the larger size of the pebbles, which at Oheyenne vary from the size of a pea to that of the head, and in the presence of thin bsds of fresh. of a pea to these of very limited extent, similar in composition to the calcareous clay-beds at the base of the Green River group. I found in these conglomerates two pieces of fossil-bones, the only traces of fossil-remains which I was able to recognize in this peculiar formation. Though I cannot positively say as yet if it closes the Lignitic period, and is therefore a member of this formation, its peculiar identity of position and of composition is worth remarking. A boring of a few hundred feet at Cheyenne would settle the question and show if, as I believe it, the Lignitio beds may be found there at a depth of 200 to 300 feet. Anyhow, all what we have seen as there at a depth of 200 to 300 feet. Anyhow, all what we have seen as
zet tends to confirm the statement already made by Dr. Hayden in 1868, (Sillman's Journal,) " that all the lignite Tertiary beds of the. West are but fragments of one great basin, interrupted here and there by upheaval of mountain chains, or consealed by the deposition of netcer formations."

\section{\$5. Cherpane to Canbon Station.}

Along the Union Pacific Railroad, from Cheyenne up the Laramie Plains, the country has been explored by Dr. Hayden, who, in his report, $(1870$,$) describes the passage from the primitive rocks, and marks$ fopthe Cretaceous, its confurther upo the plate to the Test 1 number of specimens sent to me its limits to the Trest in former years for examination, being labeled as from Rock Creek and Medicine Bow, I expected to find at these localities, at least some isolated basins of the Lignitic. This indication was a mistake; for, indeed, the Cretaceous strata are continuous along the railroad to four miles west of Medicise Bow, where they are seen abruptly passing under thick west of the Iignitic barren sandstone. Thongh I did not find any fossil-plants at Rock Creek, my visit there afforded me a good any fossil-plants at Rock Creek, my visit there afforded me a good opportunity of studying in the country around, the upper groups of the differences in the characters of both the upper Cretaceons sandstone and the Iignitic sandstone over it. Besides, the great quantity of reming of invertebrate animals, especially abundant in the upper Creremains of invertebrate animall especilly abotis of the forma representing deepmarino species characteristie of the forma tion-Ammonites, Scaphytes, and Baculites, \&c.-the matter itself, a kind of sandy calcareous shale, appears at first sight far different from that of the fucoidal sandstone. The color of the first is dark-brown or yellowish-brown, the texture finer-grained, mixed in some places with calcareons inflitrations; the banks, when exposed along the creeks calcar or cut by erosion, do not weather ing roun, conter break in largo cubic pieces, or separate in shaly layers, forming, by disintegration, heaps of broken fossil-shells, of angular fragments of rocks and of dust rather than sand. At Medicine Bow, the-line of connection of both formations is perhaps more difficult to fix than at other localities, the fucoidal sandstone here being mostly barren of remains of marine plants. Bnt from its base to its top, in a thickness of remains 200 fet, it is barren, too, of any remains of animals, while here perhaps 200 feet, it is barren, too, of any remains of animals, while here and there, branches of fucoids appear, as thrown by the waves, being generally mixed with fragments of wood and stems of dicotyledonons plants. From the cut of the railroad west of Medicine Bow, where this plants. Frome is seen overlying the Cretaceous, and where two, fine mineral springe come out from its base, it is continnons to Carbon in repeated and deeper undulations, forming basins, which at this place and around, contain the upper Lignitic formation with remarkably thick beds of combustible mineral. The coal is mined at Carbon Station by a shaft descending through the following strata:

1. Bhale, clay, and sandstone, at top Toot.

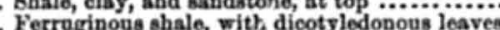
3. Clay, shale, and sandstone, with the plants at top... 4. Coal, (main)

6. Coal

7. Coal ...

Coal

-101

In following the railroad to about one mile west of Carbon, the upper coal is seen exposed in a cut, under a thick layer of compact, gritty sandstone, resembling the millstone-grit or the Mahoning sandstone of the Carboniferous formations, not only by its composition, but by the quantity of pieces of wood or streaks of coal mixed with it at its base. The wood is either petrified (not silicified) or transformed into coal, forming irregular thin layers which pass into the sandstone in varions directions, sometimes ascending nearly vertically one or two feet high, and abruptly disappearing. This bank, too, has in some irregular small cavities pebbles of sandstowe; even fragments of rolled wood transformed into coal, indicating its formation as that of a beach where the waves brought with the sand and imbedded into it materials of various kinds. Above this sandstone are beds of fire-clay with silicified wood, overlaid by thick layers of sandy shale, with fossil-leaves of dicotyledonons species, the whole topped by another thick stratum of coarse conglomerate sandstone. In the rubbish along the railroad I found one specimen of fucoid. I should have liked to examine the country with more details, especially in order to compare the distribution and the composition of this upper conglomerate sandstone with that $c$ \& the upper member of the Lignitic of Colorado, and thus to possibly recognize an analogy of formation. But my attention was claimed by the examina. tion of fossil.plants fonnd at Carbon in great quantity, and my whole time had to be grein to their study. These plants are obtained fron two horizons: No. 2 and No. 5 of the section, separated by 35 to 40 feet of measures.

\section{Carbon to Black Butte Station.}

From Carbon westward the country and its geological characters and modifications have been, too, so exactly and minutely described by Dr. Hayden in the same report of $1870, \mathrm{pp} .134$ to 140 , that, besides $\mathrm{my}$ paleontological researches, I had, in following the railroad to Evanston, iittle else to do but to record by comparison the exactness of the geological facts and descriptions already published. It was the case at Rawling's Station, the first place where I stopped, after passing Carbon, to examine what had been indicated to me by Mr. William Cleburn, civil engineer of the railroad, as "peculiar rocks, containing an immense quantity of fucoids," which, from description, I supposed might indicate

- For the commanication of this nection and other valuable information, my thanks are given to Mr. J. Williams, the able superintendent of the Carbon mines. 
perhaps the presence of the Lignitic at that locality. These rocks, a kind of siliceons, reddish-brown sandstone, hardened by metamorphism, are exposed in a thickness of 200 to 300 feet in bluffs on both sides of the railroad, half a mile west of the station. They overlie the upturned railroad, half a mile west of the station. They overlie the upturned edges of granitic rocks, which come to the surface one mile farther north,
and, indeed, they contain an immense abundance and variety of fucoids, without any traces of animal remains. I bave never seen plants of this kind fllling rocks in auch quantity, except in some ferruginons shale of the Devonian of Ohio, or in some groups of the Silurian of New York and Pennsylvania, the Trenton and the Clinton groups.

These marine plants belong to types far different from those of the fucoids of the Tertiary. This is immediately recognized, especially in their large size, as remarkable as the quantity of their remains. Some branches or trurks measure more than half a foot in diameter, while their ramifications, fllling the rocks and crossing the layers in every direction, caver large surfaces by a confused mass of flaments. They look like heaps of sea-weed crushed, flattoned, and petrified at the same time. The large-sized trunks of these plants are generally found near the base of the formation, or in close proximity to the granite rocks, while at a higher level the shales are mostly covered with small species, perhaps mere branches of the large ones. Some of these, as far as they can be recognized, are referable to Chondrites antiquus, Sternb; Buthotrephis succulosus and $B$. flexuosus, Hall, all species of the Silurian. But, as said above, they are mixed in such a way that the ascertaining of their specific characters would demand much time for a carefn study, which can be made only in place, small broken specimens being useless for that purpose. But if even I had been able to determine specifically a number of these plants, our acousintsnce with the fucoids of the old formations is as yet too limited to afford reliable points of comparison, aud therefore it wonld not be pessible to refer those of Rawlings to a peculiar division of the Silurian. That they belong to the Silurian epoch is all that can be ascertained, and thus the opinion of Dr. Hayden on the age of these fucoidal rocks is corroborated by paleontological evidence.

The same kind of fucoidal remains are seen also, but far less abun. dant, in the rel rocks overlying the primitive formations in Colorado as, for example, in passing up Glen Eyrie from what is called the Gar. den of the Gods. These plants may be remarked in the fragments strewn along the borders of the run. The formation is evidently older than that of the upturned red rocks which form the inclosure and the monuments of the garden. In these I did not find any fossil remains of any kind at this locality; but near Cañon City, from the upturned ridge of red and white sandstone from under which the soda-springs gurgle out, and which, from their position, are referable to the same formation, I obtained a few fraits of the genus Trigonocarpum. With some rare fragments of Calamites, recognized too in these rocks, they would indicate their age as true Carboniferons or Lower Permian. In crossing this ridge along Oil Creek, east of Cañon City, the underlying strata from which the bitumen there percolates, mixed with the water, are mostly beds of black shale, which appear referable to the Devonian, at least from the analogy of their compound and color. I do not know that any kind of fossil has been reinarked in connection with them, and this, too, is a point of analogy with our oil-bearing Devonian black shales, so extensively developed from Arkansas to Pennsylvania, and recognized everywhere by their geological position and the large propor- tion of bitumen which they contain, though mostly barren of fossil re. mains.

From Rawlings, still on the line of the Union Pacifle Railroad, the Lignitic formation soon comes up, bordering the belt of the Cretaceons which passes southward, and at Separation, ten miles west, a bed of coal, reported 11 feet thick, has been opened and then abandoned for a time on account of the difficulty of mining it, and of its distance from the railroad. At Creston, fourteen miles farther west, no coal has been found exposed, but a bed of lignite has been passed by a boring at 83 feet from the surface. The coal is reported 4 feet thick and of good quality. Here the strata are nearly heizontal, and it is probably the same bed which thirteen miles farther west, at Washakie Station, is indicated by a boring as being $3 \frac{1}{2}$ feet thick at 120 feet from the surface. As Washakie Station is 333 feet lower than Creston, this difference, with that of the distance from the surface to the coal, would indicate a dip to the west of about 30 feet per mile. The records of this last boring, which I owe to the kindness of Mr. John Denover, station-agent, further indicate a stratum of red paint 20 inches thick at 180 feet, and then a racuession of beds of soapstone alternating with beds of white sand. stone to 675 feet, where water was obtained. The beds bere called soapstone did offer to the bore as much resistance as, if not more than, white sandstone. Though no positive evidence can be drawn from these records, it appears, however, that the thick formation of white sand. stone, interlaid by beds of hard clay shale, represents the sandstone formation of the Lower Lignitic. Geuerally springs, mostly of mineral water, flow out at its base, near its line of superposition to the compact and impermeable clay-beds and black shale of the Upper Cretaceous.

\section{Bl.ack Butte to Rock Sprng.}

In following the railroad from Black Butte westward, the Lignitic formation, already seen at the surface of the country from below Bitter Creek Station, forms an irregularly broken ridge, whose general dip toward the east is varied by low undulations. In that way the measures slowly ascend to Point of Rocks, where they orerlie the black shale of the Cretaceous No. 4, there constituting the axis of an anticlinal, which is cut, below Point of Rocks, by the meanders of Bitter Creek. The counterface of the axis appears westward in correspoading strata after passing Saltwell Valley, and hence the dip to the west brings to the surface the upper strata of the Lignitic at Rock Spring. The section of the measures is perfectly clear and exposed in its whole length. At Point of Rocks, and near the highest part of the anticlinal axis, the Cretaceous strata are exposed 80 feet in thickness, immediately and conformably overlaid by 185 feet of the Lignitic sandstone which from its base bears fucoidal remains. It has moreover the composition, mode of disintegrations, \&c., remarked already in the same formations at the Raton. East of the station, 25 feet above the base of this sandstone, there is a bed of coal 8 feet thick. Farther east, at Hallville, a Iignitic bed, overlaid by shales vhere are imbedded a quantity of fossil-shells, is worked near the level of the valley at a short distance from the rail road. At Black Buttes a bed of lignite is worked, too, above the Eocene sandstone, as indicated by the following section taken from the railroad, half a mile east of the station

- For further details on the geology of that barren and wild country, see Dr. F. v. Hayden's Report, 1570, pp. 139, 140 
From base upward:

1. White sendstone coneretionary, weathering in cavities, with abundance of fucoils . ................................................... 2. Shale and

4. Black, sof laminated shal

5. Firo-clay, gray and chocolate colored

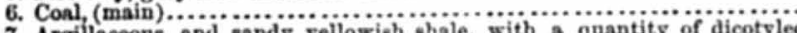

y yellowinh abale, with a quantity of dicotyled.

onous leaves.

9. Argillaceous shale atd clay.

10. Shaly sandstone, often ferruginons.

F. In. $\begin{array}{rl}118 & 0 \\ 16 & 0\end{array}$ $\begin{array}{rr}16 & 0 \\ 4 & 0 \\ 10 & 0\end{array}$ 5 年

Above this, and on the vther side of the b.lls toward the station, the and with the characters indicated for No. 1 of the section, ascends to the level of this section, does not contain any coal, and is overlaid still by about 50 feet of measures, mostly shale clay-beds, with fossil. shells mixed with plants. There is, too, a stratum of ashes or baked clay, where bones of a Saurian, shells, dicotyledonons and Sabal leave are mixed in been pieces, fragments of bones, shells, and fossil-leaves. About at the same pieces, fragments of bones, shells, and fossil.leaves. Atout at the same of baked red sbale, where specimens of dicotyledonous leaves and small shells are also found mixed together. In the strata marked on the section, other kinds of remains, too, have to be mentioned. The sandstone No. 1 of the abore section has fucoidal remains beautifully preserved. One specimen of Palimenetes is seen in an erect position preserved. One specimen of Halimenetes is seen in an erect position wide, as clearly defined upon the vertical face of the sandstone as if painted there by hand. It is upon a large detached block quite near the mine on the side of the railroad. The sandstone itse!f, fl.ll of round concretions varying from the size of an egg to chat of the head, is molded and dug by weathering in still more diversified anci remarkable forms than the same sandstone at the Raton Mountains.t In the hills forms than the same sandstone at the Raton fountains. in the depot, its walls are dug into a multitude of niches of every size and form, which the children of the station use as store-rooms for play, and where they expose, as in cabinets or shops, the vatious and curiously molded concretions found around in the sand. And above the main en spect in the Tertiary formations of ours, and this in profusion. Indeed the whole country at and around Black Butte offers rich mines of interesting and valuable materials for the $\boldsymbol{s}^{*}$ ndy of the geologist and paleontologist.

At Rock Spring, as said bove, the upper strata of the same formation come to the surface, and there a splendid bed of lignite 8 to 9 feet thick has been worked for a long time, from just above thick banks of white fucoidal sandstone. In this sandstone the remains of marine plants are as numerous as at Black Buttes, and as well preserved, too. This sandstone, from the section given below, is, with its alternate beds of hardened clay shale, about 100 feet thick. Most of its strata are

- A large Dinosaurian discovered by Professor B. F. Meek, and dug ont ' 1 pieces by

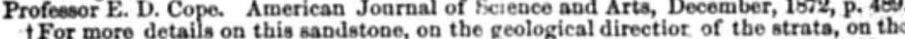
TFor more details on this sandstone, on the geological directiot of the strats, on tho
distribution of coal-beds, \&ce., from Blark Buttes to Roek Springs, see Dr. F. V. Hay. den's Report, 1870, pp. 140-142. exposed in the hills southeast of the station. Some of them have a few fossil dicotyledonous leaves. They overlie the bed of coal marked 4 feet in the section, the Van Dyke bed, which is opened and worked near the railroad, two miles east of Rock Springs.

When I passed Rock Spring a boring for an artesian well was still in progress and had already reached 1,180 feet. Mr. Frank F. Phelps, to whom I am indebted for many kind offices and valuable information, gave me the following records of this boring. Though the nature of the strata separating coal.beds is not marked, some interesting deductions may be furnished to discussion by the succession of the measures.

At 7 feet from surface, after passing sandy soil and black shale:

1. Main coal F. In.

At 117 feet, after beds of hard sandstone, shaly sandstone, and soapstone,

intercalated:

2. Coal worked two miles east

3. At 149 foet, coal

4. At 268 foet, coal 324 feet, coal

6. At 353 feet, coal

7. At 377 feet, coal

8. At 420 foet, coal

9. At 447 foet, coal

10. At 476 feet, coal

11. At 485 fert, coal

12. $\Delta t 577$ feet, coal

13. At 606 feet, coal

15. At 668 foet, coal

16. At 708 foet, coal

Between ell these coal-banks the strata passed through were constantly soapstone and sandstone; the soapstone looking like blue fire-clay, but more difficult to pass with the bore than the sandstone. From 780 to 1,180 feet, the depth reached when I was there, the strata are merely white sandstone, alternating with shale.

This record secms to show an extraordinary or abnormal development of lignite-strata. We have here sixteen berts of this coal, measuring in the whole 48 feet in thickness, in little more 700 feet of measures. This, however, is not different from what has been seen elsewhere already, in some exposures of the upper Lignitic formations. The section at Marshall's, as published in Dr. F. V. Hayden's Report, (1869, pp, 29 and 30 , marks eleven beds of lignite, which, taken all together, measure 63 feet, and this in less than 600 feet, of strata, overlying the lower sand stone and exposed above surface. There is merely at Rock Springs an increased thickness of the sandstone-beds, which is normal, and is easily understood in considering the mode and development of the Lignitio formation.

From Rock Springs to the base of the bills north of the station, six to seven miles distant, the bottom of the valley is nearly flat, bordered by low ridges of shaly sandstone, passing to mere hillocks, and then to sand and clay detritus from the northern, hills which overlie here the Lig. nitic. They belong to the Green River Group of Hayden, and appear in deed to form a distinct, well-characterized division of the Tertiary. My purpose in visiting these hills was first to see a remarkable stratum, mere componnd of shells zlned together by ferruginons and calcareons clay, the whole mass mostly silicified. These molluscs, generally small, appear fresh-water species, and of more recent types than those which I had found in the black shale over the main coal of Rock Springs. 
But I was especially anxious to ascertain if the conglomerate formation, remarked at the other localities, had here left some traces as indication of its superposition to the upper Lignitio strata. Ifothing like it is seon either at the top of the hillocks or in the broad bottorns of the valley in crossing it northward in a direct line from Rock Springs. Near this station only, the top sandstone is, here and there, strewn with loose pieces of silicified and finely opalized wood; but I have seen no pebbles with them. This exploration, however, was too rapid and superfieial to afford positiva evidence. It should be repeated under more favorable circumstances, and pursued in different directions, especially toward the upper end of the valley.

\section{8, Green River Station.}

All that can be said in a general way on the succession and the com. pounds of the strata of the Green River group is already published in the reports. As I shall have, however, to remark upon the composition of the numerous beds of bituminous shale of this formation in exam. ining the value of the combustible mineral of the Lignitic, and also to consider the relation of the fossil-plants which have been found in some of its strata, it is convenient to have for future reference a detailed sec. tion of the measures. The following is taken from near Green River Station, where the succession of strata is clearly seen and exposed in a comparatively great thickness. This section is from top of Pilot Hill downward.

1. Hard, red ferruginous sandstone in layers..................................
2. Sbaly, reddish, laminated argillaceous sandstone, with abundant remains of

Teet.

fishes ..................................................................

4. Re: shaly sandstone.

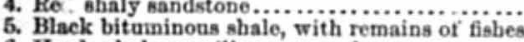

6. Hard, sbaly, argillaceous sandston

7. Black bituminous shale in bank

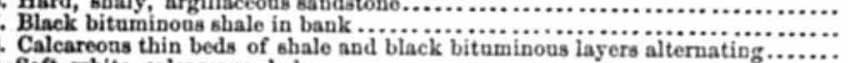

9. Soft, white, calcareous shale.

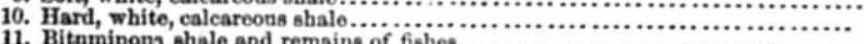

12. White, soft, calcareous shale.

14. Clay sbale, topped by half a foot of bitumin...................

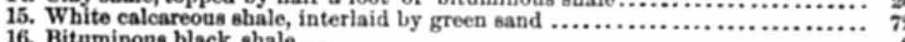

16. Bituminons black shale...................................................

17. Argillaceous ehalo...

18. Sandstone shale ...................

20. Shaly sandstone

22. Ferder laminated abale, mixed bodis..............................................

24. Fard calcareons rock .......................................................

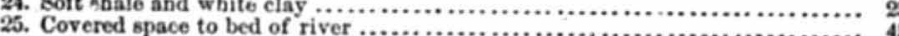

$\overline{548}$

This section indicates a thickness of about 40 feet of bituminons matter distributed in thin beds, besides the 70 feet thick bed No. $8, \mathrm{com}$ posed of alternate layers of calcareons and bituminous shales. All these shales are more or less impregnated by bitumen, and sometimes so much charged with it that it percolates through rocks of sandstone nnder them. As atmospheric action vaporizes and dissolves the bitnmen the exposed faces of the strata are generally whitish, and do not show on the ontside the appearance of their composition. But when cut into a few feet deep, the shale are found as hard and as black as eannel-coal, breaking in even fracture without marks of lamination. This has caused a great deal of useless researches, borings, and tunnelings, from unreliable re. ports on the presence of true coal at various localities around Green River Station. From my own exploration of these formations, I am satisfied that they do not have any bed of true lignite. The shales are, however, valuable, and may yield by distillation an amount of bitumen large enough to be remunerative, when this matter becomes available to some purpose in the distant localities wiere it is found. This bitumen appears to be essentially the result of the decomposition of animal matter. I have looked in vain in the shales for remains of vegetables. In the lowest stratum only, No. 16 of the section, 1 have found an obsenre im. pression resembling a leaf of grass or a narrow flattened stem, rather referable to some fresh-water plant than to a marine vegetable. From the thinness of the strata of the Green River group, their extreme diversity, their multiplication, and their compounds, they seem to be the result of deposits in skallow lakes where materials were originated and mixed. These lakes were inhabited by a prodigions.quantity of fishes, which, destroyed at repeated periods by dronght, bave partly furnished the bitumen to the shales where their skeletoni wre proserved. Whenever I had time to search for them, I have scarcely failed to f nd traces of fish-remains in the numerous beds of bituminous shale which I have examined. It is probably to the periodical drain or desiccation of these lakes, to repeated variations of level in these fresh.water basins, that is due the absence of beds of lignite; these changes having prevented the heaping, preservation, and slow maceration of vegetables, which are obtainable only under the permanent influence of water. The alternations of submersion and drougth, on the contrary, cause a total decomposition of vegetable remains resulting in the formation of mud and clay. Even ani. mal remains, especially small mollusks, are affected and soon destroyed nuder the same influence. The records attest that in Denmark, some shallow lakes have been thus flled in four years with two feet of calcareons clay by the decomposition of Characeae and thin-shelled $O y$ oles and Physas. Fossil dicotyledonous leaves have been found in yellow elay shales, near Green River Station, and have been already described. As yet, remains of this kind appear very rare in this formation.

\section{9. Evanston.}

A good description, with fine sections of the lignite-beds of this locality, has been given by Mr. A. C. Peale, in Dr. F. V. Hayden's last teport, $(1871$,$) p. 194. I have nothing to add to the observations most$ carefully made and to the details given on this remarkable deposit of combustible mineral, but wish only to make a few remarks on the dis. tribution of the strata overlying the lignite-beds, especially in rogard to the conglomerate formation which tops the hills. The sections of Mr. Peale go to the top of the upper coal-bed. From this, in ascending order, the following strata are exposed in the hill above the works of the Wyoming Coal Company:

$$
22 \mathrm{G} \mathrm{s}
$$


1. Argillaceous shale, with ferruginous concretions.............................. nous leavee

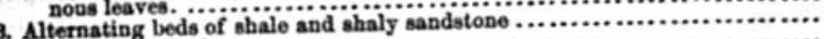

3. Alternating beds of

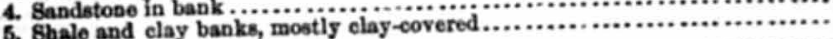

6. Bituminous ola

7. Conglomerate, lower bank

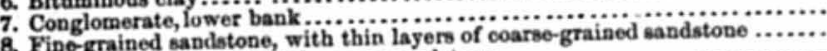

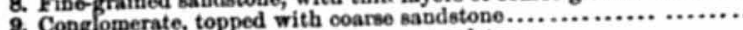

9. Conglomerate, topped with coarse sandatone

10. Hard, yellow, fine-grai

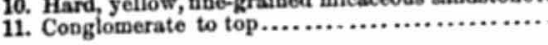

In these 547 feet of measures above the coal, the upper part, mostly In these 547 feet of alternating with sandstone, is 168 feet. Comparing conglomerate strata al Colorado Springs, above the Gehrung coal, this section to that of Colorado Springs, ab Lignitic formation, we where the same kind of conglomerate tops the Lignitic formation, we cannot but find a remarkable analogy, not to say identity, between both. At Colorado the conglomerate, as should be expected from. the greater distance to the point where the materials have originated, is composed of smaller pebbles. The thickness of the same measures is, too, rednced by erosion. But the relation and alternance of the strata too, reduced by erosion. But the said of the Upper Lignitic of Cañon City is similar. The same can be said of the Upper Lrgum this, and also from and of other localities reported by Dr. Hayden. From this, and also from the conformability of these conglomerate beds with those of the Lignitic which they overlie, I am disposed to consider them as of the same age and as marking the close of the lignitic group. The easily recognized the strata is especially remarkable at Lich vertically and sloping northeast by a dip of about $10^{\circ}$. If, as it has been supposed, this conglomerate formation was more recent and had covered Tertiary strata of different groups, this alternance of conglomerate with sandstonc strata, in pergroups, this alternan the soft bituminous clay-beds which they overlie, is fect concordance to the sof bituer, however, will be afforded on this unexplainable. Further evidence, however, wrought up for this formaimportant question. The amount of materials brought up for this formation is beyond computation. They not ouly form the essential componnds of hills over wide areas, but their debris covers the plains for pound of miles around the nuclei which now stand as mere dwindled monnments of a wide-spread, as yet inexplicable agency. The pebbles monuments of a winston vary in size from that of a composing the conglomerate of Lraston as large as the fist pea to that of the head; the most comos They are all rounded, without exception true pebbles, as if they had been rolled by water for a long time. As at the other places where they have been remarked, they are of the same materials as those which now compose the mountain-ridges of the vicinity, and are glued together by a kind of calcareons cement, hardened locally by ferruginons intiltra by a kin.

Dicotyledonous fossil-plauts are fonnd in quantity in a bituminous shale overlying the upper coal of Evanston, and, too, in the sand. shales stones marked on the rections Nos. $2,3,4$. This building-materlals. On one of the blocks nsed for construction at the mines I saw a well-preone of the biocks thed genus, in served leaf of a Populss, larger than any as yes in length withont the a fossil state. It measured the coal, the leaves are crowded, heaped upon another, and though well preserved by a thin incrustation of coal upon their surface, they are rarely isolated, and their nervation, too, being seareely distinet, their determination is difficult and somewhat nucer tain. I did not flnd at Evanston any fucoidal remains. Thesecimer. obtained by Dr. Peale, howeres have in a bard, branches of a fucoid, (Halimenites major,) labeled from that locality.

\section{§10. Coalville, Utah.}

This place is known to me only from descriptions given by Dr. Hayden, Mr. Hodge, and other explorers. No fossil remains of lavd-plants have as yet been obtained from strata in connection with the Liguitic beds. Judging from the relative disposition of the coal-beds, their thickness and their chemical compounds, I have been disposed to cosider them as equivalent to those of Evanstot. Professor B. F. Meek's ob. servations, however, as published in th is report, indicate for the geology of Coalville a series of Lignitie strafa with intermediate beds, clay and sandstone, bearing remains of evidently Cretaceous animal species, there. fore tending to refer the whole series to Cretaceous. Except the fucoid species, abundantly found at Coalville by the same observer, we have no botanical evidence to bear upon the question of the age of these strata. I believe, nevertheless, that this case is of the same nature as that of Black Butte, where Cretaceons animal fossils are found hundreds of feet higher in the measures than thick beds of lignite, immediately overlaid by shale. bearing remains of plaats positively of Tertiary age. Facts of this kind have to be judged from a general point of view, in considering the evidence of general relation. For, indeed, in a formation like the Lig. nitic, which may be called a formation of transition, the evidence given by vegetable and animal paieontology, or by laud and marine remains, can but disagree sometimes.

THE WESTERN LigNitid FORMATION CONSIDERED AS EOCENE.

Dr. Hayden in his reports bas coustantly alluded to the Liguitie group, especially to the barren sandstone underlying it, as to beds of passage or of transition between the Cretaccons and the Tertiary, often mentioning them as Eocene. No formation is exclusively limited in its char. acters, at least not in those which are supplied by fossil remains. On this account, every geological division might be considered as being a transition, and this is especially the case for the trata intermediate be. tween a marine and a land formation; as, for example, in the Carbon. iferous epoch, to which our Lizuitic has so many points of similarity. Devonian animal fossils ascend to the Subcarboniferous, or even to the true Carboniferous measures, which have also species of invertebrate animals characteristic of the Permian; and the plants which have eutered into the composition of the coal are found already, some of them at least, in the Middle Devonian, the Hanilton period; while the most common species of ferns, even of Sigillaria of the Carboniferons, have left traces of their presence high ap in the Permian. The same might be remarked on every other artificial group, which geologists have to fix for convenience and better understanding. The discussion, therefore, on the age of the formation called Eocene, and now under con. sideration, shonld not admit as evidence isolated facts in contradiction to the persistence of general characters observed orer wis in great thickness of strata, and which give to the whole a kind of 
homogeneity in correlation with the forces which have, at the same time, modified the surface of our earth. The Upper Cretaceons, from indications of the remains of a deep marine fauna, is positively characterized as a deep marine formation. Inmediately over it, the sand. stone shows in its remains the result of the npheaval of a wide sur. face, exposed to shallow marine action, as indicated by fucoidal life. The upheaval continuing, this area is bronght out of marine influence to be exposed to that of the atmosphere. It is a new land, cut in basins of various size, where fresh water is by and by substituted to brine, where vegetable life of another character appears, where swamps are filling with clay by floating plants, where peat-bogs in their growth form deposits of combustible matter, \&c. To suppose that the marine action is totally banished from such a land would demand the absurd admission of an absolutely flat surface. Of course estuaries penetrate into it at many places; their waters feeding marine species, brackish shells; their bayons inhabited by Saurians, and their remains are mixed with leaves of the trees growing on the borders and preserved together in a fossil state, without impairing the true character of the formation by what paleontology considers as types of different ages. The surface of the Eocene sandstone, before its separation from marine influence, was of course uneven. This sandstone has therefore the gen. eral characters of the Eocene, while in some troughs, Cretaceous species, still living in deep water, may bave left their remains in the sand. Even if these remains were numerous, their presence does not change the age of the formation. But on this subject, and in comparing our Bocene sandstone to the other groups established by geology, we find, in its abrupt and permanent separation from the Cretaceous, its lithological compounds, its total barrenness. from animal remains, at least generally, and the homoger ity of its flora, reliable and constant char. acters better defined than in any geologieal division admitted by science. This sandstone formation is inexplicable. It can be compared to noth. ing but to the millstone-grit of the Carboniferons epoch. How to explain why, at once, animal life seems to disappear from the bottom of the oea, to be superseded by marine vegetation 9 May this change have been caused, perhaps, by a rapid increase of temperature of the water brought up by the force acting to the upraising of the bottom into land, and afterward into chains of monntains?

Though it may be this change is evident and proves the geological discrimination of the Eocene sandstone from the Cretaceons, a scparation the more remarkable that, from numerous observations, this sandstone is reported constantly conformable to the Upper Cretaceous beds. As Dr. Hayden remarks in his description of the Lignitie group of Nebraska, "When we bear in mind the fact that wherever this formation has been seen in contact with the latest Cretaceons beds, the two have been found to be conformable, however great the upheavals and distortions may be, while at the junction there seems to be a complete mingling of sediments, one is strongly impressed with the probability that no im. portant member of either system is wanting between them."

This intimate connection of two sandstones of different ages appears to be of frequent occurrence along the Pacific shores, aud to have cansed some difference of opinion, and some confusion too, in reference to the age of these strata. Professor Gab, in a very valuable paleontological document, published in vol. 3 of the Proceedings of the California - Geological report on the explorations of the Yellowstone and Missouri Rivers, 1860
and $1860, \mathrm{p}, 30$.
Academy, page 305 , remarks, on the lower sandstone, " that it hes often been cons'dered as Eocene, but that it is proved to be of Oretaceons age by the large number of Cretaceous species which it contains, these already resembling Tertiary types." Headds, however, that these Upper Cretaceons strata are "everynohere overlaid by an immense deposit of non. fossiliferous sandstone." It is this lasi non-fossiliferous sandstone which belongs to the Eocene. It has in California the same characters which mark it on the esatern side of the Rocky Mountains. Professor Gab has found fucoidal remains in it. It has been seen all over California at the base of the Coast Range, and I believe that the lignite-beds from Oregon southward, evan from Vancouver's Island, will be recognized in the Eocene, fortned as at other localities, either near the base or within or above the sandstone. - The objections against the Tertiary age of the Lignitic are partly answered by these remarks. They have, however, to be considered in detail.

To .ny knowledge only two specimens of Cretaceons fossil have been as yet found in the Eocene sandstone of the Rocky Monntains and in strata overlying it, sonth of Golden. One specimen of badly preserved Inoceramus was seen at or near the base of the Eocens sandstone, by Dr. F. V. Hayden, and still another badly preser.ed specimen of the same genus was found by Dr. John Leconte $\because$ a bed of sandstone, over. lying the Lignitic beds of the Raton. It is useless to argue on the chances which may bave brought these ramains at the places where they have been found. These cases are exceptional and unimportant. Large companies of explorers have passed the same localities withont discovering any other marine fossil mollusk in these strata, and I have myself carefully searched the indicated stations with the same result. It is otherwise, however, with the beds of oyster and other shells remarked in great abundance from Rock Springs to Black Batte, where, too, the bones of a large Dinosaurian were found mixed with fossil-shells and dicotyledonous leaves, and which have served as anthority to many geologists for their opinion on the Cretaceous age of the strata.t The opinion of Professor Meek on this subject is especially to be considered, as be has not only given much time and care to the determination of the fossil-shells, and has himself visited the localities, but is so cautious and careful in coming to his conclusions that they merit full confldence. Now, in a letter on this subject, the celebrated professor remarks: "Looking on these invertebrate remains alone and aside of all other facts, I could scarcely doubt from their affinities that they are Eocene-Lower Eocene. Yon see there are none of the characteristic: Cretaceous genera of mollusks among them-no Inoceramus, no Ammon. ites, no Scaphites, no Baculites, not a trace of any of the long list of Cretaceous or older genera, which might be mentioned, while a majority of the forms are most nearly allied to the Eocene types, specifically." Against this evidence Professor Meek remarks on the relation of shells of the same kind found at Coalville and at Bear River, belone evident Cretaceous species.

- In a late paper, Profeseor Dawson, of Montreal, considers the fossil plants of Van couver's Island as Tertiary. 1 already came to the same oonelusion after the examination of the foesil plants of Dr. T. Evans, as published in American Journal of Beienee and Arts, vol. XXVII, May, 18 ? Pago 362 . This opinion was controverted afterwar by Dr. Newberry, who referred the Lignitio formation of Vanconver to the Creteceous coal. My remarks on Blockbutte, Cosiville, \&ce, are apparently applicable to VantAmerican Journal of Seience and Arts, December, 1872, p. 489. 
To my opinion, this fact is of great weight in discussing the question of the age of these formations. For the presence of deep marine species in strata overlying remains of more recent ones indicates a local subsidence which should be considered as an exceptional case, unimportant indeed in comparison to the persistence of general characiers. Beds of lignite of Eocene age may have been formed at a higher level or befor this supposed local subsidence. And, of course, as resulting from it and from a subsequent upheaval, fucoidal remains mixed with Cretaceon. shells; and Cretaceous saurian bones, too, with brackish mollusks and dicotyledonous leaves of the Eocene, wonld be in a position, if not ex. actly normal, at least easily explainable.

Professor F. B. Meek's letter furnishes another point of evidence on the same question, in his remarks on a peculiar species of plant which he describes, ind of which be sent me numerons specimens. It is that fucoidal plant, Halimenites, which has been mentioned already as one of the essential characteristic species of the Eocene. He writes that he found it at Coalville, at least 1,000 feet below well-marked Cretaceous beds; that it ranges also through most of the Cretaceous beds of Bear River, and through the whole of the Bitter Creek series, nearly up to the Black Butte bone-level; that he saw it too at Carbon and in the Creta. ceous beds of Fort Steele. The range of this species is indeed from the base of the Lignitic to its upper strata, those of Carbon and of Evans. ton, and, therefore, we have at Bear Creek and Coalrille shallow marine plants aud lignite-beds under Cretaceous remains. These last chsracteristic documents, or the remains of Oretaceous age, are local, merely in isolated patches; the others are recognized over the whole extent and the whole thickness of the Lignitic formations. The question is, there. fore, reduced to this: Shall we admit as Oretaceous all these land forma. tions bearing from top to bottom evident Eocene characters, on acconnt of some isolated Cretaceous deposits locally spread over them; or shal we consider the whole as presenting general characters positive enough to force its separation into a new group and call it Eocene ? In this case we should have to consider the abnormal disposition of Cretaceous re. mains as resulting from local disturbances which are observable every. where in this central basin, both by repeated undnlations, pierced here asd there by eruptive rocks, bearing irrevocable marks of the diversifled action of the forces which have modifled its surface.

As I have not visited the localities, Bear River and Coal Creek, where the abnormal distribution of the strata has been remarked, the above arguments may be considered objectionable. But how caa we dispose of an evidence, forced by comparison between our Eocene strata and th ose of the Carboniferous epoch, where, as remarked before, we recognize facts similar to those now under discussion ? We do not and cannot call the coal measures either Devonian or Permian, on account of sonne fossils mixed in their strata, and identical to species of these different formations. Would it be rational to adm it that the Eocene shells and Eocene plants under the strata bearing Cretaceons fossil-remains may be so-called Eocene colonies, decended into the Jretaceous, that the lignite-beds underlying them represent an escaped member of the Eocene, bearing. as it does, in its flora, its compounds, \&c., Eocene characters; and that these Eocene members have become of Cretaceous age by this only reason
that some Cretaceons fossils are seen over them 1 As, legitimate would it be, I think, to admit our present epoch as Cretaceous from $t \mathrm{t}$ auimal of Cretaceous types brought up by deep Eoundings from the bottom of our seas. But this subject has to be considered under another point of view.
That the great Lignitic formation of the West belongs to a land formation cannot be denied, and is denied by none. It is, therefore, to the materials preserved from the land that we have especially to look, as most reliable records for the history of this geologieal division.

GENERAL CHARACTERS OF THE FLORA OP THE AMERIOAN EOCENE.

Before entering into this subject, a few words must be said in defense of the above assertion, which assumes, for vegetable paleontolenen importance too generally contested, at least on th's side of the Atlan'ic. The first specimens of fossil-plants from the Cretaceous of the West were discovered by Dr. F. V. Hayden in 1855 . They represented dicot. yledonous leaves, mostly different from the species as yet published or known from the Cretzceons of Europe. In order to fix, if possible their relation of age, sketches of a few of these leaves were sent to Professor $\mathbf{O}$. Heer, the most reliable authority for the determination of the vegetable remains of the recent formations. The celebrated professor referred these Cretaceous plants to the Miocene. This error has been unjustly considered and remarked upon as invalidating the evidence of botanical paleontology in relation to the distribution of geological groups.

The cause of the error was esseatially in the insufficiency of the ma terials furnished for examination. The mere outlines of leaves rarels give reliable characters for the determination of fossil.plants. The nervation has especially to be considered, and this easential character is not marked upon mere sketches of leaves, or can be correctly copied only by botanists of experience. A proof that Professor Heer did notget sufficient materials to enlighten his examination is, that Professor New. berry, who had opportunity to see the specimens, recognized at once from the study of their nervation, the character of Oredneria or of Cretaceons type, in a leaf considered by Heer as a Populus. In loth genera the leaves have the same form, but the difference of nervation is recognized at first sight. Could the celebrated professor of 8 witzerland have made the mistake if the specimens had been submitted to him ? But even if the materials obtained for comparison bad been suffieient, it is questionable if a European paleontologist should not have been misled in considering the general characters of our Cretaceons fors and therefore forced to admit the same conclusions. For nothing at all was then known of our Eocene flora, and the essential types of the Miocene of Switzerland, like those of our Cretaceous flora, have a greater analogy to those of our present arborescent vegetation, than to those of our Eocene. This, of course, conld but lead to the conelnsion that both are representative of a same formation. This cavse of error does not exist now. We have got materials abundant enough to afford reliable points of comparison. More than two thousand specituens have been examined from one Eocene strata, and a comparative largo number, too, from the from one Eocene strata, and a comparative largo number, too, from the
Cretaceons. The data exposed by the determination of the species are Cretaceous. The data exposed by the determination of the species are ogy. $\Delta$ few of these data have to be recorded here, though already partly considered in a former report.

Not a single leap has as yet been fonnd in on Eocene identical with a Cretaceous species. The genera especially represented in the Cretaceous are : Sassdfras, Credneria, Platanus, Salix, Liquidamber, Owerens, Populites, Liriodendron, Proteoides, Dombeiopsis, Acer, and Juglans. Wé can dispose at once of the genns Proteoides on seconnt of its a get unknown affinity. It has been referred, as its name indicates it, to 
Australian types, but from analogy I doubt if we may ascertain the presence of any of these types even in our oldest floras. Now, we havs in our Cretaceous, as more easily recognized by their likeness to living species, leaves of Sassafras and of Liriodendron, the tulip-tree. If I should judge by the profusion of leaves of Bassafras which $I$ have seen in the shale of the Dakota group, in the valley of the Saline River, and around Fort Harker, in Kansas, I would assert that inore than two-thirds of the vegetation of this epoch did consist of species of this genus. But then, as now, however, related species appear to have lived it groups, perhaps over limited areas; for at other localities Dr. Hayden found especially leaves of Liriodendron, Juglans, and of Platanus, gener scarcely represented at Salina and Fort Hariker. The gronps may stil differ elsewhere. The present remarks, however, must be limited to what is known, and Sassafras and Liriodendron have to be considered yetas the genera the most profusely represented in the flora of the Dakota group, even more, perbaps, than they are in that of the present time. The American Eocene has not yet shown any remaits positively referable to thes a gei.era. I have described from specimens marked "six miles above Spring Canion" the lower part of two leaves as, perhaps, referable each to one species of Sassafras and of Liriodendron; but such fragments cannot be taken into consideration for positive evidence in a compari. son like this. They may represent leaves of different affinity. In the Miocene of Europe, per contra, the above genera are represented by a number of species. One of each, Liriodendron and Sassafras, are deseribed from the Miocene flora of Greenland, and more from that of Germany and Italy.-The genus Credneria, or Pterospermites, appears to represent forms of leaves of a lost tspe. We have no representatives of it at our time, nor have any been seen in the Eocene. It has left its remains, however, in the Miocene of Greenland in four different species. Seeds, too, of undecided aftinity are ruferred to Pterosper. mites from the Miocene of Oeningen. The Eocene species of Platanus, at least the three splendid species described by Dr. Newberry-Platanus Haydenii, $P$. Raynoldsii, $P$ nobilis - bave no relation either to Miocene or Cretaceous types, which are mostly analogons to Platanus aceroides. This last species, however, like its relative, $P$. Guillelm $\alpha$, are as common in the upper American Eocene as the former ones are in the lower-Oof the species of Salix I have remarked already that they are more numerous in the Cretaceous than in the Eocene of ours. They re-appear more abnndant in the Upper Tertiary cronps of Green River.-Liguidambar, the sweet-gum, has one of its species in the Cretaceous. It has been described from one leaf only, but I have found recently a number of specimens of the same near Fort Harker. Our Eocene has nothing like it, while remains of one species, Liquidambar europeum, are found over the whole Miocene of the old continent, together with a large number of forms as ret donbtfully referable to this genus. Onr Cretaceons leaf is, perhaps, of this kind, on acconnt of the entire divisions of its leaves ; but this does not change its affinity to Miocene forms of Europe. Massalongo, in his Flora-del-Senigalliese, has described and figured a Liquid. ambar scarabellianum, with the divisions of the leaves entire, a form mnch like that of our Cretaceons species, only smaller; and Unger, in Flora of Sotska, has named Platanus sirii, a leaf still more similar to onrs. These leaves are consiciered by other anthors as referable to the genus Acer. This does not make any difference. They represent a type of
our Cretaceons and of the Miocene of Europe; as yet not seen in our Bocene.-It is the same with $A$ cer (maple) and Quercus, (oak.) They are marked in our Cretaceous, the first by Acer obtusilobum, with characters of leaves seen again in the Europenn Miocene, and at onr present time on both continents; the second by a species related to some varieties of our chestnut-oak, and by two others comparable by the form of their entire leaves to our shingle-0ak, (Quercus imbricaria, Michx.) Both these types are most common in the Miocene of Europe; but, like that of the Oretaceous maple, they have not as yet been observed in our Lignitio Eocene.-The leaves which I have considered as of a Juglans, and which Heer refers to Populus, $\boldsymbol{P}$. Debeyana, are of uncertain affinity. Their analogy has not yet been recognized out of the Cretaceons.

I could pursne to some length the examination of analogies of this kind, which may be considered as negative characters of the American Eocene. Besides establishing the remarkable relation of the American Cretaceous flora with the Miocene flora of Europe and the present flora of this continent, they serve to prove the disconnection of our Eocene flora from that of our Cretaceons, indicating therefore truly separate formations.

The positive characters of the same Lignitic flora more forcibly still elicit the same conclusion. From the beginning, in the examination of the sandstone of the Raton, I have recorded the great amount of fucoidal remains in this sandstone, as an essential character of its Eocene ago. The irr gularity of distribution of marine regetable remains in the geological groups has been remarked by every paleontologist. The oldest formation, the Silurian and the Devonian, have an abundance of them. The Carboniferons, except at its base, as also the Trias and the Permian, have searcely any. In the Jurassic they begin to re-appear, and their number increases upward to their maximum degree of distribution in the Eocene. Thus, while ten species only are known from the Cretaceous. thirty-five species have been already described from the Eocene of Europe. In our Cretaceous measures a single species has as yet been found, and this from the Fort Benton Group, near Fort Harker. It seems identical with Fucoides digitatus, Brgt., but it is as yet uncertain to what section of marine vegetables this form is referable. I found it upon pieces of limestone covered with the species of large mollusks characteristic of this gronp. Referred by Bronguiart to the Dictyotites, by Geinitz to the Zonarites, by Sehimper to the Jeanpaulia of the Marsileacex, by Schenck to the Ferns, it is as yet impossible to mark its true affinity. It appears aiready in the Dias, as seen from Geinitz's descrip. tion. Any how, it is of a character far different from any of those re. marked in our Eocene fucoids. From its association with the mollnsks of deep seas, it is clearly a deep marine species.

It is as yet too soon to enumerate, even approximately, the species of fucofds of the American Eocene. A few are described in this report. But by far the largest number is unknown, and will remain nudescribed for a length of time, on account of the size and the inextricable embedding of the largest species with the sandstone. They have to be stadied in place, represented in drawing 8 , and their description can be made only from these representations.

The Eocene of Europe is, in Switzerland and Germany, a formation of an immense thickness of soft black shale generally hardened by metamorphism and sometimes transformed into valnable slates. It is the Flysch. - In this soft-grained material the small thread-like forms of marine weeds, or the Confervites, are mostly fonnd. Onr sandstone is too coarse for the preservation of such flaments; its marine flora, how. "Dale Owen, who stadied it in Switzerland, compares it to the Manvalses Terree,
Report 6, page 208 . 
erer, has, oy its resnains, an analogy in that of the sandstone of the Eocene of Hount Bulea, where, as with us, the genera represented by thick coriaceous species, Caulerpites, Delesserites, Halimeniles, Munsteria, and Chondrites, are predominant. Perhaps it will be observed that we cannot attach great importance to the distribution of vegetable remains whose forms multiply in proportion to their divisions and are generally indistinct, and whose law of distribution is so little fixed that species from distant formations are considered by some authors as identical; from distant formations are considered by some authors as identical; Cretaceous as well as from the Silurian and from the Devonian. It would be easy to prove that as fast as these deep marine plants become better stadied, their characters are recognized and their specifications fixed, but this is out of the way of these researches. Some species of fucoils of our Eocene are perfectly distinct; their characters are as clearly marked as they conld be for any dicotyledoi ous fossil-plants. These, therefore, may be compared to the Mount Boica species, and, what is more to the point, their remains, from different localities of onr Lignitic, afford, by identity or difference of characters, reliable indication of the relation of the strata. I have named already a large species of Halimenites whose stem and branches are covered with half-round tuber. cules, and which is recognized at first sight. It is represented in the Pocene flora of Elrope by Halimenites reotus and Halimenites minor, botin intimately related to the $A$ merican species. And remains of this fucoid have been observed and specimens collected in our Lignitic formations from the base of the great sandstone to its top, even in sandstone. strata overlying the Lignitic beds everywhere over the whole area covered by this formation. Professor Meek has forud fine specimens of it at Bear Creek, near Fort Steele and Coalville. I can really say that I have not explored any station of the Lignitic without recognizing this species especially abundant at Black Buttes, where, as remarked already, spleucid specimens of it are embedded in the sandstone underlying the main coal.

The genus Delesseria, in the order of the Floridex, forms now by its nmerons and beautiful species a predominent character of the marine flora of our temperate zone. Its distribution extends between $30^{\circ}$ and $60^{\circ}$ of latitude, north and south of the equator, remarkably coin. ciding with that of the Lignitic formation on this continent. The first representatives of this genns are positively recognized, in Europe at least, with the Eocene formation. Of he eight fossil species known till now and described by Schimper in his Vegetable Paleontology, the seven first ones, whose relation to this genus is uncontested, belong to the Eocene. The only species mentioned from the Cretaceous, Delesseria Reichii, Schimper, is like that Fucoides digitatus, Brgt., of doubtful affinity, being named at flrsh by Sternberg, Haliserites, and then considered by Rossmisaler, Brown, \&c, as a fern. From our Eocene sand. stone eight species of marine plants only are described; of these three are true Delesseria-two from the Raton Mountains, the other from Golden.

Coming to the examination of land vegetation, we are met at once by the appearance in our Bocene measures of a class of plants, giving cridence of the age of these measures, fully as conclusive as that of the facoids. It is that of the palms, of the section of the Sabal. Scarcely any trace of thes o vegetables has been remarked in the Upper Cretaceous of Europe. There they become somewhat conspicuous in the Eocene, but their largest development is with the Miocene. With us they appear immediately above the great Eocene sandstone, or in con. nection with every bed of lignite formed within this sandstone, and show by the profusion of their remains the remarkable place which they have in the distribution of the flora of the Eocene epoch. Their fossi remains are most abundant in the Lignitic of Fort Union, where the largest leaves of Sabal have as yet been observed. At the Raton a good half of the specimens represent fragments of leaves, of petioles, of fruits of this species. At Golden they are found in the same proportion, and at Black Butte splendid specimens of palms are mixed portion, and at Black Butte splendid specimens of palms are mixed with dicotyledonous leaves in the shale overlying the main coar; while
the bed with Saurian bones and shells, about 150 feet higher in the measures, has Sabal leaves, too, less abundant, however, than the shale of the main coal. At Evanston, in the under sandstone, a quantity remains of the sam kind are a marked feature of the scanty flora as yet known from the Arkansas and Colorado Lignitic formation. It might be argued that if some remains of palms have been found in conuection with strata recognized as Cretaceous, these plants might as well be admitted as eharacteristic of Cretaceons age in our Lignitic. I do not know of a single case positively ascertained of palm remains in the Cretaceous. But even if we had any, their abundant distribution in the regetation of our Eocene is sufficient proof that this class of plants had already acquired Eocene is sufficient proof that this class of plants had already acquired
at that epoch a remarkable development. Its origin may be discovered later by scarce remains in the Cretaceous; its preponderance in the vegetation of the Lignitic attests a more recent formation.

The Tertiary groups of Europe are not as yet clearly limited. Many of the Lignitic strata which have furnished remsins of fossil-plants to European paleontology were at first referred to the Eocene. Unger, for example, places in this formation the fossil-plants of Radoboj, in, Croatia, of Haering, in Tyrol, of Parshlung, of Sotzka, now referred to the Lower Miocene. Thus, too, the Bovey coal of England, which was considered contemporaneous to the Eocene of Wight, is now admitted as Miocene. The Tertiary deposits have been formed in basins of limited areas, and therefore the characters of their flora are not identical, even for contemporaneous deposits, on account of the diversity of the even for contemporaneous deposits, on account of the diversity of the
vegetation at varions places and under various circumstances. This explains a difficulty of identification of strata which may be met per haps in trying to circumscribe the upper limits of our Eocene. As vet in this formation, homogeneity of the essential characters is recognized every where in its flora, and when it is compared with that of some locality positively ascertained as Eocene in Europe, it indicates, too, points of identity remarkable enongh. Such is the flora of Mount points of identity remarkable enongh. Such is the flora of Monnt Promina, where a fern found at Golden in splendid specimens is Rame paper a species of Myrica, whose leaves appear to have been found in profusion at the same locality, is described and figured, indi-

- Vegetable paleontology bas not any more recent and more positive records on thin subject than those furnished by Bchimper, (Veget. Pal., vol. ii, 1871.) This work do Flabellaria, twelve of which aro from the Miocene, ten from the Eocene, and two, Fle bellaria longirectio Uvo. ceons. Of these two species schimper says that the first, from the length of its rachis, is evidently a type of a peculiar genus, and that the other, whose rachis is unknown, cannot, on that account, be positively referred to any type. The anthor still describe: twenty-two species of palms in other gonera, all from the Tertiary, mostly Eocene and twenty-three known from stems only, and these, too, all Tertiary. Admitting all the references as exact, this makes sixty-seven speoies of palms described from the Tertiary, and two from the Cretaceons. 
eating such affinity with leaves also very abundant at Black Butte, that it is as yet uncertain if the American foria 'does not represent a mere variety of the same, differing only by the larger size of the leaves. We have at Golden Quercus ngustiloba, $\mathrm{Al}$. Br., described by Heer from the Bornstaedt Eocene, and in the flora of the same locality, as in that of Golden, remarkable predominance of species of Ficus and of Cinna of Goldentiary of Europe. Some of these momum, primitise types of the Thertiary pass, with the Sabal species, into the Mliocene; for, of course, the Tertiary formations, as land formations, removed from the influence of prolonged submersion in deep marine water, have, like the Carboniferons, a permanence of the types of their flora, marked by a number of species identical in the groups even of the more remote stations. This answers the observations made on the vegetable species already published in Dr. the obser Hayden's reports, and which European an of Eocene flora, not only homologous, but identical, with Miocene species of Europe.

This comparison might be pursued farther and with more details. These remarks, however, cannot be indefinitely prolonged. Those who may desire to compare more precise points of correlation or of difference between the flora either of our Eocene and that of the Tertiary of between the will find sufficient materials for this task in the table of distribution which closes the descriptive part of the fossil flora of this report.

THE AMERICA EOCFNE IDENTICAL WTTH THAT OP EUROPE BY GENERAL CHARACTERS.

I do not believe that the divisions of our geological gronps have to be controlled by European classifications. It is advisable, however, especially on account of the diversity of the conclusions indicated by botanical and animal paleontology, to mention still a few points o analogy remarkec in the distribution and composition of the Eocene of both continents.

The Flysh or Eocene of Switzeriand is mostly a componnd of shales, The Flysh or Eocene of Switzeriand is mostly a compound of shales, hero and there interlaid by sandstone strata of great thickness and pear. This formation extends all along the northern base of the Alpine chain in different degree of thickness, in proportion to the amount of denudation to which it has been exposed. It enters the valleys, especially dons them, in constant borders them, in contant and in ceons. On the northern base of the same chain, it is present, too, in basins of limited extent, where the Upper Cretaceous strata have been left for its support. The various strata of this Eocene formation are, according to their vicinity to primitive rocks, changed by heat to a cer tain degree, And the top of these measures is overlaid by a congloneratio tain der older formations, all collo rolled pebbles, and in pieces carying in size rom the the fist. - In this formation, too, valuable beds of lignite are found; and these, though not as richly developed as in the Eocene of this conti nent, have sometimes a thickness of 6 feet, and have furnished com bnstible materials for a long time. The lignite of Niederhorn, 5,700 feet above the sea, bas been worked since the former century, and is now nsed at Bern for the prodaction of illuminating gas. The Eocene group

$$
\text { - Herr Urwelt der Schweitz, p. } 241 .
$$

of tho Paris basin has also some rich beds oflignite. Does not this read like a true epitome of the descriptions given of onrEocene?

This brings forward again what I consider the last unanswered ques. t'on in relation to the distribucion of the American Eocene. Its base is e ferywhere ascertained as immediately resting upon the Upper Oretacous; the lower sandstone is recognized as either a massive homoge-
neous compound or as interlaid al different places by beds of lignite or of shale. The fossil flora, with some difference, has the same claraeters in the strata connected with these liguite-beds, at all the stations. The group is therefore satisfactorily limited so far, but where does it pass to a higher division of the Tertiary or to the Miocene? I have already remarked that I consider tive conglomerate formation seen at Evanston and other localities as the upper beds of the Eocene. But I have not myself found any positive proof of this assertion, and as these conglomerates have been referred to different groups according to the strata which they appear tr cover, the assertion is contestable. The observations, however, of Dr. Hayden, who, after years of careful field explorations, has become the true interpreter of the geclogy of the Rocky Muuntains, will supply this last evidence. In beginning his description of the Green River Group, and in marking its superposition to the Eocene sandstone, he says:

This interesting valley (Henry's Fork) is fllled with beds which show a perfect con. formity. The fint bed is a yellow-brown, rather fine-grained sandstone, dipping $75^{\circ}$ a little west of north. Then comes a series of yellow and light-gray arenaceous or marly clays, with beds of yellow-brown and light-gray sandstones projecting somewhat above the surface. Alternating with these layers of sandstone are quite thick beds of tions. These and conglomerate composed of round pebbles of all the older forma400 feet in thickness, and are probably of Upper among the sandstone through 300 or 500 feet of sandstone which have a diminished dip $20^{\circ}$ to $30^{\circ}$, and then pass up into the calcareous layers of the Mfiddle Tertiary of Green River group.

relative position of the conglomerate as underlying the Green River Jronp is thus positively ascertainel. Comparing this with what has been described and marked in the sections of Evanston, Cheyenne, Gehrung's in Colorado, the lignite basin of the Arkansas Valler near Uañon City, the Santa Fé marls, the Gallisteo group, \&c., such remark. able analogy is seen in the composition and geological distribution of these conglomerates that the unity and contemporaneity of the formation becomes evident. The upper part of the section of Evanston is a counterpart of that of the conglomerate-beds described above by Dr. Hay. den. It is, indeed, rednced in thickness, as also in the size of the materials entered into its compound. But, as remarked already, this reduction is everywhere relative to the distance of the older rocks which have furnished the materials. And it ought to be so; for the for.antion is a kind of drift, spread over a wide area by water or by glacial agency, and of course the coarse and heaviest materials are found nearer their point of origin. It has been, but it cannot be, considered as a recent drift. I have seen no trace of recent glacial agency on this side of the Rocky Mountains, where, indeed, moraines, or heaps of materials trans. ported by glaciers, would be, I think, a kind of anomaly. The glaciers have, like the peat-bogs, a development relative to atmospheric humidity. It is not the rain which increases the density of the snow, transforms it into néve and then into ice, but the fogs. Therefore, the eastern slopes of the Rocky Mountains have suow in their high, deep

• F. V. Hayden's Geological Report, 1870, p. 69. 
gorges, but not glaciers. The ease must bave been far different at the gorges, but we whe the atmospheric humidity is manifested by the formation of the lignite-beds.

From these remarks, and as a short résumé, I am, I think, anthor ized to deduce the following conclusions: That the great Lignitio group must be considered as a whole and well-characterized formation, limited must its base by the fucoidal sandstone, at its top by the conglomerate at its base Miocene above it, our Lignitic formations represent the American Eocene.

PART I1.-THE LIGNITE; ITS FORMATION.

The greatest geologist of our time, Lyell, takes as a preamble of his Principles this admirable remark of Playfair:

Amid all the revolutions of the globe, the economy of nature has been uniform, and ber laws are the ouly things that liave resisted the geteral movement. The rivers and the roeks, the seas and the continents, have been changed in all their parta; but the laws which direct t

Certainly, every geologist is disposed to admit the exact truth of the above assertion; but how few of those who are called to teach geology are disposed to follow the adrice implied in it and to begin their in aresions in studying the changes and phenomena on which the pres. ent surface of our globe is dependent, and of which, too, it is, at least for a given time, the immediate result.

The want of precise information on actual phenomena, whose nnder stauding is important for the pursuit of geological studies, is perhaps nowhere more evident than in considering how little the formation of now and rightly admitted now, that we ha $e$, in the peat-deposits of ou time, a formation analogous to that of the coal, and that therefore we have only to study this present and actire production of nature to be ablo to understand the origin of the deposits of combustible mineral of former epochs. But how to make this study 9 Nature's works are of cor immensity that, simple as they appear to the mere ench a complex inte hertive trial of unraveling the details of one of its minutest productions. Peat bogs are not a compound or a mere heap of dead matter, brought up like the mud and sand of the rivers by some appreciable force. That the peat has grown, and is still growing, in basins which it tends to fil up to a precise degree, is well known. But this general and vague assent of a truth says nothing on the mode of growing, on the materials which supply the eompound, on the elements necessary to its preservation, on the influences affording those subsecuent transformations by which nature secretly elaborates some apparently useless vegetable débris restores them after a time as lignite, coal, anthracite, even diamond, al matters adapted to the wants of our civilization. All these questions, to be clearly understood, demand in botany, in chemistry, in physics of the earth not mere notions, but an intimate acquaintance which, even for one of these specialties, cannot be obtained by a whole life of study. There is, however, another cause of the ignorance of the phenomena which accompany the formation of the peat-bogs of our time, and of the laws which promote it. Peat.bogs have nothing attractive, nothing which speaks at first to an imaginative mind, which charms it and. tempts it to investigation. They are like cemeteries, mere resting-places for death. They have no life but vegetable life, which, in its luxuriance, is genersily enveloped in a kind of repnisive gloom. At some open pla foting makes each pace not only nncertain but startling and alarmin as dangerons. At others the bogs are thiekly interspersed by hillocks which, formed on the roots of trees and bushes, hidden under a thick earpet of mosses, offer not only an insecure footing, but are separated by gulches full of stagnant, black, muddy water, where the prospect of a plunge is not pleasant indeed. At other places still the boga are so thickly overgrown by trees and bushes that one has to use the hatehet to peaetrate them. Throngh a narrow path, edged in that way by two walls of verdure, the perspective is so limited that every kind of research becomes nearly impossible. Or, also, the trees and bushes, some standing, some inclined or prostrated in every direction, form over the surface a kind of net, whose meshes are hidden by the vegetation of the mosses, of the ferns, \&c. Those who have tried to cross a cedarswamp will never try again the same mode of shortening their journey. It is the most difficult task to pierce through a few rods of sueh a swamp, either in walking along the prostrated, half-covered trunks, by fear of tumbling down into the dark intervals, or in searching a passage upon the surface by climbing and passing across the trunks or piercing under them through the wet curtains of rank vegetation pending from their sides. Moreover, many peat-bogs are not only of dangerous, but of im possible access. In the north of Europe, and in the south of our conntry, as, for example, in the swamps near the shores of the sea from New Jersey to Texas, the bog-vegetation often begins at the surface of the water, extends over wide areas, covering abysses of water and mud of various depths. At some places the vegetable carpet is strong enough to bear trees of large size; even railroads have been built upon such kind of floating land; at others the too thin carpet is split and rent by a little weight. When the naturalist is trying to visit such swamps, he does it at the peril of his life. Peat-bogs of this kind in Ireland, as in Denmark and Sweden, too, are crossed only by narrow paths indicated by poles. On dark nights, and in trying to follow them, many a wanderer, missing the way, has never been seen again. Some of these bogs are of such dangerons access that they are never spoken of by the inbab itants of the country but with a kind of dread. In Denmark, according to legendary records, a rup upon the death-swamp was the penalty inflicted on great criminals, who rarely or ever traversed the bog, being generally ingulfed - in the attempt. Though we may doubt the truth of this legend, it is, howerer, positive that a great quantity of implements, of weapons, of ornaments, even skulls, skeletons of inbabitants of former races, are found in bogs now emptied by hydranlic enginery and worked to the depth of 75 feet or more, in the north of Europe. The museum of Copenhagen has a number of large rooms filled merely by remains of this kind. And these are not the only forbidding features of the peat-bogs of our time, not all the visible phenomena which should demand investigation and study to enable a naturalist to understand some of the more marked characters of the formation of combustible deposits.

The peat results from tue heaping oi vegetables growing at the surface of the bogs; but as water is necessary for the preservation and transformation of the vegetable matter, and as peat does not grow always in basins, but often far above the reach of any water-level, where and how is the water proenred 1 By the ageney of a mere kind of moss, the Sphagnum, which acts like a vegetable sponge. 
These mosses absorb water from their leaves, their branches, their items tremidity of the atmos derivs it from underlyin hamity of the atmosples wases, oometimes . covering wide areas by their only vegetation. They grow, too, upon slopes, even steep ones, and thus in countries where the atmosphere is charged with a large proportion of humidity, they ascend from the base to the top of high mountains. It is the case in Ireland. The cone of the Brocken, too, so well known in the German legends of cone bogs, but the peat covers, at many places, the slopes of the cone to the tops of its rocks. Nobody woulil dare to attempt descending the cone on these apparently smooth slopes of the mountain, formed by a mere carpet of mosses which, pazsing from rock to rock, covers sink-holes of great depth between them. In our country, the same phenomenon is repeated in those naked places called glades, on the slopes of the is repeated in the Alleghany or of the Adirondack Moantains. They are penings like small prairies, in the middle of thick pine-forests. The tire has ovidently not touched these places; a small spring bas developed the vegetation of the spongy mosses. They have, by and by, invaded a larger space, preventing any other kind of vegetation but that of the bogs, even covering the dead trees falling upon them, and there we have de. posits of peat upon slopes of the same degree as that of the forests around.

It would take a volume to describe in some detail and explain a few of the manifold appearances which the mere surface of a peat formation, even of small extent, offer for investigation. If one, for example, will take the trouble to traverse a peat-bog, even where its su face is flat the dryness affords a somewhat solid footing, he cannot but remark this :

1st. The essential vegetable, the moss, (Sphagnum,) is not only spread. ing and covering the plane surface, but its tufts ascend all over the debris of wood, even tha largest trees which have fallen upon the ground, and cover them. And when the swamp is in some places orer groun, ancerse as it is often the case, these mosses ascend against the trunks or above the roots, forming tufts, hillocks, around against the trank

and upon them. dryest patches, is always full of water. Take a handful of it and press it ; water will run ont of it, not in mere drops, but in rills. This moss has the softness of a sponge, and - is a sponge. If you want a proof of it put this now well-compressed and apparently dry tuft in you prool of it, putthis now well-cose it mpen a dry plate to the atmospher pocket, and when a for one cloudy night, and in the morning, you may repeat the experiment, squeeze the moss, and find it as much saturated with water as it was when taken from the swamp.

3d. The vegetation, though most generally, if not always, intermixed with Sphagnum, is not continuous or uniform over extensive areas; here with splagning we find patelies of mosses over which the crankerry als or small bushes are in full bloom; there a group of shrubs; farther, thick growth of tamaracks, in the north ; in the south, the bald cypress and magnolia, or an impenetrable grove of canes; then apparently barren surface covered by shallow water or a thin crust of black mud, in terspersed with tufts of hard sedges, rushes, \&c.; thus a continual terse cansed by reat diversity of a vegetation which, however, taken in its whole, forms an exclusive and limited group.
This much for mere surface appearances. The diversity becomes, however, far greater in penetrating nearer to the shore of the ocean, in those dismal swampe of the south where it is cansed, not merely by the variety of the vegetation, but by modifications of level from the incessant action of the water, either in seeking an ontlet, or by alternately invading low land or heaping upon it materials which raise it above invading low land or heaping upon it materials which raise it above are mot with, which formerly were covered by forests, now sank to the bottom, where, near the borders, the tops of trees, (bald cypress,) still standing, appear above the surface of the water, their trunks in. mersed 10 to 15 feet deep. A bed of mud is slowly deposited over this sunk forest, from partieles of matter brought by water, while on the borders the floating vegetation of the peat, the Sphagnum, especially, already begins preparing for the futare a new bed of materials, which may be extended over the whole surface of the lake. Suppose a depression of this floating mass, and the bottom of the lake is then overlaid by two beds of combustible matter, separated by a bed of mud while, on the borders, the peat of an uninterrupted growth has, of course, formed a single bed. This represents, if time enough is admitted, a bed of coal, compact or in one at some places, separated in two or more beds at some others. This division of the peat beds by foreign matter, either deposited or brought op by the same agency, is remarked everywbere and often continuous and inereasing in the same direetion. Some of the lakes of Switzerland are separated by peat-bogs of great extent, some of them more than fifty square miles in area. In themid. dle of the greatest of these bogs the bed of peat is, on the eastern side, 8 to 10 feet thick, without parting, but toward the west it is horizontally divided in the middle by a streak of sand, which, for six miles farther, increases by degrees to 3 feet. In coming to the borders of the lake the lower bed of peat passes uuder the sands bottom. In Holland, borings for water record one bed of peat farthest from the shores in coming nearer to them, proportionally to distance, two, three beds, or more, formed by superposition of sand and mud, causing temporary or permanent divisions of the original bed.

The same modifications are observable in the peat-deposits of this time, and their canse plainly exposed to the explorer in the swamps of this country nearer to the shores of the ocean. Here estuaries indenting the land form a true net-work of canals, lagoons, bayous, ent by narrow capes, islands of various size, some of them a mere mass of heaped vegetables, floating here and there. The lowlands ane mostly overgrown with a luxuriant vegetation, affording materials for the growth of the peat; but in some localities these swamps are slowly invaded again by the sea, which has cut a channel throngh the beach somewhere near by and brings sand over them. By and by these peat-deposits will be buried apparently forever. But if a current or a storm, or some other casualty, closes the channel, the lagoon, protected against marine influence, becomes an inland lake with a permanent level, has its brine slowly changed into fresh water by the ingress of some river, and after a while the same kind of vegetation will re-appear over the lagoon and begin its productive, work anew. There is along these low shores a perpetual contest for predominance between

- Species of Sphagnum, when growing in water, extend their filaments over the aurfaee In continuous and innumerablo ramifications, which soon form a net of flosting vegetation, where other plants by and by take root apd live. On a solid ground phase, all their stems ereet, elosely prensed togetber. $23 \mathrm{G} \mathrm{B}$ 
water and land; between the peat vegetation which tends to force back the ses in building its moors, as ramparts against invasion, and the marine force, searching an ingress, and in its charges soaling low walls to re-occupy or farther extend its domain for a while. This wall to rerof course, caluses ins alternance of foreste,

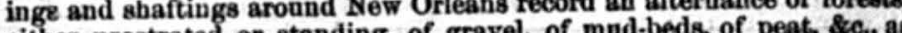
either prostrated or standing, of gravel, of mud-beds, of peat, cro., a a result of this conflict, which, of course, becomes still morn active and varied near the mouth of our great rivers. The low bottom-lands of the Arkansas and Red Rivers at their entrance into the Mississippi the Arkansas and of alternance in their stratification. The canse is show the instead of waves, tides, aud currents.

instead of waves, tides, and currents.
What has been said, as yet, teuds already to explain not only the cause of the multiplicity and variety of the deposits remarked in our Lignitic and coal measures, but also the differences observed and re. corded by experiments or analyses in the compounds of the combustible corded by expes bits cut from the same block of moderate size.

A perfect understanding, however, of the canses of all the differences A perfect understanding, howen as yet unexplained in the formation of coal and lignite, can be obtained only from the study of the mate. rials which enter into the composition of a peat-bed, when seen on a rials whesed in a vertical section. Such an examination can rarely be bank expor peat is as yet of comparatively little value, and where the rare diggings are made by enginery; heavy, value, and where the rare diggings are made by enginery; heavy, sharpened cutting-shovels, or boxes, moved by steatn, briaging out the matter from under water. The face of the banks is in that way coustantly immersed. In Europe, even now, peat is worked from large banks isolated at first from the swamps and drained by canals. The matter is cat by bot of the banks, and on matter is cut by balifing from variety of these sections the difference in the compound the vegetation of the surface may be comparativeiy studied both ways, either vertically for succession in time, or horizontally for distribution of a conteinporaneous flora. The examination of such banks of peats shows at first that, even where the peat is older and more compact, one shows at firize the bottom the layers of can recogaize and of vegetable matter which of the whole mass. Near the top the annual layers are spongy, irregular, thick, varying from one to three inches; by compression and decay they become thinner by degrees, and at the bottom are sometimes reduced to one-tenth of the thickness of the surface-layers. They show, too, irregularities resulting from the embedding of vegetables of show, too, irregurally, however, the general growth is not entirely large size. It is still iudicated by thin layers stopped, eren by prostrated forests. It is still iudicated by thin layers marking the remains of the vegetation of the Sphaguum, and when, either at once or saccessirely, the trunks of trees become embedded there is for a while a kind of local confusion of the annual layers, till, the growth of mosses and small vegetables having filled the intervening grow become horizontal again and the layers distinctly spaces, the remains after a few years marked on wider areas. Generally, vegetable remains anter a few years are mostly rendered unreoognizable by compression and maceration, which change their color and modify their characters, and, of course, the older the peat-strata are the less their vegetable compounds becom identifiable. Some kinds, however, eseape disintegration for an immense space of time. These, like some species of mosses, of sedges, twigs of coniferons or species of the heath family, may be recognized from the surface to the lowest part of the banks of anolent beds of peat 1 have many times seen strata composed eseentially of the heath; (fich vulgaris,) which enters often in great proportion into the forch, (Erica the peat in Enrope, whose brahctes with were as identiflable as in their original form, still attached to them, feet of peat. In digging 10 to 12 feet or peat. In digging for the fonndation of a state monument at Berlin, a thin bed of peat was exposed under 40 feet of drift-kand. This peat was a compound of mosses, which were so well preserved that the species could be reeognized just as if the mosses had been recently the ont of the swamps. Professor Forton, attached to the recentiy taiken vey of Ohio, found two identiflable specimens of mosses in a peat-deposit
underlying clay.beds covered with drift.

The growth of the peat in basing full of water and from immersed vegetable, results from proceedings somewhat different, but not les admirably adapted by nature to the purposed end. All the basins les the peat is formed under water bave a bottom of advance by some kinds of water-plants, Conferva, which, living totally under water, out of atmospheric influence, are mere cellular plants, and by decomposition produce, like the infusoria and small mollnsks which they feed, siliceons or clay deposits. To these capillary plants are often added the Characea and some species of mosses which, by peculiar and as yet nnexplained structure, have the property of tron peculiar anc assimilating in their tissne the property of transforming and is only after the preparation of the clay bottom, and when the basin has been rendered impermeable, that water-plants of another kind begin their vegetation. The Sphagnum among them, the floating speeieg of their vegetation. The Sphagnum among them, the floating speeies of
Hypnum, the Thypha, Sparganium, Pond-nceds, Water-lities, all plants rooting in more or less deep water, bat opening their leaves and flants at or above the surface, and thus by atoening the carbonic acid into fibrons tissne, and becoming future use as combustible mineral. The déris of heaped every year and lecay under water. The beaped every year and decay under water. These debris, generally more mixed, and mostly, too, partly decayed aud bruised before submersion, form a more conpact mass, withont recognizable annual layers, and in time may be transformed into that coal named cannel.

Swamps of this kind, however, are not always continuons eitber in s vertical or horizoutal direction. It happens in some conntries that in a peat formed by immersion of vegetables has been heaped up to the level of the water, the upper aquatic vegetation begins its work and builds high above it, a deposit of peat, where the same phenomena, viz, distinet annual layers, \&c., are remarked as in the emerged peat formation. another side the subaquatio regetation, on formation of the peat, is sometimes in full, and therefore the immersed while at another place of the same swamp, the is covered by a cranberry on covered by a cranberry-swamp or an emerged peat-bor. This is the case on some of the great swamps of North Ohio, and I stili recollect with some kind of dismay, that twenty years ago, misled by vague informations, I waded in three feet of water over the surface of an immersed peat forms tion, 80 thickly orergrown by bulrushes (Scirpus pungens, dc.) that once within this kind of thicket I lost far away, and lost my direction, too. Searehing there oorders, already for honrs, I bal fuli direction, too. Searehing there a way of egress for honrs, I had full time to investigate that unpleasant side of the formation of the peat, till at last I came to the upper part of the same swamp, the eranberry-marsh which I was anxious to explore. The dif. ference of compounds in some beds of coal which, sometimes, have layens 
of cannel-coal in the lower pari, topped by bituminous oval; or which at one end are true cannel-eoal in their whole thicknsse, passing to bitaminons in following them to some other part of the same deposits, is explained by these remarks on the formation of our peat-bogs. We find also, a remarkable identity of componnd in the bottom elay of the coal and Lignitic beds, which, too, indicates by its remains the agency of plants of a same nature or of water-plants in its formation.

In comparing peat to coal, and judging from mere appearance, onie finds at first a great difference between these combustible materials. But in following the intermediate grades which modify them according to age, the intervening links are fcund so intinately joined that it becomes impossible to separate them or to mark divisions from permanent characters. In ancient peat-bogs, the peat, especially near the bottom, becomes black, compact, intermixed by layers of erystalline, though still roft cosly matter, which only wants hardness to be comparable to true coal or even undistinguishable from it. Passing from peat to what is called lignite, or to deposits of woody matter in formations older than ours, we find in these accumulations either beds of mosses of species still recugnizable as analogons to those of our times, or heaps of trunks whose wood has still its color, its original structure, as it is seen in the present peat-bogs, but which has alrealy be ome softened to the consistence of clay. Some older deposits have their woody re. mains, trunks, and branches, already blackened but'still soft, being easily cut by shovels. Still farther into the divisions of time or of geologists, this wood, as at Golden, for example, is foand hardened, careoncentric layers of branches are as distinet as in the wood of our forests. $\Delta$ nd in the same basin, or at the same borizon, as, for example, at the Baton, the combustible matter still called lignite has become, by its ap pearance, hardness, and chemical compound, undistinguishable from the coal of the Carboniferous measures.

Chemistry accounts for the differences remarked in the various degrees of decomposition of woody materials. Is explains how the transformation of woody fibers into coal is the result of a retarded combustion by the slow combination of the oxygen of the atmosphere with the hydro. gen of the plants, converting the woody flber into carbon and increasing, proportionally to the duration of the process, the amount of fixed carbon. In this operation of nature the wood passes through all the stages of decomposition remarked in mineral combustible, from peat to anthra eite, \&c. In the lignite the work is only half done, as seen in consulting the numerons analyses given of this matter, which always indicate a proportion of carbon relative to that of water or of as yet nnburned woody fibers. In some cases the slow maceration appears hastened to its completion by subterranean heat. How else wonld it be possible to explain the transformation of lignite into anthracite in close vieinity to basaltic dikes, as at the Raton Mountains and at Placiere Mountains, New Mexico, when the same beds, at a distance, retain still the appearance and chemical compounds of true lignite?

Nothing is more admirable in nature than the apparently simple pro. cess of the formations which have bere been briefly reviewed. Nature disposes of the carbonic acid of the atmosphere and of its humidity for the food of the plants which, by a kivd of digestion, elaborate it into woody fibers. Under peculiar times and circumstances, where these The bottom of a peat-bog of Locle, 8witzerland, is formed of layen of this substance
already hardened and undistinguishable from lignite-coal. woody materials are unavafiable, it piles them foto vast magazines, care fully prepared a long time in advance, for that purpose. And then, reveraing its operation, slowly combining again the water and the carbonie acid of the wood, to return them to the atmosphere as new food for liv. ing plants, it constantly improves the valne of the stored materials for futare contingency. Man now recognizes the end of this work, enjoss its results, and can but acknowledge in it the disposition of a wonderful Providence.

The first result of the decomposition of woody matter in basins pre. pared for the formation of the peat is the generation of an acid, (acic ulmic,) soluble in water, and especially marked by its antiseptic property. Water saturated with this acid not only retards indefinitely the decomposition of the wood immersed into it, bnt, under some circumstances preserves for a length of time every kind of organic matter, even meat. The water does not receive from this compound any unpleasant taste or smell, nor any unwholesome influence. It is as palatable for drink as spring water, merely unattractive by its somewhat brownish color. Even it may be considered by its antiseptic property a preventive against ferer and other epidemic diseases, or a remedy for every kind of dis. established this fact in Europe, that the average of human life is longer for the inhabitants of the peat-bogs or of the land bordering the formations of this kind. This water, too, does not enter into decomposition even when exposed to a high degree of continued heat. It has been carried for eighteen months or more in exploratious of equatorial conn. tries, preserving its purity to the end. From this it is easily understood how trees or fragments of wood, thrown down or strewn upon the bogs, become protected against decomposition by a thin carpet of mosses im. pregnated with sh. $\mathrm{b}$ kind of water.

The ulmic acid, soluble in water, becomes fixed or solidified into a black resinous matter, by evaporation of the water, thus forming a proportion of the combustible part of the peat, and greatly increasing its value. The difference in the heating properties of the componnd, when dried ander atmospheric infuence or by compression, is sometimes as high as one-fifth. The best peat, therefore, is that which, taken from the bogs by hand or by machinery, is kneaded till the whole has been ren. dered a homogeneons paste. The operation is performed in varions ways, according to means and circumstances; by pounding with the feet, with wooden mallets, by mills, \&c. The peat thus prepared is eut or molded in pieces of suitable size, left upon the ground till somewhat bardened, then dried by saccessive exposure of the faces to the atmosphere Prepared in that way, the peat of the old bcgs of our time is as od a combustible as hard wood.

The ulmle acid of the water of the bogs, antagonistic to some kind of regetation, essentially favors the growth of plants of hard woody tissue. The flora of the peat-bogs is therefore exclusive and limited. It has mostly species with sharp-pointed narrow leaves-conifers, grasses, sedges, rushes, canes, mosses, and a few shrubs, dwarf-birch, cranberry, \&e. The bladed form of the leaves appears especially appropri. ate to the absorption of atmospheric humidity, and by their multiple surfaces to the evaporation when The mosses have not as yet been observed in a fossil state, neither in the Carboniferons nor in the Lignitic formations. The first remains of this clasa appear in the Upper Tertiary, especially in the amber. But there is not a positive proof of their absence in older formations. Moreover, the peat-bogs of former epochs have apparently had for their 
growth other kinds of vegetables, possessing the same properties with ge do not know them as yet, for the vegetable remains fossilized in sand and elay beds seem to represent species of remains fosing rather than the species which have conplants bordering the swamps,

tributed to their composition.

The evaporating and absorbing power of the plants of the bogs play another remarkable part in the economy of nature in moderating the extreme of temperature, especially greatly reducing the excess of cold. Everybody knows how even a thin fog prevents frost. The flors of our Lignitic, like that of the Coal epoch, has a number of species, whose lignitic, like that of the plants now considered as characteristic of a tropical or aftinity is with plants now considered as characteristion therefrom that at subtropical climate. It has been generally argued therefrem formation the time when our combustible minerals were in progress of formation the elimate of our country was much warmer than it is now. From the examination of the frst specimens of Tertiary fossil-piants found on this continent I was inclined to admit a same cpinion; but the more I have studied the distribution of the plant of former epochs, comparing have studied the distribution of the more I have been led to believe that ha differit with that $\mathrm{Cf}$ ours, the more $I$ of the vegetation, as indicated by iossil ences in the general characters of the regetation, ality, rather than from remains, result essendally from atmospheric hubidity, ratler than from temperature. In Ireland and in Scotland, near the mouth of the Firth
and of the Clyde, as high as $57^{\circ}$ of latitu' limit correspouding on the American continent with North Labr. the regetation under a higb degree of atmospheric humidity, already ,resents a tropical aspect. Tropical ferns, species of Hymenophyllum and Trichomanes, cover the Tropical ferns, species of rocks and tho mossy trunks of the trees, mixed will the characters of the ferns, whicb, by their luxuriance and size, recall the characters of the vegetation of the Southern Islands. - It has been remarked already that the coal and lignite beds proved for the time of their formation a far that the coal a now. If a mer greater degree of attospherion at our time cineresconding to that indi. change in the character of the vegetation corresponding between the cated by temperature in $25^{\circ}$ of latitude, or the diflerence between the sonthern swamps of ours and those of Scotland, we can easily admit, as resulting from the same cause, the facies of the vegetation of Greenlan resulting Thertiary epoch. This flora, as we know it already, has a geveral at the Tertiary epoct. relation and

These details, which indirectly throw light on the productive causes, the distribution, and the original composition of the lignite-beds, are sanctioned by the importance of a formation, justly considered as a most essential series of our American geology.

THE LIGNITIC CONSIDERED IN ITS APPLICABILITY.AREAL DISTRIBUTION AND THICKNESS OF THE STRATA.

\section{1. The Northern Lignitic Basn.}

The formation to which the name of Great Lignitic is fittingly applied The fork Mount uns, 1804:

The coal or lignite was firat observed twenty miles above the Mandan Village. The bluffs on each side of the Miseouri are upward of 100 feet high, composed of sand and elay, with many borizontal strata of earbonated wood, resembing pit-coal, from 1 to

- Sehimper, Vegetable Paleontology, vol. 1, p. 358.
5 feot ench in thioknen and ocenrring at varions elovations above the river. At afty miles aboye the village, aimilar coal-seams were noted, but bero they were obeerved to bo ou fire, emitting quantity of amoke, and a strong sulphurons smell. Further on the same sulphurons con conthued for eighty miles more; strats of conl, froqnently io a state of combustion, appearing in all the exposed faces of the bluffe. The quality of the coal improved as the party advanced near the month of the Whito Rive', eighty. five miles farther, affording a hot and lasting fire, but emitting very littlo smoke or flame. Thenee forty-moven miles to the Yellowstone River, and at a bluff eight milee up that streat, were suveral strata of cosl. For fify miles above the junotion of the Yellowatone and the Misoouri there wero greater appearances of coal than lad yet been oeen, the seams being in some places 6 feet thick, and there were also strata of burnt carth weh were afways on the same level with those of coal. The explorers bad three handred and tfirty miles. The borizontal formation of clay, loam and and with fragments of coal in the drift of the river, extended throe hundred miles more to Mnscle-sbell River, or six hundred and t trenty miles from the Mandan Village. Even alove this point, washed coal continualiy appeared on the shores of the river and at Elk Rapida, eight hundred miles from Fort Mandan, the bigh bordering blnffe, were still composed of borizontal beds of elay, brown and white sand, sof, yellowish-white sandatone, hard, dark-brown freestone, avd large, round, or kidney-shaped nodnles of elay, iron ore. Coal, or carbonated wood, nimilar to that previo' aly observed, was also coen, and wan co the grand fork of the Minsonri, and aucending two or three days' journey up Mariag River, northward, it was remarked that precisely the same geological character and coal-strate prevailed for note than sixty miles so far, therefore the explorigg party had been traveling through ur over a ligneons-deposit of sisgulariy uniform character for no less than nine bundred and eighty miles, following the winding of the river. Pursuing the south fork toward the great inlla of the Missouri, coal was still observed in blufts of dark and yellow clay at a diatance of two thousand four handred aod fifty-lour miles up that mighty river, and it was not until near the base of the Rocky Mountains, and affer one thonsand miles of traveling aeroes it, that this great regiou of coal-beds and liguites was passed.

On his return Captain Clarke descended the Yellowstone from abont north latitude $45^{\circ}$ to its nooutb, $45^{\circ} 20^{\circ}$, and every where found the same series of coal, and vari colored clays and noft sandstones, as was traversed in ancending the Miseouri.

implies "The Cosal Creek" frotn the great quing in from the sonth, whose Indian name The same coal series continued to the confluence of the Missouri, exhibiting nunter. ruptedly for seven hundred miles, in addition to the thousand previously traversed, the vast persistence of this formation. The enormous area of similar strats is further shown by the decoloration of all the tributaries that enter the Missouri from both the south and the north from the forty-second to the forty-ninth degree of north latitade.

In 1832 Prince Maximilian, of Neuwied, passed up the Missouri River, and in the splendid record of his travels mentions the occurrence in numerous localities of thick beds of lignites.

Some more detailed information on the distribution of the lignite-beds of the Tertiary are given by Mr. E. Harris, $†$ who accompanied Audubon up the Missouri to the month of the Yellowstone, in 1843. He counted, at one place, eight seams of cosl between the river and the top of the bluff, their thickness varying from 6 inches to 4 feet.

In Dr. D. D. Owen's final report of a geological survey of Wisconsin, Iowa, aud Minnesota, an account is given of Dr. John Evan's exploration of the Mauvaises Terres. He remarks, (p. 195:)

That below Fort Clarke the great lignitic formation firat shows ituelf in the banks of the Missouri. It was traced to a point twenty miles below the Yellowstone. One of the thickest and most vort

In $1850 \mathrm{Mr}$. Thaddeus A. Culbertson visited the Upper Missouri to above Fort Union, noting the occurrence of lignite-beds at various localities.

Thus, at different times, the lignite-beds of the Upper Missonri and - R. C. Taylor, Statistics of Coal, p. 175.
t In Proceedings of the Acad. of Nat. Sei., Phil., May, 18.5. 
Yeilowstone Rivers were remarked, but always in a general way, with ont giving any precise information concerning their age, their distribution, thickness, and compounds.

The same Liguitio formatious were also described from the northwest of British America, with some more details; but these observations do not concern the present researches.

From the south, too, or from New Mexico, we have records of the presence of thick coc?.beds "found in great abundance and of good quality between the placers in the Raton Mountains, and many otber places." And in the narrative of Lientenant-Colonel Emory, coal is mentioned as occurring between Fort Bent, on the Arkansas River, and Sante Fé to the north and south of the Raton Pass. One bed seen to the northward, at Captain Sumner's camp, is described as an immense fieli, the seam which cropled out being 30 feet thick. Another noticed by Colonel Emory, was seen on the bauks and near the head-waters of the Canadian River, abont north latitude $36^{\circ} 50^{\circ}$, on the 7 th Angust, 1847. It is in the reports of Me srs. Meek and Hayden, and in the numer. ous papers which these gentlemen have published from 1857 to 1861 that we obtain the first positive data, not only on the geology and paleontology of the Lignitic formations of the north, but, also, on the distribution and value of their beds of combustible minerals. The proceedings of the Acadeiny of Natural Sciences of Philadelphia, May, 1857, have a very interesting account of the Tertiary and Cretaceons of Ne. braska, by Messrs. Meek and Hayden. The section, page 8, marks the relative position of eight beds of lignite underlaid by a compact sandstone 30 feet thick, which directly reposes upon No. 5 of the Cretaceous. In the same year Dr. F. V. Hayden has a map with sections of the country bordering the Missouri River, accompanied by explanations and documents of the highest interest. This work embodies the results of three years' explorations by the anthor in the Northwest. It marks the outlines of the great Lignitic Tertiary at the sonth from the Upper Smoky Hill Fork of the Kansas River, to above White River, or the South Fork of the Cheyenne; and at the north on both sides of the Missouri River from below Fort Clarke to the Muscleshell River, the north limit narked by British America, and the southern by the head-waters of Cherry Creek and the Black Hills. The author esti. mates the area of this north basin at four hundred miles in length and one hundred and fifty miles in width, or at about sixty thousand square miles-an estimate which he rightly considers as too low. From this time to 1861 the papers of Messr8. Meek apd Hayden, mostly relating to paleontology and geology, do not furnish any materials for this part of my researches.t

- In a letter of Don Mannel Alvarez, May, 1847, quoted by Taylor, loc. eit. $\dagger$ R. C. Taylor's Statistics of Coal, p. 220 .

In order to show the amount of work performed at that time to prepare the knowledgo which wo have now obtained on the geology of the. Western Territories, and to catalogue of the memoirs publinhed by Messrs. Meek and Hayden, from 1857 to 1861 : catalogue of the memoirs publinbed by Mensis. Meek and Hayden, from 1857 to 1861 : formatious of Nebraska, \&e. (F. B. Meek and F. v. Haydev.)
May, 1857. - Loc. eit.: Notes explanatory of a map and section illustrating the geological atrueture of the Upper Missouri, \&e. (F. V. Haydeb.

Jume, 1857. - Loc. cit. : Notes on tho geology of the Mavvaises Terres of White River, Nobraska. (F. V. Haydeo.) March, 18s8.-Trans. Albany Inst.: Deseription of new organie remains from North-
caotern Kansas Permian. (Meek and Hayden.)
The geologieal report of Dr. F. V. Hayden on the exploration of the Yellowstone and Missonri Rivers, under the direction of Captain Ray. nolds, (1859-60,) published in 1869, gives besides the details on the geology of the country, some interesting data on the distribution of the lignite-beds. The more important are as follows :

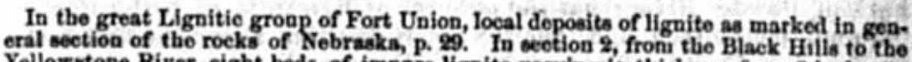
Yellowstope River, eight beds of impare lignite varying in thickneas from 3 inehes to
i, 4 , and 5 feet. Sections 3 and 4 have two beds of impure lignite with only one bed of lignite more or less pure, divided by layers of clay. Section 5 , p. 52, ou Powder River, indicates on a thickness of 356 feet of strata, thirieen beds of lignite moetly thin abd clayoy; one of them, however, No. 11, is 7 feet thiek and quite pure. Two ofher parted in thin layers by clay-beds, and therefore of little valne. Up the Yeflenerally Valley Dr. Hayden mentions, near the mouth of the Rosebod Creek, a lige Yeliousatone thick. "Three hundred yards above, it separates into two parts, 2 to a giteet each, with 6 to 8 feet of arenaceons elay botween. Five bunired yarts farther, the two beds begin again to unite, there being abont 6 inches chocolate-clay between them bed Iignite is quite pure." From the Big Horn to the union of the Yellowatone with the Sfissoni. the lignite-beds oceupy the whole cuuntry with the exception of the purtion already dencribed and a distance immediately on the river of about seven miles callec. Shell Point. The liguite-beds aro well developed, and at least twenty to thirty seams
are shown, varying in purity and thickness from a fow inehes to 7 feet."

In the records of a journey to Pumpkin Buttes and the sources of the Cheyenne River, Dr. Hayden remarks that the whole region from the Platte to Pumpkin Butte is covered with thestrue lignite formation, cots. taining numerous beds of liguite more or less pure. The section of the buttes t.is remarkably like that of the Gehrung coal in Colorado, with conglomerate beds at its top, underlaid by alternate layers of impure lignite, clay, and thin beds of sandstone, the whole measuring 428 feet. The section at Gehrung's is 426 feet. After this are seen, sloping down to Powder River, similar rocks with some thick beds of liguite, from 6 to 8 feet in thickness. Near the junction of Suake River we find in the same report the Tertiary beds prevailing to a great extent, and in a section of 80 feet six or eight seams of impure liguite which has ignited in several places.

March, 1858.-Proceedings Acad. Nat. Sci., Phil. : Description' of new organio remains from Nebraska. (Mcek and Hayden.)

June, 1858-Loc. cit.: Explanations of a second edition of a geological map of Nebraska and Kansas, de. (F. V. Hayder.)

Notember, 18ad-Report on collections obtained by the expedition under command of Lieutenant G. K. Warren. (F. V. Hayden.)

Decenber, 1858.-Proceedings Acad. Nat. Sei., Phil. : Remarks on Cretaceous beds of

Jannary, 18as.- Trans. Baint Louis Acad.: On the Bo-called Triassic rocks of Kansas December, 1858.-Proceeding Acad. Nat. 8ei., Phil.: Remarks on the lower Cretar ceous beds of Kansas and Nebraska. (Meek and Hayden.)

Jansary, 1869.-Lee. dit.: Geologieal explorations in Kansas Territory. (Meek and

Ifoy, 1060-Loc cit. : Deseription of new organic remains from the Tertiary, Cretaceous, and Jurassic rocks of Nebranka. (Meek and Hayden.)

Oclober, 1860.-Loc. cit. : Catalogue with synonyma, \&c., of the fossils collected in Nebraska by the exploring expocition under Llentenant G. K. Warren. (Meek and Jamuery, 1860.-Am. Jour. Sei. and Arts: Oa a new genus of Patelliform shells from the Cretaceous of Nebraska. (Meek and Haydee.) March, 1861 - Loc. cit.: Sketeh of the Roology of the country of the bead-waters of
the Mineouri and Yellowstone Rivers in Proc. Aead. Nat. Sei., Phit., by descriptions of new Followed in December, 1831, the sane exploring expedition of Captain W. F. Raynolds. (Meek and Hayden.) t Loe, eit., p. 50. 
The geologieal notes of Dr. C. M. Hines, fin the same report, mention beds of lignite in a number of sections in the same country t the thick ness and quality of the material are not given. He says, however, of the beds on Tullock's Creek, that the lignite in this vieinity approaches more nearly to coal, and, the beds increase in depth; of those of Clear Fork of Powder River, that the outerop of lignite is of better quality than any before seen, and that for some distance above the first camp on the Clear Fork to the junction with Powder River proper, there is thick outerop of liguite of the depth of 6 feet and upward, somewhat resembliug Cumberland coal, but of looser texture and containing less bitumen. Eight miles below the camp, this coal was seen to be on fire. Considerabie smoke issued therefrom, having a strong sulphurous smell. "The heat at this point was so intense that we could not stand with com. fort within 20 feet from whence the smoke issued. A thick layer of sandstone lying immediately above it was completely calcined."

Passing from the northern part of the Lignitic to its sonthern division, extending along the base of the Rocky Mountains from the Black Hills to New Mexico, we have, especialiy on the lines of the different railroads, detailed records on the coal-strata, mostly made with care by competent geologists. I have already quoted the most interestisg of these reports: Notes on the Geology from Smoky Hill River to Rio Grande, by Dr. John Leconte, February, 1862, soon followed by the pretiminary report of Dr. F. V. Hayden, on the United States Geolog. ieal Survey of Colomado and New Mexico, 1869. As my own explora tions bave been directed on about the same ground surveyed by these geologists, I siall now make nse of my own notes on the distribntion of the coal, using, however, former reports, either for comparison or for references for the sections of country which I have not visited.

\section{2. Tire New Mezico Lignitic Basin,}

In the Raton and sonth of these mountains, Dr. F. V. Hayden $\bullet$ men. tions, near the toll-gate sonth of Trinidad, a bed of coal 4 feet thick, of excellent quality.t Near the Vermejo Creek, six beds of coal are marked in a section of the same report, one of the beds from 6 to 10 feet tbick, and another, the lowest, 4 feet. Dr. Hayden remarks that the coal of that vicinity is equal to any ever discovered west of the Missouri River, exvept that of the Placiere Monntains of New Mexico. Of this last bed, which has been partly transformed into anthracite by the immediate contact of a large dike of volcanic rocks, this geologist gives a detailed section, marking its thickness at 5 to 6 feet on the northwest side of the Placiere Jonntains, at a distance from the dike and where the lignite bas not as yet been disturbed and changed by heat. At another pl-ce in contact to the dike, the lignite (anthracite) is a little more than 3 feet thick. Of this same bed Dr. Leconte has a section (loc. cit.) indicating 4 fect of anthracite, with a lower bed of the same materisl, of which 14 inches only could be seen, he bottom being covered. In his report, too, for the survey of the Union Pacific Rail. way, the same geologist mentions: First. A bed of lignite 3 feet thick, 4 miles south of the toll-gate of the Raton Pass. Second. Another bed, 8 feet thick, five miles sonthwest of the same place. Third. The lignitebeds of the Vermejo Cañon, visited with General Palmar, where, in a section of 275 feet, we find marked two beds of partly poor coal, respectively 10 and 15 feet thick, and two beds of excellent lignite, each

- Geological Report, 1869.

t This coal is also reported by Dr. Leconte; Notes on the Geology, dec., p, 21.
5 feet thick, separated only by 10 Inches of slate. Coal-beds of the same kind are seen in the same vicinity: is Blackmore Canon, where the li nite, not fully exposed, is reported 10 feet thick, and in the Bremer Cañon, immediately south of the Vermejo Valley, where a number of outerops, mostly obscured by land-slides, were seen, indicating at least 4 feet of good coal. Fourth. Lignite-beds in the valley of the Rio Puerco, twenty-eight miles sonthwest of Albuquerque, with an exposure of 5 feet. Finth. The lignite-beds from which the-fuel for Fort Craig is obtained, nine miles east of Don Pedro, whose section indicates a thickness of 51 feet of coal with two elay-partings of 3 inches. Besides this, Dr. Leconte was informed that a good bed of coal exists near the town of Limitar.

General W. M. 8. Palmer's report of surveys across the continent in 1867 and 1868 completes the records on the distribution of the lignite. beds south and west of the Raton Mountains by the following informs. tions: The coal of Tijeras Cañon, at a short distance northeast of the town, has been found 41 feet thick and traced by Mr. Holbrook, division engineer, for a distance of 2,000 feet by sinking small shafts along the vein. A valuable seam bus been discovered near Pan Felipe, (thickness not indicated,) within twelve miles of the Rio Grande. Coal also is reported in the Pecos Valley, five miles above Anton.Chico. On the Cimarron route of the railroad a large vein of coal, apparently 14 feet thick, has been reported by Dr. Steck, and at a number of places, similar coal or lignite beds are mentioned in the same report, without indication of thickness. On both sides of the Rio Grande, numerous beds of lignite (named bituminous coal) are found near Doña Aña and Mesilla, and others still are reported west of the Rio Grande, one three hundred miles from Albuquerque, by Dr. Newberry, who saw near the Moqui villages a bed 12 feet thick; another by Dr. Parry, who saw a bed 4 feet thick on the Zuñi Pass, near Pescado Springs; and still, by the same geologist, many beds of lignite about thirty miles west of the Rio Grande, in the Sarociuo Cañon, varying in thickness from 3 to 4 feet. A number of localities where lignite-coal bas been reported ou the different lines proposed for the ruilroad are still men. tioned in General Palmer's report. But this already gives us sufficient proof of the productiveness of the great Liguitic south of the Raton Mountains, and in countries still unexplored where the mineral deposits re as yet mostly unknown.

The lignite-beds in the vicinity of Trinidad have as yet been ecarcely opened. Some coal is hauled to the town from the base of the Raton Mountains, on the road of the Raton Pass, where, as already reported in section, the lowest beds have a thickness of 4 feet or more. According to the information received from persons well acquainted with the country, there is a great deal of coal all around the town; so much, indeed, that everybody can take it and baul it for their owu use whenever they like and witbout paying for it. As there is still an abnudance of wood, pine and juniper, in the country, and a limited population without railroade, the demand for coal is very limited indeed. But there is for the future a reserve which already demands careful investigations and a sagacious investment of money, especially by the com. pauies of railroads in process of construction to the south. This is especially the case in regard to the Lignitic deposit overlaying the Eocene sandstone irom Trinidad to the foot of the Spanish Peak. A number of beds of lignite have been already reported from this basin. near Gray's ranch, a stage-station; near Chicosa, twenty miles north of Trinidad, \&c., \&c. The coal there, being considered as of no value 
whatever, has not been looked for, nnd the numerons outerops remarked in the hills have not been tested. The lignite of this part of the country appears, bowever, of remarkably good quality, even richer in earbon appears, thas the Ilaton coal, and compact ench distillation, as ingortant quality whech in the Placiere anthreite. Th in any of the Tertiary lignite, except in the Placiere anthracite. The analysis of the lignite of Chicosa is given hereafter in a comparative table.

In resuming the remarks on the lignite of the country, it is allowed to conclude that from positive evidence there is along a nearly direct to conce of more than line rrom Pueblo to Baw lignite-beds as may be sufficient ior the future demands of a large population. The supply of coal on that line can be considered from all appearances as inexhaustible.

\section{The Colorado Lignitic Basin, prom Pueblo to Cheyenze.}

A separated number of this great basin, or rather an isolated area spared by the work of denudation along the base of the Rocky Monnt. ains, is the small Lignitic basin in the Arkansas Valley, east of Cañon City. Its exact productiveness is not as yet ascertained. The report of Mr. Nelson Clarke, already noticed, says that the coal-yielding rocks contain at least nine seams of lignite, varying in thickness from 6 inches contain at "east nine 8 feetive 6 and 7 feet thick and bu 50 feet apart; at the north, on the river, they are but 2 and 4 feet thick and at least 150 feet apat." The lowest of these seams of coal is known as the Cañon City coal, now the land property of the Colorado Improvement Compasy. The coal is 51 inches thick, black, compact, nniform in color and compound, separating in large cubic blocks by cleavage, and from uppearance not liable to disinlarge cubic blocks by cleavage, and This coal was already known and tegration by atmospheric influence. This coal was already known and ing of the Denver a d Rio Grande Railroad, the cost of transporta. tion was very high. When I passed the place the branch of the railroad from Pueblo to Cañon City *was not yet fin'shed and the lignite was hauled to Pueblo for the use of the railroad at the cost of $\$ 5$ per was Now it is already shipped from the newly opened mines at the rate of about one hundred and fifty tons per diem. Borings are in pro. cess at different places to ascertain the thickness and continuity of the veins. From what is known as yet, this small basin has a productise capacity which will afford combustible materials for a length of time. The bed of lignite formerly mentioned as the Gehrung's coal, at the base of the Colorado pisery, does not promise well for future demand. It is too thin, only 2 feet thick, too friabie, and, as worked now, the It is too thin, only 2 feet thick, too friable, and, as worked now, the isproving In thickness and quality to the sontb, where shafts could be sunk at a distance from the river. But abundance of combustible ma. carial is now easily and cheaply procured by railroad, and the cost of building a gaft and of working the coal would be above the value of

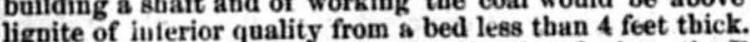

The Focese formation so largely developed along the Rocky Monntains, from the North Fork of Platte River to Cheyenne, will be for a long time to come the essential magnzine of combustible, wherefrom an abundance of excellent materials will be sapplied to the railroads, and the already large population of the country. If some of the opened veins do not yield now as largely as it wah at first expected, the reason is especially in the want of guod management in the mining, provoled oy anprofitable working. Here, as averywhere, cosl mines have been at first considered by the proprietors as true gold.mines, whose posses. sion was to bring immediately splendid profits by exploitatlon. Iiguite. beds have been opened everywhere, even far from a good market, and against great difflenity of transportation, \&e, For many, the result has been disappointment, negleet of the working of the veins, and even their total abandonment. Now railroad branches have been built or are in process of construetion from Denver, or from the Denver and Pacific Railroad to the most important coal-deposits. The supply, already fnlly equal to the demand, is inereasing every day; and if noth. ing is done by the proprietors to moderate it, they may find a new cause of loss in the superabundance of eoal mined for an overstocked market. This excitement might be dangerous for the future, if the liguite-beds already opened or worked were not thick and over extensive areas. Bui what is known of the productiveness of the Lignitic measures of this country indicates, indeed, an immense reserve of combustible ma. terials.

Most of the lignite-beds exposed along the creeks of this section have been tested. Dr. Hayden notices a coal-bed opened and worked to some extent near the cañon of the South Platte, and two beds now covered with loose materials, in all 5 feet of lignite separated by 2 feet of clay. The coal is not very good, and has not been used for years.

Going north, and before reaching Golden City, the first coal-vein seen opened is at Wheeler and Jobnson's mines, near Green Mountains, one mile east of Mount.Vernon. The coal is 7 feet thick; not of very good quality. Then, three miles east, the Rowe coal.bank, 6 feet thick, of a better quality than the former. This vein, which is noticed in Dr. Hayden's report, 1869 , dips east 67 ; is very accessible, and not troubled with mucb water. It has furnished, up to 1868 , about two hundred and fifty tons of coal, but is now idle for want of good communication. $t$ The coal-veins of Golden City, three miles north of the Rowe mines, are now opened at five different points, the liguite-beds varying in thickness from 5 to 11 , even to 14 feet. On the shaft near the railroad.line, the coal, 7 to 11 feet thick, is nearly vertica. Half a mile from this, another shaft 70 feet deep works the same bed, also nearly vertical, 9 to 11 feet of solid, very good coal. This vein of coal has been traced and opened from Rowe's coal-bank, five miles sonthwest of Golden, to a point seven miles north of Golden, and tapped in eleven different points without discovering as yet any appearance of failure in the vein. In what is called the Golden City coal-mines, the vein is opened at three different places, 0 to 14 feet thick, and has been worked continuonsly sinec 1865 . It was discovered 1861-62. The mines have furnished as yet about eight thousand tons only, and are worked at an average of thirty tons a day. The dip varies from $65^{\circ}$ to $71^{\circ}$ soutbrest.

At the Johnson's coal-mine, half a mile southwest of Golc.sn, the vein is mined 9 feet thick, to a depth of $\delta$, feet. And at Welsh \& Com. pany's coal-bank, one-third of a mile sonth of the former, the vein worked is 5 to 7 feet thick; dip, $71^{\circ}$ sonthwest; and five veins of ligh ite are seen there parallel to one another and of varions thicknesses.

Followi ng northward the same lignite-strata, which, as said above,

- Report, 1869 , pages 37 and 38.

country around are due to the kindness of 
have been tested and recognized continuons, we find them opened on the Ralston Creel; at Murphy's, five miles north of Golden, where the vein, nearly vertical, averages in thiokness 16 feet of solid coal without parting of any kind. Eighteen thousand tons of lignite have been taken from this mine since it was opened.

Half a mile sonth of Murphy's, the Mineral Land Company has opened the sane vein, 9 feet thick, elso without parting, but contorted in its uplift. The lignite is of the same quality, but the bed has not yet been worked to any extent.

North of Ralston Oreek to Marshall, the lignite is not worked now. Bat, as it has been already remarked, in the banks of all the ereeks which, descending from the mountains, have dug their beds throngh which, descending from the mountains, have dug theirmation, beds of lignite varying in thickness from 5 to 9 feet are exposed; some of them already tested have been worked formerly to some extent. The conclusion, therefore, on the continuity of the Lignitic basin from sonth of Golden, even from the North Platte to Boulder Creek, is fully warranted. It is, in a direct line, a distance of fifty miles, and even, as beds of lignite have been reported from Thomson Creek and Cacha la Pondre River, the continuity of the Lignitic beds may be admitted for fifteen to twenty miles further north. The ex. tent of the basin from east to west, or its width, is not as yet ascertained. In the space linited between the primitive rocks and the basaltic dike, where the strata are thrown up nearly perpendicular, the amonnt of coal can be computed only from the depth attainable in the working of the mines. The length of this area from the Rowe mine to Coal Creek is about fifteen miles. Thence northward, as the strata take their normal horizontal position, the lignite-beds appear to be continuous from the base of the monntains to the Platte, or for abont fifteen miles from west to east. I have no donbt that beds of lignite Ifan be found further east by shaft, as they have been found east of can ber, on the Kansas Pacifie Railroad. But as the quality of the lignite deteriorates in proportion to the distance from the mountains, the combustible mineral would be there of little value, especially while an immense amount of lignite of good quality is as yet untouched in the valley of Boulder Creek. The section at Marshall's indicates 63 feet of eosl in a thickness of 500 to 600 feet, seven of the beds varying in of coal in a from Marshall's estate little coal has been take.4 out till now, on account of the difticulty of transportation. From information kindly given by the proprietor, the mining amounts to abont twenty-five tons per day, while, with the facilities of railroad transportation, the same mine could be worked in a way to furnish at least three hundred tons per day. Most of the coal of this country is obtained from the Erie per day. Mrost miles southeast of Marshall's, where the bank is 8 to 10 feet thick. The land is the property of the Kansas Pacific Railroad, which has a branch railroad to Boulder City, and, of conrse, preserves the monopoly of trausportation. They take out of the mine an average of two hundred tons daily. A railroad is now in progress of construe tion from Julesburgh to Golden, traced through the rich Lignitic depos. its of the Bouler Valley, and passing three miles east. and north of its of the Bouls Marshall's. This railroad, of course, will chauge much the proportion of bringing to market the material in quantity relative to its quality.

The facility of transportation may not be at first an advantage to the proprietors on account of the greater competition in the market, the demand as yet not being considerable enough to justify explorations of large extent. The consumption from Denver and eities around is esti. mated at about four hundred tons per day. The lignite-bank of Erie can supply, for an indefinite time, the demand of the Kansas Pacifo Railroad, while the Denver and Rio Grande Railmad Kansas Pacifio supply from the Cañon City coal.bed, and a large orerplus now a foll Denver market or any other on its line It is evident, therefore, that thure is

glutted market than of a scarcity of is for the present more danger of a the future the than of a scarcity of combustible material, and that for the future the settlements in the valley of the Rocky Mountains, and especially along their eastern base, mav rely on a permanent and chenp supply of coal. I shonld admit the sane conclusion even in considerip that the settlements along the Kansas Pacific Railroad considering ver to the limits of Kansas will have to source. The estimate in tons of the average productiveness of a bed of bituminous coal of the old measures, is generally marked at one million of tons per foot of thickness in one square mile. Connting a single bed of liguite of the Boulder Valley at 9 feet thick, extended ainger of only twenty-five square miles, what should we find ? Dednoting one fifth for difference in density between bitumiend admitting only eight hundred thonsand tons per foot and lignite coal, or square mile. dednting atill froms in a in mining the result graw som in mining, the result would be four hundred thousand tons per foot of lignite in a square mile, or for 9 feet three million six hundred thon. sand tons, and in an area of twenty-five square miles, ninety millions of tons obtainable from a comparatively limited extent of the Lignitie basin. Though I believe that this estimate is below the reality, calculations of this kind cain never be positively reliable, and should be admitted with due caution. It is, however, of the greatest importance for the proprietors, and for the consumers too, to positively know the capacity of the lignite-beds, in order to regulate the mining, and to fix rates of price advantageous to both parties.

\section{The Lignite-Deposits along the Union Pacipio Rathoad FroM CHeYENNe to Evanston.}

The distribution and capacity of the lignite-beds of this section have been reported already in considering the geological distribution of the Eocene formation. The essential supply of coal, either for the railroad or for the demand along its line, has been, and is still, obtaned from Carbon, Rock Springs, and Evanston. The beds of lignite at Carbon are distributed in three separate basins of limited extent. Two of beginning of the construction of the railroad, being mined since the beginning of the construction of the railroad. No data bare been obtained sufficiently precise to allow an estimate of the productive capacity of the Lignitic strata there still obtainable for exploitation. The superintendent of the mines remarks that the coal is difficult to work, being unreliable and cut by faults and irregularities. Moreover, the mine has been ignited by spontaneous combustion of the slack coal, and been on fire for a length of time. Now the amount of coal obtained from Carbon is about three hundred tons dails.

At Rock Spring the vein of lignite is still thicker than at Carbon. and the material of very fine quality. It has been, and is now, mined in the same proportion as at Carbon. The produstive capacity of this could be obtained from lower beds by shafts. The area covered by the upper bed is, however, limited, and as this bed is now mined by three 
different companies, the supply of its excellent material cannot be relied upon for a great length of time.

At Evanston the enormons thickness of the coal seems to promise, for many years, an abundant supply of materials. Pat bere the thiek ness of the clay-partings and the dip of the beds cause great dificulty of mining. A part of the bank has to remain for roof, another culty or thining. part is lost by slack in the separation of the parting, as this bed, which is also of limited extent, has to supply, on one side, the Union Paciffe Company, by the Wyoming Compans, and on the other, the Central $\mathrm{Pa}$ cifie Railroad to San Francisco, by the Rocky Mountain Coal and Iron Company. This last company's mining amounts to five hunded tons. per day in the average; that of the other, to three hundred tons. per day in the private enterprise at Besides this, beds of ilgtite hat lited divers places, and are worked to a limited extent, especially at Black Buttes and Hallville. These and the already reported lignite-beds of Point of Rocks, Creston, and Washakie, promise some further supply for the future, and I have no doubt that a number of valuable deposits may be still discovered in the Lignitic basin at a short distance anil on both sides of the railroad. It is, nevertheless, certain that if the coal is not carefulis husbanded along the Union Pacific Railroad, there will be great difficulty of obtaining a large supply in a short time to come. The present prodnction of the mine of the Wyoming Coal Company is about ten thousand tons per month, while the consumption of coal by the Union Pacific Railroad averages about ninety thousand tons per year.

\section{5. Concludng Bemarkg.}

The loss of materials by mining the lignite-beds of the Rocky Mountains is especially caused-

1st. By the difficulty of sufficient roofing, on acconnt of the seareity and of the high price of the timber nsed for that purpose. At Rock Spring, a post six feet long by four incbes in diameter costs ove dollar. $2 d$. By the want of good reliable miners, who cannot be induced to go and live in such a rough and unsettled country but by a higher remu neration comparatively to the valne of the work.

3d. By the great amount of siask, cansed either by carelessness in mining a substance less hard and compact than true coal, or by disinte. gration from the walls and roofs in the mines under atmospherie influence. This slack or small coal is always difficult to dispose of, and dangerous too, being subject to spontaneons ignition, either in the mines or out of them. The superintendent of the Carbon mines, Mr. Williams, informed me that it was by neglect of the miners, who were on a strike, and during his absence, that the slaek was ignited in some part of the mites, which have continued on fire ever since.

The uncertainty on account of a future sufficient supply of good lig. nite along the line of the Union Pacific Railroad, and the constantly increasing demand of this material for the Utah settlements, for towns and stations along this railroad from Omaha to San Francisco, eveu for the California markets on the Pacific, should induce researehes by bor ings and detailed explorations for the discoveries of new depositis of ligite, and especially a mont carefol econom in mining. ignite, and especially a more carefal economy in mining. The im provement of the quality of the matter and the disposal of even it snall parts, the slack, should be attempted by repeated experiments. Experiments of this kind have been made long time ago in Europe,
and the oitall coal, which by atmospheric influence soon begomes lost into dust, has been profitably nsed by mixing it with a certain proportion of moist clay. The same method has been tried in the Iehigh anthracit region of Pennsylvania, where the coal is comparatively of far less valn than the lignite of the Rocky Mountains, aud large, expensive machinery has been erected for that purpose. As yet these experiments proved a failure, or, at least, have not given remunerative results have mixing of elay, or of any other mineral incombastible cement, cannot improve the material, especially not when, as is the case with the lignite, the hesting power of the mattor in its purity, is not always as stron, as required by enginery. It seems very probable, however, that the admixture of bitumen with small coal either pulverized orer, that the moderate size, shonld, by compression of the paste furnish in pieces of moderate size, shonld, by compression of the paste, furnish an excellent combustible naterial. The bitumen, of course, should be obtained or reduced to the consistence of a kiad of glue. I wonder that, with the immense amount of bitumen stored in the black shale of the Creen Pirer group, no trial has as yet been made by some company for the River bility of this material yet been made by some company for the appliea. bility of this material. Thick beds of these black shales are exposed all along the railroad from Rock Bprings to Bryan and farther. And some of them are impregnated with so much bitumen that, as I have said already, the matter is percolating from them through the nnder. lying sandstone. Though the shales do not consume, they are often ised for fuel by the settlens. The coal of Elko Station was for a time burned in locomotives in the Utah Valley, and this conl is nothing but black shale of the which would cost comparatively little, wonld settle this importan, question, and 1 truly believe that the result wonld be snccessfol and would confer immense advantage on the people at large interested in the coal-supply of the Rocky Monntains, and the instions and still more on the railroad and the instigators of such an enterprise. Nature has done nothing in vain; this truth cannot be too often acknowledged. This bitumen of the black shale is a complement of the as yet untinished work of the lignite matter. It depends on the ingenuity of man to render it what it snite be, fully appropriate to the wants of that population which is crowd. ing in that, as yet, undeveloped region.

I do not think, however, that without this improvement of its mat. ter, the lignite, as it is, is inadequate to the present necessity. For the Rocky Mountains, however, the present is nothing in proportion to the promised futare.

In comparing the valne of the lignite for heating power, a great number of analyses have been made, and, of course, the results arrived at hase not always proved reliable. All the lignite, and the coal, too, contain more or less water, in a degree relative to the progress of decomposition of the woody matter. In proportion as this decomposition advances the amount of water diminishes, and the compactness of the advances the with its proportion of pure carbon. It is therefore admitted, rule, that the value of a combustible of any kind, or its heating property, is proportionate to its density. The density for the combustible minerals is sometimes increased by an amount of earthy matter, easily recognizable in the proportion of rsbes. In our lignite of the West this exceptionable case is not often remarked, and the lignite-beds of the Rocky Mountains generally give a material of good quality, weighing in average one-fifth less than the best coal of ures. Local differences are remarked of conrse, bnt mostly resulting from the degree of ear which appears to ans rock appears to have been increased by the influence of the primitive $24 \mathrm{Gs}$ 
of the lignite becomes impaired at a greater distance from the motntains, in beds of the same age.

The companies and proprietors of lignite-beds make constant inquiries of the possibility of redncing or smelting iron ore with their coal. I think that this could be done with lignite, prodncing good hard coke thiuk that this could andes of which then could be used che far deprived of water that their bulk may the West have been as yet 80 far deprived of water that their bulk may be left compact by combustion. I know only of the such result; all the other lignite gives dust-coke. In confirmation of this assertion, and to end this subject, I append a few analyses made from specimens selected by this of by myself as represuling These analyses havethe incrit of being carefully made all with the same process and by the same chemist, and therefore offer perfectly reliable points of comparison. They complete the table of analyses given by Mr. James T. Hodge in his excellent paper on the Tertions as they are Tere, they present a reliable acconnt of the essential componds and of the the presits of our wester the comparative value of the more imprtant deposits of our western lignitic coal. It is to be regretted that no more care is given to the preparation of documents of this kind. Comparative analyses shonl be made by the same chemist, and the result published under a wellknown anthority, to prevent frauds or impositions by the publication of misrepresented or often false statements.

Analysees of coals by Mr. C. Leo Mees.

\begin{tabular}{|c|c|c|c|c|c|c|c|}
\hline 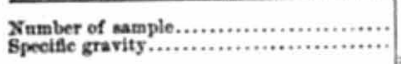 & 1. วิ15 & 1. ${ }^{c} .04$ & 1. 2200 & 1.26 & 1.28 & 1. $m^{5}$ & $\stackrel{6}{1.315}$ \\
\hline \multirow[t]{2}{*}{ 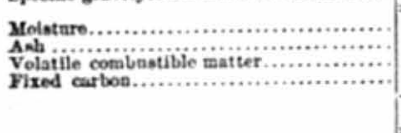 } & $\begin{array}{r}8.10 \\
53 \\
31.00 \\
\text { s1. }\end{array}$ & $\begin{array}{r}610 \\
350 \\
3 \times 50 \\
42.30\end{array}$ & $\begin{array}{l}6.25 \\
2.55 \\
31.75 \\
52.45\end{array}$ & $\begin{array}{l}1.13 \\
1.90 \\
3.65 \\
57.0\end{array}$ & $\begin{array}{r}5.0 \\
2.0 \\
3 \times 10 \\
5470\end{array}$ & $\begin{array}{l}12 \% \\
200 \\
2010 \\
4600 \\
46.0\end{array}$ & \\
\hline & 100.00 & 100.00 & 100.00 & 100.00 & 100.00 & $100, \infty$ & 100 \\
\hline 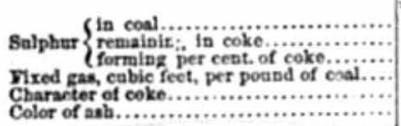 & $\begin{array}{l}0.91 \\
0.2 \\
0.320 \\
2920 \\
\text { Pulv. } \\
\text { Gray. }\end{array}$ & $\begin{array}{l}\text { a. } 917 \\
0.39 \\
0.263 \\
3025 \\
\text { Palv. } \\
\text { Gray. }\end{array}$ & $\begin{array}{l}0.91 \\
0.930 \\
0.708 \\
361 \\
\text { Polv. } \\
\text { white. }\end{array}$ & $\begin{array}{l}0.81 \\
0.617 \\
0.007 \\
0.21 \\
\text { Ging. } \\
\text { Ging. }\end{array}$ & 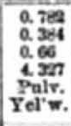 & $\begin{array}{l}0.376 \\
0.301 \\
0.5112 \\
4068 \\
\text { Palv. } \\
\text { Yamn. }\end{array}$ & \\
\hline
\end{tabular}

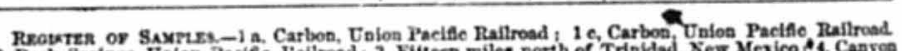

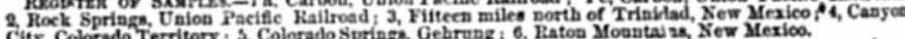

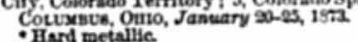

- By a young friend of mine, already an experienced chemist, Mr. Leo Mees, of Colnmbus. The analyses were made in the laboratory and under the supervision of Profoseor Wormly.
Analysea of coalo from the Rocky Mcountains by J. T. Hodge.

\begin{tabular}{|c|c|c|c|c|c|c|}
\hline Locallitices. & 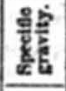 & है & ใैं & $\begin{array}{l}\text { है } \\
\text { हैँ } \\
\text { है }\end{array}$ & , & Description. \\
\hline 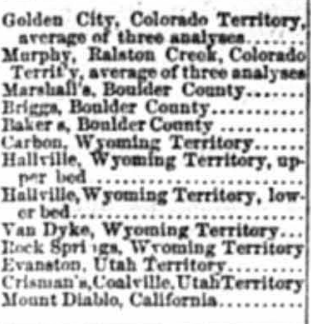 & 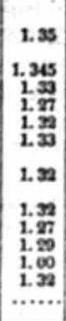 & $\begin{array}{r}12.12 \\
13.28 \\
8.12 \\
7.0 \\
8.59 \\
10.6 \\
2.98\end{array}$ & 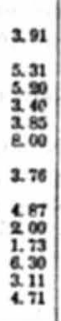 & 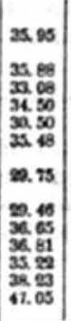 & 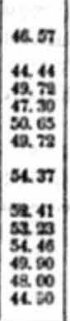 & 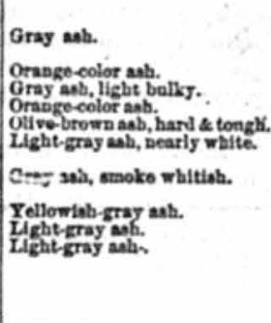 \\
\hline
\end{tabular}

ENUMERATION AND DESCRIPTION OF FOSSIL PLANTS FROM THE WESTERN TERTIARY FORMATIONS.

\section{South Park, near Castello's Range.}

A yellowish, laminated, soft shale, breaking easily and splitting in thin layers. Remains of plants well preserred and distinct, with remains of insects and feathers. Specimens collected and communicated by Mr. S. A. Allen.

\section{OPHIOGLOSSUM ALLENI, sp. nov.}

Leaf, elliptical, narrowed by a curve to the acnte base; shorter and broader than in 0 . vulgatum, $\dot{L}_{\text {. }}$, of onr time, with the same areolation The leaf is about 3 cent. long, (point broken,) a little more than 2 cent. broad, marked in the middle by the remnant of a fruiting pedicel. No fossil species of this genus has been as yet published, but a small one, O. aocenum, Mass., from the Tertiary of Verona, Italy.

Thuites callitrina, Ung., chlor., p. 22, Pl. vi, Fig. 2.

Though the fragments are small, they are rery distinct, and there is no appreciable difference from the description and figures of this species. The same specimen bears a fragment of Salix like $\boldsymbol{S}$. lingu. lata, Göpp.

\section{Planera lonatfolia, sp. nov.}

Leaves oblong, lanceolate, obtusely pointed, wedge-shaped at the base to a petiole; borders simply dentate; secondary veins tbick, simple, craspedodrome.

It differs from Planera Ungeri, Ftt., and its varieties, by longer, proportionally narromer leaves; by more oblique, straight, always simple, secondary veins, which are thicker and more distant; by more obtuse and larger teeth; some of the leaves are unequal at base and curved on one side. Average length, 4 cent., $1 \frac{1}{2}$ cent. wide. The distinct areolation is that of the species as marked in Heer, Fl. Fert. Helv., Pl 
1xxx, Fig. 3. The form is that of Myried Schlechtendali, Heer, Bornstaedt, Fl., Pl. i, Fig. 7.

\section{Elko Station, Nerada.}

Specimens on the same kind of soft laminated clay shale as the former; collected and communieated by Mr. S. W. Garman.

\section{Sequora angustrpolia, sp. nov.}

Leares short, narrow, linear-pointed, erect, or slightly appressed all around the branches, decurring at base.

It is much like the small forms of Taxodium dubium, as fignred by Ett., Bil. Fl., Pl. xii, Figs. 3, 14, 15, with leaves, however, shorter and decurrent.

\section{ThuYa Garmani, sp. nov.}

Branchlets short, alternate along a primary branch, of the same thickness; leaves nearly round, inflated, and marked by a gland at the point, narrowing downward; in four rows.

The specimen is small but very distinct; no remain of cone has been found. Its nearest affinity is with Thuya sibirica, Hort., a var. of Thuya occidentalis, L, differing by shorter, more obtuse, more inflated leares. As it is to $T$. sibirica what this variety is to $T$. occidentalis, it may be considered as a parent form of our present species.

ABres Nevadensis, sp. nov.

Leaves two ranked, horizontally spreading, 1 cent. long, 2 mill. wide, linear, abruptly pointed, obtusely narrowed at base to a short petiole, broadiy nerved.

This species, represented only by a small branch, is like the large forms of Taxodium dubinn, differing by exactly linear leaves, obtuse at both ends, larger size of branches and leaves, \&c. From Taxites olriki, Heer, Aret. Fi., Pl. Iv, Fig. 7, it differs, too, by linear, shorter, more horizontal leaves. Its nearest afinity is with our living Abies Cana. densis, Mich., being ouly slightly more robust and the leaves more abruptly rounded and not enlarged at their base.

Salix elongata, O. Web. Pal., p. 63, Pl. ii, Fig. 10.

The base of the leaf is broken; the part left, 11 cent. long, exactly correspondsin size and nervation with the upper part of Weber's figure.

\section{Raton Mountains.}

The Thalassophytes described from this locality are all from the Eocene sandstone underlying the lignitic strata. Except the species of this class, none other has been added to those already known from specimens obtained formerly by Dr. Hayden and described in Supt., pp. 12 to 16. The very hard metamorphic sandstone and shale contain. iug plants breaks under the bammer in irregular small fragments, of little value for the paleontologist.

\section{SPARRTA LAPIDEL, op, nov.}

Perithecia round, highly convex, 1 to 2 millim. broad, growing in lineal series from ander the bark and piercin'? it before opening; borders irregularly lacerated; color whitish.

This species is upon a petrifled fragment of wood, part of which is still corticated, on another part the bark has been destroyed. The borders of the opened perithecis are somewhat inflated. A single one is still entire or unopened, comparable by its form and size to the living Verrucaria nitida, Ach.

\section{ChondrItes suBsmiplex, sp. nov.}

Frond cylindrical, flattened by compression, 5 mill. wide, with rare dichotomous, long, flexuons branches, mostly of the same size, some, bowever, reduced in size to one-half from the point of division from the main stem.

This species is found mostly flattened or expanded upon large slabs not passing across layers of sandstone. Upon some of these slabs the filaments appear simple resembling Halimenites lumbricoides, Heer, (Urwelt der Schweitz.) The surface is irregnlarly ronghened and generally marked in the middle by a depression indieating the fistulose character of the plant.

ChoNdrites BULBosUs, sp. nov.

Frond plain, irregularly subpinnately divided in opposite or alternate branches, close to each other, or distant, short, intlated like irregular tuberoles.

The branches vary in thickness from two to five mill., generally five to eight mill. long, often bilobed at the obtuse point; they are, like the main stem, inordinately inflated and narrowed.

\section{HALYMENITES stRLTUS, sp. $n$ v.}

Frond cylindrical or compressed, erect, one foot long or more, dicho. tomous; branches short.

The ramification of this species is variable, the divisions being more or less open, sometimes at a right angle from an inflation of the main axis. The surface appears generally smooth; where the coating of stone is rubbed out, it appears coarsely ribbed as by a linear series of tmber. direction. It is related to Fucoides cylindricus, Sternb. Common at the Raton; found also at Golden by Professor Mreek.

\section{HALYMENTE MJOR, sp. nov.}

Frond of the same thickness auc mode of division as the former; surface marked by round contignous or disjointed tubercles 2 to 5 mill. broad and as thick.

It has the same general appearance as the former. Its branches are sometimes longer and stnaller. The stems are 2 cent. broad.

HALYMENITES AINOR, $F$. $O$.

Branches half as thick as in the former species, 8 mill. broad, marked with small tubercles. 
These branches are of the same size and form as the one figured by Heer in Urwelt der Schweitz, (Pl. xi, F. 1.) As they are, however, found in connection with the former species, at least in the same beds of sandstone, they may represent mere divisions of it.

\section{DELEgSERIA INCRASBATA, sp. nov.}

Frond sessile, trifid from its base, divisions, thick, obovate, attenuated downward to a narrow pedicel; surface plicato-rugose.

The saulstone has deep prints of these leaves, which appear as united in groups from the base, or growing in tufts. One of these leaves or divisions seen isolated is oblanceolate, abruptly short-pointed, grad. ually tapering to the base, 2 cent. wide at its broadest part, near the point, 3 mill, at base, 5 cent, long. If by the form of its leaves this plant is a Delesseria, the thickness of its divisions, jndged from their plant is a Delesseria, the thickness of jts disisions, jnot prints on the stove. is different from that of any living species of this genus. The prints, however, may bave been made by the superposition of a group of segments of the same form.

\section{Drtesserla lingulata, sp. nov.}

Leaf small, coriaceons, entire, obtuse, rounded at base, slightly con. tracted in the midide, with a broad inflated medial nerve.

The leaf or segment is 2 cent. ioug, 12 mill. broad, of a subcoriaceous or thickish consistence. The sandstone has many fragments of the same form and size.

ABietites Dubrus, Lsqx., Am. Jour. Seience and Arts, (1868,) p. 203.

Leaves erect or slightly open, imbricated around the branches, exactly lanceolate, sharp-pointed, broadest at the base, where they are abruptly contracted to the point of attachment.

I have found, probably at the same place where Dr. Leconte obtained his specimens, a quantity of branches of this species, varying from 2 cent. to 3 mill. in thickness, all indicating the same characters. The cent. to 3 mill. in thickness, all indicating the same characters. The
leaves are 8 mill. long, $1 \frac{1}{2}$ mill. broad, near the base. Stems and branch. lets are marked by the deep and distinct scars of the base of the leaves, varying in form according to the sizs of the branches. No cones or seeds have been found as yet. It is common in the lower lignitic Pocene. Good specimens of the stems have been obtained in the choco. late-clay beds of the lignite, near Fort Steele, by Professor B. F. Meek. Its affinity to living species is as yet unascertained.

\section{ARUndo Göppreti, $A l . B r$.}

Large fragments of leaves with characters of this species.

\section{Phragmites Oeningensis, $\mathrm{Al}$. Br.}

In connection with Abietites dubius in the liguitic-bearing strata, and also in fragments within the Eocene sandstone.

\section{Sabal Oampbeliti, (1) Nerob.}

It is described in Supt.,p.13. The fragments are very abundant, but always obscure. It may be a different species.
Populus moNodon, Lsqx., Supt., pp. 13 and 14.

The leaf is smalier than those already described from this place and from the Mississippi Eocene, 6 cent. long, 4 cent. wide, ovate, lanceolate, pointed, rounded at base, or abruptly narrowed to the petiole, entire and coriaceous. The nervation is that marked in description of this species.

Ornnamomum Mississipmense, Lsqx., Supt., p. 14.

Aburaint. Already quoted from this locality.

Rhamvus obovatus, Lsqx., Am. Jour. Science and Arts, (1868, p. 207.

Represented by some specimens exactly similar even in size to those obtained from Purgatory Caũon by Dr. Leconte.

\section{Gehrung's coal.bed, near Colorado Springs.}

The remains of fossil plants are here badly preserved, mixed in great number in a soft, easily disaggregating sandstone. They are mostly broken and undeterminable. The few which could be recoguized are ti., following :

\section{Sabal Campaeliti, (1) Neteb.}

The same form as that of Raton Mountains.

\section{Platanus Haydeni, Netcb.}

Two large well-preserved leaves.

DOMBEYOPSIS OBTU8d, sp. nov.

Leaf round, cordate, very obtuse, with two obtuse scarcely-marked lobes on each side, near the point at the extremity of the lateral veins, which ascend in curving from the base of the medial one.

The lower part of this leaf is broken, and therefore its description is incomplete. It is from its form and nervation a species of Dombeyopris allied to $D$. tridens, Ludw., Pal., Pl. xlix, Fig. 3, twice as large, and differing by the very obtuse, round point, and scarcely-marked obtase lobes.

\section{Frous thizpoli, $A l$. Br.}

In large identifiable fragments; no leaf entire.

\section{Golden City, Colorado.}

Most of the specimens are from a sandstone easily cut in the line of stratification, and where entire leaves, even of large size, were obtained.

\section{SCLEROTIUM RUTELLUM, $s p$, nov.}

Oval or linear, obtuse, 1 mill. broad, 2 to 4 mill. long, following or intermediate to the striæ of Flabellaria zinckeni, Heer, deeply impressed 

into tis epidermis; reddish at its surface when young; center some-
what mavillate.

It has io apparent relation to any fossil species as yet published. In some sp cimens the center looks split, as in species of Hysterium.

\section{DELESSERIA FULVA, sp, nor.}

Frond membranaceons, dichotomous, (apparently long,) linear, with a thick medial nerve; divisions linear, distant, obtuse, or enlarged at the point.

The preserved part of the frond is 20 cent. long, its average width 6 mill. The divisions are irregular in distance and position, varying in length from 5 cent. near the base of the frond to mere obtuse lobes at its upper end. Its color upon the white randstone is of a deep yel. low. It is distantly related to Delesseria Spharococooide;, Ett., from the Eocene of Promina.

Sphenopteris Eocknica, Ett., Foss. Fl. of Promina, p. 9, Pl. ii, Figs. 5-8.

Frond large, at least tripianately divided; secondary pinna long, lanceolate, taper-pointed, oblique, from a half-round narrow rachis; pinnules numerous, very oblique, close to each other, contiguous, united from below the middle, acutely lobed; veins pinnate, the divisions either simple or forking once. This form somewhat differs from the one published by Ettinghausen, by the connection of the pinnules from below the middle, while they are separated from the base in the European species; also, by the sharp-pointed lobes of the pinnules, these being described as obtuse by the author. The nervation, too, shows a noticeable difference, the secondary veins in our specimens being stroug, flat, generally simple, and ascending to the point of a lobe, or, when forking, one of the branches passing aside to one of the very acute sinuses. These differences may be specific or merely simple varieties resulting from the part of the frond represented by the speci. mens. The general appearance is the same. Splendid specimens of this species were obtained at Golden, especially by the kindness of Rev. L. Burns, the superintendent of the mining college of that place.

\section{PTERIS ANCEPS, sp. nov.}

Frond linear, lanceolate, thick nerred, with apparently entire borders; secondary veins at a right angle from the medial one, thin, though dis. tinct, forking near the base, and one of the branches forking a second time from the middle.

A mere fragment, comparable to Lomariopsis cilinica, Ett., Fl. Bil., p. 13, Pl. iii, Fig. 13, somewhat different by the nervation.

Phriamtes anngensis, Al. Br.

Fne specimen of stems with articulation and scars, were found in the white sandstone under the lignite beds. Professor Meek has also wellpreserved specimens of rootlets, with their capillary filaments from the same sandstone.

\section{CAREX Berthoud, ap. nov.}

Leaves narrow, flat, narrowly and obseurely striate, except on the borders; seeds numerous, flattened, 2 mill. wide, with an oval, slightly pointed, and slightly broader perigyninm.

The nervation of the leaves is marked only by two veins on each border, as in Oyperus arcticus Heer, Fl. of Spitzberg. The seeds, apparently attached on short pedicels, resemble those of Carex antiqua, Heer, of the Baltic flora, as represented Pl. iii, Fig. 18, being, however, larger, and the perigynia broader than the seeds, and distinct.

Fla bellaria zinckent, Heer, Fl. Bornstaedt, p. 11, Pl. ii, Fig. 3-4.

By the size of the segments, and by their nervation, the numerous and distinctly veined fragments found in the white metamorphic clay of Golden represent exactly the Europesn species. The Bornstaedt lignitie formation is considered by Heer as lowest Miocene or upper Eocene.

$$
\text { Flabellaria lataira, Stern., (Fos8., Fl., 1, Pl. xl.) }
$$

To this species of Sternberg, I refer a number of specimens, all of striated, tubulose, long, linear leaves, like those published under this name by Ettinghausen in Fl. Prom., p. 12; Pl. iii, Fig. 2-3. The striæ are coarse and deep, as figured by this anthor, but there is no remain of petiole.

\section{SABAL GoldiNa, sp. nov.}

Distinct from Sabal Campbellii, Newb, by its large triquetrous or rather deeply keeled petiole, the keel being nearly acute. The sides at the base are 5 cent. wide. The rays appear larger than in $\boldsymbol{S}$. Camplellii; the nervation is not more distinct. No specimen of the lower part of a leaf could be obtained.

\section{Palmacites, species.}

Part of a trunk of palm; an impression 15 cent. broad, slightly concave, marked in the length by deep, nearly regular, and equal stria, separated by sharp, acnte, narrow ridges, 1 mill. distant. This is not referable to any fossil species published. Specific determination, how. ever, is not possible.

\section{Populus atrenuata, Al. Br.} 12.

Of the same character as the leaf in Fl. Fert. Helv., Pl. lvii, Fig.

Quercus trungularis, Göpp., (Schotznitz, Fl., p. 15, Pl. vi, Fig. 13-17.)

Leaves ovate, attennated to a short petiole, more abruptly narrowed to an obtuse point, borders undulate above, entire from the middle downward, nervate or pinnate.

The stone where the leaven are preserved is coarse grained, the borders near the point are somewhat indistinct. The lowest pair of secondary veins ascends in an acute angle from the base of the leaf, the others, pearly 

opposite and parallel, pass in a more open angle to the borders, where they slightly and abruptly curve. The iowest pair, only branches outside. fied with Göppert's species.

\section{QUERCUS STRAMINEUS, sp. nov.}

Ieares small, broadly orate, obtusely pointed, rounded to the base, Leares small, brurved to the petiole, entire; nervation pinnate, secand abruptly recurved to the petiole, en
ondary veins thick, parallel, camptodrome.

ondary veins thick, parallel, camptodrome.
The leaf is 4 cent. long, 22 mill. broad, the secondary veins equidis. The tant, diverge in two equally thick branches, anastomosing borders, where they divide in the up and down with divisions same as in Quercus Desloesi, Heer, (Fl. Tert. Helv., p. 56, Pl. Ixxvil, Fig. 7,) except, however, that the veins are less distant, not undalate, shining, yellow.

Quercus axgustuloba, Al. Br.

We have two fine specimens of this rare Eocene species. Though not We have two fine specimens identified. One is a large leaf as the quite entire, they are positively identified. One is a large leaf as the one described 3 . The lobes of the leaves are long, diverging, linear lanceolate, obtusely pointed. Heer has published it from the liguitic of Bornstaiedt.

Fagus febonl $x$, Ung. Cblor., p. 106, Pl. xxvii, Fig. $3-4$.

Leaves orate, pointed, irregularly dentate above the middle, rounded or attenuated to a sleuder petiole, nervation simple craspedodrome.

One of the leaves is somewhat large, the lower part is destroyed. It

One other is a sinaller leaf, lanceolate. appears rounded to the petiole. The other is a sivergence. Both pointed, with the veins on a more acute angle of divergence. Both forms are represented in the Bil. flora of Etfinghansen, Pl. xv, the first leaf like Fig. 20, the second like Fig. 16. The lower veins of the small leaf have stroug fibrilla downward, like thin secondary veins.

\section{ULMUS (1) IRREGULARIS, sp. nov.}

Leaf large, coriaceous, oval-oblong, narrowed or wedge-form to the petiole, nervation pinnate, secondary veins close and deeply marked.

petiole, nervation pinuate, secondary veins destrosed in all the specimens. The borders upward and the point are destroyed in all the specine long, The secondary veins are straight from the medial nerve, except near (angle of divergence 40 slightly downward in joining it, generally the base, where they curve sibrillose. Though simple, some anormally forking from near the base; the nervation and facies are those of $U$ lmus, the leaves are doubtrully veins along the borders.

Frous asarifoli, Ett., Bil. Fl., p. 30, Pl. xxv, Fig. 2-3.

The leaf representing this species is larger than those described hy the anthor; it is, however, positively referable to it by its form, its crenulate border, and its nervation.

\section{Frous spgotane Is, sp. nov.}

Leares large, coriaceous, entire, broadly ovate-lanceolate, contracted to a short point, round truncate to the petiole pinnately ner red, the lowest pair of secondary veins opposite from the buse, branching out. side, the upper ones mostly simple, parali. i, i. regular is distance, oblique, camptodrome.

The leaf, an entire one, is 15 cent. long, 8 cent. broad in its widest diameter below the middle, equilateral. The first pair of secondary veins is basilar and branched; the others, though parallel, are at irregular distances, all curving along the borders and anastomosing with ter. tiary veins orfibrillw. Allied to Ficus Schimperi, Lsqx., of the Mississinpi Eocene, it differs by its coriacec as substance, by the basilar veins going out from the top of the petiole, by the somewhat abruptly-contracted (not tapering) point, \&e. With an entire leaf, the collection has a number of fragments of this fine species.

\section{Ficus aurictlata, $s p$. nov.}

Leaves membranaceons, entire, smootb, ovate-lanceolate, taperpointed, rounded to the base into two auricles joined at the borders below the top of the petiole, pinnately nerved; the lower pairs of sec. ondary veins opposite from the base of the leaf, the upper oues parallel, alternate, camptodrome.

The leaf described is perfect and its nervation distinct. Three pairs of veinlets curve downward from the top of the petiole, passing in curves to the borders of the auricles. All the secondary veins are inore or less branching downwards, curving along and following the borders in anastomosing with divisions of the superior ones. Fibrilla distinct, nearly continuous; the leaf, 10 cent. long, has, besides the basilar vein lets, ten pairs of secondary veins. It is somewhat unequilateral.

Platanug Raynoldsir, Newb.

Is represented by splendid specimens, but none as entire as the one described by the author, Extinct Fl. of N. Am., p. 69 .

\section{Platanug Haydenir, Newb.}

Most common at Golden. The leaves are still larger than marked by the author, some of them preserved entire.

Benzon antiquum (?), Heer, Fl. Ter. Helv., II, p. 81, Pl. xe, Figs. 1-8.

Leaf oval, obtuse, entire, narrowed to a broad petiole, pinnately nerved, lowest pair of secondary veins opposite, joining the medial nerve at a distance above the base; the others alternate, all thin and at an acute angle of divergenee.

A single leaf, doubtfully referred to this species on account of obsolete details of nervation. The surface of the leaves is pnnetate as in Benzoin attenuatum, Heer, (loc. cit., Fig. 10 ;) but the form of the leaf and the secondary veins are like Fig. 6, of 'B. antiquam.

Cinnamomum Rossmässleni, Heer, Fl. Tert. Helv., II, p. 84, Pl., xeii, Figs. 15-16.

The leaves representing this species bave the form and size of those loc. cit., Fig. 2, with numerous straight, strong nervilles, perpendicu- 
lar to the medial vein, and passing from it to the lateral ones, as in Fig. 16.

Crnnamoxux Mrssissiprense, Lsqx., Supt., p. 14.

Fine specimens of this species, of frequent occurrence in the Ameri. can Eocene, were obtained at Golden.

\section{Cissub levigatus, ap. nov.}

Leaves subcoriaceous, polished, round-oval, abruptly narrowed or broadly wedged form to the petiole, three-nerved from the base, nervation actinodrome retiform; borders undulately crenate.

The collection has many specimens, but none complete, the upper part of the loves being mostly destroyed. The leaves are petioled part of the two lateral reius diverge at an acnte angle and branch ontside, the branches parallel, running to and entering the borders in dividing.

\section{DOMCBEYOPSIS TRIVIALIS, sp. nov.}

The lower part of a leaf, round-cordate at base, entire subcoriaceous, three-nerved, lateral veins strong, curved upwards, branching outside. This leaf resembles the one in Heer's Fl. Balt., p. 74, PI. xvil, Fig. 11, named Ficus Dombeyopsis, which, however, has two pairs of lateral veins from the base, while ours has only one. As in Heer's leaf th lower part is destroyed, while the point is erased in ours, it is not pos. sible to make an exact comparison.

\section{DOMnEYOPgIS OCCIDENTALIS, sp. nov.}

Leaves coriaceons, entire, cordate-acuminate, trinerved from the base, supericr lateral veins at equal distance, alternate or opposite, camptodrome.

A number of specimens of these fine leares present all the sanie form A number of specimens of these 10 cent. broad, below the middle or toward the enlarged cordate base, narowed or tapering to the point. The lower lateral reins are much branched outside, 8 to 10 branches, curv ing to and along the borders; the upper secondary veins are either simple or sparingly divided by under branches, all the divisions cupving to and to and along the appear somewhat reflexed. The nervation is that of Dombeyopsis „randi. appear som

\section{SAPINDUS CAUDATUS, sp. nov.}

Leaf unequilateral, entire, broadly lanceolate, tapering into a long acuminate point, narrowed to the petiole on one side, rounded to it on the other.

The secondary veins are alternate, unequally distant, the lowest ones more open, curving to and along the borders and anastomosing with shorter intermediate ones. The nervation is of the same type as in sapindus falcifolius, Heer, Fl. Helv, Pl cxix, Fig. 16. I found tro sapindus follo leaves of this species; the largest 10 cent. long, 4 cent. wide in the
middle.

\section{Oraxothus PIBRHLOBUs, ap, nov.}

Leaves subcoriaceous, ovoid, obtuse, rounded to the base, (petioled ๆ) five-nerved from the top of the petiole; nervilles in right angle to the medial vein, continuous.

Species related to Ceanothus ovoideus, Göpp., (Schossnitz) Fl., p.36, Pl. xxii, Fig. 13, differing, however, by the thick substance of the leaves, their larger size, and all the lateral veins going out from the base. The lowest lateral veins aro much branched, and not acrodrome, ascend. ing only to above the middle of the leaf.

\section{RHamés Cleburi, sp. nov.}

Leaves thickish, (not coriaceous,) narrowly oval-laceolate, equally tapering from the middle upward to a long sharp point and downward to a short petiole; pinnately nerred, secondary veins elose, slightly arched in passing to the borders, where they abruptly curve along the margin.

The species is known by a number of finely-preserved specimens, with all the same characters. The leaves are variable in size, the largest 9 cent. long; the secondary veins always close to each other, parallel, simple, scarcely 5 mill. distant, abruptly enrving quite near the borders, which they follow; fobrilles numerous, strong, subcontinuous in right angle to the medial nerve. The nervation and form of these leaves, like that of the following species, as also of Rhamnus obovatus, Lsqx., is much like that of some species of the genus Bridelia of the Euphor. biacex. When better know' by their fructifieations they shall probably form a separate group.

\section{RHameus Goldianus, sp. nov.}

Leaves thickish, subcoriaceous, smooth, entire, broadly oblong orate, abruptly narrowed to a short blunt acnmen, ronnded at base to a short petiole.

These leaves, of which I obtained numerons fine specimens, vary in size from 7 to 15 cent. long, proportionally broad, have about the same nervation as the former species, the secondary veins being only slightly more distant, less oblique, (angle of divergence 40 to $45^{\circ}$ ) and nearly straight to near the borders, where they more gradnaly curve. The lowest pair generally branch more or less downward, in anastomosing with their short marginal veins; even the superior veins have sometimes one or two divisions. The species still differs from the former by its more coriaceous substance, its ronnded base, and the obtusely acumi. nate point.

\section{RHAзNos Goldinds, var. LATion, Leqx.}

The leaves considered as variety may represent a different species. They are much larger, of a thicker substance, more ronnded at the base, and passing to the petiole by a short decurrent curve. They much resemble the leaves referred to Ulmus (1) irregularie, being intermediate between this and the above species.

RHaMrus obovatus, Lsqx.

Already mentioned from the Raton Mountains, is a truly different species from Rhamnus Oleburni, to which it resembles by the nerva. 
tion. Besides differing by the form of the leaf, the secondary reins are thicker and flat, and the nervilles scarcely distinct.

RHasnus acumnatrolros (१), Heer, Fl. Tert. Helv., III, p. 81, Pl. exxvi, Fig. 3 .

A fragment only, with the point and the base of the leaf destroyed. The form of the leaf and its nervation agree with the author's figure and description. It differs much from the other species described above.

RHAMNUS RECTINERvis, Heer, Rept., (1871,) p. 295.

It is not frequent at Golden. We have only a few specimens from the white sandstone.

JUGlaxs RHasnoides, Lsqx., Rept. (1871,) p. 294.

Sparingly represented at Golden.

Juglans rugosa, Lsqx., Supt., p. 10.

Fonnd in more numerous and better preserved specimens than the former.

$$
\text { Juglaxs (picus १) Smithoniana, Lsqx., Supt., p. } 16 .
$$

The leaf referable to this species merely differs from tho one pub. lished from the Raton, by the less tapering base, which is more abruptly attenuated to a broad petiole, a difference scarcely noticeable.

\section{JUglans Schmperi, Lsqx., Supt., p. 8.}

The specimens of Golden have the same characters as described. The peculiar form of the leares identifies them easily.

\section{Canpolitues palmarux, Lsqx., Snpt., p. 13.}

A number of fruits of the same size and form as those from the Raton Mountains. They are not striated, howerer, and rather coarsely wrinkled. They may represent a different species.

Beside the leares described from Goiden's specimens, I found still there a stipule of Platanus, a leaflet, square in outline, $2 \frac{1}{2}$ cent. wide, acutely short-lobed at the two upper corners, truncate at base, withont risible nervation. It is apparently referable to Platanus Haydenii.

A number of fragments of nncertain affinity, or whose character could not be recognized; among them, leaves doubtfully referable to Alnus Kefersteinii, Göpp, others to Rhantnus Dechenii, Web., and still others to Cinnamomum Mississipiense. Lx., have been obtained from the same locality by Prof. B. F. Meek.

\section{Marshalls Estate, Boulder Valley.}

Specimens of fossil plants are here found, either in clay-beds, where the fragments are heaped and mixed together in a mass of unrecogniz able forms, or in a coarse sandstone, where the details of nervation are generally obliterated. I could, moreover, dispose of but a short time for researches in a locality which had been sufficiently explored by Dr. Hayden and other geologists. The few specimens got there represent the following species:

\section{Phragmites Oeningensis, Al. Br.}

In numerons specimens.

\section{Flabellaria zinckent, Heer.}

The same form and characters as the specimens of Golden referred to this species.

$$
\text { QUERCUS CHLOROPHYLLA, Ung. }
$$

A number of specimens of the same species which I considered as identical with this Quereus, in my examination of the fossil plants of Dr. Leconte, in Am. Jour. Sci. and $\Lambda \mathrm{rts},(1862$,$) p. 206$, and was de. scribed and tigured under this name in Proc. Am. Phil. Soc., vol, xili, p. 413 , Pl. xvii, Fig. 5 to 7 . These leaves are of a coriaceons substance 413 , Pl. xvii, Fig. 5 to 7 . These leaves are of a coriaceons substance
and have scarcely any trace of secondary veins marked on the surface; their relation is undefined. The Marshall's leaves are slightly more rounded to the petiole than those of Mississippi.

CrNnamomum APPINE (१), Lsqx., Am. Jour. Sci. and Arts, (1868,) p. 206.

The specimens are not distinct enough to ascertain if they represent this species or Cinnamomum Mississipiense, Lsqx.

The main coal of Marshall's is mixed near the bottom with large fossil. carbonized trunks, which, by cleavage, appear as cut by the ax. The same are found, too, in the same cireumstances at the Cañon City coalbed.

$$
\text { Erie Mines, Boulder Valley. }
$$

The soft, sandy shale overlying the lignite-bed is full of finely pre. served vegetable remains. But this shale is left in the mines for roof, or when taken out it is soon crumbling into small fragments under atmospheric influence. By the kindness of the superintendent, Mr. Hill, I got from the mines a few pieces of shale, which, as seen from the following descriptious, indicate the richness of the flora of that locality. Further explorations should be pursued in the mines, or in the opening of a new tannel, with sufticient anthority to obtain fresh slabs from the roof shales.

$$
\text { Sabal Campbellii ('), Newb. }
$$

A number of fragments of rays of a Sabal, probably referable to this species. The shale being soft-grained and the specimens distinct, the striz of the rays are distinguishable and may be connted. They are very thin and close, like mere woody fibres, 30 in a width of 34 mill. The rays between the plicatures are 16 mill. wide, and have, therefore, about 150 of these lines. They are all of the same thickness. 


\section{Oaulnites pecunda, op. nov.}

Branches of racemes, 2 mill. wide, smooth, with inflated borders, divided in opposite erect branchlets, half as thick, bearing on each side, and on short pedicels, simple round capsules, with a central nucleus.

The capsules are mostly opposite, rarely alternate, and close to each other along the branchlets. One of these, 2 cent. long, bears twelve of these capsules on each side. They are $1 \frac{1}{2}$ mill. wide; the black nucleus, slightly smaller, is represented by a vesicle of coaly matter easily separated from its envelope, slightly narrowed, however, toward the top of the small pedicel, which is slightly inclined frotn the main rachis. These racemes may represent the female infloresceme of some diceious species. Their relation to species of our time is as yet unknown. The species. Their relation to same specim which bears this species has, too, songth, apparently in size, oval, truncate at bese, wrinkled in the length, apparently in racemes or agglomerations, resembling those which bave been published by Ludwig in Pal., vol. viii, Pl. xliii, Fig. 13, under the name of Hyppophaë striata.

\section{CaUlinites sparganiomes, sp. nov.}

Described with better specimens from Black Butte.

FicUs plasicostata, sp. nov.

Var. LATIFolia.

Described, like the former, with specimens of Black Butte.

\section{PALIURUS ZIZYPHOIDEs, sp. nov.}

Described from Black Butte's specimens. The leaf from Erie is only smaller.

\section{Juglans Schmperi, Lsqx., Supt., p. 8. •}

The leaf is of larger size than that from Green River Station, but has the same same specimen bears on the reverse a fine the sat oval flatteued ant, with an irregerly a Juglans. It is 26 mill. long, 18 mill. broal, slightly pointed on one side, and abruptly contracted at the other to an obtuse protuberance. The only fruit comparable to this is that of Juglans venosa, Göpp, as figured by $O$. Weber in Pal., vol. viii, Pl. vi, Fig. 11. The specimens from this locality are as yet too scanty to allow a conclusion of identity between this fruit and the leaves described as Juglans Schinperi.

\section{Cercis Eocenica, sp. nov.}

Leaf nearly round, entire, of a thin texture, smooth surface, deeply cordate at base, nervation of Cercus Canadensis.

The leaf has its point destroyed; it is apparently obtuse or round. Except that it is more deeply cordate than the average leaves of our Vercis Canadensis, there is no difference whaterer between the fossil leaves and those of the living species.

\section{Carbon Station, Wyoming Territory.}

The specimens obtained at Carbon are from the same limited area, but from two different levels. In order to mark difference of vegetation according to horizontal station, these specimens are described separately.

1st. From below the main coal, $\bullet$ in a soft-grained, very hard shale, irregularly breaking by cleavage, but where the vegetable remains are distinetly preseived, some of them are of large size.

EQuUIsETUX HAYDENI, Lsqx., Rept. 1871, p. 284.

The specimens represent some rootlets and tubercles of this species. One of the tubercles split lengthwise in the middle exposes a central solid axis $1 \frac{1}{2}$ mill. thick, while the parietes or intervals from the axis to the borders, 4 mill. each side, appear formed of a spongy though compact cellular tissue, becoming more compact and darker-colored near the borders. A cross-section of another tubercle shows it to be oval or somewhat flattened by compression, 12 mill. in one direction and only 9 mill. in the other. Another specimen has a linear rootlet or stem whose main axis is 4 mill. wide, apparently central, and surrounded by cellnlar tissue of equal thickness. It is marked by distant nodi with round scars of the same form as those of Equisetum Haydenii, and is referable to this species.

$$
\text { Smmax grandrolia, Ung., Chl. Pl. Xl, Fig. } 3 .
$$

The leaf which I refer to this species is of the same size as the one figured by Unger in the Sillog., Pl. II, Fig. 8; but it has only 7 basilar veins, while Unger's leaf has 9. The same form as ours is published by Heer in F1. Tert. Helv., Pl. XXX, Fig. 8 and $8 b$. A variable species.

$$
\text { Acorus bRachystachys, Heer. }
$$

Exactly the same form as described in Rept. 1871, v. 288, from Ores. ton. It is represented by three specimens which merely differ from the Spitzberg ones by shorter and broader spadices, 5 mill. broad, 7 mill long, with only four rows of flowers or ovaries; the stem, too, is nar. rower, scarcely 5 mill. broad.

\section{Caulinites sparganiones, sp. nor.}

Described with better specimens from Black Butte.

Populus arctica, Heer, Aret. Fl., p. 100, \&e.

This species is represented at Carbon in most of its numerons varieties, with nearly round and entire leaves, or with undulate or more or less crenate borders, \&c. They positively prove that the leaves named Populus subrotunda, Lsqx., in Am. Jour. Sci. and Arts, 1868, p. 205, as also those described as $P$. Nebrascensis, Newb., in Notes on extinct floras, p. 62 , belong to this species.

POPULUS DECIPIENS, sp. nov.

Leaves broadly rhomboidal or round, enlarged in the middlé, abruptly narrowed into a very obtuse point, rounded or broadiy wedge form to

$$
\text { - Bee section of Carbon in first part of this report. }
$$


a long slender. petiole, with very entire borders; three to five nerved from the top of the petiole.

A very fine species, with leavrs scarcely variable in size, 3 cent. long and at least as broad. The thrse primary veins ascend from the top of the petic'e to three-fourth of the leaves, branching outside and anas. the petic to the the whinal pair of veins which tomosing with braches of a the leaves is somewhat ascend only to half the leaf. The texture of these leaves is somemhat thick, subcoriaceous. They are generally found on the same specimens with Paliuru Columbi, Heer, which they resemble. The slender petiole is nearly as long as the leaves. This species is distantly related to some small varieties of Populus arctica, Heer.

$$
\text { Populus attenuata, Al. Br. }
$$

The same form as already published, Am. Jour. Sci. and Arts, (1868,) p. 205. It is found at Carbon both above and below the main coal.

$$
\text { Populus mutabilis, var. crenata, Heer. }
$$

Our specimen represents an entire leaf agreeing in form and nervation with Göppert's, Fig. 2 of PI. XVI, in Sehossnitz Flora. In the Carbon with however, the teeth of the borders are large, sharply pointed outward, or less turned upward. This ditierence is not specific.

\section{Alvus KepresstenNI, Göpp.}

The same form as described in Rept. 1871, p. 292, from Evanston. The borders of the leaf, however, appear merely undulate as in Lud. wig's Pal., Vol. VIII, Pl. XXXII, Fi

$$
\text { Betula Stevensoni, Lsqx. Rept., (1871,) p. } 293 .
$$

Already published like the former from Evanston, where the species is abnudant. It is not as common at Carbon, but represented in very good specimens.

$$
\text { Quercus plataxia, Heer, Aret. Fl., p. } 109 .
$$

Leaf membranaceons, broadly ovate, rounded to the base in broad anricles, with distantly dentate borders; pinnately nerved; secondary veins numerous, craspedodrome.

There is in the collection a beautiful leaf of this species which some. what differs from the description of the author, as it is made in what differs from the discris the 1st vol. of the Arct. Fl. but exi. Fi species figured in Vol. II, Pl. XLVI, Fi. OP the sam wo the point de is nearly an exact representation of ours, and, too, has the point destroyed. It is 13 cent. wide above its base, the borders marked by short somewhat distant teeth; the lower laterai veins opposite, diverging $30^{\circ}$ somewhat distan the other pairs at a short distance from each other, from the medial one, the other lateral basilar veinlet going out at right alternate, parallel, with a thin lateral basilar veinlet goir of secondary angle from the medial nerve, just under the lowest pair of becondar once veins. These are much branched outside; the upper ones branch once or twice near the borders. This leaf has the characters of a Platanus, and I was inclined to consider it as different from Heer's species on accont of the difference in the denticulation. But in his description account of the difference in the anthor remarks, p. 57, that the differ- ence in the form of the teeth cannot be considered as specific. The authority is not refutable, being the result of the examination of a number of specimens of different localities.

\section{Ficus obr.axcerolata, ap. nov.}

Leaves subcoriaceous, obovate or oblanceolate, entire, taper pointed, gradually narrowed to a short petiole, pinnately, elosely nerved.

The form of the leaves is about like that of Ficus lanceolata, in Heer, The form of the leaves is about like that of Ficus lanceolata, in Heer,
(Fl. Tert. Helv., Vol. II, p. 62,) broader, however, toward the point, with more numerous secondary veins. There are 14 pairs of these veins in leaves $7+$ cent. long, the lowest pair at an acute angle from the medial one and following the borders; the superior ones, at a broader angle of 500 , stmight to near the borders, which they follow in anastomosing in successive bows. The relative position of the secondary veins is more regular than in Heer's species.

\section{Cocoolora LAEVIGATA, sp. nov.}

Leaves round, (cbtuse 1) subcoriaceous; borders entire, undulate; surface, smooth; nervation, brochidodrome.

Only two fragments, both representing the lower part of the leaves. The form of the point is merely indicated; the undulate borders, rounded downward, join the petiole by a short, slightly decurrent curve. The lowest secondary veins are thinner than the upper ones, the medial nerve broad and flat; the details of nervation are fike that of Cocooloba Floridana, Mich. These leaves are related in form and nervation to Fieus penninervia, Ung., as figured by Ett., Fl. Badoboj., PL. II, Fig. 2.

$$
\text { Platanus Gunlemae, Göpp., in Rept. 1871, p. } 290 .
$$

The most common species at Carbon, where its nnmerons varieties may be studied. One of the more marked ones is represented by small broadly ovate leaves, truncate at base, scarcely lobed; borders marked with large acute teeth; basilar lateral veins from quite near the top of the petiole.

\section{CnNAMOMUM APFINE, Lsqx.}

Mentioned above from Marshall's. The upper part of a large leaf with the base destroyed, 8 cent. long, 5 cent. broad, ovate, tapering into an obtuse point, the two lateral veins of the same thickness as the into an obtuse point, the two lateral veins of the same thickness as the
medial one, ascending, in curving, to near the point of the leaves, where they connect with the medial nerve without distinct anastomosing. The form is that of $C$. Buchi, Heer, except that the broadest part is below the middle, not above as in the European species.

Cniva mosum Missisgippiense, Lsqx.

Mentioned already from Golden. A number of well-preserved specimens.

Asmina Eocenica, sp. nov.

Leaves lanceolate, entire, thickish, equally tapering upward to a point and downward to a short petiole, penninerve, camptodrome. 
A large numbe: of these leaves, varying in length from 10 to 15 cent. 21 to 4 cent, wide, with a petiole about 21 cent. long; medial nerve fistinet parallel, diverging about 600 to the mosing many times with the superior veins and undulating along the borders; flbrillw thin, but distinct; some of them intermediate to secondary veins, being thicker and ascending as Tertiary veinlets to hal the leaf, anastomosing, with branches of the true secondary veins. This species elosely resembles Asimina triloba, Dun, by the form and size of the genus, A. leiocarpa, Lsqx., has been published from the Mississippi Eocene.

Achr trilonatum, var. Prodectum, Al. Br. in Heer, Fl. Tert. Helv., Vol. III, p. 47, Pl. exv, Figs. 6 to 12.

Among other fragments representing this species, there is a large leaf preserved entire 15 cent. long. narruwed at base to a long petiole, enlarging in the middle into two iong, sharply taper-pointed, nearly entire lobes, with obtuse sinusses and a middle, elongated lobe, marked by large distant teeth, a form resembling that in Heers' loc. eit., Fiys. 8, 11, 12. The narrow base and taper-pointed lobes are as in Fig. g. 8 , and the medial in Figs. 11 and 12. Our leat is at least twice as large as the European ones. Some pieces of shale of the same locality have fossil fruits of Actr with small oval nutlet and narrow erect wings, not larger than those represented in Heer, loc. cit., Pl. cxii, Fig. 21, which the author refers to Acer grosse-dentatum. Fig. 166, however, has too, in its upper purt, a fruit like the one of Fig. 21 still smaller, referred to Acer trilo. part, a fruit in ours, the support of the wing on the border is searcely arched.

\section{Palrurus Colomi, Heer, in Rept. 1871, p. 288.}

A large number of leaves all of the same character as those described from the Washakie group.

ZrZYPHU'S МЕEKII, sp. not.

Leaves ovoid, obtusely acuminate or obtusely pointec', rounded to the petiole, obtnsely crenate, three-nerved from the base.

petiole, obttar of Meek and myself. They differ little in their characters, being only slightly more or less wide. They average 5 cent. in length, from $2 \mathrm{~h}$ to 3 cent. broad; the borders are crenate from near the base to the obtuse point, the three primary veins are simple, the lateral ones ascending to or quite near the point of the leaves. In the broader leaves there is from the borders to rom the the midale of the lear; the anbstance is so the surface being generally covared by a thin coating of carbonaceous matter which obliterates the flbriliat. These are in a right angle with the medial nerve. The species is allied to Zizyphus ovatus, Web, in Pal., Vol. VIII, p. 89, Pl. vi, Fig. 1, at least for its nervation. It has also some analogy with Zizyphus hyperboreus, Heer, from which it differs by shorter, broader leaves, \&c.
RIIAMnos GoLDiavus, var. IATion, Isqx.

Described with specimens from Golden.

Juglans Dentioulata, Heer, in Rept. 1871, p. 298.

A large form, only found in fragments. It may be a new species.

Carbon, above coal.

TAxodrua puBrua, Sternb.

The same small form as the one pnblished by Heer in Aret. Flor. I, p. 89 , Pl. ii, Fig. 24 to 27 . It is represented by a number of small but distinct specimens.

Populug atrenuata, Al. Br.

Found also below the coal of the same locality.

QUERCU ACRODON, Lsqx., Am. Jour. Sei. and Arts, 1868, p. 205.

A good specimen of this fine species. The ovate pointed leaf, wedge. form to the petiole, has the borders deeply cut into large, sharp teeth, with straight, mostly simple, secondary veins, passing in an acute angle to the point of the teeth. In this new specimen, the upper secondary veins are slightly curved in ascending to the borders.

Conylus McQuirryi, Heer, in Rept. 1871, p. 292.

Represented by fragments and in various forms. I have not seen, as yei, an entire leaf of this species.

Fagus Deucalionis, Ung.

The same form represented in Arct. Fl. I, Pl. xlvi, Fig. 4. Specimen found by Professor B. F. Meek.

\section{Platanus aceroides, Gopp.}

A number of specimens, all imperfect, referable to this species by the larger size, the thickness of the leaves and the coarseness of nervation.

\section{Zizyphus Meskn, Lsqx.}

Described above from specimens of the lower shale.

ZizYPHUB HYPERBoREUs (I) Heer, Fl. Aret. I, p. 123.

Leaf large, broadly lanceolate, largest below the middle, rounded. attenuated to the short petiole, tapering into a long linear point, irregulariy crenate; five-nerved from the base.

This leaf is 10 cent. long with its short or broken petiole, 5 cent. wide; the first lateral veing are as deep and thick as the medial one. nearly acrodrome; the marginal ones, thinner, sacending to above the middle; the Tertiary veins, or fibrilla, are obliterated. This leaf 
resembles the fignre of this species as giren in the Groenl. Flora, PL 1, Fig. 20. It is, however, longer, and the lateral veins are stronger. The borders, mostly erased, appear obtusely crenate.

$$
\text { JUGlaxs RUGosa, Iaqx. }
$$

Broken specimens of a large form of this species.
There named from Carbon specimens. As their relation to living species is as named from Carbon specimens. As their relation to living species is as good idea of their forms, without figures. Among them is that Carpolithes. cocculoides, Heer, in Rept. 1871, p. 290 , which I have found also at Golden, cocculoides, Heer, in Rept. 18r. They are reserved for publication in a final Black

The npper shales, where the leaves and most of the fruits were found, The npper shales, where the leaves and most of the Carbon mines, are, though hard, easily disagreggated under nespheric influence. They are formed of sandy grayish clay and con. an their surface being coated by a pellicle mains. These are very distinct, their sures shale obtainable, one might of coaly matter. Could there stuable specimens for the study of the botan. ical paleontology of the Upper Lignitic.

\section{Black Butte Station.}

The larrest part of the specimens from this locality are from a bed of The lar main coal, in follow sandy jellow, some ing the bed behin $A$ the hils, back of the opening into the vein. The shale splits horizontally, and the leaves may be, with some care, obtained in a good state of preservation. A number of specimens described separately were found at a higher level; at one place in con nection with Saurian bones, at another with small Tertiary shells.

\section{Spheria Mrzic玉, sp. nov.}

A small species upon leaves of Myrica Torreyi, Lsqx., forming rings 1 mill. in diameter, with round black borders and very small, scarcely perceptible, scattered perithecia. Resembles Xylomites varius, Heer, Fl. Tert. Helv., P1. i, Fig. 9.

$$
\text { OPEgRAPHA ANTIQUA, sp. not. }
$$

Nucleous linear, from 1 to 4 mill. long, larger in the middle, pointed at both ends, either single or united in two or three in opposite direc tions, sometimes flexuous; perithecium thick, split in the middle, hard. The specimen shows the print or conterpart of this species molded Thecit imbedded or have into clay, where the nuclei their forms very distinctly. They grew upon a large stem of Caulinites sparganioides, Lsqx.

\section{HALIMENITES MAJOR, Lsqx.}

Described above from the Raton Monntains. The finest specimens of this species are seen in the sandstone below the coal of this locality.
Sequora' Lavasdonmu, Heer, Fl. Tert. Helv., p. 54, Pl. xxi, Figs. 3 and 4.

By the obtusely-pointed leaves, their decurrent base, their size, \&c, orr specimena are evidently referable to this species. Fragments of conifers, though very abundant in the bottom clay of the lignite beds, are rarely.found in the shale overlying them.

Phragartes Oenngensis, Al. Br.

Numerons fragments of leaves.

Flabellaria eocenica, sp, nov.

Petiole long, flat, smooth, truncate at the point of union of the rays. The petiole is broken two inches below its top, which is exactly flat or truncate; the rays, about 30 , are much diverging and expanding, from 1 mill. wide at the point of union with the petiole, to 3 cent. at a short distance above where they separate; primary veins eight, large, obtuse; space between them irregular, marked by 12 very thin obsoleto secondary strix. By the truncate point of the rachis the species is like Fig. 4, Pl i, of Flor Haring an Fig. 4, Pl. i, of Flora Haringa., Ett., which the anthor considers as an Our species, however, has the ton more straightly truncate, with a flat smooth petiole.

\section{Sabal Campbelil, (1) Newb.}

Represented by fragment 3 of leaves or rays with obsolete nervation, and fruits referable to Carpolithes palmarum, Lsqx.

Smilax obtusangula (१) Heer, Fl. Tert. Helv. II., p. 166, Pl. cxlvii., Fig. 25.

Leaf large, coriaceous, entire, hastate-cordate, seven-nerved from the base.

The leaf is too imperfect for precise determination; the lower pert only is preserved. The lobes are still longer and less obtuse, or slightly more acute than in the quoted figures of this species. It is probghly a new one. The division of the veins and their direction in the auricles cannot be seen.

\section{CAULINITES sParganiomes, sp. nov.}

Stem 12 mill. broad, flattened, borizontally wrinkled or warty, with distantly articulations, and comparatively large rootlets; branobes alternate, distant, bearing sessile small ears, or groups of flowers.

Fragments of these stems are numerous. The branch-scars are deep, round, marked in the center by a mamilla, either smooth, or with rays liverging, star-like. Smaller scars of the same form mark the point of attachment of ovate-cylindrical bodies, $3 \mathrm{mill}$. in diameter, elub-shaped or ovate-pointed, marked by protuberances like a receptacle with seeds. One of the branches bears three oval-pointed buds at a distance of 1 inch; one of them is open and appears to contain small seeds compressed between ovate, striate, thin involvcels. A specimen with fragments of stems and branches of this species is corered with small seeds, placed 
star-like upon a stightly inflated short pedicel; the seeds are obovate, apparently surrounded by a perigynium like seeds of Carex, or, rather similac by form and position to those pablished by Heer, I1. Tert. Helv. III., p. 171, Pl. cxlvil., Fig. 28, as taharpia unbeilata. The buds along the stems are sessile and may represent unopened receptacles. along the stems are sessile and may represent unopened receptacles. The relation of these remains is as jet unknown. The stems, distantly
articnlate, bearing sometimes one large branch-sear, with smaller scars in rows, might be comparable. to Phragmites. But they are entirely smooth, not striate in the length, and moreover differ by the mode of branching, and by the form of the scars. The relation to Sparganium branching and sessile cronps of flowers, or of fructification; but this analogy, too, is rendered donbtful by the mode of branching and the articulations of the stems.

Populus atrexuata, Al. Br.

A small leaf, with strongly cremate borders. The leaf is still smaller than the one in Fl. Tert. Helv., Pl. lvii., Fig. 8, and could be referred to a variety of Populus mutabilis, repando crenata, but for the deeply crenate border and the thinner substance of the leaf.

Populus leucophyll.A, Ung., in Rept. 1871, p. 296.

A small leaf, with the borders less deeply undulate-lobed than in the form represented from European, and especially from Alaska specimens. They are merely deeply undulate. The nervation is distinctly that of the species.

\section{Mrrica Torrey1, sp. nor.}

Leares membranaceous, narrowly lanceolate, tapering to a long, linear, narrow point, gradnally narrowed to a short, broad petiole, distantly toothed, penninerve.

The medial nerve is broad, secondary veins numerous, variable in distance, emerging on a broad angle of divergence, $60^{\circ}$, ascending to a marginal vein which follows the borders, separated by intermediate veinlets, anastomesing with them in broad, irregular meshes. The leaves vary from 17 cent. to 3 cent. wide, the largest is 16 cent. long from the base of the petiole, which is 2 cent. ; most of the leaves are of the larger size; the borders are distantly but distinctly obtusely toothed, as in Myrica (Banksia) longifolia, Ett., to which this species is closely related. It is, however, by its nervation, a true Lomatia, and by this thiv. Figs.9 to 13, differing essentially from it as from Myrica longifolia. by the large size of the leaves, \&c. The positive relation of these leaves by the large size of the leaves, \&c. The positive relation of these leaves small oval seeds, apparently seeds of Myrica, on the same shale as the leaves. These nutlets are 3 mill. long and nearly as wide, obtuse on one end, slightly pointed at the other, convex and narrowly obsenrels striate, resembling the fruits of Myrioa acuminata, Ung., as published in striate, resembling the fruits of Myrica acuminata, Ung., as published in Heer's Arct. Fl, p. 102, Pl. iv., Figs. 15 and 16. One of my specimens It is therefore advisable to consider this fine species as belonging to IIyrica.

\section{, lot Fioú planicostata, sp. noo.}

Leaves large, thickish, entire, elliptical or broadly ovate, slightly pointed or obtuse, rounded-subeordate to a short petiole, thrue-nerved point the top of the petiole, penninerve above, nervation comptodrome. from the represented by a large number of fine specimens. The basi. lar secondary veins are branched outside, 5 to 6 times, the upper lateral veins at a distance from the basilar ones, are closer to each other, all on the same acute angle, $30^{\circ}$, to the broad, flat, medial nerve, ascending to the immediate borders where they curve, following them as marginal and anastomosing in bows from one to the other. These secondary veins, too, are broad and flat; nervilles very distinct in right angle to the veins. The size of these leaves vary from $7 \frac{1}{2}$ to 12 cent. long, and from 5 to 10 cent. wide. This fine species is distantly related to Ficus Bchim. peri, Lsqx., of the Mississippi flora.

Ficus planicostata, var. latifoli, Lsqx.

This form differs so much from the primitive type that it shonld, perhaps, be considered as a distinct species, though the nerration is the same. The leaves are broadly round, broader than long, with a short, scarcely-marked, obtuse point, cordate at base, with the borders curv. ing downward and slightly decurring on the short broad petiole. These leaves are 10 cent. broad and 7 to 8 cent. long, resembling Ficus tiliafolia, A. Br., but of a thinner texture, of equilateral base, and of tiliafolia, A. Br., but of a thinner texture, of equilateral base, and of
less coarse nervation. Thongh there is no transitional form between this form and that described in the former species, $I$ consider them as yet as varieties.

The shales bearing these leares have also some small fruits of Ficus, probably referable to the same species. They are nearly ronnd, abruptly narrowed to a short, broad pedicel; irregularly wrinkled, of the same size and form as the fruits of Ficus dimidiata, Gray, of Cuba.

On the same specimens, too, there is a slender branch with opposite, small leaflets, which, though still unopened, are referable to this species by their nervation. The branch is smooth, inflated at the point of attachment. It bears two pairs of these leaves at a distance of 21 cent., with naked opposite branc lets between them. These leaves are scarcely 2 cent. long.

Ficus thlepolia, (?) Al. Br.

A mere fragment of a large leaf, referable to this species on account of its coarse nervation and rugose surface.

Ficus chntoNi, sp. nov.

Leaves of a thinner substance, comparatively small, entire, broadly ovate, oblong, obtuse, rounded at the base, three-nerved from the top of the petiole, with two upper pairs of secondary veins at a distance from the base, camptodrome.

This species, represented by numerous specimens, has, too, some likeness with the varieties of Ficus planicostata, Lsqx. It has, however, leaves of much thinner texture, with only two pairs of secondary veins at a great distance from the basilar ones, all much smaller in size, va. rying from 3 to 6 cent. long, broadly oval, entire, and more or less undulate on the borders. The two basilar lateral veins ascend by an acute 
angle of divergence to the borders, near the middle of the leaves, where, withont curve, they enter the margin and follow it. The two upper pairg of lateral veins are nearly opposite, diverge from the medial nerve pairs or lateras like the other divisions, the fibrilles are thick, their divisions and the areolation distinct. A beautiful small species, very distinct, though the differences are
scarcely appreciable from description.

\section{Ficus (?) conYurfolius, sp. nov.}

Leaves thick, coriaceous, oblong or ovate-lanceolate, entire, tapering downward to a petiole; penninerve; medial nerve thick; secondary veins alternate, mostly craspedodrome.

These leaves, represented in many specimens, are deeply, coarsely veined, the lowest secondary veins much divided, their branches anas. tomosing in bows along the borders, the upper ones passing to the bor. tomosing in bir the ders and entering them like their dive leaves of some species of Quercus. with a complex narration like the leaves of some species of Quercus. know of any relation to this species.

\section{Ficus Haxpenir, sp. nov.}

Leaves subceriaceons, entire, ovate, tapering into a long twisted acuminate point, round truncate, or attenuated wedge form, to a long petí. ole; pinnately nerved.

These leaves, with the form of leaves of Populus, are related to those of Fious appendiculato or Fious populina, Heer. They are, however, pinnately nerved, with numerons open parallel secondary veins, curving in mately merved with passing to the borders, and uniting in bows to tho apper onesata short distance from the borders. These secondary veins scarcely bramch, but they are joined at intervals by strong fibrillo; their angle of divergenee is about $40^{\circ}$. The nearest relation to this species, in foseil plants at least, is Ficus maravigna, Mass., Fl. Senig., Pl. xxxI, Fig. 7.

\section{Platanus Guillacis, Gopp.}

Very rare in the shale of Black Butte; represented by one good speci. men only.

\section{Benzorn antiquUM (?) Heer.}

One leaf referable to this species is, by its form and nervation, like Fig. 1, Pl. xc, of Fl. Tert. Helv. It is, however, indistinct, and its specification somewhat uncertain like that of the leaf from Golden.

Diospmos meachysepala, Heer, Fl. Tert. Helv. III, p. 11, Pl. cii, Fig8. 10 to 14 .

Leaves entire, lanceolate, obtusely pointed, narrowed to a petiole, pennately nerved, lateral veins oblique, brachiododrome.

A number of specimens, all agreeing with the figures and description of this species. The petiole is 12 mill. long, the secondary veins, emerg. ing at an acute angle of divergence, are somewhat distant, curve in bows, and anastomose along the borders.
Diosprros AxcePs, Heer, Fl. Tert. Helv. III, p. 12, Pl. cil, Figs. 18 to 18.

The leaves of this species, of which we have also many specimens from the same locality, are proportionally broader and shorter, with a shorter, thiek petiole; the nervation is more simple, the secondary veins, and their divisions more irreguharly branehing and anastomosing, veins branch outside, and their bows along the borders are formed by anastomose with the upper branches; the Tertiary divisions are, however, simple. The lower pair of secondary veins is generally opposite the other alternate, all more curved in ascending than in the former species.

VIBURNUM MARGINATUM, sp. nov.

Ieaves broadly ovate, or obovate, cuneiform to the petiole, ronnd truncate upward, abruptly short-pointed, regularly toothed, strongly pinnately veined, craspedodrome.

This species is represented by a large number of specimens, indicating its numerous distant forms. So different, indeed, are some of these leaves that but for the permanent character of their nervation it wonld be impossible to consider +3em as representing the same species. The small leaves are about $t$ cent. long, half as broad in the upper part, or above the middle, tapering downward to the petiole. The largest are 12 to 14 cent. long, fully as broad below the middle, abruptly contracted to the petiole, rounded upwards, or often nearly truncate to a short point entered by the end of the medial nerve. The secondary veins are like the medial nerve-broad, straight, distinetly marked, 5 to 6 pairs, at an acute angle of divergence, 15 te 20 , all more or less branching outside, according to their position, the brsnches straight, the largest ones snbdividing, and all the divisions entering the point of sharp teeth turned outward, regular in form and distance. The petiole is half an inch long inflated at its base. The fruit is oblong, round, truncate at one end, round, short-pointed at the other, contracted in the middle. By it nervation this species is closely allied to our Viburnum pubescens, Pursh. the dentation of the leaves is like that of Viburnum dentatum, $\mathrm{t}$, while the veins and their divisions are of the same type as in Viburnum lantanoides, Mich., and covered, as these, by a thick coating of viliosity. It extends, too, around the borders, marking them in black, like the veins and their divisions, and forming a narrow, distinct border al around the leaves. The fossil leaves especially differ from those of the living species by their attenuated or wedge-form base. Some of the species of Viburnum and Tilia, described by Professor Newberry in his notes on the extinct floras, appear to be reforable to this species; but from the descriptions it is not possible to make an exact compari. son. The ultimate nervation is distinct in many of our leaves. The thick flbrillæ in right angle to the secondary and tertiary divisions branch irregularly, forming an irregular loose netting of mostly pentagonal meshes. The leaves are dentate only from below the middle, or frotn the point where the secondary veins or divisions reach the or frotn
borders.

Vrbernum Wy mrperi, Heer, Aret. Fl., II, p. 475, Pl. xlvi, Fig. 16.

Leaf ovate, narrowed to an obtuse point, wedge-shaped, rounded to the base, penninérve, craspedodrome. 
Our leaf is slightly smaller, but exactly of the same form and nerva. tion as that published by Heer from North Greenland. It evidently differs from $\boldsymbol{V}$. marginatum by its more rounded and elongated form, by the nervation less deeply marked, the veins not blackeued, and less divided, the upper secondary veins simple, the tertiary areolation more deeply and equally marked, and the borders less deeply, acutely, and equally dentate. In the Spitzberg flora Professor Heer has described and figured Pl. XIII, Figs. 3 to 23 , some fruits which he refers to this species. Their form is different from that of the fruit of Viburnum mar. ginatum, which resembles that of Fig. 24, of the same plate, referred to Viburnum macrospermum, Heer, known only from seeds, ours being merely slightly smaller, with a small point in the middle of the round trunicate top.

\section{VimurNum contontum, sp. nor.}

Leaves small, obovate or nearly round, unequal at base, rounded on one side, attenuated at the other, curved; borders entire or obscurely serrate ; nervation, pinnate, craspedorlrome.

Two leaflets of this species, which might be considered as varieties of Viburnum marginatum, but for the irregular and different form of the lesves, and their entire borders; one of the leaves, however, is slightly toothed. The nervation is of a same type, but the secondary veins more distant and less numerous.

\section{Cissts lobato-crenatus, sp. nov.}

Leaves thickish, coriaceous, smooth, nearly square in outline ; abruptly, short obtusely pointed, round truncate to a broad petiole, crenate short. lobed all around; nervation, tri-nerved from the base, alternately pin. - nate upwards, craspedodrome.

A number of leaves variable in size from $2 \frac{1}{2}$ to 9 cent., nearly square, with generally two obtuse, short lobes on each side, crenate like the borders between them. The basilar veins branch outside, and pass into the obtuse point of a lobe. The smallest of these leaves are somewhat like some varieties of Populus mutabilis var. repando-crenate, Heer; far different, however, by the nervation.

Vrris tricuspmata, Heer, Fl. Balt., p. 91, Pl. xxviii, Figs. 18 and 19.

Leaves small, enlarged on the sides, three-lobate, lobes pointed, spar. ingly dentate.

Our specimens present a true counterpart of the figures given of this species. It is related to the former. In the small leaves, the teeth are slightly obtuse, but in the large ones they become, with the lobes, more distinctly pointed. Per contra, the large leaves of Cissus lobato-crenatus are more and more obtusely and obscurely crenate and dentate. Both forms, hovever, may represent varieties of one species of Cissus. No transition is remarked from one form to the other in our specimens.

Magnolin Inglepieidi (१), Heer, Fl. Arct., p. 120, Pl. xviii, Fig. 1.

Ienf elliptical, subcoriaceous, entire, medial nerve thick; secondary veins distant, camptodrome.

The leaf resembles by its form the figure quoted above; the nervation appears about. the same, differing only by the lowest secondary veins being in our leaves on a broader angle of divergence than that of the being in upper veins. In feer's clined. But in another, Fig. $3 a$, of the same plate, the secondary veins specimens have the lower part of the leaf destroyed; the comparison, therefore, is not conclusive, thongh these leaves belong evidently to a Magnolia of a same type.

\section{Sapindús caudatus, laqx.}

Described above with specimens from Golden. The leaves here are slightly shorter, narrowly taper-pointed or with a shorter point than those of Golden, indicating thus still more the relation of this species with Bapindus dubitu, Heer.

Aleurites Eocenica, sp. nor.

Leaves membranaceous, thickish, oval, pointed, wedge-shaped to long petiole, minutely and distantly glandulosely denticulate, penninerve; secondary veins alternate paraliel; nervation complex.

Many fragments with one leaf presorved in its whole. It is 6.1 cent. long, 2 s cent. broad in the middle, its widest part, with a petiole of the same length, $2 \frac{f}{8}$ cent. long. The nervation is complex and mixed. The secondary veins, emerging under an angle of $40^{\circ}$, either curve at a dis tance or near the borders in angular bows, their branches passing straight from the angles to the borders, where they enter a very smal ronnd glandular point; or these secondary veins themselves pass ap poth sides, and enter, too, a small gland of the borders. The same nervation and same form, consistance, \&c., of leaves are marked in Aleurites triloba, Gr., of Cuba. I consider these leaves referable to this genus.

PAlivkUs zizxphomes, sp. nox.

Leaves subcoriaceous, entire, oval, or obovate obtuse, curving down ward to a thick, short petiole, five-nerved, the two lowest lateral veins from the borders of the petiole, the other from the medial vein a little higher; camptodrome.

The leaves vary in size, the largest one, nearly round, being 5 cent. wide. They are properly three-nerved from the base, the lowest veins being rather marginal ones, much shorter than those of the first pair. These ascend in acute angle to the borders, which they follow, branching ontside; the medial nerve is pinnately divided from the middle npwand. outside; the medial nerve is pinnately divided from the middle npward.
The same species, represented by a smaller leaf, has been found at Erie.

RHAMre's RECTINEnVIS, Heer.

Represented by two good specimens.

Rhaswus Decheni, Web., Pal., ViI, p. 90, Pl. vi, Fig. 2.

A broken specimen only, representing, however, this species. It merely differs by the more deeply-marked nervilles. The secondary veins are not as strong and deeply marked as in the former species. A broken specimen from Golden by Professor B. F. Meek is also referable to this. 


\section{RHAMNUS DIscoLoR, sp, nov.}

Leaves membranaceons, entire, round or ovate, narrowed into an obtuse point, rounded to the short, thick petiole; secondary veinssimple, 8 to 10 pairs.

A fine species, with leaves varying in size from $2 \frac{1}{2}$ to 6 cent, oval, or sometimes round, emarginate, or obtuse at the point; secondary veins diverging 40 to $50^{\circ}$, curving in ascending to and along the borders where they are united by strong nervilles; always discolor, an indic where that then that they were covered with a villosity, and yellow surface of the leaves, or yellow upon the black ones, often split in the length by maceration; nervilles distinct and distant. It has some affinity of nervation with Rhamnus brevifolius, Heer, Fl. Tert. Helv., p. 78, Pl. exxiii, Fig. 27, for the curving of the veins along the borders. The lowest pair of veins join the medial nerve by a lownen (losely allied by the form of the leave and the nervation to Rhamuus Purshianus, D. C., now living in Oregon.

Juglans Baltica ('), Heer, Fl. Balt, p. 98, Pl. xxix, Figs. 9 and 10.

A fragment only, with the point and base broken. The form of the leaf and its peculiar nervation refer it to this species. The leaf is of a thin texture.

JUGlans Rugosa, Lsqx.

Represented by uncomplete but identifiable specimens.

Carpolithes palmarum, Lsqx.

A few specimens of the same characters, form, and size as those obtained at Golden.

\section{Carpolithes palcatus, sp. nov.}

A small seythe-shaped frait, attenuated at both ends, narrowly and listinctly striate in the length, 2 cent. long, 4 mill. wide in the middle, distinetly striate in the length, 2 cent. long, 4 mill. wide in the middle, as yet unknown.

\section{Black Butte, saurian bed.}

The station of this bed is abont 150 feet higher in the measures than the shale, with fossil-plants of the former section. The matter, embed. ding leaves, fragments of wood, of charcoal, ash, clay, fossil Cones and shells all kneaded and mixed together, has been hardened by fire and breaks with difficnlty and in irregular fragments. It contains an abund. ance of vegetable remains, mostly broken, however, and in a bad state of preservation.

Sabal Campbellit, Newb.

In large specimens bearing, as elsewhere, the character of rery narrow, close, indistinet striæe of the rays.

\section{Frous coryLmontus, Leqx.}

Described from the lower station, the shale abore main coal. Professor B. F. Meek found in this saurian-bed a fine leaf preserved entire.

Laurus onovata, Web. Pal, VIII, p. 66, Pl. fii, Fig. 4.

Leaf coriaceous, entire, oblong-ovate, acuminate, narrowed to a petiole, pinnately nerved, secondary veins very thin, the lowest ascending parallel to the borders.

The lowest veins of this leaf only are discernible in the two leaves found. These are slightly broader and shorter than the one figured as marked above, and could be referred to Larrus benzoidea, Web., Fig. 5 of the same plate, but for the secondary veins on a more acute angle of dirergence and the narrower medial nerve. I believe, however, that both these leaves of Weber represent the same species.

\section{Platanus Raynoldsi, Newb.}

A large fragment of this fine species. The borders are scarcely dentate or less acutely toothed than in the normal form. The substance of the leaves is evidently coriaceous.

\section{VIBURNUM DICHOTOMUM, sp. nov.}

Leaf subcoriaceous, thickish ovate-oblong, obtusely pointed, round, slightly cordate to the petiole, sharply serrate from above the middle, pinnately nerved.

The lowest secondary veins are opposite, at some distance from the apper ones, emerging on an angle of $30^{\circ}$ to $35^{\circ}$, branching thrice; the upper secondary veins are alternate and dichotomons-like, in separating from the medial nerve, two on each side; the teeth of the borders are entered either by the point of eecoudary vein or of their branches, as in Viburnum marginatum, Lsqx., to which this speeies is allied. It however differs by the greater thickness of the leaves, the smooth surface, the form of the teeth, whose points are turned upwards, and especially by the peculiar nervation. I have found a single well-preserved entire specimen of this form. Professor B. F. Meek has another fragment of the same from the same locality. This species is, by its leaves at least, intimately related to Viburnum ellipticum, Hook, of Oregon.

$$
\text { Black Butte, red baked shale. }
$$

These shales form the top of small hills abont at the same level as the saurian-beds, and at a short distance to the east. They are as hard as bricks, and of the same color. By disintegration they are parted in thin lamella in the plane of stratification, but no good specimens can be obtained by the hammer.

Phragnites Oeningensis, Al. Br.

Fragments of roots and rootlets.

MYrica TORReYi, Laqx.

Described already from the shale above the main coal of this locality. 


\section{QUERCUS WrommgtaNa, sp. nov.}

Quercus Olafseni var., Heer, hret. F., p. 471, Pl. xlix, Fig. 1.

A large ovate lanceolate pointed leaf, with borders undulate, or marked by distant short teeth; nervation penninerve, craspedodrome.

Heer, loc. eit, has considered this species as probably a variety of Onereus Olafseni, which is described in the first vol. of the Aret. Flor., with numerous figures. All these show the borders doubly For, with numerous fgures. All these show the borders doubly angle of divergence and somewhat curving in ascending to the borders. In this leaf of Black Butte, as in that considered as a variety by Heer, the borders are merely undulate, or distantly marked with short, pointed, simple teeth, while the secondary reins are on a more acnte angle, im lo the straight and comparatively much branched. The permanence of these characters, remarked in our specimens from Black Butte, force us to consider them as specific.

Eucalyptes iraeningiana (?), Ett., Hïr. Foss. Fl., p. 84, P1. xxviii, Figs. 2 to 25.

Leaves small, linear-lanceolate, pointed, tapering to the base, thickish, entire, medial nerve thick, nervation obsolete.

The similarity of these two leaves of ours with those loc. cit. Fig. 4, 7 , and 11 is perfect; but in the European species, as in ours, the nerration is obsolete, and the mere outlines of leaves of this kind, without comparison of specimens, are not sufficient for identification.

MacClintockia Lyalıir, Heer, Aret. Fl., i, p. 115, Pl. xv, Fig. 2.

A mere fragment, good enough, however, to show the characters of this remarkable species. It is the lower half of a coriaceous, entire, lanceolate, or oblong leaf, marked by five primary veins, with alternate thinner secondary ones, all neariy parallel. The details of areolation are not discernible.

\section{Rhames Oleburi, Lsqx.}

Species described from Golden specimens. Professor B. F. Meek found two fine leaves of the same species also in burnt red shale of another locality. The specimens are labeltul: In the hills vest of Black Butte.

Rhamvus sAlicifoliUs, Lsqx., Am. Jonr. Sei. \& Arts, 1868, p. 206.

Found, like the former, by Professor Meek, at the same locality.

Juglaxs rhamNomes, Lsqx., Rept. 1871, p. 294.

Represented by a large number of good specimens. However, the relation of these leaves is still uncertain; some of them, by strong fibrillas and secondary veins less curved, appear referable to Rhamnus Eridani, Heer, though different by the form of the leaves, while others have a nervation more analogons to species of Juglans, especially to Juglans rugnsa, Lsqx.

\section{Evanston.}

The materials taken out of a tunnel and heaped near its month, when former explorers visited this place, have faruished, especially, the speci. mens from which the descriptions of species were made in the former Report and its Supplement. When I passed Evanston, these shales, rich in remains of fossil plants, had been covered with slack, and the whole heap was burning. I could therefore obtain little materials in addition to those from which is derived our acquaintance with the flora of that locality.

\section{Populus arctica, Heer.}

A species common in the Upper Liguitic formation, already remarked upon with specimens from Carbon.

\section{PopUlú mutabilis repando-crenata, Heer.}

A splendid leaf of this species, 15 cent. long, without the 8 cent. long petiole, and 8 cent. broad toward its round truncate base; of exactly the same: form as Fig. 4, Pl. Ixii, of Flor. Tert. Helv. This leaf is distinctly preserved upon a block of sandstone used for construction at the mines of the Wyoming Company.

AlNus Keperstenin, Heer, in Rept. 1871, p. 292.

A species represented with numerous and well-preserved remains.

Betula Stevensoni, Lsqx., Rept. 1871, p. 293.

Like the former, very common at Evanston. I found mixed with the leaves some bracts of Betula, referable to two different species. One of the forms is comparable to the bract figured by Heer in Flor. Aret., Pl. $\mathrm{xxv}$, Fig. 25, which he refers to Betula prisca, Ett. The other, with the three divisions short and pointed, is of the same type as that of Fig. 30 of the same plate named Betula Forshammeri, Heer. Perhaps both forms belong to the same speeies. I consider, however, the first and more common one as referable to Betula Stevensoni, Lsqx., most conmonly represented by its leaves; and the seconil to Betula caudata Gopp., a few leaves of which have been fonnd at Evanston. Witb these bracts are mixed some ovate-pointed seeds, truncate at the lower part, without wings, and twice as large as the seeds of Betula. They may be referable to $A$ inus $K$ efersteinii, being, for the upper part at least, of the same form and size as those figured by Heer, same plate as above, Fig. 8. The lower part of the Arctic specimen is, however, destroyed. The shale at Evanston has, as at Carbon, many spceies of fruits which can be described only with figures.

\section{Drospiros LANCHFoliA, Lsqx., in Rept. 1871, p. 293.}

The leaves referable to this species are very numerous and variable in size. I found, in convection with them, a round or slightly oraltumid nutlet, 9 mill. in (iameter, smooth, jike that of some species of Prunus. These leaves might then be referable to a thick-leared Frunus, like P. spharocarpa, Lois., of Cuba.

26 a s 
GEOLOGICAL SURYEY OF THE TERRITORIES.

RHA3rvos meotnsenvis, Heer.

The same form as deseribed in Rept. 1871, p. 295.

\section{RHaMrus овоvatus, Lsqx.}

Represented in two badly preserved specimens. They are, however, easily ideniifiable.

Rhus Evaxsir, Lsqx., Rept. 1871, p. 293.

The specimens are of the same size and form as those described in the report.

Juglaxs Rhamsomes, Lsqx., Rept. 1871, p. 293.

Already described from the same place.

Carya antiquorum, Newb., Rept. 1871, p. 294.

I found a large number of well-preserved leaves referable to this sperill than the one formerly described. The general spectes, somerion ; the borders of the form is of the sance tyje as that of Juglos re raspedodrome, leaves, however, are crenulate and the secondary veins craspedodrome, their points and their divisions entering the crenules, the lowest.one after curving along the borders. There is a great variety in the nerva tion of these leaves. Their substumce is thickish, subcorisceous.

Cassia cononna, Heer, Flor. Tert. Helv., III, p. 122, Pl. xxxviii, Fig. 41.

The figure given by Heer represents a branch of apparently unfolding leaves. We have one specimen with a single leaf so reinarkable in form and so exactly similar to that figure eularged, $41^{6}$, loc. cit., that it is 列, however, impossible to doubt that it represents the sis uncertain if these leaves represent a species of Cassia. The youn branches of Peltophorum adnatum, Gr., of Cuba, bear leaves of exactly the same form. The half opened buds of our Gleditschia triacanthos have also their leaves of the same kind.

\section{Calycites mexapirylla, sp. nov.}

An open calyx or involncre of a detached fruit, at the top of a slen der pedicel. The point of attachment is round, 4 mill. wide, with a central small mamilla 1 mill. broad; the follicule divides at a short distance from the central point in gix linear, entire, undulate, obtuse segments, 2 from the central pint in star-like, coriaceons and cent. long from the central point, diverging star-iike, coriaceous and narrowly striate in the length. The central point evidently marks this vegetable as representing a calyx, rather than a coriaceous corolla. It may be compared to what Dr. Newberry has named Calycites polysequla, though the form of the divisions is far different. It is apparently refer. able to an involucre or persistent calyx of some Lauracece, or perhaps of able to an involucre or persistent caly of this genus have hexamerons some Dio
divisions.
GEOLOGICAL SURVEY OF THE TERRITORIES.

Carrot tTHEs arachioldes, sp. nov.

Fructifleation racemose; branches long, 3 mill. thick, bearing alternate, oblong-ovate pointed capsulex, striated in the length inflated at oue side near tibe point like a one-celled pod.

These capsules or pods are turued upward in the upper part of the branches, downward or pending in the lower part, $2 \frac{1}{2}$ cent.long, 1 cent. wide in the middle, rounded to a short pointed acumen, narrowed to the point of attachment, where they are generally somewhat more inflated on one side than on the other, distinctly striate in the leugth except on the inflated part near the point, where they ard obscurely and transversely wrinkled. These racemes of fructifleations, of which obtained good and distinct specimens, are indeed remarkable; but their relation is as yet unknown. Nothing of this kind has been published, and, except the pods of our pea-nut plant, Arachis hypogcen, $L$ which they distantly resemble, I do not know any living species to which they may be compared.

Campolithes palmarum, Lsqx., Supt., p. 13.

As yet no remains of leaves of Sabal have been found at Evanston; the relation of fruits from this locality to species of palms is still doubtful.

Professor Meek has, too, among his specimens, a few fragments of Platanus Guillelmo, Göpp., already described from this locality, and one obscure fragment of Platanus, which appears to belong to $P$. nobilis, Newb.; this last is, howerer, nncertain.

Elk Creek, near. Yellotcstone Ricer.

Specimens in fragments of hard metamorphic calcareous shale, mostly representing pieces of leaves of Platanus nobilis, Newb., labeled A. C. Peale, Jos. Savage, and O. C. Sloane.

\section{Cyperites axgustior, Al. Br.}

The specimen is distinct, and agree exactly with the fignre of this species in Heer, Fl. Tert. Helv., p. 79, Pl. xxix, Fig. 7. The leaf is 23 mill. broad, with a thick medial nerve $\frac{1}{2}$ mill. or more, smooth surface, and secondary veins totally obsolete. This fragment of leaf is enlarged at its base ( 9 ) into what appears to be a vagina, embracing a cylindrical culm (1) preserved in its cylindrical form like a small branch of petritied wood. The preservation of this grass stem is acconntable by the nature of the embedding substance, which is evidently a kind of ealeareous of the
tufa.

FAGUs antipofi, Heer, Fl. Foss. Alask., p. 30, Pl. VII, Figs. 4-8.

Leaf elliptical, narrowed by a curve to its base, lanceolate-pointed, entire, membranaceous; secondary veins straight, oblique $30^{\circ}$ to $35^{\circ}$, simple, numerous.

This form is referable to Heer's species by its general ontline and characters, especially to var. $a$; leaves ovate, lanceolate, very entire. One leaf is, however, shorter and broader and apparently more abruptly pointed, (the point is broken.) The nervilles, too, are at right augle to the medial nerve and more oblique to the secondary veins. The nervation is that of our living Fagus ferruginea, Ait. 


\section{Platanus nobilis, Newb.}

Represented by a large number of fragments.

Juglavs gugosa, Lsex.

Only an obscure specimen.

\section{Carpolithes osseus, sp. nov.}

Fruit hard, covered with a thin, bony shell, compressed, oval, round, obtuse at one end, obtusely pointed (?) st the other.

The point is half destroyed. This fruit is 6 cent. long, 3 cent. wide in the middle, irregularly narrowly striate in the length and rugose on the surface. It has the form of a large nut, like those of some species of Astrocaryum of the Palms. It is slightly flattened, apparently by com. pression.

$$
\text { Six miles above Spring Cañon, near Fort Ellis. }
$$

I bave to place in a single division a number of specimens marked with three kinds of labels, for the reason that they represent some iden. tical species from the different localities, and appear, therefore, as from the same horizon. These labels are: "Near Fort Ellis, above coal; A C. Peale, Jos. Savage." "Above Spring Cañon, near Fort Ellis; Jos. Savage, W. H. Holmes." "Six miles above Spring Cañon; A. U.Peale, Jos. Savage" All the specimens are of a very hard, metamorphic hale, breaking across the plaue of stratification, therefore, unere frag. ments, rarely representing an entire leaf. The loculities are indicated for the new or interesting species of this section.

Gyanogramara Haydenil, Lsqx., Rept., (1871,) p. 295.

Two specimens of this species, from above Spring Cañon.

\section{AnIETITES DUBrus, Lsqx.}

Described formerly with specimens from the Raton Mountains. The specimens are from near Fort Ellis, above coal, aud above Spring Cañon.

$$
\text { AnIEs SFTIGERA, sp. nov. }
$$

Leaves distant, simple, very narrow, needle fortn, in right angle around and from the branches.

These very narrow filiform leaves are 18 mili, long, less than one mill. wide, linear sharp pointed, abruptly enlarged at the base in the point of attachment to the branches, from wlich they diverge all around in right angle. The leaves are nerved, channeled on one side, keeled at the other. It has no relation to any fossil or living species known as yet.

SALisburil polymorpha, Lsqx., Ment. Jour. Science and Arts, (1859,) p. 362 .

Leaf fan-like in outline, tapering or wedge form to the base, divider upward in lobes of various forms, either linear oblong obtuse or lance. plate, short or deeply parted.
The medial vein is marked to above the middle, the veins very thin, close, straight, or nearly so, dichotonous in ascending. "From six miles above Spring Oañon."

A very fine and well-characterized species, mentioned from specimens in the collection of Dr. John Evans from Vauconver's Islaud. The plants from this locality were described and figured for a final report, which was delivered to Dr. Evans, but has never been published. short mention only is made of this species in the Journal. The presence of this leaf, easily identifled, in strata evidently Eocene, with species which, like Platanus aceroides, Quercus Pealci, Cinnamomin Kossmaessleri, ¿̃c., cannot be considered as Uretaceons, confirm my opinion on the Tertiary age of coal of Vancouver, loc. cit.

\section{OAULINITES SPARGaNiomes, Isqx.}

Described above with specimens from Black Butte.

Popdlus levcophylla, Ung.

A small leaf, representing the variety figured by Gaudin, 1st Mem., Pl. iv, Fig. 3.

"Near Fort Ellis, above coal."

Populus mutabilis, var. repando crenata, Heer.

A fine leaf, the upper half of which is, however, destroyed. The preserved part is 6 cent. long, 6 cent. wide in the middle, the petiole 5 cent. long. The second pair of lateral veins is nearer to the basilar oues than in any of the leaves in Heer Flor. Tert. Helv., p. 62; but this difference is scarcely noticeable for leavez of so variable a species as this. Though very common in the European Hiocene, it has few representatives in our Eocene fora.

SLLIX ANgusta, (१) Al. Br.

The specimen represents only the middle part of a linear leaf, 4 cent. long, 12 mill. wide, with numerous secondary, deeply-marked veins, curv. ing along the borders, and forming undulate margins by their depressions. This fragment is of the same type as that published by Lndwig in Pal. Wetter. Brannkohle, Pl, xxxi, Fig. 2d, which, too, has the borders nndulate by the depression of the veins. On account of the imperfect frag. ment, the identification is, however, uncertain.

\section{AlNus KepersternII, Göpp.}

In broken specimens. "From six miles above Spring Cañon."

QUerous Wyomingiana, Lsqx.

Like the former, in fragments. "From near Fort Ellis, above coal." Quencug Plataxia, Heer, var. Rotundipolia.

Leaf round in outline, obtuse or obtusely short-pointed, deeply cordate at base, borders undulate.

These lesves are three-nerved from the base, with two or three pairs of npper secondary veins, parallel, mostly opposite, crasperlodrome, 
branching outside, and connected by strong nervilles. This form appear' at first specifically different from Heer's species and also from the leaf referred to it from Carbon. The leaves, 9 cent. brcad and just as long, have entire undulate borders, and the base merely cordate. One of them, the best preserved, has only three pisirs of secondary veins; the lowest nearly as strong as the medial nerse, much divided outside, more acute angle, $40^{\circ}$, branching, too, and connected with stroug nervilles, the leaf, except for its form, appearing a leaf of Platanus. A number of specimens, however, present marked differences intermediate between this leaf and those from Greetand, not only in the nervation, but in the basilar, auriculate borders, which, too, in one specimen,

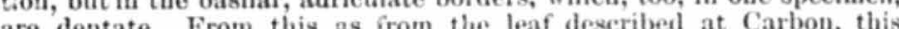
species appears very variable and well represented in our northern lig. nitie formation. I have not seen it as yet south of Carbon. The leaf of ours has evidently a long petiole.

I.aurug primgexia, Ung., Fl. v. Sotzka, p. 38, Pl. XIX, Figs. 1-4.

Leaves thick, coriaceous, lanceolnte, tapering to a long petiole; lower secondary veins at an acute angle of divergence.

One of the specimens represents the lower half of a leaf with a still longer petiole, than marked by Unger, loc. cit.; another hás ouly the upper part with the point broken. In both the character of nervation and the form of the leaves arree with those of this species. The Intest pair of form of the lesces at a ascends higher along the borders. In one of the specimens some nervilles go out from the medial uerve as intermediate veinlets to the secondary veius. The ultimate divisions, however, pass into round, very small, areolie, the waole of the same type as it Laurus princeps, Her.

$$
\text { Qtiacts PEALEt, lasqx., Rept. 1871, p. } 297 .
$$

Many specimens of this fine species indicate the form of the leares as variable from broally ovate pointed to oval lauceolate-pointed. The nervation and the form of the obtuse teeth is always as described in Rept. loc eit. One of these lenves is $7 \frac{1}{2}$ cent. long, only $2 \frac{1}{2}$ cent. broad, while another is $4 \frac{1}{2}$ cent. broad and only 5 cent. long.

Represented, like the former, by specimens from all the localities of this section.

Platants aceroides, Güpp.

A good specimen, from six miles above Spring Cañon.

\section{Fict's aCriculate, Lsqs.}

Described with specimens of Golden. The collection has an identifiable fragment, representing the lower half of a leuf from the same locality as the former.

Cinsamomum rossmässient, Heer.

Represented by three ș̣ „.mens from six miles above Spring Cañon.
Fraxinus denticulata, Heer, Arct. Flor. I, p. 118, pl. xivii, Fig. 2.

This leaf is intermediate between the one figured loc. cit., and another much smaller, with more acute teeth, (PI. XVI, Fig. 4.) It is nearly as large as the first, with large, obtuse, distant teeth, but with a distinet nervation like that of the secoud, the lowest secondary veius earring and anastomosing along the borders, with divisions or nervilles entering the teeth; while the upper ones directly end into them. There is no loubt about the identity of these leaves with those figured by Heer, but $I$ am uncertian if they represent a species of Fraxinus.

Qierces chlorophYlla, (?) Uug.

Same species of leaves as those described under this name from Jar. shall.

$$
\text { Nyssa laxceolata, Sp. nov. }
$$

Leaves subcoriaceous, entire, broadly lanceolate pointed, rounded to the petiole, secondary veins alternate, parallel camptodrome.

The leaves are if cent. long, 4 cent. broad in the broadest part, with 9 parirs of secondary alternate veins, diverging 400 from the med. ial nerve carving in axcendiug to the borlers, where they disappear; areolatiot. punctate. The nervation and areolation are as in our living Nyssa multiflora, Wang. The form of the leaves, however, is different, the fossil ones being broaler below the middle, more rounded in descend. ing to the petiole. Except Nyssa punctata, Heer, in Balt. Flor, the European tertiary specis are known ouly by the fruits. The Baltic species, like Nyssa ( 9$)$ retusta, Newb., are far different from thia one. Three species of $N$ yssa are known, by fructitientions only, from the Brandon lignites of Vermon:

Six miles above Spring Cañon.

\section{Rnayves actyinatifolius, 0 . Web.}

Lesves large, broally oval, accuminate pointed, rounded to the base; ucondary veins parallel, curving to aud along the borders; nervilles indistinct.

These leaves, represented by two fragments only, differ from Juglans rugost, I sa x., by round base and a less distinct and more regular nerva. tion. They may, however, be mere varieties of this omnipresent and polymorphous species. The same form has been fonnd at Golden.

Rirus Bella, (1) Heer, Flor. Aret. II, p. 483, Pl. lvi, Figs, 4 and 5.

The lower half of a subcoriaceous entire leaflet, gradually tapering from the middle to a petiole, appeariug part of a compound leaf. The specimen is not suflicient for a reliable identification. The nervation, like the form of the leaf, are, however, the same as in Heer's species. $\triangle$ bove Spring Caũon, near Fort Ellis.

$$
\text { Juglans rugosa, Lsqx. }
$$

The specimens from all the localities of this station represent distant varieties of this species. The leaves are especially variable in size, some still larger than the largest forms of Juglans acuminata, publisbed some still larger than the largest forms of Juglans acuminata, publisbed
by Heer, some so small that though the characters taken from nerva- 
tion aud ontline are identical, they can scarcely be recognized as belong. ing to this species. Among them are two specimens from above the coal of Spring Cañon, near Fort Ellis, representing the same leaf. It is 6 cent: tapering to in distance, son in distance, some separated by shorter veinlets, the lower ones at a broader angle of divergence than the superior ones, and the lowest shorter pair nearly at a right angle to the medial nerve; nervilles perpendicular to the lateral veins. If these characters of nervation are those of Jug lans rugosa, Lsqx., as also of .Juglans acuminata. Heer, they are those also of Juglans retusta, Heer, Fler. Tert. Helv. P. 00, Pl exxvit Figs. 40-4t; ispecies wi We lave, hevevers. We have, however, intermediate specimens which, coming from the same stations, seeur to disparage the separation of these forms into two species.

$$
\text { Juglavs dentictlata, Heer. }
$$

The same small form as the one remarked upon in Rept., 1871, p. 298. The specimens are from the same place.

$$
\text { Cassia puaseolites, Ung. Fl. v. Sotzka, p. 58, Pl. xlv. }
$$

Leaves, membranaceous; petiole elliptical, taperiag downward by a curve to the petiole; lowest pair of secondary veins at a distance from the base, opluosite.

This species is figured by Unger, with numerous leaves and one of its pods. Heer, too, has it in the same way in his Fior. Tert. Helv., Pl. cxxxvii, Figs. 66 to 74 . The numerous specimens obtained from the different localities of this station merely represent leaves. These in their different forms and variety of nervation agree so well with the European leaves that they may be referred to this species with little also the more or less rounded base oi the leaves. It is often unequilateral.

\section{GENERAL REMARKS.}

The following talte of comparison, indicatine the distribution of species at different localities, completes, to this time, the one published in the former report. For researches like those which have been letailed in this paper, aud for a science which, like vegetuble paleontology, is still. with us at least, in an incipient state, a document of this kind cannot be dispensed with. Besiles pointing out the march of the researches and the discoveries manle in the tlora of our Tertiary, the th the points of relations or of dif. ferences which may be tnore reliably considered in the discneainn ou the geological age of certain groups. It has been essentially prepared to that purpose, and, therefore, slightly moaitied or rather simplified, to render it more explicit. The characters of the Tertiary groups of Europe are not satisfactorily fixed by vegetable paleontology; therefore, the

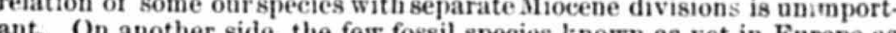
ant. On another side, the few fossil species known as yet in Europe as truly Eocene, claim a more serupulous comparison with ours on account of the conclusion admitted in the first part of this report-that the whole North American Lignitic formation is Eocene. The table, thero. fore, has a single division for the European Miocene, and another for the Eocene, both for indication of geological age; and it has, too, one for the Arctic and another for the Alaska Tertiary, for indication of original derivation of species rather than for comparison of geological divisions. The American divisions are detiued by strutigraphy as by paleontology. The Upper Tertiary or the Miocene (f) is represented in the Rocky Mountaius by the Green River Group, and some identical strata of Elk Station and of South Park. The second group in descending order, named as yet Upper Eocene, has for its essential members Carbon, Evanston, aul Washakie deposits, which may be hereafter subdivided into two (s) considered in separate geographical divis. jous, of identical ase, as far, at least, as it is known as yet, the Raton Mountains, Golden, Black Butte, and Six miles above Spring Cañon. letached areas of the same group, which have as yet furnished to ex. amination a too smal' number of fossil plants, are united with the essenual divisions. The Placer Mountaius and the Cañon City go with the Raton; the Gehrung's, Marshall's, and Erie coal deposits with Golden; the Point of Rock and Hallville, with the ppper and lower divisions of Blark Butte,; and the different localities at and around Fort Ellis, with Six miles above Spring Cañon. More precise details of the distribution of each species are given, with their descriptions. The Elk Creek division is as yet scarcely tixed by its remains of fossil plants. It could have been omitted or uniter, perhaps, with Spring Cañon but for a few peculiar species which seem to indicate a distinct flora, and which may afford matter for consideration. The distribution of the table is, besides, clear and explains itself. 


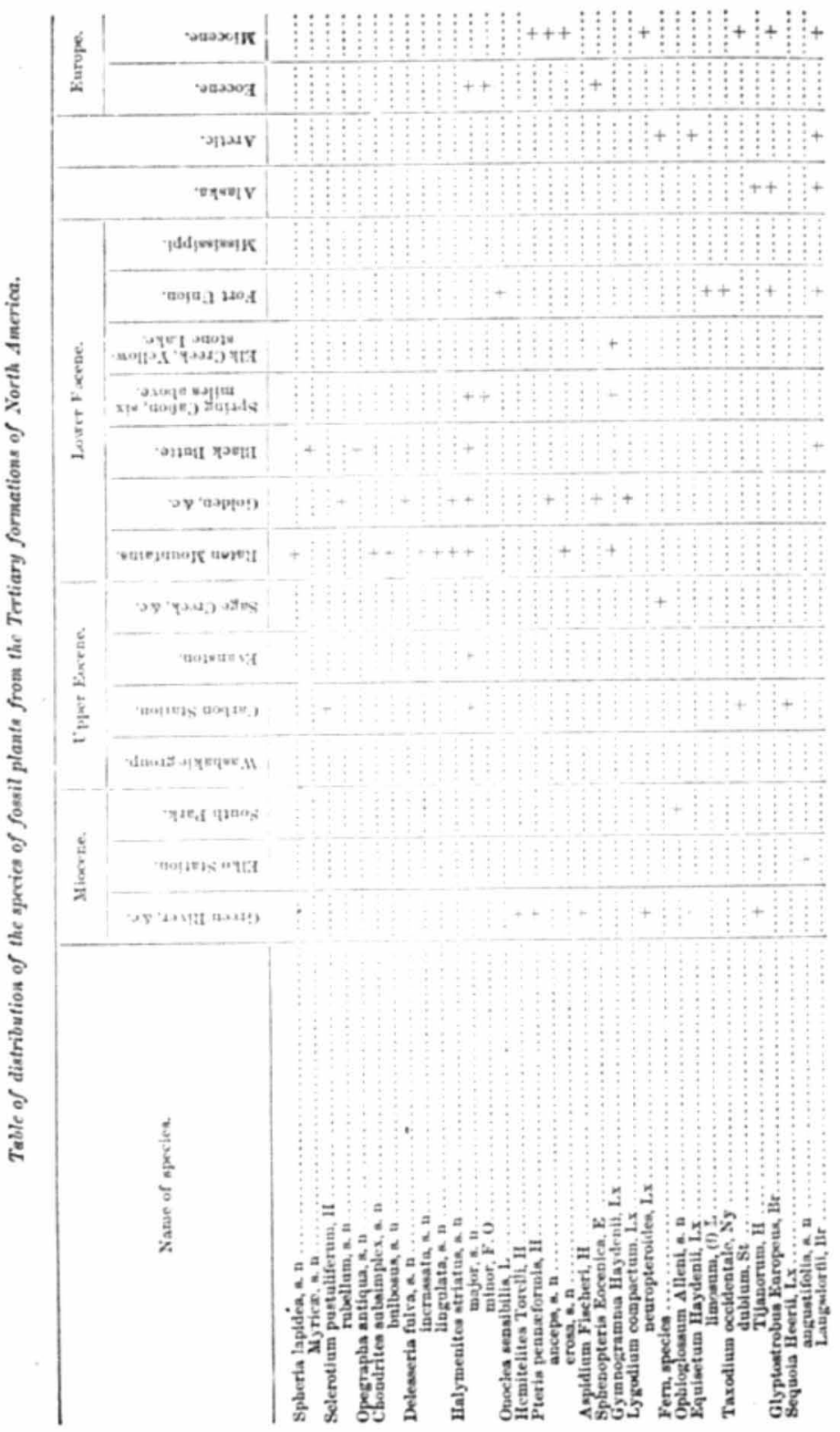

GEOLOGICAL SURVEY OF THE TERRITORIES.

411

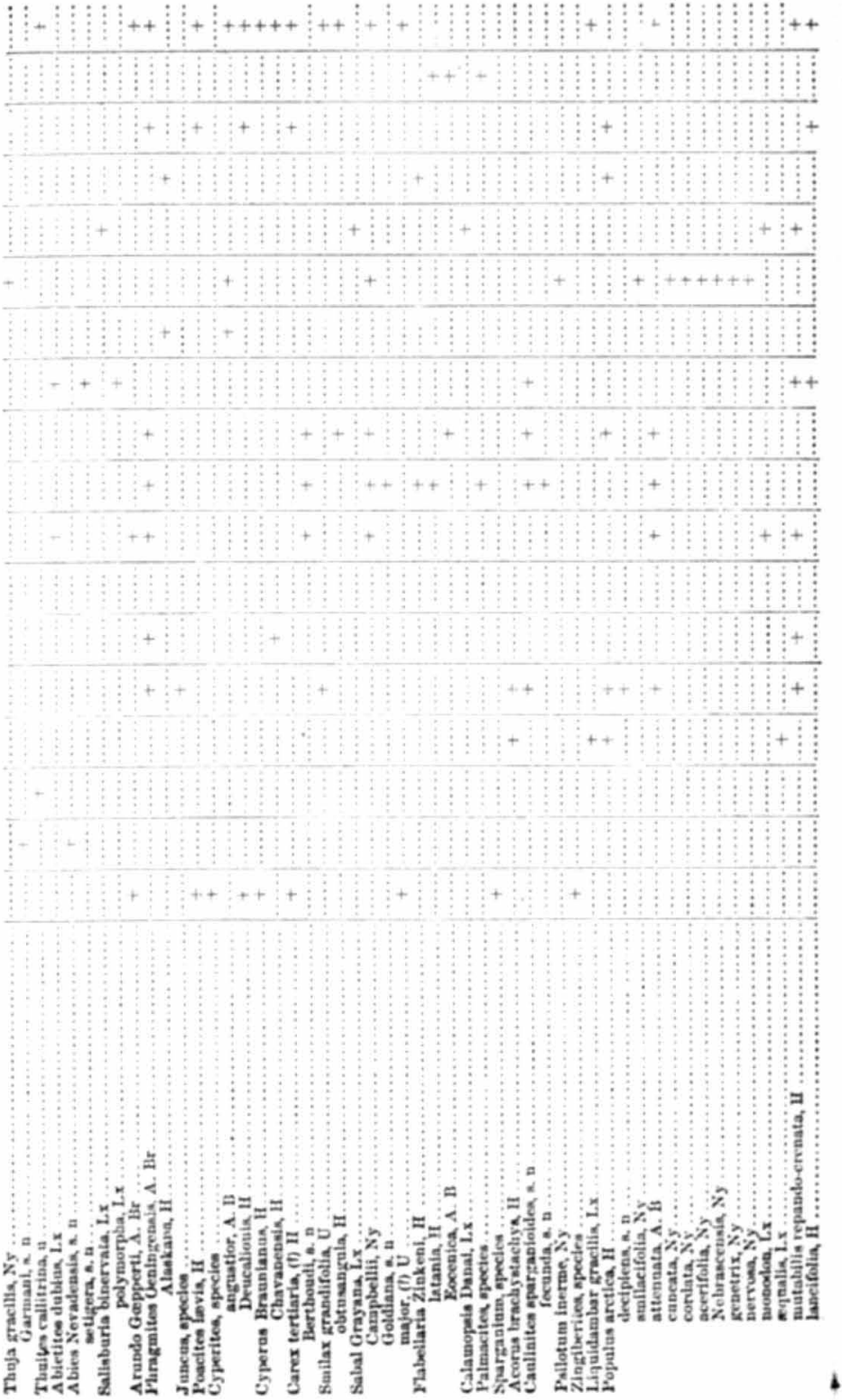




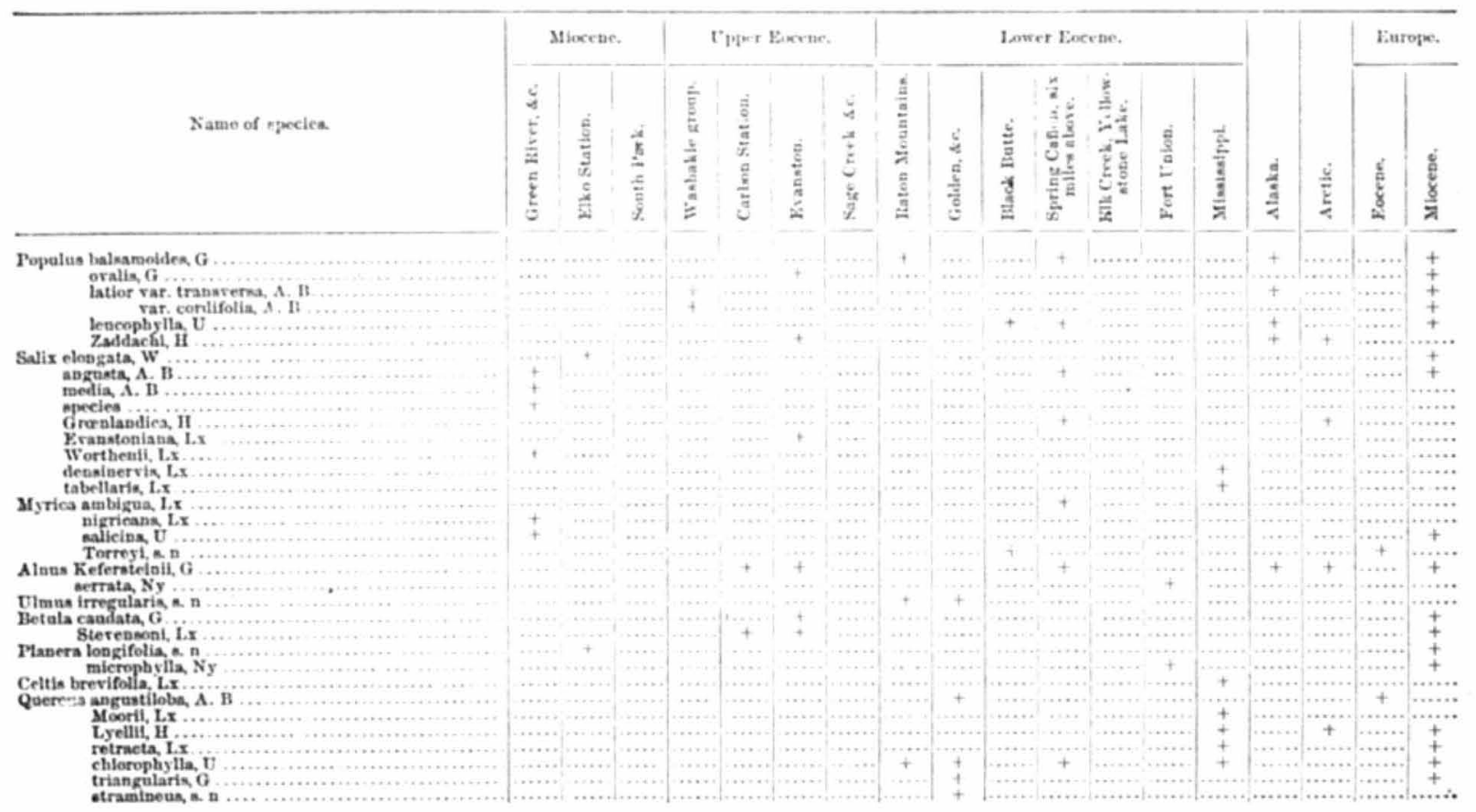

platania II.... nemalellipitica, $d$ aetminlatian tis negunilointex acrodon, $1 . x$............. seming it IIaydevit, Lx Killivianms 1.x.... Pealari, Lx Laharpi, $G$. labla, Ny cravineivis of myrtifolia, ? crandifoila $\$$ Americama, iv MeQuarri, it Antipoti, If.

Deocallotic

crmgines, if it ifruit

Yieus Kehimajerl,

cinnamomoides $\mathrm{L}$.

plasicostata, on

r. latifolia and fruit

Clintobi, a. :

narifolia, E.

oblanecolata. a .

muftinerris

vabori, Lx

Gaudini Lx

sjectabilis, no

nlmifolia t.x

Iaydenif, 2.0
aurieulata

populina, it

14atasua notilis

fayrotdxin, $\mathrm{N}$

IIayslesil, $\mathrm{Ny}$.

heterophyilla, $\mathrm{Ny}$
Gnilleimas, $\mathrm{G}$. 


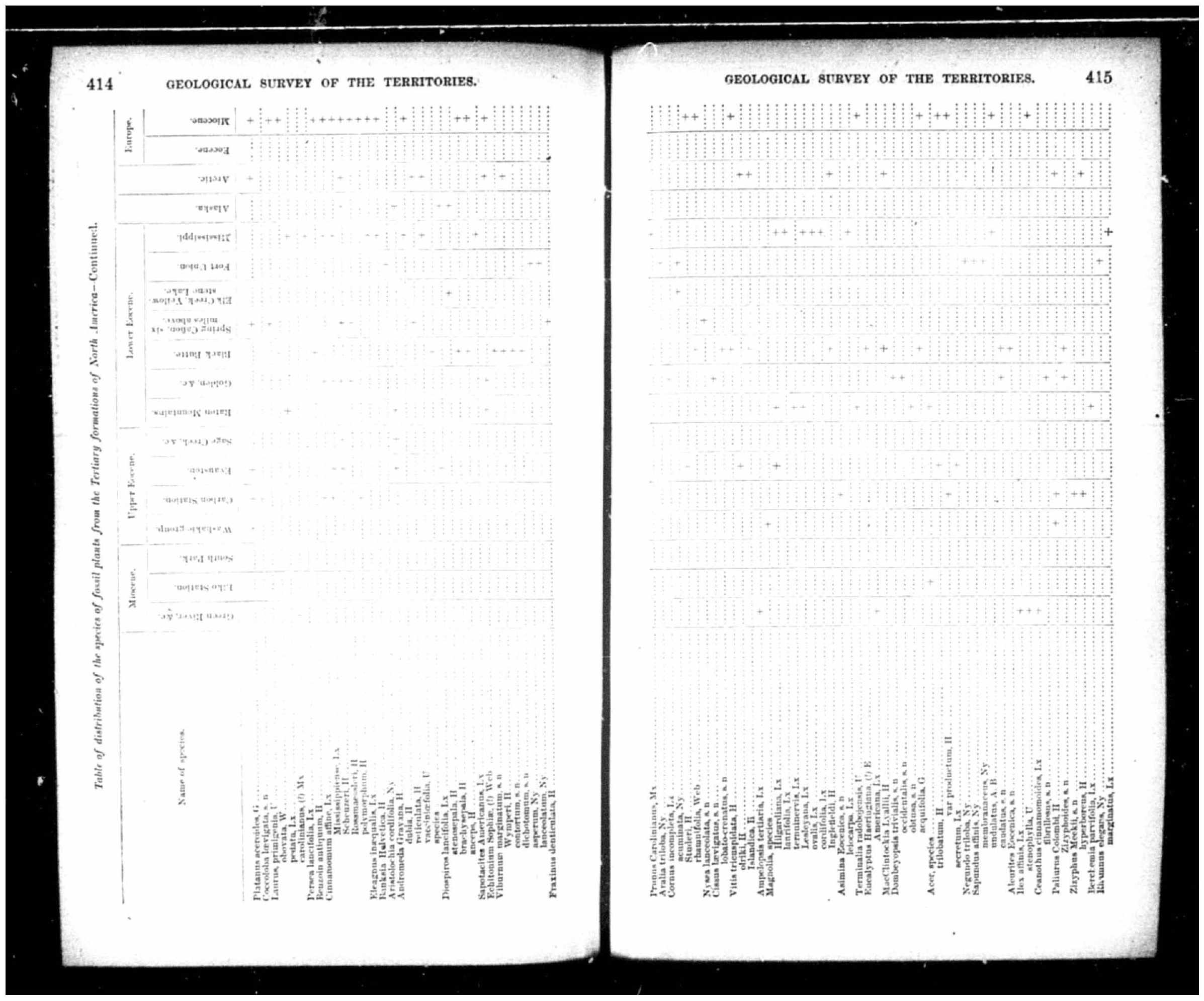



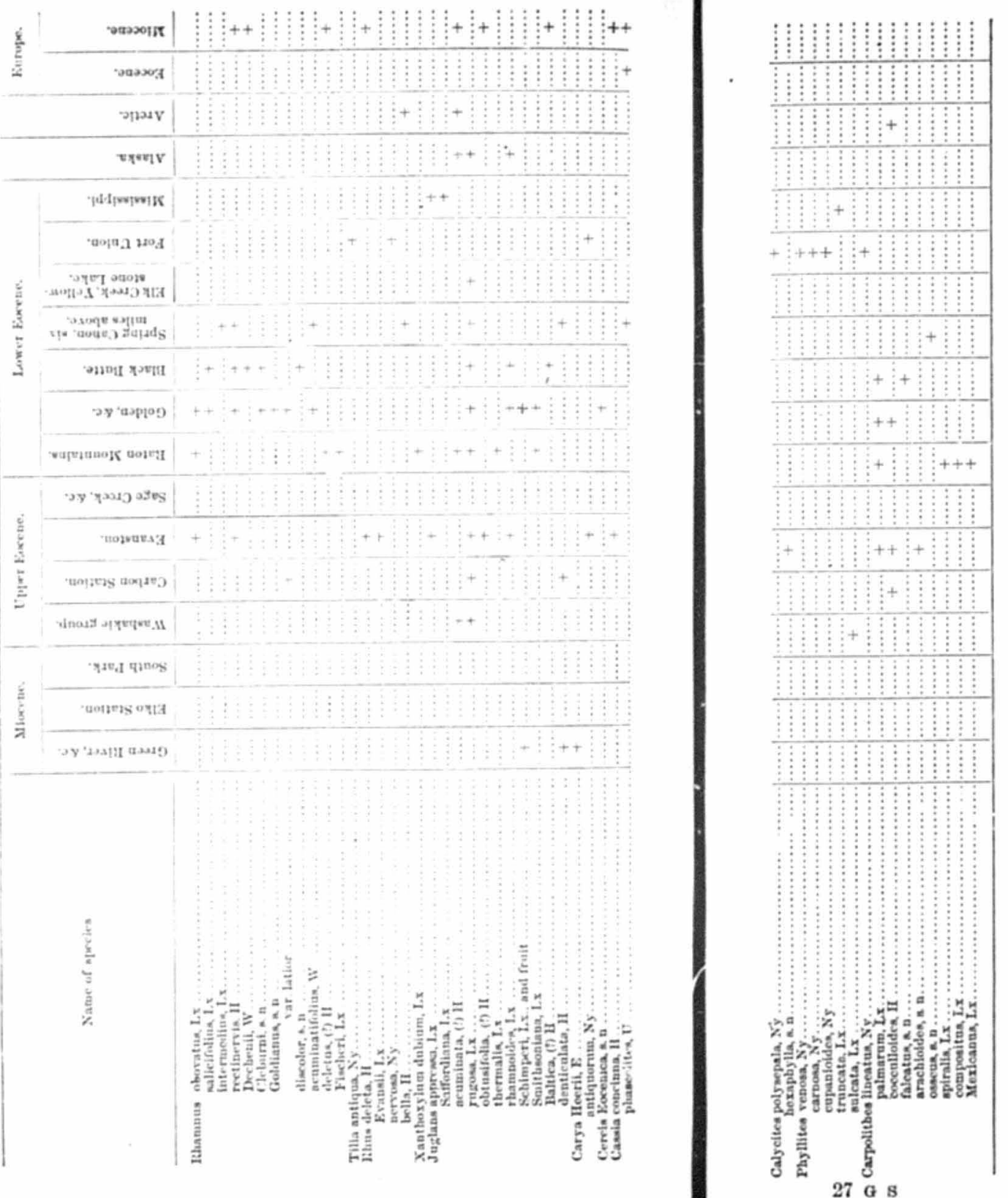
This table enumerates three bundred and ten species; that of the former report, established from the species published formerly by myself from the Exene of Mississippi and Tennessee, later, from the speci. from the Lignitic of mens which Dr. Leconte and also with the species described by Dr. Colorado and New Mexico, and also with the species described by Dr.
Newberry from Fort Union, \&e, had only one hundred and eighty species. The addition to the flora of the North American Tertiary formations amounts, therefore, to more than one hundred species. Of these, sixty-one are new forms, and forty.two had not as yet been recog. these, sixty Terting fora large number of new species is explained in considering the age of large number of new species is explained in considerin: the age of the formation where most of them have been obtained; that is, in strata which pertain to the Lower Eocene at Golden and at Black Butte. The flora of this formation is as yet little known to European paleontologists.

Considered merely in a botanical point of view, a number of these new species of ours are of marked interesi. In the class of the Lichens one species, Opegrapha antiqua, is the first of this family which has been found as yet in the old Tertiary formation. Eight species of Lichens have been mentioned by Göplpert as recognized in the amber, and three upon the bark of Lignitic wood of the Upper Tertiary of Germany, but none of themeribed, apparently on account of the in none of thenters recognizable in the Black Butte sprecies. This discovery, together with that of two species of Spheria and one of Sclerotium in the same Eocene formacion, proves that the searcity of fossil cryptogamous plants of a lower order does not indicate the absence of these vegetables at the former epochs, but is due to the maceration which soon destross the soft cellular tissue of the to the list rem South Park one species of Ophioglosxum, a tine genus which was as yet known, in a fossil state, by a single species from the Upjer Tertiary of Italy. In the Conifers we have a new Sequoia, whose relation to Sequoia gigantea, the Californin big tree, is, by its leaves at least, more intimate than that of any fossil species of this genus; a Thuya which claims our $T$. occidentalis, not as a redive, but rather as a mere vriety; then an Abies, which not as a reation a canadensis in about the same degree of aftinity. These three species belong to the Green River or Upper Tertiary formation. From the Lower Eocene we have two species of the same genus Abies, whose characters are at variance with those of any species of Conifers known as yet, either living or fossil. One species of Salisburia, $S$. polymorpha, already known from specimens of Vancourer Island, merits also to be remarked among the Tertiary Coniferous species as positively fixing the Eoceue age of the Lignitic of that island. In the Glumacea the Lower Eocene has a fue species of Carex, C. Berthoudi, found with its seeds; in the Paims, new species of Sabal and Flabeliaria; in the Spadiciflora two stems, Caulinites, with their frnits, all from Golden and Black Butte. Higher still in the vegetable series we note a splendi Myrica, M. Torreyi, with its seeds; the bracts of Betula Stevensoni; a peculiar form of oak, Quercus platania, Heer, with a variety distinct enough to be considered as a species; a number of new species of Ficus; one represented with leaves, branches, and fruits; a Cocoloba, thre new forms of Viburnum, one of them exposing by its numerous leave and its fructifications the characters of three species of our present flora; leaves of Cissus and Vitis, of Asimina, Dombeyopsis, Sapindus, Rhamnus, Cassia, \&c., all represented by numerous and weil-preserved specimens. With the leaves some still more remarkable fruits, Carpolites, whose affinity. is unkown as yet; especially that from Evanston-C.arachioidesrepresented by bunches of fructification resembling the eommon pea-nut.

The exposition of the general characters of our Tertiary flora, as indi. cated by the nomenclature of a number of its species, is, however, far less interesting and important than the documfents furnished by the table for definitively solving the question of the age of the formations which the vegetable remains represent. I shall now use these documents especially as a final summary of the arguments in favor of the assertion that the Lignitic of the Rocky Mountains is, in its whole, an Eocene formation.

1st. No section is marked in the table for the comparative distribn tion of the Cretaceous flora, for the good reason that it represents the same group of the Cretaceous, and that as yet not a single one of its species is recognized as id ntical or even positively allied to any of our Eocene.

2d. The table has in the Eocene division a number of fucoids or, marine plants, eight species; and, too, a proportionally large number of palms, all vegetabies, which are not only homologous or ideatical in forms to fossil species of the European Eocene, but which, taken alto gether, constitute two groups charactetistic of the Lower Tertiary, and of which not a single representative, as yet, has been found in connection with a true Cretaceous formation.

3d. The same may be said of some species marked in the same di. vision ; one Fern, one Myrica, one Quercus, one Cassia, \&u, identical with species admitted in Europe as positively Eocene.

4th. Of the species enumerated from the Raton, Golden, Black Butte, and Snring Cañon, a large number are allied to Eocene species, as, for example, Cinnamomum affine, $C$. mississipiense, species of Ficus, of Ceanothus, Dombeyopsis, \&c., and, considered in its essential groups, Ficus, Lau. rus, Cinnamomum, Viburnum, Cissus, Magnolia, Dombeyopsis, Sapindus, Rhamnus, Juglans, Cassia, \&e., the whole flora bears a facies which, if not positively comparable to that of the Enropean Eocene, on account of the scantiness of this flora, has, however, a marked analogy to that of the Lower Miocene. As the characters, either separately, for a number of species, or generally, in considering the facies of the groups, are identical in all the strata which we have cousidered as Eocene, it is evident that neither Black Butte nor any other locality can be separated as from a different epoch, and that, therefore, no member of the American Lignitic, as far as this formation is known by its vegetable remains, can be referred to the Cretaceous. An exception to this conclusion is elaimed for two localities, Bear River and Coalville, wherefrom no fossil remains of land-plants have as yet been obtained. But I do not see how the separation could be made for strata which contain an abuudance of Eocene fucoidal remains, and whose thick deposits of lig. nite indicate evidently, for the time, a land formation of exactly the same nature as that of the other localities. The lignite matter, indeed, by its degree of decomposition, its chemical compounds, all its characters, bears evideuce of its origin by the same kind of land vegetation, and, therefore, of its contemporaneity. On another side, the North Ameri. can Eocene is considered by European paleontologists, from the character of its flora, as related to the Miocene formation. It is, therefore, convenient to look further into the documents offered by the table in regard to this last opinion.

The proportion of species, of what is considered our Miocene flora, as marked in the first three sections, is, with that of the Aretic, 11! per cent.; of the European Miocene, 39 per cent. Onr Upper Eocene has 


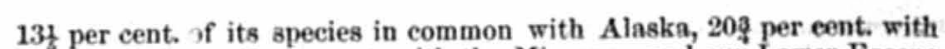
the Miocene; and our Lower Eocene has only 84 per cent. of its species in common with the Alaska, 102 per cent with the Aretic, and 25 per cent. with the European Miocene. cent. with the Aretic, and 25 per cent. with the European Mocene. Or counting the species of Alaska, Aretic, and Miocene of Europe as Miocene, the relation of the American Tertiary flora with this formation of Europe is, for the Miocene, 473 ; the Upper Eocene, $57 \frac{1}{3}$, and for the Lower Eocene, 37 per cent.

This comparison, somuthat nureliable on account of the greater or less degree of aftinity of a few species, may be, bowe*er, admitted in less degree of afling full confidence for our purpose, and proves that the tiora which we con. sider as representing our Yiocene, that of Green River, Elko, and South Park, does not bear to that of Enrope a marked aualogy by its forms. These, indeed, appear of younger type, more intimately related even by identity to species of our time. The flora of the gronp marked as Upper Eocepe has, per contra, the greatest analogy to that of the European Miocene by the identity of its most comtoon species of Populus, Quereus, Miocene by the identity of its most comtoon species of Populus, Quereus,
Ulmus, Betula, Platanus, Fagus, Sc. It may be that farther researehes may force a separation of this group from the Eocene, thongh as yet there is no apparent line of division, either in the measures or in the distribntion of the florn. I believe that the discrepancy is merely apparent, restlting from and inclienting a precedence in time of on

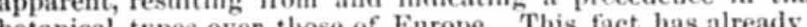
bofanieal types over those of Earope. This faet hins already been remarked upon in considering the flora of the Carboniferous formations, and it becomes the mere evident as the history of the old vegetable world is better known. The relation of the Lower American Eocene to the Siocene of Furope, 37 per cent., does not indicate a difference more marked than conld be expected between the flora of two members of the same formation; and the difference, too, is becoming more and more definite, and will continue in the same way as far as the acquaint. ance with our fossil florn is more intimate. The most common species of fossil-plants are uot only found over wide areas, and therefore collected from all the explorers, and in numerous specimens; but they pass througl the diuerent stages of the formations. The first researches bring them to view from everywhere; the selection, however, becomes bring them to view from everywhere; the selection, however, becomes more discerning and exel
supplied for comparison.

On the question of the distribution of Tertiary fossil species in regard to climatic circumstances, the table does not show anything more than what has been observed from that of the former report. The relation of our Upper Eocene flora with that of Alaska and Greenland is well defined, while the vegetable types of the Lower Eocene are rather tropical than Arctic. It is then possible that the characters which $I$ bave considered as resulting from climatic influences have a relation to differ ence of age of the formations. If it is the case, we may expect to find the flora of the Lower Eocene with the same sonthern types from Vanconver Island to the Mississippi, while the Arctic facies uay predomi. ate in the Uper Eocene from Greenland to the same southern latitude.

This important question of the regulation of Tertiary groups of vegetables according to therr geological stations, or to climatic influences, cannot be settled without long researches. Some species of the Lower Eocene appear to have, with types of the present flora of Cuba, a relation which has not been recognized before. Such are forms of Elabellaria and Calamopsis; Myrica Torreyi, conaned to a Lomatia ; Flabellaria and Calamopsis, Myrica Tomeyi, cous $F$. Clintoni, $F$ ' group of Ficus, represented by Ficus planicostata, F. Clintoni, F. spec.
tabilis, F. corylifolia;-Cissus lacigatus, Aleurites Eocenica, and the group of Rhamni; $R$. obovatus, $R$. Oleburni, $R$. Goldianus, \&e., with multinerve lenves comparable to those of some Bridelia. The points of analogy are not precise; they are merely recorded for directing further researches.

\section{Description of species of fossil-plants from the Cretaceons of Kansas.}

The specimens from which the following species are described were obtained by myself from two localities: 1st. From nine miles above Salina, in the Salina Valley, where I was kindly directed by Professor B. F. Mndge, of Manbattan Coilege. 2d. From six miles south of Fort Harker, where specimens of fossil-plants are found in abundance, but over a limited area. This locality was discovered and first explored by Mr. Charles Sternberg, who resides in the vicinity, and who a few years ago presented fine specimens from it to the Smithsonian Institution. Some of these specimens have been previonsly used for description, esprecially of Sassafras, there represented in a multitude of forms. The vegetable remains are found at both these places, as also east of Fort Harker, in a hard, more or less soft-grained, shaly, red, ferruginous saudstone, a member of the Dakota group of Messrs. Meek aud Hayden. The number of specimens, generally fine, is large, proportionally to the number of species which they represent.

\section{ZoNARITEs Digitatus, Brgt.}

Frond flat, dichotomo:is, branches of the same size or broader than the main axis, diverging in acnte angles, linear, entire, obtuse, slightly enlarging toward.

The divisions or branches of this species are somewhat broader than in the specimen figured and described by Brongniart, Veg. Foss., p. 61, Pl. ix, Fig. 1. The whole frond, as preserved, is 9 cent. long, its base slightly narrowed, the divisions 1 cent. broad, the angle of divergence alout 300 .

I have aiready remarked that the relation of this form to other kinds of vegetables is not as yet ascertained, Schenk considering it as a fern. This supposition is inadmissible on account of the connection of these remains with animal, deep marine fossils. I am even uncertain if it represents a vegetable form, and would rather consider it as a sponge. It las, indeed, a punctate or perforated-like surface, an appearance which, however, may be caused by the porous componnd of the stone. I found it about 100 feet above the red shale of the Dakota gronp in a shaly limestone especially formed of large shells of the Fort Benton group.

$$
\text { Hyanephylluy Cretaceur, sp. nov. }
$$

Frond lisear-lanceolate, bipinnately divicled; rinnze slender, from a narrow, smooth, convex rachis; wedge-form, erect, alternately lobed.

The lobes are small, truncate at the top, cuneate to the base, the nervation dichotomous, one branch ascending to the point of each lobe. It resembles Sphenopteris furcata, Brgt., of the Carboniferons measnres. Sphenopteris corruga:e, Newb., is apparsntly described from a small frag. ment of this species,-Fort Harker.

Gletchenia Kummina (१) Heer, Mol. Fl., p. 6, Pl. ii, Fig. 3.

Frond pinnate; pinnæ linear, long, pinnately lobed; pinnules connate at base, alteruate, oblong, obtuse; nervation pinnate; secondary veins 
alternate, the lower ones forking above tbe middle, the upper ones simple.

Though this form is very much like that published by Heer, (loc. eit.,) from the Cretaceous of Moletin, it differs in some points. 1. The pinnules are connate to one-fourth of their length; they are larger, more obtuse, and the secondary veins are forked. In the specimens from Moletin, the pinnules are separated to the base and have no trace of secondary veins. A small specimen publisbed by the same author from Quediinburg, Pl. i, Fig. 3, shows, however, the pinnules connate, as in the American form, with secondary veins figured simple. The frag. ment indicates a smalier form ; not separable, however, from mere differ. ence of size. I consider it, therefore, as representing the same species. As Heer has figured a specimen with fructifications, a fructified specimen of our plant may deciue the question of identity,-Fort Harker.

Sequora Reichenaachi, Heer, Mol. Fl., p. 8, Pl. i, Fig. 2-3.

The specimen represents a cone cut vertically, and thus exposing a narrow axis on which are attached horizontally, linear or narrowly ovate receptacles, attenuated at both ends, containing a small oblong seed separated by foliaceous seales. The form of the cone is the same as that of both those which are represented by Heer's figures, (loc, cit.) It is only slightly louger and narrower, and the receptacles of the seeds more closely approached to each other. The specimen does not bear any remains of leaves of Conifer, but small round, smooth branches, appar. ently referable to the same species.-Fort Harker.

\section{CaUlinites spinosa, sp. not.}

Stem or brancis cylindrical, $1 \frac{1}{2}$ cent. in diameter; its surface marked by small irregular points or depressions, resembling sears of scales; it bears apparently strong spines; one of them is marked, going out of the stem at right angles. Its scars are left in round holes through the stone. The spines and the stem, too, enlarge to the point of attach. ment.-Fort Harker.

Lieumambar mtegrifolius, Laqx., Amer. Jour. Sei. and Arts, July, 1868, p. 93.

I found at Salina three leaves of this species. They vary in size, and also in the more or less pointed form of the lobes, and in their direction. one specimen showing the lower divisions turned downward rather than horizontal.

\section{POPULITES FAGIFOLIA, sp. nov.}

Leaf elliptical, entire, subcoriaceons, tapering from the middle to a slightly obtuse point, narrowed to a thick petiole; pinnately veined; secondary veins numerous, parallel, craspedodrome.

The thick petiole is broken near the base of the leaf, which tapers to it. The general form is that of Populus mutabilis, the leaf being enlarged in the middle, and tapering upward end downward about in the satwe degree. It is 10 cent. long, 8 cent. braad, with eight pairs of secondary veius, the lower ones dividing outsile, all the reins and divisions entering the borders. The leaf 18 thickish but not quite coriaceous.-Fort Harker.
Populites SALIN sp. nov. Leaf large, thickish, membranaceous, smooth, brosdest near the base, truncate or subcordate, narrowed into an obtise
its base; borders regularly undulately lobed.

A splendid leaf, preserved entire except the petiole. It is 12 cent. wide, only 10 cent. long, triangular in outline, with the base subcordate and the borders regularly obtusely undulate-lobed. The nervation is in five primary veins from the base, all much divided, passing with the principal divisions to the point of an obtuse lobe, anastomosing with principal divisiuns to the porial nerve is pinnately divided thick perpendicular nervilles. The medial nerve is pinnately divided
from above the middle in three pairs of secondary veins. This form is remarkable, and unlike any leaf known to me; it has, bowever, a dis. tant relation to the leaf published as Acer obtusilobum, (I) Ung., in Amer. Jour. Sci, and Arts, July, 1868, p. 100. Another specimen refer. A has the nervation more distinct, much like that of a Platanus.-Salina has the
Valley.

PopUlites AFFINIs, sp. $n$.

Leaf round-quadrangular, thickish, membranaceous, rounded to the petiole, abruptly narrowed to a short point, with undulate-dentate borders; nervation pinnate, craspedodrome.

This leaf is much like the ope which I have described as Populites cyclophylla, (?) Heer, in Amer. Jour. Sci. and Arts, July, 1868, p. 93, differing, however, by its square form, its undulately distantly dentate borders, its secondary veins less numerous and more divided. The fibrills are distinct and the areolation alike.-Salina Valley.

\section{Ficus Sternbergit, $s p$. $n$.}

Leaf large, thick, coriaceons, entire, broadly oval, obtusely pointed, (i) (point broken,) tapering to the petiole; nervation pinnate, thick, coarde, camptodrome.

The leaf, destroyed in part, measures about 16 cent. in length, 9 to 10 cent. in width, has entire undulate b-rders and the nervation of a Fious. The lowest secondary veins, from a dirtance above the base, are opposite, ascend in a more acnte angle than the upper ones, (six pairs) which are, ale basilar pair, all much divided by tertiars veinlets, or thick fibrilla, anastomosing in bows along the tertiary veinlets, or thich
borders.-Fort Harker.

\section{Sassapras Cretaceovs, Newb.}

I have studied this form npon a large number of specimens, especially at Fort Harker, where it is predominant. It varies, in the size of the leares, from 4 to 14 cent. long, withont counting the petiole, which is, according to the size of the leaves, from 3 to 5 cent. long. Two forms are especially recognizable as varieties, with intermediate Two forms are es diverging lobes; the characters: one with narrower, more pointed, less diverging lobes; the
other with broader, more obtuse, more diverging divisions. The nervation is the same, generally deep and coarse; the borders are more or less marked with a few short teeth, especially on the lower sides of the lateral lobes. The following-described forms may be considered as species, not only on account of their characters, but also from their local distribution : 
Sassapras Mudgri, Lsqx., Amer. Jour. Science and Arts, July, 1868, p. 99.

The description is right. This species is found at Salina oniy. I have not seen it represented by specimens from Fort Harker.

\section{Sassafras murabilis, sp. nov.}

Leaves large, coriaceous, three-lobed, lobes diverging nearly in right angles to the medial nerve, proportionally short, obtuse; nervation very thick.

Beside the large size and broader lobes of the leaves, the species differs by the lobes of the leaves being more or less deeply cut or undulatedentate, with obtuse teeth. I have an entire leaf of this species,measur. ing 23 cent. broad, 16 cent. long, withont the petiole, which is 6 to 7 cent. in length. Though the nervation is of the same type as in $S$. cretaceus, the primary veins are twice as large, the lateral curving outside and diverging from the medial one. It has somewhat the appearance of leaves of Platanus. It is apparently an incomplete specimen of this kind which has been named and described as Platanus latiloba by Dr. Newberry.-Fort Harker.

\section{Sassafras obtusus, Lx.}

Leaves small, obtusely and equally three-lobed to below the middle; cuneate-narrowed to the long petiole; lobes oblong, very obluse ; nervation rrifid from above the base.

The leaves of this species are proportionally small, of a thinner sub. stance, with secondary veins, narrow, straight, ascending to the border of the lobes, and secondary veins thin, mostly camptodrome, parallel. In one specimen the lateral lobes are cut in one short, obtusely-pointed lobe, entered by one of the secondary veins; but in all the other speci mens the secondary veins are mostly camptodrome, simple, and the tobes entire. In report $1871, \mathrm{p} .303$, I considered this species as the same as the leaf which I had named Populices Salisburiafolia in Amer. Journ. Science and Arts, July, 186s, p. 94. It, however, differs by the more marked and diverging entire obtuse lobes, and by the secondary camp. todrome nervation. In this new species of Sassafras the lateral second ary veins are pinnately marked on both sides of the veins. In Populites Salisburiafolie the lateral veius divide on the outside only.-Salina Valley.

Sassafras recurvat's, sp. nor.

Leaves of medium size, thick, coriaceous, enlarged upward, divided to below the middle in three lanceolate pointed, long lobes, the external ones scythe-shaped outside, three-nerved from the point of the petiole.

Somewhat like the small forms of $\boldsymbol{S}$. mirabilis, differing evidently, however, by narrower, longer, obtusely.pointed lobes, by the primary nervation from the top of the petiole, and by the lateral veins dividing near the base in two nearly equal strong branches, one ascending to the point of the lobes, the other following the border and anastomosing in a curve with the upper secondary veins. Sometimes this outer division of the lateral veins seems to curve losckwards and enter another inferio lobe. But this app

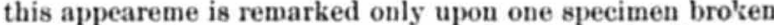
at the sides, and whose form can merely be surmised from the direction of the veins, - Fort Harker.

\section{SAssapras HarkeriaNa, sp. nov.}

Leaves proportionally small, thiek, coriaceous, cuneiform, or narrowed to the petiole, round-truncate from above the middle, three-lobed, with obtusely-pointed, very short lobes, and undulate-dentate borders between thets.

The leaves are thicker and larger than in $S$. obtusus, 9 cent. broad and as veins canptodrome, except a few, which pass into short teeth between the lobes.

\section{LAUROPHYLLUM RETIOULATUM, sp. nov.}

Leaves long, linear-lanceolate, thick, coriaceous, entire, tapering to a thick, short petiole; medial vein broad, secondary veins open, numerons, thick, short petiole ; medial vein broad, secondary veins open, numerous,
anastomosing in an irregular reticulation from above the base; camptodrome.

These leaves resemble those of some species of Laurus by their form, their texture, and the thick medial nerve; the nervation, however, is of a different type. The secondary veins numerons, close to each other at unequal distance, often intermixed with shorter veins, curve and ansstomose from near the base in Irregularly polygonal small meshes, ascending with their ramitications to the borders, and curving along them. Professor Heer has in his Flora of Moletin a species Myrtophyl lum Geinitsi, which has the same form of leaves, but a different nervation, the upper end of the veins following the borders and uniting as a kind of marginal veinlet. This character is not remarked in our leaves, of which I have many specimens with distinct nervation.

It is remarkable, that this Cretaceous Flora of Moletin, which is known as yet by eighteen species, bas one Aralia, one Craineria, oue C.'ichenia, and one Sequoia, or four species, which are, if not identical, at least intimately related to species of our Cre:aceous.

All the specimens of this species are from Fort Harker.

\section{Platanus Heril, Laqx., Rept. 1871, p. 303.}

Beside the form, whose eharacters have been deseribed, there is from Salina a leaf preserved entire, which differs by more acute lobes and its apparently membranaceous consistence.

Pterospermtes QUadratus, Jaqx., Rept. 1871, p. 301.

A number of specimens from Fort Harker, varying in size, confirm the description of this fine species. The undulations of the leaves appear more generally as short, distant teeth, entered by the point of the secondary veins and their divisions.

Prerospermtes Sternengil, sp. nor.

Leaves large, thick, coriaceous, ovate, tapering into an obtuse point, round cordate at base; - borders entire, or slightly undulate.

A splendid leaf, 23 cent. long, 20 cent. broad, deeply pinnately nerved; secondary veins more open than in the former species, with two or three pairs of simple, smaller basilar veinlets, inclined downward, or at right pairs of simple, smaler basiar se other 10 to 11 pairs above are perallel, angle from the medial nerve; the other 10 to 11 pairs above are perallel,
the lowest branching twice, the upper ones simple, all craspedorirome. 
This species, like the former, are referable to the genus Credneria, one species of which, Credneria Leconteana, Lsqx., is related to this. The description of Credneria Leconteana, as given in Amer. Jour. Sei. and Arts, July, 1868, p. 98, answers exactly the description and figure of Credneria macrophylla, Heer, in Mol. Fl., p. 16, PI. 4. Only In of the basilar veinlets is marked on $m y$ figure of this species, repono of the bar best, though in resenting our best, though inconplete, specilos; tion remarks the position of two lower secondary pairs of nerves, as observed from other specimens, and which indicate the essential character of the leaves of the genus Credneria.-Fort Harker.

Pterospermines Haydeni, Lsqx., lept. 1871, p. 302.

A good specimen of this species has been found at Fort Harker. It answers in every point the description of this species, loc. cit.

\section{Pterospermites RUGosus, sp. nov.}

Leaves rather small, coriaceons, rough and wrinkled on the surface, triangular oblong in ontline, truncate obtuse to the base, obtusely pointed, medial nerve very thick, overlapped at its base by the undulate borders.

The leares vary, at least in our specimens, from 9 to 12 cent. long and 6 to 9 cent broad. The nervation is that of the genus, three pairs of thinner basilar veins passing horizontally, or in a downward direc. of thinner to the borders. The secondary veins above are thick, emerging at an open angle of divergence from the medial nerve, branching ontsid and curving upward in ascending to the point of an obtuse lobe, or the enlarged middle of the leaves. The strong nervilles, deeply impressed into the stone, give to the leaves of this species a peculiar appearance-Salina Valley.

\section{coscrusion.}

From this enumeration of Cretaceous fossil-plants, it appears that in the twenty-three mentioned species, fourteen are considered as new; three as identical with some ones already described from Europe, but not as yet discovered in our Cretrceous strata; and six have been for. merly described from the same Dakota group. It is thus an addition of seventeen species to the American Cretaceous flora, which now has abont one hundred and twenty so-ealled species.

The remarks made in the first part of this paper, in regard to the analogy of some vesgetable forms of our Cretaceous with those of piants of our time, and also of the Miocene flora of Europe, are rather confirmed than eliminated by the descriptions of these species. They rep. resent especially forms of Sassafras, Pterospermites, Populites, with Seq uoia Reichenbachi, two ferns, \&c. Considering the relation of the Cretaceous groups, enough has been said alrady in this and in the forme report. I wishonly to record once mor the geological evidenceafforded that of the Eocene. Both these formations are now represented by a num ber of species large enough for a reliable comparison, which, made by aty palaeontologist, proves that there is not a single species, either identica or in intimate relation, in both the Cretaccous and the Eocene fiora of our continent. Even that fncoidal plant described as Fucoides digitatus, is not related whatever to any of the marine species described from the
Eocene sandstone, thongh the characters of marine vegetables appear to have been preserved somewhat longer in tbe series of geological divis. ions. Such a total discordance of types cannot be supposed for a flors of a same period, not even for members separated by a great thickness of strata. Most of the genera of animal fossils, and a large number of lowest member to the base of the Eocene. In the Tertiary formations the vegetable types represented by most of the genera, and by a large number of species, too, are recognized identical in the whole extent of the measures. The same remark can be applied to the vegetable and animal remains of all the formations. It is, then, judicions to admit as a couclusion, that such a marked disconnection of the typical character of a whole flora is a positive evidence of a new geological period, and that, therefore, the whole Lignitic of the Rocky Mountaius is, from the base of the fucoidal sandstone, a Tertiary-Eocene formation. 


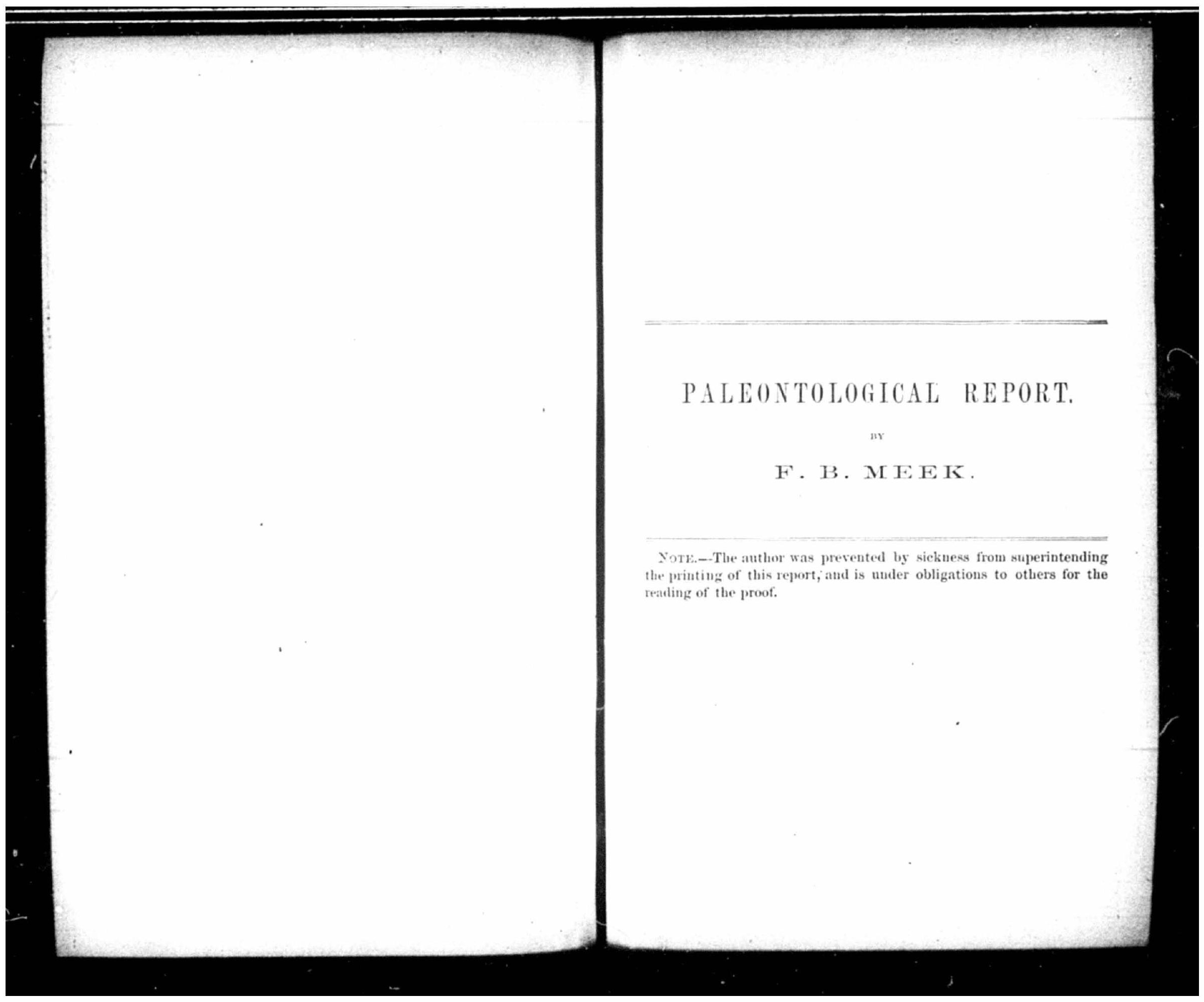


PRELIMINARY PALEONTOLOGICAL REPORT,

Cosststixg or

\section{LISTS AND DESCRIPTIONS OF FOSSILS,}

WITH HEMARKS ON TIIS

AGES OP THE ROCKS IN WHICH THEY WERE FOUND, ETC., ETC.

By F. B. MEEK. Palnontologist.

GENERAL REMARKS.

SILURIAN AGE

East side Gallatin River, d c.-All of the Silurian fossils e llected by the surves, during the explorations of 1872, evidently came frot compara. tively near the base of the system. The specimens from the e.st side of Gallatin River, above Gallatin City, Montana, were collected from four subdivisions. Those from the lowest or fourth subdivision, (numbering from above, are few, and in a fragmentary condition. Among them we have one oi those curions bodies formerly sometimes called bilobites, apparently under the erroneous supposition that they have some relations to the crustacea known as trilobites, though they are now generally regarded as marine plants, and designated by the generic name $\mathrm{Oruz}$. iana, d'Orbigny, (Rusophycus, Hall.) Along with this fossil were found imperfect specimens of Lingula, or Lingulepis, Conocoryphe, Bathyurus, $\&$ c., which, when taken together, point to a rather low position in the series, especially in view of the forms that occur in the succeeding sub. divisions above

From the third and second subdivisions, occurring successively above, we have the genera Acrotreta, Hyolithes, Agnostus, Conocoryphe, Brthy. urus, \&c., a group of types which, in the present state of paleontologieal science, conid hardly be expected to occur together, higher in the series than the Quebec group of the Canadian survey. And, when we take into consideration the entire absence among these collections of any type elsewhere peculiar to any higher horizon, and the fact that several of the species are closely allied to forms found in rocks of that age, we feel quite safe in referring these beds to the Potsdam, or Primordial zone.

Big Horn Mountain.-The same may probably be said of the rocks from, which a few fragments of Conocoryphe and Dikelocephalus were collected on the west face of Big Horn Mountain.

The few specimens from the first or upper of the subdivisions at the loeality referred to above Gallatin City, are in a fragmentary condition, but from the position of this subdivision above the others, as well as 
from the character of the fossils, and the similiarity of the rock in texture and composition to beds to be mentioned below at another locality of the age of the Quebec group, it probably belongs to that horizon.

Molade City.-The collections from Malade City, Northern Utah, inciude the genera Camerella, Orthis, Euomphalus, Agnostus, Conocoryphe, Bathyurellus, Bathyurus, Asaphus, and perhaps Dikelocephalus, most of which are common to the Potsdam and Quebee groups; but from tive affiuities of most of the species aud the actual identity of others with Quebec forms, it appears quite clear that these beds belong to that . .zon, as stated by Professor Bradley in the Am. Jour. of Science. Two of the species of Euomphalus, for instance, seem to be identical with forms described by me some time back among Mr. King's collec tions from Muddy Creek, Utah, and referred to the horizon of the New York Caleiferons group; generally reganded as representing in part at York Calcifenoms grong; generally seghed least, the Quebec; While a species of Camerella and one of Orthis seem a Canadian Quebec species, is also represented among these collections by specimens agreeing exactly with authentic examples of the same, sent from that horizon in Canada. Several of the other genera are represented by species most nearly allied to Quebec forms.

Flat.Head Pass, - A few specimens from Flat-Head Pass, Montana, consisting of fragments of Bathyurellus, and perhaps Dikelocephalus, seem also to be of the same age as the above, judging from the occur rence among them of Dilielocephalus 9 truncatus, one of the Malade species.

\section{CARBONIFEROUS AGE.}

Mystic Lake, dfe-The fossils from the outlet of Mystic Lal.e; Cañon, east side of Madisou River; Bridger Peak, near Fort Ellis; Black.Tail Deer Creek; north side Gros Vevtres Butte; Flat-Head Pass; north side Henry's Lake; and Cañon west of Gallatin River, (all in Montana, and Camp 19, Idaho, all evidently came from the same geological formation, a considerable portion of the species being common to several of these localities. They belong, without exception, to genera that are common both to the Car'oniferus and Devonian, while a smaller proportion of the genera are also represented even in the Silurian. That these fossils are not of Silurian age, however, is obvious at a flance; but as most of the species are either new, or, owing to the state of pre servation of the specimens, not in a condition to be certainly identified with known forms, almost the only guides we have in determining whether we should refer them to the carboniferous or Devonian are the absence of certain genera and the geueral specific aftinities of the entire group of forms. Some of the Producti, Chonetes, and Spirifer have rather a Deronian look, while a very tinely striated Hemipronites is very similar to some of the Devonian types of that genus. Even the forn I have referred to, $H$. crenistria, is quite as nearly like some varieties of $F$ Chemungensis (Streptorhymchus Chemungensis, of the 4th vol. Paleont,

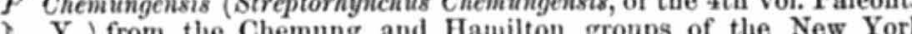
2.. Y., from the Chemung aud Hamilton groups of the New Yor Devonian, as it is like the Carboniferous forms of $H$. crenistria. According to M1r. Davidson and others, however, H. crenistria occurs in both the Carboniferous and Devonian of Europe, while the New York form, $H$. Chemungensis, differs very little from some varieties of $H$. crenistria from the Carboniferous.

- These collections consist mainly of separate valves of brachiopoids, imbedded in hard limestone.
Notwithstauding the resemblance of some of these fossils to Deronian forms, and the ct that scarcely auy of the species can be identified forms, beyond dout wer lower Carboniferous. the whole as belonging to the lower part of the low It is extremely improbable that in a collection containing so mauy other Devonian and older types, if the rock belonged to the Devonian. The entire absence of any strictly Devonian and older types of corals, The encers also favors the conclusion that this formation belongs to the Carboniferous, which conclusion is also sup. formation belongs to the specific aftinities, if not even by the specific identity, of ported by the specific aftinities, if not even by the specific ident
some of the species of Spin ifer, Productus, Chonetes, Retzia, \&c.

In looking over the collections from theso localities, I have been im. pressed with the sinilarity of their general facies (without being quit fure that any of the species are iventical) to the fauma of the Waverl che the same time that I would refer the beds from which these fossils were obtained to the Carboniferous, it should be remarked that we hav every reason to bolieve that they lelong to a lower borizon in the seri s that those from which nearly all of the collections from "Old Baldy," Mon tane, were obtained; also, than the fossiliferous beds on the divide be tain, were obtaik

Lyon Hill.-The fossils from Lyon Hill, Ophir, East Cañon, Utah, are of Carboniferous age, but it is not possible to determine, owing to the small number aud imperfect condition of the specimens, the particular horizon in that system to which they belong.

sican Valley-A few specimens from Swan Valley, Jdaho, have been hed provisionally in the Carboniferous list, but they are very frag mentary and diflicult to make out, and may belong to rocks of some it ber age.

Betceen Ross Fork and Lincoln Valley.-The species from the divide hetween Koss Fork and Lincoln Valley, marked with an asterisk in the list, are nearly all very small fossils, and occur crowded together in such great numbers that all the specimens in the collection (including stels of coken from a few fragmeuts of inainy indic foot the matrix, perhaps altogether not more than one-tenth of a cubic foot in volume. Some seven or eight of the thirty-two or thirty-three species thus found, seem to be in all respects, so far as the recimens afford the means of compari on, identical with torms occurring at the celebrated Sivergen ilill locality, near Bloomington, Indiana, while five or six others, it more may be ouly varieties of Spergen Hill species; and nearly all of the reminder belons to genera found at that locality, and so closely resemble in their small size and other characters, that they may be regarded as representative forms.

The occurrence of so many apparently identical and representative species of such a peculiar group of pigmy forms, all crowded togethe in the same way, at these two widely separated localities, is certainly a ver remarkableand interesting fact; and one, too, so far as yet kuown, without a parallel in all of our American rocks. It is all the more without a parallel in all of our American rocks. It is all the fossils has hitherto curions because not a single species of these little fossils has bitherto been identified from any intermediate locality west of Iowa and Mis souri, and even there the few species that have been found geserally occur isolated amoug larger species. In comparing two collections of such peculiar fossils from localities so remotely separated, many interesting questions bearing on the geographical distribution of species naturally suggest themselves. Adopting the view that each species, in $28 \mathrm{G} 8$ 
all cases, originatea at some single locality, and thence distributed itrelf over the world wherever we now find its remaius, and admitting that a part of these little shells, at the two localities, are really exactly identical, specifically, it may be asked, were these species created some where in the bottom of the old Carboniferons sea, at or near the Indiana locality, from which they migrated 1,200 to 1,500 miles to the northwest. ward; or, was the reverse the direction of their distribution? Such ques. tions are, of course, far more easily asked than answered; but if we to not admit that there were distinct centers of distribution for species, it would seem more probable that these forms originated at some interme. dute point, (where the strata, containing their remains, are now beneath thousands of feet of more moilern rocks,) and migrated thence sont heast. ward and northwestwarl to the two remotely separated localities.

Professor Edward Forbes maintained that to find the same group of fossils at two distantly separated localities, as in this case, so far from proving that the rocks are exactly contemporaneous, as ofteu supposel, demonstrates exactly the reverse; or, in other words, that time enongh must have intervened between the deposition of the strats at the two localities, for the migration of the species of fossils through all the intermediate distance. However this may be, there is little reason to doubt that in snch cases the rocks occupy very nearly the same relative horizous in the series of their respective districts, whatever may be the differences between their actual ages. Hence, I regard the bed from which these littie fossils were obtained in Montana as representing the Saint Lonis limestone of the Lower Carboniferous series of the Missis. sippi Valles, to which horizon the Spergen Hill beds are known to belong. It is also exident that the physical conditions affecting animal life must have been very similar at these localities during the deposi. tion of the strata in which these fossils oceur, although, lithologically, the rocks are quite dlifferent, that in Montana being a bluish-gray, somewhat crumbling semi-erystalline limestone; while that at Spergen Hill is a light-colored oolite mass.

"Old Baldy."-The collections from "Old Baldy," near Virginia City, Montana, present a group of forms that conld only, in our present state of knowledge, be referred to the Lower Carboniferons seties. The presence among them, however, of such coal-measure types as Athyris subtilita, Pleurotomaria spharuluta, Astartella Necberryi, \&e., with the aftinities of ofler species, point to a high position in this lower series while the occurrence in the same association of Pentremites Godoni an? $P$. symmetricus, or very elosely allied representative forms, together with the affinities of other types, show that their position is that of the Chester beds (or possibly of the Saint Louis inestone) of the Mississippi Valley.

A single species, lowever, Strophomena analoga, Phillips, from the same locality, would indicate that lower members of the series probably also exist there, as this species, if I remember correctly, is not known to occur above the korizen of the Burlington beds, in the Carboniferous series of the Mississippi Valley. There is thickness enough, however, of Carboniferous strata, at these distant northwestern localities, for this whole system of rocks to be developed there.

The collections from this and some of the other localities in Montana contain the first specimens of the genus Pentremites I have ever seet from any localities twest of Missonri and Iowa.

\section{JURASSIC $A G F$.}

Loırer Cañon of Yelloıstone.-The collections from the Lower Cañon of the Yellowstone, the lower beds at Spring Cañon, and those from the
Deril's Slide, Montana, are eviclently all of Jurassic age. They are nearly all bivalves, and belong to genera that also occar in the Creta ceous, aad in part in older formations than the Jurassic as well as in more modern rocks than the Cretaceous. None of them are, beyond doubt, identical with foreign Jurassic species; but from their specific aflinities to European Jurassic forms, and their positive identity, in a few instances, with species found at other localities in the West, in well. determined Jurassic beds, as well as from the entire absence among them of any strictly Cretaceous types, we can safely refer the rocks in which they ocenr to the Jurnssic.

Spring Cañon.-The few specimens from the upper beds at Spring Cañon are probably also Jurassic types, but the uumber and condition of the specimens scarcely warrant the expression of a positive opinion on this point.

Those from the lower beds near Fort Hall, Idaho, although all beloug. ing to one species, evidently came from a Jurassic rock; while a few casts from the upuer beds at the same locality, also, scem to belong to the same epoch; but the specimens being all casts, cannot be satisfacthe same epoch
torily studied.

\section{CRETACROUS AGE,}

Coalrille.-The coal-bearing rocks at Coalville, Utah, are undoubtedly of Cretaceous age, as stated by Mr. King and Mr. Eumons, and as was from the first maintained by myself. During the past summer I bad an opportunity to examine, personally, this interesting locality, and to note the thickness, order of succession, and composition of the great group of beds exposed there, as ... I as io collect and study a large series of the organic remains found in the same. From these observations it is now proposed to give, below, some remarks on this extensive series, in more detail than has hitherto been done. Before procceling to do so, however, it seems desirable that a few words should be said in regard to what has been already published respecting the geological age of this formation, as there would at least appear to be some misapprehensions on this point. Perhaps the shortest way to place this prelimiuary information before the reader will be to quote from Dr. Hayden's Report of 1870 , page 299 , the following paragraphs, written by myself, on this coal series, in a paper contributed to that report:

Some of the specimens from near Bear River, and at Coalville, Utah, from a light colored sandstone, containing beds of a good quality of brown coal, appear to belong to a member of the Cretaceons series not corresponding to any of those named in the Ppler Phoutri country, though it is, as I believe, represented by a similar sandstone Missouri. In ieco. Colonel Simpou brought from this rock, on Sulphur Creek aper tributary of Bear Biser, in Vtab." ketreral casts of Inock, on Sulphar Creek, a smal (nsils; and vith Mr. Henry Engelonann, the geologist of Colonel Simpson's survey, we referred this formation to the Cretaceons. The collecions that bave been bronght in from C'ab, by Mr. King's and Dr. Hayden's survess, confirm the conelusion that it belongs to the Cretaceous, as they contain, anong other things, species of Inocranus, dnchura, alld Gyrodes-genera that keem not to have survived the close of the Cretaceous period. In adertion to this, there is anmong Dr. Hayden's collections from this rock, at Coal. ville, a Turritella that 1 cannot distinguish by the tigure ant deseription, even specifi-
cally from $T$. Martinezensiv, described by Mr. Gabb, from one of the upper becls in Cali-

- This locality ou Bear River is really within the western border of Wyoming, hough it was supposed by me at the time of writing this paragraph to be, like Coal. vile, it Utah.

t See Proceed. Acall. Nat. Sei., Philad., 1860. 
fornia, referred to the Cretaceous. A Yodiola from the same horizon, also, appears to be specifically identical with $M$. Pedernalis, of Roemer, from the Cretaceous of Texas. Dr. Hayden also has, from a little above the coal-beds at Coalville, specimens of Ontrea, that seem much like O. Idriacnsis and $O$. Brenceri, of Gabb, from the upper beds of the California Cretaceoss. As no other fuasils were found direcisy associated with these oysters, however, nor any thar

From the attinities of some of these fossis to fortus found in the latest of the beds referred in California to the Cretaceous, and the intimate relations of these marine coal-bearing strata of Utah to the oldest Tertiary of the satme region and the apparent occurrence of equivalent beds bearing the s. mo relations to the oldest brackish-water Tertiary bets at the mouth of Judith River on the Upper Mlissouri, I am inclined to believe that these Coalvillo beds occupy a higher horizon in the Cretaceons than even the Fox Hills beds of the Upper Missonri Cretaceons series

These remarks certainly ought to make it clear enongh, one would think, that I regarded the coal-bearing strata at Coalville, Utab, and near the mouth of Sulphur Creek, on Bear River, W soming, as being of Cretaceous age. A collected during the preceding summer by Dr. Hayden's party, that I referred to the Cretaceous epoch. In this list, it

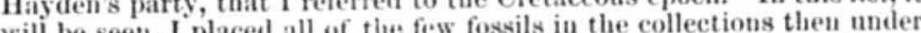

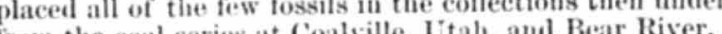
consideration, from the coal series at Coalville, Utah, ant Bear River.

In making out the Cretaceons list mentioned above, I endeavored to express, by a number opposite the name of each species, the particular
horizon in the Cretaceons series of the Upper Missouri, to which the bed that bed thit the same report cited, as follows: The ntanter the right-hand margin of the list, $\dagger$ opposite the localities, snow to which nember of the Uper Missonri Cretaceous each species belongs, the sublivisions of the Upper Missouri Cretaceous having been severally named and numbered from below upward, as follows: No. 1, Dakota no. 3, Niobrara division; No. 4 Fort Piere from localities where the several formations are well developed."

In accordance with this plan, I assigned each species in the list to its proper horizon in the Cretaceous series, by adding after the locality, "Cret. No. 1," "Cret. No. "2," \&c., according to its position, except ing those from Coalville. These I conld not refer to their precise horizon in the Cretaceons, leeause, althongh not doubting that they

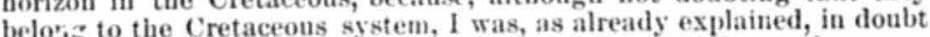
whether the beds in which they were found correspond exactly to any of the recognized sublivisions of the Upper Missonti series, being, as stated, rather inclined to think they form the closing member or divis. ion of the Cretaceous, holding a position above the horizon of No. 5 of the Eper Missouri section. Cousequently, in ouder to give expression to this doubt, as well as to follow ont the ssstem of notation, I placed opposite each of the species from Coalville, and the coal-bearing sand stones at Bear River, the words "Cret. No. q" meaning thereby, of course, that I was in doubt whether these beds corresponded exactly with any particular one of the recognized snbdivisions of the Upper Missouri series; which, it should be remembered, only represents a part of the whole Cretaceous system.

- Another quite distinct formation at the Bear River locality, containing a peculiar group of fresh and brackish water types of fossils, all entirely different from form found in the marine beds containing

me provisionally to the lower Eocene. are not exactly so in the list as printed.
In reading over the last proof of this list, it occurred to me that pos. sibly the query after the words "Cret. No. $\$$ might be misunderstood as intended to express a doubt in regard to the Cretaceons age of these species. Consequently, I struck out, with a peneil, the abbreviation "Cret," lenving it simply "Yo." after cacl of these species. But afterward I thought there conld certainly be no misunderstanding on this point, with the accompanying explasutions, and made an effort to rub out the pencil-markings $I$ had made in the proof. The printer, however, being misled by the soiling of the paper, did not understand what I wanted, and instead of leaving it "Cret. No. 1 " in all theses cases, only left it so ntter one species; while, after another, he strnck ont "Cret.," leaving it n:erely "No. 9 "; after two others he struck ont the abbreviation "No.?" leaving it "Cret., 9 " and after two others he struck it all out.

In regard to the two Coalville species, by mistake of the printer, left rith only "Cret. " after them, I admit that it might appear, to one glancing hastily over the list without reading the remarks and explanache same reoort, that I had intended to express doubts respecting their Cretaceous age. It certainly seems to express doubts respecting their Cretaceous age. It certainly seems to me, however, that any person reading, with even a moderate degree of
attention, my remarks and explanations respecting this list, aud the age of the Coalville and Bear River coal-bearing strata, in the same report, ought to understand that I did not question the fact of these beds belonging to the Cretaceous system.

$\Delta$ gain, iu giving a list of the Cretaceons fossils collected by Dr. Hay len's party, at various localities during the summer of $1870, \cdot$ in his report of 1871 , pages 375 and 376 , I placed in it a few additional forms from Coalville, nearly all of which are entirely distinct from any I had before seen fron there, or, indeed, from any other locality. These are mainly casts in hard arenaceous rock; and as I had little or no time then to work out and stmdy them, I merely placed them in the Creta. ceons list, withont specific names, and with a mark of donbt in regard to the genera to which five of them belong. I explained, however, in the accompanying remarks, that I regarded them as Cretaceous species, giving my reasons for so doing.

I have been somewhat particular in giving the foregoing statement of formerly published opinions respecting the age of the rocks under consideration, because the question-marks ured in the lists mentioned have been alluded to as if they had been used to express doubts in regard to the Cretaceons age of the coal-bearing rocks at Coalville and other localities in this region; and my opinion on this subject has been con sequently treated as if so vague and undectled that it was not even necessary for any one, subsequently arriving at the same conclusion in regard to the Cretaceons age of any of the coals of this region, even so much as to allude to it. $\dagger$

Having thus briefly cleared away some misapprel:unsions in regard to what has been well known for some years past rexpecting the Cretaceous age of the coal-deposits of Coalville, Utab, and at Bear River, Wyoming,

- It should be remembered that each of these lists only includes the collections brought in from the explorations of the preceding summer, and that they werv not in tended to include all of the known species that had previonsly been found in the satne isee a-paper on the esistence of Dinosanria in the transition beds of Wyotuing, by Prof. Edward D. Cope, read before the Am. Philosophical society, 1a72; also, Remark on the Geslogy of wyoming,
December, 1072 , page 279. 
I will proceed to describe in detail the various beds composing the great thickness of strata exposed at and near Coalville; also to explain their order of succession, the nature of the organic remains found in each, \&c.

In order that these remarks may be the more readily understood, the accompanying section has been prepared, from observations made at the locality during the past summer. It runs from the principal coal. bed near Coalville, in a northwesterly direction to Echo Cañou, a dis. tance, by a right line a little obliquely across the strike of the rocks, of perhaps three to three and a half miles.

It may be proper to explain here that the beds were not always found well enough exposed to afford absolutely exact measurements of their thickness, while the elevatious of the ridges crossed, as well as the breadth of intervening valley, were merely estimated. Another section across the same outcrops on a different line, even at no great distance from that of the section here given, would probably not agree in minor details, because the beds are liable to vary in thickness and composition at different localities in this series of rocks. The heavy beds of harder saudstone are more persistent, and, as might be expected, generally more exposed than those of softer material. Those of soft, decomposiug sandstones, shales, clays, \&c., more frequently form slopks, and consequently are more apt to he covered and obscured by loose earth. In some cases we, therefore, had no other means of determining the nature of the strata oceupying such spaces, than by examining the disintegrated surface materials, and a lew small projecting ledges. Hence some of these spaces that appeared to be oceupied by clays or shales, with only a few intercalations of sandstone, may be mainly or entirely made up of soft sandstones, or alternations of the same with clays and shales. Again, it is an important point to be remembered, that there may be other beds and seams of conl, in addition to those represented in the section, because these conls generally occur in, or are connected with, clays and shales, or other soft beds such as are most frequentiy hidden from view.

A mile or so in a southmasterly direction from Sprigg's mine, situated directly in Coalville, coal has been fount in one or two openiugs not more than about forty feet above the valley of Weber River; and the bed or beds have been by some supposed to hold a lower position in the series than the main coal (division 5) of our section. The locality of these openings, with relation to the known position and dip of the main bed, would certainly indicate for them a lower horizon in the series, and they may possibly belong lower; but from all the appearance at these excavations, (which had partly fallen in at the time of our visit,) I have the impression that this coal is merely a portion of the same bed thrown out of its natural horizon with relation to the rocks represented in the section, by the same powerful forces that upheaved and tilted all of the strata of this region. We did not see more than five or six feet of this coal exposed, but it is overlaid by a sandstone similar to that forming the roof of the main bet at Sprigg's mine in Coalville, and seemed to correspond in other respects, excepting in show. ing a (probably local) reversed dip.

Between this locality and the lowest beds represented in the section, as they are seen nearly at Coalville, there is a space not well exposed at any points examined, and consequently we did not determine the thick. ness and nature of the beds occupying the same.

Commencing, then, with the lowest strata represented in the section on the right, and describing the beds in ascending order, we have the following series:

SECTION PROM ABOUA 14 MLES NORTHEAST OF COALVILLE, IN A NORTHWESTERLY DIRECTION, TO ECHO CAS̃

8.86. :-

- No. 1. Thin bedis and seams of sandstone and elays, reddish and gray below, with some pebbly beds near the middle, and whitish and light-gray soft sandstones and clays above.

No. 2. Yellowish and reddish sandy elays.

- No. 3. Alternations of light gray and yellowish sandy, more or less laminated, class, and beds and thin layers of sandstone, with Inoceramus problematicus, Cardium subcur. tum, Lucina, Macrodon, Modiola multilini. gera, Arcopagia Utahensis, Corbula, Martesia, and many other bivalves; with Neritina pisum, Turritella Coalvillensis, Eulima funiculus, Fusus (Neptunea?) Gabbi, Melampus, de., dec.

No. 4. Light-grayish and ash-colored clays, witl occasional beds and seams of sandstones, altogether from 60 to 80 feet

No. 5. Heave teu of good coal, said to vary from 11 to is icet in thickness

No. f. Yellowish-gray sqadstone forming roof of coal, and containing Ostrea soleniseus ( $q$ ) ind Inoceramus

No. 7. Dark-colored (nearly black) clay with $\mathrm{In}$. oceramus problematicus; varying from 60 to 100 feet in thickness.

No. 8. Space mainly covered where exanined, bat apparently oceupied by clays and soft salntones, altogether perbaps 80 to 100 fert in thickness .................. 100

No. 9. 1. Massive whitish and yellowish sand. stones, with casts and impressions of a peculiar Fucoid, A ricula, Cardium, Trapezium, \&c., 45 feet.

b. Yellowish saudstone with mans bi. vlaves, 25 feet.

c. Massive whitish sandstone, with Ari. cula, Tellina, \&e., \&e., 30 feet

No. 10. Yellowish and light-gray clays, with

some beds and layers sandstone

No. 11. a. Reddish, sandy, and pebbly clays, not wel' exposed, 20 to 30 feet.

b. Conglomerate, 10 to 15 feet.

c. Bright yellow sandstone; A ricr la gas. trodes, Cardium, Tellina, Arcopa gia, (?) Gyrodes, Cyprimera isonema, Gyrodes depressa, Fusus (Neptunea ?) Utahensis, \&c., \&e., 50 to 60 feet.

d. Heavy, massive, whitish sandstone, with Ostrea soleniscus, Carlium, \&c., 70 to 80 feet.

Ft. In. 
No. 12. a. Clays and sandstones; the latter in thin layers, 55 feet.

b. Light-gray and yellowish clay, 20 feet

a. Gray conglomerate and sandstone, 42 feet.

b. Light-yellowish and grayish elays aud pebbly sand. stones, 40 feet.

c. Conglomerate, 12 to 15 feet

No. 14. Valley; no good exposures, but, probably, mainly shales and clays.

1720

No. 15. Alternations of shale and sandstone

No. 16. Coal

No. 17. Alteruations of dark-bluish fire-clay, shale, gray clay, and, moro or less, sofs saudstone. Numerous fresh brackish water and marine types of fossils mingled together, snch as Anomia, Inoceramus, Unio, Cardium, Cyrena Carltoni, Neri. ina Bannisteri, Neritina (Dostin?) bellatula, N. (D.?) car. dituionis, Eulima chrysalis, E. inconspicua, Turritella spironema, Melampus antiquus, Physa, Valeata, \&e., \&e.

No. 18, a. Coal, (Carltous bed,) 3 feet to 3 feet 4 inches.

$b$. Coal and black shale, 1 feet 2 inches.

c. Coal, 1 foot

There may be a space here of 50 to 60 or more feet, occupied by unknown bedk.

No. 19. Great, massive, light-grayish and yellowish sandstone, estimated at $2: 20$ feet

No. 20. Gray sandstone and sandy clays, with numerous Ostrea soleniscus

No. 21. Sandstones and clays

No. 22. Valley, showing at places sandstones and sandy elays, estimated thickness

No. 23. Light colored sandstones and elass

No. 24. Gray, soft satudstone, with many lasge Inoceramus, Ostrea, Cardium. \&

No. 25. Gray sandstones and clay

No. 26. Whitish sandstones and sandy clays, with fragtumuts of Ostrea lyiug loose on surface of slope

Ostrea lyiug loose on surface of slope $\ldots \ldots \ldots \ldots \ldots \ldots \ldots .150$
No. 27 . Soft, light-gray, coarse sandstone, with some pebbles 23
2350

No. 29. Soft, decomposing, light.gray, coarse sandstone, and conglomerate

No. 30. Redilish-brown conglomerate, with local streaks, and thin beds of soft, whitish sandstone, 500 to 600 feet thick. ness

No. 31. Whitish, soft, coarse sanastone, with more or less peb. bles

No. 32. Grent Echo Cañon conglomerate, (brownish tinge,) com posed of pebbles, bowlders, and sandstone, 700 feet or more 7000

Bv footing up this long list of subordinate beds, it will be seen that, if there are no faults or down-throws along the line of observation, there would be, including the great conglomerate near the mouth of Echo Cañon, anc about 390 feet of beds below the main 11 to 13 foot coal, an aggregate of some 4,680 feet of strata embraced in the section. As t.ready explained, however, it is rot pretended that the details of this section have been worked ont with the degree of precision attainable by instrumental observation, the main object in constructing it being merely to illustrate approximately the position and vertical range of fossils with relation to the coal-beds, and to give a general idea of the

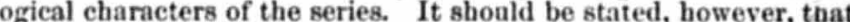
the dip and estimated distance across the strike of the strata would indicate even a greater thickness than the sum of the individual beds observed.

The dip of the beds, including the main coal (5) toward the lower part of the section, seemed not to differ much from about $8 \circ$ to $10 \circ$ below the horizon, to the northwestward; bnt it increases gradually in that direction, so that at the fourth ridge it is about 250. Between this ridge and the mouth of the cañon we observed no marked change of dip, though there appeared 'o be a slight unconformability betseen the conglomerate and the lighter colored beds below at this place; and this unconformity is more obvions at other points near here; while farther uI, near the head of the cañon, it is very strongly marked, the discord.

1 ce being, according to Mr. Emmons, as much as 250 .

Unfortunately, we have no means of ascertaining the precise distance by an air-line traversed by the section, the linear survey of the Coal. ville township not yet being completed. If we estimate the distance at three miles, and the mean dip at $17 \circ$, however, it wonld give a thickness not inaterially greater than the aggregate of heds noted in the section. If the distance should be as much as three aud a half to four miles, however, the difference would be so great as to warrant the cone'nsion that we have overestimated the dip, or, what is much more probable, underestimated the breadth of some of the valleys between the ridges, and consequently the thickness of strata hidden beneath the same. As evidences of horizontal displacements of some of the ridges, however, were oliserved, it is possible that the discrepancy may be, in part at least, accounted for in that way.

Mr. Enmons gives in Mr. King's report about 6,000 feet as the entire thickness of the Creraceons series here, exclusive of the Echo Cañon conglomerate, which is apparently Tertiary. But $\mathrm{I}$ infer that he includes in this estimate a considerable thickness $o^{\prime}$ lower strata farther up Weber River than our examinations extended.

All of the lorer beds forming divisions 1 to 6 , inclusive, of this section are seen in a low hill, or rising space, directly on the southeastern margin of Coalville, flexed around so as not to conform to the general dip and strike of the strata between this vicinity and Echo Cañon; their strike being nearly north and sonth, and their dip nearly westward, some $14^{\circ}$ below the horizon. About two miles to the northeastward, however, and at a higher elevation, coa' mines have been opened on the nain bed forming No. 5 of the section, that show this bed and the over. lying sandstone and other strata, conforming there with the general dip und.strike of the beds between there and Eeho Cañon. Between these wines and Coalville, the highly fossiliferous strata forming the division No. 3, which we know poperly holds a position below the main coal. bech, occur some hundreds of feet north of a right line betweeu these mines and the coal-mine directly at Coalville, in the same bed; thus

-Along Grans Creek we observed nome curious indications of lateral displacements. This ereek cuts very obliquely through sotwe of the ridges, which do not correspond on opposite sides. That is, the ends of the ridges on opposite sides of the creek do not on the other, as if there displacement of the strata on one or both sides of the same. 
appearing as if they really hold a higher horizon in the series than the main coal (5) of the section. At this place these more fossiliferons beds are seen in a ridge, abutting directly against the lighter-colored, more massive sandstones of division 9, forming the first ridge. In following this ridge along in a southwesterly direction we come suddenly to a point where the more massive, lighter-colored sandstones of division 9 end, and we pass, almost by a single step, upon the thinner, more fos. siliferous layers of division 3 ; the two divisions coming as abruptly together as if their strata had been sawed off and placed end to end against each other. Here the strike of the strata of these two divis. ions is nearly the same, and the dip also of both is northwestward, but those of division 3 dip at a somewhat higher angle than division 9.

This lateral displacement of portions of these lower strata is very puzzling, and had led to the conclusion that they belong above the horizon of the main coal. We were so fortunate, however, as to find them cropping ont at points within a mile to the southeastward of the coal-mine in the main bed, directly at Coalville, readily recognizable by their characteristie fossils and lithological characters, and yet clearly dipping under the division 4, which was, in the same way, traced along the outerops to where it is distinctly seen to dip under the main coal, directly at Coalville. There can, therefore, be no question whatever in regard to these beds holding a position beneath the main coal-bed that is, the lowest coal represented in the section here given,

The determinatiov of the position of these beds beneath this coal is a matter of some little interest, because it shows that in viewing this series in the ascending order, we start with a succession of highly fos silierous beds, containing a group of forms, among which we recognize the Cretaceous and older genus Inoceramus, represented by the well. known Cretaceous species $\hat{l}$. problematicus. The other fossils found it these beds seem to be all new species, though several of them are un distinguishable from forms found in the beds far above the main coul. The Turritella and. Modiola, from this locality, that I at one time thought probably islentical with Cretaceous species from California and Texas came from these beds; and although later comparisons have satisfied me tbat they are new species, they are certaiuly very closely allied to the Cretaceous forms with which I had compared them.

Althongh nearly all the fossils from these beds are certainly marine types, a few of them, such for instance as two or three species of Neretina and one of Melampus, indicate that streams of fresh water proba. bly flowed into the sea, bay, or inlet in which the marine forms lived, from close-lying land, during the deposition of these rocks.

The local displacement of portions of the lower beds of the section at Coalville, mentioned above, doubtless caused the impression at one time entertained, that the dark-colored clay (division 7 of the section) con taining Inoceramus problematicus, and perhaps iragments of Ammonites, seen in rome of the excavations there, probably held a position beneath the main coal, (division 5.) An inclined shatt, however, in conrse of exeavation directly at Coalville, during the past summer, demonstrates in the clearest aud most satisfactory manuer that its position is above the horizon of the sandstone forming the roof of this coal, as the shaft passes first down through some 50 or more feet of this clay before it strikes the sandstone immediately over this coal. Large quantities of this clay were observed lying near the top of the shaft, when we were at the locality, and numerous specimens of Inoceramus problematicus were to be seen in it.

Of course no attempt has been made to illustrate, in the accompany. ing section, this catit and local displacement of the lower beds of the same, observed here at Coulville, becanse the fracture runs so nearly parallel to the section that it could not be done.

At one place on the southeastern side of the first ridge, almost ex. actly at the point where the fault already mentioned crosses, nome coal was found in a drift excavated into the side of the hill, perhaps 80 to 90 feet above the borizon of Weber Vallev. As this coal, however, was soon found to end abruptly, on following it in, it is probably ouly a detached portion of the main bed, $(5$,$) thrown that far ont of its natural$ position with relation to the other strata, by the fault eutting through position with relation to the other strata, by the fault cutting through
the whole. As suggested by Mr. Emmons, however, it could certainly be found again at a lower position on the same side of the ridge, provided the search should be made, on the northeastern side of the line of fracture. Its position, however, on the other side of the fault, wonld be on the opposite or northwestern side of the ridge, since that end of the ridge is composed of beds really belonging below the horizon of this coal. It is probable, however, that if bodies of this coal exist on the northwest side of this ridge, near the line of fracture, they would be found so much broken up and listorted as to be of little pructical value.

Some facts observed at the locality gave origin to the suspicion that possibly the whole of that portion of the first ridge on the northeastern side of the fault may really be only a down-thrown part of the second ridge, or even that both this and the second ridges might be downthrows of the third; though the subordinate beds composing these ridges do not seem to correspond closely enough to warrant this conclasion.

The fault, or lateral displacement, mentioned in the first ridge, is also strikingly manifest in the second; the lateral movement there being more than 100 feet, precisely as if the whole ridge had been cut across by a gigantic saw, and the strata on the southwest side of this division siipled that far to the northwestward. or the portion on the northeast side as far southeastward. Evidences of this fracture are to be seen in the other ridges, and I have no doubt that it cuts through the whole to Echo Cañon, and possibly far beyond in a north or northwesterly direction, not exactly but more or less nearly at right angles to the trend of the ridges and strike of the strata."

Divisions $14.15,16$, and 17 were not seen well exposed on the line of the section, or even on the east side of Weber River, though they are doubtless exposed at some localities on that side. On the west side of the river, however, at Mr. Carleton's coal-mine, sbont two miles in a south westerly direction from Coalville, and at a higher eleratiou, these beds were cut through by a drift excarated into the side of the hill horizontally, nearly in the direetion of the dip, which is there to the northwestward about 200 below the horizon. Coal, however, has been found at, or very nearly at, this horizon on the east side of the river; while the great massive sandstone compesing division 18 forms a pue. cipitous escarpment above Mr. Carleton's mine, and thence extends concipitous escarpment above Mr. Carleton's mine, and thence extends con-
tinnously, in a northeasterly direction, to Weber River, at a point nearly opposite the third ridge on the east side, thus leaving little room to doubt that Carleton's coal and the associated beds occupy the position assigned them in the section there, as they do on the west side of the river.

-Otber similar faults, or later displacements, were also seen in the ridges at other points a mile or so farther eastward. 
As the drift at Mr. Carleton's mine penetrates almost horizontally, and nearly in the direction of the dip of the beds, of course it cuts obliquely through them from below upward. Owing to the darkness in the mine, however, and the presence of timbers at places, we conld not examine the beds there very carefully; but Mr. Carleton kindly gare ns the following detailed stritement of their thickness, order of succes. sion, \&e.:

A. Sandstone, forming the roof of the coal and shale, containing Inoceramus.

B. Coal.

C. Impure slaty coal and shale

D. Coal of good quality

E. Fire-clay

F. Soft gray sandstone. Inoceranus, Lnio, Car dium, and Anomia

G. Dark-blnish, or nearly black, and lighter colored indurated clays containing many fresh and some salt-water types of shells, such as Physa, Valeata, Syrena, Neritina, Melampus, Eulima, Turritell, \&e.

H. Shale

1. Soft rusty sandstone, with Cardium and frag. ments of other fossils.

J. Fire-clay

K. Coal

L. Shale.

M. Dark sandy shale

N. Sandstone

O. Iron ore

P. Dark shale.

Ft. In.

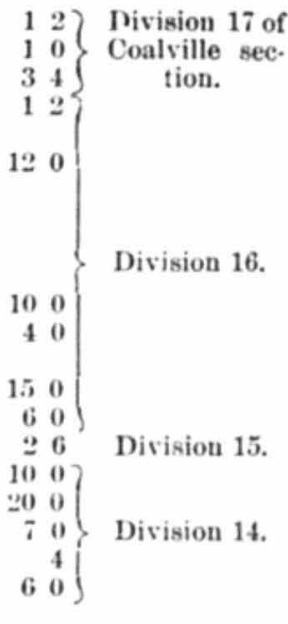

Although we could not, as stated, examine all of the beds and seams of these divisions of the rection in as much detail as desired, there being no surface outcrops of the same here, we nevertheless did see nearly al of them in place, with their characteristic fossils, in passing along the drift or gallery leading to the coal, and in part immediately over the same. At some places in the mine, the clays and thin seams of coal above the coal $D$ had fallen in, so as to expose the overlying sandstone $A$, and in the under surface of this we saw many casts of Inocerams. In the bed F we likewise saw Inoceramus, Cardihm, and imperfect examples of Unio, while from the dark clays $G$ we picked a few shells, when examining this bed in the drift. Considerable quatities of the re moved portions of all of these beds were also to be seen lying in heaps at the entrance of the drift, and that from each conld there be readily identified by Mr. Carleton, so that we had no difficnlty in referring all of the fossils found in this loose material, which had not been long ex. posed to the weather, to their proper beds.

It was the opinion of the miners here that the sandstone $A$, in which we saw casts of Inoceramus, in the mine, is the lower part of the massive dirision 18 of the section. Although this view was adopted in con. strueting the section, it is possible that it may be a lower bed of sand. stone, separated from the base of the massive stratum 15 by 50 or 60 feet of elay or other material, as there seemed to be rather too long a slope between the base of the exposed part of the sandstone 18, seen above, and the entrance of the dirit, to be filled by the beds obiiquely perforated by the same; thongh we had no means of uetermining how much of the lower part of this sandstone may be hidden in this slope.

The group of fossils found in the dark indurated clay $G$ is, in several respects, a rery interesting one, not only because every species is new to science, and all of them entirely diffirent from any yet found at any other locality, or even in any other beds at this locality, (with possibly one or two exceptions,) but on account of their modern aftinities. Here we have, from beds certainly overlaid by more than 1,000 feet of strata coutaining Cretaceous types of fossils, a little group of forms, present. ing such modern aftinities that, if placed before any paleontologist unacquainted with the facts, they would be at once referred to the Tertiary. Such examples as this illustrate the difficulties with which the paleon. tologist sometimes has to contend, and show how very cautious we should be in deciding from the aftinities of new species of fresh and brackish water types of shells (the vertical rauge of which is nnknown) the geological age of rocks in which they are found; because species of this hind, from rocks of various ages, often closely resemble each other, while they rarely present such well-narked distinctive features as we see in marine shells from different horizons. Some of the species of Physa, Cyrena, Neritina, \&c., for instance, from the clays under consid. eration, closely resemble existing species; while one or two of Melampus present but very slight differences from Paris Basin Tertiary species, figured by Deshayes under the name Auricula.

It would appear that the indurated clay containing these mixed types of shells must have been deposited in the form of tine mud, in an esta ary, or possibly a larger body of salt water, into which the fresi. water shells were swept by streams flowing in from adjacent land.• There were obably here, however, during the deposition of all this great group of coal-bearing strata, as luring the formation of the far more
ancient Carboniferous coals, various oscillations of the earth's surface, because we have every reason to believe that every bed or seam of coal, even if only a few inches in thickness, was formed in marshes, by the growth and accumnlation of vegetable matter, at or a little above the sea-level, while we find marine types of fossils through most of the in. tervesing strata; showing that after the accumulation of the material of each bed and seam of coal, there was a subsidence, and a return of the sea.

Above the horizon of Mr. Carleton's mine, we only saw marine types of fossils, though there may be other beds containing fresh-water shells higher in the series. As already explained, we saw in the sandstone supposed to be the lower part of division 18, in Mr. Carleton's coal-mine, casts of one or more species of the marine genus 1noceramus. We also saw higher in that division, on the east side of Weber River, casts of the marine genus Cardium; while in souse thinner beds of sandstone and clays forming division 19 , just above 18 , there occur, on the east side of the river, numercus casts and shells of a peculiar oyster I have called 0 . soleniscus.

This oyster, which, as already stated, occurs at several horizons far down in the series, is very psculiar, and easily recognized by i:s unusually narrow, elongated, and generally quite straight form. At the locality mentioned above, on the east side of the river, many examples of it

- It is evident that these fresb-water sbells could not, however, bave been transported very far, becanse, although quite thin, they are not water-worn, but seem to a crusbed condition, evidently from prenume during to 
were scen, presenting a curions and puzzling appearance. They had grown crowded together br thonsands, beak downward; while, in most cases, the shell itself was dissolved away, leaving only the internal casts, often 12 to 13 inches in length and only about 2 inches in breadth, standing side by side, with their longer diameters at right atgles to the plane of the bed in which they were enveloped. At first it was rather difficult to comprehend what they could be, but on drawing some of them that were loose from the eavities they were found to be the irternal casts of this peculiar oyster, showing the muscular scars quite listinctly. In a few instances, however, some of these specimen also retain the shell itself entire.

The highest horizon in this grest series of beds at which fossils were seen in situ was in division 23 of the section, (fourth ridge.) Here we found in a light-grayish, soft saudstone numerous casts and broken shells of a large Inoceramus, with fragments of Ostrea and casts of a Cardium. The Inoceramsus fond here is a suborbicular, rather com. pressed or moderately convex species, with a rather short hinge ant regular concentric undulations. It agrees well with Upper Jifssouri specimens we have always referred to $I$. nebrascensis, Owen, from the Cretacenns, excepting that none of the specimens found are quite large as Owen's type; the size being about intermediate between $I$. Sagensis, and $I$. nebrascensis, Owen, wbich, however, may be only varieties of one species. The fragments of Ostrea and casts of Cardium fonnd in the same association were too imperfect for satisfactory identi fication, but seemed to be very like forms found far below this horizon in other beds.

Along a slope formed by division 25 loose fragments of Ostrea were observed, that appeared to be the same form found associated with the Inoceramus and Cardium, in division 23 , but none were seen in place.

Beyond this, toward Echo Cañon, as we ascend in the series the same light grayish colors prevail in the sandstones and intercalated beds of conglomerate, for perhaps five or six hundred feet or ıоore before we come to the great brownish conglomerate of the cañon. These lighter colored sandstones, however, are coarser and less coherent than most of those below the division 26 . We looked earefully for fossils in these beds, but found no traces of organic renains of any kind; and, jud ${ }_{b}^{\text {:n }}$ from the coarseness of the material, it is probable that it was rapith. deposited i aring the prevalence of physical conditions unfavorable to animal life.

The same was also evidently the case, even in a far more marked de. gree, during the deposition of those huge, massive beds of brownish conglomerate, at Echo Cañon, (divisions 29 to 31 , inclusive, of the section,) which are so coarse as to present the appearauce of consolidated drift. These beds are mainly compose. of water-worn rocks of every size, from that of small pebbles to bowlders from 6 to 10 inches in diameter, the larg $r$ sizes more frequently predominating. The inter. stices are filled witl arenaceous matter, and the whole firmly cemented together. So far as examined, near the mouth of the cañon, a large majority of these pebbles and bowlders were foumd to be very hard, light grayish siliceous rock, apparently metamorphosed sandstone, though a few of igneons origin were occasionally seen. The whole formation is so massive that it would often be difficult to see in it any evidences of stratification, if it were not for occasional seams and lenticular bodies of intercalated sandstone along certain horizons. These have a deep reddish-brown color, anc, as they are liable to weather out, where exposed, they leave lines of cavities that inpart to the surface of precip- itons exposures a stratified appearance. The coloring matter by whicit the whole formation is tinged brownish red evidentiy comes from these intercalated seams of saudstone, and the same material forming the paste of the conglomerate; because the pebbles and bowlders them paste of the conglomerate; because the pebbles and bowlders them
selves forming the main body of the same, when washed, often retain little of this ferruginous tinge.

Of course we can scarceiy hope to find organic remains in such a for mation as this, which unst have been deposited by the action of powerful currents of water, in which mollusks or other organisms could not have lived; and if, by any chance, their shells or other solid parts should have been placed there, they would probably have beeu ground to pow. der by attrition among the rolling pebbles and bowlders and whirling sands. If any traces of fossils, however, exist in any part of this formation, it is among the seams and intercalated beds or lenticular masses of sandstone, or local boties of finer material, that they most probably occur.

This immense massive conglomerate not only composes the towering walls of Echo Cañon-at places forming perpendicular, or eren, orer hanging escarpments, 500 to 800 feet in height-but also rises into monntain masses on the west side of Weber River near the mouth of the ca $\tilde{\tilde{n}}$. Opposite Coalville, on the same side, five miles farther up, it likewise forms the npper part of the mountains above the Cretaceons; while south of Coalville, on the east side of the river, it is developed in such great force as apparently to form much of the entire mass of the mountains seen there. I am not sure that we saw its entire thickness exposed at any one place, but it probably attains a thickness of 2,000 feet in places.

That this great conglomerate formation is of Tertiary age, as snggested by Dr. Hasden, Mr. King, and Mr. Emmons, I know of no reason to ques. tion. This view not only accords with the fact of its position above such an extensive series of Cretaceous rocks, but with its non-conformability with the same, as well as with its remarkably coarse material. The line of separation between the two formations is probably that seprating divisions 29 and 30 of our section-that is, all below that line probably belongs to the Cretaceous - though we did not find any fossils in place abore division 23, and those found there were certainly Cretaceons types.

When referring the coal series at Coalville to the Cretaceons, in Mr. King's and Dr. Hayden's reports, I called attention to the very unusual entire absence, so far as known, of the genera Ammonites, Scaphites, Baculites, and all of those varions other Cephaloporla, as well as of many other types, so generally at once distinguishing marine Cretaceons rocks from those of Tertiary age. At the same time, however, I noticed the presence of several species of Inoceramus, one of Anchura, and one of Gyrodes, genera that do not occur in more modern rocks than those belonging to the Cretaceous period; and it was on this evidence, and the specific aflinities of some of the other types, that I was led to refer this series to the Cretaceous. The genus Cyprimera, Conrad, (and probably several other genera yet only known in the condition of casts, may now be added to the list of Cretaceons types found in this series; while the species of Cyprimera discovered here is so nearly like $C$. de. pressa, from the Cretaceous of North Carolina and Mississippi, as to leave donbts whether it may not really be the sams. We also now have the well-known Cretaceous species Inoceramus problematicus, from both above and below the main coal-bed at Coalville; while another larger Inoceramus, from far above all the coal here, is apparently identical, specitically, with an Upper Missouri Cretaceous species. 
As I have, however, mentioned faults and lateral displacements of the strata here, it may be thought by some who are yet incredulous in regard to the Cretaceons age of these coals that these disturbances of the strata may have given origin to erroneous conclusions respecting the positions of the beds containing the Cretuceous types with relation the positions of the heds contar, is simply impossible, because these fossils to the coals. This, however, is simply impossible, because these fossils occur, as elsewhere stated, both above and below the coal-beds, even in clearly seen couformable and in their natural positions with relation to each other. Cousequently it would not, in the slightest degree, weaken the foree of the evidence, even if we should admit any conceivable amount of distiubance of the beds, or even if we were to suppose the whole vast series of beds had been bodily tilted up and completely in. verted, (of which condition of things there is no evideacest beeause, eren in that case, we wonld still have unquestionable Cretaceous types both abore and below the coal-beds.

In the reports above cited, I stated some reasons for supposing this whole group of Cretaceous rocks to belong to a more recent member of that system than any of the recognized subdivisions of the Upper Mis. souri Cretaceous. The facts observed at the locality last season, however, reem to demonstrate that this is not the case. For instance, we found toward the lower part of the section, both above and below the main coal-bed, Inocerunus problematicus, a widely distributed species that is very characteristic of the Niobrara and Benton groups of the Upper Jlissouri, which there occupy positions below the mindle of the series; aud, so far as I know, this species never occurs in this country above this horizon." Arain we fonnl, far above this, in division 23 of the sec. tion, numerous specimens of it larger Inoceramus, which, if not really identical with one of those forms, is scarcely distiuguishable from $I$. Sagensis anl $I$ Vhen later members

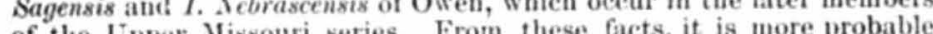
of the Upper Missouri series. From these faets, it is more probable that we lave here, at and near Coalville, representatives of the whole Upper Missouri series, with possibly even lower members, farther up Weber River, tian any of the known Upper Missouri subdivisions of the Cretaceous, If this is so-and there seems to be little reason to doubt itthe murke l difference observed between almost the whole group of fossils found here, and those of the Upper Missouri Cretaceous, would seem to indicate that there was no direct communication between the Cretaceous indicate that there was no direct communication between the Cretaceous depositail. Differences of physical conditions, however, probably also played an important part in the production of this diversity of life, since it is esident from the great predominance of class and other fiue since it is ex deposited in comparatively deeper and more quiet waters than those in $\mathrm{U}$ tab, in which coarse saudstones, with oceasional pebbly beds, predom. inate.

Although the Coalville coals, and incleed all of those of this entire region of conutry, belong, (as might be expected from their comparatively modern age, chemically speaking, to the brown-coal series, they are of unusaliy good quality, being generally as bard, black, compact, are of unusaliy good quality, being generally as bard, black, compact,
and shining as the far older Carboniferous coals. They burn much like bituminous coal, being, in fact, semi-bituminous. As they contain more

- For the information of European geologista, not familiar with the details of our geology, it shonld be stated that the entire $\mathrm{C}_{\text {pper }}$ Misoouri Cretaceous series belongs to the npper part of that system. water, however, their heating properties are not equal to those of the older Carboniferous coals, while they are more liable to crumble from exposure and handling. Still, when we take into consideration the great scarcity of wood throughout immense areas of this internal part of the continent, the thickness and extent of some of the beds, and their proximity to the Pacific Railroad, it will readily be understood that these mines must be of great value.

The main bed (division 5 of the section) must contain practically inexhaustible quantities o? coal, and has a moderately firm roof of sandstone. Some difficulties, however, will be met with at places, in mining it, on account of faults and disloeations of the strata, but not greater than in coal-mining in other disturbed districts.

It is also evident that in miving these coals, great care should be taken not to allow the refuse thrown from mines to accumulate at the entrance, in contact with the outcrop of the coal-bed in place; becanse this refuse coal, as thus exposed to the weather, is liable to take fire spontaneously, and iguite the coal in the mine, eausing great tronbie and loss, not always so much from the amount of coal consumed as from filling portions of the mine with suffocating gases and smoke, as well as from causing the falling in of the overlying strata.

At Spriggs's m'se, directly in Coalville, the strata, as already explained, do not conform to the general dip, and strike on the other side of Chalk Creek, a little north and east of here, the strike being nearly north and south, and the dip but little north of west, about 140 betow the horizon. The rising up of the beds here is almost co ncident with the western slope from a little plate.u of 30 to 40 feet elevation above the valley on the sontheast margin of the town. Formerly the mine bere was worked by drifts or galleries, following the coal directly from the surface under the inclined sandstone, (division 6, which forms, at places, the surface of the slope from the little plateau. Fire, however, was communicated from the burning slack coal at the entrance of the mine, to the onterop of the coal-bed, aud burned under, causing the sandstone to fall in, and filling parts of the mine with smoke and gases, which were escaping from cracks in the fallen-in sandstone and overlying earth when we were there.

Whether on account of inconvenience caused by the barning conl, or for other reasons we did not learn, they were, when we were at the locality, sinking a bighly inclined shaft, commencing a little above the base of the slope mentioned, and cutting down obliquely through the clay of division 7 and division 6 , to strike coal-bed some distance below the bottom of the valley.

The dip of the strata here must canse the coal to plunge beneath the valley, and, if there are no faults or fissures, to pass under Weber River, at a vertical depth of between 300 and 400 feet. It is therefore possible, as suggested by Mr. Emmons, that there may be much trouble with water in working this bed far beneath the surface here, unless the heavy bed of impervions clays (division 7 ) may prevent water from this source from percolating down to the coal-bed.

The other mines, two to two and a half miles farther northeastward, on the same bed, and at considerable higher elevations, will probably be less troubled with water. Indeed, there is little reason for doubting that slightly inclined tunnels might be started, at much lower horizons on this bed, between the mines now worked there and Coalville, and extended in a northweeterly direction, 80 as to drain themselves and all the mines on this bed above.

Of the mines over on Grass Creek, some four or five miles northeast29 G $\mathrm{s}$ 
mand of Coalville, we only visited one, owned, I believe, by Mr. Joseph Young, one of Brigham Young's sons. This mine is situated in the bot. tom of Grass Creek valley, or cañon; and as it seems to be exactly on the line of strike of the othe: mines between it and Coalville, and does $\mathrm{n}$ differ very materially in sirike, dip, and thickness, there can scarcely be any doubt that it is in the same bed of coal. This view is also supported any that seen over the mines between here and Coalville, and at Coalville; while we saw in this sandstone apparently the same oyster observed in that forming the roof of Spriggs's mine at Coalville.

The mines in the higher part of the series, althongh in thinner beds than the main one far below, must be of considerable value. That than thy Mr. Carleton, on the west silt of Weber River, in disision 17 of the section, affords a good quality of coal. The thickness of the bed is about 3 feet 4 inches, with one foot of black shale and impure coa above it, and over this 1 foot and 2 inches of coal. Where the shale is firm enough not to require much timbering to hold it up, it can probably be left as a roof to the mine; but where the shale is thin and friable, the whole thickness, including the upper 1 foot seam of coal, up to the the whole thick sandstone, will have to be taken out. Indeed it is possiblethat the shaly parting between the two may become, at places, zufticiently carbonaceous to serve for the supply of fuel for machinery at the mine, and in that case it would be the best economy to work the whole thickness. The ridge at this mine exterfis apparently without break for two miles or more, and it seems probable that the coal is equally accessible throughout the whole extent.

Bear Rirer._On Sulphur Creek, near Bear River, in Western Wyoming, there are to be seen some very interesting exposures of Cretaceous rocks, including valuable beds of coal. These exposures are directly on the Tnion Pacific Railroal, and evidently belong to the same horizon as the coal series at Coalville, Utah.

As long back as 1860 the strata, including the coal here, were referred to the Cretaceous by the writer and Mr. Henry Fingelmann, in a paper on Colonel Simpson's collections." They were also referred to the same age by Mr. King, Mr. Emmons, Dr. Hayden, and myself in 1870. $\dagger$ Ther is, however, also here, associated with the above-mentioned beds, another quite distinct formation, containing an entirely different group of fossils, consisting of a mingling of both fresh and brackish water types, which I hare always considered most probably of lower Eocene age.

While on ansin. While on an exenrsion to Wyoming aud Utah during the past sumtunity to stop at the Bear River locality to examine the rocks and collect fossils, and from our notes, observations, and collections, I have prepared the accompansing section of the strata exposed there. Most of these the aco will be seen, are thrown up inte a nearly vertical postnre, with the thrown in an approximate north and south strike; and the section, which is a little more than one mile in length, crosses the strike at right angles from east to west. Commencing at the right hand, or eastern end of thi section, aud going westward, we meet with the following strata:

- Proceerl. Acad. Nat. Sci., Pbilad, A pr., 1800, p. 130

'Proceel. Acad. Nat. Sci., Pbilad, Apr., 1800 , p.
BECTION OF THE ROCKS EXPOSED ON SULPHUR CREEK, NEAR BEAR RIVER, WYOMrNG.

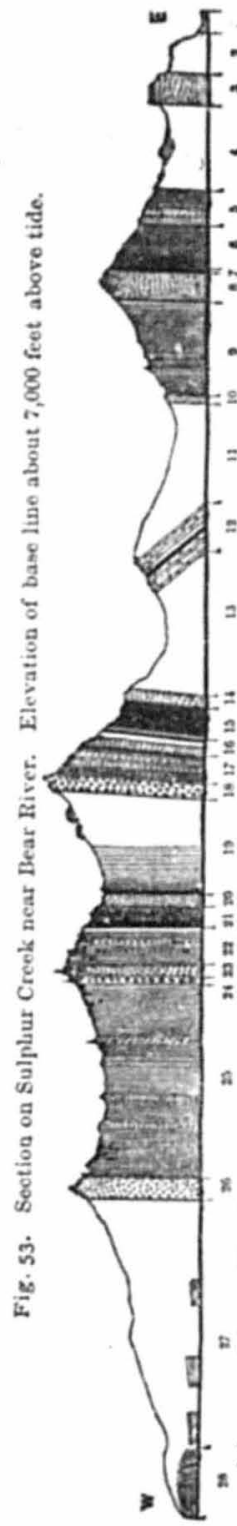

No. 1.-Black shale, only seen in bottom of Sul. phur Creek, thickness unknown.

No. 2.- Slope apparently occupied by clays, thickness perbaps 100 feet or more......

No. 3.-Soft light grayish sandstone, nearly vertical.

No. 4.--Covered space, probably occupied by clays, but showing some saudstone that may or may not be in place; perhaps room enough for 250 to 300 feet.

No. 5.-Two or three rather heavy beds of light yellowish gruy sandstone, separated by clays, probably occupying some of the space included in division 4. Near the loser part two lavers 15 to 18 inches each, of sant stone, containing Ostret soleniscus, Trap. ezium micronema, \&e. Altorether 90 to 100 or more

- - Greenish and bluish gray sandy clays, with some dark shale at places

No. 7.-Bed of good coal, said to be 78 feet in thickness

S.-Heavy massive bed of light colored sandstone, about 90 feet in thickness, stand. ing nes rly vertical, with some 3 to 5 feet of sandy clay between it and the coal of division 7 .

No. 9.-Gray santy shales with a!teruations of sandstone and clays.

No. 10.-Light gray sandstone

11.-Slope and unexposed space, perhaps 200 yards or more across.

No. 12.-Light gray sandstones and clays, in cluding a bed of gond coal, said to be zd feet in thickness; all dipping south-sonth east $55^{\circ}$ below horizon; and the sandstone abore the coal containing many easts, Inoe abore the coal containing many easts, Inoc cramus problematicus, with a few casts of together showing about................ 13.-A valley or depression showing no rocks, perhaps 150 yards across.

Yo. 14.-Ferruginons sandstoue in thin layers, dipping north-west about $80 \circ$ below hori

No. 15 - Bluish laminated clays with, at top. (left or west side,) a two-foot layer of sandstone, contafning fragments of shells not seen in a condition to be determined..... 12

No. 16.-Clays and sandstone below, (20 feet;) gray and brown pebbly sandstoue above, (25 feet) ....................... 45 
No. 17.-Brownish and bluish clays, with some beds of white, greenish, and brownish squistones

Ft. In.

o. 18.- Hard gray conglomerate, standing nearly vertical, and forming crest of hill about 350 feet high.

No. 19.- Slope showing above some masses of conglomerate, like that of division 18 , perhaps not in place, with, at places below this, some reddish clays; altogether space enough for 500 to 600 feet in thickness.

No. 20.-Greenish.white sandstone

No. 21.-Brownish elays and sandy layers

No. 22.-Brownish clays and beds of sandstone, the latter light gray below

No. 23 . Whitish sandstone - forms erest of hill about 220 to 240 feet in beight

No. 24.-Conglomerate and some red clays

No. 25.-Brownish and reddish clays with a few distantly sepa. rated thin beds and layers of gray sandstone, aitogether 750 to 800 feet in thickness

No. 26,-Gray sandstone in place, apparently connected with some masses (that may not be in place) so as to include space enough for 60 to 80 feet-forms crest of a bill.

No. 27. A long space of perhaps 260 yards or more, with only a few low exposures of light-gray sandstose, showing a slight west ward dip.

No. 28. Numerous thin seams and liyers of dark carbonaceous shales, with harder thin bands of various colored argillace. ous, arenaceous, and calcareous matter, including a few very thin streaks of coal; the whole heiag highly charged with vast numbers of fresh and brackish-water sheils, such as species of Unio, Corbicula, Corbula, Pyrgulifera, Viviparus, Melampus, \&c. Dip nearly east, about $75^{\circ}$ below the hori zon; thickness 175 to 200 feet exposed.

This section has been constructed rather with the view of giving a general idea of the upheaved and confused condition of the strata, and (so far as can be done) of the relations of the undoubted Cretaceous beds containing wotkable beds of coal here, to the fresh and brackish. water formation at its western end, than as an illustration of minute details. The elevations, as well as the horizontal distances between exposures, are only gicen from estimates carefully made at the locality while the thickness of the subordinate beds can scarcely be regarded as more than approximately correct, as they are not all sufficiently well exposed directly along the line of the section, to show their exact limits, and our examinations were not extended very far laterally. It is believed, however, that the section will be found suficiently accurate to serve the purpose for which it is given.

That the strata in which the workable beds of coal occur here (divis ions 1 to 12 , inclusive) belong to the Cretaceous, has, as already ex. plained, been well known for some years past. It is also evident that this formation belongs to the same series as the Coalville coals. The evidence of this is not only the general correspondence of the litholog. ical characters of the rocks at these localities, but the presence here of some of the same species of fossils found associated with the coal beds at Coalville. Three of these fossils, Ostrea soleniscus, Trapezium micronema, and Inoceramus problematicus, are also peculiar forms that ean be identified with the fullest confidence.
All of that portion of the well-marked Cretaceous series here forming divisions 1 to 10, inclusive, along with an important bed of coal, it will be seen, stands in very neariy a vertical posture. On going a little farther westward, however, across a lower space, showing no rocks, we come to another Oretaceons exposure, (division 12 of the section,) consisting of thin layers of light colored sandstone, including a workable sisting of thin layers of light colored sandstone, inclnding a workable
bed of coal, all dipping at an angle $55^{\circ}$ below the horizon, in a nearly south-sontheast direction. In this sandstone, above the coal, numerons casts of Inoceramus problematicus, and a few other Cretaceous foasils occur.

That the bed of coal found in this last mentioned outerop, sithongh said to agree with the bed 7 in thickness and other characters, is really not a part of the latter thrown over from above, or flexed and tirust up from beneath, is almost beyond doubt; becanse the rocks in which it is included do not agree lithologically with those immediately associated with the bed 7 , while none of the fossils filling the sandstone of division 12 were seen in any of the rocks directly associated with the coal 7 .

It therefore appears to be quite evident that there are at least two distinct beds of coal in the Cretaceous rocks here. Exactly how the beds forming division 12, with their included coal, connect with the other Cretaceous strata, included in the divisions 1 to 10 , we cannot very clearly explain. The probability is, howerer, that they, and possibly other associated strata hidden under the soil, were originally tilted with the other Cretaceons beds, ( 1 to 10, ) to a vertical posture at the time of the upheaval, and then fell over to the present inclined condition. We observed no evidence whatever that they correspond to any part of the series included in the same section farther west.

If only the strata already mentioned ( 1 to 12 inclusive) at this locality are Cretaceous there would then be, exclusive of other beds that may be hidden in the spaces 11 and 13, about 1,213 feet of rocks seen here that are certainly of Cretaceous age.

West of the out-erop of division 12, we have first another lower space of probably about 450 feet, in which no exposures of rock in place were seen. Then we come suddenly to a great series of sandstones, clays, conglomerates, \&c., more than 2,000 feet in thickness, (forming divisions 14 to 26 , inclnsive of the rection,) all standing in a vertical posture, excepting the beds from 14 to about the 18 th, all of which lean slightly to the eastward of an exact perpendicular. Whether or not all of this great series, from division 14 to 26 , should also be included in the Cretaceous along with those forming the eastern portions of the section, we were unable to determine, because we saw no organic remains in any of these beds, excepting a few undeterminable fragments of shells in the upper layer of division 15. The fact, however, that these strata stand so very nearly conformable to the well-marked Oretaceous beds, from 1 to 10 , would rather favor the conclusion that they belong to the same system of rocks, though it would not necessarily demonstrate that this is the case.

West of division 26, we come to a space of about 260 yards or more, in which no rocks were observed in place, excepting a few low out-erops of light grayish sandstone, bri little above the base line of the section. These are almost horizontal, or show only a slight inclination below the horizon toward the west; being thus strikingly unconformable to all of the other strata of the section. We saw no fossils in these beds, bnt they are almost certainly Tertiary.

Immediately on the west of the last-mentioned onterops, and nearly in contact with one of them, there is exposed, in a cut made for the pass. 
age of the railroad, one of the most interesting series of beds (division 28) anywhere to be seen on the whole line of the Union Pscific Railroad.- This cut is about 150 to 200 yards in length, and passes through the strata nearly at right angles to their strike. The beds thus exposed consist of nnmerous thin seams of dark and light grayish colors alternating, so as to present a banded or striped appearance, the darker band being more or less Carbonaceous, or eren in some cases containing thin streaks of coal; while the lighter layers are more arenaceous, calcareous, or argillaceous. All of these beds and seams are tilted up so as to dip nearly eastward at an angle of about $75^{\circ}$ below the horizon, being thus not exactly conformable to any of the other divisions of the section, though apparently upheared at the same time. They contain immense numbers of fossil shelis, belonging to a few species of fresh and brackish water types, some of which are closely allied to European Lower Eocene species.

Toward the western extremity of this ent the upper ends of the strata are suddenly flexed westward, as if they had been struck, after their upheaval, by an iceberg, or eome other tremendous force, coming from the east. There is no evidence, howerer, that this flexure was produced by any agency of this kind; on the contrary, it is almost certainly a mere fragment, as it were, of one of the folds of the strata, caused by the powerful forces to which they have been subjected, by the combined action of upheavals and lateral pressure.

This division of the section, I have always referred provisionally to the Lower Eocene, though I have, at the same time, intimated that it may set be found to belong more properly to the Upper Cretaceous. I will return to this suiject again, howerer, in another place, further on,
when speaking of Tertiary collections.

In regard to the coal beds 7 and 12 , in the Cretaceons formation here at Bear River, I should think that there can scarcely be any reasonable doubt that they will be of considerable value. The mines reasonable apparently been worked but little, and as nothing had been done in them for some time before our visit, the entrances were partly filled by the falling of the adjacent rocks and shale, so that we could not exsm. ine them very carefully. We were intormed by Mr. Thorpe, however, the owner of the property, that each of tha beds seen there is $7+$ feet in thickness, and that the coal is of excellent quality. It is donbtless simi. lar to that mined in the same formations exceedingly convenient to the railroad, which passes along so close to that in the bed 7 , that the miners' carts can run out upon a platform at the entrance of the mine and tip directly into coal-cars on the railroad; while the opening into the other bed, 12, is only about 100 to 150 yards from the road.

Below Gallatin City.-The fossils from near the Missonri River, below Gallatin City, Montana, belong clearly and beyond doubt to the Cre taceous, and about to the horizon of the Fort Benton group or subui. vision of the Upper Missonri Cretaceous series. A few of the biv dives appear to belong to the fresh or brackish water type, Veioritina, but all of the others are marine forms. It is an interesting fact that Trigonia, in this collection, is so vear $T$. Eransi from the Cretaceous beds of - Vanconver's Island, that no reliable difremes caceous from the imperfect specimens found. So far as I have been able to de.

- For a very minutely detailed section of this ent, prepared by H. R. Durkee, esq. 153. It only illustrates the Union Pacific Railroad, see Dr. Hayden's report of 1870, p. tions to the other beds seen in our section. termine, none of the species from this locality seem to be certainly identical with any of those from any of the recognized subdivisions of the Upper Missouri Cretaceous, but some of them oecur at other localities along with the characteristic forms of the Benton group.

Cinnabar Mountain.-The species from Cinnabar Mountain, Yellow. stone Valley, belong, almost certainly, to the same horizon as those from Missouri River below Gallatin, the species of Trigonia mentioned from that locality being the same found at this. There can be little doubt in regard to these fossils belonging to the Fort Benton group of the Cretaceons, because I recognize among them Scaphites rentricosus, one of the most characteristic fossils of that horizon.

Bridger Peak.-The few things from east foot of Bridger Peak, (four miles from Fort Ellis,) Montana, are nearly all mere casts in a bad state of pre. servation, but, so far as I have been able to determine, none of the species appear to be identical with any of those known from the recog. nized subdivisions of the Upper Missouri Cretaceons; though, from their general facies, there is still little room to doubt that they belong to the Cretaceons system. They are certainly not Tertiary.

Colorado Springs. A small collection from Colorado Springs, Colorado, evidently belong to the horizon of the Fort Pierre grou: of the Upper Missouri Cretaceous series.

Rock Creck,-The collectionk found by Professor Lesqnereux on Rocic Creek are all Cretaceous forms from the horizon of the Niobrara division of the Upper Missouri.

Fort Harker.-Those collected by him from near Fort Harker are also Cretaceons, and from the horizon of the Fort Benton group.

Bitter Creek series.-Along Bitter Creek, (a smail tributary of Green River, in Wroming, from Black Butte northwestward to Balt Wells Station on the Union Pacific Railroad, and at Rock Spring and some other points west of Salt Wells, there is an extensive series of rocks, in regard to the age of which somewhat different opinions are entertained. For a detailed description and sections of this formation the reader is referred to Dr. Bannister's report, forming a following section of this volume, my object bere being merely to say a few words mainly. respecting the age of this group. In general terms it may be briefly described as a vast succession of rather eof, light-yellowish, lead-gray, and whitish sandstones, with seams and beds of various colored clays, shale, and good coal, the whole attaining an aggregate thickness of more than 4,000 feet.

The invertebrate fossils hitherto fonnd at different horizons in this series present a mingling of fresh, brackish, and salt-water types, such as Goniobaris, Viriparus, Corbicula, Corbula, Ostrea, Anomia, and Modiola. All of these genera are found represented, either directly in the same bed, or very nearly 80, near the very top of the series at Black Butte Station, in Division E of Dr. Bannister's section. At Hallville, three miles farther west, and 1,600 to 1,800 feet lower in the series, in Division $K$ of the same section, a Corbicula, and another form like a Corbula, both scarcely, if at all, distinguishable from species found in the higher beds at Black if at all, distinguishable from species found in the higher beds at Black zon, at Point of Rocks, seven or eight miles farther down Bitter Oreek, great numbers of a fine large oyster also occur, above the fourth (or still higher bed) of a series of beds of coal, seen in the face ( $f$ a nearly perpendicnlar precipice, abont 300 feet above the bottom of the valley on the north side. Three or four miles west of this, and at a horizon probably 500 feet lower, in Division M, of Dr. Bannister's section, there is a bed 15 to 18 inches in thickness, almost entirely composed of mil- 
lions of sheils of Anomia and Ostrea, together with a few of Corbula, Cor. bieula, Modiola, and Goniobasis, all apparently of different species from (but some of them very closely allied to) those found higher in the series. Again, at Rock Springs, perhaps twelve miles farther westward, and not far below the horizon of the last-mentioned localities, we found numerous specimens of Corbula, Ostrea, Corbicula, Modiola, and Gonioba. sis, all associated in the same bed, the species being again distinet, excepting probably the Corbieula and Ostrea, from those found at any of the other localities, though the Corbula and Goniobasis are of the same type as those found at Black Butte.

At Bhack Butte Station, in the bed containing most of the shells al. ready mentioned as occurring there, we found, along with numerous specimens of beantiful impressions of leaves of dicotyledonous trees, some large bones of a huge reptilian. We alşo observed nearly all throngh this formation impressions of the leaves of the higher types of dicotyledonons trees, in some instances belonging to the same genera as those composing our existing forests of the temperate zone; also fragments of fan-palm leaves, and the stems of marine plants.t

From such a group of organic remains, it seems scarcely to admit of donbt that this formation was deposited in a body of water, which, although salt enough to yermit the existence of some marine types, was still probably so tempered by the infl $\mathrm{x}$ of the streams that brought in the land and fresh-water remains, as oo iv at least unfavorable to the extensire development of marine life. The presence of numerous beds and seams of coal also indicate that there were alternate elevations and depreesions of this whole region during the deposition of this formation. That is, if we admit lost generally accepted theory that such de. posits of coal were $\mathrm{fc} i \mathrm{by}$ the growth, on the spot, of vegetation in marshes at, or a little above, the sea-level. Becanse we find some marine or brackish water types between nearly all the coal-beds, thus showing that after the accumulation of the material of each bed of coal, it was again covered by salt, or at least strongly brackish, water.

It is not necessary, however, to suppose that eacb elevation was equal to the preceding subsidence, becanse the accumulation of sedimentary matter during the interval probably largely compensated for the sink. ing, so that the elevations may have been comparatively very slight to bring the bottom again slightly above the sea-level. At any rate, what. ever theory we may adopt in regard to the formation of such coals, it appears exceedingly improbable that the coal beds of this region were formed by the drifting together of the trunks and fragments of trees and other vegetation; becanse, althongh we sometimes see small frag. ments of this coal showing woudy structure, as we do in those of the old Carboniferous period, they are not in any proper sense lignite, so far as structure is concerned, but seem to have been mainly formed by the growth and accumulation of smaller kinds of vegetation, and are as persistent, compact, and homogeneons as any of the old bitnminons varieties.

From near Salt Wells southeastward to Black Butte Station, this

- On hearing of these discoveries from some friends from the East, to whom I had mentioned the same at Salt Lake City, Professor Cope visited the locality on his return bome, some time in Anguat, 1872, and dug ont more of the bones of the reptilian, which ho soon affer deseribed in a paper ment on to the Philosophical Society, as tho type of a now genas of Dinoeaurians, under the name Agathaumes sylvestrie, and expresed the opinion that it proves the rock to be Cretacoous.

All of the remains of plants collected from this and other formations by the Survey, have b en ably reported on by Professor Lesquerenx. formation shows a gentle eastward dip, which canses it to pass woder another very similar series of strata, to which Dr. Hayden has applied the name Washakie gronp. In the latter, so far as our present knowl. edge exiends, only fresh water and land types of fossils have yet been found, and we bavo always regarded it as being of Tertiary age. Exactly where the one ends and the other begins we did not see; thongh the Bitter Oreek series certainly come eastward to division $\mathrm{B}$ of Dr. Bannis. ter's section, at Black Butte, as we found its characteristio mollusean remains there in the same bed containing the reptilian bones.

Between Black Butte and Bitter Creuk Stations (separated by a dig. tance of only about six miles by a right line east and west) we observed no marked change of lithological charaeters, from the Bitter Creek series to the Washakie group, while the two series seemed to be conformable in dip. Although our observations in this interval were too limited to warrant a positive opinion on that point, we left Black Butte Station under the impression that the brackish-water types of the Bitter Creek series probably extend little, if any, higher in the series, or farther eastward, than the tops of the hills near Black Butte.

At Salt Wells station, which is situated in an anticlinal, owing to the rising of the strata, as we come westward, (see Dr. Bannister's sertion,) a lower series of rocks comen up from beneath the Bitter Creek beds. This lower group consists $/$ / thin layers of grayish and drab slabby sandstones, and shales with, at places, some appearances of ceal in the upper part. It seems to be conformable with the Bitter Ureek series, and probably belongs to the Cretaceous, though we saw no fossils in it. From exposures seen near Salt Wells, there would appear to be 700 to possibly 1,000 feet of these lower rucks here, above the valley.

In going westward from Salt T lls station we soon observe a reverse of dip, and the Bitter Creek beds again appear, dipping westward or northwestward. At, and near Rock Springs, extensive coal-beds occur in this formation, and here we found associated with or near one of these beds the fresh, brackish, and salt-water types of shells already mentioned. The dip of the strata here is to the northwestward, at an angle of $10^{\circ}$ to $12^{\circ}$ below the horizon, so that a short distance farther west the whole gronp passes under a great series of whitish, greenish, and at places reddish laminated clay of Tertiary age, forming Dr. Hayden's Green River group, and rising into hills 700 to 800 feet in beight above the valley. The strata of this latter group are distinetly unconformable to those of the Bitter Creek series, their dip being only $2^{\circ}$ to $3^{\circ}$ west. ward.

But, returning to the question respeeting the age of this Bitter Creek series, it may be stated, in the first place, that Mr. Emmons evidently regarded it as Cretaceous, as may bo seen from his remarks in Mr. King's report, published in 1870; while Dr. Hayden favored the conelusion that it is a marine Tertiary group, or a transition series between the Tertiary and Cretaceous, in his reports of that and the following years.

The oniy fossils I had ever seen from this formation, previous to vis. iting the region during the past summer, were two species of Ostrea and one of Anomia from Point of Rocks; and two shells, one, or possibly both, related to Corbicula, from Hallville. Those from Point of Recks I referred to the Cretaceons, placing them in the Cretaceous list, in Dr. Hayden's report of 187i. 'This I did, mainly because there were among them no fresh-water, or strictly brackish-water types; while up to this time we know of no Tertiary of exelnsively marine origin in all this internal region of the continent. I was also, in part, influenced in
then 
12. Conocoryphe .............. Undetermined fragments.

13. Bathyurus (१) Haydenii, Meek... Deseribed in this report.

14. Bathyurus serratus, Meek...... Described in this report.

$$
\text { Fourth or locest dicision. }
$$

15. Crusiana*

16. Lingula, or Lingulepis ........ Imperfect specimens.

17. Conocoryphe .................. Fragments.

18. Bathyurus, or Asaphus.......... Fragments.

$$
\text { FLAT-HEAD PASS, MONTANa. }
$$

Names.

1. Bathyurellus (Dikelocephalus? truncatus, Jeek

Remarkn.

2. Bathyurellus, (Asaphiscus?) ..... Described in this report.

\section{NEAR MALADE CITY, NORTnERN UTAII.}

Names.

Remarks.

1. Camerella Calcifera, Billings.

2. Orthis hippolite, Billings.(?)‡

3. Orthis.................. Very finely striated and like 0 . electra, Billings.

4. Orthis ................... larger and more compressed species.

5. Euomphalus(?) trochiscus, Meeks

6. Euomphalus (1) rotuliformis, Meek.

7. Euomphalus, or Ophileta.

8. Agnostus Josepha, Hall (?).

9. Conocoryphe ................ Fragments of perhaps soveral species.

10. Bathyurellus (Asaphiscus) Brad. leyi, Meek ............... Described in this report.

11. Bathyurus Saffordi, Billings... Only the pygidium, but agrees exactly with Canadian specimen sent by Mr. Billings.

-The namn Crutiana, d'Orbigny, 1642, (Voy. dans 1'Amer. Merid., t. 3, part 2d, p. 30, The namn Crusiana, d'Orbigny, 1842, (Voy. dans l'Amer. Merid., t. 3, part 2d, p. 30,
having priority over Rusophycus, (Lysophycus,) Hall, 1652, will bave to be retained for having priority over Rusophycus, (Lyssophyew, flall, 1852, will have to be retained for heso curious foseils.

t The specimens are all separate valves, more or less broken, or partly hidden in the matrix; but so far as can be seen they certainly agree well in size pnd all external what wider and deeper mesial sinus and more prominent mesial fold.

; A grees pretty neariy with the Canadian sbell, though its mesial sinus is somewhat wider and deeper. It may be distinet, but the specimens are too imperfect for satiafactory comparison.

These have been described in the Proceedings of the Academy Natural Eeiences, Philadelphia, Ap., 1870, p. 61, and will be figured in Mr. King's report

to agree cloecly with Profecuor Halls species, excepting in some of the minute and apparently varialle details of the mesial lobe of the head and pygidium. So far as I have been able to see, bowever, it would also seem not to have the posterior lateral angles of the cheeks armed with little projecting points, as in the Wisconsin species. wonld almost certainly beleng to a distinct species, in which case I would propose for the name Agnortus Maladensif.
12. Bathyurus, or Dikelocephalus....Fragments.

13. Bathyurellus (Dikelocephalus (1)

truncatus, Meek............. Described in this report. Occurs also at Flat-Head Pass.

14. Asaphus (Megalaspis (1) gonio. cercus, Meek ............... Described in this report. Occurs at Flat-Head Pass.

WEST FACE OF DIG HORN MOUNTAN, HEAD BUPFALO FORK.

Names.

locephalus ${ }^{*} . . . . . . . . . .$. Mere fragments.

CARBONIFEROUS SPECIES.

OUTLET OF MYSTIC LAKE, MONTANA.

Namen.

Remarkn.

1. Zuphrentis.................. small species.

2. Zaphrentis................ Fragment of a large species appar-

3. Ptilodictya (Stictopora ९) dicty. ota, Meek

4. Ptylodictya $\ldots \ldots \ldots \ldots \ldots \ldots$ A merely branching species.

5. Fenestella ................ One or two species.

6. Hemipronites crenistria, Phillips. Rather more finely striated than

usual.

An abundant medium sized species with very fine, dichotomous, radiated striæ, crossed by very minute concentric strias; spines of cardi. nal margin, five on each side of beak.

8. Productus longispinus, Sowerby .A small form, apparently agreeing with Sowerby's species.

9. Productus scabriculus, Martin (1). Specimens fragmentary.

10. Rhynchonella.

11. Spirifer, (Martinia)........... Of medium size.

12. Spirifer (Martinia) lineata, Martill.

13. Spirifer

Similar to some varities of $\boldsymbol{S}$. inere. bescens, Hall, which Mr. Davidson thought not distiuct from $S$. bisul. cata.

- The only part in the collectlon certainly known to belong to this species is the pygidiutn. This has much the general appearance of the corresponding part of a trilobite, figured by Mr. Billings, under the name of Asaph wo guadraticaudatus, (Paleont, Canada, p. 271, Fig. 258, ) out ito lateral margins are straighter and its mesial lobe proportionally longer, with only three to five segments that pass straight acrose, insteal of eight or nine arching forward. Its lateral lobes show three or four sbort seg. meth, instead of only one, while they and the lateral margins show no traces of the strias seen on Mr. Billings's species. Its lateral and posterior flattened margins are

t An anastomosing speeies, with divisions about 0.10 to 0.12 inch in brealth, by 0.04 to 0.05 inch in thickuess, and convecting so as to form a reticulated structure, with Pores small, with slightly oval form, about 0.24 inch in length by 0.16 inch in breadth. and forming six to eight longitudinal rows; non-poriferous margins rather sharp, and of moderate breadth.

$30 \mathrm{G} \mathrm{S}$ 
it wonld, when viewed in connection with its associates, and all the other known facts, furnish a strong argument in favor of the formation being at least as old as the Cretaceous. There are good reasons, howbeing at lealleving these ever, for bellieving thes depressed specitheng, as well as the coner ones, are all upper valves of the same shell, only modified in convexity by accidental circumstances of station, as their slight obliquity as seen, for instance, in a look at the interior of both, is found to be in the sam direction, instead of the reverse, as would be the case if they were opposite valves of the same shell; while among thousands of specimens no site valed bas been seen, no have any been found that would come near fitting together.

On the other hand, the Corbiculas are decidedly Tertiary in their On the other hand, the Corbiculas are decidedly Tertiary in their
peeific affinities, as well as in their subgeneric; $\boldsymbol{C}$. fracta, for instance, and $\boldsymbol{C}$. crassatelliformis, from the Hallville mines, being very closely allied to Paris Basin Tertiary forms, the first-mentioned species being the type of sub-genus, 80 far as known, peculiar to the Tertiary elsewhere. The to belong to a group (Veloritina) peculiar to the Tertiary in Europe.

But the most surprising fact to me, supposing this to be a Uretaceous formation, is, that we found directly associated with the reptilian remains at Black Butte, a shell I cannot distinguish from Viviparus trochiformis, originally described from the Lignitic formation at Fort Clark, on the Upper Missonri, a fcrmation that has always been regarded as Tertiary by all who have studied its fossils, both animal and vegetable. The by all who have studied its fossils, both animal and vegetable. The volution; but, as far as can be seen, it agrees 80 exactly with that very peculiar species in size, the form and proportions of its volutions, the slopes of its spires, its surface markings, the nature of its suture, and, in fact, in every respect so far as can be seen, that $I$ have scarcely any doubt of its identity with the same.

The occurrence of this last-mentioned species bere, along with a Cretaceons type of reptilian, and a Corbicula apparestly identical with $C$. cytheriformis of the Judith River brackish-water beds, together with the presence of Corbulas very closely allied to Judith River species, at lower prerizons in this series, and the occurrence of some vertebrates of Cre. taceons aftinities at the Judith River localities, would certainly strongly favor the conclusion, not only that this Judith formation, the age of whieh has so long been in doubt, is also Cretaceous; but tiat even the higher fresh-water liguite formation at Fort Clark and other Upper Missouri localities may also be Upper Cretaceous instead of Lower Tertiary.

That the Judith River beds may be Cretacenus, I am, in the light of all now known of the geology of this great internal region of the con. tinent, rather inclined to believe. But it wouid take very strong evi. dence to convince me that the higher fresh-water lignite series of the Upper Miseouri is more ancient than the Lower Eocene. That they are not is certainly strongly indicated, not only by the modern affinities of their molluean remains, but also by the state of the preservation of the latter. Indeed, these shells (Planorbis, Viriparus, Goniobasis, Physa, \&c.) are found loose, as they fall from the incoherent sand in great numbers, so entirely free from adhering matrix, either internal or external, and so little changed, tb - any one not familiar with the existing species of the country would naturally think them merely dead sbells of the same, picked up along the shores of the streams. The entire flora of this Upper Missouri lignite group has also always been consid- ered, by the highest anthorities on that department of paleontology, unquestionably Tertiary.

From the foregoing remarks it will be seen that our present informa From the Bitter Creek series may be summarily tion in regard to

1. That it is conformable to an extensive fresh-water Tertiary forma tion above, from which it does not differ materially in lithological characters, excepting in containing numerous beds and seams of coal. 2. That it seems also to be conformable to a somewhat differently 2. That it ness) below, apparently containing little if any coal, and believed to be ness) below, appa

of Cretaceous age.

3. That it shows no essential difference of lithological characters from the Cretaceous coal-bearing rocks at Bear River and Coalville.

4. That its entire group of vegetable remains (as determined by Profesuor Iesquerenx) presents exclusively and decidedly Tertiary afticities, fessor Lesquere frest excepting one peculiar marine plant, Cretaceous fossils, at Coalville, in thousa Utah. +

5. That all of its animal remains yet known are specifically different from ans of those hitherto found in any of the other formations of this region, or, with perhaps two, or possibly three exceptions, elsewhere.

c. . That all of its known in, of marine, brackish, and fresh of about thirteen species and warieties of marine, brakin water types, none of which belong to genera peouliar to tho cretaceous or any older rocks, but all to such as are alike common to the Cretaceous, Tertiary, and present epochs, with possibly the exception of Goniobasis, (which is not yet certainly known from the Cretaceous.

7. That, the one hand, two or three of its species belong to sec. (tions or suberitina) apparently characteristic tions or subgenera (Leptesthes and Veloritina) apparently closely allied to of the Eocene Tertiary of Europe, and are even very closely allied to species of that age found in the Paris Basin; while, on the other hand one species seems to be conspecific with, and two congenerio with, (and one species seems to sperifically to, forms found in brackish-water beds on closely related sperly allied to types hitherto deemed characteristic of the Cretaceons.

types hitherto deemed characteristic of the 8. That one species of Anomia found in it is very similar to a while a Viriparus, found in one of the upper beds, is almost certainly identical with the $V$. trochiformis of the fresh-water Lignite formation of the Upper Missouri; a formation that has always, and by all authorities, been considered Tertiary.

9. consing are 9. That the only vertebrate remains yet found in it are those of a large
reptilian, (occurring in direct association with the Viciparus mentioned reptilian, (occurring in direct association with the Viriparus mentioned type, being, as he states, a huge Dinosaurian.

It thus becomes manifest that the paleontological evidence bearing on the question of the age of this formation, so far as yet known, is of a on the Dinosaurian, the organie very conticting nature; though aside from thertiary. The testimony of the remains favor the conclusion that it is Tertiary. The testimony of the plants, however, on this point, although they donbtless represent what
would be in Europe considered clearly a Tertiary flora, is weakened by - See Mr. Banuister's section, farther on. thers inesil, however, tiary. 
the fact that we already know that there is in Nebraska in clearly Cretaceous rocks, a flora that was referred by the highest European authority to the Miocene. I do not know, however, how far Professor Les. ity to the Miocene. I do not know, however, how far Professor Les-
querenx's opinion that the Bitter Creek plants are Tertiary may rest upon specific identifications among ciem of forms known t $c$ ocur in well determined Tertiary rocks elsewhere.

$$
\text { TERTIA:Y AGE. }
$$

Brackish-toater beds of Bear River."-In redemption of the promise made, I now return to the consideration of the age of the brackish-water beds of Bear River, (division 28 of sec. -, on p. -). These have al. ways been regarded by me provisionally as Lower Focene, not only becanse their included fossil remains were closeig related to furms occurring in the Eocene lignite beds and deposits of the Paris Basin and the mouth of the Rhone, but also beeanse isons them belonged to characteristic Cretaceous types. If, however, the bads of Bitter Creek and the Judith River should tinal' ( ove to be Oretaceous, the brackish-water beds in question must s........oly be relegated to the same epoch, though they are not known to hold any species in common with the Bitter Creek beds, and but one with those of Judith River. Their approximate conformability with Cretacens beds, indicating dis. turbance and npheaval at the same time, favors this conclusion. I may add that $I$ have not been wholly withont the snspicion that they might prove to be Cretaceous, and in a report to $\mathrm{Mr}$. Clarence $\mathrm{King}$, published in his report on the geological survey of the fortieth parallel, (vol. 3, p, 466, I summed up my conclusions in the following terms:

While I am there iore willing to admit that facts may yet be discovered that will warrant the conclusion that some of thes, estuary bels, so widely distributed bere, should be in. clnded rather in the Cretacerus than in the Tertiary, it seens to me that such evidence must either come from included rertebrate remains, or from furtber discoveries reapecting the stratigraphical position of these beds with relation to of her established horizons, nince all the molnscan remains jet known frota them (my own opiniobs aro en-
tirely basec on tue latter) seem to point to a later origin.

This paragraph kas been misunderstood by Professor Cope, $†$ who has brought it into context with the statement respecting the age of the Bitter Creek co.al strata, and asserted that the nearest approximation to the point of identiqeation of the Bitter Creek strata with the Cretaceous were thus made by myself, and conveyed the impression that no positive reference had been made of any of the Bear Piver beds to this period. This, however, as has been shewn elsewhere, had been done in the most unequivocal mauner with regard to the deposits of marine coal at Bear River City, Wyoming, as well as at Coalville, Utah.

I had intendeal to make more exteuded remarks on the several Ter. tiary deposits referred to, and to have given lists of fossils from them, but sudden illness, ani the necessity for sending copy without further delay to the Public Printer, have compelled the relinquishment for the present of sac'a design.

- Until some decidedly Cretaceons fossils have been somewhere found in or above these beds, they may bo left in the lower Focene. Oar discovery of a group of frestwater shells as mudern in appearance sa those (though all different species) at Coal-
ville, far de $w \mathrm{n}$ in the Cretaceous, shows how cautious we should bo in deciding such questions.

tProceeding" A merican Philosophical Society. Extras dated in MSS. February 7, 187

LISTS OP FOSSILS COLLECTED.

SILURIAN SPECIES.

EAST SIDE OP GALLATIN RIVER, ABOVE GALLATIN CITY, MONTANA. First or upper dirision.

Names.

1. Lingulepis.

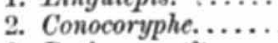

3. Bathyurus (i).

4. Asaphus (?)...

5. Acrotrela.

6. Lingula A very small shining species.

Third dirision.

7. Acrotreta subconica, Kutorga.

8. Iphidea sculptilis, Meek........

9. Hyolithes gregaria, (Theca gre. garia, M. and H.)............ Mere cast, but agrees in size and

10. Agnostus bidens, Meek $\ddagger$.

11. Conocoryphe (Conocephalites) Gallatinensis, Meek.......... See description in this report.

-Two specimens only of this fossil are contained in the collection. Theso have ex. actly the outline, and agree well in most other respecta with a form Professor Hall bas referred, doubtrully, to the shorter valve or L. pinnajormis, Owen, from the horizon of

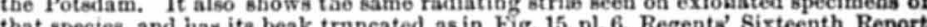

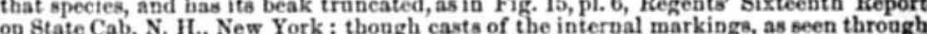
the transluce Han's figure cited, but have the same elongated trilobate outline seen in the other valve of $L$. pinnaformis.

tThis little sbell senms to be very similar to Kutorga's species, but it has the ventral valve more elevated than $A$. grmma, Billings, and the false area marked by a distine mesial forrow, said not to be defined in latter. The larger specimens measure 0.15 inch from the frout to the apex of the ventral valve and 0.11 inch in breadth. The beak of this valve is pointed, and generally bent slightly fc.ward. The surface is a deep brownisb color, shining as in Lingula, and marked by minute lines of growth. It is quite probable that a direct compariso of specimens wonld show our species to be t Retentes t Resembles a. pisiformis, Linn., (ep.,) but has a proportionslly shorter pygidinm, more truneated between the posterior points; whise its mesial lobe is shorter, highen hind, without any traces of a mesial transverse furrow. Its head is still more nearly like that of A. piriformis, but wants the mesial furrow extending forward from the glabella to the anterior margin. Its glabella is most prominent behind, where it shows a tendency to swell into a little node. Surface finely granular. 
14. Spirifer

With hinge-line much extcnded. and smaller and more numerous costa then the lnst, being much like $S$. biplicatus, Hall, from the horizon of the Waverley Group, Ohio.

15. Spirifer Mysticensis, Meek."

16. IRetzia.

CASON, EAST SIDE OF MADISON RIVER, MONTANA. Names. Remarka.

1. Platycrinites Detrched base.

2. Poterio

Some finely striated varities found

3. Hemipronites crenistria, Phillips. Some Mystic Lake.

4. Strophomena analoga, Pbillips.

5. Productus semireticulatus, Martin.

6. Productus longispinus, Sowerby (9) Same as No. 8 of list from Mystic Lake.

7. Productus scabriculus, Martin(१). Same as No. 9 of list from Mystic

Lake.
8. Chonetes. 7 of list from Mystic Lake.

9. Rhynchonella............... Same as No. 10 of list from Mystic Lake.

10. Retzia, (fragments)

11. Spirifer

Same as No. 13 of list from Mystic Lake.

12. Spirifer Mysticensis, Meek.

13. Spirifer (Martinia).

14. Terebratula, (fragments)

... An arcuate conical species.

16. Euomphalus, (fragments of large species.)

17. Pleurotomaria. (?)

BR:DGER PEAK, NEAR FORT ELLIS, MONTANA. Names.

Remarks. 1. Lithostrotion............... A compound species with small cor-

2. Hemipronites crenistria, Phillips (’)Same variety as No. 6, Mystic Lake list.

3. Hemipronites............... inuch more finely striated species. 4. Productus longispinus, Sowerby (1). Same as No. 8, Mystic Lake, and 6, Cañon, east side Madison River. CAMP No. 19, AUGUST 2, 1872, IDAHO TERRITORY.

$$
\text { Names. }
$$$$
\text { Retwarks. }
$$

\section{Lophophyllem. \\ 2. Zaphrentis.}

- A medium sized, very tranaverse species, with mucronate lateral extremities, and 12 to 15 simple, ralliating costa on each lateral slope of cach vale; mesial sinus mode, 12 to 15 simple, ranlation, with one rib in its bottom, and rarely faint traces of another on one or both sides of this toward the front; cardinal area, of moderate height, well defined, and more or less arehed with the beak. Resembles 8 . bimesialis, Hall, (Iowa Report, in size and form, but wants the lamellose imbricating concentrie stris sees on that species.
3. Michelinia .................. Small irregular coirallites.

4. Byringopora.

5. Chonetes................ Same as No. 7, Mystic Lake.

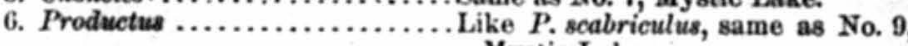

7. Henipronites erenistria, Phillips.

8. Spirifer, (Martinia)............ Same as No, 10, Mrstic Lake, and

9. Spirifer.

No. 13, East Madison River.

10. Euomphalus, (fragments.)

BLACK-TAIL DEER CREEK, MONTANA.

Names. Remarks.

1. Hemipronites crenistria, Phillips (?) Same as at Mystic Lake; Cañon,

East Madison River, \&c.

Same as No. 7, Mystic Lake; No. 8

Cañon, East Madison River, \&c.

3. Rhynchonella.............. Rather small plicated, subtrigonal;

4. Spirifer lineatus, Martin.(?) rery abundant species.

5. Spirifer ................... Same as No. 12, Mystic Lake.

6. Spirifer .................... Same as No. 14, Mystic Lake.

NORTH GROS.vENTRES BUTTE, WYOMING.

$$
\text { Names. Remark? }
$$

1. Zaphrentis.

2. Hemiprowitescrenistria, Phill ps(?)Same as at Mystic Lake, east side 3. Spirifer .................. Sime as No. 12 at Mridger Peak, \&e.

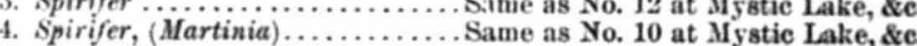
PLAT-HEAD PASS, MONTANA.

Names.

Remarks.

1. Zaphrentis...

2. Syringoporn.

3. Hemipronites crenistria, Phil.

lips (1) ................... Same as at Mystic Lake, Gros-Ventres Butte, \&c.

4. Rhynchonella............. Fragment rather large, strongly pli. cated species.

5. Spirifer .................... Same as No. 12, Mystic Lake, \&e. NORTH SIDE HENRY'S LAKE, IDAHO.

Names. Remarks.

1. Hemipronites crenistria, Phillips (?)Same variety as at Mystic Lake, \&e. 2. Prodwetus scabriculus, Martin(?)sp. Do. Do.

3. Spirifer ................. Same as No. 12, Mystic Lake, \&e.

1. Terebratula.

CANON WEST OF GALLATIN RIVER, MONTANA. Names.

Remarks.

1. Chatetes.

slender ramose species.

2. Zaphrentis.

3. Syringopora. 
4. Platycrinites ................... Mereiy the elliptic disk of the column 5. Fenestella.

6. Hemipronites crenistria, Phillips (१).............

7. Strophomena analoga, Phillips...Same as from cañon, East Gallatin

8. Chonetes .................. Same as at Mystic Iake, \&e.

9. Productus semireticulatus, Mar.

tin.................... Same as at east side Madison River.

10. Productus ................... Small hemispherical species.

11. Productusl ongispinus, Sower-

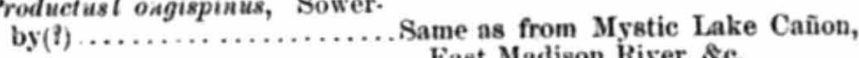
East Madison River, \&e.

12. Phynchonella............... Same as from Mystic Lake.

13. Retzia.

13. Spirifer Mysticensis, Meek....... Same as from Mystic Lake, \&e."

15. Athyris or Martinia.

16. Spirifer

17. Enomphalus.

LYơ HILL, OPHER, EAST CASToฐ, UTAH.

Names.

1. Fenestella

2. Chatetes.

3. Crinoids

4. Productu: tin (?)

5. Rhynchonella.

6. Phillipsia 7 ............... Fragments of pygidinm.

\section{SWAN VALIEY, IDAHO.}

Names.

1. Syringopora (?)

2. Ariculopecten (?)

3. Biralve.

4. Rhyphenella.

6. Spirifer.

"olp Baldy," NeAR viggrisi ciry, MoNTaNa.

Names.

Remarks.

1. Marine plant, like Fucoides eau

dagalli.

2. Zaphrentis excentrica, Meek."

- A large, slightly enrved, short turbinate species, with fossula on the doral side; mepta about seventy of principal series, which extetid inward so as to leave a moder ately broad, smooth space at the bottom of the calyx near the dorsal side, while an maty more sborter and more slender ones alternate with the larger; tabain transverse, very closely arrangeel, and oecupying a wide exceptrie space; surronnding description and figures see Mr. King's Report Surves Fortieth Parallel.)
3. Zaphrentis.

A small, slighily corved species,

4. Michelinia with fossula ventral.

Michelinie M. temuisepta, Phillips' (spe cies.)

5. Chatetes................... Slender ramose kpecies

6. Platycrinites $(\rho) \ldots \ldots \ldots \ldots \ldots \ldots$ Arms and fragments of colnmns.

7. Platyerinites Haydeni, Meek.

8. Pentromiter symmetricus, Hall

9. Pentremites Godonii, Defrance ( (

As far as can be determined from the specimens, it seems to agree well with $P$. symmetricus.

10. Poteriocrinites Montanaensis, Meek. $\dagger$

11. Erisocrinus (q) .............. Body only, appareutly of a species

12. Ptilodictya,

13. Fenestella ................. Very delicate; like $F$. plebeja,

14. Ptilopora.

15. Strophomena analoga, Phillips.

16. Orthis resupinata, Martir.

17. Chowetes .................. A medium-sized, rery finely striated

18. Productus semireticulatus, Mar.

tin, (species) ............ A swall, suleated, strongly areuate, and produced variety, apparently

19. Productus Altonensis, N. \& P. of this species.

40. Productus acaloriculus, Martin (")

21. Productus Prattenanus, Nor. wood.

2.2. Productus cora, d'Orbigny (')...This agrees with European shells, referred to d'Orbigny's species; but is more finely striated, and mueh more prodnced, than d'Or. bigny's type.

23. Productus ................ n narrower, strongly arched, mueh produced species, marked by small, very obseure concentrie wrinkles, and rery small, slightly elongated, raised points, that may have supported minute spines.

24. Hemipronites crenistrie, Phillips, (species.)

25. Camarophoria 26. Athyris subtilita, Hall.

Very similar to C.globulina, Phillips.

- A small species, with a cup-shaped body, rounded below to a cireular attachmen for the column; body-plates smooth, or obscurely granular, and joined by slightl grooved sutares; arms twenty, slender, each dividing once on the second piece abov their otigin on the very small mecond radials, composed each of a single series of small pieces, (as in $P$. modobrachiatus, Hall, Iowa Rloport, p. 542,) bearing pinnules alternately their inner lateral end.

in small species with an elongate obconical body, cotnposed of smooth plates, and on the last radtals, and composed of smali pieces, every third oue of which bears, alternately on opposite sides, a long pinanle. 
26. Spirifer lineatus, Martin, (species.)

27. Spirifer ................... Like some forms of $\boldsymbol{B}$. increbescens, Hall.

28. Spirifer triradialis, Phillips ( 1$)^{3}$

29. Spiriferina octoplicata, Sow.

erby ...................... Kay be the same as S. Kentuckensis, Shum.

30. Retzia vera, Hall (1)

31. Terebratula arcuata, Swallow (?). Almost certainly the same as $T$ bovidens, Morton.

32. Terebratula ................ A small species possibly identical with $T$. turgida, Hall.

33. Astartella Nencberryi, Meek (?) ... I can see no difference in the single specimen examined, from the Ohio species.

34. Cypricardina $\therefore \ldots \ldots \ldots$ Has the external appearance of the genus.

35. Platyceras.

36. Pleurotomaria splatrulata, Con

me specimen agrees well with de pressed varieties of Mr. Conrad's species from the western coal. measures.

37. Euomphalus ............... Fragments of cast of a large species. 38. Phillipsia .................. Fragments.

DIVIDE BETWEEN ROSS FORK AND LINCOLN VALIEY, MUNTANA.

Names. Remarks.

1. Zaphrentis Stansburyi, Hall (?)

2. Cyüinophyllum subcaspitosum,$$
\text { Meek. }
$$

3. Lophophylum or Cyathaxonia.

4. Syringopora.

5. Platycrinus

6. Pentremites Bradleyi, Mleek.

7. Pentremites Godoni, Defrance (?)

8. Pentremites conoideus, Hall.

- A very abundant, gregarions little shell, closely resombling $S$. triradialis, var. serradialis, as illustrated by Mr. Davidson, excepting that the largest of hundreds of specimess are less than one-fourth the size of well-teveloped individualo of that furn. It also differs in being constantly wider than long, instead of the reverse, and in haring the beak of its ventral valve always proportionally sborter, anleus along the mesial fold toward the front, and a corresponding very slight rid fo in the bottom of the sinus of

it may be called \&. agelaiks. corallites aro long, eylindrical, more or less flexnous, and loosely branching inatead of groving in compact, fascioulated, or asterform masoes, as in C. corpitonum, Goldfuses. It hrowing in compact, fasciedian, tranversely wrinkled, and less striated epithecs (wheu

not worn) than Goldfuse's species. ambulacra more deeply excavated along the middle, with their pore pleoes more travsverse."
9. Pentrenites subconoideus, Meek.•

10. Melonites ................. single, very thick, hexagonal, interambulacral plate, with oute: surface a little convex, and grailar.

12. Hemipronites

Very small or only about one-hale inch in diameter, with a ligft triangular area.

13. Productus ................ About half an inch in diameter, very gibbous; beak narrow, strougly incurved; surface smooth, or apparently so.

14. Productus ................ Like P. biserialis, Hall.

15. Productus eeniretieulatus, Mar-

tin, (species).............. Large and well developed.

16. Productus longispinus, Sowerby. Of usual size.

17. Rhynchowella maera, Hall (?)

13. Rhymehovelle, matata, Hall (?)

19. Athyris .................. Smell, and like Ath. hirsuta, Hall.

20. Retzia Vernieuiliana, Hall

21. Spirifer .................. Very small, like a miniature $\boldsymbol{B}$. opi. mus, $\mathrm{H}$.

92. Spirverine ................... Like 8. spinosa (Spirifera spinosa, H.,) but smaller, and apparently

23. Terebratula turgida, Hall. without spine-bases.

24. Nucula Shumardï, Hall.

25. Macrodon (1)

26. Cypricardina Indianensis, (Cypri cardella Indianensis, Ball.)

27. Cypricardella piicata, Hall (†)

28. Cypricardella subelliptica, Hall (?)

99. Nuculara nasuta (Nucula naruta, Hall ?)

30. Conocardium Meekianum, Hall (†)

31. Platyceras ................. One or more small species.

32. Ewomphalus Spurgenensis, Hall.

33. Naticopsis ................. Like Naticopsis Carleyi (Natica Carleyi, Hall.)

34. Bellerophon .............. Two suall, smooth species.

35. Holopea . ................. Fragments of very small species.

36. Pleurotomaria .............. Vers small.

37. Cythere .................. Very near $C$. carbonaria, Hall.

3S. Spirorbis annutata, Hall.

39. Phillipsia ................ Fragments of small species.

\section{JURASSIC SPEOIES.}

NEAR LOWER CASON OF YELLOWSTONE RIVER. Names,

1. An Eehinoid

Remarks.

Mainly a east of small species of an undetermined genus.

-A very small, obeonie species, mued produced below the peend-ainbulacral arras, which are very sbort. or almoet confined to the summit, as in Codester, thougat it is a
true Pentremile. 
2. Ostrea Small speeimens, of perbaps twc or three species.

3. Aryphara ................ small species of form of the $G$. dilatata.

4. Comptonectes ............... Specimen imperfect; may be $C$. bellistriata, M. and $\mathrm{H}$.

5. Pecten . Part of a valve of a rather large, strongly costate species. Not true typical Peotex.

6. Pinna .................. Near P. opalina, Quenstedt.

7. Gerrillia Montanansis, Meek."

8. Gervillia. ................. Somewhat larger than the last, but not costate.

9. Mytilus ................... Has angular umbonal slopes, and

10. Modiola (Vuleclla) subimbricata, ouly concentric markings. Meek.t

11. Mediola (Vulsella) .......... s shorter, wider, and less arcuate

12. Trigonia Americana, Meek.

13. Trigonia Montanaensis, Meek. 5

14. Crassatella (?)

15. Crassatella (₹)

16. Cueullea ........................ species than the last.

It has the external appearance of this genus, but may belong to some other.

Internal easts apparently of species of this genus.

17. Astarie (?) ............... A sinall shell like some of the Juras. sic species sometimes referred to this geuns.

18. Unicardium .................. Casts apparently of a speeies of this genus.

19. Myacites (Pleuromya) subcom pressa, Meek.

- A medium-sized, very oblique species, with posterior ear flattened and of moderate size, angular at the extretnity, and equaliug, on the hivge line, about half the length of the valves; body portion of the valves rather slender, pearly straight, or a litulo arex, in the right flattened, or less consex than in the other. Surfaco of both valves vex, leel by fine concentrio stris, and a few stronger furrown of grourth, crossed on the boily part of the left valve, by a fow slender radiating coste, meparated by wider bouly

"This is ver, like Modiola imbrieata, Sowerhy, as illustrated by Morris and Lyeett, in their Monogr. Moll. Gr. Oolite, Pl. IV, Fig. 2, exeepting that its anterior ventral portion, in frout of the umbonal ridges, is more prominent, and its posterior basal extremity more prodneed and narrowed. It is mueh less like Sowerby's original figare of that speeies.

i A tine species of the type of $T$. contata of the Old World, but differing from that and the other allied forms, in luaving the radiating costue of the corselet, or posterior dorsal region, all of uniform size.

Of the type of $T$. nigmata, Agassiz, but differing in its proportionally shorter form with saualler nodiferons costas, while it has a row of nodes down the anterior latera

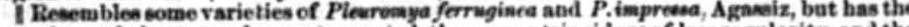
anterior end shorter and more iruneated, the concentric ridges of less regularity, and the slight concavity extending from the beaky to the anterior lasal margins of the valve this shell in the unpublished paleontological part of Jr. King's report.
20. Pholadomya Kingii, Meek.•

21. Goniomya Montanaensis, Meek.

22. Ammonites ..................Mere fragments SPRING CANON, MONTANA.

Lotcer bed.

Names. Remarks.

1. Plants................... Fragments of the same forms seen at

2. Plicatula ................. An imperfect valre-impression of one valve seen in the matrix.

3. Camptonectes .............. Same as No. 4, near Lower Cañon, Yellowstone.

4. Pinna ....................... Same as No. 6, near Lower Cañon, Yellowstone, being very like $P$. opulina, Quenstedt.

5. Mytilus ................. Same as No. 9, from Lower Cañon, Yellowstona.

6. Modiola (Vulsella)subimbricata,

Meek .................... Same as No. 10, from Lower Cañon, Yellowstone.

7. Trigonia Americana, Meek..... Same as No. 11, from Lower Cañon, Yellowstone.

8. Myacites (Plenromya) subcom. pressa, Meek.............. Same as No. 19, from Lower Caũon, Yellowstone.

Cpper bed.

9. Ostrea ................... A small nndetermined species.

10. Camptonectes.

11. Rhynchonella.

NEAR FURT HALL, IDAHO

Loicer bed.

Names. Remarks.

1. Pseudomonotis (Enmicrotis) curta, Hall, (sp.) ............ Very small and in great numbers.

2. Terebratula. Cpper bed.

3. Mytilus.

- An elongate-oblong species, quite convex in umbonal region, with beaks moderately protminent, incurved, and placed near the rounded anterior end. The posterior end is more narrowly rounded and moderately gaping. The narrow radiating costo are wasting on the ends and posterior doral region; the anterior ones (which descend
vertically from the beaks) are most widely separated, while thooe farther back are more cloeily arranged and more oblique.

t Elongate-oblong, moderately convex, anterior margin regularly rounded, posterior truseated, donal and ventral margins nearly parallel, beaks depressed, and placed nens: the anterior end. Surface having wrinklee or costw starting from before the beaki and pessing obliqrely backward and near half way to the base, where they die out, or become very obseure, and curve borizoatally backward to meet others paesing down
the posterior doral alooes. 
4. Mophoria .... Mere casts, apparently of this genus. 5. Macrodom ...................... Mere casts, apparently of this genns.

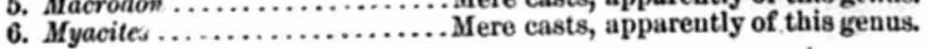
DEVIL'S SLIDE, CINAABAR MOUNTAN, YELLOWSTONE RIVER.

Names. Remarks.

1. Gryphaa calc la, Quenstedt,

2. Cucullace Internal cast, apparently of this geuus.

3. Camptonectes.

4. Trigonia elegantissima, Meek.•

5. Corinya Montanaensis, Meek.†

6. Myacites (Pleuromya) suicom. pressa, Meek.

7. Pholadomya.

8. Ammonites.

\section{CRETACEOUS LIST.}

NEAR THE MISSOURI RIVER, BELOW GALLATL, MONTANA.

Naines.

Remarks.

1. Ostrea anomioides, Meek.

2. Trigonia ................ Nearly allied to T. Eransi, Mrek. Same as No. 3, from Cinuabar Mountain.

3. Corbicula (Veloritina) inflexa, Meek.

4. Corbicula Veloritina) ......... Like the last, excepting that its beaks are more oblique, more nearly terminal, and more de. pressed. May be a variety of same.

5. Corbicula (Veloritina) ........ s small and proportionally shorter form.

6. Carditm................. A rather small, nearly circular spe cies, with fine radiating strix.

7. Inoceramus .........................

8. Pharella (') Pealei, Heek.

9. Avicula ................. Small sipecies.

10. Avioula (1) .................. Small ; of the type of A. raricosta, Rens8.

11. Modiola ... . . . . . . . . Small, smooth species.

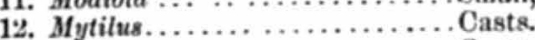

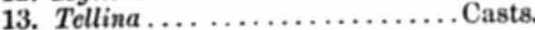

14. Corbula.

15. Anchura .................. Rough mold in matrix.

- A small speeies of the type of $T$. costata, bat having the concentrio or horiznatal costio on the sides of the valves very delicate, closely arranged, and ist elightly larger than the radiating ones on the pesterior dorsal region, or corselet. The valves aro rather compressed, about one-fourth longer than wide, and have the posterio unbonal slopes acutely angular.

t This to very similar to some varieties of C. glabra, Agassiz, but it is a smaller, proportion margins just in front of po beaks more excavated.

\section{colorado sPrings, colorado.}

\section{Cretaceous, No. 4.}

Names.

Remarks.

1. Inoceramus ................ Fragments of casts.

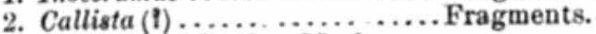

3. Anisomyon alveolus, Meek.

LAST POOT OP BRIDGER PEAK, FOUR MULES NORTH OF FOIT ELIIS, MONTANA.

Names.

Remarks.

1. Ophioderma (?) Bridgerensis,

Meck.*

2. Grypha.................. Obscure casts of a small species.

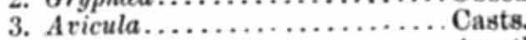

4. Pinna ................. A rather large, narrow species, wit?

Inoceramus

Crassatella .................... Casts.

6. Crassatella $\ldots \ldots \ldots \ldots \ldots \ldots \ldots \ldots \ldots \ldots$ Fragments.

8. Pholadomya ................. Fragments.

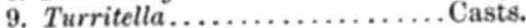

10. Gyrodes.

CINNABAR MOUNTA1, YellowstoNe vallet, MoNTANa.

Names.

1. Oxtrea.

2. Inoceram

3. Trigonia.

4. Corimya...

4. Corimya, or Thracia

5. Baculites...

6. Scaphites rentricosus, Meel.

ROCK CREEK.

Names.

Remarka.

1. Inoceramus.

2. Ammonites percarinatus, H.

and $\mathrm{I}$.

3. Ammonites, (undetermived sp.

4. Scaphites Warreuanus, M. and H.

5. Scaphites larviformis, M. ani H.

6. Scales and other fragments of

flshes.

- A small Ophiurian, with diak depressed, nearly eireular, and only 0.17 inch in breadth, showing on the doreal side ten ovate-sutrigonal radial plants, that aro joines

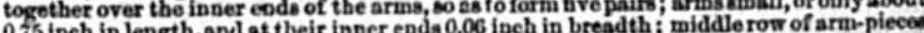

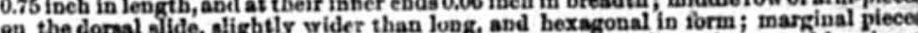

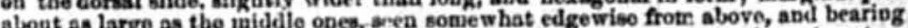
mw of very amall, short spipes. Ventral side unknown. The specimen is not woll preserved. Perbaps I should call it Ophiolcpio Bridgerensia. 


\section{FORT HARKER.}

Names.

Remarks.

1. Inoceramus problematicus,

Schloth.

2. Baculites.

Small, slender species.

LIST OP POSSILS FROM THE CRETACEOUS COAL SERIES AT COAL VILLE.

\section{Names.}

Remarks.

1. Ostrea soleniscus, Meek.•(a)

2. Ostrea Wyomingensis,Meek.(?)(a)

3. Anomia, (undetermiuted sp.)

4. Aricula (Pseudoptera) rhytophora, Meek. (a)

5. Avieula (Pseudoptera) propleura, Meek. (a)

6. Avicula gastrodes, Meek. (a)

7. Inoceramus problematicus, Seiblothein.

8. Inoceramus, (undetermined sp.)

9. Inoceramux, (nudetermined sp.)

10. Pinna, (undetermined sp.)

11. Modiola (Brachydontes) multili. nigera, Meek.-

12. Cardium curtum, M. and H.

13. Cardium subcurtum, Meek.

14. Lucina, (undetermiued sp.)

15. Macrodon, (undetermined sp.)

16. Unio, (undetermined sp.)

17. Trapezinm micronema, Meek. $(a)$

18. Cyrena Carltoni, Meek. (a)

19. Corbula, (two undetermined sp.)

20. Cyprimera subalata, Meek. $\ddagger$

21. Cyprimera (?) isonema, Meek.

w2. Tellina (t) modesta, Meek. $(b) \|$

23. Tellina (Árcopagia) Utahensis," Meek.

24. Martesia, (undetermined sp.)

25. Gyrodes depressa, Meek. (b)

26. Neritina (Neritella) Bannisteri, Meek. (a)

27. Neritina (Neritella) pisum, Meek. $(a)$

28. Nerilina (Neritella) pisiformis, Meek. (a)

- Species marked with (a) are fnlly described in another part of this report. t This is very nimilar to $C$. curtum, M. and H., but smaller, with posterior umthe

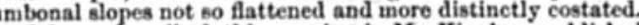

; I have described this species in Mr. King's unpublished report. It is cory like $C$. dejressa, Conrad, from the Cretaceons (Ripley Group) of North Carolins and Missis sippi, excepting that its bealcs are less flattened and a little farther forward, and it posterior dorsal outline, or alose, less straightened. Its anterior margin is also a littl ess narrowls ronoded in ontline. I have not seen its hinge, but eannot donbt, from its external characters, that it belongs to Mr. Conrad's genus Cyprimera. It may eve

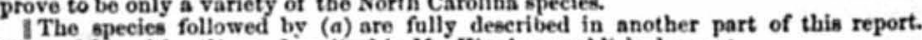
Those folewed by (b) are described in Mr. King's unpublibhed report.
29. Neritina (Dostia (?) bellatula, Meek. (a)

30. Neritina (Dostia ( $(?)$ cardei. formis, Ileek. (a)

31. Eulima (?) tr.conspicua, Meek. (a)

32. Eulima chrysalis, Meek. (a)

33. Eulima funicula, Meek. (a)

34. Turritella Coaltrillensi_, Jieek. (a)

35. Turritella spironemr. Seet. (a)

36. Turritella (Aclis (1) microveme, Meek. (a)

37. Admete (1) rhomboidea, Meek. (a)

38. Anchura fusiformis, Mieek. (b)

39. Fusus (Neptunea) Gabbi,Mleek.(a)

BEAR PIVER CITY, CRETACEOUS.

Names.

Remarks.

Ostrea soleniscus, Ieek........ Two thin layers almost composed of it.

2. Inoceramus problematicus,

Sebloth (q).............. Occurs in great numbers.

3. Inoceramus.

4. Trapezium micronemn, Meek.

5. Corbicula securix, Jleek.

6. Corbicula aquilaterulis, Meek.

7. Cardium.

FOSSILS OP THE BITTER CREEK COAL SERIES, WYOMNG.

Sames.

Remarks.

1. Ostrea Wyomingensis, Meek •...Point of Rocks.

2. Ostrea arcuatilis, Meekt......... A bout two miles north of Hallville, and at a considerably higher horizon; also at Black Butte, still higher, and three or four mites farther eastward.

3. Ostrea ................ Two miles below P. Pint of Rocks, associated with Anomia (\%) gryphorhynchus. Smaller and smoother than the last.

4. Anomia gryphorhyachus, Meek• Same as last.

- See descriptions in another part of this report.

tThis is constantly smaller, narrower, and usually thinner and deeper than 0 . IIgoningewsis, and never has its Interal margins, toward the beaks, dilated and horizontally ilattenet, as in that species. It also differs in being sometimes curved up, or without any enrvature of the beaks. Its surface ool shows rough it is often straight trowth. It is a form I have long been familiar with from this ratr obscure marks of of the Uprergion, and have someo. son of the better specimens found last munnier, with U. glabra, shows it to bo quite different, in being much more attenuate at tho beaks, and in having a larger and longer ligament area. I ata aware that the establishment of species in the genus Ostrea is unsatisfactory, but it seems desirable to bave s name by which this form cas be designated. 
5. Modiola ................. Rock Spring and Black Butte, stri. ated species.

6. Corbicula Bannisteri, Meek•.... Black Butte Station.

7. Corbicula (Veloritina) cytheriformis, M. \& H. (f) ............ Point of Rocks and Black Butte.

8. Corbicula (Leptesthes) fracta,

Meek (ILeptille, just over coal-bed.

9. Corbicula (Lept.) fracta, var. crassiuscula ${ }^{\bullet}$............... Black Butte, saurian bed.

10. Corbicula (Leptesthes) crassatelli-

formis, Meek............ Hallville, with $C$. fracta, in shale orer a bed of coal.

11. Corbula crassatelliformis, Meekt . Black Butte Station, in saurian bed. 11. Corbula tropidophiora, Meek" ...Two miles below Point of Rocks.

13. Corbula undifera, Meek• ......... Rock Spring.

14. Goniobasis insoulpta, Meek ${ }^{-}$.... Rock Spring and Point of Rocks.

15. Melania (Goniobasis १) Wyomin. gensis ${ }^{*} \ldots \ldots \ldots \ldots \ldots \ldots$ i. \& H. (१) .................. Black Butte saurian bed.

TERTIARY SPECIES.

BEAR RIVER, ESTUARY BEDS.

Names.

Remarks.

1. Unio priscus, M. \& H

2. Unio belliplicatus, Meek.

3. Corbicula (Veloritina) Durkeci, Meek.

4. Corbula pyriformis, Meek.

5. Corbula En jinanni, Meek.

6. Goniobasis chrysalis, Meek.

7. Viriparus Conradi, M. \& H.

8. Melantho (Campeloma) macros. pira, Meek.

9. Rhytophorus priscus, Meek.

- See descriptions in another part of this report

+ This shell seems to have exactly the form, and surface characters of Corbicula ( $\eta)$ crassatellformis, found flattened between the laminas of the shale over one of the coalbets at fallville, much lower in the series. It is decidedly thicker, however, and certainly has the hinge characters of Corbula. It is true, have not seen clearly the hing of a different strueture. Btill, I suspect that good specirieab fom each locality wonld show that they are not only both Corbulas, but that they ere specifically identical, thongh it will be better to keep them separate for the preseut.

\section{DESCRIPTIONS OF NEW SPECIES OF FOSSILS.}

SILURIAN FORMS.

Iphidea (II) soulptilis, Meek.

This fossil presents very much the general appearance of the ventral valve of an Acrotreta, being rounded on one side and truncated on the other, with the apex moderately prominent, and marginal on the truncated or posterior side, (viewing it as an Acrotreta, and with the truncated side inclined backward. It measures 0.11 inch in breadth, and cated side inclined backward. It measures 0.11 inch in breadth, and Its surface has a black shining appearance, indicating a phosphatic composition like Lingula, and is marked by slender, interrupted, rather distant, radiating raised lines, crossed by finer, much more crowded, and very regular, sharply-defined, concentric strix. So far as can be seen, there seems to be no perjoration in the apex.

On first looking at these littli shells, which occur associated with a well. defined Acrotreta, I had not tue slightest donbt that they belonged to a depressed species of that genus. By cutting away the hard rock, howerer, from the flattened side, corresponding to the area of Acrotreta, I found that there seems to be there a wide, open, triangular foramen, so large that only a very narrow, slightly flattened margin, representing a false area, is seen inflected on each side. This I bave seen in the only two specimens in the collection showing this side; and if there is nothing deceptive about it, Je sbell would certainly belong neither to Acrotreta nor to Iphidea. It can only be referred to Mr. Billings's genus Iphidea, even provisionally, on the supposition that, in cutting away the haril rock from the truncated side representing the false area in that genas, I may have also cut away the prominent psendo-deltidium, characteristic of that group. In that case, huwever, the psendo-deltidium would be proportionally much wider than in Mr. Billings's type, as the opening is decidedly wider, as we see it in our shells, than the false del. tidium in his species. This difference, however, might be only specific.

It is quite probable that when specimens showing clearly all the characters of this shell can be examined, it will be found to belong to in undefined genus, either of the Brachiopoda, or of some other group. In this case I would propose for this genus the name Micromitra.

I confess, however, that in closely examining these little fossils, I have not been entirely without the suspicion that they may be the terminal pieces of some extinct group of the Chitonida. The inflected character, however, of the margins, like a very contracted false area, on each side of the opening of the flat side of the shell, is against this conclusion; but even if they are the terminal pieces of some chitonoid type, the chances are still strongly in favor of its being a new genus, for which the name suggested would be equally as appropriate as for a Brachiopod. Locality and position.-East side of Gallatin River, Montana; primordial zone. 


\section{Asaphus (Megalaspis ๆ) goniocencus, Meek.}

Prgidium rather small for a species of this genus, moderately depressed, trigonal in outline, with breadth and length abont as 7 to 9 ; posterior lateral margins slightly convex in outline, and converging rapidly to the posterior extremity, which terminates in an abruptly attenuated, slightly recurved, pointed projection, the under side of which is flat, and the upper convex; mesial lobe much depressed, or very slightly higher than the lateral, and quite obseurely defined by the nearly obsolete dorsal furrows, about three-fourths as wide anteriorly as the lateral, and tapering backward and becoming obsolete before reaching the posterior extremity, in internal easts showing sometimes faint traces of nine or ten very obscure segments ; lateral lobes geatly convex, and sloping off gradually to an obseure undefined furrow, or shallow impression, near the posterior lateral margins, which are thu made to appen order, usually appearing quite smootb, or with faint traces anteriorly of one or two segments, but in some specimens, when examined carefully in an oblique light, traces of six or eight segments may be seen. Barface smooth.

Length of pygidium, 0.74 inch; breadth, 0.94 inch; convexity at the front, 0.16 inch.

The only part in the collection known to belong to this species is the pygidium. This is very remarkable for its trigonal form and pointed posterior extremity, much as we see in Dalmanites. It wants the usually well-defined dorsal furrows and segments, however, of that genus ; which swoothness gives it the aspect of Asaphus. The specimeus from which the description was drawn up are probably young individuals, as there are fragments in the collection of an Asaphus of larger size that may belong to this species. If an Asaphus at all, the form of its pygidium would indicate relations to the group Megalaspis, one species of which ( $M$. heros, Dalmann, sp.) has a similarly.formec pygidium, but with more numerous and very much more strongly-defined segments. I am not aware, however, that any species of that group has hitherto been found in this country.

Locality and position.- Near Malade City, Utah, from Lower Silurian beds of the age of the Quebec Group. Professor Bradley.

\section{Batiyurus serratus, Meek.}

Cephalic shield rat'ser distinetly convex, semicireular, being nearly twice as wide as long, regularly rounded in front, straight across behind, and having the posterior lateral angles terminating in small, short, back. ward-pointing spines; lateral margins provided with a narrow, slightij. thickened border, (sometimes becoming nearly obsolete just in front of the glabella,) defined by a shallow narrow furrow. Glabella quite con. rex, with its highest part near the middle, strongly defined by the dorsal furrows, cylindrical in form, extending very nearly to the auterior mar. furrows, cylindrical in form, extending very nearly to the auterior mar.
gin, and apparently without lateral furrows; neck-segment well defined gin, and apparently without lateral furrows; neck-segment well defined and a little backward in the middle, where it bears a small tuberele, or possibly sometimes a short little spine, direeted npward and backward; continuation of neck-furrow along the posterior margin of ebeeks rather wide and deep; fixed cheeks comparaivively wide and convex, but lower wide and deep; fixed cbeeks comparatively wide and convex, but lower
than the glabella, rounding off rather abruptly laterally. Eyes of mod. erate size, but little arched, ranging nearly parallel with each other; placed remote from the glabella, and about their own length from the posterior margins of the cheeks; palpebral lobes very small, and lower than the fxed cheeks; movable cheeks sloping abruptly laterally; facial sutures not clearly seen anteriorly, but apparently cutting the margin nearly on a line with each eye; while behind they are direeted at first obliquely outward and baekward, after which they curve backward so as to cut the posterior margin of the head, just within the inner edge of the little posterior lateral spines.

Thorax consisting of seven segments; mesial lobe narrow, rather prominent, and gradually tapering; lateral lobes depressed or flattened; plenræ with broad, rounded furrows."

Pygidium nearly semicircular, or about three-fiftb as long as wide, regularly rounded behind, and rather straight across in front, except. ing laterally, where the anterior margin rounds backward somewhat; quiteconvex, but not so much so as the cephalieshield. Mesial lobe prom. inent, cylindrical, equaling five-sixths of the entire length of the pygi. dium, with an abrupt posteriort ermination, rather decidedly more prom. inent than the lateral lobes, and showing about four obseurely-marked segments. Iateral lobes sloping off laterally and behind, where they are provided with a flattened, somewhat thickened margin, that is armed by six very short, small serrations on each side, directed obliquely backward; each showing four very obscurely-defined, broad, depressed segments that do not extend out upon the flattened and serrated margin. Surface of both cephalie shield and pygidium showing, under a mag. nifier, a slight granular appearance, as if covered by minute projecting unequal grains, with smaller pits scattered among them. Obseure traces of strim are also sometimes seen around the margin of the cheeks.

Judging from the imperfect specimens seen, a medium-sized entire specimen of this species was probably a little over 1 ineh in length, by a breadth of 0.70 inch, and a couvexity of near 0.20 inch.

The cephalic shield and pygidium here described are not positively known to belong to the same species; but judging from the fact that they occur assoeiated together, and agree well in size, convexity, propositions, and particularly in the peculiar kind of surface-grannlations, there is little room for donbting that they really belong to the same trilobite. This conelusion is also strengthened by the fact that no other cephalic shield and pygidium in the colleetion, not known to belong to other species, correspond with them in these respects.

The pygidinm resembles one figured by Mr. Billings in his Palseozoic Fossils of the Canadian Surrey, page 405, Fig. 384, and doubtfully ne. garded by him as belonging to a Dikelocephutus; but the serrations of the margin in our species are smaller and less prominent, the middle. lobe less elongated, more obtuse behind, and bas its segments much less distinctly defined; while the segments of its lateral Iobes are also. much more obseure. Its anterior lateral angles are also more rounded off. From the similarity of the two, however, there can be little donbt that they are allied species of the same genus, in which opinion Mr. Billings fully concurs on examining casts of our species sent to him.

It is almost beyond doubt that a pygidinm figured by Angelin, under the name Corynexochus spinulosus, (see Palzeontologia Seandinavien. PL. xxxiii, Fig. 11,) belonging to the same genns as our trilobite; and this raises the question whether $I$ ought not to refer our species to that

- The specimen from which these characters of the thorax are taken consiata of a

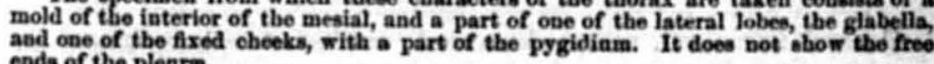
$31 \mathrm{G}$ s 
genus; his species spinulosus, not only being his first one, but the only one that he refers to his new genns, withont a mark of donbt. On the other band, the question is complicated by the fact that his typieal spe. cies is founded on a separate head, divested of the movable cheeks, and the detached pygidium alluded to above, which may, or may not, belon to the same species or genus as the head; while in the text, be places s mark of doubt after the reference to the tigure 11 of the pygidinm thing showing, as one would think, that he only refers it doubtfully to the species spinulosus. Yet, it is evident that the name spinulosus was suggested for his first species by this pygidinm, which is armed with small spines, while no spines are known to be conneeted with the bead. But another diffieulty arises from the fact that his generic name Corynex. ochus seens to have been suggested by the prominent elavate charaeter of the glabella of the heal figured by him.

For this latter reason, and the fact that the pygidinm is only connected by hin doubtfally with the head, probably most anthorities wonld view the species to which the head belongs (in ease the prgidium appertains to another form) as type of the genus. If we adopt this view, it would be somewhat doubtful whether our species could be properly referred to Angelin's genus, since its glabella is merely eslindrical, and not quite as long as the head, instead of widening out anteriorly to nearly twice its posterior breadth, and apparently slightly overhanging the anterior margin, as in the head figured by Angelin.

If the difference in the form of the glabella mentioned above shonld not be of generie imjortance, aud there should be no well-defined differences in the abdominal parts of Angelin's type, (the abdomen of which is unknown,) then our species wonld have to be referred to the same group, and take the name Corynexochus serratus. It is, however, also very elosely allied to Bathyurus, Billings, in most of its known charaeters. After examining casts of our species, Mr. Billings writes that he would not be willing to separate it generically from $B$. extans, the type of his genus; though he admits that some differences in the abdominal parts, to which I had called his attention, are rather marked. These are the presence of only seven body-segments in our type, instead of nine, as in B. extans, and the other known species of Bathyurus ; while the plaral furrows in our species are very broad and rounded, instead of narrow and sharply ent as in typical Bathyurus. The serrated, or spinuliferous charaeter of the pygidinm, in the form under considera tion, is another difference, though probably of less importance. $\mathrm{Mr}$. Billings, however, writes that he bas several new species (all from the Lower Potsdam) showing this eharaeter; which faet would seer. to argue that there may be a group characterized in part by this pecu liarity.

From all the facts, I should certainly be disposed to separate onr type at least sub-generically from Bathyurus, were it not for the doubts that still remain in regard to its relations to Corynerochus of Angelin, which, I should have remarked, would have to take precedence over Bathyurus, if fonnded on a congeneric type, beeanse it was publtshed in

Locality and position-East side of Gallatin River, above Gallatin City, Montana Territory. Potedau Group of the primordial zone.

\section{BATHYURUS 9 HAYDEN, Meek.}

General form oval, rather depressed; outline of cephalie shield un. known. Glabella narrow subeylindrical, most convex near the middle, mather well defned by the dorsal furrows, about twice as long as wide, with the anterior end sometimes apparently very slightly expunded neck segment projecting somewhat backward, ronnded in ontline behind, and nearly as bigh in the middle as the glabella in front of it; neck furrow narrow, ratber well defined, passing entirely across, and continued much wider and deeper across the posterior margin of each cheek; lateral furrows consisting of foar pairs, the posterior pair commeneing a little behind the middle and extending very obliquely backward and inward to a point about the breadth of the neck furrow in advanee of the same, where they either become obsolete, or apparently sometimes almost connect across by a shallow transterse furrow; sueceeding pairs in front very short and transverse, the anterior ones being somg times rather obscure; fixed cheeks moderately wide, or eqnaling some posterior end of the eyes, half the breadth of the glabella opposite the same point, rather couvex, but lower than the glabella; palpebral lobes very narrow, or merely appearing as little slightly raised rims at the margins of the fixed ebeeks, from which they are separated by a lipear furrow. Eyes, as determined from the palpebral lobes, about two-thirds as long as the breadth of the glabella, slightly arebed, and somewhat eon. verging forward, situated their own length in adrance of the posterior margin of the head, and two-thirds this distance at their poterior ente from the glabella. Facial suture in front of the eyes unknown, bat behind them, directed at first for a very short distance nearly backward, then curving abruptly outward, parallel to the posterior margin of the cheeks, and extending nearly to the posterior lateral angles, where thay curve obliquely backward and outward so as to eut the posterior mar. gin near these angles.

Thorax consisting of nine segments; axial lobe very narrow, or only about two-thirds as wide as each of the lateral, tapering gradually back. ward, and moderately convex; lateral lobes flattened, and lower than the axial; pleure broadly and deeply furrowed, and having their free ends apparently falcate.

Pygidium intermediate between semieireular and semielliptical, its length being about two thirds its breadth, while its posterior margin is rounded in outline, and its anterior uearly straight aeross; mesial lobe as narrow, proportionally, as that of the thorax, convex, tapering very gradually baekward, and zearly reaching the posterior border, showing five or six well-defined segments, with space enongh for one or two more behind those; lateral lobes flat, with five or six broadly furrowed segments that extend to, but not upon, a very narrow, slightly thiekened and flattened, smooth margin.

Entire surface smooth, or only showing very fine granulations under a magnifler.

Length of an entire specimen 1.15 inches, breadth about 0.70 inch.

Although I refer this species, provisionally, for the present, to the genns Bathyurus, I really do not think that it properly belongs to that genus, as illnstrated by the typical species $B$. extans. In the propor tional size of its head, thorax, and pygidium, as well as in the number of its body segments, it agrees with that genus; and its glabella, though narrower and more strongly as well as somewhat differently lobed, in not otherwise very different; while, so fur as known, its faeial sutare seem to agree in most respects. The general flatness of the whole animal, however, as well as the narrowness of its axis, and particularly the different type of its large rounded pleural farrows, (those of $B$. extans being narrow and regalar,) are strongly unarked features, which, with 
the differences mentioned in its glabella, seem to separate it from that genus.

In the narrowness of its axis, and the nature of its pleurre and plen. ral furrows, it agrees exactly with Conocoryphe; and even in its eylin. drical glabella, and, indeed, in most of the characters of its bead, so far as knowv, it agrees pretty well with some arecies of the section Ptychoparia, (ree Conocor. (Ptychoparia) striatus, Fig. 7, Pl. xiv, Barrande's Trilobites of Bohemia.) The comparatively large size of its pygidium, howevrr, and especially its innch smaller number of body segments, (9 instead of 14, at once separates it from any section of that genus as now understood. In some of its characters it seems to show affinities to cer. tain types of Ogygia. That is, in the general flatness of its form, its narrow axis, and the form and furrows of its glabella; bnt it differs in having nine instead of only eight body seguents; while its pleural furrows are of a difforent type, and its eyes are smaller, much less areuate, and nore remote from the glabella. Its facial sutures, although not clearly seen in any of the specimens, in front of the eyes, were probably, judging from some indications, not so diverging anteriorly.

If further comparisons should show it to be generically, or subgenerically, distinct from all of the groups mentioned, as I believe it to be, it may be designated by the name Bathyuriscus.

The specifie name is given in honor of Dr. F. V. Hayden. Locality and position.-East side of Gallatin
City, Montana. Potsdam or Primordial group.

\section{Bathyorellus (Asafmscus) Bradley, Meek.}

The best specimens of this species I have seen, consist of the central parts of the cephalic shield, separated from the movable cheeks. These parts of the cephalic shield, separated
parts may be described as follows :

Glabelia moderately and evenly convex, nearly oblong or truncatosubconical in outline, being a little narrower at the front than behind, and truncated anteriorly, with the anterior lateral angles rounded; exelusive of the neck segment, one-sixth to one-seventh of its length longer than wide; sides slightly convex in ontline or nearly straight, and converging gently forward from near the middle, well but not
deeply defined by the dorsal furrows, which are narrow, and continue around the front; lateral furrows wanting, or apparently sometimes very obscurely indieated by two or three pairs of extremely faidt indentations. Neck furrows narrow, but distinet, extending entirely across, and continned more strongly defined across the posterior margins of the cheeks. Neck segment rather wide in its autero-posterior giameter, and flattened in this direction, but transversely arched $\mathbf{s o}$ as to be nearly as high at its middle as the glabella. Anterior extension or limb, moderately produced, or equaling one-third the length of the glabella, (exclusive of the neck segment,) sloping gently forward from the anterior end of the glabella for about half way to the front, where there is thus formed a transverse furrow from which it rises obliquely forward in the form of a nearly flat marginal rim. Palpebral lobes comparatively large, or constituting all there is of the fixed ebeeks, lnnate, or sub-semicircular in form, depressed below the horizon of the glabella, from which they are only separated by the dorsal furrows, each oceupied by a lanate slightly convex central portion, (which might be viewed as minute fixed cheeks, ) separated from the onter margin by a shallow furrow. Eyes, as determined by the palpebral lobes, about four-sevenths as long as the glabella, exclusive of the neck segment, moderately arenate, and ranging parallel to each other, and to the longer axis of the glabella, their posterior ends extending back nearly as far as the position of the neck furrow. Facial suture starting from the anterior ends of the eyes, close in to the dorsal furrows and diverg. ing forward to the transverse furrow of the anterior extension or limb, where they are a little wider apart than the widest portion of the glabella, while beyond this they appear to curve a little inward as they approach the anterior margin. Posteriorly they curve parallel to the posterior margins of the cheeks, as far as they have been traced. Surface smooth.

Length of cephalie shield, 0.90 inch; length of glabella, exelusive of neck segment, 0.53 inch; length ineluding same, 0.65 inch; breadth of glabella at widest part, 0.45 inch; length of palpebral lobes, 0.33 inch.

I refer this species merely provisionally, for the present, to the group A saphiscus, beeause $I$ am only aequainted with it in the condition of fragments. Its glabella is slightly more convex and rather decidedly less conical than in the type of that gronp; while its eyes are larger and closer in to the dorsal furrows defining each side of the glabella, and its neck furrow narròwer and rather more sharply defined. There may be more important differences in other parts, if we had the means of comparison; but as those mentioned seem to be all sueh as may be merely specific, it most probabiy belongs to the group.

At a first glance this species reminds one of the figure of Bathyurus capax, Billings, which was also founded upon the corresponding parts of the head. It may be at ones distinguished, howerer, by the greater extension of its anterior margin in front of the glabella, as well as by its larger palpebral lobes (and consequently the eyes also) being situated farther back, and much closer inward to the sides of the glabella.

Locality and position.-Near Malade City, Northern Utah. Quebec group of the Lower Silurian.

Conocoryphe (Ptychoparia) Gallatingnsis, Meek.

Cephalic shield approaching semieirenlar. Glabella conieal-subovate, nearly three-fourths as long as the cephalic shield, widest just in front of the neck furrow, where its breadth about equals four-finths of - This group is founded on Asophiecus Wheeleri, a new species discovered by Lien-
teuant $\mathrm{G}$. M. Wheeler, of United States Topographical Engineers, in the primordial rocks uear Antelope Springs, Utah. It is nearly allied to Bathyurellus, Builings, and will, it is thought by that gentleman, inelnde a part of the species referred by him provisionally, from imperfet specimens, to the eame. It differs, however, from the Lpical forms of that genus, in baving its conieal glabells decidelly depressed, and the
nargin of the bead in front of is, first convex and sloping forward into a deep transverse mesial furrow, then rising in the form of a convex margin to the front. The mesial lobe of its pygidium is alo proportionally longer, and the free margins of the same much narrower and leas flattened and alate. It probably only forms a subgene ander Bathyurellus. From Anaphws, with which it aprees in general form and propor-

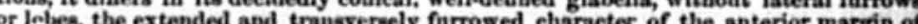
it be ad, its les arenate eyes placed more remoto from the glabella; and particularly in baving nine boty segments, instead of only eight. As in distinetly furrowed, begt they aro more pointed than is usual in that genas, though not falcate. Its surface is smooth. The generie and speeifie eharacters will bo given in full, with fllustrations, in
Lieatenant Wheeler's Report.

Several American speeles with a similar depressed, conical glabella, withont traoes of lateral furrows or lobes, bare been described from more or less couplete speeimens of the bead, ynder the name Conocrphalites. It is evident, however, from its smaller number of body segments, large p3 gidiam, and differently formed plural groves, that
doaphiseus is eutirely distinet from that group. 
its length, rounded anteriorly, racher distinetly conrex, and well deflned by rather deep dorsal furrows that are continued around its front; lateral furrows, (as seen in casts of the interior,) consisting apparuntly of three to four pairs, the posterior pair starting at one-third to one-haif the length of the glabella in advance of the posterior side of the neck segment, and ranging obliquely backward and in ward, but not connecting aeross the middle; ${ }^{\bullet}$ succeeding furrows very obscure, or in part (anterior ones) obsolete, short, and nearly transverse, or but slightly oblique; rostral margin equaling abont one-half the length of the gla. bella, exelusive of the neek segment, sloping at first forward from near the furrow aronnd the front of the glabella to a deep, nearly mestal transverse furrow, from which it rises obliquely forward in the form of a slightly convex, or somewhat flattened border, that is, a little arehed transversely; neek segment arched so as to be nearly' or quite as high in the midale as the glabella; neck furrow well defined entirely across, but deepest on each side, and continued deeper, and sharply defined across the posterior margins of the cheeks; fxed cheeks comparatively wide, or more than balf the breadth of the glabella near its middle rather distinctly cotvex, but lower than the glabella, bearing well-defined ocular ridges that extend, with a slight curve, nutward and a little obliquely backward from near the anterior end of the glabella to the front of the eyes; free cheeks unkiown; palpebral lobes very narrow, or only appearing as little raised rins on the margins of the fixed cheeks, from which they are defined by small furrows. Eres, as determined from the palpebral lobes, abont half as long as the breadth of the gla. bella, from which they are rather remotely situated near their own length in advance of the posterior margin of the eheeks, moterately arched and nomewhat converging forward. Surface nearly smooth, or only flnely grabular. Other parts unknown.

Entire length of cephalic shield, 0.43 inch ; oreadth of cephalic shield, unknown; length of glabella, inelnding neek segment, 0.31 inch; breadth of glabella, 0.22 inch; breadth across cheeks and glabella, between an. terior ends of eses, 0.46 inch.

This species is evidently closely allied to Conocoryphe (Conocephalites) teucre, Billings, and $C$. Billingsi, Shumard, but differs from both rather deeidedly in not having the lateral furrows of its glabella curved baek. ward, the middle and anterior ones being nearly transrerse, while none of the specimens show any traces of the tubercle on the neck segments seen in those species. Snch a difference would also almost certainly be found to be accompanied by others of equal or greater importance if we had the means of comparing other parts.

Among the associated specimens there are several others, consisting of the glabella, fixed cheeks, and rostral margin, that agree well with the typical specimens of the species here proposed, excepting that they have the glabella somewhat more convex, and the rostral margin in front of its transverse furrow flattened and horizontal, or even slightly sloping forwarl, instead of a little convex, and rising obliquely forward. The lateral furrows of the glabella in these are usually obseure, but nearly as in the typical form, excepting that $I$ have sot been able to make out elearly more than three pairs. The fourth, or anterior, pair, however, are exceedingly obseure, or vearly obsolete in the typieal form. Another variety or species agrees with the last, excepting in showing a few very scatiering, much coarser, projecting granules over the sur-

- Often there appears to be a small, obseure tuberele at the outer end of each of the poateriur lateral furrows of the glabella, just withis the dorsal fusrows. face, four pairs of them forming two longitudinal rows along the glabella, while the entire surface between these is very minvtely granular as in the last.

There are also numerons other smaller specimens agreeing with the last two, excepting that they show generally but the most feeble traces of lateral furrows in the glabella.

It is possible that some of these specimens may differ specifleally from the type of the specles here proposed, but I am at present inclined to regard them all as only different varieties and ages of the same.

One of the specimens associated with the others consists of portions of the cephalie shield erushed, and most of the thorax consisting of twelve of the body segments. This shows the axial lobe to be nar. rower than the lateral, quite convex, gradually tapering posteriorly, and rather strongly defined by the dorsal furrows. The lateral lobes are depressed, sloping outward from the middle, and composed of rather strongly furrowed pleura, the furrows extending straight outwardat right n Igles to the axis. It does not show the form of the free ends of the plearæ. Surface nearly smooth, or only very minutely granulated. This speeimen may or may not belong to the species here named.

If the name Conocephalites should be retained, with the limits usually allowed this group of trilobites, of course our species would have to be called Conocephalites Gallatinensis. As Conocephalus, first proposed by Dr. Barrande, had been previously used for a genus of insects, however, and Corda had proposed the name Conocoryphe before Dr. Barrande changed his name to Conocephalites, it seems to me that Corda's name will have to stand. It will also be observed that there are two strongly. marked types ibeluded in the genus by Dr. Barrande. That is, one without eyes, and having the facial sutures forming such very different curves as to give the free and fixed cheeks, as well as the frontal limb, entirely different ontlines and proportions from those of the other type, which has well-developed eyes. The first of these grouns is represented by $C$. Sulzeriand the latter by $C$. striatus. Corda, however, separated these types into two distinet geuera, placing $C$. Bulzeri in his genus Conocoryphe and $\boldsymbol{C}$. striatus in his genus Ptychoparia. I have not his work at hand for reference, but I infer from Dr. Barrande's eitations that the two species mentioned were so arranged by Corda that they may each be regarded as typical of one of these groups. If so, it certainly appears that both of his vames ought to be retained, at least in a subgenerio sense. In this case it will be observed that nean' $y$ all of the numerous speeies hitherto de eribed in this country would fall into the group Ptychoparia, as they all, with perbaps the exception of $O$. Mattherci, Hart,, and one or two others, seem to have been provided with well. developed eyes, and agree in other respects generically with $\boldsymbol{C}$. striatus. Adopting this view, the name of my C. Kingii becomes C. (Ptychoparia) Kingii, and so ou through nearly the whole list of American species yet known.

Locality and position.-East side of Gallatin River, above Gallatin City, Montana, Potsdam or Primordial Zone.

\section{CRETACEOUS FORMS.}

Ostrea solensis os, Meek. Outrea solenincus, Meek, 1870; Hayden's Geological Report, Wyoming, \&e., page 296,

Shell attaining a large size, becoming rather thick in adult examples, generally straight, greatly elongated, and comparaíively very narrow, 
with parallel lateral margins. Lower valve with moderate internal coneavity, and having the appearance of a little gutter, or elongated trough beak usually nearly straight, rather obtusely pointed, and more or less distorted by the scar of attachmenț ; ligament area of moderate size, strongly striated transversely, and provided with a large, deep longitudinal furrow; surface apparently only with moderately distinet marks of growth. Upper almost nearly flat externally, but nearly as concave as the other within; beak usually a little truncated ; ligament area marked with strong transverse strie, and having its mesial ridge very prominent, and occupying as mueh as one-third its breadth; surface as in the other valve, or perhaps a little smoother.

Length of adult examples about eighteen inches; breadth of same about 2.50 to 3 inches.

Althongh not a very unconanon species, I have seen no entire specimens of this remarkable shell. It will be readily known by its unusually narrow, elongated, and generally straight form. The shell is usually found broken into several pieces, but casts of the internal cavity are nct unfrequently met with entire. One of these now before me is nearly one foot in length and only 2 inches in breadth. It often had a curious habit of growing in groups of three shells, attached to each other by the backs of their beaks. I have seen large numbers of them elosely arranged, or vearly in contact with each other, at Coalville, all with their beaks downward, or at right angles to the planes of the sandstone strata. When found where it has grown isolated, the shell is sometimes arched to one side.

Locality and position.-This species ranges through nearly the whole thickness of the Cretaceous sandstones near Coalville, Utah, and is also fonnd in the Cretaceons conllearing sandstones at Bear River Cits, Wyoming, as well as in a sandstone ridge of same age on Union Pacific Wailroad, a few miles east of the latter locality.

\section{Ostrea axomomes, Meek.}

Shell rather small, very thin, depressed-plano-convex, and without any visible scar of attachment, varying from ovate to circnlar; rounded or sometimes a little straightehed on the hinge margin; beaks scarcely projecting beyond the outline of the cardiual margin. Lower valve very shallow ; cartilage pit unusually small, shallow, aud short. Upper valve almost perfectly flat; cartilage attachment eren shorter than that of the other valve, and slightly convex on its inner margin. Museular scars nnknown; surface of both valves with small regular concentric wrinkles most distinctly marked on the central region.

Greatest diameter of one of the largest oval specimens, 1.70 thohes; breadth, 1.40 inches; convexity, 0.23 inch.

This species is remarkable for the thinness of the shell, the slight concavity of the under valve, and the flatuess of the upper, as well as for its rounded or slightly straightened cardinal margin, and the absence of any scar of attachment, or of any traces of muscular impressions within. These external characters, and the regular small concentric wrinkles, give the exterior of the lower valve of circular specimens somewhat the appearance of a Lucina or Dosinia; while in other indiriduals it looks more like an Anomia or Placuna.

Locality asd position.-Missouri River, below Gallatin City, Montana. Cretaceous.

\section{Avioula (Pgeudoptera) propizura, Meek.}

Shell, as determined from a left "valve, obliquely ovate-subtrigonal, moderately convex along the oblique nubonal slope in front of the mid. dle, and compressed euneate behind; posterior margin with its general outline nearly vertical and slightly straightened along the middle, thence extending obliquely npward and a little forward, with a very faint sinu. osity above, to the hinge, which it meets at an obtnse augle, while it ronnds rather abruptly into the more or less rounded base below; an. terior margin ranging obliquely backward and downward nearly parallel to the umbonal slope, faintly retreating near the middle, aud from this upward to its connection with the anterior end of the binge, projecting slightly in the form of a small, short, flattened auricle, that is less than rectangular at its extreinity above, and undefined by any marginal sinus below; hinge-line of inoderate length, bat not extending quite as far back as the margin of the valve below it; posterior dorsal region flat. tened, though not forming a proper alation; beak rather pointed, scarcely rising above the hinge, rather oblique and placed very near the anterior end of the hinge, but not quite terminal. Surface ornamented by moderately distinct lines of growth which, on the anterior part of the valve, are crossed by seven or more slender raised radiating lines, and one stronger rib that extends along the ambonal slope so as to give it a slightly angular appearance, while very faint traces of fine radiating stria are sometimes seen on other parts of the valve. Right valve and hinge, and interior of both valves, uniknown.

Height, measuring at right angles to the hinge, 0.90 inch; length of hinge, about 0.75 inch; greatest antero-posterio diameter parallel to hinge, about 0.85 inch; length, measering from the beak obliquely to the most prominent part of the posterior basal margiu, 1.20 inches; convexity, about 0.23 inch.

This species appears to belong to a group of American and European Cretaceous aviculoid shells that seem to me to be sufficiently distinet from the tspical forms of Avieula (Pteria) and Meleagrina to stand together, at least as a separate subgenus. They differ from the typieal forms of Aricula in baving no extended alations or defined byssal sinus in either valve, as well as in presenting a peculiar, more or less obliquely rhombic, or subtrapeziform outline. The hinge and interior of these shells are unknown to me, but the former seems not to be provided with a gaping cardinal area, the cardinal edges being thinner and compressed. Avicula anomala, of Sowerby, (1836,) as illustrated by d'Orbiguy, in Palont. Francaise, Ter. Cret., Tome iii, Pl. 392, may be regarded as the type of this section, for, which I wonld propose the name Pseudoptera. it includes in addition to Avicula (Pseudoptera) anomala, Sowerby, Avi. cula (Pseudoptera) raricosta, Reuss, and Avicula (Pseudoptera) fibrosa, Meek and Hayden.

The two species here described are only referred to this group pro. visionally, as their right valves are not yet certainly known. There are some reasins, however, mentioned fartler on, for suspecting that this valve may have a deep byssal sinus in one, if not both, of these species. If this should be found to be the case, they cannot be properly referred to the above-mentioned group, but would fall into a group for which Stoliczka has proposed the name Electroma, typified by the recent spe. cies A vicula smaragdina, Reeve, and thus have to take the ndme Avicula (Electroma) propleura, and A. (Electroma) rhytophora. Slould Beopoli's uame Pteria, however, replace Aricula, as I believe the rules of nomenclature will require, and the section to which these shells belong, prop- 
erly fall into that genus, either as a subgenus or otherwise, then the name Pteria will have to be substituted for Avioula in conneetion with these species.

Locality and position.-Coalville, Utah; from white sandstone, 250 feet above the lower heavy bed of coal, mined at that place.

\section{AVicUla (Pseddoptera) RHYTophora, Meek.}

Shell, as determined from a left valve, but slightly oblique, rhombic. suboblong, and nearly twice as high as wide in aduit examples, but proportionally broader ard subtrigonal in young specimens; moderately convex, the greatest eonvexity being toward the anterior side, along the umbonal slope, which appears to be augular, thence cuneate posteriorly, and more or less deflected inward anteriorly; binge line very nearly equaling the greatest antero-posterior viameter, and rang. ing at an angle of about 700 to the umbonal axis; posterior margin nearly straight, or a little convex in outline along the nuddle, where it ranges at an angle of about $100^{\circ}$ to the hinge margin, but curring a little forward above, so as to connect with the latter at a somewbat more obtuse angle, while below it eurves gracefully downward and forward into the narrowly rounded or somewhat angular base; anterior margin a little sinuous in ontline in the middle, with a general direction nearly parallel to that of the umbonal siope, but compressed nearly reetangular, and projecting a little beyond the beak above, the project. ing part not having the character of an ear or distinct lobe, though defined by a shallow depression extending from the beak obliquely downward and backward to the slightly sinuous central region; beak very nearly terminal, moderately oblique, and rather compressed. Surface with more or less distinct lines of growth, and near the hinge margin well-defined, regular, vertical ridges or wrinkles, that seem not to be exactly parallel to the lines of growth. Right valve not certainly known.

Height of right val*e, 3.20 inches; antèro-posterior diameter along hinge line, 1.90 inches; height about half way down parallel to hinge, two inches; convexity, 0.70 inch.

This species will be readily distinguished from the last, not only by its much larger size and less oblique and broader form, but also by the strong vertical wrinkles along its hinge margin. It likewise seems to be entirely without any traces of the radiating costa seen on the anterior side of that species, aud has its posterior margin much more neariy vertical above, and slightly convex in outline, instead of a little sinuous there. Its umbonal slope, in the only left valve seen, seems to be decidedly angular, though this may be partly, if not entirely, due to an accidental fracture and bending of the ralre along that line. It 'looks, however, like a natural angle, with some little nodes or projecting points along its erest. In general form it presents mueh the outline of some of the large Myalinas of the western coal-measures, such as $M$. ampla and M. subquadrata, but it differs not only in its angular umbonal slope, less curved beaks and wrinkled dorsal margin, but in having its anterior margin flattened and a little extended beyond the beak in front, instead of being concave in ontline there, thus not leaving the beak quite terminal, as we see in Myalina.

I am not quite sure that I have seen the right valve of this shell, though one of the same general outline, and of corresponding size, that was observed in a large mass of rock at the locality, was believed to belong to this species. It was nearly flat and smooth, excepting fine lines of growth, and, if I mistake not, had a tolerably deep, well-defined, byssal noteh. If it really belonged to this shell, the species can bardly go properly, as alresdy stated, into the group Pseudoptera, the type of which has no traces of a byssal sinus in either valve.

Locality and position, same as last.

\section{Avicula Oxytom (i) gastrodes, Meek.}

Shell (as determined from a left valve) attaining a moderately large size, subtrigonal in general outline, rather distinetly convex, and baving a very slight backward obliquity; basal outline very profoundly rounded, the deepest or most prominent part being in advance of the middle; pos. terior margin moderately sinuous below the wing, from the extremity of which it ranges obliquely forward and downward, rounding regularly into the base below; anterior margin strongly and subangularly sinuous under the wing, thence descending with a slight forward obliquity and under the wing, thence descending with a slight forward obliquity and
rounding rather abruptly into the base; hinge margin longer than the height of the valre, the antero-posterior diameter of which (at any point below) it also decidedly exceeds, ranging nearly at right angles to the vertical axis of the shell; beak distinctly convex, rising above the hinge margin, strongly incurved, withont obliquity, and situated less than onethird the length of the hinge margin from the extremity of the anterior wing, which is subtrigonal in form, somewhat convex, a little rounded at the extremity, and very strongly separated from the abrupt shell of the umbo by a defp rounded concavity extending from the beak oblinuely to the marginal sinus below; posterior wing longer and more compressed, narrower, and more angular than the other; both wings, particularly the posterior one, projecting decidedly beyond the margin of the valve below. Surface only showing more or less distinct lines of growth. (Right valve unknown.)

Height of left valve, 1.50 inches; length of same below the wings, about 1.30 inches; length of hinge line, 1.90 inches; convexity, (of left valve alone,) 9.40 inch.

I have not yet seen the hinge of this shell, or its left valve, and there. fore bave some doubts in regard to which of the sections of the old genus A vicula it would most properly fall into. If the right valre is (as 1 am inelined to think the case) nearly flat, with a deep, sharply-cut byssal sinus, and its beak not distinet from the hinge margin, it will probably fall into a little group for which I some time back proposed the name Oxytoma, typified by Avicula Munsteri, Broun. It differs remark. ably from typical species of A ricula in its erect form, its umbonal axis being inclined a little backward, instead of strongly forward. From Prcudomonotis, with which it agrees in its erect form and the elevated, strongly incurved beak of its right valve, it differs very strongly in having decided, well-developed ears, both in front and behind. Dr. Stoliczka thinks the characters of the genus Pseudomonotis should be ex. tended 80 as to include Orytoma. Should this view prevail, the name of our species would probably become Pseudomonotis (Oxytoma) gastrodes. It seems to me, however, that Oxytoma stands more nearly related to Avicula proper than to Pseudomonotis, as typified by the Permian species P. speluncaria, so that if we unite Oxytoma to Pseudomonotis, I cannot see why we might not, on the same principle, take another step of the

-The specimen was broken to fragments in trying to detach it from the mass of 
kind and restore both to Avioula, which I am certainly not inclined to do, though I regard Oxytoma as a subgenus under Avicula.

I use the name Avieula here, as elsewhere, subject to the ehange that it is probable the rules of nomenclature will demand in the restoration of the older name Pteria, which would require the name of our species to be written Ptcria gastrodes, if it falls into that group.

Locality and position.-Cretaceous sandstones of Coalville, Utah.

Modiola (BrachYdontes) MULtilinigera, Meek.

Modeola Pedernalis, Meek, 1870; Hayden's Geol. Report, Wyoming, \&c., List Cretaceous 870; Hayden's Geol. Report, Wy
fussils, page 207 , (not Roetner.)

Shell rather above medium size, obliquely areuate-subovate; valves strongly convex along the umbonal slopes, thence cuneate posteriorly, and abruptly curved inward below the middle in front; posterior margin forming a broad, regular, convex curve, from the end of the hinge downforming a broad, regular, cory narrowly and ab. wari to the anterior basal extremity wh ruptly rounded; anterior margin rauging ward to the narrow basal extremity, and strongly sinuous along the middle, above which it projects more or less beyon' the umbonal ridge, so as to form a moderately prominent, somewhat compressed protuberance; hiuge margin nearly or quite straight, ranging at an angle of $50^{\circ}$ to $60^{\circ}$ above an imaginary line drawn from the beaks to the most pro to 60 a oblique length of the ralves; beaks nearly terminal, rather compressed. very oblique, and scarcely rising above the hinge margin; nimbonal slopes prominent and more or less strongly arcuate. Surface ornamented by fine lines of growth, crossed by regular radiating lines that are very fine, and crowded on the anterior part of the valves, but become coarser five, and crowal ridge, the largest being near the dorsal side, where they bifurcate so as to become very fine, aud curve more or side, where they bifurcate so as to become very tin.
less upward before reaching the cardinal margin.

less upward before reaching the cardinal margin. to the most prominent part of the basal margin of a large specimen, 1.90 inches; greatest breadth at right angles to the same, 1 inch; convexity, 0.76 inch.

On first examining some imperfect cast s of this shell, brought by Dr. On first examining Coalville, Utah, I was led to think it probably the form described by Dr. Roemer from Texas, under the name Modiola Pedernalis, to which I referred it provisionally, in making out the list of Cretaceous fossils for Dr. Hayden's report of 1870: Further comparisons of better specimens collected during the past summer at the same locality, oreser differences from the Texas shell. In the first place, it is distinctly more arcuate, so much so, that when placed with its hinge line in a borizontal position, the outline of its posterior margin, instead of forming an oblique backward descending curve, ranges nearly vertically. A gain, the most prominent part of its posterior basal margin is very narrowly the instead of forming a regular curve. Its umbonal ridges are rilowise down to the narrowly likewise more prominent, more arched, and extentio "projection of the ronnded posterior basal extremity. The lobe-like projection of the upper part of its atterior margiu, under the beaks and in front of the umbonal ridge, also differs in being proportionally much smaller than in Dr. Roemer's species, in which it forms about one-third of the entire valve, as seen in a side view; while in our slell it searcely forms more than one-sixth. Of course the specimens are more or less variable in these characters, but the two forms ean always be readily distinguished when good examples can be had for comparison.

In its more arcuate form, our shell agrees more nearly with Modiola ornata, Gabb, from the Cretaceous rocks of California ; but that shell differs very markedly in having its beaks decidedly less, nearly termingl. and a more decided and much more prominent lobe in front of ther, Another important difference is to be observed in the radiating strix, which on the anterior side of our shell are very minute and elosely crowded; while on that part of Mr. Gabb's species, they are as large and. distant from each other as on any other part of the valves.

If Scopoli's name Volsella should be adopted for this genns, as there are some reasons for believing may be the case, this ehange would require the name of this species to be written Volsella multilinigera.

Locality and position.- Cretaceous sandstones, near Culville, Utah, first ridge, No. 14.

Trapezrum MCronema, Meek.

Shell attaining a rather large size, elongate trapeziform, the length being a little more than twice the height, which is abont one-third greater than the convexity; anterior margin very short and ronnd; posterior margin obliquely truncated above and narrowly rounded below; base nearly straight, or faintly sinnous along the middle, rounding up rather abruptly at each end; dorsal margin long, straight, and paralle to the base; beaks depressed nearly or quite to the horizon of the dorsal margin, and located one-sixth the entire length of the valves from the anterin: markin; umbonal slopes prominently rounded from the beaks obli quely backward and downward nearly to the posterior basal extrem. ity, while below this convexity a shallow concavity extends from each beak obliquely back ward to near the middle of the basal margin. Surfuce ornamented with numerous very fine, regular, crowded, thread-like radiating lines.

Length, 2.28 inches; height, 1.21 inches; convexity, 0.90 inch.

I know nothing of the hinge of this shell, and merely place it in the genus Trapezixm from external characters. Its form and surface-markings, however, are such as to leave little room for doubts in regard io its relations to that genus or Coralliophaga.

NotE.-Sinee deseribing, in Dr. Hayden's Report of 1870, (page 301, an elongated shell, from Utab, under the name Pachymya (f) truncata, have been led, by further comparison, to think it far more probably be. longs to the genus Trapezium, and remove it provisionally to that genus under the name $T$. truncata. In the same way I wonld remove another shell, described by me in that report as Tapes Wyomingensis, to Dr. Sto. liczka's genus Baroda, under the name Barcla Wyomingensis.

Locality and position.-Cretaceous coal-bearing sandstones at Bear River City, on Sulphur Creek, Wyoming.

Corbicula (Veloritina) inflexa, Meek.

Shell longitudinally ovate, a little less than two-thirds as high as long, moderately convex; posterior extremity rather narrowly , rounded, or apparently sometimes faintly subtruneated; anterior very short, subtrun. cated, or more or less sinnous in outline, just in advance of the beaks, on the abrupt forward slope above, and rather abruptly rounded below basal margin semi-ovate, or semi-eliptic; dorsal margins inflected and forming a long convex slope from the umbonal region posteriorly; beaks 
rather depressed, oblique, incurved, and placed near the anterior end; umbonal slones not prominently rounded; surface merely showing fine, unither zather obscure mark

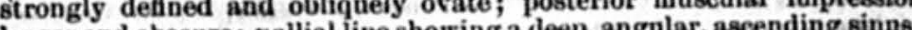
larger and obseure; pallial liue showing a deep, angular, ascending sinns; posterior lateral teeth of hinge very long, linear, and nearly or quite smooth; anterior short; cardinal teeth very oblique.

Iength of a specimen, a little under medium slze, 1.35 inches; height, 0.39 inch ; convexity, 0.68 inch.

This species is more depressed and elongated that any of those hitherto described from the far-western localities, excepting one or two from the coal formations on Bitter Creek, Wyoming, from which it differs in having its beaks placed farther forward. It will also be readily distinguished from those shells, as well as from all of the other species of the genus yet known, from any of ofr rocks, by having an augular, ascend. genus yet kine, almnst like that see ing, and comparat of in many types of the Venerida. This character is so strongly marked that it was not until I had sncceeded in getting a tolerably clear idea of the aature of the hinge that I could believe the shell related to the gronp to which. I have referred it. As was pointed ont by Mr. Tryon, some years back, the existing American species of Cyrcna and Corbietla have the pallial the more or less sinuous; while in nearly all of those from foreign foreign countries it is simple. I have also ascres the pallial line sin. the extinet North American species yet known have the pallial line sin. nous. The sinus, however, is usually shallow and rounded, or obtuse, in our fossil species; that of the shell here under consideration being nnusually deep and angular.

Locality and position.-Near Missouri River, below Gallatin City, Mon. tana, where it occurs, associated with Trigonia, Inoceramus, Cardium, Ostrea, and other marine Cretaceous fossils.

Corbicula Cyrena (?) securis, Meek.

Shell (as determined from internal casts) ovate-subtrigonal, moderately convex in the central and umbonal regions, and cuneate bebind; anterior end short, with its margin regularly rounded from below the anterior end sherts beaks into the base; posterior margin ajparently a liste tope to the pos. a slight backward obliquity from the posterior dorsal slope to the pos. terior basal extremity, which rounds abruptly into the ventral margin; dorsal outline declining nather distinctly back ward from the beaks; basal margin forming a semi-clliptic or semi-ovate curve; beaks prominent, gilbon shell from the anterior gibbous, what prominently rounded; muscular impressions shallow. (Surface and hinge unknown.)

Length, 1.67 inches; beight, 1.47 inches; convexity, about 1.15 inches.

The on'y specimen of this species yet known being merely a cast, it is not posible to determine from it, with certainty, the generic charac

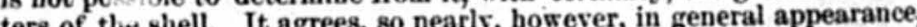
ters of the shell. It agrees, so mearly, besity, with Corbicula Durkeci, from the estaary beds near tho eamo locality, that I was at first inclined to believe it might be that species. A care fal comparison, however, with that shell, both as represented by internal casts, and by specimens showing the exterior, leaves no doubt that it is at least specifically distinct. A marked character seen in all the it is at least specing margins of the valves along the posterior dorsal slope, causing a pro. found wide suleus from the beaks nearly or quite to the posterior basal extremity, where the two are united. This character alone will distin. guish that shell from the form here under consideration, which shows nothing of the kind. Another well-marked fifference is niso observable in the muscular impressions; the anterior one in $\boldsymbol{C}$. Durkeei being very deep, while in the species here described it is so shallow as only to leave rather faint marks of its ontline on internal casts.

Locality and position.-Cretaceous sandstones, inclnding the coal at Bear River City, (Sulphur Creek,) Wyoming Territory.

\section{Corbicula zeUthateralis.}

Shell (as determined from an internal cast) subtrigonal, and nearly, or quite, equilateral, rather convex; height about five-sixths the length; anterior and posterior extremities nearly equally, and rather narrowly, rounded; ventral margin forming a nearly semielliptic curve, the most prominent part being at the middle; beaks rather prominent, and very nearly, if not quite, central; nmbonal slopes not prominently rounded; dorsal outline declining subequally from the beaks in front and rear, the posterior slope being convex in outline, and the anterior concave; mus. cular impressions shallow. (Surface and hinge unknown.)

Length, 1.72 inches; height, 1.45 inches; convexity, about 0.92 inch. One specimen of this shell shows impressions in the matrix of elongated lateral teeth, like those of Corbicula in form; but the arenaceons ma terial is too coarse to have defined the striations of these teeth, if any existed. Until the cardinal teeth can be seen, its relations to that genus cannot be positively determined, though I have little doubt that it belongs to that group. It will be readily distingushed from the last by its less elongated and equilateral form. These characters will also equally distinguish it from $C$. Durkeei, from the Bear River estuary beds.

Locality and position.-Same as last.

\section{Cymena.Carletont, Meek.}

Shell small, thin, subcircular, or with length a little greater than the height; nfoderatels convex ; anterior and posterior margins rounding from above regularly into the rounded basal outline, or with the posterior soinetimes slightly straightened, both rounding more abruptly to the hinge above; beaks rather depressed, small, abruptly pointed, incurved, nearly contiguous, and placed slightly in advance of the middle; hinge line sloping very gradually from the beaks. Surface marked with mod. erately distinet concentric lines and furrows.

Length of a medium-sized specimen, 0.55 inch; height of same, 0.49 inch; convexity, 0.32 inch.

This shell is so very thin, and so nearly resembles a rather large Spharium in form and surface characters, that I should certainly hare referred it to that genus, bad not a lucky blow separated the hinge of a right valve from the matrix in such a manner as to expose the teeth quite satisfactorily. This shows its hinge to have the charactery of a true Oyrena. For so thin a shell it has quite a stout hinge. Its cardinal teeth are rather diverging, the posterior two being welf developed, and each a little furrowed along the middle, while the anterior one (in this right valve) is mucb smaller and conical in form. The latera teeth are of moderate size, and certainly smooth, the posterior being remote from the cardinal teeth, and the linear anterior extending back 
to the latter. Internal casts sbow the muscular and pallial impressions to be well defined, and the latter to be a little straightened, or showing a very faint tenclency to form a small sinus under the posterior.

This is a rather small and an unusually thin sbell for the genns $O y r e n a$, being, as already remarked, much more liks a Spharium in these char. aeters. It is quite abundant at the loeality, but as it is only found in an indurated clay matrix, good specimens are with difficalty obtained, and from these the thin shell is very liable to break and scale off, leaving only the internal cast remaining.

Among the specimens collected there are some of a more transversels oval form and somewhat larger size than those $I$ have regarded as the types of the species here described. These may belong to a distinet species, but they agree so nearly in all other known characters that $I$ am at present inclined to regard them as merely a variety of the same.

Locality and position.-Carleton's coal-mine, Coalville, Utah. Orets. ceous.

\section{Pharella 9 Pealei, Meek.}

Shell elongate-oblong, or subrhombic, the length being about twice and $\mathrm{a}$ half the height, rather compressed; anterior margin slightly sinuous just in advance of the beaks above, and somewhat narrowly rounded below this faint sinuosity; posterior margin truncated, with a convex outline, very obliquely backward and downward, from the posterior extremity of the hinge to the prominent and very narrowly rounded or angular posterior basal extremity; hingeline propar apparently, cornparativel $y$ short, and not forming any angularity of outline at its connecilon with the sloping posterior dorsal margin; beaks rising a little above the hinge-margin, but rather depressed and placed about one-tifth the entire length of the valves from the anterior margin; basal margin long, slightly sinuous along most of its length; posterior dorsal slopes rather prominently rounded from the beaks obliquely to the posterior basal extremity. Surface only showing obscure lines of growth.

Length, 1.20 inches; height, 0.48 inch; convexity, 0.28 inch.

Knowing nothing of the hinge of this shell, I only refer it provisionally to Pharella. It does not seem to have had the extremities gaping as in that genus; but the specimen has evidently been aceidentally cotnpressed, and this may have given the valves the appearance of being closed. In general appearance it resembles Solen Guerangeri, d'Orbigny, which seems to belong to the genus Pharella. Our shell, however evidently differs from d'Orbigny's speeifically, at least in not having the posterior margius of its valves near so abruptly truncated, but rounding and sloping forward gradually into the dorsal outline above. Possibiy I should call it Modiola Pealei.

Locality and position.-Missouri River, below Gallatin City, Montana. Cretaceous.

Corbula nematophora, Meek.

Shell of abont medium size, ovate-subtrigonal, nearly equivalve and moderately convex, with height equaling two-thirds the length; anterior ontline rounded; base semi-ovate; posterior extremity somewhat prooutline rounded; base semi-ovate; posterior extremity somewhat pro-
duced and subangular or minutely truncated in outline below; dorsal outline sloping from the beaks, the anterior slope being more abrupt, and slightly concave in ontline above, and the posterior longer and nearly straight, with a greater obliquity; posterior nmbonal slopes more or less angular in each valve, from the beak to the posterior basal extremity; beaks rather prominent, and placed about one-third the length of the valves from the front. Surfice ornamented by small, reg. ular, concentric ridges, or strong lines and furrows, both of which are more distinet on the right valve than on the left, where they are some. times obsolete.

Length of largest specimen seen, 0.50 inch; height, 0.32 inch; convexity, 0.25 inch.

This shell agrees so very nearly with a form I have desoribed from Hallville, Wyoming, under the name Oorbicula 9 craseatelliformis, as al most to raise a doubt whether it may not be really the same species. I have not seen the hinge of the Hallville species very clearly, though some of the specimens seem to indieate that it can harily be a Corbula while those of a larger, but otherwise scarcely distinguishable form, associated with it, are distinctly seen not to have the characters of $C$ or bula, but to present nearly the essential features of Corbicula. Even should the stnaller of the Hallville species, however, prove to be a Cor bula, I think the form under consideration, which certainly has the hinge of the latter genus, will be distinguished, specifically, by its smaller size, more convex valves, and more distinctly striated and furrowed surface; particularly that of its right valve. It is also not so extremely thin a shell as the Hallville speeies.

I also have, now before me another very closely allied form, from Black Butte Station, Wyoming, and still more nearly like the Hallville shell referred to. So far as can be determined by comparisons with accidentally compressed, and separated valves of the Hallville shell, showing none of the hinge characters, the specimens of the Black Butte form would seem ouly to differ in being much thicker, and more strongly and regularly marked by concentrie lines and furrows." Its decidedily inequivalve characier may also be another difference, but it is not pos. sible to determine from the separated and compressed valves of the Hallville species, yet seen, whether it is inequiralve or not, though it seems not to be. Compared with the form here described, and whieb must occupy a much lower position in the series, the specimens from Black Butte differ ehiefly in being much larger, thicker sbells, somewhat more abrupt on the anterior slope, with more elevated beaks. There may also be differences in the hinge and muscular and pailial impressions, which I have had no opportanity to compare.

Should this Black Butte form prove to be distinet from both of the others mentioned, it may be called Corbula propinqua.

Locality and position.-Near Cedar City, Southern Utah, from coal. bearing Oretaceous beds, apparently belonging to the same horizon as the lower part of the coal-series at Coalville. It oceurs in great num. bers, associated with Turritella Coalvillensis, and other forms apparently identical with Coalville species.

\section{Nearriva (Dostu †) Bellatula, Meek,}

Shell small, depressed ovate, or broad slipper-shaped; apex very small, and depressed to the posterior margin, where it forms one or two minute, slightly oblique, compact turns, that do not project beyond the margin, but are souetimes even slightly overiapped by it; ipner lip very broad, or shelf-like, and occupying more than half of the under side, convex and more or less thiekened, with the inner margin coneave 32 G 8 
in outline at the middle, and provided with a slight projection on each side, but not properis crenate or dentate; outer lip nither thick, obtuse. nearis or quite smootb, and continuous arond the margins with the inner one; aperture small, and transversely seinicircular. Surface polished and ornamented by fifteen to twenty light yellowish or cream-eolored, simple radiating costæ, separated by shallow, bright brownish furrows finest.

Length, 0.31 inch; breadth, 0.25 inch; convexity, 0.12 inch.

I am in some donbt in regard to the proper disposition to make of this little shell. In most of its characters it seems to conform pretty nearly with Dostia of Gray, generally regarded as a subgenus under Neri. tina, Lamarck, (=Neritella, Humphrey.) It has a much sunaller and less prominent spire, however, and a more convex and broader inner lip, prom the type of that gronutions of the than the type of that group, and also wasts inner lip seen in the same. In its limpet-like form, tumid, greatly developed inner lip, and minutely coiled apex, it approaches Velates, Mont. fort; and I am not quite sure that I would not be nearer right to call it Velates bellatula. Still it differs from the typical form of that genus in having its apex depressed to the posterior margin, instead of being in bavid distinet denticulations seen in that of that shell.

of conrae, if Humphrey's catalogue genera are to be adopted, on Of coura, if Humpbrey's catalogue genera are to be adopted, on
ccount of their priority of date over those of Lamarck and others that were accompanied by diagnoses, the name of this shell, supposing the view bere adopted in regard to its affinities to be correct, would become Neritella (Dostia) bellatula.

Locality and position.-Carleton's coal-mine, Coalville, Utah.

Neritina (Dostia ๆ) PATELLIForms, Meek.

Shell small, thick, oval or subelliptic; nucleus nearly posterior and cenerally more or less elevated above the posterior margin, but always gener than the midosion in front of it lineted obliquls bakmand, and, in well preserved specimens, minutely lirected obliquely backward, and, in well-preserved specimens, minutely subspiral at the inmediate more or less oblique apex; inner lip very broad, or having the form of a thick, smooth, convex septum, that extends forward more than half the length of the shell; onter lip thick ened, obtuse, and smooth within; open part of the aperture small and transverely semicireular. Surface with moderately distinet lines of growth.

Length of one of the largest specimenis found, 0.62 inch; breadth, $0.50 \mathrm{inch}$; height or convexity, 0.33 inch.

This form is evidently very nearly related to the last, and may possi. bly be a more robust variety of the same. It attains a much larger size, however, than any of the specimens of that shell I have seen, and presents a more - elevated form, with a thicker and more tumid inner lip; while its nucleus is often more elevated above the margin, though not always so. At first, I thought the absence of radiating costa on this shell would very decidedly distinguish it from the last, but ou farther examination $I$ find the costre almost obsolete on one of the specimens of that species, though the bright brown color of the spaces between the speci. mens of the larger form under consideration, (broken directiy from the of course tho colors mentioned are not know was alive. same matrix,) I find a single small individasl, showing very obsenre sames of radiating brown stripes, like those occurring between the costw of the last, (the other speeimens not being in a condition to preserve marks of color.) It is possible, however, that this smaller individust. showing traces of colored stripes, may be distinet from the others. It wonld be rather remarkable if this and the last described species shonld be the same, since an interval of about 600 feet of strata oceurs between the beds in which they were found; while all of the other species, so far as known, from the two horizons, are distinct, and no shell resem. bling these forms is known to occur in any intermediate horizon.

Locality and position.-Coalville, Utal, from the Cretaceous beneath the lower heavy bed of coal mined at that place.

\section{Neritina (Dostia I) carditomes, Meek.}

Shell attaining a moderately large size, broad, oval, and depressed in form, apex posterior, and nearly or quite depressed to the margin, apparently obliqnely subspiral; inner lip very broad, or forming more than half of the under side, rather thick, smooth, and nearly flat, or somewhat convex, with its straight inner margin sharp and without teeth or crenulations; onter lip thick, very obscurely erenate within, and apparently continnous with the margins of the inner one around behind; aperture transversely semicircular, and less than half the size of the under side of the shell. Surface ornamented by about fifteen simple, narrow, sharp, and subcrenate radiating costa, separated by wider, rounded intermediate furrows; lines of growth distinct.

Length, about 0.87 inch; breadth, 0.70 inch; convexity, 0.35 incb.

This is another curions form allied to the little species I have described under the name $\boldsymbol{N}$. bellatula. When viewed from the dorsal side, as seen lying with the aperture downward, its form and strong radiatiog costa give it much the appearance of the left valve of a Cardita or Cardium. The only specimen of it in the collection bas its apex and posterior and lateral margins broken away, and its broad, smooth, shelf.like inner lip broken by pressure inward. Still, bowever, it gives a tolerably correct ides of the characters of the shell. In several respects it bly correct ides of the characters of the shell. In several respects it
agrees with Velates, and possibly might, withont impropriety, be called Velates carditoides. I suspect, however, that when better specimens can be examined, it will be found typical of an undescribed section, inelnding also the little species $N$. bellatula. If so I would propose for the group the name Velatella. I know of no nearty allied described type.

Locality and position.-Carleton's coal-mine, Coalville, Utah. Cretaceons. I am under obligations to Mrs. Carleton, the wife of the gentleman who owns the coal-mine at which the specimen was found, for the only example of the species I have seen, which was discovered by her while we were at the locality.

\section{Neritina (NeritelLia) Ba'sisistreri, Meek.}

Shell subglobose; spire much depreseedy or with its apex scarcely rising above the body whorl; volutions three to four, rapidly increasin in size, so that the last one comprises nearly the entire shell, more or less flattened, and sometimes provided with an obscure linear revolving furrow above; aperture large, snbovate, approaehing semieircular, being a little straighter on the inner side; onter lip beveled to a thin edge; inner lip of moderate breadth. Blightly concave, and flattened, with a steep inward slope, entirely smooth. Burface polished, and marked by 
crowded zigzag vertieal bands of brown and light yellowish colors; lines of growth moderately distinct.

Height of a naarly medinm-sized specimen, 0.40 ineh; breadth, 0.43 inch. Sore examples are as much as twice these dimensions.

Although the specimens show the pattern, or style, of the original coloration of this shell quite distinetiy, the colors themselves may, of course, huve been different on the living shell. Usually the zigzag markings are quite distinct on the specimens as found, but on some ex. amples the bands are blended and become fainter, so that the surface merely presents a light brownish tinge. It is always polished, however, on all the specimens seen.

This species seems to be more nearly allier to $N$. Nebrascensis, M. \& H., from Jurassic beds near the head of Wind River, than to any other form with which I am acquainted. It may be readily distinguished, however, by its more depressed spire and the slight flattening of its volutions above, as well as by its more flattened and more concave inner lip. It likewise attained a larger size than any of the specimens of that species I have seen. It is one of the most abundant shells observed at the locality, and is usually found in a better state of preservation than any of its associates.

The specific name is given in honor of Dr. Henry M. Bannister, of the Smithsonian Institution, to whom I am under obligations for valuable assistance while visiting the Roeky Monntain region during the past summer.

Locality and position.-Carieton's coal-mine, Coalville, Utah.

\section{Neritina (Neritella) Pisum, Meek.}

Shell globose; spire much depressed; volutions about three, rapidly increasing in size, 80 that the last or body turn 'which is a little de pressed alove) composes nearly the entire shell; inner lip broad, flattened, and smooth; aperture small and semicircular; surface nearly or quite smooth.

Height, 0.22 inch; breadth, 0.26 inch.

This little shell has much the form of the last, and I was at first inclined to think it might be the same, notwithstanding its much lower position in the series. A careful comparison, however, shows that it has a de eidedly broader, flatter, and straighter inner lip, while its aperture is proportionally smaller, and quite different in form.

Locality and position.-Coalville, Utah. Cretaceous, from below the lower bed of coal.

\section{Neritina pisiforsts, Meek.}

Shell small, subglobose, or obliquely rhombic, the height being slightly less than the oblique breadth; spire rather prominent for a species of this genus; volutions three to three and a half; convex; last one large, and forming most of the bulk of the shell; aperture subovate, considerably contracted by the flattened, moderately wide inner lip, which is neariy straight on its inver margin, and provided there with four small denticles, the npper one of whieh is largest. Surface smooth.

Height, 0.30 inch; greatest oblique breadtb, 0.32 inch.

This little shell agrees so neariy in size and form with the described species, $(N$. pisum, ) that they may be readily confounded, as they are fond with the aperture filled with rock. A fo:tunate fracture of one of the specimens exposed the inner edge of its flattened columella, how. ever, and thas enabled me to see that it is dentiealated, and in this respect differs from Neritina pisum, which seens to be entirely withont teeth. Further comparisons also show the two shells to differ in form, that under consideration baving a more prominent spire and a more globose outline, being less oblique.

In size and general appearance it also elosely resembles small exam. s of Neritina compacta, Forbes, from the Oretaceons rocks of India but it is less oblique, or more globose in form, and bas fonr denticles but it is leas oblque, or more globose in form, and three on its columella. It is possible 1 should eall it Nerita pisiformis, as the denticulations of its columella are rather strongly developed for a Neritina, in which genus the columella is usually smooth, or only finely crenate. Its general aspect, however, is more like species of the latter group.

Locality and position.-Coalville, Utub, from the Cretaceous beds below the heavy lower bed of coal mined there.

ADMETE 9 RHOXBOIDEs, Meek.

Shell rather small, rhombic suboral, or short subfusiform, the length being slightly more than twice the breadth at the widest part, which is near the middle; spire rather depressed-conical, subturreted; volutions fire or six; convex; last one forming about three-fourths the entire bulk of the shell, and more than balf of its length, widest near its npper part, and abruptly narrowed below so as to present an obliquely obovate form; suture rather deep from the convexity of the volutions; aperture narrow, subangular above and narrowed below to a small noteh at the base of the truncated columella, which is provided with two small obscure plaits or folds, the lower of which is formed by the twisted margin of the truncated inner lip, while the other is placed a little farther ap; outer lip sharp, with its margin slightly retreating above, and more prominent below, or near the middle. Surface ornamented by distinct rertical folds. that are nsually well developed on the volutions of the spire, and arond the upper part of the body whorl, but become ohsolete below; moderately distinct revolving lines also mark the lower part of the body volution, but these appear to become obsolete on its upper part, and on those of the spire, as specimens are nsually found.

Length, 0.37 inch; breadth, 0.21 inch; angle of spire about $58^{\circ}$.

I am much perplexed in regard to the proper disposition to make of this and the first two of the following species. In some of their characters, they would seem to be related to certain types of the Mifrina, such as Vulpecula, Blainville, $(=V$ ulpecula, Klein $)$ while in others they appear to have aftinities to the Cancellariida, being much like the genus $\boldsymbol{A d}$. mete. Without being at all satisfied, however, that they belong properly to the latter genus, I have conclnded to refer them to it, provisionall for the present, nntil better specimens can be obtained for stndy and comparison. My present impression is, that they will prove not to belong properly to any of the established genera, when all their characters can be clearly made out. If it should be found desirable, bowever, to establish a new group for their recertion, I would propose for it the name Admetopsis, from the resemblance of the shell to the typical forms of the genus Admete.

Locality and position.-Coalville, Utah. From Oretaceous beds beneath the lower heavy bed of coal at that place.

Admete 1 gregaria, Meek.

Shell small, oval, subfusiform; spire moderately prominent, conical, and apparently terminating in a pointed apex; volutions five or six, 
convex, sometimes showing a sight tendency to become shonldered above, last one forming about half the entire length of the shell, generally a little wider above, and narrowed and somewhat produced below; suture well defined, in consequence of the convexity of the volu. tions; aperture narrow, slightly louger than the spire, acnte above, and narrowing to a small, well-defined sinus at the buse of the truncated columella, which is provided with two small folds, ora of which is formed by the twisted lower edge of the truncated coluniella, while the other oceupies a position a little above, and passes around more obliquely ;
surface ornamented by comparatively rather strong, regular, vertical ridges or folds that sometimes become nearly or quite obsolete on the body volution, espeeially below its upper part. Crossing these folds and the depressions between them, mucb smaller revolving ridges and furrows may be seen on well-preserved specimens, though these are also sometimes obsolescent, excepting around the lower part of the body volution.

Length of a mecinm-sized adult specimen, 0.50 inch; breadth, 0.25 inch; angle of spire, about $42 \circ$.

This species will be at once distinguished from the last by its proportionally more prominent spire and less expanded body volution. It is a much more abundant shell than the last, being found often in consider. able numbers clustered together.

Locality and position same as last.

\section{ADMETE 9 sUBFUsIPorms, Meek.}

Shell subfusiform, with the length nearly three times the breadth; spire elongated, conical, turreted; volutions seven or eight, convex; last turn more than half the entire length; suture well defined, in con. sequence of the convexity of the whorls; aperture narrow, equaling about two-fifths the ent' $\cdots$ length of the shell, angular behind, and narrowing below to a small, sharply-detined notch at the base of the trun. cated columella, which seems to bear two small folds near its lower part, one being formed by the twisted and truncated lower magin: inner lip a little thickened; surface ornamented by distinct, regular, vertical folds that are nearly or quite obsolete on the body volution below its upper part, and regular revolving lines quite well defined on the body turn, especially its lower part, and appear to be obsolete on those of the spire; lines of growth moderately distinct.

Length, 0.50 inch ; breadth, 0.20 inch ; angle of spire, about $300^{\circ}$.

This species differs eveu more strongly from the last than that form does from the species rhomboides, baving a much nore elevated spire and a proportionally smaller boly volution and aperture. In ornamentation the three forms, however, are much alike. The species here under con. sideration shows a sonewhat more thickened inuer lip than I have yet seen in eitlar of the others.

For the reasons already expl iaed, this and the last nay have to take the names Turricula gregaria and $T$. subfusiformis, if all three do not, as suggested further back, require to be groupet together as a new section, under the numes Admetopsis rhomboides, A. gregaria, and A. subfusiformis.

Locality and position same as last.

Tereitelua Coalviliexsis, Meek.

Shell attaining ? large size, elongate-conieal ; volutions apparently ten or more, distinctly convex, the most prominent part of those of the spire being somewhat below the middle, where they are angalar; sur face below the angle flattened, or a little coneave, and sloping rather abruptly inward and downward to the suture, while above, to near the upper margin, where there is a shallow revolving coneavity a little below the suture, it is eonvex; last volution probably biangular around the micdle; suture well detiued; aperture unknown. Surface ornamented by rather obscure revolving ridges, about five of which may be counted on each volution of the spire, one being at the lower margin immediately above the suture; another, wbich is also the largest, occupying the most prominent angular part of the whorl; and above this three others occur, one being above the revolving coneavity, and at the immediate upper margin; lines of growth obsenre and making a strong backward curve in crossing the middle of the volutions.

I have nót seen specimens of this fine species suffciently well preserved to be able to give acenrate measurements, though those I bave had an opportunity to examine indicate a length of not less than two inches and a fraction, and a breadth of 0.93 inch. The angle of its spire, as taken from near the middle of a large specimen, imperfect at both extremities, measures about $23 \circ$, while smaller individuals, eomposed of tive or six of the upper volutions, show an angle of nearly $30^{\circ}$. It is, therefore, evidently a large, robust species, that increases rather rapidly in size from the apex.

Specimens of this species were brought in by Dr. Hayden a year or two since, and were supposed by me probably to belong to $T$. Martinezensis, Gabb, to which it is evidently related in size. form, and general sppearance. Since seeing the California State collection, st San Francisco, during the past summer, however, and sone additiona! collections from Coalville, I have become satisfled that the Utah shell ia distinet from Mr. Gabb's species. In this opiuion Mr. Gabb also coneurs, after seeing our specimens. The most obvions difference is that our shel has the rolutions constantly convex above the angle, and below the revolving concavity near the upper part, while in the California species the upper slope of the volutions is regtaiarly concave from the upper margin to the angle. Better specimens would doubtless show other differences.

Locality and position.-Coalville, Utah. From the Cretaceous, beneath the lower heavy bed of coul.

\section{TURritella spironema, Meek.}

Shell ratber small, or scarcely attaining a medium size, elongate conical; volutions about fifteen, increasing very gradually in size, moderntely convex, last one rounded in the middle; aperture apparently ovate; columella rather regularly areuate. Surface ormamented by squarish, rather regular revolving thread like lines, with nearly equal furrows between; about five to seven or eight of the lines and furrows are seen on each of the turns of the spire, and nearly twice as many on the body whori, where those below the middle becone abruptly smaller and more crowded than those above; lines of growth obscure and gently arehed in erossing the volution; suture moderately distinet.

Length of the largest speeimen found, 0.82 inch; breadth of body vola. tions, 0.23 inch; spire nearly regular; divergence of its slopes, abont 170 .

There is a slightly polished, appearance of the surface of this shell that is not often seen in the true Turritella, and gives origin to some doubts whether it may not belong to some group allied to Aclis or Me. nestho. As in size and general appearance, however, it sęems to cor 
respond more nearly to Turritella, I have concluded to refer it provisionally to that genus until better specimens can be obtained for study and comparison. None of those jet seen show setisfactorily the exact form of the aperture.

Locality and position.-Carleton's coal-mine, Coalville, Utah. Cretaceous.

Turritella (AClis?) Micronema, Meek.

Sinell small terete or elongate conical; rolutions about nine, nearly flat, sometimes moterately convex, increasing gradually in size, last oue ronnded or obscurely subangular in the middle; suture linear to mod. erately distinct: apertuts rhombie-subovate, augular above. Surface ornamented by fine, regular, rather crowded revolviug lines, six to eight of which may be counted on each volution of the spire.

Length of the largest specimen seen, 0.50 inch; breadth, 0.18 inch; angle of spire about $19 \circ$, with slightly convex slopes.

This may not be a Turritella, the specimens not being in a condition to show the texture of the shell, or to give a very clear idea of its aperture and lip. It would be a rather small species for that genus, and if it possessed the delicacy of surface seen in those genera it might, perhaps, with more propriety be referred to Aclis or Alenestho. The fractured with more propriety be referred to Aclis or Alenestho. The fractured angularity or a very small notch at the base of the aperture, but this may be dne to the marner in which it is broken; if not, it would seeu may be dne to the mares. It will be readily distinguished fom the speies I deseribed ander the nome $T$ spirouema, bs its les attenuated form and finer and less distinct revolving lines. It is also not nearly so attenuated toward the upper part of the spire as that species.

Locality and position.-Coalville, Utah, from the Cretaceous below the lower heary bed of coal mined at that place.

\section{Fusus (Neptusea!) Gambi, Meek.}

Shell rather small, fusiform; spine moderately prominent, conical; volutions seven or eight, convex; last one somewhit ventricose in th middile, and rather suddenly coutracted below into the narrow, slightly twisted, more or less bent, and apparently moderately produced eanal; wature suture well defled; ajol with equal, dis. cist tinct, regularly disposed varices or vertical folds, about eight of which may be counted on the penultimate volution, and less on the body-whorl, where some of them become obsolete; crossing these are also seen fine revolving lines, and, $\mathrm{n}$ little below the suture, apparently a shallow revolving furrow, that gives it a slightly banded appearance.

Leugth, including canal, about 0.87 inch; breadth, 0.40 iuch; slopes of spire straight, and diverging at an angle of about $50^{\circ}$.

The specimens of this species cot ained in the collection are quite imperfect, being mainly casts, retaining more or less of the shell. From such material it is, of course, impossible to determine, with much confi. dence, the generic affinities of shells. I have, therefore, provisionally referred it to the menus Fusus, putting in parentheses the name Nep. referred it to the gen tunca, with a tmark of doubt, to indicate that I saspect it mas bel that group, with the limits assigned it by some conchologists. It seems, however, quite as probably to belong to Tritonidea, as understood by some. The specific name is given in honor of my friend, William M. Gabb, the paleontologist.

Locality and position.-Coalville, Utah; from Cretaceous beds below the lower heavy bed of coal mined at that place.

Fusus (Neptunea i) Utahensis, Meek.

Shell of moderate size, short fusiform ; spire rather depressed, conical; volutions about four; those of the spire a little convex; last one large and ventricose, rounded or very slightly flattened around the middle and contracted rather rapidly below into a narrow canal that is longer and contracted rather napidly below into a narrow canal that is longer
than the spire, and more or less bent to the left; aperture anombic, angular above aud narrowed and prolonged into the canal below. Surface, (as determined from a cast in sandstone,) with obseure vertical ridges, about twelve of which may be counted on the penultimate volu. tion, while on the last, or body-whorl, they become nearly or quite obsolete. (Revolving lines probably also marked the surface of the shell, though no traces of anything of the kind are seen on the cast, excepting a shallow furrow above the suture on the volutions of the spire.)

leugtb, including canal, about 1.90 inches ; breadth, 0.91 inch; angle of spire, about $67^{\circ}$.

As in the last, we have not the means of determining the generic characters of this species with any degree of certainty, and merly place it provisionally in the genus Fusus with Neptunea in parentheses to in dicate that it nay be found to belong to that group. It is a rather decidedly larger shell than the last, with a distinctly less elevated spire, and more obseure vertical ridge or varices.

Locality and position,_Coalville, Utah ; from "Chalk Hill," considerably above the lower heavy bed of coal mined there. Crutaceous.

Turbonilla (Chemnitzia?) Conlvillensis, Meek.

Shell elongate-conical; volutions ten or eleven, moderately convex; last one not unch produced below, rounded or sometimes obscurely sub. ingular around the middle; suture well defined; aperture rhombic. angular around the middle; suture well defined; aperture rhombic.
suboval, being angular above and apparently a little so below; inner lip slightly thickened, rather deeply arehed, a little reflected, and closely appressed below; outer lip thin. Surface ormamented by rather strong, simple, regular, nearly or quite straight vertical ridges, crossed by regu. larly disposed revolving lines, (abont ten or eleven of the ridges and five or six of the revolving lines leing seen on each volution of the spire;) while ouly the revolving lines are continued below the middle of the body volution.

Length of a large specimen, 1 inch; breadth, 0.40 inch; angle of spire, from 200 to 250 .

None of the specimens of this species yet scen are quite perfectly pre. serred at the base of the aperture. Some of them look as if there had been a slight angularity there, while others, differing in no other respect, present appearances that leave room for doubt on this point. In some of its characters this shell rewfuds ote of the fresh-water Goniobasis, to which I was at one time much inclined to refer it, and I am hardly quite sure yet that it may not have to take the name Goniobasis Coal. vilensis. Many anthors refer \ ry similar shells to Chemnitzia, but it has not so large and produced a body rolution and aperture as the forms to which Mr. Coorad and Dr. Stoliczka propose to apply that name.*

-The genns Chenanitria, d'Orbigny, as originally proposed, is ge zerally regarded as syndesigned to use it for another group. 
If found in any of the Palreozoic roeks, most geologists would refer it to Loxonema of Phillips. Whether or not the nucleus or apex of its spire was covered as in the typical species of Turbonilla I have been unable to determine. It is a far larger shell, however, than the speeies upon which that genus was founded.

Specifically, this shell seems to be related to Turbonilla Spillmani, Conrad, (Jour, Acad. N. S, vol, iv, new series, Pl, 46, Fig. 28, but its vertical folds or costa are straighter, less crowded, and less numerous, while its revolving lines are smaller and more numerous. Its aperture also certainly differs in being decidedly more augular above, and proba. bly somewhat so below. It may likewise be compared with Scalaria Mathecsonii, Gabb, from Cretaceous rocks of Calitornia, from which it differs in having less conves volutions, or less rounded aperture, less crowded vertical ridges, and more distinct and coarse revoiving lines.

Locality and position.-Coalville, Utah; from below the lowest heavy bed of coal at that locality. Cretaceous.

\section{Eulma funicula, Meek.}

Shell subterete or elongate-conical; spire regularly tapering from the middle of the body volution to the anex, or with very slightly convex slopes; volutions about twelve, flattened; last th. $\mathrm{n}$ not much enlarged, subangular around the middle; suture merely linear; aperture ovate or rhombic-subovate; inuer lip slightly thickeued aud reflected. Surfase smooth.

Length, 0.65 inch; breadth, 0.20 inch ; divergence of slopes of spire, about 19 .

This shell has much the appearance of a slender Niso, but it certainly wants the umbilicus seen in that genus; its axis not being in the slightest degree perforated. It is even more like some recent species of Eulinella, an! may possibly bave to take the natne Eulimellu funicula when its gentric characters can be more clearly determined from the ex amingtion ot good speeinens. The luest exanules l have seen do not shor of the spire, or very clearly the form of the aperture. So far as ean be determined, however, its columella does not seem to present the straightness seen in Eulimella. I know of no closely allied Cretaceons species.

Locality and position.-Cretaceous, at Coalville, Utah.

\section{Eulma ? cmirsallis, Meek.}

Shell small, elongate subconoid, or subfusiform; spire conical ; ro Intions about eight, flattened nearly to the slope of the spire; suture nearly linear; aperture subovate; inner lip a little rellected aud mod. erafely arched ; outer lip unknown ; surface smooth.

Length about 0.29 inch; brealth, 0.12 inch.

I am by no means sure this is a true Eulima, not having seen any specimens showing very clearly the form of the aperture, or the natur of the outer lip. It has the general aspect of that genns, howerer, and may be placed there provisionally for the present, until better speci. mens can be obtained for study. It will be at once distingnished from the last, by its less produced spire, less numerous volutions, and proportionally larger body.whorl

Eocality and position.-Carleton's coal-mine, near Coalville, Utah. Cretaceous.

\section{Belma 9 inconspicua, Meek.}

Shell snall, conoid-snbovate; spire conical; volutions, eight or nine, I Ittle convex and compactly coiled; suture distinet; aperture apparently subovate; surface smooth.

Leugth, 0.17 inch; breadth, 0.07 inch; spire with straight slope that liverges at an an angle of about $22 \circ$

This is another form that I only refer with great don'st to Eulima, the specimen not being in a condicion to show the exact form and nature of the aperture. It will be ready distinguished from the last by its more conver volutions, proportionally sborter spire, aud more expanded body. whorl. It is probably not a Eulima.

Locality and position.--Same as last.

\section{MElampus antiquUs, Meek.}

Shell subovate, thin; spire moderately prominent, conical, and abruptly pointed. volutions, about eight; those of the spire very short and nearly llat; lat one large; widest above and tapering below ; suture shallow,

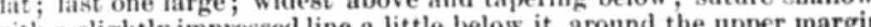
f each volution; operture nartor with four very prominent lamine or folds, with sometimes one or two wmaller ones above these, near the top of the aperture; oater lip thin sul strengthened by a few tranverse ritges within. Surface showing only five obseure lines of growth and presenting a somewhat polished appearance.

Height of a small specimen, 0.43 inch; breadtb, about 0.27 inch.

1 have only seen very imperfect specimens of this shell, but, taken fogether, they give a of them are three or fonr times the linear dimensions of that from which the above meanarenents were tahen.

Among the specimens from the same loeality and bed, there are some A weem to belong to a more elongated species, with a more produced spire characters than that described above. This form, however, as far as its characters can be made out, appears to agree with the foregoing

Locality and position._-Carleton's coal-mine, near Coalville, Utab. Cretaceous.

\section{VALTATA NANA, Meek.}

Shell small, depressed subglobose, or subdiscoidal; spire depressed rolutions three and a half, rounded; suture deep; umbilicus comparatirely small; aperture rounded suboval; surface nearly smooth or only showing fine obsure lines of growth under a magnifier.

Breact 0.12 inch; height about 0.08 inch.

Compared with V. subumbilicata, M. and H., from the Tertiary lignites of the Upper Missonri conntrs, this little shell will be readily dis. tinguished, by its smaller umbilicus, nore prominent spire, and more oval aperinre. It also has a smaller umbilicus and a less rounded perture than the recent $V$. sincera. Its spire is more cepresset, it prese living species $\vec{V}$, tricarinata, var. simplex, Say.

V. tricarinata, var. simplex, Say.
Locality and position.-Uarleton's coal-mine, Coalville, Utah. Creta. ceous. 
Physa Carletoni, Meek.

Shell rhombic-subovate, attaining a medinm size; very thin; spire short and small; volutions about three, last one very large, or forming near nine-tenths the entire bulk of the shell; aperture unknown; surface showing rather obscure lines of growth.

Length, 0.56 inch; breadtb, 0.35 inch.

The only specimen of this species I have seen is somewhat imperfect, and so connected with a portion of the areuaceons matrix that its aperture and columella cannot be seen. It seems to have most neariy resembled such recent species as $P$. Lordi, Bairl, in general form. I should not have attempted to name and characterize the species without seeing the columella and aperture, had it not seemed desirable to call attention to it as the first species of the genus hitherto found in the well-marked Cretaceous strata of this conntry.

The specific name is given in honor of Mr. Benjamin Carleton, the gentleman who owns the coal-mine at which the specimen was found, and assisted us in collecting the fossils found at the same.

Locality and position.-Curleton's coal-mine, near Coalville, Utah, in a Cretaceous bed, associated with Unio, Cardium, Inoceramus, dnomia, Neritina, and other marine and fresh-water shells.

\section{Species from the Bitter Creek series.}

Ostrea Wromingensis, Meck.

Ostrea Idriaensis / I Meek, 1672. Hayden'n Geological Report, Montana \&c., p. 375, Ostrea Wyomingentis, 3feek, 1972; ib.

Shell attaining a moderately large size, rather compressed, subovate, or trigonal-subovate, being pointed at the beaks, and more or less rounded at the opposite extremity. Lower valve usually rather shallow; beak generally somewhat acutely pointed, undistorted, and nearly always curved $\mathrm{u}_{i}$ ) ward at the extremity; ligament area comparatively small, trigonal, with the longitudinal furrow and transverse strix well defined; posterior lateral margins flattened, and rather broad, in consequence of the lateral expansion of the imbricating lamina of growth; muscular sear comparatively small; surface with only irregular imbri. eating but not strongly projecting laminæ of growth. Upper valve swaller than the other, nearly flat on the upper side and slightly con. swaller than the other, nearly flat on the upper side and slightly con-
cave within; beak less pointed than in the other valve, being usually a little truncated at the extremity, which is straight or nearly so; ligament area of the same size and nearly the same form as it the other valve, excepting that it is not curved, but directed obliquely upward and backward, and has its anterior margin forming a transverse ridge, as usual most prominent in the middle at the end of the mesial longi. tudinal ridge, which is rounded, or somewhat flattened, and continged to the point of the beak; posterior lateral margins thickened in adult shells, and only rarely showing slight traces of crenulations; surface as in the other valve.

Length of large examples from beak to anterior extremity, 6 inches ; breadth, 4 inches. Average-sized specimens are geuerally a little narrower in proportion to length.

In Dr. Hayden's report of 1872 , I referred this nyster with much doubt to $O$. Idriaensis, Gabb; but at the same time expressed the opin. ion that it would probably prove to be a distinct and undescribed speeies, and suggesting for it the name 0 . Wyomingensis, in case further com parisons should conflrm this suggestion. Since that time I have had an opportunity to see many other examples of it at the locality, as well as to examine specimens of the Culifornian shell in the collection at San Francisco, and no lonzer have any hesitation in regard to the form here under consideration heing specifically distinct. Its lower valve has con stantly a much more pointed, produced, and upward curved beak while none of the large number of specimens have the hinge and beak distorted laterally, as is not uncommonly the case in that species. It has more nearly the characters of the common recent $O$. Virginiana, and o. borcalis, but also differs from these in having the beak of its lower valve constantly more pointed and produced, as well as eurved upward instead of being merely straight, or irregularly distorted. Another marked and constant difference is, that it always bas its muscular sears decidedly smaller, in individuals of corresponding sizes, than we see in the recent shells; while it never shows any traces of the longitudinal ridges or plications often met with in the latter.

Locality and position.-Point of Rocks, Wyoming Territory, where it is sery abundaut in a thin bed just above the upper of the four beds of coal observed near the tops of the hills there. Bitter Creek series.

Anomi (Placunopis ?) GRYPhorhynchus, Meek.

A momia gryphorhywchus, Meek, 1871. Hagden's Annual Report, p. 375.

Compare Ontrea anomiaformis, Roemer, 1852. Kreid Von Texas, p. 75 , tab. ix, fig. 7 a.e

Since describing this little shell in the report cited above, I have had an opportunity to examine a very large uumber of specimens at the lo cality, and after returning home; and from these collections a fuller and more accurata description is given below.

Shell (for an Anomia) of medium size, thin and pearlaceoas, a little obliquely subovate, or more or less orbicular in ontline, usually some what narrowed toward the beak, and more broadly rounded at the opposite margin, often rather couvex, but variable in this respect ; cardi nal margin arcuate transversely, or very slightly truncated, scarcely thicker than other parts of the shell, and without any proper marginal cartilage-facet. Upper valve, (assuming the shell to be an Anomia,) in the more ventricose individuals, with the umbo somewhat attennated and curved so as to present the appearance of the under valre of a Gryphaca, excepting that the obtuse immediate apex is not quite marginal. Surface usually appearing smooth, but in well-preserved specimens (especially those most depressed in form) sometimes very faint traces of fine radiating stris, and thin raised lamellie of growth, may be seen. No scars of attachment observed on any of the specimens.

Iength and treadth of an orbicular specimen, 0.83 inch; convexity of same, 0.33 inch; breadth of an oval specimen of the same length, 0.63 inch; while there are all gradations between these extremes of form.

In fir.: describing this species, I was unable to see any traces of mus. cular scars, in any of the specimens then studied, but many of those since collected show them very clearly. They are preeisely as in $A$ nomia; that is, there are four impressions, one small one by the side of a little submarginal cartilage pit, close up under the beak, and three others near the middle of the valve, the largest one of the latter being nearest the cardinal margin, and the two smaller ones just below the large one. These three central sears are more or less nearly circular or oval, and 
usually distinct from each other, but sometimes in contact or a little blended together.

As the specimens from which the foregoing description was drawn up agree so exactly with the upper valve of Anomia, both in all internal and external characters, it may be asked, why should there be any donbt in regard to the shell really belonging to that genus ? The rea. son for doubt on this point is, that among thousands of perfect separate valves, not a single one with the usual perforation for the passage of a byssal plug, such as we always observe in the under valve of Anomia, is to be seen. While at the locality, diligent search was made, among vast numbers of well-preserved separate valves, for some traces of such a perforated valve, without success. It is true we found a few mnch depressed valves, some indeed quite flat, but all alike entirely without any perforation, or even emargination. These few flat valves found usually have the cardiual margin a little more truncated than theothers, but agree well with them in size, general ontline, texture, surface-mark. ings, and their muscular impressions, as well as in never baving their more depressed beak quite marginal. No two specimens, however, were fonnd united in such a manner as to show that the flat and convex valves belong to the same individuals. Yet it is worthy of note that if these flat and slightly convex valves are not the opposite valves of the ventricose deeper oues, we must view all of the countless thousands of individuals, almost entirely composing a bed 18 inches to 2 feet in thick. ness, as upper valves only, (assuming the fossilto be an Anomia, and believe that, by some unaccountable ageucy, these were deposited here together, without the admixture of any of the opposite valves. At one time I was inclined to think this shell might belong to Morris and Ly. cett's genus Placunopsis, which, it will be remembered, agrees with Anowia, excepting in having no sinus or perforation in the lower valse; and it is possible that this may be the case. There are, bowever, some objections to this view. In the first place, Placunopsis has not, I believe, been found above the Oolite, while the bed in which the fossil under consideration occurs, if even Cretaceous, must belong to the upper part of that nystem. Again, the flat c : depressed specimens, that this view would require to corresjond to the under valve of Placunopsis, are found, on eritical examination, to have their slight obliquity in the same direction as that of the deeper valves, instead of the reverse, as would be the case if the two forms are the opposite valves of the same shell."

From these facts, and the exact agreemeat in the number and ar. rangement of the muscular impressions. in all of these speciunens, it seems more probable that they are all the same ralve of the shell, va. rying it their convexity in different individuals. This, it is true, wonld leave unexplained the cause of the entire absence of any of the opposite or lower valves, whether it be an Anomia or a Placunopsis. Still, it is well known that currents sometimes perform curions freaks, in the way of assorting from other material and depositing objects of like kinds together.

In most respects, this shell agrees so nearly with Ostrea anomiaformis, of Roemer, (Kreid. Von Texas, p. 75, pl. ix, fig. $7 a-c$, from the Upper Cretaceous of Texas, that I have even suspected that it might be the same. His figures, however, represent a rather moro attenuated beak of the convex valves, and less obliquity, both in the convex and flat valves. A nuch more important difference, supposing bis figures to be - I mean that the obliquity is in the same diroetion, viewing the two forms both is
the rame toay either lookitg at the interior or exterior. exact in all respects, is to be obscrved in the muscular impressions, there being only one central impression represented in his Fig. $7 \epsilon$, instead of three; though above this, he shows the same kind of a little transverse cartilage $?$ pit, and small round impression by its side, seen in our shell; only both are placed farther in from the margin. Still, as the larger ceutral scar of his figure shows some slight indications of division, and the three central scars in our shell are sometimes in contact, I should not be surprised it a critical comparison would show that there are no real differeaces between the muscular impressions of the Texas shell and that under consideration. That our shell is not an oyster, however, is clearly evident, from its muscular impressions, as well as from its want of a marginal eartilage-facet, aud never having its beaks quite marginal. From the same submargiual character of the beaks in the form figured by Roemer, and its want of a true marginal cartilage-facet, as well as from its general physiognomy, I do not hexitate to express the opinion that it is not a true oyster. While looking through the California State geological collection, at San Franciseo, last summer, I saw specimens of a shell either identical with that here deseribed, or very closely allied to it, marked "San Diego, Cretaceous, Mr. Morse, collector."

Locality and position.-Two miles below Point of Rocks, Wyoming. Bitter Creek series.

\section{Corbicula (VElonitina) CYTHERiformis, M. and H.?}

Cyrena (Corbienla ?) cytheriformix, M. and H., 1860. Proceed. Acad., May, p. 176.

The shell I here refer with doubt to the above species is certainly a very elosely allied form, if not the sume. About the only external difference $i$ have been able to see, on comparison with the types of the C. cytheriformis, is that specinens here under consideration usually bave the beaks rather more elevated, a little more pointed, and slightly lese obliqne. Their posterior dorsal slope is also a little straigbter in most specimens. On examining a considerable number of individuals, however, they are fond to vary more or less in most of these characters, so that they are found to vary more or less in most of these characters, so that
if there are no differences in the, hinge and interior, the slight external differences may be only such as might be produced by local conditions.

Of the form under consideration, we have specimens showing perfectly the hinge, and muscular and pallial impressions, as well as all of the external characters. These show that the cardinal teeth ba: e the back. ward obliquity of the type of the group Veloritina, and that the laterals are elongated nearly as in Corbicula, though not quite so long, nor so distinctly striated; and that the posterior lateral is separated, by nearly its own length, from the posterior cardinal. The hinge characters are, therefore, almost exactly intermediate between Corbicula and Veloritina the chief difference from the latter group being the slender elongated character of the anterior lateral tooth, as in Corbicula. Uufortunatels we have no specimens of the typical $C$. cytheriformis showing the hinge clearly enough for minute comparisons. I suspect, however, that specific differences will be found between the hinge of that form and the speci. mens under consideration. Both have the pallia! impression provided with a sballow rounded sinus.

Locality and position.-Point of Rorks, on Bitter Creek, Wyoming, near the bottom of section seen there; as well as at a much higher bori. zon, at Black Butte Station, on the Union Pacifie Railroad, Wyoming. Bitter Creek series. 


\section{Corbicula 9 prata, var. crassidscula, Meek.}

Corbicula f fracta, Meek, 1870. Hayden's Annual Report for that year, page 314. This shell agrees so very closely in form and size, as well as in its hinge and paliial and muscular impressions, surface, characters, \&c., with the species I have described in the report above cited, from the alale over one of the Hallville beds, under the name Corbicula fracta, that it hardly seems proper to separate it specifically. Yet, in the thick. ness of the substance of these shells from the two localities and horizons, there is a very marked difference; those from Hallville being extremely thin, even in the largest specimens, the thickness not measuring more than from 0.02 to 0.03 inch, while in examples of corresponding size of those here under consideration, it measures from 0.10 to 0.12 inch in thicknes8. The latter also seem to be more convex, but the Hallville specimens being generally more or less flattened between the lamine of the shale, it is difficult to know exactly how far this want of convexity may be due to accidental pressure.

I am aware that shells fonnd in argillaceous shales are nsnally thinner than examples of the same species from more calcareous deposits; but I have never seen a difference of this kind so strongly unarked in specimens certainly known to belong to the same species. This thicker shell is, therefore, placed here provisionally as a variety of $C$. fracta, under the name crassiuscula, which it eau retain if further comparisons should show it to be specifically distinet.

In describing the species $C$. fracta, I noticed severaboints of difference between it and the characteristic forms of Corbicula and Cyrena, and suggested for the group of which it may be resarded as the type the subgeneric name Leptesthes. The peculiarities mentioned were the extreme thinuess of the shell, and its very elongated depressed form. The specimens here under consideration show that the thinness of the shell is not a constant character, though they at the same time show chat this type presents other more importint differences, of which I had seen indications before, but which I did not mention especially, because the specimens then seen were not sufliciently well preserved to permit these characters to be clealy defined. They are differences in the hinge. For instance, aithough the primary teeth do not differ materially from those of Corbicula and Cyrenn, the anterior lateral tooth differs from that of Cyrena in being linear aud elongated parallel to the linge-mar. gin, as well as sligbtly striated, thus agreeing with the corresponding tooth of Corbicula. Its posterior lateral tooth, however, on the other hand, is more nearly as in Cyrena, being shorter than in Corbicula, and placed very remote from the cardinal teeth, while the intervening cardinal margins are wide, flat, and, when the valves are united, close fittiug. Yet this tooth is also striated as in Corbicula, though less distinctly. $\Delta$ gain, the ligament is also decidedly longer than in Corlvicula, or than is usual in Cyrena, and also less protininent, there beisg apparently no elevated fulcrum for its attachment. The pallial live shows a shallos subsemicis cular sinus.

It will thus be seen that these shells combine some of the characters of both Cyrena and Corbicula, withont agreeing exactly with either. It is well known to paleontologists, however, who have stndied fossil. shelis of these groups, that there are many species that show interme diate characters between these genera, so that some eminent anthorities do not admit the genus Corbicula, but place the whole under Cyrena. Should this view prevail, the forms bere under consideration might be so disposed of. Still, even in that case, it wonld seem desirable and convenient to separate them subgenerically, by writing the nane Cyrena (Leptesthes) fracta. If the two groups Cyrena and Corbioula, however, are to be regarded as distinct genera, there would be nearly or quite as good reasons for so regarding Leptesthes as a genus.

Locality and position.-Black Butte Station, Wyoming, upper beds. Bitter Creek series.

\section{Cormicula (Velonitina) Bannisteri, Meek.}

Shell of about medium size, subglobose, the valves being very con. rex and subcircular is outline; ventral margin forming a regular semi. circular curve; anterior and posterior margins nearly equally, and more narrowly, rounded; dorsal outline declining distinctly from the beaks, the anterior slope being more abrupt and concave in outline, and the posterior very convex, with the prosterior dorsal margins of the valven inflected so as to form a deep, rather broad sulcus when the valves are united; beaks prominent, ventricose, incurved, contiguous, and placed about one-third the length of the shell from the auterior margin; luun. lar recrion impressed; surface ornamented with fine lines and small but rather distinct, somewhat regularly arranged, concentric ridges and furrows. (Hinges and interior unknown.)

Length, 0.87 inch ; height, 0.83 inch; convexity, 0.66 inch.

This is a very neat, symmetrical shell, readily distinguished from the other species yet known from the rocks of this region, by its short, very consex form, and ratber distinct, regular, concentric ridges and furrows. In one character it agrees with $C$. Durkeci, from the brackish.water beds at Bear River City, more nearly than any other species $I$ bave yet seen. That is, in having the posterior dorsal region of its valves strongly inflected, so as to form a deep, broad sulcus or escutcheon along this slope when the valves are united. Its rounded, ventricose form and stronger concentric markings, however, readily separate it from that shell, from which it also differs in being mnch sinaller, while its ribbons form shows it to be an adult shell. It is also relnted to $C$. occilentalis, M. \& H., from the estuary beds near the mouth of Judith River, but it is more rounded in outline, more gibbous, and differs in the inflected char. acter of its posterior dorsal region, its stronger surface-markings, and more impressed lunule. I have not ret seen its hinge or interior, but from its general external characters, I have little doubt that it belongt to the section Veloritina.

The specific name is given in honor of Dr. Henry M. Banaister, whe discovered the only specimen of the species I have seen.

Locality and position.-Bitter Creek series, Black Butte Station Wyoming at the same horizon as the large saurian found there.

\section{Corbula undipfra, Meek.}

Shell of moderate size, trigonal-subovate, rather convex, the inequal ity of the valves not being very strongly marked, though always obvi ous; beaks moderately prominent, (that of the right valve being only a little more elevated than the other, located in advance of the middie, contiguens, and incurved, with a scarcels perceptible forward inclination, subalar at the connection of its margin with the base; posterior dorsal slope more or less convex in ontline; anterior margin rather short and rounded; base semi-ovate in outline, being most prominent anteriorly, and somewhat straightened behind; left $33 \mathrm{G} \mathrm{s}$ 
ralve about one-fourth less convex than the other, with posterior unbovalve about one-fourth less convex the beak to the posterior basal extremnal slope distiuctly angular from the beak to the less strongly angulated ity; right valve with posterior umbonal slope less strongly atully smal surface of both valves ornamenteil with coucentric ridges, generally smal and regular on the umbonal region, but often swelling out into a few very prominent, angular folds with ronuded depressions, marked by distinc lines of growth, and some small ridges between, on the lower balf of the valves; all the ridges and folds generally becoming obsolete behind the valves; all the ridges imid folds gener but continued forward to the front. angular, posterior, umbonal slopes, bimen, 0.76 inch; heiglit to top of Lef right valre, $0.58 \mathrm{inch}$; umbo of left valve, 0.56 ; height to top of same of

convexity of the two valves united, 0 . A inch.

The most marked feature of this species is its very strongly elevated, sharp, irregular, concentric ridges that rise into larger angular folde below the middle of the valves, this $y$. ance to both valves. C. perundatu, of $\mathrm{H}$. and $\mathrm{H}_{\text {., has nearly as strong }}$ concentric ridges, but they are inuch more regular, and insteat of being sharply angular, with rounderl, broader spaces between, as in the species here described, they are broadly rounded, with narrow, angular furrows between, on that shell,

slopes of this species. Locality and position.-Tock Spring Station, Centrat
Wyoming Territory. Upler part of Bitter Creek series.

\section{Cormula tropidophora. Meek.}

Shell distinctly trigonal, witl, height a little more than three fourths the leugth, metherately conves; valves subequal, the right one being onls the feng, a litte mo com angular from the beaks

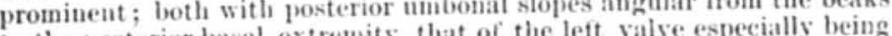
to the posterior basil extremity, that of the left vilve especially being very distinctly so, while the sides of the valves, (partienlarly that of the left valve, in front of the angular umbonal slope, are flattened; anterior outline truneated with slight obliquity from the beaks to the anteriot outhine truncated basal extremity, which is stroang horty inflected toward each other base; posterior dorsal margins abruptly intected tow slope from the from the umbonal ridge, and forming a nearly straight slope from the beaks to the posterior basal extremity, which is distinctly angular; pailial margin gently conves in outline from the front to the posterior angle: beatis moderitely prominent, oblique, incurved, contiguons, and located alout half way between the middle and the anterior margin. located about halt way between the miduth, and more or less defined Surface ornamented by fine limes of growth, and more lower half of ridges and furrows that are usually most distinct on the lower hath of the right valve. Cartilage process of the left valve spoon-shaped, rather promineut, and larger than the pit by its side for the reception of the
tooth of the other valve. Singe of right valve unknown.)

Leugth of a medium-sized specimen, 0.72 inch; beight to top of beak of of tiglin walves united, 0.33 incl.

This shell is very cloxely allied to $C$. subtrigonalis, M. and H., with whis I lave wheh I have even been inclined to think it might be identical. The typical specimen of that species is a left valve only, so that we have not the means of making a very thorough comparison. Compared witl this kft valve, however, the corresponding valve of the form under consideration although agreeing closely in general outline, is seen to be sidect, has its umbo less gibbous, and not so atrongly incurved, while its posterior umbonal rilge is much more angular. Its cartilage-process is also larger and more prominent, and the pit by its side for the reception of the tooth of the other valve is provtionally amaller. As the specimen of C.subtrigonalis is evidently (1) posterior un. Water-worn, however, the more lonal ridge may be in part, at least, due to that canse, though

other difference mentioned could hardly have been so produced. Along with the typieal specimens of the species here descrilwed there are separate right valves, apparently of this species, a little larger than the corresponding valve of the perfect specimen from which the descrip. fion was drawn up. This valve shows a distinct furrow along the inner in of the lower margin for the reception of the edge of the other valve, side of the lower margin for the reception of the ed ze of the other vane, which furrow doubtless also exists in the typul specimen, but cannot be seen because the two valves are united. There is also another right higher and shorter, and has its beaks almost exactly central, so as to prosent more nearly the outline of an equilateral triangle. This may ly.long to a distinct but allied species; if not, it would indicate a con.

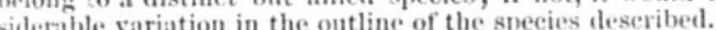

Locality and position.-Point of Rorks, Wyoming. Bitter Creek series.

Goniobasis? insctepta, Meek.

Shell terete, or ciongate-subconical; volutions apparently about ten, 作

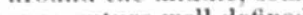
imes slightly concase above in large-specimens; stome well defined; un rture unknown. Surface ornamented by distulet, regular, nearly traight, or slightly arched vertical costre, about sixteen of which may be conted on each volution, while crossing these are smaller regular, loop, revolving furrows that eut each rib into tive or six little transrerse

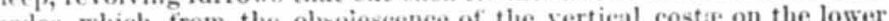
aikles, which, from the obso more or less contimous revolving lines on that part of the sheli.

The specimens of this species yet obtained are too imperfect to afford the meaus of giving accurate measurements. Iulging, however, from come of those in the collection, large adult individuals would seem to hase attained a length of 1.40 inches, with a breadth of body-volution of

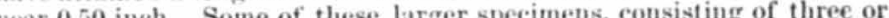
four of the lower volutions, show bat a very gradual decrease in breadth four of the lower volutions, show bat a very gradual decrease in breadth npward; while some of those composed of the upper part of the shell
indicate a divergence of abont 15 for the angle of that portion of the spine.

As none of the specimens show the aperture, it is not possible to fotermine, from those yet seen, whether this shell really belongs to the fresh water genus Goniolasis, or to some marine genus, although the

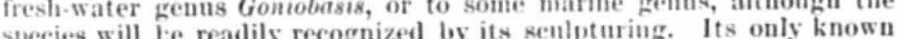
species will te readily recognized by its senlpturing. Its only known associates are fragments of Oxtrea and Modiola, with Corbula undifera, an association that would certainly favor the conclusion that it should be referred to a marine genus, in which case it woulu most probably fall into Bittium, and have to be called $B$. insculpta. We have, however, several examples of unquestionable fresh-water shells associated with marine types, in some of the rocks of this region; while the general aspect of this shell seems, as far as known, to assoriate it with Gorio. basis. The fact, too, that nearly all the specimens yet seeu are frag. mentary, seems to indicate that the species did not live in the same 
waters with the other forms fonnd associated with it, but that the specimens may have been washed into the sea from streams on the neighbor. ing shores.

In several respects this species resembles Cerithium nexicanum, Gabi, figured and deseribed in the California geological report, from the Cretaceous rocks of Mexico. It differs, however, in showing, no far as yet known, no trices of the varices seen on that shell; while the little nodes formed by the cossing of its revolving lines and vertical costae are trans. versely elongated, insteal of rounded, as on the Mexican species, which is probably a Cerithium.

Localify aul poxition.- Rock Spring, wyoming, from a little above the nain ten-foot bed of coal at that locality. Bitter Creek series.

\section{Mrlaxia Gonionasis (?) wromingersis, Meek.}

Sheli attaining a rather large size, subterete, or very elongate-conical; rolutions about nine or ten, the upper ones flattened-convex, and the lowe twe or three mern prouinent ; suture well defined but not deen. Surlace of upuer volutions oronatented by sull, regular, rather $r$ volntions ortatmented by stmail, regular, rather crowded, and slightly arehed vertieal costa, crossed by five or six reguiar revolving lines, that impart to them a granular or minutely nodular apperance; firther down, the vertical costa become less and less distinet, so as nearly or quite to disappear on the lower turns, while the revolving lines becone proportionally stronger, especially one a little abose the midlle of each volution, which develops a revolving row of rather distinct notes that are compressed from above and bolow, so as to become sharply prominent on the lower two volutions, thus giving them an angular: apprearance; though the last one is rounded be low this angle. (Aperture unknown.)

Length, about '2 inches; breadth, about 0.70 inch.

It is not probable that this shell belongs properly either to the genus Welania or Goniobasis, as those renera are now restricted by the best authorities in concholors; thougl. I huve little doubt that it will fall into Melenin, as defined and understood by those who give greater lati. tude to genera. It is probable that when its aperture can be seen, it will be found to present characters that would warrant its separation under a new generic name. I suspect, indeed, that some others of our fossilshells of this liud, frem the fresh aud hrackish water-beds of the

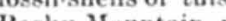
andefined groups; but until better speciueus ean be obtained, we can only range them provisionally under the established genera to which they seem to be most nearly allied. Undoubtedly at some future time specimens will be found sufliciently well preserved to enable the paleontologist to claxsify them more correctly. It seems desitable, however, in the to che time, to define them, so that they ean be used by geologists in dentifying strata, as it mas be ages before perfect specimens can be found; while those we now have can be readily identified specifically by their ormamentation and other well-marked eharacters.

Locality and position.- Black Butte Station, Union Pacific Railroad, Wyoming Territory. Upper beds Bitter Creek series.

\section{TERTIARY FORMS.}

Phisa Bridgerensis, Meek.

Shell attaining a large size, suborate in form; spire prominent, conical; volutions four and $\mathrm{a}$ half to five, moderately convex, last one large but not very ventricose; suture well defined; aperture narrow-subovate, arcuate, acutely angular above, and about twice as long as the spire; columella twisted into a rather prominent fold. Surface with fine sharp lines of growth.

Length about 1.15 inches; breadth, 0.66 inch.
This is a flne large species, with a more prominent spire than any of our recent species resembling it in other respects. None of the speci. mens found are perfectly preserved.

Locality and position.-Church Buttes, fourteen miles from Fort Iridger, Wyoming Territory. Tertiary.

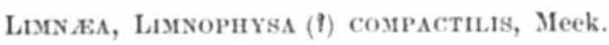

Shell rather small, slender, subfusiform; spire conieal, a little longer than the aperture; volutions about six, very little conves, and (for a Limnae compactly wound together; last one not ventricose, but rather produced below; suture divtinct though shallow, and but little oblique; prerture uarrow subovate, very narrowly rounded below, and acutely aperture narrow subovate, very narrowly rounded betow, anter lip not dilated; columella a little twisted, and angular above; outer lip not dilated; columella a little twisted, and
apparently so as to form a small oblique plication. Surface smooth.

Length of a mediun-size specimen, 0.50 inch, breadt h 0.20 inch; length of aperture 0.2 .2 inch; breadth of aperture 0.10 inch.

I have not seen specimens of this little shell showing the colnmell carly enough to be sure that it belongs to the senus Limnara. There is a compactness in the rolling together of the volutions of the spire, aud a want of obliquity and decpress, observable in the suture, that are not often seen in that genus, and remind one of rome forms referred to sections of the old genus Bulimus, such, for instance, as B. (Thats. mustus) californicus.

Locality and position.-Upperbeds of the series exposed at Separation, on the Cnion Pacific Railroal, apparently belonging to the Tertiary.

$$
\text { PUPA? LEHDY, Meek. }
$$

Shell clavate-suberlindrical, being abont three times as long as wide, a little wider abore the middle than below, and very obtuse at the anc volutions about fifteen, vers compactly coiled together, and ex tremely marrow in their sertical diameter; suture merely linear, and so sightly oblique as to appear to the eje almost at right angles to the longer axis of the shell; aperture unknown, bnt apparently small. Sur. fice ornamented by small, comparatively distinct, regular, crowded, obligue stria cf growth.

Length about 0.55 inch; greatest breadth, 0.20 inch.

The volutions of this shell are so compactly coiled, so very narrow, and show so little obliquity, as to rive it the appearance of the abdomen of some insects, the volutions looking like rings, and the obtuse apex of the spire like the posterior extremity of an insect abdomen. I have seen but two specimens, and neither of these shows the aperture; consequently it is not possible to determine whether or not it is a true Pupa. Indeed its subeylindrical form, and numerous volutions, gise it much the appearance of Holospira of Albers, and it is quite probable that when speciums showing its aperture can be examined the name mas have to be changed to Holospira Leidyi. Specifically it rather may have to be changed to Holospira Leidyi. Specifically it rather
closely resembles $H$. Remondi, an existing species found at Sonora, Mexico. It has a more obtuse apex, bowever, than that species, and also differs in having more narrow and compactly coiled volutions, and a less oblique suture. 
The specific name of this interesting little shell is given in honor of Professor Joseph Leidy, the distingusished comparative anatomist of

Philatelplia, who divesteted tore of the specimens from which the description was drawn up.

Locality and positien.-Tentiary rucks twelve miles south of Fort Bridger, Wyoming Teritory

R EPORT

$6 w_{A}$

\section{GEOLOGICAL RECONNAISSANCE} Atovg rut:

CYION PACIFIC RAILROAD. 


\section{REPORT OP A GEOLOGICAL RECONNOISSANCE ALONG THE}

UNION PACIFIC RAILROAD.

The following pages contain an account of a portion of the geological reconnaissance made by Mr. Meek and myself in the coal-bearing forma. tions along the line of the Union Pacific Railroad in the summer of 1872 , in connection with the United States geological surver of the 1872 , in connection with the United States geological survey of the
Territories, Dr. F. V. Hayden in charge. The work comprised the col. leetion of fossils from these beds, and taking sections and such col. notes as would serve for the correct establishment of the varions hori zons in which the collections were made, with a view of obtaining fuller

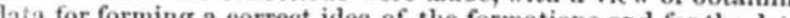
inta for ther age. I liave, therefore, given a cons tion of their age. I have, therefore, given a consecutive account of all the loeali.ies visited by us, which are not elsewhere reported on by Mr. Meek, with our examinations at each; not, however, entering into ques. tions of economic geology, or of general structure, except in so far as appeated necessary for the elucidation of the points in view. In In making this report, in arldition to those taken by myself, I have been kindly allowed the use of the field-notes of Mr. Meek.

Carbox.-The first locality where we made any examinations was Carbon Station, the easternmost point where the coal of this region has ben opened and extensively worked. Here wo stopped a day and ex amined carcully for fossils in the uatural and artificial exposures near the station. The structure here seemed a little complex, the beds consiterably fuulted and upturned, but we obtained an ajproximate section sufliciently accurate as to the relative location of the different bed from which we obtained specimens. The lifferent beds from which we obtained specimens. The coal appears to lie in a local synclinal, the dip of the rocks immediately west of the station being from 200 to 300 in a general direction from east-southeast to southeast, while on the opposite side of the little basin or trough it was about 15 to 20 , the direction varying from southwest to west or north west. From the different exjosures, and from the testimony of the miners as to the beds passed througi in sinkitug shafts, we made the following approximate rection:

\section{Section of the strata at Curbon, Wyoming.}

1. Argillaceous shale.

2. Coal

3. Sandistone and sandy shale.

4. Ar rillaceous shale.

5. Coal

6. Lifht colored sandy and argillaceons shales, with im

7.

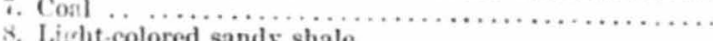

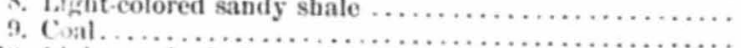

10. Light sandy beds, sandstone, and, perhaps, some conl,

(estimated) .......................... 40 to 50

Feet In

80

0

$\begin{array}{rr}59 & 0 \\ 0 & 5\end{array}$

90

18 to 200

3 to 50

$\begin{array}{ll}9 & 0\end{array}$

4 or 50 
11. Light grayish sandstone, weathering yellowish or red. dish, and varying much in hardness in different por

tions, irregularly bedded, (estimated)

Feet. In.

12. Thiu-bedded, hard, redilish sandstone

The upper members of this section, from 1 to 5 inclusive, were given as the beds, in their order, passed through in sinking an air-sbaft, and were not seen in place by either of ns. From an opening made near the railroad track, which penetrated a portion of these beds, a quantity of fragments of a lominated, ashy colorel sumlstone were thrown out, which were

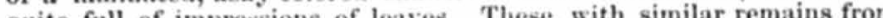
quite full of iniprt all the fossils we obtained, though it was reported to us that shells had been found in the beds underneath the main coal seam, No. 5. Number 10 of the section is nowhere well exposed, and the thickness of these beds, as well as of those immediately below, could only be estimated in a very general way. Number 11 forms the high bluff of fantantieally-weathered sumbtome, which is to be seen on the ather sorms the extremity of a ridge stretching away to the north and east. This ap. pears to be the eastern elge of an anticlinal valley, as in the opposit ridge, a mile or two distant, the beds seemed to have a reversed dip to the west or west-northwest.

ForT STEELE Our next stopping place west of Carbon was at Fort Steele, where we made some examinations of the strata in the extensire exposures along the Platte River, on the southern side of the rail road at this point. The cliffs on the northern side were not visited, as they were merely the equivalents of the beds examined, and could only present local variations. Owing to a lack of time we also did not visi the interesting localities on the railroad east of the station at the fort.

Passing up the valley of the Platte from Fort Steele, the vicinity of the post for the first mile, or a little more, is oceupied by rounded hillocks of whitish clays, which probably form the lowest of the beds which are exposed by the rift of the anticlinal at this point. Beyond that distance, however, there appears a series of ridges of harder sand stone rocks abutting immediately upon the left bauk of the river for the distance of a mile or more. The hollows, or parallel valleys between the ridges, are cansed by the enosion of the less resistant intermediate the ridges, are canses The wheres of heary-betded mrayish-buft and drab sambstones of various degrees of hardness, a!iernating to some extent with ashy and dark colored shales, amountin; altogether to several thousand fiet. The sandstones pre sented a very well warked jointed structure, perpendicular to the lamination, the sloping faces of some of the ridges, when viewed from a little distanee, af vertical strata. The dip of the y ridges along the river was nearly due south-southeast, and the angle in the lowest beds about $35^{\circ}$, then gradually increasing to over 40 or 45 in the middle of the series, and again decreasing to from 15 to 20 at the upper limit of our examinations. Beyond that point, the beds appear nealy or quite horizontal. A little below the middle of the series we found in bed of light colored shale a stratum of abont 4 feet in thick a

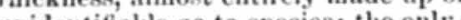
unidentifiable as to species; the only animal remains found in the whole thickness of sandstones and shales. In the upper part of the series we observed varions seams of dark carbonaceous sbale approaching lignite, and at least one small seam of conl, but without associated fossils, other than indistinct regetable remaius. In the heavy saudstone-beds we observed in several places a curious branched fucoidal impression, (Haly. menites,) which was afterward poticed by us in sandstone-beds at, vari ous localities farther west. As far as is indicated by the fossil remains found by us, there are no grounds for rendering any positive opinion as to the age of this series; the lower clays, however, have been deter mined, from fossils from that horizon, to belong to the Cretaceous, and it is not impossible that these overlying sandstoues may either wholly or in part he properly referred to that period.

RAWLISgs, - Between Fort Steele and Rawlings, the pext station west, we made no notes or collectious, but stopped several lays at the latter place to examine the lower formations there exposed. The mount ain immediately noth of the rillage is waitly composed of light-grayish or fiesh-colored syenitic granite, above which the sedimeutary beds lie tilted at various angles and in diflerent directions on the several sides of the hill. Immediately above the granite is a distinctly stratified deposit of siliceous conglomerate, passing in places into a coarse pebbly sandstone, but mainly made up of rounded pebbles of whitish quartz, rarely over one inch in diameter, in a siliceous matrix. This passes gradually into the beds above; it may be put down, however, as about 65 or 80 feet at its greatest thickness. Above this we have between 300 and 400 feet of hard grayish saudst one, approachiag quart rite, regu larly bediled, the layers seldom exceeling a foot in thickness. Its color on weatherel surfaces varies from a light gray to a reddish brown, a tinge of the latter color predominating throughont the whole; on freshly fractured surfaces, however, it is generally light gray, or is nearly white. The lower and heavier beds are almost a true quartzite; this character is less apparent toward the top, and some layers appear to be full of rough fucoidal casts, which, however, were too imperfect to be of value as specimeus. Vo other fossils whatever were fonnd, in spite of a very careful search; but while there was nothing absolutely characteristic, Mr. Mcek was inclined from their general resemblance to undoubted Silurian beds in the western country, as well as their posi. tion and the character of the contained fucoidal traces, to refer these beds to the Lower Silurian, and possibly to its lowest member. Above the satudstone is from 10 to 15 feet of dark colored ferruginons sand stone, in places containing a few pebbles, and even approaching the character of a conglomerate. The bed of iron ore worked on the north. eastern side of the mountain represents, I think, a portion of this stratum. The sandstone with its ferruginous capping is well seen in the two hills between wheh the railruad passes about a balf mile west of the station, and also in its upper portion at the base of the hill at Cherokee spriug, three or four miles northwest of the village. Un the sunthwestern corner of the mountain, the sandstone-beds which form the summit of an isolated spur extending in that direction are beanti. fully polished and finely striated from the action of sand carried by the wind, the angles of the rock still being preserved.

Immediately above the ferruginous upper layer of the sandstone is a leavy limestone formation, the total thickness of which ean hardly be less than 300 feet, and is probably much more. It is a hard, splintering roek, in places cherty, generally of a whitish or light grayish color, but with rome layers dark bluish.gray, In it we found a specimen or two of an Athyris closely resembling, if not identical with, $A$, subtilita of the coal measures; indeed, there seems to be no doubt as to the carbonifer. ous age of this rock. This limestone appears on the northeastern slope of the mountain for about 100 feet of its lower portuon, and can be seen in ridges on the plain at its base. It also caps the hills, between which the railroad-track passes just west of the station, aud is also shown in 
its full thickness in the hills near Cherokee Spring. Above the limestone is a light buff or yellowish sandstone weathering into thin laminte in the exposures which onterop in several places in the hills sonth of the railroad near the station, but we did not measnre its thickness nor see its point of junction with the bels ielow. The vertical distance between the highest outcrop of this rock visited by us and the base of the limestone we estimated at from 600 to 800 feet.

The rocks above the granite dip to all points of the compass, from nearly north on the northeustern face of the mountain, around by east and southeast, to sonthwest in the hills near Cherokee Spring. In the hills near the station it is about 100 sontheast, aud is continuous on both sides of the curious gap through which the railroad passes. It increases in angle in the higher sandstone beds, above the limestone, which I have mentioned as outcropping in the hills south of the rail road, being there not less than $20 \%$ or $30 \%$, still preserving, however, the satme direction. At Cherokes Spring the beds are also tilted at a high angle, varying from 200 to 300 , apparently greatest in the lower sand stones. In the northeastern exposures on the long slope of the mount ain it was slight, not averaging over $10^{\circ}$ or $12{ }^{\circ}$; in direction, ranging from south of east to nearly north.

Separation.-We did not atteinpt to make thorough examinations at Rawlings, or to work out the connection between these lower formations and the Cretaceous, as more time wonld have been required for this than we could have well given. We therefore passed on to Separation, the next stopping place to the west ward, where we spent one day. The station is situated in a level country with no very prominent expos ures of rock in place nearer than a mile and a half or more. At that distance, however, in a direction a little sonth of east, we reached the first of a series of low ridges extending across the country in a peneral north and south direction, composed of thin-bedded sandstones dipping at an angle of from $10^{\circ}$ to $15^{\circ}$ to the west, or a little north of west. These ridges are caused by the harder sandstone-beds standing ont prominently from the softer shales and clays which form the great mass of the beds here. Walking directly across the dip we passed over eleven of these ridges in the estimateci distance of somewhist less than two miles, the valleys between, ax a general rule, affording no extos. ures. At that distance the reries of low rilges ended in a high sloping bluff of heavy-beddet, grayish buff mantstone, faced in part with a largely eroded bluish-white bed. We noticel ten different keams of Carbonaceons shale or coal in the ridges, some of which donbtless represent workable beds. In the upper part of the first ridge, in the highest beds of the series, we collected specimers of leaves of deciduons trees, which were very abundant in some of the thin lasers of sand stone. The only other fossils we obtained were found in a six inch bed in the second ridge, from which we obtained specimens of fresh-water shells, Lymnat, Viriparus, Goniobasis, and Unio, nearly ail fragmentary or in a poor state of preservation. The more easteru ridges, the beds of which are lower in geological position, afforded no remains whatever, either animal or vegetable, to such sareh as we were able to rive.

At one point on the plain between the first ridge and the station, sancl. stone-beds appear at the surface, but with a very much reduces angle of dip, apparently scarcely over $3 \circ$ or $4 \circ$, the direction still toward the west. The strata appear to assume a horizontal position very rapidly in that direction. 'Taking the average of the angle of the dip at any point from $10^{\circ}$ up to $15^{\circ}$, between which it probably ranges, perhaps even exceeding the latter fignre, it will readily be seen that an immense thickness is included in these ridges, not less than 1,800 or 2,000 feet.
Adding to this several hundred feet of beds not well exposed, but which must intervene between the westernmost ridge and the point where the dip ceases and the strata become horizontal, we have, at a moderate calculation, from 2,100 to 2,500 feet of these whitish clays and darker shales and sandstones above the heavy.bedded sandistone in the bluft which formed the lowest geological horizon in our hurried examination at this point. We bave uo positive evidence as to the character of the intermediate beds between the more widely separated ridges, of the wash from the elevations and surface-soil covered all the evidences of stratification. stratification. An artesian boring at the station gives a record of alteruations of clays, shales, and soft arenaceous beds for some 540 feet, which is probably the usual character of the softer beds generally. The greater part of this thickness is probably of Tertiary age; the lower portion, however, may belong to the unper part of the Cretaceous. There are no posit,ve evidences of any unconformability, notwithstand. ing the stidden lessening of the angle of the dip, and no recognizable horizon of separation of the two formations in the whole series above the heary sandstone.

Біттек СвеЕк.-From Separation we passed on by railroad to Bitter Creek, making no stoppage at intermediate stations. For the whole distance there apperared to be ouly exposures of higher Tertiary beds, mostly horizontal, or nearly so, which fill the trough between these sta. tions. At Bitter Creek we stopped over one dav and examined these upper beds, as they are to be seen in the immediate vicinity of the station and in the hill known under the name of Table lock, some fonr miles or more distant.

Table lock is a spur of the range of Tertiary bills which appear for a long distance on the sonthern side of the railroal, and also to some extent it conical ontliges to the northward. In its upper portion it is itself an outlier, the strata of which this part of the hill is composed having been washed away in its immediate vicinity. The section it afforded is as follows, the beds numbered from above downward :

Section of the beds exposed in Table Rock.

1. Hard brownish sandstone, largely made up of im perfect casts of Unio, \&s

2. Shale, partly carbonaceous

3. Light-brownish sandstone, massive and incoherent

4. Sardy shales, light colored

5. Same as No, 3.

6. Shaly sandstone, light brown or buft

7. Sandstone, same as No. 3

8. Light-colored xhaly sandstone, with interealated beils of clay and shale

9. Harder and slightiy darker colored sandstone, with a great abundance of fossils, \&c., Melania, Viripa. rus, \&c., top of first bench.

10. Shaly beds

11. Sandstone beds, containing Melania, Ünio, \&e

12. Shaly beds, with a few intercalated thin layers of harder sandstone, and a four-foot seam of dark shale, about midway from top to bottom.

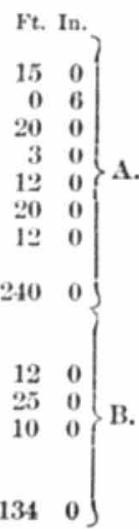

From the summit of the rock we observed, five or six miles array to the eastward, benches composed of beds superior in position to any in the above section, the thickness of which I ronghly estimated at 200 feet. The thicknesses of the different members of the section itself are in a 
reat measure only estimates, as the circumstances were not altogether fasorable to the making of accurate measurements. The dip of the strata is about east-southeast, from $3^{\circ}$ to $5^{\circ}$, apparently diminishing to the eastward.

The bed No. 9 of the section, in some of its thinner layers, appears to be almost entirely made up of fossil remains, mostly of a species of Melanian, but also a lesser proportion of a species of Viviparus. In places where the rock was decomposed the whole upper surface is cov. pres to the deptl of an inch or more with the loose casts of these fossils, which can here be gathered in any quantity, by simply scraping them off the ledges. Other layers below, No. 11, also contain numerous fossils, but in rery much less abundance, and casts of Unio are fonnd in large nutubers, while they are very scarce in the upper strata. Seareely any fossils were foum in the beds other than those specified.

In the vicinity of Bitter Creek Station, some four or five miles distant in a general westerly or southwesterly direction, Mr.

Meek examined outerops of some 275 feet of alteruat

ing beds of soft grayish and buf sondstones and whit

ish shales and clays, the uppermost of which, judg.

ing from the dip and strike, must have been as

much as 200 feet below the lowest member of the

Table Rock section given ubove. No fossils

were found except fragments of fossil-wool

nothing to characterizeany of the beds. An

artesian boring at the station penetrated

445 feet through very ximilar alterna-

tions of kandstone, shinle, See; the

most noticeable variation in the rec-

ord, as given, being the oceurr
at the depth of 1st feet of an

18-inch seam of black carbon

aceous shale. bietween the

lowest part of the

exposure at the

base of Tuble

Rock and

those ex.

atnined by

Mr. Meek

there is

a long

st reteh

of near.

Fig. 54.

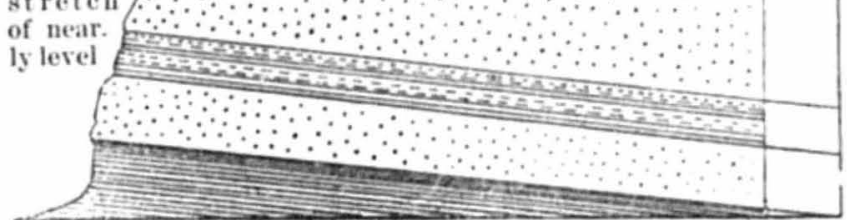

swchos AT H.ATK MTTES

conntry, affording no promineut onterops by which the character of the intermediate beds could be ascertaine.

BLACK nuTTEs.-Between the station of Bitter Creek and that of Black Buttes, the next to the west ward, is a distance of about nine miles by rail. road, but in a direct line it is much less, probably not over seven miles, if, indeed, it is that. A straight line between the two points would run almost directly across the din, which will average, in the whole distance, not over $5 \circ$ or $6 \circ$, thus givin, a probable thickness of the tilted strats, be tween the stations, of crer $\% 000$ feet. We were mable to malke detailed examination for the whole distance; the 275 feet of sandstones, \&e., examined by Mr. Meek, would be included in its upper portion, and at Black Buttes a detailed section of some hundreds of peet of the beds was male by Mr. Meek and nisself. A bove this section, looking awas was made by Mr. Meek and nyself. Above this section, looking away to the eastward, we could see near at hand, from a little eminence, sev. eral hundred feet of alternations of reddish, purple, and bluish-ashy shales and sandstones, with a few streaks of black carbonaceous shales, and beyond them, in the distance, a great derelopment of whitish bed extending as far as anything could be satisfactorily distinguished by the eye. The whole landscape wasabont as desolate as could well be imagiued, a series of steep rocky rilges, formed by the upturned edges of the harder sandstones, with irregular shallow valleys between. Some of the redilish beds suggested, by their appearance, the supposition that their color was dne to the combustion of lignite beds below, a hypothes nation. The succession of the strata will be seen on page 526, Fig. 54.

\section{Section at Black Buttes Station.}

1. Yellowish gray saudstone, vith leaves of palm, (Sabal,) se

3. Blush ashy laninated clays.

3. Thin-bedded grayish and brownish saudstone

1. Dark shale.

5. Bluish laminated clays

6. Ret laminated sandstone and shale.

7. Thin laminated sandstone (6or 8 inches) and yellowixh shales

8. Coal.

i. Jight retor

ght colored laminated sandstone, becoming darker below

10. Shale, dark colored below, and lighter and more sandy above

11. Light gray laminated, shale, eapped with a thin sand. stone.

12. Coal.

13. Arenaceous shales, with a darker seam near midalle

14. Coal $4 \frac{1}{2}$ feet, with dark shale above and below.

. Shale, darker above, with thin laminated sandstone, Oysters

16. Coal and earbonaceous shale.

17. Dark gravish buff sandstone, eoutaining ......... leaves and bones of saurian

18. Sluly beds with thin sandstone lamina

19. Coal' 2 feet, with carbonaceons shale above and below

:0. Thin laminated lark gray and light shales, contain ing anmerous fossil shells (brackish water) in lower portion; some thin lamina of sandstone 
23. Soft bluish white sandstone, mostly massive, but in places thin bedded.

24. Massive light gray or grayish buff sandstone, in places almost dark brown, also becoming laminat. ed in parts

25. Soft light grayish sandy shales and clays .........

26. Grayish buff, massive sandstone

27 . Thin saudstones alternating with grayish shaly clays, the candstones almost entirely disappearirg in the lower portion....

Feet.

15

$70\} \mathrm{F}$

12

20

G.

$130 \int^{0}$

370 to 371 feet.

The above section was mostly made up from Mr. Meek's notes, which were more minute than my own, though they agreed together in the main. It is serviceable in pointing out the exact horizon of the fossils procured here, which were mostly trom the thin layers of Nos. 15,17 and 20 , with some vegetable remains in some of the higher sand 15,17, ast instances failed tone layers. $\mathrm{N}$ art from the for over the exposures would show numerous difference? in the alternation of andstone, shale, sc., from the one above given. The broken charac ter of the ridges eaused by the superior hardness of certain strata or portions of strata over others, sufficiently indicated this variability. The coalbeds themselves, I have reason to believe, partake somewhat of this elarater; in the seetion they appeared to be of the thicknes. in the section they apros mated that a very setne of the opeting it was stated thint a very much greater thickness was found. One or two exceptions, however, may he mentioned to the general rule: the reddish sandstone, No. 6 , appeared, as far as on examinations extended, to be a pretty con-tant stratum, and the heary sandistones, Nos, 23 to 26 inclusive, with their underlying thin laninated thin lanith series of buff aud whitish massire saudstone here, Nos. 23 to 26 , is the same as that which apiears on the other side of the synclinal, at Separation, in the heavy face of grayish buff sandstone covered in place with a thin stratum of whitish rock, which formed the lowest membe of the series obsersed there. The two agree very closely in lithological characters, and apparently also in being the first rocks of this character char weth, and apparestiary bed

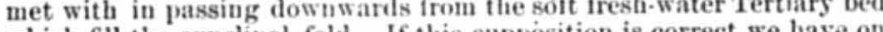
which fill the synchinal fold. If this supposition is correct we have on pretty definite horizon which will materially aid in determining approx imately the age of these beds. It is to be regretted that our examinations near Separation afforded no fossils from the strata nearest the beary sandstone.

The fossils found here, besides the vertebrate remains, were mostly from No. 20, and consisted of shells of the genera Ostrea, Anomia, Cor. bicula, Corbula, Cyrena, Goniobasis? and Viriparus, indicating a brack. ish water fauns, and one decidedly different from thrt of the sandstones farther east. The point where the fresh-water deposits begin, and the estuary or brackish-water life ceased, conld not be determined, but am inclined to think that it is not very far above these beds, perbaps a little besond the scope of the section given abov 3 . Mr. Meek was dis. posed to give the separation as very near this point, considering the brackish.water deposits most probably Cretaceous, and those above them Tertiary. It is possible that there is no very definite horizon of separa- tion, but that the two shade into each other through perhaps several hundred feet of non-fossiliferous sandstones and shales, and without fossils it is not possible to decide the puestion. In the other beds only a few oyster-shells were obtained, but fossil leaves were abundant in some and in No. 17 we obtained some huge reptilian bones. The reming portions of the staleton were exhined by Professor Cope little after our for which he has proposed the name Agathaumus sylvestris, and which he considers as affording conclusive proof of the Cretaceous age of these strata.

The thin sandstones and clays, No. 27, forming the lowest member of the section last given, appear at the base of the bluffs on the northern edge of the bottom.lands of Bitter Creek for a distance of two or three miles northwest of Black Buttes Station, where there appears below them, and apparently dipping unconformably beneath them, a massive, bluish.white soft sandstone, with some intercalated clays and barder lamine of grayish sandstone. This apparent nnconiormability is best noticed by viewing it from a little distance to the westward, but is suf. ficiently prominent at the point where the two beds appear nearest together, only a little valley intervening. At this point the dip of the underlying beds is nearly southeast about $18^{\circ}$, while that of the over. lying rocks is only from $5^{\circ}$ to $7 \circ$, and nearly due east. This unconfor. lying rocks is only from $5 \circ$ to $7 \circ$, and nearly due east. This unconfor.
mability also makes the thickuess of these lowest beds of the Black Buttes section less at this point than elsewhere; here it appears not over 130 feet, while a range of bluffs stretching away to the southward, and to all appearance capped with the heary sandstone which is seen the station, show a long slope of not less than two or three hundred feet of these beds.

The following section was taken by Mr. Meek and myself in a wind. ing walk wer the hills from a point some six miles northwest of the station, th the place where the two apparently unconformable series come toge iher, already mentioned as some two or three miles from the station at Black Buttes. It was made by walking across the dip, estimating or meas ring the thickness of each bed. In this manuer the lowest beds were first met with, bnt for the sake of uniformity with the other local sections given in this report, and for convenience of refer ence, I number the different strata in the descending order, commencing with the uppermost member already described as underlying No. 27 of the previous section:

Suction taken betuceen Black Buttes and a point six miles east of Point of Rocks.

1. Soft bluish-white sandstone, with intercalated clays aad harder grayish laminz

2. Whitish clays and shales with some laminated sand stone.

3. Coarse grayish and buff sandstone

4. Whitish grandy clays and dark carbonaceons shale with thin se clays and

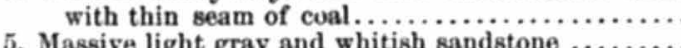

6. Whitish light gray and whitish sandstone .............. traces of coal.

7. Grayish buf sandstone, mostly heavy bedded

8. Grayish and dark carbonacons ahales with appear. ance of coal; fused and burnt red in parts........

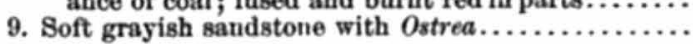
$34 \mathrm{G} \mathrm{s}$
Feet.

90

48

20

33

23

20

$20\} \mathrm{I}$ 
10. Dark laminated clays, burnt reddish in places......

11. Light colored sandy clays, passing into bluish-white sandstone.

12. Heavy bedded reddish and gray sandstone, Ostrea.

13. Light grayish and sandy clays and shales with seams of brownish sandstone, (estimated)

14. Valley, perhaps 30 to 50 feet; strata unseen.

15. Light and dark-colored shales, with probably sone thin seams of coal

16. Light drab-colored shales with some carbonaceous seams, and some thin-bedted, ripple-marked gray. ish sandstone.

17. Blnish and grayish laminated clays with some car bonaceous seams, and some thin-bedded sandstone layers in uppermost part

18. Reddish brown and grayish sandstone.............

19. Bluish and grayish laminated clays with some car. bonaceous layers

20. Grayish sandstone, weathering brownish

21. Ash-colored sandy clays and shales

22. Brownish saudstone

22. Brownish saudsto

24. Impure coal or dark carbonaceous shale

25. Carbonaceous and grayish shales or clays.

26. Bluish gray concretionary sandstone

27. A renaceous shales or clays

28. Grayish and carbouaceous shales; appearance of coal .

99. Bluish arenaceous shales or clays

30. Laminated blnish white saudstone and sandy shale.

31. Gray sandy shale.

32. Heavy bedded coasse sandstone, whitish in upper portion, and brownish buff below...

No. 1 oi this section shows signs of having been much disturbed locally. In one or two places I noticed a local dip to the south or south. locally. The beds on each other. west. This may, ferhaps, be dis the This distur bance, in cons after to be mentioned, suggested the possibility that the apparent unconformaibility between these beds and those of the previous section might in reality be due to a faulting of the strata, with lateral twisting, althongh the appearance as far as our examination extended, seemed to fasor the view. I um inclined to accept this as the true favor the character of the rocks explantion of the appearance al nothiog ing

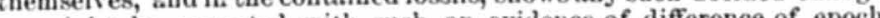
as might be expected with such an evidence of difference of epoch. Apparently the same oyster and a peculiar vegetable impression (already noted as seen in the rocks at Carbon and Fort Steele) were found in several of the sandstone layers above and belo $v$ the disturb ance.

The dip of the heary sandstone No. 32, at the base, and also at the western end the series, was nearly due east, and not over $6^{\circ}$, while, western end of the series, wase, owing to the local disturbance, that of the uppermost bed, at the east would scarcely average over $5^{\circ}$ or $6^{\circ}$, with a direction a little south of wast. There apyeared throughout to be numerous local ehanges as to degree in the dip, and the total average thickness, though greater, per. haps, than that we have giren in our estimates in the detailed section, is hardly as much as would be indicated by the angle of the dip at numerous points where it was taken.

HALLVILLE.-The horizon of the Hallsille coal is included in this section, though the mines themselves are at least one and a half miles distant from any part of the line, and are separated from it by the bottom.lands of Bitter Creek. The coal itself could not be recognized, and perbaps is only represented by some of the carbonaceous seams noticed pertwaps is onl sep. surface indications, bow deceptive, and excavations would, perhaps, discover the coal as fully developed as at that place. We visited Hallville, and made a rapid examination of the surroundings. The mines had not been worked for a considerable period, and the place was entirely abandoned at the time of our visit. The drifts had partially fallen in, and we were unable to procure any fossils from the roof-shales, \&c. of the coal; for the same reasons, we conld not get a very good section of the mines. We no. ticed, however, a considerable local disturbance, including an apparent ticed, however, a considerable local disturbance, including an apparent
sonthwesterly dip, at one of the points visited. I have already men. sonthwesterly dip, at one of the points visited. I have already men-
tioned this disturbance in speaking of that noticed at the junction of sections 2 and 3 ; it seems to be altogether local, and certainly does not extend to the corresponding beds on the other side of Bitter Creek. That noticed in No. 1 of the foregoing section, although in a higher geological position. may, os has been suggested, be due to the same cause,
and situnltanes.us. In passing eastward from Hallville toward Black and situltane us. In passing eastward from Hallville toward Black a development of some 40 feet or more of whitish sandstone and sandy shale, which could be continued by the eye in the direction of the strike across the line of the section, in which it is represented mainly by No. 5 , and perhaps partially by the beds immediately below. This band of whitish sandstone and shale, though varying in width as it was traced by the eye, formed about the best and most continuous horizon in the section. In several cases one of the lignite seams had taken fire along its outcrop, and could be traced for a considerable distance by the baked and reddened clays immediately above it; but these were not generally so continnons over so long a distance, nor vere they so valuable in determining the relative position of the Hallville beds in the series. For the most part, the remarks as to the variability of the characters of the rocks which were made in reference to the Black Buttes section will apply equally well here. The fossils found, with the exception of some leaves of dicotyledonous plants in some of the upper sandstones, and apparently the same as those noticed in the beds of the Black Bettes section, were all from beds Nos, 9 and 12, and consisted of only one or two species of oyster. The soft, sandy shale of No. 9 was in places al. most displaced by these shells, which made up, I should judge, nearly or quite one-half of the mass of the stratnm.

Passing west from Hallville, the heavy sandstone No. 32 forms high, nearly perpendicular bluffs on the right of the railroad, which here seems to run nearly along the strike of he great fold across which these sections are taken. The cliffs continue to Gorder the railroad to Point of Rocks Station, where they open somewhat, and a higher series of of Rocks Station, where they open somewhat, and a higher series of
beds come in view; beyond this place they again close in and continue
near the track for the distance of a mile and a half or more. The whole thickness of the beds is much greater than is given in the section, in which only their upper portion is included; I have roughly estimated it as much as 500 feet. For the most part the bluffs consist of a coarse, 
heavy-bedded sandstone, generally light bluish-gray or whitish in color, heavy-bedded in places turning to yellowish or even reddish brown. It includes numerous local bands or seams of shale, grayish drab in culor, and in parts dark carbonaceous with indications of coal. The rock itself in places passes into a coarse sandy shale, aud this unequal hardness causes its exposures to assume a peculiarly rugged and rough appearauce in many places, huge bastions standing out from the cliffs, and oceasionally presenting rode resemblances to architectural forms. We found presedting rade resemblances to arehitectural form, , I should judge that a more extended examination might discover them
in some of the intercalated carbonaceons shales.

POINT OP ROCKs.-In the bluffs near Point of Rocks Station, and above the heavy sandstone, are four or five different seams of coal, the uppermost one of which must be at least 150 to 200 feet above it Stil above this, near the top of the hill, we found a bed containing a great abundance of a large species of oyster, different from those found in the beds Nos. 9 and 12 of the preceding section. We did not make a close examination of the beds here, as their horizon is included in the section just described, though they do not correspond exactly in lithologiea characters. The better des slojment of the coal here may be merely local; it did not apuear so near the top of the sandstone on the line of simost too low in geological position to be referred to the horizon of the Hallville beds, although it may oceupy the same.

Commeneing at the base of the great sandstone at a point about two and a half miles west of Point of Rocks, and proceeding westward near the railroad track, Mr. Meek and 1 observed the following succession of beds in the descending order:

Seetion near the railroad beticeen Point of Rocks and Salt Wells.

1. Gray and drab sandy shales, with some harder bands of brownish sandstone.

2. Massive drab sandstone.

3. Blaish and dark colored sandy shale

4. Gray sandstone with iossils

5. Yellowish and brownish-gray sandstone and shales

6. Shaly and massive brownish and buff sandstone.

7. Shale, partly dark colored ; appearance of coal.

8. Soft bluish-white sandstone, mostly in - heary beds, some of its upper portion laminated with a little dark shale, and appearance of coal.

9. Grayish sandstone, weathering brown, shaly in places, with some whitish beds above

10. Heavy-bedded whitish sandstone

11. Brown or buff sandstone, with some sandy shale

12. Arenaceous shales and clays, yellowish or drab in color, with thin lamina of harder brownish sandstone

13. Heavy-bedded buff and bluish-white sandstone and sandy shales

14. Dark carbonaceous shale or coal

15. Soft grayish-buff and bluish-white sandstones, with yellowish-drab sandy clays and shales; some thin carbonaceous seams

16. Black carbonaceons shale or coal

17. Brownish and dark-colored shales reet.
18. Grayish-drab massive sandstones.

19. Ash-colored clays and sandy shales.

20. Whitish-buff sandstone.

21. Light-colored sandy shales, with thin carbonaceous seams.

22. Massive grayish-buff and whitish sandstone, with intercalated light-colored sandy shaies.

23. Carbonaceous shale; trace of coal.

24. Grayish and bluish white sandstone and sandy shale

25. Carbonaceons shale

26. Massire sandstone, biaish white above, grayish buf be low

27. Light-gray shale and shaly sands nne

28. Black shale and coal

29. Grayish-buff and bluish-white massive sandstones, soine portions even weathering brown, with frequent interca.

lations of soft sandy shales

The thickaesses of the different beds given above are, as in the other sections, for the most part merely extimates, such as could be made by walking over the upturned edges of the strata. I am of the opinion that, taken as a whole, the thickness is rather under than orer estimated. The angle of the dip varied in different parts of the section: in the uppermost beds, which were at the easiern extremity of the line and farthest from the axis of the fcla, the dip was from 50 to 80 , and from there the westernmost and $3 \circ$ to $5 \circ$. The direction was throughout about the same, nearly northeast. The line followed commenced, as has been already stated, near the railroad-track, two and one-half miles from Point of Rocks, and endec at a point some distance to the right of the railroad, and nearly four miles, in a nearly due northeast direction, from Salt Wells Station.

$A$ few leaves were found in one or two of the sandstone layers, but were not in any way characteristic, and the bed No. 4 was almost entirely made up of fossils and their casts, chiefly of a species of Anomia, together with oysters, Corbicula, Corbula, and a few specimens of Modiola and Goniobasis.

With this last section is completed the whole series of variegated eandstones and shales on the eastern sice of this great fold or antielinal, which contunues in the vicinity of the railroad from between Bitter Creek and Black Buttes Stations nearly to Salt Wells. The total thick. ness of this series, reckoning from a point east of Black Buttes to this place, cannot be much less than 4,000 feet, though in our estimates in the detailed sections we have rather fallen short of this total. This is mainly due to our cantion against making an overestimate, and the nature of the exposures, which in many places only consisted of a rery gradual slope or shallow valley, showing by its debris and on the sur face the general character of the beds. The sectio. 9 show the pecn. liarity of the series, its alternations of light gras, grayish buff, and whitish and brown sandstones, with drab and ash-colored shales and clays. As regards, however, the alternations themselves, these sections are for the most part correct only for the particular line on which they w. re taken, the great majority of the sandstone beds changing in respect to color, harduess, and stratification even within the distance of a feu feet. I am of the opinion, moreover, that the coal-seams also share this general character of variability, but our examinations could not be sufficiently minute to determine to what extent this is the casc.

The accompanying wood-cut is intended as a general section of the 
eries as observed by us. The general divisions correspund to those given, included in brackets, in the detailed sestions, and (1) are indicated by the same letters.

It is worthy of remark that, of the inrurtebrate fossils obtained by usas far down as to the base of the series, not one is of a characteristic Cretaceous genus, but all have rather the aspect of a collection obtained from beds of Tertiary age. It is true that Mr. Meek, and I believe Mr. Emmons also, had considered that these beds might be most properly referred to the Cretaceous, but this was rather on account of the change in the general character of the fossil fauna from purely fresh-water, as in the characteristic Tertiary of this region, to brackish. water marine, and the specitic affinities of a few of the fossils to California Cretaceous species, than from any very positive evidence. As far as I know, the only evidence of this kind is in the identification, by Profes sor Cope, of the saurian remains found by us at Black Buttes. It seems to me highly probable, and indeed
almost certain, that the workable coal-seams of Wyo. ming and Utah range from well-eharacterized Cretaceons strata, as at Coalville and Bear River City, through these beds, which may, perhaps, be best regarded as a gigantie transitien series, into the porely fresh-water beds, usually consided as of Tertiar age, as observed by us near Senaration and elsewhere.

SALT WELLS.- Near Salt Wella a rery different series comes to the surface and occupies the axis of the anti. clinal at this place. The rocks are first seen along the railroad, about four or five miles east of the station.

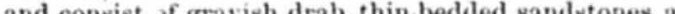

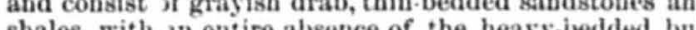
shales, with in entire absetice of the hearybedned but and whitish sandstones which form so prominent a fea ture of the overlying rocks farther east. It forms the high bluffs some two or three miles south of Salt Wells Station, but is wanting in the immerliate vicinity of the mailroad at that point, and for some distance to the west. ward, as the station itself is situated in the valley along the anticlinal anis. Two or three miles to the eastward, one or two cuts show sections of the beds close to the track, in which it is pretty uniformly a thinly laminated. dark grayish drab sandstone or sandy shale, and, is as far as we could see, entirely destitute of fossil remains. Mr. Meek examined the bluffs about two or two and a half miles southenst of the station, and fond them to consist of very much the same general character of beds, with some intercalated clays, the whole, however, show ing no very abrupt variations such as are to be seet in the rocks of the overlying keries. No fossils were found, except indistiuct traces of fucoids (?) and tracks of aunelids. The tbickness of the beds exposed in the bluff was abont 480 feet, the uppermost of which, by estimate, twas 250 to 300 feet below the base of the preceding sec. tion, making a total from the base of the bluff to the lowest member of the variegated sanustone series, of over 700 feet. Add to this the probable thickness of bedis between the bluffs and the center of the anticlinal valley, hardly under 300 or 400 feet, and we har over 1,000 feet for the thickness of this formation. It seems probable that in its upper portion it-contains some coal-seams, as at one point on the railroal, abont four or fire miles east of Balt Wells, I observed an isolated outerop of coal in the bottom of a ditch alongside the track, which, from its posi. tion, I judged to be below the heavy sandstone series. No seams were seen in any of the other outcrops near the track or in the bluffis.

Rock Sprixgs.-Passing westward from Salt Wells we find on the other side of the valle $y$ the great series of variegated sandstones and clays re-appearing, but with a reversed dip to the northwest of some $10^{\circ}$ or $12 \%$. Below it we have a considerable exposure of the thin sandstone, which here appears to stand in more perpendicular faces than on the opposite side of the valley, and has a more reddish cast. The sandstones aud clays immediately above, which on the eastern slope of the fold showed no very numerous or valuable seams of coal, here appear to be the great repository of that material; the lowest seam worked, that at the Vandyke mine, is apparently only a short distance, perhaps a few hundred feet, above the base of the series, and other veins occur within short vertical distances of each other immediately above it. We made no detailed section on this side of the anticlinal, but from our examinations we judged that no very close parallelism existed between the bed acters on both. The priucipal coal-seam worked at Rock Springs, from 9 to 11 feet in thickness, overlies a heavy bed of bluish-white sandstone very similar to many of those noticed farther east. The record of an artesian boring made at the mines gives, as it was reported to me, some sixteen seams of coal, varying from 18 inches to 8 feet in thickness, (1) only beds of carbonaceous shale, but it seems to be beyond question that the coal-seams are better developed here than farther east. Still other veins occur in a bigher horizon than was met with in the boring, but they are of less importance. Opposite the station at Rock Springs, on the opposite side of Bitter Creek, a heavy bedded sandstone of perhaps several hundred feet in thickness appears In the rocky face of a blnfr as secerpies a cousiderably higher geological position. This may possibly be the equivalent of the heary sendstone near Point of Rocks, to which it bears a resemblance, but I am not inclined to positively identify disconnected beds in this formation. It seems, however, to be not far from the same relative position to the base of the series.

Some distance below the principal coal-seam at Rock Springs, 50 to 100 feet, or even more, we found a thin seam of hard sandstone, con taining a great abundance of certain species of fossils, a strongly ribbed species of Corbula, a Modiola, and a Goniobasis, similar to those foubd near Point of Rocks, and a few imperfect specimens of Ostrea. There are other fossil-bearing beds in the vicinity, of which we heard accounts, but our specimens were all gathered in this stratum.

West of Rock Springs the ledges of this formation may be seen on either side of the railrond for a distance of five or six miles, dipping to the noritwest or west-northwest at very much the same angle as near the station. There is not, howerer, a good continuous exposure, but the upturned edges of the harder beds form slight ridges above the general level of the valley which intervenes between the station and the 
range of hills to the westward. At the base of these hills we leave the series entirely, it passing underneath the Tertiary beds of which the range is composed. We did not examine the junction of the two series, but there seems, from a passing view, to be an unconformability here, the npper beds raving a rery slight dip to the west of not over $2^{\circ}$ or $3^{\circ}$ altogether. These Tertiary beds, where they are cyt through by the gorge of Bitter Creek, which the railroad followt, appear as thinly lami. nated, whitish, or light-grasish arenaceons shales, showing in recent railroad-cuts a slightly bluish tinge. In places there appear bands of darker shale, and capping the hills as the road nears Green Birer is seen a heavier brownish or reddish sandstone bed, which forms the perpen. dicular mural escarpments and isolated castle-like knobs which form so prominent a feature near Green River Station. In some layers the shales are dark-colored on freshly fractured surfaces and seem impreg. nated with petroleum, but they all appear to weather nniformly light

yellow or whitish.
GRER RrVER.-A hill about two miles east of the station, at Greeu River crossing, on the southern side of Bitter Creek, gave the following section from a rough measurement with a pocket-level:

\section{Section near Green River Station.}

1. Heavy reddish-brown sandstone.

2. Whitish arenaceons clays or shales.

3. Reddish or brownish arenaceous shales

100 feet or more. 500 feet.

50 feet.

130 feet.

The dip was very slight, but one or two degrees to the westward, and is indeed scarcely perceptible. It is best seen on the bluffis, on the im. mediate bank of the river, above the station, where the beds are seen to dip, with some slight local undulations, to the westward; and the well. known petrified-fish bed which, at its exposure on the railroad about two miles or a little more from the station, is only 40 or 50 feet above the river, at Green River City, is said to be fonnd near the summit of the bluffs some hundreds of feet higher in actual level. The reddish sand. stone which caps the hills at the station to the eastward does not appear very prominently to the westward, and perhaps passes into aremaceons shale in that direction. It appears probable that there are some local variations in this formation, but as a whole it presents in this respect a striking contrast to the series below.

Bryas.- West of Green River City the beds seen at the river disappear, and still higher ones of the same group come in view. These we examined in the vicinity of Bryan, where we visited one or two conical buttes lying to the sonth of Black's Fork aud three or four miles from the station. We found these to consist of thinly laminated grayish sandstone or sandy shale, with, uear the summit, sone bluish, more argillaceous lasers, and on the extreme summit a stratum of harier grayish sandstone filled with rongh casts of Melanianx, Unio, \&c, and on one a great abundance of bivalve crustaceous remains, $\left(C_{y p r i s,}\right)$ all more or less silicified. The height of the buttes was not over 150 to 200 feet, the strata perfectly borizontal. Beside these buttes the conntry in the vicinity afforded no good exposures, the surface being rather level and uniformly covered with a gravelly superficies completely hiding the underlying rocks.

Bridger Station.-West of Bryan we made no stop till we reached Bridger Station, where we examined to some extent the underlying greenish-gray sandstones and reddisli clays, \&c., of the Wasateh group.
As far west as Carter the flat table-topped hills, composed of the whitish beds of the superior Bridger group, characterize the scenery, but between that station and Bridger the underlying greenish and reddish gray san'stones'appear, and near the latter station predominate. About a mile or more southwest of the station, in a bill on the right bank of Muddy Creek, and near the railroad track, the following section was taken which I copy from Mr. Meek's note-book. It shows the general character and variations of the lower formation, which is characterized by more massive saudstones and clayey teds, differing in color and other respects from the shales above:

$$
\text { Section near Bridger Station. }
$$

1. Alternations of gray, rather coarse sandstones, and reddish and ash-colored arenaceous clays, some layers of the sandstone fossiliferous

2. Massive gray sandstone, stained reddisb above . ......................

3. Asheolered and reddish sandy clays . . .......

4. Gray sandstone

5. Reddish and yellowish.gray sandy clays

Reddish and ash-colored sandy clays

. Gray sandstone

9. Whitish sandy clays

10. Gray sandstone

11. Reddish sandy clays with some soft sandstone $\ldots \ldots \ldots \ldots \ldots \ldots, 15$

12. Gray madsive sandstone

13. Reddish and yellowish elays

14. Grayish sandstone.

15. Reddish and ash-colored arenaceous clays, with perhaps some layers of sandstone..............................

The upper member of this section closely resembles, and is probably identical with, the beds forming a hill on the southeast side of the rail. road-track three-fourths of a mile or more northenst of the station. The satne fossils (chiefly rough casts of a Melavian aud a $C$ wio) ocenr in a thin layer near the top of the hill. The dip in both cases was the same, nearly east, from $4^{\circ}$ to $6^{\circ}$. From the summit we conld sec the reddish layers in ledges to the eastward, thus indicating that we were far, perhaps many hundred feet, below the top of the series. The beds seemed to dip unconformably below the more horizontal whitish strata of the Bridger gronp, and at one point, at least, I saw a pateh of the upper formation lying between the ridges of reddish sandstote. It would thus appear that there had been considerable denudation here, and that portionz of the upper group had been washed away, leaving only these outlines to indicate their greater extension in former times.

PIEDMONT.-Beyond Bridger the railroad, following the valley of Muddy Ureek, turns to the south, and then bends slightly to the eastward carrying the traveler again into the area of the higher group, bnt still showing at the base of the hills the heavy grayish sandstones and red. dish clays of the Wasatch formation. The junction was well observed in some high hills about a mile, or little more, east of Piedmont Station, in which the lower, 210 or 211 feet, was made up of the heary-bedded, grayish sandstone, weathering reddisb, with intercalated beds of softer sandy clays, the whole withont, as far as we conld detect, any trace of fos. sils, $\epsilon$ ther animal or vegetable. Above this we roughly measured with a pocket level some 229 feet of whitish beds, mostly argilaceous, but with 
three or fonr ledges of white fossiliferons limestone. The slope between each of the limestone-beds was thickly strewn with chips derived from the ledges, and the true character of the intermediate beds was largely concealed from this canse. They appeared, however, to be mainly whitish clays, with, in places, a slightly bluish tinge. The fossils were mostly fish-remains, impressions of scales, spines, and bones, but in the upher ledge we found casts of a small Planorbis, and in the lowermost one a Helix, closely resembling $H$. Leidyi, from the Tertiary of the Upper Missouri. The upper beds bere apparently dipped a little to the north of east, but scarcely more than two or three degrees altogether. north of east, but scarcely more than two or three degrees altogether.
The unconformability between them and the underlying rocks was not, as far as we could see, very noticeable at this point, though I thought that I saw in the lower heds a slightly increased dip to the eastward. These lower reddish beds are seen along the railroad to the west of this station in various places, and apparently lie unconformably upon the whitish Cretaceous strata which come into view in that direction.

AsPEN.-The Cretaceous strata which appear near Aspen Station ap. parently belong to a lower member of the formation than any of the beds examined by us either to the east or west of this point. Immedi. ately at the station they form rounded hills, or ridges, rising to the height of 200 feet or more, and composed of hard, splintering, whitish and bluish slates, the former color predominating toward the summit, and the latter appearing near the base. These slates are full of fishscales, with oceasional impressions of bones and teeth, and near the top of the hills we found a fragment of an Ammonite. The lower bluish beds are also well exposed in several cuts along the railroad for a short distance west of the station, and here also contain numerous fish re. mains; their color in places is nearly black. In one of these cuts, un. der the snow-shed just west of the station, we saw one or two thin layers of grayish limestone, full of unrecognizable fragments of fossils. The total thickness of these slates, from their lowest to their highes: exposures, cannot be less than 300 or 400 feet; they pass beneath the level of the valley to the westwarl with an estimated dip of ten or fifteen degrees in a general west-southwest direction. To the west ward, within a distance of about two miles, there appear one or two parallel ridges, which, with the valleys betweea, must represent some 1,500 feet or more of overlying strata, consisting, as far as could be seen in the exposures of light gray and whitish sandstones, and light-colored clays, or shales. The railroai cuts through the westernmost one of these ridges at a point some three miles from Aspen, where we made the fol. lowing rough section:

\section{Section at Rock $C$ ut.}

1. Light-colored shales aud shaly sandstone.

2. Whitish sandstone containing Ostrea.

3. Light-colored shaly bed

4. Heavy bedded whitish sandstone.

5. Alternating shales and thin sandstone-beds.

The heary sandstone-bed No. 4 forms the erest of the ridge, the npper beds appearing on the slope in the artificial cut. The oyster in upper beds appearing on the slope in the artificial cut. The oyster in
bed No. 2 was identified by Mr. Meek as Ostrea soleniscus, Meek, a species which we found farther west in Uretaceous beds at Coalville and elsewhere. The dip of the main sandstone was about $30^{\circ}$ in a direction nearly southwest.

A little west of this point is the iuteresting locality at old Bear River
City, where we stopped and made some examinations, the results of which are given elsewhere by Mr. Meek.

EvaxstoN.-After leaving Bear River City and Aspen, we spent a day or two at Evanston, and made sections of the rocks about the coal mines at Almy, on the north side of Bear River, some three miles to the northwest of the station. The section given below was taken in the hill back of the mines, and though not altogether a continuous one, it nexertheless represents pretty fairly the general character of the beds nevertheless represents pretty fairly the general character of the beds the summit of the hil! down to the bottom in a ravite, which enters the bottom-lands of Bear River a mile and a balf or more east of Almy ; of the rest, Nos. 25 to 39 inclusive were taken from exposures in a ravine immediately back of the village, and the remainder chiefly from artifi. cial exposnres at the mines. The thicknesses as bere given of the dif ferent leds, except in the case of the last-named ones, are, as in most of onr other sections, estimates made by the eye, more accurate meas. urements being impracticable with the attention we were able to give

\section{Section of hill back of the Almy coal-mines.}

1. Coarse, pebbly, conglomerate with some intercalated sand. stones and elays.

Yellowish and gray sandy clays, or sof, decomposing sand stoue

3. Massive gray sandstone.

4. Vellowish and gray sandy shales or soft sandstone.

5. Coarse grayish sandstone weathering brown

6. Reddish and yellowish sandy clays or shales

7. Coarse grayish.brown sandstone and conglomerate.

8 . Reddish and ash-colored sandy clays or shale 3.

9. Massive light grayish sandstone.

10. Vellowish sandy clays.

11. Coarse, pebbly, reddish-gray sandstone.

12. Soft grayish sandstone passing downward into decomposing reddish conglomerate

13. Yellowish sandy clays, some sandstone at base.

14. Sandstone and conglomerate

15. Gray and yellowish-gray sandstones and sandy shales.

16. Coarse sandstone and conglomerate.

17. Sandy clays or shales, some parts reldish.

18. Conglomerate passing into coarse sandstone

19. Yellowish sandy clays or soft sandstone.

20. Conglomerate

21. Yellowish or reddish sandy shales or clays

22. Conglomerate

23. Yellowish sandstone and sandy clays.

24. Coarse conglomerute:

95. Yellowish and whitish sandstone with some sandy clays.... 170

26. Dark-grayish san lstone and shales.... . . . . . . . . . . . 22

27. Light-colored sandy clays or shales.

28. Grayish-buff sandatone

29. Grayish sandy shales with apparently some carbonaceous seams near base.

30. Reddish and gray sandstone.

31. Grayish shales or sandy elays.

32. Reddish and gray sandstone.
Feet.

50

70

6

8

15

100 
33. Light-colored sandy abales, perbaps some Fandstone........

34. Light-gray or whit a ses, perbaps

34. Light-gray or whitish sandstone $\ldots \ldots \ldots \ldots \ldots \ldots \ldots \ldots \ldots, 1$

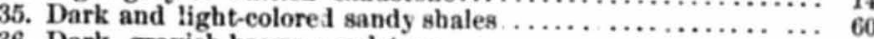

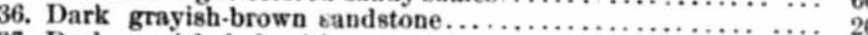

37. Dark-grayish shale with some carbonaceous layers and perhaps

some thin seams of coal near bise.

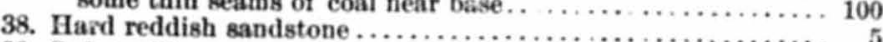

39. Soft argillaceons sandstone, some harder layers..............

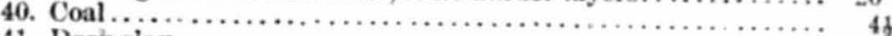

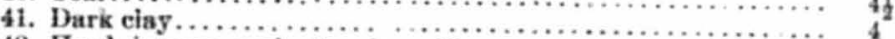

42. Hard, impure coal_" rock coal". . . . . . . . . . . . . . . . .

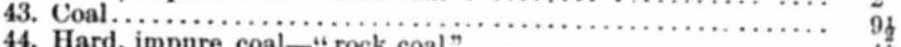

44. Hard, impure coal_ "rock coal" .................

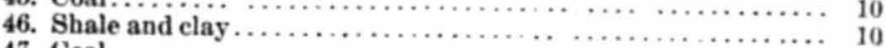

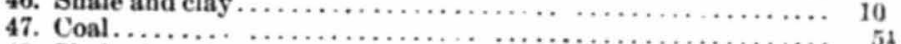

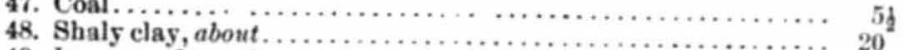

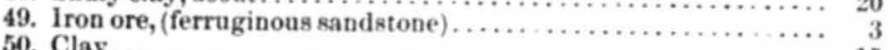

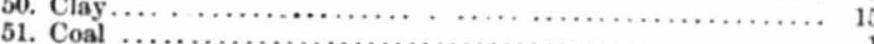

Still above the highest member of this section we conld see from 500 to 700 feet of sandstones and sandy clays or shales, which we did not examine closely. In fact, the whole of the upper part of the section is only valuable to give an idea of the alternations aud the general char. acter of the whole series. The sandstones afforled in no instanee any trace of animal or vegetable remains, and the exposures of the softer beds were such as to give no evidences of any fossil contents, bein generally slopes more or less covered with débris. The dip was through. out nearly northeast, varying perhaps a little to the eastward; its ang! averaged from $17^{\circ}$, $20^{\circ}$

The first fossils found in place were seen in No. 32, which contained impressions of large leaves of dicotyledonons trees. About this hor izon also we picked up a fragment of saudstone containing the cast of a Helix, which bowever might, judging from its appearance, has come from bed No. 30 . Farther down bed No. 34 also contained leaf impressions, and in No. 35 we found imperfect casts of bivalve shells resembling $U_{\text {nio. In }}$ In. 37 , below its middle, we found a two-foot band exposed in a prospecting trench, almost entirels made up of small fresh. water-sheils, Cyclas, Physn, \&c., all crushed together and almost unrecog. nizable, except as to genus.

Nos. 42 to 45 inclusive comprise the 26 foot seam rorked at this point. The beds below were not reen by us, tha: portion of the section having been furnisbed by Mr. Denel, superintendent at the mines of the Rocky Monntain Coal and Iron Company at this point.

We also visited the bills on the north side of Bear Rives, northeast of Evaneton, which we found to be composed of very similar strata to those in the upper part of the Almy section, viz, alteruations of coarse sandstones, conglomerates, and sandy clays. There seems to have been a considerable disturbance here besides the mere tilting of the beds, and from the altered direction of the strike, which is bere nearly north and south, we were led to suspect a considerable lateral displacement with fanlting, which might very possibly cause the appearance of the same beds in both these hills, and those abont Almy; although at finst sight these would appear much higher in geological position. We did not attempt, however, to work out the geological structure to any great extent, as it would have required more time and labor than we were well able to give fcr that purpose.

We did not discover any evidences of unconformability in the Almy rection; the whole formation seemed one continuous series. The freshwater beds containing shells are, I think, certainly conformable to the coal ; indeed, we observed thin carbonaceous seams in its immediate proximity. In the main section I have given the larger divisions, as exposed, on a line terminating at the mines, but the prospecting trench already mentioned, which was opened by Mr. Deuel some two miles below Almy, afforded the following section, which in the larger one is included in the lower part of No. 37 :

Section taken tico miles below Almy in trench.

Coal, or carbonaceous shale

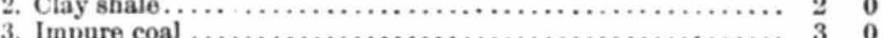

4. Hard argillaceous sandstone, containing and alnost entirely made up of minute crushed fresh-water shells........... 20

5. Coal, or carbonaceons shale ........................ 10

6. Sandy shale ................................... 12 0

7. Coal, or earbonaceous shale, with clay parting .......... $4 \quad 6$

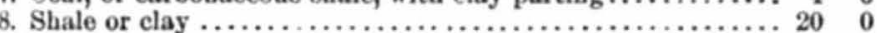

Under this, according to Mr. $T$ ael, is the heavy stratum of argillaceous sandstone, No. 39 of the section, which is seen at the mines above the main coal, and which contains numerous leaf-impressions.

The fossils found, both in this two-foot band and in the sandstones above, would indicate that the age of these beds was Tertiary, rather than Cretaceous, and that they night possibly be even more recent than Eocene. I do not know the grounds of Professor Cope's reference of the coal at this point to the Cretaceous, while he admits the Tertiary age of some, at least, of the overlying sandstones; ${ }^{\bullet}$ but as we found no break or line of demarkation in the whole 2,000 feet or more which we examined, and found our fossils in coal-bearing beds immediately above and conformable to the main coal the facts, so far as they are known to me, do not seem sufficient for such identification.

From Evanston we weut west to Echo and Coalville, which are reported on by Mr. Meek.

Pr. Acad. Nat. Sci. Philadelphia, 1872, p. 279 
0 IHE EXTINCT VERTEBRATA OF THE EOCENE OF WYOMING OBSERVED BY THE EXPEDIT!ON OF 18\%2, WITH NOTES 6 N THE GEOLOGY.

PHiladelphis, April 29, 1873.

I send herewith a detailed report of the results of the paleontological survey of the Green River Tertiary basin, undertaken last summer by myself, under your direction. The report is not complete, but includes the general determination of the vertebrata, with special momographs on some of the mammalia.

The expedition left Fort Bridger July 19, 1872, and followed the road to Cottonwood Creek, southeast eighteen miles, whence we made our first excursions into the bad lands. After this, our ronte lay along Cottonwood.'Creek to Smitl's Fork of Greu liver, thence along Black's Fork, and thence to Green River City. We then followed Bitter Creek to Black Buttes, and, leaving the line of the Union Pacific Railroad, traveled sonth towards the headwaters of the Vermillion. Before reaching this point we explored the Mammoth Buttes, which form the watershed between South Bitter Creek and Vermillion, and examined the bad lands carefully. In reaching this point we crossed a portion of the Cretacts carefuly. tions of the strata at these points.

We returned from this region, and struck Green River seventeen miles above Green River City. We proceeded northwards to the mouth of Labarge Creek, and, returuing a short distance, ascended Fontanelle 'reek to near its source in the outlying ranges of the Ham's Fork Mountains. The relation between the lake-deposits and the older strata here claimed special attention. We then descended Ham's Fork to the Union Pacifie Railioad and returned to Fort Bridger.

Special expeditions were made to the region round Evanston, and to Ellio, Nevada, with gratifying success.

I leave discussion of the general results until the close of the report. I may premise that we obtained in round numbers one hundred species of vertebrated animals of the Eocene perion, of which about sixty were new to science. We added two orders of mammals to those previously represented in this fauna in the United Siates, viz, the Quadrumana, (monkeys,) and Proboscidia, the latter in several types of remarkable interest.

The present synopsis includes only the species of vertebrata collected by the expedition, with one or two exceptions, which is respectfully submitted.

EDWARD D. COPE,

Dr. F. V. HAYDES,

Palcontologist, United States Geological Surrey.

In charge of Geological Surrey of the Territories.

$35 \mathrm{G} \mathrm{s}$ 


\section{MAMMALIA.}

QUadrumaxa.

In the Proceedings of the American Philosophical Society, 1872, p. 55.4, the writer described a species of Quadrumanous Mammal nnder the nane of Anaptomorphus cmulus, comparing is dental and other eharacters with those of Simia. In the American Jonrnal of Scienen and Arts, for November, ${ }^{+} 18 \%$, Professor 0 . C. Marsh announced that he believed that three genera previonsly deseribed by him, viz, Thino lestes, Limnotherikm, and Telmatnlestes, $\{$ were referable to the Quadrum. ana, saying that they "have the principal parts of the skeleton mueh as in some of the lenurs," Prior to cither of these determinations, the author described a new genms and specties as allied to Notharetux, Leids, nuder the name of Tomitherinm, but made no suggestion as to its ordi. nal position.

On a re-examination of the last-named genus, I am satisfied that it also should be referred to the Quadrumana, and deseribe it as follows:

\section{ToMITHERIUM, Cope.}

Dental formula in an uninterrupted series, Last molars with five tulercles, other with four; all low and slightly alternating, the outer wearing into cresests. Canines quite small. Incisors vers prominent, the median pair with transverse cutting edges. Symphysis coossified, projecting in front. In the molars, the adjacent horns of the two outer crescents unite with the anterior outer turbercle; the posterior outer is insignificant. There is a projection but no tubercle in front of the outer anterior turbercle. The premolars present but a single of the outer anterrown: the posterior, however, widened behind, and with a low turbercle. The first and second premolars are one-rooted, (not entirely a generic character

I base the distinetion between this genus and Notharetus on the smal canine, and the sub.horizontal prosition of the incisors; believing that when other portions of the skeleton are studied, other differences will appear.

The portions of the skeleton of the type species preserved are: the entire dentition of the lower jaw mitnus the crowns of the outer incisor, canine, and first premolar; the left ramus nearly complete, the extreme angle being wanting; the right lumerus complete, with right ulna and madius, the latter lacking the distal extremity; a large part of the let ilium; the right femur nearly entire; part of the left hnmerns, metir. tarsals, \&c.

The mandibular rami are quite stout, but not very deep; the sym. physeal portion long and oblique, and the coronoid and condslar por tions elevated, with axis at right angles to that of the horizontal portion. The condrle is well elevated, and the coronoid process small; the dental foramen is half way between the margins of the ascending ramus, and orposite the bases of the crowns of the molars. The inferior margin of ope jaw shows no tendency to inflection at a point immediately below this foramen, where it is bioken off. The mental foramen is divided, the exits being at points opposite those between the premolars 1-2 and $2-3$. Published Angust 7, 1872.
Putlished August 7, 1872.
Tho kumerus bas a round bead, directed backwarde and a litpe ont. wards. The tuberosities are rather small, of about equal size, and obtuse; they inclose a short bicipital groove. The bicipital crests are very largely developed, and extend to the midile of the shaft, inclosing an open groove between them. The external is narrow and most elevated, the internal more obtuse and directed inward. The shaft is thus sui. triangular in section. The distal extremity is nearly at right angies to the axix of the proximal, and is macl, expanted transwcrsoly. part of this expman

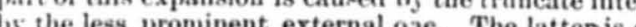
whe the less prom ala, which only sinks into the shaft at its middle. The condyles are small, the exterual the most prom neut. There is a shallow olecranar foxsi, nul no coronoid, and hence no supracondylar foramen. There is an arterial foramen above the internal tuberosity.

The ulna is compressed, and contracts rapidly to the extremity. The olecranon is broad and obtuse, and the humeris cotylus oblique to the long axis. The coronoid process is low. The shaft is remarkably curved from right to left, inward. The radius has a discoidal head, with central depression, and it was evidently capat le of complete rotation. It exhibits a tuberosity and slight flexure belos the head. The distal extremity has a horizontal triaugular section, w, th the apex internal and truncate; the shaft near it is quite flat.

The left ilium is obspatulate and flat widest at the convex crest, and slightly concave on the outer side. It is rather thin, and the impres. sion for the sacral diapophyses is elongated. The inferior border thick(ns gradually to the acetabulum; the superior is excised so as to form an open concavity.

The right femur is remarkable for its length. Its shaft is flattened from betore backward, and without flexure. The areat trochanter is large, and embraces a deep inlooking fossa. There is a flat tuberosity looking ontward just below, and the little trochanter is a little below opposite to it. The contyles are sub-similar in size, the trochlear surface wide, but not that, and the inner border thickened and considerabig elesated. The femur is 1.75 times as long as the lumerns; it was scarcely longer, though a small piece is wanting from the shaft of our

specimen.

Remarks.-Having described the more important parts of the skeleton preserved, I now proceed to consider its systematic position, and the order to wbich it should be referred.

The first impression derived from the appearance of the lower jaw and dentition, and from the humerus, is that of an ally of the coati, Nasua. The humerns, incleed, is almost a fac simile of that of Nasma, the only difference being a slight ont ward direction of the axis of the head. The some bone resembles also that of many marsupials, but the flat ilium, some bone resembles also that of many marsupials, but the flat ilium,
elevated position of dental foramen, and absence of much inflection of the angle of the lower jaw, \&c., render affinity with that gronp highly improbable, The length of the femur indicates that the knee was tirely free from the body, as in the quadrumana, constituting a narked distiuction from ansthin known in the Carnirora, including Nasua. The round head of the radius indicates a complete porer of supination of the fore fort, and is different in form from that of Carnicorc, includ. of the fore font, and is different in form from that of Carnicord, includ.
iug Nasta ; and, finally, the distal end of the radias is still more different from that of Nasua, and resembles closely that of Nemnopithecus.

We have, then, an animal with a long thigh free from the body, a forefoot capable of complete pronation and sppination, jaw and teeth quite similar to that of the lower monkeys. The form of 
the humerus and its relative length to the femur, are quite as in some of the lemurs. The most marked difference is seen in the increased num. ber of teeth; but in this point it relates itself to the other Quadrumana, ber of teeth; but in this point it relates itself to the as the most ancient types of Carnirora and Palcosyops to the latter. modern; e.g., Hyanodom to the former, and Palasyops to the latter. In its special dental characters it shows a close resemblance to smal is Hyopsodus, \&e.

\section{Tomtherium rostratum, Cope.}

Proceeding of the Ameriean Philosophical Society, 1972, . P. 470, (published by the author, August 7, 1. c., 1 73, (real $\mathrm{A}_{1}$ ril $\mathrm{P}_{1 \%}$ )

This species was abont the size of the prehensile-tailed monkey, so The first and second premolar bave but one freqtently seen in size of the base of the root, the base of the so incisors form a parabolic canine. The latter are cyinth a transrerse ones, Ename ontline, and have entire elges, the mildle pair transserse ones. Ename generally smooth, premolars somewhat striate; an indistiuct inner cingulum.

\section{Measurements.}

Length of entire dental series, (straight)

Length of symphysis natulibril

Depth ramus at second molar

Weogth crown of mcothd molar

Whith between two second moiars

Width between two eanines

Width of ascending ramas alove dental foramet

Wength of humerns.

Diameter of head

Diameter of shan at midtil.

Diameter of distal end, tratisverse

Diameter of distal c

Depth of olecranot.........

Disty of ol

Diameter extremity of ralins, proximal

Length of tlium from acetabulum.

Width near crest

Length of femur preservel

Width just below neck

Width at middle

Width at extremity

Width of trochl

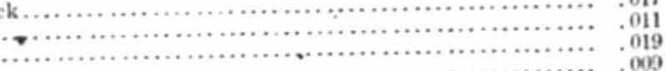

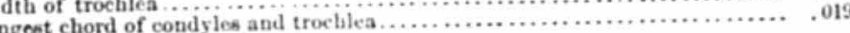

The specimens on which this species was founded were found together by the writer near to Church Buttes, Wyoning.

\section{Notiarctus, Leidy.}

$$
\text { Geological Survey, Jontana, 1671, p. } 364 .
$$

This genus is but little known, but is probably one of those which as. This gens is types.

\section{Notharctus longicaudus, Cope.}

Pantoleatea longicaudu, Cope. Proceed. Amer. Pbiloe. Sec., 1872, p. 467, (August 3.)

This form is one of those mixed types which are so abundant in the Bridger Group. Its dental formula is M. 3, P. M. 4, c. 1, incisors un. known. The molars in the only specimen known are so worn as to preclude exact description. They evidently possessed anterior and posterior lobes, separated by a valley, which was nost expanded on the inner side. The last molar exhibits a short heel posteriorly, which probably sup. ported a small tubercle. The three premolars are all two-rooted and compressed in form. The last presents a crown composed of one large anterior compressed cusp, and a much lower posterior one. There is a slight cingulum in front. The canine is lost, but its alveolus indicates that it was a stout tooth.

So far as the known dental structure goes, this species resembles nearly the Notharetus of Leidy, bat possesses a more carnassial fourth premolar.

Themandibular raw'is is quite slender, and there is a large foramen below the first true mo!:ır. The masseteric fossa is pronounced

1 originally assigned L.it 3 P. M. to this species, but now find that it porresses four, thus rese:nbling Notharctus. "t differs from all the Ninecies described by Marsl, in having the second premolar two-rooted, and from Leidy's two species in it s slender proportions.

The remains of this species were found together by the writer in the Bridger beds on Black's Fori, Wyoming.

\section{ANAPTOMORPHUS, Cope.}

Proccerlings of the American Philosophical Societs, 1872, p. 654, published by the author Oetober 12 .

This genus is represented by the left ramus mandibuli of a single species. The posterior portion is broken away, and the teeth remaining perfect are the P. M. 2 , and $M .1$ and 2 . The ramus, though small, is stout, and deeper at the symphysis than at the last molar. What appears to be the dental foramen is nearly opposite the bases of the crown of the molars. The mental foramen issues beneath the first premolar.

Dentition of the ramus mandibuli, In. 2, C. 1, P. M. 2, M. 3, total, 16. It differs from monkeys in some respects; there is no interruption in the series near the canine, and the symphysis, though massive, is not coos. sities!. Further details are, the last molar is three-lobed and elongated betund. The composition of the crowns of the preceling molars consi ts of four opposed lobes, which are very stont, and connected transversely by a thin ridge behind, or in close contact in front. The premolar tooth which is best preserved, is a perfeet second, which, while having two roots, possesses a crown which stands almost entirely on the anterior, presenting a curved sectorial crest forward and npward.

The dentition is more typically qualrumanons in this genus than in the last, and it might be referred decidedly to Lemurida were it not for the unossitied symphysis. It no doubt represents a distinct group or family from Tomitherium, and one more nearly related to the existin. types of Madagasear and South Afriea.

\section{Axaptoyonprus artue, Cope, loc. cit.}

This species was abont as large as a marmoset or a red sq̣uirrel. The euamel of the teeth is entirely smooth. 
Measurements.

Length dental line

Letgth of last nolar...

Wength of ante-penalt.

Length of three molars preserved

From the Bridger Bets of the upper valley of Green River.

CAIRIVORA.

\section{MEsOryx, Cope.}

This genus was described by the writer in the Proceedings of the American Philosophical Siciety for $1872,1.460$, and published in an adrance edition of the same paper on July 29, 187\%. It was there referred to the Carnirora, and stated to resemble Hyanodon in some respects. I propose on the present occasion to attempt a more exact determination of its strueture and relationships. The only species yet certainly referable to it is Mcsony.x obtusidens, Cope, 1. c., which is represented by a fragmentary skelcton. There are preserved portions of
the skull with the teeth, chiefly mandibular; numerous vertebre from all parts of the column ; parts of seapula, ulna and fore feet : portions of pelvis, femora, tibiz, tarsilk, metatarsals, and phalanges.

The numerous unguiculate digits, the sectorial character of the molar teeth, and the characteristic form of the astragalus demonstrate this genus to belong to the Carnirorn nissipedia. It becomes interesting, then, to determine the relations of an Eocene type of the order to the families now living.

The cervical rertelore are damaged. The dorsals are strikingly smaller than the lnmbars, being less than half their bulk. They are opisthocoelian with shallow cups, and the centra are quite concave laterally and inferiorly. The centra of the lumbars are more truncate, with a trace of the opisthalian structure, and are quite depressed in form. The median part of the series is more elongate than in the cortespond.
The of the opisthwian structure, and are quite depressed in form. ing vertebre of the genus Canis. They exhibit an obtuse median longitudinal angle, on each side of which, at a little distance, a nutritious ar. tery eitered by a foramen. The zygapophyses of the posterior lumbars have interlocking articulations, the posterior with a convex exterior ar. ticnlar face, the anterior with a concave anterior one. The sacrum is not completely preserved; three co-ossified centra remain. These are more elongate aud the diapophyses have less expansion than in Felis, Hyarna, Canis, or Vrsus. They are much flattened, aud the middle one has two slight median longitudinal angles. The caudal vertebre indicate a long tail, with stout base. Its proximal vertebre are depressed, and with broad anteriorly-directed diapophyses. The more distal vertebra have sub-eylindric centra; the terminal ones are very small.

The glenoid cavity of the scapula is shallow; the coracoid process is a short hook separated by a strong groove from the edge of the former. The spine is well developed. In the character of the coracoid, this geuns resembles Felis more than Canis or Ursus. The ulna exhibits little trace of articular face for the radius, lesa than in Felis or Caris. Its humeral glenoid face is more convex transversely in its anterior or vertical portion than in those genera, and a little more than in Crans. In the hind limb the femur resembles that of other Carnicora in all essentials. The rotular groove is narrow and elevated, the inner margin a little higher. The condyles are rather, narrow, the inner with less transverse and antero-posterior extent, and separated by a wide and tran fosan. The patella is marrow, thick, and truncate at ond proximal end of the tibia exhibits a very prominent aud well elevated crest or spine, which bounds a deeply excavated fossa. The articular faces are separated by a deep notch behind; the exterual is a little the larger and is produced into a point outwards and backwands it lacks the noteh of the antero-exterior margiu so distinct in Canis, but possesses an emargination at the onter base of the erest homologons with it The general form is howerer, more like that of Canis than of Felis, and least like the Felis, and least like that of Ursus. The the presents Carnivorons characters. The two trochlear fossa are deeply inpressed, the outer wall of the external one being formed by the fibula only. The anterior marginal crest is more elevated than the posterior, and presents an overlapping artienlar face between the fossa for a corresponding tuberosity of the neck of the astragalus. The inner malleolus is entirely withont the groove for the teudon of the tibialis posticus iunscle, and therefore different from many of the digitigrade Carnirora. It has an ovate truncate surface. On the auterior face opposite the inner trochle ar groove is a rather small but deep fossa.

The astrage lus has an elongate oblique neek and a navicular extremity slightly expanded inwards. The trochlear ridges are well elevated, and not very obiique to the true vertical plane, being much as in the dog. The distal extremity is quite diflerent from Felis, Hyana, Canis, and Vrsus in having a rather narrow convex facet next the cuboid bone ex. tending from front to rear, and in having the navicular facet pulley.like or slightly coneaye in tranverse section, while it is strongly convex antero-posteriorly. This is part of the peculiarity presented by the hind foot in this genus. Behind the navicular facet, on the superior face, is a tuberosity which stops the flexure of the foot by contact with the tibia; a trace of it is reen in the dog. The calcaneum has the compressed form of the digitigrades, but the broaler interval, and convex exterual astragaline facets resemble much more those in the bears. The cuboid facet is a frustum of a triangle with the apex direeted inwards and downwards.

The metapodial bones are rather elongate, and flattened so as to be transverse in position. A second metatarsal is more flattened than corresponding bones of Canis and Felis. Its cuneiform facet is somewhat concave transversely. The phalangeal condyles are furnished with an anterior and inferior carina, which is wanting above; the articular face is wide above as in Canis, ard is bounded by a transverse fossa as in digitigrade genera. The phalanges of the first series are elongate and enrved as in Felis, bei:g relatively longer than in $U$ rsus. Phalauges of the others series are guite short The uugues are short and flattened, their inferior surface is nearis plane, and the superior but little convex. their inferior surface is nearly plane, and the superior but little convex.
A shallow groove divides the upper face longitudinally to the extremity. The margin below is acute to a slightly contracted neck. There is no indication of collar for reception of the horny sheath, except perhaps a slight area of fracture on each sicle, and there is no projecting tuberosity below for insertion of flexer tenlon. The middle of the

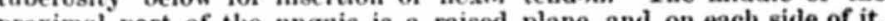
proximal part of the unguis is a raised plane, and on each side of it, at the neek, two arterial foramina enter. There is a small foramen in the groove, and several smaller ones near the margin. These ungues resemble somewhat those of some tortoises. They were found with the other phalanges, with which they agree in size and articulation, and no 
doubt belong to the same animal. It is evident that they differ in character from those of most existing Carnicora. The penultimate phalanges agree with them in the depressed form of their proximal ar. ticular faces, wanting entirely the triangular form so characteristic of Carnicora, especially of the cats and dogs. The short, flat shaft of the same is almost equally peculiar.

The cranium is fragmentary. The malar bone of the right side is similar in position and form to that of the Canida, especially in the presence of a weak angle only, to mark the posterior border of the orbit. It has a mnch less expanded union with the maxillary than in these animals, and is proximally sluallower, thicker, and more prominent. Its posterior portion is more plate-like.

There are numerous teeth preserved, but separate from the skull, and mostly mandibnlar. The inferior canine is stout especially in the root, whieh is a flat oval in section. The crown is but little curved, slightly compressed, and without edge or groove. The premolars graduate into the molars, so that the line of distinction is not easily drawn. The first premolar has a single root; the crown is slightly conic, with a small tubercle at the base behlnd. This tubercle increases in size on the premolars 2 and 3 , and becomes on the true molars a longitudinis eutting edge extending aloug the axis of the crown, not much elevated above a wide base. It ocenpies half the length of the crown in the larger molars, and is preceded by an elevated conic cusp. In front of the base of this, a small conic tubercle projects forwards, which appeared as a rudiment on the thiral premolar. The number of mandibular teeth would appear to be, P. M. 3, M. 4. No portious certainly referable to the superior molars were found.

Conclusion. In summing up, it may be accepted as a result of the above analysis that the genus Mesonyx represents a family of Carnirora digitigrada, distinct from any now living on the globe. The form of the astragalus renders it prolnable that the inner toe is wanting or rudimen. tal, and that there were four digits on the hind foot. The foot was also short, and the claws flat, and altogether without prebeusile use, but rather adapted for aquatic life. The number of molars exceels that in any recent terrestrial family of Carnirora except the Protelid $\alpha$, and their sectorial form allies it at once to the extinct Hyonodontida. To this family the genus Mesonyx may possibly be at present referred. Amongre. cent families it approaches nearest the Canido, but has structures borrow. ed from others, while its num rous mohrs constitnte a point of greater generalization than any. $M l_{\text {. }}$ ough sectorials, this character is not vearly so marked as in the existing Carnirora, the cutting edge being obtuse and occupying balf the crown only, while the elerated cone oceu. pying the remainder distinguishes the geuus from these aut from $H y \sigma$. nodon also. The lobe correspotuling to this coue is preceded in Hyanodon by a cutting edge, in Mesonyx by a tubercle.

$$
\text { Megonyx ontribess. Cope. }
$$

Proceedings American Philesophical Sor., 1872, 460, (July 29.)

This species was as large as our largest wolves. While the proportions of the limbs were not very different, the boly was rather more slender behind. The orbit was sinaller, and the cheek bone more prominent than in those animals. The long tail added to the general resemblance to the dogs. The measurements are as follows:

\section{Measurements.}

Length malar bone...

Depth malar bone in fipnt

Depth malar bone at postoribitai ati.....

Depth malar bone at middle of orbit.

Thickness malar bone at middle of orbit.....

Transverse diameter glenoid cavity of ncapula

Trabsvense diameter ulnar cavity

leagth centrum dornal vertebra
Diameter centrum do., transverno

Diameter centrum do., transverso
Diameter centrum do., vertical...

Length centrum of a median lumbar.

Diameter centrum do., tranaverse

Diatneter centrum do., vertical

Diameter centrum, fint ancral vertical .

Diatmeter centrum, first sacral transverso

Expasse of do

Length of two sacral vertebr

1ength of proximal candal

Expanse diapophyses candal

Diameter ecntrum do., vertical...

Diameter centrum distal caadal, vertiral

Diameter centrum do., transverse

Chord of femoral trochlea and condyles.

Width trochlear groovo

Width condyles

Width tibia proximaliy

Diameter do. antero-posteriorly

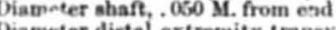

transversely.

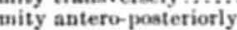

Length patella

Nugth astragaling.

Width astragalus above

Wilth astragalus distally

Width astragalus neek

Width enboid facet of taleaneum .

Depth cnboid facet of caicane

Wilth of a second metacarpal (sbant)

Depth of a second metacarpal (bead)

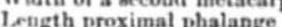

Width proximally.

Width proximally of a penultimate do.

Leugth of a penultimate do.

Iangth ungueal phalang

Width medially

Width prox. nalis..

Leugth crown of canine tooth, (worn)

Diameter of base fore and aft.

Diatueter premolar,

ength crown do.

ength bave premolar, (2)

ieight crown premolar, ( 2 )

Wisth crown true molar.

Height of cutting cigr.

M.

0.073

.073
.016
.023

015

0.3

There are no cingula on the teeth, and the enamel is perfectly smooth The appearance of the crowns as well as the bones indicates an adult The ap a

The bones of this animal were found togethar on a bluff of Cotton. wood Creek, Wyoming, by myself, while attached to Hayden's geological survey of the Territories for 1872 . 
SYNOPLOTHERIUM. Cope.

Proceedings American Philosophical Bociety, 1572, 483, (publisbed Auguat 20.)

Represented as yet by a single species, which is known from frag. mentary remains of a single individual. The portions preserved are: a large part of the skull with nearly complete dentition, the superior molars loose; lumbar and caudal rertebre; large portions of both fore limbs, including the bones of the feet; smaller portions of the hind limbs and feet.

The bones of the fore limbs are stont in their proportions. The humerus has a well-marked rugose line for muscular insertion on its posterior face, but no prominent angle. Distally the. inuer and outer condylar taberosities are almost wanting, and there is neither external aliform ridge, nor internal arterial foramen. The oleeranar and coronoid fosse are conflnent, forming a very large suzracondylar foramen. The condyles are moderately constricted medially, and there is a wellmarked submedian rib separated from the outer condyle by a constrietion. The latter is contiuued as an acute ridge on the outer side of the olecranar fossa. The inner coudyle is the more prominent, and its outer margin is a sharp, elevated crest. The ulua has a very prominent su. perior process, continuing the cot slus upwarl. The corouoid process, on the other hand, is rather low. The radial cotylus is flat and broad. The distal end is not preserved. The radius has a more transverse head than Canis or Felis, and has three articular planes, the inner being a wide, oblique truneation of the edge. The shaft is angulate below, and becomes a litttle decerer than wide near the distal end. The extremity is lost. The carpal bones are probably all present. The fore foot was found in place so that the relations of the bones are known wit a certainty. The scaphoid and lunar appear to be distiuct. The former exhibits proximally the inner tuberosity, then a slight concavity, and then the convexits, where it is obliquely truncated zo as to give a gen. eral rhomboid ontline. Beneath there are but two facets, the inner the deepest, and divided lengthwine by the truncation of the bone. The larger facet fits correctly the 0.0 . trapezinm and trapezoides. The lunar was not found in its place, but two fragments taken from the matrix just behind it, adhering to the pisiforme probably belong to it. The npper face is concave. The cuneiform is large and concave lengthwise above for the narrow extremity of the alua. Below it has a large coneave facet for the unciform. The pisiforme is of unusual size, and is as stout as the largest metacarpus, and nearly half as long as the outer (5th) metacarpal. It articulates with a thick $\mathrm{V}$-shaped facet of the cuneiform. Its extremity is obtuse and expanded. The trapezium is large and attached to its metacarpus laterally, seuding a process downwards posteriorly. If supports a narrow articular surface for the metacarpus of a small pollex or inner digit, which is not preserved. The trapezoid is smaller and of a triangular outline, with the base forwards. The magnum is a rather small bone articulating as usual with the metatarsals 2 and 3 . It is depressed in frout. The unciform is a large bone with a considerable external anterior surface. Two-thirds of its upper Burface are in contact with the cuneiform, the remaining part projecting upwards with convex face to unite with the lunare. Below it supports metatarsals 4 and 5 .

There were probably five digits of the fore foot, the inner small or radimental. The proportions are stouter than in tbe clogs, but not so much 80 as in the bears. The phalanges have a length sinilur to that seen in some bears, but the metatarsals are more elongate. The lengths of the latter are, 5th shortest, tben $2 \mathrm{~d}, 3 \mathrm{~d}$, end $4 \mathrm{th}$. Their condyles are broad, with median keel behind, and shallow supricondylar fossa in front. The first phalanges are about one-third the length of the metacarpals; the second of digit No. 2, broad and stont, and balf as long as the phalange of the first row. An ungueal phalange bas a singular form, so that the claw wight be snpposed to have a sabungulate character. It is flat, considerably broader than high, and with expanded and obtuse extremity. The articular extremity is depressed and transverse, concave in vertical, convex in transverse section. The s. terior three-fifths of the superior middle line are occupied by a deep gaping fissure, which separates the extremity into two points. The inferior face is entirely flat, there being no tendinons tuberosity. The sides are grooved, and give entrance each to a large arterial foramen proximally. grooved, and give entrance each to a large arterial foramen proximally.
These elaws resemble tlifse of Mesonyx, and differ remarkably from those of existing terrestrial Carnicora.

Of hinder $\lim b$ the only characteristic pieces remaining are the navicular, euboid, and an external euneiform bone. The cuboid is rather stout, with a slight concave facet at one extremity and two at the other one of them smaller and sublateral. The navienlar is wide and flat, and with a strongly concave astragaline facet. Below, it presents two deep oblique concave facets for the cuneiforms, with a small sublateral one on the outer side. The facets of the cuboid and astragalus indicate four well developed digits and another perhaps smaller one. Thus in this genus they were on both limbs probably 5-5, with the inner small.

The cranium is fractured above. There remain the squamosal and periotic bones, sceipital condyles, ualar and part of maxillary, both premaxillaries and the greater part of both mandibular rami. The postgleuoid process of the squamosal is produced inferiorby far below the auditory meatus, even further than in the bears. Its proximal portion inciudes, on the lower face, a strong groove at right angles to the axis of the cranium, with its defining margins acute and prominent. This is the transverse glenoid eavity of the carnivorous type. The zygoma has a wide curvature indicating a powerful temporal inuscle. The posterior angle of the malar extends well posteriorly. Its anterior portion projects, forming a longitudinal rib; there is no produced postorbital process. The tympanic bone is produced upwards and outwards and forms a tube with everted lips. The opisthotic (mastoid) separates it entirels from the exoccipital, at laminar expansiou. at pit in this bone near the me this bone mear sents the insertion of the stylohyal ligament. There is no bulla, the tympanie chamber being small and with thick walls. The charaeter of this region forbids the idea of any tapiroid aftinities on the part of this genus, and resembles that set is 1. the bears more than that of any other caruivorous type.

The prenaxillaries are vertico-oblique in postition, presenting thenareal opening directly forwards as in eats, but with a still less prominent
alveolar border. The horizontal part of this border is indeed very short, including but two small incisors. It then rises vertically, and turns obliquely backwards to the maxillary, inclosing a deep sinus with the canine tooth. From the anterior side of this siuus the larger external incisor issues, with its root extensively exposed externally. A rib ascends from the frout of its alveolus to the anterior or nareal margin of the bone. The triturating surfaces of the incisors are directed back. wards, and the alveolar edge is thickened in front of them with a tuberosity. The teeth are much worn so that the forms of the crowns caunot 
be determined, but projecting .25 inch bejond the alveoli they are compressed, the large onter tooth with a longitudinal angle in front.

The mandibular rami are quite elongate, and iudicate a cranium near the size of that of the brown bear, (Ursus arctos.) 'Their form is alender, and they have a long, rather narrow, symphysis, which projects obliquely forwards. The angle is not preserved. The mental foramen is large and issues just behind the canine teeth

The dentition is $\mathrm{I} .3$; C. $1 ; \mathrm{M} .7 \frac{7}{7}$. The canine is of very large size, especially the part protruded beyond the alveolus. The crown is stent at the base, but is soon compressed and obliquely truncated by the attrition of the inferior canine on its inuer face. Two superio-" molars preserved are three-rooted, and the section of the crown is more or less equally trilobate. The numler in the maxillary bone is estimated at seven, the number found in the ramus of the mandible. There are six two-rooted molars below and probably orfe single-rooted premolar, though this is indieated by an alveolis only. The molars are mather narrow antero-posteriorly, and are not very different in size, except that the penultimate is a little longer, and the last a little shorter than the others. Thers was evidently a longitudinal cutting edge behind, and some other shorter process on the front of the crown; the elge is pre. served on the last tooth and resembles that of Mesonyx, so that I have little donbt that the remainder of the tooth was, as in that genus, a conic tubercle. The most remarkable feature of the genus is seen in the inferior canizes. These are very large teetb, and are directed immedi. ately forwarls, as in the case of the cutting teeth of rodents. They work with their extremities against the retrorse crowns of the two external incisors above, and, laterally against the superior canine. They are separated by a space about equal to the diameter of one of them. In this space I find no alveoli nor roots of teeth; the outer alveolar wall extends far beyond the inner. The latter terminates opposite the middle of the superior canine. It may be that there are no inferior incisors.

Some of the vertebre display stout triangular neural spines; on the lumbars the posterior zyanophyees are embraced laterally by the grooved correspondents of the succeecing vertebra. Some of the caudal vertebre are long, slender, and without neural areh, indieating that this genus, like Mesonyx, had a long, slender tail.

Affinities. Having described the available parts of this form, it remains to consiler its place in the zoological system. The structure of the dentition of the upper jaw, with the mode of articulation of the man. dible, removes it from snch orders as Rodentia and Edentata. The only remaining oles with which it is necessary to compare it are the P'cris. sodactyla, Proboscidia, and Carnirora. As muny of the diagnostic bones are wanting, it is necessary to rely on collateral and empirical indica tions of relationship. From tapiroid types the development of the tympanic region distinguishes it. From Proboscidians the slender feet ty it. It then remains to compare it with Perissodactyles of the types which possess strong canine teeth. In points of resemblance to these we have the flat claws and separate scaplinid and lunar bones; nevertheless the greater number indicate truer aflinity to the Carnicora. Such are the external transverse glenoid ervity, the teeth with longitudinal crests, the slender digits, the well deceloped tsmpanic bone; confirmatory are the large canine teetl. the inicomplete orbit, and the projecting inner condrle of the bumerus. The form of the claws is not absolntely in. cempatible with the same order, as it is approximated by some of the Seals.

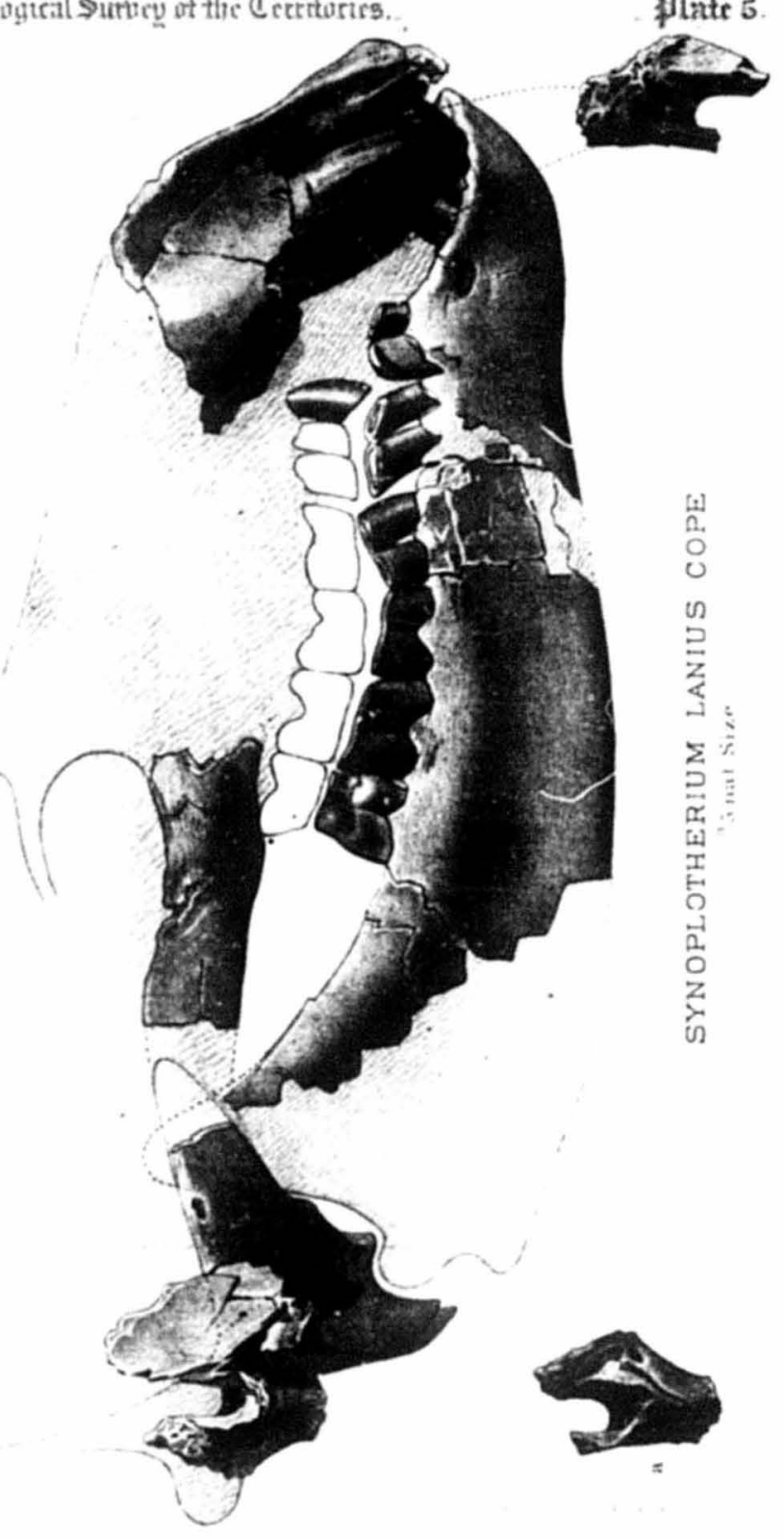


Among Carnivora, the feet are like both dogs and bears. The very prominent postglenoid ridge, and the narrow tympanic chamber" are decided points of resemblance to the bears, but the cavum tympani is even less expanded than in those animals. The characters of dentition are more like those of the Hycrodontide and Mesonyx than any other group and even the remarkable incisor-like inferior canines are approximated by the anteriorly directed canines of Hyanodon leptorhymohus, Laiz. et Par.

As a summary, it may then be concluded that the genus Synoplothe. rium is a Carnivore, presenting a number of points of resemblance to the bears, and to the extinct Hycnodons ; but that its distinct scaphoid and lunar bones, and flat clavs ally it to other forms of Mammalia, show. ing it to be a more generalized type of the order than either of the above. The peculiar approach of the lower canines is a special modifi. cation for peculiar babits, which I suspect to have been the devouring of the turtles which so abounded on land and in the waters of the same period. The slender symphysis conld most readily be introduced into the shell, while the lateral pressure of the upper canines with the lower. would be well adapted for breaking the bony covering of those reptiles.t It is not unlikely that this genus, Mesonyx, and possibly Hyonodon form port of the iest series which terminated in the Seals of the present.

\section{Synoplotheriug lanieg. Cope.}

Proceed. Amer. Philos. Soc., 1852, p. 483.

The cranium of this species is rather less than that of the grizzly bear, while the other boues do not indicate so large an animal.

Measurements.

Length glenoid eavit

0.045

Width glenoid cavity.

Diameter zy gomatio fosen.



Diameter cavum tympani...

Length ramus mandibuli preserved

Length of Aeries of beven molar teeth.

Widit of last molar crown...

Leugth of penultimate crows...

Widit of pepultimate crown.

length exposed part of inferior eanine..

Length exposed part of superior canine.

Length exposed part of onter upper incisor.

Diameter triturating-surface inferior canine

Diameter triturating-surface do., transver

Diameter sur erior canine, (antero-yos

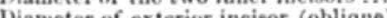

Diameter of exterior incisot, (obling

Diameter yaneal eritice

Depth nareal orifice

Depth mandibular ramus at ii. 6 . .

Thickness below of ramus at $\mathbf{M}$. 6 .

Length of a superior molar crowt.

- See Professor Flower's Osteology of Mammalia on this point.

- See Proceed. Amer. Philos. Soc, 1872, p. 484. 
Diameter condyle of humerus.

Diameter shaft of hnmerus (compressed)

Duaseter condyles of humerus.

Diameter head radius, (transverse)

Diameter bead rarlius,

Diameter cotylus of ulna, (lon;

Depth ulna at coronoid process

Leugth carpus and digit 2 without unguis.

Length two phalanges do.

Levgth metacarpal do...

Leto.

cetigia metacarpal No. 4

Length metacarpal No. 5 ......

Length cunciform, transversely

length pisiform

Wiulth pisiforn distally

Wength unciform, transvenely

Wiatl anciford, antero-posternt

Width trapezid, antero-posterionly

Lepgth trapezintm, vertically

Width scaphoiri, anteto-posteriori

Width nasictalar, anterv-posterioris.

Length navicular, trausrersely

Length ungueal phalange.

Wiath ungueal phalange ..................

Dianeter centrum of caudal vertelsra..

The dental series is uniaterrupted from the canine, if, as I believe there is au alveolus for a simple premolar behind it. This I overlooket when first describing the species, and hence gave the molars as 6 instead of 7 . The superior canine is smooth, but the inferior one of the left side has a longitulinal groove on its extero-inferior face.

Restoration.-This carnisore had a large head, with a long, rather narrow, aud trumeate muzzle. The limbs were relatively smaller, not exceeding those of the black bear (Crsus americunus) in leugth and thickness. The tail was long and siender as in the cats, while the claws were broad and flat.

History, locality of $c$ - The teeth are rers mnch morn, indicating the bard fool on which the auimal had subsisted, as well as its mature age. 1 originally described this species as resembling the remarkable genus Anchippodus" of Leidy, and subsequently (on the Short-footed Ungulata of Wyoming, Se, p. ., have alluded to the large rodent ineisor. like teeth as though they were homologous in the two genera: I there identified these teeth in Synoplotherium as canines, adding that they were probably the same in Anchippodus, Having determined the carnirorous affinities of the former genus, the homology of these apparently similar teeth in the latter becomes problematieal. With our present knowledge, the type of molar teeth in Auchippodus resembles that of many ungulates, and it is not therefore probably allied to Synoplothe. riam. Nevertheless, it is not yet certain that the teeth in question are incisors, and that the genera are in nowise related, thongh a similar modification of a remarkable character in distinct but co existent types is $y$ no means an unprecedented cireumstance.

The remains on wbich the above identification is based, were found by the writer on a terrace of the Mammoth Buttes, near South Bitter - See in Hayden's Geol. Surv. Montana, 1871, (as Trogonus.)
Hi. \$. Sorolugical \$uruev of the Cerrituries.

Plinte 6.
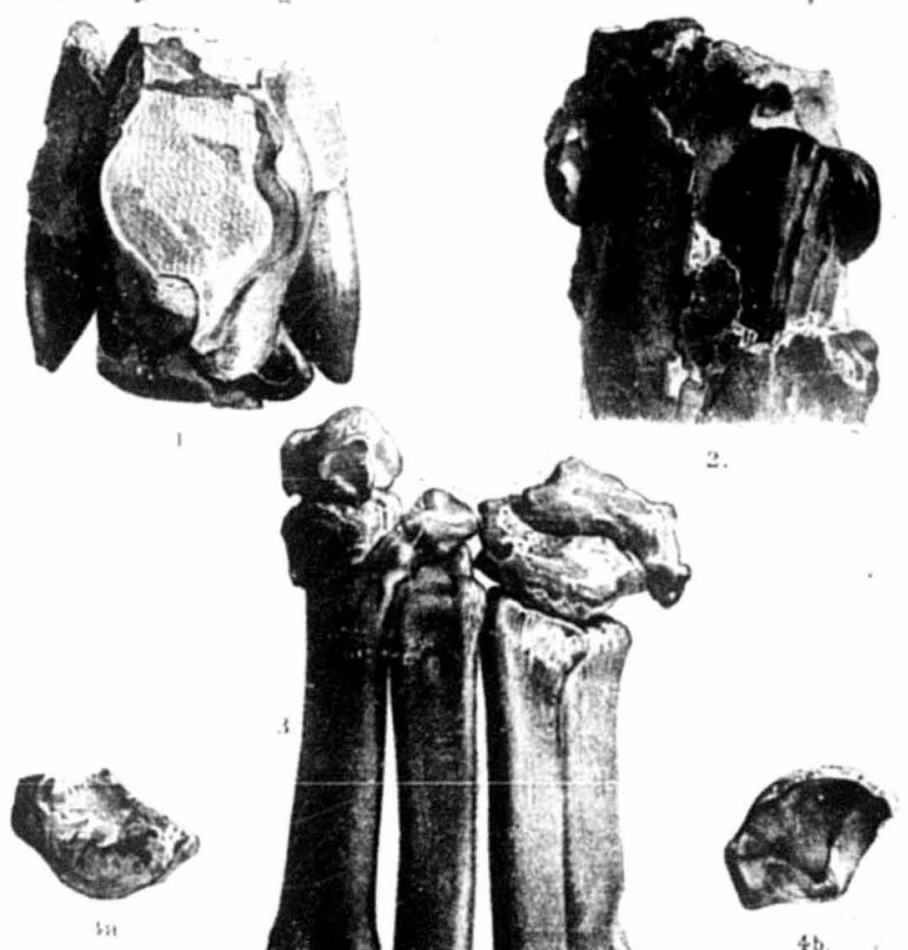

SYNOPLOTHERIUM LANIUS COPE

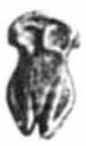


Creek, in Wyoming. The eranium and fore foot and ๆeg were excavated from the deposit.

Formation, the Bridger Group of the Eocene of Hayden.

Professor Marsh tas described two genera of Carnicora froth the same formation, embracing species approaching this one in size. They are both distinguished by the broader forms of the crowus of the inferior molar teeth, and other points.

\section{STYPOLOPHUS, Cope.}

Proceed. American Philos. Soc. 1872, p. \$66; pnblished Angust 3, 1872.

This genus embraces small species of carnixorons animals found by the writer in the Eocene formation of the Bridger Group. It is repre. sented by portions of mandibular rami of three species, rith molar aud premolar teeth.

The generic characters are seen in the composition of these molars, which have but two roots, and $\mathrm{a}$ posterior table, a is seen in tubercular molars of some Virerrida. The anterior two-thirds of the crown is composed of conic cusps. On the last molars these are in two series, two lower, of the inuer, and one more elevated, of the outer, opposite the interval between the inner. Its onter face is regulariy convex, but its posterior forms, with that of the onter series, a single flat vertical plane, which form a shur angle with the inner aus' nnter faces of the cusps.

The structure is, in general, comewhat like that of Alesonyx, Cope, but The structure is, in general, somewhat like that of Alesonyx, Cope, but
he lack of cutting edge ou the posterior lobe, and the two rows of tuber. cles separate it 'widely. Dr. Leidy' describes Sinopa as laving a sectorial tooth as in ordinary Carnirora, with an interio: cusp; hence it is not probably the present form, although oue species was about the size of the $S$. rapax.

Stypolornus insectivont's, Cope.

Proceerl. Amer. Philon. Soc. 1072, p. 469; publishéd August 7, 1872

Represented by a posterior molar and a premolar of the right side of an animal less than half the size of the $\mathrm{S}$ prongens, Cope. The molar presents three anterior trihedal acnte tubercles, of which one is exterior and more elevated than the others. Its posterior plane forms one rior and more elevated than the others. Its posterior plane forms one cular heel is low, and supports an oblique ridge which bounds a deep groove behind the outer cusp, no doubt to receive that of the upper jaw. This arrangement is not seen in $S$, pungens. The premolar is a flat cone with faint traces of a tubercle behiud and cingulum on inner side.

Measurements.

Length crown molar... 0.0050

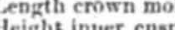

Nength heel.

Width erown

Ieight etown premoliar.

Length crown pretwolar.

Found in the Eocene Bad Iands of Black's Fork, by the write

Stytolophus puxgexs, Cope.

Loc. eit., 18:2, p. 466; publisbed Augnst 3.

This is the type of the genus, and is partially described in the generic paragraph.

The euamel is smooth. 
Measturements.

Depth ramus at last molar Length last molar

Width last molar, posteriorly

This species was about the size of the gray fox.

From the bluffs of Cottonwood Creek, Wyoming.

Stypolophus brevicalcaratus, Cope.

$$
\text { Loc. oit., p. 460; publisbed August 7, } 1872 .
$$

Established on a portion of the left mandibular ramus, containing the penultimate and ante-jenultimate molars, of an animal of larger size than the type of the genus, $s$. pungens. The molars have the general characters of the corresponding ones of that species, but differ in their greater elevation in comparison with their length, and the greater con-

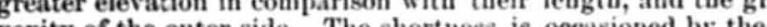
the abbreviation of the heel, which, in the last molar present, is very small and flat, without keel or tubercle on its surface. That of the molar preceding it is larger, and presents in its elevated onter margin a trace of the keel seen in the smallest species. Enamel smooth.

\section{Measuroments.}

Length of two molars Length.of peunitimate crown Width of penultimate crows. Length of penteltimate heel.

There is some similarity between Stypolophus and Triacodon, Marsh. Ii the heel of the molars of the former were wanting, thes would be those of the latter. The premolars might be supposed to lave this strueture, but the form seen in $S$, insceticorus disproves this view, In fact, I have seen both molars and premolars of Triacodon aculcatus, Cope, and the former lack the heel of the stypolophi entirely.

\section{VIVERRAVUs, Marsb. \\ Amer. Journ. Sei. Arts, 1-72, p. 127.}

Viverrayus parytyorys, Cope.

Miacis parricerus, Cope. Proceel. Amer. P'hilos. Soc. 1872, p. 470, August 7.

Established on a portion of the right ramus mandibuli, containing portious of three molars, the penultimate being perfect. As in Canida, the molars diminish in size posteriorly, the last being single-rooted, the penultimate being two rootel. The structure of that tooth is approxi-

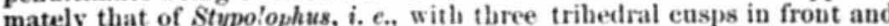
mateel the of sty bet the union not raised abore the surface of the beel. This is a valley bounded by a sharp margin which is incurved to the onter cusp, leaving a vertical groove on the outer side, as in Stypolophus sp. This genus further differs from that one in the siug/e rooted, small, tubercular posterior molar, which is wanting in that one. The ante-penultimate molar is mueb larger than the penpltimate. The crown of th. latter is laterally expanded, and bears a cingulum at the base anteroexterually. Enamel smooth.

\section{Measurements.}

Depth ranus at penultimaste molar

Leigth crown of penultimate molar.

Elovation erown of penultimate mola

Fonnd on Black's Fork of Green River. An ally of Stypolophus and Triacodon.

This species appears to belong to the genus Virerrarus of Marsh, which bears date July 22,1872 , consequeutly sixteen days earlier than Wiacis, which thus becomes a synonym. The sprecies is difierent from those described by that author.

\section{UNGULATA.}

In no group of Mammalia have the determiuations of paleontology been more signiticant than in the Ungnlata. Here, in an especial manner, the anticipations of science have been realized, in the filling up of the the series of living forms. Here especially is it evi. dent, that the existing fauna is but a fragment, and that the fauna of the pat, as we know them to-day, are but the precursors of what wemay bring to light to-morrow.

The prims The primary range of variation in $t^{\circ}$ structure of the Ungulata has
been generally admitted by zeologists to be found in the structure of the limbs and feet. Three most prominent types have been distinguished on this basis, viz: the Artiodactyla, Perissodactyla, and the Proboscidia; rith some of lesser importance, those of the Toxodontia aud Hyra. coileg. If we direct our attention to the detailed structure of the feet, cor the teetlin, tia and Omni. rora, and in Perissodactyla, between Equas and Rhinoceros. In either order canines and incisors may be present or absent, and molans assume a great variety of patterus of enamel plication. The toes in the latter order may vary from four to one. Nevertheless, the most direrse genera are bonnd together by intermediate forms, often extinct. Connecting are bound tragulus, de. In Perissclactyla, Anchitherium, Palacosyops, dce, connect the extremes. In Perissctactyla, A nchitherium, Palacosyops, de., connect the extremes.
The Proboscidians have, on the other hand, remained until recently an isolated group with but few representatives, hence its definition as an order has been more or less obreured by characters of a special nature, Arawn from the dentition, trunk, \&e., which it has been found necessary to ouit in characterizing the two orders above mentioned. These characters are so striking in their apyearance as to suggest greater systematic importance than belongs to them. Thus the trunk is not more important as a character of the Proboscidia, than it is of the Perissodactyla, where the tapir alone possesses it. Nor are the complex molars and large tusks to be regarded as a definition, for in the Phacocharas we have molars as connoun as in some mastolons, huge cauine teeth, and no incisors below; characters very different from many Artiolactyles, Sor can we regari the exclnsise union of the astragalus with the navieular as a fiul test, for in Perissodactyles the facet for union with the cuboid may be considerable (Rhinocerus) to almost nothing, (Equis.)

The occasion for this discussion is presented by the discovery by the paleontologists of Hayden's geological surveys of $1871-72$, of the remark. -Fide Gill, Arrangement of the Families of Mammals, Smithson, Minc. Coll., 1 72 , No, 230; the best analysis of, the Mammalia yet publisbed.

$36 \mathrm{G} \mathrm{B}$ 
able types Bathmodon, Uintatheritm, and Eobasilens. These genera contradict in several particulars the characters usnally assigned to the Proboscidia, while they agree with them in others, and they thus pre. sent the problem of classitication, which will ever recur so long as addi. tions to our knowledge of the life of the past continue to be made, This problem is simply the question as to what eharacters shall be retained as definitive of natnral divisions, on the discovery of intermediate forms. As our system is an expression of the possession of structural claracters, our higher groups or orders are naturally expressious of the existence of the more compre hensive characters, or those present through the most extended series of species. Hence we believe them to be also those assumed earliest in time.

In the case of the Vinqulata, the structure of the feet seems to define the greatest range of 1 :e species. Thus the Artiodactyla and Pcrisso. dactyla are digitigrade of unguligrade, while the Proboscidia are plantigrate. The first order exhibits the equal development of the thiri and fonrth toes; the kecond of the third toe, while in the Eroboscialia the structure is like the last, with more nnmerous digits. But this orler differs from both the preceding in the relations of the ulna and radiux. In Artioductyla and P'erissoriactyla the ulna diminishes greatly distally ani presents but a small carpal articular surface obliquely be hind that of the much larger radins. In Proboscidia the ulna expanding presert $x$ the larger articulation with the earpus, and the radius erosses it obliguels, aud presents its artienlar face alongside of the ulnar.

The characters of the three orders may be thus stated:

Prnonoscidia. *

Feet plantigrade but elesated belinal by a plantar pad. Toes numeroas, short, the midile (bi) largest. Ilimb limb with knee free frem the

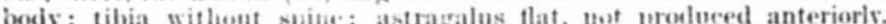
Fore limb with well develoled ulna artuenlating extensively with the carpus alongside of the smaller radius, which crosses it obliquely.

\section{Penissodactila.}

Feet digitigrale, with a look joint. Toes ridnced in number, the third largest. Hind limb with knee inclased in infersuent of body; femur with third troelanter; tihia with spine. Antragalus with pulley shaped articular face for tibia and anterior prolongation. Fore limb with ulua redueed; its carpal surface snaller than that of the radius, which supports the foot in front of the alna.

\section{AnTIODACTYLA.}

Feet digitigrade or unguligrade. Toes reducesl, the third and fourth principally and equally developed. Hind limb with knee applied to the side of the body, and elevated lock; fenur without third trochanter; tibia with large spine. Astragalus with both inferior and anterior pulley-shaped surfaces. Ulna much rednced distally, behind the radius, which includes almost the whole of the carpal articulation.

This arrangement violates previons views less than any other that would recognize the primary characters of the Eobasileus. The diffieulty of determining the limits of the two tirst-named orders is partially cansed by the fact that the Hyracoidea present the radius of the Proboscidia with the hind foot of the Perissodactyla. These animals are, how. ever, well remarded as a distinct order. Whether all the animals to be ineluded in the Proboscidia possessed a proboseis or not, is of secondary inciuded theres is nevertheless highly probable that Loxolophodon and Eobasilens possessed one, and not unlikely that such forms that apEobasilens possessed one, and not unlikely that such forms that ap-
jroach still nearer the tapirs were not without an organ such as they possess, and which Cuvier ascribed to the Palcotheria and other allies.

\section{PROBOSCIDIA.} One incisor or canine on each side; molars compound, with posteroanterior replacement; nasal bones abbreviated; astragalus articulating
with navicular only; no third trochanter .............. Elephantide. with navicular only; no third trochanter ................. Elephantide.
Veither incisors nor canines; molars simple, with vertical replacement; nasal bones shortened; (1) foot; no third trochanter.... Pinotheriider. Vo incisors; nasal bones elongate; astragalus articulating with both mivicular and cuboid; no third tmochanter................ Eobasiliida. Dention conplete, incisors present; nasal bones, Astragalns Dentition complete, i. $e$., incixors present; ? nasal bones. Astragalns articulating with both navicular and cuboid; a rudimental third tro-

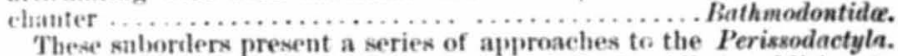
Thus the Eolnailiida agree with the typica! Proboscidia in addition to Whe abere points, in the posterior expansion of the seapula and its mient nenminution; in thery shert cervical vertebre; in the that cirval bones; in the absence of pit for ronnd ligament of the femur; in the thattened great trochanter, contracted condyles, and fissure-like intercondylar fossa of the same bone. In the longitudinal crest of the tibia separating glenoid articular fuces which are on a transverse line. In the short caleanenm, which is wider than long, and tubereular on the inferior face. In the five digits; the acetabulum not separated by a jerluncle from the iliae plaies, and the lack of angular production of the latter luevond the sacrum. Also in the three distingnishẹl sueral vertebrae, as contrasted with the fire closely co-ossified ones of the Fhinocrotida. These characters are, some of then, of subordinate value ouly.

The chief differences are seen in the craninm. though here also there are important resembiances. Thus, the palate is not excavated bethe molars posteriorly, as is Pcrissodactyla, nor are the palatine bones proluced posteriorly and separated from the maxillaries, as in Artiodactyla gen-rally. They have a shallow exeavation and accompany the maxillaries posteriorly withont interruption, as in Elephas. In Loxolophodon the malar bone forms the middle plement of the zygomatic areh, send. ing a narrow strip ouly forwayd to the neighborhool of the lachrymal. (he sicle of the face is rather greater, much as in some Periswolactyla. The dentition is not fartemoved from that of Dinotherim, and the inote of succession of the teeth was in all probability similar. The premaxillariesand nasals are excarated and exostosed for the attachment of a truuk in Loxolophodon. The lateral and oceipital erests of the cranimm, thongh difierent from the eniarged sinnses of the diploe of Elephants, represent the external walls of this structure, and fnrnish a hint as to its mode of origiu, and serve to ease the transition to Perissodactyles.

The differences in the cranium are consequent upon its anterior elongation, the nasal bones and premaxillaries becoming,thus mueh extended. The lachrymal is perforated by a small lachrymal canal in Cintatherium, 
according to Marsb, but excavated on the margin only in Loxolophodon. It is neither in Elephas. There is a post-glenoid proeess much more largely developed than in Elephantida. Other difierences of still less importance are to be seen in the anterior position of the exterior nares, and the presence of horns.

and the presence of horns.

The Bathmodontida are represented by Bathmodon. With a strueture
of the hinder limb uearly resembling Eobasileus, we have more pronounced relationships to the Perisodactyles. The scapula has the massive apieal acumination of the Elcphantida, and there is no round ligament of the femur in some of them. The astragalus has the same flattened form seen in Cintatherium, aud is even less like that of the Perissodac

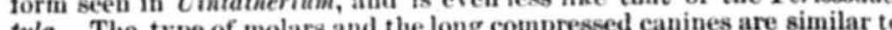
those of Loxolophodon. On the other hand, the cervical vertebra are rather longer, and there is a rudimental third crochanter of tine feun.

History, de. I originally referred the Eobasileide to the Proboscidia, on account of the structrre of the limbs, and subseqnently stated a num. ber of reasoais for this conclusion at a meeting of the Academy of Natural Seienees of Philahlo 16icuces of added. The Bathmodontida $I$ have heretotore referred to the Perisso. dactyia.

Professor.larsh, in describing a speeies of this gronp, Titanotheriun ( $?$ ) anceps, (July, 18:1, compares it with perissodactyle species, and in de seribing the tibia sas s that it, " at its proximal eud, has the femoral sur fachos

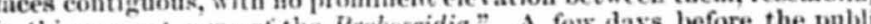
in this respect some of the Frobuscidia. A few cation of my concluxions, in a foot-note, (Jnly $22 \mathrm{~d}, 18.2$, ) he aitered the name Titanotherium to Mastodon, indicating that he had reached the same opinion. Shortly after, (American Journal of Seience and Arts, September 27 th.) he altered his view, constructing a supposed new oriler so binocerate" for their reception.

As ristis the fatiles families above mentioned, 1 have preferred using one already employed to coining a new one. This is the better conrse also, if, as is not unlikely, the distinctions on which it, as weil as the other two orders, repose, shal be broken down by new discoveries in paleontolosy.

\section{EOBASILEIDX.}

The genera of this group known to the writer are four, which differ as follows:

1. Naxal bones with that horizontal horneoresoverhanging their apex. Cervical vetebra short; malar bone much redaced in front.......... Lorolophodon.

2. Nasal bones with sinall tuberosities.

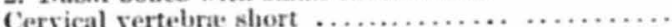

Cervical vertebra longer; the ualar bote reaching maxil.

lary face.

Eobasileus.

3. Nixal bones withont the anterior horn-cores.

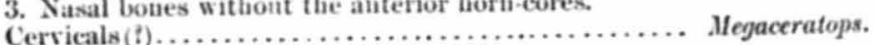

The above is the closest approximation to nature which my present material allows. It is not at all unlikely that the difference in development of the anterior nasal tuberosities seen in Loxolophodon cornatus and Eobasileus pressicornis will turu out to be only specific

The dentition of this group requires special notice. Judging from the 


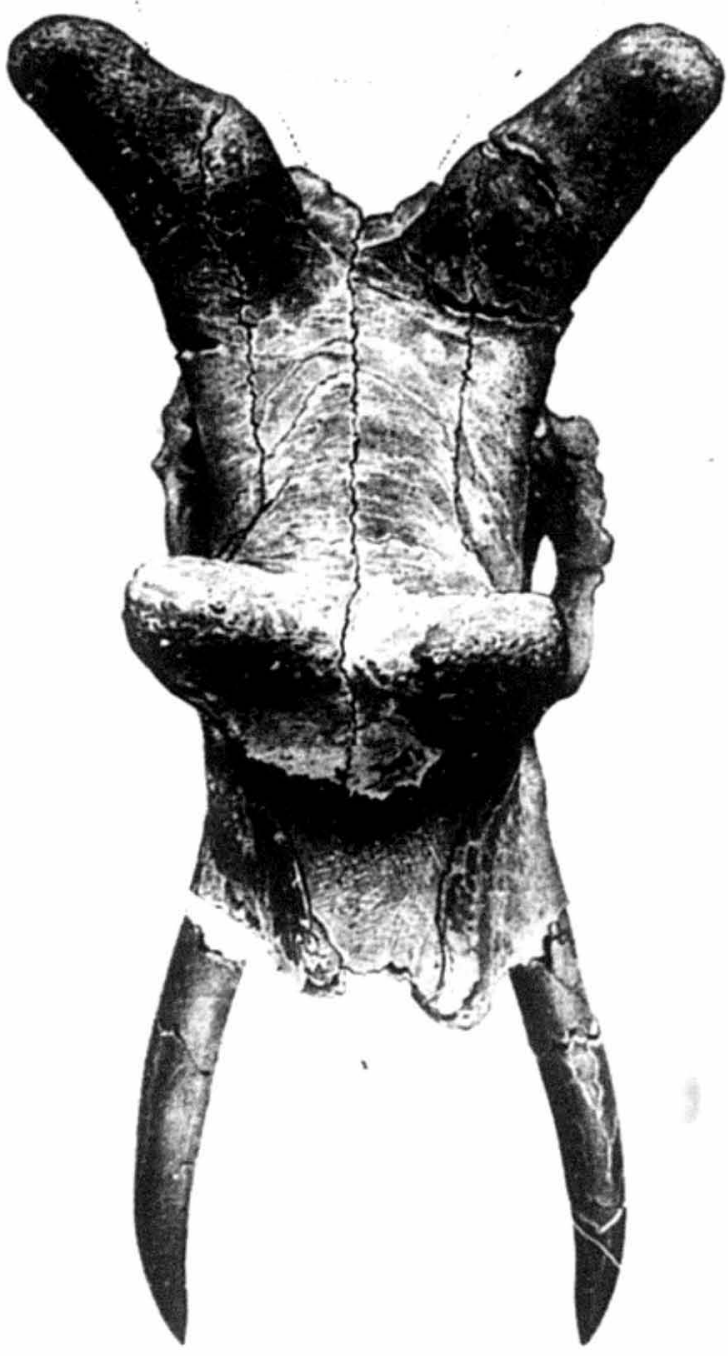

relative sizes of the teeth, I have written the molar series of Loxolopho. relatis $4-2$, but judging from the forms of the crowns, it should be $1-5$. don 4-2, but judging from the no donbt that as in other Proboscidia the However this should be, Thave no doneficient, and that there are three premolar and not the molar series is deicient, and alone, which agrees in or four true molars at least. In a mandible mals are preserved. of size with some species of Uintatheritum, six molars are preserved. Of these the posterior two display three sub-transserse crests, of which the anterior two form a cherron with open apex directed to the inside. Auterior to the front crest is at is co-ossified, exceedingly compressed, and the jaw is remats curved upwards so as to

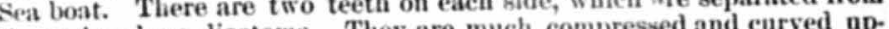
the molars by a diastema. They are mich compreso saw in contact wards and forwards, and the anterior pairissac mon the yaw incontact. The crowns are lost in the specimen. The determinatiou of these teeth is fuilited by the presence of the mental forauen below the posterior is fre This foramen issues, as is well known, posterior to the canines in onle This bin diastema. The two all Jammatia, and will the be premolar and canine respectively, and the teeth in our fossil will then be premolar and This is in conformity with the incisors must be regarded as wanting. This is in roufor great reducstructure of the upper jaw, and is rendered probable by the great reductwon of the symphisis of the lower jaw in the species. It is also suggested fy the almost universal tendency to reduction of the incisors seen in the by the of the sume extinet fauna. In Bathmodon and Palcosyops the maminas or in Ruminantia, and in Pala canines are thrown into the in several genera there are osyops the outer inclsors are anch reloct hnt two incisors. Finally, in synoplotheriem the large inerior s.ribed by myself as incisors, and which resemble the cutters of Rodentia, are immediately in frout of the mental foramen, and bear the same relation to it and to the premolar teeth, as do the canines of Palcosyops and thon to be canines, and that the in other Mamedice the probility of the fertor incison ire wantiog is a small interthith of this determination is increased the prese the canines of the upper jaw.

\section{LOXOLOPHODON, Cope.}

Procedings American Philosophical Society, 1672. p. 580, extra copies published Angust

The cranium in this genus is very elongated and compressed. The The ene muzzle is posterior shocel, which rises above the extremity of the bone. ont into a bilobed shovel, which shert and decurved. A second pair of This extremity is su'sconic, and short and dection. A externally of the horn cores stands above the orbits; each one composed exterthe posterior maxillary bone, and internally of an upward extension of the posterior part of the natsal. Behind this horn the superior margin of the temporal tossa sinks, bat rises again at its posterior portion, probably above the le rel of the middle of the parietal bones. This portion of the skull is cret of he my only specimen. The oceipital rises in a wall upward from injured in ny only splecimen. The oceipabls, a little in front of the junethe foramen magnum, and supports, probably, a little in front of fossa, a tion with the superior and inferior ridges bounding the temporal oss that third horn-core on each side. The base of this core is as stont as that 
principal extent posterior to the zygomatic areh, and is in form like a trougb, the inferior edge being recurved from the squamosal process to the summit of the occipital crest. It is narrow within the zygomatic arch, which is short, inclosing a space whose length is less than onefourth that of the craniun.

The occipital bone extends but a short distance on each side of the The occipital bone extends but a short distance on each side of the
condisles, and is separated from the mastoid by an irregular suture, condyles, and is separated from the mastoid by an irregular suture,
which is pierced by a large mastoil foramen. On the inferior face, near to each condyle, and one third the distance from its inner extremity, is a posterior condyloil foramen, isolated by a narrow bar from the extreminy of the foramen lacerum posterius. The paramastoid process is repre. sented by a small taberosity, and the mastoid by a rather larger one, some distance anterior to it.

The meatus auditorius opens upwards just below the external ridge of the temporal fossa, and at a little distance behind the post glenoid pro. cess. Its canal contracts rapidly, and extends upwards and backwards towards the labyriuth. It is separated from the foramen lacerum by but a thin wall, and if there was an expansion of the carum tympani, it must have been exeedingly amall, owing to the close approximation of the have ben exce tal and sphenoid at this point. The labyinth is lodged in a petrous mass opposite the occipito-mastoid suture, and the canals are small.

The basi-occipital contracts anteriorly, and with the sphenoid forms an uninterrupted bonudary of the foramen lacerum. This terminates opposite to the posterior boundary of the external meatus, and gives rise to a wide, shallow groove, which extends anteriorly between the pterygoid ala and the post-glenoid process, and turning outwards round the latter, grooves it. Opposite to the post-glenoid process, and just posterior to the end of the pterygoid, a small foramen enters, which is probably the fora. men oraic. Almost continuous with it is a canal which pierces the base of the pters roid longitudinally, and issues in an excavation of its externai face near the spienoid.

The pterygoids are remariable for their great length, inclosing, as they do, with the palatine process, a deep, narrow, trench-like fossi, which measures almost the entire length of the zygomatic fossa. Procenses of the sphenoid contribute to these walls, (which are thus double.) and the sphenoid roof is strongly concave. The alisphenoid is elongate anteroposteriorly, and is principally in contact superiorly with the frontal; at teriorly it las a short suture with the lachrymal. Almost its entire length

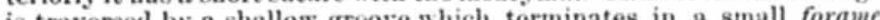

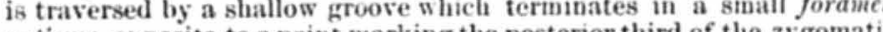
opticum, opposite to a point marking the posterior third of the zygomatic fossa, The foramen rotundum issues as ustal between the alisplenoit and the pterygoid, but is considerably anterior as well as inferior to the f. opticum. I cannot determine whether the orbitosplenoid is distinct.

The lachrymal is a large bone, of a triangular ontlive, the shorter 1. being inferior. It is entirely on the inuer face of the orbit, and, as us the elephant, separates the froutal and maxillary by its snperior prolongation. Its inlerior border is slightly notehed in front by the large foramen infraorbitale posterius, and the anterior is deeply emar ginate, passing behind the smail $f$. lachrymale.

The palate is remarkable for its length and narrowness. Its roof is chiefly composed of the maxillaries, but a very short portion is formed by the palatine plates of the 0 . o. palatina. These are protuced into a median point behind, between the nares, and exteriorly form the iuner wall of the postnareal trough for a considerable distance. The closely united maxillqries form the outer wall for a short distance, being pro 


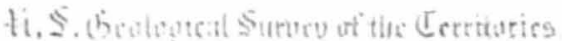

flitis $:$

luced in a contracted form behind the molar teeth. The two bones in. ante. close a small foramen in this prolongation, palatinum. The posterior nior suture of the palatine, the foramen palatinum. The posterior nares are not exeavated anterior to the line of the posterior border of the last molars. The palate is deeply concare anterioris. an elongate foramen close to the alveolus of the frst premolar, extending anterior to it. The premaxillaries aro longitudinal and septending for two-fiftlis of their length, by a large foramen arated anteriorly the incisicum, which they do not inclose. They extend and are prolonged muzzle into an acnte angle upwaris and backwards, and are prolonged forwarch above the exterior nares, which the suture reaches by an abrupt descent. The inaxillary supports the malar on a posteriorly directed process which reaches to the end of the anterior third of the arch below, ualf that distance on the side, and is bordered by a narrow strip of the mar ou ue iuner side, as far as the anterior boundary of thé of the malar on tae imer do not inclose the very large foramen incisicum orbit. The premazidaries do not inclose the

in front, and are therefore deeply furcate. The dentition is 1.0 ; C. 1 ; 1. M. 4 ; M. 2 . The caniue is a tusk of cominesere Its faug is embraced one-thirl by the pre stron forles of the minxilt y hell crantum, which exteuds upward thd backward. These have worn, and have transverse cordate surfaces of attrition. These have probably resulted from the wearing down of a chevron of two crests converging inwards, in some with an inner tubercle. On the molars this crescent is represented by $\mathrm{a} V$, with the apex inwards;

ver tubercle is at one japer published Angust 19, 1sz, as above citen, with adiagnostic deseription; the L. cornutus was there citer ans the first spes, and is here retained as the type. I again described it more fully in a paper published August 22d, citing Eobasileus (August 20th) as a syuonym, perhaps incorrectly, as indicated by the present paper. The same nounchare was emplosed in a paper real before the American Associa tor the sclence, held at Dubuqte, commencing Angust $23,18 \pi \cdot 2$.

II the paper of Angust 22-2d. I regarded this genus as identieal with that to which I had previously (February 16, 1872) applied the name Loxolophodon, and included in it the species there called Bathmodon (Lomlophodon) semicinctus, Cope. With further material this appear: hot to be eorrect; the liallumodon semicinctus butougs truly to that genus, and is very near to the $B$. radians, so that the name Loxolopho. genus, and is very near to the B. radians, so used again for don becomes a synonym in this connection, and may be used again for scribed at the former date, and had no proper claim to recogrition.

Professor Marsh, in the American journal of Seience and Arts, 1872, (September 21,) applied the name Tinoceras to a species (T. grandis) of this genus, and gave a description, in which some of the generic chacters has previously applied it without description to the Titanotherium $f$ anceps, August 24tb, it without description to the Titanotherium $f$ anceps, August 24th, ceras anceps.) As no characters whatever were assigued to it on either of these occasions, it had no value in zoological nomenclature.

- I did not receive this, and most of the other papers of Profeseor Starsh on this fanua, till early in Deoenber, 107

t Theso papera wero not receired by me till early in December, 1872 


\section{Loxolophodon cornutes, Cope.}

Lorolophodon cornatus, Cone, Proceedings American Philosophical Society, 1872, p. 560,

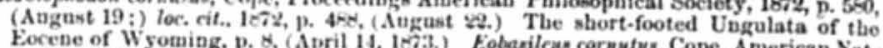
uralist, 1872, p. 774. Timocress gradin, Marsh, American Journal of Science ant. Arts, October, 1072, (published September 21,) fide Sarsh. Journal of Science and

Established on the remains of a single indivitual, which consist of a nearly perfect cranimu, the right seapula complete, several vertebra, incloding the sacral, the first or second rib, the pelvis complete, and the entire right femur; also probably the proximal end of a ridins,

The species is remarkable for the marrow form of the cranium, its width at the middle being one-fourth its length. A little in front of the middle are situated the horn cores. These diverge, the upper portion baving an outwarl curvature. The base of each is tringular with obtuse angles, in section, and the inner angle is the section of a rib-like projection which extends across the frout to its fellow and rixes half way up the horn-core Above its mather abrut termination is transveraely come is trausversely compressed, with oval obtuse apex. The core neasures M. 240 (9.5 inches) from its base in front, M. .108 (4.25 inches) in width at the base behind, and .077 (3 inches) in diameter at the apex. A slight swelling of the sides of the muzzle descents obliquely forward from the base of each horn, which enlarges below into is prominent rib, which incloses the alveolus of the easine task. In front of the horns the mizzle is rooflike; anteriorly it flattens ont, and swells a little above the posterior end of the nasil meatus. In front of this it expands again, and rises gently to the extremity of the bilobed nasal shovel, which overhang the premaxillaries, the nasal meatus, and the greatier part of the apex of the nasal bones. The latter is short and with a wide base, and resembles two lateral cones flattened together, their extremities obliquely truneate outward and exeavaterl. The composition of the upper surface of the cranium is somewhat difficult to determine, owing to the injured state of the posterior part. If we regard the bone which bounds the lachrymal behind and above, as frontal, as I did in originally describing the species, it gives an extraordiuary extent to the nasals, for the common suture of these bones extemls V.shaped backward, to a point opposite to the middle of the zyromatic arches It gives to the pasals an extent equal to that of the trontals and jasietals contion. They not only s'puort They not only s"pport the anterior lobes, but form the inner half of the median horn corts, risin, as high as the tuberosity abo described. To regard these bones as frontals would involve the improbable pecu. liarity of their extending beyond the nareal oritices, and the terminal cone of the nasals is not separated from them by snume, but by a groose otuly. The question is leculed in favor of their being bones as preserved in folnsileus boses as pror a tube is represented by a tubercle only on the side of a continuous nasal. The inmense leugth of the snout in Loxolophoion looks as thongh the naxd bones liad extended themselves forward, so as to ossify the basal por. tions of an elephantine proboscis.

The frontals descend behind the herns, with a very obtose or ronnded continuation, to the inner side of the fossa, and without any superciliary margin. They form with the posterior part of the nasals a shallow me. dian basin. The suture with the parietals is very indistinct, but if I have truly discovered it, it forms another posteriorly directed ehevron, and leaves but a narrow superciliary portion of the frontals. Above the 
Whate 3

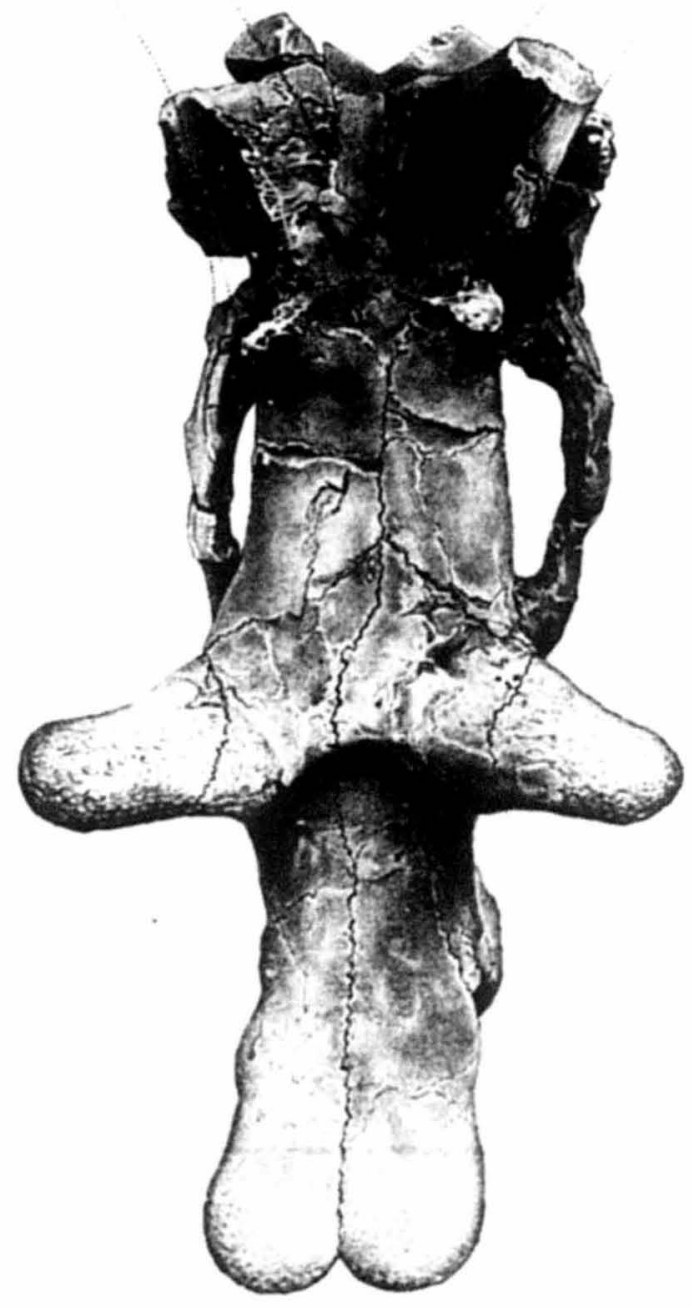
postglenoid processes the parietals rise at the mastoid region, the cracrest, but to what height is uncertain. At the sides by the temporal fosse. niam widens a little, and is excavated at the sides by the temporal fosse. Near where the lateral and posterior erests join the inferior ridge-like border of the temporal fossa, in front of a position occupied by a knob in 2 . pressicornis, is a strong horn-core with sub-cylindrie base. It sal and transverse erests, and is connected to these by an oblique ridge, sal and of which is marked with irregular, short, longitndinal rugosities. one side of which is thes portion was At the base of these elevations are three sinuses. This portion was its attachment has not been discovered by actual fit.

The occiput rises upwards for four inches above the condyles; perhaps it displased a posteriorly sloping transverse crest as in $F$. pressioornis. The paramastoid and mastoid tuberosities are narrowed and extend ob. liquely downwards and forwaris. The lower part of the exoccipital liquely downwards and forwarts. suture runs along a ridge, and there is a tuberosity in front of the thastoid foramen. An irregular A-shaped crest extends apwards with the apex at the inferior temporal erest, and its anterior limb forming part of
(ne posterior boundary of the meatus auditorius. The inferior temporal crest is directed outwards below, but forwards above.

The glenoid processes. These are not deep, but have considerable trans. glenoid processes. These are not deep, bat have little greater than the verse exteif, and are separated by a space only a little greater than the posteriorly, with crest-like superior ridge, but rouncied above anterioriy. There is not the least trace of posterior bounday of theorbit. The sinamosal process overlay the malar bone extensively, terminating in punt the latter ending obusely. The supported in front by

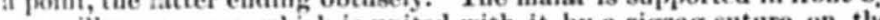
onter face nhe as equar orbitale erterius is large, and issues a short distance in front of the orbit, not so near it as in the elephants. From this point to the ridge inelosing the canine alveolus the side of the maxillary bone is deeply concave, and the palatal surface correspondingly contracted. The bone is con timul upards and ontwards as the external part and apex of the mid. die horn-cores. Anteriorly it is lumiled by the premaxillary to a point die horn-cores. Anteriory the latter; bebind as far anterior to the base of the hom as the width of the latter; bebiod
that point it is in contact with the nasals. The premaxilfary is prolonged that point it is in contact with the nasals. The premaxifary is prolonged
upwarls and backwards into a narrow tongue. Its inferior portion is convex above on each side, coneave below, with projecting alveolar borclere, which are flat and slightly concave fore and aft. The extremits of each is rugose below, supports a prominent tubercle medially and a smaller one at the superior angle.

-The exterior nares are uot separated by osseons septnm. Their lateral borders are marked on the inferior surface of the uasal and premaxillary roof by a curved ridge or erest, which converge forwarls and bound the interior concarity of the roof. This gare support to muscular or ligamentous attachments. The posterior angle of the uares is abrupily excavited with thickened walls. The palate is remarkably narrow, and is most deeply excavated between the alveoli of the tusks, or at the is most deeply excavated between the alveli of the tusks, or at the maxillo-premaxillary suture. From near this point to the palatine suture a low but sharp creat extends along the middle line. The width of the palate at the diastema is one-ninth of its length. The diastema of the palatine bones has two convergent groores on its inferior surface. 
The teeth are remarkable for the extent of the exposure of their slender roots, as well as their very small size as compared with the size of the animal. The tusk is slightly turned outwards at the tip and the inner face is worn by attritiou with some opposing tooth for one-third its length on the posteriou third. The superior margin of the enamel on this side is cherrou-shaped, the apex being only one-third the leugth from the extremity. It extends further upwards in front and on the outer side, but is worn in an oval pateh at the apex of the chevron of this side by contact with the inferior teeth, as above described. The enamel is smooth behind, rugose in front. The anex contracts regularly to a flattened behind, rugose in front. is hollow for about half its length. 'The enamel of the molars is nearly smooth. Each one has a strong cingulum fore of the molars is nearly smooth. Each one has a strong eingulum fore
and aft, which is discontinued on the iuner and outer faces except in $P$. M. 1 , and 3. . 2. In the former, it is continued on the outer side at the base of the concavity of the exterior face; on the latter, it is continued round the inner side. The grinding surface of the P. M. 1 is tripodal, and probably composed of a worn crescent and inner tubercle. The and probably composent of a word, the P. M. 4 is much more worn than others are transverse arroes shaped; the P. M. 4 is much more worn than
the others. M. 2 is larger than M. 1. its oblique crests bave evidently been worn from before. All the molars have three roots, but the posterior pair are united for part of their length in all.

The romer does not unite with the superior erest of the palatine bones. The sphenoid flattens out bebiud the postnareal trough and is co-0ssitied with the basioceipital. The latter is marked by two oval surfaces at the place of suture, with a slight prominence between. No lower jaw was found with this specimen, but from the contraction of the parts opposed to it, it was evidently very small.

Cranial measurements.

Length from end nasals to end occipital condyle, (3 feet 1.5 inches ) $\ldots \ldots \ldots \ldots . .60 .900$

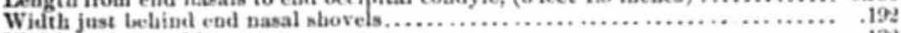
Width in front of borns ........................................................... . . Width at base of horns in front..........................................

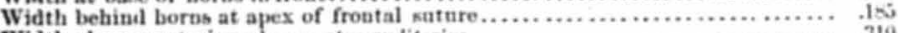
Wiath abose postemior edge mafss auditorias................................... 310 Width betweed spices hori-cores...........

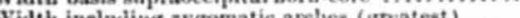
Levgth of nasal boyes to ridge between born-cotes . ...........................410 Leper of uasal bohes to froutal suture Length of zygomatic foes above. 200

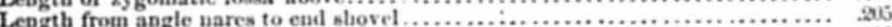

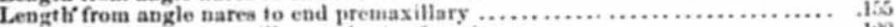
Length from end premaxillary to basis of canine ............................ .120

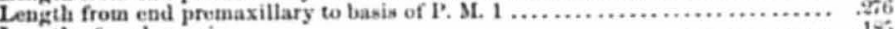

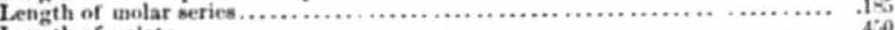

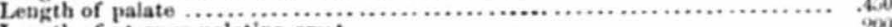

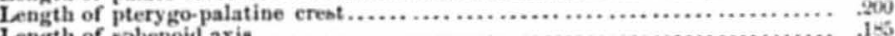

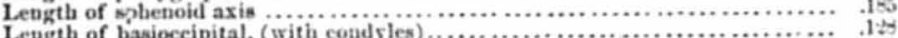
Wength of basioccipital, (winil coides With betweed tips prine Width between canine alveoli............. 每

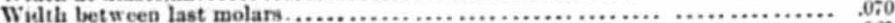

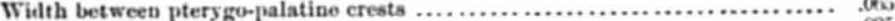

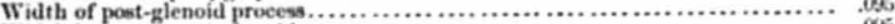

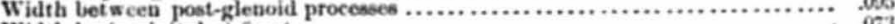

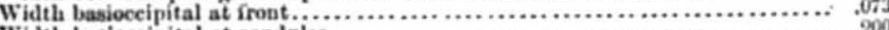
Widts basioccipteal at condyles .........................................................

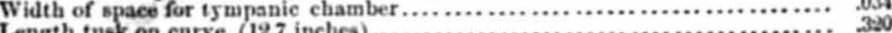




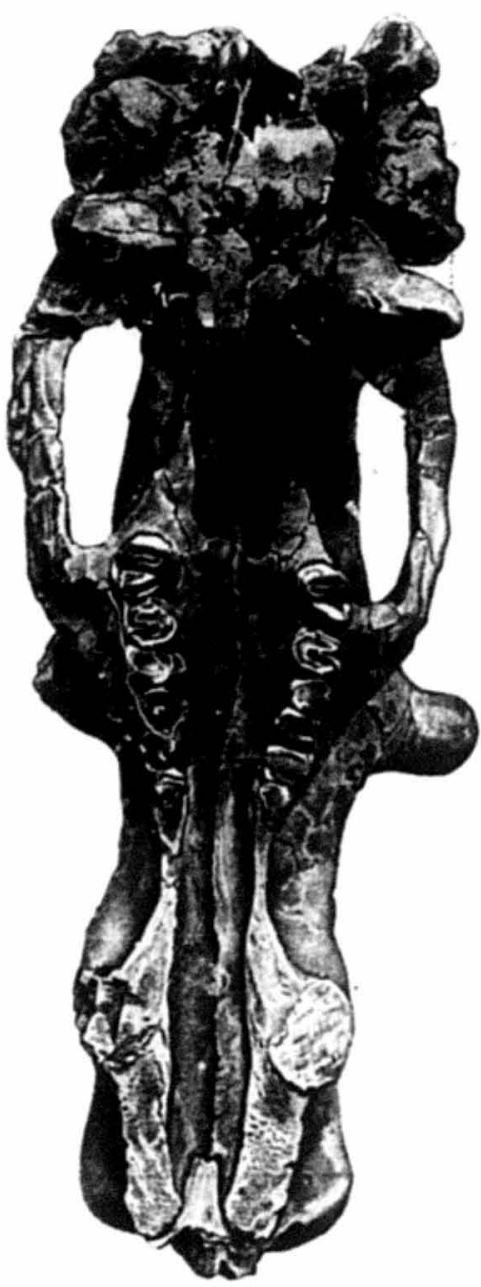

Diameter at middle do. (antero-posterior)

Diameter at baso do. (antero-posterior)

Diameter at middle do. (transverse)

.

(nen

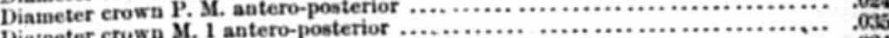

Diameter crown M. 1 transverse..........

Diameter crown M. 2 transverse.

(a)

The measurements may require some correction in respect to the The cranial walls have suffered îrom compres. supra The frontal of one side has been pushed so as to overlap that of the other by about an inch.

the front being vertical, the The scapula is of a sub-triangular form, the posterior expan. apex $c^{\prime}$ rected backwards an an angle upwam sion is considerable, as in the eleptants, while the superior angle is acnminate and much prodnced and massive. The spine is much elerated, bounding a deep supraspinous fossa. It is truncate in front, descending

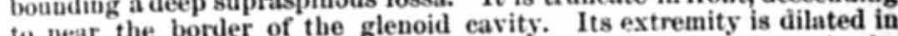
to near thion, bosteriorly ouly as in the elephants. The glenoid eavity is flattened so as to be longitudinal, and elephants. The glenoid cavity is thattened

Measurements of scapula.

Total length, $(25.25$ inches $)$

Total willh,

Gerate of

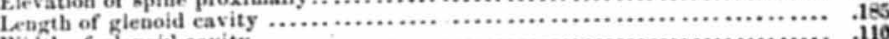

Width of glenoill eavity

The interior side of the scapula is strongiy conrex by the development of two longitudinal ribs, one corresponding to each fossa, but conment of two longitudinal section.

care in longitudinal section.

The proximal end of the radius exhibits two facets oblique to each other, the larger concare and transverse, the other oblique downwards. Transverse width M. 0.130 ; vertical .070. The extremity of a humerus not found with this individual, to which the radius applies pretty well, hos a very obliqne trochlear face, and measnres seven inches across the has a very oblique trochlear face, and maller species.

condyles. It, however, belongs th a smather species of the group it is

The femur is entire. Like that of other species of the group it is much expanded proximally and deep distally, with the shaft contracted and somewhat flattened in the plane of the great trochanter. The latter is in one plane, with its external margin turned a little backwarcs. The head is part of a globe, and is a little more elevated than the trochanter, and separated from its apex by a shallow concavity. There is clianter, and elevated nor wide, and no little trochanter. The antero-posterior axis with lateral borders subequally developed. The antero-posterior axis of the condyles is somewhat oblique to a line at right angles to the proximal end. On this account the interior condyle is the longer; its the ridges revolve from above the condsles to the posterior face of the shaft, u low external ala, and backwards thrue inches abore the condsle. The face between the ridges is concare. 
Mcasurements of femur.

Total length, (31.75 inches)

Total proximal width.

Transverse diameter at middile of shan.

Antero-posterior diameter at middle of chaft

Antero-posterior diameter condyles posteriorly

Transverse diameter condyles posteriorly.

Transverse diameter condyles distally.

M. 0.747 25 07 15 .160

The pelris has, a large transverse expansion. The iliac plates are ovoid in outline, with the apex outu ards and downwaris. The margins are ratker thin excepting the internal above the asetabulum. These are massive, and with a lorritudiual excavation. Thes terminate in a deep oblique excasation for the diapoplayses of the sacrum. The inferior margin rises compressed from just above the acetabulum. The latter is large for the size of the ilia, and its margins rise to a slight elevation beneath the exterior margins of the latter. The incisura acetabuli is obclavate, and nearly symmetrical. The os ischium is compressed anci deeper than the pubis. It possesses a tuberosity on the posterior inferior margin. The obfurator foramen is small, and is a vertical oval. The pubis is rathe. slenter and short. Its section at base is subtrian. gular; beyond, it becomes more compressed, and is spirally twisted on itself throngh a part of a circle. Its anterior margin near the symphy. sis, is strongly rugose for the origin of the pectineus musele; the rugosity extends into a baud on the outside of its proximal portion.

Measurements of pelris.

Long diameter of ilium s. Transverse diatneter at acetabulum Length inferior free margin to. Long diameter acetabulum

Sborter diameter acotabulum ...

Shorter diameter obtuator foramen

Wiath ischium to tuberosity

Loggth ischinm at tuberosity .............

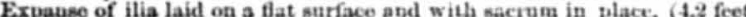

The general character of the pelvis is more like that of the elepbant than that of any Perissodactyle. It agrees with the former and differs from that of the rhinoceras in the shortness of the peclestals of the ilias or rather in the sessile position of the latter on the acetabula; also in the abseuce of production of the iliac creses in advance of and above the sacrum. It is also elephantiue in the shortness of the inferior elements of the pelvis.

Uf vertebra, there are preserved a dorsal, two lumbar, and some sacral. The first is very short and transverse. It is so injured that I ean only give measurements. The base of the transverse neurapophysis is a flat oval; both capitular articular surfaces ase deep. The anterior Jumbar is longer, but still short; its articular faces are slightly concave. The neural arch is wide, and supports the diapophyses. The sides of the centrum are concave and pierced by foramina, and there is a strong rugose bypapophyseal keel. The section at the middle is subtriangular. I have three sacral vertebre which are separated by very distinct sutares. They diminish very rapidly in size, and the centra become flattened trausverse. It is doubtifl whether there was a fourth vertebra, and the tail must have been short and slender. The articular face of the the tail must have beenter of the first is a transverse, rather hris of the second is much the stonterst. It third distally. The diapoplyysis of the second is much the stontert. It with that of the third. It is concave above, and terminates distally in a massive $\mathbf{L}$-shaped surface of articulation with the ilium. The foramina inclosed by the diapophrses are quite large. The inferior face of the first sacral centrum is slightly concave with a hypapophysial taberosity in front; it is strongly concare in the second.

\section{Measurements of rertebra.}

Atrtero-posterior diameter of dorsal.

Viameter at bottotm neural areh do.

Diatmeter at bottota nearal areli do

Diameter eentrum lambar, (vertical).

Diameter eentrum lumbar, (vertica) ....
Diameter centrum lumbar, (transverse)

Diameter centrum lambar, (transverse) ....

Length three sacral vertebra

Transverwe extent of sacrum, (15 inches).

Diameter first vertebra at freo end, (transverse) (4.6 inchen)

Diasueter linst vertebra at free end, (vertical)

Dianter last vertelora an free end, (vertical)

Diatpeter last vertebra at free end, (transverse)

Total expanse of hears of rib.

Diameier capitular face, (vertical)

Biameter tnbereular, (vertica).

Restoration.-We may ascribe to the Loxolophoilon cornutus, form and proportions of body similar to those of the elephant. The limbs, how. ever, were somewhat shorter, as the femur is stouter for its length than in the $E$. indicus. It was similar in this respect to certain species of mastodon. The tail was quite small. The neck was a little longer than in the elephants, but mnch less than in the rhinoceroses; the thiple ligamentum nuche and museles of the neck, which must needs have beea powerful to support the long of the neck, which must needs have beea powerful to support the long muzzle with its osseons prominences, and to handle with effect the terri-
ble laniary tusks. The head must have been supported sonewhat ble laniary tusks. The head must have been supported sonewhat as nuw the midule ones, extending vertieally with a divergence, when the head was at rest. The posterior and midule pair of horus were no donbt covered by integument in some shape, but whether dermal or corueous is by integument in some shape, but whether dermal or corueous is uncertain. Their penetrating foramina are smaller than in the Borida. whence I suspect that the horns had an inuer process, or were palmate as in the prong.horn at present inhabiting the same region. The nasal shovels may have supported a pair of flat divergent dermal horns, but this is uncertain; they are not very rugose.

The elevation of the animal at the rump was about 6 feet, distributed
The uncertain; they are not very rugose. as follows:

\section{Measurements.}

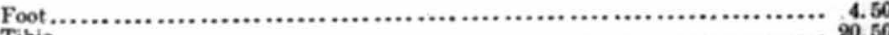

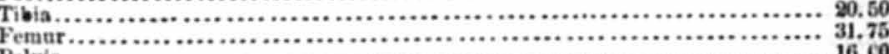

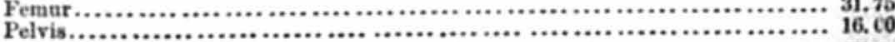


The anterior limb was stonter than the posterior, judging from the proportions in Eobasileus pressicornis, and was no donbt more elevated if of the Probosciclian character. This would give us the bypothetical elevation at the withers:

Measurements.

leg.

Eeapula, (actual)

Inctra

61.00
7.00

Neural spiues, (extremities)

Or 7 feet 5 inches.

These measurements are made from the plantar and palmar surfaces, allowance being made for the pards.

The neck, estimating from the dorsal vert rore and from the cerricals of other species preservid, could not have wers much exceeded 1 foot in length. This, adiled to the lengt h of the cranium, gives a total of near fonr
and a half feet. The obliquity of the autero-posterion axis of the cervical vertebre indicates that the head was posteriorly elevated above the axis of the dorsal rertebre. Thus it is entirely clear that the muzzle of this nnimal could not fave seached the ground by several feet, aud that, as ocenrs in the similar eases of the tapirs and elephants, there was a proboseis to suply that necessity. The indicationsderived from the boses of the muzzle contirm this conclusion, as has been already pointed ont.

Further than this, the symplyssis madibuli is very short and narrow, and its teeth conld have had no alaptation for cutting of vegetation. The mental foromen is small, and the small nutrient artery thus indieated is entirely adverse to belief in a powerful or prehensile under lip to make ap for the uselessness of the teeth. The long decurved canine teeth would, moreoser, part ially prevent thelips from touching the ground. The posterior positiou of the molar teeth indicates use for a prohoscis as well as for a loug, slencler tongue. The fact that the foramen infraorbitale of the Loxolophodon is less than in the elephants, in no wise militates against the possession of a proboscis, for it is stili smaller in the tapir,

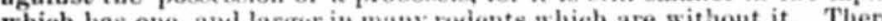

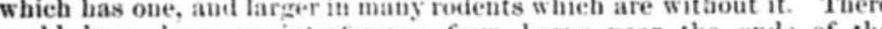
conld have the no interternee from horns near the ends of the nasal bones, for the bases of therse project beyond the origin of a proboseis, and were directed outwards, while the latter hung downwards. This species was probably quite as large as the Indiun elephant, for the individual cieseribed in uot adnit, as indieated by the freclom of the epiphyes of the lumbar vertebra, and fragments of others in my posses. sion indicate very cousulerably laryer size.

Habits. - The very weak dentition indicates soft food, no doubt of a regetable character, of what particular kind it is not easy to diviue. The long canines were no donbt for defense chiefly, and may have been nseful in pulling and entting vines and branches of the forest. The horns furnished formidable weapons of defense. That the anterior wasal pair rere not used for rootiug in the earth is evident from the elevation of the head, which would render this impossible.

This huge animal must have been of defective vision, for the orbits bave no ciistiuctive outliue, and the eyes were so overhung by the horns and cranial walls as to have been able to see but little upwards. The muzzle and eratial crests have obstructed the view both forward and backward, so that this beast probably resembled the rhinoceros in the ease with which it might have been aroided when in pursuit.

Sanonymy.-According to Marsh, he described this speeies Septem. ber 21,1872 , nnder the name of Tinoneras grandis, which thus becomes a synony'tu of Laxolophodon cornutus. As the name Timoceras had never been deseribet

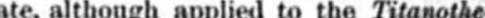
rium ( 9 ) anoeps, Marsh, previously without description, this name becomes a synouym of Loxolophodon or Eobasileus, should the two latter ultimately prove to be ideutical.

Localitv.-The remains of the Locolophoden cornutus were found by the writer in August, 1872, in a ravine of the bad lands of Wyoming. The greater part of the cranium, femur, \&e., were excavated from the base of a cliff of perhaps 250 feet in height, on the side of a ravine elevated about 1,000 feet, in the Mammoth Buttes, on South Bitter Creek. As the basin of Bitter Creek is 7,500 feet above the sea, the fossil was taken from an elevation of $8,500 \mathrm{fe} c$. The horizon is the Bridger Group of the Eocene of Hayden.

\section{ZOBASILEUS, Cupo.}

Preccellings of the American Philosophical society, 1872 p. 485, (erparata, Angust 20. )

As pointed ont above, this genus resembles Loxolophodion in the cervical vertebra, but agrees with Vintatherium in the rudimental condition of the nasil horn.cores, which are mere tubercles. The posterior or third pair of horn-cores are also very different, and probably stand on the largely developed lateral erests of the superior surface of the cranium, as in Uintatherium. They are apparently preserved in $E$. furcatum, (Istich is not the tspe of the genus,) and are compressed from base to summit; in Loxolophodon the base is nearly cyliniric.

The characters of this genus bad not been indieated in any of the deseriptions published by paleontologists prior to its establishment as above cited.

The cervical rertebre in E. pressicornis are very short. The limbs are much as in Loxolophodon, as are the seapula and pelvis. The symphysis pubis of E. pressicornis, or an ally, is short, and was separated from the ischiatic symphysis; but whether this belongs to the genus is not entirely certain.

The unciform bone, of perhaps the same species as the above, displays, as in living proboscidians, three inferior facets. The external facet is deeply concave, and unites with the snperior face by an acnte augle. It supported the small onter toe by its metatarsns directly. The other two are more nearly on one plane, aud are deeper than wide. The nneiform is in form a little less than a ouarter of a circle, and the external (auterior) depth is one balf its transverse leugth. Its suprerior surface is slightly convex.

EoBasilecs pressiconsis, Cope.

Larolophodon pressicornis, Cope. Proceed. Amer Philos. Soe., 1872, p. 5e0, (publisbed Angust 19.) Loe, cit., P. 4t8, (Augnst 22.) Eobasilnus cormufus, Cope, 1. c., p. 425,

Represented by numerous portions of the cranium, with fragments of limbs of one individual; of almost all portions of the skeleton, except the cranium, of a second. A humerus, with astragalns of a third, is of uncertain reference, while a single humerus of another specimen may belong here. Fragments of several other individuals of appropriate size may pertain to it.

The cranium is represented by nasal, maxillary, malar, occipital bones, \&c. The first named has a balf conic apex, and an oblique compressed 
tuberosity, which forms the lateral borler behind it, and is directed obliquely upward. The apex of each nasal is vertiealy compressed acute, and is deeply pitted and rugose for muscular or ligamentond attachments. The inferior lateral marginal ridge is contracted, and incloses a concave median space. The tuberosity sinks to the lavel of the median suture. The posterior part of the nasal rises to the apex of the middle horn-core, forming its inner face. The postero-superior angle of the premaxillary reaches to near the base of the horn, and is not drawn ont to a narrow apex as in $L$. cornutus. The horn is compressed antero-posteriorly at the base; at the apex obliquely iuward and forward. The outer face is concave on the lower half; the inner, convex. The posterior face is concave and the anterior couvex, when viewed from the side.

\footnotetext{
Measurements of nasal bone.
}

Width of both at tuberosity

Depth of suturs at front of tal cone

length of sutnre, from premaxillarity

Length of horn-core, (in frout,) ( 6 inches)

Diameter, (externally)

Diameter of apex

M.

$0.1: 4$

The occipital region is furnshed with an enormous transverse crest which extends upwarl and backwarl. Its margin is rently convex, and its supero-anterior face concave. The posterior is narrowed by the inferior erest-like margins of the temporal fosss, which extend from the squamosal part of the zygoma and gradually contract, terninating abruptly in a low knob where it joins the transverse erest. The poste. rior face between the former is divided into two planes by a low vertical ridge, which terminates some distance below the summit. The trans. verse erest is continued in a curse forwards on each side as the superior margin of the temporal foxsa. The specimen does not indicate whether these crests supported horns, but they are very stout.

Measurements of occiput.

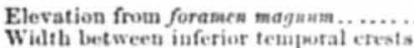

Width between inferior temporal ctests

Elevation above internal sinuses at angles.

The mastoid tuberosity is short anc. stout; the nastoid foramen is large and not piercing a crest. The ex-oceipital suture is obliterated.

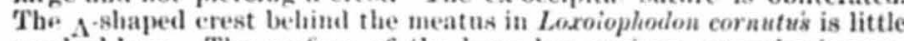
marked bere. The surface of the bone has various muscular impres. sions. The basi-occipital exhibits a low median crest dividing lateral concavities; transverse width at condvles ,077 M. The fragments of teeth are too mucharacteristic for specitie deverition. Namerons cra nial fragments accompany the above, but have not yet been properly placed.

The atlas is broken; its cotyloid cavities are rather shallow, and the diapophyses small. Its antero-posterior diameter below at the middlo line is .070; at base of diapophysis .070. The condyles of the femur present the characters of the group. There is a deep vertical groove on the inner side just above the condyle. The latter approach each other closely on each side of the intercondylar fossa and are flattened on the snperior posterior margins. Width across extremities M. .150.

At a distance of 100 or' 200 feet from the above specimen I found portions of the skeleton of a smaller animal, probably a different but allied species. It is represented by portions of ribs and limbs, of which the ulna is described under Vintatherium. Two or three hundred yards from the typical specimen, I obtained remains of almost all parts of the skeleton of what is probably the present species. The femur is identieal in eharacter. The specimen embraces cervical, dorsal, and lumbar brx, ulna, both femora and tibiz, astragalus, navicular, \&c., and large parts of the scapula and pelvis

The scapula, in its proximal portions, differs little from thit of Lamo lophodon cornutus, beyond its inferior size. The coracoid is a compressed tuberele inclosing a groove with the glenoid cavity.

\section{Measutrements.} Diameter glenoid cavity, (longitudinal)
Diameter glenoid cavity, (transverne)... M.

The os pubis displays a strong pectineal rugosity, commeneing nur the acetabulum.

Measurements.

Long diameter of acetabulum. Length common pubic suture

M. 14

The femur is nearly as long as that of Loxolophodon cornutus, but is more slender, and has a relatively smaller head. It is flattened fore and aft, and the great trochanter is much expanded and with a shallow concavity on the posterior face. There is a marked concavity on the posterior face of the shaft above the condyles. There is a rudiment of posterior face of the shaft above the condyles. There is a rudiment of
the little trochanter. The tibia is scarcely three-fourths the length of the femur, and has a rather contracted shaft, which is in section rounded triangular, one angle presenting forward, where is in section rounded rudiment in the swollen upper portion of the anterior ridge. The articn. lar surfaces are together rather narrowly transverse. They are separated by a leel which is on ratedins a f margins of the cotyli separate. The long axis of the inner of these is directed antero-posteriorly outward in front; of the other, similar but much more transverse. It overhangs the shaft outward and backwand, and supports beneath, the sub-ronnd down-looking fibular articulard, face. The distal articular snrface is distinguished from allied species by the downward prominence of the malleor rior width and the antero-posterior width, and the greater extent of the fibular articular face. The face is slightly concave antero-posteriorly, and openly sigmoidal trans. versely.

\section{Measurements of $\mathrm{leg}$.}

Length with astragalus in place. M.

Fenur, length 200 vemur, diameter ball

Femur, width at great trochanter.......

Fetunt, width at middle shan

Femur, dept b at middle shaft

Tibia, length.

Tibia, width proximal surfaces, (transverse)

Tibia, width proximal surfaces, (antero-posterior)

Tibia, iransvorse diameter shaf

Tibia, antero-posterior diameter sbaft

Thia, antero-posterior diamoter shaf, distal artioulation.

Fibula transene diameter shaft, distr articulation

37 s 


\section{Measurements.}

Fibula, transverse width at middle.

M.

Fibule, width proximal articular face

Fibula, width malleolar articular face, (transver

A section of the fibula, near the proximal end, is sub-triangular; a short distance below, sub-circular; on the distal two-thirds it is flat with the thinner edge convex in ward.

The astragalus is a flat bone, with its entire superior face occupied by the tibial articular surface. This is as broad as long, and very little convex. It is broader in front than behind; the outer margin is concave, the inner slightly convex. The posterior margin projects most on the onter side, and it is diviled by a pit-like cavity, which sends groove to the inner margin. The outer malleolar surface is an anteroposterior oval; the inner, a concavity, beyond which the inferior portion of the bone projects. The inferior face is divided by a prominent transverse angle, between sub-anterior and sub-pust rior faces. The latter receives the calcaneum on two oval surfaces, which are joined behind by a narrow strip. The navicular face is sub-rhomboid, the enboid one-third as large, and triangular, with a round base outware. The margin of the former scarcely projects beyond the superior face.

Measurements of astragalus.

Total width

Total length

Width tibial face in frot

Length tibial face, externally.

ength internal malleolar face

caneal malleolar face, antero-posteriotly

Length navicular facet

navicular facet, (anteru-posterior)

Length cuboid facet...........................

A cunciform belonging to the individual mentioned first, has been a!ready described.

Mcasurements of cuneiform.

Depth in front

Width, (transverse).

Width of interaal face

Width of second

Width of external.

M.

A distal end of a humerus was found with two astragali about 100 yards from the last individual. The articular face is very oblique to the transverse axis, but is abont equally developed on opposite sides of the shaft. The condyles are nnequal, have parallel axes, and are separated by but a shallow concavity. The fosse of opposite sides are not very large nor deep.

Measurements of humerus.

Transvere diameter, distally

Transverse of inner condylo.

Transverse of outer condyle.

Transverse diameter, olecrano
The portion of ulna just measured belongs to the individual of which 60 many fragments were found, or No. 2 .

The dorsal vertebra of the same are somewhat distorted by pressure; I will thereforedescribe a cervical of natural form. The centrum is very short, and the articular face is a wide, transverse oval. Both are slightly concave, and the axis being slightly oblique, the anterior is the more elevated. The surface of the latter is quite rugose, except on the margins. The cervical canal is wide, and the neurapophyses and parapophyses narrow. Inferior surfacu regularly convex.

Measurements of cerrical rertebra. M.

Length centrum. Length basis neurapophysis.

Length anterior articular face.

Depth anterior articular face.

Wepth anterior articular face. nasal tuberosities, which might be sexual only, this species differs from I. cornutus in the simple naso-maxillary horn-cores, which want the interior tuberosity of that species, and in the fact that they are composed exclusively on their inner sides of the nasal bones to the apex, the maxillaries forming the outer face. E. pressicornis bas also a much the maxillaries forming the outer face. E. pressicornis has also a much
wider and less massive supraoccipital basin, with lighter horn-cores, if present. Minor differences have been already mentioned.

The measurements giren by Marsh for his Titanotherium (I) anceps (later Tinoceras anceps) are considerably smaller than those of corre sponding parts of Eobasileus pressicornis, but represent more nearly a species of the size of Vintatherium robustum. When the species is suffi. ciently described, we shall be able to determine to which of the genera it should properly be referred.

Restoration.-The elevation of this animal was not much less than that of the Loxolophodon cornutus, but the proportions were more slender; as in all the species of Uintatherium in which the horns are known, these apnendages stood in front of the orbits, and nearer the nareal openinge tha ing than in the type of the former genus. The muzzle, too, is materially shorter and more contracted, and the true apex of the mazzle was not overhung by the great cornices seen in Loxolophodon. The horn-sheaths were probably simple, while in $\boldsymbol{L}$. cornutus they were probably palinate. The oceipital aud parietal crests are much more extended in this species than in the $L$ cornutus, so that in life the snout and muzzle had not sneb a preponderance of proportion as in that species. All t'.s species of this genns were rather more rhinocerotic in the proporions of the head, genns were rather more rhinocerotic in the proporions of the head, although the horns and tusks produced a very different phykiognomy.
The extremities of the nasal bones, though not excavated as in that The extremities of the nasal bones, though not excavated as in that
species, are strongly pitted and exostosed, and this, taken in connection with the elevation of the head, renders it probable that this species also possessed a proboscis.

History. - This species was originally described by the writer in a short paper, which was published and distributed August 19, 1872, under the generic name Loxolophodon. I shortly afterward referred it to the new genus Eobasileus, under the name cornutus, under the impression that it was the same as the Loxolophodon cornutus; but finding this was not the case, I again nsed the spectic name here adopted. 
Bobastleus puroatus, Cope.

Laxolcphodon bifurcatus, Cope, in extra copies on Proboseidians of the Eoone of Wyo-

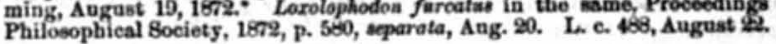

This species was originally described from a large horn-core whose extremital part resembles strongly the nasal shovel of Bobasileus cornutus, tremital part resembles strongly the nasal shovel of sobasilens described somewhat similar horn-cores from the lateral crests of the skull behind in $U$. mirabile, whence it may be that my specimen is referable to that position, altinoubit it differs much fron those of that species.

The basis is very narrow and lenticular; a short distance above it the outer side is convex. The anterior and posterior extensions of the base differ; the one is thinner, the other more massive and with a shallow groove above its commencement. The latter may be posterior. If 80 the compressed apex of the horn-core sends down a rib outwardly to the anterior and one inwardly, which disappears on the convex base. The general form is spatulate with the apex expanded obliquely across the lateral an anterio fa: is flat, the posterior convex; its surface is grooved by very small blood-vessels.

As compared with the posterior horn-core of Loxolophodon cornutus, there is every ditference. That is contiauous with one margin of the erest, this erect above it; that has a round base, this a lentieular one. It is more like that of $U$. mirabile, which I only know from Marsh's fig. ure, but abuudantl: fistinct. It is much morn e'ougate, especially above the (I) posterior part of the crest, and is thattened, and without the triangular section of that species.

Measurements of horn-oore.

The total length above crent, ( 5.5 inches)

The total length above base, (

Width acros apex, (in front)

Thickness across a

It is not certain that this horn may not belong to the $\boldsymbol{E}$. pressicornis, if it be a posterior core, of which, however, I am not yet sure. In that cuse the name furcatus, under which it was first described, becomes a synonym of $\hat{E}$. pressicornis.

UIXTATHERIÙM, Leidy.

Proceedings Academy Natural Seiences, Philadelphia, 1872, p. 169, (published Augnst 1at.) Dintemastis, Leidy, loc, eit., $D i$
ber, 1672 , (pabiished September 27 .)

This genus resembles the last in its general proportions, but differs in its more elongate cervical vertebre. The centra of these are flat at both extremities, but have not such a marked elephantine abbreviation as seen in the two genera above described. This enabled the head to approach the grounil more nearly, and as the limbs were shorter in some of the species, they no doubt modified the length of the proboscis, if present.

Several names have been applied to this genus. Professor Leidy's name, here employed, bears date early in August. Under date of Sep. tember 27 th, Professor Marsh proposed the name Dinoceras (American Journal Seience Arts, 1872) for the $U$. mirabile, but did not gire his -See Proceedingn American Philosophical Society, 1672, p. 515, where this namo is

reasons for separating it from his Tinoceras, (the names of the two bear an objeetionable resemblance, ) or those published by Dr. Leidy or my. self. As it is evidently synonymons with Vintatherium, I include it here, as is done by Dr. Leidy.

I am acquainted, by antopsy, with two species of this genus. None of them are 80 large as the Bobasileus pressicornis. U. robustum, Leidy. is smaller, and the $U$. lacustre, Marsh, smaller still. $U$. mirabile, is smaller, and the $U$. lacustre, Marsh, smaller still. $U$. mirabile, allied to it; but it may be distinct, as it wants a tubercle on the last molar. I therefore retain three species, as follows: Uintatheritum robus. tum, Leidy; $\boldsymbol{U}$. mirabile, Marsh; $\boldsymbol{U}$. lacustre, Marsh. For convenience I compare these species with those of Robasileus.

The naso-maxillary horn-cores have been seen in $E$, pressicornis and $U$. mirabile, and the nasal tubereles in the same. The posterior horncores are known in the $U$. mirabile. The posterior and lateral erests of the craninm inclose a basin-shaped concavity above in all these species; it hus been observed in all but $E$. furcatus. The dentition is similar to that in Loxolophodon, i. e., I. 0; O. 1; P. M. 4; M. 2. The first premolar in $U$. lacustre bas an internal cone and onter concave crest. The worn surfaces of the other teeth in that speeies, $U$. robustum and $U$. mirabile, are narrow ovate, with a deep exterior emargination. The true molars support two crests, which converge inwards and unite: there is a small tubercle behind the apex in $U$. lacustre and $U$. robustum. The task is long, compressed, and double-edged, as in Loxolophodon. The last inferior molar in $U$. robustum possesses three transverse crests, the pos. terior two parallel, and obliouely directed inwards toward the axis of the anterior, which is the highest.

In a specimen of one of the smaller species, the ulna widens considerably distally, being nearly as wide as the much expanded olecranon. The latter is large, flattened, and subtransverse, and presents a sharp ridge internally. On the inner side of the distal part of the articular face for the humerus is a tubercle, from which a short, wide groove runs ont on the inner face of the bone. The head of the radius is a little exterior to the middle line, and the shaft crosses the ulns in an open, shallow groove, to the inner side.

The cuboid is flat, and displays two proximal and two distal articu. lar facets in $\Pi$. furcatum. The astragalus of the same species is sub. bifurcate posteriorly, and has internally an extensive oblique malleolar foses. The calcaneum is short and massive, with two superior and one small anterior articular facet.

The species may be thuz distinguished:

1. Large species, (occipital condyles extending over about $0^{\mathrm{m}} .170$ :)

Naso-maxillary horns long; tibia with wide articular faces

Horn-cores flat, elevated 2. Species of intermediate size :

Molars smaller, with an additional tubercle on the last.

Last molar without additional tuberele, (Marsh ;) max-

illary horn-cores low, triangular ; posterior horn-cores

short, triangular in section.

3. Smallest species, (occipital condyles exteuding over about $0^{\circ} .095:$ )

Molar teeth larger, the last with a posterior expansion.

E. pressicornis. E. furcatus.

U. robustum.

U. mirabile.

U. lacustre.

Previons to describing the species I notice a part of the skeleton of a large mammal, second only in bulk to Loxolophodon and Eobasileus above deseribed. 
These ramains, which were not found in association with a cranium, consist of several vertebre, some carpal bones, and the entire hind limb of the left side except the toes and the cuneiform and navieular bones. The odontoid process is very stout, with a descending trihedral apex. Length M. .078; diameter at base, .048. A dorsal vertebra, with a single (anterior) eapitular articular face, is quite concave in front.

\section{Measurements.}

Diameter antero-posteriorls

Measureme

Diameter vertically

094

A cervical vertebra has the proportions of the dorsal as to its cent. rum, thus differing materially from species previously described. The articular surfaces are slightly concave.

\section{Neasurements.}

Length (antero-prosteriorly)

34.

The femur resembles that of the other species already described, but is remarkable for the relatively small size of the head. While the lengths of the bone are not very different, and the expanse of the great trochanter about the same, the head of $L$. cornutus is large, the present trochanter is very much smaller, and that of $E$. pressicornis intermediate. one is very much smaller, and that of $E$. pressicornis intermediate.
There is a rudimental third trochanter, and the condyles are as large as, and sinilar to, those of E. pressicornis. The external marginal con. dylar ridge is quite short. The shaft is broken and some smail pieces lost; it is now 26 inclies long, but was no doubt longer when complete.

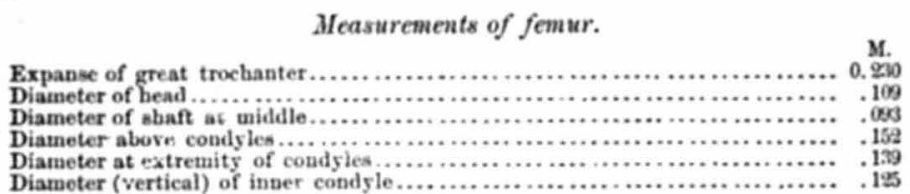

The tibia is perfectly preserved. It is short and stout, and with mass. ive extremities. The outer basal part of the spine remains and is prominent. The cotyli are not oblique; the inner is sub-round, the outer transverse, widening outwardls; their loug axes are at right angles to each other. The crest is a low rilge of contact of the cotyli. The superior fibular face is a transserse oval; the inferior much smaller than in $E$. pressicornis. The shaft is contracted, aud flattened behind and on the inuer side. The distal extremity is transserse, less truncated for the fibula than in $E$. pressicornis, less convex behind, and with a less prominent external malleolus. The point dividing the astragalus be. hind is more prominent.

Measurements of tibia.

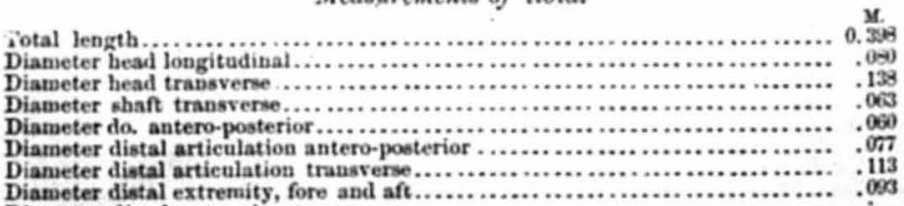

These measurements show that this bone is considerably shorter than in $E$. pressicornis; thongh of equal distal diameter. In both species the
measurements considerably exceed those given by Marsh for his Titanotherium (1) anceps. The form of the articular extremities in this animal differs from both in being more narrowed and transverse.

The fibula is larger proximally and smaller distally than in $E$, presisi. cornis. Diameter proximal articular face .039 ; of the distal .045 .

The astragalus is similar in size and form to that of $E$. pressicomis, but differs in two points. The posterior margin is deeply incised for the ligamentous insertion, and the onter lobe is clearly cut to this fossa, on the inner side. There is a pit for a ligament on the convexity of the inver part of the middle of the tibial articular face. $A$ third difference is seen on the inferior face. The inner calcaneal facet is longet and narrower, and is margined on the inner side by a large fossa parallel to its axis, which is wanting in the other species. The calcaneum is short and wide; its only anterior artieulation is with the cuboid and is small. The heel is deeper than long, and is obliquely truncate downwards and intrards.

Measurements of calcaneum.

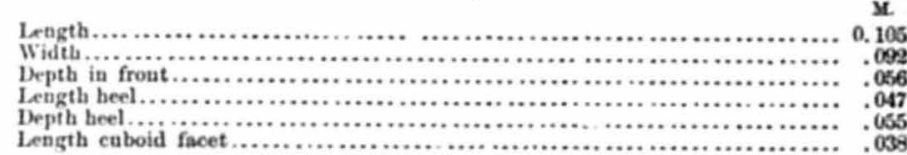

The cuboid is a flat sub-triangular bone with two unequal articular faces below.

Measurements.

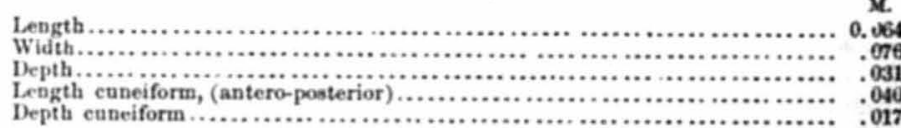

The humerus of a third specimen may or may not belong to this species. It was fonnd in another locality. Its condyles are much less oblique than in that one described under $E$. pressicornis. The olecranar fossa is shallower. It belonged to a larger animal.

\section{Measurements of humerus.}

Tranaverno diameter distally, (7.75 inches)

ransverse diameter, inner contlyle. M. 195

Remarks. - The remains were discovered by the writer in the Bridger Bad Lands, on Sonth Fork of Bitter Creek, Wyoming.

\section{UINTATHERIUM ROBUSTUM, Leidy.}

Proceedings Academy Natural Seiences, Philadelphia, 1679, p. 169, Augunt. Vintamastix atrox, Leidy, L. c.

I have been able to examine, through the kindness of Professor Leidy, the type of his description, and find it to belong to a smaller species than any of those above described. The lateral parietal and supraoceipital erests are well developed, and the latter extends obliguely
backwards. Several peculiarities are to be obserred in the dentition. 
Thus there is a great inequality in the height of the transverse crests of the posterior upper molar, the anterior, or the arched one, rising to a high cusp at its outer extremity. A small tubercle exists on the side of the inner angle of the grinding surface in the penultimate molar. of the inner angle of the grinding surface in the penultimate molar.
The same angle is mueh elevated in an anterior molar. The canine is wider distally than in $L$. cornutus, and less recurved. The mastoid process is quite prominent. The humerns has a prominent internal condyloid ridge and tuberosity, and the condyles are not very oblique. The inner posterior lobe of the tibial face of the astragalus is quite well defined; there is no median ligamentous pit on the trochlear face.

$$
\text { Measurements, (from Leidy.) }
$$

Depth lower jaw at last molar

Diameter at condyles ming.

Dr. Leidy has suggested with some reason that this species and the Dinoceras mirabilis of Marsh are identical.

Untatherium mRanile, Marsh.

Dinoceras nirabilis, Starsh, Amer. Journ. Sci. Arta, 1972, Oetober, (published Sept. 27.) Loc. cit., Jan. $2 \times$, 1873 .

The cranium of this species has been partially described as above eited, and figures in the last-named paper largely supply the deficiency. From this it is evident that it differs from Loxolophodon cornutus in the From this it is evident that it differs from Loxolophodon cornutus in the tion of the naso-maxillary horns, the perforation of the lachrymal, the anterior development of the malar, the oblique occiput, \&c. It differs from the $E$. pressicornis, besides the inferior size, in the shorter nasal bones und greater porterior approach of the premaxillary bones to the base of the horns; in the much shorter horns and greatly smaller part taken in their composition by the nasals.

These differences account for the great number of errors committed by Professor Marsh in his allusions to other species, especially Loxolophodon orrnutus described by me, (see his second article above qufoted.) Ac. cording to Marsh this species differs from $U$, robustum in the absence of a small tubercle on the last molar, and presence of one on the penulti. mate molar.

$$
\text { Measurements, (from Marsh.) }
$$

Lougth of cranium, (28.5 inches) 1. Lougth of eranium, Daso-maxillary cures Width betwuen summits nasso-maxillary cores ........................... .038

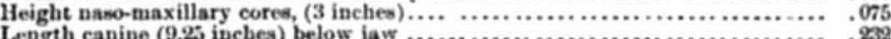

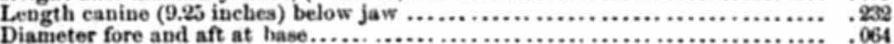

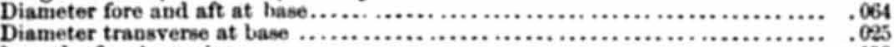

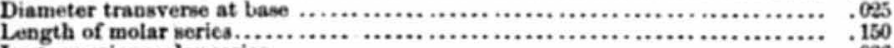

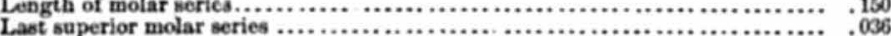

UnitatheriuM LaCl'stre, Marsh.

Dimocenas lacustrie, Marsh, 1. c. Oetober, 1872, (Published September 27, 1872.)

I have several of the teeth and the oceipital, parietal, and other portions of the cranium of this species. It is distinguished from its con- geners, apart from its smaller size, by the large size of the teeth. These are nearly as large as those of Loxolophodon cornutus, and considerably nearly than those of $U$, robsestus and $U$. mirabile. The occipital conlarger than the of these mastoid protuberance is prominent, and the post-glenoid process more produced downwards and with less fore and aft diameter than in the other two species. The inferior temporal ridge is strongly marked, and the posterior condyloid foramen is large.

The posterior molar has a wide floor extending from the posterior or traist transverse crest to the cingulum. This erest is low, and has a straw tubercle near its apex behiud. The other molars have strong fore low tubercle na, but none at ends. The worn surfaces are first V.shaped ater arrow-shaped. The first premolar has a curved outer crest and inner conic tubercle.

Measurements. M.

Disueter of oceipital foramen and condyles From exterior end condyle to mastoid. From extecior end condyle to pos' -glenoid procoes ............................. . .

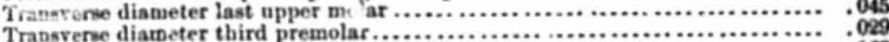

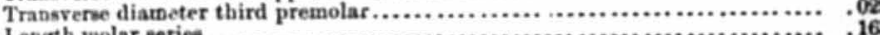

Found by the writer in the Bridger formation of South Bitter Creek, Wyoming.

\section{MEGACERATOPS, Leidy.}

Proceedings Academy Natural Sciences, 1870, p. 1. Hayden's Geological 8nrvey, Wyoming, 1872, p. 352, ("Megacerops.")

This genus is only known from the extremity of the nasal bones bearing the horn-cores. The latter are intermediate in position to the nasal and naso-maxillary horns of Eobasileus, \&c., and may represent the median pair, in which case the diagnosis of the genus should be nasal horn-cores wanting.

The genus was originally regarded by Dr. Leidy as allied to Sinathe rium, and therefore ruminant; he also supposed that it possessed a proboscis "as in the tapir." The latter proposition has mnch in its favor, especially as the aifinities of the geuus are evidently with the Proboscidia.

\section{MEgaCERATOPS COLORADOENSIS, Leidy.}

$$
\text { Megacerops coloradoentis, Leidy, L. c. }
$$

The part of this species preserved indicates an animal of the size of the largest Unitatheria. The nasal bones are co-0ssifled, and the horncores are sub cylindric, obtuse, and about two inches in length. They are situated above a point a little behind the anterior nares.

\section{BATHMODONTIDA.}

As already pointed out, the structure of the limbs and feet in this suborder is as in the order generally, and the seapula has the same form in the symphsis mandibnil is furnished with teeth, and forms a ceneral The sym ghys sing The astragalas has a very pecaliar form, being even is flat or coneave in the middle. It is turned inward in front of the 
articular face for the inner malleolus, terminating in a long point. The cuboid articular face is quite small and sublateral, and sessile like the navienlar. The fibular facet is extensive, and the internal lateral well marked.

On the other hand the coracoid process is produced into a curved hook, and is thus more largely developed than in other Proboscidians or Perissodactyles. The neek is longer than in the other Proboscidians, and the parietal bones appear to be narrowed by the approximation of the temporal fossa, as in the Rhinoceros. Almost nothing, however, is known of the structure of the skull.

The genera are two, as follows:

Penultimate molar unlike "se last, with exterual crescent and embracing ledge

Three molars alike, with two transverse crests not meet-

ing within $\ldots \ldots \ldots \ldots \ldots \ldots \ldots \ldots \ldots \ldots \ldots \ldots \ldots$ Metalophodon.

\section{BATHMODON, Cope.}

Proceedings American Philosophical Society, 1872, p. 417.

This gerns was originally chiefly distinguished by the dentition; at present many other important peculiarities are added. First, as regards presentary teeth; the two transverse cresta I find to be separated (not united) at their inner extremities, by a narrow fissure. The anterior is united) at their inner extremities, by a narrow fissure. The anterior is to the narrow cingulum. The posterior is short and straight, and bears a crest. The numbers are I. 3 ; O. 1 ; P. M. 4 ; M. 93 .

The entire mandible presents the following dentition: I. 3; C. 1; P. M. $t$. M. 3. The incisors radiate aronnd the narrow extremity of the 1. *; M. The trough.like symphysis, and have transvers the same series. Its crown canine is inclined forward, and forms part of the same series. Its crown enormously enlarged, as indicated by a symphysis in my possession. The anterior premolar approached the canine. The former teeth have an external cherron directed inward, whose extero-superior surface of anter exidate. Besides this is a little longitudinal ridge, enamel is acute cordate. Besides the true molars. On the first of which represents another chevron of the latter, both ehevrons are deveioped, the posterior the least, both with their anterior ridge boundaries lowered; they sink entirely on the last two molars, which become thus two-erested, is in those of some Tapiroids and the premolars of Dinotherium.

The sternal segments are cylindric; in one the articulations for the hrmpophyses project laterally, giving the piece a T-shaped form. The atlas has a flat diaparapophysis, presenting its edges fore and aft; the arterial canal traverses it obliquely. The coracoid is double, having a taberosity on the edge of the glenoid carity, and a prominent hook just outside of it. The lumbar vertebre are quite short. The cuneiform bone is narrow pyriform, with two triangular facets on one side, the bolis ber over the other. The nngneal pbalanges are very short, somewhat flattened, and with the terminal phalanges are very short, somewh hat flattened, and with

portion transverse and ragose as in some the remains pertaining to this genus obtained by Dr. Hayden, there are numerous individuals of apparently three species. Two of these are larger and one smaller, the latter in part indicated by an individual without epiphyses on the lumbar vertebrz. It presents marked difference in the form of the astragalus atlas, scapula, \&c. a Larger species:

Astragalus evertes in front; nearly as wide as long;

lower premolars narrower, more elevated, and rugose...B. radiass. Lower premolar bro ad, lower, and smooth................. B. semicinctus. an Smaller species:

Astragalus much wider than long, decurved in front...... B. latipes.

Bathrodon raduns, Cope. Proceodings American Philosophical Society 1872, (Fobrunry 16,) p. 418. Hayden's
Geological Survey of Mlontana, 1671, p. 350 .

In addition to the characters already assigned to these species ab above eited, I add the following:

The apex of the scapula is a massive flattened acumination with trun The spine is elevated and truncate next the glenoid care exacoid margin. cavity, which is a wise of the atlas is rounded distally, and is abont as The transverse process of the atlas is rounded distally, and in ward. The long as wide; the surface for the axis is directed obliquely inward. The fibula has the inner sharp edgo prolonged to the proximal end; the form of the latter is much as in Eobasileus. The astragalus is slightly concave in both directions on the trochlear face, most so antero-posterioriy. The anterior outline of the same is strongy and obliquer cous. The inne surface is produced sideways into a latero-anterior apex. The inne malleolar border is thus very concave; the outer is gently convex with a long fibular facet. The posterior margin concave, the inner tuberosity prominent. The naricular facet is as broad as long, and nearly sessile, being probably separated by a groove from the tibial. The cuboid face is subround, small, and sublateral; the calcaneal situated diagonally is subround, sual, as the other, is transrerse and truncate internally by a facet near the apex, at right angles. The other calcancal facet is subround.

\section{Measurements.} Length ramus maudibuli to anterior margin of coronoid process.............. 0.310 Length premolars and molars.

Wength last molar eron

Width last molar crown....

Leagth last premolar.

Width symphysis at canines.....

Diameter canines $\delta$
Diameter canines $\$$

Length exposed portion incisor

Widith crown incisor $2 .$.

Length diapoptysis atlas.

Width diapophysis atiag

Width glenoid cavit

Width glenoid cavity scapula, (straight)

Length coracoid from inner basis.

Length distal articulation fibula...

Diameter shaf fibula.

Total length astragalus, (fore and aff)

Total wieth astragalus.

Length navienlar facet

Width navieular facet.

Width coboid facet.

Length euboid facet...............

Wevgth anterior calcaneal facet.

Length posterior calcaneal...do.

Length posterior calcaneal...do.... 
The teeth are slightly rugose, and the inferior canines show atendency to imitate the form of the incisors in a slight basal angular expansion of the crown. This forms an approximation to the tapirs. The middle pair of incisors is directed outward, is the smallest, and, like all the others, has the roots much exposed.

This species was originally described from teeth of the upper jaw. I have since obtained the entire mandible (except the angles) taken out at the same place and near the same time. The size, color, \&c., would indicate that they belong to the same individnal. Accompanying the first specimens were many bones of individuals of different sizes, which I learn from the finder were all taken from within a short distance of each other. Many of them belong to the same species, as the jaws and teeth, and I have described as such those that relate properly to them as to size, mineral appearance, \&c.

The smaller specimens belong also to several individuals, and possibly to more than one species. I describe them together, but regard the astragalus as the primarily distinctive bone.

\section{BATHModon semincivus, Cope.}

Proceeding American Philoscphical Society, 1672, p. 420. Loxolophodon memicinctue,

The tooth on which this species was based shows a near relation to the corresponding one of $B$. radians.

BATHMODON LATIPES, Cope.

Proceedings American Philosophical Society, 1873, March.

Established on ailas axis, dorsal and lumbar vertebræ, scapula, hume. rus, phalange, femur, astragali, \&c., of a specimen found with the $B$. radians.

The transverse process of the atlas is stouter and less flattened at the base than in $B$. radians. The axis is but little oblique, and has a low, obtnse hypapophysis below. Its form is much as in the larger species, being rather elongate, but shorter than in Rhinocerus and other Perissodactyles. The dorsals and lumbars are short and plane; the former are obtusely, the latter acutely, kecled below. The bead of the femur has no ligamentous fossa. The astragalus is considerably broader than long, the apex turned outward in front of the inner malleolus, being especially produced. The tibial face is concave transversely, and convex anteroposteriorly at the front, plane behind. There is a posterior submarginal foramen, which is not bridged over in one specimen, produciug a deep noteh. The navicular facet has considerable transverse extent, and the anterior side of the bone is more transverse than in $B$. radians. The calcaneal facets are diagonally opposite to each other; the outer is sub. round, the inner anterior narrow and transverse. It differs in the two specimens, the perforating toramen not bein bridged over in the one (the type) with the similar posterior interruption described above. This may be due to fracture. The only ungueal phalange bas the articular face not quite sessile on the transverse rugose free extremity.

\section{Measurements.}

Dlameter diapophysis atlas, (fore and aft).

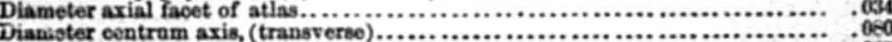
Diameter centrum axis, (vertical)............................................... 039
Length centrum axis to odontoid

Width neural canal do.

Diameter of centrum of dorsal

Diameter neural arch of same

Diameter centrum of lumbar

Diameter head of femur.

Length astragalus fore and aft.

Width astragalus.

length navicular facet.

Width navieular facet.

Width euboid facet

length cuboid facet.

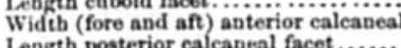

length posterior calcantal face

Length ibular, (axia).......

Length terminal phal

Width distally.

Datmeter glenoid cavity seapula $\left\{\begin{array}{c}\text { vertieal. } \\ \text { transvern }\end{array}\right.$

From the beds of the Green River epoch near Evanston, Utah, (now Wyoming.)

\section{METALOPHODON, Cope.}

Proceedings American Philosophical Society, 1872, p. :42. (Published September 20.)

In distinguishing this genus from Bathmodon, I stated that the differ. ences were in the dentition 80 far as known; i. e., that the crests of the true molars are not united internally and that the premolars are two (not three) crested. I wonld now add to the characters, that there are three molars on each side, with transverse crests, which do not unite at the apex, except in the case of the anterior, when they are slightly con. nected. In Bathmodon there is but one such tooth, the posterior. The inner or third crest of the posterior premolar of that genus is only a cin. gulum, and is not probably a generic ebaracter.

\section{Metalophodon armatus, Cope. Loc. cit.}

This species is represented by the greater part of the dental series of both jaws, which I took from a decayed cranium myself, and can thus be assured of their mutual relations. One of the true molars, at least, belonged to the milk series, as indicated by the unworn crownis of the successional teeth accompanying. Some of the premolars are but little worn.

The incisors are well developed, those of the premaxillary subequal in size. The crown has a convex cutting edge and flat inner face. The outer face is convex. In some the inner face is more concave, and is bounded by a cingulum next the root.

The premolars present a single external crescent of acuminate ontline, and a smaller, nore transverse one, within. A eingulum bounds the crown fore and aft, but is wanting at both base and apex of the triangular base. In the more posterior the crescent is more open, and the crown less transverse.

The molars present an increase in transverse extent of the external crescent, and the interior one is wanting. In the posterior two the an- 
terior ridgecurves round at the apex of the $<$, but is separated by awn. siderable interruption from the posterior. Thelatteris shortened, and ter minates externally in a conic tubercle, which approaches theouterextrem. ity of the anterior ridge. In the last molar the posterior ridge is shorter, nearly straight, terminating at a cone at each extremity.

The canine is damaged, but was of large size, amounting in one or the other of the jaws to a tusk. The probably superior is compressed, with acufe edges. The inner face gently convex, the outer more strongly so, with an acute ridge on its anterior convexity, inclosing an open groose, wath the interior cutting elge. This surface of the dentine, when ex. posed, has a transversely wrinkled character, but no trace of "engine. twrning" in the fractures.

In the mandible, premolar and molar teeth are recognizable; the char. acter of the incisors remaining uncertain. As usual in the ungulates they possess a relatively smaller transverse diameter than do the cor. responding teeth of the maxillary. They change very materially in form from the front to the turminus of the serics, and, in conneetion with the superior molars, are very instructive as to the generic connec. tion of different types of dentition.

The peculiarity of the premolars consists in the fact that, lursides the single exterual erescent exhibited by those of the upper jaw, they have a rudimental second one in the position it should occupy in correspond. ing teeth of Palieosyops. The inner borler of the crown is conves, and

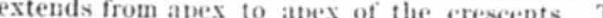

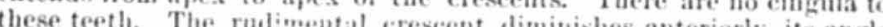

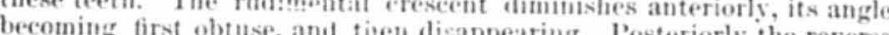

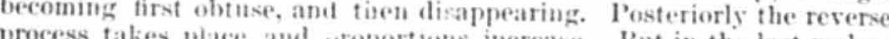
process takes place, and proportions increane. But in the last molars they do not assume the proportions seen in Palcotherium and allied forms. They increase in lhe elevation of corresponding ridges of the crescents and decrease in the others, so that the resultant form is aearly like that of Dinotherium or perlays Louliodon. The onter ritge of an crescent appears as a cingulum, which sinks 'o the base of the cromb

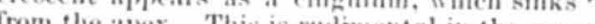
rom the alpex. This is rudmuthal in the genera just mentioned. The corresponding boumling rudge of the ther crescent is reduced to a rudiment extending diagonally across the valley between the remaining crests, as is seren in not a few genera of the Eocene.

\section{Measurements of the tecth.}

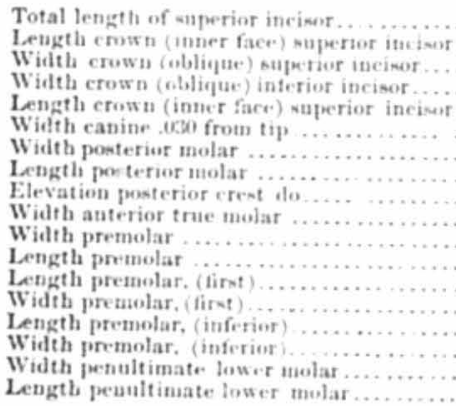

In comparison with mentoms of the premolars are of similar size, but more elevated.

This large nngulate ras fnund in a stratum below those of the Green River group of Hayden, or in the lower beds of that series, near Black Buttes, wyoming.

It is not certain that the last-named species of Bathmodon does not be. long to this genus. All three are distinct from the M. armatus, the latter, though young, being considerably larger than Bathonodon latipes.

\section{PERISSUDACTYLA.}

PAL.EOSYOPS, Leidy.

Hayden's Geolngical Survey of Montana, 1021, page 358; (1) Proceedinga Academy Satnral sciences, Philadelphia, 1071, 1, 11 . Limnohyms Marsh, American Journal

This genus has been partially deseribed by Professor Ieidy, and much light is thrown on its structure by the materials obtained by the survey of Isi:. As pointed out by Leidy, this genus differs from Palcotherium in the isolation of the internal cones of the superior molars from the ex. ternal longitudinal crescentoid crests, and in the presence of but one inner tubercle on the crescentond crests, and in the presence of but one inter fubercle on the lant three premolars instead of two. There is but oue internal cone on the last superior molar. Number I. 3, C. 1, P.M. 4. M. 3. Number of inferior molars similar; true molars, with four wote tubereles alter ag in pairs and connected by oblique crests, which thus form two 1 's, with their apices exterior. The last molar adds a tifth posterior tubercle. The last premolar lacks the posterior of tulercles, - and the first is compressed. The canines are separated by a slight interval from the premolars, and are in continuity with the incisors.

The dental characters are generically identical with those of Titano therium, Leidy, which must be referreci to the Perissodactyla, and not to the Artiolactyla, as left by Leidy in the "Extinet Mamnalian Fauna of Dakota and Nebraska," though originally referred by him to this order.

The species origually named by Leidy Pelacosigops paludosus belong to the succesting genus, Limnohyus, Leidy. He afterward incloded

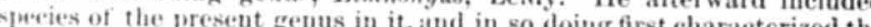
kenus. Hence I agree with him in retaining the generic name for the latter, and not the former, as is done by Marsh. The original form was not charactetized generically, a brief specitic description only being guen.

$$
\text { PALAOSYops havidens, Cone. }
$$

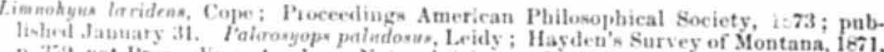
p p. p. 113

Azpecies about the size of the Anoplotherium commune, Cnv., and inter. mediate beiween the Palaotherium magnum and $i$. medium. It is considerably larger than the existing tapirs, and was one of the most abundant of the quadrupreds of the Eocene of North America.

It is chiefly represented by a nearly complete cranium with dentition, from Bitter Creek, and a cranium lacking the posterior part of one side and the lower jaw, from Cottonwood Creek. The molars have the gide erai form of those of $L$. robustus, but the second superior premolar has but one outer tubercle. The cingula are much less developed than in that species; those between the inner cones of the molars being entirely absent. These cones are low, and, with the rest of the erowns of all the 
teeth, covered with smooth and shining enamel. The anterior median small tubercle of the first true molar is wanting. The last true molar has but one interior er:

The canine tooth is rowerful and bear-lik ; the outer incisor is the largest. The premaxillary bones are short, and the side of the face clevated and plane to the convex nasal bones. The nasal bones are long, narrow, and convex. Zygomatic arch massive.

\section{Measurements.}

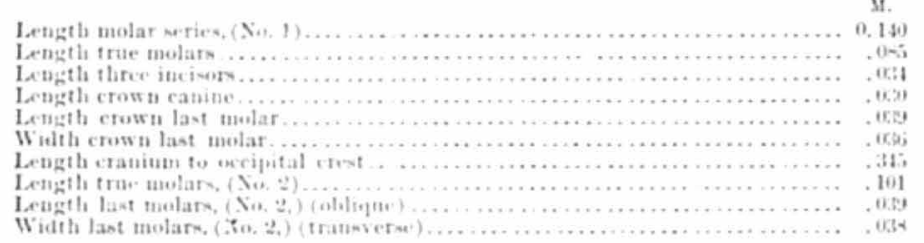

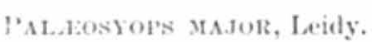

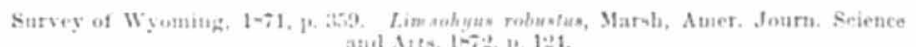
Sumerous sprentuens from Cottonwool Creek, Black's Fork, Bitter Creek, se.

$$
\text { Pal.dosyops vallomes, Cope. }
$$

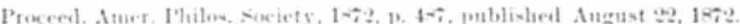

Represented by the dentition of one maxillary bone with other bohes of one imblividual: a portion of the same dentition of a second; with both rami of : ine mandible, with completedentition, of it third. The spe. cies is distimguished he the cletails of the dental structure, and by the superior size. It esceeds, in this respeet, the P'alcrosyops major, Leidy; while the three posterior lower molars measure 4.25 inches in length, the same teeth of the present anmal measure 5 inches. The last superior molar of another sperimen measures 2 inches in length ; in the third the tirst trie molar is 1.5 ineh in length, while the last inferior molar is 2.95 inehes lone. The peraliarity in the structure of the supe rior molars consists in the existence of two strong transverse ridges, which conuet the muer tuberele with the onter crescents, inclosing a pit between them. These are most marked on the premolars, where also is found the peculiarity of the almost entire fusion of the outer crescents into a siagle ridge. There united erescents are narrower than in $P$ mojor, and the summits of all the crescents are relatisely more elevated. The number of inoer tubereles is the same as in that sirecies; all the teeth have very stroug hasal cingula, which rise up or the inner tuberele. The inferior molars are relative, narrower than in $r$. major, and the postetion tuberele of the hast is larger and lotger, and is at elevated cone. The inner tubereles in all the lower molars have broader bases and less acumination.

The bones containing the maxillary and mandibular teeth were not found together in any instance, so that it is possible that the different series may represent difterent spucies. So other species of the genuwas, however, foumd in the localities to which the respective parts could be referred. Should these prove not to pertain together, the lower jams may be regariled as typical of the speecies.

Found in the Mammoth Buttes, on South Bitter Creek.
LIMNOHYUS, Leidy.

Proceedingo Acalemy Natural Seiences, Plailulelphia, 1072, p. 242, Paleronyops, Marob,

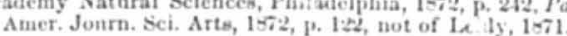

This genns only differs from the last in possessing two conic tubercles of the inner series on the last superior molar, instead of one, a charac ter first pointed out by Marsh.

\section{Lrsiony PALUDOSts, Leidy.}

Procecting Acaleng of Natural Sciences, Phiallelphia, 1-70, p. 113, not of later

My expeclition did not obtain any specimens which I can as yet certam

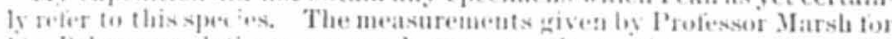
lis Peldensyops laticeps approach very nearly to this one. Thus the wilth of the erown of the last superior melar is .4. .035; in 1 . laticeps .010 ; in L.diaconus, Cope, it is .017.

\section{Lrunonyes phacoses, Cope.}

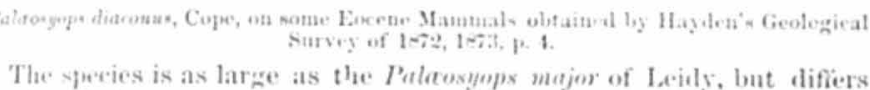
in line relative proportions of the terth. Thus the last three molars laves the satme antero-pesterior length, while the space erenpied by four pre. molat is shorter. The anterior and pusterior cinsula of the true molare we ley stong, but it is not well mathed on the inuer side between the
come. The latter are atcutely conie, and the mesian anterior tuberele is stromgly developed. Ilthongh the wearing of the teeth indieates maturits, the enamel is coarcely and obtusely rusese. The fourth pre.

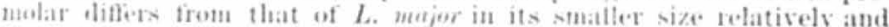

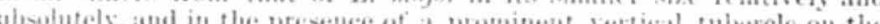
outer fiece rising to the : ande of the heep noteh between the lobes. The thirel premolar is as wide as the fouth, amd about as large as the corwensing tooth in L. anajor, but different from it in the absence of tolerele and ridge that mark its external face. The tirst premolar has Ant teots, and the cambe is latge atud stout.

This latere Palewetheroid is represented log parts of the two masillary

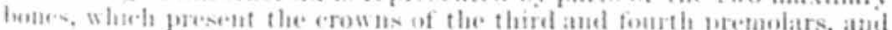
of the veroul and third true molars, with the base's of the other molas atud pretuolars,

Weasurements.

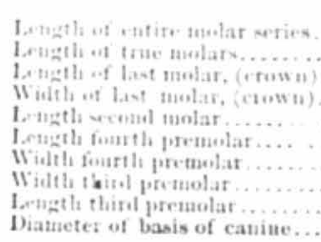
s linis (11:3)

The $L$. paludosus, Leidy, is similar to this species in the ragosity of the enamel of its teeth, but appears by the measurements to be distiuctly smaller, so as to relate to it about ats to $P$. major.

$$
8 \mathrm{G} \mathrm{s}
$$


In comparison with Marsh's description of his $P$. laticeps, the measure. ments are all larger, and the enamel is as rugose as in $L$. major, instead of smooth. The shortening of the premolar series is greater in $P$. diaconus; thus in $P$. laticeps the two sets of molars are related as $49 \mathrm{~mm}$. to 61 ; in the present one, as $106: 6.5$; were the proportions similar, the length of the premolar series should $6 x^{-69} \mathrm{~mm}$.

From Denry's Fork of Green laiver.

Lisworyes fostivalis, Cope.

Palarongops fontinalis, Cope; Proceedings of American Philosophical Society, 1673,

The smallest of the tapiroids of this series, being about the size of a dog. It is represented especially by a considerable part of the cranint of an individual in which the last superior molar is not quite protruded, but with the ofleer molars and last premolar of the permanent dentition in place. The enamel of these teeth is in accordance with the age, deli. eately rugose, and while the cingulum is present fore and aft, it is want. ing internally and externally. The anterior median tubercle is present on all the true molars, and the bases of the acute inner cones are in contact. The sagittal crest is truncate, and the squatmosal portion of the zygoma very stout. The nasal bones are together very convex in transverse section.

\section{Mcasurements.}

Length of true molar merien, (2.75 inches)

Wenth of laxt molar

Letsigth of petuntimate melar ....

Length of petmitimate molas ....

Depth minamosal process.

Fommd by the writer on a bluff on Green River, near the mouth of the Big Sandy, Wyoming.

HYR.ICHYUS, Leidy.

Geological Survey of Montana, 1871, p. 360

'This genus was originally deseribed by Leidy from portions of skele tous of individnals from the Eocene Tertiary of Wyoming. He recognized it as related to the Lophiodon of Cuvier in clentition, and as sharine with characters of that Eocene genus peculiarities which beloug to the exist. ing geaus Tapirus.

Having obtained a large series of remains of this genus, including more or less numerous portions of six species with nearly complete skeleton of 11 . crimius, Leidy, I propose to give such an acconnt of its osteology as will place its relations on a certain basis.

The chatracters which distinguish its dentition from those of the allied genera are as follows:

Tapirus, Briss, Lotcer yac: Third molar two-crested; three premolars, the third and fourth with two transverse crests. Upper jav: Sesen molars, first with an inner heel tubercle; other premolars with two transverse crests.

Hyrachyus, Lejdy. Lotcer jase: Third molar with two erests ; four premolars, third and fourth with one transverse and one longitudinal crest.
$U_{p p e r}$ jaw : Seven molars, first without interior heel; premolas with two trauscerse crests.
Lophiodon, Cnvier. Loncer jase: Third molar with three cross.crests ; premolars three, Nos, 2 and 3 with longitudinal crests. Upper jano: Premolars with longitudinal crest only, No. 4 with two transverse crests. Cpper jase: Premolars with only one transverse crest.

In Hyrachyos the nasal bones are elongate, and unite with the maxil. laries auterior to the orbit; in $H$. eximius above the foramen infra-orbitale exterius : in Tapirus those bones are much shortened, and either do not unite with the maxillaries or join them and the frontals above the orbit at different points from the anterior to the posterior borders. The tem. poral fosste are so extended as to produce an elevated sagittal crest, which is bifurcate behind, each projection continuing along the outer margin of the occipital region as a lateral crest. The tympanic bone is unossified beneath the meatus auditorius esternus, which is bounded in front by a strong postglenoid process. Posteriorly it is bounded by a long Aresending mastoid process of the squamosal bone, nearly closing it process, which is compressed from before lackward and curves back. ward and iuward. The foramen magnum has prominent supero-lateral margits which are nearly straight, and unite at a right angle abore.

The dentition is thus: I. ${ }_{3}^{3}$; C. I; P. M. : ; M. . 3 ; a considerable diastema separates the premolars and the canine.

In the species studied, the vertebra are divided as follows: C. 7 ; D. 18: L. 7 ; S. 5 ; C. (?). Of the cervicals the seventh only is not pierced by the arterial canal. The atlas has a broal flat "transerse" process. exterior digits halved; the former have two roverted proximal proeeses the torter one, The astragalus exhibits a doeply frooved mulextensive troc'lear are, wit the les for the cuboid bon.

From the above it is evident that this genus is nearly allied to Tapi. rus and cannot be removed to another fimily. Profesor Leidy states that the pretnolars differ from those of Tapious in having "but one in die $\mathrm{r}$ lohe connected with the exteral crest by two transverse erests." The apprearance of one lobe is produced by the posterior curviture of the anterior transverse crest rond the inner extremity of the posterior

1 now proceed to describe the skeleton more exactly.

$$
\text { IIYRACHY's PRAcers, Marsh. }
$$

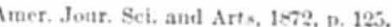

From Sonth Bitter Creek.

$$
\text { Hracmes Exmuts, Leidy. }
$$

$$
\text { Hayden's Geol. Survey Sontana, 1671, p. } 361 .
$$

Cranium,- In the specimen to be described, the anterior portion from the glenoid cavities is wasting. The sagittal crest is quite elevated, and the lateral occipital quite prominent and superior margin of the squamosal portion of the zygoma. Four wo tious foramina pierce the parietal bone near its middle and above the paramastoid process, and two enter the squamosal above the postglenoid process. The paramastoid process approaches near the occipital condsle by its posterior border. I cannot discover the sutural boundaries of the mastoid bone, but that separating the paramastoid boundaries of the process in frout of it is distunct. The condyle of the 
sive, and the posterior border of the latter extends backward with a slight obliquity.

\section{Measurements.}

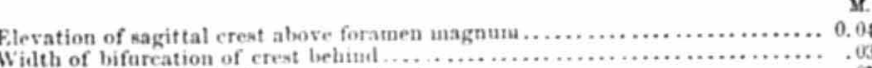

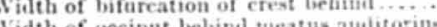

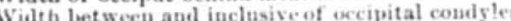

Width temporal fossa at meatis.

Wilth meatus anditorins.

Depth of ratuus beluint.

In further illustration of the species I add measurements of teeth, \&c., from another specimen :

\section{Mcasurements.}

Letagth of la

Lengith of la

Iaruth of inf

ferior molar metir.

Cugth of premoiat

Width of last minlar.

Depith ramus at timb true molir.

Vertelore.-The atlas is elenply incised anteriotly above. It is ratleer short, aud its traverse processes are tiat, thit, alnent as long as broad, and with regular conves distal margin. The arterial foramen isstes and with reglis whe anterior some distance nbove atrosterior base of the transterse mocess. It enters at the notel at the posteriof base. The neural areh is quite convex, and its anterior margin is ob. tusely rounded. The axis is near the same length, and bears a promb. neut aud elongate faminate nemal spine. Its diaparapophysis is narrow and overlape the parapophy sis behind it threesuaters of an inch; it is

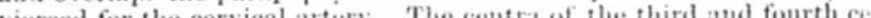
vicals are atout equat in length to that of the axis, lont the remaining ones shorten sucersively to the seventh, which maintains a length somewhat greater than its width. The paraponhsses of these, except the seventh, are flattened, and have considerable antero posterior extent, their extremities overlamping. A short and rather narrow and stout diapophysis is prosent un the sisth cervical; on the seventh it is larger,

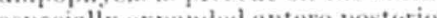
is no paramophisis. The fourth, fifth, sixth, and seventh have strongly is 110 paranophysis. The fourth, fifth, sixth. and

\section{Measurements.}

Length of atlas, lat wewt artieular

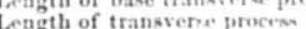

Diameter newal eanal in fent ...

Siameter of auterior espanc.

Diameter of tolalerpatis

Latheth axis along basis nemral areh

Elevation crest (rectangular) from pasteriur zvgapephysi.

Length parapophysis of littu ecrical on margiti...

Extent zygapophyses of litth cersical on margin...............

Expane zygapoptyses of tift cerrical on margin bebind

Elevation neural spine of $C .6$.

Elevation neural spitie of $\mathrm{C}$ :

Dengtir centrum lectow y.

in

(n)

$\operatorname{lin}$

$x_{10}$

.0051

The measuremetics indicate that the neural spines of the sixth and seventh are quite elevated, the latter nearly equal to that of the first. dorsal.

The spines of the dorsal vertebra are elevated in the front of the The spines of the distance above the scapula. They shorten and widen series rising some distace of the series backward. The extremities of all rapidly from the middle of the series backward. The extremities of all Iron the scapula posteriorly are turned forward. The metapophyses are and on the eighteenth, their elevation is about 4 that of the neura tine. The diapophysis is extended besond the tubercular articulation, Wu the eirliteenth dorsal; the extension and expansion increases rapidly the lunbars. On the fourth they are as wide at the base as .66, the l.uth of the centrum, and maintain their widtl, being directed anteriorly. On the sixth and seventh they are still wider and longer, and very thin. They present a projecting transverse surface backward ouefourth the length from the base for articulation with the seventh lumbar and first sacral respectively. The centra of the lumbars are inoressed and slightly opisthocolian, except the last, which is flat. They are contracted and keeled below.

Thi.e sacrum is long and narrow, and thoroughly co-ossitied in the precimen. The diapophysis of the tirst aud part of that of the second five attachment to the ilium. The intervertebral forimina are rather sinall.

\section{Measurements.}

fength of doral werteber along milllles of nenral spines...

1.Figth of dorsal verto

1.cugth of sacrum along centrit.

irameter centrum fint lomal, (transiners.).

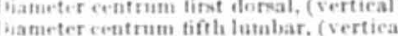

Hatueter centrum tifth lubibar, (transverse)

Length do..........................

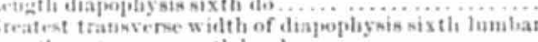

length centrum eesenth lumbar

franswerne thatueter centmin first nacral.

Tratisverse expanse diapophyses do.

Tratincere diaitister end of last kacrai

Elenstion netural spipe second dorsal .

Fevation neural spine seventh dorsal alowe ncapula

Fievation neural spine eighteenth dorsal, (from arch behind)..

M.
0.420
.290
.170
.019
.019
.020
.020
.039
.065
.030
.034
.036
.048
.020
.043
.005
.035
.037

The ribs are long and slender, the first but little expanded distally Mul united ith the maumbrimu sterui a little behind its midlle. They munher eighteen, but as the last is quite long, there may have been another pair of shorter ones not yet exposed in the matrix.

\section{Measurements.}

leng h first

whth tirst, distalig.

ugth eigliteenth........... $\}$ from tubercle

Is.

.018

110

There are four sternal segments preserved, with a fragment of another. They are distinct, and the first is the largest. It is a lougitudinal plate, placed on edge, with the anterior border strongly excavated. The in. 
firior margins of the succeeling segments are thickened, but the com. pressed form remains, the section being triangular.

The scapula is large for the size of the animal. It has an approxi. mately triangular form, the base beug superior. The posterior augle is right, but the anterior renularly rounded. The apex supports the gle. noid envity on a neck which is contracted by a shallow exeavation of the anterior marcin. The latter is bounded nest the gleneid eavity lo the short obtuxe eroracoit, whieh stamb a short by

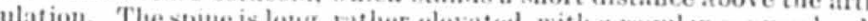
ulation. The spune is long, rather elevated, with a regular convex border
curved backward.

\section{Measurements.}

Length of thre - sternal segments

length of tirst nte-ral regimest.

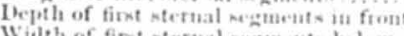

Witth of finst sternal segentit be low

Wilth of thisel stermal swoments

Wingth of keapula, (wicilian)

Wisth of

Wislth of ghenoil cavity

II.

$x_{i=4}$

ind

.015

Hunerus.-Tir heal is durected a little inside of direetly backing The bieipital greose is very deep and the inter tuberosity large and

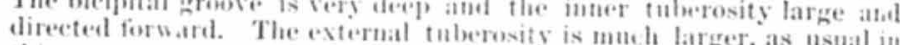
this grom of this gromp of ungulates, ant rises in a hook-like ales above the level of the leat. The extermal bieipital ridge is lateral, and not very proms. nent, extending on one-third the length of the shaft. The shatt is mot erately compresed at the midelle, but transversely flattemed below. It is nearly straight. The condyles are narrow, and the inner and onter tuberosities almost wanting; their position marked by shallow concavi ties. The external continues in a laceral crest which turns into the shaft below the lower third. The inner condyle is both the widiest and most prominent ; the exfernal has its eariua at its midelle, and its ex.

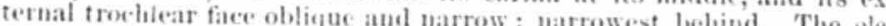
cranar and coronoid fossat are deep and produce a small supra-cond gar
foramen.

The ulna exhibits a large and obtuse olecranon, concave on the ex. termal face. Its glenoid eavity is narrowed and elevated behiud; in front it widens, and there the ulna receises the trauscerse proximal in of the radius, which overhauss it on both sicles. leaviug the lits tions of the right and left coronoid processes about equal. The vertical diameters of the shaft of the ulna are about erual throughont. Its section is triangular, the base bejug next the ralias for the proximal third. This is followed by an edge next the ulna, and the base of the section is on the onter inferior aspect, on account of the direction of an angle from a short distane beyond the outer coronoid process to the base of the uluar epiphysis, where it dixaprearse bistally there

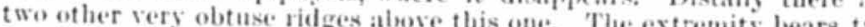

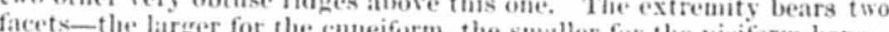
The the larger for the cuneiform, the smaller for the pisiform bone.

The ralius is thronghout its length a stonter bone than the ulna and bears much the greater part of the carpal articulation, viz: with the seaphoid, lunar, and part of the cuneiform bones. This articulation is transverse to that of the ulna, which is thus at one side of and behind it. The head is a transverse oval in section, the ra sower of and bethind The articul:.r face consists of one and a half trochlea, the latter wider aud internal. The shaft is a transverse oval in section, with an angular ridise along the middle externally, aud the distal part proximally. A broad groove marks the upper fitce of the epiphysis, where the shaft has a vertical inner face.

\section{Measurements.}

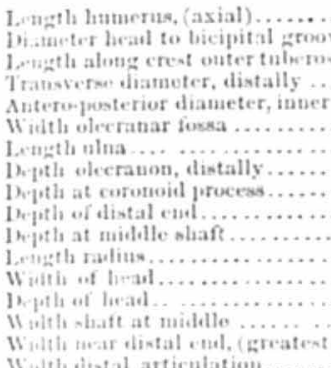

The elements of the carpus are distinguished for length, and for re. duction of width. The anterior faces of all are considerably longer than broad, but the longest faces of the cuneiform, seaphoid, and trapezoides are antero-posterior. The facets are as usual in the earpus; sea-

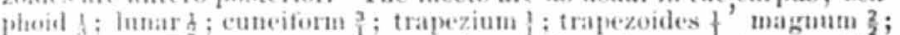
Thifor The cuneiform has a rather l shaped exterual tace. Tue pisifurm has $t$ wo proximal facets and is enlarged and thickened distally; presed inward, it reaches the seaphoid. The trapezium is a suall sulmiseoid bote with consex outer face. The magnum is as broal as deep in front, where its surface is swollen: it is produced behum inte a batulate alecursed hook. The unceform has a narrow sub acute hook behind, with wide base.

\section{Veasurements.}

Wilth of carpals of first row togethet

Wiath of limare, outer fare.

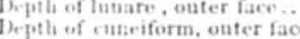

Wilt of

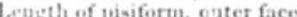

lepth distally, unter face...

Whith thene carpale of eccond toss

Width magnum, onter face

1) bejth magtam, outer face

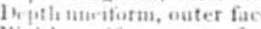

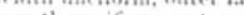

Length uneiform, antero-postering

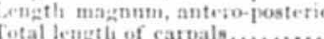

The wetecaruals are guite slender. The fint only is wanting; the third is rather stonter than the others, while the fourth is considerably
the tuost slender. Its distal extremity is oblique, with prominent median keel, which is wantung on the suprerior aspecs. The proximal facets of these bones are respectively (2d) 2 , (3il) 2 , (fth) 1, (5th) 1 . There is a short, shallow grome near the proximal ent of $\mathrm{No} 3$. The phalanges correspondiug are lost in the specimen. 
Measurements.

Length of firth metacarpal

Fist mated length of foot.

Distal diameter of fifth metacarp.........

Proximal diameter of metacarpal

Proxinal diatneter of fourth netacarpal

Proximal diameter of serot metacal.

$\mathrm{M}$.

1070

019

012

.017

The above are taken on the articular faces transversely

The pelris is perfectly preserved. The ischium is but little over half measuriug from the midlle of the acetabulum. That ilinu is a tricalinte lowe wider than that forming the "crest, which is subsioner shorter and cular portion. The crest expands resy slightly distally forward and downward. The ischiopubic suture is a long one, and the obturator foramen a long oval; the inferior pelvic elements do not form a trans. foramen a long oval; the inferior
verse, but meet at an open angle.

\section{Measurements.}

Length ilinm to acral border

Wringth ilium to crest

Wirfth creot

Wisth peduncli

length ischint from mialdie of acetalinini .

Wisth iachicm jreteriotly.

Weagth obturator foramen.

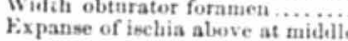

Femur.-The head projects inward on a well-marked neck. The trongly recurved and presents an aned neck. The great well. It rises to au incurved apex mues prominence of the frout of tue finur is cosing trochanter. The outer thechanter. The thin, and at a point two. firtus the length from the proximal end is produced into a low thind cochanter, which in curved forward and thickened on the margin. The 作 harrow. It is contimuous witl the surfaee of the the more so, and is the shorter and more vertical; the external is longer angle, which is terminal face is marked by two fossa. side the distal eut of the aidue bous onc in front of the other just out. side the distal end of the ridge bordering the trochlea. Little trochanter

\section{Hensurements.}

Total length

I'roximal width of head and trochanter.

Witth just alove to calge thind treclianter.

Wulth of coucts les.

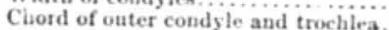

The tibiu has a broad prominent crest, which is remarkable in being deeply fissured longitudiually at its smperior portion. The tendinons notch separates the outer portion of the crest from the spreading margin of the outer cotyloid face. The crest disappears at the proximal mind, and the shaft becomes flattenes in front and on the inner sroximal third, tal articular extremity is impressed by 1.3 trochlea, the outer bing completed by the fibula. The posterior tuberosity is more nearly median than usual, hence the inner margin of the inner trocblea is low posteriorly, and the inner malleolus has a considerable beveled inferior margin. The filula has a slender shoft. but little compressed. The head is expanded fore and aft, and the malleolus is quite stout.

\section{Measurements.}

Length of tibia.

Diameter from onter angle of heal to inner angle of creat.

Diatueter distal end, (greatest)

Diameter articnlar face, transserse

iameter articular face, fore and aft...

Both hind fect are perfectly preserved. The astragalus is rather elongate and compressed, the lower face truncate with two longitudinal bounding ridges, the outer of which is discontinued before reaching the heel. The surface between them is striate grooved. The outer face is slightly concave. The astragaline facets are much expanded inward ; the outer is transverse and strongly convex, and separated by a groove from the inner, which is longitudinal and nearly plane. The posterior elge of this, aud convexity of the onter facets are received into a trans. vere groove of the posterior part of the lower face of the astragalus. verse groose of the posterior part of the lower face of the astragalus.
The culoid facet is diagonal, and is bounded within by a third narrow The entoid facet is diagonal, and is bounded within by a third narrow facet for the astragalus. The astragalus has a strongly convex deeply grooved trochlea; the convexity extends over $158^{\circ}$. The trochlea is nearly in the vertical, a little oblique to the longitudinal axis of the foot. The exterior malleolar facet is well marked, and bounds a lateral fossa above. The neek of the astragalus is broad and not contracted, but not wider than the trochlea. Its navicular facet is wide and concave, the cuboid narrow, with a long angle behind. The cuboid is quite elon. gate, and with a narrow anterior face; it his a large posterior tuberosity not projecting much posteriorly. The navicular is flat, with a sigmoid proxinal face, convex on the infuer side, concave on the outer. It has the three cuneiform facets lelow the inner antero-posterior. The inner is a tlat bone with antero-posterior plane and apex directed back. ward, and cousiderably oblique facet for the second metatarsal. The mesocuneitorm is much the smaller, and brings the third metatarsus a short distance proximal to the fourth. The ectocuneiform is a little whler than deep. The metatarsals are three, and are rather slender. The two outer are equal i: length, and the median but little wider proximally, the increased width being more obvious distally. They lave no proximal grooves, and the outer has a low outer tuberosity. The facets of the second row of tarsals are $\$+1$ The phalanges, inciuding un gneal, are $3,3,3$. The proximal ones are longer than, including untracted at the ends; the penultimate are still stouter in form. ungues of mildle line are symmetrical and broad, with the margin segment of an ovoid, and slight contraction at the neck The proximal articulation is bounded by a fossa on each side, which is in its turn isolated by the elongate process found in the tapir and in the horse. The margin is marked by radiating stria separated by grooves, of which the median is the most marked. The lateral ungues are contracted on the inner sille, and only possess the proximal fossa and hook on the outer side. The median distal groove is well marked.

Measurements.

Length of hind foot from beel. M. 
Depth ealeaveum behinil.

Width calcaneum at astragilus.

Greatent axial length of astracialius.

Width betriven trochlear erests ast ragalns.........

Length neck between trochlear, outer sude

Width bead between trochlear

Wielth navicular

Letigth navicular at midale.

Length culoin

Length ectocuneiform in frot

Width ectocuneiform in frots

Width mescenneiform in frout.

Length thesocuneiform in front

Length entocuneiform at sid.

Depth cntocunciform at nitlo.

Length of metatarsus 11 . .

Length of metatarsus Iit

Width of metatarsus If proxitualt

Width of metatarsus III proximali

Width of metatarsus II distall

Jeugth median phalandes 1 .

Wirlth median phalanges 1 .................

Depth median phalanges 1 distally

Leugth median platauges If .

leugtl, median phalanges unguis..

Width of articular facet unguis.

Width of neck of facet ungui

Width of greatest expanse facet ingzui

Length platauge of metatareal 11

Length ubgus of meta

Length tuetarsus atul phalatages IV ... a resteration of this spectes:

Measurements.

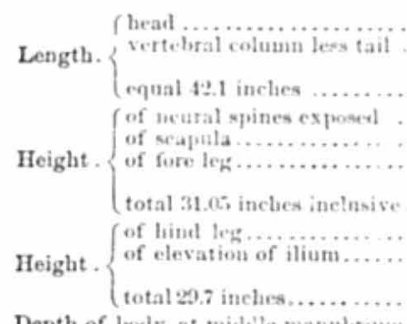

Depth of lrody nt midatle

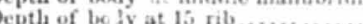

Allowance being made for the obliquity of the luumerus, scapula, femnr, and iliun, the elevation in life was-

At the withers, (2t.6 inches)

At the rump...

The size of this species was, then, that of a large sheep.

Comparison of the skeleton teith that of Tapirus roulini.-For the oppor. tunity of making this comparison I am inclebted to the Snithsonian Institution, which possesses a skeleton of the above species of tapir from Ecuador, presented by President Moreno.

Cranium.-In addition to the geueric characters mentioned at the commencement of this description, the $H$. eximius and $T$. roulini differ as follows: in $H$. eximius there is (1) a ligh sagittal crest which is want ing in $T$. roulini, $T$. malayanus, and approximated in $T$. terrestris. (2) The erest of the squamosal part of the zygoma is continuous with the lateral occipital erest, which is not the case in existing tapirs.

Vertebre.-(1) The arterial canal of the atlas is not isolated in front as in $T$. roulini, but notehes the basis of transverse process. (2) The axis is longer than in $T$. roulini. (3) The neural spines and especially the metapophyses of the posterior dorsal rertebre are anore elevated (4) The end of the centra of the lumbars are flatter, and more depressed.
(5) The diapophyses of the same are wider and longer and thiuner, and the penultimate articulates with the last by an angular process, which is not the case in $T$, roulini.

Scapula.-(1) This bone is equal in size to that of a T. roulini, of con. siderably greater general dimensions, and is hence relatively larger. (2) The spine is not angulate as in that species, has a larger base, and larger elevated margin. (3) The neek is more contracted, and (4) the coracoid is not recurved as in $T$. roulini. (5) The sinus bounded below bs the latter is much shallower, aud not bordered above by a recurved hook of the margin.

IInmerus,- (1) It is relativels smaller in $H$. eximius, (9) The internal licipital ritge of $T$, roulini is winting. (3) The exterual endy is shorter, whence its border is nearer its troelucas rib. The radius has a natrower head, (1.) the extermal articular plane hein. The radius has a natrower head, $(1$, ) the external articular plane being hortened. (2) The shaft is whler with a more acute longitudinal lateral ridge medially, and more rounded distal end. The ulua is (1) absolutely nearly as long at in T. roulini, being thus relatively longer. (2) It has three weak, longi tudinal ridges on a convex outer face; in $T$, rutlini the external face is divialed by a very prominent longitudinal angle from the radial cotylus, which spreads distally, sending one angle to the upper and another to the lower base of the distal epiphysis.

Cirpus. - This part is (1) absolutely and relatisely smaller than in $T$. roulini. (2) The pisiform is more cylindroid distally. (3) The seaphoid is more produced backward on the inner side; the exeavation of the intier side is more contiuued as a concasity of the outer side of the front.

The unciform has an acute tuberosity behind; in T. roulini it is short, vertical, and obtuse. (4) The trapezoides has a shorter, wider, and more swollen extermal face. (j) The pisiform is small aud convex, instead of being larger and that.

The mefacarpads (1) are absolutely atad relatively smaller. (2) The inner (II) has a more oblique phat infeal articulation, which is short above and with the keel prolenged upward, instead of being, as in $T$. runlini, distal ouly.

The pelcis is distinguished by the much longer plate of the ilium, whose extrenity constitues the crest. (1) The erest is also shotter, and more antetior. In $T$. roulini this plate does not so much exced the sikral plate in length. (2) The pules and ilia are not so horizontal, but meet at nearly a right angle, aud (3) the ischiopubic common snture is considerably longer. (1) The obturator foramen is a wore elongate

The femur is very similar to that of $T$. roulini, being no smaller in rel. ative size. (1) The great trochanter is wider fore and aft, and with margin more continucl on the anterior nspect of the extrenity of the sliaft. (2) The third trochanter is mearer the michlle of the length. (3) The condyle surfaces are continuous with the rotular, not isolated as in T. roulini. The latter also (4) lacks the two fossa on the outer murgin 
of the external seen in $H$. eximius. (5) The rotulor groove is also nar rower in the latter and not so deeply excavated as in $T$. roulini.

The tibia is (1) resluced in size, and esperially contracted distally ; the relative widths of the ends are $6 \mathrm{~cm}: 3.5$; in $T$. roulini $7.5 \mathrm{~cm}$ to 5 , (2) The erest is more prominent, and is deeply fissured by a groove, which is represented by a shailow concavity in $T$, roulini. The groove (3) es. ternal to this is deeper. (4) The posterior inner tuberosity of the distal end is more median, hence the inner trochlear groove is further removed from the anterior inncr malleolus, which has, therefore, a greater inner (not outer) extent.

The tarsus (1) is generally longer and narrower, except in the case of the cuboid boue, (․) which is shorter than in $T$. roulini. (3) The astra. galus has a narrower neck, which, therefore, appears more on the inner side. (4) The facet for the cuboid is smaller. (5) The iuner tuberosity of the head is more prominent. (6) The calcmenu is more slender, with larger cuboid facet, especially ponteriorly. The metatarsus is absolutely nearly as long as in $T$. roulini, and, therefore, relatively longer and more slender. (2) The median (III) is nearly similar to the others in width; in the $T$. roulini, much larger tuan the lateral.

The pualanges of the first eross series are more contracted distalls.

The more inportant differences between the skeleton of the two species in addition to those pointed out under the head of the geuns, are those of the ulna, the reapula, the lumbar vertebra, the ilium, and the crest of the tibia. The seapula is more like that of Tapirus terrestris, while the ilium is apiroxinated by that of $T$ malayanus atrong lising species; its form leans toward the Equiue series, and not to the Palcotheroid.

\section{Conclusion.}

From the preceding it is evilent that there lived in North America durmg the Eecene perionl a type of Thpiride only differing generieally frou that now existing in South America. Thus one form of the many feestiar and primitive ones of that time still persists in the tropies and sonthern hemisphere, which claims more ancient character than the rhimorerus, elephants, ambl other remains of Viocene time.

The aftinities of Cercoleptes and Yasua to the types of the same period have bero shealy indieated, and with the present case may be regared as conirmatory of the proposition stating the early geological state of the existing Fiune Neotropicat

$$
\text { IInacmes mpricates, Cope. }
$$$$
\text { On sotne Noeene Matumalia, S.c., 1-73, p. 5; ptublished March o }
$$

This tapir is onaller and uore slender than the H. agrestis, Leils, but exhibits an equal a ize of posterior molar teeth, which are thus relavisels larger than in that speetes. It is represented first by both maxillary

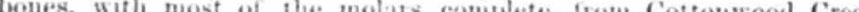
Wyemiug; the by the siche of the face, with plete, with symphysis and portions of all the incisors, from South Bitter Creek, and by part of mambibular ramus, with teeth, from Green River, with probably other sperimens.

The molars diffir from those of the other Ilyrachyi, and resemble those ealled Helaletes, in t'.e presence of a prominent ridge, which descends on the inner side of the principal (median) outer cusp, not quite reaching - Ree of the 1'rimative Typer of the Mamnalian Orden, 10ro. i See Urigit of Geuera, j. 99 and preced the valley below. It wears into a prominen ioop. The anterior cusp is much less elevated than the median, and is separated from the latter by a cousiderable ridge. The ony cingulum on the molars is on the outer side of the first. Enamel smooth.

Measurements No. 1.

Length of five molars. M.

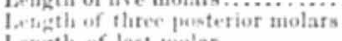

1.ergeth of last wolar..

Width of last raolar

Wilth of peunttimate molar.

In the more perfect specimen all of the molar bare two transrorse crests, except the P. M. 1. The lower molars possess strong anterior prolongations of their posterior crests : the third and fourtb premolars have one elevated transverse crest near their middle, and the second is much compressed. The first I cannot find. Symphysis rather short for the genus.

Mcasurements No. 2.

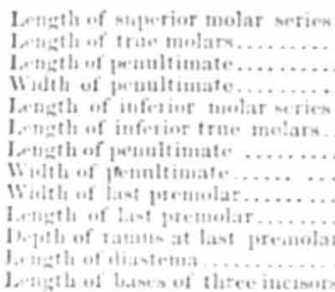

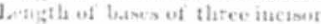

IIrachrt's Agrartis, Leidy.

Common everswhere.

HrRscart's noörs, Marsh.

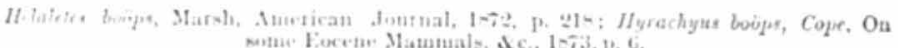

Bitter Creek and Blacels sork.

Hrtachus Naxes, Marsh.

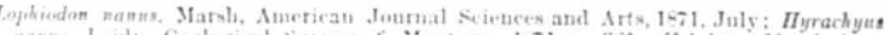

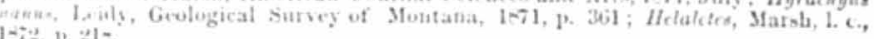
Cottonwood Creek.

\section{AxCHIPPODUS, Feidy}

Procecdings Acalemy Natural Sciences, Philatlelphia, 1-6ic. pr. 292; Trogosus, Leidy,

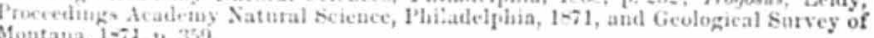
Axchippods minon, Marsh.

Palaosyop minor, Marsh, American Journal Science and Arts, 1971, July; Trogosus cantoridens, Leidy, Geological survey of Montaua, 1er1, p. 300.

Cottonwoor Creek. 
OROHIPPUS, Marsh.

American Journal Seience and Arts, 1872, (published August 7.)

Superior molars, with two external crescentoid crests, and two inter. nal cones, which are connected with the former by low oblique crests which are directeal to the anterior bases of the onter tubercles.

This genus conctitutes an approximation of the Limnohyus type to Anchitherium, and probably connects effectively the equine and tipisvic divisions.

Orompres procyonisus, Cope.

Proceedings American Philosophical Society, 1872, p. 466, Angust 3. (HFlotherium.)
Orohippms pumilus, Marsh, 1. c., August 7, 1082.

This spectes is distinguished by its small size, as it did not much ex. ceed the raccoot in dimeusions. The size of a right superior molar is as follows:

\section{Measurements.}

Length

Wirfth posterior

Width anterior

The crown presents fonr tubercles, of which the inner are flat on the anterior, the onter flat on the exterual sicle. The anterior cross ridge has a irihedral tubercle, and a low tubercle intervenes between the two postesior in front of them. $\Lambda_{n}$ anteriog and $n$ posterior ciugulum. Euamel strooth.

\section{Genera Incerta Sedis.}

OROTIERIUM, Marsh.

American Journal Science abil Arts, 1R72, p. 217

Orothenum vasaccilise, Cope.

On some Eocene Mammals, Sc., p. 3.

Lophiotheriun macrienor. Cope. Proeceding American Philomophical Sncie'y, 872, July 11, (extras.) Notharctus ra anciensis, Copere, 1. c., 1-72, 474.

This species is similar to the next in most respeets, the correspouding molars differing in the more elevated yoke between the tubercles of op. posite sides, and the prosence of a posterior median tubercle.

Represented by a portion of the left ramus of the lower jaw, contain. ing one tooth in perfect preservation. The structure of this indicates it to be the second true molar, and presents certain features of distinction from the same tooth of the L. syleaticun, described by Dr. Leidy. The crown presents four tuberctes, which are arranged in pairs, the separa. tion between the right and left lobe of each being slight, thus giving the tooth the appearance of having two transverse crests as in Hydrachyus. The two anterior and outer posterior tubercles are fissurę by wearing, but the inner posterior consists of two acute crests, which meet, presenting an acute angle toward the adjoining tubercle. The outer pos. terior tubercle sends a descending crest obliquely to the base of the inner anterior tuberele, as in L. syleaticum. A small tubercle occupies the space behind the interval between the posterior tubercles and gives origin to a cingulum whica passes round the bases of the onter tubercles. It extends round the front of the tooth to the outer anterior tubercle. Wear would produce stuall angular crescents from the two posterior and in anterior tubercle. Greatest length of crown, M 0.008 ; wilth .006 . The enamel of the tubercles is rugose.

This ungulate was of abont the size of the L. sylraticum, or equal to the raccoou. It differs considerably from that species in the less isola. tion of the tubercles of the molar, and the crescentic form of the inner posterior.

From Green River beds near Evanston, and the same near Black Buttes, Wyoming, on opposite sides of the Bridger Basin.

\section{Orothentua silvaticus, Leidy.}

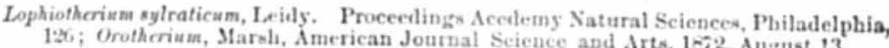
From Black's Fork, Wyoming.

\section{OLIGOTOMUS, Cope.}

On some Eocene Mammals, \& c., March 8, 1-73, p, 2.

Char. gen.-Molars constructed much as in Hyopsodus and Lophiothe. rium, viz, with two external subtrihedal cusps, which wear into eres. cents, the posterior connect 'd by a low obliqne ridge with the losis of the anterior cone of the inner side; the latter with two coniensus. premolars; the interior molars are probubly six, leaving four true
molars,

$$
\text { Oligotomes cisctus, Cope. }
$$

$$
\text { Loc. cit. }
$$

Char. specif,-In this animal the cusps of the molars are elevated, the exteran most so, the anterior being sonewhat bilobate. Premolars the two fangs. There is a rudimental posterior tubercle in $\mathrm{M}$. 1 and 2 , and a strong cingulum romat the onter side of the crown. In an adult with worn teeth the enamel is obseurely rugose.

\section{Measurements.}

Let, gh th of five molan

Letrigth of two premolar

Length of $M$.

Winth of M. 2 anteriorly

Depth rames at frout of $\mathrm{P}$ if

From Cottonwood Creek, Wyoming.

\section{ANTIACODON, Marsh.}

American Journal seience and Arts, 1872, p. 210

\section{Astiacodon pygmaus, Cope.}

Lophiotherium pygmerum, Cope. Proceedings Ameriean Philosophical Society, 1972, extras, July 20; Anticoodon renuatus, Jarsh, Americau Journal Beieuce and Arts, 1872, (published August 13.) Hyopsodus pygacise, Cope, loc. cit., P. 461.

From Cottonwood, Wyoming.

Represented by a portion of the right mandibular ramus, with the penultimate and antebenultimate molars in perfect preservation. These M. 0526 


\section{GEOLOGICAL SURVEY OF THE TERRITORIES.}

teeth present four cusps, of which the outer are crescentoid in section, the inner conic. They are all elevated, and the inner anterior is in both teeth compressed and bifid. It receives an obligue ridge from the onter posterior erescent, which also sends a ricige to the posterior inner. Enamel smooth.

\section{Measurements.}

Length of penultimate nolar. Width of penultimate melar belinit... s.

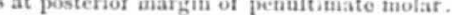

This is a small mammal, about equal in size to a weasel.

\section{ANTIACODON FURCATUS, Cope.}

On some Eocene Mtanuals, S.e., p. 1, March \&, 1-73.

Established on a part of the right ramus mandibuli, with the three molars and last prenolar in perfect preservation. The crowns of the molars are composed of two external, chevron-shaped tubercles, the apices rising as acute cusps, atul two internal cones, the interior of which is flattened aud strongly biud, both points being more elevated than any of the others. The ensps are neatly opposite to each other, and he, hind the interval between the two posterior rises another, not so ele vated as the others, except on the posterior molar. Here it is elevated, and nearly equicistant trom the two in front of it. The ename smooth, and there is no cingulum on either side. Tie premolir consixts sefoth, of a principat sectorial cosp, and has a smaller but stont acute anteriot cusp, wiblı a small rudiment of another behimal; a stout cusp rises from the inner posterior margin of the principal one, giving it a subbitad appearance.

\section{Measurements.}

Length of four molars

Wenth of the true melar

Length of last true molar

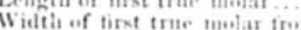

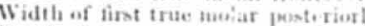

Depth of ramos at frotit of $y$

Depth of raums at frout of 1 .' MI. liast

This species differs from the last in the presence of the posterior tubercles on the M. $2-3$, and the absence of exterual cingulum. The

sizes are not very different.

From the bluftis of the Upper Green River.

The genus to which this species belongs differs from Hyopsodus in the carnivorous form of the last premolar, which has a well developel an. terior cusp. I refer it to the same genus as the last species, though it charicters have never been pointed ont by the anthor of the name. (Professor Marsh,) nor are the characters which distinguish it from Homa. codon of the same author discoverable. He states that the cusps in $n$. ragans are "isolated," n eharneter which does not apply to A. furcutus, in which they are related much as in Hyopsodus.
GEOLOGICAL SURVEY OF THE TERRITORIES.

\section{MICROSYOPS, Leidy.}

Proceedings Academy Natural Seiences, 16i2, p. 20.

Microsyops vicarius, Cope.

On some Eocene Mammals, \&c., 1873, p. 1.

Fonnded on portions of the mandibular rami of two individuals from the Bai Lamds of Cottonwood Creek, Wyoming. These represent minal considerably smaller than the Hyopsodus paulus, and represent an bly only three premolars. This is believopodus paulus, and with proba. size of the last premolar, and the anterior contraction of them the small The moiars have no exterual cinulum ner antetion of the tirst molar. deveribei to exist in the $1 /$. grueilis, by nor antero external tuberosity hese cones have simple aplees and the oblique conneting ridges of both genera.

\section{Meusurements.}
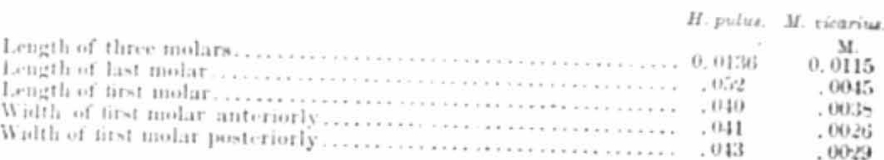

11 Mol'soles, Leidy.

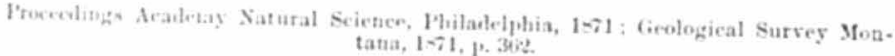
Hyolsods patels, Leids.

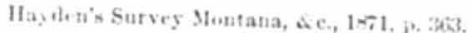

From Cottonwood and Sonth Bitter Creeks.

IR OIIEXIA.

PARAMYS, Leidy. Geol. Survey, Montana, 1-71, p. 3is:

P'ARAMY' leptonts, Cope. On sotne Eocene Matnmalia, \&c., 1073, p. 3. (Publislued Mareh 8.)

Established on a right mandubular ramus with all the teeth preserved. It indicates an animal of about the size of the $P$. delicatus, Leidy, and than half the diameter of the same tittle more have two anterior separate, and threoth in those species. The molars median smallior separate, and three posterior contignons, cones, the it deep exmarest. The anterior and posterior of both sides separated by sion. The anterior tooth is peculiar in its greater compres. kion. The posterior tubercles are not separatesl, and the anterior situate behind the outer, and connected with the posterior inner by a
concave ridge. 
Measurements.

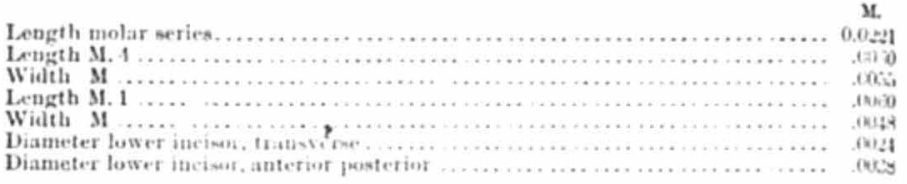

From the South Bitter Creek, Wyoming.

\section{ParaMys Undass, Marsh.}

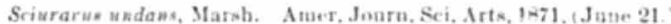

A smaller species thath the P. delieatixximus, leduly. The dental phar acters of the mandibular series are generically identical with those of the species of Paramyx.

From Upper Gicen liver.

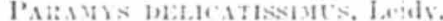

Black's Fork.

PARsus discatol, Levily,

Cottonwood Creck and Blark's Fork.

Params Delicates, Leidy.

Black's Fork.

\section{PSELDOTOMUS, Cope}

Procestings Amer. Philosophiral society, 1-72. p. 407, (Angust 3.)

This genus is represented by the nearly complete craninm, with east of the hrain case of the typical species. The cranimm is of depresed form and with constierably expanded zygomata. The muzzle is broat and but little clevated, so that the nasil meatus is between the alveola of the superior incizors. The fronta! bone is very short, and the supet ciliary margin and orbits small, and without postfontal process. The temporal fossate are large, and contract the banin ease behind the orbnts to a striking de.cree. Their anterior margins rise fiom the postfroutal angles and convere backward, meetiug in a sapittal ridere opmosite the anterior part of the squamosal bone. The pariecal bones increase rapidly in wilth to the squamosals, which also extend horizontally to their zygomatic portion. They do not extend very far on the superiot aspect of the skull, nor backward hesoud the auditory meatus. The occipital region is concave and surrounded by a prominent crest.

The foramen infraorbitale exterius has an interior position, being a little above the alveolar border; it is rather small and round. There is a prominent tuberosity on the ander side of the basal part of the molar bone, just exterior to the position of the second molar of Are

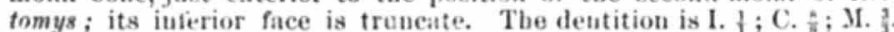
The incisors are rather small for the size of the skull, and much as it Arctomys. The inner face is truncate, the outer continuous with the anterior by the lack of separatiug angle. The thin enamel is extended part way on the outer face. At in point twice as far in front of the pre maxillo-maxillary suture as the latte is from the line of the zygema, the incisors are widely separated from each other, whence they are uot probably in contact when they issue from the premaxillary bones. The mandibular cutters are less widely separated by a narrow prolongation of the symplaysis. The exposure of the tooth is lateral, its direction nearly anterior. It projects asteriorly very little beyond the symphysis, and has a horizontal trituratiug surface below the level of the latter. There are alveolas for but three molar teeth, each wh the latter. The teeth themselves are not contained in them, but wree roots. lost before the craninom was entoubed in the boene mere apparently :ion of the tirst molar is oceupied by spongy boce int. The posi.

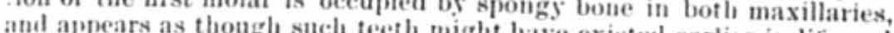
heet shed. the th sted. The prerygond lamina are prolonged, inclosing a trough. The foramen orale is well developed and simple, and bounded trongh. and before by a ridge. There are no additional foramina in this region The space for the otie bulla is moderately large; the basieranint axis is

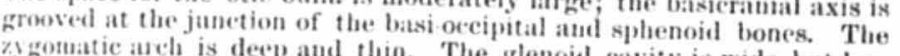
pitudimial. The glenoid cavity is wide but lon. gitulinal. The cast of the brain inclicates smooth oval hemispheres wheh leave the cerebellum and olfactory lobes entirely exposed. The lafter are ovoid and expatuded laterally. This genus is allied to, if not antually a member of, the sciurida. The hroadth and alled to, if not form reminds one of Arctomys, but the contraction behind the orbits is very ditherent, resembling rather the form of Fiber. The lateral separa. tion of the incisors, superior and inferior, is a marked peculiatity.

$$
\text { Psetmotomes maxs, Cope. }
$$

$$
\text { Loc. cit. }
$$

The enamel of the superior incisors is not groved, but has a delicate striate seulpture. The inferior incisor cloes not project as far as the alveolar border of the jaw ; its surface worn by the upper incisor is hor. izontal and anterior. The inferior diastema is a thin edge, and hos ramus is deep there. The temporal surfice of the pred and the

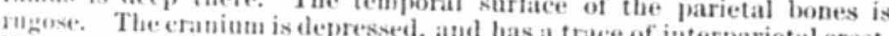
The anterior marein of the temporal foss is trencer interparietal erest. ou anterior marpin of the temporal fossa is marked by a curved anglo on each sile of the frontal bone. The supra orbital arch is very short

$$
\text { Measurements. }
$$

Wngth craninn, ( $3 \% \mathrm{~s}$ in $)$

Wilth cratum, (withont $2 y$ goma

Wilt cratuitum,

With of meciput ................

Width ipjer cutting tooth

Depth upjer entting tonth

Length esposed part lower tooth.

Wilith expomed part lower tooth.

From the Bad Lands of Cottonwoorl Creek.

$$
\begin{aligned}
& \text { M A RS U PI A I I A. } \\
& \text { TRIACODON, Marsh. }
\end{aligned}
$$

Aner. Journ, Bei. Arta, 1rit, July.

This genus is placed here on the authority of Marsh.

Trucodon aculeatus, Cope.

Proceed. Amer. Philos. Soc., 1872, p. 460, (July 29.) Establisbed on two teeth of the molar and premolar series. The mo-
lar is subtriangular at the base of the crown, one side being convex; 
the oppo-ite angle nearly right and the two remaining sides flat. The crown is divided into three elevated trihedral cones, one at each angle Their adjacent angles are acute, and the angle of union is fissured like the same point in the sectional tooth of carnicora. The smaller lobes are of equal elevatiou, but the crown of one is expanded so as to be slightly spade-shaped. The enamel is smooth.

\section{Measurements.}

Flevation of highest cusp. Elevation of shiottet

Lang diabeter base of crowt

long diameter base of that side.

The premolar is smaller, with sherter atswis ant one of the reduced to a rudiment. This species is near $T$. fallar of Marsh, but the tooth he descuibes is narrower in proportion to its length, and has the auterior lobe little over half as high. The measurenaents of this species are somewhat larger than those gion by Marsh for his $T$. gradis, (Amer. Jouru. Sei. Arts, Angust 13, 18:2.

$$
\begin{aligned}
& \text { IF I'T TIA. } \\
& \text { cRucomil. } \\
& \text { cliocontles } \\
& \text { Croconules ctavis, Cope. }
\end{aligned}
$$

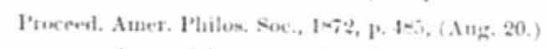

This is a large species, with a muzzle of narrowed proporions, and sufficient depth to give it a broad oval section. The masal bones appear to have reached the nasal orifice. The anterior superior teeth are very large, especially the canine. The inferior tooth correspondiug is large, and oceupies an emargination which approaches near to the uaxal suture. The pitting of the muzzle is fine, and the swollen interspates much the wider. The teeth have stont conic crowns, with well-ilerel. oped cutting edges, and coarse striate sculpture. The mandible is acuminate to the narrow extremity, and has a long symphysis, which extends to opposite the third tooth behind the noteh. The cersieal vertebra preserved have round cups; they have a simple elongate hypopophysis, with a pit behiud it; shoulder very prominent.

\section{Jeasurements.}

Length of ratuns, with tecth.

Nebith of symbyxis.

Width of ramns at end of nymbivats.

Width of ramis at rid of mataliblis.

Width of maxilary at third tonth a
Width of maxillary at notel aleove. and Leidy, aud is of larger size.

Crocodilts ellototil, Leidy.

Geological survey Montana, 1-71, p. 366.

Abundant in the Bad sands.

Crocodiles sulcipents, Cope.

Procedings American Philosophical Society, 1072, p. 565, (October 12.)

A medium-sized species with cranium deeply and roughly pitted. The chief character is at present visible in the teeth. The larger of these are of subcyliadric and short conic crown, which is superficially grooved from basis to near apex; sulci coarse, open.

Upuer Green River.

\section{Crocontles gianselut, Marah.}

American Jourual Sci. Aits, 1-z1, June.

Cranium from South Bitter Creck.

Croconlles Lrobox, Marsh.

From various localities.

$$
\text { Loc. ait. }
$$

DIPLOCYNODE'S, Pomel.

DHeoryonts stmedtes, Coge

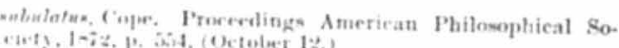

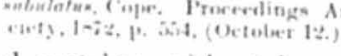

Some of the cervical vertebra without hypopophyses. Their cups remul, whth smooth lordering surface of the sides of the centrnm: The jaws only are preselved from the canium; the premaxillary is strongly pittet, but the dentary has renote shallow pits on the outer face and shallow grooves below. lent of shallow pits on the outer

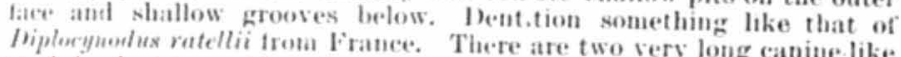
teeth in the premaxillary bome near its posterior bargin directed some what batkward; these are preceded atter a space by a medium sized tooth, which affer a similar spate is preceded by another large tooth. Anterior to this the anceli are lant. Two rery smooth cornpressed straight teeth in the front of the ramus mandibuli. These are followed abruptly by a distantly set series of sulwequal teeth of not one-fonrth the size, varyimg little to the back of the law : all the long teeti bave stheompressed crowns with oplosed rutting edges, amb are smooth except at their hases. These ate distantly suleate, the separating

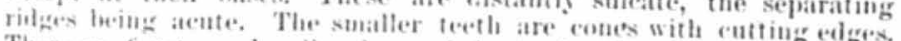
There are fouteen alveroli and one pit in the dentary bone from the pos. terior end to the begimumg of the shert symphysis.

$$
\text { Heaxurenents. }
$$

1ength of alveolar keries to lectititing of xymphysis....

Dianeter alvolus of nevetuth temoth....

Giestation eighth teot

Chatueter at lase

13. pth of d ntary at base

Elevation of first lower canim.

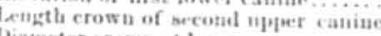

phatieter crown at bas.

Giameter of exvical, (with ball)

Piameter of cup, vertical

i.ngth of a posterior donsal.

Diatueter of cup, transwerno

Diameter of cup, vertical.

Found on the bluffs of Upper Green River.

This species agrees in some respects with the very brief lescription giveu by Marsh for bis Crocodilus liodon. He does not mention the flutiug of the base of the crown so remarkable in this species; and 
states the vertebre to be "strongly rugose" near the extremity, a character not seen in the present animal. The Diplocynodus subulatus was about as large as the Mississippi
alligator.

$$
\text { Dirlocy sodes polyodox, Cope. }
$$

Species nova.

lepresented by portious of eranium and teeth, with probably some vertebra foumb close to them. This crocodile is similar in size to the 1). xubulatus, or our alligator. It diflers uuch from the last in the rangement of the teeth. There is one pre conineutly large canine oppo. site the symplysis, (in $I$ ). xubuintus this tooth is opposite the posterior eut of the same., which is followed by nine very small teeth, whose round alveoli are only separated by very thin walls. Following the last of these immediately is another very latge tooth, with nearly round alveolus, which is closely succeedecl by other smaller tweth of larwer size than those in frout of it, and not diftering in this resecet anger

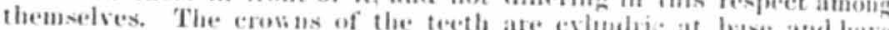
a double ridge on the anterior onter aspect. The enanel is obsoletely rugose, striate at the base. The external surface of the dentary bone is deeply and coarsely pitted: at its anterior part the pits are close, deeps. and suall; on the inferior face they are deep, short grooses. There is a series of close, suall toramina alumg the inter side of the alscolate

\section{Measurements.}

Wepth of aymplayis.

Diatueter anterior canitie twoith

Distance of natme from niralian

Wepth destary botse at batter........ teetl anteries differs in many respects from the one last described. The teeth, anteriorly, are much more closely placed, and the anterior and middle canines are less separated, and more mumerous small teeth oceung. the interval. The splenial bone has a larerer shame in the symphsas, and

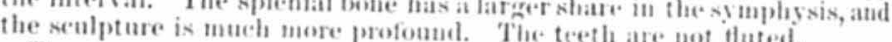

The type specinen was found on the blutts of Lper Green kis er by the writer.

\section{AILIGITOR, Cuv}

The species deseribed below belongs to this genus so fat as determin able from characters of the cromium and dermal scouta.

The axial portion of the basi-oceipital bome is a trauscerse vertical blate with vertical cainat on the distal half. The trontal bone exhibit no crests, and the erotaphice foramina are opera. The quadratojugal arch is stout. The dermal seuta are not coessitied, and with the cranium are decply pitted.

Arlititor hatriodox, cope.

Pocecelings Atmericau Philonophical Society, 1772, p. 544

The anterior and posterior teeth of this species differ exceediugly in shape; the former are flattened, sharp-edged, and slightly incurved the edges not serrate. Those of the premaxillary boue are subequal in

size, while one behind the middle of the maxillary is larger than the rest. The posterior teeth have short, very obtuse crowns, with elliptic fore aud aft outhe. They resemble some forms seen in Pycuodont fishes, and are elnsely striate to a line on the anex. The upper surtace of the cra nimu is pitted, the frontal and parietal bones with large, deep, and chasely placed concavities. The former is perfectly plame, and the latter iv wide. The sigumosal arch is also wide, and the crotoplate foramiua ate latge and open.

The termal seuta are very large for the size of the animal, and were not united by suture. They are heelless aud deeply pitted, with smooth margins.

The vertebral centra found with other specimens are ronnd. The co ossitied neural areles indicate the adult age of the animal.

$$
\text { Measurements. }
$$

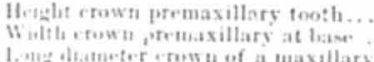

1.-9h shatueter crow of a maxillary

Wiltit: varietal

Winth iroutal, ponterior.

Widilo froutal, intererlat

The variation in the form of the teeth is a slipht exayereration of that reen in the dentition of varions species of a socerlitiaus.

This species was about three feet in lewgth, found by the writer in one of the lowest beds of the Giten River Tertiary epoch, near Black Buttes, II youmg.

The derimal seuta of this species are very abundant in some of the

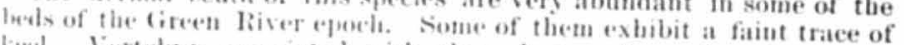
fiecl. Vertebra associated with them have subround articular ex. toenities.

\section{TESTEDI I A T}

\section{AxEstes, Cope.}

I'rewad. Amer, Philus bociety. 1072, 1. 462. (Published July 29.)

This is a genus of Trionychida, which is represented by a species not fully kown. The type specimen is represented by bones of the limbs and larions vertebra, with the postabilominal bone of the left side.

The general characters ate those of Trionyx. The seapula is elongate, the precoracoid loug and narrow, and the coracobl of nediam widt The humetus is sigmoid, with widely spreading bicipital ridges and flat tened extremity with marginal groose. The femur is aloo carsed, but lews strongly than the humpros, aroote. The femur is also carved, but lidge. The clas the hmm.rus, and has a median anterior low angular The. The datis atle lar, sone curved and some entirely straght. The cervical veltebra are s latively large and elongate. The two sacrals are free trom the carapece above, have broad articular surfaces for diapophyses, and flattener centra. The caudals are procotian, and bave short diapoplyses. The postabiominal bone has somentate have seen in existing Triony. It presents two dentate processes forward
for the hyosternal, and two inward to its mate in front. It is pro. longed backward and inward into a fiat process. It is especially prolonged backward and inward into a fiat process. It is especially dis. tinguished by its tenuity, and the entire absence of the superficial sculpture of Trionyx. The usual dense layer 18 present, but is quite 


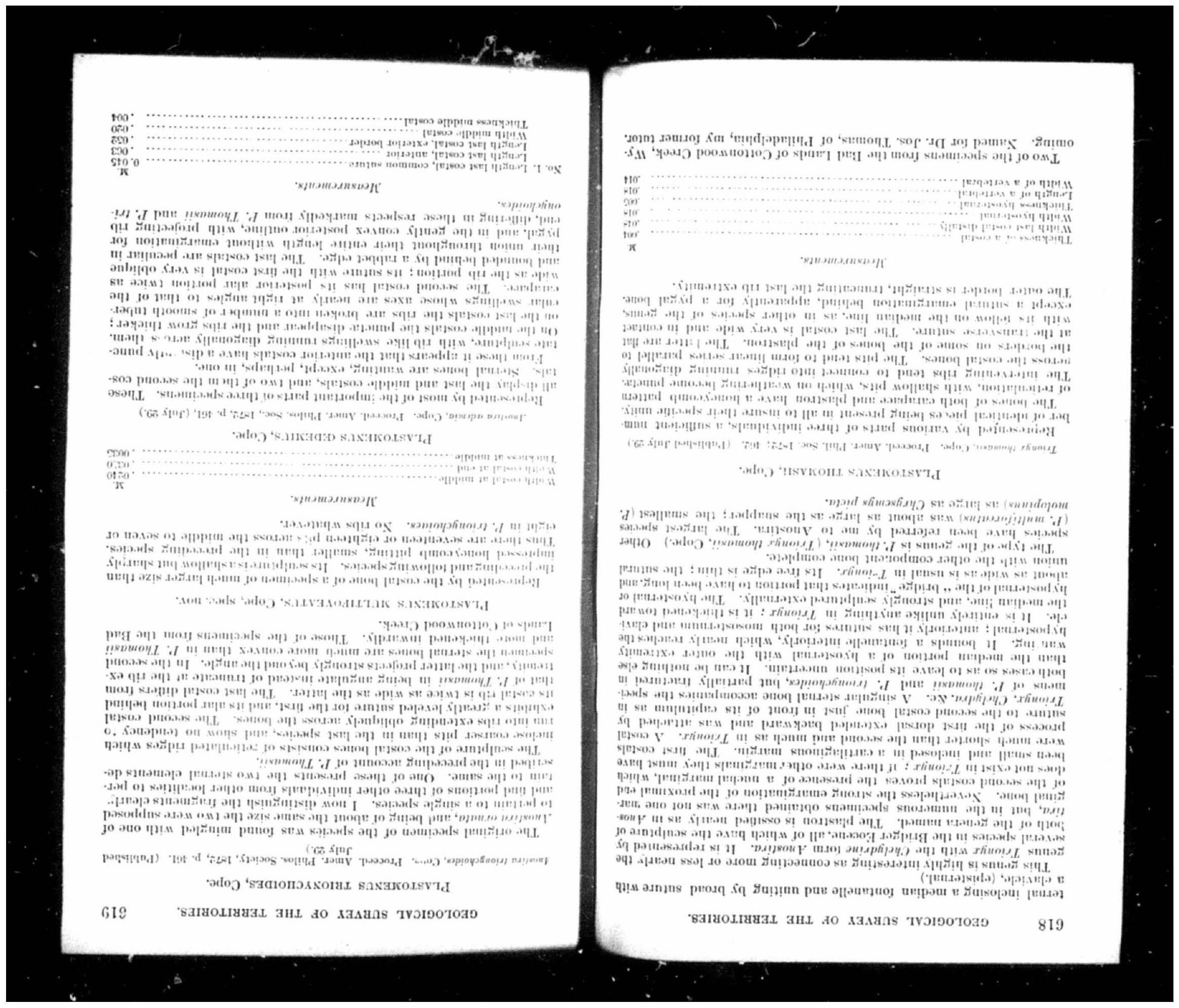


No. 2. Wilth first costal, proximally

No. 3. Width tirst cosfat lie-hind nib, distally

Two of the specime

$$
\text { P'LASTOMEYI'S }
$$

P'lastomext's yolopisus, Cope.

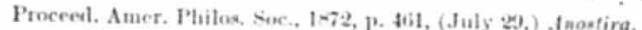

First costal bone with wide rib, the aliform border behind it not more than half its wilth. Suture for tirst costal distal, obliguely tautation end of rib. vertical and not oblique. External surface of the coarsely pitted, and with obseure oblique ribs. Median costals with

This strecies is wear fine

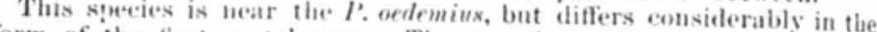
form of the first costal oone. The type is smaller than those of the
latter.

$$
\text { Heasurements. }
$$

Wilth tirst costal at extremity.......

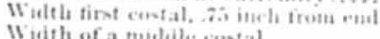

Whith of a mintili. contal

From the Bridger group, Wyoming.

A.sostilid, Ixidy.

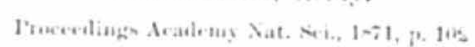

In this genus the ephletmis was thin and allerent to the bones, and not disider: into senta, The earapace is composed as in Eimydider of costal vertebral and margitual loones, the last nuited to the first hy antere

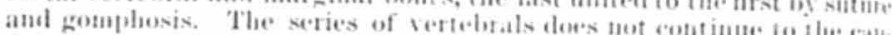
dal, except by the intervention of a pyal. The stermam is cruciform,

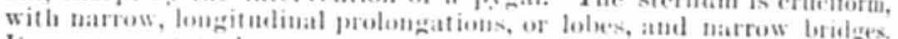
It appears not to have pesseserif atay fontanelles, but the presences of

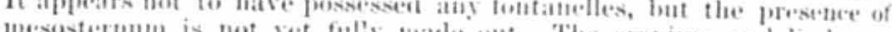
mesostertum is not yet fully mate out. T'le cratum and limbs ate unkaown. This gemus nast ine regarded as an intelestumg intermediate type, connecting Plastomenus and Chelyelra, or Ilermatemys, In shin and sculptue it is blenteal with the first; in earapace and plastrot, most like Chelydru.

Two species, a large atud a small, are known.

$$
\text { Axostma ranthas, Cope. }
$$

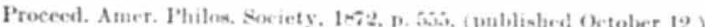

Based on two marginal bones, one from the front, the other from the

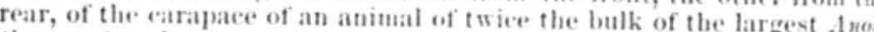
tire yet found. Apart froh size, the senlpture is peculiar. it esos in the anterior of elosely packed vermicular ridges which rum ont that on the posterior and upper ealge. In the posterior it consists of only closely placed minute tubercles over the whole surface.

\section{Measurements.}

Length front on free edge Wength posterior on free edge..

Bad Lands of Ham's Fork, Wyoming.

\section{Anostira orsata, Leidy.}

Loc, cit.

From Bad Lands of Upper Green River and Cottonwood Creek.

$$
\text { BAFNA, Leidy. }
$$

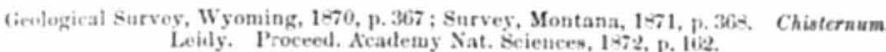

Family Bacnida agreeing with the Adocida $\boldsymbol{*}^{\bullet}$ in the presence of inter grthar se inta, and the absence of coössification of the ischium and pubis with the plastron, but differing in the presence of an intersternal bone on eath side, as in the Pleurodira. As generic characters, it possesses two marginal intergular plates, which resemble the gulars of Emydida; it has a veries of intermarginal seuta, and the free lobes of the sternum are harrowed and shortened; the bridge is very witle. The dermal sutat arevery where listinct. The mesosternal bone is in form between T shaped and sagittate. The last pair of marginals, iustead of being in contact, are separated by a wide emargination.

The atlinities of this genus are complex and interesting. It wond be a plenrerlire, but for the fact that the pelvis is not coursitied sith the Jistron: nevertheless there are rudiments of this union in the form of a shallow pit on each. The posterior or ? ischialic is near the posterior cul, and on the lateral margin of the postablominal bone; it is of a twonw wal form. The anterior is shallow, and sublaterally impressed into the sile of the upright septum, which supports the carapace. Whether it receised the pubis or not is uncertain.

The double istergular scuta is not found in any existing genus of Plevereliert.

The pasterior margin of the carapace is excavated, as in Chelydra, hut the margin is more arched in this position in Chisternum. The form suggests the presence of a large tail, and the serrate margin of the carapace posteriorly reminds one again of Chelyelra. There are in B. arenose fourteen marginal scuta, without the nuchal; in Chelydra serpentina, as in Emydida, but thirteen.

There are prominent asillary and inguinai septa, as in some Emydida. They are compred of the produced edges of two coüsified costal nolles.

The aftinities appear to be to Adocus on the one side, and Mydraxpidide on the other, perhaps as descembant of the former and aneestor of the latter. It also prossesses traces of other relationships of Adocus, $i, e$, to liermatemys, aud more remotely to Chelydra.

\section{Batisa mentarca, Cope.}

Bac̈n hidraica. Proceed. Amer. Philon, Society, 1872, p. 463, (published July 29.)

General form depressed and discoid, as wide as long. Bridge wider than long, but the leugth equal to the width of the bases of the sterual lobes. Anterior lobelonger than wide at the base, and narrowed at the "xtremity. Th. inguinal and axillary septa are very prominent. The elge of the carapace from the frout to the inguinal region is without ctuargination. All the osseous elements are coüssified.

The seuta are well distinguished. The unchal is very small and wider than long; the first marginal is shorter but more prominent. The second and third are larger but narrow ; the fourth and fifth are wider, but the

$$
\text { - Proceed. Amer. Ptilos. Soc., 1870, p. 547. }
$$


sixth widens by an inwari projection of its border so as to meet the in. tercostal suture between the second and third costal scuta. From this one to the uinth (as far as preserved) the inner margins are produced far as to make the scuta nearly twice s wide as long, when vient from above. The first costal is small, its posterior border is cursed The first vertebral is pyriform, trumeate in front. It is (perbaps abmor. mally) divided by a transverse suture into a quadrate anterior aud cordate transverse posterior portion. The other vertebrals are somew hat longer than broal and are separated by sutures convex anteriorly.

The intermarginal scuta are all wider than long; their number is normally four, but a narrow one is intercalated behind the inguinal on one side. The longitudiual suture of the acutes of the plastron is exceed ingly tortuons, winding between points more than an inch apart. The Fulars and intergulars are transveree and bounded by transverse sutures They ercs the median suture (which is straght on the anterior lobe some distance apart. The humerals are long and the humeropectoral scutal suture is couver backward, its extremities reaching the marein in front of the axillap. The anterior extremity of tie anterior sternal lobe has a ifuadribbate outline.

The surface is smooth except along the lines of intercostal sutures, where short grooves parallel to the general asis alternate with protu. berances having the same direction, the whole having somewhat the ap. pearance of sculptured chatacters.

\section{Veasurements.}

Length carapace (axial) (19 inchee
Width carapace (axiat) (19 iteluen

Length of plastrun from groin

Width of base anterior loine.

Nidth extrenity noterior lole (at mular-

Length of anterior lobe (at gulars)....

Width of unchal sente

angth trichal seute.

Wength thirrl marginal.

Width third marginal.

bength eighth marginal

This species, when compared with its nearest alls, C. undatum, differs in the greatly wider markinal senta; in the latter the corresponding ones (6-7-8-9) are much longer than wide, as in most other tortoises. The intermarginal seuta are of more elongate forms, and the normal number is five in $B$. undata, insteat of four. Tle sculpture in the longer known species is entirely distinet, consisting of pits and tubercles seattered generally over the surface, while the peculiar seupture of the suture lines is wanting. (. hebraicum is relatively wider.

Bad Lands of Cottouwoot Creek,

BAiNA CNDATA, Leidy.

Geological Survey, Montana, 1721, p. 360

A partially complete specimen of this species presents the following characters. The anterior lobe of the plastron is as wide as that of $B$ hebreica, but little more than half as long. The posterior lobe is trun. cate at the extremity. The nnchal scute projects beyond the first mar. ginal; the reverse is the case in the type of $B$. hebraica. The posterior sutures of the intergular and gular scuta have a common center, and that of the gular has a rectangular curvature, the neariy trausverse micdlle portion slightly convex forward. The suture separating the femoral and anal scnta is similar, but reversed in direction, presenting two obtuse right angles, two portions being transverse and one longi. tudinal on ench side.

From Black's Fork and other localities.

$$
\text { BAEXA ARENOSA, Leidy. }
$$$$
\text { Lor, cit. Bä̈na affnis, Leidy, ibid. }
$$

A perfect speciunen of smaller size than those of the preceding species, and oue about equal to the Ptychemys rugosa, is not dixsimilar in form. The carapace is strongly convex, and ail its component parts, as wel as these of the plastron, are co-ossified. The sutures of the intersternal botes are visible. The posterior end of the carapace is arched upward, mil smothly excavated; the postero-lateral borders are thin, and decply notched as the ends of the scutal sutures. Similar but shal. lower etuarginations mark the borders of the marginal scuta. The anterior margin is slightly concave. The lobes of the plastron are narrow, the posterior wider and slightly emarginate. The bridge is wide, and not more than half as long as the width of the base of the posterior lole.

The zeneral surface is minutely rugose or shagreened, on the plastron strongls so, and without other sculpture. The carapace is marked by strong zinoves disposen! in a regular manner. A double groove extends alons the median line of the secend, third, and fourth vertebral seuta. Other grooves are nearly parallel to this one, whose extremities di verese to the angles of the vertebral scuta. At the anterior angles of the costal scula oblique grooves converge toward the vertebrals, and are continued backward as parallel to the median line. They are separated by parallel tuberosities. On the first and last vertebral seuta there are transverse grooves next the aljacent vertebrals, and longitudinal ones toward the margins of the carapace.

The scuta are well marked. The marginals are all longer than wide, except the four preceding the last, which are all wider than long. The last is suboval, and is very small, while the anal is altogether wanting. The muchal is divided, (it is single in $B$. hebraica;) the first marsinal is very small and projecting; the third is longer, while the fourth, fifti. and sixth are rather short. The vertebral scuta are all louger than wide, and the fourth is deeply emarginate to receive the last scute. The first is a broat triangle with anterior angle truncate, and the two basal ones cut off to a less degree.

The sutal sutures of the plastron are but little sinnons. The intergulars hase precisely the form of gulars of Eimydes. The pesterior gular siture croxes the median line a short distance posterior to those of the intergulars, and each half consints of an obtuse $\mathrm{V}$ directed backward. The posterior huneral suture originates in front of the axills. There are four intermarginal scuta on the one side and three on the other, the arditional one being a stuall one behind the left axillary. The femoro anal suture is uearly straight.

Measurements.

Wength of carapace, (axial)

Wenth of carapace, (

length of plastron

Lengtb of posterior

Width of extremity anterior lobe 
Wiutt of extremity postesior lole

lebs th of unchal scuta.

1. Wutth of thiril marzinal . .

Witith of thitd marginal

Width of fourth marginal

Length of fourth matginal.

Width of cinlath matrinal

This species diflers in many details fro.a the preceding species, nota. bly in the form of the marginals. The anterior are wider than in either species, while the median are narrow as in $C$. undetume The seenter is very distinet from that of either.

From th. Bat Lands of Ham's Fork, Wyoming.

$$
\text { Baliva roxdrasa, Cope, sp. nov. }
$$

Established on numerous fragments of a specimen of a species which I cannot reter to this genus with rertainty, but which agrees with the speejes abeady known in some particulars of structure. Thus the last marginal plates wete separated by an exeavation of the posterior border; at least this is the only position to which I can refer al portion the earapace where the enareinal seutes sishlenty eertion the lateral rabs of the bridge are received into a deep pit between tro contals.

The unrginal and other lones are very massive, much more so that in any other kinewn water-tortoise of this formation. The margins the former are thickened. especially at the last marginal sente, which s ou in massive photulerance. The sutures are entively reare, which

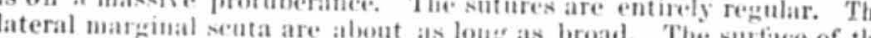
(1) postegses a median rib sim. lar to that in Dermatemys rymuinge uxix.

$$
\text { Measurements. }
$$

Wength of an anterior marginal sent.

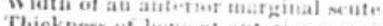

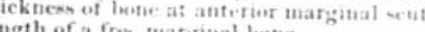

Width of a free matrinal loon

Length of tirst marpianal of bridg.

From the Bad Lands of Ham's Fork, Wyoming.

$$
\text { DEMMATEMYS, Gray. }
$$

$$
\text { Baptemys, Leiity, for, cit. }
$$

This genus is similar to Euys in the structure of the carapace and plastron, except that the lobes of the latter are narrower and shorter. The senta are similar, excepting that there is a series of intermarginals on the bridze on each side. There are thirteen marginals on each side, those of the last pair in contact throughout. In a specimen of the onls species known, I find a trace of an intergular scute as is sometimes seet in $D$. berardii, now living in Mexico.

Dermatemys wromingensis, Leidy.

From various localities. 
of the middle front. The posterior lobe is somewhat flared and bas a wide beveled margin, and is deeply notehed behind, the notch being close and the lobes projectiug.

The surface is delieately sculptured with obsolete ridged lines across the axis of the costal boues. The vertebral region is somewhat swollen

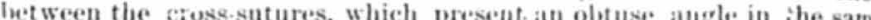

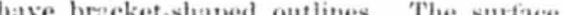
eridgex which diverge in every direction from the median inlooking angle of one end, but are mostly longitudinal.

In old specimens this delicate seulnture might become obsolete.

\section{Heasurements.}

Lestigth of plastron

Wiilth of, at groin.

With $\operatorname{lip}$

Wenth lip

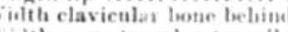

Whath externally

The knes byenternal terliall

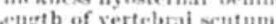

Wifth of vertebral acetum

Wilth of a cestal leotie

Thiekness of a cortal botic

Found in the Bad Lands of Sonth Bitter Cresk by the writer.

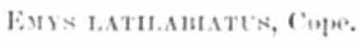

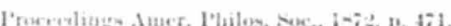

Represented by a perticet mpecimen of a tostoise of a broadly oval form, and someshat tertestria! habit. Its prominent characters are to lu. seen in the plastron, of which the pestertior lobe is deeply bitureate. The anterior lobe is peculate in the numstat walth of the lip-like pro

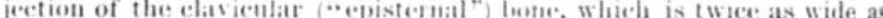
ii) E. ryomingensix, and not prominent. bones all smooth; margins of lobes of plastron thickened.

There are three scars, perhaps of muscular insertions near the poste vior margin of the phastron, one oval one opprosite to each lobe, and one found one opposite te the noteh.

As eompared with E. septariux this species bas no snch septa nor sentpture: the ematrgination of the plastron is more open, and the lip sauch shorter and wider.

$$
\text { Mensurements. }
$$

Length of carapace.

Widtu of carapace

Witht of lip of plastron

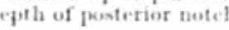

From near Black's liork of (ireen liver.

Ems wromixgexsis, Leidy.

Abundant in the Jiridger formation.

$$
\text { Euys gravis, Cope. }
$$

Notomorpha graris and X. garmanii, Copke, Proceed. Amer. Philns, Roe., 1972, p. 476, 477.

The preceding names were used to designate what were supposed to represent different species, which were stated to differ in the form of the episternal bone. This difference appears with further observation " be less important than was supposed.

This species is known by portions of severa: specimens. The type is "1f Fet than any of the last described, and equaleil some of the che idh of the orean in dimensions. The right hyosternal bone indicates Indh resemblance and diflerence from the $N$. textudinca. The former is aen in the internal thickening parallel to the margin, bounded behind ly a decp groove extending to the axilla. A peculiarity, in which it difters from the N.testudinen, is seen in the posterior position of the lumero-pectoral dermal suture, which originates at the axilla the rphlovesternat suture is concave. The thickencel pertion of the efinter

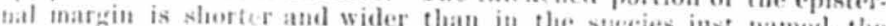

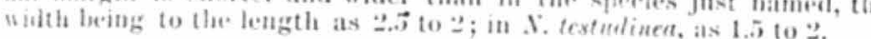

\section{Measurements.}

Whicknes of hyosternal anteriotly.

Surfaces not seulptured.

From Giren River strata, near Evanston, Wyoming.

$$
\text { Eus thatudnets, Cope. }
$$

$$
\text { Notonarerpha teotudinra, Cope, lec rit., p. } 425 .
$$

laepresented by portions of four wr more individuals. In one of these materior lolre of the plastron is in part preserved. The mesostem

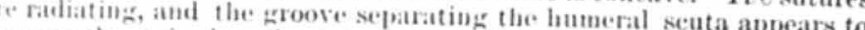

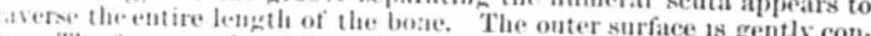
x. The free marsin of the epistermal aud hyter surface is gently conind with an internal thickening, as in Cistuilo. Testudo, bones is acute,

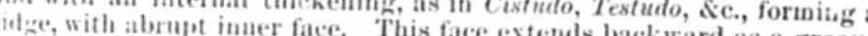
the wither face. This for Uthenth prosess of the hyoste Arongh the extremity of the episternal bouc is lost, and the mexo. crabl rabits no trace of the intergular seute, the onter sutures of the mlar senta ate se fir posterior as to reuder it highly probable that the interzular plate esinted. marmin the las suture reaches the fum posterior suture of the ences the margin half way between the axilla aud the photernal suture, and is not marked by a noteh. The last womed suture transverse. On the xiphisternal bones the groose the anterion and of the anals is planly visible. It is regularly conses forwari,

In a second speciment of alont the same size parts of two costal bones re preserved. They are thick, and display the usmal cestal aul bones mal seute-sutures, the latter oue in a rroove, for the andhe of the vertrobals is elevated, and the costals project shoulder-like just outside
the groove. lit a third specimen, a little larger, xiphisternals with several margi-
nals are preserved. A free posterior marginal is regularly recursed, and the scnte-sutures are deeply impressed. The marginal recurred, vidently heestines are deeply fmpressed. The marginat seuta have The first margina

In none of the specimens are the surfaces sculpturel. 


\section{Measurements.}

No. 1.

Width plastron at axilla

Length plastron from axilla. (apjoximate.

Thicknes hyosternal at mesosterual

Thickness hyostern

Width meessterial

Thicknes of a vertebral.

Thicknes of siphisternal. (in

Thicknese of xiphisternal at pubst...

M.

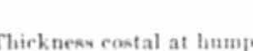

Width of contal.

............

No. 3.

Widith of posterior marpinal.

latug th of posterior margina

The mesosternat, though found with No. 1, does not fit it exactly and does not helong to it.

From Green liver formation near Evanston, Wyoming.

\section{EMYs etTusets's, Cope, sp. nov.}

Represented by numerous portions of several specimens. These per tained to a species of about the size of the salt-water terrapiu, Malo coclenmys palustrix, There is no dorsal leed, and the seatal sutures though distinct, are not very much impresed, nor the interspaces swol. len. The lip of the plastron is narrow, thick, and not notehed; the sutures of the gular seales do not extend on to the menosternum. The margins of the lobes of the plastron are a little thickened and the $\mathrm{sp}$ tures of the bones coarse, and at the hypoxiphisternal junction, \&c. with gomphosis. (It is fine and close at this point in E. testudineus.)

The costal sutures for the bridge are projecting and curved in one position; in the other straighter, and very near the margin of the cos. tal bone. Surfices smooth.

Alundant in the red beds which lie between those of the Green Rivet and Bridger epochs at Black Buttes, Wyoming.

$$
\text { Ems MEgatlax, Gope, s, . nov. }
$$

Tupresented by remains of two specimens. They pertained to a spet ies of about the size of that last described. The mated peculiarity consists in the broad and abruptly sumben sutures which separate the co nsists in the broad aud abruptly sunhen sutures which separate the
cermal scuta of the carapace. This is visible on vertebral, costal, and marginal bones, where the area between the sutures are abruptly separated. The sutures partialiy interrupt the dorsal earina. This is wide and low. The sculpture is otherwise smooth. The scutal suturs are not so impressed on the plastron, and those of the gular scutes ex leid on the mesosternal bone.

Measurements.

Length of a marginal

Wilth of a marginat.

Length of a vertebral $x$

.016

The vertebrals are subquadrate in form. Neither carapace nor plas. tron is thick. The mesosternal is transverse, diamond-shaped, and an. gular in front.

\section{Mcasurements.}

Wength
Width

From the Green River beds at Black Buttes. A third but uncharac teristic series of fragments, from the first lignite-bed above the Cretaceous, probably belong to this species.

$$
\text { Emys pacrylomus, Cope, sp. nov. }
$$

Established on fragmentary sp. cimens of a spmeies similar in size to the last. The principal differenc is to be seen in the scutal sutures, wheh, thongh strongly marked, are sot so widely and deeply impresede Though they are fine, they interrupt the dorsal carima, which swells up from it, and divides the that proximal portion from the much swolle marginal part of the marginal bones. The mesosterual bone is similar in form to that of the last species; the only specimen is obtusely rounder In front, and bears part of the gular senta.

From Gireen River beds, near Black Buttes.

\section{EMYs terrestris, Cope.}

Talizotheca terrestris, Cope. Procecd. Amer. Philow. Soc., 1872, p. 464

In this sprecies, and the following, the lip only is inclosed by the gular wuta, which only reach the apex of the mesosternal. In neither are the articulations of the bridge with the costals known. Represented by three individuals, one of which may be regarded as the type. They are il thinner than the E. polycyphus, aud larger, being about equal to the I romochelys odoratus of our povds.

In the type specimen the carina of the vertebral bones is interrupted by a deep sutural groove, which is less pit-like than the $E$. polycyphus. The bone itself is broader than long, being, perhaps, from the polycyphus. of the carapace. The clavicular (episternal) bone is preserved. It is characterized by the consideralie and abrupt projection of that is inclosed by the gulat sentum, which resembles projection of that part In in Testudo. The edge of this part is entire and acute. The posterior part of the projection forms a stap-like prominence behind, on the supetior or inner face. The bone is almost as wide as long, and the mexosternal causes a very slight medium truneation, but overlapped much

\section{Measurements.}

1/ngth vertebral bone

Width vertebral boue

1. usth epinternal.

Wittl epintertual,
Widt th of a costal

Thickness proximally

In the second specimen, a strong groove is seen to bound the lip of the front lobe of the plastron, as in the species of Notomorpha. In it the marginal is seen to be stont, a little recurvel, and sharp.eiged. A vertebral differs from those descrioed in being longer than wide. In a third individual, the gular lip is not so prominent as in the type, and the me. 
sosternal bone truneates the clavicular exteusively, giving it thus a more dongate form. The gular senta expands to its front marpin. The mar. -inal bone is stout and sharpeclged, and is not so deeply impressed by the dermal suture as in $P$. polycypha.

$$
\text { EMYs POLYCYPHe, Cope. }
$$

Palerothena polycypha, Cope. Ptroceed. Atner. Philos, Soc., 1-72, p. 463.

This species of tortoixe is indieated by vertebral, costal, and margin:al bones of very small individuals. These bones are, however, not only thoroughly ossified, but are very stont, indieating the andult age of the animal. The deeply-impressed sental sutures, and heavy proportions as well as the elevated carina of the earapace, iudieate affinity wit

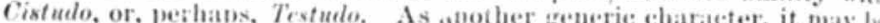
noted that the vertebral bones are subquadrate asd support the neural canal without interveniug laminas.

The carina of the carapice is abruptly interrupted eecasionally ; some times witl, sometimes without, a patr of pits, one on each side. The marginal bones are well reeurved, aud the seutal sutures are deeply in pressed on them.

Heasurements.

1...ngth of vertehral lone

Lerngth of margital trota.

This is the least of the tertoises of the Bridger formation.

\section{IIADRIANUS, Cope.}

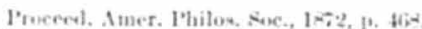

This genus resembles Text do in form, but has two anal senta, as it most Emydide. The claws ar, short aud stont; an ungual phalange is a long oval vieweel from above, and is oval in section, with obtuse edges. The articular surface is subinferior. A cervical vertebra is of moderate length, and has a very prominent anterior zygapophysis. The centrum presents two distinct convex articular surfaces anteriorly, aud one trans. verse one behind. A sacral is free from the carapace above; it presents two subround articular cups posteriorly and outwardly; the anterior are broken off. These characters are observed in a large specimen of H. Corsonii.

\section{Hadranes alzamiatus, Cope.}

I'rocted. Amer. I'hilos, suc., 1n'? p. 471.

This large land-tortoise is nearer in general form to the $H$. corsonii than to the H. octonarius, but diflers frem both in the absence of the projecting lip of the anterior lobe of the plastron, which is thus simply truncate. The mesosternum is not cordate, but has much the shape of that of $H$. corsonii, that is, rhombic. The seutal sutures are deeply impressed. The plastron is strongly concave. Carapace without irreg ularities of the surface. Length is inches.

From the Bad Lauds of Cottonwood Creek, Wyoming.

\section{Hadrianug octonaries, Cope.}

Proceed. Amer. Philos. Soc., 1872, p. 468.

The $H$. octonarius is distinguished from its cougener in many mars It is of elongate form, strongly contracted at the bridges, but expanded and arched above the limbs. The carapace in quite convex. The plas. tron bas the posterior lobe emarginate rather than bifureate, as seen in II. Corsonii. Each projection represents a right-angled triangle rather than a wedge. The anterior lobe presents an elongate lip, which is expanded, and slightly emarginate at the end. The mesosternal bone is heart-shaped, the posterior emargination being wide and deep.

The anterior margit of the carapace is somewhat flared above the limbs. The nuchal sentum is very narrow transversely, but elougate. The carapace descends and is incurved in the mildle of the posterior margin.

\section{Metsurements.}

Wenthth, (be-low)

Width at hind limbir.

This species differs from the $/ 1$. Corsonii in many imporiant points. It s. perhaps, the largest of our extinet land fortoises, and is founded on a beautifully perfect specin. Irom the blufts of Cottonwood Creek.

\section{Habraxts Comsosur, leidy.}

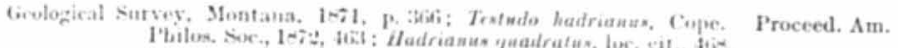

Indicated by many individuals, two nearly perfect, another chiefly represented by a complete plastron. This proves the existence of very massive species of the terrestrial genus Testudo. The plastron presents a short wide lip in front, wheh is turned outward forming stroug angle with the plane of the muturned frout of the lobe. This

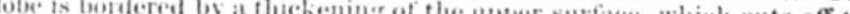
bifureat", The posterior lobe is deeply bifurcate, each postabiominal projecting as a triangle. There is a notch at the outer augle of the femoral viute. The hyposternal bone is greatly thickenes within the margin above, and an clevated ridge bounds the basin of the plastron behind, as before. The middle of the plastron is thiti.

The carapace is without marked keel or serratious. It is remarkable for its expanded and truneate anterior outline, which is nearly straight

length carapace, $4.750= \pm 9$ inches; willth, .630. The marginal senta are narrow, and there is a large nuchal plate.

Abundant in the Bridger beds.

$$
\begin{gathered}
\text { L A C E IR T I L I A. } \\
\text { NAOCEPIIALUS, Cople. } \\
\text { Proced. Aner. Philos, Soe, 1 1 72, p. 46r, (Juls } 29 .)
\end{gathered}
$$

Establisherl on an incomplete craninm, with vertebra: found associated. No teeth are preserved, nor any part of the mathlible. The remaining portions of the cranium are, however, highly characteristic.

The occipital descends posteriorly, and bears a pair of lateral ridges, which converge rapidly posteriorly. This boue is united with the pirie. tal by suture, which is transverse; its outline is rectangular, so ass al. most to reach the frontals, which are prolonged rectangular, so as al. the parietal, leaving but a narrow exposure of the backward on each side the parietal. These extend backward, and are broken off processes of men, but they probably formed parts of arches. 
and there is no parietal fontanelle. The bone is triangular in outline with the apex anterior, dividing the frontals. These are contracted at the orbits, and have a projecting supercilliary head; anteriorly they an thickened. The postfrontals are of remarkable form. They are nas sive, and, compressed from before backward, they rise considerably above the level of the front, and beur on their snminits a cotyloid cably, which is trunsverve to the axis of the eranium; the use of this prity, wion is obsure of this projec tion is obscure. There is an exoccipital foramen, and a large one in the posterior part of the frontal opposite the postfrontal elevation.

The sphenoid is a compressed keel-shaped bone, rounded below, and with broad ala along much of its length. The oceipital condyle is sub. condate, depressed in outline, with a vertical obtuse angle in the middle, and the silles somewhat plane.

A dorsal vertebra preserved has a single vertical capitular process, and a short hypopophysis. The neural canal is large, and the neura pophyses are attached by sutures. The cup is nearly round, very slightly transwetse, and vertical.

This genus differs from Glyptoxaurus, Marsh, in the total lack of eranial shields, and from Sanira, Leidy, in the nearly round vertebral centra

$$
\text { Naockphales ponktets, Cope. }
$$

$$
\text { Loc. cil., P. 465. }
$$

The cranium is smooth above, except the anterior part of the frontals which are finely ragose.

$$
\text { Measurements. }
$$

Wintth craninm at post frontal.

Width parietal be-biut.

Depth post frutats

Depth presphroid anteriorly

From the Bad Lands of Cottonwood Creek.

SANIVA, Leidy.

Geolog. Survey, Wgoming, 1970, p. 3id

Saxiva Exsidexs, Leidy. Loc, cit.

Vertebra, \&e, from Black's Fork. The charactersagree with those of Igvanavu, Marsh, except in the greater depression of the vertebral wentra.

THINosaUlivs, Marsh.

American Journ. Sci. and Arts, October, 1872.

Tumosavies l.Fptodus, Marsh.

A considerabie number of remains from Mammoth Buttes (Bitter Creek) agree nearly with Marsh's description, l. e.

$$
\text { OPHIDIA. }
$$

Protagras lacustris, Cope.

$$
\text { Proceed. Amer. Pbilos. Soc., 1872, p. 471, August } 7 .
$$

A serpent of abont the size of the existing pine snake, (Pityophis melanolencus,) and allied to the water-snakes of Tropidonotus and allied benera.
A vertebra before me has the longitu.linal bypopophysial keel of that gronp, which terminates in a very obtuse point. The ball looks exten sively upward. The uppe. articular extremity of the parapophysis is short and obtase, and the inferior equally so, and directed shortly down. ward, their articular faces being continuous with each other. an obtuse latero-inferior keel backward, which terminates in front of the ball. The angle connecting the diapophysis and zygapophyses is strong, while the former was narrow; in the specimens it is broken.

Measurements.

I.ength of ceatrum with ball. (below)

Hilevation before, (total)

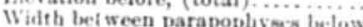

Wilth of articular cup...

1hpth of articular cup ...

Depth of inferior keel.

From the Bad Lands of Cottonwood Creek.
This species is allied to the Botrus of Marsh.

\section{EATRACHIA}

The vertebral column and part of the cranium of a prohably incom. pletely developed tailless Batrachian were procured by Dr. F. V. Ilayden, from the fish-shales of the Gifeen liver epoch, froin wear Green liver City, Wyoming. They are not sufficiently eharacteristic toenable me to determine the relation of the sinecies to huown forms a enable the oldest of the order yet discovered, the fussil remains of and it is

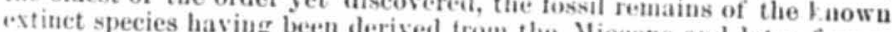
tions.

\section{P I S C E .}

\section{CLASTES, Cope.}

Order Ginglymodi : Mandibular ramus without or with reduce fissure of the dental foramen, and without the groove continuous with it in Ifpidesteus. One series of large teeth, with small ones extrior to them in the dentary bone, the inner superior aspect of that bone with out prominent dentiferous or rugose rib.

The species of this genus resemble in many ways the Lepidostci of the present day. Their scales are rhombic and pierced by a duct on the lateral line. The cranial bones are distrubuted variously accordiug to the species tubereles of ganoine, istributed variously accordiug to the species. Some of these fishes crached a large size, exceeding any now lising; others resembled the

The cilostci in this respect.

The characters assigned to this genus are derived from the unde.

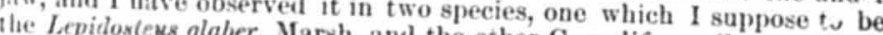
the Lepidosiens glaber, Marsh, and the other C. cycliferus, Cope.

$$
\text { Clastes anax, Cope, spec. nov. }
$$

Represented by some cranial bones, and especially by a posttemporal, - which indicate a very large species of gar, two or three times as large as the alligator.gar of the Mississippi, (Atractosteus ferox.) The bone has a free ovate posterior outline, and its superior surface is covered 
with a thick layer of dense bone, which bas not the brilliant surface of ganoine. This substunce is thrown into elevated corrugated ridaex which are generally transverse to the long axis of the bone, and inosen. late and are interrupted frequently. The spaces between are as wide as the bases of the ridges.

$$
\text { Mcasurements. }
$$

Wilth of botw

thiekness of linit.

Found in the liat lants of Han's Fotk.

$$
\text { Clasti:s atrox, laidy. }
$$

$$
\text { Lepidontems atrox, Leidly. Proceral. Acaul. Nat. Sei., Philaula., 1mi3. }
$$

Abumdant, and represented by both rough and smooth seales, the former from the anterior part of the body.

\section{Chastracichimes, Cope.}

Established on mumerons remains of a small species, in which the seales are rather wide, and generally with obtuse extremital angles, and freguently in certan regions of the boly cutirely roumded at the pos terior border. Fragments of the cranial bones are ornamented pas sattered tubercles of ganoine of rounded form, and not distributed in lines, as in some species. In a fragment from the posterior part of ihe mandible there is a single row of large terth, with a series of minute ones between them, on the outer edge of the bone. The external face presents a smooth superior sufface, and a rugose inferior portion which is marked by irregular lines of points of ganoine.

\section{Measurements.}

Depth of dentary be, we.

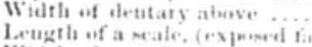

Wirith of a rale, (evpresi fia

From Mammoth Buttes.

$$
\text { Clagtes glamen, Marsh. }
$$

Abundant.

$$
\text { Lepidoster, glaher, Marmb. I'rocecul. Acad. Nat. Sci., } 18 \% .
$$

\section{PAPPICHTHYS, Cone.}

Gen. nos. Halecomorphorum.

Family Amidide: Vertebrie short, the dorsal with prominent dia pophysis; the sides of the centrum striate-grooved. Yaxillary bone with a supplenentary bone on its distal upper bonder, and supporting a single series of teetls. Dentary bone with but one series of teeth; surface of cranial bones sculptured.

This genus difiers from the existing $A$ mia, in the presence of only one series of teeth, instead of several, on the bones about the mouth. The posterior part of tue dentary bone, or perbaps another element, is cor. ered with tine graniform teeth, as in Amia calra.

ered with tine graniform teeth, as in Amia calra.
Species of the gcnus are numerously represented in the beds of the Briager Eocene. Some of them bave been referred to A mia by Marsu.

\section{Pappichtirs plicatus, Cope, spec. nov.}

Established on a series of bones of the skull and vertebre. The cranial lones are deeply grooved, and with parallel ridges between. The out: face of the dentary is roughly grooved on the inferior balf of its posterior two-thirds. The inner face is marked by a strong groove near its midille to the symphysis, above which it is very convex; below it extends 10 : thin edge. The dental alveoli are shallow aud in close contact; there are six in, $025^{\mathrm{m}}$ at its millule, where it is also 019 deep. The teeth the. come smaller at the symplysix. The maxillary bone is roulike groxi. mally, but flattens out mnch distally, and is there slightly rugose on the outer face. The teeth are smaller than the mandibulars, there bevis at the midille fourteen in .025". The alveoli are larger proximally. The depth of : \& bone at the beginning of the suture for the supplementars maxillary is $.090^{\mathrm{m}}$. The sujerior extreanity of the byomandibular is broad and that. The inferior quadrate is thickened hehind, and has at sublongitudinal condyle distally. The squamosal suture of the ptery goid atjoins it.

Sumint cranial ridges at $.010^{\mathrm{m}}$, 10. The vertebro preserved are quite short, and have sessile diaprophyses; they are broader than deep.

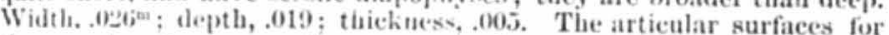
the nemral arehes are confluent, so as to have a subquadsate outline.

Another spreimen is represented by numerons fragments. One of these is the proximal half of the os maxillare. This exfmemity rises in a curv, is monewhat deprissed, and is exeavated below. The inner time is very conves, the outer flatter and with squamosal suture for premas illary externat to the extremity a half ineh. $A$ fragment of the palatin. exhibits a series of large marginal teeth and a plate of smaller oues within them, thus resembling $A$ inia ; the superior face exhibits a cleep longitudinal groove, which opens out posteriorly. The proütic bone is at half disk, thickened on the staight edge, and with concave sides, with a flat tuberosity on one of then. On some of the cranial bones the riclges are interrupted. The dorsal vertebra of this specimen have the centra broader than deep, and with projecting diapophyses. The neural ar. ticular faces are for its own areh and that of the next vertebra, and then are two narrow grooves on the inferior fice. They are nearly or quite distinet. As this is observed on vertehtat with elongate diajophyses, and they are confluent, or one is wanting on those with sessile diapongy ses, it is probable that the position of the neural arehes is shiffed on the dorsals, an arch being confined to a single centrum on the posterior ones, as ocenrs ou the caudals only in A mit calra.

The specimens came from distinct localities on Cottonwood Creek.

\section{PAPpicntuYs sclenops, Cope, sp. nov.}

Established on a ramus of the mandible of one, and other similar specimens of other individuals. These indicate a large fish, equal in size to the alligator gar of the Mississippi. The dentary bous is more compressed and deeper than in $P$. plicatus. The longitudinal groove runs above the midale line, and the portion of the bone below it thins to an edge. The upper portion is thickened, and the alveolur border is wide and bounded by an angle on the inner side. The alveri are large and shallow; in .025 searcely three find place. Near the symphysis is a smaller ove, which is separated by a considerable

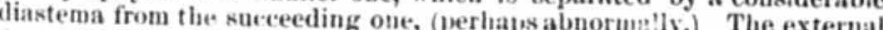
face of the bone is rough aud sometwhat tubercular. 
Measurements.

Depth dentary at symphysis...

Depth dentary at middle.

Depth dentary at eleventh tootl.

PAPpichtiYs L.evis, Cope, spec. nov.

Represented by varions fragments including dentary and vertebral bones. The former differs from that of the species jurt teseribed in the smaller size of its teeth, there being six in a space occupied by but four in it, at a point where the dentaries of equal depth. In other words, there are four in $.0250^{\mathrm{ta}}$. The alveolar faces are also much more oblique, being in fact continuous with the inuer face of the bone. The external face of the dentary is smooth, and thus different from that of $P$. sclerops. A dorsid vertebra is but little wivler than deep, and is the

\section{Measurements.}

Depth of dentary near middle.

Thickness of dentary near middile

Depth centrum of vertebra...

Wilth centrum of vertebra.....

From the bluffs of Cottonwood Creek.

PAPPICHTHYs sysirsis, Cope, species nova.

Established on a number of vertebra of an individual of much smaller size than any of the preceling, and which was about the size of the largest growth of A. calra. The form of the dorsal centra is a litte wider than deep; the caudal deeper than wide. What distinguishes these from the vertebra of the species above described is the lack of "iistinction between the articular facets of the adjacent neurapophyses. These are almost conf .ent, instead of uearly or quite isolated as in the P. lavis and P. plicatus.

\section{Measurements.}

L/ nuth of centrum, dorsal

Wepth of ce'trum, donal.

With of $c$ atrum, dornal.

Pr.pth cen.rum, candal.

Widh ceritrum, candal

The dorsals of the above specimen have short diapophrses and might be regarded as posterior, and the anterior miglit be anticipated to present a different type of artieulation with the neurapophyses as in $P$. pli. catus. But a vertebra of the same size and form, but with long diapophyses, from another locality, (Upper Green River,) presents the same sulquadrate articular faces sliohtly constricted in the midalle- Henee 1 suspect this character to be characteristic of the suecies.

PAppichthys consosir, Cope, spec. nov.

This species is, perhaps, rather smaller than the last. A dorsal restebra with inferior diapophyses is but little wider than deep. The

- Desicated to Dr. Joseph Corson, formerly stationed at Fort Bridger, to whota 1 aa under many obligations, professional and otherwise. articular surfaces for the neurapophyses are 8-shaped, the area confluent. A marked peculiarity is seon in the dentary bone. It is much curved in the vertical plane as well as in the horizontal, and must have inclosed a wide mouth. The groove is median, and the inferior and superior surfaces reach it by a nearly equal slope. The former leaves the alveoli without horizontal border, though the latter themselves open on a hori. zontal plane. There are four and a fraction in $.010^{\mathrm{m}}$

Measurements.

Depth of ratnas at mieldle...

Thicktiess of ramus at middile.

Letagth posterier doral vertebia

Depth tosterior deral vertebria..

Wilth posterior dorsal vertebra

From Upper Green River.

\section{PHAREODON, Leidy.}

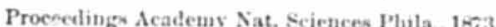

This genus belongs to the order of Nematognathi, as I discovered by varions specimens in my possexsion.

The usual modification of the anterior vertebre exists in this genus. The mass is carinate below, and bears two longitudinal carities sepa. rated by a low partition above. The palatine bones support a mass of teetl, there being one exterual series of large ones rather abruptly pointed, and several series of small ones of little elevation, whose size diminshes invard. The dentary bone is narrow and deep wose size diminshes inward. The dentary bone is narrow and deep and supports a single series of elosely placed sleuder teeth, which together form a comb. The bases of these teeth are rugose-striate, and the apices abruptly acuminate.

The vertebre are short, and with reticulate ridges on the sides. There is a pit on each side, and there are two pits on each of the sides above and below. The vertebra apjears to be a caudal, and the connate hemapophysis issnes from between the lateral and inferior pits and has a round pit at its base.

The remains of spines are of rather small size, and are strongly striate and weakly sermate. The pectoral had the hinge arrangement of hineastex.

The single series of long conic teeth in the dentary bone is a peculiar feature, shared by few if any recent genera.

Pharfodon acutus, Leidy.

Represented by numerous remains. The teeth as preserved are black, with white, translucent, slightly incurved apices. The deutary bones are deep, incurved, and with an erect elevated point at the symphysis; their outer surface is rugose, with deep longitudinal grooves and pits of irreg.
ular sizes.

\section{Measurements.}

Depth destary at sympluysis M.

Depth dentary at fourfeenth tooth

1xugth of eiglith tooth.

Dianteler of right tooth at base.

Diatueter of a caudal vertebra.

Letgith of a caudal vertebra

Frotn Upper Green River. 
Phareodon serickes, Cope, spec. nov.

Established on three teeth which differ from those of the $P$. acutus in

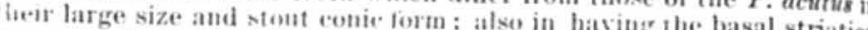

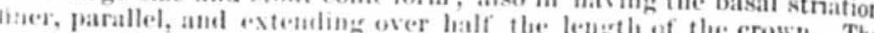

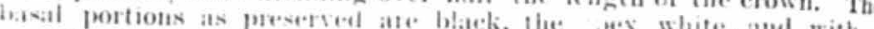
mistitly abrupt contratien.

$$
\text { He.tanirmentx. }
$$

1. Anth of crown.

butever of crowit at bia

Nin. 1. No. 2. Ne., 3

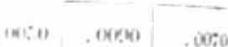

Fiom Upper Giren River.

RHIXk.ISTE, Cope.

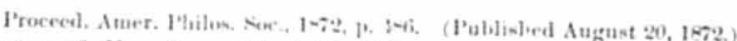

A genus of Nematergnathi which tifters from Plareodon in possessing the Ustait bant of bristle like tereth on the dentary bone, the serim treing numerons, (in $R$. calrus.) The basi-oecipital boue exhibits a pit on the mishlle line below, and a surface for attachment for the inferiog branch of the postemupral on each side, $(K$. calrus, $K$, smithii $)$ The masditied anterior vertebsal mass ix deeply

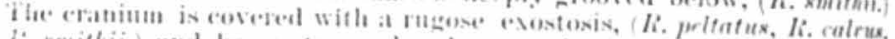
h. smithii.) and has a strong elosed groese in the position of the usual loutoparietal fontanelle. The vertetora (lit the position of the usual vides of the centra only striate with the (

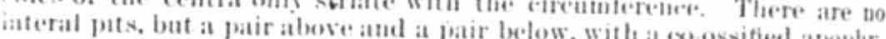
sis at the batse of one of then.

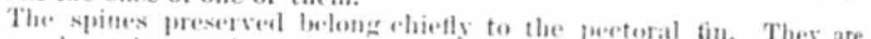
strongly striate and weatly dentate. and have the usmal himge with

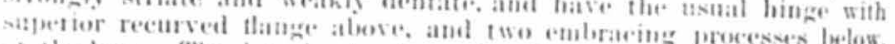
at the base. The dorsal spine is weatier in $k$. calcus, but strong in $k$.

This genus is alliegl to the recent lehthaturus, but diflors ( $k$. smithii) is yelturtux the sunt in

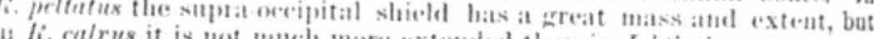

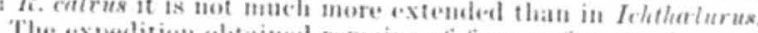

The expedition obtaimel remains of fonr or tise species of this genus, the first of the oader foumd extinet in this comutry.

. Liheastes; a latre, matsive muehal shichal.

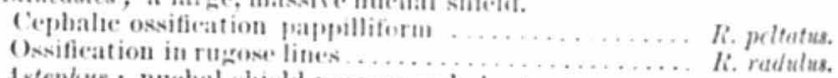

11. Astephus ; nuchal shicld narrow atul short.

Cephalie ossification in suesth lines ; one basi-eccipital

pit ; fretoral spines rerrate on both edges

Thire basi-occipital pits; pectoral spines serrate o.

both edges

Pectoral spines serrate behind only curved . . . . calrus.

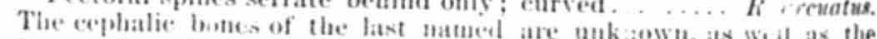
spitie's of li, radulus.
GFOLOGICAL SURVEY OF THE TERRITORIES.

\section{Rhiveastes peltates, Cope.}

Procect. Aner. 1'tilum, Sinc, $1072,4=4$;

Vistablished os cranial and other bones, with spines of a siluriform tish of the size of the largest species of Amiurus. The form in the exansise rugosity of the external long surfaces reminds one of some of the Brazilian Dorudex. The frontal fontanelle is elosed, though very dis. tituctly marked by a groove of the surface not rugose. The rukosity consists of innumerable, packed osseous papillat. The cranial ossiticd tion is continued posteriorly as a shield, which is strongly convex from sule to side. The spine is symmetrical, and probably dorsal. It is com. presed and curved antero-posteriorly, and is decply grooved behind. Laterally it is elosely striate-grooved ; the asterior face is marrowed, whtuse, and minutely serrate with cross ridges: each side of it is rugose,

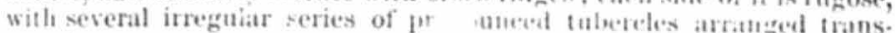
versely.

$$
\text { Measurruents. }
$$

Wisth frontal lone near fromt of font:anel1].

Thithines at do

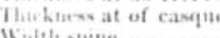

With thine

From South Bitter Creek.

linseastras nabteve, Cope, spee. nov.

liepresented by numerons broken cranial lowes, which present a pattean of exostosis quite distinet from that observed in ot her speceses. This consists of elosely plated erenate ricises, which rabliate from various points and are sometimes broken up, but alway songh or serrate on the

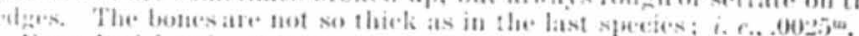

From Lial Latuds of Cottonwood crieck.

$$
\text { Rnimistas smtun, Сope. }
$$

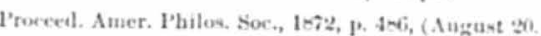

lepresented by remains of several individuals, including one with vertelere, basi oceipital, opereular, and other cranial bones with spines. Ther indicate a fish of the size of the large cat fishes of the Ohio bines. The pectoral spines are quite compressed and distinctly striate-grooved on ihe sides. The posterior groove is ocenpied by short, spaced, recurved teeth; the anterior by an areate edge boutuded by a groove on each side. which has a fine, close serration. The surface of the modificl vertebral Inas is striate ridged ; that of the lasi exeipital still more strongly ridged. There is a median pit behind, and the points of attachment of the in tiner limb of the posttemporal is in front of it, smooth, and withon ieserted edges. The opereulnm has a large, compressed, sessilecul wout

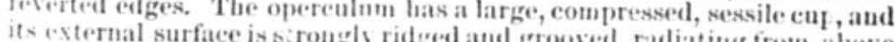
its cxternal surface is sirongly ridged and grooved, radiating from above in fient.

\section{Measurements.}

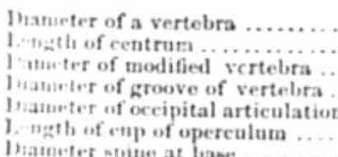

Bhanieter of a vertebra

1. "isth of centrum

Thater of modified vcrtebra

Muthirint of groove of vertelifa

hilaw ter of occipital articulation

Hath of ctip of operculam

bisucter mpate at 004 from baso 
Another pectoral spine is larger; diameter at base, .010 .

From the Mammoth Buttes and Laclede, on South Bitter Creek.•

\section{RHineastes calvus, Cope, sp. nov.}

Represented by numerous specimens, including most parts of the cra. nium, spines, de.

One of these shows the supra occipital production to have the form of an equilateral triangle, with a sums of the posterior border on each side of it which advances in front of the epiotic bone below. Shortly in front of this point the deep groove representing the fontanelle com. mences. The cranial rugat are lines paraliel to the fontanelle, which diverge to the marzins of the occipital prolongation, and are frequently connected by cross-rulges. The frontal portion of the skull is mech expanded laterally, and the part beneath inelosed by the prefrontals particularly wide. The fontanelle in this region does not appear to have been entirely elosed. The surface is here also strongly rugose. The vomer has a T-shaped anterior extremity, which is immediately followed by two transverse parallelogrammic patehes of premaxillary brush-teeth in several rows. They are about twice as long as wide and in contact medially. The antetior margin of the prenaxilla projects their length beyond them, and is perfectly smooth and has a smooth rounded border. The basi-oceipital has a subcordate cotylus. In front of the median inferior pit are three groove-pits; the articular fare for the posttemporal is opposite the former, and is rugose and has strongly reverted edires.

\section{Measurements.}

Diameter occipital articulation

Diameter baso supra-oceiputal shichl

Wiatheter base nupra-oceput
Width front alove orbits

Length frotn vomer to premaxillary torrler

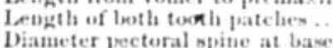

The pectoral spine is serrate on both edges. The base of the dersal is symmetrical and articulates with its interneural bone by two latera! flat and one convex median anterior condyles, whose surfaces an curiously rugose. The interneural has a rugose median superior keel, which terminates in a point which is received into a pit of the base of the spine; there is a similar prodnction on the posterior side for a simi. lar purpose. The basis of the spine proper is stualler than that of the pectoral, and is about as wide as deep.

In a number of tragments of another individual, found together, the basi-occipital has the characters already described. The dentary bou is curved inward, and is acute below, widening rogularly to the alveolar border. There is no groove on the intuer face, while the outer is striategrooved and has a series of pits along its lower middle.

\section{Measurements.}

Diameter uccipital articulation Width alveolar face

Depth of ramus at midile

- Named for my respected frient Daniel B. Smith, of Germantown, many yeass prin. cipal of Havefforl College, aud a student and lover of natural sciences.
A part of the operculum of a third indisidual (with similar spines) displays great rugosity and elevated radiating ridges; length of articu-
lar cup, M. .0065.

The specimens are chiefly from the Bad Lands of the Upper Green
River.

\section{RHineastes arcuatus. Cope, spee. nov.}

There are numerous spines about the size of those of the last species, wuich differ in the want of the fine serrated anterior edge. I select one as the type, which belouged to the pectoral fin of the right I select one unbroken, and is curved from base to apex. The ratier is ac. It is ath oblique posterior taucation. The apex. The latter is acute by the teeth of the posterior edge are closely sat; is strongly striate, and tally, the distal proximally. In the proximal point dis. anteror serration; in many speciuns specimen there is a trace of surfaces of the epiclavicular aud exacoul striate, as is the case in all the specoies bones are strongly rugose. charatetistie froguent is that aprectes of this genus, and the most of the pectoral spine.
of that portion of the seapular arch at the base

Levgth of npisic on curve

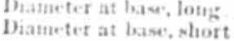

The recurved plate of the base is rugose, as in other eat-fishes. The pines aper Gren liver.

The spitues are less compressed than in $k$. calcux.

$$
\text { TIRICHOPHANES. Cope. }
$$$$
\text { Proceed. Atuer. Philos. Soc., 1 -72, p. } 4 \text { s. }
$$

Alied to Erisuatopterus, Cope, and to the family of Cyprinodontider. lorsal and anal thes short, each with a long and short strifons ray ou the anterior margin. Ventrals beneath the dorsal. Opereulum with a longi.

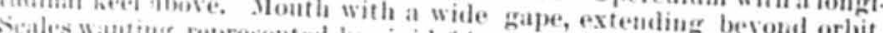
impertant chatraters of the by rid fringes or hair iike bolies. Several the slesimeil described. This is ase not very distinctly displayed by neion. The premaxillar. This is especially the case with the maxillary areale of the month. but whether avidently forms a large part of the ruce of twath and number of brathes is not certain. The pres.

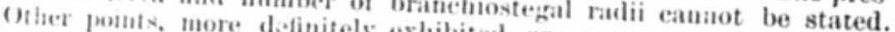
serrations, directed are a preopereulum withous width a mate a inte

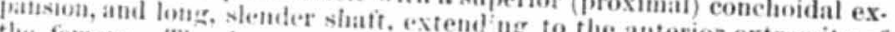
the femora. The latter are quite sleugr the anterior extremity of and groeved to the apex, but slender and acuminate anteriorly. p.rent any marleod postes, aplarently not furcate. They do not Caudal fin furcate. tin; those of the anterior rags ver spines wanting in front of clorsal

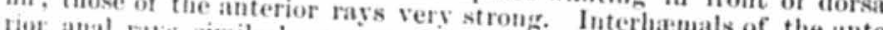
aul sul rays similarly strong. Caudal fin embroeing ouf the ante and supported by separated hamal spines separate Tricophanes from Erismatopterus ane The characters which and short muzzle and in the peculiar are seen in the large mouth former character it resem the peculiar covering of the body. In the

$$
41 \mathrm{Gs} \text { s }
$$


is not seen in any genus. The bristle-like bodies are scattered over the whole extent of the fish, excepting the head and the fins, and are arranged in little aggregations, which are irregularly disposed. The processes themselves lie irregularly together, as though free from each other, and are evidently not the impressions of keels of the seales. Traces of other seales are not visible, and the bodies described would suggest the existence of an ossitied ctenoid fringe on a less fully calsi. fied seale, or possibly without such basis.

\section{Trichorhases Haxs. Cope.}

$$
\text { Loc, cit., too. }
$$

Vertebra, D., 9; C.. 1.5; six between interneural spine of dorsal and interhamal of anal tin. Radii, D. II, (?) 6 , (soft rays somewhat injured ; A. II, 7 ; V. and P. net all presersed; caudal rays numerous, forming a deeply bifucate fin. The ventrals reach a little over half way to the anal, and the latter about half way from its basis to that of the candal fin. The dorsal fin, laid backward, reaches the line of the base of the first anal ray. The first dorsal ray is a little nearer the end of the muz zle than the origin of the eaudal tin. The muzzle is very obtuse, and, if the spereimen be not distorted, not longer than the diameter of the orbit. The gape extends at least to the posterior line of the or bit. The subor. bital region is deep posteriorly. In its present somewhat distorted condition, the specimen measures in-

Total length

Heal.

Candal tin

Leogth tlersal spit

Length anal wpine

ength hair-like berlie

From the paper coal of ('sino, Nevada.

AMYox. Cope, Gen. Nor, Catostomidarum.

$$
\text { Iroceed. Aurt. Philos. Soc. 1872, p. 4-0. }
$$

Allied to Bubalichthys. Dorsal fin elongate, with a few fuleral spines in frout, and the iuterior jointed rays osseons for a considerable part of the length; a few short osseous rays at front of anal fin; scales cycloid; caudal fin emargmate; mouth rather large; terminal.

The characters of this genus appear $t$, be those of the Catostomida. There are three broul branchiostegals. The vertebre are short, and the bama spines on the caudal fin are distinct and rather narrow. In one specimen a pharyugeal bone is completely preserved. Not having it before me at the moment, I merely observe that it is slender, and with elongate iuferior limb. The teeth are arranged comb-like, are truncate, ani ummler absut thirty to forty. This and other portions of the structure will be more fully deseribed when the whole series of spe cimens is investigated. The bones bordering the mouth above are little displaced, and the lower jaw projects beyond them, and is directed obliquely upward. The dentary bone is slender and toothlese, and the angular is distinct. The premaxillary appears to extend beneath the whole length of the maxillary. Should this feature be substantiated, it will indieate a resemblance to Cyprinida. The maxillary has a high expansion of its superior margin, aud then contracts toward its extrem. ity. Above it two bones descend steeply from above, which may be ont
of position. The preoperculum is not serrate The "sell developed. This form approaches, in its. The superior ribs are Cyprinida through Bubalichthys. It is the firsterior mouth, the true chimile found in this country.

$$
\begin{aligned}
& \text { Amyon sentale. Cope. } \\
& \text { Loe cit., p. } 481 .
\end{aligned}
$$

This tish occurs in considerable numbers in the Osino Shales, and mumerons specimens have been procured. Two only of these are beiore the at present; they are of nearly similar length, viz, M. O. .12 and 105. The most elevated portion of the dorsal ontline is immediately in front of the dorsal fin. From this point the bods contine immediately is the caudal fin. The dorsal fin is long, and is elevated in regularly concave in outline, the last rays long, and is elevated in front and ons-lalf the length of the fin in frout of quite short. They terminate vines are stout in front and went of the candal fin. The interneural There are a thent tront and weak behind. Radii, III. 26, and (t) II spine ant the about twenty-three vertehre between the first internenral spine and the end of the series in the former specimen, in which, also, there are no distinct remains of seales. In the second, in which, also, wow bo trace of lateral. There are six or seven lougitudinal wrs above the vertebral colnmn. The anu fin is presen Fongitudinal hamazeif; the rays are not very long, and hu is preserved, somewhat Therpanded into a keel anteriorly; vento The anterio The ribs and supplementaries are well develog; ventral fins injured. rate is a broal bone, with deep emargination fored. The inferior quad. .9. 2 in front of dorsal fin, y

From the paper-coal of Osino, Nevadath basis of dorsal, .026.

OF WATE FAUNA OF THE EOCENE

$$
\begin{array}{r}
\text { OF WYOMING. } \\
\text { OF }
\end{array}
$$

The number of species above recorded, as obtained by the expedition, is as follows:

$$
\text { MAMMALA, (45.) }
$$

Quadrumana

Carnivora

P'roboscidia

Perixsolatictyla

Redentia

Marsupialia

Incertie sedis

Incerta sedis

AVEs, (3.)

Species.

Crocodilia

Testudinata

Latcertilia.

Ophulia.
3 
BATВACHIA, (1.)

Incertie sedis

PISCLS, (26.)

Ginglymodi

Haleconorphi.

Nematoguathi.

Plectospomisli

Isospondyli

Percesoces.

Total number vertebratia

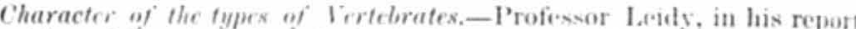

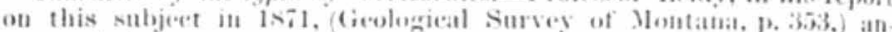

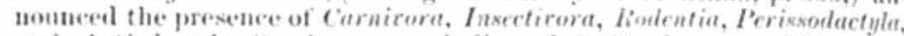
and Artimletyla Omuirorn, concluding that Quetrumead, Chiroptero.

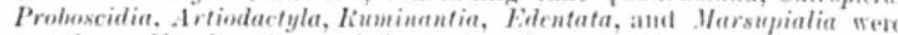
wantiug. He also observed the entire absence of horses. The result of the survey of the present year confirm these statements as to the

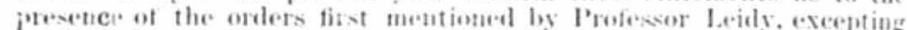

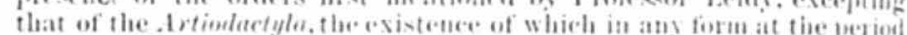

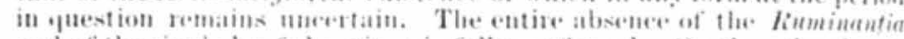

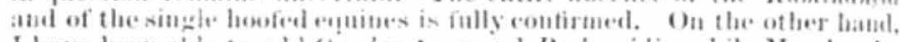

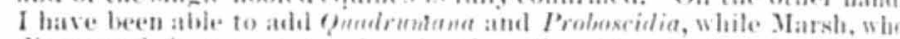

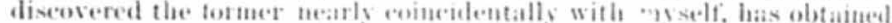

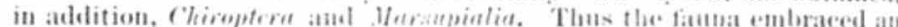
extensive series of types of Vammalia, whose chatacters it will be well to flance at in revien.

Of the quatrumana nete are typiest forms, and all are mueh more gen. cralized than the existing tamilies. of the six carnirora, two, at least are fiar from recent fortus, and combine important teatues now found

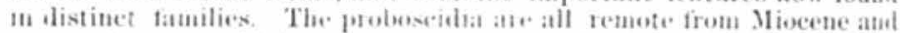
recent forms, combining features of perisorlactsles, of the periso dactyles, sis species (Hyrachyex) pertain to a persistent type, which still

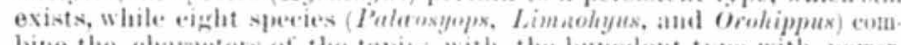
bine the chatacters of the tapiss with the butodont type with power. ful canime teeth, from which alse the artiendactslat omnivora sprong The genera marbed "Ineertae sedis" are all or mearly all genemelized forms, having athuties to the gromp in guestion. The rodentia, so far as known, appear to be more or less similar to living types. Of the forty five speeres of Manmatia enumerated, at least twenty eight may be regardet as generalized in a high degree, while not a few others will probably le foumi to present the same peeuliarity within a lesser range of variation.

The ordinal charaeters of the Reptilia are well defined. and there is uothine known among Crocorlilie remat bably distinct from these e.xist ing at the present time. The same may probably be said of the Lacen tilia and ophidia, though their genera ate not so well known. It is in the tortoises that we have evidence of generalized forms again, which only relate, it is to be nowed, to the subdivisions of the order, and not, as in the Mammalia, to other orders. Of the thirty two species, ten be. long to typieal forms now existing, and nine (Triony,r, Dermatemys, ant Hadriunus) to forms which exist or closely resemble existiug genera, but which are somewhat mixed in character. Thirteen represent gevera (Bicna, Anostira, Plastomenus, Axesius) which are extinct and general ised in character, the tirst three in an especial manner, as has been pointed out.

The orilers of the fishes are equally well distinguished, and so far as known, the types differ only in minor respects from those at present in habiting North . Imerican waters. Generalized types are unkasent incepting, perhajs, in the very highest division. (Erismatopterus, Asine ops.

As a result of this and other palieontological investigations conducted larpely in North Anerica, aud substantiated by those in other countries, the priols of establishument of the existing order of things in the his

tory of the vertebrata, may be stated as follows:

The reent orders of tishes were in existence in the Cretaceons period. and probably earlier. Their period of evolution was in the Devonian. ami perhaps in the Carboniferous preriods. The existung orilers of reptiles were all established in the locene; the period of oriters of repthe three Mesozoic ages, especially the Trias. The ordersof birds were inclsate in the Cretaceous, but when they were fully differentiated is

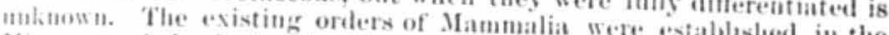

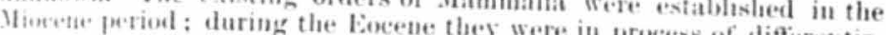
tou and were less or seareely distinctly detimed.

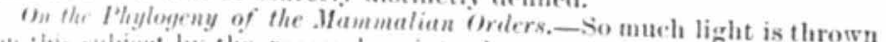
on the sulgect by the researedes inte the structure of the fossil yow Inatha of the Eocene formation, that it reems opeture of the fossil Mam. to fis subject I deem it deusut it sems opportune to call attention mith the care the for the same as with the reptiles of the Thats, i. e., that the family types are all mote generalized, aud the ofdits thot hearly so widely distmguished as in hater periods of the

The sucession of later forms which has terminated in the horke, has

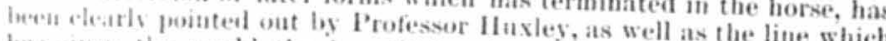
has given the world the beautiful haxley, as well as the lite which

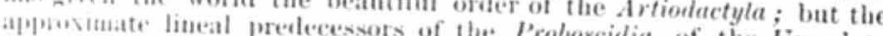
apponstuate lneal preclecessors of the Proboseidia, of the Ungulate atmols as is whole, of the Guedrumane, (including man,) and of the "isterar, have not been clearly pointedi ont.

The Helaus Eolusileus has been shown to be a Proboscidian which combines some important features of the Perissodacty Proboscidian which

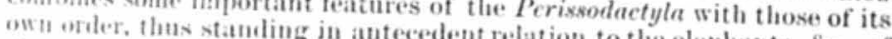

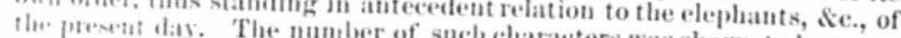
at fore number of such chatracters was shown to be some. chat inerasedi in buthmolon, which therefore stands still ne rer to the common pont of departure of the two orders. This point is to be found III : pes marer the clawed orders, (Unguiculata,) in the unmber of their higits, (4-i, ) and in which the transverse and lougitudinamber of their molar teeth are broken oy into tubereles more logitudinal crests of the Whe of dentition being derived aceors more or less connected, either pamint tration being derived accordiug as such tubercles are ex. pamed transversely or longitudinally. We have several genera which answer this description so far as the teeth are concerned, but unforImatedy the digits are unknown; such are Oligotomus, Orotheriun, The tvpe of Tomitherium, Lemurine monkegs and such seady described, evidently stands between tuhercue France Frauce, The dentition of the two types is indeed but little different in the Quadrumanons and Ungulate types respectively, being a continu. - On the short-footed Uuguhata of Wyouing, page 3. 
ous series of I. 2 or 3 ; C. 1, P. M. 3-4; M. 3; the canines but moderately developed.

A comparison with Vasun reveals no distant aftinity. As above re. marked, the fore limb presented a freat similarity in this genus and Tomitherium. The teeth, thongh less mumerons, in the molar series hav the cutting type anterior and tuberenlar posterior, in both gencris. Notharctus, Leidy, resem les Vusun still more than does Tomitherium,

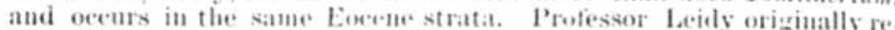
garded it as a Carnisore, and subserflently (Ilavden's Survey Montana,

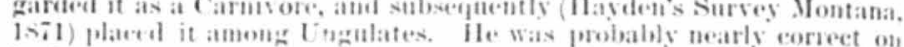
both oceasions, and that ouly a techuieal hose will ultimately decide. whether it be not a monker.

But the zenus which aserelates more definitely the orders Carnirore

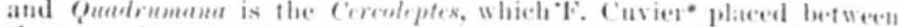
the two. Its two contine premolars and three true molas with the on

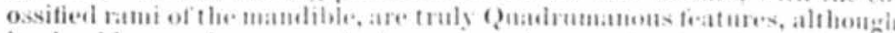
it should on other gromuds be regarded as a platutignate Carnivore Several of the estimet generat of the Wyommg Eocene will prove to be allied to this form.

Cercoleptes does not. loweser, present us with the ultimate original type of the C'armirem. Surh atype must also generalize the seals, with

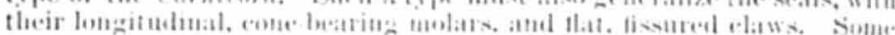
of the seals also unite the seaphoul and lunar lomes later in life that

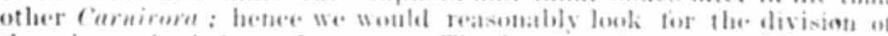
these bones in their predecescors. The tlat clawerl fenera of Wroming

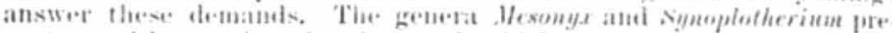

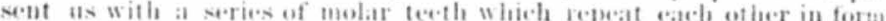

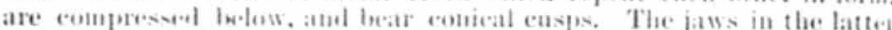

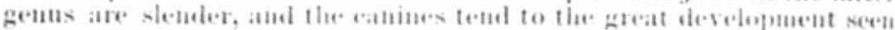

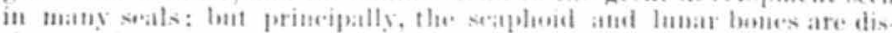
timet, and the elaws that and widely tissmest. The tympande bone is more like that of the beta and some sobls, than that of the digitigrate

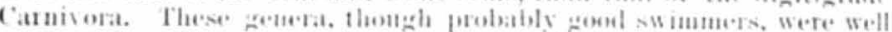
removed from the seals in the strueture of the lone bones of the limbs, and were probalsly remote in their aneestry.

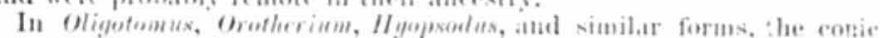

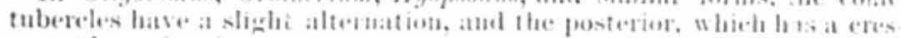
centedel section in wearing, incines to comnertion with both the inner. conic tubercles by low risiges. These riblese are fally developed it

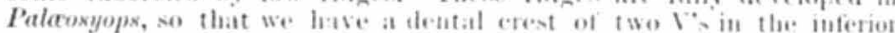

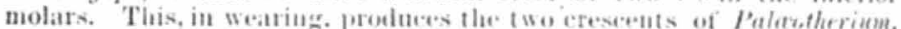
The addition of two tubreles on the inner side talkes place in the lugher

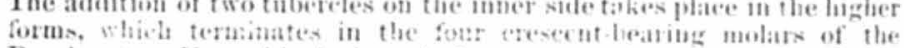
Ruminates. Ilow this is done is best proven by examples from the maxillary teeth.

In Orotherium raxaccirnse, there is a temdeney for the conie tubereles

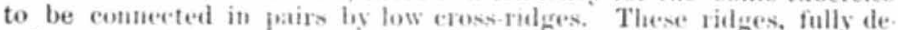
veloped, produce the two cross arests of Hyrechyus and Tapirus. In Rhinocerus, the outer portion retains a erescentoid torm, giving rise to an L-shaped erest. In Buthmenton diagonal didges apprar. Which would result in two $\mathrm{V}^{\mathrm{s}}$, is in Palcosyops, were it not that both transterse and oblique elements of the posterior $V^{*}$ disappear, leaving but one such in the middle and posterior part of the mandibular series. In Vintatheriun the diagonal from the posterior erest never appears, leaving a trans. erse crest and a $V$ on the true molars.

In the superior molar series, the exterior flattening of the exterio

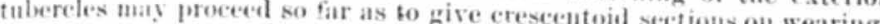
and their lonitudinal extent may be ste hes ton sections on wearing, their hases. A similar suecession of form as to canse them to unite at molars, e.g., in Orutherium sylraticum. In both Palacosyops and Hyra.

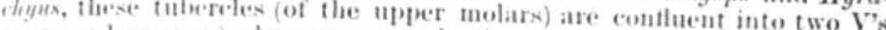

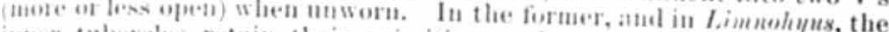

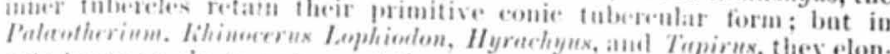

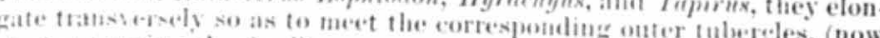
ctend a te

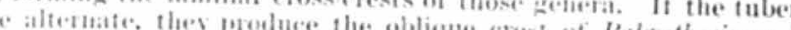

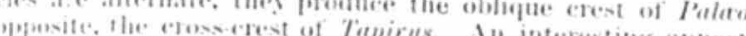

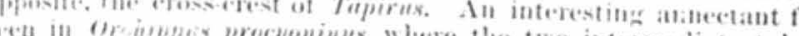
which somate the imer cons, where the two intermediate tubereles,

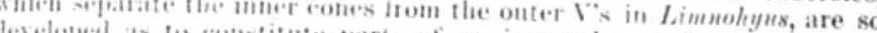
ede.

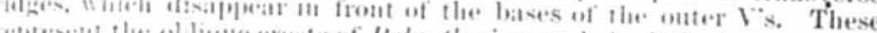

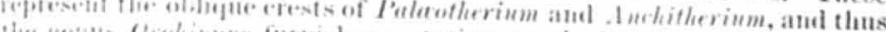

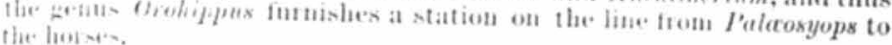

lt. wh the other hamd, the inner tubereles flatten like the outer on

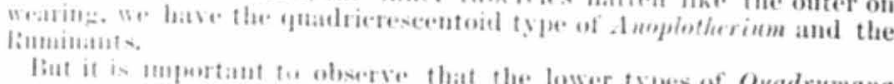
Fit if is 1 mportant fue observe that the lower types of Quadrumana and carwirem present the quadritulerculate crowp with tendency to Alallenting of the onter tulnereles, as seen in these bowest Tngulate. In

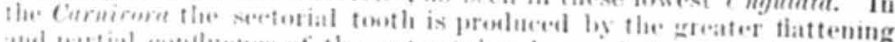

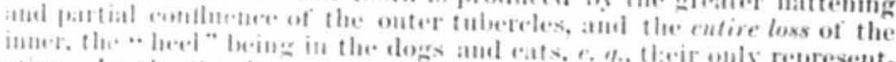

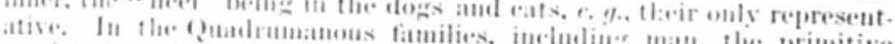

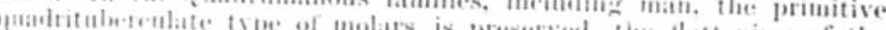

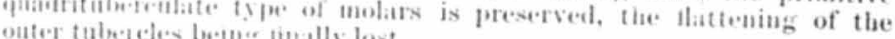

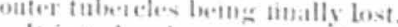

It is to be observed that the lines of Engulatu, Outulrumenes, and Car. mone originate in phantizrase types, a state of things quite preslomi.

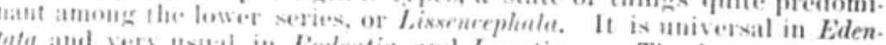

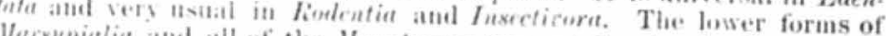
forsemente and all of the Monotremes present it. In the Marsupials lements, fogulates, aud Carnisores, we have series whose highest ex. presien is in the most highly digitigrade gener.

The acompanying diagram is designed to express to the ere more clearly the propositions matle above. By comparing it whe more table publisled by Professor Gill. Procecolings of a ciation for the Advancement of Science, for Isit, the Americin Asso blance between the twe may be observed, as well as certin close resen-

I wish to be the be to be thiderstoot thit the to be regitriled in the light of types of groups. There is no other mode of explaning the facts than that in accordance with the law of "homosimila groups," i. e., that several genera of one group have uudergone similar moditication into corresponding ones of a second group."

$$
\text { - See Origla of Gearta, page ST. Prop. v. }
$$



These genera had a common origin near the Jurassic predecessor of
Protostega.

Triony $x$ appears to represent another point of departure. It s plastron presents a grale of development near to that of Propleura, aud its nine cosfal bones have a similar significance. Its halfositied its nine wanting the marginals, is inferior. Its peculiar samessited carapace, Facene Anostirn, which is asen in the of the Crteticeons, which alds (Chelye Chelydra in form, and in Adocus a remarkable manner. It is choselydrine and Pleurodire characters in turn near to duoxtira. Hostomed by Plastomenu, which is in

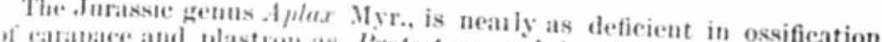

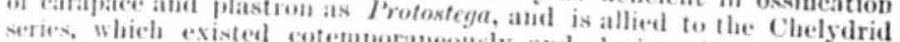
divedus represents cotempraneously and during the Cretaceons. Fimal tys represents a rather more advanced form, with distinct mar. Finat bones, athd with antinities to Chelyelra of a decided distmet mar. was probably its ancestor. Allied to it we have such forms as ddocus attul berne, which, while inrnished with fully ossitied shell, all Adocus the contracted form of plastron see in dibsticed sliell, still present several points of affinity to the pleen in Foochelys and Cheligtra, and

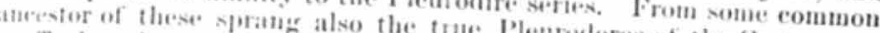

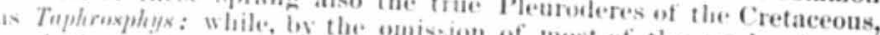

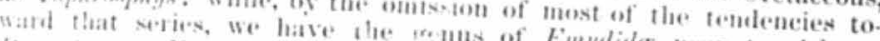
Irimatemegs. From this poimt ue

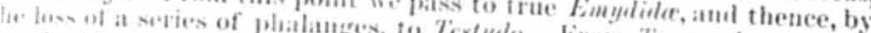

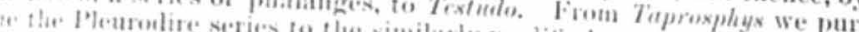

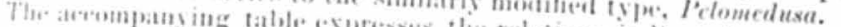

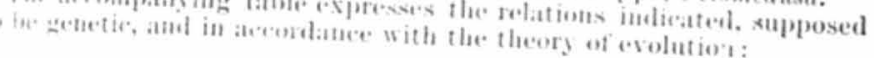

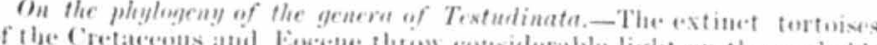

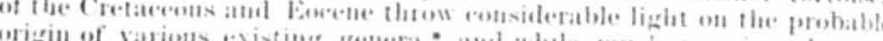

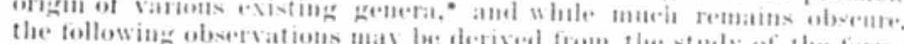
iil question:

The order makes its appearance in the Triassie perionl, for I am as.

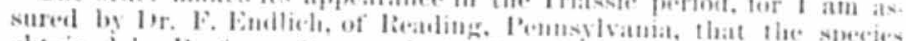

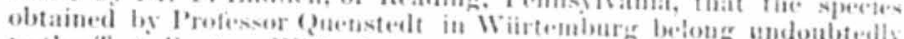
to the Textidimata. With their special strueture we are not yet fully

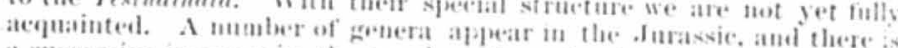

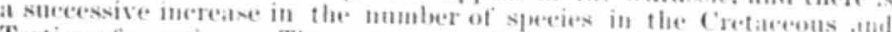
Tertiary formations. Three structural features of importace ans , the earlier forms. First, the incomplete nuton and osvifieatione mark the

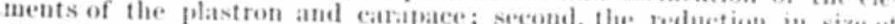
the lobes of the plastron; thind, the natater

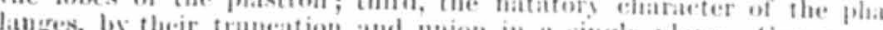

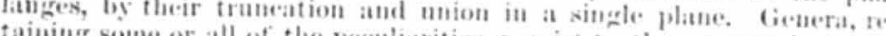

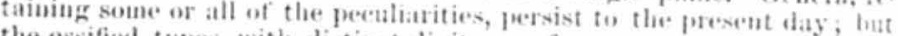
the ossified types, with distinct digits, are far more abundant, and comparatively rate in the period of the Inral. sinhurgis, whish is with.

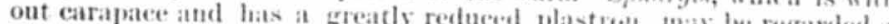

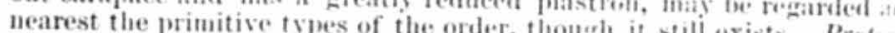
tega, of the kunsas Cretaceous is its tega, of the Kansas Cretaceous is its nearest extinct ally known. Pro fostega is superior in the well-feveloped marginal bones, and prepare the way for consideration of the varions gentera, with incomplete shieh

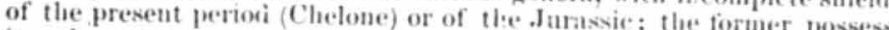
iing the natatory extremitics, some of the latter

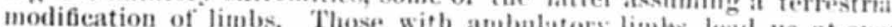

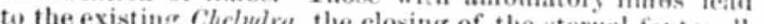
to the exinterinal fontanelles being an companied by a contration of its extent, in respect to the brialges and lobes. In Propleura of the Cretaceous we have a state of thmgs inter meliate between some of the Jurassic genera, as Itliochelys and Chelone.

"Bce on the Extinct Tortoises of the Cretaceous of Now Jersey; Proceeding:
Amer. Assoc. Adr, Science, 1$$
\text { intoveritatic }
$$

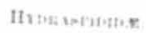




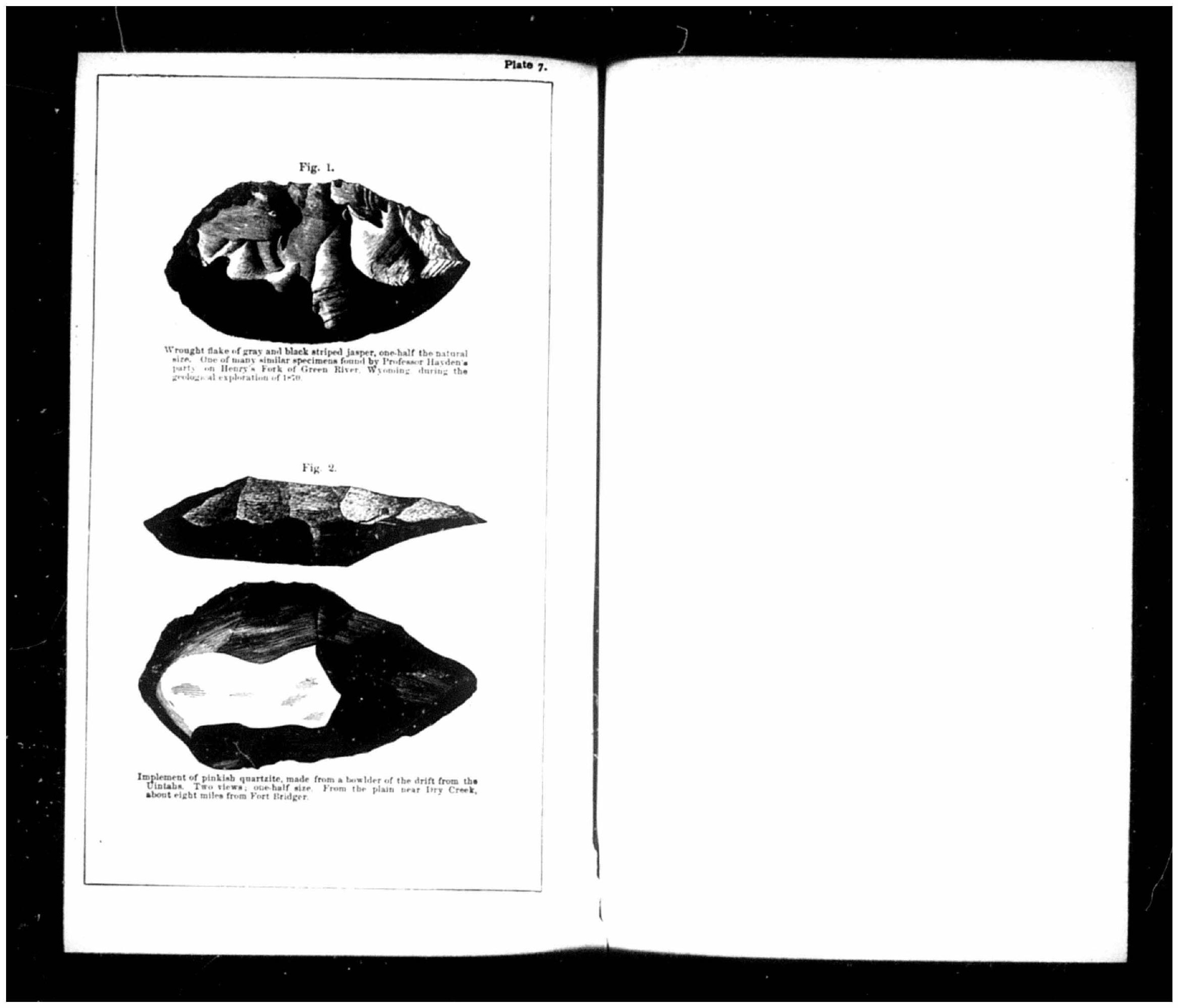



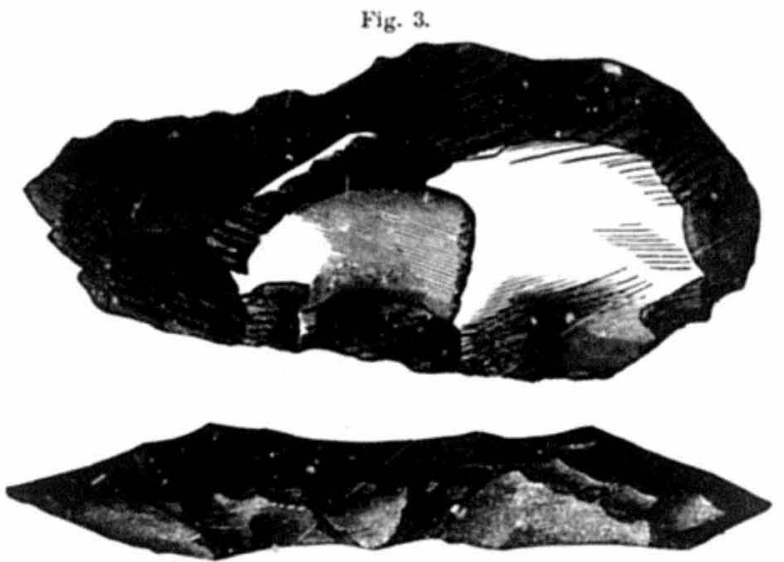

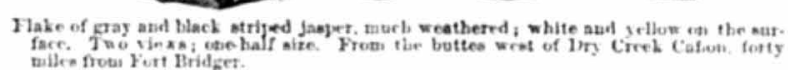

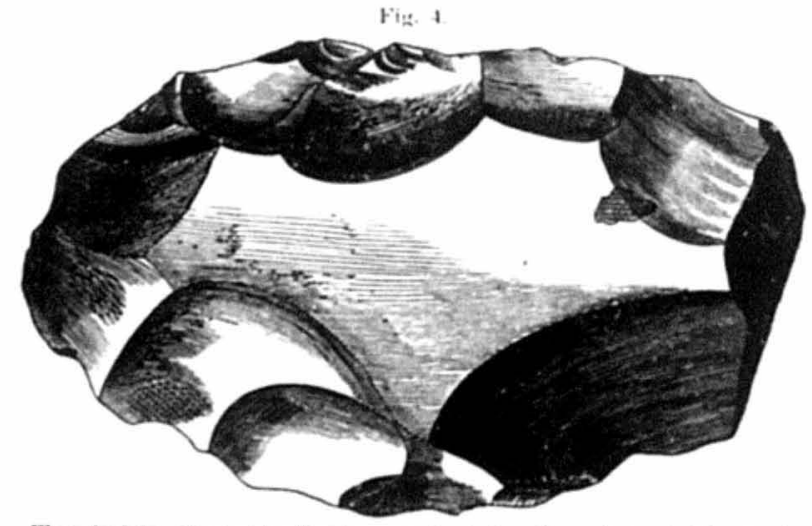

Wronght take of brownish yellow fasper, natural aize. Frota the besd of Dry Creek.
OS REMAINS OF PRIMITIVE ART IN THE BRIDGER BASIN OF SOUTHERS WYOMING.

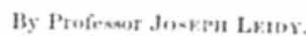

Fort Bridger oceupies a position in the midst of a with plain at the hase of the Uintah IIountains, and at an elesation of npward of 6,000 fiet above the seatevel. The neighboring country, at a remote geolog. real period, appears evilently to have been oceupied by an iumense tre-water lake, and the ancient lakedleposits now form the basis of
the region. These deposits have been subjected to a vast amount of the region. These deposits have been subjected to a vast amount of

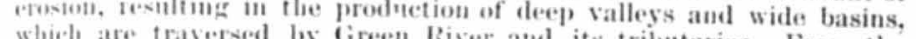
wheh are traversed by Green River and its tributaries. From the valley of Cireen liver, the ancient lake-deposits rise in succession as a s.ties of broat table-lands, or tertaces, and narrower fat-topped hills, which extend to the flanks of the surromdiug uneuntuins.

The sumws of the Uintah, Wahsateh, aud Gher mone

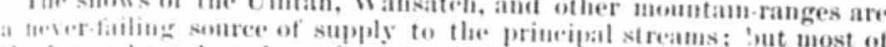
the leser hranches, dependent for their supply on the winter snows of

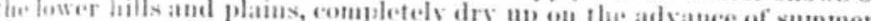

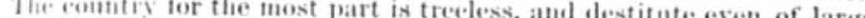

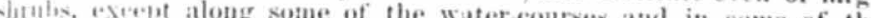

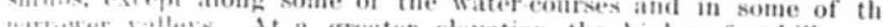
mamenter valless At a greater elevation the higher foothills and flank of the I intah Mountans ace covered with a dense forest growth, from which the roeky summits of the latter proset, as bare of vegets. tion as the plains betow.

The elevation of the Bridger Basin and the very little rain fall of the region are conditions unfavorable to a luxuriant veretation. The priu. cipal stowth of the plains consists of sage-bushes, (. Irtemisict triclentata.) intermingled, lowever, with many other less abumdant, and, in proper

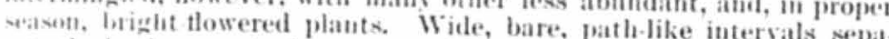
rate the bushes, or the interspaces are occupied by seanty grasses

The that topped hills of table-dands arising from the valless and evended plains, independent of the higher mountan-ranges, form the most characteristic feature of the landseapes in Southera Wyoming.

The fiat-topped hills or terraces, worn into all sorts of shapes, some. times appeating in the distance as extensive fortifications, at others as grat walled cities, huge castles, psramids, mounds, \&e, are familiagly known suder the name of buttes. This word is of French origin, and siguities a bank of earth or rising grouml. Similar features under simi. lar combitions are frequent in many parts of the continent west of the
Yississippi.

The buttes in the neighborhood of Fort Bridger are composed of nearly horizontal strata of varions colored indurated elays and sand. stones. In most localities visited by the writer the clays predominate. and are usmally greenisb, grayish, ash.colored, aud browish When anexpred they are compuct, homogeneous, and of stong hurdnes. When composition they vary from nearly pure elay to such as are highly arenaceous, aud gradite into those in which sand largely predominates.
Exposed to atmospheric agencies they readily disintegrate, and the Exposed to atmospheric agencies they readily disintegrate, and the
declivities of the buttes, generally destitute of vegetation, are usually 
invested with crumbling material from a few iuches to a foot or more in depth.

The sandstones are more frequently of various shades of green, but are also yellowish, and pass into shades of brown. They are compact and hard when unexposed to the weather, and are usually fine-grained, but also occur of a gravelly character. Disintegrating less rapidly than the contiguous clays, masses are often seen resting upon narrow eoues of the latter, contributing greatly to the picturesque aud of times fantast appearance of the buttes.

The buttes in some localities contain beds of impure limestones, highly calcareous clays, and harder siliceous clays. In others they cot. tain thin seams of tibrons arragonite, brown and striped jaspers, flint. and not unfrequently notules of agate and chalcedons. Ylany of the table lands and lesier lantes in the vicinity of the Uintah llountaine are thickly covered with irift from the latter, consisting of Mountains bowlders of reel and gray compact sundstenes or tum buwlders are generally small, but ace sume lasker portzites. The

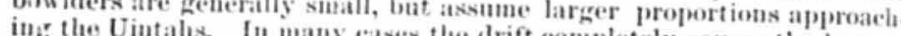
in: the descending upon the declivities so as entirely to conceal their structure. Usually, however, it is aceumulated in the ravines of the declivities. leaving bare the intervenug ridges of light-colored elays and sand stonex.

Many buttes in other loealities are nearly or quite free frotn trit materials. Cthers, again, are strewn with more or less angular frim ments of rock, consistimg of the harder materials from the terrach themselves, and these likewise oceur with the mingled drift from mountains. In some leralities the stone-s strewn oser the louer buth and plains are broken and theed in such atrewn over the lower butteaesume the appearance of ruck works of art With them cases the

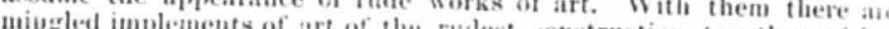
few of the finest thentest onstruction, together with it few of the fircst finish. In some places the stone implements are s numerons, and at the same time are so rudely constructed that oue is constantly in doubt when to consider them as natural of accidental and when to view them as artifieial. Some of the plaius are sem thints strewn with the natiral and artificial splintered stomes that alogh as if the $y$ hiul heeth the

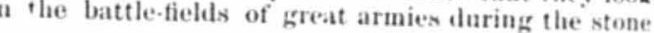
age.

Representations of a few of the flaked stones are given in Figs, 1 to 12. These with little doubt may be viewed as rude implements art. The vast numbers of similar stones to be fount on the butes a plains near Fort Bridger, and their gradition to undonded ans.min fragments with which they are that thes should be couxidered as suchled, alowe renders it iuprobable

The splintered stones, iucluding the implements of art, appear greatly to differ in age. Some of the specimens of black and brown and striped jaspers, and of black flint, resembling the chalk thint of Europe, are sharp and fresh in appearance as if the chalk fint of Europe, are as from the parent block. Otluers are wern, and have hechty firoke removed, and are so deeply. altered in color as to their sharpedges ancient. Thus reme of the look exply ancient. Thins some of the specimens composed of brown or hlack iasper have the surface of a dull, chalky aspect extendiug to the depth of the fourth of an inch.

The question arises who male the stone implements and when, and why should they occur in such igreat numbers in the particular localities
indicated.

My friend, Dr. J. Van A. Carter, residing at Fort Bridger, and well 


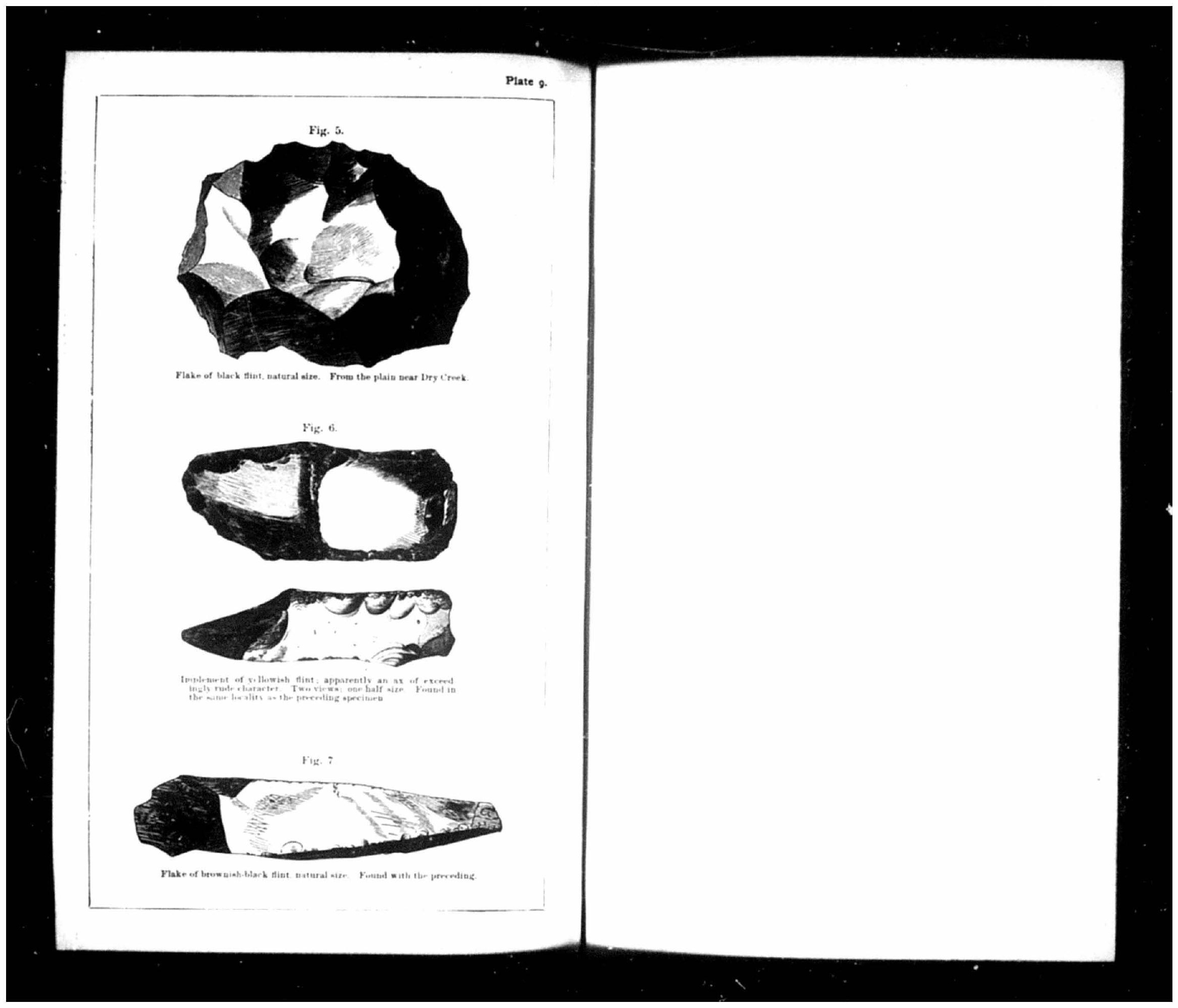




$$
0
$$




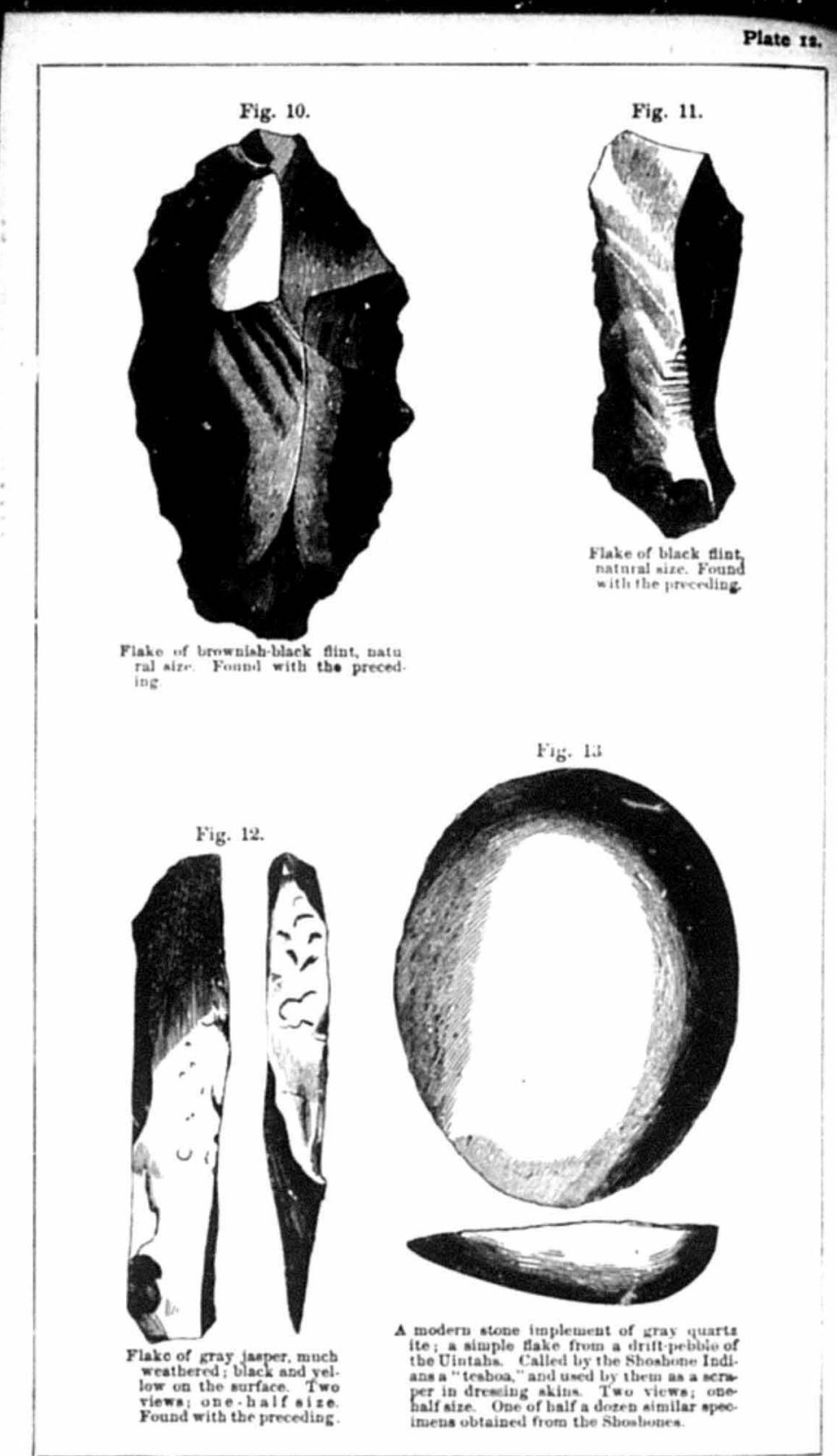

ANCIENT YOUNDS OP DAKOTA.

$$
\text { By C. Tuumas, Ph. D. }
$$

Winile at the orthern Pacific crossing of James River, in Dakota Terricory, during the past summer, I was informed by the oflicers of the military post at that place that there were some mounds in the vicinity which were supposed to $1:$ artificial.

Colonel Burke, who was al charge of the post, very kiudly consented to allow several soluiers and some Sioux seouts, who were willing to acompany us to assist in opening one of these to tast the correctness of this ophinon: and General II. W. Thomas, whe took great iuterest in thie subject, agreed to conduct the operations.

There mounds are situated on a high prairie east of Pipestone Creek, aluat two miles southeast of Jamestown, near the bluff which over. hang the narrow valley of the ereek. The position is a commanding nne oretleoking a latge extent of country toward the north and west, but to the south and east the prairie rises a little higher than at this puint. lont between this point and the higher ground in the latter dimes. toun thare is a broal slight defression.

The three mounds in this group are situated in relation fo each other as represented in the annesed wood-cut, and are connected with each - ther by low rilges, evidently the remaius of walls of some kind.

I. the central mound, is the largest, being about 210 tient in cireum. Fig. 56. ferenceat the base, as I judged by carefully paring it; it is about 8 feet ligh in the cen ter, the top having evidently been worn down conxiderably by the wisct bin sey an the material deposited arout the base perhajes slightly en. larging its original circuinference. A balger-hole entered near the apex, penetrating it obl tuely ane 4 or 5 feet.

$B$, situaterl , ' he southwest of $A$, about ift $f . c$ distant, is nearly as 1.rye as the latter, and apparently similar in every respect except that it appears to be more worn and not gunite so regular in its outlines.

C, the third, is situated ahont 36 f feet almost directly east of $A$, and is about half the size of that mouml.

$D$ and $E$ are the low ridges connecting these mounds: they are abont 15 to 18 feet broal, and frem $2 \operatorname{tn} 3$ feet high. Another broad and
somewhat indistinct ridge, marked $F$ in the cut, runs southeast from $A$, fading ont at the distance of alout in the cut, $A$, fading ont at the distance of about 400 feet.
Commencing on the north side of $A$ at $G$, we made an opening about 3 feet wide and extending a little besond the conter. About 2 feet from the surface, near the center, we began to find human bones and the bones of an animal, apparently those of the buffalo; the remains of only one 
or two individuals were found here. Below these a few rocks, but by no means regularly placed, sere fonnd; next we came upon the remains (human) of a number of individuals, at which point we ceased operations. to be six or seven individusis were disinterred. There did not appear to be any great regularity as to the position of the skeletons; in one (thongh in this instauce the two on the side. and one perpendicular, skull.) In most conform to the position of the skuf.) In most cases the heads appear to be coward the sonth. Over Tha a laver of some hard mixiure, mueh like mor contaning a white or ashy substance resembling the alkaline de mortar, this section. Mingled with the bones near the tol, as beforosits of were those we stryposed to be of the buffing: a beated, found, but no implements of any linl go to the bottom. we could not say there we

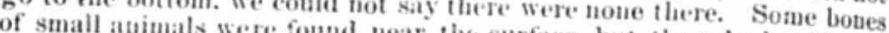
of small athimals were found near the surface, but these had evidently peen cartied into the badger-hole.

The Sioux scouts, who were full-hoos and unable to speak Englisb, out objection, and when astancy at the work, handling the bones with shook their heads in peoly. if they knew any thing about these moubls

The layer of hard asling

for mbless we suppose firesed earth is somewhat diflicult to account huried and covered for fines were kitudled here after the bodies were

IV. due into por some other purpese.

embankment /), but for some distance along the middle of the ridge or ben more than a simple disterer nothing to indiate that it had ese we often see the seftlers of the prexent day un or wall. possibly of sorl, as

As 1 have not stuited these ancient remains of the fe western prairiex of this conntry, and do mot desese to spemains of the former inbabitant. pleasure in adiline thu followine to speculate in retard to them, I take respecting these and some other monuds he opeen lis General Thomas vious to uny arrisial:

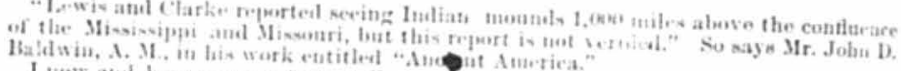

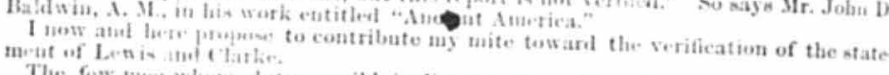

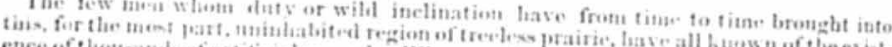

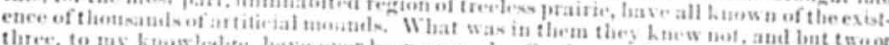

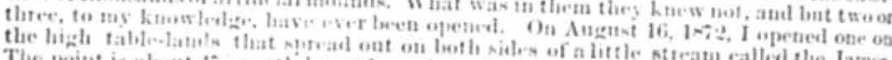

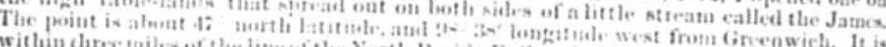

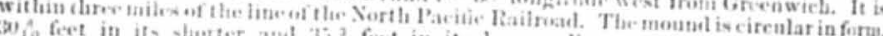

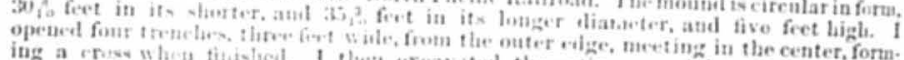

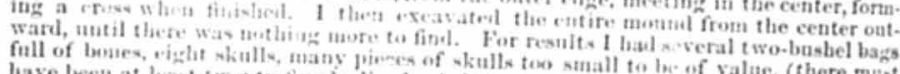

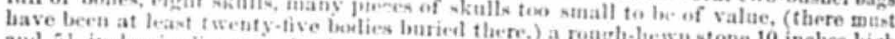

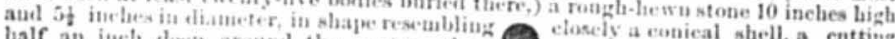

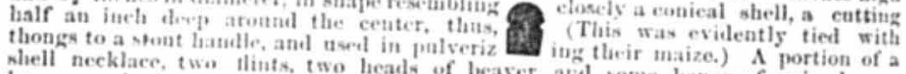

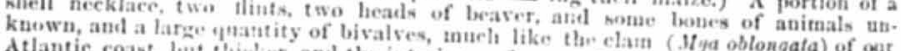
oflongata) of ou Is this moutul, and its thothands of duplicates all over this conntry, the work of the
present race of ludians, or is it not? 1. The Indiats liere and their loabits

always have buriel their deal in trees lave been known for sotwe eighty years. Thes never meddle with theth ifferwares and on slight and insecure scaffoldings, and the

They bad not the slightest objection, were full of curiosity, aud said they knew nothing of who was buried there. Haul these been their ancestors, tradition would have pre served the fact. They take asy meddling with their deal in high dudgeon, as was instanced lately. A surgeon at a neighboring post look the body of a little papoose of a

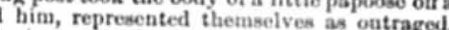
and the post commander wiscly ordered it given up. If, then, wounds had boen the burial-places of the ancestors of the preseut frutians, they would bave known it and cerTyen watehed me some thents, and tinally wits of untautied buffalo-hide trailing lechind them on the ground, and examinen Derghioring mounds. Theg had evidently received a now roveration as to them. Iruguois. This tribe and their habits have been kuown erer since the a branch of the Sorth America was discovered and setlled, and wo hear of no such custow coast of

3. The mounls and their contents are apparently of great antiquity. They are, in every ease, on the very highest point in the ir itumeliate neighborluool, and perfectly at a point about 500 feet aloovethe conteming dry that the Jaues River in entirely dry

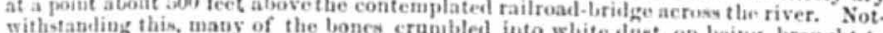
the air, like those found in Herenlaneum and Poonpeii, atu it was abeslug brought to

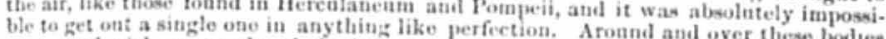
stones ant sicks were placed, doubtles to preserse the remains from the eseotodied

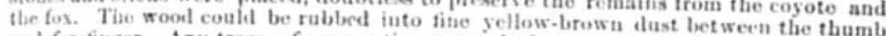
and foretioger. Any trace of escavation around the mound for dirt to lecap it with

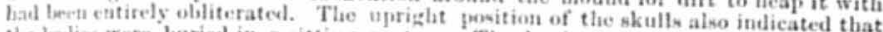
the bollics were baried in a sittiug posture. The leg-bones, however, lay lower and 4. The number of monuls indicates a denes popnlation than wer has heen known bere, of that the natural rewources of this region cat now support by the cleze. At

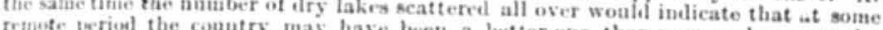
latere proplatatio country luman e fowng argument, howeres, comes with the skull. It is unlike that of any giosing narrow and pituched from continent; the frontal lone being low, receling. centrr. The cavity of the cranium is full seven inelirs long, and a reantescot in the half inchers wide. The orlital rodges or eyebrotrs are excessively developed, like cithot lower jaw, are set very far the the frot, anes rut down very low and deep toward the towarl the bottem. The nose, front, and are not wile at top, bnt widen very much that of the Indian. The nuperior maxillary is oucsthaly, is much moro aquiline than

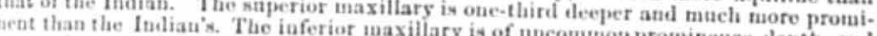
poset far excecting that of the Indian. The an of shaject than the Indian's, The foramen magnusa or a spiual corn enters the Leat, is peculiarly stmall. The cond loid pase of sknil, where the tiat on the working sur wces, and at such an angle an to pet the head upward, oblong, more than any race we know to-lay on this continent. Set one of these skult, with

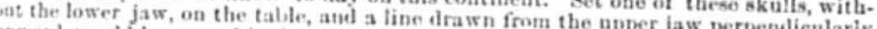
is atd it in and a goot inch and a half in front of the forebead. Sot on the lower Mesican Co. Guttgisal, formerly an engineer on the

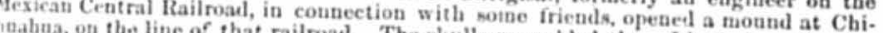

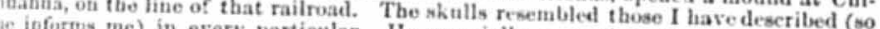

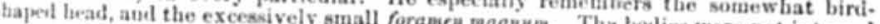

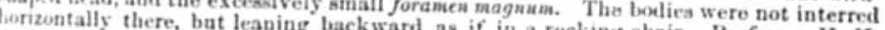
suith, lnivensity of Penpsylvania, has one of

if five times as large. A heavy embankment, some the monnd lescribed, is one four futs nearly southwest 150 feet, connectiug it' with another moun wide by 3 high, uotil lomt in the prairie.

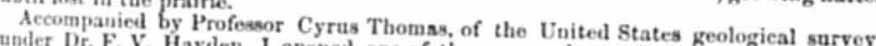
and found 1 . Hayden, 1 openesl one of these mounds, at the end of Angunt, 1 ro colot of the superiments of skulls, sinilarly disposed in all respects. The whitish opinion that funeral rites esthe inclined to the peculiar character of this rich earth and the here. He wan udable to account for the $42 \mathrm{~g} s$ s 
We cut through one of the embankments, and, turning a right angle, followed it to along its center satficiently to satisfy us that it contained no buman remaias.

Who, then, wero these northern mound-builders $f$ This question must bo anstren wero on of Northern Obio at least; that they deteriosated fore works are peen as far noth nortbern section, until they becate the people their al ails century in this batre

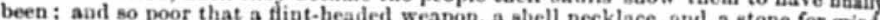

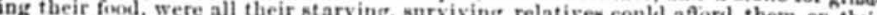
sorrowfnl journey to the spirit land.

PART III.

SPECIAL REPORTS

\section{ZOÖLGY AND BOTANY.}


REPORT ON THE MAMUALS AND SIRDS OF THE EẌPEDITION. By C. H. Mrumax.

SIR: I take pleasnre in presenting my report on the mammals and biris collected during the past season for publication in your report.

I desire to tender my thanks to Mr. S. W. Jaycox for his assistance in the collections. I collected, from the 5 th to the 21 st of June, one hundred and twenty bird-skins, and fifty two nests with eggs.

I wish to express my indebtedness to Mr. Platt, whose collections in my department would have been larger had he not also had charge of the alcoholic and botanical collections made by that branch of the expe. the alcoholie and botanical collections made by that branch of the expe-
dition under your immediate control. I wish also to state that I am under great obligations to Professor S. F. Baird and Mr. Robert Ridg. way, of the Smithsonian lustitution, for aiding me in various ways.

The total number of bird-skins collected is three hundred and thirteen; of nests, with eggs, sixty-seven. I found no birds at Téton or Fire. Hole Basins specifically different from those collected at other piaces on our route.

I remain, yours, very respectfully,

I). F. Y. HAYDEN,

Lnited States Geologist.

\section{HART MERRIAM.}

MI A M A L,S.

Order 1.-RAPACIA.

(Sub order CARNIVORA.)

Family 6.-Mustelid.e.

(Sub-family Martinc.)

Putorius pusillus, Aud. and Bach., (least weasle:)

\begin{tabular}{|c|c|c|c|c|c|}
\hline \multirow{2}{*}{ No. } & \multicolumn{2}{|c|}{$\begin{array}{l}\text { Smithsotian cata- } \\
\text { logue-number. }\end{array}$} & \multirow{2}{*}{ Sex. } & \multirow{2}{*}{ Date. } & \multirow{2}{*}{ Locality. } \\
\hline & Skull. & skin. & & & \\
\hline 7 & 12416 & 11102 & Jus. & July 22,1872 & Téton Basin, Tiaho. \\
\hline
\end{tabular}

Hab.-Minnesota to Puget's Sonnd; New York, (De Kay.) 
Gulo luscus, Sabine, (Wolverine :)

\begin{tabular}{|c|c|c|c|c|c|}
\hline \multirow{2}{*}{ No. } & \multicolumn{2}{|c|}{ Catalogue-number. } & \multirow{2}{*}{ sex. } & \multirow{2}{*}{ Date. } & \multirow{2}{*}{ Locality.. } \\
\hline & Skull. & Skin. & & & \\
\hline 54 & 11034 & 11094 & \& & Aug. 10, 1872 & Yellowstono River, Wyo. \\
\hline
\end{tabular}

Hab.-Salt Lake and Black Hills, Nebraska, to Arctic America ; (North. ern New York, Aud. and Bach.)

\section{(Sub-family Melina.)}

Mephitis mephitica, var. ocidentalis, Bd., (California skunk:)

\begin{tabular}{|c|c|c|c|c|c|}
\hline \multirow{2}{*}{ No. } & \multicolumn{2}{|c|}{$\begin{array}{l}\text { Smithsonian cata- } \\
\text { logue-nutmber. }\end{array}$} & \multirow{2}{*}{ Sex. } & \multirow{2}{*}{ Dute. } & \multirow{2}{*}{ Locality. } \\
\hline & Skull. & Skin. & & & \\
\hline $\begin{array}{l}24 \\
45 \\
55\end{array}$ & $\begin{array}{l}12409 \\
12410\end{array}$ & $\begin{array}{l}11095 \\
11096\end{array}$ & $\frac{8}{8}$ & $\begin{array}{l}\text { Aug. 13, } 1772 \\
\text { Sept. } 8,1772 \\
\text { Jute } 5,1972\end{array}$ & $\begin{array}{l}\text { Lower Gegre: Basin, Wyo. } \\
\text { Shoobone Lake, Wyo. } \\
\text { Ogden, Utah. }\end{array}$ \\
\hline
\end{tabular}

Mab.-High central plains to the Pacific.

Mephitis bicolor, Gray, (little striped skunk:)

\begin{tabular}{|c|c|c|c|c|c|}
\hline \multirow{2}{*}{ No. } & \multicolumn{2}{|c|}{ Catalogne-number. } & \multirow{2}{*}{ Sex. } & \multirow{2}{*}{ Date. } & \multirow{2}{*}{ Lecality. } \\
\hline & Skull. & Skiu. & & & \\
\hline$s t$ & ..t. & 11136 & - & June $2 \pi, 1872$ & Marsh Valley, Jiabo. \\
\hline
\end{tabular}

Hab.-Sonthern Texas and California; northward to Idaho on westera slope of Rocky Mountains.

$$
\text { Family 7.-UBside. }
$$

Ursus horribilis, Ord., (grizzly bear:)

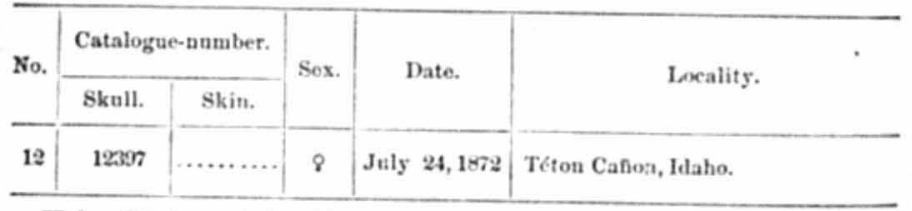

Hab.-Plains of the Upper Missouri to the Rocky Mountains, and along their base; thence to the coast of Califoruia.
Ursus Americanus. Pallas, (black bear:)

\begin{tabular}{|c|c|c|c|c|c|}
\hline \multirow{2}{*}{ No. } & \multicolumn{2}{|c|}{ Catalogue-number. } & \multirow{2}{*}{ Sex. } & \multirow{2}{*}{ Date. } & \multirow{2}{*}{ Locality. } \\
\hline & Skull. & 8kin. & & & \\
\hline 2 & 122890 & ............ & 8 & Ang. 10,1872 & Heury's Lake, Idabo. \\
\hline
\end{tabular}

Hab.-United States generally.

\section{Order III.-RODENTIA.}

Family 9.-Scrunid E.

Sub-family, Sciurina, the true squirrels.

Sciurus hudsonius, Pallas., (red squirrel:)

\begin{tabular}{|c|c|c|c|c|c|}
\hline \multirow{2}{*}{ No. } & \multicolumn{2}{|c|}{$\begin{array}{l}\text { Smithsouian cata- } \\
\text { logue-number. }\end{array}$} & \multirow{2}{*}{ Sex. } & \multirow{2}{*}{ Date. } & \multirow{2}{*}{ Locality. } \\
\hline & Skull. & Bkin. & & & \\
\hline $\begin{array}{l}23 \\
30 \\
31 \\
37 \\
31 \\
31\end{array}$ & $\begin{array}{l}12421 \\
12422 \\
12423 \\
12424 \\
12425 \\
12420\end{array}$ & $\begin{array}{l}11107 \\
11108 \\
11109 \\
\ldots \ldots \ldots \\
\text { iiiiiz.... }\end{array}$ & $\begin{array}{l}8 \\
8 \\
\frac{8}{8} \\
\\
-\end{array}$ & $\begin{array}{l}\text { Aug. } 8,1872 \\
\text { Aug. 17, } 1872 \\
\text { Aug. } 20,1872 \\
\text { Aug. } 30,1872 \\
\text { Aug. } 31,1872 \\
\text { Sept. 17, 1872 }\end{array}$ & $\begin{array}{l}\text { Henry's Lake, Idalo. } \\
\text { Upper Geyser Basin, Wyo. } \\
\text { Lower Geyser Rasin, Wyo. } \\
\text { Fort Ellis, Mont. } \\
\text { Lower Geyser Basin, Wyo. } \\
\text { 8uake River, Wyo. }\end{array}$ \\
\hline
\end{tabular}

IIab.-Labrador (latitude $56^{\circ}$ ) to Mississippi, and in the United States from the Atlantic to the western slope of the Rocky Mountains.

Tamias quadrivitattus, Rich, (Missouri striped squirrel:)

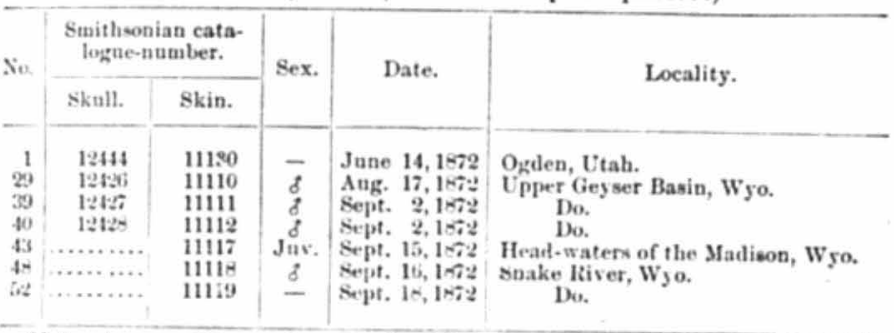

Hab.-C Pper Missouri to locky Mountains, and west to the Caseade Range; along the Rocky Mountains as far south as Fort Stanton, New Mexico.

Spermophilus grammurus, Bach., (line-tailed squirrel :)

\begin{tabular}{|c|c|c|c|c|c|c|}
\hline \multirow{2}{*}{ No. } & \multicolumn{2}{|c|}{$\begin{array}{l}\text { Stmithonian cata- } \\
\text { logue-number. }\end{array}$} & \multirow{2}{*}{ Sex. } & \multirow[t]{2}{*}{ Date. } & \multirow{2}{*}{ Locality. } & \\
\hline & Skull. & Skin. & & & & \\
\hline $\begin{array}{r}2 \\
3 \\
4 \\
56\end{array}$ & $\begin{array}{l}12445 \\
12446 \\
12447 \\
12449\end{array}$ & $\begin{array}{l}11131 \\
11132 \\
11133 \\
11135\end{array}$ & $\frac{\overline{8}}{81}$ & $\begin{array}{l}\text { June } 15,1872 \\
\text { June } 15,1872 \\
\text { June } 17,1 \times 72 \\
\text { Juve } 8,1672\end{array}$ & $\begin{array}{c}\text { Ogden, Utah. } \\
\text { Do. } \\
\text { Dor. } \\
\text { Do. }\end{array}$ & . \\
\hline
\end{tabular}


Hab.-Head of Arkansas River; along the Rocky Moantains to So nora; north ward to Idaho Territory.

(Sub-family Castorina.)

Spermophilus lateralis, Rich, (Say's striped squirrel:)

\begin{tabular}{|c|c|c|c|c|c|}
\hline \multirow{2}{*}{ No. } & \multicolumn{2}{|c|}{$\begin{array}{l}\text { Smithouian cata- } \\
\text { logue-number. }\end{array}$} & \multirow{2}{*}{ sex. } & \multirow{2}{*}{ Date. } & \multirow{2}{*}{ Locality. } \\
\hline & Skull. & skin. & & & \\
\hline$z$ & $1: 217$ & 11100 & - & Ang. 10,1 1 - 2 & Heury's Lake, Idaho. \\
\hline
\end{tabular}

Hub.-Roeky Yountaius to Caseader, aud between about latitude $38^{\circ}$ $26^{\prime}$ to latitude t $^{\prime}$.

Spermophilus mallix, Kennicott

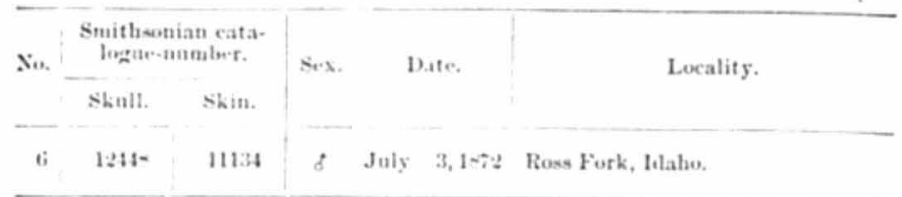

Hub.-Rorky Mountain region.

spermophilus tornsendii, Bach., (Townsend's spermophile:)

\begin{tabular}{|c|c|c|c|c|c|}
\hline \multirow[t]{2}{*}{ Sin, } & \multicolumn{2}{|c|}{$\begin{array}{l}\text { Smithsonian cata. } \\
\text { bogne-number. }\end{array}$} & \multirow{2}{*}{ S.:.} & \multirow{2}{*}{ Date. } & \multirow{2}{*}{ Locality. } \\
\hline & skuil. & skin. & & & \\
\hline 16 & 12410 & 11104 & - & July $29,1-72$ & Tóton Canoti J taho. \\
\hline 10 & $124: 31$ & 11115 & - & An. 1,1-7: & Bo. \\
\hline i: & $1 \div 432$ & 11116 & d & Alg $1,1-72$ & \\
\hline 24 & 12419 & i11es & o & $9,1<2$ & Henry's Lake, Idaho. \\
\hline
\end{tabular}

Hab.-Rocky Mountains, to the north.

Arctomys flurirenter, Bachman, ( yellow footed marmot :)

\begin{tabular}{|c|c|c|c|c|c|}
\hline \multirow[t]{2}{*}{$\mathrm{Nio}$} & \multicolumn{2}{|c|}{$\begin{array}{l}\text { Struthsonian cata. } \\
\text { loguc-nan yer. }\end{array}$} & \multirow[t]{2}{*}{$\operatorname{sex} x$. } & \multirow[t]{2}{*}{ Date. } & \multirow{2}{*}{ Locality. } \\
\hline & Skull. & skin. & & & \\
\hline 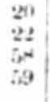 & $\begin{array}{l}1240 ; \\
12407 \\
12753 \\
12754\end{array}$ & Yiiigh & $\frac{-}{8}$ & $\begin{array}{l}\text { Aug. } 4,1872 \\
\text { Ang. } 7,1072 \\
\text { July } 27,1872 \\
\text { July } 27,1072\end{array}$ & $\begin{array}{l}\text { Téton Basin, Itaho. } \\
\text { North Fork, Llaho, } \\
\text { Sear Fort Ellis, Mont. } \\
\text { Do. }\end{array}$ \\
\hline
\end{tabular}

Hab.-Black Hills, Nebraska.
Castor canadensis, Kuhl, (American beaver:)

\begin{tabular}{|c|c|c|c|c|}
\hline No. & $\begin{array}{c}\text { Catalogue- } \\
\text { number. }\end{array}$ & Sex. & Date. & Locality. \\
\hline & skull. & & & \\
\hline 9 & $\begin{array}{r}12404 \\
2 \ldots \ldots\end{array}$ & $\overline{-}$ & $\begin{array}{l}\text { July } 22,1072 \\
\text { July } 22,1072\end{array}$ & $\begin{array}{c}\text { Téton Basin, Idabo. } \\
\text { Do. }\end{array}$ \\
\hline i1 & 12403 & 8 & July $21,1-72$ & Téton Cañon, Idaho. \\
\hline
\end{tabular}

Hub.-Throughout the entire area of North America.

Family 10.-SAcCoMY1D \&.

(Sub-family Geomyine.)

Thomomys fulrus, (mountain pocket rat:)

\begin{tabular}{|c|c|c|c|c|}
\hline $\begin{array}{r}\text { Smiths } \\
\text { logue }\end{array}$ & $\begin{array}{l}\text { n cata. } \\
\text { aber. }\end{array}$ & Sex. & Date. & Lecalite \\
\hline skinll. & Skin, & & & \\
\hline $\begin{array}{l}1: 1: 1: 1 \\
1: 1: 1\end{array}$ & $\begin{array}{l}11106 \\
111: 06\end{array}$ & $\frac{8}{2}$ & 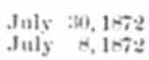 & $\begin{array}{l}\text { Téton Cañon, Itaho. } \\
\text { Fort Ellis, Mont. }\end{array}$ \\
\hline
\end{tabular}

Muh.-San Franciseo Mountains, New Mexico, to Fort Yuma and San Diego, nortluward in Kocky Mountains to Montana.

Family 11-MURID.

(Sub-family Dipodine.)

Jaculus hudsonius, (jumping mouse:)

\begin{tabular}{|c|c|c|c|}
\hline $\begin{array}{l}\text { Stait hosonian cata- } \\
\text { logne-number. }\end{array}$ & Sex. & Date. & Locality. \\
\hline Shit. & & & \\
\hline $\begin{array}{l}111: 99 \\
11125\end{array}$ & $\stackrel{8}{\varnothing}$ & $\begin{array}{l}\text { Ang. } 31,1872 \\
\text { July } 14,1 \in 72\end{array}$ & $\begin{array}{l}\text { Uprer Madison Cafion, Wyo. } \\
\text { Fort Ellis, Mlont. }\end{array}$ \\
\hline
\end{tabular}
and west to the Pacific Ocean.

(Sub-family Murina.)

Mus muscrlus, Linn., (common mouse:)

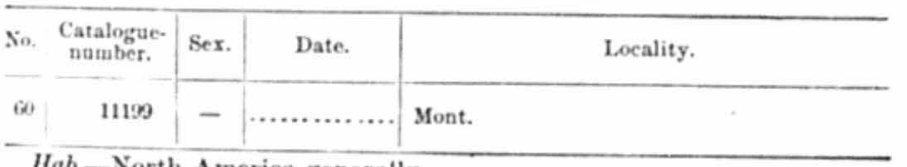

Hab,-North Ameriea generally. 
Hesperomys leucopus, var. sonoriensis, Lee. :

\begin{tabular}{|c|c|c|c|c|}
\hline No. & $\begin{array}{l}\text { Catalogan } \\
\text { number. }\end{array}$ & Sex. & Date. & Locality. \\
\hline $\begin{array}{l}42 \\
49 \\
61 \\
62\end{array}$ & $\begin{array}{l}11121 \\
111: 22 \\
11: 00 \\
11: 01\end{array}$ & $\begin{array}{l}\bar{b} \\
\delta \\
\delta \\
\delta\end{array}$ & $\begin{array}{l}\text { Sept. } 3,1072 \\
\text { sept. 16,1072 } \\
-, 1782\end{array}$ & $\begin{array}{l}\text { Lower Geyser Basin, Wyo. } \\
\text { Snake River, Wyo. } \\
\text { Mont. } \\
\text { Do. }\end{array}$ \\
\hline
\end{tabular}

Hab.-Upher Missouri and Rocky Mountains to El Paso aud Souora. (Sub-family Arricoliner.)

Arricola riparia, Ord., (bank mouke:)

\begin{tabular}{|c|c|c|c|c|}
\hline No. & $\begin{array}{l}\text { Catalogue- } \\
\text { number. }\end{array}$ & Sex. & Date. & locality. \\
\hline $\begin{array}{l}33 \\
36\end{array}$ & $\begin{array}{l}11123 \\
11124\end{array}$ & $\stackrel{8}{-}$ & $\begin{array}{l}\text { Aug, } 30,1 \sim 72 \\
\text { July } 10,1>72\end{array}$ & $\begin{array}{l}\text { Lower Geyser Basin, Wyo. } \\
\text { Fort Ellis, Mout. }\end{array}$ \\
\hline
\end{tabular}

Mab.-United States to Rocky Mountains.

Family 12.-Hrstaicid.E.

Erethizon epixnthus, Brandt, (yellow-haired poreupine:)

\begin{tabular}{|c|c|c|c|c|}
\hline No. & $\begin{array}{c}\begin{array}{c}\text { Catalogue- } \\
\text { uamber. }\end{array} \\
\text { Skull. }\end{array}$ & six. & Date. & Locality. \\
\hline 20 & 12405 & 8 & Aus. 10, 1-i: & Iletury's Lake, Llaho. \\
\hline
\end{tabular}

Hab.-Upper Missouri; whole Pacific coast.

$$
\text { Fanily 13.-IxpontD.E. }
$$

Lepus callotis, (f) Wagler, (jackiss or mule rabbit:,

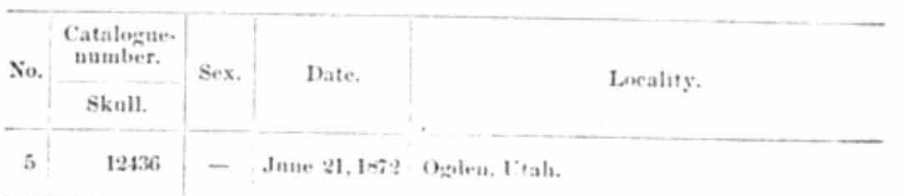

Hab.-Xorthern Mexico, through Southern Texas, and west throngh New Mexice to the Rocky Mountains, north to the Yellowstone; Fort
Boise, Oregon, (?) Southern Sonora. (?)

\begin{tabular}{|c|c|c|c|c|c|}
\hline \multirow{2}{*}{ No. } & \multicolumn{2}{|c|}{$\begin{array}{l}\text { Smithsonian cata- } \\
\text { logue-unmber. }\end{array}$} & \multirow{2}{*}{ Sex. } & \multirow{2}{*}{ Date. } & \multirow{2}{*}{ Locality. } \\
\hline & Skull. & Skin. & & & \\
\hline$x$ & 12411 & 11097 & 8 & Aug. 29,1872 & Lower Geyaer Basin, Wyo. \\
\hline 44 & 12412 & 11093 & \& & Sept. 7,1072 & Shokhone Lake, Wyo. \\
\hline 46 & 12413 & 11099 & \& & Sept. 11,1672 & Lewis Lake, W yo. \\
\hline $4 i$ & 12414 & 11100 & is & Sept. 15,1872 & Snake River, Wyo. \\
\hline 50 & 12415 & 11101 & Juv. & Sept. 17, 1072 & Hart Lake, Wyo. \\
\hline
\end{tabular}

Lepus bairdii, Hayden, (Baird's rabbit :)

Hab.-Pine regions about the head-waters of the Wind and Yellow. stone Rivers.

I was fortunate enough to secure fice specimens of this rare and rematkable rabbit. Heretofore but one specimen of this species has been

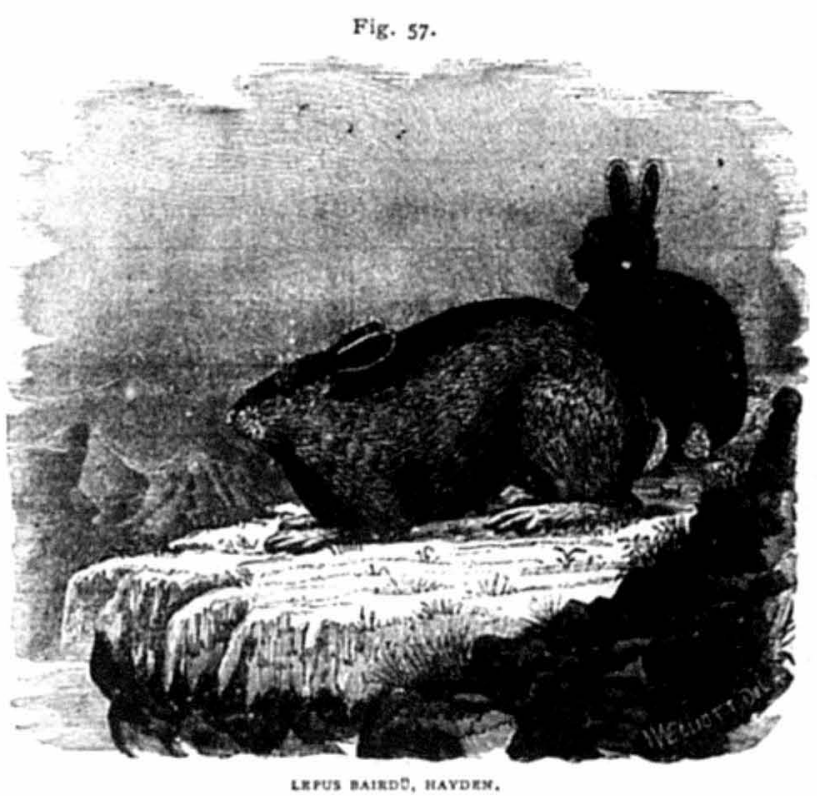

brought before the scientific wor' 1 , and it (No. 4263) is now on exhibition in the Smithsonian Institution. It was collected in the Wind River Mountains by Dr. Hayden in the month of June, 1860, and was described by him in the American Natnralist, (vol. iii, No. 3, May, 1s69.) Un. fortunately :h sex of this speeimen was not determined.

One very curious fact relating to Lepus bairdii is that all the males have teats and take part in suckling the young. I say all the males, becanse four out of the five specimens procured were adult males, and all had large teats full of milk, and the hair around the nipple was wet aud stuck to it. showing that they were then nursing their young. 
As we found no females, we thought this might be an hermaphroditio form; so Dr. Josiah Curtis and myself dissected a large male-No. 4 (12412, 11093)-which we found to contain the usual genital organs of the male, but no uterus, ovaries, or other female organs. I dissected another old male-No. 46, $(12413,11099)$-with the gans. I dissected gret exceedingis that I was anable to procure a female specimen; 1rom the limited number of speit, both sexes to Joth sexes take patt in suckling their young.

I publish the foilowiug lettrer from Dr. Curtis, verifying the abore

Wasursarox, D. C., Fibruary $20,1873$.
Dean StR: When npon that part of our explorations last summer which embraced the region alout the beal-waters of the Snake River, I naw several speeimens of the rabbit (rpas bairdii, Hayden) which yon had secured, and the adulta gave exteraa sigus of having been suckled, but gave esery other evidence of being true males. dissected one non we well as myself, beyond a doubt upon this point, I very carefolly dissected one nomistakably-marked specimen, abd found conelnsive evidence of is

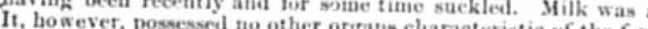
ali the male oossessed no other or gatis characteristic of the female sex, but it did bave Yours, resinetfolly,

$$
\text { Mr. C. Hatre Mentmas. Nituratist Enited States Geological Surrey. }
$$

Lagomys princeps, Rich, (little chief hare:)

\begin{tabular}{|c|c|c|c|c|c|}
\hline \multirow{2}{*}{ No. } & \multicolumn{2}{|c|}{$\begin{array}{l}\text { Smithsonian cata- } \\
\text { logue-number. }\end{array}$} & \multirow{2}{*}{ Sex. } & \multirow{2}{*}{ Date. } & \multirow{2}{*}{ Loeality. } \\
\hline & Skull. & Skit. & & & \\
\hline 10 & 12430 & $: 1114$ & - & July 24,1872 & Téton Cafion, Idaho. \\
\hline
\end{tabular}

Hub._-Soutlr Pass of Rocky Mountains, no:thward.

\section{Order VI.--REMINANTIA.}

Family 16.-CERvid .

(Sub-family Cervina.)

Alce americanus, Jardine, (American moose:)

\begin{tabular}{|c|c|c|c|c|}
\hline \multirow{2}{*}{ No. } & $\begin{array}{l}\text { Catalogne- } \\
\text { uumber. }\end{array}$ & & Date & \\
\hline & Skull. & & & \\
\hline $\begin{array}{l}13 \\
14 \\
15\end{array}$ & $\begin{array}{c}12999 \\
12400 \\
\cdots \cdots \cdots\end{array}$ & $\begin{array}{l}8 \text { nù. } \\
8 \text { juv. } \\
8 \text { juv. }\end{array}$ & $\begin{array}{l}\text { July } 26,1 \approx 72 \\
\text { July } 26,1872 \\
\text { July } 26,1072\end{array}$ & $\begin{array}{l}\text { Teton Cañon, Idabo. } \\
\text { Do. } \\
\text { Do. }\end{array}$ \\
\hline
\end{tabular}

Hal.-Northern portions of the Easteru United States to Labrador wheuce it extends west to the Pacifie Ocean.

\section{Family 17.-OAvicorNin.}

(Sub-family Antilopinc.)

Antilocapra americana, Ord, (prong-horn antelope:)

\begin{tabular}{|c|c|c|c|c|}
\hline \multirow{2}{*}{ No. } & $\begin{array}{l}\text { Catalogue- } \\
\text { number. }\end{array}$ & Sex. & Date. & Locality. \\
\hline & Skull. & & & \\
\hline $\begin{array}{l}21 \\
53\end{array}$ & $\begin{array}{l}12402 \\
12401\end{array}$ & Juv. & $\begin{array}{ll}\text { Aug. } & 5,1872 \\
\text { Oct. } & 4,1872\end{array}$ & $\begin{array}{l}\text { Middle Fork, Idaho. } \\
\text { Cañon Creek, ldabo. }\end{array}$ \\
\hline
\end{tabular}

IIab.-Plains west of Missouri, from the Lower Rio Grande to the Saskatchewan, and west to the Cascade and Coast Ranges of the Pacific slope.

\section{Order IX,--CHEIROP'TERA, THE BATS.}

$$
\text { Family.-Vespertulionme. }
$$

Nycticejus crepuscularis, Allen.

\begin{tabular}{c|c|c|c|c}
\hline So. & $\begin{array}{c}\text { Catalognce } \\
\text { number. }\end{array}$ & Sex. & Date. & Locality. \\
\hline 1 & $111: 7$ & - & Ang. 31, 1872 & Lower Geyser Basin, Wyo. \\
\hline
\end{tabular}

Hab,-United States, from Atlantic to Pacific.

Vespertilio lucifugus, Leconte, (the blunt-nosed bat :)

\begin{tabular}{c|c|c|c|c}
\hline No. & $\begin{array}{c}\text { Catalogne- } \\
\text { unumber. }\end{array}$ & Sex. & Date. & Locality. \\
\hline 2 & 11128 & $\&$ & Aug. 31, 1872 & Lower Geyer Basin, Wyo. \\
\hline
\end{tabular}

Hab.-North America generally.

Vespertilio yumanensis, Allen, (the Gila bat:)

\begin{tabular}{c|c|c|c|c}
\hline No. & $\begin{array}{c}\text { Cataliggue- } \\
\text { number. }\end{array}$ & Sox. & Date. & Locality. \\
\hline 3 & 11129 & $\&$ & July 25, 1872 & Hot Springs, Montana. \\
\cline { 2 - 3 } & & &
\end{tabular}

Hab.-Eastern slope of Rocky Mountains to Pacific coast. 


\section{B I R D S.}

Sub-class 1.--INSEssores, PERCHING BIRDs. Order 1.-PASSERES, PASSERINE BIRDS. (Section OSCINES, SINGERS.)

Family 1.-TCRdide, THE THRUshes.

Turdus (Planesticus) migratorius, Linn., (common robin:)

\begin{tabular}{|c|c|c|c|c|c|}
\hline No. & $\begin{array}{l}\text { Catalogue- } \\
\text { number. }\end{array}$ & Sex. & Date. & $\begin{array}{l}\text { Measure- } \\
\text { meuts. }\end{array}$ & Locality. \\
\hline $\begin{array}{l}102 \\
200 \\
255 \\
274\end{array}$ & $\begin{array}{l}61650 \\
62275 \\
62276 \\
62277\end{array}$ & $\begin{array}{l}8 \\
8 \\
8 \\
8 \\
8\end{array}$ & $\begin{array}{l}\text { June } 18,1872 \\
\text { July } 30,1872 \\
\text { Sept. } 6,1872 \\
\text { Sept. 16, 18:2 }\end{array}$ & $\begin{array}{r}10+\times 15 \\
92 \times 16 t \\
9+\times 15 z \\
10 \$ \times 16 \%\end{array}$ & $\begin{array}{l}\text { Ogden, Utah. } \\
\text { Téton Cafion, Idaho. } \\
\text { Soarce of the Madison. } \\
\text { Stake River, Wyo. }\end{array}$ \\
\hline
\end{tabular}

Hab.-Continent of North America to Mexico.

Madison River, thy of about thirty robins near the head-waters of the Madison River, Wyoming Territory, on the 6th of September. The snow Was about an inch in depth, and the tlock-oue of which I shot ( No, 255 -seemed to be moving southward. They were quite abundant on Suake River during the latter part of September. At all other places on our route robins were seldom met with.

Galeoscoptes carolinensis, Linn., (cat-bird :)

\begin{tabular}{|c|c|c|c|c|c|}
\hline No. & $\begin{array}{l}\text { Catalogue- } \\
\text { Damber. }\end{array}$ & S:x. & Date. & $\begin{array}{l}\text { Measure- } \\
\text { ments. }\end{array}$ & Locality. \\
\hline 9.) & 61623 & s & Jnue 15,1872 & $87 \times 11$ & Ogten, Utah. \\
\hline
\end{tabular}

Hab.-Eistern United States to Salt Lake Valley and WVashingto Territory. I was surprised to find Lake Valley and Washingto Lake Valley as they are in all our Eastern States. At Ogden I found one of their nests-No. 52, (16310); it was on a bush in a marsh, abon four feet above the ground, and contained five fresh eggs.

Oreoscoptes montanus, Baird, (mountain mocking-bird:

\begin{tabular}{|c|c|c|c|c|c|}
\hline No. & $\begin{array}{l}\text { Catalogue. } \\
\text { number. }\end{array}$ & Sex. & Date. & $\begin{array}{l}\text { Measure- } \\
\text { meats. }\end{array}$ & Locality. \\
\hline $\begin{array}{l}41 \\
42\end{array}$ & $\begin{array}{l}\text { Gifis } \\
\text { 61652 }\end{array}$ & $\frac{8}{3}$ & $\begin{array}{l}\text { June } 11,1872 \\
\text { June } 11,1872\end{array}$ & $\begin{array}{l}9 \beta^{2} \times 12 \\
9 \times 12\}\end{array}$ & $\begin{array}{l}\text { Salt Lake, Utah. } \\
\text { Do. }\end{array}$ \\
\hline
\end{tabular}

Hab.-Rocky Mountains; sonth to Mexico, and along valley of Gila and Colorado, and to San Diego, California.

This plain colored songster is quite numerous about Salt Lake, where we found them breeding; we also found them northward Salt Lake, where and in the Téton Basin. I found its nest-No. $26(16296)$-near the shore of Salt Lake; it was placed at the foot of a sage-brash; was built of sticks, lined with fibrous roots; it was unusually large for the size of the bird, (measuring over eight inches in diameter,) and contained four fresh eggrs.

Family 2.-CrNchide, THE DIPPERs.

Cisclus mexicanus, Swains., (water-ouzel:)

\begin{tabular}{|c|c|c|c|c|}
\hline $\begin{array}{l}\text { Catalogue- } \\
\text { number. }\end{array}$ & Sex. & Date. & $\begin{array}{l}\text { Measure- } \\
\text { ments. }\end{array}$ & Locality. \\
\hline $\begin{array}{l}62341 \\
62442\end{array}$ & के & $\begin{array}{l}\text { July } 14,1872 \\
\text { July } 14,1072\end{array}$ & 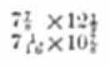 & $\begin{array}{l}\text { Mystic Lake, Mont. } \\
\text { Do. }\end{array}$ \\
\hline
\end{tabular}

IIab.-Rocky Mountains from British America to Mexico.

The American dipper, or water-ouzel, is a rare bird in the district thrugh which we passed, being met with only at Ogden Cañon, Mystic Lake, atul in a little cañon east of the Téton Range, near Jackson's Lake. It is truly a wonderful bird, being able not only to walk, but also to fls, into the water. During the latter part of September, when the snow was about an inch deep and was still falling, I took my gun and entered one of the caũons a few miles north of Jackson's Lake, in the hope of meet. ing some rare birds. I had not gone far, when, to my great delight, I $a s$ a pair of water-ouzels on a rock in the middle of a rapid stream which flowed out of the cañon. To my great surprise one of these birds dove directly iuto the rapids, and in a few moments returned with a worm in its mouth. I shot one of the biris, which, to my great chagrin, fell into the water and was earried under by the current, and I was an. able to secure it.

(The nest of the water-ouzel (Cinclus mexicanus) was discovered by our artist, Mr. W. H. Holmes, about half a mile from Mystic Iake, Iontana Territory, while he was sketching a beautiful little fall wake, by one of the monutain streams. The bird was observed to fly directly through the falling water, disappearing from view. Snspectiug that a nest uust be there, we returned the following day, when, with the assist ance of Mr. Holmes, I secured the nest, containing three young, and shortly after shot both the old birds. The nest was made of moss, measuriug nearly a foot in diameter and six inches in denth. It was bnilt upon the edge of a narrow shelf of rock, and so uear the fall that the ontside was constantly wet with spray, while the interior was dry and warm. The birds entered it by a small lateral opening in the lower half of the nest, the top being built up against a projecting rock.-W.
B. PLATT.

Family 3.-SAxiculide, THE SAxicolas.

Sialia arctica, Sw., (Rocky Mountain blue-bird:)

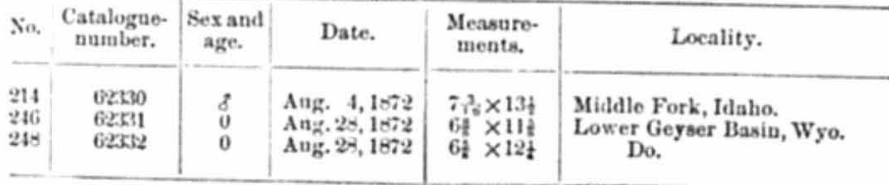

Hab.-High dry central plains; Upper Missouri to Rocky Mountain Range and south to Mexico. Rare on the const of California. 


\section{GEOLOGICAL SURVEY OF 'THE TERRITORIES.}

The Rocky Monntain blue-bird seems to prefer a country which has been burnt over, and is covered with stumps and fallen timber. It is not a common species in the district through which we passed.

$$
\text { Family 4.-SYLVID } \approx \text {, THE WARBLERS. }
$$

Regulus calendula, Licht., (ruby-crowned kinglet:)

\begin{tabular}{|c|c|c|c|c|c|}
\hline No. & $\begin{array}{c}\text { Catalogue- } \\
\text { uumber. }\end{array}$ & $\begin{array}{l}\text { Sex and } \\
\text { age. }\end{array}$ & Date. & $\begin{array}{l}\text { Mleasure- } \\
\text { ments. }\end{array}$ & Locality. \\
\hline$\frac{331}{207}$ & $\begin{array}{l}62533 \\
62534\end{array}$ & $\begin{array}{l}0 \\
8\end{array}$ & $\begin{array}{l}\text { Ang. } 20,1072 \\
\text { Sept.14, } 1072\end{array}$ & $\begin{array}{l}4+2 \times 7 \\
4 \times 7+6\end{array}$ & $\begin{array}{l}\text { Lower Geyser Basin, Wyo. } \\
\text { Suake River, Wyo. }\end{array}$ \\
\hline
\end{tabular}

Hab-Dorth America from Atlantic to Pacific.

This pretty little bird is probably abundant in early spring and in October, althongh I saw but two of them during the summer and in evident that they breed in the Yellowstone country, from the fuct that obtained a young one-No. 231, (62333)-there on the 20th of Angust.

$$
\text { Family 5.-PARIDA. }
$$

(Sub-fumily Parina, the Titmice.)

\begin{tabular}{|c|c|c|c|c|c|}
\hline No. & $\begin{array}{c}\text { Catalogue- } \\
\text { number. }\end{array}$ & Sex. & Date. & $\begin{array}{l}\text { Measure- } \\
\text { ments. }\end{array}$ & Locality. \\
\hline $\begin{array}{l}211 \\
212 \\
256 \\
259\end{array}$ & $\begin{array}{l}62349 \\
62500 \\
62551 \\
62352\end{array}$ & $\begin{array}{l}\text { s } \\
\text { d } \\
\text { g } \\
\text { g }\end{array}$ & $\begin{array}{l}\text { July } 31,1072 \\
\text { July } 31,1072 \\
\text { Sept. } 7,1072 \\
\text { Sept.16, 1072 }\end{array}$ & 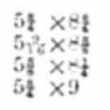 & $\begin{array}{l}\text { Téton Cañon, Ilaho. } \\
\text { Do. } \\
\text { Shoshone Lake, Wyo. } \\
\text { Suake River, Wyo. }\end{array}$ \\
\hline
\end{tabular}

Parus montanus, Gambe'., (mountain titmouse:)

Hab.-Pacific coast of United States to Rocky Mountains.

Téton Cañon was the first place where we observed this species probably because it was the first place on our ronte where we foun coniferous trees.

The mountain chickadee is an abundant species in the Fire-Hole Ba sin, and also from the source of Snake River to where it leaves the wooded mountain sides and flows through an open plain. This bird, like our "chickadee," ( $P$. atricapillus, ) is very tane, aud evidently likes the company of man, as they flit about from limb to limb in search of their food within a few feet of you, without even looking up, or showing any signs of fear or even surprise at your presence. This species mas easily be distinguished from our eastern $P$. atricapillus by the white front and the white line over the eye, cutting off a black one through it.

(Sub-family Sittina, the Nuthatches.)

Sitta aculeata, Cassin, (slender-billed nuthatch.)

\begin{tabular}{r|c|c|c|c|c|}
\hline No. & $\begin{array}{c}\text { Catalogue- } \\
\text { number. }\end{array}$ & Sex. & Date. & $\begin{array}{c}\text { Measure- } \\
\text { ments. }\end{array}$ & Locality. \\
\hline 240 & $6229:$ & \& & Aug. 27,1672 & $6 \times 11$ & Lower Geyser Iasin, Wyo. \\
\hline
\end{tabular}

Hab.-Pacific coast of United States to Rocky Mountains.

\section{GEOLOGICAL SURVEY OF THE TERRITORIES.}

This may be considered as a rare bird in the tract of country through which we passed, as I saw but one specimen, which I shot-No. 240, $(62097$.

Family 7.-Troglodvtide, THE Wrens.

(Sub-family Campylorhynchine.)

\begin{tabular}{|c|c|c|c|c|c|}
\hline No. & $\begin{array}{l}\text { Catalogue- } \\
\text { uaruter. }\end{array}$ & Sex. & Date. & $\begin{array}{l}\text { Sieasure- } \\
\text { ments. }\end{array}$ & Locality. \\
\hline 64 & 610054 & $s$ & June 14, 1972 & $6+99$ & Ogden, Utah. \\
\hline
\end{tabular}

Salpinctes obsoletus, Cab., (rock-wren.)

Mab.- IIigh central plains through the Rocky Mountains to the Coast and Cascade Ranges, (but not on the Pacific coast ?)

This birl is very properly enlled the "rock-wren" for high up the mountain sides and among the rocks it lives, lays its egus, and teaches its young the use of their tiny wings. They are noisy creatures, and seem to take great pleasure in darting from rock to rock, keeping generally oitt of sight.

I shut the first of this species that I saw on one of the rocky spurs of the Wahsateh liange, near Ogden-No. 64. (61654.) They were quite abundant on the robky hills near the Hot Sulphur springs, ten miles worih of Ogden.

\section{(Sub-fauily Troglodytina.)}

\begin{tabular}{|c|c|c|c|c|}
\hline $\begin{array}{c}\text { Sis Catalogue- } \\
\text { namber. }\end{array}$ & Sex. & Date. & $\begin{array}{l}\text { Sfeasure- } \\
\text { mentm. }\end{array}$ & Locality. \\
\hline $\sin 2$ & 8 & Oct. i4, 1 $\rightarrow:-2$ & $58 \times 7$ & Fort Hall, Itaho, \\
\hline
\end{tabular}

Cistothorux palustrix, Cab., (long-billed marsh-wren.)

Wab,- Worth Anerica from Atlantic to Pacific, north to Gireenland. Fort Hall is the only place where I fonnd the long.billed unarsh-wren. suw several of them there, but succeded ouly in obtaining one soed. men-No. 302, (62327.) This bird, though not gay in colors, is a sweet sougster.

\begin{tabular}{|c|c|c|c|c|c|}
\hline Nis. & $\begin{array}{l}\text { Catalogne- } \\
\text { natuln-t. }\end{array}$ & Sex. & Date. & $\begin{array}{l}\text { Measure- } \\
\text { ments, }\end{array}$ & Locality. \\
\hline & tertsos & ? & $\begin{array}{l}\text { July } 10,107: \\
\text { July } \\
0,1-72\end{array}$ & $\begin{array}{l}43 \times 6 ? \\
4 \times 6 ?\end{array}$ & $\begin{array}{l}\text { Yorth Fork, Idaho. } \\
\text { Fort Ellis, Sfont. }\end{array}$ \\
\hline
\end{tabular}

Troglodytes parkmanni, Aud., (Parkman's wren:)

Hab.-Western America, from the high central plains and Upper Mis. sonti to the Pacitic.

This little bird, very similar to our house-wren, ( $T$. adon, ) was quite common at North or Henry's Fork of Suake River, Yiddle Fork Tuiton Cañon, and Fort Ellis. I found its nest, on the 20 th of July, at Middle 
Fork; it was in the hollow of a small tree that had broken off abont ten feet high and still rested against its stump. The nest contained fire young birds, and was composed of small sticks laid loosely together. The parent-birds were greatly incensed at my approach, and darted about my head in an angry manner.

Faimily 8.-MotachlLm, THE Wagtarls.

Anthus ludoricinus, Licht., (tit-lark:)

\begin{tabular}{|r|c|c|c|c|c|}
\hline No. & $\begin{array}{c}\text { Catalogue- } \\
\text { number. }\end{array}$ & Sex. & Date. & $\begin{array}{c}\text { Measure- } \\
\text { ments. }\end{array}$ & Loeality. \\
\hline $2 \times 1$ & $6229-$ & $\delta$ & Sept, $21,10 \% 2$ & $61 \times 10 i$ & Snake River, Wyo. \\
\hline
\end{tabular}

Hab.-North Americagenerally; Greenland, (Reinhardt.) Accideutal in Europe.

We met with this bird only on Snake River and in the vicinity of Jackson's Lake; there we foumd a few flocks of from ten to fifty.

\section{Family 9,-SYLvicolide, THE WOOD.WArmLens.}

Geothlypis irichas, Cab., (Maryland yellow-throat:)

\begin{tabular}{|c|c|c|c|c|c|c|}
\hline No. & $\begin{array}{c}\text { Catalogne- } \\
\text { number. }\end{array}$ & Sex. & Date. & $\begin{array}{l}\text { Measure- } \\
\text { ments. }\end{array}$ & $\begin{array}{l}\text { No.of nest } \\
\text { and egg\%. }\end{array}$ & Locality. \\
\hline $\begin{aligned} 83 \\
39 \\
310\end{aligned}$ & $\begin{array}{l}61601 \\
62434 \\
62344\end{array}$ & $\begin{array}{l}8 \\
8 \\
8 \\
8\end{array}$ & $\begin{array}{l}\text { June } 17,1672 \\
\text { July } 9,1872 \\
\text { July } 11,1672\end{array}$ & $\begin{array}{l}5 \times 7 \\
3 \times 7 \\
4 \times 7\end{array}$ & 44 & $\begin{array}{l}\text { Ogden, Utah. } \\
\text { Fort Killis, Jiont. } \\
\text { Do. }\end{array}$ \\
\hline
\end{tabular}

Hab.-North America, from Atlantic to Pacific.

This little warbler is quite abundant at Ogden, Utah, and also on the Madison River, and at Fort Ellis, Montana Territory; I saw none else. where. I obtained the nest of this bird at Ogden-Xo. 44, (16308) \&; No. 83, (61661,) shot. It was found in a clump of bushes in a marsh, about six inches above the ground, and was composed of dtied grass and rushes; it contained four fresh eggs.

Icteria longicauda, Lawr., (long-tailed chnt :)

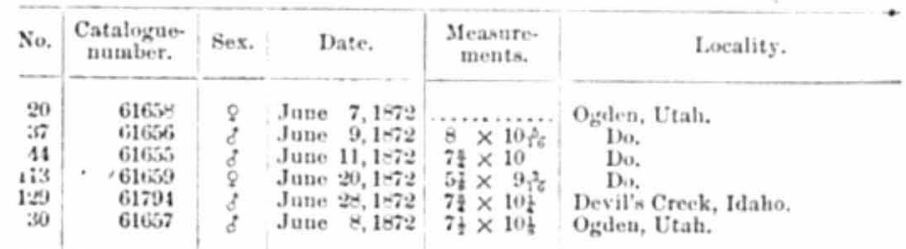

Hab.-High central plains of the United States to the Pacific; sonth into Mexico.

The long-tailed chat is a common bird in the scrub-oak bushes at the foot of the Wahsatch Range, near Ogden. It is a peculiar bird, and like our eastern species, (Icteria virens,) is always heard, but seldom seen. They are shy, suspicious creatures, and although, when disturbed, they tit about in a scolding, angry manuer, they generally manage to keep out of sight. You hear them in the bushes, imitating the mewing of cot, the shrill notes of the jay, sometimes singing like a catbird, and yet, again, they sing sweetly in their own peculiar manner. They have a strange habit of elevating themselves in the air to the height of thirty or forty feet, then, poising themselves for a moment, they descend again to the bushes; during their descent they jerk themselves about in the air, at the same time uttering clear, ejaculated notes, which can be heard for quite a distance, and are not altogether unpleasant to the ear. I found the nest of this bird on the 15th of June; it was on a scrub-oak near a small stream; was about four feet above the gronud, and contained three young birds and one egg. The egg resembled, in size and color, that of our eastern species, (I. virens.)

Dendroica audubonii, Baird, (Audubon's warbler :)

\begin{tabular}{|c|c|c|c|c|c|}
\hline Xio. & $\begin{array}{l}\text { Catalogne- } \\
\text { uumber. }\end{array}$ & Sex. & Date. & $\begin{array}{l}\text { Measure- } \\
\text { ments. }\end{array}$ & Locality. \\
\hline $25=$ & $\begin{array}{l}62.45 \\
62.46\end{array}$ & $\overline{8}$ & $\begin{array}{l}\text { Sept. } 7,1872 \\
\text { Sept. } 15,1872\end{array}$ & $\begin{array}{l}52 \times 94 \\
54\end{array}$ & $\begin{array}{l}\text { Shoshone Lake, Wy } \\
\text { Snake River, Wyo. }\end{array}$ \\
\hline
\end{tabular}

Mab.-Pacific coast if United States to central Rocky Mountains, south to Mexico.

Aulubon's warbler, though similar in most respects to our eastern yel. low rump warbler, ( $D$. coronata, ) is easily distinguished from it by hav. ing the chin a d throat yellow instead of white. During the latter part of September $\perp$ saw several flocks of these birds on Snake River; they appented to be on their way sonth.

Dcudroica astira, Baird, (yellow warbler:

\begin{tabular}{|c|c|c|c|c|c|c|}
\hline sin. & $\begin{array}{l}\text { Catalogne. } \\
\text { number. }\end{array}$ & Sex. & Date. & $\begin{array}{l}\text { Measure- } \\
\text { tuents. }\end{array}$ & $\begin{array}{l}\text { No. of nest } \\
\text { aut egds. }\end{array}$ & Loeality. \\
\hline (4) & 61600 & \& & June $\theta, 1-\pi 2$ & $5 \times 25$ & 24 & Ogden, Utah. \\
\hline
\end{tabular}

Hab.-United States from Atlautic to Pacific; south to Guatemala and West Indies.

Yellow warblers were common at Ogden, as they were at all places where there was a stream of water phose banks were lined with busbes. I found the nest of this bird at Ogden-No. 24, (16294; ) it was on a wil. low, about three feet above the ground, and contained four fresh eggs.

.yiodioctes pusillus, Bonap., (green black-cap warbler:)

\begin{tabular}{|c|c|c|c|c|c|}
\hline No. & $\begin{array}{l}\text { Catalogue- } \\
\text { number. }\end{array}$ & sex. & Date. & $\begin{array}{l}\text { Measure } \\
\text { ments. }\end{array}$ & Locality. \\
\hline & $\begin{array}{l}62347 \\
62348\end{array}$ & \& & $\begin{array}{l}\text { Ang. } 13,1772 \\
\text { Sept. } 26,1672\end{array}$ & $\begin{array}{l}4 ! \times 7 \\
5 ! \times 7 \\
5\end{array}$ & $\begin{array}{l}\text { Lower Geyser Baxin. } \\
\text { Second Téton Lake. }\end{array}$ \\
\hline
\end{tabular}

Hab.-United States from Atlantic to Pacific; south to Guatemala. 
We met with this beautiful warbler but twice during the summer. Oh the first oceasion we were just entering the Lower Geyser Basin, when I observed a pair of these little birds in a grove of small pine trees; they were hopping about on the ground, and upon my approach flew up into a tree, out of which I shot the male-No. 227, (62347.)

The second and last time that I saw this species was at the Second Téton Lake, where I saw a male high up in a pine tree. I secured him 3lso.

Family 10.-Hinundinid 2 , THE Swallows.

Hirundo horreorum, Barton, (barn-swallow:)

\begin{tabular}{|c|c|c|c|c|c|}
\hline No. & $\begin{array}{l}\text { Catalogue- } \\
\text { number. }\end{array}$ & Sex. & Date. & $\begin{array}{l}\text { Measure- } \\
\text { ments. }\end{array}$ & Locality. \\
\hline 214 & $\begin{array}{l}62298 \\
62296\end{array}$ & $\overbrace{0}^{8}$ & $\begin{array}{l}\text { Aug. } 2 \varangle, 1072 \\
\text { Aug. } 2 \varangle, 1672\end{array}$ & $\begin{array}{l}7 \times 124 \\
54 \times 114\end{array}$ & $\begin{array}{l}\text { Lower Geyser Basin. } \\
\text { Do. }\end{array}$ \\
\hline
\end{tabular}

Hab.-North Ameriea, from Atlantic to Pacific.

Barn-swalluws are common at most places between Fort Hail, Idaho, and Ogden, Utah. They are also numerous at Fire.Hole Basin, Wyo ming Territory, where I obtained two specimeus-No. 244, $(62995$, in No. $247,(62296$.

Petrochelidon lunifrons, Say, (eliff-swallow:)

\begin{tabular}{|c|c|c|c|c|c|}
\hline No. & $\begin{array}{l}\text { Catalogue- } \\
\text { unmuler. }\end{array}$ & Sex. & Date. & $\begin{array}{l}\text { Mreasure- } \\
\text { ments. }\end{array}$ & Locality. \\
\hline $14 \pi$ & 61724 & 8 & July 3,1072 & $6 \times 12 i$ & Ross Fork, Italio. \\
\hline
\end{tabular}

Hab.-North Ameriea, from Atlantic to Pacific.

This is another common species of swallow. We found them ver plentiful in the vicinity of Great Salt Lake; thence north to Fort Hall, where they were also abundant. I obtained the nest of this speciesNo. 58, (16312, - - 8, No.147, shot at Ross Fork, Jdaho Territory, on the $3 \mathrm{~d}$ of July. It was composed of numi, and was fastened to the bank of the creek, and about eight feet above the water. The nest contained two fresh eggs.

Tachycincta thalassina, Sw., (violet-green swallow:)

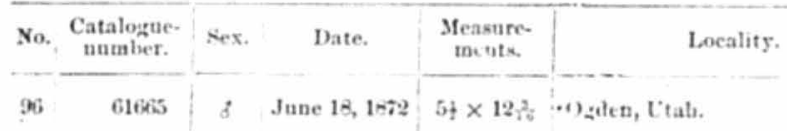

Hab.-Rocky Mountains to Pacific; south to Mesice; east to Saltillo, Mexico.
This bird, the tuost beantiful of all the swallows, is quite common at Ogden Cañon. Where we obtained the only specimen collected-No. 96 , (61665.) The only other place on our route at which we found this species was the Grand Cañon of the Yellowstone. There I saw a few of them, but did not succeed in obtaining any specimens.

Cotyle riparia, Boil., (bank-swallow :)

\begin{tabular}{c|c|c|c|c|c}
\hline No. & $\begin{array}{c}\text { Catalogue } \\
\text { number. }\end{array}$ & Sex. & Date. & $\begin{array}{c}\text { Measure- } \\
\text { ments. }\end{array}$ & Locality. \\
\hline 40 & 61664 & $\&$ & June 11, 1872 & $\ldots \ldots \ldots \ldots . . . \ldots$ & Salt Lake, Utah. \\
\hline
\end{tabular}

Hab._United States, from Atlantic to Pacific; common at Salt Lake, and from there to Snake River.

I obtained the nest of the bank-swallow in a hole in a sand-bank by the side of Salt Lake. It contained seven fresh eggs-No. 25, (16295, ) \&, No, 40, shot.

Family 13.-Lanid ж, тив SHrikes.

Collurio borealis, Baird, (great northern shrike:)

\begin{tabular}{|c|c|c|c|c|}
\hline iv. Catalogue- & Sex. & Date. & $\begin{array}{l}\text { Measure- } \\
\text { ments. }\end{array}$ & Locality. \\
\hline cesto & 8 & Oet. 12,1872 & $10 \xi \times 14 \xi$ & Fort Hall, Idaho. \\
\hline
\end{tabular}

Hab.-Northern regions, from Atlantic to Pacife; is winter south, through most of the United States.

As the shrike or butcher-bird is confined to the cooler portions of Imeriea, it was net with by our party but once, and that was in Octo. ber, at Fort Hall, Idaho Territory. There I securegl one specimen, No. $-97,(62 * 270$.

Collurio cxcubitoroides, Baird, (white-rumpel shrike:)

\begin{tabular}{|c|c|c|c|c|c|}
\hline Nin. & $\begin{array}{l}\text { Catalogue. } \\
\text { number. }\end{array}$ & Sex. & Date. & $\begin{array}{l}\text { Measure- } \\
\text { ments. }\end{array}$ & Locality. \\
\hline $\begin{array}{c}43 \\
31\end{array}$ & 61752 & $\begin{array}{l}? \\
0\end{array}$ & $\begin{array}{l}\text { June 11, } 1672 \\
\text { Oct. } 13,1672\end{array}$ & $\begin{array}{l}8 i \times 12 i \\
8 \times 12 i\end{array}$ & $\begin{array}{l}\text { S.At Lake, Utah. } \\
\text { Fort Hall, Jaho. }\end{array}$ \\
\hline
\end{tabular}

Hab.-Missonri plains and fur countries to Pacific coast ; eastward into Wisconsin, Illinois, and Michigan. (f)

Salt Lake and Fort Hall are the only localities at which I found the white-rumped shrike. At the former place, on the 11th of Juue, I saw a pair of them, and succeeded in shooting tha female-No. 43, (61752.) It is evident, from the lateness of the season, that they breed here. 
Poocaetes gramineus, var. confinis, Baird, (grass-finch:)

\begin{tabular}{|c|c|c|c|c|c|c|}
\hline No. & $\begin{array}{l}\text { Catalogue- } \\
\text { nutuber. }\end{array}$ & Sex. & Date. & $\begin{array}{l}\text { Measure- } \\
\text { ments. }\end{array}$ & $\begin{array}{l}\text { No. of nest } \\
\text { and eggx. }\end{array}$ & Locality. \\
\hline $\begin{array}{r}4 \\
6 \\
35 \\
91 \\
151 \\
152 \\
242\end{array}$ & $\begin{array}{l}61674 \\
61675 \\
61676 \\
61677 \\
61778 \\
61777 \\
62008\end{array}$ & $\frac{\overline{8}}{\frac{8}{8}}$ & $\begin{array}{lr}\text { June } & 5,1872 \\
\text { Juue } & 5,1872 \\
\text { June } & 8,1672 \\
\text { Juue } 17,1872 \\
\text { July } 7,1072 \\
\text { July } 7,1872 \\
\text { Aug, } 2,1672\end{array}$ & 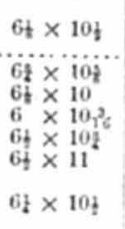 & $\begin{array}{r}10 \\
7\end{array}$ & $\begin{array}{l}\text { Ogden, Utab. } \\
\text { Do. } \\
\text { Do. } \\
\text { Salt Lake, Utab. } \\
\text { Fort Hall, Idaho. } \\
\text { Do. } \\
\text { Lower Geyser Bavin, } \\
\text { Wyo. } \\
\text { Shoshoue Lake, Wyo. }\end{array}$ \\
\hline
\end{tabular}

Hab.-High central plaius to the Pacitic.

This bird-a mere western variety of our common grass-finch or bay wingel buntiug, ( $P$. gramineus - is a very common species at Salt Lake, and in fact it was common all along our route, except in the densely.

I found several nests of these birds. They were placed on the ground-generally under a sage-brush-and were composed of grass, laid rudely together. They lay four or five light-colored, spotted eggs
in the sarly part of June.

Chondestes grammaca, Bonap', (lark-fiuch :)

\begin{tabular}{|c|c|c|c|c|c|c|}
\hline So. & $\begin{array}{c}\text { Catalogue- } \\
\text { number. }\end{array}$ & Sex. & Date. & $\begin{array}{l}\text { Measure- } \\
\text { ments. }\end{array}$ & No. of nest. & Locality. \\
\hline $\begin{array}{l}24 \\
6 \\
65 \\
35 \\
94 \\
124 \\
241\end{array}$ & $\begin{array}{l}\text { 6160\% } \\
61600 \\
61630 \\
61671 \\
61726 \\
62007\end{array}$ & $\begin{array}{l}8 \\
8 \\
8 \\
8 \\
\frac{8}{8} \\
8\end{array}$ & 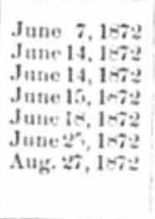 & 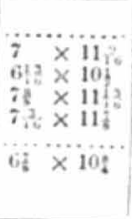 & $\begin{array}{l} \\
\cdots \\
\cdots \\
\cdots \\
\cdots \\
\cdots\end{array}$ & $\begin{array}{l}\text { Ogilen, Utah. } \\
\text { Do. } \\
\text { Do. } \\
\text { Do. } \\
\text { Do. } \\
\text { Bear Biver, Utah. } \\
\text { Lower Geyset Basin, } \\
\text { Wyo. }\end{array}$ \\
\hline
\end{tabular}

Hab.-From Wisconsin and the prairies of Illinois (also in Michigan,) to the Pacific coast ; south to Texas and Mexico.

This plain but rich-colored sparrow is quite abundant at Ogden, and from there to Snake liver. It is also commond and Wyoming Territory, where I obtained one specim at Fire-Hole Basin, collected the nest of the lirk fiuch on the 1 theimen, No.241, (62307.) 1 similar in material and situation to that just deseribed, and contained fon that of the grass-tinch. ( $P$. confinis) as the phed, and contained tive fresh eggo.

As the plumage of this bird is richer and deeper than that of the grass finch, so are its eggs much more beautiful, their spots and mark.
ings being darker and more distinct.
Zonotrichia leucophrys, Sw., (white-crowned sparrow:)

\begin{tabular}{|c|c|c|c|c|c|}
\hline No. & $\begin{array}{l}\text { Catalogue- } \\
\text { untaber. }\end{array}$ & Sex. & Date. & $\begin{array}{c}\text { Measur. } \\
\text { ments. } \\
\text {. }\end{array}$ & Locality. \\
\hline $\begin{array}{l}225 \\
202 \\
2 \times 3\end{array}$ & $\begin{array}{l}62300 \\
62001 \\
62302\end{array}$ & $z_{\delta}$ & $\begin{array}{l}\text { Ang. 12,1672 } \\
\text { Sept. 12,1672 } \\
\text { Sept. } 23,1872\end{array}$ & $\begin{array}{l}62 \times 10 \\
7 \times 10 \\
7 \times 98\end{array}$ & $\begin{array}{l}\text { Madison River, Mont. } \\
\text { Lewis's Lake, ivyo. } \\
\text { Suake River, Wyo. }\end{array}$ \\
\hline
\end{tabular}

Hab.--United States from Atlantic to the Rocky Mountains, where they become mixed up with $Z$. gambelli Greenland, Reinhardt.

Ifadison River was the first place on our route where we met with this fineh. There they were quite abundant. as they were at Lewis's Lake, where I obtained a fine specimen in winter plumage. Here they were very shy, and it was with great difficulty that I secured a single specimen. We also found them in considerable numbers along Snake siver.

Zonotrichia gambelii, Gambel, (Gambel's finch :)

\begin{tabular}{c|c|c|c|c|c}
\hline Ni. & $\begin{array}{c}\text { Catalogue- } \\
\text { number. }\end{array}$ & Sex. & Date. & $\begin{array}{c}\text { Measure- } \\
\text { ments. }\end{array}$ & Lxality. \\
\hline 500 & 62299 & 0 & Oct. $13,1 \times \% 2$ & $6 \$ \times 8 \%$ & Fort Hall, Idahe
\end{tabular}

Hab.-Rocky Mountsins to the Pacifie const.

We met with a few flocks of these birds at Yellowstone Lake, and at Fort Hall, where I obtained one specimen, No. 300, (62299.) This spe. cies is aimost exactly like the preceding, $Z$. leucophrys, the only notice. able difference being in the black stripe on the side of the crown, which, in leucophrys, passes down over the npper half of the lores and in front of the eve, sending back a short brauch to it, which cuts off the white superciliary stripe. In Z.gambelii the superciliary stripe passes conting. ously forwarl to the lores, cutting off the black from the eye. In habits it resembles the white-crowned tinch just described.

Junco oregonus, Sclater., (pink-sided suow-bird:)

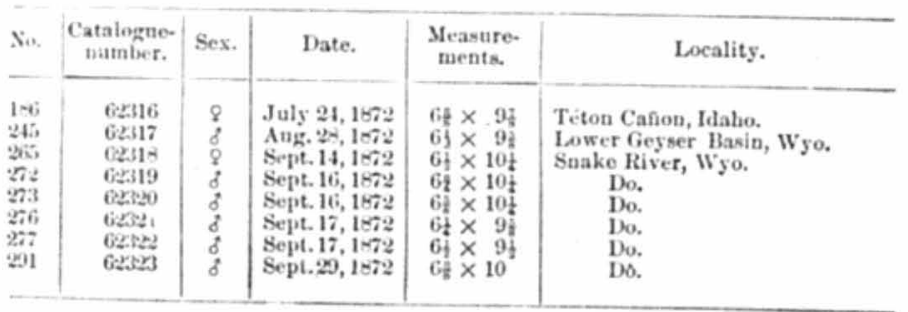

Hab.-Pạcific coast of the United States to the eastern side of the Rocky Mountains; stragglers as far east as Fort Leavenworth in winter
and Great Bend of Missouri. 
We first met with the pink-sided snow-bird at Téton Cañon, where I secured one specimen, No. 186, (62316.) After this they were very plenti. ful all along our route, until we emerged from the pine forests and once more entered the sage-brush plains. We generally found them in flocks of from fifteen to twenty, moving about from tree to tree in search of their food.

One day, while out shooting in the Lower Geyser Basin, I saw a snow. bird in a pine tree. I fired and it fell, and supposing it to be dead, I searched about on the ground, under the limb on which it had been sit. ting, but found no traces of it. I at last discovered a small feather on the edge of a inouse-bole, and thinking that the wounded bird might have taken refuge in this subterranean abode, I commenced digging after him with my fingers; I had not gone far before I thonght I felt feuthers abead grasping them with my thumb and finger, I commenced pulling; the biri came a little way, then, making a violent effort, escaped farther into the hole, leaving in my hand two tail-feathers.

Having no impiements to dig with, except those with which nature had provided me, I was compelled to give up the chase.

Spizella socialis, Bonap., (chipping sparrow:)

\begin{tabular}{|c|c|c|c|c|c|}
\hline No. & $\begin{array}{c}\text { Catalogue- } \\
\text { number. }\end{array}$ & Sex. & Date. & $\begin{array}{l}\text { Measure- } \\
\text { ments. }\end{array}$ & Locality. \\
\hline $\begin{array}{l}153 \\
178 \\
243 \\
2060 \\
252 \\
970\end{array}$ & $\begin{array}{l}61779 \\
62511 \\
62312 \\
62313 \\
62515 \\
62314\end{array}$ & $\begin{array}{l}0 \\
0 \\
8 \\
8 \\
3 \\
0 \\
8 \\
8\end{array}$ & 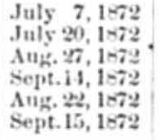 & 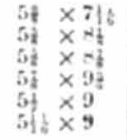 & $\begin{array}{l}\text { Fort Hall, Idaho, } \\
\text { Conant Creek, Llaho. } \\
\text { Lower Geyser lasin, Wyo. } \\
\text { Snake River, Wyo. } \\
\text { Yellowntone River, Wyo. } \\
\text { Suake River, Wyo. }\end{array}$ \\
\hline
\end{tabular}

Hab.-North America, from Atlautic to Pacific.

Our common ehipping sparrow is too well known to need description.

Melospiza fallax, Bairl, (mountain song-sparrow :)

\begin{tabular}{|c|c|c|c|c|c|}
\hline No. & $\begin{array}{l}\text { Catalogne- } \\
\text { nutnber. }\end{array}$ & sex. & Date. & $\begin{array}{l}\text { Measure- } \\
\text { ments. }\end{array}$ & Locality. \\
\hline $\begin{array}{r}63 \\
175 \\
293 \\
299 \\
304\end{array}$ & $\begin{array}{l}61673 \\
62503 \\
62504 \\
62505 \\
62506\end{array}$ & $\frac{\frac{8}{9}}{8}$ & $\begin{array}{l}\text { June } 14,1072 \\
\text { July } 10,1072 \\
\text { Oet. } 12,1072 \\
\text { Oet. 13, } 1072 \\
\text { Oct. 14,1 1 72 }\end{array}$ & $\begin{array}{l}675 \times 84 \\
64 \times 84 \\
64 \times 8 \\
65 \times 84\end{array}$ & $\begin{array}{l}\text { Ogdeb, Utah. } \\
\text { North Fork, Ilaho. } \\
\text { Fort Hall, Ilaho. } \\
\text { Do. } \\
\text { Do. }\end{array}$ \\
\hline
\end{tabular}

Hab.-Rocky Mountain region from Fort Thorn to the Colorado.

The mountain song-sparrow was common at Ogden, as it was at Fort Hall and on the North Fork of Snake River. I found several nests of this bird at Ogden, about the 1st of June. They were bnilt in a clurap of bushes in a marsh, about six feet above the ground, were composed of dry grass and rushes, and contained four to six eggs.
(Sub-family Spizina.)

Guiraca melanocophala, Sw., (black-hesded grosbeak :)

\begin{tabular}{|c|c|c|c|c|c|c|}
\hline Nia. & $\begin{array}{l}\text { Catalogne- } \\
\text { number. }\end{array}$ & Sex. & Date. & $\begin{array}{l}\text { Measure- } \\
\text { ments. }\end{array}$ & $\begin{array}{l}\text { Number } \\
\text { of nest. }\end{array}$ & Locality. \\
\hline 5 & 61605 & $d$ & June 5,1872 & $8 t \times 121\}$ & & Ogden, Utah. \\
\hline 16 & $\begin{array}{l}61686 \\
61697\end{array}$ & $\bar{s}$ & $\begin{array}{l}\text { June } 6,1072 \\
\text { June } 7,1999\end{array}$ & n.............. & & Do. \\
\hline pl & $\begin{array}{l}61607 \\
61600\end{array}$ & 8 & June 8, 1872 & $8 \times 12+6$ & & $\begin{array}{l}\text { Do. } \\
\text { Do. }\end{array}$ \\
\hline & 61609 & o. & June 8, 1872 & $81 \times 12$ & n............. & Do. \\
\hline 52 & 61690 & s & Jutae 12, 1672 & $475 \times 12$ & …......... & Do. \\
\hline $1=0$ & 62874 & 8 & July 22,1872 & $8 t \times 12 t$ & 63 & Téton Basin, Idaho. \\
\hline
\end{tabular}

Hab.-High central plain from the Yellowstone to the Pacific. Tablelands of Mexico.

Black-headed grosbeaks are quite numerous among the scrub-oaks at the foot of the Wahsatch Mountains. Here I obtained six good speci. mens. I obtained one of their nests at the First Cottonwood Creek, Teton Basin, Idaho Territory, on the 2:d of Jnly. It was on a cotton. wood sapling, about five feet above the ground, and was composed of pieces of grass and vines laid earelessly together, with their ends stick. ing out four or five iuches; it contuined two fresh eggs-No. 63, (16317, ) No. 180 shot. They are peculiar in their habits: sometimes yon may hunt half a day without getting more than a glimpse at them, as they tit about from bush to bush, yet their song, which at times is searcely distinguishable from that of our common eat-bird, (Galeoscoptes Caro. linensis,) seldom escapes your ears; at other times you canuot walk about for ten mintes without seeing several of them perched up on the ton of the highest bushes near by, entertaining yon with their song, without evincing the slightest symptoms of fear.

Cyanospiza amana, Baird, (lazuli finch:)

\begin{tabular}{|c|c|c|c|c|c|c|}
\hline No. & $\begin{array}{l}\text { Catalogue- } \\
\text { number. }\end{array}$ & Sex. & Date. & $\begin{array}{c}\text { Measure- } \\
\text { ments. }\end{array}$ & $\begin{array}{l}\text { Number } \\
\text { of nest. }\end{array}$ & Locality. \\
\hline 13 & 61691 & 8 & June 7,1072 & & & Ogden, Itah. \\
\hline$* 2$ & $616 \% 2$ & $d$ & June $\div 1872$ & & & Do. \\
\hline 然 & $\begin{array}{l}61683 \\
61623\end{array}$ & $\&$ & June $8,1+72$ & $6 \times 93$ & & Do. \\
\hline$\approx *$ & $\begin{array}{l}61634 \\
61695\end{array}$ & is & $\begin{array}{l}\text { June } 4,1072 \\
\text { June } 9,1<72\end{array}$ & $\begin{array}{l}5 \times 9 \\
5 \times 9\end{array}$ & .. & Do. \\
\hline $4:$ & 61696 & si & June 11,1072 & $5 \times 9\}$ &. & $\begin{array}{l}\text { Do. } \\
\text { Do. }\end{array}$ \\
\hline Hi: & 61000 & 8 & June 11,102 & $5 \frac{1}{5} \times 9$ & & Do. \\
\hline 4: & 61027 & i & June 11, 1072 & $6 \times 94$ & ....... & Do. \\
\hline s. & $616 \%$ & 8 & Jnue 11,1872 & $54 \times 9 \frac{1}{2}$ & & Do. \\
\hline 49 & $61: 09$ & \& & June 11,1072 & $6 \times 9 \%$ & & Do. \\
\hline (i) & 61701 & 8 & June 11, 1 102 & $54 \times$ is & & Do. \\
\hline 61 & 61702 & 8 & June $14,15 \% 2$ & $516 \times 9$ & & Do. \\
\hline 65 & $61: 03$ & q & June 14,1072 & $36 \times 4$ & 6 & Do. \\
\hline$\therefore$ & $61: 04$ & \&. & June 14, 1672 & $5 \times 9$ & …....... & Do. \\
\hline 82 & 61105 & \& & Jane 14,1872 & $5+5 \times 87$ & ……..... & Do. \\
\hline 73 & 61700 & \& & Jube 15, 1e\&2 & $5 \times 9$ & ............. & Do. \\
\hline 34 & 61507 & 8 & Jnne 15,1572 & $51 \times 016$ & ......... & Do. \\
\hline 86 & 61703 & \& & June 17, 1672 & $5+\times 8$ & …........ & Do. \\
\hline 114 & 61709 & 3 & June 20,1872 & $5+x+i$ & ............. & Do. \\
\hline 116 & 61710 & 8 & June 20,1872 & $58 \times 916$ & ........... & Do. \\
\hline 117 & 61711 & \& & June 20,1572 & $5 \times 916$ & $\cdots \cdots \cdots$ & Do. \\
\hline $\begin{array}{l}118 \\
183\end{array}$ & $\begin{array}{l}61712 \\
62324\end{array}$ & 8 & $\begin{array}{l}\text { June } 20,1879 \\
\text { July } 22,1-72\end{array}$ & $\begin{array}{l}54 \times 84 \\
51 \times 9\end{array}$ & …........ & Do, \\
\hline & & & July $22,1 \in 72$ & & & Tóton Basin, Idaho. \\
\hline
\end{tabular}

Hab.-High ventral plains from the Rocky Mountains to the Pacific. 
The lazuli finch, or blue linnet, is very common near Ogden, and in the bushes that borler some of the streams in Téton Basin. There are but few of our western bir's that rival or evell equal this handsome little bird, either in beanty of plumage or sweeth ss of voice. They are greenish blue above, the heal and neek being of the same color; the upper part of the breast is eluestunt, separated from the throat by a fain whitecresent, and the belly is white. They seem to take great delight in perching themselves ap amony the branches of some serub oaks, hot fit apart, trying to see who shall exeel the other in pouring forth their sweet melodies.

I obtainit three mests of this neweiss at Oaden; one, No, S, (16283, was ou a serub-oak about three feet high, and the other two, Nos

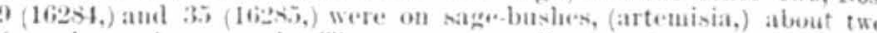
reet above the groumi. The egge, generally four in mumber, are haid

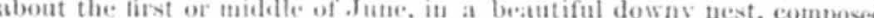
of fibrous grasises atul wool, lined with hair.

Pipilo megelony, Batird, (spurred towhee.)

\begin{tabular}{|c|c|c|c|c|c|c|}
\hline No. & 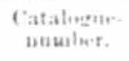 & $\because x$. & Date. & $\begin{array}{c}\text { Meand } \\
\text { motht. }\end{array}$ & 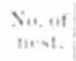 & Ioncality. \\
\hline s & 61eis- & \& & Jus $71-8$ & & & Bleterta, I'tah. \\
\hline$: z$ & bitis? & d & Jutu n, iriz & $-1 c \times 11 \%$ & & Ins. \\
\hline 50 & (Iflin-1) & is & Jute $1: 1,1-2$ & $-1 \times 11$ & a1 & $1 \%$ \\
\hline $5 i$ & filti-1 & 8 & Jute 1: $1-8$ & $\Rightarrow \times 11$. & 32 & 14. \\
\hline 67 & & 3 & Juav $14,1-6$ & $-x 11+$ & & lis. \\
\hline e) & Gillo- & : & Iatue $11,1-7$ & $\because \times 11$ & 34 & in. \\
\hline$\%$ & Giti- -3 & , & Bute lis, $1-70$ & $-i \times 11$ & & is. \\
\hline 119 & GH:-1 & s & $J$ & $\because \times 114$ & & 1) \\
\hline
\end{tabular}

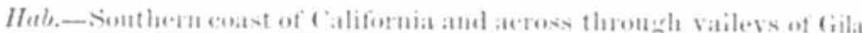

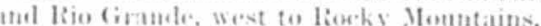

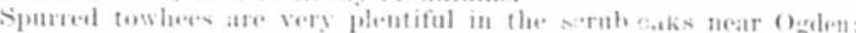
we saw none elsewhere. In habits they greatly resemble the blach

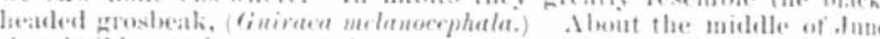
they build a rule mest of dry grass ant leaves: this is plated on the

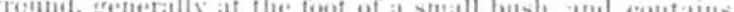
lipht-iolored ewas, spotted with reddish brown.

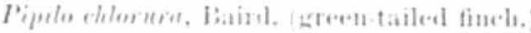

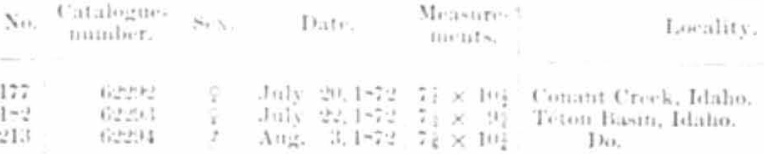

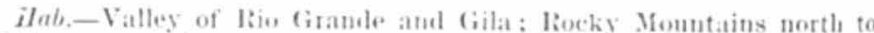
Yellowstone laike: semth to Vovieo.

We did not meet with this species in abundance at any locality on our route.
Family 17.-ALACDIDA, THE LAIKS.

Fremophila cormuta, Boie., (honed sky.lark.

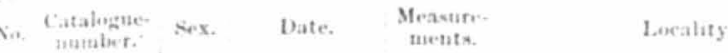

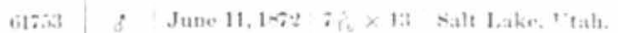

Hab.-Everywlere on the praties and desert plains of North America Alantie States in winter.

The lorued lark is met with in preater abumblance than any ether bind on rut great western plains. They are very tame, often letting you pass whim six or eight fect of them without ipsearing distmbed, and then dary genetally run a little to one sule instead of taking thight.

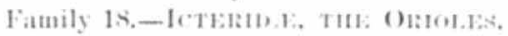

Sub-fauily Ieterina, the Griwles proper.

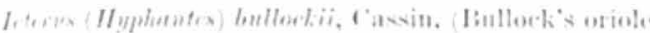

\begin{tabular}{|c|c|c|c|c|c|c|}
\hline 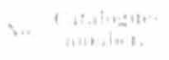 & $\therefore .1$ & & fats. & $\begin{array}{l}\text { Movure } \\
\text { Hette }\end{array}$ & $\begin{array}{c}\text { Nonalewe of } \\
\text { ne-t. }\end{array}$ & Lamainty. \\
\hline$+1: 1: 4$ & 8 & Ju世 & $\therefore 1-2$ & & $\because(1+;: 31)$ & 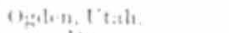 \\
\hline $1,1: 11$ & & Jatu- & $\therefore 1+2$ & & (1) (10itiz) & Iro. \\
\hline $61: 11$ & $t$ & Inme & $1,1-2: 2$ & & $1:(16263)$ & L.o. \\
\hline +4:15: & is & Inu. & 1., $1-2: 2$ & & 1.: (listis) & $1 \%$ \\
\hline $4=1218$ & $z$ & Into. & ti, $1-2: 2$ & $\times 1: 1$ & it (1tig,ti) & b... \\
\hline$+4: 1=$ & i & I Ian. & $7.1-2:$ & & $19(1+2,4 \pi)$ & Ih. \\
\hline (.1:1:1 & : & lum. & $1 \div 1-\cdots$ & $\times 1:$ & $\because(1054-)$ & in \\
\hline$+11: 34$ & $i$ & Intar & $1 \because 1-23$ & $\times 11$ & (a) (1,202) & I $1,0$. \\
\hline n1:?1 & $?$ & Juse & $11.1=2$ & $\times 11$ & an (1+igon) & in., \\
\hline nit:2 & 3 & Itus: & $1-1-20$ & $=\times 1=$ & $1-(1602-)$ & 1).. \\
\hline $1.17 \%$ & 2 & futue & $1-.1-2: 2$ & $-1 \times 12_{2}$ & & ino \\
\hline 1.121 & & Inum & $1-1-20$ & $\because \times \mathrm{Ii}_{6}$ & & in... \\
\hline $1,17 \cdots$ & $z$ & Tuter & $34,1-29$ & $\because \times 1 \div$ & & lowil-ficek thalwo. \\
\hline $1,17-1$ & 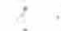 & Inti. & $2-1-2$ & $\times 121$ & & the. \\
\hline$+1,1 ;-1$ & ¿ & Intw & $\because-1<* \because$ & $-\times 1: 4$ & & Ino. \\
\hline$n+1 ;-5$ & & Inн & $\because-1-2 \because$ & $-\quad \times 1: 3$ & & [b.. \\
\hline
\end{tabular}

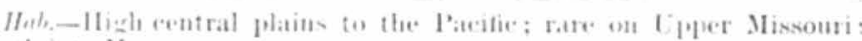
with into Yi:xieo.

The westerts oriole, in my opinion at least, is the most beantiful of all ont western birds. They are very abumiant in a laree marsh between 1).

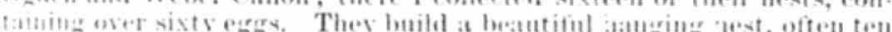

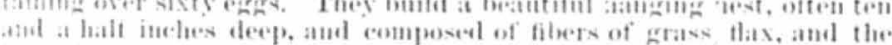
inter lark of vines, and are gererally lised with wool. The tirst lot

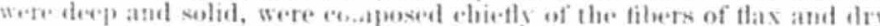

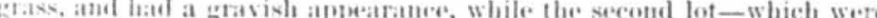

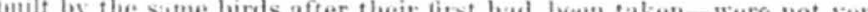
deep, had evidently treen made in havte, and were prineipally composed of the inner bark of small bushes and vines. fiving them a hownish lowk. They generally conceal their ne-ste amonge the leases on the tol at a willow, from right to ten feet above the groumb, in such a position hat it rocks to and fro whenever there is a lithle wind. 
(Sub-family Agelaina, the Sta-lings.)

Dolichonyx oryzitorus, (bobolink ; reed-bird :)

\begin{tabular}{|c|c|c|c|c|c|}
\hline No. & $\begin{array}{c}\text { Cataiogue- } \\
\text { number. }\end{array}$ & s.x. & Date. & $\begin{array}{c}\text { Measuro- } \\
\text { ments. }\end{array}$ & Locality. \\
\hline $\begin{array}{r}85 \\
97 \\
101\end{array}$ & $\begin{array}{l}61720 \\
017: 00 \\
617: 0\end{array}$ & $\begin{array}{l}d \\
q \\
q \\
8\end{array}$ & $\begin{array}{l}\text { June } 17,1072 \\
\text { Juwe } 1 \approx, 1072 \\
\text { Jutue } 18,1082\end{array}$ & 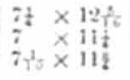 & $\begin{array}{c}\text { Ogden, Utah. } \\
\text { Ioo. } \\
\text { Do, }\end{array}$ \\
\hline
\end{tabular}

Hab.-Eastern North America to Rocky Mountains; westwari, to Salt Lake and bast Humbolelt Mountains.

The only place on our ronte where we met with these birds was in the Great Salt Lake Valley; here they were quite abundant.

Agelaius phaniceus, Virill., (red-winged slackbird:)

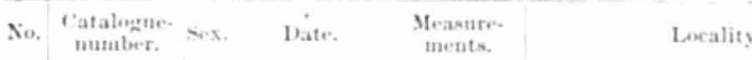

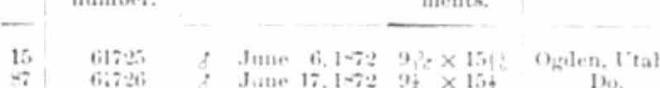

Mab.-Cnited States, from Atlantic to Pacific.

lied.winged blackbirds were very common near Ogden, whete ther were beeding. This, as well as the preceding species, is too common to need deseription.

Ianthocephalus icterorphalus. Baird, (yellow-headed blackbird

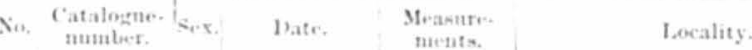

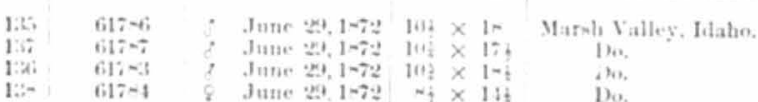

IIab.-Western America, from Texas, Illinois, Wisconsin, and North Rea liver to California, south into Mesico. Greenland, Reinhardt.

I saw a few yellow-headed blackbirds in a marsh near Salt Lake. The only other plice where we found them was at Marsh Creek, near Car penter's lanch, Idaho Territory. IIere I obtained four good specimens and one nest. The nest was fastened to a clump of rushes in a marsh, about five feet above the water, and was composed of dry swamp-gras It had no lining, and presented the same appearance inside as out. it was very solid, and contained four nearly fresh eggs of a light greenis color, evered with darker spots.

\begin{tabular}{|c|c|c|c|c|c|c|}
\hline No. & $\begin{array}{l}\text { Catalogue- } \\
\text { vumber. }\end{array}$ & $\operatorname{sex}$. & Date. & $\begin{array}{l}\text { Measure. } \\
\text { ments. }\end{array}$ & No, of nest. & Locahity. \\
\hline $\begin{array}{r}3 \\
13\end{array}$ & $\begin{array}{l}61733 \\
61752\end{array}$ & $\stackrel{8}{8}$ & $\begin{array}{ll}\text { June } & 5,1072 \\
\text { Jane } & 6,1072\end{array}$ & & $\begin{array}{c}6(16277) \\
\ldots . . \cdots \cdots\end{array}$ & $\begin{array}{c}\text { Ogden, Utab. } \\
\text { Do. }\end{array}$ \\
\hline
\end{tabular}

Sturnella noglecta, Aud., (westeru lark:)

IIab,-Western America, from high central plains to the Pacific; east 1.) Petubina, Dakota.

The western lark, a mere variety of our common eastern meadow lark, (S. matgua,) from which it is scarcely distinguishable by the casual nbserver, is as common west of the locky Mountains as the latter eneries is in our Easiern States. The song of the two birds is, however, cutirels different. I procured three nests of this species at Ogden; fhe ditler essentially from those of our eastern species in being rudely coustrueted of dry grass placed loovely in a little hole in the ground, with constructed of dry grass placed loovely in a little hole in the ground, with
no aim at concialment, while our meadow lark builds a neat covered nest perfeetly concealed in a bunch of grass. The eggs closely resemble these of s. matyon.

(Sub-family Quiscaline, the Crove Blaclbiris.)

Sorolecophatars cyanocephalus, Cab., (Brewer's blackbiral:)

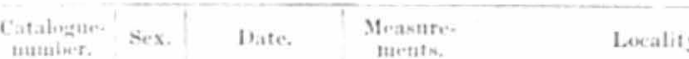

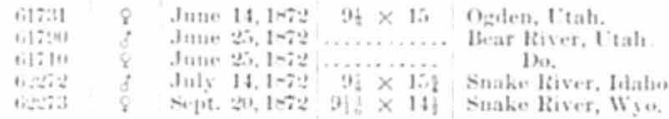

Mab,-Migh central plans to the Pacific, south to Mexico; Pembina, Dilioutit.

Birewer blackbird, west of the Recky Mountains, takes the place of wh comtuon rusty blackbiri, (S. ferrmgineus, ) which it closely resembles. W. met with them in abundance at nearly all points on our rote, al. dhatint they were not so common in the densely- Wooded regioms on the mometime is they were atmeng the husies and cottonwoods bovlering the streatus and rivers that run through , a dry, arid plaius, Thes

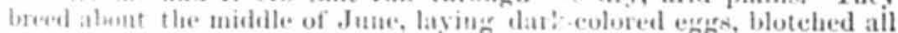
oser with datk brown anel pheoblate.

$$
\text { Family 19.-Convm A, Tue Crows. }
$$

(Sub-family Garrulina, the Jays.)

Pict hudsonich, Bonap., (common magpie:)

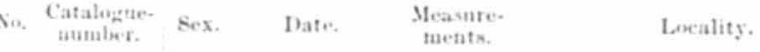

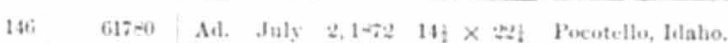

Hab--Aretic regions of North America; United States, from the high central plains to the Pacific, north of California. 
At Ogden I found an old nest of this bird, showing that they had re. cently lived here. They are still quite abundant in Ogden Caũon, and at many other places in the Wahsateh Range near Ogden. Port Neuf Cañon is th" tirst place where we found magpies. Here they were very common, as they were at Pocotello, where I obtained a good specimen, No. 146 (61700. 1 also saw a few at Fort Hall and on Snake River, abont forty miles above the fort. We saw none after this until on our return, when we met them on snake River, cast of the Titons. Afte this they were common all the way down till we arrived within about fitty miles of Ogden.

Cyanurat macrolopin', Bairil, (longecrested jay:

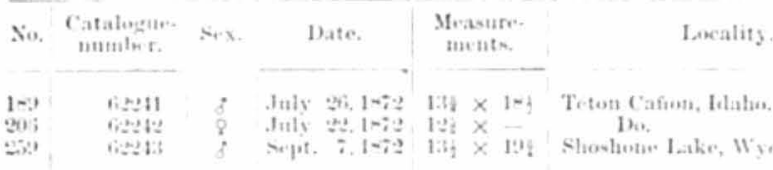

Hab,-Central line of Rocky Mountains to table lands of Mexic

This splenticl bird is $\mathrm{t}_{1}$. Rocky Mountain representative of Stellerjay. ( $($. stelleri, which it diflers trom, principally, in having a whit spot weer the cye, the erest being longer and fuller, the streaks on fhe forebead being white insteal of greenish blue, and the whole head being darker.

The lengerested jay is not an uncommon bird in the Wahsateh Moun ains. They are quite numerous, however, in the Teton lange, where oistimes two specimens.

At sheshene Lake, en the ith of Siptemler, I saw a tlock of abont

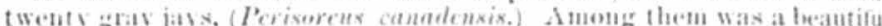

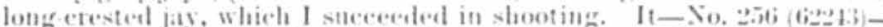

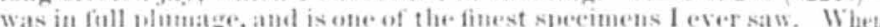
first disturbed they Hy about in an angry, seolding matuer, offering you at the shot ; lout fon inust not delay long, for they seon lese theris cun osity ind retire into the forest, keeping themselves hid atmeng the pine

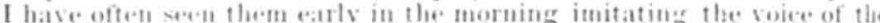

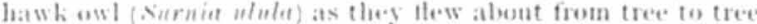

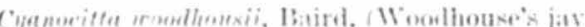

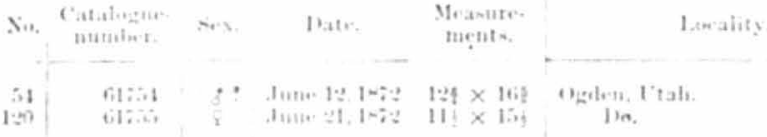

Hab.-Central line of lareky Mountains,

Woodhouse jas is aquite commen at the foot of the Walisateh lange. where I obtained two spreimens, the only ones that were seen by any of our party duriug the summer. They are the Roeks Mountain repres'nt ative of the (aliformit jay, $(C$. californica, which they greatly resemble

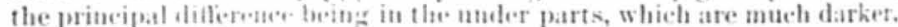
aud in the bill, wheh is lonser and more slemeler. They are looth weserth representative of the Florida jay, (C. flori $n a$,) which they elosely resemble, the chief points of difference being in the undertail coverts, which are white in the former and blue in the latter, and in the entire under parts, which are much darker in floridana than in californica. These slight differences are no greater than those caused in many other species by the great difference in climate and longitude.

Perisoreus canadensis, Bonap., (gray jay :)

\begin{tabular}{|c|c|c|c|c|c|}
\hline Sio. & $\begin{array}{l}\text { Catalogue- } \\
\text { thutaber. }\end{array}$ & Sox. & Date. & $\begin{array}{l}\text { Measure- } \\
\text { ments. }\end{array}$ & Locality. \\
\hline 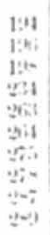 & 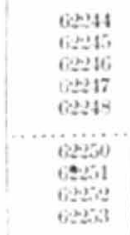 & $\begin{array}{l}\frac{8}{8} \\
8 \\
5 \\
8 \\
8 \\
8 \\
\frac{8}{8} \\
8\end{array}$ & 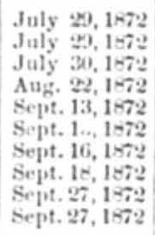 & $\begin{array}{l}114 \times 174 \\
11 \times \times 17 \\
1: 4 \times 17 \\
10 \times 17 \\
19 \times 18 \\
114 \times 17 \\
114 \times 14 \\
114 \times 16 \\
114 \times 17 \\
12 \times 1 \%\end{array}$ & 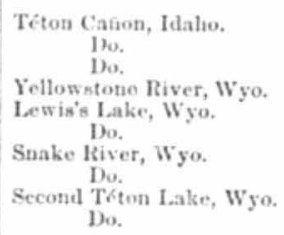 \\
\hline
\end{tabular}

Intb.-Northern Ameriea into the northern partis of Lnited States, from Atlantic to Pacific; more sonth in Rocks Mountains.

Wi. first met gray jays at the T'́ton Caũon, where they were guite numerons, as they were northward to the Grand Cañon of the Yellow. stone, and lown Snake River on the east side of the Teton Range. They were generally very tame, often alighting on a limb within ten feet of rie, thent, after eyeing me for a few moinents, would disappear in the tonest. I remember one occasion, near Yellowstone Lake, when these hirds catme about our camp, evidently in search of eatables, I cut of a fists small pieces of elli meat and seattered them about on the ground within a few feet of me; then one of the jays, which had beeu watehing me closely from a neighboring liml, darting down, seized a piece of the dimest and thes with it into a tree near by, and, after devouring it, cetmrted for more. I have often heard bunters and others state that they hat known these jays to be so bold as to light on their shoulders?

\section{(Section CLAMATORES, CRYING-BIRDS.}

Family 23.-TYranide, the Trrant Fly.cateuers,

Tyathus carolinensis, Baird, (king birl:)

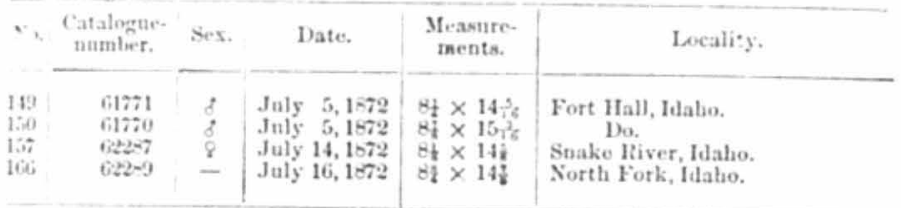

Iteb,-Entire continent of North Americi

We found king-birls quite common at Ogden, thence northward to Snake River, where I found one of their nests, No. 60, 16314 ;) it was on a rose bush, about four feet from the gronnd, and contained three fresh eggs. These birds must have raised one brood before this, as, tor days before, I fonn? a nest at Blackfoot River 'twenty-fice miles from here) that contained young birds that were nearly full. grown.

$$
44 \mathrm{G} \mathrm{s}
$$


Tyrannus rerticn/'s, Say, (Arkansas fly-eateher:)

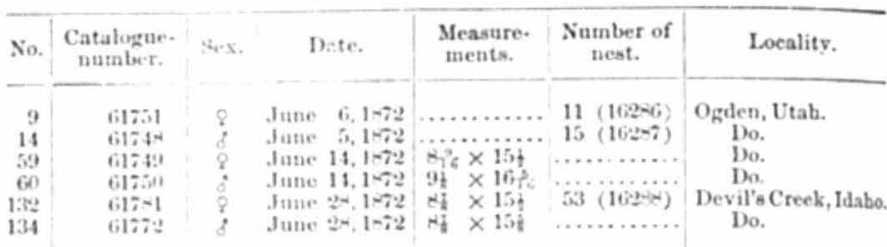

Hab.-Western Xorth Ameriea, from the high central plains to the Pacific.

Arkiusas llyeatchers are numerous in the Great Salt Lake Basin, as they are streams between Salt Lake and Fort IIall. From the 5th to the 2sth of June I collected four of their nests; they were placed on willows or cottonwools, from eight to fifteen feet above the ground; were com. posed of fibrous roots, pieces of dead sage-brush, (artemisia) dry grass, Ne., linel with wool and other soft substances. The first nest that found is really very beautiful, a well as curious; it is composed of fibrous roots, stallis of dry grass, rool, pieces of sage-brush, with here with a feather oreasionally showing itself: there is much wool on the ontside :and atl throngh the nest, giving it a soft, downy appearance This boutiful structure contained four cream-colored eggs, spotted with rendisli and datk brown, the spots being most numerous near the large end.

Tyranuus rocifreme, Sw., (Cassin's fly-cateher:

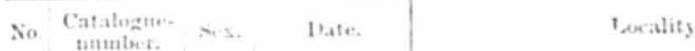

$$
\begin{aligned}
& \begin{array}{l|l|l|l|l|l}
\hline & 61 \% 4 & \& & \text { Mag } \% 9,1-72 & \text { Cheyente, Wyo. }
\end{array}
\end{aligned}
$$

Hab.-Peros liver, Texas, and into Mexico table-lauds; north th Cheyenne, Wyoming Territory.

Cherenue is the only place where I observed this species; there

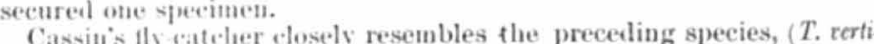
culis, ) but is a sily distinguished from it on comparison ; the yellow of the breist is luirhter, and the shoulders are more olivaceous; the bill the brest appreciable character, however, is seen in the tail. In rerticulix the whole outer weh of the external feather, incluting the shatt, is purely and abruptly yellowish white. In the species now muler romsicleration, the shaft of the outer tail-feather is dark brow? it souter websaud the tips of the other feathers being light brown, with the extreme enlores only being of a tolerably pure yellowish white.

Sayornis sayus, Baird, (Say's fly·cateher:)

\begin{tabular}{c|c|c|c|c|c}
\hline No. & $\begin{array}{c}\text { Catalogue } \\
\text { number. }\end{array}$ & Sex. & Date. & $\begin{array}{c}\text { Measnre- } \\
\text { meuts. }\end{array}$ & Locality. \\
\hline 122 & 61769 & $\delta$ & June $25,10 \% 2$ & $8 \times 13 \$$ & Bear River, Utah T. \\
\hline
\end{tabular}

Hab.-Missouri and central high plains westward to the Pacific and south to Mexico.

Bear liver is the only locality where this species was observed

Contopus borcalis, Baird, (olive-sided fly-catcher:)

\begin{tabular}{|c|c|c|c|c|c|}
\hline So. & $\begin{array}{l}\text { Catalogue- } \\
\text { natmber. }\end{array}$ & Sex. & Date. & $\begin{array}{l}\text { Measure- } \\
\text { meuts. }\end{array}$ & Locality. \\
\hline$\underset{100}{20}$ & $\begin{array}{l}61729 \\
6 \geq 2-9 \\
62800\end{array}$ & $\begin{array}{l}\delta \\
\vdots \\
\delta\end{array}$ & $\begin{array}{l}\text { June } 8,1-72 \\
\text { July } 27,1 \rightarrow-2 \\
\text { July } 27,1 \rightarrow 2\end{array}$ & $\begin{array}{l}712 \times 13 \\
72 \times 124 \\
74 \times 134\end{array}$ & $\begin{array}{c}\text { Ogten, litah. } \\
\text { Téton Cafon, Itaho. } \\
\text { Do. }\end{array}$ \\
\hline
\end{tabular}

Mab.-Rare on either coast. Not observed in the interior of the Luited states, except to the north. Found in Greenland, (Reiuhardt.) liut three specimens of this rare species were observed: one at Ogden, aud the other two at Téton Cañon.

Contupus richardsonii, Baird, (short-legged pewee:)

\begin{tabular}{|c|c|c|c|c|}
\hline $\begin{array}{l}\text { Catalegite- } \\
\text { uamle'r. }\end{array}$ & sex. & Date. & $\begin{array}{l}\text { Meanute- } \\
\text { tuebate. }\end{array}$ & Locality \\
\hline & $\frac{8}{8}$ & $\begin{array}{l}\text { Jnue } \\
\text { July } z\end{array}$ & $8 \times 10$ & then, Lt. \\
\hline
\end{tabular}

Hab,-High central dry plains to the Pacitie; Rio Grande Valley, Mab,- High central dry plams to the Pracion

The present species is a western race of our common wood pewee, $(C$. irens, which it is searcely distinguishable from except on comparison. The most appreciable diflerence is seen in the breast, which in Richard. sonii is nearly of a uniform olive brown, while in rirens the middle line of the breast is paler than the sides.

Eimpidonax pusillus, Cab., (little fly-eateher:)

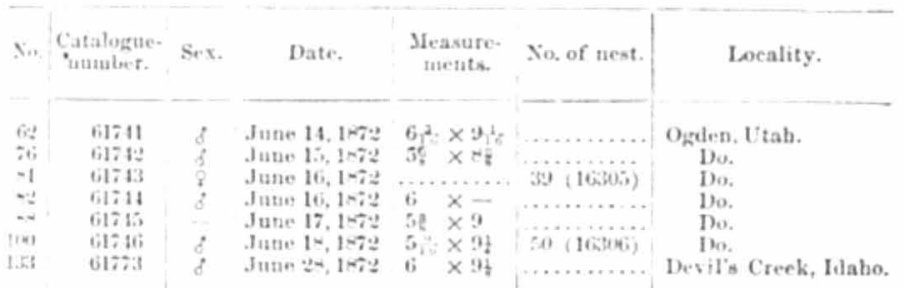

IIub-High central plains to the Pacifie; fur countries; sonthwari into Mexico.

This western race of $E$. traillii was very common in the Salt Lake Valley, where I collected seren specimens and three nests. They build it theat, compact little nest, which they place in the fork of a rose or other small bush, about five feet above the ground. It is composed of fibrous grasses, tlax, wool, and other soft substances, interworen with a fiw leaves of swamp-grass. It is a curions fact that this bird places all 
the wool and other soft, downy substances on the outside of its nest, lining it with the rough stalks of dry grass.

About the middle of June it lays four light cream.eolored eggs, spas. ingly spotted with dark reddish brown near the large c ad.

\section{Order 2.-STRISORES, SHRIEKING BIRDS.}

Family 28,-Alcedisid.E, THE KisGasming.

Ceryle aleyon, Boie., (belted kingfisher:)

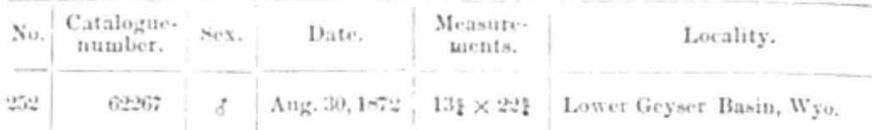

Hulb-The entire continent of North America.

Kingfishers were rare birts along our ronte, as this was the only specimen seen.

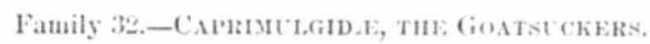

Aitrostomus uuttalli, Cassin, (1roor-will:

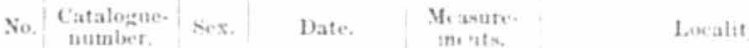

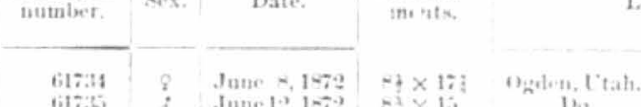

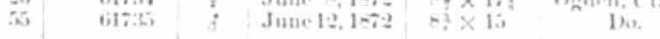

Hab.-High central plains to the Pacifie coast.

This rare bird was only found on the rocky slojes at the font of th. Wahsateh Mountains; here, on the 12th of June, 1 obtained their eggs; they were pure white withont spots, and were linid in a slight cavity is the bare ground, without any nest. They contained full grown embrgos and would doubtless have hatehed in a few hours. The male biri, No. $55(61735$,) was shot as he left the nest, and as the feathers were ror ofl his belly by sitting, it is evident that both male and female take part

\begin{tabular}{|c|c|c|c|c|c|}
\hline No. & $\begin{array}{l}\text { Cataloguce- } \\
\text { number. }\end{array}$ & Sex. & Date. & $\begin{array}{l}\text { Neasure- } \\
\text { inents. }\end{array}$ & Localicy. \\
\hline $\begin{array}{l}130 \\
169 \\
205 \\
230\end{array}$ & $\begin{array}{l}61755 \\
62254 \\
62255 \\
6225\end{array}$ & 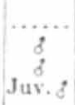 & $\begin{array}{l}\text { June } 29,1-72 \\
\text { July } 17,1872 \\
\text { July } 31,1-72 \\
\text { Aug. } 20,1072\end{array}$ & $\begin{array}{l}94 \times 23 \\
9 \times 23 \\
6 \% \times 16 \%\end{array}$ & $\begin{array}{l}\text { Marst. Creek, Idaho. } \\
\text { North Fork, Idaho. } \\
\text { Teton Cañon, Idaho. } \\
\text { Upper Geyser Basin, Wyo. }\end{array}$ \\
\hline
\end{tabular}
in the incubation.

Chordeiles henryi, Cassin, (western uight-hawk:)

Hab.-Rocky Mountains, from Saskatchewan to Yexico.
This Rocky Mountain race of our common night-hawk ( $P$. popetuc) wis quite common in the Salt Lake Basiu, thence north to Yellowstone Iate, where they were very numerous.

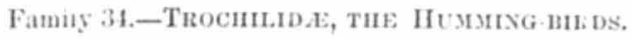

Trochilus alexandri, Boure. and Muls., (blackechinned humming-birel:)

Cafalogne- Sex. Date.
number.

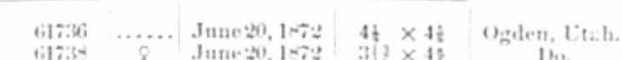

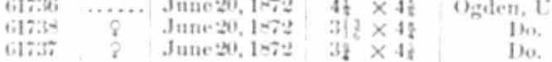

Itab,-California, Utah, Arizona, and southward.

IBat chinned lumming birds were not uneommon near (G)den, where 1 whained three specimens; they were breeding there, but I was unable iv dismer any of their nests.

\section{Stellute calliope, Gould, (calliope humming bird:)}

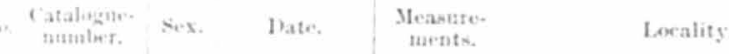

$$
\begin{aligned}
& \text { 11 fisal } 8 \text { July } 3,1-72 \mid 33 \times 4 \text { Fort Ellix, Mont }
\end{aligned}
$$

Mab--Monntains of Montana, Washington, Oregon, and Calitornia, (1) $11 .+\mathrm{sicos}$

This quecies was only observed at Fort Ellis, Montana Territory.

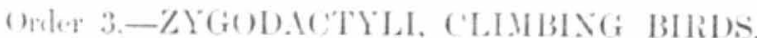

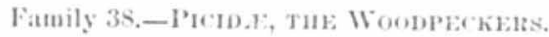

Pin hurrisii, Aud., (IIarris's woolpecker:)

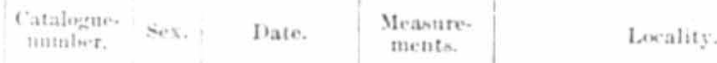

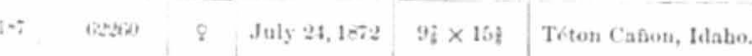

Ilni.-From the Pacific coast to the eastern slope of the Rocky Mountains.

This western race of $P$. rillosms was quite abumdant in the Toton Canon, thenee northwarl, following the pine forests, to Yellowstone Lake, and the heat-waters of Snake liver. 
Picoides arcticus, Gray, (three-toed woodpecker :)

\begin{tabular}{|c|c|c|c|c|c|}
\hline No. & $\begin{array}{l}\text { Catalogue- } \\
\text { nm+uber. }\end{array}$ & sex. & Date. & $\begin{array}{l}\text { Measure- } \\
\text { meuts. }\end{array}$ & Locality. \\
\hline 236 & $\cos 21$ & 8 & Aug. $50,10,2$ & - $45 \times 14 i$ & Lower Geyser Busin, Wyo. \\
\hline
\end{tabular}

Hab.-Northern portions of the Lnited States to the Aretie regions, from the Atlantic to the Pacitie.

But one specimen of this species was observed on our route.

Picoides dorsalis, Baird, (striped three-toed woodpecker:)

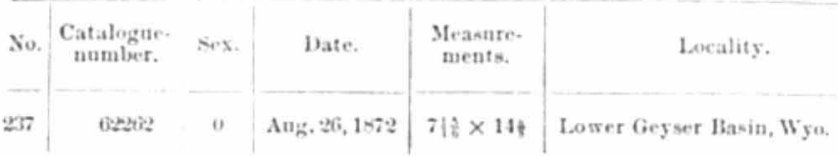

Hab.-Rocky. Mountain region.

One morning. while at breakfast, in the Lower Geyser Basin, I sar this and the preceding species busily engaged seatching for grubs in dead tree near camp. I took my gun and snceceded in slooting both birds. This also is the only specimen of its species seen during the summer.

sphyropicus trilliamsonii, Baird, (Williamson's woodpecker:)

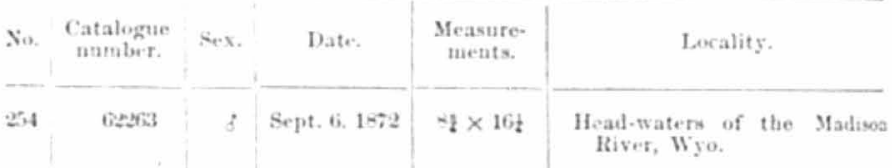

Hub.-Roeky Mountaius to the Cascade Mountains.

As we were crossing the main divide of the Rocky Mountains, on the 6 th of September, when the ground was covered with suow, I sueceeded in shooting the only specimen seen of this rare and beantiful rood peeker.

sphyropicts thyroideus, Baird, (brown-headed woodpecker:)

\begin{tabular}{|c|c|c|c|c|c|}
\hline No. & $\begin{array}{l}\text { Catalegue- } \\
\text { number. }\end{array}$ & sex. & Date. & $\begin{array}{l}\text { Measure. } \\
\text { ments. }\end{array}$ & Locality. \\
\hline 236 & $622=0$ & Juv: & Aug. 13, 1072 & $9 \times 15$ & Madison River, Mont. \\
\hline
\end{tabular}

Hab.-Wooded Rocky Mountain regions to Pacific slope.

This is another rare species, but two specimens of which were seen.
Melanerpes torquatus, Bonop., (Lewis's woodpecker:)

\begin{tabular}{|c|c|c|c|c|c|}
\hline Xv. & $\begin{array}{l}\text { Catalogna } \\
\text { natuler. }\end{array}$ & Sex. & Date. & $\begin{array}{c}\text { Measure. } \\
\text { ments. }\end{array}$ & Locality. \\
\hline $\begin{array}{l}1: \\
1 ; i \\
1 ; 4\end{array}$ & $\begin{array}{l}6250 \\
0250 \\
6256\end{array}$ & $\begin{array}{l}q \\
d \\
q\end{array}$ & $\begin{array}{l}\text { July } 17,1-72 \\
\text { July } 1-72 \\
\text { July } 1+1<72\end{array}$ & $\begin{array}{l}11 \times 211 \\
11 \times 21 \frac{1}{2} \\
103 \times 201\end{array}$ & $\begin{array}{c}\text { North Fork, llaho } \\
\text { De. } \\
\text { Do. }\end{array}$ \\
\hline
\end{tabular}

Iab.-Western America, from Black IIills to Pacific

Surth, of Henry's Fork of Suake River, is the ouly locality on our poute where this species was met with; here, on the ith of July, they were quite common, and very shy, and I pursued them for several hours before obtaining a specimen. On the 1sth, however, they were still more numerous, and I secured two specimens without much difliculty.

Colaptes mericanнx, Sw., (red-shafted flicker:)

\begin{tabular}{|c|c|c|c|c|}
\hline 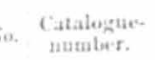 & six. & Date & $\begin{array}{l}\text { Measure } \\
\text { ments. }\end{array}$ & Lecality. \\
\hline tenst & $\underset{f}{q}$ & $\begin{array}{l}\text { July } 16,1-79 \\
\text { Sept 16,1 }\end{array}$ & $\begin{array}{l}11+\times 198 \\
13 \times 21\end{array}$ & $\begin{array}{l}\text { North Vork, Wlaho, } \\
\text { suabe River, Wyo. }\end{array}$ \\
\hline
\end{tabular}

Hob-Western North America, from IBack Ilills to l'acifie.

Ghis western tepresentative of $C$. auratus was met with at North Fork, Téton Cañon, and Suake River, but was not abundant at either of these places. At Lewis's Lake, however, they were quite numerous; there, on the 13th of sutember, I counted twenty-seven in one floek.

\section{()rier 4-RAPTORES. BIRIS UF PREY.}

$$
\text { Family 40.-STrignd, tm: OwLs. }
$$

otus rilseniauus, lexeon, (longerared owl:)

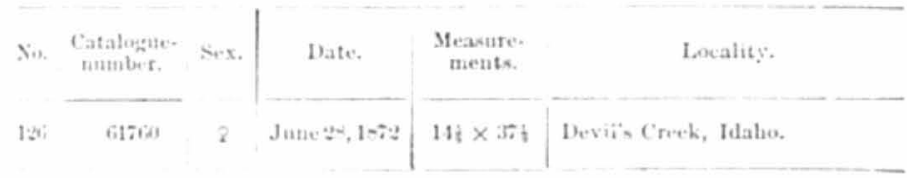

Iab-The whole of temperate Vorth Ameriea.

I shot this sprecimen of the long eared owl as it was sitting in a willow, directly under its nest, which was made of sticks about three eighths of an inch in diameter: it was about one foot deep and two feet in diame. ter: the nest was empty, the young having probably flown away. 
Athene hypugaa, Bonap., (prairie-owl:)

\begin{tabular}{|c|c|c|c|c|c|}
\hline No. & $\begin{array}{l}\text { Catalogue- } \\
\text { number. }\end{array}$ & s.x. & Date. & $\begin{array}{l}\text { Measure- } \\
\text { ments. }\end{array}$ & Locality. \\
\hline $\begin{array}{l}18 \\
1.25 \\
143 \\
148 \\
156\end{array}$ & $\begin{array}{l}61637 \\
61761 \\
61763 \\
61762 \\
61764\end{array}$ & $\begin{array}{c}8 \\
8 \\
5 \\
8 \\
8 \\
311 .\end{array}$ & $\begin{array}{l}\text { June } 9,1-72 \\
\text { Jume } 36,1-72 \\
\text { Inly } 1,1-72 \\
\text { July } 5,1-72 \\
\text { July } 9,1-72\end{array}$ & $\begin{array}{l}9+3 \times 27 c \\
9+24 \% \\
5 \times 16 \%\end{array}$ & $\begin{array}{l}\text { Ogden, Utah. } \\
\text { Malad Valley, Idaho. } \\
\text { Port Neuf Iiver, Idaho. } \\
\text { Fort IIall, Jaho. } \\
\text { Do. }\end{array}$ \\
\hline
\end{tabular}

Hab.-Prairies and other open portions of the United States, from the Mississippi to the Pacific.

These little owls were very plentiful on the great plains and prairies, between Omaha and the Black Hills. There they live and breed in the de serted holes of the prairiedogs, (Cynomys ludoricianus.) They went also quite numerous in the Salt Lake Valley and uorthward io Suak River; here they take up their abodes in the old holes of the badger (Taxiden americana, Waterh.) and coyote, (Canis latrans, Say.) Thes breed in May, laying pure white eggs.

Surnia ulula, Bonap., (hawk-owl:)

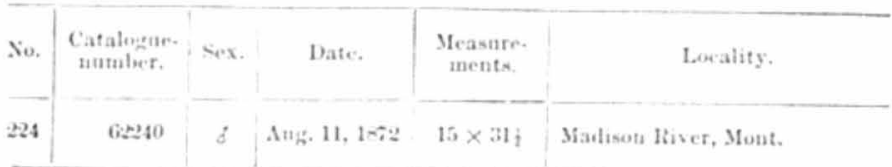

Hab.-Northern regions of both continents.

This specimen of the hawk-owl is the onl one seen. I shot it in broal daylight as it flew past me and lit on a dead pine tree.

Family 41.-Fulcoside, Dilral Bund of Prey.

(Sub fumily Fatconiar, the Faleons.

Timunculus sparecriux, Vieill., (sparrow-hawk:

\begin{tabular}{|c|c|c|c|c|c|}
\hline No. & $\begin{array}{l}\text { Catalogue. } \\
\text { numier. }\end{array}$ & Sex. & Date. & $\begin{array}{l}\text { Sheasure- } \\
\text { ments. }\end{array}$ & :encality. \\
\hline $\begin{array}{l}161 \\
168 \\
171 \\
184\end{array}$ & $\begin{array}{l}62236 \\
62255 \\
62255 \\
62235\end{array}$ & 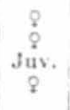 & $\begin{array}{l}\text { July } 16,1-72 \\
\text { July } 17,1072 \\
\text { July } 18,1<72 \\
\text { July } 22,1072\end{array}$ & 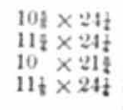 & $\begin{array}{c}\text { North Fork, Idaho. } \\
\text { Do. } \\
\text { Do. } \\
\text { Téton Basin, Idaho. }\end{array}$ \\
\hline
\end{tabular}

Hab.-The entire continent of America.

Sparrow hawks were quite numerous at the North Fork, 'Tetou Basia, and on Snake River, east of the Téton Rauge.
(Sub-fa'nily Accipitrina, the Haicks.)

Accipiter fuscus, Bonap., (sharp-sbinned h:wh :)

\begin{tabular}{|c|c|c|c|c|}
\hline $\begin{array}{l}\text { Catalogue- } \\
\text { number. }\end{array}$ & Sex. & Date. & $\begin{array}{l}\text { Measure- } \\
\text { ments. }\end{array}$ & Locality. \\
\hline 6024 & $\stackrel{8}{-}$ & $\begin{array}{l}\text { Aug. } 20,102 \\
\text { Aug. } 20,1072\end{array}$ & $12 \times 24 i$ & $\begin{array}{c}\text { Lower Geyser Basin, Wyo. } \\
\text { 10. }\end{array}$ \\
\hline
\end{tabular}

\section{Hul,-Throughout North Ameriea ant Mexico.}

This species was only met with in the Lower Geyser Basin, where it w:is quite common.

\section{(Sub-family Buteonine, the Buzsard-haseks.)}

Iuteo sacainsoni, Bonap., (Swainson's hawk:)

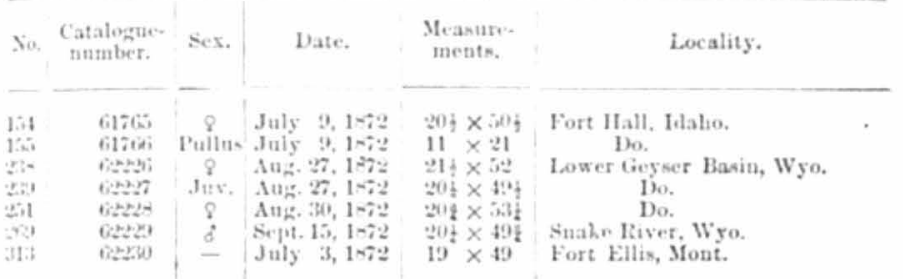

Hab.-Western North America: accidental in New England.

This species, though nor at all numerous, was the niost abundant brecies of hawk along our route. On the 9th of July I obtained one of their wests at Lincoln Valley, near Fort Hall, ldaho Territory. It was foumd on a serub-cedar on a side hill, about nine feet above the ground, and was composed of sticks, lined with fine strips of inner bark; it was hearly flat, and measured twenty-seven inches in external diameter by ten in thickstess; it contained one young bird and one egg; the eggwhich contained a full-grown embrvo, which was dead and partly de. compred-was white, and measured $2 \frac{5}{16}$ inches in length by iq in breadth.

Butco montanus, Nuttall, (western red-tail :)

\begin{tabular}{|c|c|c|c|c|}
\hline $\begin{array}{c}\text { So. Catalogue. } \\
\text { number. }\end{array}$ & Sex. & Date. & $\begin{array}{l}\text { Measnre. } \\
\text { ments. }\end{array}$ & Locality. \\
\hline 62231 & ? & July 29,1872 & $234 \times 54$ & Téton Cañon, Ilaho. \\
\hline
\end{tabular}

Ilab.-Western North America.

This western representative of $B$. borcalis was only met with in Téton Cañon, where I saw but one pair, the female of which I secured. 
(Sub-family Milvine, the Kites.)

Circus hudsonius, Vieillot, (marsh-hawk:)

\begin{tabular}{|c|c|c|c|c|c|}
\hline No. & $\begin{array}{l}\text { Cataiogue- } \\
\text { number. }\end{array}$ & sex & Datc. & $\begin{array}{l}\text { Measure- } \\
\text { ments. }\end{array}$ & Locality. \\
\hline$\{x 22$ & 62zss & $\mathbf{J}_{\text {ux }}$ & Aug. 9, 10,2 & $21 \div \times 50$ & Henry's Lake, Ilaho. \\
\hline
\end{tabular}

Hab.-All of Sorth America and Cuba.

Marsh-hawks were quite abundant in the Salt Lake Basin, thence northward to Ienry"s Lake, and down Suake River.

$$
\text { (Sub family Aquiline, the Eagles.) }
$$

Pandion carolinensis, Bon., (fish-hawk:)

\begin{tabular}{|c|c|c|c|c|c|}
\hline No. & $\begin{array}{l}\text { Catalegue- } \\
\text { nutnber. }\end{array}$ & s.x. & Date. & $\begin{array}{l}\text { Sleasure. } \\
\text { ments. }\end{array}$ & Locality. \\
\hline 220 & 60252 & Juv. & Ang. $7,1-72$ & $23 \times 624$ & Sorth Fork, Haho. \\
\hline
\end{tabular}

Hab.-Throughout temperate North America.

Fish-hawks were only met with on the North Fork of Snake River: here I shot one speciuen as it was soaring around its nest.

\section{Sub-class 2.-CERSORES, SCHATCHING BIRDS.}

Family 49.-TEтraoxid.z, THE: Grovst.

Tetrao obscurus, var, richardsonii, Douglas, (Richardson's grouse:

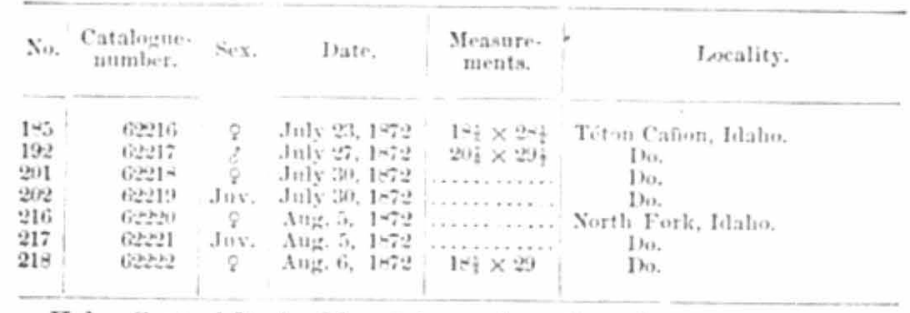

Hab.-Central Rocky Mountains and nortlıward.

This bird is easily distinguished fom the $T$. obscurus by the tail, which in the latter is broadly tipped with light slate, while in $T$, richardsonit the terminai band is nuch uarrower and more imdi tinct, or wanting entirely. The species was not abundant, being met with chiefly in the Téton Mountains. I obtained one of their eggs in Téton Cañon; it wis light colored, sparingly spotted with brown.
Centrocereus urophasianus, Sw., (sage-cock:)

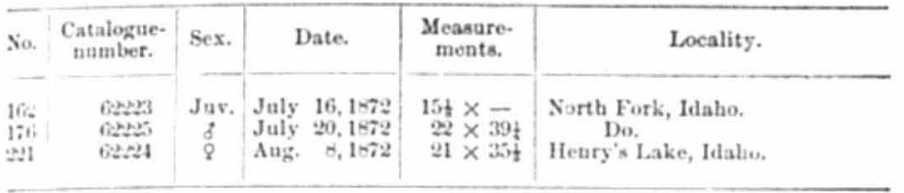

\section{Hab.-Sage plains of the northwest.}

Whe found sage-hens quite numerous in the Salt Lake Basin, thence northward to Ifenry's Lake, also in the Téton Basin and on Snake River, easi of the Téton Range.

Pedivectes phasianellus, Baird, (sharp tailed grouse:)

$$
\begin{aligned}
& \begin{array}{c|c|c|c|c}
\text { Catalugue. } & \text { Sex. } & \text { Date. } & \begin{array}{c}
\text { Measure. } \\
\text { menta. }
\end{array} & \text { Locality. }
\end{array}
\end{aligned}
$$

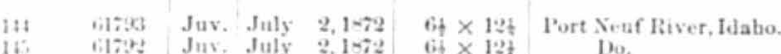

Hab-_ Xorthern prairies and plains, from Wiscousin to Cascates of Oregen and Washington.

II. Int with this speeies at Port Neuf River, thence north to Fort H.all and suake River.

bonase umbellus, var. umbelloides, Baird, (gray monntain grouse:)

$$
\begin{aligned}
& \begin{array}{c}
\text { S. Catalogur- sex. } \\
\text { number. }
\end{array}
\end{aligned}
$$

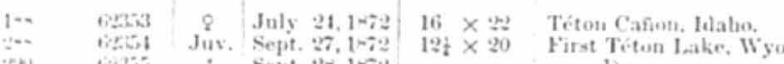

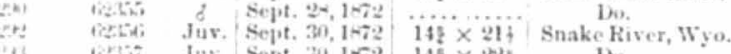

Mab.-llocky Mountain region.

This western race of our eastern ruffled grouse (B. umbellus) was not an ahumbant species, though it was found throughout the pine forests from Téton Cañon to the Yellowstone.

Order 8.-GRALLA, WADING BIRIS.

\begin{tabular}{|c|c|c|c|c|}
\hline $\begin{array}{l}\text { Catslongue } \\
\text { mumlere. }\end{array}$ & Sex. & Date. & $\begin{array}{c}\text { Seasnre. } \\
\text { ments. }\end{array}$ & Locality. \\
\hline $\begin{array}{l}\text { 61645 } \\
\text { 6.5.62: }\end{array}$ & $\begin{array}{l}8 \\
8 \\
8\end{array}$ & $\begin{array}{l}\text { June 17, } 1 \text {-72 } \\
\text { Ang. } 24,1772\end{array}$ & $\begin{array}{r}94 \times 204 \\
104 \times 19\end{array}$ & $\begin{array}{l}\text { Salt Lak Utah. } \\
\text { Lower Geyoer Basin, Wyo. }\end{array}$ \\
\hline
\end{tabular}

Family 53.-Chamadmid. THE, Plovers.

. Fyintitix rociferus, Cassin, (killdeer:).

Hab.-North Imerica to the Arctic regious; Mesico, South America. 
The killdeer was one of the fow birds that were common all along our route. They were very numerous about Salt Lake and in the Ger. ser Basin. At the latter place they were in perpetual fear of the marsh hawks, (Circus hudsonius, which inade great havoe among them.

$$
\text { Family 55.-Scoloracida, THE SNIPEs. }
$$

(inllinago urilsonii, IBonap., (Euдlish snipe:)

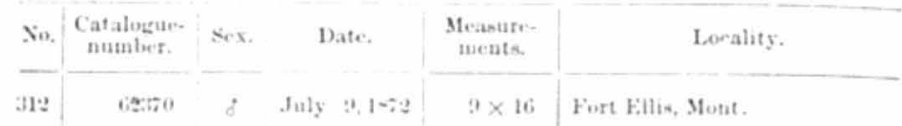

Hab.- Gntire temperate regions of Sorth America.

Actodromus batidii. Cones., [Baird's sand.piper:

$$
\begin{aligned}
& \begin{array}{c}
\text { Xo. Catalogue ses. Date. Measure. } \\
\text { namber. } \\
\text { monts. }
\end{array}
\end{aligned}
$$

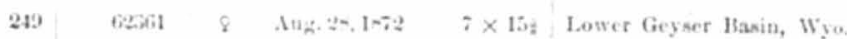

Hab.-Western Nort'i America; aceidental on Atlantic coast.

The Lower Gerser basin is the only locality where these birds wer. seen. There 1 siw a flock of atbout thirty specimens. I fired into their midst, wounding reverul, only one of which, No. 249, (62361, I secured.

Symphemin semipalmata, Harlt., (willet:)

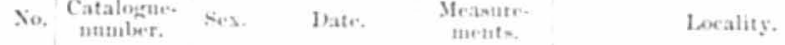

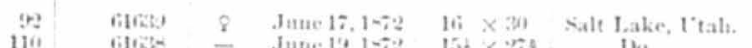

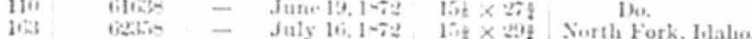

Hab.-Entire temperate regions of North Ameriea: South America.

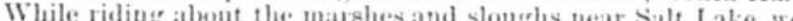
generally escorted by a troupe of twenty or thirty willets, who kept continnalls flying alout over our heads, uttering loud, clattering notes They wonld often datt down in a bee line for our heads, and when

\begin{tabular}{|c|c|c|c|c|c|}
\hline No. & $\begin{array}{l}\text { Catalogta- } \\
\text { number. }\end{array}$ & Sex. & Date. & $\begin{array}{l}\text { Measare- } \\
\text { ments. }\end{array}$ & Locuitty. \\
\hline 235 & 62360 & - & Aug. $23,1-72$ & $143 \times 25$ & Fellowstotie Lake, Wyo. \\
\hline
\end{tabular}
within eight or teu feet of it, turning suddenly and gracefully to one side, they would rise again to repeat the performance.

Gambetta melaroletea, Bonap., (tell-tale:)

Hab.-Entire temperate regions of North America; Mexico.

\begin{tabular}{|c|c|c|c|c|c|}
\hline Nis. & $\begin{array}{l}\text { Cataloguce } \\
\text { number. }\end{array}$ & sex. & Date. & $\begin{array}{l}\text { Measure- } \\
\text { ments. }\end{array}$ & Locality. \\
\hline $1 \%$ & 02059 & 8 & July $10,1+72$ & $\mathrm{Ni} \times 1: 3$ & North Fork, Idalto. \\
\hline
\end{tabular}

The tell-tale, or stone-snipe, was very abundant on the shores of Yellowstone Iake.
Tringoides macularius, Gray, (spotted sand-piper:)

Meh.-Eutire temperate North America; Europe.

Sumenias longirostrix, Wilson, (lougbilled curlew:

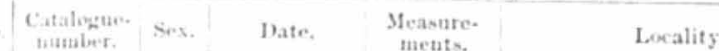

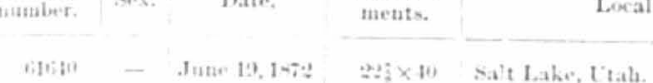

Ineis.-The entire temperate regions of North America.

(1) the "thl of . June I saw a flock of fift, curlews near Bear River. It was a rany day, and they were running about anong the sage-brush, (anteraisa.) Upoin ny near approach they took to wing, andafter cir. wha almot for a few minutes settled down agin. Thoy were quite common at Silt lake, and north to the Verth Fork of Snake River.

\section{Family itj.-PHatanoponde, rHE: PHuLropes.}

I'heleropus vilsonii, Sab., (Wilson's phatarepe:)

\begin{tabular}{|c|c|c|c|c|c|}
\hline sis. & $\begin{array}{l}\text { Catalo: } \\
\text { uumiler. }\end{array}$ & Ser. & Wate. & $\begin{array}{l}\text { Measure. } \\
\text { ments. }\end{array}$ & Locality. \\
\hline $\begin{array}{l}l_{1 \rightarrow 4} \\
1 \%=4\end{array}$ & $\begin{array}{l}\text { 61641 } \\
\text { Gitid2 }\end{array}$ & $\stackrel{8}{-}$ & $\begin{array}{l}\text { June } 19,1072 \\
\text { Jutue } 19,1672\end{array}$ & $\begin{array}{r}17+\times 294 \\
10 \% \times 309\end{array}$ & $\begin{array}{l}\text { Salt Lake, tital. } \\
\text { Do. }\end{array}$ \\
\hline
\end{tabular}

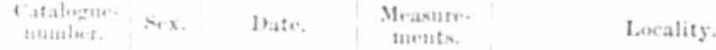

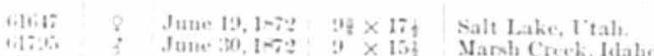

Herio-- Fotire temperate regions of North America; New Mexico, (Dr.

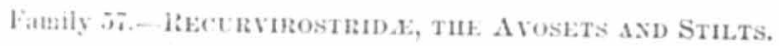

liecurrirostra americana, Gim., (American aveset :)

Hab.-All of temmerate North America; Florida, (Mr. Wiirdemann.) Avorets were quite numerous about Salt Lake, thence northward to the North Fork, opposite the Crater Buttes. In habits they resemble the willet, (Symphemia semipalmata.) 
Himantopus nigricollis, Vieill. (black-necked stilt:)

\begin{tabular}{|c|c|c|c|c|c|}
\hline No. & $\begin{array}{l}\text { Catalogue- } \\
\text { number. }\end{array}$ & sex. & Date. & $\begin{array}{l}\text { Measure- } \\
\text { ments. }\end{array}$ & Locality. \\
\hline $\begin{array}{l}103 \\
106\end{array}$ & $\begin{array}{l}\text { 61644 } \\
\text { Giftit:3 }\end{array}$ & 8 & $\begin{array}{l}\text { Juue } 19,1-72 \\
\text { June } 19,1-72\end{array}$ & $\begin{array}{l}14 i \times 2 t i \\
14+27\end{array}$ & $\begin{array}{l}\text { Salt Lake, Utah. } \\
\text { Do. }\end{array}$ \\
\hline
\end{tabular}

Hab.-United States generally.

We procured the eghs of this species on the 17 th of June at Sal Lake. They were four in number, and were laid on a pile of drift-wood, in the edge of a little bay of the lake. The eggs measure 13 inehes length by 1,3 in lorealth, aud are of a light yellowish bown eolor, spotted and blotehed with dark brown and black, the spots being most numerous near the large end.

$$
\text { Family jo,-Gintid.e, the Crases. }
$$

Grus canadensis, Temm, (saudhill erane:)

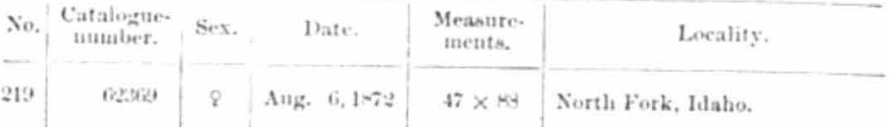

Hab.-Whole of western regions of United States; Florida.

Satd hill cranes were first met with on North or Henry's Fork, thenee north to lellowstone Lake, and sonth to Snake River, ledow Jaekence Lake. They were quite numerous in all this region, but as they rets very shy it was diflicult io obtain a shot at them.

\section{Famils 67.-RALLID TE, THE: RAILs.}

Porzana caro'ina, Vieill, (common rail:)

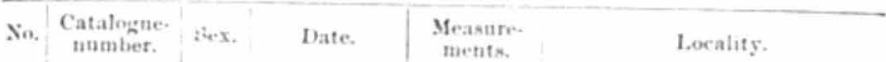

$$
\begin{aligned}
& 7901646 \text { \& June 15,1-72 } 9 \times 13 ; \text { Oplen, Itah. }
\end{aligned}
$$

Hab.-Entire temparate regions of North $\Lambda$ merica.

Rails were quite common in a marsh at the foot of the Wabsateh Range. Here I secured one specimen, No, 79 , (161616) and two nests

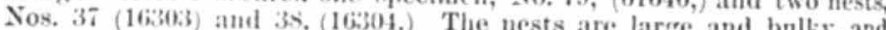

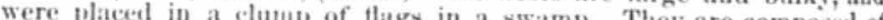
marsh-grass, and contain twelve drab-colored eggs, spotted with choco-

\section{Sub-class 3,-XATATORES, THE SWIMnERS.}

Order 9.-LAMELLIROSTRIS, ANSERINE BIRDS.

$$
\text { Family 69.-ANATIDA." }
$$

\begin{tabular}{|c|c|c|c|c|}
\hline $\begin{array}{l}\text { Catalingue- } \\
\text { nutaber. }\end{array}$ & Sex. & Date. & $\begin{array}{l}\text { Measure- } \\
\text { nenta. }\end{array}$ & Locality. \\
\hline 6estion & \& & $\begin{array}{l}\text { Sept. } 23,1-62 \\
\text { sept. } 23,1=72\end{array}$ & & $\begin{array}{l}\text { Suake Korer, Wyo. } \\
\text { Do. }\end{array}$ \\
\hline
\end{tabular}

(Sub-family Cygnine, the Sicans.)

Cygnus buccinator, Rich., (trumpeter-swan :)

Hab.-Western America, from the Mississippi Valley to the Pacifie.

These large and heantiful birds were only met with on Suake River, in the vicinity of Jackson's Lake.

\section{(Sub-funily Anatine, the Rirer ducks.)}

Anos boschas. L.inn., (mallard:

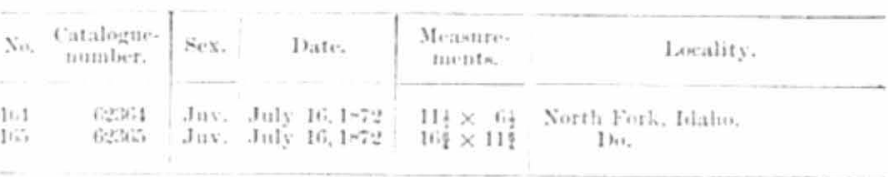

Mab-Entire continent of North America and areater part of Old Norlil.

Infilat acuta, Jenyus, (sprigr tail; pin-tail:

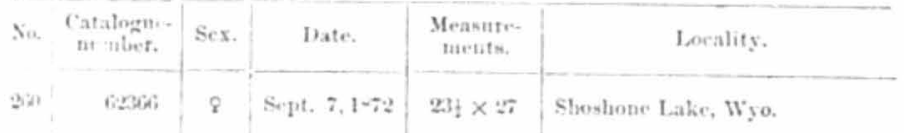

IInb,_-Whole of North America and Europe.

Querquedula cyanopterus, Cassin, (red-breasted teal:)

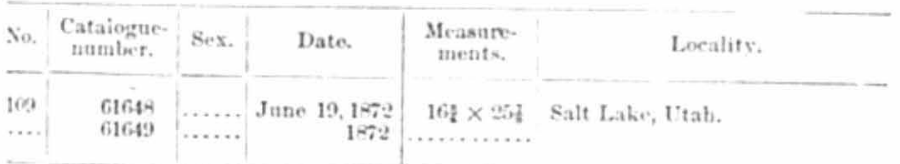

Hab.-Rocky Mountains to Pacific; accidental in Ionisiana.

I found the nest-No. 55, (16321)-of this species on the 29th of June, 
at Marsh Creek, Idaho Territory. It was in the swamp-grass, was lined with down, and contained niue eggs.

Chaulelasmus streperus, Gray, (gadwall:)

\begin{tabular}{|c|c|c|c|c|c|}
\hline No. & $\begin{array}{l}\text { Catalogue- } \\
\text { number. }\end{array}$ & Sis. & Date. & $\begin{array}{l}\text { Measure- } \\
\text { ments. }\end{array}$ & Locality. \\
\hline 159 & $6: 263$ & ? & July 15, 1-72 & $194 \times 23\}$ & Market Lake, Jlaho. \\
\hline
\end{tabular}

Hab.-North Ameriea generally, and Europe.

On the 29 th of June I found the nest of this bird at Marsh Creek. It was lined with down, and contained three fresh eggrs.

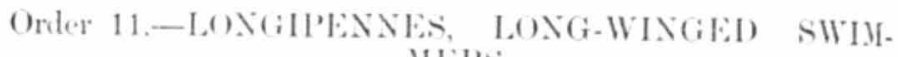
MERS.

Family 76,-LAIID.E, THE GtLLS.

Sub-family Sternina, the Terns.)

Sternu fosteri, Nuttall, (Foster's tern:)

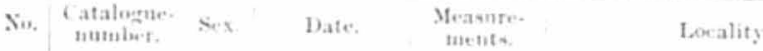

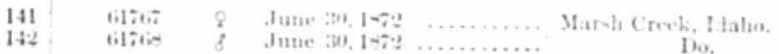

Ifab.-North Aneriea gererally.

o O L O C i I.

Sub-cias I.-1NSEsores, THE PERCHERS.

Urder 1.-I'Asstilis.

(saction OSCINES, SINGERS.)

Family 1.-TUndD 2 , THE THrusmes.

Turelus sicainsonii, Cab., (olive-backed thrush:

\begin{tabular}{|c|c|c|c|c|c|}
\hline No. & $\begin{array}{l}\text { Catalogine. } \\
\text { unatiber. }\end{array}$ & Date. & $\underset{\substack{\text { Enest. } \\
\text { nost. }}}{ }$ & Locality: & Remarks. \\
\hline 62 & 16316 & Jniy :21, $1-2,2$ & 2 & Téton Basin, Itaho. & Eggs fresh. \\
\hline
\end{tabular}

This nest was found on a dead cotton-wood sapling, among the branches of a pinetree, on the side of a caũon; it was about fire feet above the ground, and was composed of dry grass, lined with âner stalks of the same. Its measurements were as follows: Depth, outside, 5.50 inches; inside, 2 inches: diameter, outside, 3.75 inches; inside, 3 inches.

Turius andubonii, Baird, (Audubon's thrush:)

\begin{tabular}{|c|c|c|c|c|}
\hline 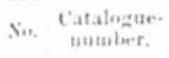 & Date. & $\begin{array}{l}1 \text { lighe in } \\
\text { hest. }\end{array}$ & Lorality, & Remarks. \\
\hline 1t:at:4, & Inty 16, 1 102 & 3 & Fort Ellis, Mront & Eiggs freesh. \\
\hline
\end{tabular}

This nest was situated in a small pine-tree about eight feet from the crouml, in the pine regions of the mountains. Sest bulky, deeply saucer. inteses locent hy

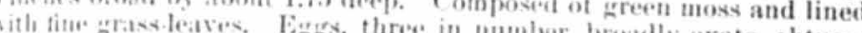

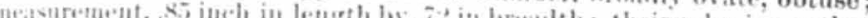
(1) of

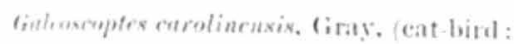

$$
\begin{aligned}
& \text { bate linem } \\
& \text { I,wality }
\end{aligned}
$$

Remarks,

E. ¿ू" nearly freah.

$\therefore+\cdots \cdot 1 \cdot 1 ; \cdot-$

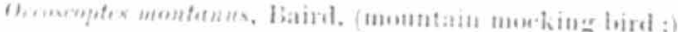

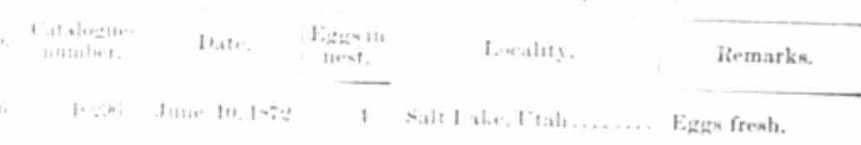

S.e.

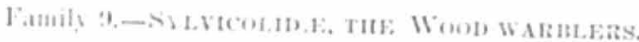

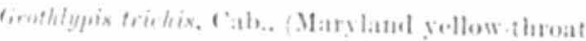

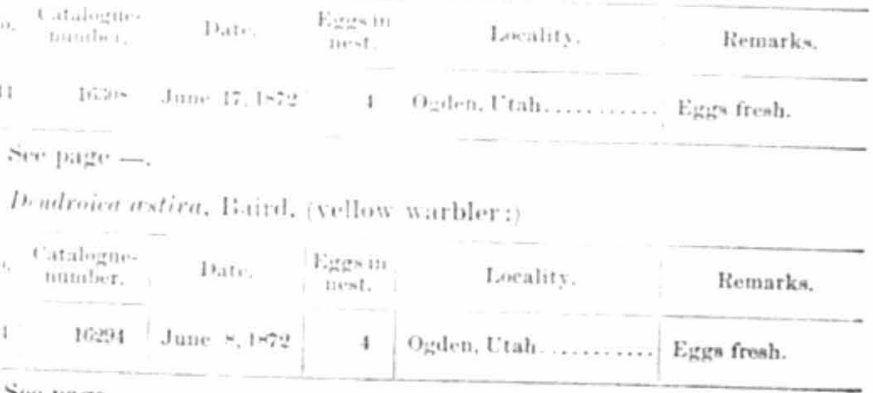

See page -

1.) $\mathrm{G} \mathrm{s}$ 
Family 10.-Hirundivid

Hirundo tunifrons, Say., (eliff swallow :)

\begin{tabular}{|c|c|c|c|c|c|}
\hline No. & $\begin{array}{c}\text { Catalogue- } \\
\text { number. }\end{array}$ & Date. & $\underset{\text { Legse in }}{\text { Ext. }}$ & Lecality. & Remarks. \\
\hline 58 & 16212 & July $3,1 \times 2$ & 2 & Rues Fork, Jaho..... & Egga fresh. \\
\hline
\end{tabular}

see page -

Cotyle riparia, Boil., (bauk swallow:)

\begin{tabular}{|c|c|c|c|c|c|}
\hline No. & $\begin{array}{l}\text { Catalogue } \\
\text { number. }\end{array}$ & Date. & $\begin{array}{l}\text { Firgo in } \\
\text { uest. }\end{array}$ & Locality & Remarks. \\
\hline 25 & 16205 & Jute $10.1-72$ & 7 & Salt Lake, l'tah. & EgEM fres' \\
\hline
\end{tabular}

See page -

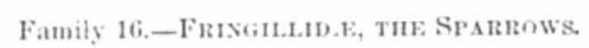

Pooccetes gramineus, var. confinix, Baird, (grass finch :)

\begin{tabular}{|c|c|c|c|c|c|}
\hline No. & $\begin{array}{l}\text { Catalogue } \\
\text { unmber. }\end{array}$ & Hate. & $\begin{array}{c}\text { Kogn in } \\
\text { west. }\end{array}$ & Lencality. & Remarks. \\
\hline 10 & $16 z-1$ & $\operatorname{Jun} n 5,1=2$ & 4 & Ogden, Itah. & $\begin{array}{l}\text { V.gencontained latge } \\
\text { embryos. }\end{array}$ \\
\hline 24 & 1,022 & June,$+ 1<2$ & 4 & ...... do & \\
\hline
\end{tabular}

see page -

Coturniculus passerinus, Bonap., (yellow-winged sparrow :)

\begin{tabular}{|c|c|c|c|c|c|}
\hline No. & $\begin{array}{c}\text { Catalogue. } \\
\text { number. }\end{array}$ & bate. & $\begin{array}{c}E: \ldots \times m \\
\text { twot. }\end{array}$ & Locality. & Remarks. \\
\hline z & nitero & Jutue $5,1-72$ & 4 & Ogden, trah. & Egga fresh. \\
\hline
\end{tabular}

I found this nest on the gromud, by the side of a sage-bush. It was very light, being carelessly construeted of fibrous roots and grasses lined with tiner pieces of the same. It measured 4.35 inches in extersa diameter, and contained four white eggs, spotted with reddish brown.

Chondestes grammaca, Bonap., (lark-finch :)

\begin{tabular}{|c|c|c|c|c|c|}
\hline No. & $\begin{array}{l}\text { Catalogue } \\
\text { number. }\end{array}$ & Date. & $\begin{array}{l}\text { Egges in } \\
\text { nest. }\end{array}$ & Locality. & Remarka \\
\hline$\frac{22}{65}$ & $\begin{array}{l}16: 92 \\
16 \geq 83\end{array}$ & $\begin{array}{l}\text { June } 7,1072 \\
\text { June } 16,1 \rightarrow 2\end{array}$ & $\begin{array}{c}5 \\
\ldots \ldots\end{array}$ & 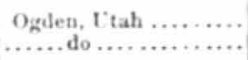 & Eggs freah. \\
\hline
\end{tabular}

See page -
Spizella bre:ceri, Cass, (Brewer's sparrow :)

\begin{tabular}{r|r|r|r|r|r|}
\hline No. & $\begin{array}{c}\text { Catalogue- } \\
\text { number. }\end{array}$ & Date. & $\begin{array}{c}\text { Eggo in } \\
\text { nest. }\end{array}$ & Locality. & Remarks. \\
\hline \multirow{6}{*}{61} & 16315 & July 21, 1871 & 3 & Conant Creek, Idaho. & Nearly freah. \\
\hline
\end{tabular}

I found but one nest of Brewer's chipping sparrow. It was placed on a sage-brush about one foot above the ground, and was composed entirely of the stalks of dry grass, lined with finer pieces of the same. Its external diameter measures 2.80 inches by 2.30 in depth; inside, 2 inches broad by 1.60 deep. The eggs are greenish blue, spotted with chocolate brown, the spots being most numerous at and forming a ring around the large end.

\begin{tabular}{|c|c|c|c|c|c|}
\hline $\mathrm{No}$ & $\begin{array}{l}\text { Catalogue- } \\
\text { untmber. }\end{array}$ & Date. & $\begin{array}{c}E_{\text {gRs in }} \\
\text { nest. }\end{array}$ & Locality. & Remarks. \\
\hline 34 & 16501 & June 13,1072 & 4 & Ogden, Vtah. & $\begin{array}{l}\text { Egga contained large } \\
\text { embryos. }\end{array}$ \\
\hline
\end{tabular}

\section{Sce page -}

Passerella schistacea, Baird, (slate-colored sparrow :)

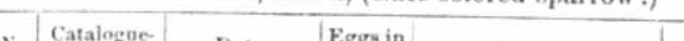

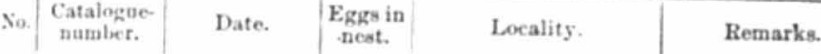

\begin{tabular}{l|l|l|l|l|l}
\hline 16 & 16200 & June 6, 1072 & 6 & Ogden, Utah.......... & Eggs fresh.
\end{tabular}

This nest was found on a bush in a marsh, about six feet above the ground. It was composed of dry swamp.grass, covered on the ontside with dead leaves, with here and there a lite shaped, very compact, and was lined with fine hair. It measured abont 4.25 inches in external diaineter by grass and It was 1.90 inches deep inside by 230 broad Theter by 2.75 deep. it was 1.90 inches deep inside by 2,30 broad. The eggs were light greenish blue, spotted and blotehed all over with dark brown.

Guiraca melanncephala, Sw., (black-headed grosbeak:)

\begin{tabular}{c|c|c|c|c|c}
\hline No. $\begin{array}{c}\text { Cataloguc. } \\
\text { tumber. }\end{array}$ & Date. & $\begin{array}{c}\text { Eggs in } \\
\text { nest. }\end{array}$ & Loeality. & Remarks. \\
\hline 63 & 16317 & July 22, 1572 & 2 & Tóton Basin, Idaho... & Eggs fresh. \\
\hline
\end{tabular}

$$
\text { See page - }
$$

Cyanoxpiza amona, Baird, (lazuli finch :)

\begin{tabular}{|c|c|c|c|c|c|}
\hline No. & $\begin{array}{l}\text { Catalogne } \\
\text { nutuler. }\end{array}$ & Date. & $\begin{array}{c}E_{g g s} \text { in } \\
\text { neet. }\end{array}$ & Locality. & Remarka. \\
\hline $\begin{array}{r}\stackrel{8}{9} \\
9 \\
3 \\
3\end{array}$ & $\begin{array}{l}16203 \\
16204 \\
10205\end{array}$ & $\begin{array}{l}\text { June } 5,1872 \\
\text { June } 5,1872 \\
\text { June 14, } 1672\end{array}$ & $\begin{array}{l}3 \\
4 \\
4\end{array}$ & 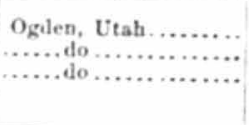 & $\begin{array}{l}\text { Eggs freah. } \\
\text { Do. } \\
\text { Eggs contained small } \\
\text { embryos. }\end{array}$ \\
\hline
\end{tabular}

See page - 
Pipilo megalonyx, Baird, (spurred towkee:)

\begin{tabular}{|c|c|c|c|c|c|}
\hline No. & $\begin{array}{l}\text { Catalogue- } \\
\text { nutuber. }\end{array}$ & Date. & $\begin{array}{c}\text { Eggs in } \\
\text { nest. }\end{array}$ & Locality. & Remarks. \\
\hline $\begin{array}{l}31 \\
32 \\
35 j\end{array}$ & $\begin{array}{l}16299 \\
16300 \\
16302\end{array}$ & $\begin{array}{l}\text { June } 13,1 \sim 2 \\
\text { Jute } 13,1072 \\
\text { Jutue } 14,1072\end{array}$ & $\begin{array}{l}4 \\
5 \\
4\end{array}$ & 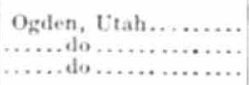 & $\begin{array}{l}\text { Egges nearly fresh. } \\
\text { Egta freah. } \\
\text { Do. }\end{array}$ \\
\hline
\end{tabular}

$$
\text { see page - }
$$

\section{Family 18.-ICteride, the: Orioles.}

(Sub-family Agelaune, the Slarlings.)

Xanthrocephalus ieterocephalus, Baird, (yellow-headed black bird.)

\begin{tabular}{c|c|c|c|c|c|} 
So. $\begin{array}{c}\text { Catalogue } \\
\text { number. }\end{array}$ & Date. & $\begin{array}{c}\text { Eggss in } \\
\text { nest. }\end{array}$ & Locality. & Remarka. \\
\hline 5 & 16311 & June $30,1-72$ & 3 & Manh Vallog, Ldaho ...
\end{tabular}

\section{See page -}

starnella neglacta, Aud., (western lark:)

\begin{tabular}{|c|c|c|c|c|c|}
\hline No.. & $\begin{array}{l}\text { Catalogue. } \\
\text { number. }\end{array}$ & Pate. & $\begin{array}{c}\text { Figes it } \\
\text { wat. }\end{array}$ & Locality. & Remarks. \\
\hline 6 & 16277 & June $5,1 \sim 72$ & 3 & Ogilen, Utah.... & Egga contained \\
\hline $\begin{array}{l}21 \\
43\end{array}$ & $\begin{array}{l}1628 \theta \\
16 \pi 99\end{array}$ & $\begin{array}{l}\text { June } 7,102 \\
\text { June } 15,1072\end{array}$ & $\begin{array}{l}6 \\
\vdots\end{array}$ & ….. do .... & $\begin{array}{l}\text { large etmbryos. } \\
\text { Do. } \\
\text { Do. }\end{array}$ \\
\hline
\end{tabular}

See page -

\section{(Sub-family Ieterinc.)}

Icterus bullockii, Bonap... (western oriole:)

\begin{tabular}{|c|c|c|c|c|c|}
\hline sin. & $\begin{array}{l}\text { Catalogue. } \\
\text { number. }\end{array}$ & Wate. & $\begin{array}{l}\text { Eigs in } \\
\text { tyest. }\end{array}$ & Locality. & Remarka. \\
\hline 2 & 16261 & Jane $5,1-7:$ & 6 & Ogden, titah .... & Egga nearly freah \\
\hline 3 & lithiz & & 6 & h o do & Do. \\
\hline 13 & 10264 & $\begin{array}{l}\text { June } \\
\text { Jane fi, } 1>7-2\end{array}$ & 5 & $\begin{array}{l}\text { do } \\
\text { do: }\end{array}$ & $\begin{array}{l}\text { Egh fresl. } \\
\text { E. for nearly fresl. }\end{array}$ \\
\hline 14 & 16265 & June $6,1-72$ & 4 & to & $\begin{array}{l}\text { E.ghs nearly fresh. } \\
\text { Egys freeth. }\end{array}$ \\
\hline 17 & 10206 & Jute $6,1-72$ & 4 & to & Do. \\
\hline 19 & 16267 & June $7,1-72$ & ti & to & Eges nearly fresh. \\
\hline 3 & 16abis & June $1 \%, 1-7 \%$ & 5 & do & 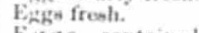 \\
\hline (3) & 16269 & June $12,1-72$ & 6 & do & Efas contained \\
\hline $\begin{array}{l}33 \\
411\end{array}$ & 16270 & Inbe $13,1 \sim 72$ & 5 & do & Figen fresh. \\
\hline $\begin{array}{l}411 \\
41\end{array}$ & 1627 & June 15,1962 & 5 & . do . & io. \\
\hline $\begin{array}{l}41 \\
45\end{array}$ & $16: 28$ & June $15,1-72$ & 5 & . to & Do. \\
\hline $\begin{array}{l}45 \\
46\end{array}$ & 10623 & Jutue $17,1-72$ & 3 & ... do & Do \\
\hline $\begin{array}{l}465 \\
47\end{array}$ & 1624 & 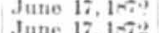 & 1 & do. & Po. \\
\hline 4 & 16286 & $\begin{array}{l}\text { June } 17,1-72 \\
\text { Juthe } 17,1 \rightarrow 72\end{array}$ & $\begin{array}{l}3 \\
2\end{array}$ & 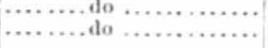 & $\begin{array}{c}\text { Do, } \\
\text { Eg s }\end{array}$ \\
\hline & & & & & stnall embryos. \\
\hline
\end{tabular}

(Sub-family Quiscalina, the Crow black-birds.) Scolecophagus cyanocephalus, Cab., (Brewer's black-bird :)

\begin{tabular}{|c|c|c|c|c|c|}
\hline No. & $\begin{array}{l}\text { Catalogue- } \\
\text { number. }\end{array}$ & Date. & $\begin{array}{l}\text { Eggh in } \\
\text { nest. }\end{array}$ & Locality. & Remark. \\
\hline 66: & 16319 & June $15,1 \div 2$ & ....... & Ogden, Utah............. & Eggw nearly fresh. \\
\hline
\end{tabular}

$$
\text { (Suction Clamatores, crying birels.) }
$$

Family 23.-Tyraxide, the Truant Fly.catcuers.

\begin{tabular}{|c|c|c|c|c|c|}
\hline Niv. & $\begin{array}{l}\text { Catalogre- } \\
\text { ntaber. }\end{array}$ & Date. & $\begin{array}{c}\text { Eggs in } \\
\text { uest. }\end{array}$ & Locality. & Remarks. \\
\hline (i) & 16314 & July 14,1472 & 3 & Snake River, Ilaho ..... & Eggs fres'l. \\
\hline
\end{tabular}
Tyrannix carolinensis, Baird, king-bird:)

\section{See page -}

\begin{tabular}{|c|c|c|c|c|}
\hline $\begin{array}{c}\text { Catalogue- } \\
\text { number. }\end{array}$ & Date. & $\begin{array}{c}\text { Eigks in } \\
\text { nest. }\end{array}$ & Locality. & Retnarks. \\
\hline $\begin{array}{l}32-6 \\
10207 \\
162=-1 \\
162-9\end{array}$ & 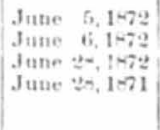 & $\begin{array}{l}4 \\
1 \\
2 \\
4\end{array}$ & 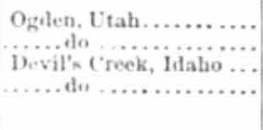 & $\begin{array}{l}\text { Egges fresh. } \\
\text { Do, } \\
\text { Do. } \\
\text { Eggo nearly ready } \\
\text { to hatch. }\end{array}$ \\
\hline
\end{tabular}

Tyrannus rerticalix, Say, (Arkansas fly cateher:)

\section{see page -}

\begin{tabular}{|c|c|c|c|c|c|}
\hline Sw. & $\begin{array}{l}\text { Cataloguc- } \\
\text { tutmber. }\end{array}$ & Date. & $\begin{array}{c}\text { Egits in } \\
\text { nert. }\end{array}$ & Locality. & Remarks. \\
\hline $\begin{array}{l}30 \\
\vdots 1 \\
41\end{array}$ & $\begin{array}{l}16305 \\
16306 \\
16307\end{array}$ & $\begin{array}{l}\text { June } 15,1-72 \\
\text { June } 17,1-72 \\
\text { June } 17,1-72\end{array}$ & $\begin{array}{l}3 \\
4 \\
4\end{array}$ & $\begin{array}{l}\text { Ogden, Utah } \ldots \ldots \ldots \ldots \\
\ldots \ldots \ldots \text { do } \ldots \ldots \ldots \ldots \ldots \\
\ldots \ldots \text { do } \ldots \ldots \ldots \ldots \ldots\end{array}$ & $\begin{array}{l}\text { Eggs fresh. } \\
\text { Do. } \\
\text { Do. }\end{array}$ \\
\hline
\end{tabular}

Empidonax pusillus, Cab., (little ty-eateher:)

$$
\text { Order II.-STRISORES. }
$$

\begin{tabular}{|c|c|c|c|c|c|}
\hline No. & $\begin{array}{l}\text { Catalogue- } \\
\text { number. }\end{array}$ & Date. & $\begin{array}{c}\text { EqLwitu } \\
\text { nest. }\end{array}$ & Locality. & Retnarks. \\
\hline 2 & $16: 98$ & June 12,1872 & 2 & Ogden, V'tah .... & $\begin{array}{l}\text { Eggs contained } \\
\text { full-grown em- } \\
\text { bryos. }\end{array}$ \\
\hline
\end{tabular}

Family 32.-CAPHinlgid a, THE Goat-suckers. Antrostomus nuttalli, Cassin, (froor will :) 
Order IV.-RAPTORES, THE BIRDS OF PREY.

Family 40.-STRigID E, THE OWLS.

Athene hypugaa, Bonap., (prairie-owl:)

\begin{tabular}{c|c|c|c|c|c}
\hline No. & $\begin{array}{c}\text { Cataloguc- } \\
\text { number. }\end{array}$ & Date. & $\begin{array}{c}\text { Egggs in } \\
\text { nest. }\end{array}$ & Locality. & Remarks. \\
\hline 97 & 1029 & June 10,1072 & $\ldots \ldots . .$. & Salt Lake, Utah......... & \\
\hline
\end{tabular}

See page -

$$
\text { Family 41.-FALCONID } 2 .
$$

(Sub-family Buteonine, the Buzzard-hateks.)

Buteo sacainsonii, Bonap., (Swainson's hawk:)

\begin{tabular}{c|c|c|c|c|c|c}
\hline Xo. & $\begin{array}{c}\text { Catalogue- } \\
\text { number. }\end{array}$ & Date. & $\begin{array}{c}\text { Egge in } \\
\text { neet. }\end{array}$ & Locality. & Remarka. \\
\hline 59 & 16313 & July & 9,1672 & 1 & Fort Hall, ldaho ........ & Egg decayed. \\
\hline
\end{tabular}

See page -

$$
\text { Orler V.-PULLASTRA. }
$$

Family 43.-Columbid e, THE Pigeons and Doves.

Zenaidura carolivensix, Bonap., (common dove:)

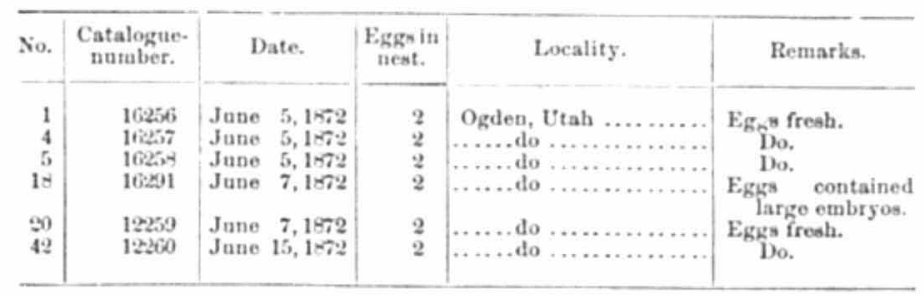

Mourning or ground doves were very numerous in the Salt Lake Val. ley, where I collected twelve of their eggs. They lay two white eggs, either in a slight excavation in the ground lined with a few pieces of straw or dry grass laid loosely together, or in a neat nest of fibrous roots, which is placed on a bush from two to five feet above the ground.

\section{Sub-class II.-CURSORES.}

Order VI.-GALLIN E.

Family 49.-Tetraonide, the Grouse.

Tetrao richardsonii, Baird, ( Richardson's grouse :)

\begin{tabular}{c|c|c|c|c|c}
\hline No. & $\begin{array}{c}\text { Catalogue- } \\
\text { number. }\end{array}$ & Date. & $\begin{array}{c}\text { Eggk iu } \\
\text { nest. }\end{array}$ & Locality. & Remarks. \\
\hline 64 & 16318 & July - 1672 & 1 & Tóton Caton, Idaho.... & Egg stale. \\
\hline
\end{tabular}

See page -

Order VIII-GRALLF.

Fandly 57̈.-Recurvinostrid Himantopus nigricollis, Vieill, (black-necked stilt :)

\begin{tabular}{l|c|c|c|c|c|}
\hline No. & $\begin{array}{c}\text { Catalogne- } \\
\text { number. }\end{array}$ & Date. & $\begin{array}{c}\text { Eggs in } \\
\text { nest. }\end{array}$ & Loveality. & Remarks. \\
\hline 49 & 16009 & June 17,1772 & 4 & Sal: Lake, Utah ........ & Eggo freah. \\
\hline
\end{tabular}
See page -

\section{Family 6ï,-RALLID}

\begin{tabular}{|c|c|c|c|c|c|}
\hline Siv. & $\begin{array}{l}\text { Catalogte. } \\
\text { number. }\end{array}$ & Date. & $\begin{array}{l}\text { E.ghw in } \\
\text { nest. }\end{array}$ & Locality. & Remarks. \\
\hline 5 & 16303 & June 15,1072 & 12 & Ogdet, Vtah.... & Eggs coniained \\
\hline ist & 10304 & June 15,1072 & s & ...... do & $\begin{array}{l}\text { One young bird in } \\
\text { nest. }\end{array}$ \\
\hline
\end{tabular}

Porzana carolina, Vieill, (common rail:)

See page -

\section{Sub-class III.-VATATORE;, THE SWIMMERS.}

Order IX.-LAMELLIROSTRES.

$$
\text { Family 69.-ANАTIDж. }
$$

\begin{tabular}{|c|c|c|c|c|c|}
\hline No. & $\begin{array}{l}\text { Catalogute- } \\
\text { number. }\end{array}$ & Date. & $\begin{array}{c}\text { Eggrs in } \\
\text { west. }\end{array}$ & Loeality. & Remarks. \\
\hline$\therefore$ & 16221 & June $29,1 \div 72$ & 9 & Sarsh Creek, ldiaho.... & $\begin{array}{l}\text { Eggo contained } \\
\text { large embryos. }\end{array}$ \\
\hline
\end{tabular}

(Sub-family Anatina, the Rirer-ducks.)

Querquedula cyanopterus, Cassin, (red-breasted teal:) 
Chaulelasmens streperus, Gray, (gadwall:)

\begin{tabular}{|c|c|c|c|c|}
\hline 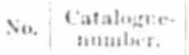 & Date. & $\begin{array}{c}\text { Eigit in } \\
\text { hist. }\end{array}$ & Locality. & Rewarks. \\
\hline laters & 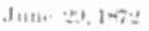 & $a$ & Marsh Ciceh, thato.... & Figne fresh. \\
\hline
\end{tabular}

See parge -

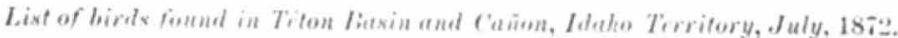

This list is of course, very imperfert, wing to the short time we spent in the basin: bet it will serve to give some bilea of the birds found in that region.

Oresacoptex montauns, Baird. Mountain nocking-bird.

Throlus mitraterius, Linn. Common robin.

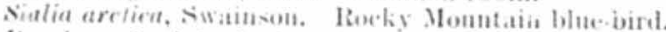

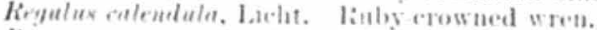

Prirux montanux, (Bamluel, Youintain titmons.

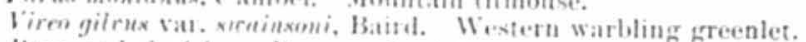

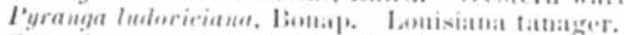

Carpailueus caxsinii, labiral. Cassin's purple finch.

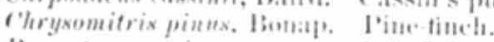

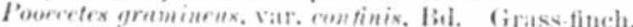

Jun aregnux, siclit. P'ink sided smow birel.

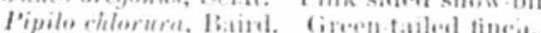

Eiremophiln cornute. Boie. Ilotued skis lark.

sturnella neglerta, Aud. Western mesulow-lark.

Cyenura metolopha, liard. 1.moerested jay.

Perisoreus conadensis, lionapy. Giray jay.

Corens cernirowes, Bartatu. Ameriean raven.

Tyrenния carolinensix. latiral. King biril.

Contopue burralis, Baird. Olive sided flyateher.

Contopus richardsonii, Bairit. Short legiged newee.

Eimpielonas pusillus, Cab. Little li eatcler.

Crryle aleyon, Boie. Beited bing-fislaer.

Cherdeiles henryii, Cassin. Western night haswe

Piens harrixii, Aul. Harris's weodperker.

Buter montanux, Vuttall. Wieteru real tail.

Tetras obsearus, var. richarsonii. Richarison's grouse.

Centrentecus urophusianux, Sw. Singecoek.
List of birdx found in Fire. Ilole Bhain, Wyoming Territory, A ugust, 1872.

This list, like the preceling, and for the same reason, is very imper fect, and will aduit of many ahlitions.]

Turdus migratorius, I.inn. Common robin.

Sialia arctica, Sw. Rocky Mountain blup-bird.

kegulus calendula, Licht. líbs-crowned wren.
Parus montanus, Gambel. Mountain titmonse.

Myiodioctes pusillus, Bonap. Green black cap warbler.

Mirundo horreorum, Barton. Barn swallow.

Ponecetes gramineus, var, confinix, Baird. Grass-finch.

Chondextes gramnaca, Bonaip. Iark-tinch.

Junco orcgonus, Sclat. Pink-sided snow-bird.

Carpodacus cussinii, Bairol. Cassin's purple finch.

Chrysomitrix piuns, (?) Bonap. Pine-fiuch.

Sicolecophagus cyanocephalux. Brewer's blackbird.

Cyanura macrolopha, Bairil. Long tod jay.

l'erixoreus canudeusis, Bonap. Grity jus:

Picicorrus columitianus, Bonal, Clark crow.

Corrus carnicorus, Bartram. American raven.

Tyranuи curolinensis, Baird. King-bird.

Empidonax pusillus, Cab. Little flyeateher.

Ceryle aleyon, Boie. Belted king fisher.

Chordciles henryii, Cassin. Western night-hawk.

Picus harrisii, Audubon. Harris's woodnecker.

Picoides arcticus, Giray. Three towd woodpecker.

l'icoides doralis, Baird. Stripnd three toed woodpecker.

Accipiter fuscus, Bunap. Sharp-shinued hawk.

Buteo arainsonii, Bonap. Swainson's hawk.

Circus huisonius, Vieillot. MLarsh harrier.

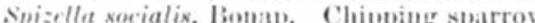

Sitta acuienta, Cassie. Slemder billed muthateh.

Girus canalensis, Temm. Sand hill crase.

Egiulitis reciferux, Cassin. Killdeer.

Etodromus bairdii, Coues. Baird's sand piper.

Bernicla canadensix, Boie. Canada goose.

Pelecanus erithrorhynchus, Gin. American pelican.

List of the birds found in Ctah Territory.

Notr.-The following list embraces all the species known to have teren taken within the limits of the Territory of Utah. For some of them I am indebted to Mr. Allen, Mr. Henshaw, and Mr. Ridgway.)

1. Turdus pallasi

2. Turtus swatinsonii.

3. Turdus audubonii.

4. Planesticus migratorins.

i. Galeoscoptes earolineasis.

6. Oreoscoptes montanus.

7. Cinclus mexicanus.

S. Sialia aretura.

9. IRegulus calendula.

10. Parus montanus.

11. Parus septentrionalis.

12. Campylorliynchus brunneica pillus.

13. Catherpes mexicanus.

14. Salpinetes obsoletus.

1.i. Cistothorus palustris.

16. Troglodytes parkmanni.
17. Anthus ludovicianus.

1s. Geothlypis trichas.

19. Geothlypis maegillirrayi.

20. Ieteria longricauda.

21. Helminthopuaga ruficapilla.

2.2. He!minthophaga celata.

23. Dendroica audubonii.

24. Dendroica blackburuiz.

27. Deutroica astiva.

26. Mviodioctes pusillus.

27. Setophaga ruticilla.

2s. Hirundo horreorun

29. Petrochelidon lunifrons.

30. Tachycineta bicolor.

31. Tachycineta thalassina.

32. Cotyle riparia.

33. Stelgidoptery $x$ serripennis. 
34. Vireo swainsonii.

35. Vireo olivacens

36. Vireo plumbens.

37. Ampelis cedrorum.

38. Collurio excubitoroides.

39. Pyranga ludoviciani.

40. Carpodacus cassinii.

41. Carpeclacus froutalis.

42. Chrysomitris tristis.

43. Clırysomitris psaltria.

4. Chrysonitris pinus.

45. Lencosticte tephreotes.

46. Passerculus alaudinus.

47. Yooecetes gramincus, var, confinis.

48. Coturniculus passerinus.

49. Chondestes grammaci.

50. Zonotrichia lencophrys.

51. Zonotrichia gambelii.

52. Junco oregonus.

53. Junco caniceps.

54. Poospiza bilineata

5.5. Poospiza belli.

56. Spizella socialis.

57. Spizella breweri.

5s. Nelospiza fallas.

59. Melospiza lincolnii.

60. Passerella selistacea.

61. Calomospiza bicolor.

62. Calatnospiza melanocephala.

63. Cyanospiza ameral.

64. P'ipilo megalonyx.

65. Pipilo chlorura.

66. Passer domesticus, (introdueced.

67. Eremophila cornuta.

68. Dolichonyx oryzivorus.

69. Molot hrus pecoris.

70. Agelaius phaticeus.

71. Xanthrocephalus icterocepha. lus.

72. Sturnella neglecta.

73. Feterus bullockii.

74. Sicolecophagus cyanocephalus.

75. Corvns carnivorus.

76. Corvus americaun.

7i. P'icicorrus columbianus

98. Gymnokista cyanocephala.

79. Pica huchonien.

80. Cyanura macrolopha.

81. Cyanocitta woodhoasii.

8:. Perisorens cunadensis.

83. Ty rannus carolinensis.

84 . Tyrannus vertiealis.

85. Sayornis sayus.

86. Contopus borealis.
87. Contopus virens, var. richard. sonii.

88. Empidonax pusillus.

89. Empidonax difficilis.

90. Empidonax hammondii.

91. Empidouax obscurus.

92. Ceryle alcyor:

93. Antrostomus nuttalli.

94. Chordeiles henryi.

95. Trochilus alexandri.

96. Selasphorus platycercus.

97. Picus harrisii.

98. Splyropieus nuchalis.

99. Sphyropieus williamsonii.

100. Sphyropicus thyroideus.

101. Melanerpes torquatus.

102. Colaptes mexicanus.

103. Otus wilsonianus.

104. Athene hypugas.

105. Falco peregrinus

106. Hspotrioseiria columbarius.

107. Timnunculus sparverins.

105. Aceipiter ftacas.

109. Buteo sw:

110. Buteo montanus.

111. Archibuteo sancti-jobannis.

1i2. Cireus hudsonius.

113. Aquila camadeusis

114. Halisetus lencocephalus.

11.5. Cathartes aura.

116. Zenadura rolinensis

117. Tetrao obseurus.

115. Centrocereus urophasianus.

119. Pediacetes phasianellus.

120. Bonasa umbellus, var. nubel.

$$
\begin{aligned}
& \text { Boistes. } \\
& \text { loina }
\end{aligned}
$$

121. Ortyx virginianus. (Introduced.)

122. Lophortyx californicus. ( $\mathrm{It}$ troduced.

123. Iophortsx gambelii.

124. Egialitis vociferus.

12\%. Evialitis nivosus.

126. Gallinago Wilsonii.

127. Macrorliamphus griseus.

128. Peclidma alpina, var ameri cana.

129. Actoulromus minutilla.

130. Gaubetta melanoleuca

131. Gambetta flavipes.

132. Tringoides macularius.

1:53. Aetiturus bartramius.

134. Numenius longirostris.

135. Symphemia semipalmata.

136. Phalaropus wilsonii.

137. Recurvirostra americana.
138. Himantopus nigricollis.

139. Grus canadensis.

140. Ibis ordii.

141. Ibis alba.

142. Ardea herodias.

143. Botanrus lentiginosus.

14. Nyctiardea grisea, var. navia.

145. Rallus crepitins.

146. Porzana carolina.

147. Porzana jamaicensis.

148. Fulica americana.

149. Cyguus americanus.

150. Anser hyperboreus.

151. Anser gambelii.

152. Bernicla canadensis.

153. Anas Losehas.

154. Dafila acuta.

15.5. Nettion earolinensis.

156. Querquedula cyanoptera.

15i. Spatula elypeata.
158. Chaulelasmus streperus.

159. Mareca americana.

160. Aix sponsa.

161. Fulix marila.

162. Fulix aftinis.

163. Aythya americana.

164. Bucephala albeola.

165. Erismatura rubida.

166. Mergus americanus.

167. Pelecus us erythrorhynch us.

16.5. Gracult is dilophus.

169. Larus californicus.

170. Larus delawarensis.

171. Chroicocephalus philadelphia.

172. Xema sabinii.

173. Sterna fosteri.

17. Colymbus torquatus.

175. Podiceps cornutus.

176. Podilymbus podiceps. 


\section{COLEOPTERA}

Br Geo. H. Hors, M. D., Puraprlphis

The species collected during the expedition of 1872 are very few in number, and add searcely anything to our knowledge of distribution. and an unusually small number of new forms. They are distributed as follows :

YELLOWSTONE I.AKE.

Cincindela 12-guttata, Dej. Carabus todatus, Fab.

Agabus, n. sp.

Colymbetes binotatus, Harr. Gyrinus picipex, Aubs. affinis, Aube.

Silpha lapponica, Hbst. Canthon simplex, Lee.

Diplotaxis brericollis, Lew.

Melanophila longipes, Sity.

A uclastes druryi, Kloy.

Ailelncera profusa, Cind.

Caloenemis dilaticollis, Mann.

Iphthimus serralus, Mauu.

Tragosoma harrisii, Lec.

A rgaleus nitens, Lec.

Criocephalus protractus. Iee. agrestis, Kloy.

Haltica bimarginata, Say.

THTON BASIN.

Ciciulela montana, Lee.
Amara polita, Lec. gibba, lec.

Harpalus oblitus, Lee. Diplotaris tristes, Kby.

silis, t1. sp.

Eleodex humeralis, Lec.

Coutharis sphericollis, Say.

\section{SNAKE; RIVER.}

Plutynus deplanafus, Mén. Tiothopus zabroides, Lee. Harpalux oblitus, lece. Amphizon lecontei, Matth. Colymbeies seminiger, Lec.

Dytiscus coufluens, Sis.

Dytixeus confluens, Say.

Acmacodera mirta, Lee.
Elemies tricostata, Say.

Cantharis nuttali, Say. cynnipennis. Lec.

Epicauta puncticollis, Mann. maculata, Sas.

Chrysomela philadelphica, Linn.

The most interesting of all the species collected is Amphizon lecontri Matthews, deseribed in July, 1siz, by Rev. A. Matthews, in a pamphlet ixsued by E. Janson, of Lindon, entitled "Cistula Eintomologica," 1:!. It differs from our well-known $A$. insolens, Lec., hy the dorsum of the elytra being depressed along the middle from neir the base to the apex, so that each elytron along its middle appears subcostate. Another species has been described by the same auther, (p. 119 .) but I canus see auy character by which it can be separated from the long series of A. insolens before me. It has been named Amphizon, foxcphi. The two sexes of Amplazod do not difter grantly: the antenthe of the anale aru

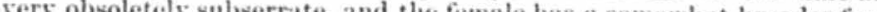
of body.

Of the three new species little need be sad here. Two are water heetles, and the family is now in process of revision. The Telephoride. silis, will be described, with many other new forms, in a fortheoming review of the entire gronp.

It is rather remarkable that no representatives of the families Histeride, Coccinellide, and Curculionida appear, and very few Tene. brionida, although the region has on other oceasions yielded many representatives of all these families. 


\title{
NOTES ON ORTHOPTERA.
}

\author{
By Cruvs Thomas, Pr. D.
}

Although the collection of Orthoptera made last season was not so large as some former collections made by the survey, yet it was one of consid. erable interest, as it contained a few new species, and assisted in determin. ing the range of other species already known. The collection was ehiefly made by Messrs. Carrington and Brown; a few Curtis, One very important bottle of speeimens was collected by Dr. Ilayden perang, wile temp in in Southern Montana; in this I found a new species of Platyphama, the first of this genus found in the United States, though a few species have been obtained from Mexico. It also contained a new species of Chryso. chraon, somewhat peculiar in having the sides of the pronotum irregu. larly waved and slightly converging in frost

$A$ s the descriptions of the new species are given in $\mathrm{my}$ "Synopsis of the Acridida of North America," which is now in conrse of publication, I will not repeat them here, but will only add such notes in regard to colors, habits, localities, \&c., as are not fully given in that work; and in doing this I shall not attempt to arrange them ss tematically.

I have not as yet male a thorough examination of the collection, yet I have gone over it sufticiently to satisfy myself that there are no new species except those already mentioned. Although this is the case, the collection is not without interest, as it brings to view forms which were not seen in the broad intervening space between Southern Wyoming und the borders of Montana. It also reveals the iuteresting fact that Edipoda atrox, Scudd., hitherto found only in California, re-appears in the Yellowstone Basin. In the same basin we again meet with Decticas of the lock dividing range of the Rocky Mountains. The ubiquitous Caloptenus spretus is seen in nearly every bottie of the collection from Ogden northward.

The following kpecies were found in the Yellowstone Basin, probably all from the limits of the National Park: Caloptenus spretus, Plotypham montana, Pezotettix obesa, Stenobothrus curtipennis, CEdipoda atrox, $\boldsymbol{E}$. undulata, llecticus trilineatus.

It is somewhat singular that but two or three crickets are found in the eutire collect.on.

The collection which I made during my exeursion to the northwest was comparatively small, as 1 did not attempt to collect any except those species or varieties which isinared to be new, or where there existed some doubt in my mind as to the coloring, in which eise notes were made at the time As before stated, I give these notes without any attempt to arrange the species systemat.

In addition to the collections mentioned, I also received, specimens from Jefferson County, Alabama, collected by Dr. G.T. Deasen; from Fast Tennessee, through Theophilus Rogan, eso; und from Nissipsi, I suppose through $\mathrm{Yr}$. D. ment a very valuable collection made by Professor Glover, in Florida, some years ago.

In the collection from Mississippi I find a very large, fine specimen of 
Elipoda discoiden, Serv. In that from East Tennesseg ! had the plea. sure of fucing the first specimen of Pyrgomorpha I have seen; the speries is described in my Synopsis. In Professor Glover's collection found a new species of Tryxalis, the first, so far as I am aware, that has been found in the United States; also Stenacris chlorizans, Walk. I at first overlooked Walker's description, and placed it among the eslindri

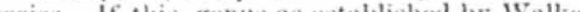
be retained, it will be necessary to remove other species from Opomale and place them here; and the position of the eyes will then be the only distiaguishing feature of .lesops.

Edipord phanicoptera, Gierm.

I met with this species (June 21) in Southern Dakota, between Yauk. ton and Springlied, (Bn IIomme Counts.) The wings, though usually of the bright wed commen to this species, are fremently sellowish, with but a fant reddish tinge. These specimens vary slizhtly from the usual type in the form and size of the spots of the elytra, the variation being towaral E. correllipes, Hahl.

(E. discuidea, Serv: (E. rugosa, Seudd.; OE. corallipes, IIald.; OE. Halde mannii, Seudli.; (E. paradoxa, Thos.

My investigations the past season have increased my doubt in resprect to the distinction of these species. I have now in my collection spreci mens from Mississippi, Washington City, Lllinois, Nebraska, Kansas. Dakota, Colorado, Wroming, and Utah, and although there are slight varations in the marki urs of the elytra, the rugosity of the thorax, and the color of the disk of the wings, vet these variations fade so insensibly from one into the other that there is uo possiblity of fixing the line of distinction. Locality appears to have something to do with these varia tions, but does not govern them entirely. For example, a specimen before me, from Mississippi, has the clisk or basal portion of the wing an orangered, while anther, by the side of it, from Nebraski, has it lemon-yellow

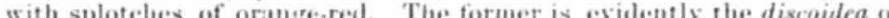
Serville, aud the latter stauds abont miclway between rugosa and coral. lipex. When we examine them cloxely, the following diflerences are seen: taking the first as the stamlard, (both females, the latter has the pronotum slightly shortened, and more wrinkled and rusose, bein sligbtly tubereulate, the posterior femora at little less ilitated, and the contour as a general thing more full and rounded; the spots on the elytra are a little farrer, thongh vers similar in form and position. When we remember that the former is from a loeslity of rank vegetation and moist atmosphere, while the latter is from a locality just the opposite. will not this acount for the differences in the pronotum? If these stood alone, I might suppose they were ditierent species; but pinned close beside is a smecimen (a temale) from Sonthern lllinois, with the base

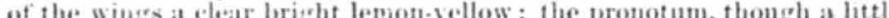
more shortenesl, yet in other respects is much like the speciuen from Mississippi, the spots on the elstra enlarged, the small ones apparently absorbed into the harger, tire spaces also comparatively large, yet the specimen is smaller than either of the others. The specimens from II ashington correspond very elosely with the last, (from lilinois,) but are rather sinaller, and the pronotum is slightly more rngose on the disk. Vow, if we pass to the western plains, we fiud the Haldemannii of Seudder and corallipes, Hald., which are absolutely so closely allied that thes searcely constitute different varieties, it being an impossibility to dis tinguish alcoholic specimens except in extreme cases. These are of larger size than the rugosa, the wings yellow at base, and the inside of the posterior femora generally a bright coral-red, the pronotum somewhat more wriukled and rugose than the Nebraska specimen, (which has, as I should have stated, the posterior femora orange-yellow inside and the tibia yellowish, tingel with red;) the spots on the elytra are more broken up. In Utah, we meet with auother variety which resembles very closely the corallipes except that the wings are pale-red at base and the inside of the posterior femora yellow.

In consideration of all these facts, we are certainly justified in thinking it highly probable that these are but varieties of the same species, the differences being attributable to the differences of climate and food, those in the moister climate, where the vegetation 's ranker and where they are less exposed to the sun, being darker and "plumper" than those found ou the more arid plains of the West.

\section{QE. kioica, Thos.}

Female. - The central foveola of the vertex is not exactly quadrilateral, bat somewhat hexagonal. Parts of the month, pectus, and venter yel. lowish-white. Face, dirty brown 'ateral carinae distinct, reaching the corners of the face; cheeks, di. ny or dark brown; from the upper margit of each eve a pale stripe runs back to the pronotum; the pos. terior part of the occiput fates, backward, from dusky to yellow; pronotum dusky with paler spots. The angles or longitudinal corners when folded) of the elytra are marked with a narrow yellow stripe; the upper (posterior) narrow field dusky; rest as described in re. port of 1871. Posterior tibia bright blue, with an indistinct, pale riug below the knee; apex black. Tarsi pale yellow. Wings pellucid with a few fuscous dots near the apex; nerves and nervules of the apical portiou dusky; rest pale or white.

Dimensions.-Length, .87 inch; elytra, .86 inch; posterior femora, .52 inch; posterior tibia, .46 inch; pronotum, .20 inch.

Taken at Lincoln, Nebraska, August 3.

E. tenelurosa, Scudd.

Var. With disk of the pronotum pale, cinereous, Tomonotus psendo. nictanus, Thos.

Antenna fuscons, and considerably flattened toward the extremity. The pale portions of the mouth and face are slightly tinged with pale rufous. The disk or basal portion of the wings a very bright brick-red. Posterior femora with three distinet white bauds; posterior tibis black, with a white ring below the knee.

Taken at Lincoln, Nebraska, August 3.

E. verruculuth, Kirb.

In the southwestern part of Minnesota, (Angust 19,) I noticed quite a number of individuals of this species sticking to the weeds along the road. side. Supposing them to bo alive, I stopped to collect some, when, to my surprise, I found they were all dead; again and again I repeated the experiment, but with the same result. All these appeared to be females; their colors as bright as though living.

Stenobothrus maculipennis 9 Scudd.

Female.-Face dull, rusty yellow; cheeks and sides of the heal brown, darkest immediately back of the upper part of the eve, where it forms an ill-defined stripe which runs back to the pronotum. Oeciput and disk of the pronotum pale brown.

The black or dark-brown stripe running back from the eye continues $46 \mathrm{G} \mathrm{S}$ 
along the apper portion of the side of the pronotum, passing over the lateral carina upon the disk of the posterior lobe; the lateral carina yellowish. The elytra have a pale stripe along the iower (or anterior) fleld, near the margin; a narrow stripe along the middle field is marked with black or dark fuscons spots, four or five in number; the portion with black or the tinged with reddish purple. Wings transparent but tinged, especially the front and apical portions, with reddish purple; the nerves and nervules of the front portion dusky. Posterior femora pale yellow; a narrow dusky stripe along the upver carina (or rib) of the disk; two pale dusky spots on the inside of the upper carina. The posterior tibia has the lower two-thirds it the of the un of the under surface dusky, the rest pale yellow;

The pronotum expands but moderately on the posterior lobe, the The pronotum expands but moderately on the posterior lobe, the approximation beiug in auvance of the midale; posterior margin ob. turely rounded; no entering angle on the posterior lateral margin, though it slightly (very slightly) curves inward from the humerus to the lower angle.

The sub-anal plate of the male is slightly elongate, fleshy, entire, and rounded at the tip.

Dimensions. - - Length, .75 inch; elytra, .60 inch; posterior femora, .46 inch; posterior tibia, . 35 ineh; pronotum, .13 inch. \& Length, .64 inch; clytra, .52 inch; posterior femora, .40 inch; posterior tibia, 36 inch.

Abuadant in the vieinity of Omaha, Nebraska, August 1. This inde

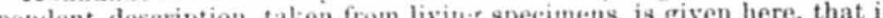

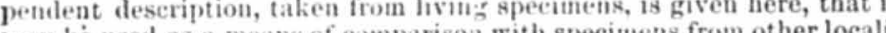
may be used as a means of comparison with specinens from otber locali. ties, as there is so much difliculty in distinguishing some of Mr. Scudder's closely allied species, if in fact they are distinct, which is a matter of some doubt.

\section{Caloptenus occidentalis? Thos}

In the Minnesota portion of lied River Valles, at Glyndon, on the Northern Pacitic road, and near Morris, on the Saint Paul and Pacitic roal, I found a small variety of this gemus quite abundant, which, though differing slightly trom occidentalis, appears to belong to that species.

Foveola of the vertex elongate. rounded in front; frontal costa solid love the ocellus and slightly weleste below it, with a row of punctures ear side. The pronotum has the lateral carina toleravis well defined and almost right angled, especially in the male. Elytra and wings about as long as the abdomen in the female. Posterior femora reach the tip of the abdomen. Antenna extend to the posterior extremity of the pronotum. Prosternal spine broadly transverse at the base. The cerci prome slightly; the tip of the sub-anal whate is nutire, not notehed. Color of the liring insect.-The face is sometimes almost milk. white, with
a faw luteous or purplish dots sprinkled over it; the cheeks are pale, but in hlack stripe, quite narrow, runs down the sulcus below the eyc; the nsual black stripe behint the eye, extending upon the pronotum, is pres. ent, but is very suable. The lateral and posterior margins of the pro notire are berdered ly a loread pale, purplish band; a very nareow

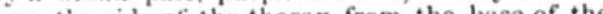
white stripe extetus dow ane the elytra to the insertion of the posterior legs. The elytra are almost uni. form in color; sometimes a few dim lots can be seen along the middle field, yet many specimens appear to have them unspotted; the general color is a dark ashy brown, wings transparent, tinged with blue; this bluish cast is very evanescent, almost wholly disappearing from a specimen kept for ten hours, though not immersed in any liguid. nal face of the posterior femora thal face of the posterior femora is crossed by three oblique dark and two intermediate white bands; the dark bands cross over to the upper margin of the inner face; inner fave and under side yellow. The pos terior tibia pale greenish blue, generally with a datk ring near the base; spines black. Tarsi dark above, white beneath. Abdomen dark, tled above; the posterior margins of the segments bluish white; venter yellowish waite.

Length about .8 or .9 of an inch. July 5-11.

\section{C. biviltatus, Say.}

This species is very variable, both in color and size, yet it is easily re. cognized in almost any of its numerous variations, and it is only the more particular investigation that causes the entomologist to doubt the identity. I herewith give some notes in regard to the varieties met with the past summer in the Northwest.

Omaha, August 1.-Female, living specimen. Stripes on the pronotum very distinct, rather broad, reddish sellow, the intermediate space a velvety black, (or dark fuscous.) The general color of the sides of the insect, a purplish red; the face, and the external face of the posterior femora, the same color; the upper, external carina of the the postertor ora, shining black; posterior fer mitons; the base on the sisk. WVings tusp spots near and nervoles ans and nervales along the front margin dusky; rest colorless. The pos. terior femora have two black spots on the upper margin of the internal face; the spines of the posterior tibie, black. These specimens were found abundant on a tall weed much like hem. These specimens were ferentialis and Acridium emarginatum. In some specimens the dark stripe along the posterior femora oceripies the upuer half of the disk then there is above this a yellow lime. letwen the upper lateral and dorsal carina, and then a dark strige. Hong the upper margin of the in ner face. The general color is sometumes dath ashy green, which prevails on the head, sides, and beneath. Th. .erci of the males are broad, extending back a short distance. leaving a rounded protrusion on the lower edge. Subranal plate obtase and entire at the tip.

In Platte bottoms I noticed quite a number of individuals of this species in the long rank grass, with the general color a oright yellow, while others were ashy green, yet the two varieties wero frequently seen pairing. This yellow variety was also seen at Sioux Falls, Da. kota, August 25.

\section{C. differentialis, Thos.}

The iuclividuals of this species fonnd at Omaha Aurnat 1 in com pany with the previous species, had the antenna red; general color of the head and thorax, pale olive; abdomen and pectus, bright sellow.

Dimensions. - \& Length, 1.2 inches; elytra, 1 inch ; posterior fermora, .63 inch; posterior tibie, .58 inch; pronotum, .24 to .26 inch.

$\Delta$ North Platte I noticed quite a number of the dark variety of this species, with bright yellow stripes. This variety has the posterior fem. ora markel with black bands, ind the general cc!or is quite dark, al most a black. These were found congregated on a large weed growing profusely in the Platte bottoms, and were often seen pairing with other varieties. 
Acridium emarginatum, Uhl.

Male.-Taken at Ouaba, Augast 1. Face greenish yellow; a row of Male.-Taken at Ouratin of the frontal costa, and a row across th o upper part of the elypeus. Palpi and antenna bright row across tho upper part of the heal and prouotum bright $y$ llow, ex. yellow. The dorsal stripe on the head awn the front nearly to the cen. tending forward over the vertex and down the front nearly to the cen tral ocellus; its extension on the suture o. the elytra yellowish white; it is bordered ach side by a broad, dark greenish brown stripe, which fades on the sdes into reddish brown on the elytra, and paler greenish brown on the pronotum, these latter colors occupying the entire sides. brown on the prototum, these over it golden dotes. Wings trausparent, The pronotum has seattered over t golden dotes. pale greenish yellow at base, the front margines corresponding in color with pale reddish brown; nerves and nervules corresponding carina, with the parts. Abiomen with a dark stripe along the dorsin carina, sides purplish green, each segment having a ring of black flots on the posterior marrin. The cerci very breal, somewhat notehed at the apex, paste purplish; subanal plate with a broad, square noteh at the apes. pale purplish ; sub-anit phate ou them. Interior aud middle legs The elytra bave no spots water. Posterior femora greenish externally, striped internaliy with blow dots along each pale dall green or olve exterually, with a row of blick dots along each margin of the tisk; internal face fuliginous or priphish; a row of black dots along the upper hargin. ['osterior tibia, with the posterior and inner face black, exterior face grvenish purple, becoming black above spines white at base, black at tips. Pulvilli remarkably large, oblong spines
ovate.

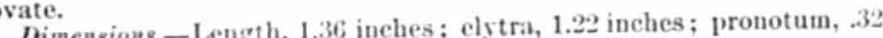
Dimensions.-Lengtb, 1.36 inches ; clytri, 1.2- inches,

inch; posterior fewora, .. inch; posterior tibis, reside ehiefly on high, This and the two preceding species appear to reside chiefly on light, rank weeds, not beitg properin the other two, as it appears to adapt itself to almost any situation.

Opomala birit: ta. Serv.

I met with t. \& species at Lincoln, Nebraska, also at Manbattan, in Kansas.

Pcmalc-Head and thoras rufous, except the stripes, which are red. Pcmale.-Hean and thoras rufots, except the stripes, which are rah.

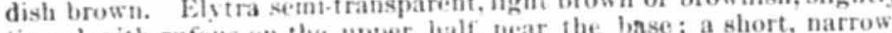
tinged with rufous on the tiper hinf, hear the wings pet white stripe neat the base, along the lower (from, margin, lucid, with a faint greenish yellow tinge; herves and nervules most dark. Four anterior legs rutons; posterior femora rufous above and on the dist yellow beneath; posterior tibia yellow. Venter and pectu. the dist:

Dimensionx.-Lngth, 1.5 inchea; elytra, 1.13 inches; pronotum, .2.5 inch; posterior femora, .90 iuch; posterior tibiac, 1.1 inclues. August 3.

Omnatolampis riridis, Thos.

Syo. Catoptenas riridis. Thos

Sincoln, Vebraska, A ugust 5.-Imong the orthoptera met with at this place, I noticed this species quite abuudant in the luxuriant green grass. Lam now tolerably well satistied that it belongs to Ommatolampis of Burneister, aud have, therefore, placed it in that genus, and berewith give full description from lisiug specimens, the males and females give a fill dercely any differences in size or color.

The sertex, on cose examination, aprears to be somewhat hexagoual, as in Acridium, with a slight central depression; frontal costa sulcate; sides nearly parallel and punctured; lateral carine nearly or quite par. allel; eyes as heretofore described. Posterior lobe of the pronotum punctured. Pectus covered with minute hairs. Elytra same Pongth as abdomen. Posterior femora reach the tip of the abdomen.

Color--Bright pea-green throughout, except the following mark. ings: Antenna rufous except the basal joint, which is green. A small, dusky spot between the eyes, a dark spot beneath the eyes, which is bordered in front by a white stripe. A narrow white stripe runs along the upper margin of each eye, and extends back. ward along the lateral carina of the pronotum. A median dusky stripe runs along the disk of the pronotum, the central portion pale and sometimes almost white; a black stripe extends along the sides of the anterior lobes of the pronotum, which is bordered by white; the lateral margins have a minute white line along them, sometimes interrupted by black punctures. There is an oblique white line on the side of the misothorax, running to the base of the middle leg; a similar but larger one on the metathorax, running to the base of the posterior legs. These limes are generally shauled in frout with black. Elytra semitrans. parent, almost uniform green, there being sometimes a pale ashy-brown shade on the upper (posterior) portion. Wings pellucid; when living,
the front margin is slightly tinged with bluish green, and the posterior the front margin is slightly tinged with bluish green, and the posterior
half with very pale rufous; but these shades are often very dim and evanescent. The posterior femora are green, except a rufous band above the knee; the upper and lower carina (or ribs) of the disk have generally a tbreat !ike line of white along them, and the apper is sometimes bordered above with a pale rufous line. Posterior tibia green; spines tipped with biacic; tarsi green: the mulvilli rufous.

The cross incisions of the pronotum were not dark in these specimens, as mentioned in my original deseription, which was taken chiefly from alcoholic specimens.

Dimensionx,-Length, I to 1.10 inches; elytra, if inch; posterior femora, . 633 iuch; posterior tibia, .58 inch; pronotum, .25 inch. 
ODONA'T'A FROM THE YELLOWSTONE.

Br Dr. H. Hugrs.

LESTES.

L. diejuncta, Selys.

Known before from Brit. America. (A few specimens.)

L. congener, Hag. Syn. N. Amer. Neurop., 67, 5. (A male.)

\title{
AGRION.
}

Two species, but not well enough preserv sd for description; probably described species.

\author{
GoMPHUS.
}

G. (Herpetogomphus) vipirinus 9 Selys.

The species is described by Barou De Belys Longehamps, from Mexico. The specimen is not so preserved as to be sure of the identity; at least it belongs to no other known species. (One fragment.)

G. colubrinus 9 Selys. Hag. Syn. N. Amer. Neurop., 101, 7.

Known from Hudson Bay, Brit. America. One male, in poor condi. tion, if not belonging to this species is new but nearly related.

\section{ISCHNA.}

A. constricta, Say. Hag. Syn. N. Amer. Neurop., 123, 8.

Common, at least represented by many specimeus; a species common everywhere east of the Mississippi from Canada to Maryland, and hitherto west to Wisconsin.

A. eremita, Scudd. Proc. Bost. Nat. Hist. Soc., $\mathbf{x}, 213$.

Taken in abundance at Hermit Lake, White Mountains, N. H., by Mr. Scudder, and also common in Saskatehewan and Fort Resolution, Great Slave Lake; taken by Mr. Kennicott and Mr. Seudder. (One female.)

A. multicolor, Hag. Syn. N. Amer. Neurop., 121, 4.

Known before only from the Pecos River, W. Texas; Cordova, Mexico, and the Upper Missouri; a decidedly western species. (Few specimens.)

A. propinqua, Scndd. Proc. Brit. Nat. Hist. Soc., $\check{z}, 214$.

Fragments of one male and female, not sufficient to identify decidedly; probably this species. Known before from N. England.

\section{LIBELLULA.}

L. nodisticta, Hag. Syn. N. Amer. Neurop., 151, 3.

Formerly only known by a young male collected in Mexico by Mr. Baussure. (Male and íemale) 
L. forensis, Hag. Syn. N. Amer. Neurop., 154, 9.

Formerly uuly known by a male from California, in the Berlin Museum. (Male and female.)

L. zaturata, Uhler. Hag. Syn. N. Amer. Neurop., 152, 4.

Known before from California, Cape San Lucas, and San Diego, and from Mexico, Cordovs, Tampico; a decidedly western s[ecies. (One fragment.)

L. flavida, Hag. Syn. N. Amer. Neurop.. 156,15.

Known before from Pecos River, W. Texas. (One fragment.)

\section{MESOTHEMIS.}

M. simplicicollis, Hag. Syn. N. Amer. Neurop., 170, 1.

Common throughout from Massachusetts and Illinois to Mexico, Florida, and Cuba. (One female.)

M. longipennis, Burm. Hag. Syn. N. Amer. Neurop., 173, 7.

Common everywhere as the foregoing species. (Male aud female.)

M. oorrupta, Hag. Syn. N. Amer. Neurop., 171,3.

Known from Illinois, W. Texas, Mexico. (One female.)

H. composita, nov. sp.

Milk-white, with a yellowish tinge on the head, front, month parts; threv transverse shining black lines behind the eyes; lobe of the pro thorax stuall, rounded, yellowish white; thorax yellowish white, a tle bluish; two large not well-defined brown bands on the westhorat two oblique black lines on each side, and a third one between them not depassing the stigma; abdomen thickest at the base, black, each segment with an elongated milk.white spot on each side, and another similar one on the second and third segments; venter covered with a whitish pow. der, the second and third segments with a large ulongated milk.white spot; appendices biack, short, cylindrical; the tnbercle between the white; valvar opening with a ronnded excision; feet black, femora white behind; wings hyaine, a small yellow spot at the base; neuration black; the costa milliwhite; the pterostigma large, oblong, black; fourteen antecubitales; two posteubitales; three series of areoles after the triangle; membranula white.

Long. corp., 17 mill.; exp. alar, 76 mill.

The species is related to 1. . corrupta. (One female.)

\section{DIPLAX.}

D. assimilata, Hag. Syn. N. Amer. Neurop., 174, 1.

Known from the northern and middle parts of the United States. Known from
(One fragment.)

D. scotica, Donov. Hag. Syn. N. Amer. Neurop., 179, 9.

Common in Europe, N. Asia, and collected at N. Red River by Mr. Kennicott. (A few specimens.)

D. vicina, Hag. Syn. N. Amer. Neurop., 175,4

Common in the north of the United States. (Several specimens.) D., spec. nov.

Nearly related to $D$. rubicundula Say, but different by the genital parts. (Only two males, imperfect.)

\section{Species not belonging to Odonata.}

\section{HET ERINA.}

H. Californica, Hag. Byn. N. Amer. Neurop., 59, 2.

The fragments of three males are not to be separated from the type in my collection. (Some fragments.)

POLYSTGCHOTES.

P. punctatus, Hag. Syn. N. Amer. Neurop., 206, 1.

Very common everywhere in the whole Cnited States. (Numerons specimens.)

\section{STATHMOPHORUS.}

Spec.-Only a male related to St. Argus, Harr., perhrps distinct. The male of St. Argus is still unknown.

\section{PTERoNarCYs.}

Pt. Californica, Hag. Syn. N. Amer. Neurop., 16, 5.

A female; a decidediy western species.

\section{MYYRMELEON}

\section{M. diversus, nov. $\mathrm{sp}$.}

Brown, covered with grayish powder; head pale ye"owish near the mouth and the eyes; two black spots on the clypeus; front largely shining black, brown mat behind the antenux; on each side of the occiput a yellow spot, and near the middle a yellow band, attenuated and inter. rupied in the micldle; antenna short, black, anoulated fonely with yellow, the tips enlarged brownish; palpi sellow, the last joint black; last joint of the labial palpi longer, ovoid, black, cyliudrical at the truneated tip; prothorax qualrangular, a little narrower and rounded before, dull yellowish, with two interrupted brown lines in the middle, and one on each side, not reaching the anterior part; thorax and abdomen brown, a final yellowish triangular spot on the segments; legs yellowish; femora be. hind in the middle, tibiæ inside, and basal joint on tip black; spurs as long as the first joint; wings hyaline, veins yellow, spotted with black on the radius, and most of the small fureations; stigma small, whitish. The species belongs to the genus Myrmeleon, and is related to the $M$. formi carium. I believe a specimen in very bad condition, from the Pecos River, W. Texas, belongs here. (Two specimens.) 


\section{DESCRIPTIONS OF NEW SPECIES OF MALLOPHAGA COLLECTED}

BY C. H. MERRIAM WHILE IN THE GOVERNMENT GEOLOGICAL SURVEY OF THE ROCKY MOUNTAINS, PROFESSOR F. V. HAYDEN, UNITED STATES GEOLOGIST.

BY A. 8. PACKard, JR., M. D.

Menopon picicola, n. 8p. (Fig. 58.)

Body slightly more than twice as long as broad. Head lunate, being much shorter than wide, well rounded in front, with a lobe on each side. Antenne short and slender, terminal joint nearly twice as long as penulti. mate. Head with three long hairs from posterior division, and two oblique dark spots in the middle. Prothorax with a median square area half as wide as head, with two rings on each side, makirg the entire segment three-fourths as wide as head. Abdomen regularly oral, two-thirds as wide as long, terminal segment large and broad. Segments convex, with a slight ridge crossing betind the middle of each segment. Two or three long hairs project from hind edge of each segment, and nu. merous finer hairs. Legs moderately long, tibiæ long, a third longer than femora ; tarsi with second joint long and slender, eading in two large claws. Pale horn color.

Length, .08 inch. Ten specimens. From Picoides arcticus and $P$, dor salis, (Nos. 236 and 237.) August 26 , 1872 , at Lower Geyser Basin, Wyom ing Territory. This is more closely allied to $M$. citrinella, Denny, ${ }^{\bullet}$ than

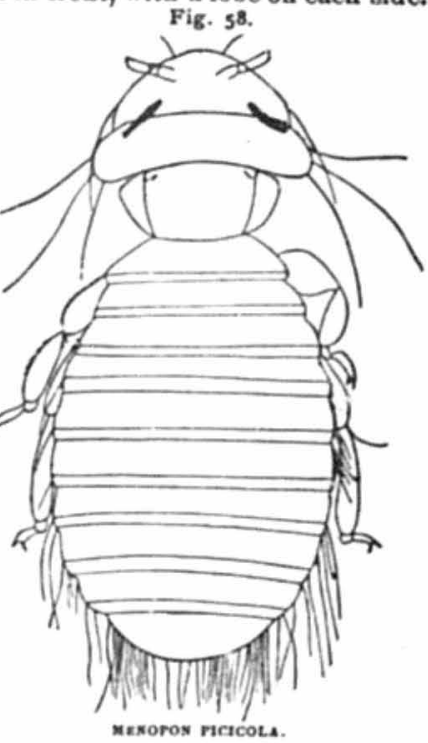
any other species I am acquainted with, but differs in the shorter. broader head. The form of the prothorax is very different, being transversely oval instead of squarish, as in $M$. citrinella.

Goniodes Merriamanus, n. 8p. (Fig 59; $a$, male antenns.)

Head about as broad as long, fuli, convex, broad, and regularly rounded in front of insertion of antenua. Deeply excavated in middle, receiving basal two-thirds or basal joint of autenna; on posterior edge of the noteh a prominence, and still posteriorly a large prominence, giving a square appearance to bead posteriorly, which at hinder edge suddenls contracts where it is articnlated to prothorar. IIead about two-thirds as wide as abdomen. Prothorax about hall Abdomen ovate or pear-shaped, being broadest just before the end. It

- Monographia Anoplurorum Britannisb. London, 1842. 
is whitish, corneous on the edges. Antenna recurved, four-jointed, basal very large, second as long as first is thick, third and fourth slender, subequal; fourth as long as second is thick. Legs stont, second pair with stout spines on inner side of tibiæ; tarsal joints very indistinct, short, with a long curved claw.

Length, .10 inch. One specimen.

From Tetrao Richardsoni, (No. 219.) Collected August 5, 1872, at North Fork of Snake River, Idaho.

It is very different from $G$. tetraonis Denny, and closely allied to $G$. Colchici Denny, especially in the pyriform shape of the abdomen. The head in one species is rather longer and more produced in front of the antenna, the prothorax is rather longer and broader, and the mesothorax wider and shorter in proportion.

Goniodes mephitidis, n. sp. (Fig. 60.)

Head short, abont as long as broad, well rounded in front, with a nar. row curved sinus in the middle; widest behind the middle, with well.
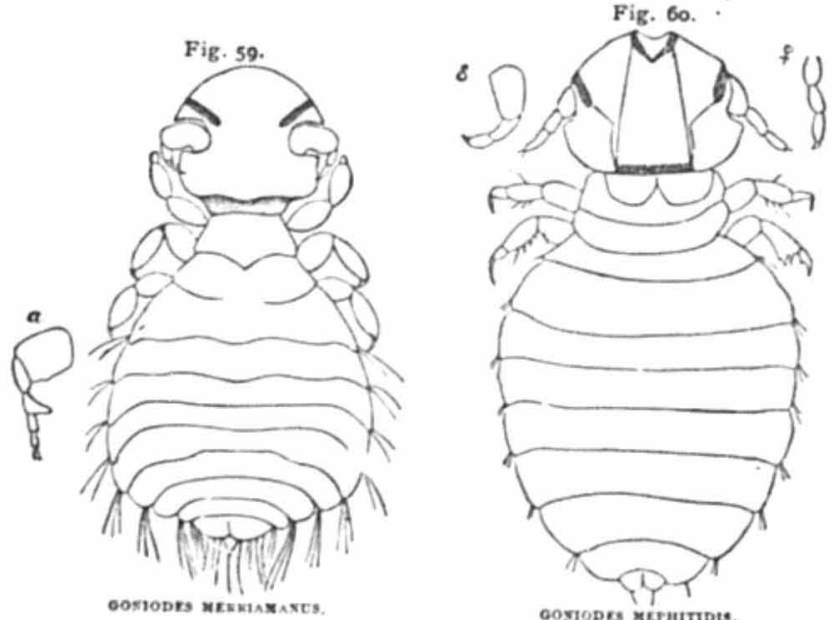

marked lateral projections. Two dark spots on each side of the sinns; side of head in frout of the projections lined with black. of the sinns; black line across hind edge of head, ending on each side in two black points, and sending obscure prolongations anteriorly. Antenns four jointed; basal joint very large, three onter ones filiform, third consider ably longer than second, fourih minute, short. Prothorax corneous slightly narrower but distinc: from mesothoracic segments, the sides which are prodnced hook-like berond it little longer than broad, white. with several long spines wh the distally, long hairs on the onter side. claw as long as itself seen wit'- the tarnal joint ends in a curved slender claw as long as itself, seen wit': the naked eye; head and thorax appear pale testaceous; abdomen white.

Length, .06 inch. Seven specimens.

From a skunk (Mephitis) collected August 13, 1872, at Fire-Hole Basin,

It differs from auy species figured by Denny in the notch in front of head, and short, broad lnvate mesothoracic segment, and long oval form of abdomen.

Nirmus buteonivorus, n. sp. (Fig. 61.)

A very large species, long and sleuder; head long, oblong, subtrape. zoidal, half as wide in front as at base; front truncate, with prominent rounded lateral wings on each side of head, behind inser- Fig. 61. tion of antennæ, more prominent than usual. Antennæ just reach as far as the front edge of head; four-jointed; two basal joints of much the same size and length, two two basal joints of ming onter much smahler, fourth slenderer, nad a than third. A large, round inflated swelling on under side, just behind the mouth, and behind the singie.jointed minute labial palpi, apparently forming a sucker to draw mouth near to skin of bost. Mental region bebind flat. tened, rather narrow. Prothorax small, rounded square, incised on each side; a transverse impressed line crossing the anterior third, and, with the longitudinal line, dividitig the surface into four square spaces, the two anterior hal as long as two posterior. Abdomen, including meso and metathorax, regularly ovallanceolate, two and a half times as leng as wide, with fine long hairs alorg edge. Legs

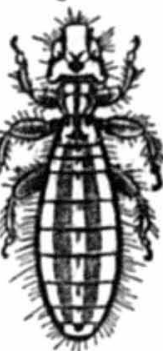
rather large and long, with tarsi on three hinder pair of legs, basal joints much swollen and enlarged, with a white swollen disk-like undezsurface for holding on to skin of host; second joint remarkably long and slender. Edge of head white, and whole body black, front edge of head white, hind edge black, a dark scutellate spot just belind the middle of the head; two round black spots under base of head; two black spots projecting inward at front edge of mesothorax; a brown stripe across hind edge of each abdominal segment, interrupted on anterior four rings by median line of the body. Joints of legs edged with black brown.

Specimens vary much in extent and intensity of dark lines and spots, as usual.

Length .40 inch. Twelve specimens.

From Butco Sicainsonii, (No. 239.) Collected Angust 27,1872, at Lower Geyser Basin, Wyoming Territory.

Differs a markably in form and size from any figured hy Denny.

I have in describing this species used, for comparivon, a specimen of this genus from Goose Lake, Siskiyon Fig. 62. County, Cal., (J.Holleman,) in which the head is triangular, and the tarsal joints not dilated, and second Its host not indicated.

Docophorus syrnii, n. sp. (Fig. 62; a, antenua; $b$, hind leg.

Head a little longer than broad, being a little longer than usual; two-thirus as wide as abdomen. Month cavity deeply excarated. Trabeculse small, acutely pointed, projecting slightly beyond the head. Two oblique slifbtly beyond the head. Two oblique chitinous bands diverge from base of head to upper side of base of trabecula ; antenna fourth joint much shorter than fint. Pro thorax trapezoidal, half as wide as head; me. sothorax wide, projecting considerably bey ond the succeeding segment; edge more bu!ging

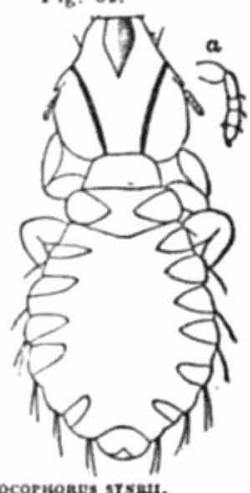




\section{4}

GEOLOGICAL SURVEY OF THE TERIITORIF',

than others. Abdomen regularly oval, but little broader than long, with the usual triangular pale horny pieces on each side of segments, with a few long hairs, especially toward end of body.

Length,, 09 inch. Four specimens.

Lives on Syrnium nebulosum, ( 8 No. 55, private collection.) Collected November 24, 1872, at Locust Grove, New York, by C. H. Merriam.

of the species figured by Denny, it approaches nearest in the form and shape of the head to D. testudinarius, (Children,) Back's Narrative, \&c. It is allied in form to D. ostralegi Denny, but the prothorax is shorter; and to D, icterodes Nitzsci but the head is much broader. From D. communis Nitzsch it differs considerably, the heac being shorter and broader, and the trabecula much smaller, judging from Denny's figures.

\section{DESCRIPTION OF NEW PARASITIC WOH.MS FOUND IN THE BRAIN AND OTHER PARTS OP BIRDS.}

\author{
Br A. S. PACKard, Jr., M. D.
}

Among the zoological specimens collcsted by Mr. O. H. Merriam, in explorations under Professor Hayden in the summer of 1872, were speci. mens of an apparently undescribed worm found "under the eyes" of a hawk. In describing this worm, we had occasion to compare it with an undescribed species of the same genus of worm in the museum of the Peabody Academy of Science, and found by Mr. Walker in the brain of the night-hawk,

Indeed, one of the most obscure subjects in zoology is the history and development of animal parasites, and especially those which take up their abode in the brain of different animals. Professor Wyman has described, in the "Proceedings of the Boston Society of Natural History" for October 7, 1868," a species of round worta in the brain of seventeen out of nineteen specimers of the Anhinga, or snake-bird, shot in Florida thus proving that " their presence in the cranial cavity might be called the normal condition of this bird." He remarks that "parasites have the normal condition of this bird." He remarks that "parasites have
occasionally been found infesting the brain or its membranes in man and animals, but far less frequently than in the other regions of the body. The number of species thus far observed is quite small, and are chiefly referable to the genera Tania, Filaria, Trichina, and Diplosto. $m u m$, and confined almost wholly to man and domesticated animals, such as the sheep, reinileer, dromedary, horse, and ox ; and, among wild animals, to the chamois, roebuck, and a few others. That they have not been more frequently seen in the wild species is, without doubt, due to the fact that the brains of these have been so seldom examined for the purpose of detecting them." These worms, "which correspond very nearly, if not identical, with the Eustrongylus papillosus, Diesing," were found in every instance coiled up on the back of the cerebellum, their number varying from two to eight. The male is only half as thiek as the female, and the end of its body is always more closely coiled than in the female.

This worm is viviparous, the young hatehing in the oviduct. Their earlier stages are unknown, but the analogy of the Gordiaceous and other worms leads to the supposition that the parasite of the brain of the Anhinga is one of the migratory kinds, and that a part of its life, at least, is passed in a locality quite different frotn that in which it was detected. The manner in which the transfer of the embryo is effected, outwardly to some other animal, or the water, and then back to another Anhinga, is wholly nnknown.

Eustrongylus butconis, n. sp.

This thread-worm seems to agree generically with the species of Eus. tronyglus, said by Professor Wyman to "correspond very nearly, if not identical, with the Eustronyglus papillosus Diesing, found in the brain identical, with the Eustronyglus papillosus Diesing, found in the brain
of the Anhinga bird of Florida. Our species is, however, much shorter and thicker.

-An abatract; with figures, of thin intereating paper may also be found in the "Atwerican Naturalist," vol. 2, p. 41, 1869. 
Male-(Fig. 63, a, magnified ten times.) Body cylindrical, rather short and thick; head cylindrical, pointed, conical, much slenderer than

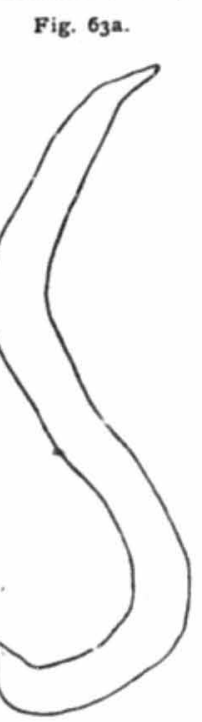

Fig. 63b.

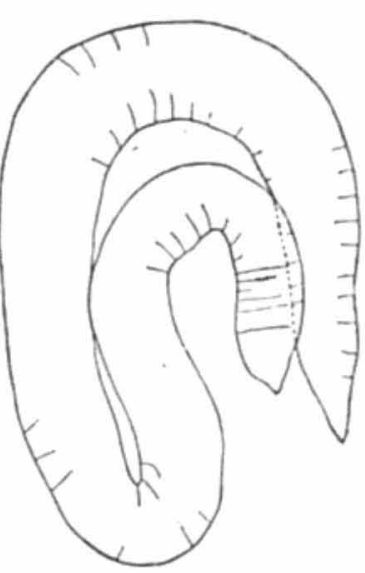

rustrongries avtroxis.

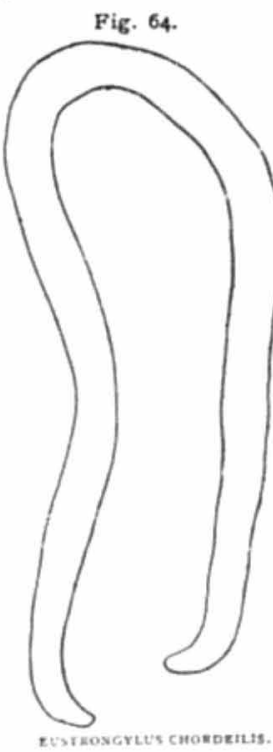

xrsteoscris

the other end. I can perceive no papilla around the end of the head. End of the body rather more incurved than, in the female, bluntly conical; penis forming a single spiculum, a little curved, and inclosed in a bivalved sheath, one valve being truncate and the other pointed, and reaching nearer the end of the penis then the truncate valve.

reaching nearer the ro o individuals.

Length .40 inch. cwo individuals.
Female.-(Fig. 63, b, magnified ten ti..es.) Over twice as large as Female.- Fig. 63, b, magnified ten tic.es.) Over twice as large as papilla that I can see; end of the body obtuse; extreme tip slightly mucronate.

Length one inch. Two individuals.

Four specimens, taken from "under the eyes of Butco Stcainsoni, (No. 269,) collected September 15, 1872, at Snaku River, Wyoming Territory," by $\mathbf{C}$. H. Merriam.

Eustrongylus chordeilis, n. sp. (Fig. 64, magnified ten times.)

An outline figure of a worm, generically identical with E. buteonis, is introduced in order to bring out more clearly the specific characters of the latter species. Two females were taken by Mr. C. A. Walker "from the brain of the night hawk, (Chordeilis Virginianus,) shot in June, at Campton, New Hampshire, and preseated to the unuseum of the Peaboly Aeademy of Science, at Salem, Massachusetts. It is a much slendere Aead

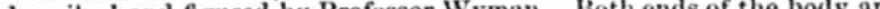
- Both ends or the body are much alike, the anal end being much more pointed than in $E$. butconis, and the anterior end of the body less tapering.

Leugth .70 inch.

Vote-We wonld invite the special attention of the members of the surves and other traveliug and collectiug parties to the preservation in alcohol of the parasites of birds, mammals, snakes, lizards, and frogs. Search for them in the brain, uvder the skin, and in the intestines, lungs, and liver of all these animals. Also look for various bot-fly larve under the skin of the buffalo, deer, elk, squirrels, and all sorts of mammals.

The beaver in Europe is tenanted by a singular flattened parasite, somewhat flea-like, the discovery of which is to be looked for in this country. Moreover, hair-worms (Gordius), and the intestinal worms of the Indians are much desired.

$$
47 \text { G S }
$$




\section{DESCRIPTIOY OF NEW INSECTS.}

BY A. S. PackatD, JR., Y. D.

DMPTEROUS LARYA FOUND IN THE GIZZARD OF PICOIDES ARCTICUS.

Fig. $65, a$, dorsal, $b$, ventral riew of larva; $c$, end of boly; $d$, side view of end of body; $e$, dorsal view of end of body; $f$, head, greatly magnified.

Body white, eylindrical, a little flattened, with twelre segments exclu. sive of head, the regments moderately conves. Head very minute, sunken in the small pro. thoracic segment, (which is much smaller than the second or mesothoracis segment ;) subtriaugular ( in form, a little longer than broad; a transterse. suture just in front of in sertion of antemate indi. cates the posterior edin. of the elypens. ylindrical, two-jointed. the second joint longer than basal, and rather slenderer, its tip reachin as far as the end of the heal.

Terminal serment of the body much smaller and
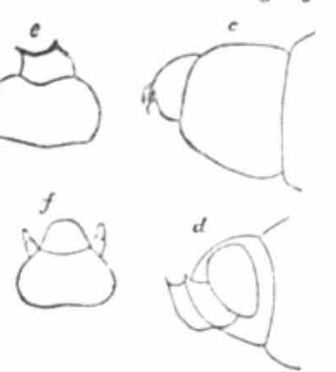

माн
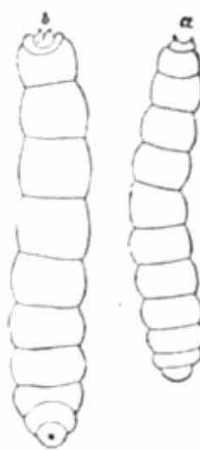

narrower than the penultimate, bearing two large, stont, upenred corneous hooks, with adjoining bases; nine stigmata, one on prothorax and one on tirst eight abdominal segments, round minute, corneous, the ninth round, with a round ares on one side.

Length 35 inch; 135 stucimens taken "from the gizzard of Picoides

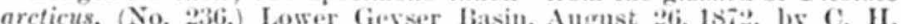
Merriam." Some of these larvil were half grown. Most of thin were perfectly preserved; a few had been partially digested. Whit them were associated a part of the boty of a Cerambycid larva, and a portion of the elytra of a scolytus.like beetie, so that they must have come from under the bark of some tree.

This larva, remarkable for its large size, its minute heal, and terminal upeurved hooks, like those of many coleopterons larva living under bark, seems to be related to the young of the Cecilomyiada, or perhaps a closely allied group, from the two-jointed antenns, the general form of the minute head, and the presence of nine stinmatal. Several Cecidomyia larve have a pair of aual appeudages, though not so marked as in the present form. 


\section{ARACHNIDA.}

Ixodes boxis Riley. (Packard, in First Repori Peabody Academy of Science, 1869, Fig. 66, fully gorged individual, natural size, and another empty, enlarged; Fig. 67, mouth-parts much enlarged.)

A reddish coriaceous flattened species, with the body oblong oval, contracted just behind the middle; heal short and broad, not spined

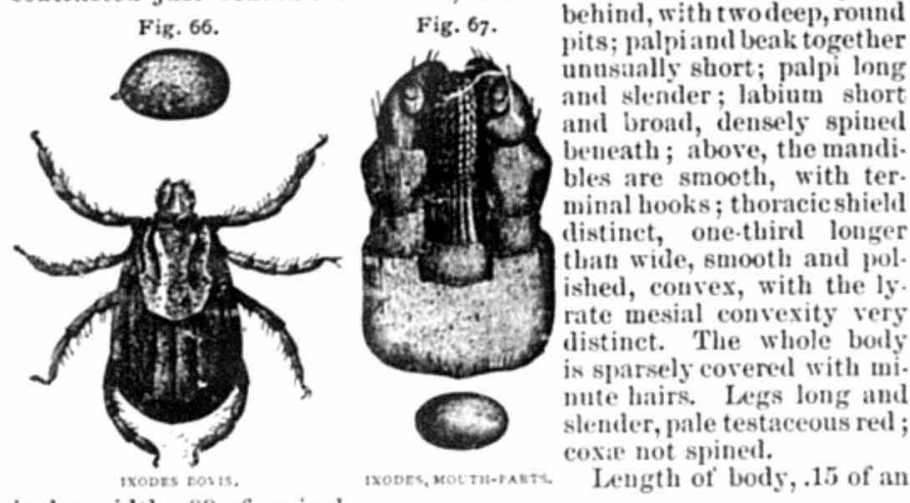
inch: width, .09 of an inch.

This species, which occurs in great abundance at times on cattle in the West, and Texas and Central America, was also detected by Mr. Jerriam on a porcupine, (Erethizon epiranthus,) August 10, 15\%2, at Henry's Lake, Idaho Territory; and on Lepus Bairdii, (No. 47,) col. lected September $15,15 \mathbf{S}^{2}$, at Snake River, Wyoming Territory.

Argns Americuna n. sp. (Fig. Gs.)

Though our specimens are from Texas, (Belfrage, yet this interesting

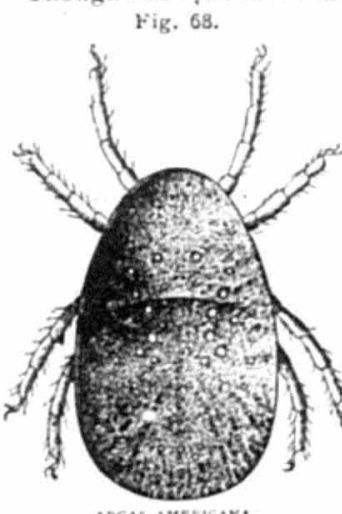

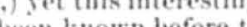

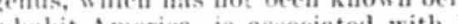
boris, having been received in a lot of Lxoles taken from eattle.

Body very flat and thin, oval, with the head and mouth-parts concealed by the overreaching dorsal portion of the body, which is bent uwward around the toargin, though the edge is not revolute. Body above covered with very uumerous little round pits, large in the middle and beconing smaller on the edge. There are two large, conspicuous oval nits on middle of the anterios third of body ; just in front of the middle a trausverse curved row of six smaller pits, three on each side. Behind are six prominent pits, three on each side. On posterior thira of the body are rows of these punctures radiating outward. The edge of the body is ronghly granulated. Marmin of body beneath pitted as and between the legs and on the head. Pami long and sleuder when stretched out, not reaching the edge of body. Legs large and stout, hind pair just reaching edge of body. Claws long and curved, as usual.

Length, .26 inch; breadth, .15 inch.

It is nearly allied in form to Argas Persicus, (see Plate 33, Fig. 6, D., Insectes A ptères, Walkenaer et Gervais,) but differs in the edge of body being more finely grauulated, and in the pits posteriorly being arranged in radiating lines, The Persian Argas is extremely tronblesome to the last, and the American speeies is moticed here as it was found among a number of Ixoules bor is taken by Mr. G. W. Belfrage from cattle in Texas. 


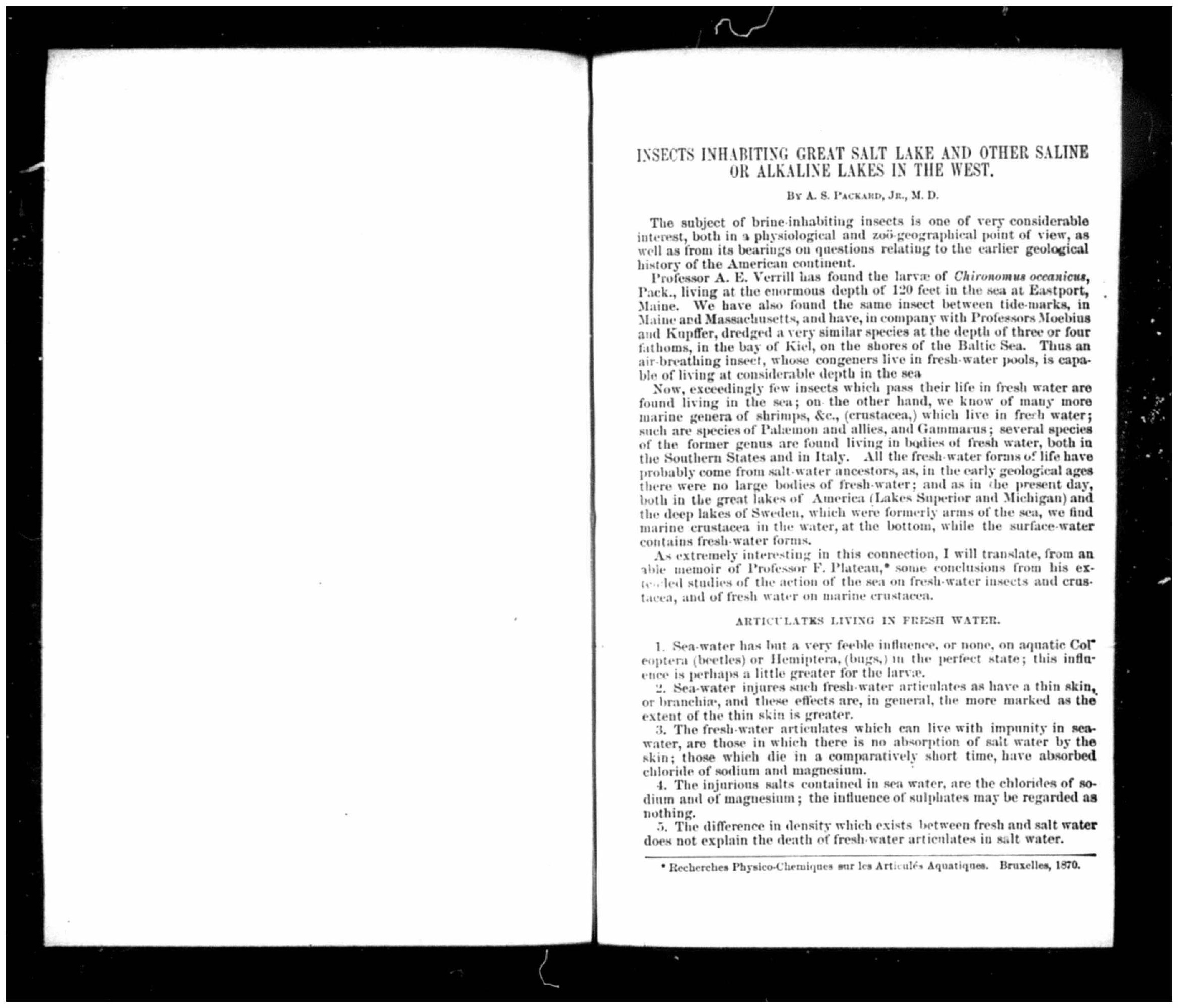



6. When fresh-water articulates pass by a very slow transition from
fresh into kalt water, and when, during this transition, reproduction has taken place, the new generation resists much longer the action of saltwater than the ordinary individuals of the species.

\section{MARIXE CRUSTACEA.}

7. The most common crustacea of onr shores die in fresh water, after a time, varying with each species, but not passing beyond nine hours. 8. Marine crustacea plunged in fresh water lose the salts (especially the chloride of sodium) with which their tisstes are impregnated.

9. In the greater number of cases the presence of chloride of sodium is a part of the indisjensable conditions of the existenze of marine crus. tacea. This salt seems to be the sole necessity.

10. Small individuals, and those which, having just motilted, have the teguments thin, resist less than the others :he influence of liquids of exceptionable composition.

11. The difference between the densities of sea and fresh water ean. not be considered as the cause of the death of marine crustacea in fresh water.

12. (Applicable to the two groups.) The principle of endosmose ex. plains the absorption of salt by the thin tegument or branchial surfaces of fresh-water articulates placed in rea-water; the diffusion of gases aud dialysis, operating with nore energy for the chlorides of sodinm and magnesium than for the sulphate of magnesinm, showing in virtue of which cause that the chlorides alone of sea-water are absorbed. Finally, dialysis explains how marine crustacen, when placed in fresh water, lose in this liquid the salts with which they were impregnated.

So much has been said about the absence of life in the Great Salt Lake, that an erroneous impression may prevail as to the life of that, and similar thongh smaller lakes. With a view of imparting what knowledge we now have as io this subject, in oriler to earnestly call the attention of those who live near the shores of Great Salt lake, and travelers and collectors to this subject, I will give a brief account of what is known regarting articulate life in these saline waters.

In 1852 Mr. T. R. Peale preparel for Staushury's "Re'sort on the Valley of the Great Salt Lake of Ctah," 1. 379, an ircount of the iusect. life of the lake. He stater that in a maxy of exuvine of inverets lorenght larvas and exusiae of the puns. of Chirouonus, and fragments of other tipulial:e.

Afterward Mr. S. A. Briggs, of Chicago, noticed and figured in "Science (iossip," (Iomlon,) a creature whose zoologieal position he did not know. It was the larva of a species of Ephydra.

This pupate case was afterward describerl by me under the name Ephydre gracilis." The specimens were collected by Mr. Sereno Watson. Other specimens of the larvie, as well as pupae and adult flies, were collecteil by Mr. S. A. Garman, and also by Mr. J. A. Allen, and are in the Museum of Comparative Zoology at Cambridge, and will be described hereafter. The Epluydra sometimes occurs in large quantities.

I have also received from. Mr. (iarman two specimens of Corixa taken by him from the lake.

Undoubtediy other insects will be fonnd in Salt Lake, and we trust some one of the readers of this article will make a careful examination of the shores of the lake, and carefully preserve and forward to the office of the survey every trace of life he may find.

In proof of this supposition, I may state that the late lamented Pro. fessor Torrey, in 1870, made an exceedingly interesting collection of insects in the brine of Clear Lake, California. This collection comprised two aquatic beetles, (Laccophilus decipiens, Lec., and Berosus punctatissimus,) and the early stages of three tlies, i. e., a species of Tanypus, Stratiomys, and Ephydra Californica Pack.

This last species lives in the "excessively salt, but also strongly alkaline" Lake Mono, in California. The late Mr. Horace Mann, jr., retnarked that the indians about Mono Lake eat the pupa-cases of Ephydra in* large quantities.

Two hemipterous insects also inhabit Clear Lake, i.e., a Gerris-like form, Hydrotrechus robustus Uhler, and Corixa decolor Uhler.

The genus Ephydra is also an inhabitant of salt-vats and of the shores of the ocean. The larva lise on decaying organic matter.

We now come to that strange crustacean or shrimp-like creature, the Artemia, an animal found in different parts of the world in salt-vats, saline pools and lakes. The family to which it belongs is, par excellence, a fresh-water group, and thongh the respiratory surface of the false gills presents an enormous extent, and one judging by the prineiples advanced by Platean, as quoted above, (section 2,) would think this to be the last animal to be readily alapted to a saline life, yet it flourishes in inmense numbers in the densest and strongest brine.

The brine crustacean of Salt Lake was first described by Professor A. E. Verrill, in the American Journal of Science and Arts, November, 1369 , under the name of Artemia fertilis. It was collected at Salt Lake by Messrs. Sereno Watson, D. C. Eaton, and S. A. Briggs. The former ailudes to its occurrence in vast numbers.

Mr. S. W. Garman, who has specially observed this creature while alive in the lake, writes the following notice of its habits to the American Vaturalist for December, $18 \mathrm{2} 2$. "A peculiarity of the little crustacean (Artenia fertiliso, Verrill) living in the waters of Salt Lake, which onght to be noticed, is that of its congregating in masses of strange appear ance in the water. When the maxses are small they sometimes stretel ont so as to have the form of a serpent. All other times they represent rings, globes, and varions irregular figures. A gentle breeze does not affect the water filled by Artemis, so that while the water on all sides of thesu dense congregations is slightly ruffled, that which they oceupy remains as if covered by oil, thus indicating the figure of the mass. If attention was called to them by reeing on the surface the figure of a great. s.rpent in one place and in another what appeared to be a small stream of comnaratively still water flowing out through the lake. Though $\mathbf{I}$ waded out to and through these immense bodies, I conld not positively ascertain that the individuals were traveling in a common direction; the time was too short to determine this, vet 1 thunk it is the fact."

It is apparent that a study of the habits of this animal is much to be desired, and collections of the eggs, young, and both sexes in large quantitiex and preserved in strong atcohol, are greatly needed for the fur Ger elucidation of its monle of life ant structure.

We bave shown that the animal life of the mreat Salt Lake is, we had almost said, abuudant, and the idea of Profexsor Ibairal, if carried out, of stocking this lake with fish, is not an impracticable one so far as natural food for such tish is concerned. 


\section{BOTANY.}

Br Jons M. Coertrr.

Washingtox, D. C., April 15, 1873.

There are certain other remarkable crustacea found living in pools which are apt to dry up late in the summer, which are allied to the Artemia, and are locally abundant in the far West. This notice is inserted to call the attention of travellers and collectors, as well as members of the survey, to them.

First, the shelled crustacea, or Limnadia and Estheria. These are singular crustacea, which are protected by a ralv. like expansion of tie back, so that the body is inclosed by two shells, and the creature bears a most remarkable likeness to the bivalves of pools and streams, (Cyclas.) In Texas a species of Limnadi (L. Texana Pack.) is quite common, ac. cording ro Mr. Belfrage, in Western Texas in the early spring. It oceurs in muddy pools made after rains, and wholly disappears with the first drying of the pools. "As far as I have seen, they are onls found in the woody bottom-lands and always near creeks." It may also be looked for in Colorado, Kansas, and Montana, and probably Ärizona.

With these bivalved crustacea occur usually in great numbers, when found at all, Artemia-like animals, the Branchipns, specimens of which are most desirable to compare with the brine crustacean. But the most interesting of all these phyllopod crustaceans is the Apus, an animal found abundantly at times in pools in Kansir, aud Texas, and Mexico, and the plains of the Rocky Mountaius. In collecting the $\Lambda_{\text {pus, large }}$ numbers of the young and old are desired, preserved in strong alcohol, and the exact date and locality should be inserted in the bottle, writen on a piece of firm paper, in pencil or ink.

These animals are about an inch long; a round shield, bearing simple and compound eres, protects the front part of the borly, while the hinder portion is long and narrow, consisting of many seguents, bearing beneath leaf-like gills. The body ends in two long feelers, much like those arising from the heal. They have been fouth by Von Siebold to be parthenogenons, i. e., the females produce young from eggs without union with the other sex.

Sorth America is richer than any other quarter of the globe in species, bough it is a remarkable fact that none are known to exist east of the Mississippi River.
Srn: I have the honor of presenting to you my report upon the botanical specimens collected this last summer.

1 have separated the botany of the region I traversed into three divisious, sufliciently distinct, in my opinion, to form as many separate floras, and have given their different conditions of soil and climate.

I have included in my notes upon the mountain-flora a short table of timber-liues, showing the variation in the height of the timber-line, depending on the latitude and the presence of elevated plateaus or large polies of water. The latitude is given with each peak, but the other conulitions are so well known it was thought unnecessary to include them.

I lave also added three tables comparing the flora of the western slope of the Toeky Mountains, between latitudes $43{ }^{\circ}$ and $46^{\circ}$, with that of the eastern slope. The tables were compiled from the collections of 1571 and of this last season, and are necessarily imperfect, though they will serve to give some idea of the distribution of phenogamons vegeta. tion on both slopes of the dividing-ridge.

Of grasses, about sixty species were obtained; of mosses, fifty-three strucies; of lichens, sixtr-six species, including varieties, of which one is probibly new to science, and two new to the continent. Among the few Fungi collected, two new species have been described by Charles II. Peck, esq. There probably will be in the whole collection nearly 1,200 species of plants.

I wish here to express my thanks for the many favors I have receired frum butanists. To Professor Thomas C. Porter were intrusted all the doubtful specimeus and new species of Phenogamia, and I am under the greatest obligation to him for his prompt attention and ready response, as well as for the great interest he has always show in my work. Hi. very kinlly consented to make a re examination of my whole collection of I'henogamiar, except the Conifere, and to correct the mis. takes of inexperience.

Throuth the kiuduess of Dr. George Vises, I have had access to all the collections at the Agricnltural D.partment, which proved of infinite service. I would thank him also for the interest he took in my work, and for the valuable assistance he repeatedly rendered me.

Thanks are due also to Henry Willey, esq., Charles H. Peck, Leo Levinereux, S. T. Olnes, George Thurber, and others for the determination of those sprecies to which they have devoted special attention.

The study of western flora is an immense field onen now to all lovers of botany, and many rich harvests are waiting to be reaped by the industrious collector. Iloping that under your auspices in the future, is in the past, much information may be added to our comparatively meager knowledge of western botany,

I am, very respectfully, your ubedient servant,

Dr. F. V. HAYDFs,

JOHN M. COULTER.

United States Geologist. 
The plauts satalogued in the present volume were all collected during the season of 1872 . I was attached to the party under command of Captain Stevenson, and remained with it through the whole summer, $\mathrm{U}_{\mathrm{p}}$ to the Fire Hole Basin, Philo J. Beveridge acted as my assistant. and proved himself an active, earnest worker. Jlost of the collection was pressed by him, and the care he always took has made handsome specimens.

In the party under the immediate direction of Dr. Hayden, Mr. Wal. ter Platt took charge of the botanical collections, and render good service in the region he traversed. Although the plants common to the mountain raumes and valley along the vellowstone are not esentially different from those foumi along Snake laver, yet it is interesting to note the fact of their existeuce on both the eastern and western water-sheds. A slight difference can be triced, but by no means sufti. cieutly great to justify making two distinct tloras, one of the eastern, the other of the western slope.

Collections were commenced in the last of May at Ogden, Utah, where our permanent camp was located until the last of June. During this time a fine opportunity was affiraled for studving the local flora of the plain borklering on Gireat Salt Lake, as well as that part of the Wahsatch range of mountains, near which (Ogden is situated. The flora of this great basin has been so thoroughly examined and described by Sereno Watson in his final report that very little can be saitl in adal. tion. Several trips were made to the sluores of Great Salt Lake, and collections were obtaines of the flora of that peculiar region. During our stay of a month over ilire hundred species were collected, repre. senting fully the June vegetation of that locality. Representatives were obtained from four different conlitions of soil and temperature. viz, the borders of Salt Lake and its neighboring alkaline marshes; the commen sandy sage-brush plain, somewhat enriched here by the irrigation universally practices in Utah; the alluvial deposits along Orfen and Weber Rivers; and the momntains of the Wahsatch Range. On the latter very few alpine plants were discoverel, for a sub-alpine flora clothes almost entirely the highest peaks,

From Ogilen collections were male in the latter part of June along the stage-route to Fort Hall: in .Iuly from Fort IIall to the Téton Basin and western slopes of the Titon Range; in Angust, up Henry's Fork to Heury's Lake, across the "Tyghee" l'ass and into the Fire-llole B: sins. After this date the towering season had about passed, and only a few species not before collecterl were notices!. Collections were maile in September and the first of October down the South Fork of Snake River, principally of plants in an alvancel siate of fuitage. On $O$. tober 11 we closed our collections at Fort IIall, having been about five months in the fichl.

I would divide the plants collected into three separate and distinct floras, viz:

1. The flora of the plains from Ogden, Ctah, to the Titon Basin.

II. The flora of the Téton Range and Mountains along the Yellow

III. The flora of the Geyser Basins.

Althongh a few flowers are common to all these civisions, as can be seen in the following entalogue, ret the main features are very distinet.

I. The Flora of the plains is exactly what has been so often seen and described on all the vast "sage-brush" deserts of the West. It is pecu. liar to this dry, sandy region, yet much more luxuriant than one would imagine from the nature of the soil. At the same time it becomes ex tremely monotonnus, as a few species exhanst the number, and you can tremely thom C.C. Parry, in his "Botany of the Mexican Boundary," the peculian. C. C. Parry, in his "Botany of the Mexican Boundary, "the peculian." ties of the scenery of a conntry depend upon its vegetable productions." Thus one who has ever traveled across these sand deserts will not fail to picture the immense cring of indiviters the scenerr of the country has a in exactly what to expect, loses the zeal he would possess in a more varied region. Occasionally, where a stream has made a richer soil, there is a cliange from desert to valley flora, and the more brilliant hues of the vegetation, from the delicately tinted petals to the rich green leaves, is weres to the eyes and awakens new zeal.

On all these plains au entire absence of trees is noted, except a few of stunted growth along the larger streams; while the mountain-ranges are sparingly timbered with Conifere from base to summit, intermixed along some of the foot-hills with "bitter cottonwood." Upon the plains around Orden a variation in the flora is noted as we near Great Salt Lake. The higher types seem unable to exist in the strongly alkaline soil, ind give place to the Chenopodiacec. This family is well represented here, as is common along all bodies of salt water, not so much by the number of species as by the immense display of individuals. Smail I'olygonums and Fuphorbias also mat the ground in places, but are by no means so abunilant as the Chenopods, ehiefly represented by the fenus Obione. Wherever the soil is largely charged with alkali the " grease-uod" (Sureobatus rermiculatus) is very abundant. In almost cornia herbacen, and Eurotia lanata, as well as numerous other chenopodiaceous plants.

Farther back, toward the mountains, the higher types appear again, and with a greater richness of color than seems possible in such soil. of course the Artemesias are common everywhere, and especially $A$ tridentata, completely covering the plains a d far up the mountain slopes. Among the shrubby Artemisias can be seen the beantiful Calo-
chortus Nuttallii, the "Sego" of the Mormous, numerous Phlorex and chortus Nuttallii, the "Sego" of the Mormous, numerous Phlorex and oralifolium, E. heracleoides, and $E$. umbellatum, several species of $E_{n o-}$ thera, Astragalus, Phacelia, and many others equally important that might be mentioned. Along the water-courses may be seen two bright Mimuli, M. Lercisii and Y. luters, several labiate plants, two species of rose, $R$. fraxinifolia and $R$. blanda, many Ranuneulacex, the two brilliant Capparidace, Cleome aurca and Cleome integrifolia, several Onagracea, sc.

All of these orders are far surpassed by the Composita, both in the great variety of species and the immense display of individuals. Se. reno Watson estinates that they comprise one-serenth of western colrections, and he by no means overestimates them.

II. The flora of the mountain-ranges. The plants collected from the Wahsatch Mountains, near Ogden, are, for the most part, sub-alpine, and almost identical with those collected at equal altitudes on the Téton Range, and seem to be identical with those common to every range it the Northwest. But the Tétons rise so much higher, and are exposed the Trom to snow and winds, that above 10,000 feet, I gathered a tlora such as I saw nowhere else ou the trip. Appar. 
ently delicate plants were seen blooming through the suow, and regeta. tion, thongh limited in species, seems abundant until within three hum. dred feet of the summit of Mount Ilayden, where all plant life ceases, except a few lichens elinging to a bare rock, which is swept continually by tierce wials. A fine field was presented here for the collection of truly alpine plants, aud no opportunity was lost for obtaining anything peculiar to this great clevation, untustially exposed, as it is, to tempests. All the alpine plants are noted in the catalogae, and the elevations given at which they were collected. The Teton lange is heavily tim bered with Conifere, chelly Pinus ponderexe, to an altitude of il, 000 feet, this being the average timber-lime of the whole range. The maxi mum erowth is at an altitude between s,000 and 10,000 fect. A mathed difference is observed, however, between the western and eastern slopes, the latter being much more densely timbereal than the former, and the trees much lariger and less twisted and guarled. This seems to result from the fiet that on the eastern side the Tetous rise almost sheer out of the plains, presenting an enormons perpendicular wall, hehind which the trees of the eastern slone are completely sheltered; while on the west, the peaks are roumded down into the plains by the fout hills, and this whole. broad, sloping side is exposed to every blast from the north and west.

One noticeable feature in the tree-life on the mountains is the abrunt. ness with which it terminates at the average height of 11,000 feet. Tall, straght Conifere are seent growing to the very edge of this line, and one step takes us from a forest to a bleak, open waste, where not a tree can live, except a few struted and twisted forms that have been bent out of all shape by the aperineumbent mass of snow that rests upon them during the winter. These stunterl forms, sometimes even with their tops matted close to the ground, are always foumd growing behind some wall of rock or steep bank, where the winter snows accumulate in immense drifts aud completely cover amel protect them duriug the blight. ing winters of that hioh altitude. Aceording to Parry ".the so-called timber-line marks the extreme point of mininum winter temperature, below which no exposed phatogamous veretation can esist." All life above thes limit is buried by the deep winter suows, and thus protected ; fuence in this truly alpite rexion miny plants are foumd that are counmon at much lower altitules. The tlowerime seasun is necessarily short, and we were fortunate in leing upon the Thtons in the very midst of it during the last part of . Inly.

I have said that all phatenogamous life ceases within 300 feet of the sum. mit of Mount Ilayden, which is abont 13,500 feet above the level of the so:at. This is owing to the great sharpness of the prak not allowing the stow to rest 11 ron it, but to aceumulate in wreat banks upon its lower slopes. Hence there is no protection for platuts during the long winters abose this bauk, and we puss sudhenly from a bright, varied alpiue veretation to bleak, lichen-covered rocks, just as, 2,000 feet below, wh passed sudilenly from forest growth to a low, matted regetation. It is uoticeable that the timber-line becomes lower as we alvance farther north in almost a fixed proportion to the latitude. The altitude of this line was aceurately measured by Mr. Henry Gaunett mon every mount. ain he ascended, and I insert below a table containing the altitude of this line upon several peaks, together with their approximate latitudes. We were unfortunate in obtaining no accurate measurement upou the Tetons, and hence the altitude of the timber-line upon this isolated range is but approximate.

The timber-liues in Colorado are mostly from Parry's measurements.
I include also a few peaks on other continents, for the sake of comparison, the latitules of which are auproximate, as their positions are well known. The table is arranged aceording to the latitudes, commencing at the northernmost poiut and ruming south.

\begin{tabular}{|c|c|c|}
\hline Name. & Latitude. & $\begin{array}{c}\text { Ele- } \\
\text { vatiou. }\end{array}$ \\
\hline & $\circ \quad 1$ & \\
\hline $\begin{array}{l}\text { Timber-line on Bridger's Prak, Montana............. } \\
\text { Timber-line on Mlount Delato, Mo tana ........... }\end{array}$ & & 9,002 \\
\hline $\begin{array}{l}\text { Tiuler-line on Monnt Delano, Me tana ........ } \\
\text { Timber-line on Ward's Peak, Stontana........ }\end{array}$ & 32 & $8,7 \times 4$ \\
\hline & wi & 9,156 \\
\hline 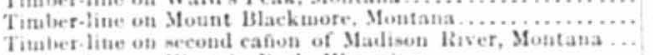 & 45 & 9,500 \\
\hline 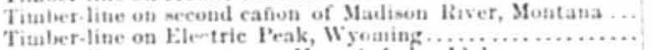 & & \\
\hline 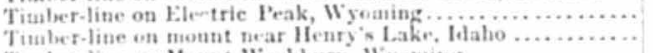 & 65 & 9,442 \\
\hline 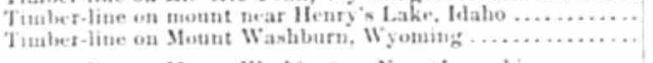 & $\therefore$ & 9., 363 \\
\hline 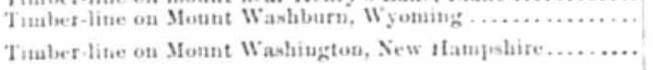 & 44 & $9,: 900$ \\
\hline Tumber fite on Monnt Washiugten, New thatughire.......... & 44 & $\left\{\begin{aligned} & 5,(6 n) \\
& \text { to } 5,200\end{aligned}\right.$ \\
\hline 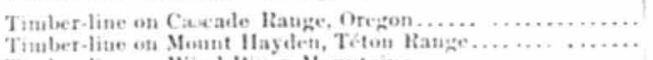 & 4 av: & (1) 7,000 \\
\hline 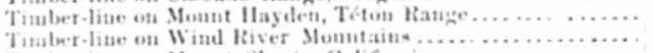 & $4: 414$ & 11,000 \\
\hline 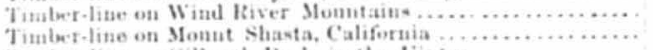 & 43 & 1", line \\
\hline 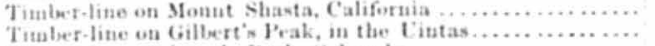 & 41 & 5.000 \\
\hline 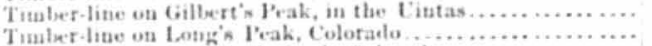 & 40 & 11,100 \\
\hline 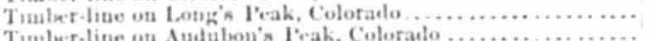 & 40 & $10,-010$ \\
\hline Tumler-line on Anduloon's Irak, Culorato .................... & (1) & 11,525 \\
\hline Timber-line on Jount Engelmanu, Colorado .................. & 0 & 11,519 \\
\hline 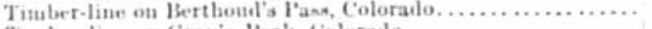 & 39 & $11,+16$ \\
\hline Timbler-'ine on Gray's l'eak, Colorado...................... & wi & 11,643 \\
\hline Timber-litue on P'ike's l'eak, Colerado ..................... & 34 & 12,040 \\
\hline Timber-line in Colorado in getueral....................... & …... & $\left\{\begin{array}{l}11,000 \\
\text { to } 12,000\end{array}\right.$ \\
\hline Tiuber-line on San Francisco Sount, Arizona ............... & 35 & 11,547 \\
\hline FothitGX reshs. & & \\
\hline 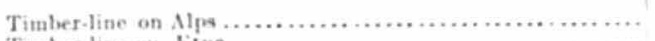 & 17 to 4100 & 6,500 \\
\hline Tituber-line on .Etua .................................... & $: 78$ 4t & 6,000 \\
\hline 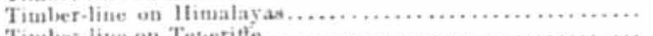 & So to 300 & $11 .+00$ \\
\hline Timber-line on Teseritte ............................ & 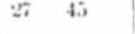 & a, 7000 \\
\hline Timber-live on Andes, in South Aurrica ................... & & to $1 \%, 000$ \\
\hline 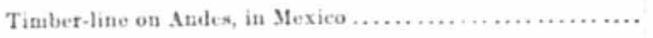 & & $12, \pi 00$ \\
\hline
\end{tabular}

It will be seen that there is a very regular increase in the elevation of the timber-line as the latitude decreases, subject of course to variations when in the neighbotheon of high table lands or seas. As we the timber.line rapidly sinks, until it is rarely over approach the sea the the the upon the momtan-peaks that rise above elevated plateans, it reaches an elevation of nearly 13,000 feet.

This immense extent of high land of course raises the temperature, and, by allowing the height of the timber-line to depend upon the mean annul temperature of the place, the difference between the height of the line near table-lauds aud seas is accounted for.

The Waluteh liange, near Oreden, is almost entirels dextitute of trees, their place being supplied by tangled shrubs. Occasionally a small, stanted pine is met with, and the common jumiper, (J. occidentalis.) The most common shrub is the Ceanothus celutinus, forming patches so tangled as to be almost impassable to the climber. The Cercocarpus ledifolius, or "mountain mahogany," was also noted in considerable abundance to the height of 7,500 feet. 
III. The flora of the Fire-Hole Basin is distinct, from the fact that it is a region so cosered with hot springs and geysers, giving in the geyser. ite, scattered everywhere, an unnatural soil, and creating an artificial warmtil. The gejserite is a bleak, barren waste, supportiug only plants peculiar to itself, ind seeming to kill eversthing of is diflerent mature. A great number of the lot springs have made deposits until they have almost closed themselves 'p. On top of this a soil has collected, the spring underneath keeps it warm, and the luxuriant growth of a regular lost-bed is the result. The plants that grow in such situatious are not all of them diflerent in species from those that grow in the valleys near by, but thes spring up much ranker and attain two or three times their usual size. To some plants of common species the soil gives such a dis. colored appearance as to make them at first scarcely recognizable. For instance, take the Gentians that are represented here so profusely. $G$. detonsa, $G$. aftinis, and $G$. Amarella were repeatedly met with disguised be perfectls black stems and veins, leaves unusially dark, amd petals with the black appearance common to dried specimens. This was the case only in the immenliate neighborlend of the hes springs. Flsewhere they retained their original coloring, though growing much ranker than I ever saw them.

The plants growing on the geyserite are chietly of the composite

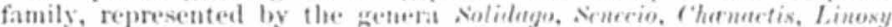
ris, intennaria, and fichillen. In some of the hot sprimes in both Eprer and Lower Geyser basins an dlga was discovered frowing, but it came

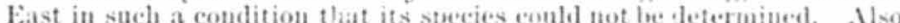
in the Lower Basin were found some orange colored confervoid specimens, concerning which Charles II. I'eck, escl., to whom they were sent, re marks, "I believe they have been dowetibed under the name Conferret turantiaca, but it is now generalls regarded as the primary state of some piant of higher order, moss or fern.

In all this western recrion the lotanist notices the absence of one great group of plants. The Ferns are almost unrepresented here, owing to the rreat dryness of the climate. Heing fond of dark, damp places, they are selifom fonme in this elesated regron, where the air is dry and pure. Oecasionally, in some dark and unsually damp cañon, is fex stunted forms were fombl, and then in no great abumblance. Two locali. tiev only were noted where Ferns were foumd in any size and abundance once in the aw Giver Basin, diseovered on Shosluone Late, being there the hot-1 "rrowth before mentioned; and next under the shadow of the Tétons, on the eastern slope, where a mountain-stream had made a rich deposit, anl no sunlight could come on account of the inmenso growth of Conifere. Jat sevell genera were found, incluting ten species, viz, one Pteris, two P'ellaus, one Cryptomramme, two Aspidiuns, one Cystopterix, one Lotrychium, and two Hemisits, Ot these the Cys topteris fragilis was by far the most abundant. Botrychium lunarioides, var. obfiquem, was found only in the Geyser basin.

Moses were very abundant, both along the cold streans of dark cañons and also upon the bare rocks of the mountain tops. A consider able collection was made, numbering fifty two species. Some were easily determined by comparing with dried and labeled specimens, but the doubtful ones were sent to Leo Lesquerenx, esil, C'olumbus, (hio, who has done them full justice. ft will be noticed that some were unable to be determined on accont of having no fruit, especially specimens of the genns Bryum. The order nsed in cataloguing them is that of the "Musci Boreali-Americani" of Sullivant atul Lespuerenx.

Lichens were common on the voleanic rock of the Téton Range. Some of the peaks seemed perfecis covered with them, hardly a square inch being seen that did not bear some brilliantly-colored specimen. They sermed to zrow in greater abumdance and more brilliancy of color on hatsaltie rock thatl on granite. Specimens were obtained mostis late in the season, and rather a large collection 16 ds secured. They were seut

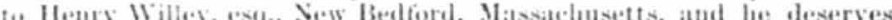

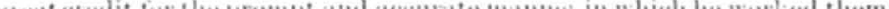

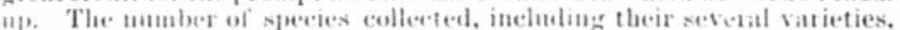

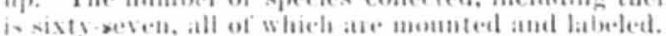

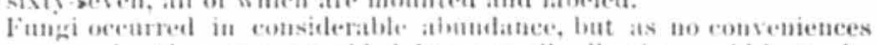
foi preserving them were povided, leat a small collection conlel be made. They were se-nt to Chater II. Peek, Albany, Xew York, who has done more than could be expected with the very indillerent material sent to him. Tha tlewhy fumgiare harel subjects to deal with in the tield, and several espetients were reserted to for perersing them. An attempt

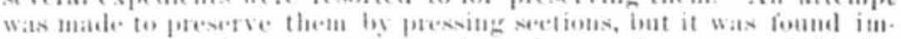
possible to kerep them trom ghimg thermselves to the paper suitable for foresing flowers, and thos ruinug specimens. The vers few that 1

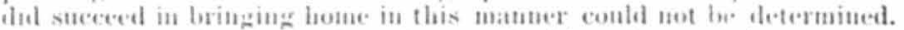
The list of fumei therefore is tat her smatl, at hough containing two new

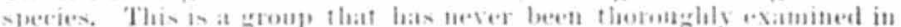
the West, and I hase ne doubt that a rose selestifie insestigation

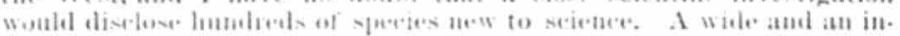

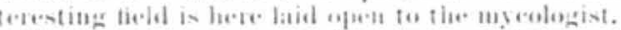

For the conseniene of these meterested in comparing the thora of the

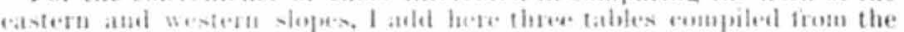

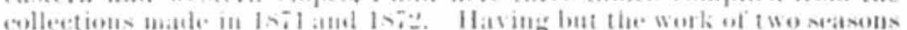

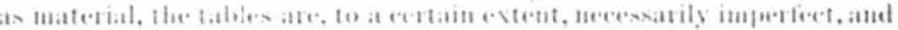
future collections will make thats eortertions, but they will serve to

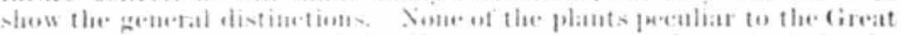

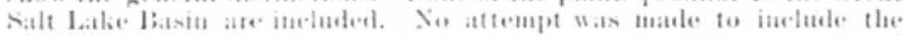

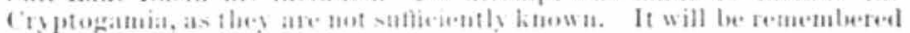

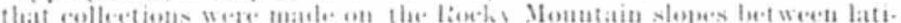
turle $4: 30$ atnd tho

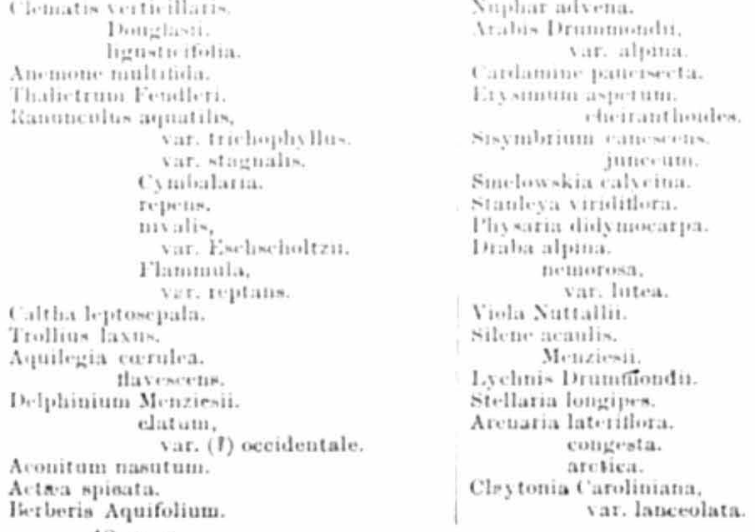


Claytonia Chamikonis. Taliuum pygmaxum. Spharalcea acerifolia.

Liaum perente.

Geranium Richarkloni.

Fremontii.
Lupiuas poly pluyllux. casopitiven. lasiliorus.

Trifolium langine

Triolium longipes

Ayeyrniza lepideta.

Astragalus hymglottis

Oxytropis iamlestio

Thermejeis falace

cenus tritleram.

strietum

resia fiontemi.

Potemtilla imations. millegrata. divervifuha plandintome

Inbas Nuthantus.

Anelanelawe Costadenote.

Riles bracteonm.

liachetre.

Sasefraga nisaliv.

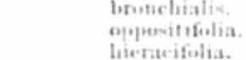

punetata.

Tellima Jats pater.

Mitella petutatuln.

Henclura parsifilia.

Parnassia bimingata.
Epilohinu pantalatum.

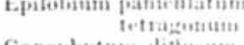

Gagophysnu liftionm.

Einothera trilelom.

lieteranth.
bicutio.

Menteclia lacvicaulim.

Bhplenrum ratnueulonde.

Carum Gairinth.

Danorrliza tajala.

trorting

Cymopter for

Heraclenu lanatus

Corntin fonle-acertia.

Syuphoricarpus montanuk.

Lonicera involuctata.

Galium boreale,

A fariue.
tritidum.

Vucharantliera capescens.

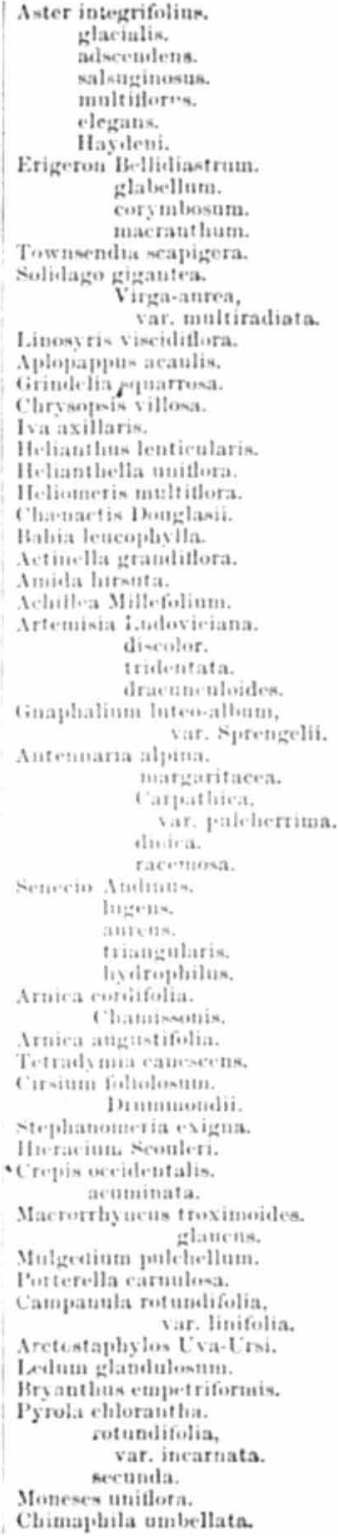

Aster insegrifolium.

biacintiks.

salerginesus.

mnitifilor.".

eleganx.

Erigeros Ih-Hitiantrum glabellum. corsmbosum

Townendis acapisern.

Solislago gigantera. Viga-anrea, var, multiradiata.

Linosy ris viseidithora.

Aplopippens acaulis.

clirsenters villos.

Clarysopwis villo

Hi.liantlus lenticularis.

H.Miantiefla unitlora.

Heliotner is multitlora.

Chomatis Douglanit

Actimella staulitlota.

Amida harneta.

Achillea Millofolinm.

Irtemisia i.tutovieian. diecoler. dravenentwides.

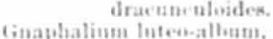

var. Suterigelis.

marzaritacea.

var palelerrima.

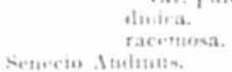

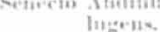

Ine-ne

triangularis.

Araca cortifolta.

cratis

Irnies attegtstifulia.

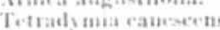

Cirsiun fintolasem.

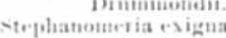

I1.-tacima Fonlen.

Crepin oceidentalis.

actuminata.
Mactorthyous t foximoides.

Suluevintm gulchenens.

Yulgevintm julchellum.

Potferelia carnulena.

Campatula roturulifolia,

Arctustaphylos Cvatin

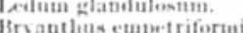

Pyrola chloratitha.

otundifolia,
var. incarnat

vecunila.

Moneses unitlota.

Chimajila umbellate.

Ptrrospora Andromedea.

Jouet topa Hyperpitys.

Thelecatheon Mratlia.

Inilruace septestrion

Lysimachia ciliata.

Collimaia parvitlota.

ientstenon cotot

Mimulan denatos

Ylimmon arwist.

Vironica aten

nerpyllitiolia.

Cotille Nmericina

'edicularis firmulandica.

racemosa.

Orthocarpess lutens

Pinavus Fremontii.

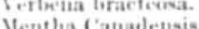

Memithe var. glabrat.

Dracocephalum parvitlorum,

Brumella vulgarie.

Stachyo paluntris.

Mertensia Sibirica.

Echnos acrumua de-tlexnm,

sar, Aloribumitus.

Eritrichitun villosmm. var. arotienderes. leiscarpatu.

I'hacelia cirrinat,

Pericya.

Phlex lotgifolia.

Cillia coturata.

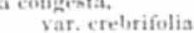

putugene.

Polemonit. Niplartesa.

ceruleum.

Francta njectios.

Gentiana athinis.

Apocynum eanabinum.

Cpocynum cannabin

meitum capitatobritum.

Slonolepis clenoporiodes.

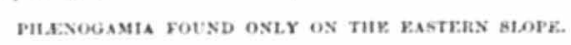

Ranunculns Nelsonii.

Sisturtium obtusuth.

Cardamine hirsnta

Arabis hirsuta.

Drummonulic.
perfoliata.

perfoliata.

Vesicaria alpina.

Draba glacialis.

Lepidium intermedinm.

Yela Canaleneis.

canina,

Cleome integrifulia.
Obione canescens.

Erimgontum ovalifolinm.

umbellaium. bicrotliecum.

Oxyria digzna.

Pinmes salicifor

tompluibium. tenue. Bistorta.

Shepberslia Canaders

Arecuthobium Anericanum.

Euphorbia nepyllifolia.

Betula ocendentalio,
glatidulusa.

Nhus incana.

Salix arevica.

Iongifiolia. Poprolus tromulavides.

Pinus tlesilis.

cotitorta,
var. Latifolia.

Duaglasii.

Engelmatni.

Guniperus orevidentalis.

Trmatrisuca.

lot cusegeton perfoliates.

var. lanceolatus.

Ilabeuaria hyperlorea.

Spiranthes Romanzofiana.

Iris teuax.

Sinyrnetinm Bermndiani.

Zygadetios Suttalli.

Streptopus amplexifolius.

Smilacina racemora.

stellata.
Calochortus Nuttallii.

earyearpas.

Hili omaditura.

Alliuta brevistyint tellatum.

Silene Douglasit.

Arenaria Fentleri.

Stellaria crassifolia.

Ceratingorralis.

var. Bebringianum.

Sagina Linnari.

Parenychia sexsiliflora.

Spraguea umbellnta.

Claytonia linearis.

Malvastrum MIunroanum. 
Malvastrun cocciueum. Geranium Carolinianum. Rhus aromatica. var. trilobata. Astragalus tliphysu.

$$
\text { Canadensis, }
$$
var. Mortoni. Kentrophyta. alpious. tegetarins. caryocarptis. var A var. Americanu frigidux. pancitlots.

Oxy tropis multiceps. Lathyrus palnstris. Spirza cespitona.

Cercocarpas ledifoliu. Siblabldis procumbers. Chamiathonion erecta.

Potentilla pulcherrima. var, strigesa fisca.

cratagus sabgusea. Rilec hirtellum oxyeantboiles
prostratum. ceteutm.

Saximaga caspintion Heucliera eylindric. Parnassia parvittera. Nedum stenopetalum. thenlanthum Fiplothum angustifotiun angustifolitan
suffruticoman. alpinum. var. putpure

Paura coccites.

Meutzelia ornatus.

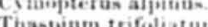
Ciaspiuta trifoliatum

Cometis

Galium triflorut

I.iatris posetata.

Aster Engelmant

talcatur.

Towrsendia graudittora.

Enigerot acre. acre.
compoitum. campitosum. cabescetse.

Diplopappus alpitu.

Linengrio Horaris.

Aplopappus lanceslatus. innloules.

Rudbeckia lacitiata. Meliantbus Nutualli.
Heiauthus petiolat is. Hy menoprapptis tetunifoli Artemisia tritista$$
\text { vulgario. }
$$$$
\text { frigitla. }
$$$$
\text { kichariontiana }
$$

Aruica lengifolia.

Senecio cants.

Cinsium uminlatum.

Echinais carliuside.

vat. zutaus.

Lypodeamia ofurut

Crepis rumeriata

Anderwoni

Taraxacntu Ben-.lrot

Gaillardia aristata.

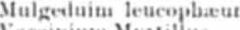

Kiatuia olaura

var. mictophy lla

Plantago rrieperia.

P'rimula farimua.

Antrosace tiliternus.

l'ent-temen glanen.

$$
\begin{aligned}
& \text { var, steronepalus. } \\
& \text { Menciesil. } \\
& \text { cistatux. } \\
& \text { attrutuatus. }
\end{aligned}
$$

I.tumerlla aynatica.

Gotheris pitimatifila.

Vorotaca vat twim

Trimetas entellat

1.уеори Virginien-

Sotarda tistaloma.

Lephanthus urtice foslius.

Eatrintiont glompratum.

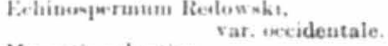

Msueotionstratica

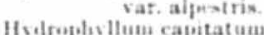

Fratrongyllim captatum.

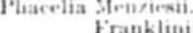

Nermoghila pars iflera.

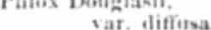

Gilia pailla.

Poletsutintu curvaleum,

Gecutiana Amarelienissimun. arella,

Aporsmum andro-semifolium.

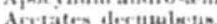

Exybaphus auguatifolios.

Alistita fragrans.

Blitum polymorphntm.

Suada deptessa.
E.riogonum ovalufolium

Polsgonem vivir. tenutic

Eiphorbia glyptosperma.

Eupherbia dictyosperma.

f'inus manophylla.

Meuriesit.

Janinerus communis

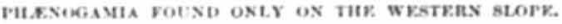

Clentatis ligusticifolia. var. brevittura. pina,

var. Och
Raunneulus aftinis.

$$
\text { atoneus. }
$$

Iriphininm scopulotum.

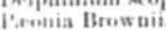

Dicentra unitiora. palustre. var. hispidam.

Cartatnine oligosperm.

Aralis retrofracta.

Praba stellata.

Wraba stellatia.

Lepidium montanum.

Barlarea rulgarik

Viela curullata.

Trotic aufea.

मуре-ricum Seconicri.

Litpinus pusillux.

Trifolium Kimsii.

Hedlsarum Mackrnzi.

intragalus pietus.

Oxytropis nana.

Spirwa dntumes.

Inetulefentia,

Millefolium.

foutu tnacrophyllutn.

Potentilla arguta.

divernifolia,
var, tutltineta.

Iragaria veaca. reaca.

Resa blanda.

fraxinifolia.

identata.

Dryas octopertala.

Sitella tritida.

Soctum Rhouliola.

Enothera marginat. neapoislea.
Antina.

Gaura parvitlora.

Cythrini alatum.

Sium lineare.
Lemna minor.

otamogeton rufescens.

Xerophyllum tenax.

Fritillaria padica.

Eruthronim aparpurea.

Alfium Scbenoprasuta.

bisceptrum.
Triglochin maritimum.

1'rowartes trachycarp.

Cicuta maculata.

Conioselimum Canalense.

Vonicera Utahens

var, sylvatica.

Eupatorium porpoream.

Aster pulehellus.

Tow nectulia ntrigona.

Erigeron filifolium.

solulago Grabiratitlorum.

Gniradonio, var. Npecta
rlomigata.

Linosyris Hewarlii,

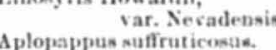

A plopappus aufiruticosa

Balsamorthiza Hookeri. sagittata.

Rullberkia oecidentalis.

Ii.-lianthella multica

Ginathalium mierocephalnm.

Antennaria Carpathica.

Aruica latifolia.

serecio Fendleri.

Stephanbundus.

Stephanomeria paniculata
Nalacothrix sonchoides.

Crepis nama.

Vaceiuium osalifolium. Myrtillwithm.

Pyrola apliylla.

Pinge. pie.

Kaimia plauca.

Plobioles.

Glaux maritima.

Aphyllon unittorum.

Phelipara erianthera.

Utricularia vulgaris.

l'entstetuen acominaty

$$
\text { glater. }
$$

confertus.

yanathos

Menziesii,
var. Lewisii.

Mimulus moschatus.

tloributilus
luteus,

var, alpisus. 


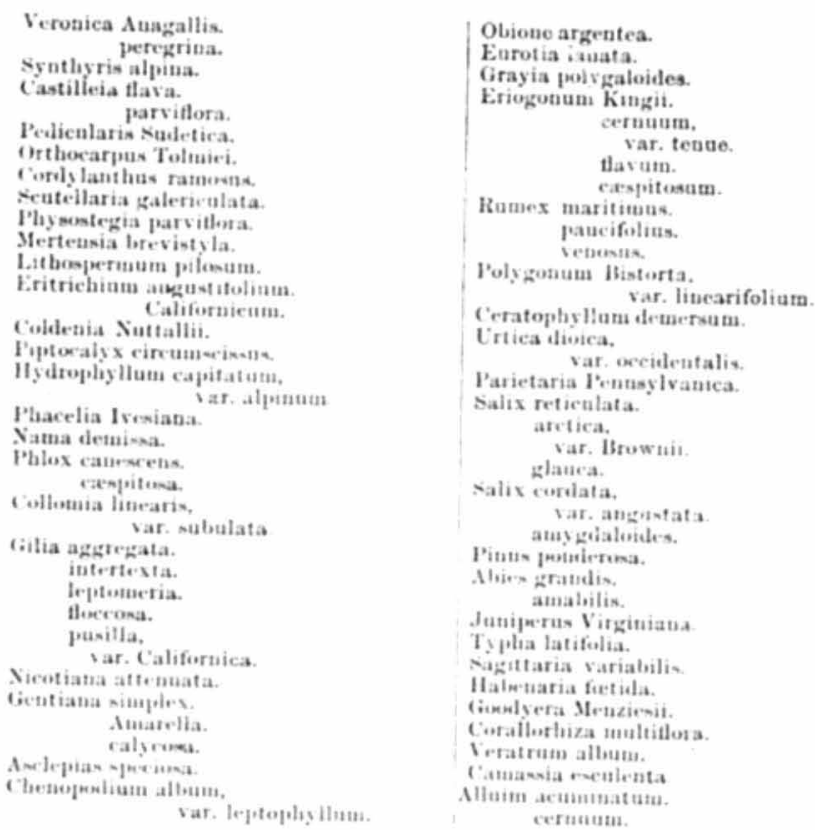

RINIXTHARE.

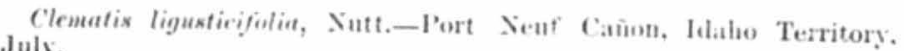
July.

Clematis ligusticifolia, Nutt., var. brexilloru, T. \& G.- Blackfoot River, Lalaho Territory. Iuly; near IBrigham City, Utal, Territory, Jume

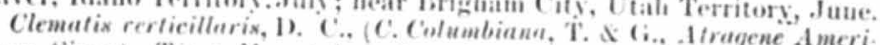

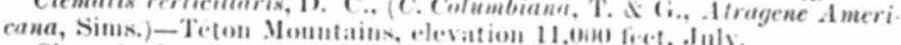

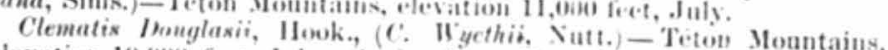
elevation 10,006 fert, July; Suake liser Valley; Fort Ellis, Montaua Territory.

Clematis alpian, Mill, var. Ochotensis, Gray,-Teton Mountains, elev:A. tion 10,000 feet, inly:

Anemone multitila, D. C.-Mountains near Clarl s Fork, Wyoming Territory, elevation 9,000 feet, Auzust; Snake liver Valley, July; Fort Ellix, Montana Territory. At this last locality roth red and why ; Howers were collected.

Anemone multifidu, D. C., var.? " Dwarf, 6-8'; divisions of the leaves lance-ovate, becoming glabrous; petals 5 to 6 , deep red; heads of ear pels glolose; carpels woolly below, smooth above; style recurved." Professor Porter.-Téton Range at 10,000 feet altitude, July 24.

Thalictrum Fendleri, Engelm.-Red Mountain, elevation 9,600 feet, September; Tét on Range, elevation 10,000 feet, July ; Fort Ellis, Mon. tana Territory; Heury's Fork of Snake River.

Iyosurus aristatus, Benth., (Lond. Jour. Bot., 6, 458.)-Black Buttes,
Kaинисulus aquatilis, L. *ar. trichophyllus, Chaix.-Near Ogden, Hah Territory, June; Heart Lake, September; Suake River Valley, Auguxt.

Ranumcrlus aquatilis, L., var. stagnalis, 1. C.-Divide between Marsh Ranuculus aquatilis, L.,

and Malade Valleys, June.
Ranumulus Flammula, L., var. reptans, Gray.-Henry's Fork of Snake River, Auzust ; Téton Basin, July; Trail Creek $y^{\prime}$, antains, September. Lапипсulus Cymbularia, Pursh.- Near Ogden, Utah Territory, May ; Fort Ellis, Montana Territory, July; Heury's Lake, Idaho Territory, August.

Rаnинсulus affinis, R. Br.-Téton Mountains, elevation 10,000 feet, July.

Ranunсulus niralis, Is. Br., var. Eschscholtzii, S. Watson.-Upper Téton Cañon, Juls.

Raиuдсulus repens, L.-Near Ogden, Utah Territory, June; Henry's Furk of Suake River, August ; Teton River, July.

Lanuaculus macrunthus, Scheele, (R. repens, var, macranthus, Gray.)(O)den C:anon, Ltah Territory, June.

Rаниисиlus adoneux, Gray, (En. Hall and Harbour's Plants, p. 56.)-

Ifenry's Lalie, Itlaho Territory, August.

lianneulus Velsonii, Gray, (Proc. Am. Acal., May, 1872, p. 351.)Villowrome lake, 1sit.

Cultha Irptosepala, 1). C.-Téton Monntaius, elevation 11,500 feet, July.

Trolliux lurux, Satisb.-Téton Mountains, elevation 12,000 feet, July; Trail River Mountains, September.

1 quilegin cervilen. James.-Téton Mountains, elevation 8 to 10,000 feet. Flowers were noted of four distinet colors with all their intermediate shates, viz, white, blete, pink, atnd buff; July

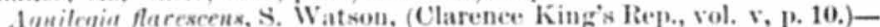

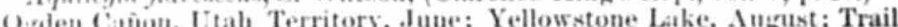
liver Yount:ains, Septeminer; mountaius near Henry s lake.

Delphinium elatwm, L., var. (?) occidentale, S. Watson.-T'Ton Foot-halls,

Drlphinium Mensicsii, D. C.-Near Ogden, Utah Territory, May ; Teton Vountains, elevation 10,000 feet, Juls.

Delphiniun scopulornm, Gray, (Plautac Wrightiana, 2, p. 9.)-Téton Foot.hills, August 3 .

Aconitum nasutum, Fisch.-Yellowstone Lake, August; Upper Gey. rer Basin, Séptember: Téton Caú̀n, Ju!̣.

Actera xpicata, L., var, arguta, Torr.-U pper Téton Cañon, July.

Pernain Rroicnii, Dongl, - Snake liver Valles, July. Every specimes found had but two carpels instead of 3-5. The seeds are eaten by the Boise Indians as beans.

BERBERIDACEA

Berberis Aquifolium, Pursh.-Plains and foot-hills near Ogden, Utah Territory, June; Lower Fire-Hole Basin, Angust, in fruit.

\section{NYMPHACE.E.}

Nuphar adrena, Ait.-Henry's Fork of Snake IRiver, July; Lower Falls of the Yellowstone, August 4.

\section{PAPAVERACE.E.}

Argemone Mexicana, L., var. hispida. Torr.-Near Brigham City, Utah Territory, June 25. 


\section{FIMARIACEA.}

Dicentra uniflora, Kellogg ined., (by Professor Thomas C. Porter.) Dwarf, 3-i'; seape 1-ilowered, furuished with one or two linear bracts; flowers 6-i" long, apparently purple; sepals oblong, obtuse, $3-4^{\prime \prime}$ long, deep purple; outer petals contracted in the middle, the lower half with deep rounded spars, the upper hooded part obe, the lower half with short spreading; inner trotals alsonted part oblong and widely recurved, triangular wings, not crested. Summit of a mountain near Ogden, Utah Territory, and in the Téton Range at 10,000 feet altitude. Mr. Coulter says," It grows on the mountain tops where the snow. has just meltel, or even rarely in the snow itself. Where the snow trace of them were found, although the plant was collected both in any trace of them were fonnd, althongh the plant was collected both in Jnne and Anguxt. I had described this plant as a new species, and named it D. niralis, when I learned from Dr. Gray that it had been discovered in the Sierra Nevala, as early as 1870, by Mr. Kellogg, who was abont publishing it as 1 . uniflura.

\section{CRUCIFER.}

Nasturtium officianle, Br.-Weber River, Utah Territory, June. Doubtlexs introcluced.

Nasturtium currisiliqua, Nutt. MSS.-Henry's Lake, Idaho Territory. August.

Fasturtium obfusum, Nutt.-Growing in the spray of the lower fall of the Yellowstone, Augut.

Nasturtium palustre, D. C., var. hixpidum, Gny.-Gireat Salt Lake, June.

Barbarea rulgarix, R. Br._-Snake Ricer Villey, Angust.

A rabix Drummondii, (iray.-Near Gyden, Dtal, Territory, June.

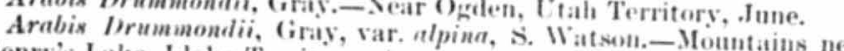
Henry's Lake, Idaho Territory, Angust. S. Watson.-Mountains near

A rabis retrofracta, Graham.-Xear Ogden, Utah Territors, Jume: Th.

ton Basin, July 21; Shoshone Lake, September; lesl Mountain, eleva. tion 10,000 feet; a very dwarf form.

Streptanthux cordatux, Nutt.-Near Ogden, Utah Trritory, Iune.

Cardaniue hirsuta, L.- Yellowstoue Lake, August.

Cardamine panciscta, Betuth.-Téton Cañon, July. Cardamine oligoxperma, Nutt.-Téton Mount ins, elesation 10,000 feet,
July. Vexicaria aretica, Richaruls.-Téton Mountains, elevation 10,000 feet,
July.

Physaria didymocarpe, Gray.-Téton Monntains, elevation 12,000 feet,

Wraba aurea, Vahl.-Téton Mountains, elevation 12,000 feet, Jaly.

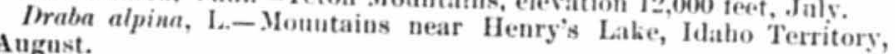
August.

Draba alpina, L., var., S. Watson, (near D. glacialis, var., , Hook.)Teton Mountains. elevation 12,000 feet, July.

Draba glacialis, Adams, (D. alpina, var. (?) S. Watron.)-Mountains near Ogden, Utah Territory, elevation 9, 000 feet, June.

Draba steliata, . Iacq., (Watron in Clarence King's Rep., vol, r, p. ?1. Téton Mountainx, clevation 11,000 feet, July.

Sisymbrium junceum, Bieb.-A form (?)-Snake River Valley, July. sisymbrium canescens, Nutt.-Weber River, Utah Territory, Jnie;
very variable. "Ah.tsah of the Pah.Utes." Watson.
Smeloucskia calycina, E. Mever.-Téton Mountains, devation 12,000 feet, July; mountaius aloug Clark's Fork, Wyoming Territory, elevation 9,000 feet.

Erysimum cheiranthoides, L.-Snake River Valley, July.

Erysimum axperum, D. C.- Near Ogden, Utah Territory, May; Téton Mountains, elevation 10,000 feet, July.

Stanleya ciridlflora, Nutt.-Port Neuf Cañon, Idaho Territory. Jnly ; Suake liver Vailes:

Thelypodium Nuttallii, S. Watson, (Streptanthus sagittatus, Nutt.) Near Ogden, Utalı Territory, June; divide between Marsh and Malade Valleys; Yellowstone Lake, August.

Brassica Sinapistrum, Boissier.--Fort Hall, Idaho, July. Doubtless introduced.

Icpidium sativum, L.Flowers rose-colored. Weber River, Utah Territory, Juue, Probably introduced.

Le pidium montanum, Nutt.-Malade Valley, Utah Territory, June; Snake River Valles, July, Very abundant. A dwarf form was found near fort Ilall, lalibo.

Thlaspi cochleariforime, D. C., (T. alpestre, L., Watson in Clarence King's liep., vol. v, p. 31.)-Mountaius near Ogden, Utah Territory, elecation 9,000 feet, Junc.

Raphanus satirus, L.-Plains near Ogden, Utah Territory, June. Just beginuing to run wild.

VIOLACE.F.

Viola canina, L., var. sylcestris, Regel.-Upper Geyser Basin, Septomiler.

Viola Canalensis, L.-Union Pass, Gallatin River, September.

Viola Nuttallii, Pursh.-Little Cottouwood Cañon, Utah Territory, June; Clark's Fork, Wyoming Territory, elevation 9,000 feet; Trail ('mek Mountains, s.ptember; Titon Range, elevation 10,000 feet, July. Viola Nuttallii, I'ursh. var. renosa, s. Watson. (Clarence Kiug's Rep., vol. v, p. 35.) - Mountains near Ogilen, Utah Territory, June.

\section{CAPPARIDACE.F.}

Cleome integrifolia, T. \& G.-Great Salt Lake, June.

Flome aurea, Vutt.-Ogden Cañon, Utah Territory, June; Snake liver Valles, July. Very abundant.

\section{CARYOPHYLLACEX.}

Saponaria racneria, L., ( Vacearia vulgaris, Host.)_Near Ogden, Utah Territory, June; Fort Ellix, Montana, July.

silene acaulis, L, - Téton Mountains, elevation 12,000 feet, July 29.

Silene Douglaxii, Hook.-Yellowstone Lake, Angust.

Silene Douglaxii, Ilook, var. (?) (S. Watson, in Clarence King's Rep., vol. v, p. 36.)-Fort Eilix, Montana Territory.

silere Menziesii, Hook.-Wooled cañon of Téton River, July.

Lychnis Drummondii, S. Watson, (Silene Drummondii, Hook.)-Upper Cañon of the Madison, August ; Yellowstone Lake; Heart Lake, September; Snake River Valley, July.

Cerastium nutans, Raf.-Gallatin Cañon, Montana* Territory, Septeinber.

Cercstium vulgatum, L. var. Behringianum, Gray,-Monntains near Clirk's Fork, Wyoming Territory; elevation $\mathbf{9 , 0 0 0}$ feet, August. 
Cerastium arrense, L.-Iower Fire-Uole Basin, August.

Cerastium arrense, L. var.-Yellowstone Lake, August.

Stelleric longipex, Goldie-OOrden Cañon, Utalı Territory, Junc; Henny For of Suake River, Jnty.

Arenaria congexta, Sutt.-Shoslioue Lake, Septeuber; Téton Basin, July; Snake River Valley, August.

Arenaria pungenx. Nutt.-Teton Mountains; elevation 11,000 feet, July.

Arenaria rerna, L.-Trail Creek Mountains, Septeuber; Téton Moun:ains, elevation $1:$, (hoo feet.

Arenaria aretict, Stev,-Red Mountain; elevation 10,000 feet, September.

Arenaria lateriftort. I.-Trail liver Mountains, Siptember; Téton Mountains, elevation 11,700 feet, Inly: Satake laver Valley, August.

Sagina Liunci, Prest, - Lower Fire Ilole Basin, Auguat.

$$
\text { PORTILACACE.E. }
$$

Talinum pyquerum, Gray.-Tower Falls, August ; Red Mountain; e.e.

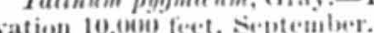

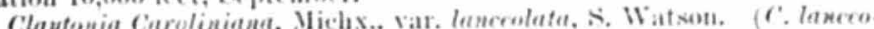

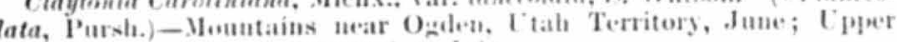
Téton Cañen, elevation 10,000 feet, duly.

Claytonit limtris, Hook.-Mountains along C'latk's Fork, elevation 9,000 feet surust.

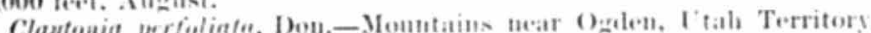

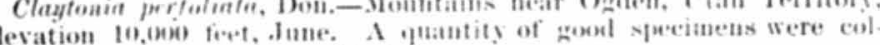
lected, but wete unacesuntably lost.

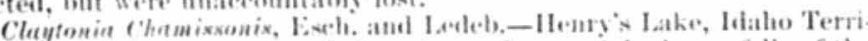
tory, Angust: Yellowstone Lake: spraty Hower of the lower falls of the

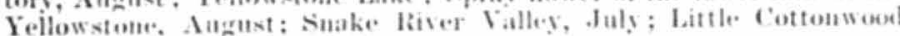

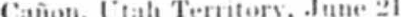

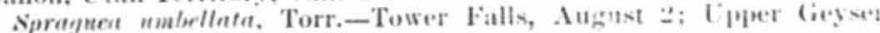
Basin hear lot spring

Lencisia redicied, I'l.-Fort Eilis, Montana.

HYM:RUACE:

'Iyperienu Seonleri, Hook.-Swamp near Ogilen, I'tal, Territory, Iune 13; Snake liver Valley, July.

\section{MALACE.E.}

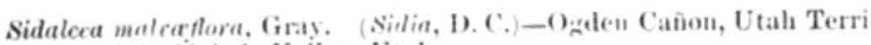
tory, June $1.2 ;$ Malade Valley, Utah.

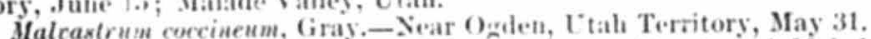

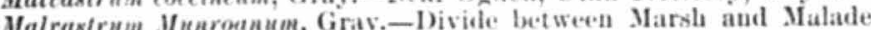
Valleys, June :29.

Spharaleet acerifolia. Nutt.-()gden Cañon, Utah Territory, June; Téton Basin, Jujy; Jackson's Lake, September.

Malea rotundifolia, L.-Xear Ogden, Utah Territory, June; doubtless introduced.

\section{LINACEE.}

Linum perenne, L.-Ogden Cañon, Utah Territory, June; Téton Mountains, elevation 10,000 feet, July; Trail Creek Mountains, September; near Jackson's Lake, in fruit.
Liнum Kingi, Watson, var, sedoiles, Porter,-Vintah Mountains, Wroming Territory, Algust; Dr. Joseph Leilly.

\section{GEIRANTACF:A:}

Geranium Richardsonii, Fisel. \& Mey.-Near Ogden, Utah Territory, Yay: North Fork of Sinake lliver, July

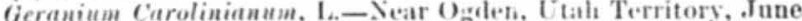

Gerauimu Eremontii. Torr, var.-Two torms, probably varieties of $G$. Fremontii, were foud near Heary's lake, Idaho.

\section{CELASTIIXE:.E.}

Pachystima myrsinitex, Ii.ıf. (Oreophila myrtifolia, Nutt.)-Near Ogden, Lituh Territory, June.

RHANACV.

Ceanothus relutinus, Dougl.-Yountaius near Ogten, Utah Territory, June.

\section{SAPISDACE.E.}

Acer glabrum. Torr. (1, truartitum, Nutt.)-Viear Oglen, Utah Terri. tory, June; monntains along Clark's Fork, Wyoung Territory, elesa. tio: 8,000 teet.

\section{AXICAIBLACE.E.}

The following two speries wore noted, but as specimens have been brought in lnefore, and they are mupleasaut subjects to handle, they were not collectul.

Wher toricodemdron, L.- Vear Ogden, Ctah Territory, June. Klus glatwid,
Territory, Iuly.

LE:TYITOS.E.

Lupinux pusillus, Pursh.-Black foot Liver, Idaho, July 13.

Lиріии parriflorux. Xutt.-Divide bet ween Marsh and Malade Valleys, June: Teton Baxin, duly.

Lupinux scricens, Pursh._Ogden Cañon, Vtah Territory, June.

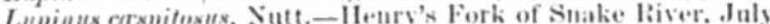

Lupinus ornatux, Dsül.-Teton Baxin, July; Henry's Fork of Snake River, Angust.

Lapinus polyphyllus, Lindl.-Upper Téton Canon, July 28; near Brigham City, Utah, June.

Lupinus lcucophyllus, Lindl.-P'ort Neuf Cañou, Idaho, July; Téton Baxin, Angust.

Lupinus lariflorus, Dougl.-Trail Creek Mountains, September. Medicago satica, L.- Near Ogden, Vtah, June; Fort Hall, Idaho. Doubtless escaped.

Trifolum longipes, Nutt.-Plains near Ogden, Utah, June; Téton Basin, July,

Trifolium Parryi, Gray.-Brigham Cañon, Utah, June. "Ripe legume stiped, stipe elongated, equaling in length the erect teeth of the calyx." Professor Porter. 
Trifolium rariegatum, Nutt.-Near Ogden, Utab, June; Little Cotton. wood Caũon, Utıh, Juıe.

Trifolium Haydeni, P'orter. (Hayden's report for 1871.)-Mountains near Henry's Lake, libiho, Auzust.

Psoralea lancrolata, I'ursl._- P'ains near Ogden, Utah, June.

Astragalus Canadensix, I._-P'ort Nenf Cañon, Itaho, July,

Astragalus Cantenxis, L. var. Mortoni, \$. Watson.-Port Neuf Cañon, Itaho, July.

Astragalus hypoglottis, L._-Suake River Valley, July ; near Fort Ellik, Montaua, July:

Astragalus Utahensix, T. and (i. (Gray's Rer. I. c., 213.)-Ogden, Utah July.

Astragalue Geyeri, Gray,-IBlackfoot River, Idaho, July.

Astragalus tegetarius, S. Witson.-Near Fort Ellis, Montana, July;

Snake River Villes, Anzulst.

Astragalus campestrix, Ciray,-Near Fort Ellis, Montana, July; Téton Basin ; monntains near Ilenry's Lake, Ldaho, Angust; Grand Ciñon of the Yellowstone; Clark's Fork, Wyoming. Very variable in the breadth of the leaves.

Astragalus junceus, Gray, (A. dirersifolius, Gray.)-Near Ogten, Utah,

Jane; Suake River Valley, July.

Astragalus alpinus, L.-Yellowstone Lake, August.

Astragalus pictus, Gray._- Sulake River l'laius, July. Oceurs in great abutulance.

Oxytropix nana, Nutt.-In fruit. Henry's Fork of Snake River, July, Orytropis Lamberti, Pursh.-In frut. Snake River Valley, July.

Glycyrrhiza l-pidota, Nutt._Sand Creek, Idaho, October.

Hedysarum Mackenzii, lich._- Year Ogden, Utah, Jute.

Hedysarum boreale, Nutt. - Bear River, Utah, Jume; Trail Creek

Mountains, September; Teton Mountains, elevation, 10,000 feet, July

Yellowstone Lake, August; remarkably glabrous.

Vicia Americana, Muhl.-Swamp near Ogden, Utah, June; Divide.

between Marsh and Malaule Valleys, near Brigham City, Utah.

Lathyrus polyphyllus, Nutt.-Plains near Ogolen, Utah, June.

Lathyrus paluxtris, L.- Near Ogden, Utab, May.

Lathyrus jaluvtrix, L., Form.- Fear Black foot Biver, Idaho, July.

Lathyrus pulustris, I., var. myrtifolius, Gray.- Near Ogden, Utah,

June. The speciunen was collected, but unfortunately lost.

Pisum arrense, L. Accidental. - Port Neuf Cañon, Idaho.

Thermopsis futucen, D. C.-Divide between Marsh and Malade Val. leys, June.

ROSACEA.

Prunus demissn. W:alp.-Divide between Marsh and Malade Valleys, June.

Spirca dumosn, Nutt.-(S. ariafolia, var. discolor, T. and G.)-Twin. Buttes, on Henry's Futk of Suake River, July.

Spira opulifolia, L--Ogelen Cañon, Utah, June.

Spiran opulifolin, L. var. pauciflora, Hook.-Monntains near Ogden, Utah, June.

Spirca betulafolia, Pallas.-Téton Mountains, elevation 11,000 feet, July.

Spirca betulafolin, Pallas, var. rosea, Gray.-Shoshone Lake, Septem. ber; mountains near Henry's Lake, Idaho, August Spiraa Millefolium, Torr. (P. F. R. Rep., vol. is, p. 83, t. 5.) Snake
River Valley, Idaho, John M. Coulter; Ophir, Southern Utah, E. S. Blackicell.

Rubus Nutkanus, Mos-Ogden Cañon, Utah, June; Téton Mountains, elevation 10,000 feet, July.

Rubus strigosus, Michx.-Madison River, August; Yellowstone Lake; Téton Basin, July.

Purshia tridentata, D. C.-Divide between Marsh and Malade Valleys, Juue.

Cercocarpus ledifolius, Nutt. "Mountain mahogany."-Mountains near Gglen, Utah, June.

Drydas octopetala, L.-Téton Mountains, elevation 12,000 feet, July. Geum strictum, Ait,-Near Fort Ellis, Montana, July.

Geum macrophyllum, Willd-Divide between Marsh ahd Malade Val.

levs, June; Teton River, July.

Geum triflorum, Pursh. - Mountains near Henry's Lake, August; mountains along the Yellowstone, elevation $8-10,000$ feet; Téton Basin, July.

Fragaria Virginiana, Ehrh._-Yountains near Heury's Lake, Idaho,

August; Tétou Basin, July.

Fragaria resca, L.-Ogden Cañon, Utah, June; Téton Basin, July.

Potentilla Norregicu, L., a form approaching P. ricularis.-From Ross

Fork to Fort Hall, Idaho, July,

Patentilla Norregica, L.-Malide Valley, Utah, June 27.

Potentilla millegrana. Engelm.-Port Neuf Cañon, Idaho, July ; toothills of the Téton Range, August.

Potentilla direrxifolia, Lehm.-Yellowstone Lake, August.

Potentilla dirersifolia, Lelam., var. multisecta, S. Watson. (Clarence

King's Rep., vol. v, p. S6.)-Tieton Mountains, elevation 11,500 feet, Iuly.

Potentilla phicherrima, Lehn.-Near Ogden, Utah, June.

Potentilla gracilix, Dougl.-Divide between Marsh and Malade Val.

less, Jnue : Fort Ellis, Montaua.

Potentilla gracilis, Dougl., var. flabelliformis, Nutt.-Heury's Fork of

Suake Ruver, July.

Potentilla Anscrina, L.-Near Ogden, Utah, May.

Potentillt fruticose. L.-Malate Valley, Utah, June; Henry's Lake, Idaho, Anzust; Yellowstone River, elevation 6,400 feet; Téton Basin, Inly.

Potentilla glandulosa, L.-Üper Téton Caûon, Juiy ; Henry's Fork of Suake River, Angust.

Potentilla arguta, Pursh.-Divide between Marsh and Minlade Valleys, June.

Iresia Ciordoni, T. and G.-Red Mount،in, elevation 10,000 feet, September: Téton Range, elevation 10,000 feet, July.

Kosa blanda, Ait.-Divide between Marsh aud Malade Valleys, June; Fall River, ldilio, July.

Rosa fraxinifolia, Bork.-Téton River, July 23 . Collected in fruit but not in tower.

Cratagus rieularis, Nutt. (?) (Watson, in Clarence King's Rep, vol. v, p. 92.)-Near Ugden, Utah, June.

C. ategus sanguinea, Pallas, var. Dotglasii, T. and G.-Fort Ellis, Monhaua, July.

Amelanchier Canadensis, T, and G., var, alnifolia, T, and G,-Divide between Marsh and Malade Valleys, June; Teton Mountains, elevation 10,000 feet, July: 


\section{SAXIFILAGACE.X.}

Sarifraga oppositifolia, I_-Teton Mountains, elevation 12,000 feet, July.

Saxifraga brouchialis, 1.-Mountains near Henry's Lake, Idaho, An. gust.

Sa.xifraga puactata, L._- Yellowstone River, July ; Upper'Tston Cañon.

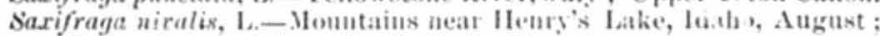
Upper Teton Canon, July; Clark's Fork, Wyoming.

saxifraga hierneifolia, Wahlst. and Kit.-Foton Basin, July.

Saxifraga Jenexii, Ihongl.-Teton Mountains, elevation 11,000 feet, July.

Tellima parriglora, IIook.-Titon Caũon, July.

Tellima tenella, Benth. and IJook.-Vear Ogilen, Utah. June; Titon Mountains, elevation 10,000 feet, July.

Mfitella pentandra, Hook.- - Pper 'Teton Cañon, July.

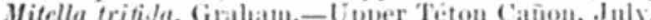

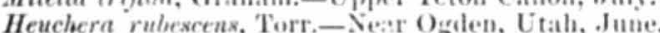

Heuchera cyliulrica, Dougl.- Itot springs along the Yellowstone, ele. vation 6,200 feet, September; Grand Cañon of the Yellowstone, August; Lower Fire-Hole Basin.

Ieuchera parrifolit, Nutt,-Ogilen Cañon, Utah, June; divide be. tween Marsi and Malade Valleys; Teton Basin, July. A very dwart form was found at Fort Ellis, Montana.

Parnaxsia parriflora, D. C.-Lower Fire-Hole Basin, An:xust.

Parnassia fimbriata, Banks.-Teton Canon, July; spray flower of the Great Falls of the Yellowstene, Angrust phealwaters of Suale River, September.

Ribes lacustre, Poir.-C Puer Téton C:aton. Iuly

Kibes lacustre, Poir., var., an Alpine form, (Watson, in Clareme King's Rel, vol, v, p, 99.) (K. setoxum, 1)ougl.) Titon Monutains, ele. vation 11,500 feet, Iuly.

Ribes riscoxisximum, Pursh.-Upuer Téton Cañon, July; mourtains near Henry's Latie, libibo, Angust.

Ribes bracteosım, Dougl.-Téton Caño:ı, Aแğust.

$$
\text { CRASSULACE.L. }
$$

Sedum Rhodioln, D. C.-Mountains near [Tonry's Lake, Lhaho, Augnst ; Téton Mountains, elevation 1:,000 fect, July.

Sedum rhodanihum, Gray.- Tower Fills, Angust; Upper Falls of the Yellowstone.

Sedum stenopetalum, Pursh,_Mountains near Oæden, Ctah, June; Fire-Hole liver, Aurust.

Sedum debile, s. Watson.-Wountains near Orden, Utah, June.

\section{HALORAGE.N.}

Myriophyllum rerticillatum, I,-Ilenry's Fork of Snake River, Angust. Hippuris culgurix, L-Near Ogden, Utah, June; common on Henry's Fork of Snake River, July.

\section{ONAGRACE.E.}

Epilobium augustifolium, L.-Divide between Marsh and Malade Val. leys, June.
Epilobium suffruticssum, Nutt.-Mountains near Ogden, Utah, June. Epilobium tetragonum, L.-Near Brigham City, Utah, June; Téton Cañon, Juls; Snake River Valley, August.

Epilobium paniculatum, Nutt.-Plains near Ogde" Utah, June; Téton foot-hills, August; Snake River Valley, July; mouatains near Henry's Lake, Idaho.

Zauschneria Californica, Presl._-Mountains near Ogilen, Utah, June. Clarkia rhomboidea, Dougl.-Mountains near Ogden, Utah, June. Gayophytum ramosissimum, T. and G.-Near Ogden, Utah, June. Gayophytum racemosum, T. and G.-Téton foot-hills. August. Gayophytum diffusum, T. and G.-Téton foot-hills, August. Gayophytum diffusum, T. and G.-Tetou foot-ling, Enothera biennis, L.- Snake River Valley, July.
Enothera albicaulis, Nutt.-Nesr Ogden, Utah, June. Enothera albicaulis, Nutt., var. Nuttallii, Engelm,-Divide between Marsh and Malade Vallers, June 29 ; Yelowstone River, August. Enothera triloba, Nutt.-Ogden Cañon, Utalı, June 15; Port Neuf Cañon Iduho, July'?'; Henry's Fork of Snake River, July 18; Yellow. sione Lake, August 23.

Gnothera marginata, Nutt.-Port Neuf Valley, Idaho, July 1. Enothera marginata, Nutt., var. purpurea, S. Watson.-Wot springs along the Yellowstone, elevation 6,700 feet, September 39.

Enothera scapoiden, Nutt.-Suake River Valley, July 16.

Enothera heteranthut, Nutt.-Téton Basin, July 11.

Enothera Andina, Nutt.-Twin Butt is on Henry's Fork of Snake River, Itaho, July 1ti.

Gaura biennix, L.-Port Nenf Cañon, Idaho, July 1.

Gaura parriflora, Dougl.-Port Nenf Cañon, Id ho, July 2; Syake liver Valley, July 19.

Gaura coccinea, Nutt.-Between Boteler's Ranch and Fort Ellis, Mont:แ1, July 21 .

LYTHRACE.F.

Lythrum alatum, Pi:rsh.-Mountains near Henry's Lake, Idaho, Au(m)

\section{LOASACE.X.}

Ienṫ̈lia albicaulis, Dougl., var, integrifolia, S. Watson.-Port Nenf Cañon, Itlaho, July:.

Meatzelia laricaulix, T. and G.-Mountains along the Yellowstone; Twin Buttes on Henry's Fork of Snake River, July 25.

\section{UMBELLIFER A.}

Bupleurum ranunculoiles, L.-Henry's Lake, Idaho, Angust 9; a taller form from Union Pass, Gallatin River, September 12. (See catalogue in Hayden's Rep. for 1si1.

Cicuta maculata, L.-Port Neuf Cañon, Idaho, July 2; Snake River Valley.

Carum Gairdneri, Benth and Hook,-Téton River, July; Snake River Plains, August; Fall Rive, Idaho, July 19. A common article of food among the Indians of Idaho and Wyoming, who call it "yamp." It is very palatable and nutritions, having somewhat the flavor of carrot. Sium augustifolium, L._.Malade Valley, Utah, June.

Sium lineare, Michx.-Port Neuf Cañon, Idaho, July. 
Osmorrhiza nuda, Torr.-Near Ogden, Utah, Jnne; Upper Téton Oañon, July.

Myrrhis occidentalis, Benth. and Hook.-Suake Riser Valley, July. Cymopterus faniculaceus, Nutt.-Mountains near Ogden, Utah, eleva tion 10,000 feet, June.

Cymopterus longipes, S. Watson.-Near Ogden, Utah, May to June, 1871 .

Thaspium trifoliatum, Grav,-Union Pass, Gallatin River, September. Angelica Breceri, Gray,_Swamps in Snake River Valley, July. Conioselinum Canadense, T. and G.-Upper Téton Cañon, July. Peucedanum simplex, Nutt.-Mountains near Ogden, Utah, elevation 9,000 feet, June.

Ferula multifida, Gray, (Leptotania, Nutt.)—Ogden Cañon, Utah, June. Heracleum lanatum, Michx.-Upper Téton Caũon, July.

CORNACEX.

Cornus Canadensis, L.-Madison River Cañon, August.

Cornus pubescens, Nutt.-Swamps on Téton River, July.

\section{CAPRIFOLLACEX.}

Linnaa brealis, Gronov,-Lower Fire-Hole Basin, August; Yellow. stone River; (ibbon's Fork of Malison River.

Symphoricarpas montanss, H. B. K.-Ogdè C:añon, Utah, June; Yel lowstone IRiver, August; Snake liviver Valley, July; Téton Cañon. Symphoricarpus occidentalis, R. Br._Snake IRiver Valley, July. Lonicera incolucruia, Banks.-Ogden Cañon, Vtah, June; Tower

Falls; Téton Mountains, elevation 10,000 feet, July,

Ionicera Utahenxis, S. Watson.-Upper Téton Canon, July.

sambucus racemost, I., var. puhens, S. Watson, (S. pubcus, Michx.) -

Little Cottonwoot Cañon, Utah, June; Upper Teton Canon, July. Sambucus glauca, Nutt.-Near Ogden, Utah, Juue.

\section{RUBIACE.E.}

Galium Aparine, L.-Ogden Cañon, Utah Territory, June; along the Yellowstone, elevation 6,400 feet.

Galium multiflorum, Kellogg, (G. hypotrichium, Gray.)-Near Ogden, Utah, June.

Galium trifidum, L.-Henry's Fork of Snake IRiver, August.

Galium boreale, L.-Divide between Marsh aud Malade Valleys, June; Heury's Fork of Suake River, July.

\section{VALERIANACEA.}

Valeriana dioica, L., var. syleatica, S. Watson.-Near Ogden, Utah, June; Red Mountain, elevation 9,000 feet, Septembet.

Valeriana edulis, Nutt.-Téton Mountains, elevation, 11,500 feet; July ; near Henry's Lake, Idaho, August.

Plectritis congesta, D. C.-Plaius near Ogden, Utah Territory, June.

\section{CoMPosit $E$.}

Eupatorium purpureum, L.-Snake River Valley, Juiy.

Aster integrifolizs, Nutt.-Téton Basin, August; Henry's Fork of Snake River; Upper Cañon of the Madison.
Aster adscendens, Lindl.-Upper Geyser Basin, Angust.

Aster adscendens, Lindl., var. Parryi, S. Watson.-Téton Basin, July ; Trail Creek Mountains, September.

Aster multiflorus, Ait.-Shoshone Lake, September.

Aster glacialis, Nutt.-Trail Creek Mountains, September; Téton Mountains, elevation 11,000 feet, July.

Aster pulchellus, D. C. Eaton.-Téton Mountains, elevation 12,000 feet, July.

Aster salsuginosus, Rich.-Téton Mountains, elevation 12,000 feet, July.

Aster salsuginosus, Rich., var. B., T. and G.-Upper Téton Cañon, July.

Aster Maydeni, Porter, (Hayden's Report for 1871.)-Shoshone Lake, September.

Aster Sayi, Nutt, (Gray in Proc. Am. Acad., May, 1872, p. 389; Hall's Oregon Coll., 246.)-Téton Range, elevation 10,000 feet, July.

Aster elegans, T. and G.-Fall River, Idaho, July ; Téton Mountaius, elevation 10,000 feet.

Aster Engelmanni, Gray, (A. elegans, var. Engelmanni, D. C. Eaton.)Madison River Can̂̃on, August; Téton Range, elevation 10,000 feet, July.

Toionsendia scapigera, D. C. Eaton.-Union Pass, Gallatin River, July; Téton Mountains, elevation 10,000 feet.

Toicnsendia strigosa, Nutt.-Snake River Valley, Idaho, July.

Toncuscndia grandiflora, Nutt.-From Boteler's Ranch to the Yellow. stone, July.

Macharanthera canescens, Nutt.-Madison Cañon, Angust; Téton Basin, July. Several forms were found.

Erigeron grandiflorum, Hook.-Téton Mountains, elevation 10,000 feet,

July. A very dwarf form was found at Shoshone Lake, September.

Erigeron acre, L.-Mountains along Clark's Fork, Wyoming, elevation 9,000 feet, Angust.

Erigeron Bellidiastrum, Nutt.-Near Ogden, Utah, June; Ross Fork to Fort Hall, Idaho, July; Snake River Valley.

Erigeron maoranthum, Nutt. - Wooded Cañon of Tóton River, July.

Very variable in size.

Erigeron glabellum, Nutt.-Near Ogden, Utah, June; Téton Basin,

July: Upper Téton Cañon.

Erigeron corymbosum, Nutt._Divide between Marsh and Malade Val.

leys, June; Lower Fire-Hole Basin, Angust.

Erigeron filifolitm, Nutt.-Henry's Lake, Idaho, August ; from Ross

Fork to Fort Hall, Idaho, July.

Solidago Virga-aurea. L.-Téton foot-bills, August.

Solidago Virga-aurea, L, var, multiradiata, T. and G.,-Mountains near

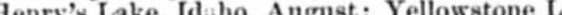

Solidago Virga-aurea, L., var. Alpine form, 554 of Watson's collection. Clarence King's Rep., vol. v, p. 154.)-Red Mountain, elevation 10,000 feet, September.

Solidago Guiradonis, Gray, var. spectabilis, S. Watson. (Clarence King's Rep., vol, v, p. 154.)-Téton Basin, August.

Solidago nemoralis, T. and G.-Headwaters of Madison River, September.

Solidago elongata, Nutt.-Téton foot-hills, August.

Solidago gigantea, Ait.-Téton foot-Lills, August; Yellowstone Lake; Henry's Fork of Suake River.

49 G 8 
Solidago gigantea, Ait.-A form, 562 of Watson's collection. (Clarence King's Kep., vol. v, p. 156.) - Port Neuf Cañon, Idaho, July. Linosyris graveolens, T. aud G.-Lower Fire-Hole Basin, Angust. Linosyris viscidiflora, T. and G.-Near Brigham City, Linosyris viscidiflora, T. and G., var. serrulata, Torr. (Stansb. Rep. Ed. 2, p. 389.)-Near Bringham City, Utah, June.

Linosyris viscidiflora, T. and G., Var. latifolia, D. O. Eaton-Leaves from $2-3$ long. Mountains along Malade Valley, Idaho.

Linosyris viscidiflora, T. and G., var. puberula, D. C. Eaton.-Fall River. Idaho, July.

Linosyris riscidiflorn, T. and G. "A form 8 flowered," Professor Por ter.-Twin Buttes on Henry's Fork of Snake River, July.

Aplopappus suffruticosus, Gray. (Macronema suffruticosa, Nutt.) (Proc. Am. Acad., 6, 542.)-Snake River Valley, July.

Aplopappus lanceolatus, T. and G.-Around the hot springs in both geyser basins, August.

A plopappus acaulis, Gray.-Mountains near Henry's Lake, Idaho Ter ritory, August.

Aplopappus Nuttallii, T. and G.-Near Fort Bridger, Wyoming, August,

Aplopappus uniflorus, T. and G. A form with the radical leaves en tire or nearly so. Henry's Lake, Idaho, Angust 8.

Grindelia squarrosa, Don.-Port Neuf Valley, Idaho, July 1.

Chrysopsis villosa, Nutt.-Henry's Fork of Snake River, July 18;

around the hot springs of Lower Fire-Hole Basin, August 13 . 'Very variable.

Chrysopsis villosa, Nutt., var. hispida, Gray.-Madison Lake, Septem. ber 4 .

Ira axillaris, Pursh.-Malade Valley, June; abundant in Snake River

Valley, July 26 ; near hot springs along the Yellowstone, Angust. Wyethia amplexicanlis, Nutt.-Malade Valley, Utah, June 27.

Balsamorrhiza sagittata, Nutt.-From Ross Fork to Fort Hall, Idaho, July 3.

Kudbeckia occidentalis, Nutt.-Ogden Cañon, Utah, June 15; Tétot Ionntains, elevation 10,000 feet, July 24; Snake River Plains, August. Helianthus lenticularis, Dougl.-Malade Valley, Utah, June 27 ; Snake River Valley, July.

Melianthus Nuttallii, T. and G.-Lower Fire-Hole Basin, August 29. Helianthus petiolaris, Nutt.-Weber River. Utah, Jnne 19. Helianthella multicaulis, D. C. Eaton.-Fall River, Idaho, July 19. Helianthella truiflora, T. and G.-Upper Treton Cañon, July $: 6$. Heliomeris multiflora, Nutt.-Téton River, Idaho, July 23 . Chanactis Douglasii, Hook. anıl Aru.-Ogden Cañon, Utah, .June 15 Fire-Hole River, August; Garluner's River, Montanon, Ctah, June 15 Itlaho.

Chanactis Douglasii, Hook. and Arn.-Alpine form, monntains near Henry's Lake, Idaho, August 9; Lower Fire.Hole Basin.

Bahia lencophylla, D. C.-Henry's Fork of Snake River, July 18 ; Féton Basin, July 2

Actinella grandiflora, T. and G.-Téton Mountains, elevation 12,000 feet, July 30 .

Layia glandulosa, Hook. and Arn.-Twin Buttes on Henry's Fork of Snake River, July 16.

Layia heterotricha, Hook. and Arn.-Near Ogden, Utab, June 5.

Wadia racemosa, T. and G.-Ogglen Cañon, Utah, June 15.

A mida hirsuta, Nutt.-Téton Mountains, elevation 10,000 feet, Jnly 24.
Achillea Millefolitum, L.-Near Ogden, Utah, May 30 ; very abundant everywhere on the route.

Matricaria discoidea, D. O.-Great Salt Lake, June 17.

Artemisia dracunculoides, Pursh.-Snake River Valley, October; Yel. lowstone Biver, August 23.

Artemisia tridentata, Nutt-Xellowstone Lake, August 23; Snake River Valley, July. The cotamon form all over the West.

Artemisia discolor, Dougl.-Snake River Valley, October; Lower Fire-Hole Basin, August.

Artemisia Ludoriciana, Nutt.-Weber River, Utah, June.

Artemizia Ludoriciana, Nutt., var. Douglasiana, D. C. Eaton. (A. Douglasiana, T. and G.)-Yellowstone Lake, Angust; Market Lake, Idaho, July.

Artemisia Ludoviciana, Nutt., var. latifolia, T. and G.-Yellowstone Lake, August 5 ; Port Neuf Cañon, Idalio, July.

A rtemisia cana, Pursh.-Yellowstone Lake, August.

Artemisia frigida, Nutt._Near Fort Bridger, Wyoming, August, Dr.

Joseph Leidy.

Gnaphalium Iuteo album, L., var. Sprengelii, D. C. Eaton.-White Mountain Hot Springs, Montana, elevation 6,400 feet, July; Geyser Basin on Shoshone Lake, September.

Gnaphalium palustre, Nutt.-Great Salt Lake, June.

Guaphalium microcephalum, Nutt._Shoshone Lake, September.

Antennaria margaritacea, $\mathrm{R}$. Br.-Henry's Lake, Idaho, August 8.

Antenuarie Carpathica, R. Br.-Shoshone Lake, September 6.

Antennaria Carpathica, K. Br., var. pulcherrima, Hook.-Henry's Lake,

Idaho, August 8; Lower Fire-Hole Basin, September; Téton Basin, July 21 .

Antennaria alpina, Grertn.-Ogden Cañon, Utah, June 15; Fort Hall, Idaho, July ; Upper (ieyser Basin, August.

Antennaria dioica, Gartn.-Yellowstone River, August 22; Suake River Valley, July 30.

Antennaria dioica, Gertn., var. rosea, D. C. Eaton.-Téton Basin, July

Antennaria racemosa, Hook.-Monntains near Henry's Lake, Idaho, August 9.

Arnica longifolia, D. C. Eaton.-Grand Cañon of the Yellowstone, August 22.

Arnica augustifolia, Vahl.-Divide between Marsh and Malade Valleys, June 29.

Arnica Chamissonis, Less._Divide between Marsh and Malade Val. lers, June 29; swamps along Henry's Fork of Snake River, August. Arnica latifolia, Bongard.-Téton Mountains, elevation 10,000 feet, Inly.

Arnica cordifolia, Hook.-Ogden Cañon, Utab, June; Téton Basin, July; Trail River Mountains, September.

senecio lugens, Richards.-Téton Mountains, eleration 10,000 feet, July; Yellowstone Lake, Angust.

senccio lugens, Richards, var. Hookeri, D, C. Eaton.-Monntains near Heury's Lake, Idaho, August.

Senecio lugens, Richards, var. exaltatus, D. C. Eaton.-Lower FireHole Basin, August; Mountains near Ogden, Utah, June. Senecio hydrophilus, Nutt.-Henry's Lake, Idaho, August.

Senecio triangularis, Hook.-Henry's Fork of Snake river, August;

Yellowstone Lake; Red Mountain, elevation 10,000 feet, September; Téton River. 
Senecio Serra, Hook., (Watson, in Clarence King's Rep., vol. v, p. 189 under $S$. Andinus.) - Téton Mountains, elevation 10,000 feet, July. Senceio Andinus, Nutt.-Divide between Marsh and Malade Valleys, June; Shoshone Lake, September.

Senecio aureus, L.-Ogden Cañon, Utah, June; Teton Basin, July.

Senecio aureus, L., var. obovatus, T. and G.-Divide between Marsh and

Malade Valleys, June.

Senecio aureus, L., var. croceus, Gray.-Yellowstone Lake, August.

Senecio canus, Hook.-Around hot springs in Lower Fire-Hole Basin,

August. The form with entire leaves.

Senecio Fendleri, Gray. (Pl. Fendl., p. 108.)-Malade Valley, Idaho,

June. With uncommonly long petioles.

Senecio multilobatus, T. and G.-Near Ogden, Utah, June.

Senecio subnudus, D. C.-Lower Fire-Hole Basin, near hot springs, August.

Tetradymia canescens, D. C.--Snake River Plains, July.

Several species of Cirsium were collected, probably $C$. foliosum, C. Drummondii, and some others, but the material was too meager for satisfactory determination of these mixed species.

Stephanomeria minor, Nutt.,(including S.runcinata, Nutt.)-Near Brig.

ham City, Utah, June; Fort Hall, Idaho, July; a slender, unbranehed torm.

Stephanomeria exigua, Nutt.-Snake River Valley, July.

Micracium Scouleri, Hook.-Snake River Valley, Idaho, July ; Malade

Valloy, Juue.

Jicracium albiflorum, Hook.-Upper Cañon of the Malison, Angust.

A small, single-flowered, alpine form was found on the hills around the

Upper Geyser Basin.

Lygodesmia juncea, Don., var. dianthopsix, D. C. Eaton. (Clarence

King's Rep., vol. v, p. 200.)-Ogden Cañon, Utab, June; near Great Sal

Lake.

Malacothrix sonchoides, T. and G,-Twin Buttes on Henry's Fork of

Suake River, July; Port Neuf Cañon, Idahe.

Crepis Andersonii, Gray.-Lower Fire-Hole Basin, August.

Crepis ocidentalis, Nutt.-Marsh Valley, Juue; Fire-Hole River, August.

Crepis occidentalis, Nutt., var. gracilis, D. C. Eaton.-Mountains nea Henry's Lake, Idaho, August.

Crepis acuminata, Nutt.-Plains near Ogden, Utab, June; Téton Basin,

July; Bear Riser Valley.

Crepis nana, Richards. (Fl. N. Am. 2, p. 4\$8.)-Téton Mountains, elevation 12,000 feet, July.

Macrorrhyncus ylaucus, D. C. Eaton, var. laciniatus, D. C. Eaton.Snake River Plains, July.

Macrorrhyncus troximoides, T, and G._Swamp near Ogden, Utah, June; Henry's Fork of Snake River, July; Red Mountaiu, elevation 10,000 feet, September.

Taraxactm Dens-leonis, Desf.-Ogden Cañon, Utah, June. Collected in abundauce, but lost.

Muigedium pulchellum, Nutt.-Port Neuf Cañon, Idaho, July.

Slulgedium leucophaum, D, C.-Giallatin Cairou, Septemler.

Sonchus asper, Vill.-Ogilen Cañon, Utah, June. Collected with sov.

eral ther specimeus and lost.

G.illardia aristata, Pursh.-Union Pass, Gallatin River, Montana, Sept ember.

\section{LOBELIACEX.}

Porterella carnulosa, Torr. (See Cat. Haydea's Rep. for 1871.)Swamp on Henry's Fork of Snake River, Augnst.

CAMPANULACEA.

Campanula rotundifolia, L.-Elevated plateau, Montana; Snake River Valley, July.

Campanula rotundifolia, I. var. linifolia, Gray,-Mountains along the Yellowstone, elevation 6,000 feet; Téton Basin, July.

Specularia perfoliata, A. D. C.-Hot springs ten miles from Ogden, Utah, June.

ERICACEA.

Vaccinium uliginosum, L.-Henry's Fork of Snake River, Angust; Shoshone Lake, September.

Vaccinium myrtilloides, Hook.-Henry's Lake, Idaho, August.

Vaccinium myrtilloides, Hook., var. macrophyllum, Gray.-Upper Téton

Cañon, July:

Vaccinium Myrtillus, L.-Yellowstone Lake, Angust.

Vaccinium oralifolium, Smith.-Upper Téton Cañon, July.

Arctostaphylos Ura.Ursi, Spreng.-Yellowstone River, August ; Lower

Fire-Hole Basin, July. The "Kinnikinnick" of the Indians.

Kalmia glauca, Ait.-Shoshone Lake, September, growing on gey serite.

Kalmia glanca, A it., var. mierophylla, Hook.-Monntains along Clark's Fork, Wyoming; elevation 9,000 feet; August. A small alpine form was found upon the Rocky Kountain divide, near Shoshone Lake, Sep. tember.

Iryanthus empetriformis, Gray. (Proc. Am. Aead., vol. vii, p. 367.)Thton Mountains; elevation 12,000 feet, July; Rocky Mountain divide, near Shoshone Lake, September.

Ledum glandulosum, Nutt.-Tower Falls, August; Shoshone Lake, September.

Pyrola rotundifolia, L., var. incarnata, Gray.-Téton Cañon, July.

Pyrola chlorantha, Swartz.-Upper Téton Cañon, July; Fall River, Idaho, August.

Pyrola secunda, L.-Fire-Hole River, Angust ; Upper Téton Cañon, July.

Pyrola aphylla, Smith. (Pacific Railroad Rep., vol. vi, p. 80 of the Bot.)-Henry's Lake, Idaho, August.

Pyrola picta, Ilook.-Fall River, Idaho, Angust.

Yoneses uniflora, Gras.-Upper Téton Caũon, July.

Chimaphila umbellata, Nutt.-Eastern cañons of the Téton Range, Sentember.

Ionotropa Hypopitys, L.-Red Monutain ; elevation 10,000 fect, September; Lower Fire-Iole Basin, A ugust.

Pterospora Andromedea, Nutt.-Jackson's Lake, September. Speci. mens were found at this locality four feet high; along the Yellowstone.

\section{PLANTAGINACEX.}

Plantago major, L-Weber River, Utah, June. Doubtless introduced. Plantago Patagoxica, Jacq., var. gnaphalioides, Gray.-Near Ogden, Utah, June; Snake River Valley, very abundaut. 
Plantago Patagonica, Jacq., var. aristata, Gray. - Henry's Fork of Snake River, July.

PRIMULACEX.

Androsace septentrionalis, L. Alpine form, 753 of Watson.-Trail River Mountains, September; Téton Mountains; elevation 10,000 feet, July.

Dodecatheon Meadia, L.-Ogden Cañon, Utah, Juue.

Dodecatheon Meadia, L. Alpine form of $\mathrm{S}$. Watson, $756,2-8^{\prime}$ high.Upper Téton Uañon; elevation 10,000 feet, July; mountains along Clark's Fork, Wyoming; elevation 9,000 feet.

Lysimachia ciliata, L.-Swamp near Ogden, Utah, June; Twin Buttes, on Henry's Fork of Snake River, July.

Glaux maritima, L.-Malade Valley. Utah, Juue.

LENTIBULACE..

Utrieularia vulgaris, L., var. A mericana, Gray,-Henry's Fork of Snake River, Angust 5.

OROBAXCHACEA.

Phelipara erianthera, Engelm. (Orobanche multiflora, Nutt.)-Snake River Valley, Idaho, July ; "The 'Too-whoo' of the Pah.Utes, by whom it is eaten."-Watson.

Aphyllon uniflorum, T. and G.-Mountains near Ogden, Utah, June 13; Téton Cañon, July 16.

A phyllon fasciculatum, T. and G.-Snake River Valley, Idaho, July 17 ; from Boteler's Rauch to the Yellowstone, July 23.

\section{SCROPHULARIACE:}

Serophularia nodosa, L.-Near Ogden, Utah, June 5. Abundant every. where near settlements.

Collinsia parriflora, Dongl.-Plains near Ogden, Utah, June 5; Téton Cañon, July 24; Yellowstone Lake, August 23.

Pentstemon Menziesii, Hook., var. Douglasii, Gras. (P. Douglasii, Hook.)-Trail Creek Mountains, September; Clark's Fork, Wyoming.

Pentstemon Menziesii, Hook., var. Lercisti, Gr.-Henry's Lake, Ilaho, and Téton Mountains.

Pentstemon glaber, Pursh.-Near Ogden, Utah, June; Fall River, Idaho, July.

Pentstemon cyananthus, Hook.-Mountains near Ogden, Utah, elevation 9,000 feet, June.

Pentstemon acuminatus, Dougl.-From Ross Fork to Fort Hall, Idaho, July.

Pentstemon cristatus, Nutt.-Mystic Lake, near Fort Ellis, Montana, July.

Pentsten 'n humilis, Nutt.-Monntains near Ogden, Utab, June.

Pentstemon glaucus, Grah.-U Uper Téton Cañon, July.

Pentstemon gla ueus, Grah., var. stenosepalus; Gray.-Along the Yellow stone, elevation 6,700 feet, July.

Pentstemon confertus, Dougl.-Téton Basin, July.

Pentstemon confertus, Dougl., var. corruleo-purpurens, Gras.-Monntains along the Yellowstone, elevation 7,000 feet, September; Yellowstune
Lake; Svake River Valley, July; Fall River, Idaho. A very dwarf form was found on the mountains near Ogden, Utah.

Pentstemon deustus, Dongl.-Henry's Fork of Snake River, July.

Pentstemon heterophyllus, Lindl., var. latifolius, $\mathrm{S}$. Watson. (Clarence

King's Rep., vol. v, p. 222.)-Near Ogden, Utah, June.

Mimulus Leccisii, Pursh.-Near Ogden, Utah, Jane; Upper Téton

Can̂on, July; Yellowstone Lake, August; Trail Creek Mountains, September.

Mimulus lutens, $\mathrm{I}_{\text {. }}$-Near Ogden, Utab, June. This species is found everywhere in the West in the greatest abuudance and variety of form and size.

Mimulus lutens, L. Depauperate form, 790 of Watson.-Near Salt Lake City, Utah, June.

Mimulus floribunlus, Dougl.-Foot-bills of the Téton Range, August. Mimulus moschatus, Dougl.-Henry's Fork of Snake River, August;

Téton foot-hills, July.

Mimulus rubellus, Gray, (Mex. Bound. Rep., p. 116.) (Watson, in

Clarence King's Rep., vol. v, p. 225.)-Near Ogden, Uta', June.

Eunanus Fremontii, D. C.-Crater Hills, Wyouning, August; Twin

Buttes on Heury's Fork of Snake River, Idaho, July.

Synthyris alpina, Gras.-Téton Mountains, elevation 10,000 feet, July. Veronica Anagallis, L.-Near Ogden, Utah, Juue; Heart Lake, Sep tember; Téton River, July.

Veronica Americana, Schwein.-Near Brigham City, Utah, June.

Veronica alpina, L.-Trail Creel Mountains, September.

Veronica serpyllifolia, L.-Teton River, July.

Veronica peregrina, L.-Téton River, July.

Castilleia linariafolia, Benth.-Divide between Marsh and Malade

Valleys, June.

Castilleia affinis, Hook. and Arn.-Malade Valles, Idaho, June.

Castilleia affinis, Hook. and Arn., var. minor, Gray.-Mountaius along

the Yellowstone, elevation 6,400 feet, July.

Castilleia parriflora, Bong.-Divide between March and Malade Val-

leys, June.

Castılleia pallida, Kunth.-Ogden Cañon, Utah, June; Téton Moun

tains, clevation 10,000 feet, July. The red variety was also found.

Castilleia flara, S. Watson.-Ross Fork to Fort Hall, Idaho, July; Téton Basin.

Orthocarpus Tolmiei, Hook. and Arn.-Suake River Valley, July; near

Fort Bridger, Wyouning, August. Dr. Joseph Leidy.

Orthocarpus luteus, Nutt.-Twin Buttes, on Henry's Fork of Snake River, July.

Cordylanthus ramosus, Nutt.-Téton foot-hills, August; Snake River

Valley, July.

Pedicularis Granlandica, Retz.-Henry's Fork of Snake River, August, in tlower; Shoshone Lake, September.

Pedicularis bracteosa, Benth.-Lower Falls of the Yellowstone, August; Trail River Mountains, September; Téton Mlountains, elevation 10,000 feet, July:

Pedicularis racemosa, Dougl.-Yellowstoue Lake, August; Téton Moun. tains, elevation 10,000 feet, July; Shoshone Lake, September.

Pedicularis Sulctica, Willd.( ( )-Téton Mountains, elevation 10,000 feet, July.

Pedicularis Parryi, Gray.-Uintah Mountains, Wyoming, August. Dr. Juseph Leidy. 


\section{VERBENACEX.}

Verbene hastata, L-Near Brigham Oity, Utab, June.

Verbena bracteosa, : Fichx.-Near Brigham City, Utah, June; Blackfoot River, Idaho, July.

LABIATE.

Mentha Canadensis, L.-From Ross Fork to Fort Hall, Idaho, July ; Henry's Fork of Snake River; Yellowstone Lake, Angust.

Mentha Canadensis, L., var. glabrata, Benth.-Henry's Fork of Snake River, August.

Lycopus Virginicus, L., var.-Lower Fire-Hole Basin, August. Lophanthus urticafolius, Benth.-Near Ogden, Utah, June. Dracocephalum parviflorum, D. C.-Weber River, Utah, June; Snake River Valley, July.

Physostegia parciflora, Nutt. (Gray, in Proc. Am. Acad. May, 187\%, p. 371.) (Dracocephalum variegatum, Ventenat.)-Suake River Valley, July.

Brunella vulgaris, L.-Swamp near Ogden, Utah, June; Henry's Fork of Suake River, A'gnst; Téton Basin, July.

Scutellaria resinosa, Torr.-Near Ogden, Utah, June.

Scutellaria galericulata, L.-Henry's Fork of Snake River, August.

Marrubium vulgare, L.- Near Ogden, Utah, June 18.

Stachys palustris, L.-Near Brigham City, Utah, June 25; Suake

River Valley, July; Fort Ellis, Montana, Siugust.

Stachys palustris, L., var. aspera, Gray.-Weber River, Utah, June 19

Monarda fistulosa, L.-From Fort Eilis to Boteler's Rauch, Montaua, July.

\section{BORRAGINACEA.}

Lithospermum longiflorum, Spreng.-Omaha, Nebraska, May 18; foothills near Ogden, Utah, June.

Lithospermum pilosum, Nutt., (L. ruderale, Dougl.) - Port Neuf Cañon, Idaho, July 2.

Mertensia Sibirica, Don.-Red Mountain, elevation 10,000 feet, Sep.

tember 11; Téton range, elevation 10,000 feet, July 24 .

Mertensia paniculata, Don.-Near Ugden, Utah, June.

Mertensia brevistyla, \& Watson.

239.)-Montensia brevistyla, S. Watson. (Clarence King's Rep., vol. v, p.

239.)-Mountains near Henry's Lake, Idaho, August; Trail Creek

Iountains, September.

Piptocalyx circumscissus, Torr.-Market Lake, Itaho, July.

Eritrichium rillosmm, D. C., var. aretioides, Hook.-Téton Mountains, elevation 12,000 feet, July.

Eritrichium augustifoliun, Torr.-Near Ogden, Utah, May; Snake

River Valley, July. Eritrichium Californicum, D. C.-Near Ogden, Utah, May ; Snake
River Valley, July.

Eritrichium glomeratum, 1. C.-Mystic Lake, near Fort Ellis, Mon. tana, July.

Eritrichium lciocarpum, S. Watson. (Clarence King's Rep., vol. v, p. 244.) (Krynitzkia leiocarpum, Fisch. and Meyer.) - Snake River Valley, July. A form was found at Ogden, Utah, that answers to $E$. muricula. tum, Torr., referred by Watson to $E$. leiocarpun. The nutlets are
plainly granulated.
Eritrichium crassisepalum, T. and G.-Mystic Lake, near Fort Ellis, Montana, July.

Echinospermum Redonoskii, Lehn., var, occidentale, S. Watson. (E. Kedocskii, Gray.)-Great Salt Lake, June 15.

Echinospermum deflexum, Lehm., var. floribundum, 8. Watson. (E. foribundum, Lehm.)-Little Cottonwood Cañon, Utah, June 21 ; Téton Iouitains, elevation 10,000 feet, July 24.

Coldenia Nuttallii, Hook. (Tiquilia brevifolia, Nutt. Bot. Mex. Bound., 136.)-Market Lake, Idaho, July 15. On voleanic sand.

Myosotis sylvatica, Hoffm., var. alpestris, Koch.-Along the Yellow. stoue, July.

\section{HYDROPHYLLACE $E$.}

Hydrophyllum capitatum, Dongl., var. alpinum, S. Watson.-Téton Mountains, elevation 10,000 feet, July 24.

Nemophila parviflora, Dougl.-Along the Yellowstone, July.

Phacelia circinata, Jacq.-Ogden Cañon, Utah, June 6; Divide between Marsh and Malade Valleys, June 29; along the Yellowstone, elevation 6,400 feet, July; Trail Creek Mountains, Wyoming, September 14. Phacelia Menziesii, Torr.-Near Ogden, Utah, May 2s; Mystic Lake, near Fort Ellis, Montana, July.

Phacelia sericea, Gray.-Upper Téton Cañon, July 28; Red Mountain, elevation 9,600 feet, September 11.

Phacelia sericed, Gray,-A dwarf alpine form was found on the mountaius around Henry's Lake, Idaho, August 9.

Phaceliu Iresiana, Torr. (Ives's Col. Exped., Bot. Rep., 21.)-Twin Buttes on Henry's Fork of Snake River, July 16 ; Market Lake, Idaho, on voleanic sand.

\section{POLEMONIACEX.}

Phlox canescens, T. and G.-Téton Mountains, elevation 12,000 feet, July.

Phlox caspitosa, Nutt., var, rigida, Gray. (Near P. Douglasii, Hook.) - Malade Valley, Utah, June; Trail-Creek Mountains, Wyoming, Sep. tember.

Phlox caspitosa, Nutt., var, condensata, Gray. (Proc. Am. Acad., vol. viii, p. 254.)-Trail Creek: Mountains, September.

Phlox longifolia, Nutt.-Yellowstone River, July; Fall River, Idaho; Market Lake; Fort Hall; several forms were found. Fort Ellis, Montana.

Phlox longifolia, Nutt., var. brevifolia, Gray.-Trail River Mountains, September.

Collomia grandiflora, Dougl.-Near Ogden, Utah, June.

Collomia linearis, Nutt.-Near Ogden. Utah, June; foothills of the Téton Range, July,

Collomia linearis, Nutt., var. subulata, Gray.-Foot-hills of the Téton Mountains, August.

Collomia tenella, Gray,-Near Ogden, Utab, June.

Gilia liniflora, Benth., var., pharnaceoides, Gray. (Proc. Am. Acad., rol. viii, p. 263.)-Fort Ellis, Sontana, July.

Gilia pusilla, Benth.-Fort Ellis, Montana, July.

Gilia pungens, Benth.-Plains near Ogden, Utab, June.

Gilia pungens, Benth., var. squarrosa, Gray.-Along the Yellowstone, eleration 6,200 feet, September; Snake River Valley, July. 
Gilia intertexta, Stend-Foot-hills of the Taton Mountains, August. Gilia floccosa, Gray.-Snake River Valley, July; Market Lake, Idaho. Gilia congesta, Hook., var. crebrifolia, Gray,-Snake River Valley, July; Twin Buttes on Henry's Fork of Suake River.

Gilia aggregata, Spreng.-Near Ogden, Utah, May; $I$ ar River, June.

In the Teton Basin the form with white flowers was found.

Gilia leptomeria, Gray.-Snake River Valley, July.

Polemonium confertum, Gray.-Téton Mountains, elevation 12,000 feet,

July; monntains on Clark's Fork, Wyoning, elevaticn 9,000 feet.

Polemonium caruleum, L.-Heury's Fork of Suake River, August ; Lower Fire-Hole Basin.

Polemonium caruleum, L., var. foliosissimum, Gray.-Yellowstone Lake, August.

\section{CONVOLVULACER.}

Calystegia sepium, L.-Malade Valley, ldaho, June.

Cuscuta _- (f)-The specimen found was too young to determine anything as to its species. It was growing on Oxytropis Lamberti, Henry's Fork of Suake River.

SOI ANACEA.

Solanum triflorum, Nutt.-Uintah Mountaius, Wyoming, August. Dr. Joseph Leidy.

Nicotiana attenutat, Torr.-Market Lake, Idaho, July.

GENTIANACEA.

Gentiana Amarella, L.-Henry's Lake, Idaho, Angust; Heart Lake, Wyowing, September.

Gentiana detonsa, Fries.-Henrs's Fork of Suake River, August. This species oceurred in the Fire.Hole Basins in great abundance, but with leaves and stems so black as to be scarcely recognizable. "The peinu. cles are shorter, and the lobes of the corolla more strongly lacerate fringed than usual. It approaches $G$. crinita, with which it is probably identical." Professor Porter.

Gentiana affinis, Smith.-Téton Basin, August; along the Yellowstene, elevation 6,400 feet; Henry's Fork of Snake River, August.

Gentiana simplex, Gray. (Pacif. R. R. Rep., vol. vi, p. 87, pl. 16.) "It accords well with the description and figure, except that the leaves are shorter and the lobes of the corolla rounded, very obtuse, and occasionally furvished at the base with a few smalt teeth." Professor Porter. Henry's Fork of Snake River, August.

Gentiana calycosa, Griesh., (in D. C., Prod. 9, p. 115, and Hooker's Fl. Bor. Am. 2, p. 48, t. 146.)-Téton Cañon, 10,000 feet altitude, “ It varies from the typical form in its shorter calyx and calyx-lobes, and the srooth edges of its thinnish leaves." Professor Porter.

Frasera speciosa, Dougl.-Téton Caũon, July; Suake River Valley.

Sucertia perennis, L.-Uintah Mountains, Wyoming, August. Dr Joseph Leidy.

Hesperochiron pumilus, Porter. (Villarsia pumila, Griesbach.)-Near Ogden, Utah, June.

\section{APOCYNACE F.}

A pocynum androsamifolium, L.-Near Ogden, Utah, Jnne.

A pocynum cannabinum, L.-Divide between Marsh and Malade Vallers,

\section{ASCLEPIADACEX.}

Asclepias speciosa, Torr.-Port Neuf Cañon, Idaho, July; Snake River Valley

Acerates decumbens, Decaisne.-Hot springs ten miles from Ogden, Utah, June.

NYCTAGINACEA.

Abronia fragrans, Nutt.-Foot-hills near Ogden, Utah, June. Two or three specios of Abronia were collected but unfortunately lost.

\section{CHENOPODLACE.}

Chenopodium album, L.-Port Neuf Cañon, Idaho, July; Twin Buttes on Henry's Fork of Suake River. Common everywhere on the route. Chenopodium album, L., var. leptophyllum, Moq.-Snake River Valley, July.

Chenopodium album, L., var. "Near the var. integrifolium, Ledeb." Professor Porter.-Yellowstone Lake, August.

Chenopodium hybridum, L.-Henry's Fork of Snake River, July; Yel. lowstone Lake, $\Lambda$ ugust.

Blitum capitatum, L.-Henry's Fork of Snake River, August; Téton Basin, July.

Blitum polymorphum, C. E. Meyer, var. humile, Moq.-Near Great Balt

Lake, Utah, June.

Monolepis chenopodioides, Moq. (Blitum Nuttallianum, R. and S.)-Téton Basin, July.

Obione canescens, Moq.-Great Salt Lake, Utah, June; Blackfoot River,

Ilaho, July ; Port Neuf Cañon; Marsh Valley

Obione confertifolia, Torr.-Great Salt Lake, Utah, June.

Obione argentea, Moq.-Great Salt Lake, Utah, June; Snake River

Valley, July.

Grayia polygaloides, Hook. and Arn.-Snake River Plains, July.

Eurotia icnata, Moq.-Near Great Salt Lake, Utah, June; Snake

River Plains, Jnly. "Known as 'white sage' and 'winter fat.' Is

valuable for fattening stock." Watson.

Kochia prostr sta, Shrad.-Near Fort Bridger, Wyoming, August. Dr.

Joseph Leidy.

Salicornia herbacea, L.-Great Salt Lake, Utab, June; Lower Fire-Hole Basin, Angust.

Halostachys occidentalis, S. Watson, (Clarence King's. Rep., vol. v, p. 293.) - Near Great Salt Lake, June.

Sarcobatus vermiculatus, Torr. (Fremontia rermicularis, Torr. Frem. Rep.)-Black Buttes, Utah, June. Known as "grease-wood."

\section{A MARANTACEX.}

Amarantus albus, L.-Snake River Valley, July. "Remarkably red for the species." Professor Porter.

\section{POLYGONACEX.}

Eriogonum heracleoides, Nutt,-Near Ogden, Utah, June; along the Yellowstone, elevation 6,200 feet, August; Snake River Valley, July. Eriogonum umbellatum, Torr.-Near Ogden, Utai,, June. 
Eriogonum (Heterosepala) ovalifolium, Nutt.-Near Ogden, Utah, May; Lower Fire-Hole Basin, August; Snake River Valley, July.

Eriogonum ovalifolium, Nutt., var. tenuis, Benth.-Near Bozeman, Montana, elevation 6,400 feet, July.

Eriogonum (Capitata) Kingii, T. and G.-Mountains near Henry's Lake, Idaho, August.

Eriogonum microthecum, Nutt.-Port Nenf Cañon, Idaho, July ; Snake River Valley.

Eriogonum brevicaule, Nutt.-Near Fort Bridger, Wyoming, August. Dr. Joseph Leidy.

Eriogonum cernuum, Nutt., var. tenue, T. and G.-Snake River Valley, July.

Ëriogonum flavum, Nutt.-Snake River Plains, August; Lower FireHole Basin.

Eriogonum salsuginosum, Hook.-Fort Bridger, Wyoming, August, Dr. Joseph Leidy.

Oxytheca dendroidea, Nutt.-Grows in great abundance in Suake River Valley, July.

Oxyria digyna, Campd.-Near Henry's Lake, Idaho, Angust; Téton Mountains, elevation 12,000 feet, July; Trail Creek Mountains, Wyorning, September; common on all the mountain-tops in the Suake River region.

Rumex renosus, Pursh.-Snake River Valley, July 14; Black Buttes,

Utah, June 16.

Rumex longifolias, D. C.-Near Brighain City, Utah, June 25.

Rumex salicifolius, Weinm.-Near Ogden, Utah, June 7; Téton Basin, July 21.

Rumex maritimus, L.-Henry's Lake, Idaho, August 8.

Rumex (Acetosa) paucifolius, Nutt.-Snake River Valley, August.

Polygonum aviculare, L.-Near Ogden, Utah, June; Henry's Lake, Idaho, $A$ ugust 8 .

Polygonum aviculare, L., var. latifolium, S. Watson, (Cl. King's Rep., vol. v, p. 315.)-Snake River Valles, July.

Polygonum aviculare, L., var. erectum, Roth.-Weber River, Utah, June 19.

Polygonum tenue, Michx.-Téton Basin, August 2; Snake River Val ley, July.

Poiyzonum teжue, Michx., var. latifolium, Engelm.-Snake River Val ley, Angust.

Polygonum amphibium, L.-Henry's Fork of Snake River, August 5. Polygonum amphibium, L., var. aquaticum, Willd.-Divide between Marsh and Malade Valleys, June 29.

Polygonum amphibium, L., var. terrestre, Willd.-Madison Cañon, ingust 10; near Red Mountain, Wyoming, September 12.

Polygonum Persicaria, L.-Near Brigham City, Utah, June 25. Very probably introduced.

Polygonum viciparum, L.-Fire-Hole River, Angust 10.

Polygonum Bistorta, L., rar.oblongifolium, Meisn.-Upper Téton Caũon, July 28; Henry's Fork of Snake River, August; Trail Creek Mountains, Wyoming, September 13.

Polygonum Bistorta, L., var. linearifolium, S. Watson, (Cl. King's Rep., vol. v, p. 317.)-Mountains near Henry's Lake, Idalso, Angust 9; Red Mountain, Wyoming, elevation 10,000 feet, September 11.

\section{ELEAGNACEX.}

Shepherdia Canadensis, Nutt.-Téton Basin, July 21.

Shepherdia argentea, Pursh.-Near Fort Bridger, Wyoming, Angust. Dr. Joseph Leidy.

SANTALACEE.

Commandra pallida, D. C., (Prodr. 14, 636.)-Téton Basin, July 21. LORANTHACEE.

Arceuthobium Americanum, Nutt., in Herb. Durand. Fonnd growing on Pinus contorta.-Henry's Fork of Snake River, August 5; along the Yellowstone. (See Cat., Hayden's Rep. for 1871.)

CERATOPHYLLACEA.

Ceratophyllum demersum, L. (?)-Henry's Fork of Snake River, Au. gust 6.

CALLitrichaces.

Callitriche verna, L.-Henry's Fork of Snake River, August 6. EUPHORBIAE.E.

Ëuphorbia dictyosperma, Fisch. and Meyer.-Plains near Ogden, Ũtah, Jume.

Euphorbia serpyll:rolia, Pers.-Near Ogden, Utah, June 16; Lower Fire Hole Basin, August; Snake Rirer Valley, July.

URTICACE.E.

Urtica gracilis, Ait.-Weber River, Utah, June.

Urtica dioica, L., var. occidentalis, S. Watson. (Clarence King's Rep., vol. v, p. 321.) - Foot hills of the Teton Mountains, August.

Parietaria Pennsylcanica, Mubl.-Blackfoot River, Idaho, July.

BETULACEX.

Betuia occidentalis, Hook.-Port Neuf Cañon, Idaho, July. Betula glandulo:a, Michx.-Upper Cañon of the Madison, August. Alnus incana, Willd.-Téton foot-hills, July.

\section{SALIOACEF.}

Salix longifolia, Muhl-_Henry's Fork of Snake River, July; divic between Marsh and Malade Valleys, June; foot-hills of Téton Moun tains, August.

Salix nigra, Marsh, var. amygdaloides, Anders.-Plains near Ogden, Utab, June; Port Neuf Cañon, Idaho, July; Téton Basin.

Salix cordata, Muhl.-Near Ogden, Utah, June.

Salix cordata, Muhl., var. augustata, Ahders.-Snake River Vulley, August.

Salix Barrattiana, Hook.-"With ovaries nearly smooth!" Professor Porter. Along streams in Téton Basin, July. 
Salix glauca, L.-Swamp on Henry's Fork of Snake River, August ; Upper Cañon of the Madison.

Salix glauca, L., var. pullata, Anders,-Upper Téton Cañon, July ; Red Mountain, Wyoming, September.

Salix arctica, R. Br.-Snake River Valley, Angust ; Téton Mountains, elevation 12,000 feet, July.

Salix arctica, R. Br., var. Bronenii Anders.-Téton Mountains, eleva. tion 12,000 feet, July.

Salix reticulata, L.-Téton Mountains, elevation 12,000 feet, July; mountains near Ogden, Utah, elevation 10,000 feet, June.

Populus tremuloides, Michx.-Téton foot-hills. Common everywhere in the West on foot-hills and following the courses of streams. It is known as "quaking asp."

Populus balsamifera, L., var. angustifolia, S. Watson, ( $P$. angustifolia, James.-Along the streams of the Teton Basin, July $\%$; common every where in the Northwest, in the lower altitudes; known as "bitter cot tonwood."

CONIFERT.

Pinus contorta, Dougl.--Henry's Lake, Idaho, on mountains, Au. gust 5 .

Pinus contorta, Dongl., var. latifolia, Engelm. (Red Pine.)-Mount. ains along Henry's Fork of Snake River, August 5; Lower Fire Hole Basin, August.

Pinus ponderosa, Dougl. (Yellor Pine.)-Téton Range, elevation 6-8, (400 feet, July 22.

Pinus flexilis, James,-Mountains near Henry's Lake, August 9; Téton Mountains, elevation $i-11,000$ feet, Juls 24.

Abies Engelmanni, Parry, (White Pinc.)-Thton Mountains, elevatinn 7-9,000 feet, .July 24

Abies Menziesii, Limil. (Balsam.) - Grand Cañon of the Yeilowstone, elevation $7-8,000$ feet, Angust 22 .

Alvies amabilis, Forbes,(f)-Teton Kange, elesation 8-10,000 feet, July 26.

Abies grandis, Lindl. (White Spruce.)-Mountains near Ogden, Utah. elevation 7-9.000, June 13; Trail River Moutatins, Wyoming, ele. vation 6-9,00i feet, Soptember 13.

Abies Douglaxii, Lindl. (Stramp Pine.)-Mountains near Ogden, Utah. elevation $7-9,000$ feet, June 8 ; Téton Mountains, elevation $7-10,000$ feet, July 24.

Juniperus comvi unis, L., var, alpinn, L._-Mountaias near Ogden, Utah, Jume 11, elevation 9-10,000 feet : Lower Fire. Hole Basin, August.

Juniperus Virginiuna, L. (Red Cedar.)-Mountains along Henry"s Fork of Snake River, 6-7,000 feet altitude.

Juniperus recidentalis, Hook.-Mountains near Ogilen, Utah, elevation

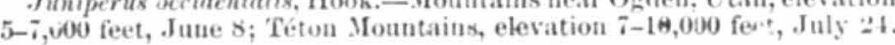

\section{LEMNACF:E.}

Lema trixulea, L-Common in the waters of Henry's Fork of Snake River, Angust; it also oceurs in great abundance apon the small streams in the two Geyser Basins.

Lemna polyrrhiza, L-In the waters of Heury's Fork of Snake River, August; Jackson's Lake, September.

\section{TYPHACEA.}

Typha latifolia, L.-Snake River Valley, July ; in swamps near Fort Hall, Idaho, in great abundance.

Sparganium simplex, Huds., var. androcladum, Engelm.-Weber River, Utah, June.

\section{NAIADACEA.}

Zannichellia palustris, L.-Yellowstone Lake, 1871.

Potamogeton perfoliatus, L., var. lancevlatus, Robbins.-Henry's Fork of Suake River, August 6.

Potamogeton pectinatus, L.-Upper Geyser Basin, August.

\section{ALISMACEA.}

Triglochin palustre, L.-1 ot Springs, ten miles from Ogden, Utah, June 24.

Trrachin maritimum, L_-Swamps near Ogden, Utah, June 18: Upper

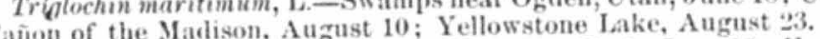

Cañon of the Madison, August Sagittaria variabitis, Engel

Fork of Snake liver, August. Marth Malade Valleys, June 29.

Sagittaria rariabilis, Engelm., var, dirersifolia, Gray.-Weber River, Utah, June 19.

\section{ORCHIDACEN.}

Habenaria hyperborea, R. Br.-Swamps near Ogden, Ctah, Jnne 7; Cpper Titon Cañon, July 28.

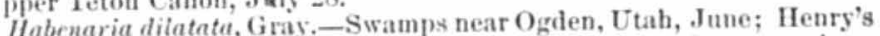
Fork of Snake River, August: Téton River, July. Common along

almost all the streams in the West. Triton River, July.

Spirathes Ros Valles, July; Téton Spiranthes Romanzojuma, Che Lasin; Shoshone Lake, September; Jackfoot-hills, A ugust; Fire. Iole Basin; Shoshone thake, Septe son's Lake. Common almost anywhere along the route.
Goodyera Ienziesii, Limdl.-East cañons of Téton Range, September. Epipactis gigantea, Dougl._Swamps wear Ogden, Utah, June.

Corallorhiza multiflora, Nutt.-Shoshone Lake, Wyouing, September.

IRIDACE.F.

Iris tenax, Dougl.-Téton Basin, July.

Tis teratho, June; Henry's Fork of Snake River, Angust.

\section{LILIACEA.}

Zygadcnus glauens, Nutt.-Upper Cañon of the Madison, August; Te on Cañon, July; Trail Creek Mountains, Wroning, elevation 10,000 feet, September. 
784 GEOLOTICAL STRVET OF THE TERRITORIES.

Zygadenux Nuttullii, Gr..-Ogden Cañon, Utah, June; Trail Creek Mountains, Wromiag. September.

Xerophyllum tenax, Dougl.-Fort Ellis, Montana, to the Yellowstone, July,

Veratrum album, L.-Foot-hills of the Téton Mountains, August; swaup near Ogden, Utah, June.

Prosartes trac'iycarpa, S. Watson.-Mountains near Ogden, Utah, June; Gallat in Cañon, September.

sereptopus amplerifolius, D. C.-Upper TCton Cañon, Juiy 24 Sichorall Cuñ 4 ; Teton Basin, July 21.

Canou wear Ogten, Utah, Stlata, Desf.-Year Ogden, Utah, May 31; Téton Mount ains, eleration 10-11,000 feet, July 24.

Fritillario atropurpurea, Sutt.-Mountains near Ogden, Vtah, eleva. tion 9,040 feet, June \&. In fruit.

Fritillaria pulict, Spreug._Mountains near Ogden, Utah, elevation

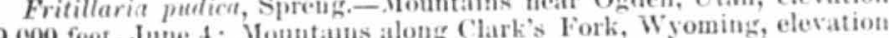
9,000 feet.

Calochortus Vuttallii, T, and G.-Dear Ggden. Vtah, May 31; Snake River Plains, July; Henry's Fork of Snake River, July 17. "The 'Sego' of the Utes and Mormons." Watson.

Calochertus entycarpus, S. Watson. (C. King's Rep., vol. v, p, 348.; Uechers slightiy fron

Henry's Fork of Snake Piver, August 5 ; thers Noutlalii, and the two are indistinguishable except in 11,500 feet, July;

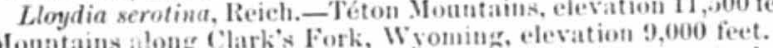

Ionstains atong Clark Fork, Pursh._- Yountains near Ogdes, Utab. elevation 9,000 feet, .June.

Camassia esculenta. Lindl-_Henry's Fork of Suake River, July. The

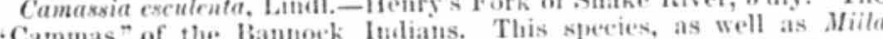
the form. grandiflora, are both known to the Tmlians as cam "Green Catmmas, the latter "Llue Cammas, from the color of the b!ossoms. The former is the one ased for food, while the latter is care fully avoided as being poisonous, although a large quantity must be eaten infore any serious effect can be noticed.

Willa Utah, June; Téton Cañon, July.

Allium brecistylum, S. Watson. (Clarence King's iep., vol. v, 1) 350.)- Epper Teton Cañon, July.

Allium bisceptrum, S. Watson, (loc. cit., 1. 351, pl. xxxvii.)-Ogden

Cañon, Čtah, June.

Allium stelletum, Fraser,_Snake River Valles, July.

Altium stellatum, Faseok.-Titon Basin, Inlv.

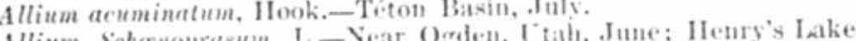
liabo, August.

JUXACE.

Juncus Balticus, Deth. var, montanux, Engreln.-Títon Cañon, July.

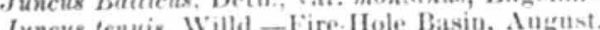

Juncus bufoniux, L.- Henry's Fork of Snabe Riser, July.

Juncus Mertensianus, Bong.-Uintah Mountains, W yoming, August.

Dr. Joscph Leidy.

Juncus riphioidex, E. Yeyer,-Yellowstone River, August.
GFOLOGICAL SURYZY OF THE TERRITORIYS.

CYRERACE.E.

Determined by S. T. Olney, Esq.

Cyurex inflerus, Muhl._Near Ogden, Utah, June 16.

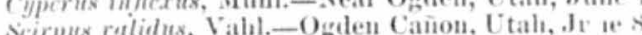

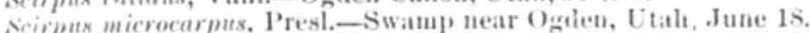

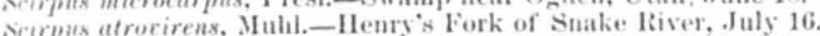

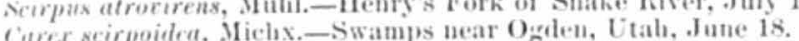

Cirex tisticha, Hudson._Swamps near Ogden, Utah, June 16.

Carer Mouglasii, Boott.-Male. Divide between Marsh and Malade

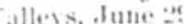

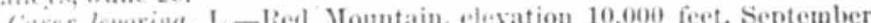

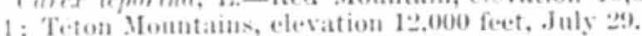

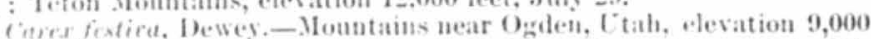
4. Jus: Twin Buttes, on Ilenry Fork of Snake liver, July 16 ; all laiver, ledain, July 20; Wooded Cañon, Treton liver, July 23; Téton

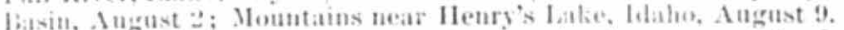

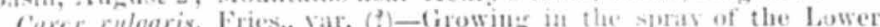
Fills of the Vellowstone. Anfust 2:-2.

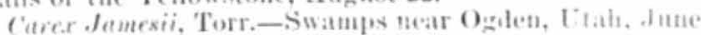

Cotex Jemesii, Torr. var. Neboskensix, Olney, (f'. Sebreskensis, Dewey, ('larence King's lRep., vol. v, p. 36t.) -Mahade Valley, Vtah, Jume.

Cacrlaciniale boott. - Intermediate l. ween the type and C. . Iamesii

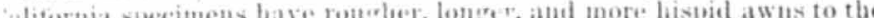

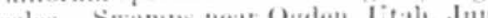
Carer rigita, Goot.-Terminal spikes-male. lied Mountain, Wyo.

ming, clevation 10,000 feet, septembet. Sule. River, July: Teten Basin,

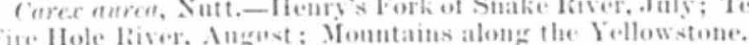

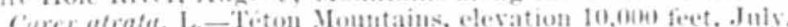

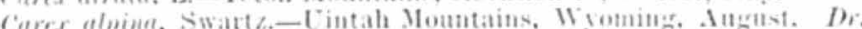
Jeseph Leidly

(arer nigut. All., C. atrata, var, nigra, Boott.)-Thiten Mountains, eleation 11 , (ino) thet, July.

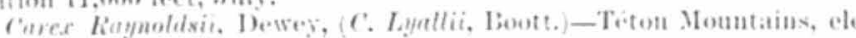

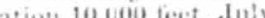

Gerca cupillarix, J-Eintah Mountains, Wyoming. August. Ir.Joseph

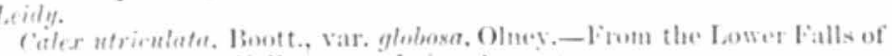
the Yellowstone to Yellewstohe Lake, Lugrist.

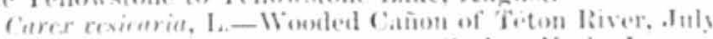

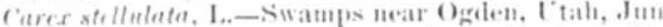

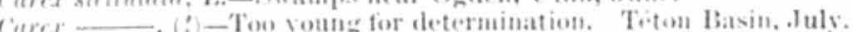

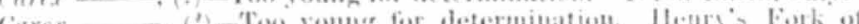

suake liver, July,

\section{GI:AMINACH.1.}

Deternined by l)e (ien, Viasey.

Iloperarus qlaneus, 1. (?)-Thiton foot hills, Angust; Snake River Ville.y, July

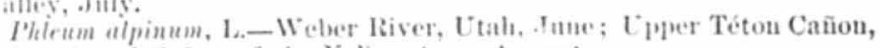
Iuls: Cirand Canon of the Yellowstone, Angust.

Vilfa cryptandra, Torr.,-Suate River Valley, July.

50 G $\mathrm{s}$ 
Vilfa airoides, Trin.-Gireat Salt Lake, June; hot springs, ten miles from Ogalen, Utah; Marsh Valley, Idaho.

Vilfa axperifolin, Xees. and Meyer.-Port Nenf Valley, Italıo, July common in loth Geyser liasins, Angust; Twin Buttes on Henry's Fork of Snake liver.

Vilfu depenproter. Torr.-Blackfoot River, Idaho, Inly: Henry's Fork

of Snake River: Upper Gerser Basin, Angust.

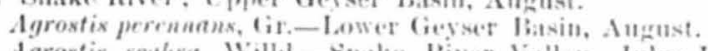

Agrostis sembra, Willel-Cuale River Valley, Inly; Lower Geyser Basin, August : lackson's Lake, september.

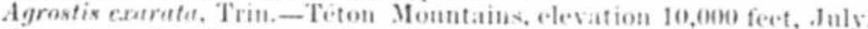

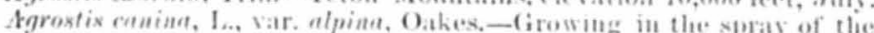
Giriud Falls of the Yellowstome. Auroust.

Cinna trumblimeren, I. - L nim Pase, Giallatin River, September.

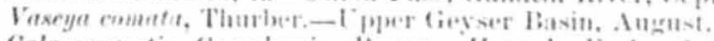

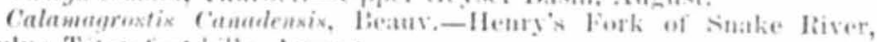

July; Teton fout hills, Angust.

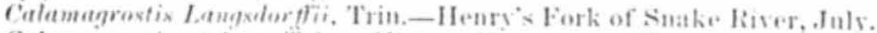

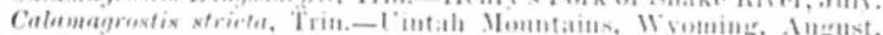

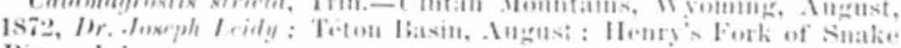
River, July.

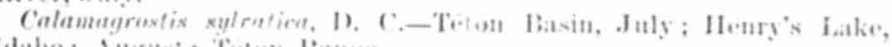
Idaho; Anzast ; Teton lianzer.

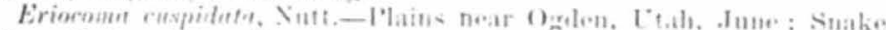

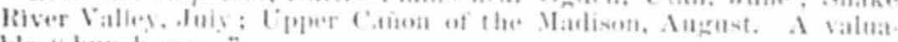

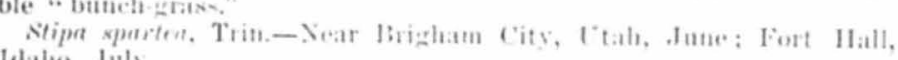

Stipa comatu, Trin._- Suake Itiver Ilans, Iuly.

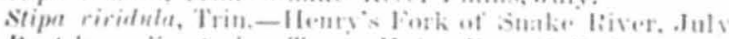

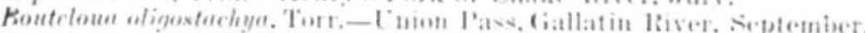

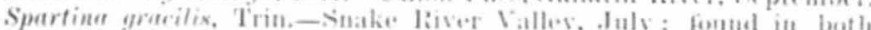
Giever liasins, In:mit.

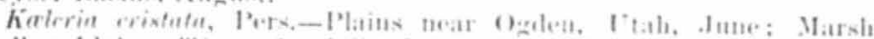

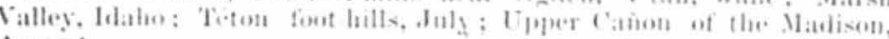

August.

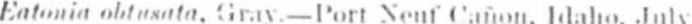

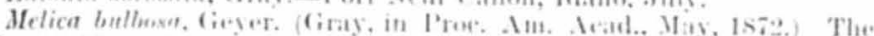

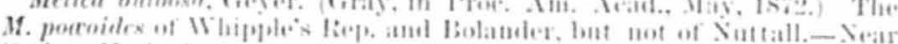

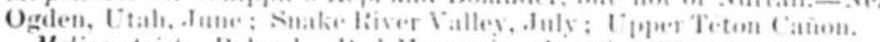

Melicat stricter. Beland. - lied Yountain, elevation 10,000 feet, Septem. ber

Glyceria nereme, Trim.-Port Venf Valley, Ldaho, July; Shoshone Lake, Siptemlur.

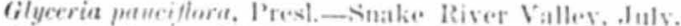

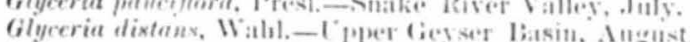

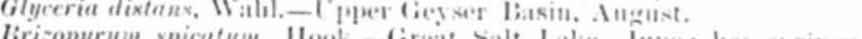

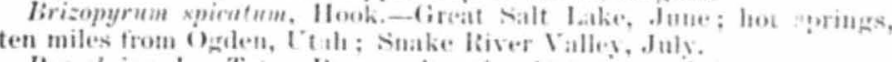

Poa nlpiun, 1.-Teion Ianze, elevation 10,060 fert, Iuly.

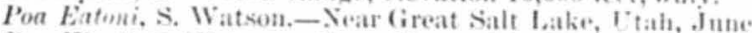

Poa Kingii, s. Watson._- Vear Great Salt Lathe, Utal,, Inte; Terou Range.

Pon tenuifolin, . Nutt.-Cintah Mountains, Wyoming, August, 1s:2. Dr.Joseph Leilly.

Atropis Californica, Munro.-Malade Valles, Utah, Jun,

Festuca tenella, Willd.-Plains near Ogden, Utah, June.
Festuca microstachys, Nutt.-Plaius near Ogden, Utah, June. Bromus breciaristatus, Tharber, (?) (Cerotochtert, Ilook.)-Marsh Val, fey, ldaho, Jume; Teton Basill, July.

Bromus ciliatus, $\mathrm{l}$.- V prer Canon of the Madison, Angust.

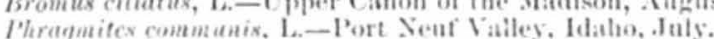

Triticum repens, L.-Port Xenf Cañon, Idalıo, July; Snake liver alley. It is koown as "l, lue joint," and is valuable for hay and graz. af. Fouthl also in the Lipher lievser Batsill, August.

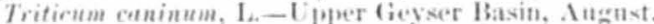

Tritienm strigosum, Stend.. (Bromus, Bieb., T. Atpilopoides, Turez.)Ti.ton baxin, July.

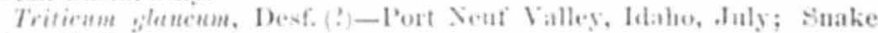
liver Valley.

Hordenm puxillum, Xutt.-Xar-h Valiey, ldaho, Inly: Suake River alle-1: loton foot-hills, dngust.

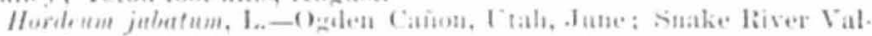

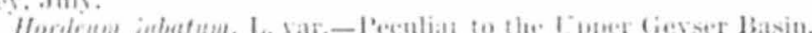

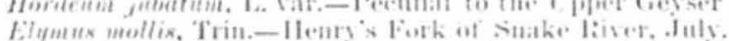

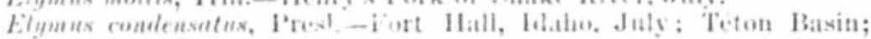

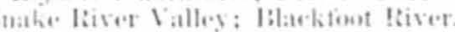

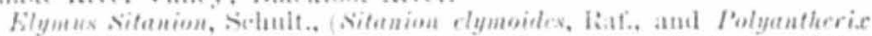

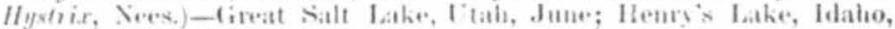

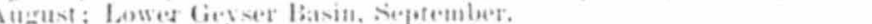

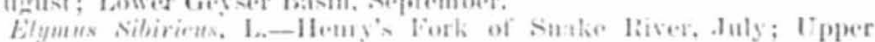
(ievser Jasin. Alleust.

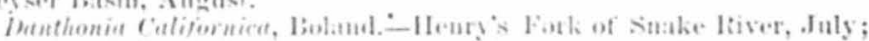
Titon foot hills, August.

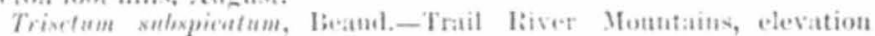

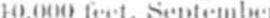

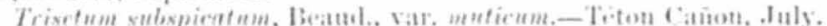

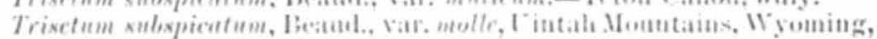
August, 15:2. Jr. Josrph Leidy.

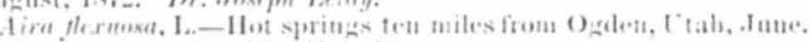
dira cerspitosa. L.-lire-1lole liser. Mugust.

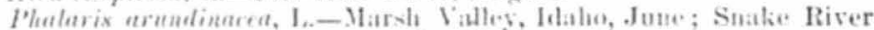

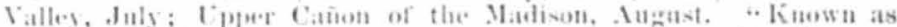

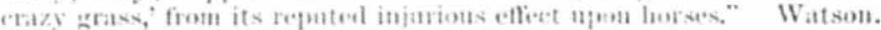
Prateme capillare, 1.- Vellowstone labe, Angust: very common in looth Geyser basins.

\section{NQTESTIFE.E.}

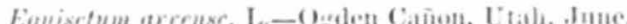

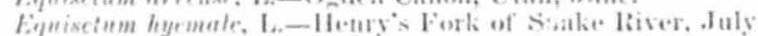
Eiquisetum protense, Ehr. - Ileny v Fork of Sinthe Riser, July

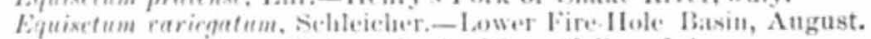
Equisetum reirquides, Miefıx._Suake River Valley, July.

$$
\text { F'..IC1:S. }
$$

I'teris aquilina, L. - Shoshone Lake, September; Upper Geyser Basin, Angust.

Peller Breceri, D. C. Faton,_Mountains near Ogden, Utah, June; Téton Range, Jnly.

Pellara densa, Hook,-Jackson's Iake, September 23. 
Cryptogramme acrostuthoiles, 1R. Br.-New Gevser Basin on Shoshone Like, September 6 .

Aspalimm Lowehilis, swartz.-C Pper Teton Canon, Jaly 2s.

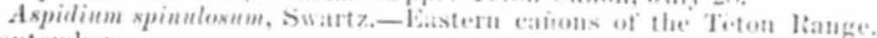
September.

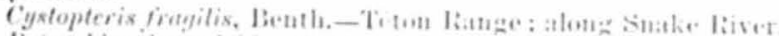

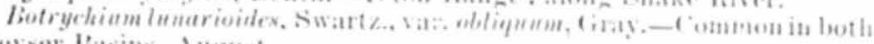
Geyser basins. Angual.

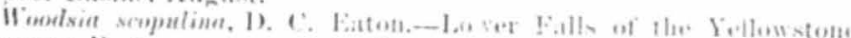

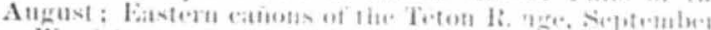

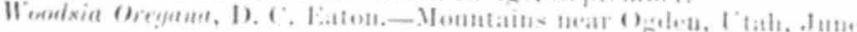

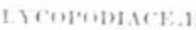

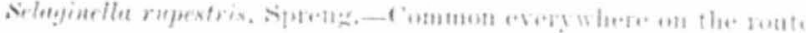

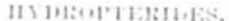

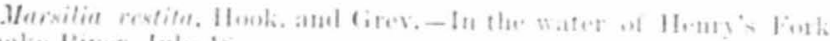
Suake litver, Iuls is

11: 1:11:1:1:

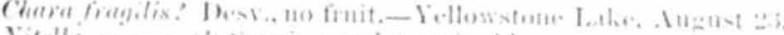

Mither

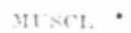

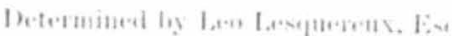

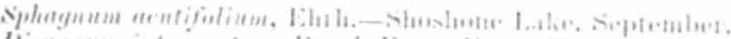

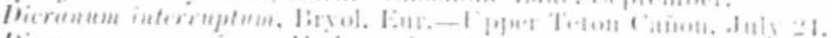

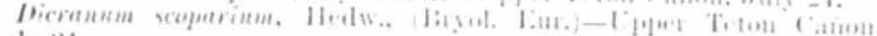

Inly 21 .

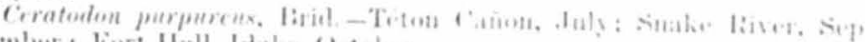

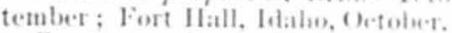

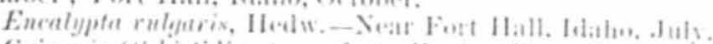

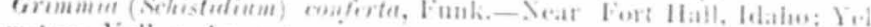

lowstone Valley, Inthast.

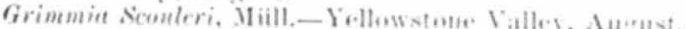

Grimmia calyptrato. Ileok.-Fort Ilall, Jalalio. Juis.

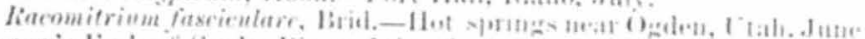

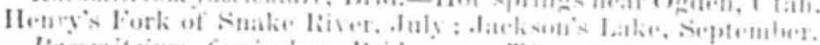

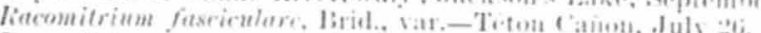

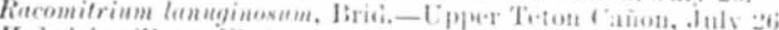

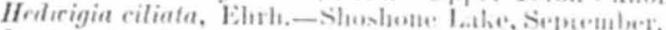

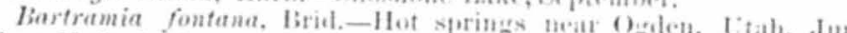

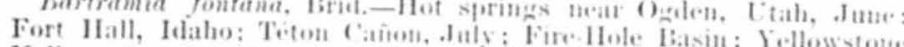

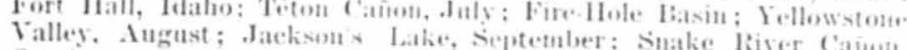
Valley,
Octolier.

Burtramia fontana, Brill, var,-Titon Cañon, . Inly 24.

Bryum pyriforme, Hedw.-Yellowstone lake, Duguxi :3.

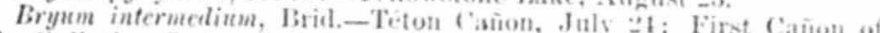
the Gallatin; Jackson's Lake, September.

Bryum bimum, Schreb.-First Cañon of the Gallatin, stetile; Fort Hall, Idaho, Iuly,
Bryum pscudo triquetrum, Bryol. Enr.-Shoshone Lake, September.

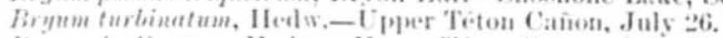

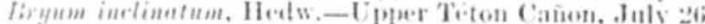

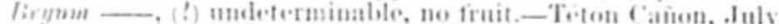

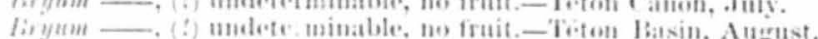

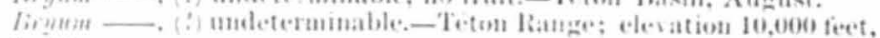

1.1. $\because 4$

Cirynm - (!) muleterminable, no fruit.-Teton Canon, July 26.

li, yum - , t? no truit.-Yellowstone. Valley, August 23.

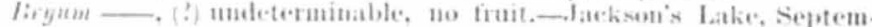

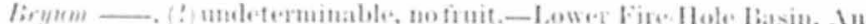

anst.

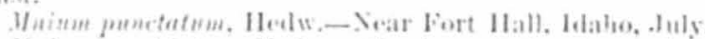

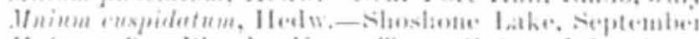

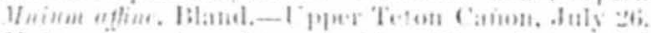

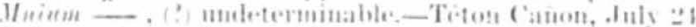

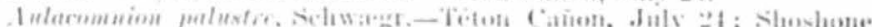

lakke. Septemule.

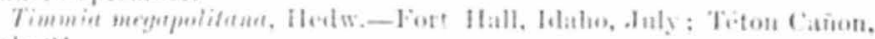
ali 21.

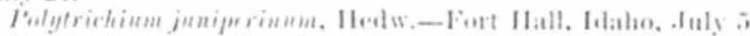
Fontinalis antipyetict. L. - Ilenry 's Fork of Snahe liver, July 16

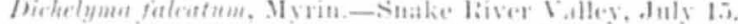

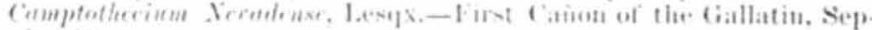
:.mber 18 .

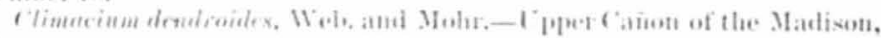
Angust.

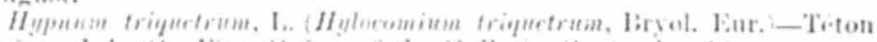

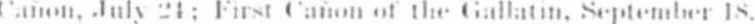

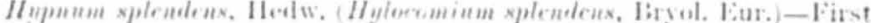

Canen of the Giallatiun siontember 10

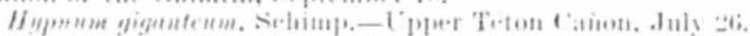

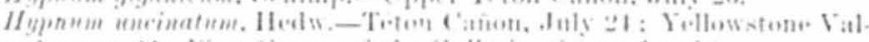

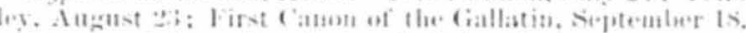

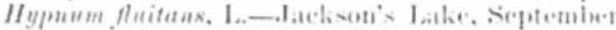

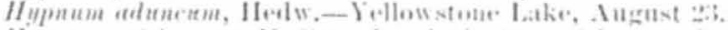

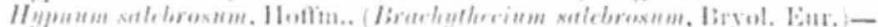

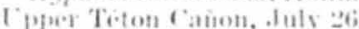

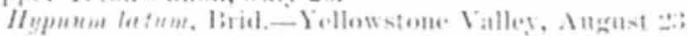

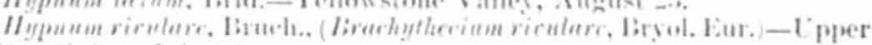
Titon Canon, Juls : 26.

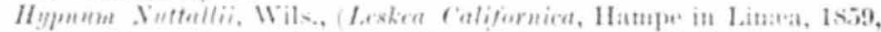

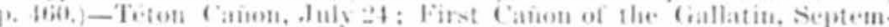
lier. $1 \mathrm{~s}$.

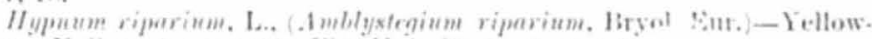
whe Valley. Angust 23; Fire-Hole Basin, September.

Hypum riperiam. I.. var._- Snake River Valles, July.

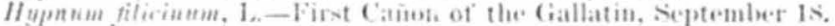

Mypun irrigum, Wils, var. fallex, Brid.-Vear Fort Ilall, Idaho, InI 1 .

HETATIC.

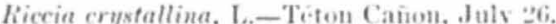

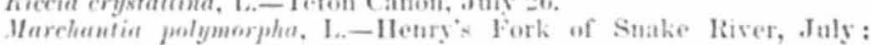
Slosbone Lake, reptember 6. 


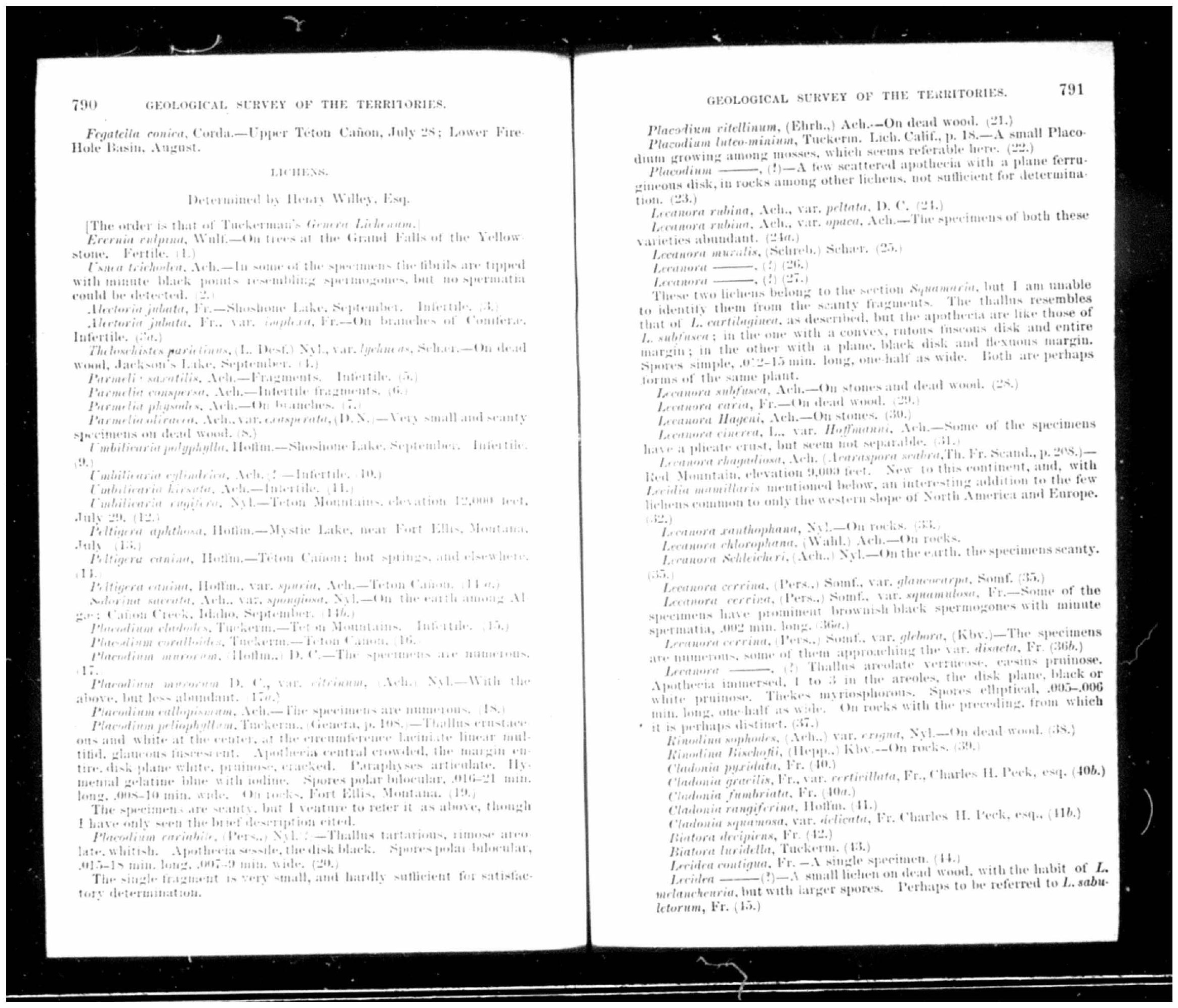


Lecidea spilota, Fr. - I single specimen. (46.)

Lecidea polyeurpa, Flk. A sin-le specimen. (4i.

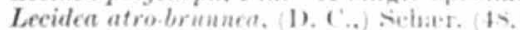

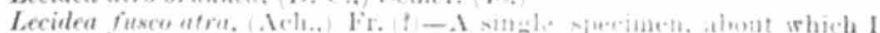
an not certain. (49.

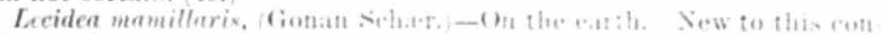
tinent. $(50$.

Lecider cotulexcenx, Anz, $A$ single frazument, it

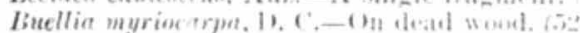

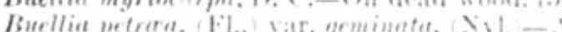

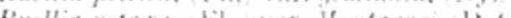

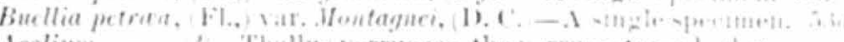

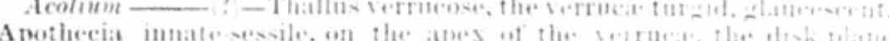

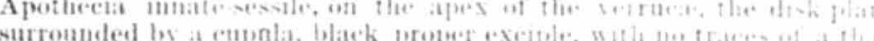

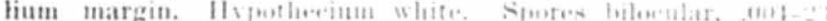

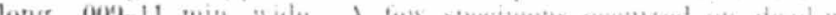

beriegs

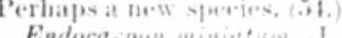

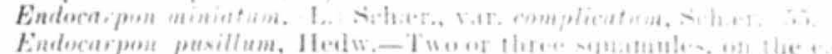
(iti.

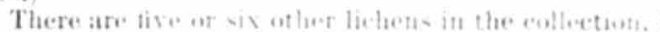

insuflicient for determanation.

$$
\text { Fixis. }
$$

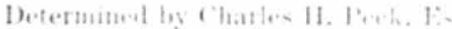

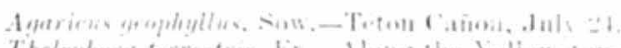

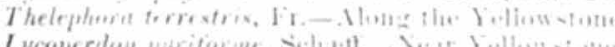

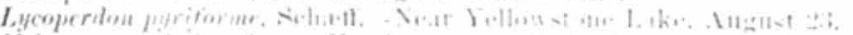

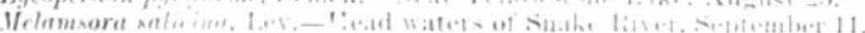

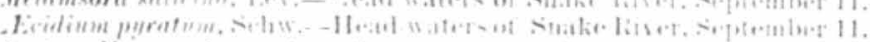

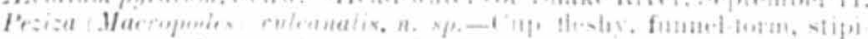

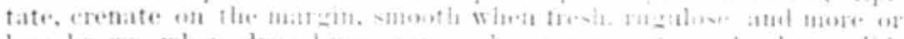

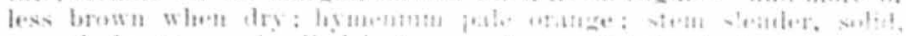

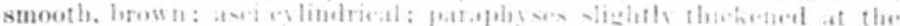

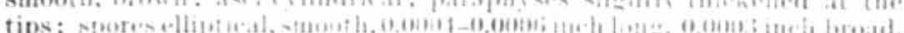

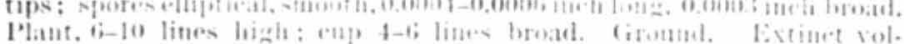

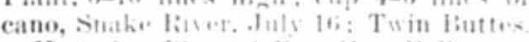

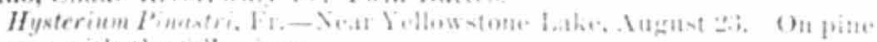

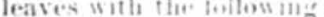

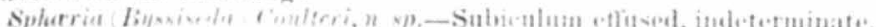

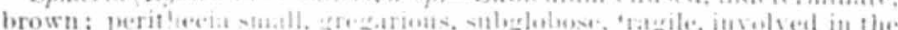

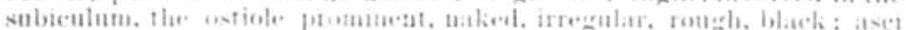

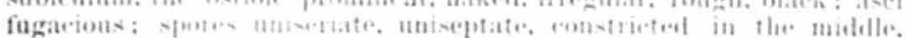
colored, 0.600

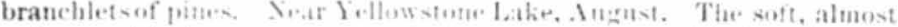

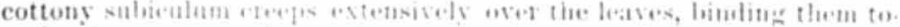

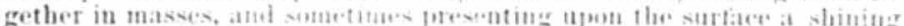

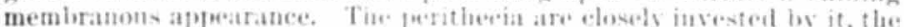
rather large ostoola atome protruding above it. Dedieated to its dis. coverer, J. M. Coulter.

Clecaria formesa, ['ors,-Tatison's Lake, Suptember.

Geaster hygronnetricue. I'ers.-. No locality.

$$
\text { MLA.E. }
$$

Zygneme funtane, (?)-Common in IJenry's Fork of Suake River. 


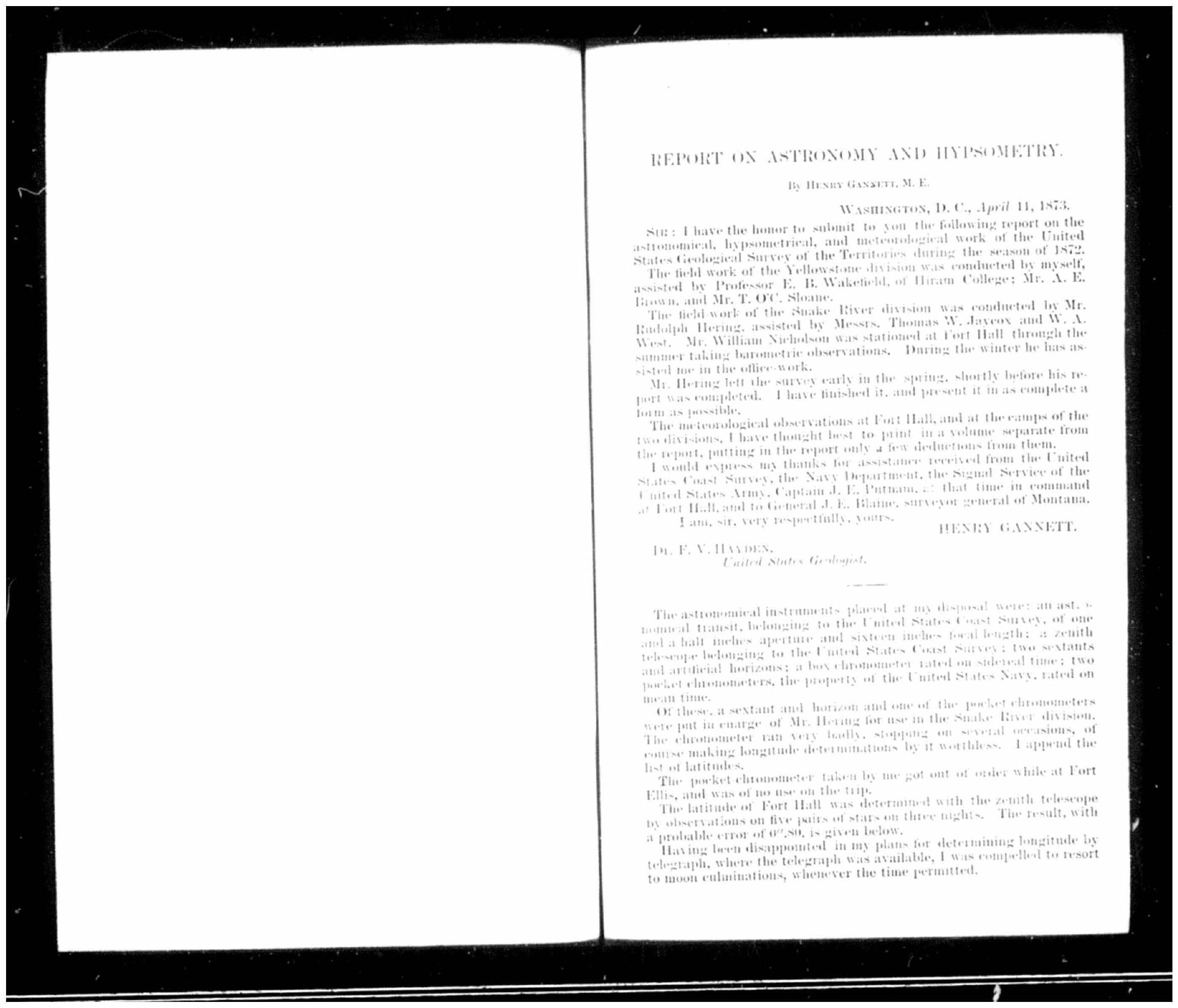


At Fort Hall I observed through one lunation, obtaning seven cul. min tions, which gave the rewalt submitted below, with a possible erro of 7.4 seconil.

The latitude of Fort Ellis, aud of all other stations besides Fort Hall, wats determined with the sextant, by observations on P'olarisand a south star, whenever possible, and on the sun whenever the movements of the" party permitted.

For the determination of the lengitale of Font Ellis, I selecented in obtaining only two moon colminations. I have atopted the longitnde. given by chronometer in preference.

The longitudes of the other stations in the list of astronemieal posi.

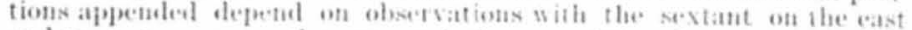

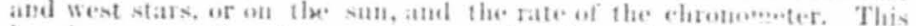

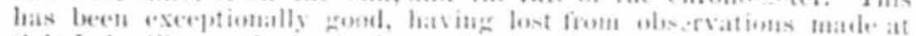

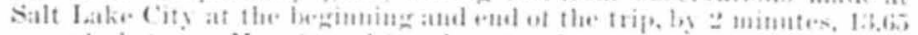

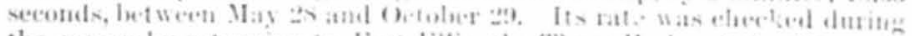

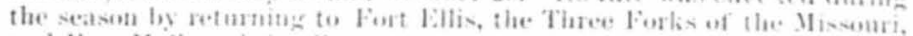

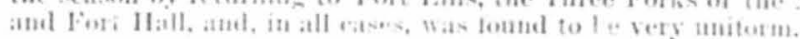

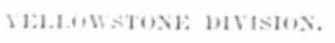

t.ist of axtrmemical poxitions.

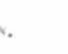

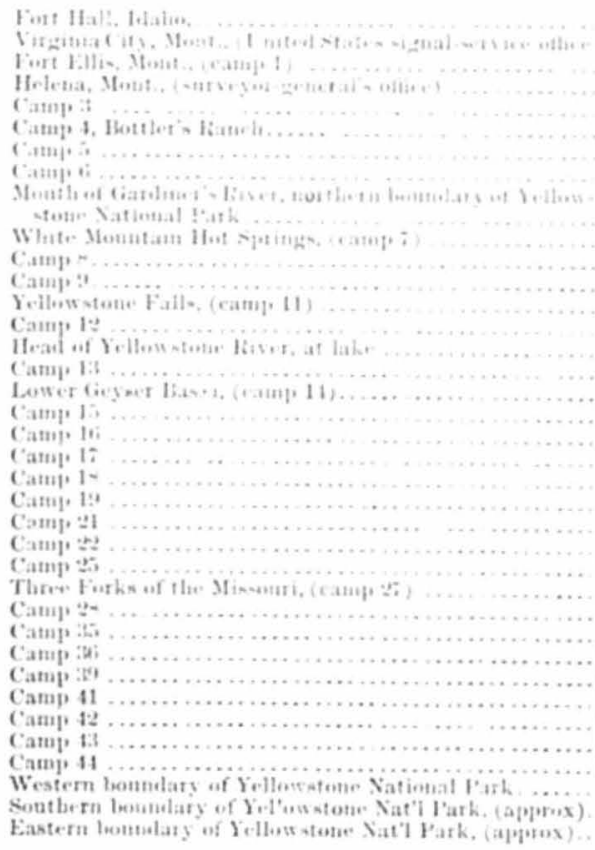

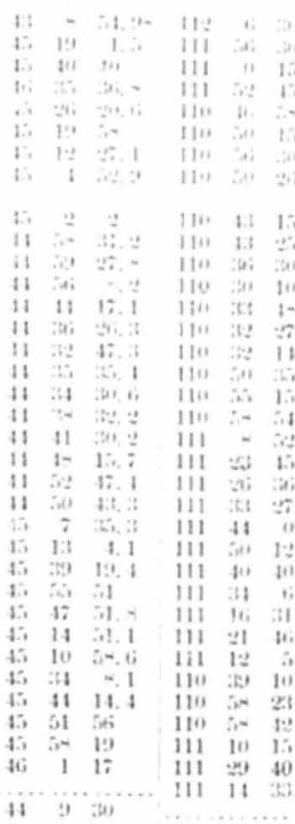

The magnetie variation was determined by observing the azunuth of Polatis with the gradienter, an instrument realing to minutus: the re

mlis are to be depenterl on to that dewree of precision. I appeme the 
much interest, I paid considerable attention to that posion of the route up Henry's Fork of the Suake River, over Raynold's Pass and down the Madison, a route which has recently begun to attract attention, over which we traveled; $i$. e. from the valley of Henry's Lake over lias. nold's Pass, and thence down the Madison Riser to the Three loorlis ot the Missouri. The route pursued by our train down the Madison, fiom the foot of the Middle. Canon, is by no means the easiest ronte. A rail. roid can follow elosely the bituk of the river with little expense trom this point to the head of the lower Canon at Meadow Creek.

The valley of IIenry"s Latie is broal and perfectly level, but very swampy mear the latke. A road coming un llemrs sork of the suate. would inake a sweep around the lake, keeping at a distance of about at mile from it on the e.st side. The sumnit of laynohl's l'ass ean be reateded by easy zrates of thot more than 60 feet per mole, witlum any eutting. The pass is vers broat, with perfectly smooth approateres on

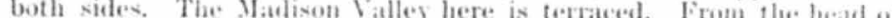

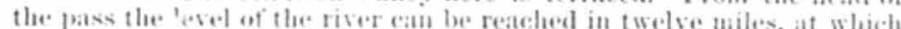
point the valley contracts by at atade not exereding 75 feet mer mile. The valhey is natrow for three to four miles, with several spurs crossim

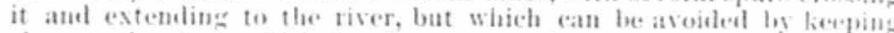
close to the river, which insolves some embankment. Below this the

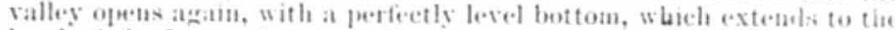

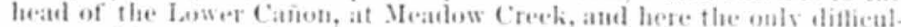
ties on this route will he met. The fall of the Machisen from the fout of the Midalle Canon to this point averages 2 ; feet per mile. The lower Canon is from information which 1 have gathered from reliable soures.

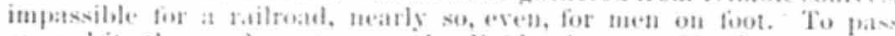

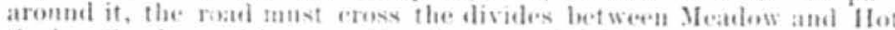

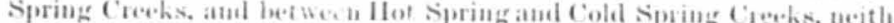
er of them high. hat, so far as I huew them, involving arades tom stere

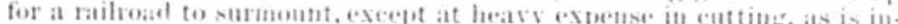
dieated in the elevations and distances on this route given below. The

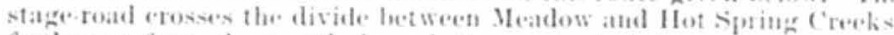
farther up from the mouth, by a better route, but I have llo data cous

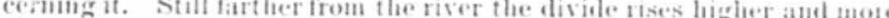
abruytly.

The elevation of Yellowstone Lake, ats well as that of seracral other points, ats determined by my observations this year, will be seen to ditler materially from that given in the report of the survey for $1 \times-1$. This diflerence ariees from the want of a barometric base for the work of 157 !, the observations being referted directly to the seaflevel. In the case of Yellowstone Lake, svnehronous observations were tabeh at lin. ler's Rauch, but they were not used as base obsersations. Makiure uxe of these, they give the same result that I obtain.

For the computation of elevations, finyot's tables have been used.

The elevations are given in feet above the level of the sea canless othervise indieated.

Cames of Fellocatome dirizion.

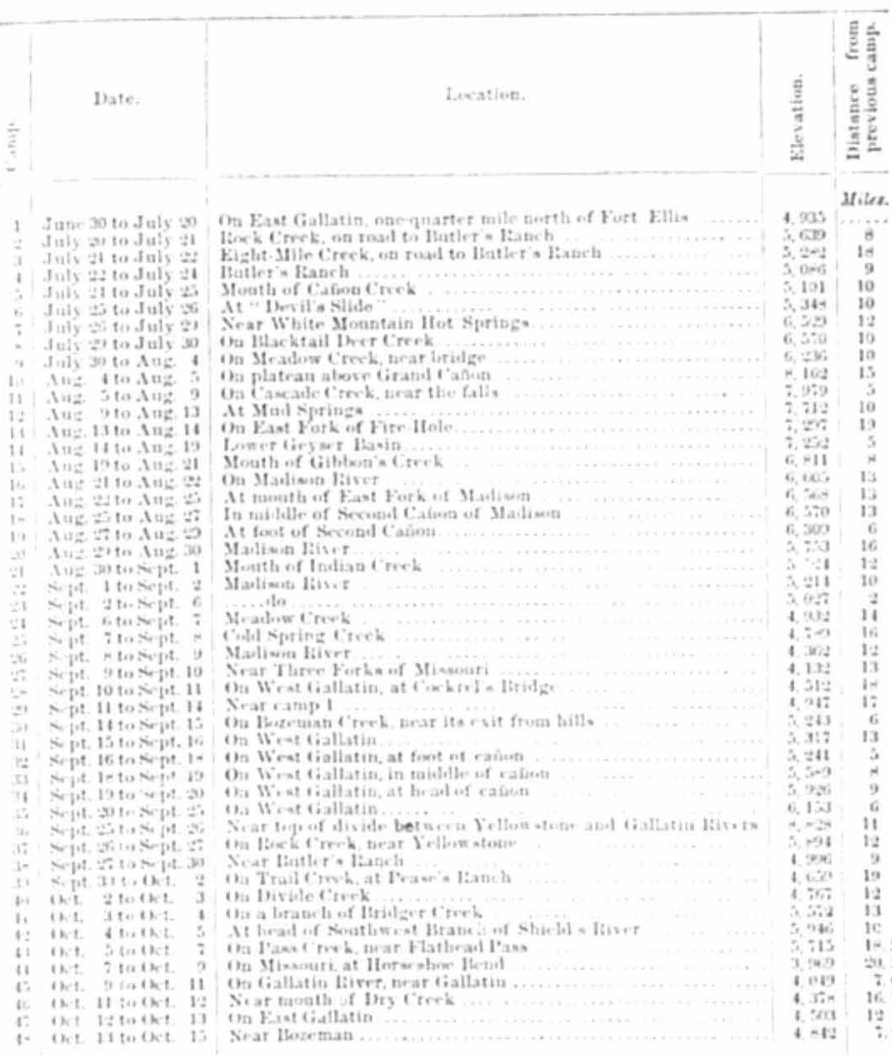

Heights of perks and dirides.

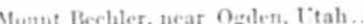

Yoant Patuan, near fort itall, Dlaho

Ariilizer's Peak

Mount Ellis.

Elect ric P'eak .......

Slomt Washlinm

Miberty Peak....

Oidl lhaldy, near Virginia Cit

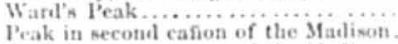

Peak in recont cafien of the Maliwon.

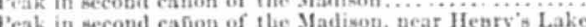


Heights of pealis and dirides-Continued.

Peak in secont canon of th. liellow stem.

Divile hetween the rellowntome and Gallatin, on lbannock tail ...

Ted Rock bus

Ty hliee Pass

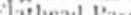

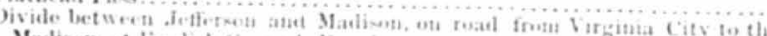

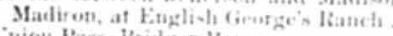

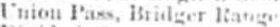

Bivide betwern Sellowetote and Gallatin livers, of toal from fort bili

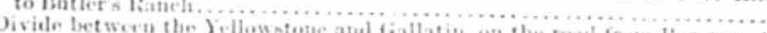

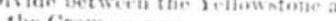
1)e Crow agene

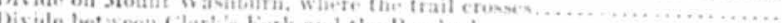

ble

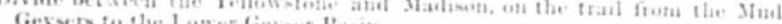

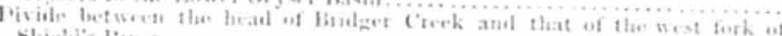

rellowatom i

Henty $\times 1 . a k+1$

Myotic: !.ik

On Thertre I'rok

Oa Grount Wa-1hmin

in Wart's in

(1) Yloust is:

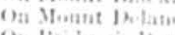

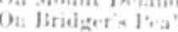

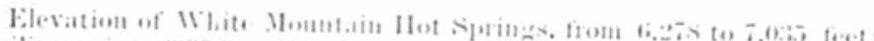

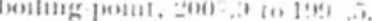

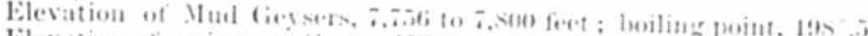

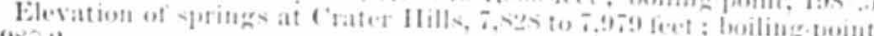
$19 \times 3.2$.

The Geyser basins are very tlat: the range of elevation in the atea ocemped in the shrings and gessers not exceeding lon fiet in each
basin.

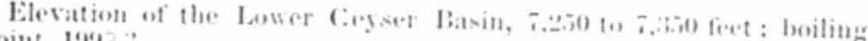
point, 19!?

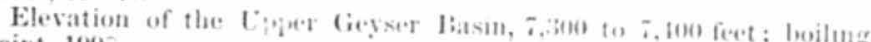
point, 199\%

Sulphur springs on the divide between the Fellowstone and Giallatin,

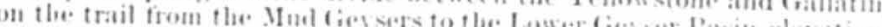

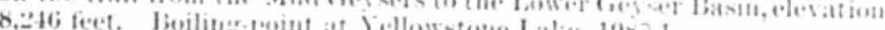

List of elerations on Yelloicstone Rirer.

At Yellows:one Lake.

At Bud liegsers........

it tey of upper fails

falls, 140 feet.

II.

tount of Tower Creek

it britlye, month of East fork.

Weath of Gareliner's liver

It "Pevils slite"

touth of Canon Creek

At liutier Ratich .........

At himat of comer

Elerations on the East Fork of the Fellowstone.

\begin{tabular}{|c|c|c|}
\hline $\begin{array}{l}\text { Stiles from } \\
\text { tuouth of } \\
\text { Shield's } \\
\text { River. }\end{array}$ & Elevation. & $\begin{array}{l}\text { Yall per } \\
\text { mile. }\end{array}$ \\
\hline$j 05.5$ & 7.794 & Ficet. \\
\hline 90.5 & $\begin{array}{l}7,705 \\
7,603\end{array}$ & $\begin{array}{r}13.3 \\
1.3\end{array}$ \\
\hline 90.0 & 7,455 & 136.0 \\
\hline$\pi, 0$ & 6,207 & 67.9 \\
\hline 74.0 & 5.978 & 76.3 \\
\hline$\therefore 4$. & 5,300 & 20.9 \\
\hline $4 \div 0$ & 5,160 & 33,3 \\
\hline$\therefore \rightarrow 0$ & 5,000 & 10.2 \\
\hline $2 \sim 0$ & $4,9 \times 5$ & 7.3 \\
\hline$\therefore 11$ & 4,643 & 17.1 \\
\hline
\end{tabular}

\begin{tabular}{|c|c|c|c|}
\hline & $\begin{array}{l}\text { Miles from } \\
\text { forkn. }\end{array}$ & Elevation. & $\begin{array}{l}\text { Fall per } \\
\text { mile. }\end{array}$ \\
\hline & & $5,9=6$ & Fiet. \\
\hline & & 6,206 & . \\
\hline $\begin{array}{l}a . . \\
a\end{array}$ & 6 & $6.4: 66$ & \\
\hline & $\therefore$ & 6,536 & 50 \\
\hline & 10 & $6,5-6$ & $\begin{array}{l}75 \\
\text { an) }\end{array}$ \\
\hline i. & 13 & $6,-206$ & 140 \\
\hline Herat of Muldie Branch of Fast Fork . & & 7.506 & \\
\hline
\end{tabular}

(a) Measuresl by ancroid.

List of elerations on the Mardison Ricer.

\begin{tabular}{|c|c|c|c|}
\hline & $\begin{array}{l}\text { Miles from } \\
\text { month. }\end{array}$ & Elevation. & $\begin{array}{l}\text { Fall per } \\
\text { mile. }\end{array}$ \\
\hline 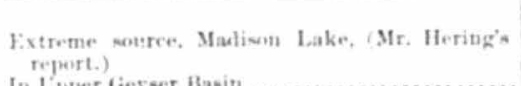 & 170 & -.301 & $\begin{array}{l}\text { Fet. } \\
\text { n......... }\end{array}$ \\
\hline 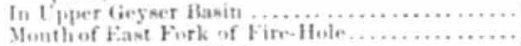 & $\begin{array}{ll}160 \\
14 \pi\end{array}$ & 5,357 & 93. 4 \\
\hline 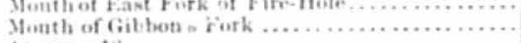 & $\begin{array}{l}14 \pi \\
142\end{array}$ & 7. 2.37 & 10,8 \\
\hline At ramp 16 ....................... & $1: 2$ & 6.604 & 15.7 \\
\hline It thouth of East Fork of Maulison... & 116 & 6,567 & \\
\hline In micitle of kecotid cafion............ & 103 & 6.344 & 16.8 \\
\hline Three miles above camp :20 & $i_{i=1}^{n 1}$ & 5,683 & 29.9 \\
\hline 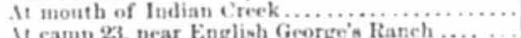 & 16 & $\begin{array}{l}5.494 \\
5,026\end{array}$ & $\begin{array}{l}13,3 \\
42.5\end{array}$ \\
\hline & 41 & $\begin{array}{l}3,026 \\
4,448\end{array}$ & 12.7 \\
\hline 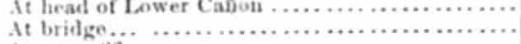 & 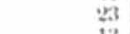 & 4,521 & 18.2 \\
\hline 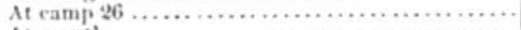 & 13 & 4,336 & 16.5 \\
\hline & & $4,1: 2$ & 17.5 \\
\hline
\end{tabular}

$$
31 \text { G } 8
$$


List of elecations on the Wist Gallatin Rirer.

Milex from Elevation. Fall per

- Tret.

At forkn of Weot Gallatim, near hroul lat itule t5

At camp si.

At camp its

At himile.

Youth.

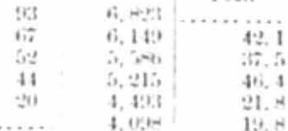

Mincellanemes clerationx on strenthx.

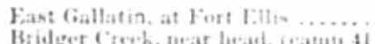

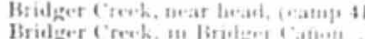

loass freek? at thet of

Cottonweral c

lozeman Cin

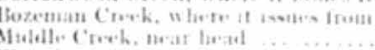

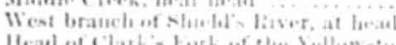

Heat of Clathin fork

Mleatit of

slosight

Hiciolit ot

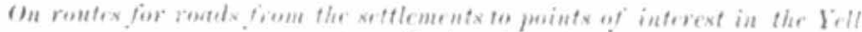
stone Ditimal Park.

The only rontes in nase at present are the Yellewstone and Madison

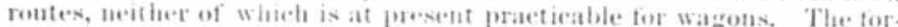

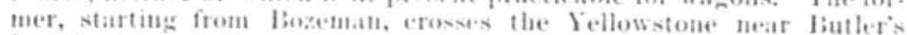

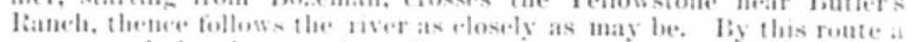
wagots-soad aldeaty estends to the mouth of Cañon Creek, which in the latter part of luly was ls inches deep and bo feet wide.

In the serout canon, the inountains which form the west wall come. down to the water's alge, very steep and ragged, and the pasage of it wath a watron-roat will involve considerable outley in blasting aud em. bankment. The east side is comparatuvely easy of passage, but this would involve throwing two bridges across the river, wheh is here, at the lowest stage of the wat.r, 500 feet in width. This eanon is about eight miles in lempth, three.fourths of which, however, present no rreat obstacle to a road. Above this canon the valles is level and open, with no timber as far as the fort of the thind eamon, at the mouth of Gardi.

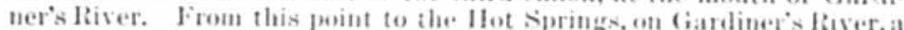
distance of about seven miles, it road can easily be mate, thongh it must cross two high spurs from sepulehre Yountain.

The trail up the Yellowstone croses Giardiner's River by a bridge, then

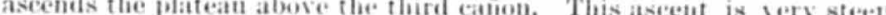
and a wagon road will require much wruding. On the top the platean is quite level, withent titnter. far as Cache Valley, near the thouth of Last Fork, to which it descends by easy arades. Thence it follows the river anite closely to Tower by easy grades. Thence it ills. The descent to the ereek Creek, wich it crosses just abore the falls. is extremeiy steep, and some better point of crossing must be dis.
cosered. The creek is in a canon most of its length, and in the begin. ning of August was about 18 inches deep and so feet in width.

From the mouth of Tower Creek, southward fur 15 miles, the Yellow. Tone is in the Grand Cañon, the numerons impassible cross-eañons of which require that the trail keep back at a considerable distauce from the ricer, passiug rouml to the west of the summit of Mosut Wash.

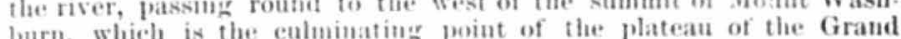
burn, which is the eulmmatme pont of the platean of the Grand reiching at its highest point nearly to the tumber line on the north side. Passiag rouml to the west site of the spur, the trail becomes very difficult from fallen timber, rock-slides, and strep side-hills.

From the top of the divide to the falls on the platean no difliculties

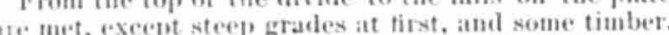

re met, except steep grades at first, ind some timber.

The crossing of Cascate. Creek, near the falls, involves, by the trail which we followed, erossing a deep, narrow canon, diflicult even for pack animals. I have no doubt that a better crossing can be found two or three miles farther up the ereek. Between this puint and Crater Hills are two sloughs, which extend several miles back from the river.

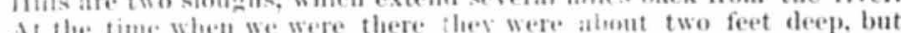
Arem there to Yellowstone lake there is no difliculty whatever, except from live timber.

We crosidal to the geyser basins from the mul geysers. For nine miles the trail led through an open country, mearly level. Thence to the tol of the divide we met with a tolerably heavy growth of timber. ()i hu whe of the divide the live timber is very dense, while the Con is thickly covered with fallen timber, making onr paxsage with The This condition of things extends for four or the train very diflient. This condition of things extends for four or Fire llole liver. The valles, as far as the mouth of the east fork, is Huite marshy in some places, but little difticulty will be foum in locat lio a harel road.

The

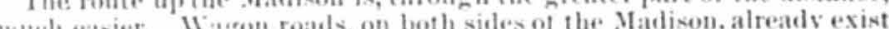

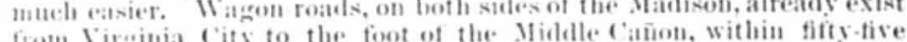
from Virginia City to the foot of the Middle Canon, within fifty-fise miles levold's Paxs, to Sawtelie's lanch, at Henry's Lake. The trail througli the Middle Cañon, and thence to the geyser basins, follews the uast side of the river. Wagons have been through this thllows the It the lueat ot this ane fork of the Madison, which, in the latter part of August, was a slug fisl, wimling stream about 200 feet wide and $2 \frac{d}{2}$ feet deep.

From the Niddle to the Upuer (anon the valley is broad, flat, and sliarsely timbered.

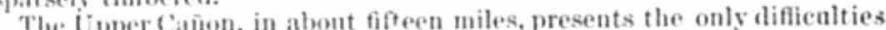

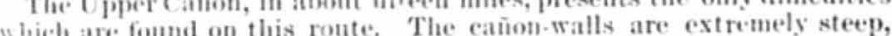
which are found on this ronte. The cainon-walls are cstreme step, III some places precipitous, and, much of the was, cotne close to the Fork, which enters the Madison in the midelle of the canon, must be

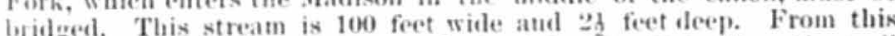
cone Hole River the trail is obliged to kepp baek from the river. It is very rongh, and badly obstructed by live and dead timber. 
To build a roal throngh this cañon, on this side of the river, will be expensive. The other side, here the south side, of the river appears much easier, and, if the Mildile Canon can be passed on that sile of the river, a route on that side, throughout the whole distance, is to be re commended. The road should then cross the Madison to tb north side, in the Upver Cañon, two or three miles below the month of Gibbon's Fork. There remaius on this route the upper part of the cañon to be passed, which, as stated above, presents some difficulties.

LISTS OF ELEVATIOSS AND DISTANCES ON nOUTRS TO TIL YEILOW STOSF NATIOSIL PARK.

Route from Bozeman to Felloiextone Latie, by icay of Yellowestone Rirer. Mite. H. Hesatwon,

Bozeman

arly level, with mooth prates to-

Fort tilli.

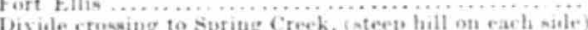

spritig Creek

Sterp lesent, then uniform slope up to-

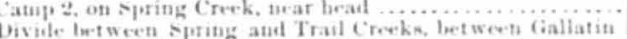
and Yellowntone

Liform siope to-

Trail Creek, at cromiti

Long rolling hills to-

Divide betweet Trail and Eight-Mile Creeks... mooth to-

Camp 3, on Eight-Mlile Creek. near Yellowstone ....

In level river bottom to-

Camp 5, at month of C a fints C ieck

cond Cafion of the lifllow stone liver:

smeoth to-

\section{Inifurm slope to-}

Heal of Nocutal f cuinuth

Camp 6, urar Deril's slit.

Gra'e nearly uniform in ruves lwotton to

Bridgo over Gardner's Liwe-s, tore its month....

Live to

Virry beavy grades to

Level to

\section{Grate nearly uniform 'ton}

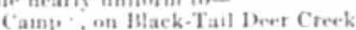

Grade very irregular, on folling plateau, t...

Grude wmie what irregular to-

Camp 9, in Cache Valley, near mouth of East Fork ...

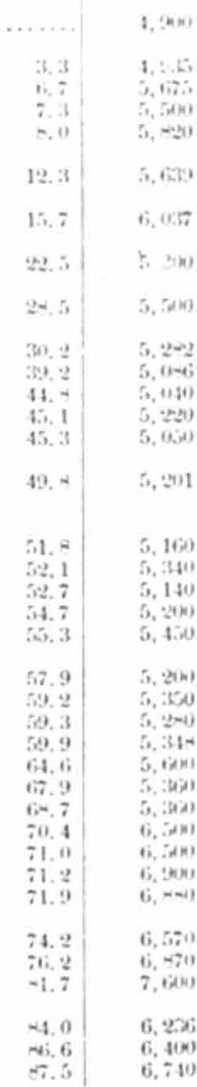

Routc from Bozeman to Yellorestone Lake, dc.-Continued.

\begin{tabular}{|c|c|}
\hline Mtiles. & Elevation. \\
\hline 67.6 & 6,500 \\
\hline 6.9 & 6,620 \\
\hline & $\begin{array}{l}7,200 \\
7000\end{array}$ \\
\hline 90.2 & \\
\hline 94.3 & 8., 800 \\
\hline 8.2 & 8,600 \\
\hline 36.3 & 8.760 \\
\hline 101.2 & $z, 162$ \\
\hline 106i, 7 & 7,979 \\
\hline 107. . & $7,8: 00$ \\
\hline $107 .=$ & 2,000 \\
\hline 109.4 & 7.800 \\
\hline ing.7 & 7,940 \\
\hline 110,3 & 7,920 \\
\hline 110.9 & $7, x=0$ \\
\hline 112.9 & 7,620 \\
\hline 113.4 & Z. 900 \\
\hline 113.7 & $7,7: 0$ \\
\hline 116.7 & 7,712 \\
\hline & 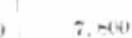 \\
\hline
\end{tabular}

Cratie nearly uniform to

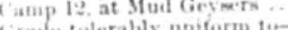

Me tolerably uniform to-
Yellowstone Lake, ai heal of river

to the Mut lieysers, on the Jellowston.

\begin{tabular}{|c|c|}
\hline Miles. & $\begin{array}{l}\text { Eteva- } \\
\text { tous. }\end{array}$ \\
\hline & $4,1: 2$ \\
\hline $\begin{array}{l}16.5 \\
90.4\end{array}$ & $\begin{array}{l}\text { 4. } 360 \\
\text { 4. }\end{array}$ \\
\hline 97.7 & $4.7 e 9$ \\
\hline 29.8 & 5,400 \\
\hline 36.1 & 5,000 \\
\hline 37.8 & 5,640 \\
\hline $\begin{array}{l}3.6 \\
39.3\end{array}$ & $\begin{array}{l}5,30 \\
4,900\end{array}$ \\
\hline 42.5 & 4,958 \\
\hline 61.3 & 5,214 \\
\hline 71.3 & $\begin{array}{l}5,524 \\
5,700\end{array}$ \\
\hline-0.6 & 5,900 \\
\hline$\leftrightarrow, 9$ & 5,753 \\
\hline-40 & $\begin{array}{l}6,300 \\
6.200\end{array}$ \\
\hline - 6.9 & 6,600 \\
\hline 93.9 & 6,100 \\
\hline $9+2$ & 6,309 \\
\hline 104.9 & 6,570 \\
\hline
\end{tabular}

Gallatin City. (Three Forks of the Minour

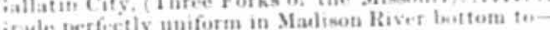
Canp 26 , on Matison

lirate perfectly uniform in river bottem ti"

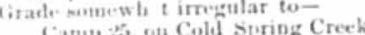

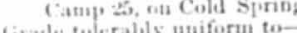

Whule between Cold soring and Hut spritug Creeks...

Girate nnesth to

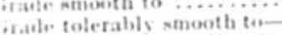

Buvile between Ifot Spring and Me atow Creeks.

Camp 24, on Meadow Creek

Cimele inesfectly sumeth to

Cane 2 , opposite Virginia City, ou Mtudinon.

irale uniform to-

Canuple at month of Indian Creek. ...

Grade tolerably uniming to-
Catup :00, on Madison.

cirale good to...

Twlerably uniform grale to

Grate perfectly utiforn toCamp 19, at foot of sinta.

Camas lo, in muddle of canon. 
lioute from Galiatin City to the Geyser Basins, dec-Continued.

Gitale irregular to

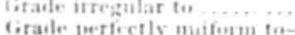

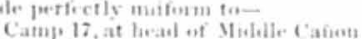

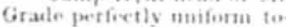

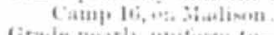

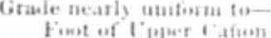

irate perfectly unaform to.

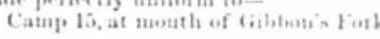

Very itrmular prate to-

Heat of 1 Pिe- Canota

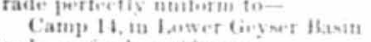

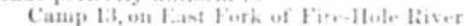

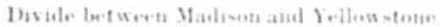

Grade irregithar th

Shitr. Eleva-

$100.4 \quad 6,6240$

119,46 6. 50;

$10,4 \quad 6,405$

1:सi. 4 6i:

$11.31 \quad 6,-11$

13.0 $7,2 x=$

$14-: \quad \therefore, 44$

132,7202

$1: 2: \quad 2 \pi z$

The ordinary meteorologieal obervations were mate hourly in caup They will be found pronted in full in the bulletin of meterorologicalober vations. I will make a shent rexume of them. Thes were mate at

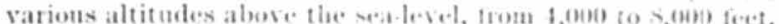

At Fort Ells, elevation 4.955 feet, the mean termerature during the

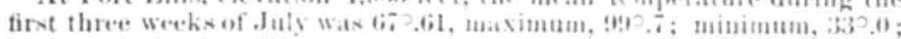
lowest relative humidity $: 21$.

On the lst of July, there exerurrel a heary snow storn, in which about four inches of wow tell. which melted on the following das:

On the 17th, there wats a smart shower of hati. The minimum temper

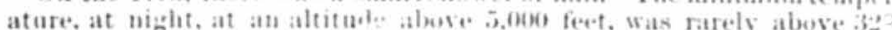
The lowest temperature experiencel during the trip was in the camp at the mouth of Cibbon's linth, elevation 6,s11 foet, 1:2, in the latter part of Auguat. At the head of the West Gidlatin River, elevation

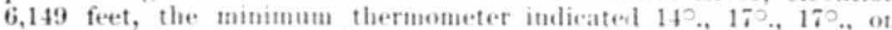
three several nights in the lister part of september. Maxmum temper atures, during the day, ranges from 6.5 ' to 9.35 , indieating a great range of temperature during the day

Tt monge of relatise humidity is also very great, reaching, near the midde of the day, as low as .30, and on several ocrasions even lower. The lowest relative humidity recorded during the trip was.... Most of the rain which we experienced during the season was in the form of showers, which were of tolerably frequent oceurrence, but very few long storms ocenrring during the seasoln.

A storm of rain and hail of two days duration was experienced at Yellowstone Falls, near the end of July. A heary snow storn, in which four inches of snow fell, occurred at the heal of the West Callatia, neat the end of September.
In common with two other members of the party, I had rather a sin. gular expertence. We were ascending a moutain near the Gardiner's River Surings, called on the map Electric Peak. I quote from my notes writur ou the following day: A thunder-shower was approaching as

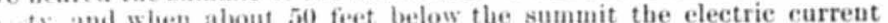
c... rackline nose, similar to a rapid discharge of sparks from a friction machine. Immediately after, I began to feel a tingling or pricking cencition in thy head and the euds of my fingers, wheh, as well as the wo whe the noise, which

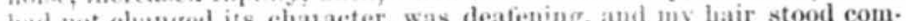
(absolutely paintul. Taking off my hat partially relieved it. I started down again, and met the oflets 25 or 30 fect below the sumit. They were affected similatly, but in a less degree. Ou. of them attempted to go to the top, but hut proceeded but at few feet when he received quitea severeshock, We then returned down the momution alout 300 feet, and to this point we still heard and felt the electriets

I have received returns of meteorological records kept at Bozeman, Montana, ly Mr. Peter Koch, a thoroughly reliable observer. These records are published in full in our ansual fulletin of meteorological

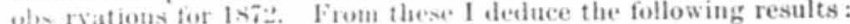

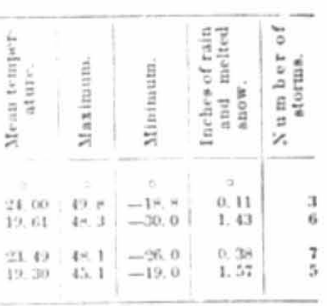

Yr. Kowh records, on the loth of December, "'two distinet shoeks of arthinake, at 4.30 p. 11 ., and on the 11 th oue shock, at 6.30 a. m. All

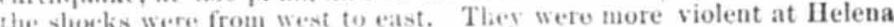
and loer Iotlge than here." 


\section{NOTES UN THE CLIMATE OF MONTANA.}

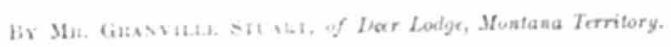

The winter of $1857-2$ s was very mild. Snow did not lie longer than The winter of $18,-40$ was very mild. sinow did not lie longer than a fell days on atis of the prticle and horses in

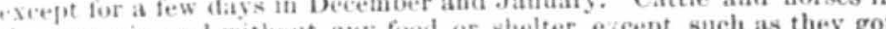

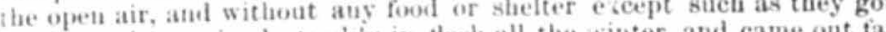
on the pratie, rained steadily in tlest: all the winter, and came out fat in the spring.

The wiuters of $18,5-59$ and $15,59-60$ were very similar, averaging, probably, attle colder, and with a little more suow, but quite pleas. probably, in the main.

ut in the mam. The winter of $1360-61$ showed a gratual ince the winter would it over former years, but still stock tha weil; and

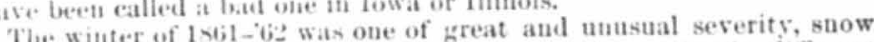

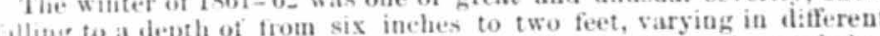
chlthe the alley. I have observed that ritley s.

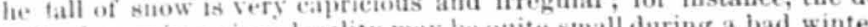

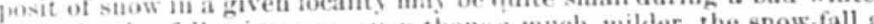

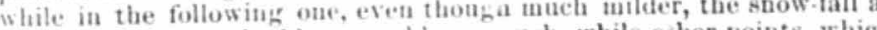
that point will be double or treble as atuct, while ocher points, when himb suow durim the tirst, will be compantuvely free from it dur.

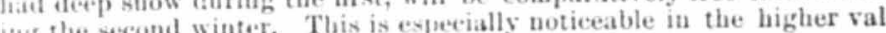
ain- the second trinter. The to another.

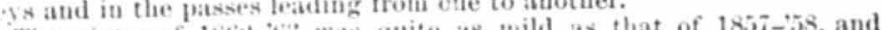
The winter of 1so--6s was quite as tnife as that of 18si-je, and throughout the conntry, as far as salt lake, it was even mider, for wagons drawn by both horses and oxen made two trips, in mid-winter, finm lanuock City to Salt Lake City and back, with heary loads, and

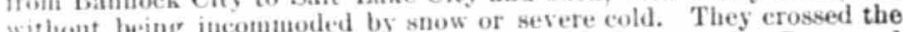
Herticine Lodge Pass) and minir monger ford for their thitnats than bunt large num. lias not been accomplished since, many parties triving lost lam he three bers of cattle and mules in trying to make one trip in each of the three suecesling winters. The lowest temperature in beer lodge during this winter was Uetober.

The wincer of 186:-itit was but litte inferior to the preceding one, The thinter of 1s6s-alless, although it was show lying but a few days at a time in the Iuite deep on the mountitus, and the weather accurred on January colder. A severe storm of mind and iriving snow occurred on January i, in which the about a week.

The winter of 186t-'or showed an increased degree of cold and snow

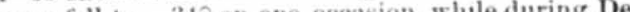
again. The teniph cember and January the cold was severe; but the snow was not deep 
until March, during which month more fell than in all the rest of the winter, and the minimum temperature was - 270. Stock did well enough without any feed during this winter.

The latter half of the winter of $1865-66$ was quite severe, snow lying in the valleys, while the lowest temperature was - 340. No stock clied, however, although none were fin.

The winter of 1866-67 was very mild until the 24th of December, with no snow, but from this time until April it was the worst wuter ever known in the Territory. Snow fell to a considerable depth in all the valleys, and was accompanied by a very long spell of continued cold, varying $-10^{5}$ to -32 . The month of Mareh, in partictlar, was absolutely terrific, on twentyeight out of thirty-one moruings the tem. perature being below zero, being, I believe, without precedent in any other country. Yet, strange and almost incredible as it may appear, scarcely any cattle died, although few of them had any foed or any sleelter otber than the willows along the streans. No horses died, although they, too, had to subsist on the range all winter.

The winter of 1 sti- -6 was comparatively mild, with but little snow : coldest day, $-30^{\circ}$; no sufferiug among stock; grass abumd hnt and not

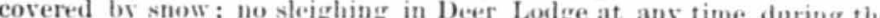
winter; valley dry and dusty: the same being the ease in nearly all parts of the Territery.

The winter of 1565-69, as those of $1857-58$ and $1862-63$, was vers mild, being almost no wir ter at all, when the latitude and altitude are taken into cousideration. No snow of any consequence.

The winter of 1 stog-70 was quite mild, with little stow in the vallers, and little hay was nsecl.

The winter of $1 \times 70-71$ was also open and pleasant. Stock kept in g onl condition on the range.

The winter of lsil-72 was a very severe one, commeneing with a terrifie stera of wind and suow on the $23 \mathrm{~h}$ of Noveminer. The greate. depth of show in Deer iodge at any time was 1"' inches. The deith howeser, on the mountains was very great. The loss in cattle conld uot, however. have excesled 2 per cent of the number in the Territory, for a large part of the hay-erops of the three presious years was on haud. Hence there was but little suffering among stock, except in a few local ities and anong herds of Texas cattle driven in during the fall, which, being thin in flesh and not accustomed to snow and cold weather, sus fered severely:

By using a little care and foresight in preserving the hay and straw that ean be accumulated with but little labor and expense during the mild winters, all danger of loss of stock during severe seasons will be avoiulet.

It seems that ou hard winters come exactly five years apart; for instance, those of $1961-62,1567-68$, and $1871-72$ were all severe, while the intermediate ones were all very mild.

The snow-fill at Deer Lodge (latitude about $46: 27^{\prime \prime}$; altitule aboro sea, 4 , itis feet) for the last five vears has been as follows:

In the winter of $1867-65,20+$ inclies, in seventeen storms, not including what melted as it fell. (ireatest depth at any one time, $2 t$ inches. It the winter of 1 stow 69,169 inches, in fourteen storms. Gireatest depth,

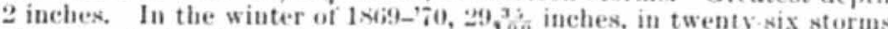
Greatest depth at any time, 4 inches, and that for a few days only. In the winter of $1870-71,45,3$ inches, in forty-reven storms. Giratest depth at any time, 3 inches. In the winter of $1871-72,8646$ inches, in forty-eight storms. Greatest depth at any time, 12 inches.
The mean temperature at Helena, Montana, for 1866, was. The mea temperature at Deer Lodge, Montana, for 1868 The mean temperature at Deer Lodge, Montana, for 1869 The mean temperature at Deer Lodge, Montana, for 1870 The mean temperature at Deer Lod Le, Montana, for 1871 . The mean temperature at Helena, Montana, for January, 1867 The meau temperature at Helena, Montana, for February, 1868. Thi. .

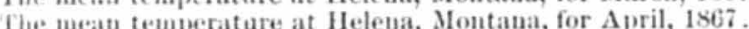

The mean temperature at Deer Lodge, Siontana, for November, isco The mean temperature at Ifelean, Montana, for December, 1867 . The fall of rain and melted snow at Ilelena, in 1866 , inches. (16.50 The average fall of rain and melted snow at Deer Lodge for four vears, 19.11 inches

A series of olservations shows that Missonla County, Montana, alti tul. 3,3th feet, ) enjogs an averaye temprerature of 50.5 higher than Deer

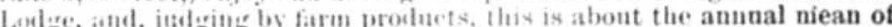
the Farie valley of Sun River, Mismuri, Gallatiu, Jefferson, Mudison, Stinking Water, and Beaverhead. It thus appears that by far the greater part of the Territory has an ammal mean temperature of about $48^{\circ}$

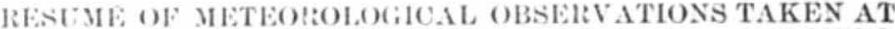

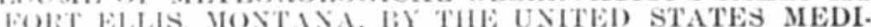

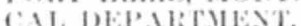

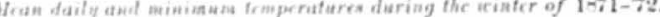

\begin{tabular}{|c|c|c|}
\hline Date. & 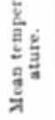 & 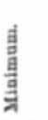 \\
\hline $16,2$. & 。 & \\
\hline Feb : & -34 & $\begin{array}{l}-51 \\
-51\end{array}$ \\
\hline & 12 & $\begin{array}{l}-31 \\
-30\end{array}$ \\
\hline : & as & 10 \\
\hline$?$ & 13 & $\begin{array}{c}10 \\
2\end{array}$ \\
\hline 11 & ฆ & \\
\hline 18 & 3 & -1 \\
\hline is & is & -10 \\
\hline 15 & 8 & is \\
\hline $\begin{array}{l}16 \\
17\end{array}$ & 3 & $\begin{array}{l}12 \\
10\end{array}$ \\
\hline is & 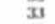 & ${ }_{21}$ \\
\hline 19 & a & \\
\hline 90 & is & 3 \\
\hline$\approx 2$ & $n$ & 4 \\
\hline 21 & 12 & \\
\hline 等 & $n$ & $10^{\circ}$ \\
\hline 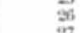 & ii & io \\
\hline 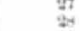 & $\begin{array}{l}15 \\
17\end{array}$ & -13 \\
\hline Yarch & 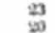 & -8 \\
\hline 2 & 9 & i \\
\hline 4 & $\underset{7}{2}$ & 15 \\
\hline $\begin{array}{l}5 \\
6 \\
5\end{array}$ & $\begin{array}{l}31 \\
23\end{array}$ & $\begin{array}{l}15 \\
14\end{array}$ \\
\hline
\end{tabular}


Mean daily and minimum temperaturen, \&c--Continued.

\begin{tabular}{|c|c|c|c|c|c|c|c|c|c|c|c|}
\hline Date. & 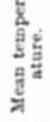 & 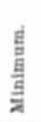 & Date. & 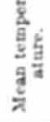 & 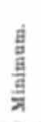 & Date. & 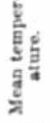 & 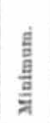 & Date. & 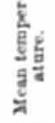 & 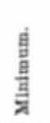 \\
\hline 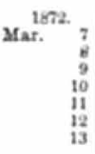 & $\begin{array}{l}0 \\
27 \\
25 \\
16 \\
10 \\
19 \\
15 \\
2\end{array}$ & $\begin{array}{c}0 \\
10 \\
0 \\
0 \\
3 \\
0 \\
8 \\
8\end{array}$ & $\begin{array}{r}1572 \\
\text { Mar. } \\
15 \\
16 \\
18 \\
17 \\
11 \\
19 \\
50\end{array}$ & $\begin{array}{l}0 \\
11 \\
5 \\
13 \\
13 \\
11 \\
19 \\
15\end{array}$ & $\begin{array}{l}0 \\
-4 \\
-6 \\
-6 \\
-3 \\
0 \\
\vdots \\
0\end{array}$ & 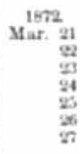 & $\begin{array}{r}9 \\
21 \\
16 \\
15 \\
2 \\
16 \\
21 \\
17\end{array}$ & $\begin{array}{r}0 \\
3 \\
0 \\
-10 \\
-90 \\
0 \\
8 \\
4\end{array}$ & $\begin{array}{r}1872 \\
\text { Mar. } \\
\text { of } \\
3 \\
31\end{array}$ & $\begin{array}{l}0 \\
20 \\
20 \\
34 \\
32\end{array}$ & $\begin{array}{l}\circ \\
13 \\
18 \\
14\end{array}$ \\
\hline
\end{tabular}

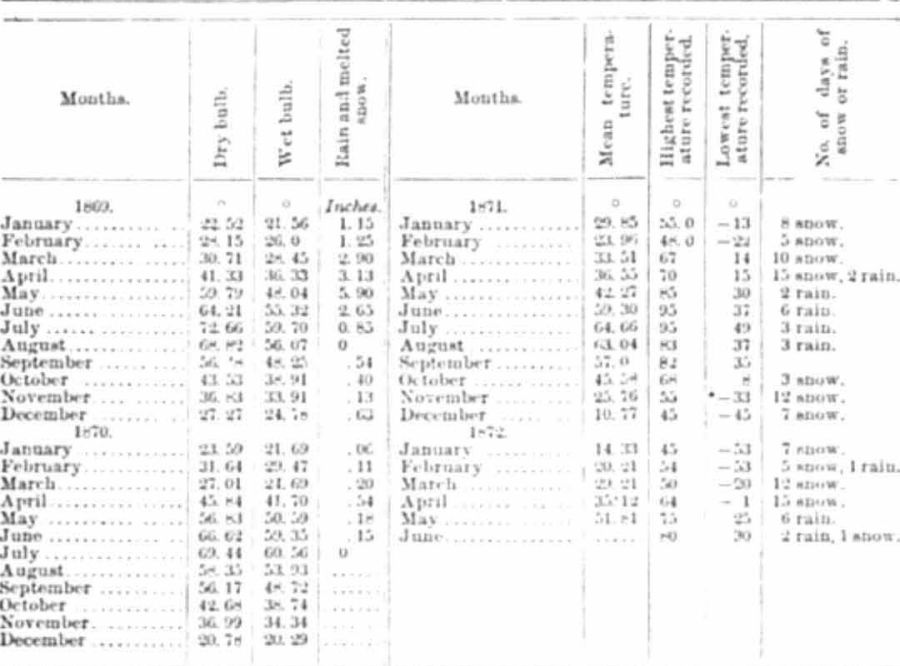

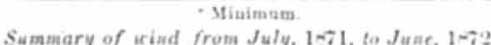

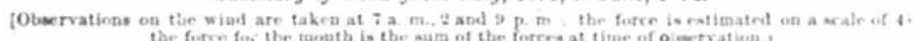

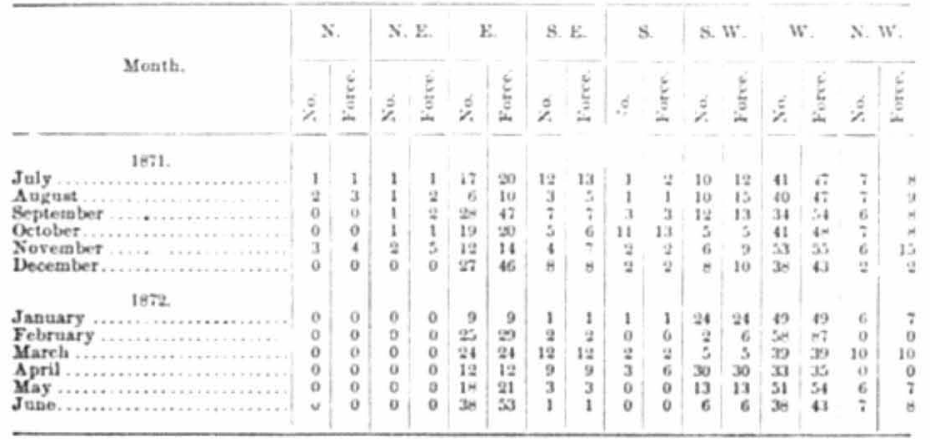

SNAKE RIVER DIVISION.

List of latitudes determined astronomically.
Camp

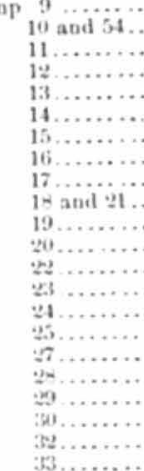

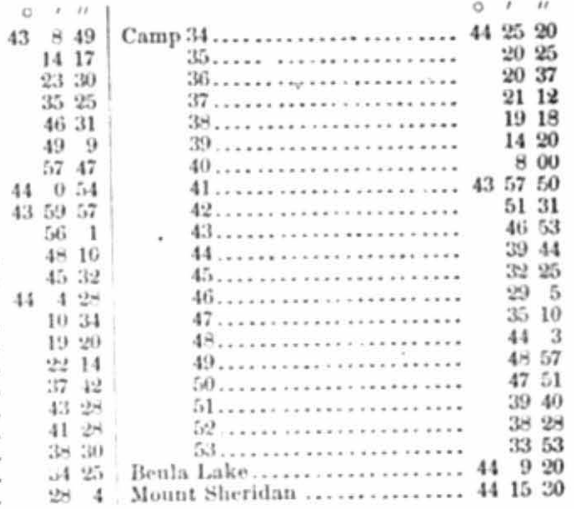

MAGNETIC VARIATION.
The magnetic variation was determined by observing the azimuth of Polaris with a Wurdeman's gradienter, the verniers of which read to single minutes.

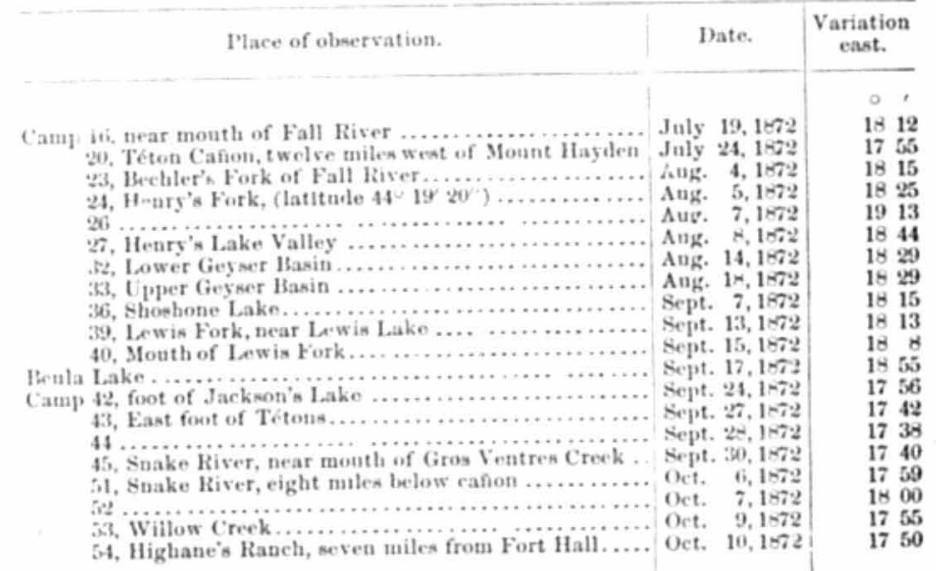




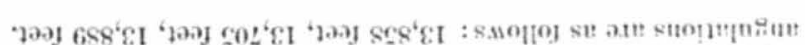
-11 จ

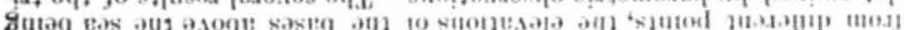

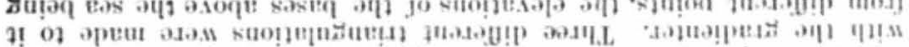

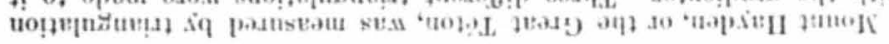

218,6

sat.

626

$6066^{2}$

298

$9 \mathrm{grt}$

$902 \%$

en: $:$ :

1069

600.

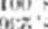

920
100
$9 x$
802
800

$809 \%$

6002

iti

900

056

$0 \leq 2$

$\theta 50 \%$

600
$t i n$

006 :

911

706 .

2069
2002
000

$\operatorname{moc}_{\cos 2} 2$

$082 \cdot 2$

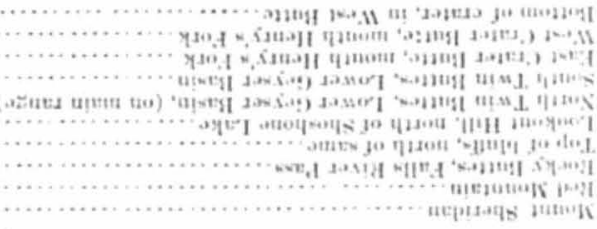

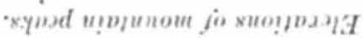

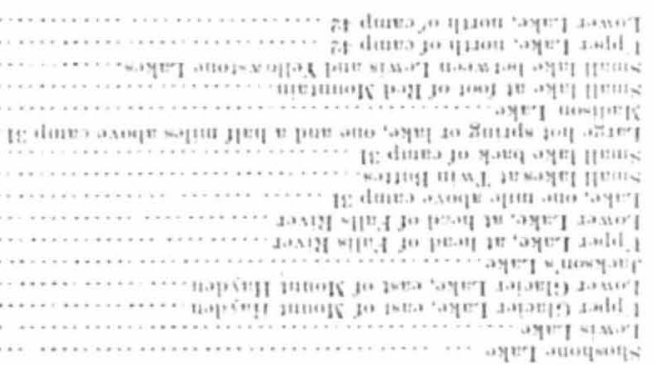

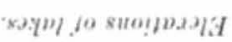

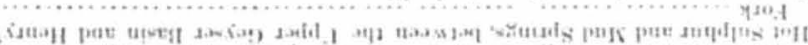

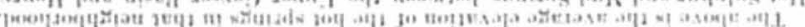
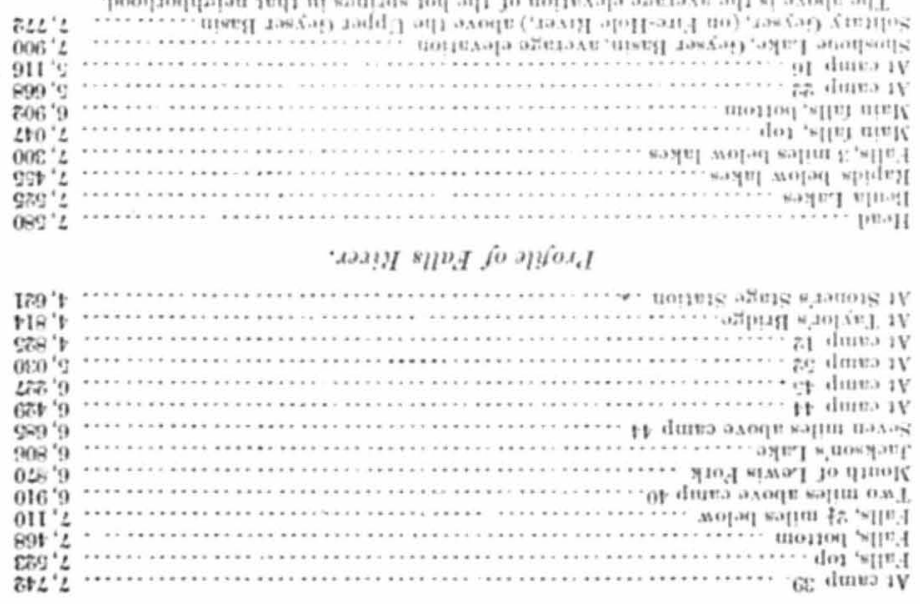

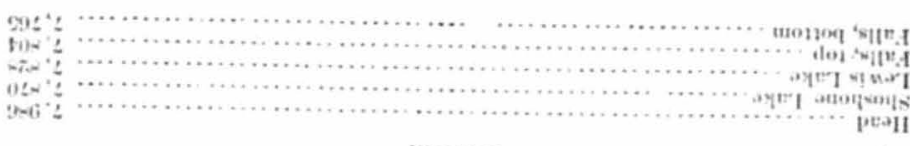

'Ho!

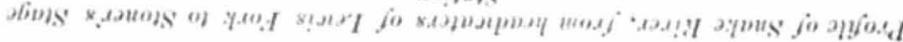
Hit

at: $\therefore$ :

ist

and

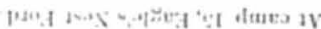

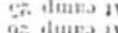

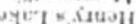

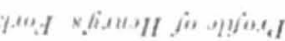

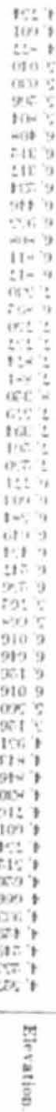

it 130

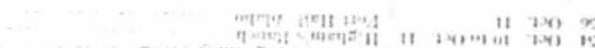


The first triangulation was made under more favorable circumstances than the others, and I give it a double weight; and adopt, therefore, as the elevation of Mount Hayden above the sea, 13,833 feet.

The result from an aneroid reading was 13,784 feet.

Mount Moran, (elevation determined by triangulation, 12,809 feet

Sawtelle's Peak, (measured in same way,) 9,070 feet.

Passes and dirides.

Thton Pasa

Tyghee Pass

Water-shed between Fire-Hole, Snake, and Henry rork

Highest point ou the divide between the East Fork of the Fire-Hole and Yellow.

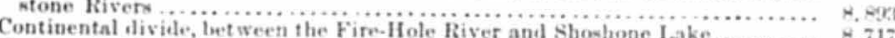
Eastem divide, from hrad of Falls River to Snake River .......

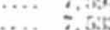

Cotatinental divine, between the Firo-Hote, weet of the Lower Geymer Banin

Divide bet ween Malade River and Marsh Creek.............................. 8,20

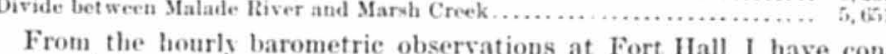
structed the following mean monthly curves of hotary oscillations from 7 a. m. to 9 p. m., for the months of June, July, August, and September:

Jut.

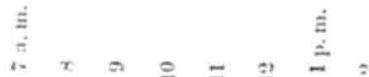

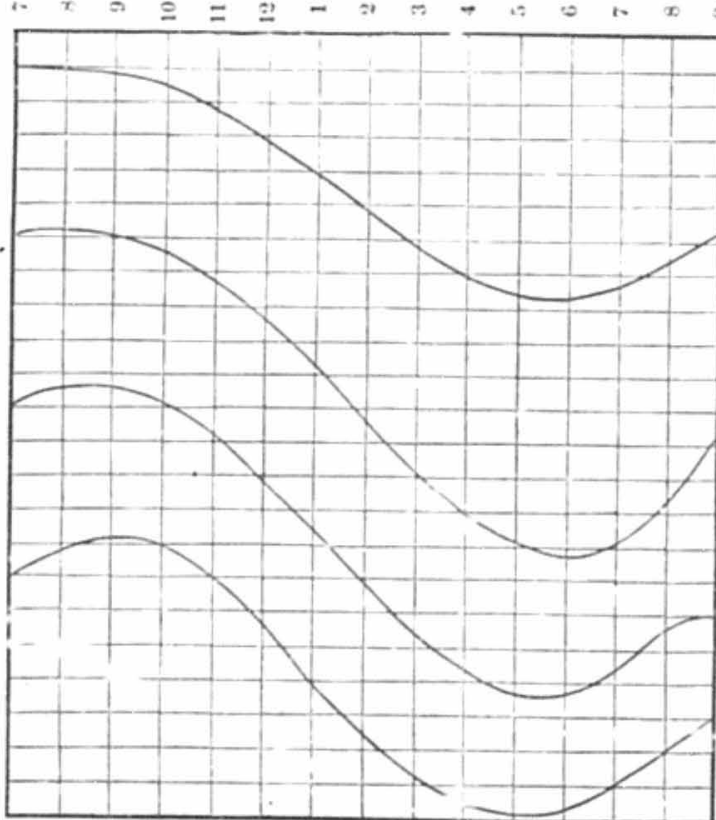

The honzoutal divisions represent hundredth of an itich of the harometric colunath
The mean temperature from June 4 to $25 \ldots \ldots \ldots \ldots \ldots . . .64 .62$ The mean temperature from July 13 to $31 \ldots \ldots \ldots \ldots \ldots \ldots \ldots, 70^{\circ} .44$ The

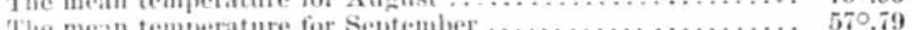

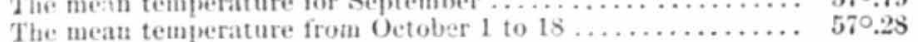

$$
5: 68
$$




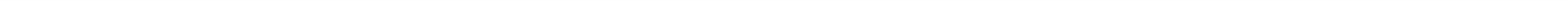




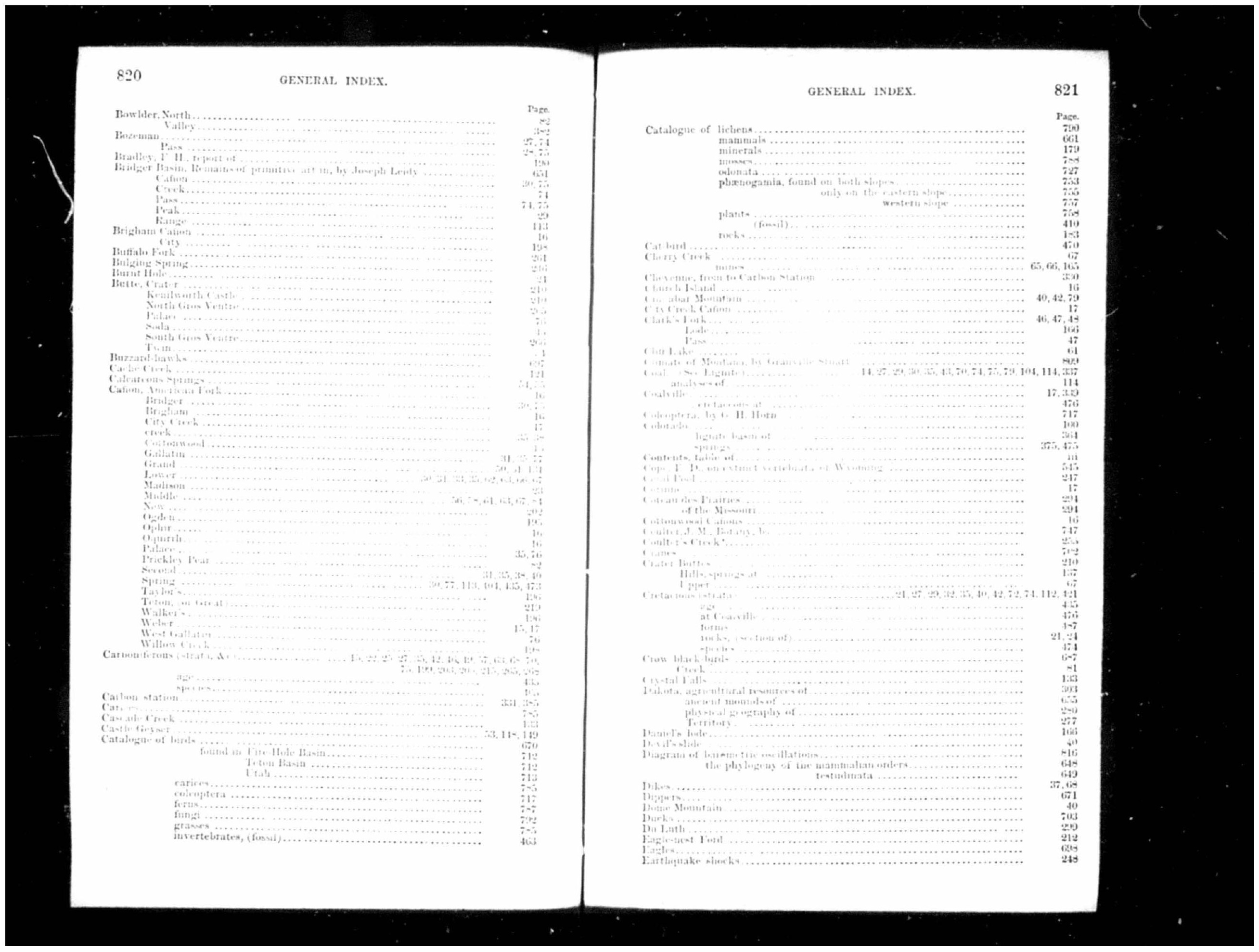




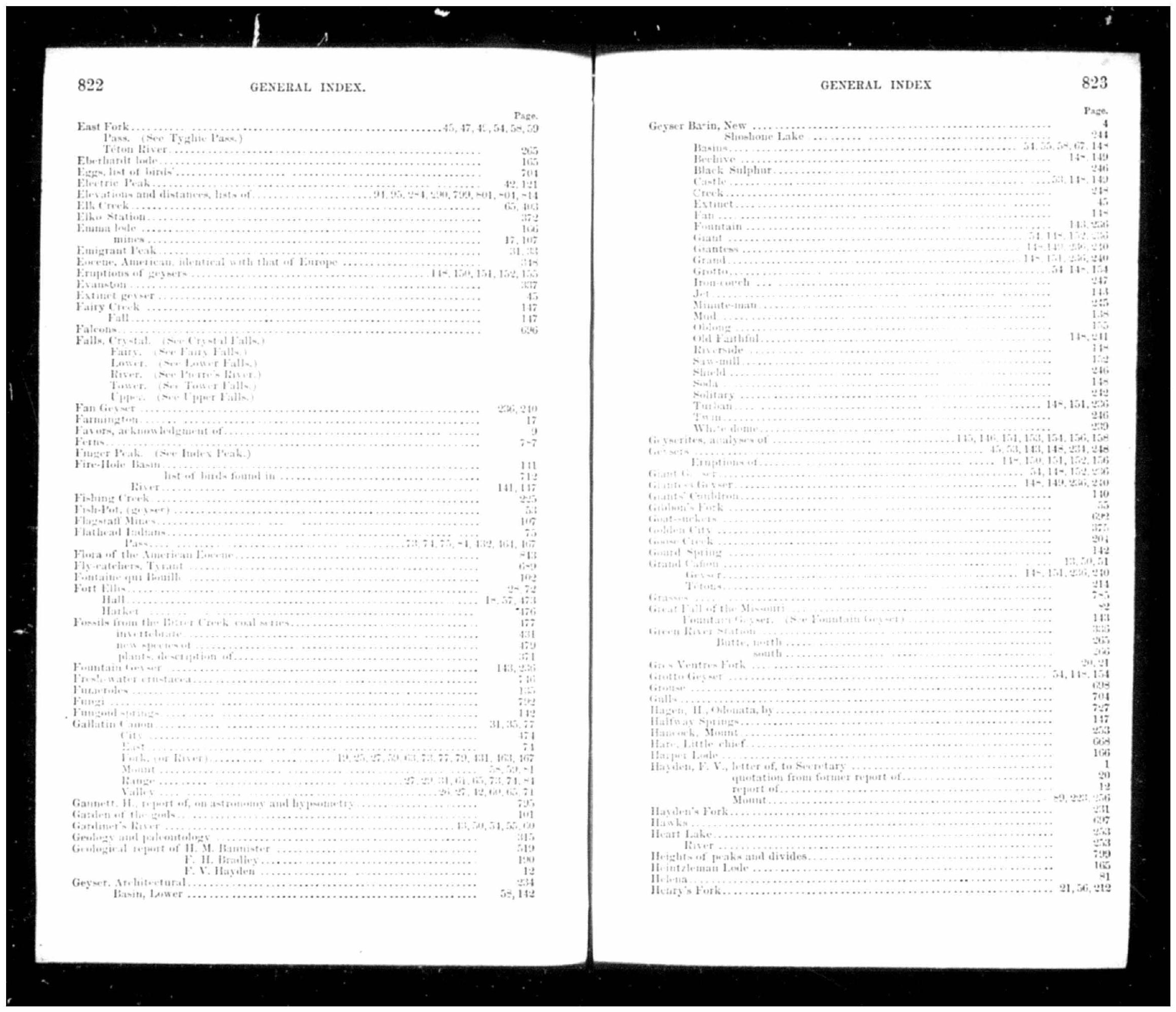




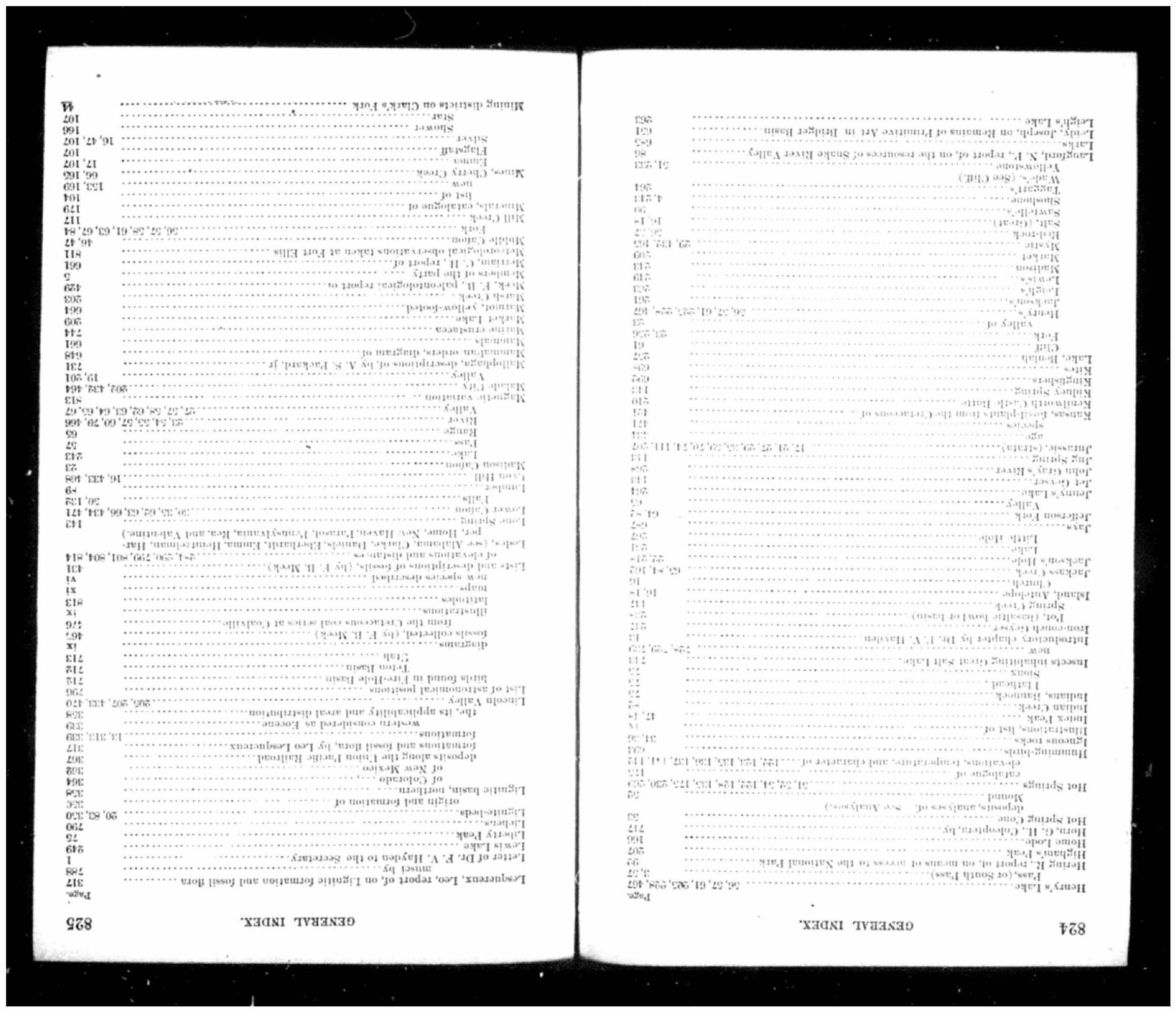




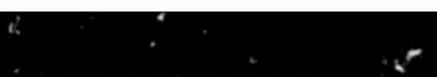

Mintesota, agricultural resourees of physical geograplyy of ..
statintic. of tloe crops of

Minnte Man. (деyser)

Mississipt River ........
Missouri, great falls of the River

Liper Tertiary Palis of
Montana, notes on the climate of

Montatia, noter

Minrmon Mule Creek

Yossen

Houtu of Daketa, ancisent

Mount Blackmor.

$$
\text { Hancoek }
$$

Hastion

Patnam

Montait, Cimmatat

Mountains, Bige if.

$$
\text { Wig II, }
$$

Gilfatin

Mater

kat

Saltwent kiver

Sonth law liket

Tetion

Wiml livir

Mouse lank

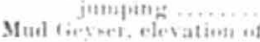

springs

"Mtrkh Pot"

Mystic Lake

National l'ark...

$$
\text { meane of the tow }
$$

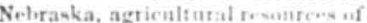

New Canon

Hasen Lome

Sesten, figmuth lasin of

Niagara group

North Girom bution linth.

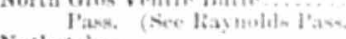

Nuthatelias

Onk-leat spriting

Otonata, liy II. Hagen

Orilen

$$
\begin{aligned}
& \text { Cañon } \\
& \text { Creek } \\
& \text { Peak. }
\end{aligned}
$$

Old Raldy, (peak)

Faitliful, (geyser) ...

Olney, S. T., Cypheraces by

Ophir Cafnon.

Oquirth Montains

Orioles. 

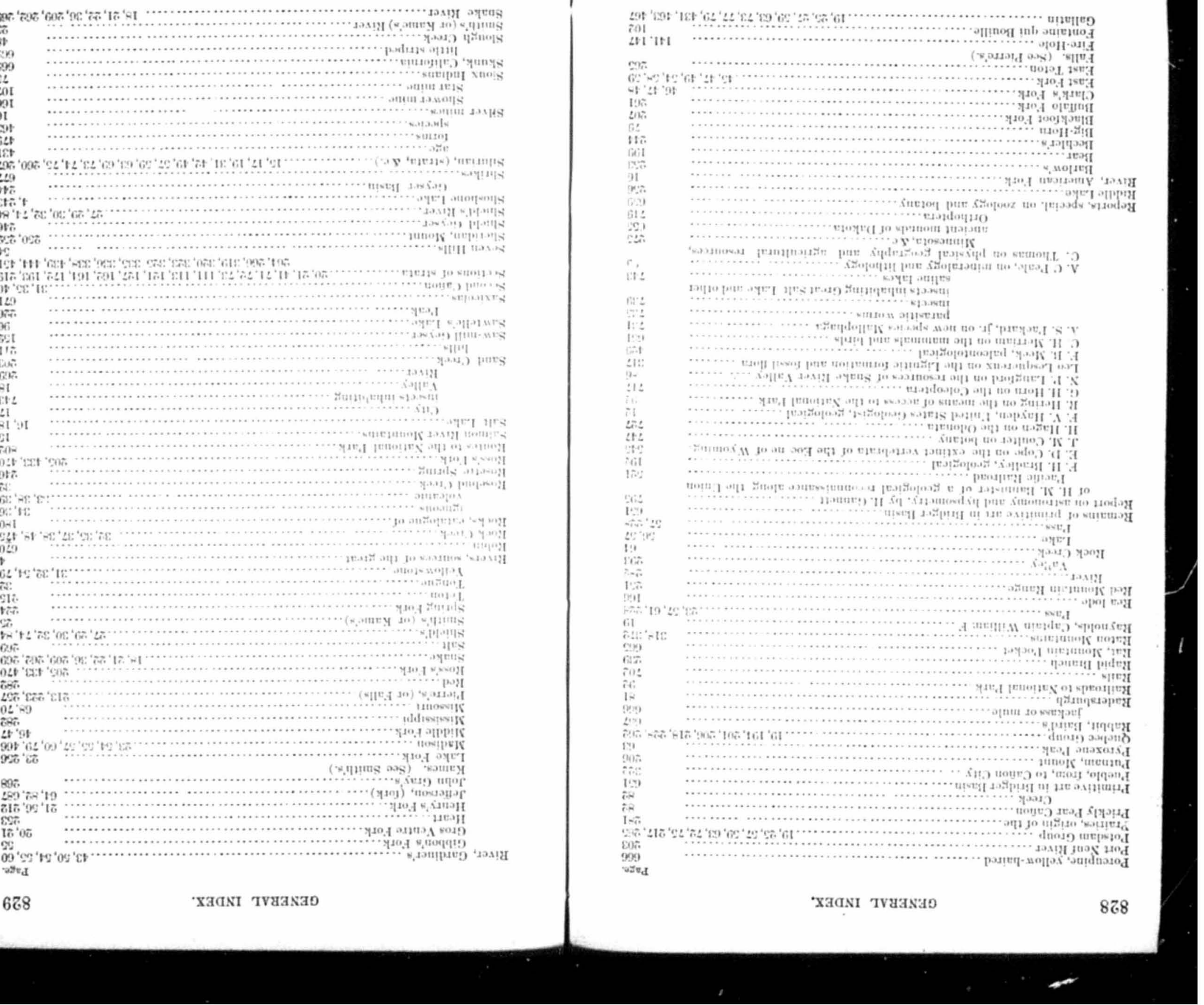
Snake Rirer Basin

Page.

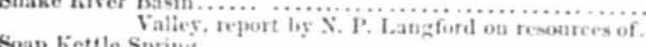

Soap Kettle Sprin

Geyser.

Solfataras .........

South firns Veutere Binto.

$$
\text { Pari. }
$$

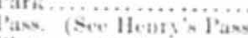

Spanistite th

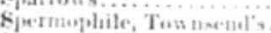

spritng, Deiling:

Ibulging

Caril I'and

Crexh

rink

Gimat.

fili:

kisin.

lota

M..h-linat.

Rowette.

Sol, ket

suplain

Thati

Spring Wisthtol.

lieat liseis

calearion

it reater ilito.

fungowi.

ila

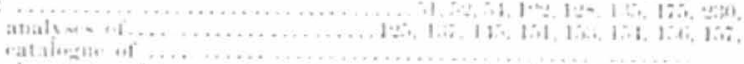

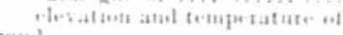

at tual whaten

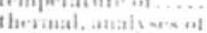

Sphynx 1 at

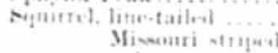

Ifive

Sta ing

39

Ararty cendet.

Streatax dirmetinter

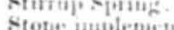

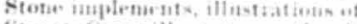

Sulphar sprime

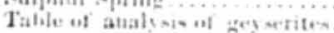

distaners aud revatiots-...

Tazgart in Lake.

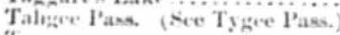

Tayle s bridge.
Taylor's Cation.

Temperature of pprings

Tertiars

bels of the Viper Misestari

forms.

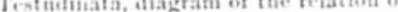

Teton Basin

lint of bitus found in

Canion

Grate.

Kan,

Thertal oy rin

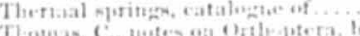

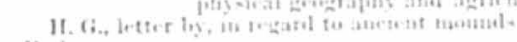

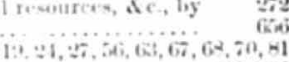

Thruslie

Thas sining

Timiner lime

Tovgu inive

Towntaplay, wertical

Tone Crever.

Traul crowh

Ti:

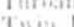

and Then

Thathone

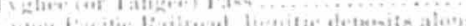

Inet lition

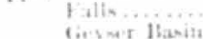

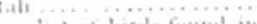

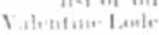

(c)

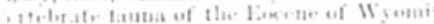

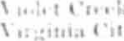

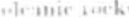

Nuturin 1 .

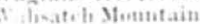

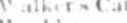

II:athing

Matren, lewtenant

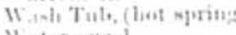

Yianl, brat

Yaseld hast

thint ciallatin cafon

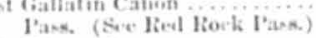

With ins

Wulow Cresh Cañon ...

Mind River Sloutatails.

Wurt-watblers.
$17,20,32,25$

14,21

478

6799

2,202

65
272

$=17,2=1$

7.51, -140

1,000

203

4.1, 80

51,237

16

74, 75

.. $50,1: 5$

it, 14-

15. 100

itio

643

$3,3-39,23$

i 207

106

19

67

15,17

299

700

190

602
69.3
$103,102,128,134$ 
Wrens...

Yellowstone Lake.

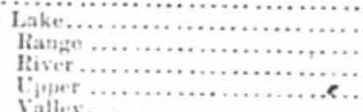

Zoology and botany
INDEX OF SYSTEMATIC NAMES.*
Abies balsamea. . . doaglasii. nevalesia netigera.

Abietites inbins

Accipiter fuscus

Accipitrina...

cer giabrum.

grandidentatuit

irilobatum

Acorins bracliystacby

Acridhum emarginatut

Acrovleta...

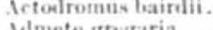

$$
\text { rluouboides }
$$

Egialitis verifer

Cechna cotsetricta.

$$
\text { eremita... }
$$

proping̣n.

Agelaina

Ktelaitus phonicets.

Agnontus

Nrion

Neverint:

Nee amerix

Meurites eoceniea

1lya.

Slligater heternion

Jnila kefernterilie

Anarantace

Aminomit

Anacaruliace:ule.

Anaptotnorplins r.....

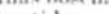

Anatid.

Anchiprotis minor

Anchipposits

Anen

ploerlignchus

thostira ornata ...

Anthns ludovicinus.

Autiacolon furcatus.

pygmasts

Antrostomas nuttali

A росувасеж ........

- Notr. This index includns the names of all kepera and species except those foand obly in the cato 53 G $\mathrm{s}$
Page

252

372
404

74, 404

697

192
192

328

724

700 501 
Aquilina

Arctomys flavivester

Argas americal 7

Arthrophyeus uarlain

Artiolactyla ...

Arundo gopperti
Arvicola riparia

Arvicolina

Asaphus goniocereur

Asclepiadaca

Athene hypugat

Atrypa.
Avicula.

$\underset{\substack{\text { gastrodes } \\ \text { proplenta } \\ \text { rhytophora }}}{ }$

Avieuloytophora.

A vieulofecter.

Axetns bye.......

Baenlite

Baïna arenosa

besicaler

Batlimedop

latipes.

Bathmolontida.

Bathyneltus bratles

Bathyorus

Batrachia ...................

haydeni
serratus.
.........
densus.

Benzoin antiquum.

Berberidlaces

Betulacese

Betula stesenseni.

Bonasa umb il

Borraginacese

Brteo montant.

Buteoninas

Callitrichacea

Caloptenus hivitiatus differentialie

Calycites bexaphylla

Campanulaces

Camptonectes......

Capparidacea.

Caprimuleriste.

Carlium

Carex berthonei.

Carnivora

Carpodactis cassinit

Carpolithes arachonile. faleatus.

partus.....

Carya antiqnorum

Caryoplyyllacese

Cassia concinna
phaseolites.

Costor can

tensis

Caulinites fecumla sparganioides Cavicormia. spiuosa ...

Catothas filirillosus. velutinus.

Celastritis:

Cettrincerens uropliasianay.

Ceratophyllaces

Cercocarpus levlifolin.

Cervida

Cervinar

Chataces

Clatartrisil.

Chable lasuns ot reperus.

Chicimptera.

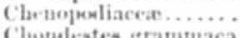

Chondrites billowas

subsimplex.

Choraleiles his

Chryentaing

Cunclialer

Cimelns mesiratns

Cimbatsomum aftin.

rementimeri

Circns hatrensias.

Cissus larvigatur......

Cistothorus palustris

Clamatores

Clantes atuax

atrox .....

glatur.

Coecolelea lavigat

Coccothranstime

Colaptes mesi

Colmoptera

Collurio bereali-.

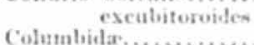

Columblida.

Composita.

Contervoli.

Cotsifets

gallatimeneis

Contopus lencalis.

Consolvulacea

Corlieula sepulateratis bautinteri. cytheriformis. fracta.

$$
\text { iminexa }
$$

Cerbula nematophora. trophislophera

Corrida

Corylus mequarryi untifir-r. 
Coturnieulns passerinn

Cotyle riparia

Crassatella

Crocodilia.

Crocodilus clavis

$$
\begin{aligned}
& \text { elliottii.. } \\
& \text { frimnellii } \\
& \text { fioulon ... }
\end{aligned}
$$

Crucifer. sulciferus.

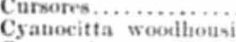

Cyanospiza amorna

Cyanura macrolopha.

Cyguinas

Cygurs buccinator.

Cyperacese.

Csperitesangrastion.

Cyrena carlet

Delesseria fulva

Dendroica aretiva...

atuluboni

Derniatemyn "youid; ;etis!

Dicellocephalion

Diospiros ancipes ....

Diplax assinciful

$$
\begin{aligned}
& \text { scotica. } \\
& \text { vicina. }
\end{aligned}
$$

Diplocynerles polvertur.

Diporlina

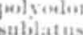

Diptera larva.

Docophorus asruil

Dolichenyx oryziveni.

Doubeyopis ubtuna

occidentali

Eleaguacear

trivialis

Empulenax provill

Emys cuthuetus.

fravis .....

mecranlax. .

pachylomits

peptarias

terrestris

testulineus

Eolasileitla.

Eobasileus fureat us.

Equinetaces

Equisetutu haydeni

Eremophilla corninta

Erethizot cpixant lu

acalypt us haringiana

$$
\text { furicula... }
$$

Enphorliacens.....

Enstrougsles buteonis...

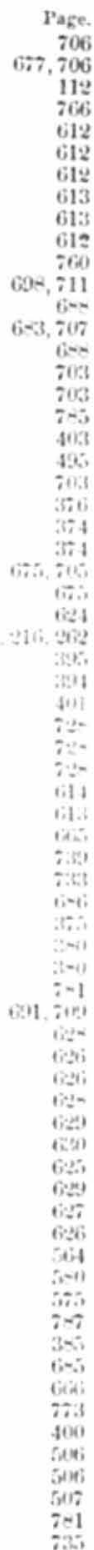

Eustrongylns chordeilis

Everoia vulpina.

Fagus antipofi...

deucalion
feronia.

Falconida

Falconina ....
Ficus asarifolia.

auriculata

clintobic...

hasdenii.

oblanceolata.

ostat

neectalutis

Filiee

$$
\text { tiliafolia }
$$

labellaria eocenica latania
rinekent.

Fraxinuv sentuculat.

Fringilliclice.

Fuma

Fusus fablit .....

Galcoscoptes carolineusit.

Gallisa

callinago wilsomit.

Ganbetta anelanoletuci.

tarrulina

Gentianaces

Gestiana crinita

Geothlypis trielia.

Geramiacese

Gleith rieharilson:

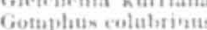

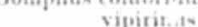

Goniobasis insettlpta

merriamants.

Gralla

Graminacea

Girnida

firus canadeusi

Girypliana

intraca melatiocepu.ja

Cymingramma baydenit.

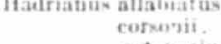

Halymenites octonation

octoriatios.

striatus...

Halysites catenipora.

liemipronetes.

Hepaticas.

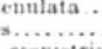

Hopperomys levcopus.

feetarina californica.

Mimatitopis sigricolli.

$$
\begin{aligned}
& \text { horreoruta. } \\
& \text { lunifrons. }
\end{aligned}
$$


Holoragex

Hydrophyllaces
Hydropterides.

Hymenophyllum cretacenta.

Hyopsedus paulu.

Hypericacea

iyrachy:

agrarius

bovis...

impliati.

Hystricida

pribee 1 in

leteris lougicautia.

Icteridla

eterus bullockii . .

toeceratums.

lubidea sculptili

Ixodes lowis.

Jaculas buelenin.

Juglans baltica

denticnlata
rlamenostes

rugosa.

stuitheontais.

Jrueas:

tegonin.

Juniperm occilentalis...

Labiata

Lagoms princepe.

Lamelliruat res.

Laniide.

Laridar

Latix americana

ticulatum

Leguminowi

Lemnaces

Leporidi:

Lepus bainlii.

Lestes calnetis.

Libellula flavista

$$
\text { forensis.... }
$$

I.ichens...

-

Liliace:

Limnara compactilix.

Limuohyos diaconus.

$$
\text { fontinalis }
$$

Linacese

Linguta.

Liquilambar integrifolius.

Ioasaceat

Lobeliacea

Longipentes.

Loranthaces

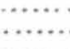

Loxolophodou

Lycopodiacea

MacClintockia lyalli .

Sacrocb ilus.......

Slagnolia ingletield .

Mallophaga.

Malvacea.

Manupialia.

Slartina

Megaceratops coleradecusi

Selampes antiquots.

Melanerpes torjuaftis

Melania wyon

Yelosingat

Lenopa fallax.

Mephitis bicolos...

mephitica.

Hesonyx obtuxiden......

Slesothenis composit a ...

cormpt:......

entmplicollis .

Metalephodon armatus.

Micronyegm vicarius

Modiola.

multilinigera

Motacilludite.....

Yurititic.

Muritia.

Yas monevilus.

Mintelulat.

Myascites sulecompuress

Myiesliocter prisillas.

Myrica tormyi..

Mirtueleoth diverstis.

Saialaceas

Yataterestus.

Natatore

unisteri

bellatula.

$$
\text { pateliiformis }
$$

pisiformis.

Nirmas buteoniserns.....

Notharctus.

Vnmenins longicamins

Syetaginacest

Nycticejns crepusenlaris.

Nymphacese

Oina lanceolata.

Obleila.

Geriata.

discoidea.

discoidea...........

kiowa...

paradosa..

rugosa. 
Cadipoda tenebrcsa.

Oligotomus cinctus.

Ommatolampis viridis

Onagracea

Opegrapla antiqua

phidia

Ophileta...............

phioglossum alleti.

Oromala biving

Oreoscoptes montanus

Orobancliace:

Orohiplus procyotints

Orotherintm sylvaticum .

Orthis

Orthoptera

Oscines

Ostrea.

anomioide

Otns wilmoniamu.

Paleosyopre lavidetie majot

Paliurus colotnlsi

zizyptioises
Palmacites

Palmacite

Papaveracea

Pappichtiy,

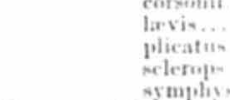

Paramse delicatior

$$
\text { delieation. }
$$

delicat is

leptodos
undans

Pariule

Paritie ............

Pansetculus alandinis

Passerella schistac a

Passere:

Pealícer tes phanianeditio

Perissolactyla

Petrochelidos limifron.

Peziza vulcatalis.

Phalaropontida ....

Pbalampens wilsoni

Pharelia pralei.

mericens.

Pinna

Pinus flexilis.

Pipilo chlorura

Pisces

negalonyx

Planera longifolia

Plantaginace

Plastotnenus molopinus.

foxeatisu

ivlemin:

rionycheides

Flatanus aceroudes

guillelmat.

fiagdenia.

netili.

rayuolelsii.

Polemoniacre

Pingranace.............

Ponsters pranineus.

Fopultea aftuis

fazifolia

Populus aretica

arctica ....

atseminatas

letacollyslla.

motraton

imanluit.

Portulacacest

Porrana car"

Probiancia

Irotluctin.

lempioputios

Trutagras lacustris

Perudotactertiv

1'medudotam ......

Ites is anceps

P'tetonareto californiea

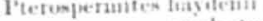

gilladratus

"nipalerialy

phoritas justlio.

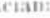

Quantimama

Queteus arrombing

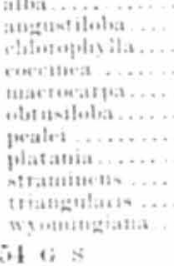

Paze

252

684, 708

635

371
773

617

620
619

619

iiiz, 309,400

0,304

307,394

(2.

79: $: 09$

$-700$

$+2$

325,401

in $7,340,300,392$

392,405

401,405

$\cdot 6 i 1.099$

70,262

i.

116

Pholatomyaticeis.

Phragmites aningensis.

Physa bridgerensis.

carletoni
Pica hudsonica

Picoides areticus

Piens harrisit. 
Querquedula cyanopterus.

Rallida

Ranuneulacea

Rapacia .

Raptores....

Recurvirost ra americana.

Recurvirost ridas

Regulns
Reptilia

Rhatunaces

Rhamnus acrominatifulio

$$
\begin{aligned}
& \text { cleburni } \\
& \text { Arechenii }
\end{aligned}
$$

dieculor

goldiaun

otrivarus

nalicifolina

Rhineartes

$$
\text { arcuatus }
$$

calvus

jeltatus...

Rhus bella ralulus evanini
glaber

Rhynchote

Rosace

Rubiaceir

Raminantia....

Sabal cample lli

Saccomyida

Salicacert

Salisburia polymorphia

Salix angusta

Salpinctes obsoletin

Saniva ensidens . .

Sattalaceas.

Satalacea

Supindirs caudatu.

Saseafras cretacesens

$$
\text { harkeriana }
$$

mirathic.

mudgin
olstusts

Saxicolidlas.

Saxifragacea

Sayornis kay

Scajhites.

Selurida

Sciurina ...............

Sclesotintm ruliellu.

Scolecophagus cyanocephatia

Scolopacida.....

Sequoia angustifolia.

$$
\text { reichenbachi. }
$$

Sialia aretica.

Sitta aculeata.

Stmilax grandifolia.

$$
\text { obtusangula. }
$$

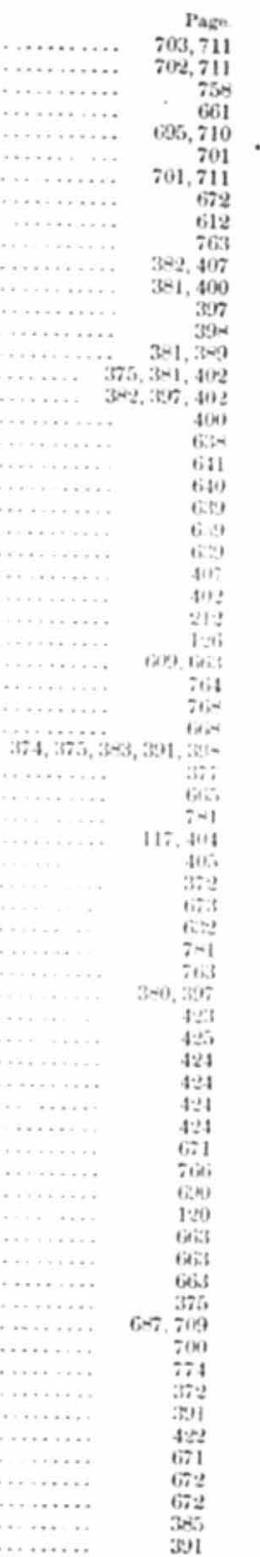

spermophilus gratnmum. lateralix.....

Spbatia coulteri

(ownica.

spheria lapinte.

oply ropicus the roulend.

"rilliamonit.

spitifer...

lineata.

Spictial bow werti

spizellina

Sipizina

Stathmopherin-

Stellula callioger.

Stenobot torn macnlipentas.

Sterna finter

ste nins

Strigular.

Strouloun.

stounolega

stypolophe forevealearatio inectivorn.

-

- Shicoludie

SHivila

s mphemia remipalmat.

sitepplothersut

Tachseineta thalaning

Tamaian enaltivitattu.

Tinagritic

Taxolium dohum.....

Trtrautaitic

Trtran slectir

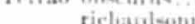

Thinosanrus loftedin.

Themenuy fulsus...

Thutes callitrina.

Thuya garmani

Tinnonenlus sparsetion

Totatherintu

Trapezinu rostratum

Triacoblen aculeat to

Trigonia.... hians

Tringomericantis.

Tring ines mactiani

Trionys cutu.

$$
\text { Puttatus..... }
$$

Trochininat

.

Trochitus alexandri.

Troglodyten park tuann

Troglodytida

Trogleny:itio

Turhouilla coalvilletsis.

Tindidis au

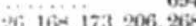

7

Paze.

664

664

376

390

694

707

679
$6 \times 3$

609

695

70

25,710

92, 709

78

560
559

606

174,705

702

700
557

676

663

309
615

602,711

690

63

371

371
372
696

346

548
493

611

641
649
171

$1: 0,171$

111

701
617
617

617

616

(1)

673

673

670,704 


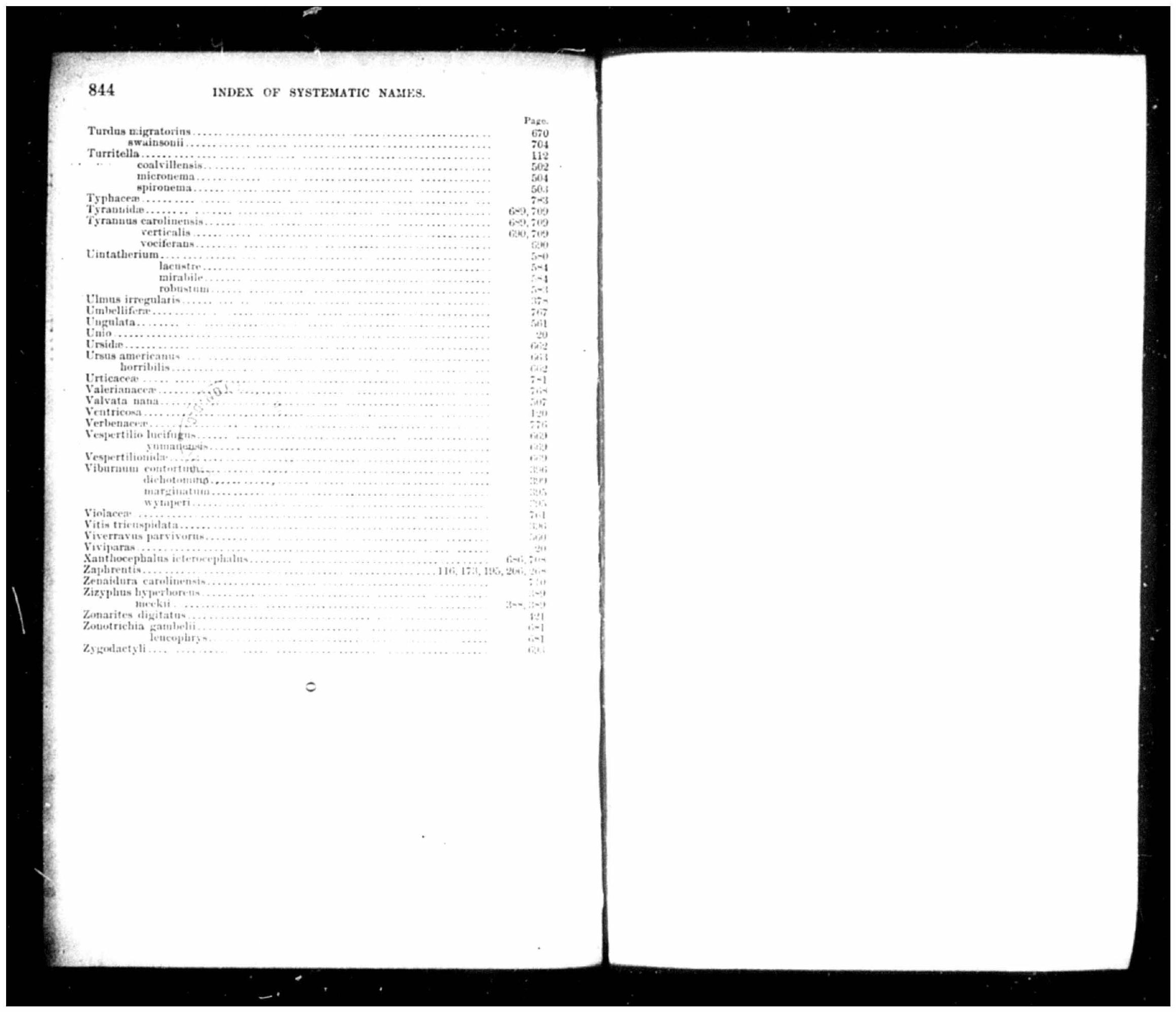



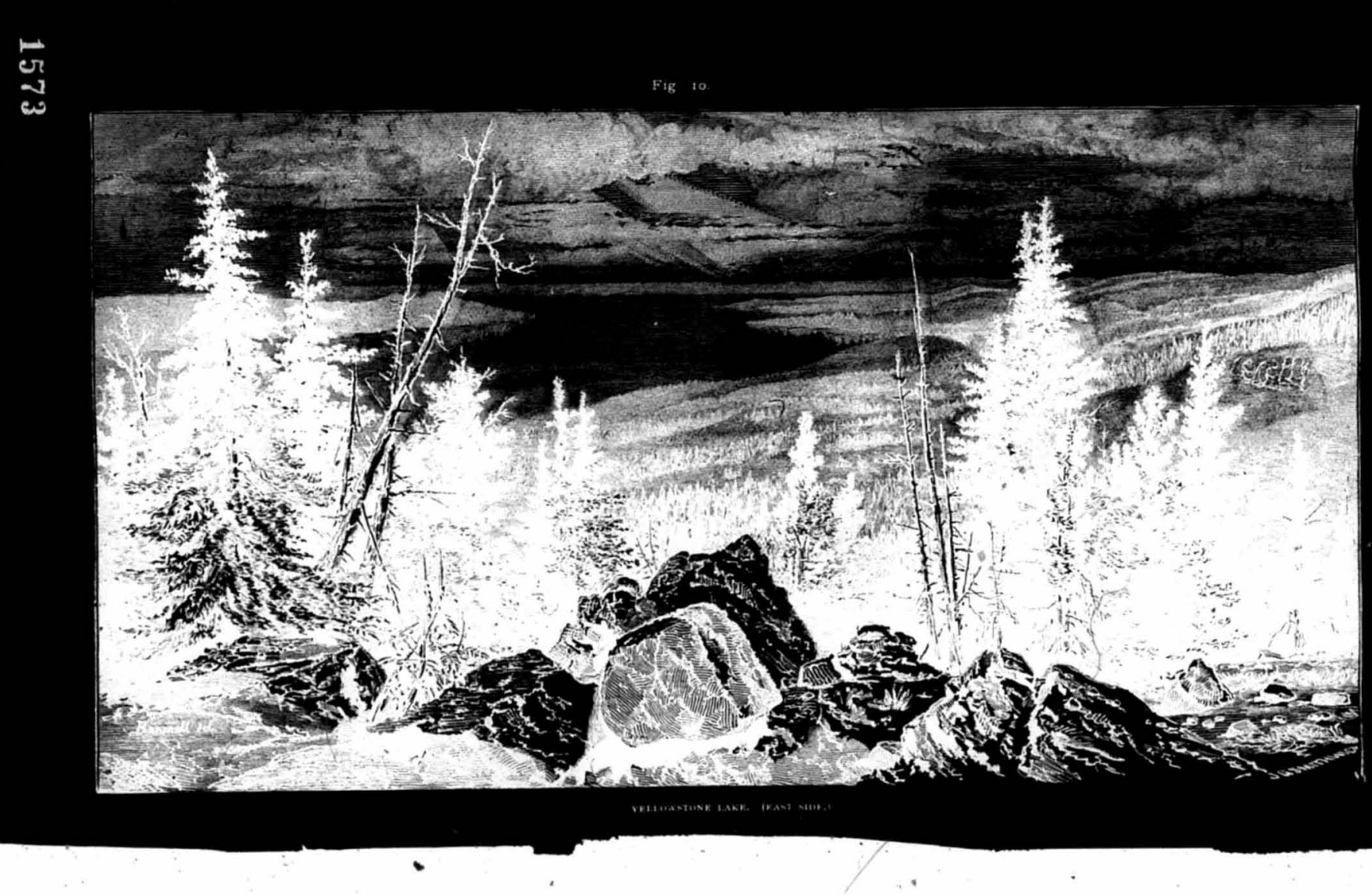

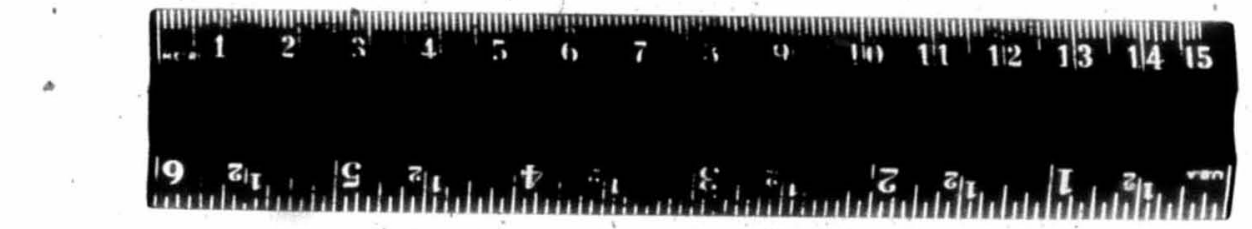




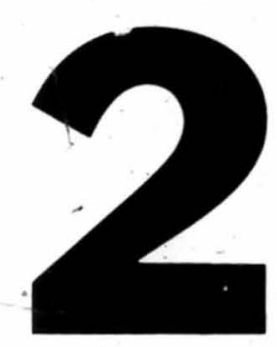

-

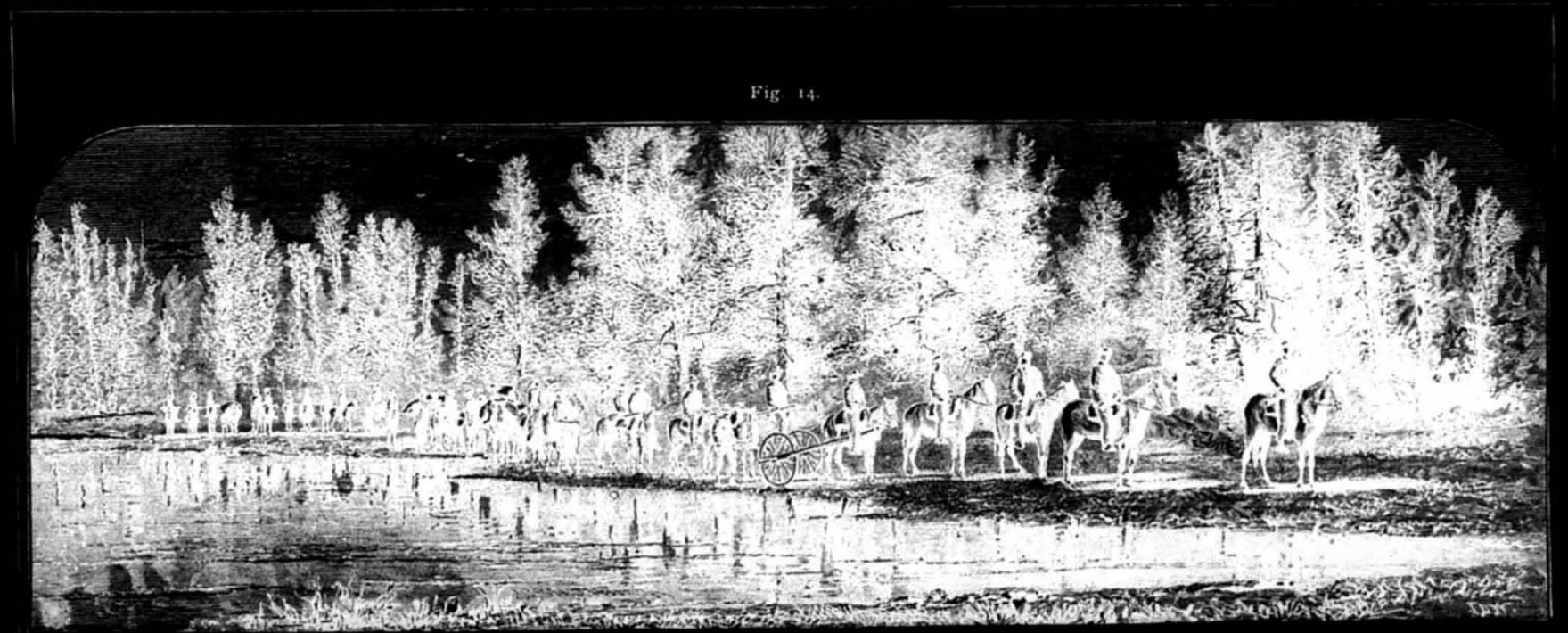

1573

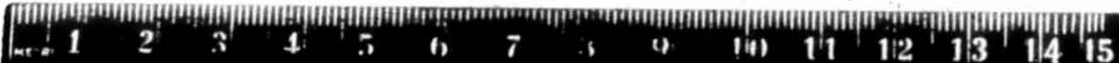

9. ${ }^{2} z_{3}$ 

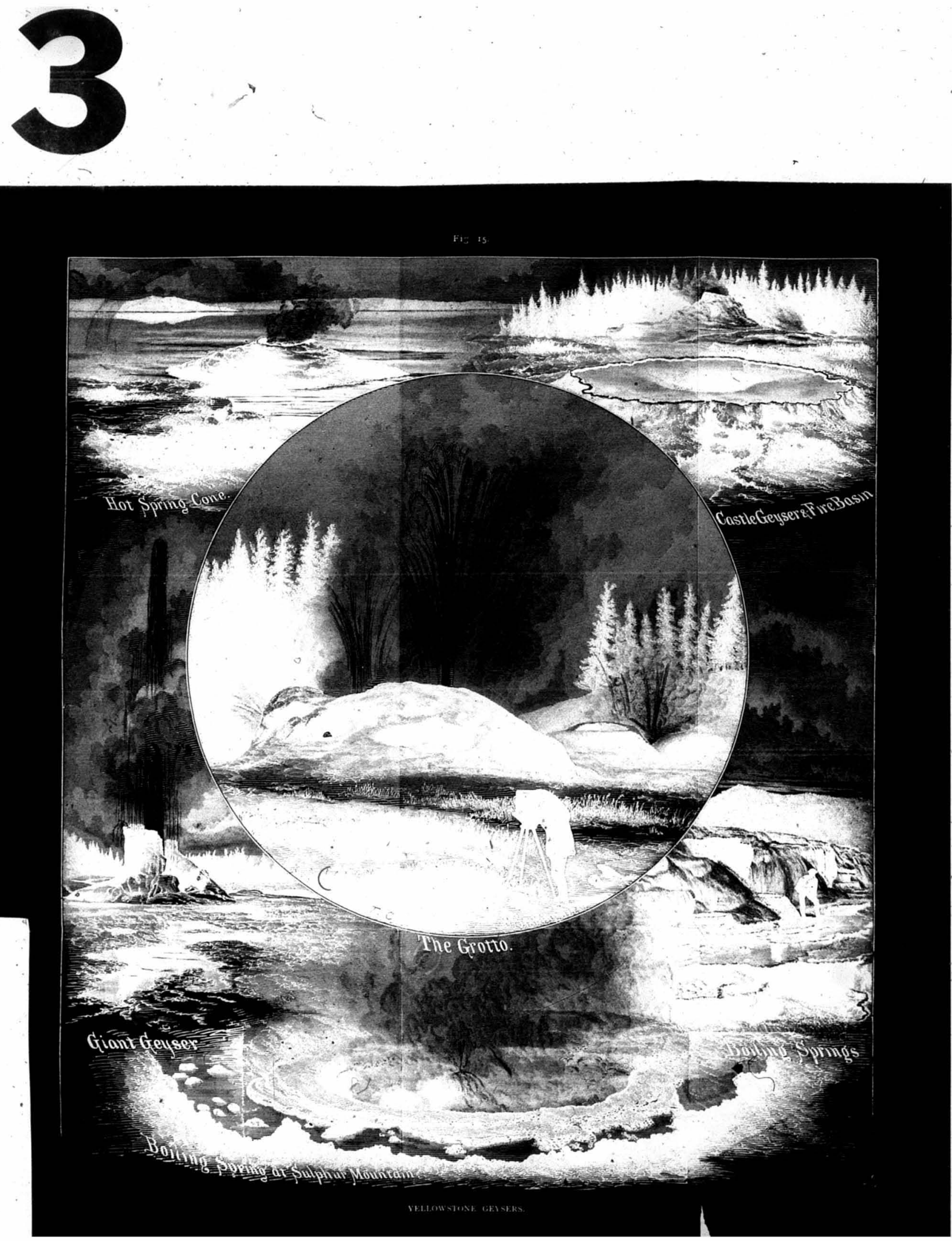

FV. HAYDEN IN CHARGE

I. IKE: IIENRY. WEST FORK OF SNAKE RIVEP

TAHGEE. MADISON AND RED ROCK PASSES GUSTAVUS R BECHLER

\section{PHSCTELLL. UPPER MADISON}

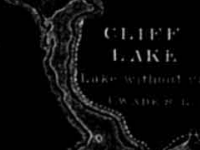

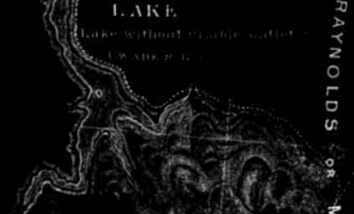

$4 x^{3}+x^{3}$

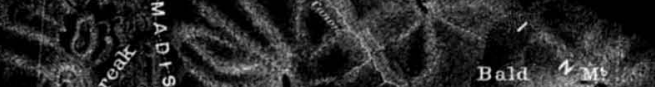
C.

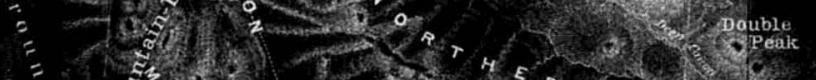

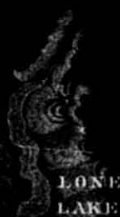

$$
=0^{3}
$$

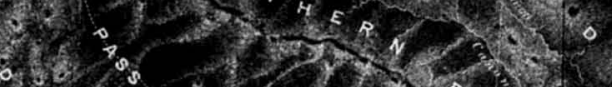

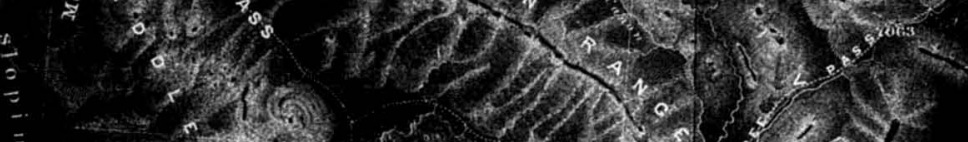

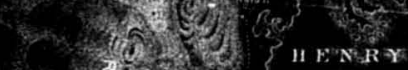

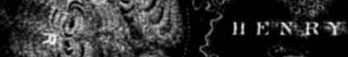
(3) $5,(2,3)$

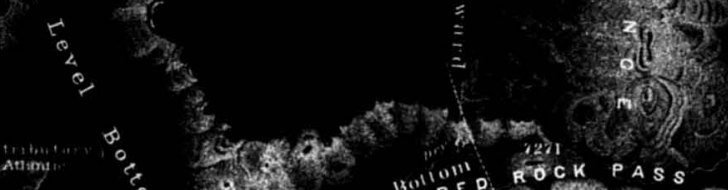

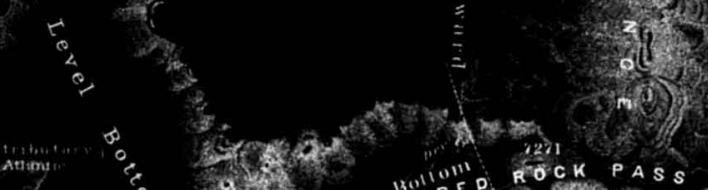

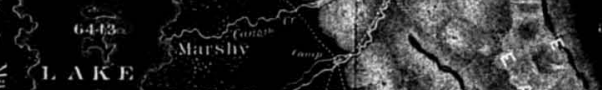
${ }_{i} r_{C_{2}}$

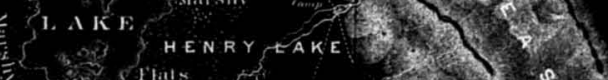

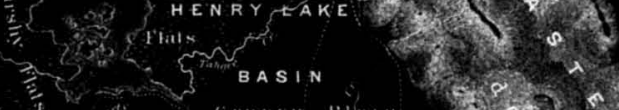
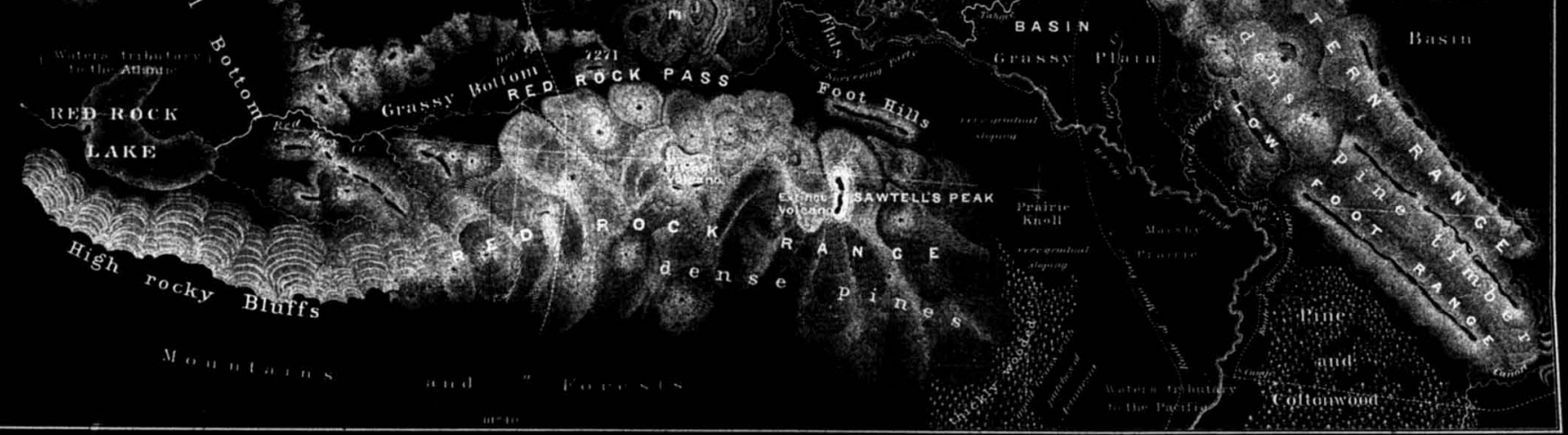
5

.
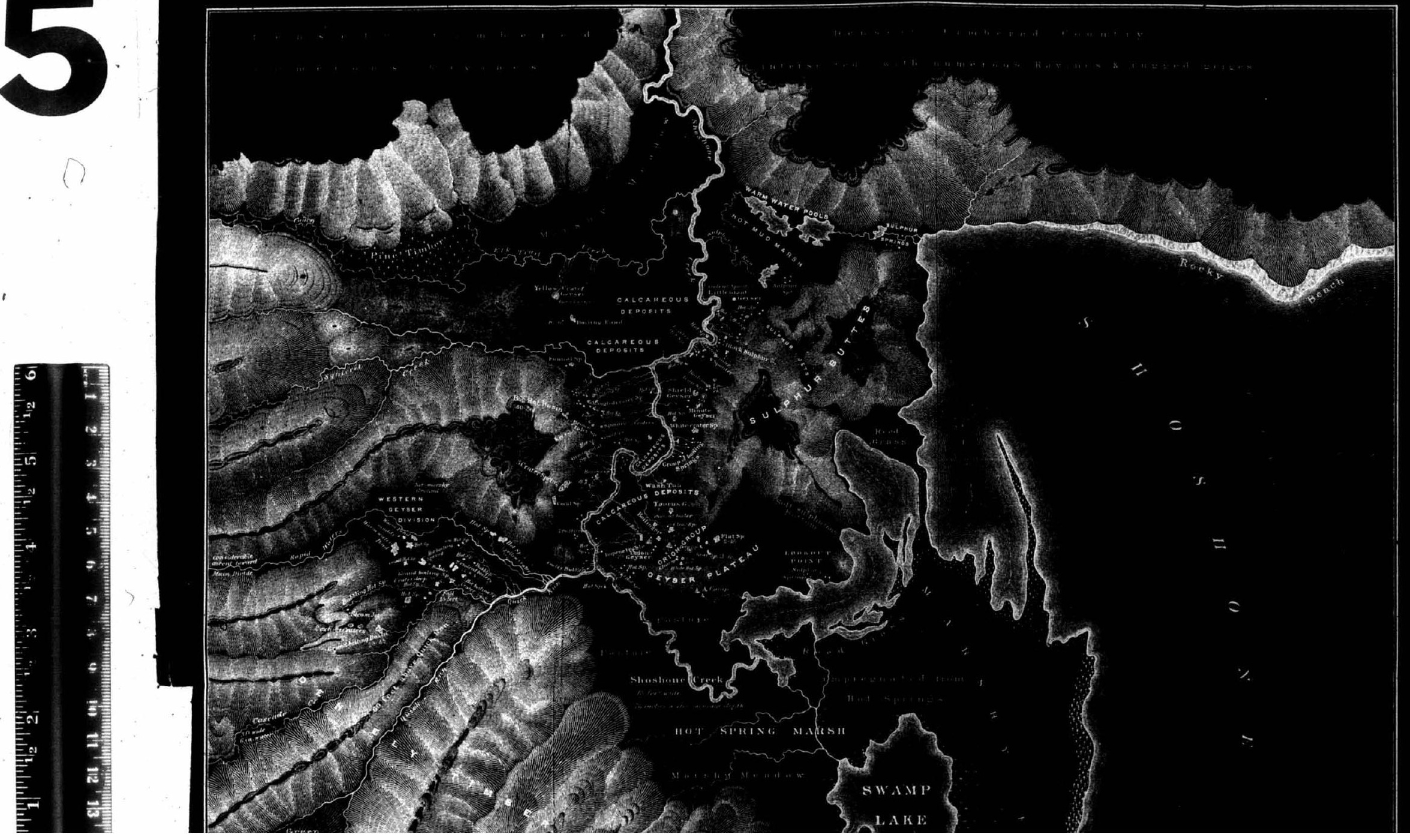
